\title{
EL DERECHO A LA REAGRUPACIÓN FAMILIAR DE LOS EXTRANJEROS PROCEDENTES DE TERCEROS PAÍSES
}

\author{
Autora \\ M. ${ }^{a}$ Elisa García López \\ Director \\ José Luis Cascajo Castro
}

Septiembre, 2012

Universidad de Salamanca 
(C) ELÍSA GARCÍA LÓPEZ Noviembre 2012

Zamora, España 
A mis padres, con amor y todo mi agradecimiento. 

The New Colossus

Give me your tired, your poor,

Your huddled masses yearning to breathe free, The wretched refuse of your teeming shore.

Send these, the homeless, tempest-tossed to me.

I lift my lamp beside the golden door

Dame a tus cansados, a tus pobres, a tus multitudes hacinadas anhelantes de respirar en libertad, a los miserables rechazados de tu atestada orilla.

Envía a éstos, los desamparados, lanzados por la tempestad hacia mi. Yo alzo mi lámpara al lado de la puerta dorada

Emma Lazarus

El nuevo Coloso, extracto, 1883 



\section{Contenidos}

\section{CAPÍTULO I \\ EL MARCO TEÓRICO Y CONCEPTUAL \\ DE LA REUNIFICACIÓN FAMILIAR}

1. UNA NUEVA ETAPA DE LAS MIGRACIONES INTERNACIONALES: INMIGRACIÓN, DERECHOS HUMANOS Y FAMILIA

2. LA FAMILIA EN EL CONTEXTO MIGRATORIO INTERNACIONAL................................ 19

2.1 Familias transnacionales: Nueva geografía familiar inter-fronteriza ............................... 21

2.2 La institución familiar ante la sociología y el derecho ....................................................... 27

2.3 Derecho interno y familia: La familia ante el derecho migratorio ...................................... 29

3. CONCEPTO Y TIPOLOGÍA DE LA INMIGRACIÓN FAMILIAR .......................................... 33

3.1. La Reunificación Familiar en sentido estricto ..................................................................... 36

3.2 La Formación Familiar............................................................................................ 41

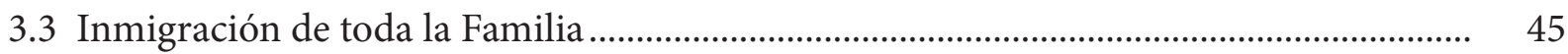

3.4 Reunificación de la Familia Extensa..................................................................................... 45

4. EL CARÁCTER INTRÍNSECAMENTE PROBLEMÁTICO DE LA REUNIFICACIÓN

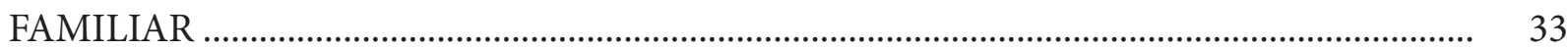

4.1 La RF como elemento central de la política de inmigración ............................................... 49

a. $R F$, control de flujos migratorios y asentamiento permanente .................................... 49

b. El efecto multiplicador de la RF................................................................................ $\quad 52$

c. La inmigración familiar y la formación de cadenas y redes migratorias ..................... 56

d. La inmigración familiar y la feminización de los flujos migratorias ........................... 61

4.2 La RF como vehículo de integración de las políticas de extranjería ..................................... 63

4.3 Migración familiar y derechos humanos: La dialéctica aparente entre limitaciones internas e internacionales........................................................................ 68

4 NUEVAS FACETAS PROBLEMÁTICAS VINCULADAS A LA RF ........................................ 89

a. Incremento de la inmigración matrimonial y de los matrimonios de conveniencia... $\quad 89$

b. RF y Dificultades para la integración en el Estado Receptor....................................... 93

c. RF y Mercado de Trabajo............................................................................................ 95

5. RAZONES PARA EL ACTIVISMO JUDICIAL EN MATERIA DE RF:

UNA PROPOSICIÓN TEÓRICA. 


\section{CAPÍTULO II \\ LA MIGRACIÓN FAMILIAR EN EL SISTEMA \\ INTERNACIONAL DE DERECHOS HUMANOS \\ Y EN EL ÁMBITO DEL CONSEJO DE EUROPA}

1. LA RF EN EL SISTEMA INTERNACIONAL DE DERECHOS HUMANOS........................ 109

1.1 La RF como derecho implícito: Búsqueda de un derecho matriz..................................... 109

1.2 Anclaje normativo de la Reunificación Familiar en el Derecho Internacional de los derechos humanos

2. EL ARTÍCULO 8 DEL CONVENIO EUROPEO: DIFICULTADES Y POSIBILIDADES INTERPRETATIVAS INHERENTES A SU ESTRUCTURA Y CONTENIDO.

2. 1 La vida familiar como norma de principio.

2.2 Los límites al respeto a la vida familiar (art. 8.2 CEDH): Conceptos Jurídicos Indeterminados

2.3 La Familia, concepto culturalmente condicionado

2.4 La vida familiar, derecho de construcción jurisprudencial.

3. LA INTERPRETACIÓN DEL CONVENIO EUROPEO DE DERECHOS HUMANOS ...... 134

3.1 Principio de la efectividad o del efecto útil .................................................................... 136

a) Reconocimiento de obligaciones positivas .................................................................. 137

b) La protección de rebote: la RF como derecho indirecto derivado del derecho al respeto a la vida familiar..................................................... 141

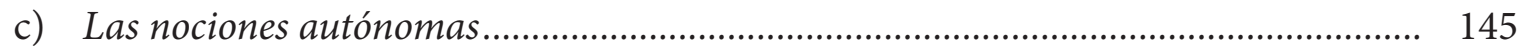

3.2 Principio de interpretación evolutiva............................................................................ 151

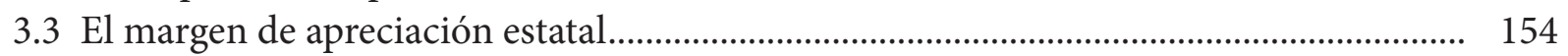

a) Efectos del margen de apreciación............................................................................ 160

b) El Artículo 8 CEDH y el Margen de Apreciación Estatal........................................... 163

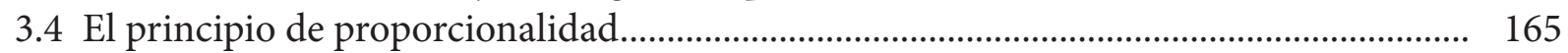

4. LA VIDA FAMILIAR: EL CONCEPTO DE FAMILIA EN LA JURISPRUDENCIA DEL TEDH

4.1 El método Escalonado de Enjuiciamiento: Sus particularidades en presencia de obligaciones positivas.

4.2 El Leading case: Asunto Marckx contra Bélgica, Sentencia de 13 de junio de 1979....... 171

a) Vida familiar: Obligaciones positivas y negativas ..................................................... 174

b) La exclusión del apartado segundo del artículo $8 \mathrm{CEDH}$ :........................................ 176

c) La trascendencia de la sentencia Marckx contra Bélgica ........................................... 176

5. LA CONSTRUCCIÓN JURISPRUDENCIAL DEL DERECHO A LA RF DE LOS EX TRANJEROS POR EL TEDH:

$5.1 \mathrm{La}$ familia del extranjero en la jurisprudencia del TEDH ............................................... 179

a) Vida Familiar Real y Efectiva ................................................................................. 182

b) Preexistencia de la vida familiar .............................................................................. 186

6 PRIMERA ETAPA EN LA CONSTRUCCIÓN JURISPRUDENCIAL DEL DERECHO A

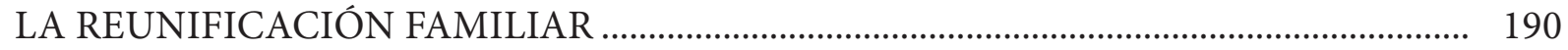

6.1 Abdulaziz, Cabales y Balkandali contra Reino Unido .................................................. 191

a) La aplicabilidad del artículo 8: vida familiar y derechos migratorios ....................... 193 
b) La extensión de la vida familiar.

c) El cumplimiento del artículo 8: Criterios aplicables.................................................... 196

6.2 Gül contra Suiza, STEDH de 19 de febrero de 1996

a) Opinión disidente del Juez Martens a Gül contra Suiza .......................................... 211

6.3 Ahmut contra Holanda, STEDH de 28 de noviembre de 1996 ...................................... 214

7. EL VIRAJE JURISPRUDENCIAL PRODUCIDO CON LA SENTENCIA SEN: LA RF COMO CONTENIDO MATERIAL DEL DERECHO AL RESPETO A LA VIDA FAMILIAR

8. RECOMENDACIÓN DEL COMITÉ DE MINISTROS SOBRE EL ESTATUS LEGAL DE LAS PERSONAS ADMITIDAS POR MOTIVOS DE RF

9. RECOMENDACIÓN 1686(2004)DELAASAMBLEAPARLAMENTARIA.MOVILIDAD HUMANA Y DERECHO A LA REUNIFICACIÓN FAMILIAR

10. LA CONFIRMACIÓN DE LA LÍNEA JURISPRUDENCIAL PROGRESISTA ...................... 242

10.1 Sentencia Tuquabo-Tekle y otros contra Holanda .......................................................... 242

10.2 STEDH Rodrigues da Silva and Hoogkamer contra Holanda, de 31 de enero 2006..... 248

a) RF, Expulsión y casos fronterizos: Criterios de Clasificación ...................................... 250

10.3 Sentencia Konstatinov contra Holanda, de 26 de abril de 2007 ...................................... 260

11. EL TALANTE RUPTURISTA DE LA ÚLTIMA LÍNEA JURISPRUDENCIAL ................... 265

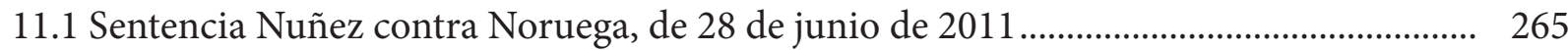

11.2 Casos Agraw contra Suiza y Osman contra Dinamarca: Las dificultades de deslinde

entre obligaciones migratorias positivas y negativas ante supuestos fronterizos............ 272

11.3 Informe de la Asamblea Parlamentaria en torno a la Reunificación Familiar................. 277

\author{
CAPÍTULO III \\ LA REAGRUPACIÓN FAMILIAR \\ EN EL DERECHO COMUNITARIO
}

1. DE LA INTERNACIONALIZACIÓN A LA ASUNCIÓN DE COMPETENCIAS MIGRATORIAS EN LA UE.

2. LAMIGRACIÓNFAMILIARENELDERECHOCOMUNITARIO:BREVEPANORAMA NORMATIVO.

3. LA REGULACIÓN DE LA INMIGRACIÓN FAMILIAR CON ANTERIORIDAD AL TRATADO DE AMSTERDAM

3.1 Resolución sobre la armonización de Políticas Nacionales relativas a la Reunificación Familiar

3.2 Propuesta de convenio relativo a las normas de admisión de nacionales de terceros países en los EEMM

3.3 Resolución sobre medidas en materia de lucha contra los matrimonios fraudulentos..

4. LA DIRECTIVA 2003/86/CESOBREELDERECHO A LA REAGRUPACIÓNFAMILIAR: SU AZAROSO PROCESO DE GESTACIÓN 
4.2 La propuesta modificada de Directiva .............................................................................. 354

4.3 Tercera Propuesta de Directiva: Las claves para comprender la actual Directiva .......... 356

5. LA DIRECTIVA 2003/86 DEL CONSEJO SOBRE EL DERECHO A LA REUNIFICACIÓN

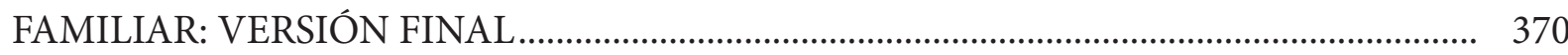

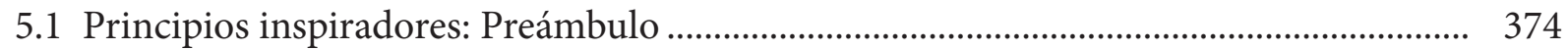

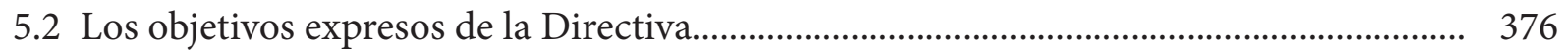

5.3 Ámbito personal de aplicación de la Directiva ............................................................... 380

a) El concepto de reagrupante: la doble titularidad activa del derecho ........................... 381

b) Requisitos que debe reunir el Principal o sponsor...................................................... 382

c) Miembros de la familia a efectos de RF:

Familiares reagrupables

5.4 El procedimiento para el ejercicio del derecho a la RF.................................................. 396

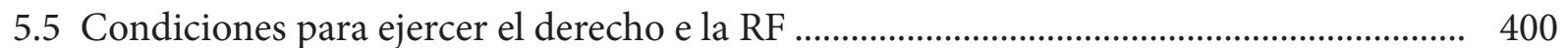

5.6 Estatus de los familiares admitidos por causa de RF...................................................... 404

5.7 Valoración de la Directiva 2003/86: La adecuación de la Directiva para el logro de sus objetivos explícitos.

a) La concesión de un derecho a la RF para los ciudadanos extracomunitarios............. 410

b) La Directiva ante la armonización de las políticas nacionales sobre RF................... 410

c) La Directiva ante el objetivo integrador................................................................... 416

d) ¿Qué tipo de derecho subjetivo configura la Directiva?............................................... 422

6. EL RECURSO DE ANULACIÓN CONTRA LA DIRECTIVA SOBRE EL DERECHO A LA RF: LA SENTENCIA DEL TJUE EN EL ASUNTO C-540/03 ......................................... 423

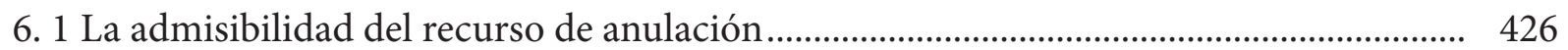

a) ¿Se dirige realmente el recurso contra un acto de las instituciones comunitarias?...... 427

b) ¿Las disposiciones recurridas pueden ser separadas del resto de la Directiva sin alterar su esencia?: El carácter separable de las disposiciones recurridas..

6. 2 Fondo del asunto.

a) El test internacional aplicado por el TJUE................................................................. 431

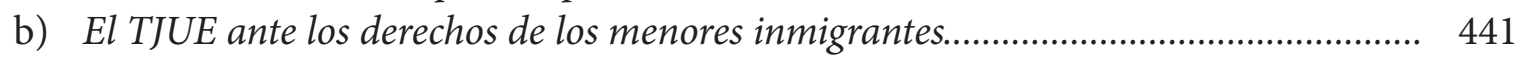

c) La validez de la imposición de prolongados periodos de espera.................................... 449

d) La supuesta naturaleza jurídica fundamental del derecho al respeto de la vida familiar y la inadecuación del nivel de escrutinio efectuado por el TJUE .......................... 451

6. 3 Valoración de la Sentencia del TJUE en el asunto C-540/03 ........................................... 453

a) La interpretación conforme del TJUE ........................................................................... 453

b) Riesgos asociados al uso del test internacional, con predominio del test convencional de Estrasburgo..

7. LA RESPUESTA DEL TJUE ANTE LA PRIMERA CUESTIÓN PREJUDICIAL SURGIDA EN TORNO A LA APLICACIÓN DE LA DIRECTIVA 2003/86/CE EN UN ESTADO MIEMBRO: EL CASO CHAKROUN.

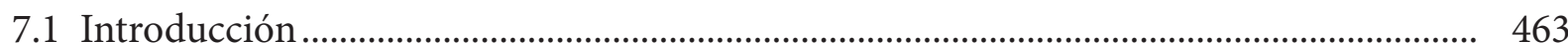

7.2 Contexto del asunto Chakroun: Litigio Principal y Cuestiones Prejudiciales................. 464

7.3 Primera Cuestión Prejudicial: Observaciones de las partes y respuesta de la Corte de Luxemburgo.

7.4 La Segunda Cuestión Prejudicial: Observaciones de las partes y respuesta de la Corte de Luxemburgo 
7.5 Principales aportaciones de la sentencia Chakroun y sus implicaciones sobre el entendimiento de la RF de los extranjeros no comunitarios

8. LA RELACIÓN ENTRE EL ARTÍCULO 8 CEDH Y LA DIRECTIVA COMUNITARIA SOBRE EL DERECHO A LA RF.

8. 1 La doble condición de las disposiciones del Convenio de Roma en el ámbito comunitario.

8. 2 El derecho al respeto de la vida familiar como Principio General del Derecho Comunitario

8.3 El relativismo del case law de Estrasburgo y la amplia evolución jurisprudencial en materia de RF

8.4 La existencia de vida familiar: Miembros de la familia que pueden ser reagrupados....

8.5 La amplia titularidad activa del derecho.

8.6 Canon de protección de la RF en la Jurisprudencia de Estrasburgo respecto al derivado de la Directiva 2003/86

8.7 La condición esencial para el ejercicio del derecho: La residencia legal del reagrupante..

8.8 Las restricciones legítimas al derecho a la reunificación familiar....

8.9 Exigencias derivadas de la Jurisprudencia en torno al artículo $8 \mathrm{CEDH}$.

\section{CAPÍTULO IV}

LA REUNIFICACIÓN FAMILIAR EN EL

ORDENAMIENTO JURÍDICO ESPAÑOL

1. LA EXTRANJERÍA EN EL DERECHO HISTÓRICO.

2. EL MARCO CONSTITUCIONAL ESPAÑOL EN MATERIA DE EXTRANJERÍA E INMIGRACIÓN

2.1 La elaboración constituyente del artículo $13 \mathrm{CE}$............................................................. 520

2.2 Particularidades del estatuto constitucional de los extranjeros....................................... 523

3. EL ARTíCUlO 10 DE LA CONSTITUCiÓN ESPAÑOLA COMO CONTEXTO INTERPRETATIVO DEL ARTÍCULO 13.1 CE...

3.1 Dignidad humana y derechos de los extranjeros.............................................................. 532

3.2 El criterio interpretativo internacional del artículo 10.2 CE........................................... 535

4. EL TRIBUNAL CONSTITUCIONAL ANTE EL ESTATUTO DE LOS EXTRANJEROS: UNA DOCTRINA INESTABLE E INACABADA

4. 1 La primera jurisprudencia del T.C. en materia migratoria .

4.2 La segunda etapa en la construcción del Régimen de los Derechos de los extranjeros en España por parte del TC

4.3 Tercera etapa en la evaluación de la jurisprudencia Constitucional relativa al estatuto de los extranjeros

4.4 La STC 236/2007, de 7 de noviembre.

a) Los motivos concretos de inconstitucionalidad........................................................ 583

b) El T.C. Español ante la Reunificación Familiar...................................................... 587

b.1 El debate doctrinal previo............................................................................... 587

b.2 La naturaleza jurídica del derecho a la RF: Su matriz constitucional ................ 590

b.3 Valoración de la STC 236/2007.......................................................................... 595

4.5 La trayectoria del T.C. en materia de extranjería e inmigración .................................... 597 
5. LA CONSTRUCCIÓN NORMATIVA DE LA RF EN ESPAÑA: ANÁLISIS EVOLUTIVO DE SU REGULACIÓN CON ANTERIORIDAD A LA VIGENTE LEY DE EXTRANJERÍA.

6. LA REGULACIÓN DE LA RF EN EL SIGLO XXI: UN INESTABLE MARCO NORMATIVO

7. LA LEY ORGÁNICA 2/2009 ¿ÚLTIMA REFORMA DE LA LEY DE EXTRANJERÍA? MODIFICACIONES EN EL RÉGIMEN DE LA INMIGRACIÓN FAMILIAR.

7.1 La titularidad activa del derecho a la RF.

7.2 Familiares reagrupables

7.3 La protección de los vínculos creados en el Estado de acogida: La figura del arraigo....

7.4 Requisitos y efectos de la reagrupación familiar.

8. EL PODER JUDICIAL ANTE EL DERECHO A LA RF: BREVE RESEÑA JURISPRUDENCIAL 


\section{INTRODUCCIÓN}

El presente trabajo de investigación analiza el surgimiento, evolución y contenido actual del derecho a la reunificación familiar - en adelante RF- de los nacionales procedentes de terceros países. En términos simples, y con los matices que se detallan en el cuerpo de la tesis, la RF consiste en el derecho que ostentan los extranjeros regularmente asentados a reunirse con sus parientes dentro del territorio del Estado receptor, en condiciones más beneficiosas que las establecidas en el régimen general que rige la entrada y establecimiento de los no nacionales.

La migración familiar se ha convertido en el principal cauce de asentamiento de extranjeros, tanto a nivel mundial como en la mayor parte de países integrantes de la UE. En la última estadística europea publicada al cierre de esta investigación doctoral, España figuró como el país comunitario que había otorgado un mayor número de permisos de residencia por razones familiares, constituyendo la migración familiar un $43 \%$ del total de las autorizaciones de residencia emitidas, erigiéndose como la principal tipología migratoria.

La RF constituye, en sus orígenes, un derecho de construcción jurisprudencial en Europa. La labor pionera en su peculiar proceso de extracción normativa corrió a cargo de las instituciones de Estrasburgo - tanto de la extinta Comisión como del TEDH—, enlazando su protección con el derecho convencional a la vida familiar. Con base a esta disposición, los órganos del Consejo de Europa lograron trascender la literalidad del Convenio de Roma para dotar de cobertura jurídica específica a las familias migrantes, en dos situaciones particulares: protección frente a las expulsiones que amenazaban su continuidad y tutela de la reagrupación familiar. Al estudio de ésta última dedicaremos en exclusiva el presente trabajo.

La inicial resistencia estatal al reconocimiento jurídico del derecho a la RF —las más de las veces consentido en la práctica de forma altamente discrecional, pero carente de consagración normativa explícita-, desencadenaría la activista participación del poder judicial supranacional en la tutela de lo que no constituía un derecho en la letra de la ley y hubo de ser extraído de su espíritu. Para ello harían uso de principios interpretativos que potenciaban la efectividad de los derechos convencionales.

La construcción del TEDH penetraría posteriormente en el derecho comunitario, donde el Tribunal de Justicia de la Unión Europea afianzaría la RF en el seno del derecho a la vida familiar, primero para los nacionales de los Estados partes y los miembros de sus familias que se trasladaban a otro EM, para insertarse después en el colectivo de extracomunitarios. A partir del impulso del derecho comunitario, esta construcción irradiaría al ordenamiento español.

Por su parte, en el ordenamiento español el diseño constitucional del estatuto de los extranjeros que emana de la reserva legal contenida en el artículo 13.1 de la Constitución muestra una firme vocación internacional. La RF obtuvo entre nosotros una consagración jurídica tardía, a remolque del derecho internacional, especialmente a instancias de la incorporación de España a la UE. Tal circunstancia provocó un reforzamiento de la influencia internacional sobre su configuración y diseño 
normativo, potenciado asimismo por la cláusula interpretativa del artículo 10.2. CE. Ello explica el peso que ostenta en nuestro trabajo el derecho internacional público, pese a elaborarse desde una perspectiva constitucionalista.

Este particular itinerario normativo marca la hoja de ruta de nuestro estudio. En suma, a lo largo del presente trabajo se intentará responder a las siguientes preguntas: (1) ¿por qué la RF es una materia altamente sensitiva dentro del ya de por si complejo ámbito migratorio, tanto desde el punto de vista social, económico, político y, consecuentemente, también jurídico?; (2) ¿por qué es éste un derecho de construcción inicialmente jurisprudencial?; (3) ¿por qué la reserva de ley que rige en materia de extranjería remite en primer lugar a los tratados internacionales?; (4) cómo dicha reserva convencional ha operado sobre la construcción de la RF en el ordenamiento jurídico español; (5) cuál ha sido el íter del ordenamiento español en esta materia, mediante un recorrido por los diversos instrumentos jurídicos que han ido pergeñando este derecho en nuestro país.

Dichas cuestiones se van contestando a lo largo de los cuatro capítulos que integran este trabajo. En el capítulo primero se aborda el fenómeno migratorio desde una perspectiva multidisciplinar, fundamentalmente sociológica, como el contexto necesario para entender las dificultades, retos y dilemas que afronta el Estado receptor al acometer el desarrollo normativo de la RF y las políticas públicas implementadas en este ámbito, especialmente la colisión entre la protección de los intereses nacionales por una parte, y el derecho internacional de los derechos humanos de otra.

En este primer capítulo se identifica el colectivo de los extranjeros procedentes de terceros países como una "minoría insular". Esta inserción permite comprender en primer lugar que la construcción del derecho a la RF haya corrido a cargo del poder judicial, y las razones que explican el activismo judicial existente en esta materia. En segundo término, la construcción teórica propuesta alumbra la peculiar redacción de la reserva de ley contemplada en el artículo 13.1 de la Constitución Española a fin de configurar los derechos de los extranjeros, que remite en primer lugar al legislador internacional y que en absoluto supone un pleonasmo constitucional.

Dado que la RF se enraíza en el derecho internacional de los derechos humanos —en adelante DIDH-, el capítulo segundo se inicia realizando una trayectoria por el marco legal internacional que ha permitido el surgimiento de un todavía incipiente y débil derecho humano a la RF en textos internacionales relativamente recientes. Pero el grueso de este capítulo se dedica al estudio evolutivo de la jurisprudencia emitida por el Tribunal Europeo de Derechos Humanos en materia de RF. Para abordarlo, previamente se identifican los elementos estructurales de la norma convencional a la que ha quedado anclada en Estrasburgo la protección de las familias migrantes porque, a nuestro entender, la estructura normativa de dicha disposición explica en gran parte el tipo de estrategia interpretativa acometida por el TEDH para su interpretación y aplicación en el contexto migratorio. Asimismo, se ofrece un recorrido por los principales principios interpretativos empleados por el TEDH en el ámbito de la vida familiar de los extranjeros, que han permitido el alumbramiento en su seno del derecho a la RF; Se intenta una sistematización de las principales aportaciones que el TEDH ha realizado en esta materia, con la finalidad de extraer de su elevado casuismo un cuerpo doctrinal coherente que facilite la comprensión de los criterios jurisprudenciales de Estrasburgo así como su aplicación interna por parte de los jueces y tribunales que a diario acometen demandas en este ámbito. El afán de sistematización — presente también en el ánimo del TEDH en las últimas sentencias que integran esta compleja rama jurisprudencial—, resulta muy pertinente en vista de los problemas que ha provocado - y sigue ocasionando- la ambigüedad de esta materia, que ha abonado el terreno para una comprensión parcial, superficial y algo rebasada de esta rama jurisprudencial. 
El capítulo tercero realiza un recorrido por la trayectoria normativa seguida por la migración familiar de los extranjeros procedentes de terceros países en el derecho comunitario, tanto antes como después de que la UE asumiera competencias comunitarias parciales en materia migratoria. El énfasis se sitúa en la comprensión de la Directiva sobre el derecho a la RF, analizando en profundidad su laborioso proceso de elaboración, no solamente porque ello sirve para entender las razones que subyacen a su contenido final, sino también porque ilustra en la práctica las múltiples dificultades que arrastra la construcción de un régimen comunitario migratorio, exacerbadas además como consecuencia de las peculiaridades jurídicas establecidas en su momento por el Tratado de Ámsterdam. Las complejidades implícitas a la regulación de la migración familiar, fruto de la tensión implícita entre el respeto a los derechos humanos y a la soberanía estatal, se demuestran de forma fehaciente en esta norma. Asimismo, el capítulo tercero aborda la jurisprudencia emitida por el Tribunal de Justicia de la Unión Europa en torno a la Directiva comunitaria sobre RF, en las dos ocasiones en las que, hasta el momento, ha tenido ocasión de interpretarla. Con sus pronunciamientos, este Tribunal está cincelando y rediseñando en la práctica el marco en el que se desenvuelve la aplicación nacional de esta importante norma comunitaria, de ahí la importancia de detenernos en su estudio. El capítulo tercero ofrece finalmente un análisis comparativo de las principales aportaciones que se derivan del TEDH y del TJUE en esta materia, y de las exigencias que la incorporación de las doctrina de Estrasburgo implica para una adecuada comprensión de la Directiva comunitaria señalada — muchas de las cuales han sido a su vez recientemente incorporadas por el Tribunal de Luxemburgo-.

El capítulo cuarto se centra en el estudio de la RF en el ordenamiento español. A fin de situar en perspectiva la regulación de la extranjería en nuestro país, iniciamos el recorrido en esta materia con un breve repaso por el tradicionalmente benigno tratamiento que el derecho histórico español proporcionó a esta materia. Junto al análisis de los diversos instrumentos jurídicos que fueron dando cobijo a la RF hasta finalmente, ser reconocida legislativamente con la ley de extranjería actualmente vigente - $\mathrm{e}$ intensamente reformada - , se analizan en profundidad las principales sentencias emitidas por el Tribunal Constitucional en el ámbito general de la extranjería y, en particular, el único pronunciamiento que ha abordado directamente el alto tribuna en materia de RF. Nuestro estudio finaliza efectuando un breve recorrido por algunos de los más importantes pronunciamientos emitidos por el poder judicial en materia de RF, a fin de dar cuenta de su potencial protector y de vanguardia - anticipatorio de futuras reformas normativas - en nuestro ámbito de estudio.

Finalmente, el tratamiento normativo de la RF conforma un régimen heterogéneo, estructurado principalmente en base a la nacionalidad que ostente el inmigrante primario. El presente trabajo aborda en exclusiva la migración familiar ejercida por ciudadanos procedentes de terceros países, asentados en el ámbito geográfico español y europeo, esto es, de aquellas familias íntegramente constituidas por nacionales extracomunitarios. Queda excluido de nuestro estudio tanto el régimen aplicable a los ciudadanos comunitarios y a los miembros de sus familias - aun cuando estos últimos procedan de terceros países-, como el estatus que rige la RF de los refugiados.

Para concluir esta breve introducción me parece oportuno delimitar el radio del objeto de estudio indicado en el título de esta tesis: Pese a su generalizada nomenclatura, la RF constituye un tipo específico dentro de la migración familiar. A efectos de simplificación, constituye una extendida costumbre doctrinal tomar la parte por el todo, utilizando en sentido amplio el término de RF como sinónimo de migración familiar. Los textos normativos inciden en la misma línea, —a la cual nos adherimos en este trabajo - , de modo que, cuando se utiliza el término de RF, sin más puntualizaciones, se emplea en su acepción extensa. No obstante, en la primera parte de nuestro estudio se identifican las diferencias conceptuales entre las diversas tipologías que integran la migración familiar. 



\section{CAPÍTULO I \\ EL MARCO TEÓRICO Y CONCEPTUAL DE LA REUNIFICACIÓN FAMILIAR}

\section{UNA NUEVA ETAPA DE LAS MIGRACIONES INTERNACIONALES: INMIGRACIÓN, DERECHOS HUMANOS Y FAMILIA}

Concluida la segunda guerra mundial la sociedad internacional, conmocionada, emprendió la tarea de construir un sistema internacional protector de los derechos humanos, en vista de que la experiencia reciente evidenciaba dramáticamente que la tutela de éstos no debía circunscribirse al ámbito exclusivo del Estado nacional. Esta iniciativa marcará el inicio de lo que hoy conocemos como Derecho Internacional de los Derechos Humanos - en adelante DIDH - , basado en la concepción de que, junto a los Estados como sujetos del Derecho Internacional, se reconoce también cierta subjetividad internacional al individuo ${ }^{1}$, que pasa a ser titular de derechos que trascienden las fronteras nacionales de los Estados. Con ello, el derecho internacional dejaba de ser un sistema exclusivamente interestatal, para asumir una dimensión axiológica que daría lugar a un progresivo proceso de humanización de esta rama jurídica².

Por esa misma época, los países de Europa occidental comenzaron a reconstruir sus infraestructuras y a recibir un volumen creciente de flujos migratorios internacionales, a fin de abastecer las insuficiencias de mano de obra doméstica generadas por sus economías en rápida expansión ${ }^{3}$. A tal efecto, en Europa se desarrollaron programas de reclutamiento de trabajadores extranjeros, bajo el paradigma del trabajador huésped o invitado — guest worker, gastarbeiter -, del que Alemania constituía el país prototipo. Durante las siguientes tres décadas, caracterizadas por altas cotas de crecimiento económico, los países de Europa occidental importaron mano de obra extranjera, registrando la llegada de importantes flujos migratorios, entre los que predominaban los habitantes de las excolonias de ultramar y los trabajadores procedentes del sur de Europa, Turquía y el norte de África, principalmente ${ }^{4}$.

1 Manuel PÉREZ GONZÁLEZ afirma que, en la fase de desarrollo actual de la sociedad internacional, la cuestión de la subjetividad internacional del individuo es todavía objeto de controversia doctrinal en el ámbito del derecho internacional general. Se admite, sin embargo, una tendencia hacia su reconocimiento, aunque "todavía sujeto a fuertes restricciones". Véase "La subjetividad internacional (II): La personalidad internacional de otros sujetos"; en DÍEZ DE VELASCO, Manuel (coord.). Instituciones de Derecho Internacional Público. Madrid, Tecnos, decimotercera ed., 2001, pp. 250-251.

2 PECES-BARBA MARTÍNEZ, Gregorio; FERNÁNDEZ LIESA, Carlos R. y LLAMAS CASCÓN, Ángel. Textos básicos de Derechos Humanos (Con estudios generales y especiales y comentarios a cada texto nacional e internacional). Madrid, Aranzadi Editorial, 2001, p. 268.

3 CASTLES, Stephen y MILLER, Mark J. La era de la migración. Movimientos internacionales de población en el mundo moderno, traducción al español de Luis Rodolfo Morán Quiroz. México, Porrúa, 3a edic, 2004, p. 90.

4 Sólo el segundo tipo de trabajadores extranjeros llegados a Europa tras la postguerra - los procedentes del sur de Europa, Turquía y norte de África- encaja con propiedad en la categoría de trabajador invitado, pues los extranje- 
A diferencia de los países clásicos de inmigración ${ }^{5}$ —EEUU, Canadá y Australia - cuyas políticas promovían el asentamiento permanente de los inmigrantes ${ }^{6}$ y la reagrupación familiar ${ }^{7}$, en el modelo europeo, por el contrario, los incipientes sistemas migratorios se basaban en la asunción de la temporalidad y la aplicación del principio de rotación ${ }^{8}$. La "filosofía subyacente" consistía en promover la entrada de los inmigrantes considerados necesarios para el sistema económico, bajo la premisa de que constituirían una inmigración predominantemente masculina, que terminaría retornando a su país de origen. Los inmigrantes eran concebidos como "unidades temporales de mano de obra" ${ }^{10}$ y se evitaba la reunificación familiar. Con ello se pretendían impedir las dificultades a la movilidad y al desplazamiento internacional asociadas con la instalación de la familia del inmigrante en la sociedad receptora, en el entendido de que la llegada de la familia del extranjero preludiaba su instalación definitiva en el Estado receptor.

ros oriundos de las colonias de ultramar disfrutaban de un régimen de derechos más privilegiado que les permitía asentarse en el país europeo de destino y en ocasiones acceder a la nacionalidad, como en el caso del Reino Unido hasta la década de los ochenta del pasado siglo. CHOLEWINSKI, Ryszard. "The Protection of the Right of Economic Migrants to Family Reunion in Europe"; en The International and Comparative Law Quarterly, Vol. 43, No. 3, 1994, p. 570. Sobre estas dos principales tipologías de extranjeros, Michael Samers distingue entre países que con propiedad se ajustan al modelo de trabajador invitado o migración rotacional — Alemania, Austria y Suiza - respecto a países con regímenes migratorios de establecimiento permanente o "neocolonialistas" que acogían a antiguos habitantes de las colonias — Reino Unido, Francia y los Países Bajos. SAMERS, Michael. “'Globalization', the Geopolitical Economy of Migration and the 'Spatial Vent'“; en Review of International Political Economy, Vol. 6, No. 2, 1999, p. 170. Con mayor propiedad, Christian Joppke denomina a estos últimos regímenes migratorios, sistemas “postcoloniales". JOPPKE, Christian. "Why Liberal States Accept Unwanted Immigration?”; en World Politics, No. 50, 1998, p. 271.

5 Para su concepto, seguimos la definición apuntada por Cornelius y Tsuda, quienes entienden por "classic countries of immigration those that were founded, populated, and built by immigrants in modern times. As a result, immigration is a fundamental part of the founding myth, historical consciousness, and national identity of these countries, and they anticipate and welcome large numbers of immigrants"; en CORNELIUS, Wayne A; TSUDA, Takeyuki; MARTIN, Philip L y HOLLIFIELD, James F. Controlling Immigration. A Global Perspective, second edition. California, Standford University Press, 2004, p. 20.

6 Martin y Houstoun apuntan a la emergencia del nacionalismo en Europa junto con el desarrollo del Estado Social de Derecho europeo como causas explicativas de estas diferentes políticas migratorias a ambos lados del Atlántico, mientras en EEUU se promovía la inmigración permanente y la visión del inmigrante como un potencial ciudadano. MARTIN, Philip L y HOUSTOUN, Marion F. "European and American Immigration Policies"; en Law and Contemporary Problems, No. 45, vol. 2, 1982, p. 30. En el mismo sentido se pronuncia Hollifield, quien contempla el caso de Francia como una excepción relativa al modelo del guest worker, pues se trata de un país europeo que gozaba de tradición migratoria — desde el último cuarto del siglo XIX - y había demostrado cierta apertura al asentamiento permanente. El mismo autor subraya que, pese a la diferencia apuntada, resulta común tanto al sistema migratorio de EEUU como al europeo, la impronta liberal democrática sobre la que ambos reposan. HOLLIFIELD, James Frank. Immigrants, Markets and States: the Political Economy of Postwar Europe. Cambridge, Harvard University Press, 1992, p. 16.

7 KOFMAN, Eleanore. "Family-Related Migration: A Critical Review of European Studies"; en Journal of Ethnic and Migration Studies, vol. 30, No. 2, 2004, p. 243. HING, Bill Ong. Deporting Our Souls. Values, Morality and Immigration Policy. Cambridge, Cambridge University Press, 2006, p. 118.

8 CHOLEWINSKI, Ryszard. "The Protection of the Right of Economic Migrants to Family Reunion in Europe”, op. cit., p. 570. MARTIN, Ph. L y HOUSTOUN, M.F. “European and American Immigration Policies”, op. cit., p. 35.

9 KRALER, Albert \& KOFMAN, Eleonore. Civic Stratification, Gender and Family Migration Policies in Europe. Paper presented at Conference European Dynamics of Citizenship, Public policies and migrant activities. IMISCOE Network Cluster B3, Legal Status, citizenship and political participation. Central European University, Budapest, 31 May-2 June 2006, p. 2.

10 CASTLES, Stephen y MILLER, Mark J. La era de la migración...op. cit., p. 94. En una línea similar, Javier DE LUCAS ha denunciado la visión instrumental del inmigrante que dominaba los sistemas migratorios bajo el paradigma del trabajador invitado circunstancia que, a su juicio, dificulta enormemente su integración en el país de destino. "Algunas propuestas para comenzar a hablar en serio de política de inmigración”; en DE LUCAS, J y TORRES, F. (eds.). Inmigrantes: ¿cómo los tenemos? Algunos desafíos y (malas) respuestas. Madrid, Talasa, 2002, p. 29. 
Bajo la lógica rotatoria de la inmigración estacional, los sistema europeos presuponían que la recomposición de la unidad familiar del trabajador extranjero habría de producirse en el Estado de origen, no en el país de destino. En consecuencia, si el inmigrante deseaba la reunificación familiar - RF-, ésta tendría lugar cuando el mismo retornase a su tierra natal ${ }^{11}$. El sistema descansaba sobre la base del retorno voluntario y la negación implícita tanto de la reagrupación familiar como del establecimiento permanente ${ }^{12}$, descargando con ello la posible responsabilidad que pudiese incumbir al Estado receptor. En este esquema de inmigración temporal, las necesidades laborales y económicas informaban con carácter exclusivo las políticas de entrada y residencia de extranjeros y los escasos derechos reconocidos a los inmigrantes a menudo no se reflejaban a nivel legislativo ${ }^{13}$. La RF constituía un aspecto frecuentemente obviado en el ámbito normativo ${ }^{14}$ - con la excepción de aquella correspondiente a los habitantes de las excolonias-, si bien era consentida en la práctica por muchas políticas públicas. Con todo, los regímenes migratorios europeos constituían sistemas "relativamente liberales"15.

La recesión económica que tuvo lugar a raíz de la crisis del petróleo de los años 1973-74, redujo las fuentes de trabajo, lo que condujo al cierre de fronteras. El cierre de fronteras provocó un cambio radical en las políticas migratorias, inaugurando una etapa de fuertes restricciones, con objetivos de "inmigración cero"16. El cambio es de tal magnitud que puede afirmarse, siguiendo a Arango, que por entonces comienza a perfilarse una nueva era de las migraciones internacionales ${ }^{17}$, donde éstas adquirirán tal importancia que darán origen a lo que con autoridad se ha dado en llamar "la era de la migración" ${ }^{18}$. La extraordinaria significación que a partir de entonces asumiría la inmigración internacional, con su enorme potencial para la transformación social ${ }^{19}$, ha llevado incluso a señalar que “estamos ante una revolución transnacional que está reestructurando la sociedad a escala planetaria"20.

11 PERRUCHOUD, Richard. "Family Reunification"; en International Migration, No. 27, vol. 4, 1989, p. 512.

12 CASTLES, Sthephen y MILLER, Mark J. La era de las migración..., op. cit., p. 25.

13 Guiranudon y Lahav advierten al respecto que el modelo de trabajador invitado que finaliza en 1973 constituyó un "process that did not always require legislation because it had not preceded from legislation in the first place". GUIRAUDON, Virgine y LAHAV, Gallya. "A Reappraisal of the State Sovereignty Debate. The Case of Migraiton Control”; en Comparative Political Studies, vol, 33, No. 2, 2000, p. 175.

14 Pese a ello, desde el ámbito político se era consciente que la RF constituía un proceso en marcha que se estaba apenas iniciando, consentida por muchas políticas públicas de la época, pero sin incorporar cambios legislativos expresos ni reformas en la ejecución de sus políticas en la materia. KRALER, Albert and KOFMAN, Eleonore. Civic Stratification, Gender and Family Migration Policies in Europe, op. cit., p. 2

15 La calificación corresponde a Eleonore Kofman, quien más adelante se encarga de especificar el sentido en el que está usando el término liberal: "Liberal in the sense that migration policy was not aimed at restricting entry of aliens but rather at ensuring a sufficient suply of (cheap) labour", ídem, nota a pie de pág. №. 4, p. 3 .

16 Si bien, como acertadamente puntualiza Joaquín Arango, "el término no debe tomarse al pie de la letra, sino asintóticamente, entendido como el menor volumen posible de inmigración”. ARANGO VILLA-BELDA, J. "Dificultades y dilemas de las políticas de inmigración"; en Anuario de la Facultad de Derecho de la Universidad Autónoma de Madrid, No. 7, 2003, p. 57.

17 ARANGO, Joaquín. "Inmigración y diversidad humana. Una nueva era en las migraciones internacionales"; en Revista de Occidente, №. 268, 2003, p. 5.

18 La expresión corresponde a CASTLES y MILLER, dando título a una obra ya clásica en torno a las migraciones contemporáneas. La era de la migración. Movimientos internacionales de población en el mundo moderno.

19 ARANGO, Joaquín. "Inmigración y diversidad humana. Una nueva era en las migraciones internacionales", op. cit., p. 12.

20 Colectivo IOÉ. "Flujos migratorios internacionales. Marco de comprensión y características actuales"; en Migraciones, No.9, 2001, p. 33. Si bien los autores precisan que el número de inmigrantes internacionales a escala global representa una cifra que se sitúa ligeramente por encima de la tasa anual de crecimiento de la población del planeta. "Por tanto, en el cómputo global se trata de un fenómeno de alcances bastante limitados y se puede afirmar que desde el punto de vista cuantitativo la migración internacional es la excepción, no la regla, entre los grupos humanos”. 
En conjunción con las dinámicas de la globalización —-dentro de la cual la migración representa un factor clave $e^{21}$ - los flujos migratorios se mundializaron ${ }^{22}$, experimentando volúmenes, aceleraciones e intensidades sin precedentes ${ }^{23}$, contrariamente a los objetivos político-gubernamentales. Se produjo además una extraordinaria diversificación tanto de los flujos, como de los países de origen y de destino de migración. A éstos últimos se incorporarían de forma progresiva los países de la cuenca del Mediterráneo, entre ellos destacadamente España, que históricamente se habían caracterizado por constituir países emisores de mano de obra.

Todo ello tendría lugar, paradójicamente, en un marco caracterizado por la disminución en términos relativos de la demanda laboral en los países receptores ${ }^{24}$. En este contexto económico no sólo no se ralentizaría la atracción de nuevos inmigrantes, sino que se haría evidente que la mayoría de los trabajadores huéspedes habían llegado a Europa para quedarse $e^{25}$ - con la excepción parcial de los inmigrantes procedentes del sur de Europa ${ }^{26}$-, y pese al desenvolvimiento de múltiples planes para facilitar su retorno y expatriación voluntarios ${ }^{27}$, en lo que por ello ha sido calificado como un "espectacular ejemplo de fracaso político nacional múltiple"28.

21 CASTLES y MILLER. La era de la migración ..., op. cit., p. 5.

22 ARANGO, Joaquín. "Inmigración y diversidad humana. Una nueva era de las migraciones internacionales", op. cit., p. 12.

23 A nivel mundial los flujos migratorios experimentaron un notable crecimiento desde mediados de los setenta del pasado siglo. La Organización Internacional de las Migraciones estimó que en el año 1975 existían 85 millones de migrantes internacionales en el mundo, cifra que representaba un 2,1\% de la población mundial. Para el año 2000, estos flujos se habían duplicado, de forma que los migrantes ascendían a 175 millones de personas en el mundo, representando un 2,9\% de la población mundial. Las últimas estimaciones apuntan a que en la actualidad son ya 214 millones el número global de inmigrantes internacionales, cifra que constituye un 3,1\% de la población total del planeta. Si de forma hipotética la población migrante mundial se congregase en un solo Estado, éste constituiría el quinto país más poblado de todo el planeta aunque, en la realidad, el porcentaje de inmigrantes varía de forma muy acusada de un país a otro. International Migrant Stock: The 2008 Revision. UN, Department of Economic and Social Affairs, 2011. Disponible en http://esa.un.org/migration/. Las mismas cifras son ratificadas por la OIM, en $A$ propósito de la migración. Hechos y cifras, 2011. http://www.iom.int/jahia/Jahia/about-migration/facts-and-figures/ lang/es

24 ARANGO, Joaquín. “Inmigración y diversidad humana..., op. cit., p. 12.

25 La expresión se hizo famosa a raíz de la obra de CASTLES, Stepehn; BOOTH, Heather y WALLACE, Tina. Here for Good: Western Europe's New Ethnic Minorities. London, Pluto Press, 1984. En esta línea, Freeman afirma que "even faced with widespread unemployment, the mayority of migrants preferred to stay on. Moreover, many had children born or reared in the host country who where even less likely to return". FREEMAN, Gary. "Can Liberal States Control Unwanted Migration?”; en The Annals of the American Academy of Political ans Social Science, vol. 534, 1994, p. 26.

26 HANSEN, Ransall. "Migration, Citizenship and Race in Europe: Between Incorporation and Exclusion"; en European Journal of Political Research, No. 35, 1999, p. 417.

27 En torno a dichos planes, Freeman señala que "it had been expected that migrants would go back home voluntarily once their immediate economic goals had been obtained, alter they had worked for a period of years, or if poor economic conditions made them redundant. In fact, none of these expectation proved realistic. (...) Active efforts by governments to stimulate return through financial and other inducements were unsuccessful, and governments' ability to coerce return was sharply constrained by diplomatic, legal, and political considerations". FREEMAN, G. "Can Liberal States Control Unwanted Migration?"; op. cit., p. 26.

28 La expresión corresponde a Ransall Hansen, quien aclara que los Estados europeros fueron incapaces o bien carecían de voluntad para forzar su salida. HANSEN, Ransall. "Migration, Citizenship and Race in Europe: Between Incorporation and Exclusion”, op. cit., p. 417. Miller y Martin también subrayan el completo fracaso de los Estados Europeos en materia de programas de retorno de migrantes. MILLER, Mark J. y MARTIN, Philip A. Administering Foreign-Worker Programs. Lexington, MA, Lexington Books, 1982, p. xv. 
Esta situación desmontaba parte de la virtualidad explicativa de la teoría neoclásica de la migración $^{29}$, conforme a la cual los flujos se vinculaban con la existencia simultánea de factores internos de atracción y factores externos de expulsión o rechazo — pull and push factors, respectivamente- que desembocaban en la inmigración concebida como un factor esencialmente económico, cuyo mantenimiento dependía del beneficio mutuo que obtuviesen tanto las sociedades de origen como las de acogida. La persistencia de la inmigración en el nuevo contexto de recesión convertía a la economía en una variable explicativa necesaria, pero no suficiente, para la continuación de los flujos ${ }^{30}$; en definitiva, mostraba las deficiencias de la teoría neoclásica de las migraciones, convirtiéndola, en palabras de Castles y Miller, en un modelo teórico "simplista, individualista y ahistórico"31. De otro lado, la continuación de los flujos en un marco de escasez e inestabilidad laboral, provocaba la suspicacia temerosa de las sociedades de acogida y correlativas reacciones de "fronterización"32 en los Estados del norte y "fortificación" ${ }^{33}$ en sus políticas públicas de extranjería e inmigración, lo que terminaba emplazando a los flujos en un tortuoso terreno propicio para los prejuicios y las contiendas electorales. Desde la década de los noventa del pasado siglo, la inmigración y las políticas implementadas para su contención, se convertirían por ello en uno de los temas políticos más controvertidos en Europa ${ }^{34}$.

Esta nueva etapa vendría, además, caracterizada por el desarrollo y proliferación de la inmigración clandestina ${ }^{35}$, que en algunos países receptores llegaría a convertirse en una característica estructural del sistema migratorio, como es el caso español ${ }^{36}$. Este cúmulo de circunstancias situaría a la inmigración internacional como uno de los mayores retos, si no el mayor, al que tendría que hacer

29 Esta teoría se basaba a su vez en las "leyes de las migraciones" formuladas en el último tercio del siglo XIX por Ernest Ravenstein, considerado el primer teórico de las migraciones internacionales, quién realizó su análisis sobre la base de un estudio deductivo del censo inglés. Basándose en las leyes de Ravenstein, Lee introdujo nuevos factores explicativos de los movimientos migratorios —entre ellos destaca el concepto de "obstáculos intervinientes" que se desarrollan en el espacio intermedio existente entre los factores de atracción del país de destino y los factores de expulsión del país de origen de la inmigración-. Además de éstos, Lee incluía factores personales del inmigrante como causas que influían poderosamente en el hecho migratorio. Por ello, la teoría de Lee tenía un marcado carácter psico-social en contraposición a la teoría demográfica de Ravenstein. Además Lee subrayó el predominio de los factores internos de atracción en las decisiones migratorias. LEE, Evereth S. "A Theory of Migration"; Demography, No. 3, vol. 1. 1966, pp. 47-57. Para una visión de las teorías de Ravenstein, vid. ARANGO, Joaquín. "Las <Leyes de las Migraciones> de E. G. Ravenstein, cien años después"; en Revista Española de Investigaciones Sociológicas, 1985, No. 32, pp. 7-26.

30 AVCI, Gamze. "Immigrant Categories: The Many Sides of One Coin?"; en European Journal of Migration and Law, No. 1, 1999, p. 203.

31 CASTLES, S. y MILLER, M. J. La era de la migración..., op. cit., pp. 35-36.

32 Colectivo IOÉ. "Flujos migratorios internacionales. Marco de comprensión y características actuales"; en Migraciones No. 9, 2001, p. 36.

33 La expresión corresponde a LAHAV, Gallya. "International versus National Constraints in Family-Reunification Migration Policy"; en Global Governance No. 3, 1997, p. 368.

34 HOLLIFIELD, J. F. Immigrants, Markets and States: the Political Economy of Postwar Europe, op. cit., p. 213.

35 CASTLES, S y MILLER, J. J. La era de la migración..., op. cit., p. 121. Aun a sabiendas de las dificultades para su cálculo y que la cifra exacta constituirá siempre una incógnita, la Organización Internacional del Trabajo estimó a a principios de la década de los noventa que el número de inmigrantes irregulares en Europa occidental rondaba los dos millones seiscientas mil personas. Baldwin Edwards ha señalado que un canal que termina engrosando el número de extranjeros irregulares se vincula a las peticiones de asilo, estimando que más del 75\% de los solicitantes de asilo cuyas peticiones han sido denegadas permanecen en Estados Europeos de forma irregular. BALDWIN-EDWARDS; M. SCHAIN, M. A. "The Politics of Immigration. Introduction"; en BALDWIN-EDWARDS \& SCHAIN (eds.). "The Politics of Immigration in Western Europe" (Special Issue); en West European Politics No. 17, vol. 2, 1994.

36 ARANGO, Joaquín. "España: la inmigración en la encrucijada”; en HERRERA CLAVERO, F.; ROA VENEGAS, J.M.; RAMÍREZ SALGUERO, S.; RAMÍREZ FERNÁNDEZ, S; MATEO CLAROS, F. (coords.). Inmigración, interculturalidad y convivencia. Ceuta, Instituto de Estudios Ceutíes, Congreso Nacional sobre inmigración, interculturalidad y convivencia, 2004, p. 31. 
frente el Estado Constitucional ${ }^{37}$. Y, a juzgar por la creciente brecha Norte-Sur, la era de la migración parecía destinada a prolongarse ${ }^{38}$.

En el ámbito específico de la inmigración de carácter familiar, la imposibilidad y el temor a los movimientos transnacionales, consecuencia del cierre de las fronteras, provocaron la estabilización de los flujos migratorios en los países europeos receptores y el recurso a que el residente se reuniese con sus familiares extranjeros en el seno de dichos territorios. El retorno al país de origen se convirtió en una opción irracional desde el punto de vista del inmigrante ${ }^{39}$, por el peligro que él mismo corría de quedar fuera de las fronteras del país de acogida ${ }^{40}$, mientras paralelamente la RF se erigía en una opción cada vez más deseable ${ }^{41}$. Al igual que ocurría con otras categorías migratorias, la reagrupación familiar demostraría su resistencia a la crisis económica y laboral, si bien con mayor intensidad, ya que los flujos familiares parecen resultar menos porosos a las fluctuaciones económicas que la migración laboral ${ }^{42}$. Naturalmente ello trajo consigo el incremento de la importancia de la RF en Europa, tanto desde el punto de vista cuantitativo como cualitativo, si bien esta figura tardaría

37 José Asensi Sabater comienza su exposición señalando: "si algún dato altera el orden jurídico de los estados del mundo desarrollado ése es probablemente el de las migraciones”. Véase Políticas de la sospecha. Migraciones internacionales y principios constitucionales. Valencia, Tirant lo blanch, 2004, p.11. En idéntico sentido, las instituciones comunitarias califican la inmigración como el "mayor reto" al que deben enfrentarse las sociedades europeas. Exposición de Motivos del Informe del Parlamento Europeo sobre la propuesta modificada de Directiva del Consejo sobre el derecho a la reagrupación familiar (COM (2002) 225- C5-0220/2003 - 1999/0258 (CNS)), p. 47. Por su parte, Christian Joppke estima que la inmigración reta alguna de las características principales del Estado Nación. JOPPKE, Christian. Immigration and the Nation-State: The United States, Germany and Great Britain. Oxford, Oxford University Press, 1999, p. 262.

38 Castles y Miller afirman al respecto que "hay varias razones para esperar que se prolongue lo que llamamos la era de la migración: las crecientes desigualdades de riqueza entre el norte y el sur tal vez impulsarán a un número creciente de personas a moverse en busca de mejores condiciones de vida; las presiones políticas, ecológicas y demográficas pueden forzar a muchos otros a buscar refugio fuera de sus propios países; el creciente conflicto político o étnico en gran cantidad de regiones puede llevar a futuros traslados masivos; y la creación de nuevas áreas de libre comercio causará movimientos de mano de obra, sea o no que esto se halle en las intenciones de los gobiernos involucrados. Los estados en el mundo entero se verán cada vez más afectados por la migración internacional, sea como sociedades receptoras, como países de emigración o como las dos cosas". CASTLES, S. y MILLER, M. J. La era de la migración. Movimientos internacionales de población en el mundo moderno, op. cit., p. 15.

39 Sobre este aspecto, Martinello señala que: "Cuando muchos países europeos ponen oficialmente un término a cualquier nueva inmigración de trabajo y apoyan la vuelta al país de origen en 1973-1974, esas decisiones acentúan y aceleran el proceso de establecimiento de los inmigrados en Europa. Serán raros los que pidan beneficiarse por ejemplo de las ayudas al retorno ofrecidas por ciertos países como Francia. Saben muy bien que, una vez de vuelta en su país, les será mucho más difícil volver a Europa si lo desean. De una manera general, las políticas de control estricto de la inmigración pueden producir como consecuencia la implantación definitiva de no pocos inmigrados que pensaban de hecho volver a su país. Si resulta tan difícil atravesar las fronteras, ¿no es preferible quedarse? ¿Vale la pena correr el riesgo de salir sin estar seguro de poder volver?”. MARTINELLO, Marco. La Europa de las migraciones. Por una política proactiva de la inmigración. Barcelona, Bellaterra, 2003, pp. 116-117.

40 En este sentido Naïr y Goytisolo indican que paradójicamente, la consecuencia más llamativa del aumento de las migraciones familiares es que "favorece la instalación definitiva en los países de acogida y la ruptura de las relaciones de los inmigrantes con sus naciones de origen”. Esta afirmación requiere de matización, puesto que la ruptura de relaciones se refiere fundamentalmente al proyecto de retorno definitivo al país de origen, que desaparece, pero no necesariamente a los vínculos con el país de origen. NAÏR, Sami y GOYTISOLO, Juan. El peaje de la vida. Madrid, Aguilar, 2a ed., 2001, p. 22.

41 HOLLIFIELD, James F. Immigrants, Markets and States: the Political Economy of Postwar Europe, op. cit., p. 116.

42 Dumon se centra en el caso de Francia, señalando al respecto que "it's noteworthy that even a sharp decline in migration movement, probably due to the declining economic situation, did not entail a sharp decline in migration of the family reunion type". Si bien Dumon puntualiza que el caso de Francia pudiera ser atípico y que no existen datos estadísticos que permitan extraer generalizaciones al respecto. DUMON, W. A. "Family Migration and Family Reunion"; en International Migration, vol. 14, No. 1-2, 1976, pp. 55 y 56. En una línea similar, MALGESINI, Graciela y GIMÉNEZ, Carlos. Guía de conceptos sobre migraciones, racismo e interculturalidad. Madrid, Catarata, 2000, p. 241. 
en irrumpir en los diversos ordenamientos jurídicos nacionales, conquistando un reconocimiento normativo muy tardío ${ }^{43}$.

En suma, la introducción de fuertes restricciones a la entrada y permanencia de extranjeros desencadenó un cambio de paradigma migratorio que a su vez propició el desarrollo de nuevas dinámicas migratorias. El modelo de trabajadores extranjeros invitados desaparecía, dejando al descubierto sus múltiples incoherencias internas ${ }^{44}$, y el cierre de las fronteras fomentó y aceleró la instalación de una inmigración de carácter permanente con tendencia a traer a sus familiares extranjeros al país receptor ${ }^{45}$. "Como resultado, los vínculos familiares reemplazaron a las necesidades del mercado laboral como criterios de admisión primarios" ${ }^{46}$. Y este reemplazo tuvo lugar de forma extraordinariamente acelerada, pues en aquellos Estados Europeos que habían recibido flujos migratorios desde la segunda postguerra mundial, los familiares migrantes sustituirían a los inmigrantes laborales como la categoría más importante de entradas oficiales ya desde finales de la década de los setenta ${ }^{47}$.

Esta circunstancia dio lugar a la transformación de una inmigración individual de trabajadores fundamentalmente masculinos ${ }^{48}$, a una migración de composición social y demográfica mucho más heterogénea, caracterizada por el predominio de los familiares de los inmigrantes ya instalados en los países receptores ${ }^{49}$. Esta transformación constituía un auténtico cambio estructural de los flujos

43 En torno a este aspecto, Santos Arnau matiza que la aparición de la RF en los textos legales se produciría en Francia mediante el Decreto No. 76-383 de 29 de abril de 1976, siendo reconocido con el estatus de derecho a principios de la década de los ochenta, mientras que en Bélgica su reconocimiento se produjo mediante la Ley de 15 de diciembre de 1980, e Italia, por su parte, lo consagró en la Ley No. 943 de 30 de diciembre de 1986. SANTOS ARNAUR, Lidia. "Conceptos jurídicos indeterminados y discrecionalidad: especial referencia al visado para la reagrupación familiar”; en PICÓ LORENZO, Celsa (dir.). Extranjeros. Madrid, Consejo General del Poder Judicial, 1994, p. 459.

44 Las insuficiencias del modelo de trabajador huésped y la visión puramente economicista del inmigrante, fueron resumidas en la célebre frase del escritor suizo Max Frisch “pedimos mano de obra, llegaron personas”, pronunciada en 1965.

45 Recientemente han surgido opiniones disidentes en torno a esta visión doctrinal mayoritaria que vincula el auge de la inmigración de carácter familiar con el bloqueo de la inmigración laboral. Entre ellas, González Ferrer se pronuncia explícitamente en contra del esquema tradicional que subraya la importancia decisiva de las políticas migratorias oficiales en el comportamiento de los flujos migratorios internacionales. Al menos en lo que respecta a Alemania, González Ferrer ha demostrado histórica y empíricamente que la inmigración de los familiares dependientes - cónyuge e hijos principalmente - se había producido ya con anterioridad a la clausura de los programas de reclutamiento de trabajadores extranjeros, resultando casi simultánea a la llegada del sponsor. Esta autora concluye con rotundidad que "el fin de los programas de reclutamiento no puede sugerirse como la principal explicación del proceso de reagrupación familiar", dado que "la migración femenina fue cuantiosa con anterioridad al cierre de fronteras en 1974, y que la mayor parte de las entradas que tuvieron lugar a partir de entonces estuvieron protagonizadas por menores más que por esposas de los originales < trabajadores invitados>”. La autora subraya que las medidas de restricción de la migración familiar aprobadas a principios de la década de los ochenta iban dirigidas fundamentalmente no a los cónyuges de los trabajadores invitados, sino a los cónyuges de los hijos de dichos trabajadores extranjeros, concluyendo "que la principal fuente de inmigración a Alemania en las últimas décadas ha sido la importación de parejas más que la RF en sentido estricto”. GONZÁLEZ FERRER, Amparo. Estrategias familiares y laborales en la emigración. Reagrupación familiar, elección de parejas y empleo de los inmigrantes en el país de destino. Madrid, Consejo Económico y Social, 2008, pp. 48 y 59.

46 DELAET, Debra L. U.S. Immigration Policy in a Age of Rights. Westport, Praeger Publishers, 2000, p. 14.

47 Kofman especifica que dichos países eran Francia, Alemania y el Reino Unido. KOFMAN, Eleonore. Contemporary European Migrations, Civil Stratification and Citizenship. Paper presented at International Migrations: New Patterns, New Theories. Notthingham Trent University, 11-13 September 2000, p. 6. Sin embargo, el caso francés resulta paradigmático de la rapidez con la que la inmigración familiar ascendió dentro del ranking migratorio, pues ya en 1974 la inmigración familiar superó en cifras a los flujos de trabajadores extranjeros individuales, tal y como apunta DUMON, W. A. "Family Migration and Family Reunion”; op. cit., p. 56.

48 MARTIN y HOUSTOUN. “European and American Immigration Policies”, op. cit., p. 33.

49 Colectivo IOÉ. "Flujos migratorios internacionales. Marco de comprensión y características actuales"; en Revista Migraciones, No. 9, 2001, pp. 21 y 34. 
migratorios, con tendencia a convertirse en inmigraciones definitivas. En palabras de Sami Näir, "ya no se trata sólo de una simple transferencia temporal de mano de obra, sino también, y sobre todo, de un verdadero desplazamiento de población que pretende ser duradero (...) y que modifica a un tiempo la estructura social de los territorios de salida y la estructura nacional de los países de acogida"50.

La RF, considerada tradicionalmente como una forma secundaria de inmigración ${ }^{51}$, se convertiría de forma inesperada en un componente creciente de nuevas llegadas de inmigrantes ${ }^{52}$. Desde entonces, su importancia no ha dejado de aumentar hasta constituir la vía principal de entradas legales de inmigrantes en Europa durante las pasadas dos décadas ${ }^{53}$, dando lugar a más de la mitad de los flujos migratorios regulares que penetran en la mayor parte de los países europeos. En los años noventa la reunificación familiar pasó ya a constituir el canal principal de inmigración legal en la $\mathrm{UE}^{54}$, dominando claramente en la actualidad las afluencias de inmigrantes permanentes ${ }^{55} \mathrm{y}$ situándose por encima de la inmigración de carácter laboral. En lo que va del nuevo siglo, y pese a la grave crisis económica que a partir del año 2007 ralentizó los flujos migratorios internacionales en los países de la OCDE, la RF se ha consolidado como la categoría migratoria dominante a nivel mundial -con la excepción de Japón y Corea ${ }^{56}$. Y, mientras tipologías migratorias con características humanitarias próximas, como el asilo ${ }^{57}$, experimentan retrocesos constantes, la RF mantiene su tendencia expansiva ${ }^{58}$.

Es más, en claro contraste con el declive experimentado últimamente en la inmigración de carácter laboral, la inmigración vinculada a la familia continuó creciendo, constituyendo en la actualidad la única categoría migratoria cuyas cifras no registraron descensos ${ }^{59}$. Los últimos datos dispo-

50 NÄIR, Sami y GOYTISOLO, Juan. El Peaje de la Vida. Madrid, Aguirlar, 2a ed., 2001, p. 39.

51 JOPPKE, Christian. "Why Liberal States Accept Unwanted Immigration?”; op. cit., p. 282. KOFMAN, Eleonore. "Family-Related Migration: A Critial Review of European Studies"; en Journal of Ethnic and Migration Studies, vol. 30, No. 2, 2004, p. 248.

52 HANSEN, Randal. "Migration, Citizenship and Race in Europe: Between Incorporation and Exclusion”, op. cit., p. 417.

53 KOFMAN, Eleonore and KRALER, Albert. Civic Stratification, Gender and Family Migration Policies in Europe, Paper presented at Conference European Dynamics of Citizenship. Public Policies and Migrant Activities. Central European University, Budapest, 31 May- 2 June 2006, p. 29. KOFMAN, Eleonore, "Family-Related Migration: A Critical Review of European Studies", op. cit., p. 243.

54 Kofman estima que la mitad de las entradas legales en la UE — que cifra en un millón cuatrocientas mil personas al año- proceden de la reagrupación familiar. Ídem, p. 144.

55 International Migration Outlook. SOPEMI, 2008 Edition, Summary in Spanish, p. 2. Los datos recopilados corresponden al año 2006.

56 International Migration Outlook: Annual Report. SOPEMI, 2010, p. 20. El último informe disponible en el momento de cerrar estas páginas corresponde al año 2011, con datos relativos al año 2009, "Trends in Migration Flows and in the Immigrant Population”; en International Migration Outlook 2011. SOPEMI, 2011, pp. 42 y 43.

57 A nivel mundial, se estima que en la actualidad la cifra de refugiados ronda los 15,4 millones de personas. Los cambios en la clasificación metodológica empleada por el Alto Comisionado de las Naciones Unidas para los refugiados impiden establecer análisis comparativos entre las cifras registradas antes y después del año 2007, si bien la OIM ha registrado un descenso en el porcentaje de refugiados en los contingentes de extranjeros, que ha pasado del 8,8\% en el año 2000 a representar un 7,6\% en el año 2009. International Migrant Stock: The 2008 Revision. ONU; disponible en http://esa.un.org/migration

58 International migration Outlook: Annual Report. SOPEMI, 2010, p. 20. International Migration Outlook;

59 Del año 2007 al año 2008, los flujos migratorios globales de carácter permanente registraron un retroceso del 6\%, constituyendo el mismo el primer declive experimentado por la inmigración internacional desde que las instituciones del Sopemi llevan estudiando el fenómeno migratorio. La caída de los flujos se aceleró en el año 2008, registrando un descenso del 7\% en el ámbito de la migración laboral. En este contexto global, la inmigración vinculada a la familia constituyó la única categoría migratoria que experimentó un ligero crecimiento, concretamente del 3\%. Las cifras expuestas corresponden a un estudio de carácter global. El propio Informe especifica que las cifras de RF 
nibles a nivel internacional señalan incluso el paradójico incremento de la importancia relativa que ha adquirido la migración familiar, pasando a suponer el $47 \%$ de la migración total —cuando en el año 2008 apenas representaba el 41\%—, mientras que la migración laboral constituye un 20\% de los flujos migratorios permanentes ${ }^{60}$.

La misma tendencia, si bien notablemente más atenuada, se observa en la UE. Los datos más recientes emitidos al respecto por Eurostat ${ }^{61}$, confirman la posición principal que la migración familiar ostenta entre las concesiones de autorizaciones de residencia - representando un porcentaje del 28.2\% del total de los permisos emitidos, seguido de cerca por la migración de carácter laboral, que supone un $27,6 \%$ - en un contexto en el que los flujos migratorios experimentaron un descenso del 6\% frente a un incremento del 13\% registrado en las emigraciones. La RF, aun suponiendo todavía la proporción más elevada de la migración legal en Europa, experimenta sin embargo cierta tendencia decreciente en dicho contexto geográfico, cuya causa no reside en la disminución de los flujos provocada por la crisis económica, sino en lo que la propia Comisión Europea $^{62}$ ya ha denunciado como creciente propensión de los EEMM a la imposición de requisitos más estrictos para su ejercicio, en un intento por limitar sus cifras e incrementar la eficacia en la gestión migratoria. Con todo, la migración familiar, constituye todavía la principal causa para la emisión de permisos de residencia en más de la mitad de los países integrantes de la Unión Europea $^{63}$.

En definitiva, la migración vinculada a la familia se afianza como una categoría resistente o, como mínimo, poco sensible a la grave crisis económica imperante a nivel mundial ${ }^{64}$. La raíz de

varían según los países. En algunos Estados de la OCDE, la inmigración familiar experimentó subidas como consecuencia de previos incrementos en la afluencia de trabajadores extranjeros que llegaron al país de destino sin sus familias; en otros países, sin embargo, se registraron reducciones en las cifras de inmigración familiar, como consecuencia de las mayores dificultades que experimentaron los inmigrantes para cumplir con los requisitos económicos exigidos para la RF así como cubrir los costes del transporte para sus familiares, en un contexto de crisis económica en el que los trabajadores extranjeros resultan especialmente perjudicados. Datos extraídos de International Migration Outlook: Annual Report. SOPEMI, 2010, pp. 27-29 y 32.

60 International Migration Outlook: Annual Report 2011, op. cit., p. 43. El último informe emitido por SOPEMI, correspondiente al año 2012, y con cifras relativas al año 2010, llega a conclusiones que ratifican lo expuesto. Como consecuencia de la crisis económica y la disminución en la demanda de trabajo, la inmigración laboral decreció, representando tan sólo el 21\% del total de los flujos. En este contexto, "la inmigración familiar fue la principal categoría de entrada en 2010, representando el 36\% de los flujos (el 45\% si se incluyen los movimientos de familiares acompañando a trabajadores)". International Migration Outlook, Annual Report 2012, p. 22.

61 Los últimos datos corresponden al año 2009, emitidos en el informe anual de Eurostat correspondiente al año 2011. Europe in figures. Eurostat regional yearbook 2011. Bélgica, Comisión Europea, 2011, pp. 144-146. En el mismo sentido, si bien con información más específica, se pronuncia la siguiente publicación de Eurostat, donde puede leerse: "About 660000 new permits, that is $28.2 \%$ of the EU total, were granted for reasons related to family, 646000 (27.6 \%) for employment and 510000 (21.8\%) for education purposes. Compared with 2008, the number of new permits issued for employment (which was the main reason in 2008) fell by 142000 . Also the number of permits issued for family reasons fell between 2008 and 2009, but to a lesser extent (-26 000), while permits for education increased by 53 000". SCARNICCHIA, Lucilla. Residence permits issued to non-EU citizens in 2009 -Issue number 43/2011, p. 1.

62 Comisión Europea. Libro Verde sobre el derecho a la RF de los nacionales de terceros países que residen en la UE. Bruselas. 15.11.2011. COM (2011) 735 final, p. 1 y nota a pie de página no 4 .

63 SCARNICCHIA, Lucilla. Residence permits issued to non-EU citizens in 2009 -Issue number 43/2011, op. cit., p. 2.

64 La escasa sensibilidad o receptividad de la migración familiar al contexto económico recesivo es confirmada en "Trends in Migration Flows and in the Immigrant Population"; International Migration Outlook: Annual Report 2001, op. cit, p. 43. También en el Informe previo, correspondiente al año 2010. International Migration Outlokk: Annual Report 2010, p. 29. En el mismo sentido, MALGESINI, Graciela y GIMÉNEZ, Carlos. Guía de conceptos sobre migraciones, racismo e interculturalidad, op. cit., p. 241. De forma idéntica, PAPADEMETRIOU, Demetrios; SUMPTION, Madeleine, and Aaron TERRAZAS, Aaron with BURKERT, Carola, LOYAL, Stephen and FERRERO-TURRIÓN, Ruth, confirman expresamente que los inmigrantes de larga duración y, dentro de ellos de forma 
la menor afectación de las condiciones económicas y laborales sobre la migración familiar parece residir en las cadenas y redes migratorias que se generan a alrededor de la familia, que explicaría la persistencia de este tipo de inmigración en contextos de fuerte recesión económica ${ }^{65}$.

La trascendencia de la inmigración familiar en la UE ha venido a difuminar las diferencias existentes entre los países europeos y los países de larga tradición migratoria ${ }^{66}$ : Su importancia no hace sino crecer en contextos de políticas migratorias restrictivas en conjunción con altas tasas de denegaciones de solicitudes de asilo ${ }^{67}$.

Lejos de las pretensiones gubernamentales, el cierre de fronteras y la implantación a partir de la década de los setenta de políticas restrictivas, dirigidas a desincentivar y disminuir drásticamente la inmigración laboral, no se tradujeron pues en una reducción de los flujos migratorios, sino mucho más modestamente en una alteración en su composición ${ }^{68}$ y en la emergencia de nuevas categorías de inmigrantes ${ }^{69}$. Antes bien, los países europeos, que por entonces declararon expresamente no ser países de inmigración ${ }^{70}$, se convertirían — muchos de ellos muy a su pesar ${ }^{71}$-, en Estados de inmigración con fuertes tasas de residentes extranjeros.

destacada los flujos migratorios resultantes de la RF son menos susceptibles a la recesión económica. "Migration and Immigrants Two Years after the Financial Collapse: Where Do We Stand?". Report for the BBC World Service, Migration Policy Institute, 2010, p. 25.

65 MALGESINI y GIMÉNEZ señalan que la continuación de la inmigración familiar en contextos de crisis económica se debe en gran parte a las redes y cadenas familiares, fenómenos que "pueden ayudar a explicar por qué se producen rigideces en las respuestas de los inmigrantes frente a situciones desestimulantes en la sociedad receptora". Guía de conceptos sobre migraciones, racismo e interculturalidad, op. cit., p. 241.

66 MARTIN, Ph. L y HOUSTOUN, M.F. “European and American Immigration Policies”, op. cit., p. 53. AVCI, Gamze. “Immigrant Categories: The Many Sides of One Coin?”, op. cit., p. 204.

67 Los informes de SOPEMI-OCDE de diversos años inciden reiteradamente en los incrementos registrados en la inmigración de carácter familiar en relación directamente proporcional a los aumentos en los porcentajes de peticiones de asilo que fueron denegadas. En el mismo sentido, Kofman y Kralen han señalado que parece existir una relación directamente proporcional entre el incremento de la inmigración familiar de un lado y las restricciones a la inmigración laboral y a las admisiones de refugiados por otro, si bien ello no significa que en países con tasas elevadas de inmigración laboral y de refugiados — como es el caso del Reino Unido- las cifras de RF no sean importantes, pues en estos últimos supuestos también se aprecian incrementos sustanciales en las admisiones por causa de reagrupación familiar. KRALER, Albert and KOFMAN, Eleonore. Civic Stratification, Gender and Family Migration Policies in Europe, op. cit., p. 2.

68 Entre las nuevas formas de migración que se apuntan como tendencias en el laboratorio europeo, el Prof. Sami Naïr destaca, junto al incremento de las migraciones familiares, el aumento de las migraciones cualificadas, la feminización de los flujos, así como un fuerte incremento de las migraciones clandestinas, de las peticiones de asilo y de la demanda migratoria. La exposición de estas tendencias la realiza en el capítulo titulado "La nueva fisonomía migratoria en Europa”; en Y vendrán... Las migraciones en tiempos hostiles. Barcelona, Planeta, 2006. pp. 43-48. En el mismo sentido se pronuncia AVCI, Gamze. Immigrants Categories: The Many Sides of One Coin?; op. cit., p. 201.

69 AVCI, Gamze. “Immigrant Categories: The Many Sides of One Coin?”, op. cit., p. 201.

70 GEDDES, Andrew. "International Migration and State Sovereignty”; en International Migration, vol. 39, №. 6, 2001, p. 35.

71 En este sentido Francisco Fonseca Morillo ha afirmado que "para una gran parte de los EEMM de la Unión, con la excepción tal vez del Reino Unido su conversión en países receptores netos de emigración constituye todavía un fenómeno no asimilado y con el que una gran parte de sus opiniones públicas y políticas no se identifican”. FONSECA MORILLO, F. "Los derechos de los nacionales de terceros países en la Unión Europea. Situación jurídico-política tras la proclamación de la Carta de los Derechos Fundamentales de la Unión”; en Revista CIDOB de Afers Internacionals, No. 53, 2001, pp. 77-95, (p. 78). En la misma línea, Cornelius y Tsuda clasifican a Francia, Alemania, Holanda y Gran Bretaña dentro de lo que denominan países de inmigración reacios o renuentes a la misma; en CORNELIUS; TASUDA; MARTIN y HOLLIFIELD. Controlling Immigration. A Global Perspective. Second Edition, 2004, op. cit., pp. 183-334. 
Esta paradoja desembocaba en un incremento de la preocupación pública ante la creciente "brecha entre la política oficial de puertas cerradas y la realidad de comunidades inmigrantes en expansión”72, determinando un progresivo malestar generalizado hacia las políticas migratorias que, a su vez, fomentaba un elevado índice de inestabilidad legislativa en esta materia ${ }^{73}$. De otro lado, la inmigración, tradicionalmente apreciada y valorada como un fenómeno positivo, sería percibida con preocupación y de forma crecientemente adversa ${ }^{74}$, surgiendo corrientes de opinión pública contrarias a la recepción de flujos que resultarían "poderosamente influyentes en el diseño de las políticas estatales"75. La actual recesión económica parece haber recrudecido la percepción general de la ciudadanía con respecto a la inmigración ${ }^{76}$.

Pese a las restricciones en la contratación de trabajadores inmigrantes, los incrementos más sobresalientes en el número de extranjeros procedían tanto de la RF como del asilo ${ }^{77}$; esto es, de aquellas categorías migratorias sobre las cuales el Estado había perdido parte de su anterior poder exclusivo de control. La causa se debía en gran medida a la consagración de estándares internacionales de

72 FREEMAN, Gary P. "Migration Policy and Politics in the Receiving States"; en International Migration Review, vol. 26, No. 4, 1992, p. 1155.

73 Arango señala sobre este punto que "muchos países europeos salen aproximadamente a una ley de inmigración, o equivalente, por legislatura. Ello apunta a una evaluación negativa de los resultados de esas políticas, que pone de manifiesto un estado de insatisfacción con las mismas correlativo al observado en el plano de las opiniones públicas, en contraste con los sentimientos que solían prevalecer en el pasado". ARANGO, Joaquín. "Dificultades y dilemas de las políticas de inmigración”, op. cit., pp. 53-54. En idéntico sentido se pronuncian Cornelius y Tsuda, estimando que los múltiples cambios legislativos que afectan a las políticas migratorias de los diversos países receptores se producen frecuentemente sobre una base anual. CORNELIUS y TSUDA. "Controlling Immigration: The Limits to Government Intervention"; en CORNELIUS et alter. Controlling Immigration. A Global Perspective, second edit., 2004, op. cit., pp. 16-17.

74 ARANGO, Joaquín. "Inmigración y diversidad humana. Una nueva era de las migraciones internacionales", op. cit., p. 20. CORNELIUS; TSUDA; MARTIN y HOLLIFIELD. Controlling Immigration. A Global Perspective, 2004, op. cit., p. 19.

75 LÓPEZ SALA, Ana María. Inmigrantes y Estados: la respuesta política ante la cuestión migratoria. Barcelona, Anthropos editorial, 2005, p. 166.

76 Desde el año 2008 el estudio anual Transatlantic Trends ha estado rastreando cómo la opinión pública de nueve países receptores - EEUU, Canadá, Reino Unido, Francia, Alemania, Italia, Países Bajos y España- percibe la inmigración, su grado de apoyo a ésta y a las políticas implementadas para su integraión en un contexto comparado. En su último informe, correspondiente a su tercera edición, señala la existencia de una "tendencia de creciente pesimismo" en torno a estos temas, habiéndose registrado un aumento de los porcentajes de ciudadanos que conciben a la inmigración como un problema antes que como una oportunidad. Sin embargo, el estudio matiza que esta cuestión ha variado poco desde el año 2008, situándose EEUU, Reino Unido y España como la banda de países que ven a la inmigración como un problema, mientras que la opinión pública de Francia, Alemania, Países Bajos e Italia se muestra dividida al respecto y, por su parte, los canadienses conciben a la inmigración como una oportunidad. Asimismo, se apunta el descontento generalizado con la gestión gubernamental de la inmigración - salvo en Canadá, donde las opiniones al respecto están divididas-, y un empeoramiento de la percepción del impacto de los inmigrantes legales en el mercado de trabajo, pese a que en todos los países encuestados se había registrado una mejora en la actitud hacia los inmigrantes legales, y una preocupación respecto a la inmigración de carácter ilegal. En el caso europeo, la inmigración ilegal preocupa a un promedio del 67\% de los ciudadanos. Respecto a EEUU, Italia y España —que constituyen los países más afectados por la inmigración ilegal—, el estudio señala que constituyen "los únicos países donde la mayoría afirma que en sus países hay más inmigrantes ilegales que legales". Transatlantic Trends: Immigration 2010, pp. 3, 5 y 22. www.gmfus.org/trends/immigration/doc/TTI2010_English_Key.pdf

77 Desde la década de los ochenta las peticiones de asilo en Europa occidental fueron en aumento hasta que, tras la caída del muro de Berlín, el sistema llegó a considerarse colapsado, surgiendo la denominada "crisis del asilo". Esta situación llevó a observar con cinismo lo que tradicionalmente había constituido uno de los más antiguos derechos humanos y a difuminarse la distinción clásica entre migrantes económicos y refugiados políticos, sospechando que detrás de la mayoría de solicitudes de asilo latían motivaciones económicas solapadas. Finalmente, condujo a la elaboración de estrategias a fin de luchar contra lo que dio en llamarse el "abuso del asilo". FREEMAN, G. "Migration Policy and Politics in the Receiving States", op. cit., pp. 1155-1157. 
protección mínima de derechos, derivados del derecho internacional de los derechos humanos, con el que habíamos iniciado la exposición de este apartado. En el epicentro de este sistema se situaba la persona humana, con independencia de su adscripción a un concreto Estado nacional.

Pese a ello, el derecho internacional tradicionalmente no se había preocupado por las cuestiones migratorias ${ }^{78}$. De hecho, constituía un principio profundamente asentado del derecho internacional general entender la ordenación de la entrada, permanencia y derechos atribuidos a los extranjeros como una competencia exclusiva del Estado nacional, íntimamente vinculada a su soberanía y regulada de forma discrecional y unilateral por las legislaciones del país receptor. En el caso de la reunificación familiar, su conexión con la familia y el encaje de ésta dentro de esquemas propios del derecho privado, no hacía sino subrayar su ubicación dentro de los asuntos internos de cada Estado, sobre los cuales no debía inmiscuirse el derecho internacional. Sin embargo, este estado de cosas comenzó a cambiar a raíz de la aparición del DIDH y la legitimidad y prestigio tanto internacional como interno asociados al reconocimiento y respeto de los derechos humanos, que llevaron a calificar esta época como el "tiempo de los derechos"79. Las dinámicas humanitarias pasaron al primer plano del fenómeno migratorio en la década de los ochenta, a raíz de la suspensión oficial de la inmigración laboral decretada los años previos ${ }^{80}$.

El peso de los estándares internacionales de protección era obviamente superior en las democracias liberales occidentales ${ }^{81}$, asentadas históricamente sobre la base del respeto estatal a los derechos individuales, lo que provocaba que en dichas democracias las dinámicas migratorias destapasen de forma mucho más abrupta las múltiples paradojas y contradicciones implícitas al Estado Constitucional de raíz liberal ${ }^{82}$. Entre ellas ocupaba un lugar destacado el hecho de que los Estados nacionales habían construido el sistema internacional de derechos humanos insertando en él los valores liberales que se encontraban en la base de sus sistemas jurídicos, políticos y económicos internos. Este "liberalismo incrustado" 83 terminaba reforzando los compromisos liberales, democráticos y humanitarios de los países receptores de inmigración ${ }^{84}$ con aquellos procedentes del ámbito internacio-

78 PERROUCHOUD, R. International Migration Law. Martinus Nijhoff Publishers, revised second Edition, Dordrecht, London, 1988, p. 366.

79 La expresión corresponde a BOBBIO, Norberto. El tiempo de los derechos. Madrid, editorial Sistema, 1991.

80 HOLLIFIELD, James F. Immigrants, Markets and States: the Political Economy of Postwar Europe, op. cit., p. 12.

81 De hecho, la mayoría de los autores ciñen sus análisis a las políticas migratorias implementadas por los países liberales receptores y que, por tanto, cuentan con instituciones y procesos democráticos liberales. A modo de ejemplo, Freeman señala que los "Estados no liberales no están sujetos por las mismas limitaciones políticas y constitucionales", por lo que no le son de aplicación las consideraciones tradicionales en torno a las restricciones que éstos experimentan a la hora de ejecutar políticas de contención y restricción migratoria. FREEMAN, G. "Can Liberal States Control Unwanted Migration?", op. cit., p. 19.

82 Hollifield ha destacado que la inmigración, especialmente en sus cuatro facetas más destacadas —ciudadanía, soberanía, trabajo y derechos humanos - ha destapado con crudeza lo que él ha denominado la "paradoja liberal": Aunque los mercados liberales se basan en el principio de no intervención, éste llega a su grado máximo de incumplimiento en la regulación de los flujos migratorios. Como afirma el propio autor, ni las democracias más liberales se han resistido a regular los mercados laborales a fin de evitar la competencia y confrontación entre los trabajadores autóctonos y los inmigrantes. Hollifield subraya que frente a los esfuerzos por promover mercados libres, la inmigración constituye un tema altamente controlado, al menos en principio, matiza el propio autor. Las contradicciones y falacias que subyacen a la ideología liberal explican también el hecho de que sean las democracias liberales quienes enfrentan mayores dificultades para controlar con eficacia los flujos migratorios. Immigrants, Markets and the States: the Political Economy of Postwar Europe, pp. 3-42.

83 La expresión se debe a James Hollifield, en el capítulo primero de su obra Immigrants, Markets and States: The Political Economy of Postwar Europe, op. cit., esp. pp. 26-28.

84 CORNELIUS, Wayne A; MARTIN, Philip L. Y HOLLIFIELD, James F. (eds.). Controlling Immigration. A Global Perspective, 1994, first edit., Stanford University Press, 1994, p. 230. 
nal, ejerciendo una poderosa influencia delimitante sobre dichos Estados, "cercando" 85 sus políticas migratorias y determinando modificaciones en las mismas a fin de adaptarlas a las disposiciones constitucionales e internacionales, en ocasiones en contra de la propia voluntad gubernamental cuyas resistencias ante los valores liberales tuvieron que ceder ante la intervención de los Tribunales administrativos e incluso Constitucionales ${ }^{86}$.

La inmigración en la nueva era se convertía así en toda una "prueba para el liberalismo en su vertiente económica y política”" ${ }^{87}$, mientras los estándares internacionales informaban y presionaban las políticas migratorias internas, determinando cierta expansión de los derechos de los migrantes en tiempos de restricción migratoria ${ }^{88}$. La influencia del DIDH en materia migratoria resultaría determinante gracias a la intermediación ejercida por los tribunales internos, cuya jurisprudencia había sido a su vez penetrada por los parámetros internacionales.

En aquellas categorías migratorias íntimamente asociadas a los derechos humanos - RF, asilo y refugio- la influencia de los estándares internacionales era superior que en los restantes elementos de la política migratoria y el Estado se veía obligado a admitirlas de forma más o menos renuente ${ }^{89}$. Como afirma Hollifield, los familiares de extranjeros y los solicitantes de asilo "apelaban a las sensibilidades humanitarias de los regímenes liberales. Resulta difícil oponerse a la RF o rechazar la entrada de una persona que corre un riesgo personal"90. En definitiva, la vinculación con los derechos humanos insertaba a los familiares del residente legal extranjero, junto con los refugiados, dentro de la categoría de "inmigrantes humanitarios" ", dificultando la legitimidad de su limitación estatal, incluso en tiempos de estrictos controles migratorios, y con ello exacerbando las dificultades internas que los países receptores de inmigración experimentaban para poder ejecutar con eficacia

85 Ídem.

86 HOLLIFIELD, op. cit., pp. 222-223. También Christian Joppke, quien ha subrayado el origen interno, fundamentalmente jurisprudencial, de gran parte de los derechos de los inmigrantes en Europa, quienes actuaron, en palabras del propio Joppke, "en abierta oposición a un ejecutivo restriccionista”. Si bien, a diferencia de las tesis sostenidas por Hollifield, Joppke niega la importancia del DIDH en el surgimiento y la extensión del círculo de los derechos de los migrantes. JOPPKE, Christian. "Why Liberal States Accept Unwanted Immigration?"; op. cit., esp. pp. 271, 281-293. JOPPKE, C. "Courts, the new constitutionslism and immigrant rights: The case of the French Conseil Constitutionnel”; en European Journal of Political Research, No. 43, 2004, pp. 823-844. JOPPKE, C. "The Legal domestic Sources of Immigrant Rights: The United States, Germany and the European Union"; en Comparative Political Studies, vol. 34, No. 4, 2001, pp. 339-366. En el caso de Alemania, el poder judicial asumiría con decisión la tutela de los derechos de los migrantes a partir de la segunda mitad de los setenta, precisamente cuando las políticas y actuaciones administrativas se tornaron extremadamente restrictivas hacia ellos. GONZÁLEZ FERRER, Amparo. Estrategias familiares y laborales de la emigración, op. cit., p. 50.

87 HOLLIFIELD, J.F. Immigrants, Markets and States: The Political Economy of Postwar Europe, op. cit., p. 6.

88 En contra de la tesis que estima decisiva la influencia del DIDH en el ámbito migratorio, cabe mencionar las doctrinas de Freeman, quien afirma explícitamente situarse en contra tanto de la "tesis del declive de la soberanía" que subraya la pretendida pérdida de control del Estado Nación sobre sus fronteras, como la denomina "tesis restriccionista" oficial con la que los Estados industrializados pretenden atrincherarse frente a los flujos crecientes. Freeman señala que la expansión de los derechos de los inmigrantes se debe más a dinámicas internas propias de los procesos políticos domésticos que al derecho internacional, al tiempo que subraya que el Estado Nacional retiene todavía un importante y creciente poder de control sobre los flujos migratorios. Entre sus múltiples escritos, conviene destacar FREEMAN, Gary P. “The decline of sovereignty?. Politics and immigration restriction in liberal states”; en JOPPKE, C. (ed.). Challenge to the nation-state: Immigration in Western Europe and the United States. Oxford, Oxford University Press, 1998, pp. 86-107.

89 Dichas figuras incluían a familiares de inmigrantes establecidos, refugiados, inmigración de retorno o étnica (vinculada a las antiguas excolonias) así como un pequeño porcentaje de inmigrantes altamente cualificados. GEDDES, Andrew. "International Migration and State Sovereignty..., op. cit., p. 35.

90 HOLLIFIELD, James F. Immigrants, Markets and States..., op. cit., p. 11.

91 CORNELIUS, Wayne A; MARTIN, Philip L. Y HOLLIFIELD, James F. (eds.). Controlling Immigration. A Global Perspective, 1994, first edit., Stanford University Press, 1994, p. 286. 
sus políticas de contención migratoria ${ }^{92}$. En consecuencia, el asilo y la RF se convertían en una de las escasas excepciones pasivamente toleradas por los Estados receptores ${ }^{93}$, disminuyendo la intensidad del margen de maniobra estatal en estos ámbitos, al tiempo que pasaban simultáneamente a constituir los aspectos políticamente más candentes y sensibles — hot issues ${ }^{94}$ - dentro del ya de por sí controvertido ámbito de la extranjería y la inmigración, que ha sido elocuentemente calificado como un tema "políticamente radiactivo" $"$ en nuestros días-.

Los dilemas y retos que esta situación representaba para las democracias liberales se acentuarían según progresaba el sistema internacional de los derechos humanos. Las sociedades europeas de acogida se encontraban atrapadas en la "contradicción entre la existencia de fuertes reticencias a la admisión de inmigrantes y el reconocimiento de obligaciones morales y políticas, consustancial a su condición de sociedades democráticas organizadas en Estados de Derechos garantistas"96. Enfrentados ante un fenómeno de dimensiones crecientes, los Estados receptores se emplearon a fondo para restringir la RF — dentro del marco permitido por el DIDH - , para lo cual se vieron obligados a utilizar sutiles instrumentos y, en más de las ocasiones, a recurrir a la cooperación internacional en busca de fórmulas que les permitieran reforzar la eficacia sobre los controles a la entrada y residencia de extranjeros en sus territorios ${ }^{97}$. En este contexto, se ha advertido que "las políticas de migración familiar están operando como instrumentos de control, restricción y selección de migrantes"98, situándose la familia del extranjero en el primer plano de atención y preocupación del control migratorio.

92 Ídem, p. 230. Los autores apuntan a la existencia de compromisos liberales, democráticos y humanitarios de los países receptores de inmigración, como causantes del declive en la capacidad de control y contención migratoria, señalando que "liberal commitments inhibit, to varying degrees, the implementation of draconian Systems of monitoring populations and deporting undocumented people (...). The liberal and humanitarian commitments of Western States do prevent them from establishing a hypothetically "perfect" system of immigration control, from fully shielding themselves from unwanted or illegal migration".

93 FOURLANOS, G. Sovereignty and the Ingress of Aliens: With Special Focus on Family Unity and Refugee Law (Paperback). Stockholm, Almqvist \& Wiksell Internat, 1986; PERRUCHOUD, Richard. "Family Reunification"; en International Migration, 1989, №. 27, vol. 4, p. 516; LAHAV, Gallya. "International versus National Constraints in Family-Reunification Migration Polices"; en Global Governance, №. 3, 1997, p. 353. JOPPKE, Christian. "Why Liberal States Accept Unwanted Immigration?"; op. cit., p. 281.

94 CORNELIUS, Wayne A; MARTIN, Philip L. Y HOLLIFIELD, James F. (eds.). Controlling Immigration. A Global Perspective, first edit., 1994, op. cit., p. 286.

95 La expresión correspode a FANJUL, Gonzalo, quien se muestra crítico hacia las más recientes propuestas restrictivas de reforma del régimen migratorio español, en vísperas de la aprobación el último reglamento de extranjería, señalando que "nuestro régimen migratorio está más influido por la miopía y la demagogia que por el sentido común y la pedagogía pública que necesita este asunto”. El País, 7 de marzo de 2011.

96 En otro pasaje de su estudio, Joaquín ARANGO señala de forma descriptiva que "los países europeos se encuentran entre el Scylla del reconocimiento de obligaciones morales y políticas, propio de sociedades democráticas, y el Caribdis de fuertes reticencias hacia la recepción de inmigrantes y su plena incorporación a la sociedad y a la nación", op. cit., p. 54. Véase “Dificultades y dilemas de las políticas de inmigración”, op. cit., pp. 54 y 57.

97 LAHAV, Gallya. "International versus National Constraints in Family-reunification Migration Policy"; en Global Governance, No. 3 (3), Sept-Dec 1997, pp. 349-372.

98 GIL ARAUJO, Sandra. Las políticas de migración familiar en Europa. El control de la inmigración a través de las familias, op. cit., sp. 


\section{LA FAMILIA EN EL CONTEXTO MIGRATORIO INTERNACIONAL}

Generalmente la migración constituye un asunto familiar, y no individual ${ }^{99}$. Las investigaciones tradicionales en torno a los flujos migratorios ignoraban esta circunstancia, encuadrando las decisiones de emigrar en la interacción entre dos niveles analíticos - macro y micro-, respectivamente configurados por condiciones estructurales en las sociedades de origen y destino, junto con las motivaciones y objetivos personales del inmigrante, individualmente considerado. En ese marco teórico, la emigración era contemplada como una decisión habitualmente masculina, de carácter racional, individual y fundamentalmente económica ${ }^{100}$.

Las investigaciones efectuadas en este campo desde mediados de la década de los ochenta han venido a construir puentes entre los dos niveles de análisis tradicionales, sobre la base de la observación del contexto social en el que las migraciones tienen lugar, en la medida en que condicionan poderosamente el proceso migratorio. Dichas investigaciones se centran en las redes sociales y los lazos que vinculan a los inmigrantes más allá de las fronteras nacionales, expandiéndose tanto en la sociedades de origen como en las de acogida, e incluyen además consideraciones de género en los análisis migratorios. Sobre la base de las redes sociales, los estudios recientes subrayan de forma unánime la primacía de los lazos familiares en el proceso migratorio, convirtiendo a la inmigración desde sus orígenes en un proyecto familiar ${ }^{101}$. Conforme a los mismos, tanto en su gestación como mero proyecto migratorio, como en su ejecución y en sus consecuencias sobre la vida familiar, la familia desempeña un papel central en todo el ciclo migratorio. Por ello, los estudios recientes señalan a la familia transnacional como la unidad de análisis fundamental en el estudio de las migraciones contemporáneas ${ }^{102}$.

99 BAJO SANTOS, Nicolás. "La familia migrante y sus redes"; en Anuario Jurídico y Económico Escurialense, №. 36, 2003, p. 689.

100 NAUCK, Bernhard y SETTLES, Barbara H. "Immigrant and Ethnic Minority Families: An Introduction"; en Journal of Comparative Family Studies, vol. 32, №. 4, 2001, p. 461; GONZÁLEZ TRORRALBA, Herminia. "Familias y hogares transnacionales: una perspectiva de género"; en Puntos de Vista, Cuadernos del Observatorio de las Migraciones y de la Convivencia Intercultural de la Ciudad de Madrid, №. 11, 2007, pp. 7-8; BOYD, Monica. "Family and Personal Networks in International Migration: Recent Developments and New Agendas"; en International Migration Review, vol. 23, No. 3, 1989, p. 640.

101 LÓPEZ SALA, Ana María. Inmigrantes y Estados: la respuesta política ante la cuestión migratoria. Barcelona, Anthropos editorial, 2005, p. 58. En el mismo sentido inciden Nauck y Settles, para quienes "even in the situation of $<$ Pioneer migration $>$, when the first family member is "sent", migration is typically a family project, for which information is gathered collectively, and resources are pooled". NAUCK, Bernhard y SETTLES, Barbara H. "Immigrant and Ethnic Minority Families: An Introduction", op. cit., p. 462; BOYD, Monica. "Family and Personal Networks in International Migration...", op. cit., p. 639; Sobre la inmigración en tanto que proyecto familiar desde sus inicios, también se pronuncian con rotundidad CEBOLLA BOADO, Héctor y GONZÁLEZ FERRER, Amparo. La inmigración en España (2000-2007). De la gestión de flujos a la integración de los inmigrantes. Madrid, Centro de Estudios Políticos y Constitucionales, 2008, p. 108.

102 Herminia González entiende por unidad de análisis, "los principios de organización fundamentales para la discusión teórica”, señalando que su identificación constituye uno de los aspectos más difíciles de esta materia. Más adelante, la propia autora precisa el concepto de familia y de hogar que maneja, afirmando que: "Familia es un término polisémico que designa, a la vez, individuos o unidades familiares y relaciones. En cambio, el hogar o el grupo doméstico hace referencia al conjunto de personas que comparten un mismo espacio de existencia, siendo éste un espacio de trabajo y producción así como también un espacio de descanso, de convivencia, y de consumo, por lo tanto de reproducción". GONZÁLEZ TORRALBA, Herminia. "Familias y hogares transnacionales: una perspectiva de género", op. cit., pp. 7, 12 y 13. Con igual contundencia se expresa GONZÁLEZ FERRER al afirmar que las familias constituyen los principales agentes en las decisiones migratorias. Estrategias familiares y laborales en la emigración, op. cit., p. 13. 
Las motivaciones para emigrar están profundamente vinculadas a la familia ${ }^{103}$, tanto en su sentido nuclear como extenso, y a menudo proceden de estrategias familiares que trascienden las visiones clásicas puramente economicistas. De hecho, la teoría de la nueva economía de la migración laboral ha enfatizado el rol que corresponde a la familia en las decisiones migratorias, de modo que aunque se ejecuten de forma individual, tales decisiones constituyen el resultado del esfuerzo común de todos sus miembros ${ }^{104}$. Como tal, la emigración de un familiar activa un proceso de beneficio colectivo, conforme al cual las remesas que recibirán los parientes que permanecieron en las comunidades de origen servirán para aliviar las presiones económicas y laborales y proveer de mejores oportunidades educativas a las siguientes generaciones ${ }^{105}$. De esta forma, se da origen a una red transpersonal y transnacional de complejas relaciones de ayuda mutua e influencias recíprocas entre los países de origen y destino de la inmigración.

En este contexto, una vez que el ciclo migratorio se ha iniciado, generándose simultáneamente una red transnacional de influencias, el proceso migratorio se transforma en una cadena migratoria $^{106}$ que atrae a nuevos parientes al mismo país receptor. De ahí que muchos flujos migratorios contemporáneos tengan lugar en forma de migraciones familiares en cadena o bien actúen promovidos y facilitados por la existencia previa de redes de parentesco en el país receptor, que constituyen auténticas cadenas migratorias que pueden llegar a desafíar las políticas migratorias oficiales ${ }^{107}$.

En consecuencia, junto a la mejora en la calidad de vida asociada a las oportunidades laborales y de servicios que proporciona el Estado receptor, el denominado "escenario geográfico del parentesco" 108 desempeña un papel clave en las decisiones migratorias. En la actualidad, la inmigración famliar constituye además un fenómeno crecientemente complejo ${ }^{109}$, en coherencia con la

103 Malgesini y Giménez lo proclaman con rotundidad: "Sin duda, cualquier conclusión sobre las motivaciones de la inmigración debe incluir la existencia de una familia dependiente como un sesgo o como una variable fundamental. La familia, las cadenas de amistades, los lazos comunitarios previos son la clave de muchos de los movimientos migratorios recientes a las naciones industriales". MALGESINI, G. y GIMÉNEZ, C. Guía de conceptos sobre migraciones, racismo e interculturalidad, op. cit., p. 241. En un nivel más pragmático, y referido estrictamente al caso español, se ha constatado que la decisión de emigrar se produce normalmente bajo la influencia que ejerce el entorno social del emigrante. Destacándose que, de dicho entorno, "son precisamente los familiares quienes más peso tienen en estas redes de influencia que contribuyen a perfilar la decisión migratoria”. SVEN REHER y REQUENA. "La reciente experiencia migratoria en España”; en SVEN REHER, David y REQUENA, Miguel (eds.). Las múltiples caras de la inmigración en España. Madrid, Alianza Editorial, 2009, p. 311.

104 NAUCK, Bernhard y SETTLES, Barbara H. "Immigrant and Ethnic Minority Families: An Introduction", op. cit., p. 462. LÓPEZ SALA, Ana María. Inmigrantes y Estados: la respuesta política ante la cuestión migratoria. Barcelona, Anthropos editorial, 2005, p. 58. GONZÁLEZ FERRER, Amparo. Estrategias familiares y laborales en la emigración. Reagrupación familiar, elección de parejas y empleo de los inmigrantes en el país de destino. Madrid, CES, 2008, p. 13. 105 LÓPEZ SALA, Ana María. Inmigrantes y Estados..., op. cit., p. 58.

106 NAUCK y SETTLES. “Immigrant and Ethnic Minority Families..., op. cit., p. 462. En este contexto, Malgesini y Giménez han indicado que la cadena migratoria "es el mecanismo o correa de salida-entrada- (y eventualmente) retorno de los inmigrantes de un determinado origen, frecuentemente determinado geográficamente", enfatizando al tiempo que el "proceso de reagrupación familiar (...) puede llegar a constituirse en una cadena migratoria, ya que es una vía normalizada de entrada de inmigrantes, que tiene un corte muy difícil de establecer o de controlar por parte de las autoridades". MALGESINI, Graciela y GIMÉNEZ, Carlos. Guía de conceptos sobre migraciones, racismo e interculturalidad. Madrid, Catarata, 2000, p. 58.

107 BAJO SANTOS, N. “La familia migrante y sus redes”, op. cit., pp. 690 y 691; BOYD, Monica. "Family and Personal Networks in International Migration: Recent Developments and New Agendas”, op. cit., p. 649.

108 COOKE, Thomas J. "Migration in a Family Way"; en Population, Space and Place, No. 14, 2008, p. 262.

109 En este sentido, se ha afirmado que "there is increasing evidence that family migration is more complex than the simple conception that people migrate from areas with relatively low wages and/or full employment opportunities to areas with higher wages and more employment opportunities". Si bien conviene matizar que este artículo estudia la migración interna en EEUU - la calificada por dichos autores como inmigración interregional一, sin embargo sus apreciaciones pueden extrapolarse a la inmigración de carácter internacional. WITHERS, Suzanne D; CLARK, 
mayor complejidad y variedad de estructuras y formas de vida familiares contemporáneas, de difícil aprehensión jurídica.

En base a lo expuesto, los estudios más recientes en el ámbito de la sociología y la demografía sugieren incluso que gran parte de lo que tradicionalmente ha sido considerado inmigración individual, debería concebirse como inmigración familiar ${ }^{110}$, pues la familia se encuentra en la base del proyecto y del desarrollo del ciclo migratorio. E incluso, en clara contradicción con los modelos explicativos tradicionales, se ha demostrado que hasta la inmigración tipificada como laboral "es desde su mismo origen una migración familiar"111 —al menos en lo que respecta al círculo familiar más íntimo constituido por la pareja e hijos del sponsor. Estas aportaciones doctrinales supondrían la necesidad de revisar y relativizar las categorías migratorias tradicionales -inmigración laboral/ familiar-, en la medida en que todas ellas girarían en torno a la familia como unidad básica decisional y motivacional.

\subsection{Familias transnacionales: Nueva geografía familiar inter-fronteriza}

Si bien, con carácter general, el estado ideal de la familia es la unidad y la vida en común ${ }^{112}$, esta situación puede no ser factible por múltiples circunstancias. Una de las más relevantes en la actualidad es la creciente separación física entre las fronteras nacionales de diversos Estados a la que se ven sometidos los miembros de las familias, como consecuencia de la intensidad del fenómeno migratorio.

Entre las múltiples consecuencias derivadas de los flujos migratorios, a nivel individual destaca el fuerte impacto que provoca sobre la vida familiar de los inmigrantes implicados ${ }^{113}$. Si el extranjero/a aún no ha formado su propia familia, la emigración del país de origen provocará una repercusión menor sobre su vida familiar, al tiempo que el individuo gozará de mayor libertad individual para los desplazamientos transfronterizos. Sin embargo, cuando el inmigrante ya ha constituido su propio núcleo familiar, la incidencia de la decisión de emigrar sobre su vida familiar es de primer orden. Además, la propia inserción del individuo en una familia que depende de él, incrementa las dificultades de cara a la movilidad internacional con fines migratorios ${ }^{144}$ : menor

Willian A y RUIZ, Trizia. "Demographic Variations in Housing Cost Adjustments in US Family Migration"; en Population, Space and Place, No. 14, 2008, pp. 305-306.

110 Thomas Cooke incluso va más allá, señalando que si se adopta una definición más amplia de la inmigración familiar, que no se ciña a los miembros de la familia nuclear y que tenga en cuenta los profundos desarrollos y evoluciones que están teniendo lugar en la vida familiar, "casi toda la migración podría ser definida como inmigración familiar". En palabras del propio Cooke, "a broader view of family migration encompasses not only the migration of a family, but individual migration events that are made within the context of a family (such as divorce) and migration events that are made with respect to events in the lives of distant, extended family members. From this view, nearly all migration could be defined as family migration. This is a point worth evaluating both empirically and theoretically"; en COOKE, T. "Migration in a Family Way", op. cit., p. 260.

111 GONZÁLEZ FERRER, Amparo. Estrategias familiares y laborales en la emigración, op. cit., p. En esta línea, la autora recomienda "no identificar la categoría de admisión del inmigrante con sus razones para emigrar", dado que las razones económicas y familiares se encuentran indisolublemente entremezcladas tras dichas tipologías. Ídem, p. 201.

112 En este sentido, se ha matizado que "la familia como una unidad social no puede ser protegida en detrimento de sus miembros, como se ilustra en casos de abuso infantil o de violencia doméstica, en los que el Estado puede intervenir para proteger a los individuos". LAHAV, Gallya. "International versus National Constraints in Family-Reunification Migration Policy”, op. cit., p. 360, traducción propia.

113 PERRUCHOUD, Richard. "Family Reunification", op. cit., p. 509.

$114 \mathrm{Al}$ respecto, se ha afirmado que "mobility has always been one of the fundamental characteristics of the human species. However, while unattached people are free to move, family relations may restrict the mobility of family 
libertad individual, mayores costes del transporte colectivo, incrementos de los riesgos que la incertidumbre del proyecto migratorio puede generar en los miembros de la familia, especialmente sobre los menores. Por ello, la existencia de familiares dependientes fue en su momento considerada por la teoría neoclásica de las migraciones como uno de los “obstáculos intervinientes"115 que dificultaban el proceso migratorio.

Sea cual fuere la situación personal del inmigrante, lo cierto es que la política de control de flujos instaurada a partir de mediados de los setenta, ha sembrado de trabas la travesía migratoria. El inmigrante además suele experimentar una difícil situación económica, social e incluso política que le inserta por definición en un colectivo extremadamente vulnerable en su país de origen ${ }^{116}$, vulnerabilidad que persiste en el país receptor ${ }^{117}$. La conjunción de ambas circunstancias convierte al proyecto migratorio en una empresa muy arriesgada ${ }^{118}$, que conviene iniciar y acometer de forma aislada con respecto al resto de la familia. La prudencia aconseja que uno de los miembros de la familia - por lo general, el cabeza de familia ${ }^{119}$ o aquel más dotado para encontrar un empleo en el país de destinotome la delantera para, una vez asentado en el nuevo Estado y minimizados los riesgos de la aventura migratoria, intentar reunirse en el territorio de acogida con la familia que dejó atrás en el país natal.

members. Hence, the factors underlying migration are likely to differ between attached and unattached people". NIVALAINEN, Satu. "Determinants of Family Migration: Short Moves versus Long Moves"; en Journal of Population Economics, No. 17, 2004, p. 157.

115 Otro de los obstáculos intervinientes especificados por Lee es la distancia, sobre la cual el mencionado autor afirma que, aun siendo el obstáculo más estudiado, no es el de mayor importancia. La influencia de los obstáculos intervinientes depende de los individuos y de las concretas circunstancias e impedimentos que éstos experimenten, de modo que lo que para algunos constituirá un auténtico obstáculo insuperable para la emigración, para otros será irrelevante, señala Lee. LEE, E. S. “A Theory of Migration”, op. cit., p. 51.

116 HOLLIFIELD, James F. Immigrants, Markets and States: The Political Economy of Postwar Europe. Cambridge, Harvard University Press, first ed., 1982, p. 7.

117 BUSTAMANTE, Jorge. "Immigrant's Vulnerability as Subjects of Human Rights"; en International Migration Review, vol. 36, No. 2, 2002, p. 340.

118 GÓMEZ CRESPO, Paloma. "Gestación y puesta en práctica de la reunificación familiar como estrategia”, op. cit, p. 76. En el mismo sentido incide Richard Perruchoud, quien afirma que: "Abandonar su propio país para trabajar en el extranjero o comenzar una nueva vida en otra parte constituye una empresa que está sembrada de dificultades. La inmigración a otro país puede incrementar las oportunidades y contribuir al mejoramiento de los niveles de vida, pero no cabe duda que puede suponer también obstáculos y penurias. Los trabajadores migrantes encaran a menudo la discriminación, en forma colectiva o individual, y pueden ser objeto de hostilidad y explotación. En la actualidad, la magnitud de los problemas vinculados con la migración ha llevado a que ésta sea cada vez más un tema de preocupación para muchos gobiernos. Además, tanto los gobiernos como las comunidades locales receptoras suelen tener una percepción negativa de la migración. Dicha percepción desencadena a veces reacciones que resultan en el maltrato de los trabajadores migrantes lo que, en algunos casos, culmina en la denegación de sus derechos humanos". PERRUCHOUD, Richard. "Normas legales para la protección de los trabajadores migrantes". Organización Internacional para las Migraciones, op. cit., p. 275.

119 DE LUCIA, Amelia. "Human Migratory Flows"; en International Journal of Anthropology, vol. 19, No. 1-2, 2004 , p. 6. 
Lo expuesto explica una de las tendencias más acusadas de nuestros días, a saber, el hecho de que la inmigración de la familia generalmente no se produzca de forma simultánea, sino en etapas sucesivas $^{120}$, predicable también de los supuestos de emigración por motivos políticos ${ }^{121}$.

De otro lado, las estrategias migratorias familiares demuestran ser extremadamente variables y flexibles ${ }^{122}$, a fin de poder adaptarse y maximizar las oportunidades que el inmigrante encuentre en su nuevo asentamiento. En ocasiones la RF se plantea de forma premeditada antes de emigrar, como un objetivo a priori ${ }^{123}$, que forma parte del proyecto migratorio y que se buscará una vez que el extranjero principal o sponsor haya logrado cierta estabilidad y condiciones básicas de subsistencia en la nueva sociedad. En otras, se trata de estrategias puramente adaptativas, de decisiones familiares planteadas a posteriori, tras la entrada y residencia del inmigrante "principal" en el país receptor, en vista de las dificultades y los altos costes económicos que implica visitar de forma frecuente a la familia que se ha dejado atrás, junto a los problemas afectivos causados por la separación familiar y ante la perspectiva de una estancia mucho más larga que la inicialmente prevista ${ }^{124}$. Sin olvidar que "los condicionantes externos compuestos por políticas de inmigración, políticas y coyunturas económicas tanto en los países de origen como en los de acogida o, incuso, de carácter mundial"125 constituyen factores macro que interactúan con las decisiones familiares, en la determinación de recurrir a la RF.

Tanto si se trata de un objetivo previamente planificado como de una estrategia decidida sobre la marcha, el carácter fraccionado de las migraciones que implican a miembros próximos de la familia genera dos efectos de primer orden: De un lado, provoca una fractura de la unidad familiar, transformando a las familias de migrantes en grupos sociales geográficamente dispersos ${ }^{126}$ ó espacialmente fracturados ${ }^{127}$, con consecuencias en ocasiones devastadoras tanto sobre los familiares dejados atrás,

120 BATTISTELLA, Graziano. "Family Reunification: Policies and Issues”, op. cit., p. 244. Por este motivo Richard Perruchoud afirma que los problemas de la RF son de naturaleza duradera: subsistirán siempre y necesitarán ser resueltos en tanto todos los miembros de una unidad familiar no se muevan al mismo tiempo. PERRUCHOUD, Richard. "Family Reunification"; en International Migration, №. 27, vol. 4, 1987, p. 509. Una visión diferente a la mayoritaria se encuentra en GONZÁLEZ FERRER, quien ha demostrado que la inmigración del cónyuge e hijos se produce de forma casi simultánea a la llegada del trabajador extranjero al país receptor "como parte de una estrategia familiar orientada a maximizar el ingreso disponible en el menor tiempo posible"; en Estrategias familiares $y$ laborales en la migración, op. cit., P. 197. El caso español parece confirmar estas conclusiones: las cifras disponibles hasta el año 2007 indican que "la reagrupación del cónyuge se produce casi de inmediato"; en CEBOLLA BOADO, Héctor y GONZÁLEZ FERRER, Amparo. La inmigración en España (2000-2007). De la gestión de flujos a la integración de los inmigrantes. Madrid, Centro de Estudios Políticos y Constitucionales, 2008, p. 105.

$121 \mathrm{Al}$ mencionar la ruptura de hecho de los vínculos familiares como uno de los problemas centrales que origina la emigración, Bernardo, Vilas y Cuadra señalaron en su momento que "incluso en la emigración política, la salida del país de origen rara vez afecta a todos los componentes de un núcleo familiar”. BERNARDO, S; VILAS, A. y CUADRA, L. I. "Reagrupamiento familiar”; en ALVAREZ, Aurelia; SANTOS, Lidia; CONABLE, Barber. Jornada sobre el Reglamento de la Ley de derechos y libertades de los extranjeros. Barcelona, Ajuntament de Barcelona, 1995, p. 50.

122 GÓMEZ CRESPO, Paloma. "Gestación y puesta en práctica de la reagrupación familiar como estrategia”; en Migraciones No. 5, 1999, p. 63.

123 DÍEZ-PICAZO, Luis María. Sistema de Derechos Fundamentales, op. cit., p. 46. El autor prosigue señalando que "más que ningún otro sector del ordenamiento, los derechos fundamentales constituyen un auténtico 'derecho jurisprudencial': es precisamente la jurisprudencia la que completa el enunciado a menudo lapidario de las declaraciones de derechos, dotándolas de concreción y certidumbre".

124 Ídem, pp. 61-69.

125 Ibidem, p. 69.

126 BOYD, Monica. "Family and Personal Networks in International Migration: Recent Developments and New Agendas", op. cit., p. 643.

127 La expresión ha sido tomada de LANDOLT, Patricia y DA, Wei Wei. “The spatially Ruptures Practices of Migrant Families: A Comparision of Immigrants from Salvador and the Peoples's Republic of China”; en Current Sociology, vol. 53, No. 4, July 2005, pp. 625-653. 
—especialmente los hijos menores ${ }^{128}$ - , como sobre aquellos instalados en el país de destino ${ }^{129}$ — no en vano la inmigración constituye "uno de los acontecimientos más estresantes a los que puede enfrentarse una familia" ${ }^{130}$ _. Dicha fractura tiende a ser restablecida a lo largo del tiempo, ya que, de hecho, la reunión con los familiares más cercanos suele formar parte de las estrategias migratorias ${ }^{131}$. De otro lado, da lugar a la irrupción de la reunificación familiar como un fenómeno de extraordinaria importancia, tanto por su influencia en el número de entradas que soportará el país receptor - el denominado efecto multiplicador-, como por su trascendencia a corto y largo plazo en la configuración social, demográfica y cultural de la sociedad de acogida, por no hablar de sus posibles implicaciones económicas en las estructuras del Estado del bienestar propias de la Europa occidental y sus destacados efectos sobre el país de origen. De ahí que se haya afirmado que la "reagrupación familiar convierte a la inmigración en un fenómeno social total” ${ }^{132}$ con profundas consecuencias en las sociedades de destino y origen de la inmigración.

Una de las características mas relevantes de la migración de nuestros días es la extraordinaria importancia que las redes interpersonales ejercen en la planificación y ejecución de los flujos mi-

128 Desde múltiples áreas — sociología, psicología - se ha estudiado el desgarro psicológico que la desintegración familiar consecuencia de la inmigración genera respecto de los hijos y el miembro de la pareja que permanecen en el país de origen, cuando el que emigra es uno de los progenitores. Los parientes que son dejados atrás experimentan una mejora en sus niveles económicos e incluso mayores posibilidades culturales como consecuencia de las remesas que reciben, pero los últimos estudios efectuados destacan que este mayor bienestar económico no compensa el desgarro psicológico que los niños sufren, de modo que en conjunto disminuyen significativamente sus niveles de felicidad. Estas conclusiones se extraen con rotundidad de un artículo que analiza empíricamente el impacto que la inmigración provoca sobre los familiares dejados atrás en la ciudad de Cuenca, en Ecuador. Este estudio concluye que la emigración de la familia provoca en los familiares que quedan en el país de origen una disminución de su felicidad, y ello pese al incremento en el bienestar económico provocado por las remesas. Sus tres autores afirman que: "remittances, the monetary inflows that often accompany migration, cannot compensate for the absence of household members through migration. This is interesting because it is often claimed that the raiso d'etra of international migration from developing to developed economies is the acquisition of additional monetary resources from abroad for family back home to enjoy. But it does not appear that these transfers can be used to raise the happiness levels of the family left behind. As such one cannot compensate the family left behind for the absence of loved ones with remittances from abroad". BORRAZ, Fernando; POZO, Susan y ROSSI, Máximo. And what About the Family Back Home? International Migration and Happiness. Documento Na 03/0, Departamento de Economía, Facultad de Ciencias Sociales, Universidad de Montevideo, marzo 2008. Disponible en: http://ssrn.com/abstract=1155108, p. 18. Para una visión muy completa y matizada en torno al impacto que la emigración provoca sobre los hijos menores véase SUÁREZ-OROZCO C. y SUÁREZ-OROZCO, M.M. La infancia de la inmigración. Madrid, Morata, 2003. En torno al impacto que la separación de uno o ambos progenitores provoca en los menores dejados atrás, en la reestructuración familiar y sobre los roles de género, resulta especialmente recomendable el siguiente libro, si bien conviene aclarar que se trata de un estudio relativo a los hijos de inmigrantes filipinos dejados en el país de origen — colectivo que supone aproximadamente 9 millones de niños-, SALAZAR PENAS, Rhacel. Children of Global Migration. Transnational Families and Gendered Woes. Stanford University Press, 2005.

129 Al principio los problemas afectivos y familiares provocados por la separación se centran en "la nostalgia, el distanciamiento afectivo y discrepancias ante la situación creada”, pero Gómez Crespo señala que éstos se intensifican con el paso del tiempo, de modo que las carencias afectivas pueden dar lugar a algo más grave que la nostalgia, llegando a generar situaciones insostenibles. La autora destaca el miedo que los progenitores extranjeros residentes en el país de destino sienten a perder el cariño de sus hijos, provocando problemas de culpabilidad y de relación filial. "Con la prolongación de la estancia en el país de acogida más allá de lo previsto, estos problemas de carencias afectivas y de dificultades en las relaciones internas de la familia se agravan, y la RF puede perfilarse como una estrategia para superarlos", añade la autora. GÓMEZ CRESPO, Paloma. "Gestación y puesta en práctica de la reagrupación familiar como estrategia", op. cit., pp. 64-65.

130 SUÁREZ-OROZCO, C. y SUÁREZ-OROZCO, M.M. La infancia de la inmigración, op. cit., p. 125.

$131 \mathrm{KHOO}$, Siew-Ean. "Sponsorhip of relatives for migration and immigrant settlement intention"; en International Migration, vol. 41, No. 5, 2003, p. 180.

132 GÓMEZ CRESPO, P. “Gestación y puesta en práctica de la reagrupación familiar como estrategia”, op. cit., p. 69. 
gratorios. Estas redes son creadas a raíz de la presencia de familiares y amigos en el Estado receptor, conectados con sus parientes en el país natal. Incluyen una gran variedad de estructuras familiares y de contactos que van más allá de los vínculos familiares ${ }^{133}$ y que resultan enormemente facilitadas por las nuevas tecnologías de la información ${ }^{134}$. Constituyen redes migratorias transnacionales que ejercen una poderosa influencia tanto sobre el país de destino como sobre el de origen y que actúan como conductos de información y asistencia social y financiera de futuros inmigrantes ${ }^{135} \mathrm{y}$, con ello, "aumentando la verosimilitud de la emigración al bajar los costes, elevar los beneficios y mitigar los riesgos del movimiento internacional"136.

La presencia de redes transpersonales de carácter transnacional determina la creación y el mantenimiento de las denominadas "familias transnacionales" caracterizadas por la persistencia de vínculos tanto con el Estado de origen como con el de destino, lo que a su vez provoca redes de influencias recíprocas y un fuerte impacto en ambas sociedades ${ }^{137}$. Este tipo de familias transnacionales, también denominadas multilocales o multisituadas, son concebidas como aquellas cuyos miembros "viven algo o la mayor parte del tiempo separados unos de otros, pero aún se mantienen unidos y creando algo que puede ser visto como un sentimiento de bienestar colectivo y de unidad, principalmente "familyhood", incluso a través de las fronteras nacionales"138.

La localización espacial dispersa que caracteriza a estas estructuras familiares impide su identificación con el hogar o la vivienda común ${ }^{139}$, como es habitual en las familias occidentales no afectadas por las dinámicas migratorias. De otro lado, la fluidez que las redes imprimen en las estructuras y formas de vida familiares, dificulta la tradicional y simple distinción entre redes familiares nucleares y extensas, desdibujando así mismo las fronteras entre las familias y las propias redes ${ }^{140}$. La complejidad social, junto a la dificultad para la aprehensión teórica de este tipo de familias migrantes transnacionales, ha llevado a que las mismas hayan sido conceptualizadas como un "fenómeno

133 GREESE, Gillian; DYCK, Isabel y MCLAREN, Arlene. "Reconstituting the Family: Negotiating Immigration and Settlement". Research on Immigration and Integration in the Metropolis (RIIM), Centre of Excellence, Vancouver, 1999, Paper 99-10, p. 7. Disponible en: http://riim.metropolis.net/Virtual\%20Library/1999/wp9910.pdf

134 NAUCK, B y SETTLES, B.H. ”Immigrant and Ethnic Minority Families: An Introduction”, op. cit., p. 462.

135 BOYD, Monica. "Family and Personal Networks in International Migration..., op. cit., p. 639.

136 MASSEY, D; ARANGO, J.; GRAEME, H.; KOUAOCI, A; PELLEGRINO, A y TAYLOR, E. "Una evaluación de la teoría de la migración internacional: el caso de América del Norte; en MALGESINI, Graciela (comp.). Cruzando fronteras. Migraciones en el sistema mundial, op. cit., p. 229.

137 KOFMAN, Eleonore y MEETOO, Veena. "Family Migration”; World Migration Report 2008: Managing Labour Mobility in the Evolving Global Economy. International Organization for Migration, Geneva, p. 154.

138 BRYCESON, Deborah Fahy y VUORELA, Ulla (eds.). "Transnational Families in the Twenty-first Century”; en BRYCESON, D y VUORELA, U (eds.). The Transnational Family. New European Frontiers and Global Networks. Oxford/New York, Berg Publishers, 2002, p. 3. Posteriormente, Bryceson y Vuorela advierten que la separación geográfica y la dispersión entre parientes, propia de las familias transnacionales, no constituye un fenómeno nuevo provocado por la globalización, pues formó parte de la Europa colonial y de las sociedades de asentamiento de inmigrantes, sin embargo la "sociedad de la información", las estructuras capitalistas y el comercio internacional lo han intensificado hasta convertirlo en parte de las formas de vida cotidiana de los europeos. Ídem, p. 7.

139 Ibidem, p. 28. En el mismo sentido HO, Christine G. T. "The Internationalization of Kindship and the Feminization of Caribbean Migration: the Case of Afro-Trinidadian Immigrants in Los Angeles"; en Human Organization, vol. 52, No. 1, 1993, pp. 32-40. Y, confirmando esta conclusión, pero en su aplicación específica al caso español, concretamente a las familias transnacionales surgidas a raíz de la migración del colectivo de peruanos y ecuatorianos residentes en España, donde la mujer habitualmente lidera autónomamente el proceso migratorio, provocándose el fenómeno de la maternidad transnacional o a distancia, vid. PARELLA, Sónia. "Los vínculos afectivos y de cuidado en las familias transnacionales. Migrantes ecuatorianos y peruanos en España”; en Migraciones Internacionales, vol. 4, No. 2, julio-diciembre 2007, espcialmente las pp. 152, 171 y 173.

140 GREESE, Gillian; DYCK, Isabel y MCLAREN, Arlene. "Reconstituting the Family: Negotiating Immigration and Settlement", op. cit., p. 7. 
elusivo", de difícil cuantificación y de dinamismo social "interminable"141, advirtiéndose que las mismas "pueden extender, difuminar y en adición convertir en problemáticos los límites y significados de la familia"142.

La dispersión geográfica internacional de la familia del inmigrante puede ser considerable, llegando a dar origen a redes familiares en varios Estados nacionales simultáneamente. Este fenómeno ha llegado a denominase "migración ramificada"143, dando lugar a "familias multinacionales"144 de inmigrantes con múltiples ramificaciones geográficas extendidas a tres o más países - por contraste a las denominadas familias binacionales con ramificaciones en dos Estados diversos- como consecuencia de la emigración de parientes desde un mismo Estado de origen a muy diversos países de destino.

Muchas familias transnacionales encajan dentro de la categoría de familias multinacionales, sometidas a un grado altísimo de dispersión geográfica internacional, con parientes - tanto cercanos como extensos - en múltiples Estados y, pese a ello, preservando fuertes vínculos y contactos frecuentes. Además, y frente al modelo predominantemente masculinizado de la migración tradicional, estas estructuras familiares se caracterizan por el protagonismo que ejercen las mujeres en su creación y subsistencia ${ }^{145}$.

Como consecuencia de la extraordinaria diversificación tanto de los países de origen como de destino que caracteriza a los actuales flujos migratorios internacionales, el circuito geográfico en el que se extienden este tipo de familias es tan amplio que constituye una auténtica diáspora ${ }^{146}$. De ahí que a la dispersión internacional de estas familias se la denomine "diáspora familiar"147. Constituye un fenómeno de importancia cuantitativa en aumento y especialmente ilustrativo tanto del transnacionalismo propio de las migraciones internacionales en un mundo globalizado ${ }^{148}$, como de la separación geográfica familiar provocada por la emigración.

141 BRYCESON, D y VUORELA, U. “Transnational Families in the Twenty-first Century”, op. cit., p. 3.

142 GREESE, Gillian; DYCK, Isabel y MCLAREN, Arlene. "Reconstituting the Family: Negotiating Immigration and Settlement", op. cit., p. 6.

143 Se trata de una nueva terminología que, lejos de estar consolidada, constituye tan sólo una propuesta de su autor. El mismo aclara que "in the abscense of any generally accepted term, we proposed the term "branch migration" for the migration of related persons from the same source country to differents destination countries”. PARR, Nick; LUCAS, David y MOK, Magdalena. "Branch Migration and the International Dispersal of Families"; en International Journal of Population Geography, No. 6, 2000, p. 213.

144 Ídem, p. 215.

145 HO, Christine G. T. “The Internationalization of Kindship and the Feminization of Caribbean Migration: the Case of Afro-Trinidadian Immigrants in Los Angeles", op. cit., pp. 32-40. El caso español revalida las consideraciones expuestas, al confirmarse el papel de la mujer como pionera y sustentadora de la migración, al menos en lo que respecta a aquellas trabajadoras extranjeras vinculadas en España al servicio doméstico. Vid. DÍAZ GORFINKIEL, Magdalena y TOBÍO, Constanza. “¿Una nueva organización familiar?. Madres trabajadoras y servicio doméstico inmigrante: percepciones e implicaciones”; en Revista de estudios de juventud, No. 67, 2004, p. 128.

146 El término diáspora, aplicado al ámbito migratorio, designa la dispersión territorial de grupos étnicos en varios países y carece de la connotación peyorativa o dramática con que esta noción nació en la época clásica y fue aplicada históricamente. Sobre las diásporas en la actualidad y su significado cambiante, resulta fundamental la consulta del libro que dio origen a esta nueva aplicación de la terminología diáspora COHEN, Robert. Global Diasporas: An Introduction. Seatle, University of Washington Press, 1997.

147 PARR, Nick; LUCAS, David y MOK, Magdalena. "Branch Migration and the International Dispersal of Families", op. cit., p. 215.

148 Castles y Miller consideran que el aumento del transnacionalismo constituye una de las consecuencias de la globalización. Estiman que cabe entender por transnacionalismo aquellos "comportamientos o instituciones que de forma simultánea afectan a más de un Estado". La era de la migración. Movimientos internacionales de población en el mundo moderno, op. cit., p. 11. 
En este contexto, Kate Jastram ha destacado que el incremento de familias disgregadas por las fronteras estatales a causa de la migración de alguno de sus miembros está provocando una nueva geografía familiar de carácter inter-fronterizo ${ }^{149}$. La división interestatal de las familias constituye un problema de alcance global, y dimensiones difícilmente cuantificables, pero con potencial expansivo, hasta el punto de que ya se anticipa que constituirá una "característica definitoria de las sociedades en muchos países en el siglo XXI ${ }^{150}$ ".

En definitiva, tal y como se desarrollan los flujos migratorios en nuestros días, la inmigración suele implicar la separación de la familia ${ }^{151}$, dando lugar a familias migrantes espacial o geográficamente fracturadas ${ }^{152}$. Cuando la unidad familiar está fragmentada por las fronteras, su reconstitución exige el cruce de las mismas. El restablecimiento de la familia en tales circunstancias expone a sus miembros a rígidos controles migratorios así como al cumplimiento de estrictos y a menudo restrictivos requisitos. Y es aquí donde se produce un punto de intersección entre dos segmentos del orden jurídico hasta hace poco distantes: la extranjería y la protección de la familia.

La nueva geografía familiar de carácter inter-fronterizo ${ }^{153}$ exige de los Estados difíciles equilibrios entre los controles migratorios y sus obligaciones internacionales de respetar y promover la vida familiar, traduciéndose en restricciones crecientes sobre la capacidad estatal antes enteramente discrecional de controlar la admisión y condiciones de residencia de los extranjeros, que analizaremos a lo largo del presente trabajo.

\subsection{La institución familiar ante la sociología y el derecho}

La familia constituye la unidad básica en la estructuración de la sociedad. El Diccionario de la Lengua Española define a la familia como un "grupo de personas emparentadas entre sí que viven juntas". Para la Sociología, en palabras de Anthony Giddens, la familia "es un grupo de personas directamente ligadas por nexos de parentesco, cuyos miembros adultos asumen la responsabilidad del cuidado de los hijos" ${ }^{\prime 54}$. La esencia o denominador común del concepto de familia es la relación existente entre dos ó más personas y la necesidad afectiva y/ o material de continuidad de la misma. Giddens también destaca la diferente concepción de la familia existente entre las diferentes culturas de los pueblos del mundo, añadiendo que el concepto de familia varía incluso dentro de las fronteras de un mismo Estado nacional.

Desde el punto de vista sociológico, dos parecen ser pues las características más sobresalientes de la familia como institución social. De un lado, su universalidad, ya que toda sociedad conoce

149 JASTRAM, Kate. "Family Unity: The New Geography of Family Life"; en Migration Information Source, Mayo de 2003. Disponible en Internet: www.migrationinformation.org

150 Citado por JASTRAM, K. Ídem. p. 2. La cita corresponde a una frase pronunciada por la entonces comisionada especial de la ONU para los derechos humanos de los migrantes, Gabriela Rodríguez Pizarro.

151 BATTISTELLA, Graziano. "Family Reunification: Policies and Issues”, op. cit., p. 244.

152 LANDOLT, Patricia y DA, Wei Wei."The Spatially Ruptures Practices of Migrant Families: A Comparision of Immigrants from Salvador and the People's Republic of China"; en Current Sociology, vol. 53, No. 4, July 2005, pp. 625-653.

153 La expresión corresponde a Kate Jastram en "Family Unity: The New Geography of Family Life", op. cit., s. p.

154 GIDDENS, Anthony. Sociología, (con la colaboración de Karen Birdsall), traducción de Jesús Cuéllar Menezo. Madrid, Alianza, 4a edic, 2004, p. 231. 
alguna forma de organización familiar; de otro, su carácter variable y la múltiple diversidad de estructuras familiares a que puede dar lugar ${ }^{155}$.

Ahora bien, la configuración técnico jurídica de la familia depende, prima facie, del derecho interno. El derecho de familia ha sido tradicionalmente insertado en el ámbito del derecho privado, siendo considerado una rama específica del derecho civil ${ }^{156}$. De ahí que el derecho de familia haya sido una materia habitualmente resistente a las influencias procedentes del ámbito internacional. Ello supone que a la enorme heterogeneidad social de las estructuras familiares le corresponde una correlativa disparidad jurídica. La configuración jurídica de lo que sea familia variará en función del concreto contexto histórico, cultural y social de cada país; incluso en un mismo país integrado por diversos grupos étnicos con patrones culturales propios pueden existir diferencias importantes en el concepto de familia, fenómeno particularmente visible en los Estados compuestos ${ }^{157}$.

Pese a la heterogeneidad de la concepción jurídica de la familia entre los diversos ordenamientos del mundo, el denominador común es que todos ellos tienen un concepto de familia al que brindan algún tipo de protección jurídica. Esta tutela ha ascendido al ámbito constitucional, conteniendo la mayoría de las Constituciones occidentales algún tipo de protección de la familia, habitualmente concebida como una garantía institucional.

155 Ambas características son comúnmente destacadas en los estudios de sociología que exploran la institución familiar. A modo de ejemplo rescatamos dos de ellos. Gelles y Levine afirman que "la familia, como institución social, es universal; toda sociedad conocida tiene familias. Pero qué forma toma ésta y qué funciones cumple varían con el tiempo y en las diversas sociedades". GELLES, Richard J y LEVINE, Ann. Sociología (2a ed.). Cuaderno con aplicaciones en países de habla hispana. MacGraw-Hill, México D.F., 2000. p. 423. En el mismo sentido se pronuncia Ralph Linton, quien partiendo del carácter social de la familia, llega a idéntica conclusión: “(...) las pautas ideales que dirigen y controlan las interacciones sociales nunca se repiten en idéntica forma en dos sistemas sociales distintos. Así, pues, se deduce que las instituciones que se derivan de las combinaciones de esas pautas serán diferentes en su forma y contenido. Sin embargo, todos los sistemas sociales conocidos contienen instituciones que corresponden, de modo general, a lo que llamamos familia". Ralph Linton, "Universalidad y diversidad de la familia"; en MARTÍN LÓPEZ, Enrique. Textos de Sociología de la Familia. Un relectura de los clásicos (Linton, Tönnies, Weber y Simmel). Madrid, Ediciones Rialp, Instituto de Ciencias para la Familia, Universidad de Navarra, 1993, p. 47.

156 Si bien esta inserción no constituye una característica pacífica para la doctrina civilista. Entre otros, Ruggiero señala que el derecho de familia constituye la disciplina jurídica que ofrece más singularidades. De este modo ha destacado la presencia de determinadas peculiaridades del derecho de familia - existencia de un interés familiar que se superpone al interés individual de los miembros de la familia, el carácter ético de sus normas, la presencia de limitaciones específicas al principio de la autonomía de la voluntad, una amplia intervención de la autoridad pública, entre otras - que lo alejan del ámbito privado, aproximándolo al derecho público. Por ello concluye que el derecho de familia constituye una rama autónoma del derecho. RUGGIERO, Roberto. Instituciones de Derecho Civil, traducción de la $4^{\mathrm{a}}$ ed. italiana anotada y concordada con la legislación española por Ramón Serrano Suñer y José Santa-Cruz Tejeiro. Madrid, Instituto Editorial Reus, D.L. 1977-1979, 4a edic. Tomo II, vol. II. pp. 5-15.

157 En torno a los Estados compuestos y a la distribución de las competencias legislativas — entre las que se encuentra el derecho de familia - Hans Kelsen afirma que "la descentralización permite una aproximación mayor a la idea de la democracia que la centralización. Esta idea es el principio de autodeterminación. La democracia exige la máxima conformidad entre la voluntad general expresada en el orden jurídico y la de los individuos sujetos a este orden; de aquí que el orden jurídico sea creado, de acuerdo con el principio mayoritario, por los mismos individuos sometidos a dicho orden. La coincidencia del orden con la voluntad de la mayoría es la meta de la organización democrática. Pero las normas centrales del orden, válidas para la totalidad del territorio, pueden fácilmente entrar en contradicción con la voluntad mayoritaria de un grupo residente en un territorio parcial (...). La mayoría de toda la nación puede ser socialista o católica, y la de una o más provincias liberal o protestante. A fin de atenuar la posible contradicción entre el contenido del orden jurídico y la voluntad de los individuos sujetos a éste, y de acercarse en la mayor medida posible a la idea de la democracia, puede ser necesario, en ciertas circunstancias, que determinadas normas del orden jurídico sólo sean válidas para ciertos territorios parciales, y que tales normas sólo sean creadas por el voto mayoritario de los individuos que viven en esos territorios". KELSEN, Hans. Teoría General del Derecho y del Estado, 5ª reimpr. Traducción de Eduardo García Máynez. México, UNAM, 1995, p. 371. 


\subsection{Derecho interno y familia: La familia ante el derecho migratorio}

La conformación actual de la familia en el ámbito occidental ha experimentado una profunda transformación, estando regida por el principio de libertad de configuración. Esta situación se ha trasladado al ámbito jurídico, enfatizando el derecho de familia lo que Friedman ha denominado la primacía de la elección ${ }^{158}$. De la vida familiar contemporánea surgen múltiples estructuras familiares basadas en la autonomía personal y afectiva, que en ocasiones escapan a las clasificaciones convencionales. De hecho, la inestabilidad de la estructura familiar propia de nuestros días, en conjunción con los avances en genética y la creciente proliferación y tolerancia social hacia nuevas formas de vida en familia, han permitido florecer un universo de constelaciones familiares extraordinariamente complejo y heterogéneo.

La emergencia de nuevas relaciones y formas de vida íntima que desafían los parámetros convencionales ha sido dramáticamente etiquetada como crisis de la familia ${ }^{159}$, dando lugar al surgimiento de nuevas categorías conceptuales, como la llamada "familia opcional o negociada" 160 o la denominada "familia de elección"161, que constituyen un fenómeno social en auge y, más allá, una

158 En palabras de Lawrence Friedman, "the family today is far different from the family of yesterday. It is essentially a coming together of individuals; it is an arrangement of individuals, for individuals, it is much more brittle, malleable, friable than in the past. And the family, as such, no longer has much legal status or meaning. Family law is still a vital, significant field of law; but it has become a law about individuals (...). And because family law is a law about individuals it is also a law that stresses the primacy of choice, of free and voluntary actions". El rápido y revolucionario cambio que se ha producido en el derecho de familia constituye para Friedman una consecuencia del cambio que la familia en sí misma ha experimentado "a una velocidad de torbellino", según lo califica el propio autor. FRIEDMAN, Lawrence Meir. Privates Lifes. Families, Individuals and the Law. Harvard University Press, 2004, pp. 1 y 13. Posteriormente, Friedman destaca que las sociedades occidentales comparten una cultura jurídica común, que califica como "cultura de la modernidad", una de cuyas características más destacadas consiste en que, mientras las sociedades tradicionales situaban en la familia o en el clan el origen de los derechos y obligaciones, de modo que éstos jurídicamente hablando derivaban del estatus que una persona ocupaba dentro de la sociedad o dentro de la familia, en las modernas sociedades occidentales se ha producido "el ascenso del inidviduo como la fuente - "locus" - de los derechos y obligaciones (...). La familia como unidad jurídica se disuelve; y los miembros individuales suben al poder". En definitiva, para este autor el derecho de familia se caracteriza por una acusada tendencia a la "entronización del individuo y de las elecciones individuales". Ídem, pp. 2-5 y 14, respectivamente, traducción propia.

159 Weeks, Heaphy y Donovan se desmarcan de la creencia de que la familia esté en crisis, señalando que se trata más bien de un cambio en la familia tradicional: "many of the values the family is supposed to represent are not in crisis. On the contrary, they are being reinvented in a variaty of <experiments in living $>$ through which new patterns of commitment are being enacted in everyday life". WEEKS, Jeffrey; HEAPHY, Brian y DONOVAN, Catherine. Same Sex Intimacies. Families of Choice and Other Lilfe Experiments. London, Routledge, 2001.p. VII, prefacio. En una línea similar, Friedman al hablar sobre la transformación que ha experimentado el derecho de familia a lo largo del último siglo, subraya lo que denomina "el declive de la familia, legalmente hablando", entendiendo por tal la primacía del individuo y de sus opciones de vida particulares sobre la estructura familiar en tanto que origen real tradicional de los derechos y obliaciones. En un pasaje posterior matiza en torno al concepto de la decadencia de la familia, señalando que "the family has not dissolved. It has changed and broadened. It has become more elastic. In some ways, it is a much weaker institution. But it still has a vast reservoir of strength". FRIEDMAN, Lawrence M. Privates Lives. Families, Individuals and the Law, op. cit., pp. 1 y 11, respectivamente.

160 La terminología ha sido acuñada por REGAN, Milton C. Jr. Family Law and the Pursuit of Intimacy. New York, New York University Press, 1993, pp. 47-51. Sobre este tema, Friedman subraya expresivamente que la vida familiar ha conducido a un "menú de opciones: permanecer soltero, cohabitar o casarse; y, estando casado o no, decidir si tener o no tener hijos". Y, en torno a la terminología acuñada por Regan, indica que "lo que es opcional es naturalmente un asunto de pura elección; lo que es negociado, sin embargo, implica a otra persona - una pareja, esposo, hijos..” FRIEDMAN, L. M. Privates Lives..., op. cit., p. 8.

161 Weeks, Heaphy y Donovan utilizan esta terminología en referencia exclusiva a relaciones privadas no heterosexuales y si bien señalan que los cambios sociales afectan también a las personas y formas de vida heterosexuales, sin embargo advierten que dichos cambios adquieren más resonancia en aquellas personas que desafían los modos tradicio- 
auténtica "revolución inacabada"162. Los autores de esta última denominación - familia de elecciónseñalan que, al compás de profundos cambios socioeconómicos y culturales, las sociedades occidentales iniciaron en la década de los sesenta y setenta un nuevo período de la historia de la humanidad, que se acentuaría en las décadas siguientes, caracterizado principalmente por "la aparente ruptura con las asunciones tradicionales en torno a las trayectorias vitales individuales". Frente a la "biografía standard" que incluía el noviazgo heterosexual, el matrimonio y la vida dentro de una familia nuclear, ha habido un movimiento que ha permitido a los individuos adoptar una personal "biografía de autorealización"163.

Este movimiento emancipador se enmarca dentro de un proceso de individualización en el que la persona individualmente considerada, más que la familia y la comunidad a la que pertenece, se ha convertido en el foco primario de la vida contemporánea, quedando liberado de las expectativas sociales en torno a una vida familiar tradicional ${ }^{164}$. En definitiva, para estos autores "las familias de elección" son meros precursores de nuevas posibilidades relacionales que el predominio de la autonomía personal y un clima de tolerancia social están permitiendo emerger. Retomando a Friedman, podría afirmarse que la vida familiar está impregnada por la "ideología de la elección", dando lugar a una esfera privada definida cada vez más según los deseos, anhelos y necesidades del individuo, elegidos libremente y generadores de un ámbito cada vez más expandido constitutivo de una auténtica "república de la elección" - "Republic of choice"165.

Sin embargo, esta situación de profundo individualismo y libertad de opción está muy lejos de ser predicable del ámbito migratorio, obviamente no por una cuestión ética ni filosófica, sino por razones de contención de flujos. Las familias migrantes están imbuidas del mismo grado de diversidad y heterogeneidad ${ }^{166}$ que caracteriza a las familias de nuestros días. Pese a ello, el principio de libertad de opción no rige en la inmigración familiar, correspondiendo al Estado receptor la definición jurídica de familia. De hecho, una característica esencial de la inmigración vinculada a la familia, entre la que se sitúa la RF, reside en que la noción de familia establecida con carácter general por el Estado

nales de vida y que poseen "identidades sexuales disidentes". Los propios autores identifican de modo no exhaustivo estas categorías disidentes: lesbianas, gays, homosexuales, bisexuales, queers. WEEKS, J; HEAPHY, B; DONOVAN, C. Same Sex Intimacies. Families of Choice and Other Lilfe Experiments, op. cit., pp. 3-5.

162 Ídem, p. 80.

163 WEEKS et alter. Same Sex Intimacies. Families of Choice and Other Life Experiments, op. cit., p. 81. En un sentido idéntico a Weeks, Heaphy y Donovan, Milton Regan afirma que las relaciones familiares han sido redimidas de las expectativas de comportamiento comunes o generalizadas, siendo la vida familiar construida por sus miembros en base a sus deseos y aspiraciones. REGAN, M. C. Family Law and the Pursuit of Intimacy, op. cit., p. 25.

164 WEEKS et alter, op. cit., p. 81, traducción propia y libre.

165 FRIEDMAN, Lawrence Meir. Privates Lifes. Families, Individuals and the Law. Cambridge, Harvard University Press, 2004, pp. 8-14 y 146. El propio Friedman matiza reiteradamente que si bien la zona de la elección —zone of choice - se ha ampliado considerablemente en las modernas sociedades, sin embargo no es infinita y, de hecho, es mucho más estrecha de lo que la mayoría de la gente cree pues, a juicio de este autor, no somos conscientes de las profundas limitaciones que nuestra cultura y las normas y hábitos sociales imponen sobre nuestro espectro de opciones, por no hablar de la capacidad intrusiva de los medios de comunicación y de los avances tecnológicos. Ídem, p. 15 Para una mayor profundidad sobre este tema, puede consultarse FRIEDMAN, L. M. The Republic of Choice: Law, Authority, and Culture. Harvard University Press, 1998.

166 En torno a la heterogeneidad y variedad como características propias de las familias de inmigrantes de nuestros días, Greese, Dyck y McLaren han señalado que "thus we cannot speak about 'the' immigrant family because this denotes a far too static picture of what is a shifting set of complex social relations, with unpredictable outcomes". GREESE, Gillian; DYCK, Isabel y MCLAREN, Arlene. "Reconstituting the Family: Negotiating Immigration and Settlement". Research on Immigration and Integration in the Metropolis (RIIM), op. cit., p. 4; En idéntico sentido se manifiesta KOFMAN, Eleonore. "Famiy-Related Migration: A Critial Review of European Studies", op.c it., p. 249; BRYCESSON y VUORELA (eds.). The Transnational Family. New European Frontiers and Global Networks, op. cit., pp. 6 y 24. 
Nacional como base de sus respectivos derechos privados, no es aplicable en materia migratoria. En síntesis, la RF reposa sobre una definición autónoma de familia —esto es, sobre una calificación jurídica $a d$ hoc- ${ }^{167}$, determinada por el país de acogida, y que no es coincidente con la noción de familia establecida por el mismo país para otros propósitos, tales como hereditarios, o para el derecho de familia en general ${ }^{168}$.

Constituye además otra señal distintiva de las clásicas sociedades de inmigración respecto de los países europeos que, mientras las primeras incluyen definiciones amplias de familia y promueven la RF, los segundos sin embargo no contemplan los vínculos familiares como una prioridad de las políticas migratorias y recogen definiciones jurídicas estrechas de la familia, a las que, además, suelen aplicar principios interpretativos extraordinariamente restrictivos ${ }^{169}$. En la definición de familia a efectos de la reagrupación de extranjeros, los Estados receptores europeos aplican visiones tradicionales y conservadoras, que restringen los parientes a aquellos comprendidos dentro de la familia nuclear, en su sentido más restrictivo posible ${ }^{170}$. De modo que "aunque los modos de vida en común han sufrido una alteración radical en los Estados europeos, los inmigrantes deben todavía conformarse con los esquemas del matrimonio tradicional como base para la entrada en la mayoría de los Estados europeos"171.

Las definiciones angostas de familia funcionan a modo de "mecanismos selectivos para condicionar los flujos de ciertos stocks de inmigrantes"172. Esta circunstancia nos conduce a otra de las señas distintivas de la inmigración familiar en general y de la RF en particular: la definición de familia se erige como una de las vías principales, si no la fundamental, para el control y contención de la RF. De ahí que se haya afirmado que, en este ámbito, "ninguna definición es adoptada nunca in abstracto, sino que está íntimamente vinculada al objetivo a alcanzar y no constituye un fin en sí misma"173.

Existen, sin embargo, mecanismos adicionales a la noción de familia que han demostrado ser altamente efectivos para el cumplimiento de las finalidades de restricción y selección de entradas, tales como la imposición de condicionantes y exigencias ulteriores para la reunión de la

167 En un estudio realizado desde el punto de vista del derecho internacional privado, su autora matiza que tanto el legislador español como el comunitario han optado por dotar de una califiación jurídica ad hoc a la familia del extranjero, rechazando el método conflictual propio del derecho internacional privado, que hubiera supuesto la aplicación de la ley nacional del extranjero, que suele regular el estatuto personal. En consecuencia, los miembros de la familia reagrupables son aquellos determinados expresamente por la ley de extranjería e inmigración del país de acogida de que se trate, coincidiendo pues con el "modelo de familia de la ley de la autoridad pública encargada de autorizar el reagrupamiento". GARCÍA RODRIGUEZ, Isabel. Matrimonio e Inmigración. El control del consentimiento matrimonial en la reagrupación familiar. Madrid, Colex, 2008, p. 59.

168 Perrouchoud ha matizado que "very often, in particular on humanitarian grounds, the definition of family is closely related to the ability of sponsors to finance the travel, lodging, care and maintenance of the family members". PERRUCHOUD, Richard. "Family Reunification”; en International Migration, op. cit., p. 514.

169 KOFMAN, Eleonore. “Family-Related Migration: A Critial Review of European Studies”, op. cit., pp. 243.-244.

170 Como excepción a lo dicho, Kofman ha señalado que "ha habido cierto reconocimiento de nuevas formas de vida en común y changing gender relations and sexual orientations", poniendo como ejemplo el grado relativo de apertura que representa el artículo 4.3 de la Directiva comunitaria sobre RF. En base a dicha disposición, es posible cierta definición extensiva de los miembros de la familia que ampare a las relaciones afectivas estables no casadas. Pero en todos estos supuestos, matiza la autora, se exige demostrar que los nuevos modelos familiares son semejantes a la familia nuclear. KOFMAN, Eleanore. Civic Stratification, Gender and Family Migration Policies in Europe, op. cit., p.3.

171 KOFMAN, E. “Family-Related Migration...”, op. cit., p. 245, traducción propia.

172 LAHAV, Gallya. "International versus National Constraints in Family-Reunification Migration Policies”, op. cit., p. 363.

173 PERRUCHOUD, R. “Family Reunification”, op. cit., p. 515. 
familia. De hecho, una característica en la que últimamente están convergiendo los países de larga tradición migratoria y los Estados europeos, reside en que ambos sistemas, pese a contar con puntos de partida radicalmente divergentes en la consideración y el tratamiento normativo de la reagrupación familiar, manifiestan la tendencia a incorporar requisitos crecientemente selectivos en las regulaciones jurídicas relativas a esta materia ${ }^{174}$. Por eso se ha aplicado de forma recurrente a las sucesivas reformas que endurecen los requisitos para poder ejercer la RF, el tópico de que "el diablo reside en los detalles" 175 , pues regulaciones que proclaman formalmente el derecho, pueden terminar vaciándolo de contenido mediante la introducción de múltiples y gravosas condiciones de ejercicio.

De otro lado, es habitual que existan diferencias en la concepción de la familia entre el Estado de origen y el receptor, especialmente cuando median grandes distancias geográficas entre ambos. Los países emisores suelen contemplar un concepto tanto jurídico como sociológico de familia más amplio, con sólidas redes de solidaridad mutua que se extienden mucho más allá de la familia nuclear, junto con valores culturales propios y a menudo divergentes de los imperantes en las sociedades occidentales. Es obvio que la restrictiva noción autónoma de familia que rige en materia migratoria ignora estas diferencias ${ }^{176}$, pudiendo chocar frontalmente con los esquemas familiares autóctonos de los inmigrantes y, a un nivel más pragmático, desposeyendo a éstos de redes de ayuda que pueden resultar de gran utilidad para el éxito del proyecto migratorio en la sociedad de acogida, especialmente en contextos económicos debilitados y de cara al cuidado de los hijos menores de los inmigrantes mientras éstos trabajan ${ }^{177}$. En este sentido, se ha señalado que la familia constituye "una fuente de recursos para generar estrategias"178, hasta el punto de que "dentro de un sistema existente de parentesco, los lazos intergeneracionales fuertes y las relaciones estables de intercambio son probablemente los más eficaces mecanismos de seguridad social en el contexto relativamente inseguro de la

$174 \mathrm{Al}$ explorar esta tendencia hacia la convergencia, Lahav subraya que la misma se ha producido pese a los que países tradicionales de inmigración permanente "habían sido los más fervientes defensores de la inmigración familiar". LAHAV, Gallya. "International versus National Constraints in Family-Reunification Migration Policies", op. cit., p. 363. KOFMAN, Eleanore. "Family-Related Migration: A Critial Review of European Studies”, op. cit., p. 250. HING, Bill Ong. Deporting Our Sould. Values, Morality, and Immigration Policy, op. cit., p. 120. CORNELIUS, Wayne A; TSUDA, Takeyuki; MARTIN, Philip L. y HOLLIFIELD, James F. (eds.). Controlling Immigration. A Global Perspective, second Edition, op. cit., pp. 108 y 147. En esta línea, el Informe de SOPEMI del año 2010, constata la existencia de una clara tendencia a la imposición de criterios más estrictos para la RF. International Migration Outlook 2010, op. cit., p. 67. En torno a la aproximación entre modelos migratorios y a la percepción de la migración familiar en Europa y en los países no europeos de la OCDE, se pronuncia asimismo el último informe sobre flujos migratorios internacionales emitido por SOPEMI. International Migration Outlook, Annual Report 2012, p. 10.

175 La expresión es habitualmente utilizada en múltiples artículos que explican de forma crítica las reformas emprendidas en materia de RF tanto en EEUU como en Australia. A modo de ejemplo, cabe citar un documento que analiza la reforma emprendida en Australia, instando a pronunciarse en contra mediante una carta enviada al ministro australiano de inmigración: “The Devil is in the Detail. Changes ito General Skills-Family Migration”, disponible en http://www.crescentsofbrisbane.org/Files/Skills\%20Family\%20Migration\%20Changes.pdf

176 TICHENOR, Daniel J. Dividing Lines. The Politics of Immigration Control in América. Princeton University Press, 2002, p. 254.

177 Kofman señala que "the generally limited conceptualisation of the family leaves little consideration for problems generated by caring at a distance, cultural differences in familial relationships, and the role of grandparents or other collateral relations in providing nurturing and support for different members of the family". KOFMAN, Eleonore. Civic Stratification, Gender and Family Migration Policies in Europe, op. cit., p. 3.

178 GÓMEZ CRESPO, Paloma. "Gestación y puesta en práctica de la reagrupación familiar como estrategia”, op. cit., p. 66. 
migración"179. En definitiva, otra de las características destacadas de las legislaciones de inmigración y extranjería es que recogen un concepto occidental de familia "etnocéntricamente sesgado"180.

En tanto que la familia y su protección jurídica constituían un asunto propio del derecho interno, cuando las injerencias procedían de las autoridades estatales internas, poco podía hacer el individuo para salvar su núcleo familiar, pues no había para ello facultad subjetiva alguna que se sobrepusiera a la potestad soberana del Estado. Esta situación ha cambiado como consecuencia de la progresiva internacionalización de los derechos humanos, que no se ha detenido ni ante el derecho de familia ni ante la encrucijada representada por la interconexión entre la vida familiar y el derecho migratorio.

\section{CONCEPTO Y TIPOLOGÍA DE LA INMIGRACIÓN FAMILIAR}

En el ámbito europeo, el incremento de la inmigración familiar se percibió como una consecuencia ni deseada ni prevista del cierre de fronteras ${ }^{181}$, a modo de efecto colateral del bloqueo a la inmigración laboral. Esta imprevisión explica que, desde el ámbito doctrinal la inmigración asociada a la familia fuese escasamente estudiada y construida teóricamente de forma marginal respecto de la inmigración de carácter laboral, sobre patrones generalistas y arraigados en consideraciones de género. La inmigración familiar se enmarcaba en el esquema de una inmigración inicial predominantemente masculina ${ }^{182}$ y la posterior reunión en el Estado de acogida con los familiares dependientes más próximos, fundamentalmente cónyuge e hijos. En este esquema migratorio, la pareja del trabajador extranjero era típicamente una mujer no trabajadora, cuyo desplazamiento se justificaba por motivaciones exclusivamente familiares y de quien se presumía un exiguo interés en la inserción laboral en el país de destino, de ahí la utilización de la descriptiva terminología de trailing wife o

179 NAUCK, Bernhard y SETTLES, Barbara H. "Immigrant and Ethnic Minority Families: An Introduction"; en Journal of Comparative Family Studies, vol. 32, No. 4, 2001, p. 462, traducción propia. En un sentido similar se pronuncian Gillian Creese, Isabel Dyck y Arlene Tigar McLaren, quienes enfatizan el rol fundamental de apoyo que desempeña la familia durante todo el proceso migratorio, señalando que su existencia permite al extranjero adoptar estrategias flexibles a fin de afrontar las circunstancias a menudo precarias a las que se enfrentan los inmigrantes en el país de destino. Su estudio se circunscribe al seguimiento de familias de inmigrantes recientemente instaladas en determinados barrios de la ciudad canadiense de Vancouver. “The 'Flexible' Immigrant? Human Capital Discourse, the Family Household and Labour Market Strategies"; en Journal of International Migration and Integration, vol. 9, №. 3, 2008, pp. 269-288.

180 GÓMEZ CRESPO, Paloma "La aplicación de la normativa de <reagrupación familiar>: ¿Flexibilidad o arbitrariedad?”; en OFRIM Suplementos, No. 7, 2000, p. 95.

181 KOFMAN, Eleonore. "Family-related migration: a critial review of European Studies", op. cit., p. 248. En contra de esta interpretación mayoritaria, véase GONZÁLEZ FERRER, Amparo. Estrategias familiares y laborales en la emigración, op. cit., especialmente pp. 61-69 y 197-204.

182 Este esquema fue descrito por Bohning a principios de la década de los ochenta: el hombre como cabeza de familia emprendía de forma pionera y aislada el proyecto migratorio para posteriormente reunirse en el país receptor con sus familiares dependientes de él mediante la RF. Véase BOHNING, W.R. Studies in International Labour Migration. London, Macmillan, 1984. KOFMAN ha sintetizado las razones que explican la inicial negación de la migración vinculada a la familia en el ámbito doctrinal, político y jurídico europeo, del siguiente modo: "Family-related migration has been neglected because of the emphasis in migration studies on the individual, a heavily economic focus, and an association with female migration based on the dichotomy of male producer and female reproducer". En este marco conceptual la inmigración familiar era vista como "female dependents following the male breadwinner as the primary migrante”; en "Family-Related Migration...”, op. cit., pp. 243 y 248, respectivamente. Desde mediados de la década de los noventa este modelo homogéneo ya no retrata de forma fidedigna la extraordinaria variedad del ciclo migratorio, que cada vez más frecuentemente es iniciado por las mujeres. Sobre estas cuestiones, aplicadas al marco español, véase DÍAZ GORFINKIEL, Magdalena y TOBÍO, Constanza. “¿Una nueva organización familiar? Madres trabajadoras y servicio doméstico inmigrante: percepciones e implicaciones”, op. cit., especialmente pp. 127-129. 
tied-mover ${ }^{183}$. En definitiva, la inmigración relacionada con la familia era conceptualizada como una "forma de movimiento dependiente y altamente feminizada, con escasa relevancia para la participación en la fuerza laboral" 184 , constituida básicamente por mujeres dependientes y niños, y catalogada por ello dentro de la migración no económica ${ }^{185}$.

El estudio de la RF fraguaría así en un marco teórico masculinizado, estereotipado y simplista, cuyas características principales se construirían por contraposición a la inmigración de carácter laboral, llegando a reflejarse incluso a nivel legislativo mediante sistemas que otorgaban preferencias de entrada a familiares dependientes en función del sexo ${ }^{186}$.

Las consideraciones apuntadas explican que, desde el punto de vista político, la inmigración familiar en el ámbito europeo fuese considerada como una inmigración de carácter secundario ${ }^{187}$ frente a la inmigración laboral. Si la inmigración laboral partía de una motivación fundamentalmente económica, ésta se consideraba ausente de la inmigración familiar; si los migrantes económicos eran sometidos a pre-requisitos de entrada selectivos como consecuencia de la restricción migratoria, los familiares reagrupables obtenían la habilitación jurídica para entrar y residir en el país de destino en virtud de los genuinos lazos familiares que mantenían con el residente extranjero - sponsor o principal—, pero no por sus capacidades, cualificaciones o habilidades laborales.

Sin embargo, y como consecuencia del extraordinario dinamismo que caracteriza esta materia, las características sociológicas de las familias migrantes han ido transformándose, perdiendo parte de su virtualidad explicativa las premisas teóricas sobre las que se construyó inicialmente la RF. Y, más allá de los cambios en los modelos sociales y familiares, la mayor movilidad internacional que lleva aparejada la globalización, ha provocado la irrupción de modelos migratorios muy complejos y está cuestionando la propia operatividad del dualismo entre migración económica o laboral versus migración no económica o de asentamiento ${ }^{188}$, sobre la cual reposaba la construcción dogmática tradicional de la RF.

183 GONZÁLEZ FERRER, Amparo. Estrategias familiares y laborales en la emigración. Reagrupación familiar, elección de parejas y empleo de los inmigrantes en el país de destino. Madrid, CES, 2008, p. 15.

184 KOFMAN, Eleonore y MEETOO, Veena. "Family Migration”; en World Migration 2008: Managing Labour Mobility in the Evolving Global Economy. IOM, 2008, op. cit., p. 151.

185 GONZÁLEZ FERRER, Amparo. Estrategias familiares y laborales en la emigración.., op. cit., p. 15.

186 El ejemplo clásico reside en la legislación del Reino Unido, que hasta la década de los ochenta permitía a los residentes masculinos traerse a sus esposas, pero no autorizaba la situación inversa, esto es, que las residentes extranjeras femeninas pudiesen reagruparse con sus maridos extranjeros en territorio inglés, situación que llegaría a ser enjuiciada por el TEDH. Kofman califica esta situación como "discriminación patente" en función del sexo y la raza. KOFMAN, Eleonore. Civic Stratification, Gender and Family Migration Policies in Europe, op. cit., p. 2.

187 KOFMAN, Eleonore. "Family-Related Migration: A Critial Review of European Studies”, op. cit., p. 248. GONZÁLEZ FERRER, Amparo. Estrategias familiares y laborales en la emigración, op. cit., p. 15. En esta línea, Joppke observa que a fin de manejar la inmigración familiar, "los Estados europeos aceptaron un lenguaje de inmigración primaria y secundaria que es desconocido en los Estados Unidos. La inmigración primaria es activamente reclutada, como en el régimen del guest-worker, o pasivamente tolerada en ausencia de restricciones, como en un régimen postcolonial. La inmigración secundaria tiene lugar después de la parada en el reclutamiento o la introducción de restricciones, en reconocimiento a los derechos familiares de los inmigrantes primarios". JOPPKE, Christian. "Why Liberal States Accept Unwanted Immigration?”; op. cit., p. 282, traducción propia.

188 REA, Andrea. "La europeización de la política migratoria y la transformación de la otredad"; en Revista Española de Investigaciones Sociológicas, No. 116, 2006, p. 159 El autor prosigue afirmando que "la entrada de turistas o estudiantes alimenta los nuevos procesos migratorios tanto como la inmigración laboral, el asilo o la reagrupación familiar. Además la libertad de movimientos dentro de Europa refuerza los movimientos migratorios”. En la misma línea se inscribe GONZÁLEZ FERRER, quien insiste en la necesidad de desvincular las motivaciones que empujan al emigrante con las diversas categorías migratorias de admisión de extranjeros. Estrategias familiares y laborales de la emigración, op. cit., p. 201. 
Una de las tendencias actuales de los flujos migratorios internacionales ha venido a cuestionar los patrones teóricos tradicionales que servían de sustento a la RF: Se trata de un cambio sustancial en la composición por sexos de los flujos migratorios provocado por la creciente feminización que éstos han experimentado desde la década de los sesenta ${ }^{189}$, acelerada en el contexto de la globalización.

El término feminización resulta, sin embargo, algo engañoso ${ }^{190}$. No alude a un incremento radical en término absolutos del número de mujeres migrantes — si bien su número ha aumentado, no lo ha hecho de forma altamente significativa ${ }^{191}$, salvo en lo que respecta a algunos países. La feminización denota más bien la existencia de una tendencia creciente entre las mujeres extranjeras a inmigrar de forma independiente ${ }^{192}$ en busca de mejores condiciones de vida - si bien las motivaciones en el caso de la inmigración femenina han demostrado ser más amplias, no restringiéndose a la búsqueda de trabajo como motivo primordial del desplazamiento internacional—, bien sea solas o iniciando el ciclo migratorio familiar. Esta tendencia se traduce asimismo en su mayor participación económica, especialmente en una actividad ligada a la inmigración que resulta trascendente para el país de origen: el envío de remesas a los familiares. La feminización apuntada ha cancelado la tradicional "mirada ciega" 193 que tanto desde el ámbito doctrinal como el político existía en torno al papel desempeñado por las mujeres en el ámbito migratorio, pero también ha venido a alumbrar nuevos fenómenos problemáticos adicionados a la RF, al menos en lo que respecta a su percepción para las sociedades de destino. Los explicaremos en su momento.

189 CASTLES, S y MILLER, M. J. La era de las migración. Movimientos internacionales de población en el mundo moderno, op. cit., p. 22. Colectivo IOÉ. "Flujos Migratorios Internacionales. Marco de comprensión y características actuales"; en Migraciones, No. 9, 2001, p. 34.

190 United Nations-INSTRAW (International Research and Training Institute for the Advancement of Women). Feminization of Migration 2007. Gender, Remittances and Development. Working Paper 1, Santo Domingo, República Dominicana, p. 2.

191 Hania Zlotnik ha subrayado que es posible rastrear el porcentaje de la evolución de los flujos migratorios femeninos desde 1960 hasta el año 2000. La autora señala que a lo largo de estas tres décadas el porcentaje de mujeres inmigrantes aumentó apenas dos puntos en términos absolutos: en 1960 las mujeres inmigrantes representan el 48\% del total de los flujos migratorios presentes en los países desarrollados, mientras que en el año 2000 el porcentaje de mujeres migrantes constituía un $51 \%$ de la población migrante mundial establecida en países desarrollados. Su análisis parte de una constatación que puede resultar sorprendente. En palabras de la propia autora: "For more than 40 years, female migrants have been almost as numerous as male migrants. In 1960 there were 35 million female migrants and 40 million male migrants; by 2000, although the total number of migrants had more than doubled, the gap between females and males remained about the same, 85 million female migrants versus 90 million male migrants". ZLOTNIK, Hania. The Global Dimensions of Female Migration. Migration Information Source. March, 2003, sp.

192 "Although a net feminization of flows has occurred in certain regions, what has really changed in the last decades is the fact that more women are migrating independently in search of jobs, rather than as 'family dependants' traveling with their husbands or joining them abroad". UN-INSTRAN. Feminization of Migration 2007, op. cit., p. 2.

193 Colectivo IOÉ. "Flujos Migratorios Internacionales. Marco de comprensión y características actuales", op. cit., nota a pie de página №. 27, p. 16. En un sentido similar se expresa el informe "Feminization of Migration 2007", donde se afirma explícitamente que "in addition to this change in the pattern of female migration, the other significant change taking place concerns the level of awareness on the part of migration scholars and policy-makers as to the significance of female migration and the role of gender in shaping migratory processes and, most importantly, the increasingly important role of women as remittance senders". UN-INSTRAN, Feminization of Migration 2007, op. cit., p. 1. También incide en el mismo aspecto González Torralba, quien repasa la evolución de la literatura sociológica y antropológica en torno al papel de la mujer en el ámbito migratorio, destacando que los estudios actuales han logrado superar la visión tradicional que consideraba a la mujer migrante como invisible e inactiva en la migración. GONZÁLEZ TRORRALBA, Herminia. "Familias y hogares transnacionales: una perspectiva de género”, op. cit., p. 8. En la misma línea se inscribe GONZÁLEZ FERRER, quien destaca que a partir de finales de los ochenta, la literatura especializada ha logrado superar la anterior omisión de la experiencia migratoria femenina en los estudios especializados. Estrategias familiares y laborales de la emigración, op. cit., p. 15. 
A efectos de su conceptualización, conviene enmarcar la RF dentro de un marco de mayor amplitud. La RF constituye una faceta específica dentro de un concepto más genérico que engloba los distintos tipos de procesos migratorios vinculados a la familia y que por ello ha sido denominada "migración familiar"194. La inmigración familiar constituye un fenómeno intrínsecamente heterogéneo y muy complejo, susceptible de ser subdividido en las siguientes categorías:

- La Reunificación, reunión o reagrupación familiar en sentido estricto.

- La Formación familiar.

- La inmigración de toda la unidad familiar.

- La reunificación de la familia en sentido extenso, los denominados "sponsored family members".

\subsection{La Reunificación Familiar en sentido estricto}

En el ámbito internacional, la reunificación familiar en sentido estricto designa "la reunión junto a una persona que reside en un país del que no es nacional de los miembros de su familia más próximos que residen en otro país, en condiciones de entrada y residencia más favorables que para el resto de extranjeros" ${ }^{195}$. En el contexto específico de Europa, la RF supone la reunión, dentro del territorio del Estado receptor, del extranjero residente con su familia nuclear, tal y como ésta es definida por la legislación migratoria de dicho Estado ${ }^{196}$. Y, recurriendo a una definición formulada dentro del ámbito doctrinal español, se entiende por RF "la <llamada $>$ que un inmigrante instalado legalmente en un país receptor realiza a sus familiares más directos para que se le unan en el proceso inmigratorio, con el permiso de las autoridades de dicho país"197.

En consecuencia, la RF implicaría el derecho a inmigrar ${ }^{198}$ - abarcando tanto el derecho de entrada como el de residencia en el país receptor- al menos respecto de los familiares más próximos

194 La Organización Internacional para las Migraciones considera la Migración Familiar (Family Migration) como un "concepto más general que cubre la reunificación familiar, la migración de toda la unidad familiar y la formación familiar”. Migration Terminology. World Migration 2008, op. cit., p. 493.

195 KAYSER, P. "Le regroupemente familial dans le droit communautaire. La Convention Europeénne des droits de l'homme et le droit interne francaise"; Revista La Semaine Juridique, 67è annèe, №. 21-22, 2 junio 1993, p. 235. Citado por SANTOS ARNAU, Lidia. "Conceptos jurídicos indeterminados y discrecionalidad: especial referencia al visado para la reagrupación familiar”; en PICÓ LORENZO, Celsa (dir.). Extranjeros. Madrid, Consejo General del Poder Judicial, 1994, p. 455. Si bien, en el ámbito internacional existen múltiples definiciones de RF que, con diversas variantes, exploran este concepto. La Organización Internacional de las Migraciones maneja la siguiente definición de la reunificación familiar, a la que considera sinónimo de la reunión familiar: "Process whereby family members separated through forced or voluntary migration regroup in a country other than the one of their origin". "Migration Terminology". World Migration 2008, IOM, op, cit., p. 493. La misma OIM ha publicado un Glosario sobre Migración, dentro de la colección de estudios dedicada al Derecho Internacional de las Migraciones, donde se define la reunificación familiar como el "proceso por el cual los miembros de un grupo familiar, separados forzosamente o por migración voluntaria, se reagrupan en un país distinto al del origen. La admisión es discrecional del Estado receptor”. Derecho Internacional sobre Migración, IOM, No. 7, 2006, p. 65.

196 KRALER, Albert y KOFMAN, Eleanore. Civic Stratification, Gender and Family Migration Policies in Europe, op. cit., p. 3. En el ámbito del Consejo de Europa, podemos encontrar la siguiente definición de RF, de un carácter relativamente neutro: "Family reunion is the term used to describe a situation in which members of a family come to join one of its members (the "sponsor"), who is lawfully resident in another country". Apartado segundo de la Recommendation 1686 (2004), on 23 November 2004. Human mobility and the right to family reunion.

197 MALGESINI, Graciela y GIMÉNEZ, Carlos. Guía de conceptos sobre migraciones, racismo e interculturalidad. Madrid, Catarata, 2000, p. 353.

198 SCHIBEL, Yongmi. Los derechos de movilidad en Europa. Grupo de Política de Inmigración (MPG), Bruselas, enero de 2006 , p. 3. 
del extranjero residente legal, bajo un régimen jurídico más ventajoso que el que rige con carácter general la entrada y permanencia de los extranjeros en el territorio del mismo Estado. En contrapartida, los familiares extranjeros admitidos por motivos de reunificación familiar suelen gozar de un haz de derechos inferiores a aquellos reconocidos a los inmigrantes de carácter laboral ${ }^{199}$. Esta circunstancia procede del carácter dependiente de la admisión de los parientes en el Estado de acogida, vinculada y derivada de la residencia del familiar extranjero allí instalado legalmente.

Esta dependencia determinará la concepción tradicional de la RF como un derecho derivado, circunstancia que queda patente en la propia terminología usada para describir al residente extranjero cuya estancia legal en el Estado receptor activará la posibilidad de reunirse posteriormente con sus familiares más cercanos, denominado "principal", "sponsor", solicitante primario ${ }^{200}$, migrante primario $^{201}$ e incluso "patrocinador"202 o, más genéricamente, "primo-inmigrante"203. Dicha dependencia se transmite asimismo al estatus del familiar reagrupado, que permanecerá subordinado al del reagrupante y a las vicisitudes que éste experimente, al menos durante un tiempo inicial de estancia en el país de destino, tras el cual podrá acceder a un estatuto autónomo según las condiciones fijadas por la legislación interna del Estado de acogida.

La RF en sentido estricto constituye el tipo de migración familiar dominante en el ordenamiento y en la doctrina jurídica, hasta el punto de que resulta muy común el empleo retórico del término RF como sinónimo de todo tipo de migración familiar, tomando la parte por el todo - a modo de sinécdoque-, pese al carácter mucho más amplio y englobador de éste último. Para la definición de la RF en sentido estricto resulta vital el carácter preexistente de los vínculos familiares del extranjero residente, que resultaron fracturados como consecuencia de la emigración no simultánea de los miembros de la unidad familiar. En síntesis, el arquetipo de la RF está definido por la precedencia de los lazos familiares, cuya existencia es anterior a la entrada y al establecimiento del reagrupante o principal en el Estado receptor, quien dejó atrás a su familia como consecuencia de la decisión de emigrar.

En este marco clásico, la RF en sentido estricto constituye una típica situación transnacional. Esta perspectiva parte de la premisa de que cuando el residente extranjero solicita la RF con sus familiares, éstos se encuentran residiendo en un tercer Estado, que habitual - aunque no necesariamente- es el Estado de origen. En consecuencia, la concesión de la RF implicará el desplazamiento geográfico internacional de los familiares y su entrada regular a través de las fronteras del país de destino, a fin de reunirse allí con el residente. Sin embargo, la realidad complica este sencillo supues-

199 KRALER, Albert y KOFMAN, Eleonore. Civic Stratification, Gender and Family Migration Policies in Europe, op. cit., p. 2.

200 World Migration 2008, op. cit., p. 153.

201 La denominación "migrante primario", poco habitual entre la doctrina española especializada en migración familiar, constituye la traducción de la expresión recogia por LAHAV, Gallya, en "International versus National Constraints in Family-Reunification Migration Policy", op. cit., p. 363.

202 El término aparece frecuentemente en la versión en castellano de la página web de la Organización Internacional para las Migraciones, al referirse a la RF. Sin embargo, se trata de una denominación que no ha tenido apenas acogida entre la doctrina española, no incluyéndose como tal en casi ninguno de los escritos analizados para la redacción de esta tesis doctoral, donde sin embargo es muy habitual hablar de reagrupante o principal, o incluso utilizar el término inglés "sponsor", equivalente al de patrocinador antes mencionado.

203 El término "primo-inmigrantes” es usado por Joaquín Arango para aludir a una categoría en la que aún encajando el sponsor, es más amplia. Arango califica como primo-inmigrantes a "los que inician la cadena migratoria, abren caminos, colonizan una tierra incógnita para ellos; y que después serán seguidos por inmigrantes derivados, familiares, paisanos o amigos que llegarán por el previo establecimiento de éstos”. ARANGO, J. "España: la inmigración en la encrucijada", op. cit., pp. 25 y 26. 
to jurídico. La importancia que el inmigrante otorga a su vida en familia, en conjunción con las propias dificultades inherentes al ejercicio de la RF — sometida al cumplimiento de gravosas condiciones jurídico-económicas - determinan que en ocasiones los familiares reagrupables se encuentren ya en el territorio del Estado de destino, si bien de forma irregular, dando lugar a la denominada "RF de hecho", de importancia cualitativa no desdeñable ${ }^{204}$.

En todos los supuestos de RF, el particular estatus jurídico que ligue al principal con el Estado receptor ostenta un carácter determinante para el despliegue del derecho a la RF y las modalidades en que ésta tenga lugar. Constituye una condición común a los diferentes regímenes jurídicos existentes en materia de RF la exigencia de la regularidad de la estancia del reagrupante. Pese a la gran heterogeneidad que ha presidido la regulación de la RF en el ámbito europeo - al menos inicialmente- la residencia legal del reagrupante se ha erigido siempre en una condición sine qua non ${ }^{205}$ presente de forma constante. Y ésta constituye además una característica esencial al régimen jurídico de la RF a nivel mundial, en vista de que ningún país industrializado concede la RF a los inmigrantes indocumentados ${ }^{206}$.

Adicionalmente, la experiencia legislativa y la práctica administrativa arrojan claridad respecto a un aspecto más controvertido: junto a un estatus jurídico regular, el particular estatuto social ${ }^{207}$, económico y/o profesional que ostente el reagrupante ocupa un lugar muy destacado a efectos del despliegue del derecho a la RF. Dicho sin eufemismos, los extranjeros ricos ó los profesionalmente cualificados, lo tienen más fácil — si bien conviene precisar que la migración cualificada queda fuera del objeto del presente trabajo-.

En definitiva, la RF ha estado y sigue estando presidida por la existencia de una pluralidad de regímenes jurídicos en función de la cualidad jurídica y social predicable del extranjero principal o sponsor. Y aquí es donde surge una de las paradojas más criticadas a nivel doctrinal, pero también más asentadas a nivel legislativo: pese a la importancia ética, social y jurídica predicable de la familia y del derecho a la vida familiar, su correlato jurídico, la RF, está presidida por diferentes y en ocasiones muy diferenciados estándares normativos en función del particular estatus que ostente el principal -nacional del Estado receptor, extranjero comunitario, extranjero procedente de un tercer país, estudiante extranjero, inmigrante altamente cualificado, refugiado, desplazado, beneficiario de protección subsidiaria, etc.- - De hecho, una señal distintiva de la regulación jurídica de la RF es que la nacionalidad del reagrupante constituye la característica determinante de la máxima intensidad posible en el disfrute del derecho: si el reagrupante ostenta la nacionalidad del Estado receptor o de un Estado miembro de la UE, gozará de un régimen jurídico mucho más privilegiado que si se

204 La cuantificación de la RF en sí misma resulta problemática como consecuencia de la escasez de datos oficiales. Consecuentemente, dichas dificultades se incrementan exponencialmente cuando se trata de estimar el volumen real de entradas de familiares en virtud de la RF de hecho. De otro lado, la intensidad de la RF de hecho, está provocando las suspicacias estatales hacia cualquier movimiento de familiares en dirección al país de destino. En esta línea, las visitas familiares, en tanto que constituyen, "a preparatory step towards the reunification of a family", están siendo enormemente obstaculizadas. PERROUCHOUD, Richard. “Family Reunification”, op. cit., p. 517.

205 PERRUCHOUD, R. "Family Reunification", op. cit., p. 513.

206 DELAET, Debra. U.S. Immigration Policy in an Age of Rights, op. cit., p. 10. LAHAV, Gallya. "International versus National Constraints in Family-Reunification Migration Policy”, op. cit., p. 361.

207 Kraler y Kofman afirman que "family reunion is a right often restricted to skilled and permanent migrants. Where family reunion is also available for temporary and unskilled migrants, it is by and large granted under more unfavorable conditions, notably with regard to the right to remain in the case a marriage mails. Thus, effectively, socioeconomic status has important implications regarding the nature and scope of the right to family union". KRALER, Albert y KOFMAN, Eleonore. Civic Stratification, Gender and Family Migration Policies in Europe, op. cit., p. 8. 
trata de un ciudadano de un tercer país, aunque en ambos supuestos los familiares sean extranjeros no comunitarios.

Esta diversificación de regimenes jurídicos en función del concreto estatus del reagrupante constituye una característica predicable de los regímenes migratorios existentes en la UE y ha ido in crescendo desde finales de la década de los ochenta ${ }^{208}$. Refleja, asimismo, el alto nivel de diversificación de la inmigración internacional propia de la misma época. Pero en el contexto de la inmigración familiar, la doctrina ha destacado que esta diferenciación de derechos conduce a un elevado grado de fragmentación y estratificación civil ${ }^{209}$ entre los extranjeros, provocando nuevas formas de desigualdad social y efectos de largo alcance, que resultan profundamente contradictorios con los objetivos comunitarios de cohesión e integración sociales y de lucha contra la exclusión y la discriminación, ampliamente enfatizados por la UE desde finales del siglo $\mathrm{XX}^{210}$. La intensidad de estos efectos colaterales de las políticas de RF parece ser directamente proporcional al grado de restricción predicable de las mismas, de modo que a mayores dificultades e imposición de requisitos más selectivos para la entrada de los familiares migrantes, mayor estratificación social entre los extranjeros afectados ${ }^{211}$.

La extraordinaria relevancia cuantitativa y cualitativa que ha adquirido la RF, ha inducido a la creciente "fortificación del Estado" 212 para el mantenimiento del control sobre sus resortes legislativos. En vista de que los estándares internacionales constriñen la soberanía estatal en este ámbito, la fortificación estatal se ha centrado en la restricción oblicua del derecho. Para ello dos elementos del contenido del derecho resultan fundamentales pues constituyen, a nuestro juicio, los dos resortes clave de los que depende la vitalidad y el grado de eficacia real de la RF, con independencia de la ampulosidad de su formulación jurídica: de un lado, la particular definición de familia a efectos de la reagrupación; de otro, las concretas condiciones establecidas para el ejercicio del derecho.

La noción de familia a efectos de la RF posee una extraordinaria relevancia pues determina prima facie sus más destacados efectos cuantitativos - multiplicadores - sobre las entradas de parientes extranjeros. Pese a ello, no puede subestimarse el carácter determinante que también ostentan las concretas condiciones de ejercicio establecidas para la RF. Requisitos excesivamente onerosos

208 KOFMAN, Eleanore. Contemporary European Migrations, Civic Stratification and Citizenship. Paper presented at International Migrations: New Patterns, New Theories. Nottingham Trent University, 11-13 September 2000 , p. 6. Este artículo ha sido también publicado en la revista Political Geography vol. 21, №. 8, 2002, pp. 1035-1054.

209 Por estratificación civil se entiende "how "legal discrimination" (unequal legal statuses) is linked to broader patterns of inequality". Civic Stratification, Gender and Family Migration Policies in Europe: A Comparative Analysis of Family Migration Policies and Their Impact on Persons Affected by Them in 9 European Countries (AT, CZ, DE, DK, ES, FR, IT, NL, UK). 2008. Project management: Veronika BILGER, Albert KRALER. International Centre for Migration Policy Development, p. 6.

210 KRALER, Albert y KOFMAN, Eleanore. Civic Stratification, Gender and Family Migration Policies in Europe, op, cit., pp. 11 y 12. Desde el año 2006 al 2008, el International Centre for Migration Policy Development, bajo la coordinación de BILGER, Veronika y KRALER, Albert, emprendió un proyecto de investigación destinado a analizar las políticas de inmigración familiar implementadas en 9 países de la UE, con el fin de determinar el impacto que las crecientes restricciones legales tienen sobre los inmigrantesy sus familias, así como descubrir las estrategias que adoptan los migrantes para afrontar tales restricciones y organizar sus respectivas vidas familiares. El proyecto señala cómo dichas restricciones tienen, entre otros motivos subyacentes, el cambio en la visión de la familia que de ser tradicionalmente considerada como un factor extraordinariamente benéfico para la integración de los inmigrantes ha pasado a ser percibida como un obstáculo en el proceso de integración. Vid. Civic Stratification, Gender and Family Migration Policies in Europe: A Comparative Analysis of Family Migration Policies and Their Impact on Persons Affected by Them in 9 European Countries. Disponible en http://research.icmpd.org/1445.html

211 Ídem, p. 12.

212 LAHAV, Gallya. "International versus National Constraints in Family-Reunification Migration Policy"; en Global Governance No. 3, 1997, p. 368. 
pueden vaciar materialmente de contenido al derecho, pese a su proclamación formal ${ }^{213}$. Entre las condiciones habituales - junto a la ya señalada en torno al carácter regular de la residencia del principal一, destaca la exigencia de cierta estabilidad en la estancia del reagrupante, lo que se traduce en la imposición de plazos previos más o menos extensos de permanencia legal en el país receptor antes de poder solicitar la RF con sus familiares - el denominado plazo de espera. Su importancia debe ser evaluada a la luz de la vulnerabilidad de los vínculos familiares ante el paso del tiempo, especialmente cuando hay hijos menores implicados, de modo que plazos excesivamente largos pueden conducir a un vaciamiento del derecho. Junto a estos condicionantes, las legislaciones han exigido otros muchos requisitos adicionales - recursos económicos para asegurar la subsistencia de la familia, cierta estabilidad laboral, vivienda adecuada, seguro médico...etc. - , cuya intensidad y rigor son variables, pero cuya importancia práctica es de primer orden.

Y, más allá de los dos resortes señalados, todo el derecho migratorio ha constituido desde sus inicios una rama impregnada de una alta dosis de discrecionalidad administrativa, fomentada por la abundancia de conceptos jurídicos indeterminados que han conferido una elevada cuota de ambigüedad y condicionalidad ${ }^{214}$, muy propicia para el mantenimiento de áreas flexibles donde los Estados puedan manejar cómodamente sus intereses nacionales. Adicionalmente la extranjería y la inmigración constituyen ámbitos donde la aplicación del criterio de oportunidad o conveniencia política se produce con mayor intensidad que en otras áreas ${ }^{215}$, circunstancia que propicia y es a su vez fomentada por la discrecionalidad administrativa ya apuntada.

La RF no constituye ninguna excepción en este sentido, sino más bien todo lo contrario. Como se ha destacado desde los primeros escritos doctrinales sobre esta materia surgidos en el ámbito europeo, la introducción de conceptos y requisitos para el ejercicio de la RF suele hacerse bajo formulaciones legales vagas, que permiten niveles elevados de discrecionalidad en su interpretación y aplicación por las autoridades ejecutivas, de forma que éstos puedan adquirir distintos matices según que el concreto contexto económico, social, cultural y político de cada Estado aconseje decantarse por interpretaciones restrictivas o liberales ${ }^{216}$. El margen es obviamente muy superior cuando tales condicionantes no vienen marcados por el poder legislativo, sino en instrumentos jurídicos

213 En referencia a los primeros proyectos de Directiva comunitaria sobre el derecho a la RF, Cholewinsky señaló que la introducción del derecho a la RF podía estar en peligro de convertirse en superflua en la práctica, como consecuencia de las onerosas condiciones impuestas para su ejercicio. CHOLEWINSKY, Ryszard. "Family Reunification and Conditions Placed on Family Members: Dismantling a Fundamentla Human Right?"; en European Journal of Migration and Law, No. 4, 2002, p. 273; En idéntico sentido se manifiesta Richard Perrouchoud al subrayar la importancia de las concretas condiciones de ejercicio establecidas para la RF, señalando que aun cuando la RF es una de las escasas excepciones admitidas por los Estados en tiempos de estrictos controles migratorios, sin embargo, "las condiciones que han de reunirse para la misma (definición de la familia, medios financieros, adecuado alojamiento) están a veces tan restrictivamente diseñadas como para llevar a una erosión del principio de unidad familiar". PERROUCHOUD, R. "Family Reunification”, op. cit., p. 517, traducción propia.

214 LAHAV, Gallya. "International versus National Constrainst in Family-Reunification Migration Policy”, op. cit., p. 354; Para Santos Arnau, "toda política de extranjería (...) precisa de un cierto margen de maniobra que permita a la Administración ir ajustándola a las diversas variables e intereses que confluyen en su formulación: control de flujos migratorios, coyuntura económica y mercado de trabajo, condiciones sociales etc... En ese contexto, la Administración puede entender que los conceptos jurídicos indeterminados le proporcionan un margen de arbitrio muy conveniente a dichos efectos, permitiendo no sólo un ajuste de la política de extranjería a la coyuntura general, si no, incluso, permitiéndole tomar en consideración circunstancias y necesidades de índole local, modulando territorialmente su aplicación”. SANTOS ARNAU, Lidia. "Conceptos jurídicos indeterminados y discrecionalidad: especial referencia al visado para la reagrupación familiar”, op. cit., p. 442.

215 VIDAL FUEYO, Ma del Camino. Constitución y extranjería. Madrid, Centro de Estudios Políticos y Constitucionales, 2002, p. 42.

216 PERRUCHOUD, R. “Family Reunification..., op. cit., p. 513. 
promulgados por el poder ejecutivo y administrativo, circunstancia que, por otro lado, resultó muy habitual en las primeras formulaciones jurídicas de la RF en los distintos sistemas europeos. El caso español resulta paradigmático de esta faceta, pues las primeras regulaciones de la RF, lejos de asentarse a nivel legislativo, solían condensarse en una variada gama de normas administrativas de segundo orden -órdenes ministeriales, circulares e instrucciones- hasta el punto de ser una norma reglamentaria la primera en dar cobertura jurídica a este derecho ${ }^{217}$.

Reunidos los requisitos y exigencias para poder acceder a la RF, los familiares que encajen en el concepto de familia legalmente establecido, podrán acceder al territorio y residir junto con el principal en el Estado receptor, sin que les sean de aplicación las normas generales que rigen la entrada y residencia de extranjeros por fines laborales. En consecuencia, en esta materia es mucho más relevante examinar en primer lugar el concreto estatus que ostente el reagrupante, más que las condiciones generales de entrada y acogida de extranjeros en dicho estado, pues, como señalamos, dicho estatus será el determinante para las modalidades de ejercicio de la RF y el concreto régimen jurídico aplicable a la misma ${ }^{218}$. Con todo, esta tesis restringe su ámbito al estudio del régimen predicable al colectivo de reagrupantes constituidos exclusivamente por nacionales procedentes de terceros países y los miembros, también extranjeros, de sus familias.

\subsection{La Formación Familiar}

La formación familiar — también denominada “inmigración matrimonial”, formación de parejas a través de la migración o incluso "importación de parejas" ${ }^{219}$ - abarca diversos movimientos migratorios que giran en torno a la entrada y establecimiento en el territorio del Estado receptor de la pareja extranjera del reagrupante - habitualmente casado o en vísperas de celebrar su matrimonio, si bien incluiría también a la pareja de hecho en aquellos supuestos en que su admisión esté contemplada por la legislación del país de destino ${ }^{220}$.

La nota común a los desplazamientos migratorios insertados dentro la formación familiar, reside en el hecho de que los vínculos familiares se han formado con posterioridad a la entrada y residencia del principal en el país de destino, frente al carácter preexistente de los vínculos familiares en la RF en sentido estricto. Además, la formación familiar suele amparar una noción más amplia de reagrupante, abarcando a los propios nacionales del Estado donde la familia extranjera pretende reunirse - en cuyo caso, si se trata de un nacional, no resulta pertinente hablar de la posterioridad de los vínculos familiares al establecimiento en el Estado receptor. La formación familiar incluye

217 AJA FERNÁNDEZ, Eliseo. "Veinte años de doctrina del Tribunal constitucional sobre los derechos de los inmigrantes"; en La democracia constitucional: estudios en homenaje al profesor Francisco Rubio Llorente, vol. 1. Madrid, Congreso de los Diputados, 2002, p. 448. Aja califica esta situación -la regulación de la extranjería y la inmigración por normas administrativas, muchas veces a través de simples circulares- como un "problema general serio".

218 PERRUCHOUD, R. "Family Reunification", op. cit., p. 513.

219 CEBOLLA BOADO, Héctor y GONZÁLEZ FERRER, Amparo. La inmigración en España (2000-2007). De la gestión de flujos a la integración de los inmigrantes, op. cit., p. 87.

220 En la definición proporcionada por Cebolla Boado y González Ferrer, la formación familiar "hace referencia a la entrada de nuevos inmigrantes que son admitidos al país receptor para constituir una pareja”. La inmigración en España (2000-2007). De la gestión de flujos ...., op. cit., p. 83. KRALER y KOFMAN apuntan la siguiente definición: "family formation, including marriage migration, in which a migrant joins a settled migrant or non-migrant to form a family - usually though not necessarily through marriage": KRALER, Albert y KOFMAN, Eleanore (coords.). "Family migration in Europe: policies vs reality"; en IMISCOE: A Network of Excellence on International Migration, Integration and Social Cohesion in Europe. Policy Brief, №. 16, agosto 2009, p. 2. 
figuras tan abundantes como los matrimonios mixtos o tan controvertidas como los matrimonios de conveniencia, constituyendo uno de los aspectos más complejos dentro de la inmigración familiar.

Esta categoría fue tradicionalmente encuadrada como un subtipo específico dentro de la reunificación familiar ${ }^{221}$ y su tratamiento estadístico se realizaba desde la perspectiva miope de entender la formación familiar como un mero aspecto de la $\mathrm{RF}^{222}$. En la actualidad la migración matrimonial todavía permanece injustificadamente encajada como una subcategoría de RF, al menos en lo que respecta a su tratamiento jurídico en el ámbito europeo ${ }^{223}$. Pese a ello, a nivel normativo fue marginada con respecto a la RF en sentido estricto ${ }^{224}$, circunstancia que todavía puede detectarse. Sin embargo, desde nuestro punto de vista, la formación familiar alberga características muy singulares y, especialmente, sus efectos diferenciados con respecto a la RF en sentido estricto, la hacen merecedora de una conceptualización e incluso de un tratamiento normativo diferenciado ${ }^{225}$.

Sobre la inmigración matrimonial se concentran múltiples facetas problemáticas para el Estado receptor, por tres motivos principales: En primer lugar, sus efectos multiplicadores sobre las entradas de extranjeros son mayores y sin límite temporal alguno, en comparación con aquellos propios de la RF en sentido estricto, pues ésta última suele agotarse con la llegada al país de destino del cónyuge e hijos del reagrupante. Frente a ella, la formación familiar no sólo implica a las primeras generaciones de inmigrantes, sino a los descendientes y, además, suele potenciarse entre las segundas y subsiguientes generaciones, siendo por ello el tipo de migración familiar con efectos multiplicadores más intensos y persistentes cronológicamente ${ }^{226}$ y con mayor incidencia en la formación de cadenas migratorias. En suma, mientras los efectos de la RF son cronológicamente decrecientes, la incidencia de la inmigración matrimonial sobre el número de admisiones de familiares en el país receptor se incrementa conforme avanza el tiempo desde el inicio del flujo migratorio ${ }^{227}$ - hasta el punto de afirmarse que constituye "una fuente potencialmente infinita de nueva inmigración" ${ }^{228}$ - En segundo lugar, la formación familiar puede conllevar más retos de cara a la integración, pues implica para el Estado receptor "afrontar generaciones de recién llegados una y otra vez"229, habitualmente en edad adulta y, por consiguiente, supuestamente con mayores dificultades de adaptación a su nuevo entor-

221 KOFMAN, Eleonore. “Family-Related Migration: A Critial Review of European Studies”, op. cit., p. 246.

222 KOFMAN, Eleonore. "Family Migration”; en World Migration 2008, op. cit., p. 155.

223 En sentido crítico en torno al mantenimiento de la concepción de la formación familiar como un tipo de reunificación familiar se posicionan también CEBOLLA BOADA y GONZÁLEZ FERRER. La inmigración en España (20002007)..., op. cit., p, 87.

224 En el tercer y cuarto capítulos de nuestro estudio, tendremos ocasión de analizar, al estudiar el ámbito comunitario y el interno español, la proliferación de definiciones amplias de RF, que amparan los vínculos familiares tanto previos como posteriores a la estancia del reagrupante en el país de destino. Sin embargo, un análisis cuidadoso de la legislación, nos lleva a concluir que la prioridad de los vínculos preexistentes es obvia, tanto en la mayor tutela que reciben como en las mayores facilidades para la reunión con los familiares.

225 En idéntico sentido se pronuncian CEBOLLA BOADO, Héctor y GONZÁLEZ FERRER, Amparo. La inmigración en España (2000-2007). De la gestión de flujos a la integración de los inmigrantes, op. cit., pp. 83-84.

226 En palabras de Cebolla Boado y González Ferrer, "mientras que la RF afecta únicamente a los inmigrantes de primera generación que poseían familia antes de emigrar y, por tanto, tiene lugar muy al comienzo del flujo migratorio, la migración para la formación de parejas no se restringe a las fases iniciales de los flujos migratorios sino, antes al contrario, suele intensificarse a medida que el flujo se consolida, siendo más frecuente entre los hijos de los inmigrantes de primera generación que se han criado a caballo entre el país de origen y de destino y, además, parece ser particularmente frecuente entre determinados grupos étnicos”, Ídem, p. 83. En torno a la persistencia cronológica de los efectos de la migración matrimonial, vid. KOFMAN, Eleanore. Civic Stratification, Gender and Family Migration Policies in Europe, op. cit., p. 7.

227 GONZÁLEZ FERRER, A. Estrategias familiares y laborales en la emigración, op. cit., p. 19.

228 CEBOLLA y GÓNZALEZ. La inmigración en España (2000-2007)..., op. cit., p. 87.

229 Ídem, p. 83. 
no. Y, en tercer lugar, dado que los valores culturales suelen transmitirse dentro del núcleo familiar, es la figura a la que se le adjudica mayor capacidad de perpetuación de los valores tradicionales de la sociedad de origen ${ }^{230} \mathrm{y}$, por ende, un potencial superior de repliegues culturales.

Los efectos señalados explican que las ambigüedades que proliferan en materia migratoria sean especialmente fructíferas en este específico tipo de inmigración familiar. De ahí que, formalmente los distintos regímenes jurídicos suelan partir de un concepto amplio de RF, que abarcaría tanto los vínculos previos como los posteriores al establecimiento del reagrupante en el país de destino. En consecuencia, dichos regímenes suelen prever un tratamiento conjunto y aparentemente nivelado de ambos tipos de migración familiar - RF en sentido estricto y formación familiar-. Sin embargo, un análisis más exhaustivo de los mismos revela que la formación familiar o inmigración matrimonial constituye un aspecto especialmente problemático y por ello dificultado a nivel jurídico, lo que resulta tanto más evidente si la referencia comparativa se sitúa en la RF en sentido estricto. En vista de todo ello, la consideración normativa diferenciada de la formación familiar podría mitigar dichas ambigüedades, difícilmente justificables de otro modo, al tiempo que podría incrementar la eficacia de las políticas de control de flujos ${ }^{231}$. Pese a ello, dado que este trabajo se realiza desde parámetros fundamentalmente jurídicos, $-\mathrm{y}$ en vista de que en el ámbito normativo europeo predomina un concepto amplio de RF, inclusivo tanto de la RF en sentido estricto, como de la formación familiar- a efectos de simplificación se empleará el término de RF en sentido extensivo, abarcando con él también a la inmigración matrimonial.

Siguiendo a Kofman ${ }^{232}$, dentro de la formación familiar es posible distinguir dos categorías separadas:

1. Aquella inmigración familiar que tiene lugar cuando las segundas y subsiguientes generaciones de hijos de origen inmigrante establecidos en el Estado receptor, traen o desean traer a sus esposos/as o prometidos/as, procedentes del país natal de sus progenitores o del ámbito geográfico más amplio constituido por la denominada diáspora familiar ${ }^{233}$.

En este primer tipo de formación familiar, los reagrupantes estarían constituidos por aquellos descendientes de inmigrantes asentados en el país de destino y que elijen pareja dentro del entorno étnico del que proceden sus progenitores. La inclusión de las personas de origen inmigrante que actuarán como reagrupantes parte de las segundas generaciones en adelante, y sin límite temporal ni tampoco espacial - la pareja puede encontrarse no sólo en el Estado de origen de los progenitores, sino en cualquier otro tercer Estado en el que la familia transnacional ramificada cuenta con parientes y contactos-, lo que de entrada revela ya sus más prolongados efectos temporales con respecto a la RF en sentido estricto. De otro lado, los reagrupantes, en tanto que hijos de inmigrantes, incluyen

230 GONZÁLEZ FERRER, A. Estrategias familiares y laborales en la emigración, op. cit., p. 198.

$231 \mathrm{La}$ necesidad de diferenciar la RF en sentido estricto de la formación familiar por constituir dos estrategias migratorias muy diferentes, con efectos claramente desiguales, es ampliamente estudiada y enfatizada por GONZÁLEZ FERRER, quien insiste en su tratamiento separado a fin de lograr políticas de inmigración efectivas. Vid. Estrategias familiares y laborales en la emigración, op. cit., especialmente pp. 53-59. En idéntico sentido, CEBOLLA BOADO y GONZÁLEZ FERRER, señalan los retos específicos que la formación familiar plantea de cara al control de flujos y la integración. Los mismos parecen "seguir pasando desapercibidos para gran parte de los gobiernos europeos, incluido el nuestro". La distinción entre ambas resultaría, a jucio de ambos autores, esencial de cara al diseño de las futuras políticas migratorias tanto europeas, como españolas. La inmigración en España (2000-2007)..., op. cit., p, 87.

232 KOFMAN, Eleonore. "Family-Related Migration: A Critial Review of European Studies”; en Journal of Ethnic and Migration Studies, vol. 30, No. 2, 2004, pp. 243-262 (esp. pp. 246-247); KOFMAN, E y MEETO, V. "Family Migration", op. cit., pp. 155-158.

233 MEETO, Veena y KOFMAN, Eleonore. “Family Migration”. World Migration 2008. OIM, op. cit., p. 155. 
tanto a individuos que ya han sido naturalizados en el Estado receptor como a extranjeros que todavía no han adquirido la nacionalidad de dicho Estado. Si el reagrupante goza de la nacionalidad del país receptor, se multiplican las dificultades para restringir esta modalidad migratoria ${ }^{234}$.

Por su parte, dentro de los familiares reagrupables se insertaría la pareja extranjera del reagrupante, abarcando tanto al cónyuge como al prometido/a. Es muy habitual que la categoría de reagrupantes protegida por este primer subtipo de formación familiar, esté constituida por personas de origen inmigrante que se encuentran plenamente arraigados en el país de destino, donde muy frecuentemente han nacido o bien han sido criados desde tempranas edades, y con cuyo territorio guardan muchas más conexiones e identificaciones culturales que con el entorno ya lejano de sus progenitores. Sin embargo, la sociología ha destacado que, incluso en el supuesto de que los vínculos con el país de origen de sus padres sean ya débiles, los individuos de origen inmigrante muestran cierta tendencia a encontrar pareja en dicho entorno ${ }^{235}-\mathrm{o}$ dentro del espacio geográficamente más amplio constituido por las comunidades de origen dispersas en terceros Estados. De ahí que pueda afirmarse la existencia de cierta tendencia endogámica entre las personas de origen extranjero, al menos en lo que respecta a sus preferencias y vínculos sentimentales, y que este subtipo esté experimentando constantes crecimientos ${ }^{236}$.

2. El segundo tipo de formación matrimonial se produce cuando el reagrupante, - entendiendo por tal tanto un extranjero residente permanente en el Estado receptor como un nacional de dicho Estado-, trae o pretende traer a dicho país una pareja que no ostenta la nacionalidad de dicho Estado, a la cual ha conocido durante una estancia en el extranjero, bien sea por motivos de estudio, trabajo, o simplemente por vacaciones. "En este caso, el matrimonio es un efecto secundario de la razón que originó el viaje al extranjero"237.

Si el reagrupante cuenta con la nacionalidad del país de destino, surgen los matrimonios mixtos o interétnicos ${ }^{238}$, de importancia cuantitativa creciente. Para nuestro objeto de estudio, los matrimonios mixtos relevantes son aquellos en los que el cónyuge extranjero reside en un tercer país, donde habitualmente ha tenido lugar el romance o incluso sin necesidad de que, al menos inicialmente, medie traslado físico por parte del reagrupante nacional, como consecuencia de las múltiples posibilidades de romance virtual ofrecidas por Internet ${ }^{239}$. Este tipo de matrimonios interétnicos han sido profusamente estudiados por la sociología, considerándose su existencia como indicadores de

234 CEBOLLA BOADO y GONZÁLEZ FERRER. La inmigración en España..., op. cit., p. 87.

235 LIEVENS, John. “Interethnic Marriage: Bringing in the Context through Multilevel Modeling”; en European Journal of Population, 1998, vol. 14, p. 121.

$236 \mathrm{Al}$ respecto, Kofman afirma que la expansión se debe al crecimiento de las segundas y siguientes generaciones que continúan casándose con "parejas externas", siendo especialmente característico de las poblaciones Turcas y de los inmigrantes procedentes del Norte de Africa. "Family-Related Migration: A Critial Review of European Studies”, op. cit., pp. 246-247.

237 MEETOO, V y KOFMAN, E. “Family Migration”. World Migration 2008. OIM, op. cit., p. 155.

238 Lievens, en un estudio relativo a los matrimonios mixtos conformados por turcos y marroquíes residentes en Bélgi$\mathrm{ca}$, ha demostrado que aquellos grupos de inmigrantes que logran obtener mayor movilidad social y mayores niveles educativos, así como aquellos que viven en distritos donde la lengua dominante es la del país receptor y a su vez proceden de zonas más urbanizadas en sus respectivos países de origen, tienen probabilidades superiores de contraer matrimonios mixtos. Estas conclusiones avalarían la denominada tesis asimilacionista, que contempla a dichos matrimonios como indicativos de integración en el país de destino. LIEVENS, John. “Interethnic Marriages...”, op. cit., p. 150.

239 En torno a este tipo de "cross-border marriages", Kofman y Meeto han señalado que "the majority of the couples are introduced with the prior intention of marriage and have either no or only a comparatively short period of courtship. The Internet is increasingly replacing face to face contact (hence the rather derogatory "mail- order brid label" as a means of introducing potencial spouses". "Family Migration”. World Migration 2008, op. cit., p. 156. 
integración ${ }^{240}$ en las sociedades de destino - esto es, como un "barómetro más relevante que las encuestas de comportamiento, en torno al grado en que las minorías étnicas están orientadas hacia la cultura dominante"241.

La formación familiar, con sus dos subtipos, constituye una categoría cuya importancia no hará sino aumentar, en vista de múltiples circunstancias convergentes: las mayores facilidades para el desplazamiento internacional, las nuevas tecnologías de la información y el extraordinario auge adquirido por las redes sociales, la formación de sociedades crecientemente interculturales y, por ende, más propensas al mestizaje, así como la ya apuntada tendencia endogámica de las segundas y posteriores generaciones de inmigrantes y el auge de los matrimonios mixtos o binacionales.

\subsection{Inmigración de toda la Familia}

La tercera categoría de inmigración familiar cubre la inmigración conjunta y simultánea de todo el núcleo familiar. Esta modalidad migratoria fue relativamente habitual en el pasado en los países de larga tradición migratoria ${ }^{242}$, pero en la actualidad su reconocimiento suele restringirse a los trabajadores altamente cualificados ${ }^{243}$, quienes se benefician de un régimen jurídico más privilegiado, pudiendo disfrutar del derecho a llevarse de forma inmediata a sus familiares más próximos al Estado de destino.

Ya señalamos en su momento que las políticas migratorias restrictivas implantadas a partir de los setenta dificultan enormemente la migración de toda la familia ${ }^{244}$, sembrando de riesgos la empresa migratoria, de ahí que ésta suela producirse en fases sucesivas, mediando entre ellas la RF de los miembros que en principio fueron dejados atrás en el país de origen. Pese a ello, en vista de la tendencia en aumento a promocionar la inmigración de sectores profesionales muy cualificados, cabría presuponer que esta modalidad migratoria constituya una categoría en auge, incrementando su importancia cuantitativa en un futuro ${ }^{245}$.

\subsection{Reunificación de la Familia Extensa}

Cabría hablar de un cuarto tipo de inmigración familiar, si bien se trata de una categoría marginal, existente únicamente en sociedades de asentamiento que gozan de larga tradición migratoria ${ }^{246}$,

240 TRAPPENBURG, Margo. "Restricting Family Rights: Philosophical Reflections on Transnational Marriages”; en HONOHAN, I; JENNINGS, J. (eds.). Republicanism in Theory and Practice. London, Routledge, p. 174. SCOTT, Sam and CARTLEDGE, Kim H. "Migrant Assimilation in Europe: A Transnational Family Affair"; International Migration Review, vol. 43, No. 1, 2009, p. 64.

241 COLEMAN, David. "Trends in fertility and intermarriage among immigrant populations in Western Eurpe as measures of integration”; en Journal of Biosocial Science, n² 26, 1994, pp. 107-136, traducción propia.

242 En palabras de Battistella, y en contraste con lo que sucede en la actualidad, "long gone are the images of entire families disembarking from steamboats on to Ellis Island or reaching the shores of South America". El propio autor señala a pie de página que Australia constituye una excepción, pues desde 1970 la familia como unidad ha emigrado a dicho país, hasta el punto de que más de la mitad de los extranjeros ingresaron como parte de una pareja o familia nuclear. BATTISTELLA, Graziano. "Family Reunification: policies and Issues”, op. cit., p. 244.

243 KOFMAN, Eleanore. Civic Stratification, Gender..., op. cit., p. 4.

244 BORRAZ, Fernando; POZO, Susana y ROSSI, Maximo. And What About the Family Back Home?. International Migration and Happiness, op. cit., p. 2.

245 KOFMAN, Eleonore y MEETOO, Veena. "Family Migration"; Wold Migration 2008: Managing Labour Mobility in the Evolving Global Economy. International Orgamization for Migration, op. cit., p. 156.

246 Ídem. 
por lo que resulta poco extendida e incluso de difícil traducción al castellano - "sponsored family members"-.

En esta categoría los vínculos familiares que habilitan para entrar y residir en el país receptor con el sponsor son entendidos en un sentido muy amplio, de modo que cubren múltiples parientes no incluidos dentro de la familia en sentido nuclear - tales como hermanos/as, tíos, abuelos, etc., e incluso históricamente llegaron a amparar a individuos que no encajarían si quiera en la categoría de familiares en sentido amplio. Como ejemplo extremo de familia en sentido extenso, hasta incluir categorías en nada asimilables a los parientes, se puede citar el caso de ciertas políticas migratorias implantadas en algunos países de América Latina a principios de la década de los cincuenta del pasado siglo, que permitían incluso la inmigración de amigos del reagrupante, incluyéndolos dentro de la noción amplia de familia a efectos migratorios ${ }^{247}$.

Dado que se trata de miembros no incluidos dentro del núcleo familiar, al menos según los parámetros occidentales, constituyen flujos migratorios dejados enteramente a la discrecionalidad del Estado receptor ${ }^{248}$ y sobre los cuales la tutela ofrecida por el DIDH arroja muy escasa eficacia jurídica. Por ello habitualmente son excluidos de la protección que se otorga vía la RF, como ocurre en el contexto europeo, donde este tipo de vínculos no encajan en la categoría de familiares reagrupables.

En el supuesto de EEUU, la admisión de parientes en sentido amplio fue introducida en 1965, a raíz de la aprobación de la Immigration and Nationality $\mathrm{Act}^{249}$, que la permitió incluyéndola dentro del sistema preferencial, graduando las entradas de forma piramidal en función del vínculo concreto de parentesco y el tiempo previo de residencia legal del reagrupante. Sin embargo, sobre estas categorías de parientes se aplican límites cuantitativos muy estrictos - $\operatorname{cupos}^{250}$-, los familiares están tipificados dentro de las "categorías no preferenciales" y, habitualmente, su ingreso al país se suele hace depender de la nacionalización previa adquirida por el reagrupante. Ambas vías pretenden amortiguar el potencial multiplicador que sobre las entradas de extranjeros supondría la admisión incondicionada de esta categoría amplia de familiares ${ }^{251}$.

247 Migration of Family Units and Family Reunion. The ICEM Experience. Document MC/SAI/II/19. Second ICM Seminar on International Migration. Geneva, 1975, p. 6. En el mismo sentido, PERRUCHOUD, R. "Family Reunification", op. cit., p. 515.

248 De ahí que Kofman y Meetoo los califiquen como "flujos discrecionales” y señalen además que allí donde están contemplados, como en EEUU, estén sometidos a límites numéricos así como a condiciones de entrada muy estrictas. "Family Migration", op. cit., p. 156.

249 BUCHANAN, William. "Myths of Family Reunification. Immigrants disrupt families to start process"; en The Social Contract, fall 1996, p. 34, si bien conviene matizar que el autor se muestra muy crítico en torno a la admisión de este tipo de familiares.

250 Sobre este punto ARCOS, Crescencio, ex subsecretario de Homeland Security para Asuntos Internacionales de USA, puntualiza que "la cuota de inmigrantes legales designada anualmente por los Estados Unidos en términos globales es de aproximadamente 675,000 personas. De esa cuota anual, a México solo se le han asignado de 15,000 a 18,000. Es importante señalar que el sistema de cuotas limita la posibilidad de números de cuotas asignadas a las categorías preferenciales en solo un 7\% del total". El autor enfatiza la preocupación, confusión e incluso estancamiento que el tema de la RF genera en EEUU, señalando que "la preocupación inicial surge de las cantidades elevadas de inmigrantes autorizados que solicitan la entrada legal de sus familiares que permanecen en el país de origen, además del potencial que se avecina con la posibilidad de que los indocumentados reciban estatus migratorio y, a su vez, soliciten a sus familiares"; en "El empantamiento migratorio en los EEUU: Derechos humanos y reunificación familiar”. IV Simposio Internacional de Inmigración y Derechos Humanos: Inmigración y Familia, Valencia, 9 de abril de 2010, p. 4.

251 JASSO, Guillermina y ROSENZWEIG, Mark R. "Family Reunification and the Immigration Multiplier: U.S. Immigration Law, Origin-Country Conditions, and the Reproduction of Immigrants”; en Demography 23, 1986, pp. 291-311. 
Esta cuestión debe examinarse en conjunción con la vinculación de la inmigración a cuestiones de seguridad nacional a raíz de los ataques terroristas de septiembre de 2011 y el altísimo número de inmigrantes irregulares existente en EEUU — una bolsa aproximada de 12 millones de "sin papeles", con el consiguiente potencial multiplicador en el caso de que se produjese su hipotética regularización-. Todo ello explica que sobre esta categoría de familiares reagrupables se estime que, en términos reales, el período de espera previo ${ }^{252}$ para poder proceder a la RF pueda tornar en inviable el derecho formalmente existente.

\section{EL CARÁCTER INTRÍNSECAMENTE PROBLEMÁTICO DE LA REUNIFICACIÓN FAMILIAR}

La RF — entendida en sentido amplio - condensa y ejemplifica gran parte de las dificultades y tensiones inherentes a las políticas migratorias ${ }^{253}$. Esta situación surge en parte como consecuencia de que la inmigración familiar se sitúa en el punto de confluencia de varias de las facetas de las políticas implementadas para gestionar la llegada de flujos migratorios y su asentamiento en los países de destino, habitualmente informadas por principios y objetivos contradictorios que terminan desembocando en la propia regulación de la reagrupación familiar.

Para encuadrar bien este tema, resulta de utilidad recordar que las políticas relacionadas con los extranjeros se asientan sobre un trípode clásico: son los denominados tres ejes de las políticas de inmigración ${ }^{254}$. De un lado, comprenden las normas reguladoras de la entrada y el control de los flujos migratorios; el segundo eje está constituido por las disposiciones relativas a la demanda de asilo y la situación de los refugiados y, finalmente, el tercer eje reposa sobre las medidas destinadas a la integración de los inmigrantes, incluyendo las normas relativas al acceso a la nacionalidad. En los últimos tiempos se ha incorporado un cuarto eje, constituido por las políticas de cooperación al desarrollo a fin de aminorar las causas productoras de emigración, entre las que cabe destacar la opción promovida por Sami Näir que involucra a los propios inmigrantes en este proceso, denominada "codesarrollo"255. Si bien este último eje "cumple ante todo, una función legitimadora, de relaciones

252 Se ha señalado que sobre estas categorías "pudieran darse esperas de aproximadamente 120 años para muchos que buscan traer a sus familiares a vivir a los Estados Unidos". en ARCOS, Crescencio. "El empantamiento migratorio en los EEUU: Derechos humanos y reunificación familiar", op. cit, p. 4.

253 En el mismo sentido se expresa Santos Arnau, para quien las tensiones y la confluencia de intereses propia de la inmigración encuentran en la RF “uno de sus puntos álgidos”. SANTOS ARNAU, Lidia. "Conceptos jurídicos indeterminados y discrecionalidad: especial referencia al visado para la reagrupación familiar”, op. cit., p. 443.

254 ARANGO, Joaquín. “Dificultades y dilemas de las políticas de inmigración”, op. cit., pp. 54-55.

255 Sobre el tema pueden consultarse, entre la amplísima bibliografía ya existente, NÄIR, Sami. "Flujos migratorios y codesarrollo"; en Tiempo de paz, No. 57, 2000, pp. 122-126. NÄIR, S. "Codesarrollo para las migraciones"; en Estudios en homenaje al profesor Gregorio Peces-Barba, Vol. 4. Madrid, Dykinson, 2008, pp. 657-674. MALGESINI, Graciela. "Reflexiones sobre migraciones, cooperación y codesarrollo"; en Arxius de sociologia, No. 5, 2001, pp. 123146. MONTES DEL CASTILLO, Ángel. "La integración de los inmigrantes en los proyectos de desarrollo. Algunas condiciones para que funcione el codesarrollo"; en MARTÍNEZ MARTÍNEZ, M. M. y MONTES DEL CASTILLO, A (coords.) Migraciones, cultura y desarrollo. Murcia, Universidad de Murcia, 2008, pp. 205-216. PÉREZ YÁÑEZ, Rosa María. "Renovadas orientaciones en la gestión de la migración: las propuestas provenientes del codesarrollo"; en SALINAS DE FRÍAS, Ana (coord..). Inmigración e integración: aspectos sociales y legales. Madrid, Sequitur, 2008, pp. 77-110. CORTÉS MAISONAVE, Almudena. "Codesarrollo y Migración: una lógica transnacional. Reflexiones desde el Caso Español”; en Puntos de Vista: Cuadernos del Observatorio de las Migraciones y la Convivencia Intercultural de la Ciudad de Madrid, No. 8, 2006, pp. 7-27. 
públicas, cuando no de mera alimentación de buenas conciencias" ${ }^{256}$ y puede subsumirse en el primer eje, en tanto que política preventiva del control de flujos ${ }^{257}$.

Dado que la cuestión relativa al estatus de los refugiados queda excluida de nuestro estudio, conviene partir de la distinción establecida por Jiménez Piernas ${ }^{258}$. Este autor efectúa un deslinde entre política pública de inmigración -integrada por las normas sobre control de flujos y regularización de los no nacionales - frente a la política pública de extranjería - constituida por las disposiciones relativas a los derechos fundamentales reconocidos a los extranjeros. El equilibrio entre ambas ramas de las políticas públicas migratorias suele ser difícil de alcanzar, especialmente en tiempos de restricción migratoria y reacciones de sospecha y temor ante la llegada de flujos, resultando claramente predominante la política de inmigración.

Aplicando la anterior distinción, la concesión de la RF supone inicialmente para las autoridades internas la obligación de otorgar el derecho de entrada y residencia a los familiares del residente extranjero, encajando dentro de la políticas públicas de inmigración, directamente relacionadas con el control de flujos. Pero, posteriormente, la RF da acceso a un haz de derechos de carácter económico, social y cultural, en su mayor parte, actuaciones todas ellas que englobarían la política pública de extranjería en cuanto determinantes del concreto estatuto jurídico de los extranjeros. La RF encaja por tanto simultáneamente en ambos ejes de las políticas migratorias -inmigración y extranjería-, de modo que concentra y acumula las dificultades propias de cada una. Las escollos se comprenden mejor si tenemos en cuenta que cada una de las ramas se basa en principios discordantes, contradicciones que terminan vertiéndose en las legislaciones y políticas reguladoras de la RF, en cuanto derecho situado a caballo entre ambos ejes.

Pero no se acaban aquí las dificultades inherentes a la RF, pues la vinculación de esta categoría migratoria con los derechos humanos desemboca en la penetración parcial del derecho internacional en asuntos migratorios. De ahí que a las contradicciones anteriores, se le añada la tensión procedente entre el Estado Nacional, tendente a proteger su soberanía y sus intereses nacionales en el marco de las políticas de reagrupación, y el DIDH, cuya influencia termina cuestionando e invadiendo parcelas que tradicionalmente constituían el buque insignia del Estado Nación, como lo es el ámbito migratorio ${ }^{259}$.

En referencia a esta confluencia de tensiones contradictorias que convergen en la migración familiar, Birkman ha señalado muy acertadamente que la "reunificación familiar podría ser vista, de un lado, como un tema humanitario o de derechos humanos, $y$, de otro lado, como un asunto relativo a la inmigración que puede ejercer presiones sobre el mercado laboral o las facilidades sociales, tales como alojamiento, educación y las facilidades médicas"260.

Las contradicciones y tensiones entre las que se desenvuelve la RF no constituyen un campo nuevo, pues han venido siendo abonadas desde los inicios del Estado Constitucional moderno, a raíz de la dicotomía entre los derechos del hombre y los del ciudadano que se encuentra en los cimientos

256 ARANGO, Joaquín. “Dificultades y dilemas de las políticas de inmigración”, op. cit., p. 55.

257 Ídem.

258 JIMÉNEZ PIERNAS, Carlos. "La comunitarización de las políticas de inmigración y extranjería: especial referencia a España”; en Revista de Derecho Comunitario Europeo, No. 13, 2002, p. 864.

259 En este sentido, Gallya Lahav estima que la inmigración constituye la "última personificación de la soberanía”; en "International versus National Constraints in Family-Reunification Migraiton Policy"; op. cit., p. 349.

260 BRINKMAN, Gisbert. “Family Reunion, Third Country Nationals and the Community's New Powers”; en Elspeth Guild and Carol Harlow (eds.). Implementing Amsterdam: Immigration and Asylum rights in EC Law. Oxford, Hart Publishing, 2001, p. 243. 
de la construcción de este tipo de Estado, si bien en la etapa actual estas contradicciones resultan especialmente agudas ${ }^{261}$. La inmigración constituye además un ámbito donde estas presiones afloran de forma muy abrupta porque la protección de los intereses estatales en el control de los flujos, la regulación del mercado laboral y el asentamiento de los extranjeros, suele entrar en conflicto con los compromisos adquiridos por los Estados en materia de derechos humanos ${ }^{262}$. No en vano, se ha señalado que el principio de soberanía, en tanto que personifica las prerrogativas que corresponden al Estado nacional, "se ha convertido en uno de los mayores obstáculos para la protección internacional de los derechos humanos"263. Posteriormente tendremos ocasión de analizar algunos de los tópicos que subyacen tras estas visiones tradicionales.

Finalmente, cabe señalar que la extraordinaria importancia que ha adquirido la RF en el contexto europeo ha determinado la emergencia de nuevas facetas problemáticas, que están irrumpiendo con fuerza en el ámbito político y en el debate social, complicando aún más el complejo entramado en el que se venía desenvolviendo la RF. Veámoslo detenidamente.

\subsection{La RF como elemento central de la política de inmigración}

\section{a. RF, control de flujos migratorios y asentamiento permanente}

La primacía de la RF entre los cauces regulares de entrada de extranjeros en Europa la convierte en un elemento primordial a tener en cuenta en la formulación de las políticas relativas a la admisión de extranjeros. En consecuencia, aplicando la teoría del trípode de ejes de las políticas migratorias en conjunción con la distinción formulada por Jiménez Piernas, la RF constituye un faceta esencial del control de flujos, insertada por ello como uno de los aspectos más sustanciales de las políticas públicas de inmigración.

La importancia cuantitativa de la RF testimonia esta faceta de la RF, pues en el ámbito europeo desde la década de los ochenta la entrada de familiares extranjeros representa numéricamente la proporción más alta ${ }^{264}$ del número de entradas legales. Y, a su vez, de esta vertiente de la RF como parte esencial de las políticas públicas de inmigración, emana gran parte de la trascendencia política que ha adquirido esta categoría migratoria ${ }^{265}$.

Pero, más allá de esta cuestión numérica, la reunificación familiar constituye una categoría migratoria especialmente propensa al asentamiento permanente ${ }^{266} \mathrm{y}$, en la que, consecuentemente, las

261 LAHAV, Gallya. "International versus National Constraints in Family-Reunification Migration Policy”, op. cit, 352. 262 Sobre este punto, Ryszard Cholewinski ha afirmado que "the disjunction between the International commitments states enter into to safeguard human rights and compliance with such rights is most vivid when fundamental rights conflict with state interests in the field of immigration". CHOLEWINSKI, R. "Family Reunification and Conditions Placed on Family Members: Dismantling a Fundamental Right”; en European Journal of Migration and Law, No. 4, 2002, p. 271. En idéntico sentido se pronuncia CORTÉS MARTÍN, José Manuel. "Inmigración y derecho de reunificación familiar en la Unión Europea: ¿mínimo común denominador de las políticas nacionales?”; en Anuario de derecho europeo, No. 4, 2004, p. 27.

263 LAHAV, Gallya. "International versus National Constraints in Family-Reunification Migration Policy", op. cit., p. 353.

264 PERRUCHOUD, R. “Family Reunification”, op. cit., p. 513.

265 KOFMAN, Eleanore. Civic Stratification, Gender and Family Migration Policies in Europe, op. cit., p. 3.

266 Khoo ha estudiado la fuerte correlación existente entre la atracción de parientes al país receptor por parte del residente que solicita la RF y la intención de asentamiento permanente en el Estado de destino. Para ello realizaró un análisis longitudinal basado en tres entrevistas realizadas a una muestra constituida por un colectivo de 5.192 inmigrantes principales o primarios — usando la misma terminología que el artículo— recién llegados a Australia 
entradas autorizadas tienden a convertirse en migración permanente o de larga duración, cuando no, a naturalizarse en el país de destino, dependiendo del grado de dificultad y ventajas inherentes a las concretas políticas de nacionalización. Por ello, la RF a nivel internacional es categorizada dentro de los tipos de inmigración permanente ${ }^{267}$.

Existen múltiples elementos inherentes a la RF que explican su inserción dentro de las tipologías de inmigración permanente. Con carácter general se ha señalado que las categorías migratorias vinculadas a razones humanitarias - entre las que, como se indicó, se incluye la RF- manifiestan una tendencia más acusada al establecimiento definitivo pues, a diferencia de lo que sucede con los inmigrantes cualificados, en ellas el retorno no constituye una "opción realista" 268 . Es más, entre dichas categorías humanitarias, la RF representa el tipo específico donde es mayor la propensión al asentamiento permanente, esto es, donde la correlación entre la llegada de familiares y la decisión de radicar de forma duradera en el país de destino, se produce de forma más intensa ${ }^{269}$. Esta circunstancia explica que la RF sea considerada "un importante factor en la transformación de los programas de trabajadores extranjeros temporales en inmigración permanente"270 — como ejemplifica el caso de Europa occidental - contribuyendo al cumplimiento de lo que ha sido calificada como la "ley de hierro de la inmigración laboral": "nada hay más permanente que los trabajadores temporales"271.

De otro lado, la RF constituye la materialización de una decisión habitualmente adoptada en familia como parte de un proyecto cuya finalidad última reside en la obtención de un beneficio colectivo para los miembros de la familia, que exceda los sacrificios individuales acometidos por éstos. Pero incluso en aquellos casos en que la reagrupación no forme parte del proyecto migratorio inicial, convirtiéndose en una estrategia planteada con posterioridad al establecimiento del inmigrante principal en el Estado receptor, se ha demostrado la existencia de una clara "conexión

durante tres períodos temporales distintos — seis meses, año y medio y tres años y medio, respectivamente, con posterioridad a su entrada en Australia-, durante los cuales se repetían las entrevistas al colectivo seleccionado en torno a su intención de permanencia en Australia. Las segundas y terceras entrevistas resultaban cruciales a la hora de extraer el efecto de "family sponsorhip" sobre la intención de asentamiento. El autor advierte que en dicha decisión existen otros factores que también revisten importancia, tales como los respectivos países de origen, el nivel de satisfacción con el tipo de vida en el país de destino, si la decisión de emigrar se realizó con el fin de mejorar la vida de la familia, así como la edad y el género de los inmigrantes. Por ello, estos factores fueron incluidos en el análisis como variables de control. El artículo concluye que la RF constituye la categoría migratoria donde es mayor la tendencia al asentamiento definitivo en el Estado receptor. Frente a la RF, la inmigración cualificada presenta una propensión mucho menor a establecerse de forma permanente en el país de destino, ante lo cual el artículo sugiere que aquellas políticas que faciliten la reagrupación familiar de esta categoría de inmigrantes cualificados, facilitarán al mismo tiempo y de forma indirecta, el establecimiento de dichos trabajadores. KHOO, Siew-Ean. "Sponsorhip of relatives for migration and immigrant settlement intention"; en International Migration, vol. 41, №. 5, 2003, p. 193. En idéntico sentido, Näir y Goytisolo han subrayado la vinculación entre la RF y la instalación definitiva del inmigrante en el país de acogida. NAÏR, Sami y GOYTISOLO, Juan. El peaje de la vida. Madrid, Aguilar, 2a ed., 2001, p. 22.

267 Así se desprende de los sucesivos informes del SOPEMI, donde la RF se inserta dentro de las categorías de inmigración permanente. A modo de ejemplo, en el informe emitido en el año 2008 y relativo a datos sobre flujos migratorios correspondientes al año 2006, se constata el incremento en la RF y se señala explícitamente que la RF constituye la categoría de inmigración permanente dominante a nivel mundial. International Migration Outlook: SOPEMI, 2008 Edition, Summary in English, p. 2.

268 KHOO, Siew-Ean. "Sponsorhip of relatives for migration and immigrant settlement intention"; op. cit., pp. 186, 191 y 193.

269 Ídem, p. 193.

270 FREEMAN, Gary. “Can Liberal States Control Unwanted Migration?”; en The Annals of the American Academy of Political and Social Science, vol. 534, July 1994, p. 21.

271 CORNELIUS, W. A.; MARTIN, P. L. Y HOLLIFIELD, J. F. Controlling Immigration. A Global Perspective, first edition, 1994, op. cit., p. 86. 
entre el alargamiento de la estancia en el país de destino y el planteamiento de la reagrupación”272. En este sentido, y a un nivel más genérico, la doctrina ha señalado que, con independencia de que la reagrupación forme o no parte de los fines familiares, aquellos proyectos migratorios iniciados con el objetivo general de obtener un mejor futuro para la familia, tienden a una mayor intención de asentamiento definitivo ${ }^{273}$.

Además, en la RF en tanto que tipo específico de inmigración familiar, los factores familiares desempeñan un papel determinante en la decisión de los inmigrantes de instalarse permanentemente en el Estado receptor ${ }^{274}$. En este proceso resultan esenciales las segundas generaciones, cuya mayor facilidad para socializarse en la cultura del país de destino determina su arraigo más rápido en el Estado de $\operatorname{acogida}^{275}$, arrastrando consigo a toda la familia y provocando la estabilización de sus miembros en dicho territorio, con independencia de los planes primitivos de los progenitores ${ }^{276}$. La instalación definitiva en el país receptor tendrá consecuencias de largo alcance tanto sobre los sistemas de bienestar social como sobre la propia configuración interna de las sociedades de acogida, que experimentarán la formación de minorías étnicas y procesos de creciente multiculturalización y heterogeneidad social.

La cuestión del asentamiento permanente de inmigrantes resultaba pacífica en los países de larga tradición migratoria, construidos en base a la presunción de que los inmigrantes acabarán estableciéndose de forma definitiva ${ }^{277}$, y sobre la percepción de los mismos como potenciales ciudadanos que, a la larga acabarán naturalizándose, poniendo con ello un "clausura formal al proceso migratorio" 278 . Pero el asentamiento definitivo constituye una cuestión más problemática para aquellos Estados sin tradición histórica migratoria y que se resisten a concebirse como países de inmigración con tapices sociales crecientemente heterogéneos - resistencia que se refleja asimismo en la ambigüedad ${ }^{279}$ con que los países de Europa occidental regulan la naturalización, cuestión que sigue dependiendo de la soberanía interna de cada Estado.

272 GÓMEZ CRESPO, Paloma. "Gestación y Puesta en práctica de la reagrupación familiar como estrategia”, op. cit., p. 63.

273 KOO, Siew-Ean, “Sponsorhip of relatives for migration and immigrant settlement intention”, op. cit., p. 186.

274 Ídem, p. 179. En similar sentido, CORNELIUS, Wayne A; MARTIN, Philip L. Y HOLLIFIELD, James F. (eds.). Controlling Immigration. A Global Perspective, first edit., op. cit., p. 90. Y, en referencia al caso español, CORNELIUS, Wayne A; TAKEYUKI, Tsuda; MARTIN, Philip L. Y HOLLIFIELD, James F. (eds.). Controlling Immigration. A Global Perspective, 2004, second edit., op. cit., p. 389.

275 Castles y Miller han afirmado al respecto que el proceso de establecimiento definitivo del inmigrante en las sociedades de acogida "está ligado de manera particular con la situación de los hijos de los migrantes: una vez que van a la escuela en el nuevo país aprenden el idioma, forman relaciones de grupo entre iguales y desarrollan identidades biculturales o transculturales, con lo que se hace cada vez más difícil que los padres regresen a sus terruños". La era de la migración. Movimientos internacionales de población en el mundo moderno, op. cit., p. 41. En idéntico sentido, aunque en referencia al contexto histórico de las migraciones temporales de trabajadores invitados a Europa occidental, que terminarían convirtiéndose en definitivas, FREEMAN, Gary. "Can Liberal States Control Unwanted Migration?"; en The Annals of the American Academy of Political ans Social Science, vol. 534, 1994, p. 26.

276 Gómez Crespo también señala que "los gastos de la familia, una vez reagrupada, crecen, y la posibilidad de ahorrar para volver al país de origen se hace cada vez más difícil (....) de este modo, la estancia va prolongándose cada vez más, lo cual puede implicar un distanciamiento cada vez mayor con respecto al país de origen y los familiares que allí quedan”. GÓMEZ CRESPO, Paloma. "Gestación y puesta en práctica de la reagrupación familiar como estrategia”, op. cit., pp. 78 y 80.

277 AVCI, Gamze. "Immigrant Categories: The Many Sides of One Coin?”; op. cit., p. 207; KHOO, Siew-Ean. “Sponsorhip of relatives for migration and immigrant settlement intention”, op. cit., p. 196.

278 ACVI, Gamze. “Immigrant Categories...”, op. cit., p. 207.

279 Ídem. 
En cualquier caso, estudios empíricos han demostrado que los factores familiares resultan determinantes tanto para todas las decisiones migratorias en general como, en particular, para optar posteriormente por la instalación definitiva en el país receptor ${ }^{280}$. Esta circunstancia sin duda pesa en la formulación de las políticas públicas relativas a la RF y explica parcialmente la tendencia a la imposición de múltiples trabas para su ejercicio, en la que, como ya apuntamos, están convergiendo los países clásicos de migración con los Estados europeos ${ }^{281}$.

\section{b. El efecto multiplicador de la RF}

En íntima conexión con esta faceta de la inmigración familiar como elemento fundamental de las políticas públicas de inmigración, se encuentra uno de sus aspectos más controvertidos: el denominado efecto multiplicador de la RF, definido como "el número total de inmigrantes traídos —al país receptor- por cada inmigrante original"282.

La RF multiplica exponencialmente el número de entradas, pues al otorgar el derecho de residencia al sponsor, el Estado receptor se verá obligado a aceptar nuevas admisiones posteriores a favor de los familiares del residente - número de admisiones obviamente superior al representado inicialmente por los reagrupantes admitidos. El fenómeno se complica aún más si se tiene en cuenta que los familiares reagrupados podrán a su vez en un futuro actuar como reagrupantes de sus propios parientes - la denominada RF en cadena o en cascada ${ }^{283}$, cuya terminología en inglés — bola de nieve: snowball family reunification ${ }^{284}$ - resulta enormemente gráfica del potencial multiplicador futuro implícito a esta tipología. Esta situación "crea el potencial para un crecimiento geométrico

$280 \mathrm{KHOO}$, Siew-Ean. "Sponsorhip of relatives for migration and immigrant settlement intention”; op. cit., p. 197. Este estudio llega, por otro lado, a una conclusión sorprendente: aquellos inmigrantes que han recurrido al proceso de la RF para traerse a la comunidad de acogida a sus padres y/o sobrinos, son los que ostentan una mayor probabilidad de erradicarse de forma definitiva en dicha comunidad. Para el caso español, vid. SVEN REHER y REQUENA. "La reciente experiencia migratoria en España”; en SVEN REHER, David y REQUENA, Miguel (eds.). Las múltiples caras de la inmigración en España. Madrid, Alianza Editorial, 2009, especialmente pp. 310-313.

$281 \mathrm{Si}$ bien, conviene en este punto precisar que las similaridades que comienzan a emerger entre las políticas migratorias existentes a ambos lados del Atlántico se refieren fundamentalmente, como aclaran Cornelius y Tsuda, a características existentes al nivel de políticas "macro", dotadas de la suficiente estabilidad como para poder evaluar su grado de convergencia, mientras las políticas migratorias implementadas a nivel micro cambian en todos los países receptores a un nivel vertiginoso - los autores aclaran que las políticas micro cambian anualmente, mientras que las políticas macro sólo cambian una o dos veces en cada generación-. CORNELIUS y TSUDA. "Controlling Immigration: The Limits to Government Intervention”; en CORNELIUS et alter. Controlling Immigration. A Global Perspective, second edit., 2004, op. cit., pp. 16-17.

282 JASSO, Guillermina. "Sponsors, Sponsorship Rates and the Immigration Multiplier"; en International Migration Review, vol. 23, n 4, 1989, p. 856, traducción propia.

283 La expresión fue usada en Bélgica, si bien con cierto carácter peyorativo porque daba cobertura también a supuestos de abuso de la RF en los que el inmigrante legal en territorio belga se casaba - previo precio concertado- con un extranjero/a de su comunidad natal, habitualmente situada en Africa, con la finalidad de que éste último obtuviera acceso al territorio belga para, posteriormente, divorciarse. La situación de abuso se atajó mediante una reforma que supuso que aquellas personas extranjeras que habían obtenido permiso de entrada mediante la RF, no podían a su vez dar entrada a otras personas. Wayne A; MARTIN, Philip L. Y HOLLIFIELD, James F. (eds.). Controlling Immigration. A Global Perspective, first edit. Stanford, Stanford University Press, 1994, p. 246.

284 Sobre el efecto multiplicador y a propósito de lo que él mismo denomina "snowball" family reunifcation, Battistella precisa que el temor a una supuesta invasión de migrantes familiares no está apoyado por las investigaciones. A continuación, y citando a Böhning y a Wequin añade que "empirical information, in fact, demonstrates two things: first, that a relativelly small number of spouses and children remain separated; and second, that by no means all of those who might theoretically be entitled to enter an EC State, if a liberal family reunification regime became the rule, would actually immigrate". Citado por BATTISTELLA, Graziano. "Family Reunification: Policies and Issues", op. cit., p. 246, nota a pie de página número 11. 
en el número de personas habilitadas para la admisión"285, de ahí que provoque en los gobiernos receptores temores ante los hipotéticos "efectos de inmigración incontrolada a partir de la RF" 286 , lo que llevó incluso a explorar los efectos supuestamente "explosivos"287 producidos por las cadenas migratorias creadas y estimuladas a partir de los vínculos de parentesco.

Para enfocar adecuadamente este tema, conviene en este punto recordar que las diversas categorías legales de entrada de extranjeros, terminan desembocando en la RF, de ahí que se haya afirmado que "las políticas de inmigración, en última instancia, acaban seleccionando familias más que individuos"288. A nivel doctrinal, se ha destacado que "las migraciones laborales de carácter fundamentalmente individual, tarde o temprano evolucionan en un volumen importante a migraciones familiares"289, e igualmente, aquellos países que experimentan volúmenes crecientes de refugiados, cuentan con niveles superiores de $\mathrm{RF}^{290}$, por mencionar sólo dos de las categorías más importantes. Incluso los mal denominados procesos de regularización extraordinarios, terminan engrosando las cifras de admisiones futuras de parientes extranjeros ${ }^{291}$. Lo que supone, desde esta perspectiva inflacionista de la RF, que "cada nuevo inmigrante crea un gran reservorio de inmigrantes potenciales"292.

Este aspecto de la RF ha sido profundamente estudiado en EEUU durante la década de los ochenta, donde se le denominó "efecto multiplicador" de la $\mathrm{RF}^{293}$. Los efectos multiplicadores inherentes a la RF no se desencadenan de forma inmediata. Existen dos razones básicas para ello: de un lado, la frecuente imposición de períodos de espera por parte del Estado receptor y, de otro, los distintos proyectos migratorios del reagrupante y su familia, que pueden aconsejar retrasar la llegada de los familiares, incluso aún cuando ya se reúnan los requisitos materiales y formales exigidos para poder acceder a la RF. En consecuencia, la visibilidad de estos efectos y de la propia RF exige que el país receptor haya experimentado un cierto grado de madurez como país de inmigración ${ }^{294}$. Esto explica que en países que constituyen destinos relativamente recientes de inmigración, como

285 Borjas y Bronars prosiguen afirmando que: "In theory, the immigration multiplier, the number of immigrants who will be admitted in the future as the result of one current admission, can be quite large". BORJAS, George J. y BRONARS, Stephen G. "Immigration and the Family"; en Journal of Labor Economic, vol. 9, No. 2, 1991, p. 124, nota a pie de página número 4 , traducción propia.

286 MALGESINI, G y GIMÉNEZ, C. Guía de conceptos sobre migraciones, racismo..., op. cit., p. 356.

287 GOERING, John. “The 'explosiviness' of chain migration”; en International Migration Review, vol. 23 , №. 4, 1989.

288 GONZÁLEZ FERRER, Amparo. Estrategias familiares y laborales en la emigración. Reagrupación familiar, elección de parejas y empleo de los inmigrantes en el país de destino. Madrid, CES, 2008, p. 11.

289 GÓMEZ CRESPO, Paloma. “Gestación y puesta en práctica de la reagrupación familiar como estrategia”, op. cit., p. 69.

290 KOFMAN, Eleonore. Civic Stratification, Gender and Family Migration Policies in Europe, op. cit., p. 2. Si bien, la propia autora señala que la proposición inversa también es cierta.

291 CORNELIUS, Wayne A; MARTIN, Philip L. Y HOLLIFIELD, James F. (eds.). Controlling Immigration. A Global Perspective, 1994, first edit., op. cit., p. 355. La regularización como forma de promover la RF ha tenido en España un escenario donde poder revalidar reiteradamente este efecto.

$292 \mathrm{Si}$ bien los propios autores puntualizan a renglón seguido "que gran parte de ese potencial no se actualiza". MALGESINI, G. y GIMÉNEZ, C. Guía de conceptos sobre migraciones, racismo e interculturalidad, op. cit., p. 354.

293 La bibliografía sobre este aspecto de la RF es amplísima en el ámbito norteamericano. A modo puramente ejemplificativo, véase por todos HEINBERG, John; HARRIS, Jeffrey y YORK, Robert. "The Process of Exempt Immediate Relative Immigration to the United States"; en International Migration Review, vol. 23, №. 4, 1989, pp. 839-855; JASSO, Guillermina, and ROSENZWEIG, Mark R. "Family Reunification and the Immigration Multiplier: U.S. Immigration Law, Origin-Country Conditions, and the Reproduction of Immigrants"; en Demography No. 23, August 1986, pp. 291-311. GOERING, John. “The 'explosiveness' of chain migration: Research and Policy Issues. Introduction and Overview"; en International Migration Review, vol. 23, №. 4, 1989, pp. 797-812.

294 ADROHER BIOSCA, Salomé. "La entrada, la permanencia y la salida de extranjeros de España”; en ADROHER BIOSCA, Salomé, CHARRO BAENA, Pilar (coords.). La inmigración. Derecho español e internacional. Barcelona, Bosch, 1995, p. 287. 
España, la RF supusiera a principios del nuevo siglo un "fenómeno apenas incipiente"295 y que, pese a la extraordinaria intensidad y aceleración que la llegada de flujos experimentó hasta el año 2008, ésta tardara más tiempo en reflejarse en un incremento paralelo en las entradas de familiares. Con todo, para el año 2009 —último disponible con cifras de la UE - España figuró ya como el país comunitario que había otorgado mayor número de permisos de residencia por razones familiares ${ }^{296}$.

Los efectos multiplicadores de la RF difieren según cual sea la concreta categoría de inmigración familiar implicada. Ya señalamos que la formación familiar o matrimonial generaba efectos multiplicadores aparentemente superiores y, desde luego, más prolongados en el tiempo que la RF en sentido estricto. Y, en ambos supuestos, éstos pueden quedar enmascarados en aquellos países que, como España, cuentan con facilidades en las políticas de naturalización, como ocurre con los colectivos iberoamericanos ${ }^{297}$.

La cuantificación exacta del potencial multiplicador de la RF ha sido siempre una cuestión compleja y escurridiza, sobre la cual los cálculos estatales solían errar, en parte debido a las insuficiencias crónicas de los datos oficiales y fuentes estadísticas en torno a la dimensión familiar de los flujos ${ }^{298}$. Inicialmente las proyecciones formuladas por políticos y funcionarios públicos estadounidenses en torno al volumen de futuras entradas a fin de evaluar el impacto y acomodar las políticas a implementar en esta materia, terminaban subestimando el número de admisiones finales de familiares. Esta situación a la larga condujo a la situación inversa, esto es, a sobreestimar anticipadamente el efecto multiplicador sobre los parientes más inmediatos, que finalmente no parece ser excesivo y que, para el supuesto de EEUU, ha sido expresamente calificado como "limitado"299.

295 SANTOLAYA MACHETTI, Pablo. El derecho a la vida familiar de los extranjeros. Valencia, Tirant lo Blanch, 2004, p. 144.

296 Concretamente, un informe de Eurostat señala que España emitió en el año 2009 un total de 125. 288 permisos de residencia por causa de RF - lo que supone un $43 \%$ del total de autorizaciones de residencia emitidas en España dicho año- constituyendo la cifra más elevada de los permisos emitidos por razones familiares de todos los países integrantes de la UE. Fue seguida por el Reino Unido, que el mismo año concedió 121. 268 autorizaciones de residencia por RF. SCARNICCHIA, Lucilla. "Residence permits issued to non-EU citizens in 2009 for family reunification, employment and education", Eurostat, n 43, 2011, p. 2.

297 SANTOLAYA MACHETTI, Pablo. El derecho a la vida familiar de los extranjeros. Valencia, Tirant lo Blanch, 2004, p. 144.

298 Las dificultades derivadas de la escasez de datos estadísticos en materia de RF y la imposibilidad subsecuente de realizar proyecciones fiables sobre el potencial multiplicador de la RF han sido abundantemente denunciadas desde múltiples espectros doctrinales, tanto a nivel internacional como interno. A modo de ejemplo, DUMON, W. A. en un artículo muy temprano criticaba la falta de datos fidedignos en este ámbito, subrayando la importancia de la "disponibilidad de estadísticas y su uniformidad y continuidad", en "Family Migration and Family Reunion"; en International Migration, vol. 14, No.1-2, 1976, pp. 78-79. También Kofman denuncia el estado excesivamente "rudimentario" de los datos estadísticos en esta materia, que ni reflejan los diferentes tipos de movimientos migratorios que involucran ni tampoco permiten seguir la huella de la recomposición de los grupos familiares a través del tiempo y del espacio; en "Family-Related Migration: A Critial Review of European Studies", op. cit., p. 246. Por su parte, Cebolla Boado y González Ferrer califican como "lamentable" el estado de la información estadística oficial en el ámbito de la reagrupación familiar, señalando la "necesidad urgente de publicar cifras comprensibles y creíbles que permitan a los ciudadanos y a los investigadores evaluar la política migratoria en esta materia”. CEBOLLA BOADO, H. y GONZÁLEZ FERRER, A. La inmigración en España (2000-2007). De la gestión de flujos a la integración de los inmigrantes, op. cit., pp. 85 y especialmente p. 97. GONZÁLEZ FERRER, Amparo. Estrategias familiares y laborales en la emigración. Reagrupación familiar, elección de parejas y empleo de los inmigrantes en el país de destino. Madrid, CES, 2008, p. 15. En torno a la imprecisión como característica crónica de los datos oficiales en torno a la inmigración en general en España, resulta de interés el artículo de opinión de IZQUIERDO ESCRIBANO, Antonio. El éxito de lo impreciso. Diario El País, 5 de agosto de 2002.

299 Jasso y Rosenzweig estimaron que, para EEUU, el índice multiplicador se encontraba por debajo de la unidad. Adujeron dos razones principales para ello. En primer lugar, una de las vías potencialmente más amplias para la entrada legal de familiares en dicho país reside en el concepto extenso de familia aplicado para habilitar la entrada de los 
En similares términos parece comportarse la RF en los restantes países de larga tradición migratoria, habiéndose señalado que pese a que la RF ha supuesto una "asombrosa" proporción de la inmigración legal, sin embargo, en términos relativos, las tendencias apuntan a su mantenimiento de forma marcadamente estable desde la década de los ochenta y, para el supuesto de Canadá y Australia, se han experimentado incluso retrocesos ${ }^{300}$. Sin embargo, estas observaciones están lejos de ser pacíficas ${ }^{301} \mathrm{y}$, en el contexto europeo, se han alzado voces que alertan de la existencia de "indicios de que la magnitud del multiplicador migratorio pudiera ser tan importante o más de lo estimado para los Estados Unidos"302.

Sea en un sentido amplificador o minimizador, lo cierto es que las previsiones y pronósticos formulados en este ámbito terminaban provocando múltiples "consecuencias inesperadas" así como una gran confusión ${ }^{303}$ - no privativas de EEUU - , hasta el punto de indicarse agudamente que "ningún factor contribuye más a viciar la capacidad estatal de planificar la inmigración legal que la RF"304. Podría decirse por ello que los efectos multiplicadores que genera la RF sobre el número de entradas y de autorizaciones de residencia de extranjeros en el territorio del Estado receptor son previsibles, pero difícilmente cuantificables, siendo aconsejable una alta dosis de prudencia ${ }^{305}$ a la

denominados "sponshorship family members", pero su admisión exige la naturalización del sponsor, lo que termina desembocando en una incidencia final menor que la que en principio cabría estimar de este tipo de RF. De otro lado, porque muchas de las solicitudes de visa para entrar en EEUU no desembocan en inmigrantes propiamente dichos. JASSO, Guillermina y ROSENZWEIG, Mark R. "Family Reunification and the Immigration Multiplier: U.S. Immigration Law, Origin-Country Conditions, and the Reproduction of Immigrants"; en Demography 23, 1986, pp. 291-311; En el mismo sentido se pronuncia LAHAV, Gallya. "International versus National Constraints in FamilyReunification Migration Policies", op. cit., p. 366. Igualmente, Malgesini y Giménez señalan que "hay un gran abismo entre las cantidades teóricas de parientes que podrían entrar y la cantidad que entra realmente. Esto puede tener varias explicaciones: bajas tasas de nacionalización en muchos grupos, el hecho de que algunos miembros ya estén en Estados Unidos y el de que no todos los miembros de la familia tratan de ejercer sus derechos a ingresar en EEUU”. Guía de conceptos sobre migraciones...., op. cit., pp. 354 y 355.

300 LAHAV, Gallya. "International versus National Constraints in Family-Reunification Migration Policies", op. cit., pp. 364-365.

301 Los últimos estudios apuntan a que el índice multiplicador neto se ha incrementado en los últimos años, situándose en torno al 4.3 en el período que va de 1972 a 1997. Ello supondría que la admisión de un trabajador extranjero que a la larga actuase como reagrupante de sus parientes, implicaría la entrada de cuatro personas extranjeras más por cada trabajador no nacional incorporado al sistema. El estudio se ciñe a la incidencia multiplicadora sobre la primera y segunda generación de descendientes del inmigrante primario, distinguiendo su incidencia directa e indirecta sobre ambos en el siguiente sentido: "Out of the 4.3 total, 2.1 would be the total of all family members directly/indirect/y sponsored by the principal immigrant, and 2.2 would be second-generation immigrants born to these immigrants (principal immigrant and all of the family members he/she directly/indirectly sponsored". YU, Bin. "Immigration Multiplier: A new Method of Mesuring the Immigration Process", 2006, pp. 14 y 15. Para un estudio más detallado de esta cuestión, vid., del mismo autor. Chain Migration Explained: The Power of the Immigration Multiplier. New York, Lfb Scholarly Pub Llc, 2008.

302 CEBOLLA BOADO, H y GONZÁLEZ FERRER, A. La inmigración en España (2000-2007)..., op. cit., p. 86.

303 Teitelbaum establece múltiples ejemplos sobre el diverso carácter de las consecuencias no previstas derivadas de los pronósticos fallidos en torno a la incidencia multiplicadora de la RF. A modo de resumen, alerta sobre el caso de Alemania occidental al iniciar su sistema de trabajadores temporales, sin imaginar que terminaría desembocando en una inmigración permanente, o el surgimiento de partidos de extrema derecha en Francia, Bélgica y otros países de Europa occidental, como consecuencias no previstas de la puesta en marcha de sus sistemas de asilo e inmigración.TEITELBAUM, Michael S. "Skeptical Noises about the Immigration Multiplier"; en International Migration Review, vol. XXIII, No. 4, 1989, p. 897.

304 FREEMAN, Gary P. “Can Liberal States Control Unwanted Migration?”, op. cit.,, p. 21.

$305 \mathrm{Al}$ respecto, Teitelbaum ha advertido sobre la necesidad de ser prudente e incluso humilde y hasta excéptico al intentar cuantificar la incidencia multiplicadora de la RF. La experiencia en EEUU demuestra, a juicio de este autor, que las previsiones de los políticos en torno a dicha incidencia, siempre fallaron a la baja, encontrándose con números que sobrepasaban enormemente las aparentemente realistas estimaciones iniciales. Su potencial inflaccionista 
hora de realizar previsiones teóricas anticipadas en este ámbito. Además, y para desesperación de los países receptores, lo único que parece resultar claro en torno a la concreta incidencia inflacionista implícita a la RF son dos puntos concretos: en primer lugar, resulta incierto proyectar los datos y experiencias pasadas sobre las estimaciones de entradas que tendrán lugar a largo plazo en el futuro y, en segundo lugar, paradójicamente la RF está dotada de un potencial multiplicador tanto mayor cuando más intenso sea el carácter restrictivo del régimen de entradas aplicables a los extranjeros ${ }^{306}$.

Con independencia de la magnitud exacta del efecto multiplicador, éste convierte a la RF en uno de los mayores desafíos para el país receptor. Como consecuencia de la misma, los Estados europeos han registrado incrementos acelerados en el número de entradas de extranjeros procedentes de terceros países, alimentando las ya existentes suspicacias estatales ante el fenómeno migratorio y fomentando la percepción por parte de las autoridades públicas internas de que la inmigración familiar constituye un tipo de "inmigración impuesta y no deseada" ${ }^{307}$ sobre la que es necesario aplicar criterios más selectivos.

Junto a esta dimensión ampliamente estudiada de la RF, existen otros aspectos vinculados a esta faceta de la RF en tanto que elemento de las políticas públicas de inmigración, que no suelen destacarse en los análisis jurídicos - por contraste a las perspectivas sociológica, politológica, antropológica y geográfica-. A continuación los expondremos muy brevemente pues, a nuestro juicio, poseen una incidencia potencialmente elevadora del efecto multiplicador de la RF y, además, ayudan a la mejor comprensión de su marco normativo y de las complejidades que subyacen a esta materia. De otro lado, la conjunción de todos los elementos vinculados a esta dimensión de la migración familiar, explica por sí misma que ésta se haya convertido en el "gran caballo de batalla de la política de control de flujos" 308 .

\section{c. La inmigración familiar y la formación de cadenas y redes migratorias}

La inmigración de nuestros días se desarrolla en un marco promovido por la facilidad y rapidez de los transportes y de la información. En este contexto, la imagen del inmigrante desarraigado y sin apenas contactos con su tierra natal se torna cada vez más lejana ${ }^{309}$. En su defecto, surgen potentes redes transnacionales basadas en complejos sistemas de lealtad y obligaciones mutuas ${ }^{310}$, que implican y conectan a las diversas sociedades implicadas en el fenómeno migratorio, entre las que se desarrollan múltiples y fluidas relaciones familiares, económicas, religiosas, políticas, informativas etcétera, que traspasan las fronteras. Esta situación ha llevado incluso a acuñar un nuevo término, que da idea de la interconexión del inmigrante en nuestros días, al tiempo que advierte del anacro-

sobre el número de entradas ha solido ser subestimado en el pasado, provocando efectos inesperados. El autor hace por ello una llamada a la moderación a la hora de pronosticar futuribles en el ámbito de la RF, en vista del carácter mudable de este fenómeno y su conexión con factores exógenos al Estado-Nación. TEITELBAUM, Michael S. "Skeptical Noises about the Immigration Multiplier"; en International Migration Review, vol. XXIII, No. 4, 1989, pp. 893-899.

306 TEITELBAUM, Michael S. “Skeptical Noises about the Immigration Multiplier”, op. cit., p. 899.

307 KOFMAN, Eleanore. Civic Stratification, Gender and Family Migration Policies in Europe, op. cit., p. 5. JOPPKE, Christian. "Why Liberal States Accept Unwanted Immigration?"; op. cit., p. 266.

308 La expresión corresponde a CEBOLLA BOADO, H. y GONZÁLEZ FERRER, A. La Inmigración en España (20002007)..., op. cit., p. 81.

309 GLICK SCHILLER, N; BASCH, L y SZANTON BLANC, C. “From immigrant to transmigrant: Theorizing transnational migration"; en Anthropological Quarterly, 1995, No. 68, p. 48.

310 BRYCESON y VUORELA. The transnational Family: new European Frontiers and Global Networks, op. cit., p. 220. 
nismo de la concepción tradicional del inmigrante como una persona que, al instalarse en el Estado receptor, pierde de forma progresiva sus raíces y sus vínculos con la comunidad de origen ${ }^{311}$ : se trata de la figura del "transmigrante" 312.

Los transmigrantes son definidos como aquellos "inmigrantes cuyas vidas diarias dependen de múltiples y constantes interconexiones a través de fronteras internacionales y cuyas identidades públicas están configuradas en relación a más de un Estado-Nación”313. La migración transnacional y los transmigrantes constituyen un patrón en aumento, tanto en Europa como en EEUU, pero en el que todavía no encajan la mayoría de los inmigrantes ${ }^{314}$. Con independencia de la magnitud de este fenómeno, lo cierto es que la transnacionalidad fomenta la creación espontánea de cadenas ${ }^{315} \mathrm{y}$

311 En el contexto español, un estudio publicado por el Observatorio Permanente de las Migraciones insiste en que el desarraigo del inmigrante constituye una imagen obsoleta. Sus autores señalan explícitamente que "estas concepciones binarias ya no son válidas a la hora de captar las actuales migraciones internacionales en su complejidad”, reclamando nuevas conceptualizaciones que muestren la complejidad de las redes desarrolladas por los inmigrantes. Vid. SOLÉ, Carlota, PARELLA, Sonia y CALVANCANTI, Leonardo (coords.). Nuevos retos del transnacionalismo en el estudio de las migraciones. Madrid, Ministerio de Trabajo e Inmigración, 2008, p. 13.

312 El término surge en la doctrina estadounidense a principios de los años noventa a fin de dar cuenta de las fluidas relaciones que los migrantes mantienen con sus comunidades de origen y con ello romper con la metodología tradicional que analizaba únicamente los cambios operados por la migración en la sociedad de destino. De otro lado, constata las deficiencias del enfoque tradicional pues aunque los inmigrantes estén integrados en las respectivas sociedades receptoras, ello no supone la pérdida de vínculos con los países natales. El término transmigrante se debe fundamentalmete a las aportaciones de tres autoras — Glick Schiller, Basch y Szanton—, quienes comienzaron a aplicar dicha terminología al estudiar a los inmigrantes procedentes del Caribe asentados en los EEUU. El libro fundacional de esta terminología es GLICK SCHILLER, Nina; BASCH, Linda y SZANTON BLANC, Cristina. Towards a Transnational Perspective in Migration: race, class, ethnicity and nationalism reconsidered. New York, New York Academy of Sciences, 1992. Junto a esta obra, resulta de interés también, GLICK-SCHILLER, N. "Citizens in Transnational Nation-States: The Asian Experience"; en OLDS, K; DICKEN, P; KELLY, P.F.; KONG, L. YEUNG, H.W.C. (ed.). Globalisation and the Asia-Pacific: Contested Territories. Londres, Routledge, 1998.

313 Las mismas autoras señalan que "in the United States several generations of researchers have viewed immigrants as persons who uproot themselves, leave behind home and country, and face the painful process of incorporation into a different society and culture. A new concept of transnational migration is emerging, however, that questions this long-held conceptualization of immigrants, suggesting that in both the U.S and Europe, increasing numbers of immigrants are best understood as <transmigrants>". GLICK SCHILLER, N; BASCH, L; SZANTON BLANC, C. "From immigrant to transmigrant: Theorizing transnational migration", op. cit., p. 48.

314 Castles y Miller advierten de la necesidad de evitar abusar del término, pues para que la figura del transmigrante exista con propiedad es necesario, a su juicio, que "las actividades transnacionales sean una parte central de la vida de la persona”, como característica definitoria básica del transmigrante. CASTLES y MILLER. La era de la migración..., op. cit., pp. 43 y 44.

315 El concepto clásico de las cadenas migratorias procede de la década de los cincuenta, cuando J.S y L.D MacDonald las definieron como "el movimiento a través del cual los presuntos emigrantes se enteran de las oportunidades, son provistos de transporte y obtienen su instalación inicial y empleo, por medio de relaciones sociales primarias con emigrantes anteriores". Citado por PEDONE, Claudia. Tú siempre jalas a los tuyos. Las cadenas y las redes Migratorias ecuatorianas hacia España. Tesis doctoral dirigida por María Dolores García Ramón. Universitat Autónoma de Barcelona 2004, p. 103. Disponible en: http://www.tesisenxarxa.net/TDX-1027104-170605. En la doctrina española, cabe destacar la definición de cadenas migratorias ofrecida por Malgesini y Giménez, para quienes “el concepto de cadena migratoria hace referencia a la transferencia de información y apoyos materiales que familiares, amigos o paisanos ofrecen al potencial inmigrante para decidir su viaje”. MALGESINI, Graciela y GIMÉNEZ, Carlos. Guía de conceptos sobre migraciones, racismo e interculturalidad, op. cit., pp. 57 y 58. 
redes $^{316}$ migratorias que sirven de apoyo a los inmigrantes, que a su vez estimulan la inmigración y crean fuertes vínculos entre sociedades emisoras y receptoras ${ }^{317}$.

Sin embargo, el factor clave para el surgimiento tanto de las cadenas ${ }^{318}$ como del concepto más amplio de redes ${ }^{319}$ migratorias lo constituye la inmigración de carácter familiar. Ya desde los años cincuenta, se señaló que las cadenas migratorias se erigen fundamentalmente en torno a la familia, tanto la nuclear como la extensa. Se trata de un aspecto de la inmigración muy estudiado por sociólogos, antropólogos y politólogos. Estas cadenas informales, al basarse en lazos de solidaridad, reciprocidad y ayuda mutua, no sólo fomentan la adaptación del extranjero que ya ha llegado al país de destino $^{320}$, sino que también sirven para promover y facilitar el desplazamiento inicial del inmigrante desde su Estado de origen hacia aquel país receptor en el que cuenta ya con algún familiar lejano -o simplemente amigo, conocido o incluso paisano- pues las mismas reducen sensiblemente los costes de transacción y los riesgos que lleva implícito el proceso migratorio ${ }^{321}$.

De ahí que la formación de redes y cadenas migratorias genere un proceso de movilidad cumulativa que se retroalimenta a sí mismo ${ }^{322}$. En base al mismo, los migrantes pioneros actúan como precursores o eslabones precedentes para las posteriores migraciones de los familiares ${ }^{323}$. Una vez que la llegada de los migrantes precursores ha iniciado el proceso migratorio, el surgimiento de redes y

316 Frente a las cadenas migratorias, las redes migratorias constituyen una noción más amplia, que no se restringe al círculo familiar. En tanto que estructura mayor a las cadenas, éstas pueden formar parte de las redes migratorias. En palabras de Malgesini y Giménez, "las redes son estructuras mayores, extendidas y relativamente afianzadas, que desarrollan una dinámica propia, pudiendo incluso desprenderse de los estímulos y desestímulos de la sociedad receptora”. MALGESINI, G. y GIMÉNEZ, C. Guía de conceptos sobre migraciones... op. cit., p. 58. Un concepto de redes puede encontrarse en un artículo colectivo escrito por Massey y otros autores, para quienes "las redes de migrantes son conjuntos de vínculos interpersonales que conectan a migrantes, antiguos migrantes y no migrantes en su área de origen o de destino a través de los lazos de parentesco, amistad y comunidad de origen compartida". MASSEY, D; ARANGO, J.; GRAEME, H.; KOUAOCI, A; PELLEGRINO, A y TAYLOR, E. "Una evaluación de la teoría de la migración internacional: el caso de América del Norte; MALGESINI, Graciela (comp..). Cruzando fronteras. Migraciones en el sistema mundial, op. cit., p. 229.

317 GLICK SCHILLER, BASCH, SZANTON. "From immigrant to transmigrant.”, op. cit., p. 48.

318 En un sentido similar, Castles y Miller hablan de la RF en conexión a “otros tipos de migración en cadena”. La era de la migración, op. cit., p. 90. En sentido divergente se manifiesta Honohan, quien señala que la formación de tales conexiones y enclaves no constituye un "riesgo específico de la reunificación familiar, sino de cualquier clase de migración en cadena, en la que grandes números de personas de una particular nacionalidad o religión inmigran y se asientan con gente de iguales orígenes". HONOHAN, Iseult. "Reconsidering the Claim to Family Reunification in Migration”; en Political Studies, 2008, p. 5, traducción propia.

319 Mónica Boyd afirma literalmente que "kinship ties are a major source of personal networks in migration"; en "Family and Personal Networks in Migration”, op. cit., p. 661. En idéntico sentido se pronuncian GURAK, Douglas T. y CACES, Fe. "Redes migratorias y la formación de sistemas de migración", en MALGESINI, Graciela (comp.). Cruzando fronteras. Migraciones en el sistema mundial. Barcelona, Icaria-FHE, 1998, p.96.

320 GURAK, Douglas T. y CACES, Fe. “Redes migratorias y la formación de sistemas de migración”, op. cit., p. 80. Pese a ello, los propios autores aluden a la existencia de estudios que enfatizan el rol de las redes en el mantenimiento de fuertes vínculos y contactos con las sociedades de origen, mientras pueden desarrollan un papel minimizador de los contactos con la sociedad de acogida, mucho más amplia que la de origen. En el mismo sentido se pronuncian Malgesini y Giménez, advirtiendo que aunque las cadenas y redes migratorias facilitan el proceso de salida y de llegada del inmigrante al país receptor sin embargo, en contrapartida, también pueden restar oportunidades de movilidad social a los recién llegados como consecuencia de la existencia y fuerte presencia de su grupo étnico-cultural en la sociedad de acogida; MALGESINI y GIMÉNEZ. Guía de conceptos sobre migraciones..., op. cit., p. 57.

321 HOLLIFIELD, James F. “The Emerging Migration State”, en International Migration Review, vol. 38, №. 3, 2004, p. 889.

322 FAIST, Thomas. The volumen and Dynamics of International Migration and Transnational Social Spaces. Oxford, Oxford University Press, 2000, p. 157.

323 BAJO SANTOS, Nicolás. "La familia migrante y sus redes”; en Anuario Jurídico y Económico Escurialense, op. cit., p. 691. 
cadenas migratorias vinculadas a la transnacionalidad y al mantenimiento de vínculos entre estos migrantes con sus parientes y conocidos en las comunidades de origen, provoca efectos inductores a la inmigración sobre los potenciales migrantes. Por ello se ha afirmado que "el parentesco y los lazos familiares transnacionales suministran continuamente crecientes oportunidades migratorias" ${ }^{24}$. De este modo, una vez establecidas, las cadenas y redes migratorias basadas en vínculos personales de carácter preponderantemente familiar, se convierten en "conductos adicionales de inmigración" ${ }^{25}$, con efectos estimuladores sobre nuevas inmigraciones ${ }^{326}$ y que, por ello, pueden convertir la inmigración en un fenómeno que se auto-perpetúa ${ }^{327}$.

Faist ha señalado que "las políticas de admisión de los países de destino no permiten la recepción de todos los inmigrantes deseosos de venir, en parte porque los deseos de los potenciales migrantes de salir de sus países de origen crecen más rápidamente que las oportunidades previstas por los canales de admisión legal" ${ }^{28}$. Pues bien, como el propio Faist advierte, esta brecha resulta ampliada por la existencia de redes y cadenas migratorias ${ }^{329}$, que propician el proceso migratorio y de establecimiento en la sociedad de acogida ${ }^{330}$.

Una vez iniciados, los flujos migratorios se mueven por dinámicas propias pues las redes y cadenas migratorias actúan con independencia de las políticas migratorias oficiales $y$, con frecuencia, a pesar de ellas ${ }^{331}$. Sin embargo, los flujos pueden ser acelerados o ralentizados por factores externos. Es obvio que las políticas migratorias estrictas provocan efectos desaceleradores sobre los flujos. Pues bien, la RF constituye un ejemplo típico - junto a las políticas basadas en el principio de non refoulement que sirve de base al asilo y refugio - de factor exógeno que acelera las dinámicas endógenas de los flujos migratorios ${ }^{332}$, lo que explicaría en parte su célebre resistencia a contextos económicos recesivos. Dicho más sencillamente, a través de la concesión de visados por motivos de reagrupación familiar, el propio gobierno del país receptor "refuerza y formaliza la operación de las redes migratorias" 333 .

En consecuencia, podría establecerse un paralelismo entre el proceso de la RF, la subsiguiente creación de cadenas y redes migratorias y el surgimiento de cierto "efecto llamada" sobre los potenciales inmigrantes pertenecientes a colectivos próximos a los extranjeros ya establecidos, aún cuando éstos no pertenezcan a la categoría de familiares que pueden optar a la RF. En este sentido, se ha advertido que la familia "ha sido un nuevo <imán> atrayendo inmigrantes a los países de acogida"334.

324 NAUCK, Bernhard y SETTLES, Barbara H. “Immigrant and Ethnic Minority Families: An Introduction”; en Journal of Comparative Family Studies, vol. 32, No. 4, 2001, p. 463.

325 MASSEY, Douglas S. Worlds in Motion: Understanding International Migration at the End of Millenium. Oxford Universtiy Press, 1998, p. 61.

326 BOYD, Monica. "Family and Personal Networks in Migration”, op. cit., p. 661.

327 HOLLIFIEDL, James Frank. “The Emerging Migration State”; en International Migration Review, op. cit., p. 889.

328 FAIST, Thomas. The volumen and dynamics of International Migration and Transnational Social Spaces, op. cit., pp. 157-158, traducción propia.

329 Ídem, p. 158.

330 BOYD, Monica. "Family and Personal Networks in International Migration: Recent Developments and New Agendas"; International Migration Review, vol. 23, No. 3, 1989, p. 642.

331 MASSEY, Douglas S. Wolds in Motion, op. cit., p. 61.

332 FAIST, Thomas. The volumen and Dynamics of International Migration and Transnational Social Spaces, op. cit., p. 158.

333 MALGESINI y GIMÉNEZ. Guía de conceptos sobre migraciones..., op. cit., p. 354.

334 AVCI, Gamze. "Immigrant Categories: The Many Sides of One Coin?”; European Journal of Migration and Law, op. cit., p. 203. 
Recurriendo a la terminología de las teorías neoclásicas de la inmigración, los vínculos familiares constituirían un poderoso factor de atracción - pull factor-, especialmente potente cuando las vías tradicionales - inmigración laboral - están fuertemente restringidas. Y, en vista de que la experiencia demuestra que la atracción ejercida por las redes familiares puede actuar con mayor rapidez que las demandas políticas o económicas del Estado receptor ${ }^{335}$ - y ello incluso en contextos económicos recesivos como el actual-, cabría afirmar, utilizando nuevamente las teorías neoclásicas, que la existencia de redes y cadenas familiares reduciría la susceptibilidad del inmigrante hacia los factores clásicos de atracción representados por las fuerzas del mercado laboral del Estado receptor ${ }^{336}$. Lo que, de otro lado, revela que la propia existencia y formación de redes y cadenas migratorias en las sociedades receptoras desmiente algunos de los presupuestos que sirven de sustento a las teorías neoclásicas, - especialmente su acusado individualismo y el peso extremo concedido a la ley de la oferta y la demanda en las decisiones migratorias-, convirtiendo a la inmigración en un "fenómeno social colectivo" 337 .

En consecuencia, en íntima conexión con el establecimiento de cadenas migratorias sobre la base de vínculos familiares extensos, surgiría un efecto colateral de la inmigración familiar que repercute sobre el tradicional efecto multiplicador intrínseco a la misma. Los vínculos familiares en sí mismos se convierten en un factor de atracción de nuevos flujos, no sólo por su capacidad de habilitar jurídicamente la entrada a los familiares más próximos del residente, sino porque facilitan y proporcionan asistencia a la llegada de personas del entorno próximo, aún sin encajar en la categoría de parientes. Este efecto facilitador de nueva inmigración, generado por las redes y cadenas migratorias, ha sido considerado como "extremadamente poderoso" 338 , de ahí que no sea descabellado extraer un potencial multiplicador no despreciable sobre el número de entradas futuras de parientes y amigos. Sobre este tema, Castles afirma que "los vínculos familiares con frecuencia proporcionan tanto el capital financiero como el cultural que hacen posible la migración. (...) Una vez que se establece un movimiento, los migrantes siguen sobre todo 'rutas conocidas'; reciben la ayuda de parientes y amigos que ya están en el área de inmigración. Las redes basadas en la familia o en el origen común, ayudan a proporcionar albergue, trabajo, orientación en los procedimientos burocráticos y apoyo en las dificultades personales. Estas redes sociales hacen que el proceso migratorio sea más seguro y manejable para los migrantes y sus familias. Los movimientos migratorios, una vez iniciados, se convierten en procesos sociales autosostenidos"339.

335 LAHAV, Gallya. "International versus National Constraints in Family-Reunification Migration Policy”, op. cit., p. 354.

336 MILLER, Mark j. Opportunities and Challenges for Migrant and Migrant-Background Youth in Developed Countries. Short version Report submitted to United Nations Social and Economic Council, 15 July, 2006, p. 6.

337 MALGESINI, G y GIMÉNEZ C. Guía de conceptos sobre migraciones..., op. cit., pp. 57-58.

338 PAPADEMETRIOU, Demetrios. International Migration: Global Trends and Issues. Migration Policy Institute, 2008, p. 2.

339 Castles y Miller prosiguen señalando: "Las redes de migración aportan, además, la base para los procesos de establecimiento y formación de comunidades en el área de inmigración. Los grupos migrantes desarrollan su propia infraestructura social y económica: lugares de oración, tiendas, cafés, servicios profesionales como los de abogados y médicos, amén de otros servicios. Esto se vincula con la reunificación familiar: a medida que se incremente el tiempo de estancia, los migrantes originales (sean trabajadores o refugiados) comienzan a traer a sus cónyuges e hijos o fundan nuevas familias. La gente comienza a ver sus perspectivas de vida en el nuevo país". La era de la Migración..., op. cit., p. 41. En idéntico sentido se pronuncia BOYD, Monica en torno a la inmigración como proceso autosostenido a raiz de la formación de redes sociales. "Family and Personal Networks in International Migration: Recent Developments and New Agendas”, op. cit., p. 641. 
El potencial de atracción de la inmigración familiar desafía incluso los impedimentos legales, proporcionando habitualmente canales ilícitos de entrada y permanencia ${ }^{340}$. En este último supuesto, encajarían dos situaciones: la denominada RF de hecho, que tiene lugar cuando el reagrupante se trae a sus familiares más próximos - aquellos que encajarían en la definición legal de familia a efectos de reagrupación - pero sin recurrir al procedimiento legalmente establecido para ello, por no reunir todos los requisitos previstos para ello; así como también el supuesto en el que reagrupante promueve y facilita la llegada de familiares en sentido amplio o simplemente amigos y conocidos por ejemplo extendiendo una carta de invitación-, que habitualmente penetran en el país huésped con visado de turistas para, finalmente, sobrepasar el tiempo de estancia legalmente permitido por dicho visado - tres meses en el ámbito comunitario-.

La influencia de los lazos familiares en el contexto de la inmigración irregular no debe ser subestimada, pues "los vínculos informales encarnados en las redes migratorias con frecuencia debilitan las políticas migratorias oficiales que ignoran los intereses de los migrantes"341. Esta circunstancia da lugar al surgimiento de otra faceta problemática adicional de la RF, pues sus efectos inductores sobre nuevas admisiones de extranjeros no se detienen en los cauces regulares, pudiendo, en consecuencia, proyectar también su potencial multiplicador sobre futuras entradas irregulares, circunstancia que, obviamente, presenta grandes dificultades para su cuantificación y aún mayores para su previsión.

\section{d. La inmigración familiar y la feminización de los flujos migratorias}

Un aspecto relativamente novedoso de los ciclos migratorios internacionales, que a nuestro juicio puede tener cierta incidencia potenciadora - al menos en el corto plazo- del efecto multiplicador de la RF, es la feminización de los flujos migratorios, de la que ya dimos cuenta en páginas anteriores de este trabajo.

Pese a la tendencia anteriormente apuntada, conviene en este punto precisar que las mujeres siguen constituyendo el colectivo más beneficiado por la migración familiar ${ }^{342}$, pues la admisión de parientes dependientes a efectos de reagrupación continúa, con carácter general, estando "desproporcionadamente" ${ }^{43}$ dominada por extranjeras que penetran en el Estado receptor como cónyuges o parejas de hecho ${ }^{344}$. El porcentaje todavía representado por las mujeres dentro de la RF puede alcanzar las dos terceras partes de las admisiones de familiares dependientes. Sin embargo, este porcentaje tiende a disminuir a partir de las segundas generaciones de inmigrantes ${ }^{345}$, donde son frecuentemente las mujeres quienes actúan como reagrupantes de sus parejas masculinas.

340 FAIST, T. The volumen and Dynamics of International Migration and Transnational Social Spaces, op.c it. P. 158; MASSEY, Douglas S. Worlds in Motion: Understanding International Migration at the End of Millenium. Oxford Universtiy Press, 1998, p. 61. CORNELIUS, Wayne A; MARTIN, Philip L. Y HOLLIFIELD, James F. (eds.). Controlling Immigration. A Global Perspective, 1994, first edit., op. cit, p. 230.

341 CASTLES; MILLER. La era de la migración. Movimientos internacionales de población en el mundo moderno, op. cit., p. 43.

342 Comunicación de la Comisión Europea al Consejo, al Parlamento Europeo, al Comité Económico y Social y al Comité de las Regiones sobre inmigración, integración y empleo, COM (2003) №. 336 final, de 3 de junio de 2003, p. 27.

343 KOFMAN, Eleanore. Civic Stratification, Gender and Family Migration Policies in Europe, op. cit., p. 4.

344 MEETOO, V; KOFMAN, E. “Family Migration”. World Migration 2008. OIM, op. cit., p. 151.

345 KOFMAN, E. Civic Stratification...., op. cit., p. 4. 
En este sentido, se ha destacado que la RF ha desempeñado un papel clave al determinar un reparto más equitativo ${ }^{346}$ en la distribución por sexos de los flujos migratorios, cancelando el anterior predominio del inmigrante masculino, propio del modelo migratorio del trabajador invitador. En otras palabras, la RF potencia la aludida feminización de los flujos internacionales ${ }^{347}$.

Existen algunos factores que contribuyen a reforzar este impacto potenciador de la RF sobre la feminización de los flujos: de un lado, y por motivos fundamentalmente económicos, las tendencias sociológicas parecen apuntar a que, de entre los posibles familiares reagrupables, las parejas de los reagrupantes constituyen los primeros parientes en ser reagrupados - pues ello permite una "mayor acumulación de ahorros y envío de remesas"348_; de otro, las oportunidades educativas y laborales, y el clima de mayor libertad que suelen experimentar las mujeres extranjeras en los países desarrollados de acogida, actúa como un auténtico "magneto"349 que induce la llegada de más mujeres deseosas de experimentar las mismas oportunidades y convertirse en agentes económicos y sociales por derecho propio.

Apuntamos en su momento que, en nuestro objeto de estudio, la creciente feminización de la inmigración internacional se traduce en el incremento del número de mujeres que actúan como reagrupantes una vez instaladas en la sociedad de acogida. Se podría ir más allá y señalar la existencia de cierta relación entre cifras crecientes de mujeres reagrupantes y una mayor utilización de la RF. En este sentido, desde la sociología se ha apuntado la mayor propensión entre las mujeres inmigrantes a la RF, en el sentido de que tienden a traerse temporalmente antes a sus familiares especialmente hijos menores- y acuden con más frecuencia que los hombres migrantes a la RF. En España ya existen estudios que demuestran la mayor proclividad de las inmigrantes femeninas a la reagrupación ${ }^{350}$. Así mismo se han analizado las causas de esta propensión, destacándose entre ellas el temor de las mujeres extranjeras a perder el contacto con sus hijos, e incluso que éstos puedan sufrir abusos en el país de origen durante su ausencia ${ }^{351}$.

El protagonismo ascendente de las mujeres como pioneras del proceso migratorio, termina provocando un reforzamiento del ya de por sí acusado carácter familiar de las migraciones internacionales. Para el contexto español, se ha destacado que "las mujeres se han convertido en el primer eslabón de la cadena migratoria, y con ello el proyecto migratorio se ha tornado eminentemente familiar"352.

346 Avci, en referencia al colectivo de inmigrantes turcos como uno de los más significativos de los asentados en Europa occidental, señala literalmente que "as a result of family reunification, a more even distribution emerge. This can be see in the activity rates of the labour force of number of non-workers dependents". AVCI, Gamze. "Inmigrants Categories: The Many Sides of ONe Coin?; op. cit., p. 211.

347 Sobre este punto, se ha afirmado que "by permitting the family reunification of legally admitted migrants, developed countries facilitate the admission of migrant women”. ZLOTNIK, Hania. The Global Dimensions of Female Migration. Migration Information Source. March, 2003, sp.

348 Los datos corresponden a España, entre parejas constituidas íntegramente por personas con nacionalidad extranjera. Cebolla y González Ferrer, los autores del estudio, indican que "la reagrupación del cónyuge se produce casi de inmediato", de lo que los autores extraen que ello forma parte de la estrategia migratoria familiar. CEBOLLA BOADO, H. y GONZÁLEZ FERRER, A. La inmigración en España (2000-2007). De la gestión de flujos a la integración de los inmigrantes, op. cit., p. 105.

349 ZLOTNIK, Hania. “The Global Dimensions of Female Migration”; Migration Information Source, 2003, op. cit.

350 Entre otros, cabe destacar un estudio que se centra en el comportamiento de los colectivos ecuatorianos inmigrados en España. PEDONE, Claudia. Tú siempre jalas a los tuyos. Las cadenas y las redes migratorias ecuatorianas hacia España, op. cit., pp. 408-409.

351 Ídem.

352 PEDONE, Claudia y ARAUJO, Sandra Gil. "Maternidades transnacionales entre América Latina y el Estado español. El impacto de las políticas migratorias en la estrategias de reagrupación familiar”; en SOLÉ, Carlota, PARELLA, 
La conexión de estas circunstancias - creciente feminización de los flujos, promovida en parte por la RF, la cual, a su vez, se traduce en una cronológicamente más temprana y cuantitativamente más intensa utilización de la RF y, por ende, en un fortalecimiento de las migraciones familiares internacionales- parece indicar que, aquellos países de destino que experimenten tasas más altas de mujeres entre los colectivos de inmigrantes establecidos en sus respectivos territorios, quizá sean más proclives a experimentar cifras más elevadas en el número de familiares extranjeros admitidos por causas de RF, que aquellos Estados receptores que cuenten con una proporción más elevada de hombres migrantes. En definitiva, en el primer tipo de países apuntados, el efecto multiplicador de la RF puede ser mayor, por lo que parece razonable establecer cierta relación entre la mayor feminización de los stocks de inmigrantes y cierta elevación del potencial multiplicador de la RF, al menos en lo que respecta a las entradas iniciales de parientes extranjeros.

Para el caso español, y dentro del régimen general, las cifras más recientes señalan el predominio de las mujeres extranjeras residentes procedentes de América central y del Sur, así como de la Europa no comunitaria, constituyendo un porcentaje del $54 \%$ del total de no nacionales residentes en territorio español. Asimismo, se constata la existencia en los últimos años de una tendencia en aumento a la feminización de la inmigración en nuestro país ${ }^{353}$.

\subsection{La RF como vehículo de integración de las políticas de extranjería}

Para abordar este tema, partiremos del concepto de integración proporcionado por el antropólogo social Carlos Giménez. Este autor concibe la integración como un proceso que involucra y modifica a un tiempo tanto a los inmigrantes - en tanto que grupos minoritarios - como a la propia sociedad de acogida. Para Giménez, la integración consiste en la "generación de cohesión social y convivencia intercultural, mediante procesos de adaptación mutua de dos segmentos socioculturales jurídica y culturalmente diferenciados, mediante el cual 1) las personas de origen extranjero se incorporan en igualdad de condiciones, derechos, obligaciones y oportunidades a la población autóctona, sin por ello perder su identidad y culturas propias; 2) la sociedad y el Estado receptor introducen paulatinamente aquellos cambios normativos, organizativos, presupuestarios y de mentalidad que se hagan necesarios"354.

Sobre esta base conceptual, conviene subrayar que la unidad familiar constituye una de las dimensiones clave en los procesos de integración ${ }^{355}$. La RF, en tanto que instrumento jurídico para la

Sonia y CALVANCANTI, Leonardo (coords.). Nuevos retos del transnacionalismo en el estudio de las migraciones. Madrid, Ministerio de Trabajo e Inmigración, 2008, p. 151.

353 Extranjeros residentes en España a 30 de junio de 2012. Principales resultados. Madrid, Ministerio de Empleo y Seguridad Social, Observatorio Permanente de la Inmigración, septiembre de 2012, p. 8. Conforme a dicho Informe, "el porcentaje de mujeres ha pasado del 40,70\% a finales de 2002 al 46,55\% de la actualidad". No obstante, sin tener en cuenta la procedencia del colectivo inmigrante residente en España, el 53, 45\% de los extranjeros inscritos en el régimen general son hombres.

354 GIMÉNEZ ROMERO, Carlos. “¿Qué entendemos por integración de los inmigrantes?. Una propuesta conceptualizada"; en Entreculturas, 1993; GIMÉNEZ, C. "La integración de los inmigrantes y la interculturalidad”; en Arbor, CLIV, No. 607, 1996, pp. 119-147. Una definición muy similar, también en MALGESINI, G. y GIMÉNEZ, C. Guía de conceptos sobre migraciones, racismo, ..., op. cit., p. 251. Conceptos muy próximos se encuentran en otros autores, como, por ejemplo, STOCKLE, Verena. “¿Qué entendemos por integración social de los inmigrantes”; CHECA y OLMOS, F; CHECA OLMOS, J. C. y ARJONA GARRIDO, A. (coords.). Inmigración y derechos humanos: la integración como participación social. Barcelona, Icaria, 2004, pp. 17-46.

355 GIMÉNEZ ROMERO, Carlos. "Familias en la inmigración. Su integración en la sociedad receptora”; BOROBIO, Dionisio (coord.). Familia e Interculturalidad. Universidad Pontificia de Salamanca, Salamanca, 2003, p. 196. En idéntico sentido se pronuncia la Comisión Europea: "aunque el papel de la familia varía de una cultura a otra, suele 
recomposición de la unidad familiar en el ámbito migratorio, se convierte así en una vía fundamental para fomentar la integración del inmigrante en la sociedad de acogida ${ }^{356}$, promoviendo su bienestar y estabilidad emocional y, con ello, su adaptación y participación en la nueva sociedad ${ }^{357}$. La presencia de la familia del inmigrante reduce los riesgos de desestabilización psicológica inherentes al cambio radical de vida que supone toda migración ${ }^{358}$, resultando asimismo ser de utilidad para la propia sociedad de acogida.

En este proceso, la familia ha de entenderse tanto en su sentido nuclear como extenso. Ya señalamos que la existencia previa de cadenas y redes familiares de parentesco en el país de acogida minimiza los riesgos inherentes al proceso migratorio, además de beneficiar la adaptación del extranjero en la nueva sociedad ${ }^{359}$. Las nuevas teorías de la migración basadas en la perspectiva de las redes sociales primordialmente constituidas por vínculos de parentesco, han subrayado también su importancia a efectos de la inserción del inmigrante en la sociedad de acogida, hasta el punto de ser consideradas como los factores clave que predicen con mayor probabilidad el éxito del proceso integrador de los extranjeros ${ }^{360}$. En definitiva, la inmigración familiar también facilita y promueve la incorporación de los extranjeros en el país de destino, "delegando la responsabilidad de la integración a la unidad familiar"361.

Esta faceta de la migración constituye ya un tópico de aceptación temprana ${ }^{362}$ y generalizada desde las distintas corrientes que estudian la inmigración familiar, e inserta de pleno derecho a la

ser especialmente importante en el proceso de integración, en la medida en que constituye un punto de referencia fijo para los inmigrantes en el país de acogida. A este respecto, es fundamental la reagrupación en torno al núcleo familiar". Comunicación de la Comisión Europea al Consejo, al Parlamento Europeo, al Comité Económico y Social y al Comité de las Regiones sobre inmigración, integración y empleo. COM (2003) №. 336 final, de 3 de junio de 2003, p. 27.

356 International Labour Conference (ILO), 87th Session, Migrant Workers, Report III (1B), Geneve, June 1997, apartado 472.

357 HONOHAN, Iseult. "Reconsidering the Claim to Family Reunification in Migration"; en Political Studies 2008 , pp. 5 y 8. Por su parte, Greese, Dyck y Tigar enfatizan el papel clave que desempeña la familia, especialmente en las fases iniciales del proceso de integración. CREESE, Gillian, DYCK, Isabel y TIGAR MCLAREN, Arlene. "The 'Flexible' Immigrant? Human Capital Discourse, the Family Household and Labour Market Strategies"; en Journal of International Migration and Integration, vol. 9, №. 3, 2008, pp. 269-288.

358 En torno al stress y, en numerosas ocasiones, al trauma asociado al proceso migratorio, especialmente en sus fases iniciales, Amelia de Lucía afirma con rotundidad que cualquier tipo de migración provoca un "shock psico-socioantropológico" y que, lógicamente, "this is even more so in the case of flights from situations involving danger to one's life". DE LUCIA, Amelia. "Human Migratory Flows"; en International Journal of Anthropology, vol. 19, №. 1-2, 2004, p. 10.

359 GURAK, Douglas T. y CACES, Fe. “Redes migratorias y la formación de sistemas de migración”, op. ci., p. 80.

360 Nauck y Settles indican que el capital social constituido por los vínculos familiares ya existentes en la sociedad de acogida sustituirán al capital humano -integrado por la educación individual, las habilitades y el desempeño o rendimiento laboral - como factores predominantes de predicción del éxito de la integración futura del inmigrante en la sociedad receptora. NAUCK, Bernhard y SETTLES, Barbara H. "Immigrant and Ethnic Minority Families: An Introduction"; en Journal of Comparative Family Studies, vol. 32, №. 4, 2001, p. 646.

361 LAHAV, Gallya. "International versus National Constraints in Family-Reunification Migration Policy”, op. cit., p. 366.

362 En 1974, el Informe Preparatorio que elaboró la Organización Internacional del Trabajo (ILO) de cara a la futura adopción de la Convención No. 143 -Convenio sobre las Migraciones en Condiciones Abusivas y la Promoción de la Igualdad de Oportunidades y de Trato de los Trabajadores Migrantes—, señalaba literalmente que: "Uniting migrant workers with their families living in the countries of origin is recognized to be essential for the migrants' well-being and their social adaptation to the receiving country. Prolonged separation and isolation lead to hardships and stress situations affecting both the migrants and the families left behind and prevent them from leading a normal life. The large numbers of migrant workers cut off from social relations and living on the fringe of the receiving community create many well-known social and psychological problems that, in turn, largely determine community attitudes 
RF como uno de los elementos esenciales a considerar en la formulación de las políticas públicas de extranjería, según la distinción efectuada por Jiménez Piernas. De hecho, la propia UE ha declarado explícitamente que el derecho a la RF constituye "de por si, un instrumento imprescindible de la integración" 363 .

En materia de integración de los extranjeros, dentro del ámbito doctrinal español, destacan las aportaciones realizadas por Javier de Lucas. Para este autor, el reconocimiento de derechos actúa como una condición previa necesaria para que pueda tener lugar la integración de los inmigrantes ${ }^{364}$. Desde este prisma, el reconocimiento de derechos a los inmigrantes se convierte en "la forma jurídica de la integración social"365. Pero la integración es un proceso muy complejo, bidireccional ${ }^{366}$ y multidimensional —abarca múltiples frentes, laboral, social, cultural, jurídico, educativo, etcétera. Su éxito depende de múltiples factores y dinámicas, entre los que ocupa un lugar prioritario el estatus legal conferido al reagrupante y a los miembros de su familia, y su inserción laboral ${ }^{367}$. En síntesis, la integración jurídica y laboral constituyen los elementos básicos del proceso de inserción de los extranjeros en la nueva sociedad, en el sentido de que condicionan poderosamente todas las restantes dimensiones implicadas en dicho proceso.

towards migrant workers”. ILO: Migrant workers, Report VII(1), International Labour Conference, 59th Session, Geneva, June 1974, p. 27.

363 Comunicación de la Comisión Europea al Consejo, al Parlamento Europeo, al Comité Económico y Social y al Comité de las Regiones sobre inmigración, integración y empleo, $\mathrm{COM(2003)} \mathrm{No.} 336$ final, de 3 de junio de 2003 , p. 5.

364 LUCAS, Javier de. "El marco jurídico de la integración"; en Jueces para la Democracia, No. 38 julio de 2000 , p. 8. También en "El desafío de las fronteras. Derechos humanos y xenofobia frente a una sociedad plural”. Madrid, Temas de Hoy, 1994.

365 Para Marina Gascón, dos son las grandes cuestiones que la inmigración lanza a la discusión política: la cuestión de las fronteras, esto es su mayor o menor apertura, dando lugar a políticas migratorias respectivamente generosas o restrictivas, y la cuestión de la integración. Respecto a la cuestión de la integración en la sociedad de acogida, las palabras de la autora resultan muy elocuentes: "De todas formas, la inserción de los inmigrantes en la sociedad de acogida no depende ni exclusiva ni principalmente de difusas e ingobernables actitudes sociales, sino que está también ligada a las acciones políticas concretas; y en particular al reconocimiento de derechos (....). Es evidente que la primera condición de la integración es la garantía de los derechos que aseguran las necesidades básicas. Dicho muy simplemente: sin tener cubierto un mínimo vital, los inmigrantes estarán por fuerza desintegrados, como desintegrados están los propios ciudadanos a los que la lacra del desempleo arroja a una vida de marginalidad. Por eso la integración está muy vinculada a la seguridad legal y a la continuidad laboral. Y por eso una política de integración que pretendiera resultar eficaz habría de empezar por los papeles, por el derecho a tener derechos, por proporcionar a los inmigrantes un estatuto jurídico estable y seguro que les permita insertarse en el mercado laboral como trabajadores de pleno derecho". GASCÓN ABELLÁN, Marina. Nosotros y los otros: El desafío de la inmigración. Lección inaugural del curso académico 2000. Ciudad Real, Gabinete del Rector de la Universidad de Castilla-La Mancha, 2001, pp. 13, 14 y 15.

366 Groenendijk ha analizado los diversos conceptos de integración que están surgiendo en el ámbito comunitario, si bien insiste en que la perspectiva clásica de la inmigración, tradicionalmente presente en materia migratoria, concibe la integración como un "two-way process": the resident population of the receiving country has to create room for the immigrants, otherwise they are unable to integrate". GROENENDIJK, Kees. "Legal Concepts of Integration in EU Migration Law"; en European Journal of Migration and Law, №. 6, 2004, p. 111. En idéntico sentido se expresa Javier de Lucas, para quien la integración "supone aceptar que el inmigrante es parte activa en un proceso bidireccional que involucra en el cambio también a la sociedad de acogida”. DE LUCAS, Javier. "Algunas propuestas para comenzar a hablar en serio de política de inmigración”; en DE LUCAS, J. y TORRES, F (eds.). Inmigrantes: ¿cómo los tenemos?. Algunos desafíos y (malas) respuestas. Madrid, Talasa, p. 27.

367 Carlos GIMÉNEZ ha destacado que existen nueve dimensiones esenciales para la integración exitosa de los inmigrantes: jurídica, laboral, familiar, residencial, vecinal, educativa, sanitaria, cívica y cultural. Giménez subraya sin embargo la importancia suprema que entre ellas ostentan la integración jurídica y laboral. Si la integración jurídica y laboral es precaria, el proceso integrador terminará apoyándose en unos "pies de barro", afirma gráficamente el autor. Máster en Migración y Relaciones Intercomunitarias. $3^{a}$ promoción, 2001-2002, clase impartida el 13 de septiembre de 2002, bajo el título "Aproximación a la historia de la inmigración en España". 
La migración familiar como vehículo de integración exige que los ordenamientos de extranjería prevean fórmulas para la incorporación de los familiares extranjeros que entran al país ${ }^{368}$ a fin de fomentar su adaptación y participación, cuestión que finalmente tendrá una repercusión positiva en la coherencia social del país. Para evaluar la adecuación de las concretas políticas públicas implementadas en el ámbito de la RF, en tanto que instrumento favorecedor de la integración, a nuestro juicio tres aspectos normativos resultan esenciales: En primer lugar, el concreto estatus concedido a los familiares reagrupados, esto es, el conjunto de derechos otorgados a los parientes autorizados a residir en el país receptor, bajo la perspectiva de que cuanto más seguro sea su estatus, más se favorecerá su integración ${ }^{369}$. En segundo lugar, el acceso a las prestaciones sociales puede desempeñar un papel de primer orden a fin de fomentar la participación de los inmigrantes en la vida económica y cultural del país de destino, además de disipar el riesgo de exclusión social al que, por sus condiciones económicas, puede estar más expuesto el colectivo de inmigrantes. En este punto la importancia de las corporaciones locales, en tanto que instancias más próximas al individuo, resulta clave ${ }^{370}$. Adicionalmente, la implementación de políticas para luchar contra la discriminación y xenofobia, a las que también se suele enfrentar el colectivo de inmigrantes, desempeña un papel fundamental para facilitar la integración de los extranjeros, en vista de que un tratamiento igualitario se erige como un poderoso instrumento de integración ${ }^{371}$.

Esta faceta de la RF, en tanto que instrumento clave de la política de extranjería, se traduce en la necesidad de conceder a los familiares admitidos en el país derechos adicionales a su autorización de entrada y residencia. Muchos de estos derechos están vinculados a las estructuras del Estado de bienestar propias de los países de Europa occidental y, por ende, implican esfuerzos presupuestarios para el Estado receptor.

En este contexto, las primeras actuaciones públicas que exige desplegar la RF podrían insertarse dentro de la categoría de los derechos de primera generación, puesto que exhortan a las autoridades internas a no realizar injerencias ilegítimas en el derecho a la vida familiar de aquellos inmigrantes regulares que reúnan los requisitos legalmente establecidos: esto es, en concurrencia de los requisitos jurídicamente exigidos, expedir el visado que habilite el ingreso de los familiares del reagrupante en el país receptor - en el caso de proceder de un Estado donde dicho visado sea obligatorio- y autorizar su entrada y residencia. Sin embargo, las actuaciones públicas subsiguientes son múltiples y constituyen derechos conexos a la concesión de la RF — cuyo reconocimiento e intensidad concreta depende fundamentalmente de la legislación interna del Estado de acogida. Este conjunto variado de derechos conexos encaja dentro de tipología de los derechos de segunda generación: acceso a la educación pública para los hijos de los inmigrantes, a las estructuras y prestaciones de salud públicas, ayudas para vivienda, cursos para aprender la lengua de la sociedad de acogida, etcétera. Como es bien sabido, los derechos sociales, económicos y culturales se traducen en prestaciones de carácter

368 GALLYA, Lahav. "International versus National Constraints in Family-Reunification Migration Policy”, op. cit., p. 366.

369 GROENENDIJK, Kees. “Legal Concepts of Integration in EU Migration Law”, op. cit., p. 113.

370 Para Carlos Giménez la participación del inmigrante constituye un elemento esencial para su incorporación a la sociedad de acogida así como "una dimensión clave en el proceso de integración social y un requisito imprescindible si se quieren buenos resultados para la acción institucional y social". Para dicho autor, "una de las piedras angulares de la participación del inmigrante es todo lo relativo al marco territorial de convivencia social: municipio/distrito/ barrio" pues constituye el lugar idóneo para que los inmigrantes tomen parte activa en la vida de su comunidad. GIMÉNEZ ROMERO, Carlos. "Dinamización comunitaria en el ámbito de la inmigración. Apuntes y propuestas sobre participación, mediación y codesarrollo"; en RUBIO, Mo José y MONTEROS, Silvina (coords.) La exclusión social. Teoría y práctica de la intervención. Madrid, CCS, 2002, pp. 101 y 107.

371 GROENENDIJK, K. "Legal Concepts..., op. cit., p. 113. 
positivo con implicaciones sobre las arcas públicas ${ }^{372}$. La condicionalidad económica implícita a los derechos de segunda generación determina que su garantía jurídica sea más problemática que los derechos de primera generación. Desde esta perspectiva, la RF se convierte en "una fuente de costes económicos y sociales de educación y formación —entre otros - que antes corrían a cargo de los países de origen"373.

En base a estas consideraciones, podríamos calificar la RF como un derecho mixto, que reúne en su contenido facetas propias de los derechos de primera y segunda generación, o bien, coincidiendo con García Vázquez, incluirlo dentro de los derechos dotados de una clara proyección social ${ }^{374}$. Aplicando una categoría más asentada, la RF constituiría un típico derecho multidimensional ${ }^{375}$, en la medida en que aúna simultáneamente derechos típicamente liberales que generan obligaciones de abstención para los poderes públicos — no interferir en la obligación de expedir un visado de entrada, cuando proceda, y una subsiguiente autorización de residencia a los familiares del residente-, con múltiples derechos prestacionales derivados de los anteriores.

La RF concebida como vehículo de integración, desemboca pues en otra faceta problemática de este derecho: su naturaleza jurídica parcialmente prestacional, con implicaciones presupuestarias, que terminan modificando los costes del inmigrante primario en el mercado laboral ${ }^{376}$. Podríamos incluso ir más allá y añadir que la RF constituye un derecho en su gran parte prestacional, pues mientras las actuaciones enclavadas en los derechos de primera generación se agotan con la expedición del visado y las subsiguientes autorizaciones de entrada y residencia - junto con las pertinentes sucesivas renovaciones de la autorización de residencia, dependiendo a su vez del tiempo de residencia con que cuente el reagrupante-, las relativas a derechos prestacionales se dilatan en el tiempo. Esta circunstancia puede despertar recelos en la sociedad de acogida, especialmente entre los sectores sociales autóctonos más empobrecidos, que pueden percibir como recursos escasos son repartidos entre un colectivo cada vez más amplio, donde la situación en principio más vulnerable de los extranjeros puede en ocasiones situarles en un puesto aventajado de cara a su asignación.

El Estado de acogida debe sopesar estas circunstancias al regular la RF, lo que se traduce en la necesidad de tomar en consideración los intereses nacionales, a menudo en pugna con los intereses individuales del inmigrante y aquellos que protege el derecho internacional de los derechos humanos. Aquí surge el conflicto que provocará múltiples dilemas al Estado receptor y que se traducirá a su vez en la existencia de contradicciones internas difíciles de acomodar en la regulación y formulación de políticas públicas relativas a la admisión de los familiares de los extranjeros residentes.

372 Para un estudio en profundidad en torno a este tema vid. CASCAJO CASTRO, José Luís. La tutela constitucional de los derechos sociales. Madrid, Centro de Estudios Políticos y Constitucionales, 1988.

373 GÓMEZ CRESPO, Paloma. "Gestación y puesta en práctica de la reagrupación familiar como estrategia”, op. cit., p. 69.

374 GARCÍA VÁZQUEZ, Sonia. El estatuto jurídico-constitucional del extranjero en España. Valencia, Tirant lo Blanch, 2007, pp. 49-94.

375 RUIZ MIGUEL, Carlos. "La naturaleza jurídica multidimensional de los derechos fundamentales”; en APARICIO PÉREZ, Miguel Ángel (coord.). Derechos constitucionales y pluralidad de ordenamientos. Barcelona, Cedecs editorial, 2001, pp. 165-177.

376 LAHAV, Gallya. "International versus National Constraints in Family-Reunification Migration Policy”, op. cit., p. 366. 


\subsection{Migración familiar y derechos humanos: La dialéctica aparente entre limitaciones internas e internacionales}

Con independencia de su encaje concreto en un particular derecho humano que actuará como derecho matriz — cuestión que abordaremos más adelante-, las raíces jurídicas de la RF, en sus orígenes más remotos, se depositaron en acuerdos internacionales, así como en normas y factores situados más allá del Estado ${ }^{377}$. En ausencia de una voluntad estatal interna para su consagración jurídica y ante las dificultades que ello comportaba, la migración familiar de los extranjeros encontraría inicialmente su sustento en el Derecho internacional Público, tanto a través de tratados internacionales habitualmente bilaterales que regulaban concretos aspectos migratorios entre dos países, incluyendo en ocasiones un reconocimiento expreso de la RF, como, con carácter más amplio, a través del DIDH. El surgimiento de un corpus normativo de facultades inherentes al ser humano, no vinculadas a la nacionalidad y previas al Estado - que había tenido profundo arraigo en las teorías del derecho natural que sirvieron de base al nacimiento del Derecho constitucional moderno - tomó forma en una rama específica del derecho internacional, en vista de la necesidad de asegurar una protección efectiva de los derechos humanos más básicos, situada por encima e independientemente de la tutela otorgada por los respectivos derechos internos.

Tradicionalmente, el derecho internacional general prestó escasa atención al tratamiento de los extranjeros ${ }^{378}$, encauzando la tutela de este colectivo dentro de los límites más bien estrechos ofrecidos por el principio de reciprocidad, que obligaba a los Estados a tratar a las personas no nacionales presentes en su territorio de modo similar a como a su vez el país de origen de estos extranjeros trataba a sus propios nacionales. Además, la protección jurídico-internacional de los extranjeros correspondía también al derecho consular, si bien la misma corría a cargo del Estado de origen y no del país de acogida del extranjero. Pero estas cuestiones se consideraban, con carácter general, pertenecientes al poder discrecional de cada Estado, y habitualmente carecían de regulación jurídica.

Como ha destacado Carmen Tiburcio, cuando las normas migratorias hicieron su aparición en el panorama normativo, fue con el objetivo de satisfacer objetivos nacionales variables, empezando por asegurar una mano de obra barata y sana- de ahí que las legislaciones de los principales países de destino, como Australia, EEUU, Canadá y Nueva Zelanda, introdujesen exigencias de salud para los potenciales migrantes - y, posteriormente, a finales del siglo XIX, "poner fin e invertir la inmigración no deseada por motivos raciales"379, dando lugar a normativas de selección migratoria profundamente discriminatorias.

La preocupación por los derechos de los extranjeros se aceleraría a lo largo del siglo XX, desde cuyos inicios, los trabajadores migrantes internacionales pasaron a estar "nominalmente" 380 protegidos por el derecho internacional. La Organización internacional del Trabajo hunde sus raíces en los años veinte, dando inicio a un lento pero constante proceso de transferencia parcial de la regulación de los derechos de los trabajadores migrantes al ámbito internacional. La internacionalización de

377 Ídem, p. 353.

378 TIBURCIO, Carmen. The Human Rights of Aliens under International and Comparative Law. The Hague, Martinus Nijhoff Publishers, 2001, p. xvi.

379 Ídem, p. xviii.

380 SAMERS, Michael. "<Globalization>, the Geopolitical Economy of Migration and the <Spatial Vent>”; en Review of International Political Economy, Vol. 6, No. 2, 1999, p. 172. 
los derechos humanos, iniciada al finalizar la segunda guerra mundial, vino a fortalecer la tendencia unilateral de los diversos Estados de mejorar la condición jurídica de los extranjeros ${ }^{381}$.

En este contexto, la conexión de la inmigración familiar con los derechos a la vida familiar y a la protección de la familia, principalmente, convertirían a la RF en una categoría migratoria penetrada por el derecho internacional de los derechos humanos. De hecho, ya apuntamos en su momento que la construcción y justificación de la RF en el ámbito occidental reposa sobre preocupaciones y consideraciones humanitarias ${ }^{382}$. Especialmente relevante resultaba la $\mathrm{RF}$ en tanto que mecanismo para permitir la unidad familiar, pues el altísimo valor intrínseco de la familia ${ }^{383}$ —en tanto que célula básica de la sociedad y por ello un principio internacional universalmente reconocido- terminaba impregnando la propia naturaleza y concepción de la $\mathrm{RF}^{384}$. Esta vinculación a los derechos humanos permite entender que a los familiares del residente se les exima del cumplimiento de las habitualmente onerosas condiciones que para la entrada y residencia de los extranjeros establecen los regímenes generales de inmigración y extranjería ${ }^{385}$ - mismas que, de ser exigidas, implicarían la negación de la RF. Desde esta perspectiva internacional, la regulación de la inmigración de carácter familiar debe estar regida por consideraciones humanitarias que pueden colisionar con las concretas necesidades económicas y laborales de los mercados de trabajo autóctonos, de ahí la inserción de la RF como un tipo de migración internacional no laboral y de carácter humanitario.

La vinculación a los derechos humanos detraía parcialmente ciertas categorías migratorias de la soberanía exclusiva del Estado-Nación, para ubicarlas en un complejo entramado normativo caracterizado por la interacción de diferentes regímenes jurídicos: nacional, internacional y en ocasiones también regional. A nivel jurídico, ello se traducía en la imposición de limitaciones internacionales

381 STEIN, Eduardo. "Evolución de la protección jurídica de los trabajadores migratorios en el derecho internacional"; en Cuadernos de Trabajo sobre Migración No. 4, 2001. Organización Internacional para las Migraciones, p. 8. Disponible en: http://www.acnur.org/biblioteca/pdf/3963.pdf

382 CORNELIUS, Wayne A; MARTIN, Philip L. Y HOLLIFIELD, James F. (eds.). Controlling Immigration. A Global Perspective, 1994, first edit., op.cit., p. 230.

383 En un interesante artículo, Iseult Honohan analiza las posibles justificaciones que laten detrás de la consideración de la RF como un criterio particularmente relevante a efectos de la admisión y residencia de los extranjeros, en vista de que constituye la vía de entrada legal actualmente más numerosa y por ello dominante en el ámbito migratorio. El artículo se formula en parte como consecuencia de un artículo previo de Matthew Gibney, titulado "The Ethics and Politics of Asylum", donde este último autor se cuestionaba la legitimidad de la prioridad dada a la RF especialmente con respecto al asilo - que ocupa un lugar numéricamente muy inferior en el número de autorizaciones de residencia - para terminar concluyendo que las solicitudes de asilo deberían merecer, al menos, igual consideración y peso que las relativas a la RF. En respuesta a este artículo de Gibney, Honohan bucea entre las razones que militan a favor de esta prioridad de la RF — el valor de la familia, la mayor posibilidad de integración de los familiares extranjeros, la específica naturaleza de las obligaciones estatales implicadas - y en contra de la misma - la RF viene a constituir una "herencia de privilegios" y el efecto multiplicador implícito a la RF. Entre los argumentos que militan a favor de la primacía de la RF, la autora destaca la importancia superior que ostenta "el valor intrínseco de la familia" como criterio legitimador para la admisión de los familiares de residentes extranjeros instalados en un Estado. HONOHAN, Iseult. "Reconsidering the Claim to Family Reunification in Migration"; en Political Studies 2008 , p. 6. Disponible en la dirección: http://www3.interscience.wiley.com/cgi-bin/fulltext/121489647/PDFSTART

384 De igual forma se pronuncia Ryszard Cholewinski, quien partiendo de la importancia intrínseca de la familia y del principio de unidad familiar, deriva el carácter fundamental del derecho a la RF. En palabras del propio autor, "the smallest, closest and yet most important community to many persons is the family unit. The enjoyment of many rights, particularly economic, social and cultural rights, would be meaningless without affording protection to this wider context in which individual human beings locate and express themselves". CHOLEWINSKI, Ryszard. "Family Reunification and Conditions Placed on Family Members"; en European Journal of Migration and Law, №. 4, 2002, p. 274.

385 En este sentido, Richard Perruchoud afirma que "to some extent, it can be said that the conditions of entry and residence applicable in a given country to aliens in general are largely irrelevant to the subject matter"; en "Family Reunification", op. cit., p. 513. 
que constreñían la amplitud del margen de apreciación nacional para la intervención normativa restrictiva - léase control de flujos- especialmente sobre aquellas categorías migratorias más estrechamente vinculadas con los derechos humanos, y no hay que olvidar que los diversos sistemas de RF implementados en los países occidentales han sido en sus orígenes construidos y justificados sobre bases humanitarias ${ }^{386}$. El DIDI terminaba con ello incidiendo sobre prerrogativas estatales íntimamente vinculadas con la soberanía nacional, como son la determinación de las condiciones de admisión, residencia y derechos de los extranjeros. De hecho, se ha señalado que el "control de fronteras constituye la esencia de la soberanía estatal" ${ }^{\prime 38}$.

A medida que el DIDH iba incrementando su solidez y su nivel de influencia sobre la migración internacional, el Estado nacional quedaba atrapado ${ }^{388}$ en un dilema, especialmente intenso en el ámbito migratorio: debía acoger y tutelar un número cada vez más amplio de facultades subjetivas que respondían a intereses no sólo diversos sino, en ocasiones, profundamente contradictorios protección de intereses nacionales en materia económica, laboral etc., versus salvaguardia de los compromisos internacionales adquiridos por el Estado en virtud de su participación en Tratados internacionales protectores de derechos humanos. Los mismos correspondían a las pretensiones e intereses subyacentes a los múltiples niveles normativos que interactuaban simultáneamente en materia migratoria. De otro lado, la existencia de flujos migratorios en constante aumento evidenciaba las mayores presiones y dificultades que afrontaba el Estado nacional para controlar las migraciones internacionales masivas.

El dilema se intensificó como consecuencia de las enormes mutaciones que la sociedad internacional enfrentó a partir del último tercio del siglo XX: A raíz fundamentalmente de la globalización, y a medida que crecían las desigualdades a nivel planetario - incrementándose paralelamente la potencialidad migratoria de dichas regiones-, la sociedad internacional se convertiría en una sociedad crecientemente compleja, heterogénea, interdependiente, desequilibrada y global ${ }^{389}$. Surgía con ello una "sociedad mundial" 390 caracterizada por el debilitamiento de la centralidad del Estado en las relaciones internacionales y el desarrollo y proliferación de nuevos actores no estatales.

Estas mutaciones provocaron la aparición de un nuevo tipo de Estado que ha llegado incluso a ser calificado como Estado "post-soberano" ${ }^{391}$. El Estado concebido como el actor único y principal de las relaciones internacionales, dotado de autonomía y con capacidad de acción ilimitada para intervenir sobre su propio territorio, parecía erosionarse. Fenómenos como la globalización desestabilizaban ${ }^{392}$

386 CORNELIUS, Wayne A; MARTIN, Philip L. Y HOLLIFIELD, James F. (eds.). Controlling Immigration. A Global Perspective, 1994, first edit., op. cit., p. 230.

387 HOLLIFIELD, James F. Immigrants, Markets and States: The Political Economy of Postwar Europe, op. cit., p. 5.

388 Lahav señala literalmente que: "As migration issues have been increasingly caught between domestic and International constraints, states are forced to deal with competing and contradictory interest; between state obligations to the individual, enshrined in International human rights instruments, versus competing nacional interest and fundamental state prerogatives to determine who shall enter its territory". LAHAV, Gallya. "International versus National Constraints in Family-Reunification Migration Policy”, op. cit., p. 349.

389 ARENAL MOYÚA, Celestino del. "Cambios en la Sociedad Internacional y Organización de las Naciones Unidas"; en Jornadas sobre el Cincuenta Aniversario de las Naciones Unidas. Madrid, Colección Escuela Diplomática, No. 2, 1995, p. 10.

390 ARENAL MOYÚA, Celestino del. "La nueva sociedad mundial y las nuevas realidades internacionales: un reto para la teoría y para la política”. Cursos de Derecho Internacional y Relaciones Internacionales de Vitoria Gasteiz. №. 21, 2001-2002, p. 25.

391 VALLESPÍN OÑA, Fernando. “Globalización y política: la crisis del Estado”; en ARTETA AISA, Aurelio (coord.). Teoría política: poder, moral, democracia. Madrid, Alianza editorial, 2003, pp. 402-423.

392 CASTLES y MILLER. La era de la migración. Movimientos internacionales de población en un mundo moderno, op. cit., p. 58 . 
al Estado-nación exacerbando las tensiones y las contradicciones inherentes a los regímenes migratorios, pues mientras la globalización impulsaba la libre circulación de bienes, servicios, mercancías, capitales e información, esta libertad coexistía con el mantenimiento e incluso el endurecimiento de las restricciones a la entrada de extranjeros. De este modo, la globalización hacía más evidente que nunca el dualismo ya existente entre la libertad que regía la salida de personas del territorio de un Estado y las restricciones a la entrada ${ }^{393}$. La paradoja se encrudecía aun más por el hecho de que la integración global de los mercados incrementaba los niveles de la migración internacional ${ }^{394}$.

Además, la globalización parecía poner al descubierto cierta debilidad estructural del Estado nacional para afrontar de forma unilateral fenómenos -tanto internos como externos- que constituían auténticos desafíos estatales, y que ya no discurrían por entero dentro de sus fronteras. En parte, porque muchos de los retos que enfrentaba el Estado-Nación tenían su origen principal en causas exógenas al Estado, pero que provocaban efectos endógenos difíciles de encarar con las capacidades exclusivas del Estado-nación. La inmigración constituye uno de estos fenómenos y quizá el que más reveladoramente pone de manifiesto la existencia de factores y actores situados más allá de la jurisdicción del Estado — pobreza, subdesarrollo, deficiente distribución de los recursos a escala mundial, falta de libertades políticas, problemas medioambientales etc., especialmente evidentes en los denominados Estados frágiles ${ }^{395}$ - pero con significativos efectos endógenos en los países desarrollados ${ }^{396}$.

En este panorama, los Estados se encontraban en un difícil contexto, pues aunque la sociedad internacional seguía en su mayor parte organizada en torno a los esquemas clásicos de base estatal,

393 Joppke explica que estas contradicciones habían caracterizado la migración internacional en el sistema estatal moderno desde sus inicios pero, al desaparecer la mayoría de las barreras al movimiento como consecuencia de la globalización, la contradicción entre salida libre y entrada restringida se convertiría en especialmente sobresaliente. JOPPKE, Christian. Immigration and the Nation-State: The United States, Germany and Great Bretain, op. cit., pp. 2 y 3 . En un sentido similar, aunque sin mencionar expresamente la influencia de la globalización, Gallya Lahav ha destacado que las contradicciones existentes entre los derechos individuales y los derechos del Estado, personificadas en el derecho internacional, fueron compatibles mientras las democracias liberales eran capaces de mantener mercados libres y fronteras abiertas. Sin embargo, estas contradicciones que en el anterior sistema eran poco significativas, se convertirían en críticas a raíz de las políticas de contención migratoria que comenzaron a implementar las democracias liberales en la década de los setenta del pasado siglo. LAHAV, Gallya. "International versus National Constraints in Family Reunification Migration Policies", op. cit., p. 353.

394 HOLLIFIELD, James. “The Emerging Migration State”; International Migration Review, vol. 38, No. 3, 2004 , p. 902.

395 Por Estados frágiles se entienden aquellos que se caracterizan por sufrir un fuerte proceso de deslegitimación provocado fundamentalmente por su incapacidad para satisfacer las necesidades básicas de su población, para monopolizar el uso de la fuerza en su territorio y finalmente, por la incapacidad para controlar su territorio. Se trata de un concepto que guarda algunas similitudes - pero no es idéntico-, a la noción de Estado fallido surgida en la postguerra fría y ampliamente utilizada en la doctrina política de los años noventa, cuando tales Estados se convirtieron en los principales receptores de ayuda humanitaria. En torno a las diferencias entre estos dos tipos de Estados, puede consultarse VILANOVA TRÍAS, Pere. “””Estados de facto” versus “fallidos o frágiles”?: Unas notas acerca de la dificultad teórica para establecer nuevas tipologías”; en Relaciones internacionales: Revista académica cuatrimestral de publicación electrónica, No. 10, 2009. DUFFIELD, Mark. "Los Estados frágiles y el retorno de la administración nativa"; en Relaciones internacionales: Revista académica cuatrimestral de publicación electrónica, №. 8, 2008. Sobre los Estados frágiles, resulta de interés, AGUIRRE, Mariano. "Los conflictos económicos y sociales y la paz: el caso de los estados frágiles"; TEZANOS, José Féliz y GUERRA, Alfonso (coords.). La paz y el derecho internacional: III Encuentro Salamanca. Madrid, Sistema, 2005, pp. 73-82.

396 VALLESPÍN OÑA, Fernando. "El futuro de la política en un mundo globalizado: el papel de los Estados". Conferencia pronunciada el 3 de abril de 2002, dentro del XIII Seminario Permanente de Administración y Economía Política: Globalización y distribución territorial del poder. Madrid, Consejo Económico y Social, 3-5 de abril de 2002; LAHAV, Gallya. "International versus National Constrainst in Family-Reunification Migration Policy”, op. cit., p. 350. 
sin embargo estos esquemas parecían resultar poco eficaces para hacer frente a los retos que planteaba el nuevo escenario mundial ${ }^{397}$.

La globalización de los flujos y la internacionalización del derecho migratorio se traducía, a juicio de un importante sector doctrinal, en una reducción de la capacidad estatal autónoma de decisión política en materia migratoria ${ }^{398}$. La importancia del tema hizo que, a nivel académico, los estudios se multiplicasen a fin de analizar cómo las migraciones internacionales comprometían la soberanía estatal y la aparente correlativa pérdida de control y de efectividad del Estado nacional sobre sus políticas migratorias, especialmente obvia frente a la inmigración irregular ${ }^{399}$. Estas visiones dieron origen a una tesis en torno a la "pérdida de poder" 400 estatal o al "declive de la soberanía"401, que sería ampliamente sustentada por numerosos sociólogos y politólogos adscritos a las corrientes "globalistas"402.

397 En palabras de Martín y Pérez de Nanclares, "en un plazo de tiempo relativamente breve hemos vivido todo un cúmulo de mutaciones que dejan al aire las severas contradicciones existentes entre una regulación de la realidad basada todavía en ordenamientos jurídicos de esquema básicamente nacional y un mundo globalizado en el que los Estados han perdido claramente su condición de solistas". MARTÍN Y PÉREZ DE NANCLARES, José. "El reto de la inmigración: sobre la conveniencia de una política común europea al estilo de la prevista en la Constitución Europea"; en Revista General de Derecho Europeo, №. 11, 2006, s.p. Para Sassen, "la existencia de dos regímenes diferentes para la circulación del capital y la circulación de los inmigrantes, así como también de dos regímenes igualmente distintos para la protección de los derechos humanos y para la protección de la soberanía estatal, plantea problemas que no pueden ser resueltos mediante las viejas reglas del juego". SASSEN, Saskia. Losing Control? Sovereignty in an Age of Globalization. New York, Columbia University Press,1996, p. xvi.

398 SASSEN, Saskia. "Beyond Sovereignty: De-Facto Transnationalism in Inmigration Policy; en European Journal of Migration and Law, No. 1, 1999, p. 192. MESSINA, Anthony M. "The not so Silent Revolution: PostWar Migration to Western Europe"; en World Politics, vol. 49, №. 1, 1996, p. 139.

399 Castles y Miller estiman que la capacidad del gobierno para regular y controlar la migración no regular es "como mucho fragmentaria y limitada"; en La era de la Migración..., op. cit., p. 122. Para una visión más profunda de este tema, analizando las causas que convergen para explicar tanto el fracaso de las políticas gubernamentales para lograr los objetivos expresamente declarados de sus políticas migratorias, como el hecho de que éstas habitualmente provoquen consecuencias no previstas ni deseadas, resulta de mucha utilidad la lectura de CASTLES, Stephen. "Factors that Make and Unmake Migration Policies"; en International Migration Review, vol. 38, No. 3, 2004, pp. 854-884. Una visión crítica a esta percepción doctrinal y social generalizada en torno a la escasa eficacia del Estado frente a la regulación de los flujos la proporciona Gary Freeman. Este autor descompone el estudio de la política migratoria en diversas áreas, para terminar concluyendo que si bien es cierto que las políticas gubernamentales registran fallos, sin embargo su capacidad de control sobre los flujos fue superior en la década de los noventa que en épocas previas, señalando que las tendencias apuntan a un aumento en las capacidades de control que, en cualquier caso, dependen y son diversas según el concreto Estado y la específica área de la política migratoria implicados. FREEMAN, Gary P. "Can Liberal States Control Unwanted Migration?", op. cit., pp. 17-30.

400 Esta tendencia doctrinal es denominada así por Andrew Geddes, quien se muestra crítico en torno a la misma, especialmente en lo que respecta a la UE. GEDDES, A. "International Migration and State Sovereignty in an Integrating Europe"; en International Migration, vol. 39, №. 6, 2001, p. 28.

401 La expresión corresponde a Freeman, quien también se manifiesta en sentido crítico sobre esta visión tradicional, argumentando que las democracias liberales conservan su poder para controlar los flujos migratorios. FREEMAN, Gary. "The Decline of Sovereignty? Politics and Immigration Restriction in Liberal States"; en JOPPKE, Christian (ed.). Challenge to the Nation State: Immigration in Western Europe and the United States. Oxford, Oxford University Press, 1998, p. 86. FREEMAN, Gary P. “Can Liberal States Control Unwanted Migration?”, op. cit., pp. 17-30.

402 Entre los más representativos, cabría citar a SOYSAL, Jasmin. Limits of Citizenship. Migrants and Postnational Membership in Europe. Chicago, University of Chicago Press, 1994; JACOBSON, David. Rights Across Borders: Immigration and the Decline of Citizenship. Baltimore, Johns Hopkins University Press, 1996; SASSEN, Saskia. "Beyond Sovereignty: De-Facto Transnationalism in Inmigration Policy"; en European Journal of Migration and Law, op. cit., sin embargo esta última autora señala que, pese al impacto que el sistema económico global ha tenido sobre la soberanía estatal, el Estado continúa ejerciendo el papel más importante en la elaboración e implementación de las políticas migratorias; en "Beyond Sovereignty: De-Facto...", op. cit., p. 177. 
Visto en perspectiva, el supuesto debilitamiento del poder estatal en materia migratoria constituiría una faceta específica dentro de un proceso más extenso y progresivo. Este proceso aunaría la erosión y relativización que el despliegue del DIDH ha ejercido sobre la soberanía de los Estados ${ }^{403}$ con los efectos también debilitantes de la globalización sobre el mismo concepto ${ }^{404}$, cuya limitación a nivel interno se había iniciado a la par del constitucionalismo liberal. De hecho, el debate en torno a la corrosión que las poderosas fuerzas del sistema económico global en combinación con los flujos migratorios internacionales masivos provocaban sobre la capacidad del Estado nacional en materia de control fronterizo, se enmarcaba dentro de un debate más amplio en torno a la supuesta influencia debilitante que la globalización y el derecho internacional han ejercido sobre este tipo de Estado. No en vano, la inmigración internacional se encuentra situada, precisamente, en la encrucijada de dichos debates ${ }^{405}$, puesto que, como se ha señalado, la soberanía estatal "no es en ningún aspecto más absoluta que en materia de emigración, naturalización, nacionalidad y expulsión”"406.

En las visiones globalistas, la internacionalización de la inmigración venía a ser considerada como una cuestión que terminaba expropiando ${ }^{407}$ ciertas parcelas de soberanía estatal y en la cual los reiterados fracasos que los países receptores afrontaban para hacer frente a la contención de los flujos se interpretaban como un señal obvia de la pérdida de capacidad de control migratorio del Estado Nacional. La expropiación de soberanía en materia migratoria era concebida como un aspecto concreto dentro de la dinámica "desnacionalizadora" inherente a la lógica de la globalización ${ }^{408}$. Asimismo, el DIDH era contemplado como un régimen global que había logrado dibujar límites cada

403 CARRILLO SALCEDO, José Antonio. Soberanía de los Estados y derechos humanos en el Derecho Internacional contemporáneo. Madrid, Tecnos, 1995, p. 19.

404 Para una visión de esta cuestión, dentro del ámbito doctrinal español, vid. HINOJOSA MARTÍNEZ, Luis Miguel. “Globalización y soberanía de los Estados”; en Revista Electrónica de Estudios Internacionales, No. 10, 2005, pp. 1-14. Hinojosa observa la evolución en el concepto de soberanía, partiendo de una observación que considera obvia: el abandono de la noción tradicional — absoluta — de soberanía. Constata además que, paradójicamente, la "crisis del Estado" se refiere a los países más poderosos del planeta, y no a los más pobres, entendiendo por tal la pérdida de la capacidad de influencia de las autoridades públicas de los países desarrollados a la hora de diseñar el modelo político y social en las respectivas sociedades nacionales. Ídem, p. 2. Asimismo, para una síntesis de la limitación de la soberanía, tanto en sus facetas interna como externa, vid. CARRERAS, Francesc de. "Función y alcance del artículo 10.2 de la Constitución”; en Revista Española de Derecho Constitucional, No. 60, septiembre-diciembre 2000, espc. pp. 321-325.

405 GUIRAUDON, Virginie y LAHAV, Gallya. "A Reappraisal of the State Sovereignty Debate. The Case of Migration Control"; en Comparative Political Studies, vol. 33, №. 2, 2000, p. 163.

406 ARENDT, Hanna. “The Origins of Totalitarisnism”. San Diego, Hartcourt Brace Jovanovich, 1973. Citado por JOPPKE, Christian. "Why Liberal States Accept Unwanted Migration?”; World Politics, vol. 50, No. 2, p. 267.

407 Las autoras se manifiestan en contra de esta concepción, señalando que deben tomarse con mucha precaución los argumentos globalistas. GUIRAUDON y LAHAV. "A Reappraisal of the State Sovereignty Debate. The Case of Migration Control", op. cit., p. 188.

408 Sassen considera que la globalización involucra dos tipos distintos dinámicas: De un lado, la formación de instituciones y procesos globales, como por ejemplo mercados financieros a nivel global o los Tribunales para juzgar crímenes de guerra, cuyas prácticas se producen a escala global. Pero también engloba otro tipo de procesos que no tienen lugar necesariamente a escala global, pero que la autora incluye dentro del concepto de globalización. Este segundo tipo de procesos tienen lugar dentro de territorios e instituciones que han sido construidos en términos nacionales, pero que se incluyen en la globalización porque constituyen procesos que involucran redes y formaciones transfronterizas. Para la autora mencionada, "what makes these processes part of globalization even though localized in national, indeed subnational settings, is that they involve transboundary networks and formations connecting multiple local or 'national' processes and actors, or involve the recurrence of particular issues or dynamics in a growing number of countries”. Sassen señala que la globalización en este segundo sentido, esto es, vista desde dentro del propio Estado, provoca que determinados componentes del Estado Nación estén siendo objeto de una "incipiente, altamente especializada y parcial desnacionalización”. SASSEN Saskia. “Globalization or Denationalization?”; en Review of International Political Economy, Vol. 10, No. 1, 2003, esp. pp. 13 y 14. 
vez más precisos sobre las políticas migratorias ejecutadas a nivel doméstico, siendo estos límites considerados de carácter externo a dichas políticas. De ahí que incluso se percibiera el régimen internacional como una fuente de emanación y legitimación de derechos superior al debilitado Estado Nacional, a los derechos de base estatal como un ámbito en retroceso ${ }^{409}$ y se hablase de la devaluación de la propia ciudadanía con base nacional ${ }^{410}$.

La inmigración familiar, en tanto que materia particularmente controvertida dentro de la inmigración, venía a situarse en el medio de estas dinámicas contradictorias, ejemplificando la tensión conflictiva entre la soberanía nacional y los derechos humanos consagrados en el ámbito internacional, así como los límites que las democracias liberales debían soportar y sus repercusiones sobre las políticas de control migratorio. Y, mientras las cifras crecientes de familiares extranjeros dependientes parecían reflejar las preocupaciones humanitarias de los países avanzados, también venían a arrojar dudas sobre el grado real de control que las democracias liberales ejercían sobre los flujos migratorios.

En el centro de esta tensión, tal y como era percibida por los teóricos de la globalización, dos aspectos parecían ser sobresalientes en lo relativo a la RF: de un lado, la presencia de intereses contradictorios entre el Estado nacional y el DIDH, lo que convertía a estas dos ramas del derecho - interna e internacional - en ordenamientos inherentemente contradictorios ${ }^{411}$; $y$, de otro, la existencia de límites derivados de ambos niveles, que parecían actuar en sentido diametralmente opuesto, pues mientras las restricciones impuestas por el derecho internacional operaban en sentido expansivo sobre el contenido del derecho a la vida familiar y la RF, las restricciones impuestas a nivel interno - en tanto que reflejo y salvaguardia de los intereses internos y de las prerrogativas nacionales propias de la soberanía estatal- debilitaban el contenido de la RF o, con carácter más general, estrechaban aún más el frágil estatuto jurídico de los extranjeros. En esta concepción, la internacionalización de la inmigración supondría una erosión de la soberanía nacional, constriñendo la autonomía administrativa del Estado ${ }^{412}$ para imponer restricciones internas a la RF de los extranjeros residentes legales en sus territorios. Dicho de forma más simple, el DI marcaba límites a la políticas migratorias internas, resultando en una reducción de la capacidad del Estado-nación para regular y controlar sus fronteras ${ }^{413}$.

Sin embargo, este panorama tradicional en torno al declive de la soberanía nacional en asuntos migratorios presentado por los "globalistas", ha sido cuestionado. Se ha señalado que la tensión dialéctica sobre la que pivotaban estas visiones es más teórica que real, puesto que las mismas no

409 SASSEN, Saskia. Losing Control? Sovereignty in an Age of Globalization. New York, Columbia University Press, 1996; SOYSAL, Yasemin. Limits of Citizenship: Migrants and Postnational Membership in Europe. Chicago, University of Chicago Press, 1994.

410 SOYSAL, Jasmin. Limits of Citizenship. Migrants and Postnational Membership in Europe. op. cit., especialmente pp. 136-163. La autora, poniendo como modelo ejemplificante lo sucedido en los regímenes migratorios basados en el paradigma del trabajador invitado, explica la sustitución de la ciudadanía nacional por un nuevo sistema en que la incorporación de los individuos a la comunidad y la adjudicación de derechos no se hace sobre la base de la adscripción a una comunidad nacional, sino sobre la base de la personalidad, esto es, tomando como fundamento "los derechos humanos como principio organizativo a nivel mundial". Por eso la autora denomina a este nuevo modelo de incorporación y de adjudicación de derechos "ciudadanía post-nacional".

411 LAHAV, Gallya. "International versus National Constraints in Family-Reunification Migration Policies", op. cit., p. 353.

412 Hollifield recurre a los casos de Francia y Alemania para ejemplificar esta reducción de la capacidad autónoma administrativa del Estado en materia migratoria. HOLLIFIELD, James F. Immigrants, Markets and States: The Political Economy of Postwar Europe. Cambridge, Harvard University Press, 1992, p. 94.

413 LAHAV, G. “International versus National Constraints in Family Reunification Migration Policies”, op. cit., p. 351. 
tienen en cuenta la "susceptibilidad de los instrumentos internacionales hacia los intereses nacionales y el control migratorio" ${ }^{414}$, ni el hecho de que la construcción del DIDH se realizase sobre la base del respeto a la soberanía nacional y la protección de los intereses estatales ${ }^{415}$. En este sentido, se ha destacado una notable paradoja que pone en entredicho las consideraciones clásicas ya expuestas: La tendencia a la universalidad de los derechos humanos y la influencia creciente del derecho internacional y de las estructuras internacionales en el derecho migratorio se traducen en restricciones sobre el control que ejerce el Estado-Nación sobre los extranjeros que entran en su territorio. Pero, simultáneamente, y en dirección opuesta a la anterior dinámica, existe un tendencia a la imposición de limitaciones migratorias crecientes en materia de RF, aunque muchas veces éstas sean establecidas de forma oblicua a fin de no chocar frontalmente con los estándares internacionales. En palabras de Gallya Lahav, "si los instrumentos internacionales delimitan la autoridad nacional para controlar las fronteras, entonces ¿ cómo podemos explicar el fracaso en la extensión de derechos universales en la forma de reunificación familiar para los migrantes? Más aún, ¿cómo podemos justificar el constante crecimiento de limitaciones estructurales a la reunificación familiar?" ${ }^{416}$.

Esta constatación hace que Lahav y Guiraudon, entre otros autores, partan de una visión de la "naturaleza interactiva de las condiciones nacionales e internacionales, así como de las políticas y de los factores inherentes al proceso migratorio en sí mismo" ${ }^{417}$. Para estas autoras, la creciente internacionalización del derecho migratorio no parece haberse traducido, al menos por el momento, en una pérdida de poder del Estado-Nación en esta materia ni en un correlativo debilitamiento de sus estructuras de control migratorio y de protección de sus respectivos intereses nacionales a través de las políticas internas. Y ello ha sido así porque el Estado Nacional ha demostrado tener una gran adaptabilidad ${ }^{418}$ para hacer frente y sortear las limitaciones que la globalización, el incremento de flujos y fundamentalmente, las restricciones normativas que los regímenes protectores de derechos humanos les imponían.

A fin de incrementar la eficacia en la gestión de los flujos, el Estado ha recurrido a lo que las autoras denominan una "multifacética devolución de poderes decisorios, de vigilancia y de ejecución en el ámbito de la política migratoria" ${ }^{119}$. Esta devolución consiste en un proceso múltiple de reparto competencial y de delegación de funciones migratorias, que ha tenido lugar en tres distintos niveles, involucrando o "cooptando" a actores diversos: De un lado, hacia instancias situadas por encima del Estado, mediante foros internacionales de cooperación con países emisores de emigración y, especialmente, con países vecinos que enfrentaban similares problemáticas, como ilustran Schengen o el tercer pilar de la UE. Estos foros europeos han intervenido con el fin de incrementar los controles externos, expandiendo las fronteras de la Unión y propiciando una armonización en

414 Ídem.

415 Ibidem, p. 354.

416 Ibídem, p. 352.

417 LAHAV, G y GUIRAUDON, V. “A Reappraisal of the State Sovereignty Debate. The Case of Migration Control”, op. cit., p. 168, traducción propia.

418 Ídem, pp. 176 y 190. La naturaleza adaptativa del Estado Nacional frente a la inmigración, que le ha permitido afrontar con éxito las fuerzas de la globalización sin perder su poder soberano, ha sido también subrayada por Christian Joppke, quien estima que el Estado-Nación constituye una organización elástica — “resilient Nation-States”, en palabras del propio autor. Frente a los globalistas, Joppkke subraya que en la actualidad puede observase tanto "una tenaz insistencia de los Estados a mantener su control sobre sus fronteras", como "crecientes limitaciones sobre la soberanía tradicional derivadas de los derechos humanos", si bien estima que dichas limitaciones son más internas que externas. JOPPKE, Christian. Immigration and the Nation-State: The United States, Germany and Great Britain, op. cit., pp. 4 y 260.

419 GUIRAUDON, Virginie y LAHAV, Gallya. "A Reappaisal of the State Sovereignty Debate. The Case of Migration Control", op. cit., p. 164. 
materia migratoria que califican de sustancial entre los Estados Europeos ${ }^{420}$. De otro, los Estados Nacionales han recurrido también a una devolución en sentido descendente que, usando las técnicas propias de la descentralización, ha otorgado poderes en el área migratoria a las autoridades locales democráticamente elegidas. La transferencia de funciones migratorias ha tenido lugar incluso hacia fuera, compartiendo competencias el Estado nacional con actores privados no estatales, tales como empresarios y compañías privadas de transportes, a quienes se les ha trasladado responsabilidades sancionatorias en el caso de toparse ante inmigrantes irregulares.

Los efectos de este reparto competencial están muy lejos de restar poderes al Estado Nacional, pues con él los Estados no han pretendido en ningún momento renunciar al control de los flujos, sino simplemente trasladar el nivel de dicho control. El resultado de la devolución puede resumirse en tres aspectos: (1) la "creación de una 'cadena vertical de decisión política', que sorteaba muchas de las pretendidas limitaciones existentes en un modelo horizontal de políticas públicas nacionales y/o incorporaba nuevos actores, cuyos propios intereses coincidían con aquellos de las agencias nacionales de control"; (2) la extensión de las responsabilidades nacionales ${ }^{421}$; (3) y, finalmente, la instalación de un "control político remoto, de modo que los extranjeros ni siquiera lleguen a alcanzar el país receptor y por lo tanto no puedan reclamar protección judicial”222.

Las aludidas técnicas de delegación política no han sustraído ni expropiado soberanía estatal en asuntos migratorios ${ }^{423}$. Antes bien, constituyen métodos que las autoras califican de "desnacionalización, descentralización y privatización" del control migratorio, a través de los cuales los Estados recobran su soberanía nacional e incrementan la eficacia en el control de los flujos migratorios ${ }^{424}$. De ahí que Christian Joppke las califique a su vez como técnicas de "renacionalización de las políticas migratorias" que actuarían como "antídoto a la desnacionalización” ${ }^{425}$ descrita por los globalistas.

Estas consideraciones son especialmente aplicables al ámbito internacional, el más relevante para esta parte de nuestro estudio, pues la integración europea ha provocado, a juicio de estas autoras, una fusión de intereses nacionales dando lugar a un "orden supranacional prevalente, consistente en Estados fuertes comprometidos en hacer un fondo común de soberanía, basado en la restricción migratoria y un control más efectivo" ${ }^{226}$. En resumen, la delegación de poderes a instituciones supranacionales sirve para incrementar la efectividad del Estado en el control de flujos, pero en un

420 Ídem, pp. 178 y 179.

421 Ídem, p. 177.

422 Ibidem, p. 178.

423 En sentido idéntico que Lahav y Guiraudon, aunque en referencia únicamente a las actuaciones migratorias en el ámbito comunitario, se pronuncia Andrew Geddes, quien ha afirmado: "it is argued that far from weakening EU member states or symbolizing some 'loss of control', EU cooperation and integration have thus far helped member states consolidate and reassert their ability to regulate International migration through the use of new EU-level institucional venues. This raises legitimacy issues as the EU moves into politically sensitive policy areas". En torno a cómo el desarrollo de la política migratoria comunitaria afecta a la capacidad soberana de los Estados de regular los flujos internacionales, el autor se aleja de la tesis de la pérdida de poder, afirmando que "cooperation and integration between EU member states on migration policy do not neccessarily weaken these states in the sense that they "lose" or "surrender" power to the EU. Member states now share power- that much is clear- but his does not mean that their relevance is waning. Instead, EU responsabilities provide new International venues for the pursuit of policy objectives". GEDDES, Andrew. "International Migration and State Sovereignty in an Integrating Europe"; en International Migration, vol. 39, №. 6, 2001, pp. 21 y 22.

424 GUIRAUDON y LAHAV. "A Reappraisal of the State Sovereignty Debate. The Case of Migration Control”, op. cit., p. 165.

425 JOPPKE, Christian. Immigration and the Nation-State: The United States, Germany and Great Britain, op. cit., p. 3.

426 GUIRAUDON y LAHAV. "A Reappraisal of the State Sovereignty Debate. The Case of Migration Control”, op. cit., p. 165. 
marco de mayor libertad, menor transparencia e inferior democracia, eludiendo o reduciendo sensiblemente el control judicial y, por lo tanto, con un menor coste político interno ${ }^{427}$. De este modo, la cooperación europea ha servido para "fortalecer los brazos de los ejecutivos nacionales (particularmente los ministros de interior), a expensas de los tribunales y los parlamentos" ${ }^{2} 28$.

En esta nueva panorámica de las relaciones entre la globalización, el DIDH y el control de la migración, los Estados nacionales, a fin de reconciliar la eficacia del control migratorio con las exigencias liberales protectoras de los derechos, buscaron - y encontraron- nuevas vías que les permitieran "el logro de sus objetivos políticos internos sin enfrentar los tipos de limitaciones legales y políticas que encontraban a nivel nacional" ${ }^{229}$. De ahí que el recurso del Estado Nacional a foros de integración regional europea en materia migratoria haya sido definido como el "escape a Europa" ${ }^{\text {"30 }}$, permitiendo a los Estados el logro de sus objetivos migratorios internos sobre la base de la transferencia de la toma de decisiones a un ámbito de mayor libertad de acción, eludiendo las limitaciones políticas y jurídicas internas que afrontarían en el ámbito nacional. Ello permitiría además a los gobiernos nacionales "minimizar la visibilidad de decisiones políticas poco < vendibles $>$ en el ámbito interno y recuperar así cierto margen de maniobra"431.

A la luz de estas consideraciones, el Estado Nacional continúa siendo fuerte en materia migratoria $^{432}$, e incluso hay quien apunta que los Estados han incrementado sus capacidades para controlar

427 En palabras de las propias autoras, “international or transnational fora may enhance the degrees of freedom and legitimacy of national policy makers by providing International leverage to appeal to domestic constituencies and public opinion back home while containing judicial oversight". GUIRAUDON, V. Y LAHAV, G. "A Reappraisal of the State Sovereignty Debate. The case of Migration Control”, op. cit., p. 181.

428 GEDDES, Andrew. "International Migration and State Sovereignty in an Integrating Europe"; en International Migration, vol. 39, No. 6, 2001, p. 22. Gary Freeman va incluso más allá señalando que, contrariamente a las visiones convencionales, el control del Estado sobre la inmigración está "innegablemente incrementándose a lo largo del tiempo, no descendiendo", pero insistiendo asimismo en la necesidad de distinguir según los países y desagregar también aquellas concretas áreas políticas que, dentro del amplio espectro migratorio, resultan más complejas. FREEMAN, Gary. “The Decline of Sovereignty? Politics and Immigration Restriction in Liberal States”; en JOPPKE, Christian (ed.). Challenge to the Nation State: Immigration in Western Europe and the United States. Oxford, Oxford University Press, 1998, pp. 86-107.

429 GEDDES, Andrew. "International Migration and State Sovereignty in an Integrating Europe"; en International Migration, vol. 39, $\mathrm{N}^{\circ} .6,2001$, p. 28.

430 Geddes señala que al intentar restringir formas de migración consideradas como no deseables, el Estado nacional encontró limitaciones políticas y legales que derivaban de sus propios derechos internos, de modo que recurrieron a fórmulas de cooperación internacional dentro de la UE pues las mismas "no están sujetas a similares restricciones legales y políticas". En torno a esta tesis escapista y citando a Freeman y Hollifield, Geddes afirma que "the form of cooperation is likely to be intergovernmental with some tendencies towards 'lowest common denominator' restrictive policies". Its main weakness is that it addresses the "shift" to Europe, but pays little attention to the effects. The EU is seen as an external venue to which member states escape without thinking about the ways in which EU responsibilities feed back into domestic contexts". GEDDES, A. "International Migration and State Sovereignty in an Integrating Europe", op. cit., p. 28.

431 CEBOLLA BOADO, H. y GONZÁLEZ FERRER, A. La inmigración en España (2000-2007)... op. cit., p. 81. Los autores recurren al íter restrictivo recorrido por la tramitación de la Directiva 2003/86/CE del Consejo de 22 de septiembre de 2003 sobre el derecho a la Reunificación Familiar como ejemplo de la recuperación del control migratorio por parte de los Estados europeos, mediante la transferencia de la toma de decisiones al nivel supranacional constituido por la UE.

432 En este aspecto Christian Joppke afirma con contundencia que "no hay evidencia de que la soberanía del Estado liberal nacional para aceptar o rechazar extranjeros esté menguándose" y que, de hecho, "el control de las entradas se convierte en una de los pocas áreas en la que los Estados pueden todavía ser fuertes”. JOPPKE, Christian. Immigration and the Nation-State: The United States, Germany and Great Britain, op. cit., pp. 262 y 3, respectivamente. JOPPKE, C. “Why Liberal States Accept Unwanted Immigration?”, op. cit., p. 270. En similar sentido, Delaet sostiene que los países industrializados han demostrado su eficacia en el control migratorio, siendo éste más exitoso en los Estados europeos que en EE.UU. DELAET, Debra. US Immigration Policy in an Age of Rights, op. cit., p. 14. En el 
la migración internacional ${ }^{433}$. Además, la imagen del DI como fuente de obligaciones internacionales protectoras de derechos humanos, que resultan no sólo externas a las políticas migratorias diseñadas por el Estado Nacional, sino profundamente contradictorias - pues mientras las primeras impulsan a la extensión de derechos de los migrantes, las internas protegen intereses nacionales dirigidos a la contención y restricción de los flujos-, no resulta muy realista. Dicho de forma más simple, el DI también puede servir para cobijar y justificar la contención de flujos y la reducción de los derechos de los extranjeros ${ }^{434}$, por lo que no resulta válido conectar de forma exclusiva el fracaso de las políticas internas de control migratorio con las limitaciones derivadas del DI.

Dado que los intereses nacionales y el poder de control del Estado sobre sus fronteras y los extranjeros que penetran a través de ellas en sus territorios, pueden resultar reforzados por los instrumentos internacionales, dotándoles de legitimidad y realzando la autoridad del Estado nacional ${ }^{435}$, resulta obligado, sin negar la importancia del derecho internacional, buscar alguna fuente alternativa que ilustre con mayor agudeza la procedencia de los obstáculos jurídicos a las políticas migratorias internas restrictivas. Y, a nuestro juicio, la respuesta se puede encontrar, fundamentalmente, en el derecho interno ${ }^{436}$, especialmente en las normas constitucionales que consagran derechos individuales procedentes de los esquemas liberales sobre los que se constituyó el Estado Constitucional, esquemas que, en nuestra opinión, han resultado reforzados por el DIDH, pues como señalamos al principio de nuestro estudio, la formación del DIDH había bebido de las mismas fuentes dogmáticas

mismo frente se sitúan Cornelius, Martin y Hollifield, quienes toman como punto de partida la imposibilidad de que en países democráticos receptores de flujos y atados a su vez por compromisos liberales y humanitarios, existan sistemas "perfectos" de control migratorio, capaces de impermebealizar al Estado receptor de migración indeseada o ilegal. Sin embargo, puntualizan que "they do not prevent States from establishing systems of Immigration control that, in global perspective, are very effective indeed - when effectiveness is measured not against some utterly unrealistic ideal of zero immigration, but rather against the extremely large and rapidly rowing global demand for admission. Seen from the inside - that is, from the point of view of the citizens of favored countries - immigration control may be strikingly imperfect; but seen from the outside - from the perspective of those turned down for tourist visas, or those at the end of a twenty-year waiting list for admission, or those willing to pay large sums of money and undertake risk voyages in order to circumvent barriers to entry- immigration control appears all too effective. Of course, control is not absolute; but states have the capacity, and the will, to influence the "price" of entry, including specifically the price of illegal entry. There will always be people willing to pay the price, even to the point of risking their lives". CORNELIUS, Wayne; MARTIN, Philip y HOLLIFIELD, James. Controlling Immigration... first edit, 1994, op. cit., p. 230. Desde una perspectiva más general, la influencia de la globalización sobre la soberanía estatal ha provocado una profunda evolución sobre dicho concepto, pero el mismo pervive ostentando "una importancia capital”. En palabras de Hinojosa Martínez, "el Estado continúa siendo el principal núcleo de poder en la sociedad internacional y, en consecuencia, permanece como el eje central en torno al cual se articula el derecho internacional. Por tanto, persiste la vigencia de la noción de soberanía como elemento constitutivo del Estado y base del derecho internacional actual"; en HINOJOSA MARTÍNEZ, L. M. "Globalización y soberanía de los Estados", op. cit., p. 14. En la misma línea, CARRILLO SALCEDO señala que la soberanía estatal constituye el principio de partida ineludible para la comprensión del DI. Soberanía del Estado y Derecho Internacional, op. cit., p. 103.

433 FREEMAN, G. "The decline of sovereignty?. Politics and immigration restriction in liberal states"; en JOPPKE, C. (ed.). Challenge to the nation-state: Immigration in Western Europe and the United States, op. cit., p. 101.

434 En palabras de LAHAV y GUIRAUDON, "the coexistence of transs/International and national migration norms has been underestimated because globalist have overlooked the fact that International rules also sanction states to adopt all types of restrictive migration policies"; en “A Reappraisal of the State Sovereignty Debate...”, op. cit., p. 181.

435 LAHAV, Gallya. "International versus National Constraints in Family-Reunification Migration Policies”, op. cit., p. 368.

436 En este sentido, seguimos las propuestas de JOPPKE, LAHAV, GUIRAUDON y Gary FREEMAN. Este último autor sostiene que los fracasos políticos que afronta el Estado nacional frente a sus intentos de controlar de forma restrictiva los flujos se deben más a factores políticos internos que a presiones externas —léase globalización de los flujos y limitaciones procedentes del régimen internacional. FREEMAN, Gary P. “The decline of sovereignty?. Politics and immigration restriction in liberal states"; en JOPPKE, C. (ed.). Challenge to the nation-state: Immigration in Western Europe and the United States. Oxford, Oxford University Press, 1998, p. 87. 
liberales. El punto de engarce entre estas dos ramas del derecho, necesario para que ambas, lejos de actuar en sentidos divergentes, hayan podido funcionar sinérgicamente en favor de los derechos de los migrantes se encuentra en la jurisprudencia, tanto interna como internacional.

En esta línea de razonamiento, Joppke ha señalado que "las normas y obligaciones de derechos humanos no se enfrentan con los Estados nacionales desde afuera. Más que planear en abstracto por el espacio global, la protección de los derechos humanos es un principio constitutivo del EstadoNación. Las migraciones de postguerra han introducido una cuña entre el principio de la protección de los derechos humanos y un segundo principio constitutivo del Estado-Nación, la soberanía popular"437. Este autor sostiene que, al menos en lo que respecta a los Estados liberales, la imagen del Estado nacional constreñido externamente por obligaciones internacionales protectoras de los derechos humanos no resulta correcta, pues en estos Estados "la protección de los derechos humanos se halla incrustada en el derecho y las tradiciones internas" ${ }^{\text {"438. }}$. Joppke se pronuncia en un sentido similar al "liberalismo incrustado" propuesto por Hollifield y ya apuntado al inicio de este trabajo. Esta consideración lleva a Joppke a concluir que aunque "la soberanía y los derechos humanos siguen constituyendo principios conflictivos, ambos se encuentran localizados bajo las raíces del Estado liberal", de modo que los regímenes internacionales protectores de derechos y su influencia interna sobre los regímenes migratorios nacionales, constituirían una "autolimitación a la soberanía nacional”439.

La argumentación ofrecida por Joppke coincide en parte con la expuesta previamente sobre el tema por Gary Freeman ${ }^{440}$. Este último autor, tras cuestionarse si las democracias liberales receptoras de flujos pueden controlar la inmigración no deseada, responde en sentido afirmativo, no sin antes aclarar la necesidad de disgregar las políticas migratorias y distinguir según los países liberales, a fin de evitar incurrir en lo que califica como "generalizaciones exageradas" 441 . Freeman constata que el Estado nacional de nuestros días cuenta con una fuerte infraestructura para gestionar los

437 JOPPKE, Christian. Immigration and the Nation State: The United States, Germany and Great Britain, op. cit., p. 4.

438 Para Joppke, la supuesta oposición entre el régimen externo de protección de derechos humanos y la soberanía de los Estados puede justificarse en el caso de los Estados no liberales o las democracias en ciernes o de reciente creación. Immigration and the Nation State..., op. cit, p. 262. En un artículo posterior, el mismo autor afirma que sólo los Estados liberales están acosados por el problema de la inmigración no deseada (inmigración irregular, RF y asilo), pues dicha inmigración no resulta problemática en el resto de los Estados, señalando asimismo que la lógica de la globalización y el régimen internacional de derechos humanos no puede explicar por sí misma por qué los Estados occidentales aceptan inmigrantes no solicitados. Como ejemplo, cita la situación de los Estados receptores de Oriente Medio productores de petróleos, que han resultado ser extremadamente eficaces en mantener fuera de sus fronteras y expulsar a los inmigrantes no deseados. JOPPKE, C. "Why Liberal States Accept Unwanted Migration?", op. cit., pp. 268 y 269.

439 JOPPKE, C. Immigration and the Nation State: The United States, Germany and Great Britain, op, cit., p. 263. También, del mismo autor, "Immigration Challenges the Nation-State"; en JOPKKE, C. (ed.). Challenge to the NationState. Immigration in Western Europe and the United States, op, cit., p. 19. En idéntico sentido, Lahav y Guiraudon señalan la importancia de los factores domésticos internos limitantes de las políticas migratorias nacionales, entre los que destaca lo que denominan la "self-impopsed judicial control on state action". GUIRAUDON y LAVAH, "A Reappraisal of the State Sovereignty Debate. The Case of Migration Control”, op, cit. p. 164, nota a pie No. 2.

440 FREEMAN, Gary. "Can Liberal States Control Unwanted Migration?"; en The Annals of the American Academy of Political and Social Science, vol. 534, 1994, pp. 17-30.

441 Sobre esta base, Freeman clasifica las políticas migratorias en cuatro grandes segmentos - gestión de la inmigración legal, control de la migración ilegal, administración de los programas temporales de trabajadores y la gestión de las solicitudes de asilo y refugio - cuyo análisis efectúa de forma separada y en función de determinados países liberales para establecer las siguientes conclusiones: en primer lugar, que la capacidad estatal de control migratorio está "ciertamente creciendo, no declinando, a lo largo del tiempo"; que algunos Estados poseen más capacidad que otros, que las capacidades de control de determinados países varían sustancialmente a través de las cuatro arenas de la política migratoria ya destacadas y, finalmente, que estas capacidades fluctúan periódicamente en conjunción con ciclos de abundancia y de crisis. FREEMAN, G. "Can Liberal States...?”; op. cit., p. 19. 
flujos migratorios - mayor que la existente en épocas precedentes y además con poderes en aumento-, si bien la ejecución de sus políticas restrictivas encuentra sus mayores dificultades en el ámbito doméstico, no en el internacional. Freeman se apoya en factores procedentes del proceso político interno para explicar la protección de los derechos de los extranjeros en los Estados liberales de inmigración, especialmente en las clientelas políticas - empresarios deseos de mano de obra barata y grupos pro-inmigrantes - cuyas presiones explican el avance en el reconocimiento de derechos de los extranjeros pese a la retórica oficial restrictiva.

Sin embargo, existe un ámbito excepcional donde Freeman sí constata que la capacidad estatal para controlar la migración se ha "escabullido" y donde la influencia del DIDH ha sido muy relevante: se trata de la capacidad estatal para seleccionar migrantes de acuerdo a criterios étnicos o en función de determinados orígenes nacionales, muy habitual durante el siglo XIX y buena parte del XX, pero eliminada como consecuencia de la implantación del principio de no discriminación. A juicio de Freeman, esta circunstancia "representa una restricción sustancial sobre las políticas nacionales" ${ }^{\prime 42}$.

Por su parte, Joppke, reformula el interrogante lanzado por Freeman, cuestionándose por qué los Estados desarrollados aceptan más inmigrantes de los pretendidos por sus políticas generalmente restriccionistas, esto es, por qué aceptan inmigración no deseada y si dicha aceptación denota una devaluación de la soberanía nacional. Joppke coincide con Freeman en afirmar la solidez del Estado Nacional frente a la inmigración y en adjudicar a factores internos que inducen a una autolimitación de la soberanía - y no a condicionantes externos propios de un sistema global-, los fracasos de las políticas migratorias de control; sin embargo discrepa en el carácter concreto de dichos factores. Para este último autor, el proceso político puede explicar la expansión de derechos de los migrantes y la tolerancia hacia la inmigración irregular en EEUU, donde los grupos de apoyo a los inmigrantes están bien organizados ${ }^{443}$, pero estos factores políticos no resultan extrapolables al caso europeo a partir del cierre de fronteras acaecido en los setenta. A juicio de Joppke, la aceptación de inmigrantes no solicitados -irregulares, RF y asilo- en Europa no puede concebirse en términos de clientelas políticas $^{444}$, por lo que no encontraría justificación en el proceso político, sino en el proceso legal.

442 La eliminación no ha sido total, pues FREEMAN señala a Gran Bretaña y a Japón como países que siguen incorporando criterios étnicos o nacionales en sus políticas migratorias. Ídem, pp. 19-20.

443 Joppke estima que el proceso político interno explica por qué EEUU debe aceptar inmigración no deseada o no solicitada, como ocurre con la inmigración ilegal, especialmente la procedente de México. El autor señala, siguiendo a Gary Freeman, que junto a la lógica de las clientelas políticas -empresarios y grupos de apoyo de inmigrantes luchan a favor de la contratación y derechos de los extranjeros-, existe una razón adicional para la política liberal desarrollada por este país en esta materia: lo que Freeman denomina "la norma antipopulista", muy fuerte en este país y consistente en la prohibición de seleccionar los flujos de inmigrantes en base a criterios étnicos o raciales. Esta norma se traduce a su vez en el principio de universalismo, en aplicación al país de origen de los inmigrantes y está alimentada por la concepción de EEUU como una nación de inmigrantes, así como por el principio de no discriminación y de defensa de los derechos civiles. La norma antipopulista y las presiones de las clientelas políticas explican que EEUU termine aceptando inmigración no deseada, pese al sentimiento popular existente en contra de la misma. JOPPKE, C. “Why Liberal States Accept Unwanted Migration?”, op. cit., especialmente pp. 272-281.

444 JOPPKE señala que en Europa no existe un lobby pro-migratorio afianzado, comparable al existente en EEUU, de modo que tras el cierre de fronteras de los setenta, las políticas migratorias europeas se enfocaron en la protección de los intereses políticos nacionales. En sus propias palabras, "states now uniformly disregarded their single strongest client, employers interested in cheap foreign labor, and acted on behalf of collective goals such as social integration or the integrity of nationhood" "Why liberal States Accept Unwanted Migration?", op. cit., p. 282. En torno a la inexistencia de un sistema organizado en apoyo a los derechos de los migrantes en Europa, también se manifiestan Lahav y Guiraudon. Ambas autoras sostienen la debilidad de los grupos de defensa y organizaciones de inmigrantes y su falta de estructuración a nivel europeo, concluyendo, en una línea similar a la sostenida por Joppke, que "the crafting and diffusion of normas have taken place within the legal sphere, which explains our emphasis on Interna- 
Ello debido fundamentalmente a la existencia de normas constitucionales liberales protectoras de la persona frente al poder estatal, con independencia de su nacionalidad, en conjunción con las obligaciones morales que los gobiernos receptores consideraban adeudar a los grupos de inmigrantes que gozaban de mayor asentamiento en el país. A juicio de Joppke, las limitaciones internas sobre la ejecución de políticas migratorias restrictivas que experimentan los países europeos, están "desigualmente distribuidas" 445 . La distinta intensidad de las obligaciones morales hacia los inmigrantes, explicable según estemos ante regímenes herederos de sistemas de trabajadores invitados o postcoloniales, justificaría, según Joppke, esta desigual distribución de cargas humanitarias sobre los regímenes migratorios. El carácter de estas obligaciones morales difiere pues según el tipo de régimen migratorio del país europeo de destino, siendo superiores y por ello dando lugar a un régimen más protector en los países que habían importado trabajadores invitados ${ }^{446}$, como Alemania, que en aquellos con regímenes postcoloniales, como el Reino Unido, que no habían solicitado, sino aceptado pasivamente inmigrantes. Por ello, en los regímenes postcoloniales, el Estado no se sentía moralmente tan condicionado, lo que explicaría el desarrollo de políticas migratorias de mayor firmeza y menor generosidad en tales regímenes.

La existencia de normas constitucionales liberales y de obligaciones morales explican, para Joppke, la tolerancia primero y el posterior reconocimiento de derechos en favor de los familiares dependientes. En este proceso la actuación activista del poder judicial interno resultó esencial. Los tribunales se apoyarían en ambos elementos para proteger constitucionalmente la inmigración familiar, logrando colmar las lagunas jurídicas existentes en esta materia, impidiendo los recortes de la RF e impulsando la intervención del poder legislativo y, con ello, reduciendo el alto grado de discrecionalidad administrativa inicialmente existente en este ámbito. El autor explica lo ocurrido en Alemania como el ejemplo más generoso, pues los trabajadores invitados lograron mediante el proceso legal descrito el reconocimiento de su derecho a residir de forma permanente y, posteriormente, a traerse a su familia nuclear, aún en contra de la retórica oficial que insistía en negar la condición de Alemania como país de inmigración. En Europa, la aceptación de inmigrantes no solicitados, como los familiares de residentes, constituiría un ejemplo de "inmigración jurídica o moralmente tolerada" 447 .

Desde esta perspectiva, las dificultades que afrontan las políticas migratorias internas de carácter restrictivo al recortar los derechos de los extranjeros, se explicarían como consecuencia de "un proceso legalmente dirigido de soberanía auto-limitada" 448 , antes que como consecuencia de un proceso global de limitación de las políticas internas. En esta línea, ya desde la década de los setenta, Josef Isensee ${ }^{49}$ señaló que, una vez que los extranjeros eran admitidos en su territorio, el Estado

tional and national judicial institutions and the ways that their rulings are taken into account by other branches of movement". GUIRAUDON, Virginie y LAHAV, Gallya. "A Reappraisal of the State Sovereignty Debate. The Case of Migration Control", op. cit., p. 166.

445 JOPPKE, C. “Why Liberal States Accept Unwanted Migration?”, op. cit, p. 272.

446 Y aún dentro de los países que habían contado con sistemas de trabajadores extranjeros invitados, Joppke señala que la intensidad de las obligaciones morales difiere según estemos ante inmigrantes primarios, esto es activamente recrutados, o inmigrantes secundarios, aquellos llegados tras el cierre de las políticas de reclutamiento de los setenta. Los inmigrantes primarios estaban respaldados por fuertes obligaciones morales, mismas que se iban sucesivamente diluyendo frente a los inmigrantes secundarios y terciarios. JOPPKE, C. "Why Liberal States..?”, op. cit., p. 282. 447 Ídem.

448 LAHAV y GUIRAUDOU, op, cit. p. 189.

449 ISENSEE, Josef. Die staatsrechtliche Stellung der Ausländer in der Bundesrepublik Deutschland; en Veröffentlichungen der Vereingung der Deustschen Staatsrechtslehrer. Bruyter, Berlin, 1974, pp. 49-106. Citado por LAHAV y GUIRAUDOU. “A Reappraisal of the State Sovereignty Debate...”, op, cit. p. 189; y también citado por JOOPKE, Immigration Challenges the Nation-State, op. cit., p. 19. Este último autor, al comentar la obra de Isensee, distingue 
contaba con poderes auto-limitados para su tratamiento jurídico y no podía disponer a su antojo de los derechos de este colectivo. De modo que la señalada autolimitación implicaba que el Estado tenía poder para decidir admitir o rechazar la entrada de no nacionales por sus fronteras ${ }^{450}$, pero ya dentro de las mismas, el extranjero disfrutaba de la protección de la ley, quedando recortados los poderes soberanos del Estado Nacional. Cuestión que, considerada desde una perspectiva más extensa, constituye una proyección interna de la ascensión del principio del respeto de los derechos humanos fundamentales - al menos en lo que respecta a su "núcleo duro" o derechos más esenciales- a norma imperativa de ius cogens del $\mathrm{DIDH}^{451}$.

Nuestra visión del tema se encauzaría dentro de las consideraciones anteriores, siguiendo principal, aunque no plenamente, la obra de Christian Joppke, con cuyas conclusiones confluyen parcialmente otros muchos estudios ${ }^{452}$. Al igual que Joppke, sostenemos que el proceso político interno no resulta especialmente relevante para explicar el proceso extensivo de reconocimiento de derechos a los inmigrantes experimentado en Europa. Junto a la argumentación por él ofrecida para refutar el razonamiento de Freeman en torno a la importancia de las clientelas políticas, ofrecemos un argumento adicional: el hecho de que el proceso político desatiende las necesidades de los inmigrantes como consecuencia de la generalizada extensión de la identificación entre nacionalidad y ciudadanía propia de la tradición jurídica liberal ${ }^{453}$, lo que termina desembocando en la exclusión de los no nacionales respecto del cuerpo electoral y del ejercicio de los derechos políticos, salvo contadas excepciones - ejemplificaría una de tales excepciones el sufragio municipal de los extranjeros en España, siempre que exista un acuerdo que les reconozca tal derecho y sean residentes en nuestro país.

Sin embargo, a diferencia de Joppke, quien minimiza la importancia del régimen internacional de derechos humanos en el ámbito migratorio - afirmando incluso que la insistencia doctrinal en este punto constituye "la construcción social más inflada en la reciente ciencia social"454_, nuestra postura subraya la importancia del DIDH, al menos en lo que respecta al concreto y progresivo proceso de desarrollo y consagración jurídica de la RF en el ámbito europeo, proceso en el que la labor desarrollada por la Convención Europea de derechos humanos, tal y como ha sido interpretada por el Tribunal de Estrasburgo, ha resultado determinante, impregnando a su vez el derecho comunitario.

entre la soberanía sobre las entradas y la subsiguiente autolimitación de la soberanía sobre el trato dispensado a los extranjeros, una vez que éstos han sido ya admitidos en el territorio del Estado receptor.

450 Tendremos ocasión de señalar en siguientes capítulos que también la soberanía sobre la entrada ha sido objeto de autolimitación como consecuencia de la actuación sinérgica de la jurisprudencia interna e internacional, las normas constitucionales protectoras de derechos y el DIDH, especialmente el CEDH en el ámbito de la RF.

451 ABELLÁN HONRUBIA incluye el derecho a la vida, el derecho a la integridad física, el derecho a la libertad y la seguridad personal como parte integrante del núcleo duro irrenunciable e inderogable de derechos humanos. ABELLÁN HONRUBIA, Victoria. "Internacionalización del concepto y contenido de los derechos humanos"; en JIMÉNEZ DE PARGA, R; ABELLÁN HONRUBIA, V. y FERREIRO LAPATZA, J. J. Tres lecciones magistrales. Inauguración de los cursos 1995-1996, 1996-1997 y 1997-1998. Universidad de Barcelona, Marcial Pons,1998, pp. 43-44.

452 A modo puramente ejemplicativo, LAHAV y GUIRAUDON también indican que no se deben exagerar las limitaciones normativas internacionales sobre el control migratorio. A juicio de ambas, "liberal domestic norms guaranteed by constitutions, legislation, and jurisprudence have had a more significant impact on national control policies and need to be taken under consideration as well"; en "A Reappraisal of the State Sovereignty Debate..", op. cit., p. 164.

453 SANTOLAYA MACHETTI, Pablo y DÍAZ GRECO, María. El sufragio de los extranjeros. Un estudio de Derecho Comparado. Madrid, Centro de Estudios Políticos y Constitucionales, 2008, pp. 11-12.

454 JOPPKE, C. “Why Liberal States Accept Unwanted Immigration?”, op. cit., p. 293. 
A nuestro juicio, el DIDH vino a vigorizar las normas liberales protectoras de derechos que constituían el pilar sobre el que se erigió la estructura del Estado Constitucional moderno. De esta forma, más que una limitación externamente impuesta, la protección internacional de los derechos humanos vino a sedimentarse sobre la capa de los valores, principios y derechos reconocidos en las Constitucionales nacionales, gracias fundamentalmente a la actuación del poder judicial y la aceptación de sus decisiones por parte de los poderes nacionales ejecutivo y legislativo. En el contexto específicamente español, el artículo 10.2 CE, en conjunción con la actitud internacionalista del TC, facilitaron este proceso.

La adición de normas y valores internacionales protectores de la persona permitieron al poder judicial interno contar con más mecanismos para poder oponer resistencia a las tendencias restrictivas que en materia migratoria emprendieron los gobiernos y las legislaturas internas desde los años setenta. Pero, a su vez, en este proceso, la jurisprudencia internacional, especialmente la desarrollada por el TEDH, resultó especialmente poderosa como consecuencia de su alto grado de difusión y penetración tanto en los países pertenecientes al ámbito del Consejo de Europa, como en la Unión Europea. Dentro del espacio geográfico europeo, "donde las normas internacionales pueden con mayor probabilidad afectar los resultados políticos domésticos" ${ }^{355}$, los criterios jurisprudenciales del TEDH fueron incorporados por los tribunales domésticos, frecuentemente al máximo nivel a través de los Tribunales Constitucionales, reforzando la posición de los extranjeros instalados en el territorio de dichos Estados, con independencia de la nacionalidad de los mismos. En suma, a nuestro juicio, la autolimitación de las políticas migratorias internas en materia de RF procede, en su mayor parte, de factores constitucionales ${ }^{456}$ profundamente arraigados en el Estado receptor, interpretados por la jurisprudencia interna con criterios procedentes del DIDH. La evidencia de ello es que cuando la Comisión y posteriormente el TEDH aceptaron las demandas que, en materia de migración familiar, se enclavaban dentro del derecho a la vida familiar del artículo $8 \mathrm{CEDH}$, lo hicieron alentados por la previa aplicación a los extranjeros de las normas constitucionales de protección de la familia por parte de los tribunales internos ${ }^{457}$.

Una visión asimismo armónica de la interacción entre las dinámicas interna e internacional en materia migratoria y de la importancia respectiva de las mismas, a la que también nos adherimos, la ofrece Delaet. A juicio de esta autora, las visiones que restan importancia al DI en el ámbito migratorio afirmando que el recurso al ámbito internacional puede servir para legitimar políticas na-

455 LAHAV y GUIRAUDON. “A Reappraisal of the State Sovereignty Debate.., op. cit., nota al pie No. 10, p. 169.

$456 \mathrm{Al}$ respecto, Joopke ha destacado que "constitucional politics better explain the generosity and expansiviness of Wester states towards immigrants than the vague referente to a global economy and an International human rights regime". JOPPKE, C. "Immigration challenges to the nation-State”..., op. cit., p. 267. En sentido idéntico, LAHAV y GUIRAUDOU, ponen en el primer plano de importancia a las leyes y la jurisprudencia nacional, afirmando que "state sovereignty has been kept in check by national human rights guarantees more than by a transnational discourse or International legal norms". En base a esta argumentación concluyen que "therefore, the main divide does not lie between the International and the national but between the judiciary and the executive and between law and politics"; en "A Reappraisal of the State Siveregnty Debate..., op. cit., p. 189. En una línea similar, Freeman considera a los factores políticos internos como los principales obstáculos al control migratorio, señalando posteriormente que "las políticas migratorias de los estados democráticos, a pesar de las extendidas percepciones en sentido contrario, tienen un número de características que tienden a ser compasivas con la inmigración y que minan un régimen estricto de control migratorio". FREEMAN, G. "The decline of sovereignty?. Politics and immigration restriction in liberal states"; en JOPPKE, C. (ed.). Challenge to the nation-state: Immigration in Western Europe and the United States, op. cit., p. 102 y 88. También Hollifield otorga primacía a la protección legal y constitucional interna, para explicar la acumulación de derechos que los migrantes han experimentado desde la postguerra a la actualidad. HOLLIFIELD, James. “The Emerging Migration State”; en International Migration Review, vol. 38, No. 3, 2004 . p. 901. 457 JOOPKE, C. “Courts, the new Constitutionalism and Immigrant Rights”, op. cit., p. 837. 
cionales restrictivas, ayudando y cooperando con el Estado Nacional, parten de una visión idealista y distorsionada de la realidad, que sitúa el foco comparativo en una situación imposible de libertad absoluta de circulación de las personas. Delaet considera que el marco comparativo relevante desde el que poder evaluar la influencia ejercida por las normas liberales - donde se enmarca el DIDH y las normas constitucionales protectoras de derechos- en la regulación de los flujos internacionales no puede colocarse entre los distintos países, sino dentro de un mismo país y a lo largo del tiempo ${ }^{458}$. Aplicando esta perspectiva histórica ${ }^{459}$, Delaet concluye que todos los regimenes migratorios de los países industrializados avanzados han registrado influencias de las normas liberales, si bien con distinta intensidad, de modo que las normas internacionales no pueden considerarse en modo alguno como irrelevantes ${ }^{460}$.

Pese a ello, Delaet matiza que no puede hablarse todavía de la existencia de un régimen migratorio formal a nivel internacional, sino más modestamente de diversas normas liberales internacionales de importancia variable, en función de las políticas internas y los grupos de intereses existentes dentro de cada Estado, condiciones ambas que determinan el concreto impacto de las normas internacionales sobre los regímenes migratorios internos ${ }^{461}$. Finalmente, Delaet concluye su análisis afirmando que "el debate político interno sobre la inmigración no ha sido inmune a la influencia de factores externos sino, más bien, tiene lugar en un mundo interdependiente. Aunque el derecho soberano de los Estados para regular sus fronteras permanece sustancialmente intacto, los Estados, en un mundo crecientemente interdependiente, no pueden impedir el flujo transnacional de ideas. El incremento en el apoyo transnacional de los derechos civiles básicos y de la RF como normas humanitarias ha alterado el discurso político que da forma a los debates políticos migratorios en la mayoría de las democracias liberales. Está por verse si las normas liberales sobrevivirán al asalto de una nueva oleada antimigratoria y a un sentimiento restriccionista en la mayor parte de los países industrializados avanzados" ${ }^{362}$.

Tomando conjuntamente las tesis expuestas anteriormente, formuladas por separado por Lahav, Guiraudon, Joppke, Freeman y Delaet, las trataremos de aplicar críticamente a nuestro ámbito de estudio, a fin de obtener una visión equilibrada de la influencia del régimen internacional sobre la RF. Nuestro punto de partida reside en considerar que las normas que restringen la discreción esta-

458 Delaet señala más adelante que "if current policy restrictions in most advanzed industrializad countries are compared to historical efforts to restrict international migration, especially those based on racial, ethnic or nationalistic criteria, rather than to a model based on a complete freedom of movement, then it can be seen that liberal norms have impacted the ability of most advanced industrializad countries to regulate International migration". DELAET, Debra. U.S. Immigration Policy in an Age of Rights, op. cit., p. 10.

459 Sobre la necesidad de incorporar una dimensión histórica a la hora de evaluar la capacidad del Estado Nacional para gestionar la inmigración internacional, también insiste abundantemente Gary Freeman, quien sobre esta base señala que "if we step back from the present crisis and take a larger view, there is no doubt that the democracies have more and better means to control their borders, monitor foreigners within their territory, and manage International flows than they did twenty, fifty, or one hundred years ago". FREEMAN, G. "Can Liberal States Control Unwanted Migration?"; op. cit., p. 29.

460 DELAET, D. U.S. Immigration Policy in an Age of Rights, op. cit., p. 11.

461 Ídem, p. 15. Si bien en este punto conviene precisar que la autora examina el sistema migratorio de EEUU, de ahí la coincidencia parcial con Freeman respecto a la importancia de los grupos de presión y las clientelas políticas.

462 DELAET, D. Immigration Policy in an Age of Rights, pp. cit. p. 18. Aun suscribiendo la visión de Delaet, desde nuestro punto de vista, la afirmación de esta autora en torno al carácter intacto de la soberanía nacional debe ser matizada, pues si bien es cierto que el Estado nacional mantiene una fuerza preponderante, el derecho internacional ha permeado sobre el concepto clásico de soberanía estatal. Sin embargo, Freeman se manifiesta en términos casi idénticos, señalando que "los poderes soberanos de los Estados para regular sus fronteras y los términos de pertenencia a sus sociedades permanecen substanciales". FREEMAN, G. "The decline of sovereignty?. Politics and immigration restriction in liberal states", op. cit., p. 101. 
tal en el tratamiento jurídico otorgado a los extranjeros pueden estar generadas tanto interna como externamente ${ }^{463}$, otorgando primacía a las procedentes del nivel interno - en tanto que fuente primigenia de cuyo vigor depende la subsiguiente actuación del DIDH, a partir de cuya intervención el efecto expansivo sobre los derechos de los extranjeros se irradiará por un ámbito geográfico mucho más amplio.

En un período temporal relativamente breve, la RF ha pasado de ser un facultad discrecional al arbitrio del país receptor, a estar impregnada por parámetros internacionales de protección de la familia y la vida familiar. Éstos, en conjunción con las normas y valores constitucionales que tutelaban la familia, la vida familiar y el entorno privado en que ésta se desarrolla, han determinado una "drástica disminución de la base jurídica para la imposición de restricciones sobre la migración familiar" " ${ }^{464}$, recortando la discrecionalidad estatal en el tratamiento jurídico otorgado a los familiares de los extranjeros. Esta reducción se ha traducido en la existencia de límites no solamente sobre la capacidad estatal soberana de determinar los derechos que corresponden a los parientes extranjeros una vez admitidos en su territorio - ya apuntada por la doctrina alemana desde la década de los setenta del pasado siglo- sino, también, sobre la propia delimitación de aquellos extranjeros que podrán entrar en su territorio con fines de reunificación familiar y el estatuto jurídico predicable correspondiente a los mismos.

Este progreso ha sido posible debido fundamentalmente a factores internos que desembocaban en una autolimitación del Estado en materia migratoria, gracias a la actuación de los Tribunales internos ${ }^{465}$, quienes en un terreno abonado por la notable expansión alcanzada por determinadas normas del DIDH, procedieron a la penetración, interiorización y posterior incorporación de los estándares internacionales, dando lugar a un proceso de interacción normativa que podemos calificar como bidireccional. En virtud del mismo, la jurisprudencia interna interpretaba y aplicaba normas dogmáticas o principios jurídicos constitucionales preexistentes, sirviéndose de la intermediación de normas y criterios jurisprudenciales internacionales - estos últimos procedentes del TEDH fundamentalmente-, que amplificaban el efecto protector de las normas constitucionales y constreñían al poder ejecutivo. Pero, a su vez, la irradiación normativa - o "cooptación institucional" como ha dado en llamarse entre la doctrina internacionalista - se producía desde el DIDH a los ordenamientos internos en aquellos aspectos del derecho de extranjería sobre los que existía una base constitucional previa - léase la protección de la familia consagrada al máximo nivel interno- que permitía

463 GUIRAUDON, V y LAHAV, G.” A Reappraisal of the State Sovereignty Debate...”, op. cit., p. 190.

464 Nauck y Settles estiman que esta tendencia está además inducida por la creciente movilidad internacional y las oportunidades que ello implica de cara a los contactos sociales de carácter internacional. NAUCK, Bernhard; SETTLES, Barbara H. "Immigrant and Ethnic Minority Families: An Introduction"; Journal of Comparative Family Studies, vol. 32, No. 4, 2001, p. 463.

465 JOPPKE, Christian. "Immigration Challenges the Nation State"; en JOPPKE, C. (ed.). Challenge to the nation-state: Immigration in Western Europe and the United States. Oxford, Oxford University Press, 1998, pp. 5-46, especialmente pp. 19-20. Si bien resulta adecuado puntualizar que Christian Joppke no comparte la tesis sobre la importancia del régimen internacional de derechos humanos en la restricción de la soberanía estatal en materia migratoria y la consiguiente expansión de derechos de los inmigrantes. Joppke estima que este proceso se debe más a la "política constitucional" desarrollada por los tribunales internos, especialmente los Tribunales constitucionales, que suplieron las deficiencias y lagunas legislativas mediante una política judicial activista de reconocimiento de derechos. Menciona el caso de Alemania occidental como un supuesto emblemático al respecto y estima que dicha política constitucional explica que Estados renuentes a concebirse como países de inmigración - como Alemania- terminaran convirtiéndose en tales por razones constitucionales (p. 19 y 20). Para este autor, en el ámbito migratorio, la soberanía de los Estados está más delimitada internamente que internacional o externamente. 
a la jurisprudencia internacional pronunciarse sobre determinadas materias ${ }^{466}$, por lo que cabría incluso considerar el proceso descrito como circular.

Ambos niveles normativos desempeñaban funciones trascendentes en el proceso interactivo descrito: las normas internas servían para acomodar y materializar jurídicamente las garantías internacionales, constituyendo el "pilar sobre el cual las normas internacionales eran elaboradas" ${ }^{\text {" }}$ y, a su vez, los criterios y normas internacionales actuaban esclareciendo, especificando e, incluso, en aquellos supuestos de mayor activismo judicial, pudiendo alumbrar nuevos contenidos de las normas jurídicas internas que se encontraban en estado latente en la periferia o halo de incertidumbre del contenido de derechos constitucionales - o, empleando una terminología norteamericana que resulta especialmente gráfica para este supuesto, facultades ya subyacentes en las zonas de penumbra de determinados derechos internos - y que la impregnación de la jurisprudencia interna de criterios internacionales permitían sacar a la luz.

La invocación de normas internacionales por parte de la jurisprudencia interna constituye con carácter general un proceso reciente, ignorado durante décadas ${ }^{468}$, pero que últimamente está experimentando una creciente y rápida expansión ${ }^{469}$.

En el ámbito concreto de la RF, el recurso al DIDH por parte del poder judicial doméstico ha resultado muy eficaz, ya que sobre su base los tribunales administrativos e incluso constitucionales han logrado paralizar tanto las prácticas administrativas como los intentos de restringir la RF por vía legislativa, constituyendo Alemania, Francia y, en menor medida, Holanda los ejemplos más relevantes ${ }^{470}$. La intervención del poder judicial interno ha resultado determinante para lograr superar las debilidades del soft power del DIDH, dotando de efectividad interna a sus normas ${ }^{471}$. Incluso aquellos autores que se resisten a proclamar la influencia del DIDH en el avance de los derechos de los extranjeros en general, coinciden en exceptuar la RF como un ámbito donde la relevancia del DI no puede negarse ${ }^{472}$, situando el derecho al respeto de la vida familiar, tal y como es concebido por

466 JOOPKE, C. "Courts, the new Constitutionalism and Immigrant Rights”, op. cit.p. 837.

467 En el mismo sentido, GUIRAUDON y LAHAV, quienes en referencia al sistema protector del Consejo de Europa, califican este proceso de interacción entre las dinámicas nacional e internacional, como un proceso de "transmisión de normas"; en "A Reappraisal of the State Sovereignty Debate. The Case of Migration Control”, op. cit., p. 171.

468 GUIRAUDON y LAHAV. “A Reappraisal of the State...”, op. cit., p. 172.

469 En torno a la evolución que este proceso ha experimentado - que los autores califican como una forma de "coordinación interjudicial"-, resulta muy conveniente la lectura del siguiente artículo, si bien con la precisión de que su análisis se limita a un ámbito, la política exterior, tradicionalmente muy deferente y poco poroso a la influencia internacional. BENVENISTI, Eyal y DOWNS, George W. "National Courts, Domestic Democracy, and the Evolution of International Law”; en The European Journal of International Law, vol. 20, No. 1, 2009, pp. 59-72.

470 SASSEN, Saskia. Losing Control? Sovereignty in an Age of Globalization. New York, Columbia University Press, 1996, op. cit., p. 72. JOOPKE, C. "Courts, the new Constitutionalism and Immigrant Rights: The Case of the French Conseil Constitutionnel”; en European Journal of Political Research, №. 43, 2004, pp. 823-844. LAHAV y GUIRAUDON. "A Reappraisal of the State Sovereignty Debate", op. cit., pp. 171-175.

471 JOPPKE, C. “Why Liberal States Accept Unwanted Immigration?”; op. cit., p. 269.

472 En este sentido, Joppke señala la importancia de las normas constitucionales tanto en Alemania como en Francia, sobre las que se apoyaban los tribunales administrativos y constitucionales —en el caso de Francia, el Consejo de Estado y el Consejo Constitucional Francés-, señalando al DIDH como irrelevante en el proceso de constitucionalización de los derechos de los extranjeros. Sin embarbo, exceptúa el caso de la RF, donde los tribunales siempre se han apoyado en el artículo $8 \mathrm{CEDH}$. El caso Francés resulta paradigmático, pues con carácter general, la progresiva constitucionalización de los derechos de los extranjeros se explica por un proceso de interacción entre el Consejo de Estado y el Consejo Constitucional, apoyándose ambos en normas integrantes del denominado bloque constitucional, tales como las disposiciones constitucionales que consagraban la libertad y el debido proceso. De dicho bloque de constitucionalidad, las normas internacionales no formaban parte, como el propio Joppe se encarga de subrayar. Sin embargo, el autor puntualiza que, en el proceso de derivar derechos de familia para los extranjeros residentes, el 
el TEDH, en una posición destacadísima dentro de dicho ámbito de influencia. De ahí que incluso se haya señalado que la relación entre tribunales nacionales y la progresiva creación constitucional de derechos de los inmigrantes constituye un "proceso espurio"473 porque está condicionado por normas internacionales .

Quizá el reflejo más obvio del resultado amplificador y sinérgico que ofrece este proceso de interacción normativa interna/internacional — gracias a la actuación activista del poder judicial—, sea la lenta pero imparable ascensión protagonizada por la RF a través de sus diversas fuentes reguladoras, aspecto que lleva aparejada una correlativa escalada de sus garantías jurídicas: desde el modesto escalón de meras prácticas administrativas, hasta lograr encaramarse al rango legislativo para, incluso, en algunos supuestos todavía excepcionales, encontrar acomodo en las normas constitucionales protectoras de la familia ${ }^{474}$. El ejemplo más estilizado de este proceso ascendente ha sido recientemente personificado por la UE, donde a principios del presente siglo la RF ha conseguido el difícil logro de convertirse en una auténtico derecho subjetivo comunitario. Por su parte, los nacionales de los países comunitarios han disfrutado de este derecho desde la década de los sesenta del pasado siglo, con un nivel superior de protección y con independencia de la nacionalidad que ostentaran sus parientes reagrupables.

Y, más allá del espectro exclusivo de la RF, la influencia de los valores, principios y derechos constitucionales consagrados en las Constituciones de los países receptores, en conjunción con los parámetros internacionales, explica que resulte inevitable para los países liberales receptores de flujos internacionales aceptar ciertos niveles de inmigración, tanto regular como irregular ${ }^{475}$. Y ello, pese a militar dos poderosas circunstancias en su contra: la implantación de políticas migratorias restrictivas que aspiraban a conseguir objetivos cercanos a la inmigración cero, y la subsiguiente crisis de legitimidad que el fracaso recurrente de estos objetivos expresos o implícitos de las políticas migratorios ha provocado a nivel interno, creando "una fractura entre la retórica de una política restriccionista y una realidad migratoria expansionista" $"$.

En definitiva, el sistema internacional "informa” el derecho migratorio gracias a la acción mediadora de los tribunales internos, permitiendo interpretar en sentido expansivo y reforzar las normas constitucionales protectoras de derechos que resultan aplicables a los migrantes, especialmente

Consejo de Estado basó su emblemática decisión de 1978 sobre el artículo 8 CEDH, norma que ahora goza de eficacia directa en Francia. El pronunciamiento aludido es la decisión GISTI de 8 de diciembre de 1978, donde el Consejo de Estado dedujo el derecho a llevar una vida familiar normal del párrado décimo del Preámbulo de la Constitución de 1946, conforme al cual "la nación asegura al individuo y a la familia las condiciones necesarias para su desarrollo". El autor califica esto como una "incuestionable influencia de fuentes jurídicas extra-nacionales" en los derechos de los inmigrantes en Francia. JOOPKE, C. “Courts, the new Constitutionalism and Immigrant Rights”, op. cit.p. 837. 473 Ídem, p. 836.

474 Nuevamente, en este aspecto los casos protagonizados por Francia y Alemania resultan paradigmáticos.

475 ARANGO, Joaquín. "Dificultades y dilemas de las políticas de inmigración”, op. cit., p. 61. En el mismo sentido se expresan Papademetriou y Hamilton, quienes han puesto de relieve que resulta inevitable para las sociedades democráticas abiertas y liberales tener que tolerar un cierto nivel tanto de inmigración legal como ilegal, pues de hecho ésta última constituye un producto natural de la inmigración legal, que tendrá lugar con independencia de la dureza con que se emplee el Estado en detenerla. PAPADEMETRIOU, Demetrios y HAMILTON, Kimberly A. Converging Paths to Restriction: French, Italian and British Responses to Immigration. Washington DC, Carnegie Endowment for International Peace, 1996, p. 33. También se insertan aquí las doctrinas de Freeman, quien agudamente ha observado "just as no country is willing to expend the resources and bear the cost necessary to reduce crime to near zero, neither would it be racional to try to establish impervious borders. We should assess the problem from the perspective of what a reasonable level of illegal immigration might be". FREEMAN, Gary. "Can Liberal States Control Unwanted Migration?"; op. cit., p. 22.

476 JOPPKE, Christian. “Why Liberal States Accept Unwanted Migration?”; en World Politics, vol. 50, No. 2, 1998 , p 266. 
aquellas que protegen la familia. Sin embargo la influencia condicionante del DIDH y su incorporación en las políticas migratorias internas tampoco debe sobredimensionarse, pues constituye un proceso lento, tardío y, todavía, muy parcial y asimétrico.

Dicho influjo se ha concentrado en tres áreas ${ }^{477}$, que constituyen con diferencia los ámbitos más relevantes de influencia internacional sobre la tutela de los derechos de los extranjeros: de un lado, la protección contra tratamientos inhumanos o degradantes, que se ha traducido en la disminución de la discreción estatal sobre la deportación de extranjeros cuya expulsión a un tercer país acarree el riesgo de imposición de torturas; de otro, la proscripción de la selección de inmigrantes en base a criterios étnicos ${ }^{478}$; y, finalmente, la tutela del derecho a la vida familiar, la más importante para nuestro objeto de estudio. Ésta última se ha desplegado, a su vez, en dos sectores de influencia internacional muy destacada: en primer lugar, la protección frente a las expulsiones, siendo este sector de la jurisprudencia internacional el más sedimentado y prolífico en ramificaciones internas, cuya capacidad para "circunscribir la capacidad administrativa de expulsar a ciertas categorías de extranjeros" constituye un "hallazgo sorprendente para los académicos que dudaban del soft power del derecho internacional" ${ }^{479}$; en segundo lugar, el derecho a la vida familiar se ha proyectado intensamente sobre la RF, categoría que aun emergiendo cronológicamente antes, sin embargo todavía carece del grado de madurez de que disfruta el anterior área, pero que actualmente está sometida a un gran dinamismo y a un proceso de creciente expansión. Conviene señalar que estas dos últimas áreas relativas a los derechos de los extranjeros corresponden a su vez a dos prerrogativas estatales esenciales, la soberanía sobre la expulsión y la admisión de extranjeros ${ }^{480}$.

La penetración de estas dos últimas categorías jurisprudenciales vinculadas al derecho a la vida familiar, tanto en las políticas migratorias domésticas como en los criterios jurisprudenciales internos, no puede calificarse como menor, logrando colarse, aunque con claroscuros, en el ámbito comunitario. De esta situación cabría deducir la emergencia de un todavía muy incipiente régimen migratorio internacional o "derecho de los migrantes" 481 , que reconoce un conjunto limitado de facultades que "pueden ser esgrimidas por inmigrantes incluso contra la voluntad del Estado que los alberga" 482 y que, pese a encontrarse "en fase infantil, (...) está haciendo progresos"483, especialmente relevantes en el ámbito regional europeo, representado por el Consejo de Europa y por la UE.

El éxito de este proceso de interacción normativa, al menos en lo que concierne a aquellas áreas vinculadas al derecho a la vida familiar - protección frente a expulsiones y RF- se debe, a nuestro juicio, a la acción sinérgica de tres elementos: la jurisprudencia, tanto interna como internacional - y, en este último caso, el papel estelar ha corrido a cargo del TEDH - que actuaría como elemento conector; las normas internas protectoras de derechos, especialmente las de carácter constitucional que giraban alrededor de la protección de la familia y/o la vida familiar; y, el DIDH. La interacción

477 En este punto, Guiraudon y Lahav reducen a dos las áreas de mayor influencia de la jurisprudencia internacional sobre los derechos de los extranjeros: protección contra tratamientos inhumanos y el derecho a una vida familiar normal. GUIRAUDON, V y LAHAV, G. "A Reappraisal of the State Sovereignty Debate. The Case of Migration Control", op. cit., p. 167.

478 ARANGO, Joaquín. "Dificultades y dilemas de las políticas de inmigración”, op. cit., p. 58. Ya indicamos anteriormente que este área de influencia era rescatado incluso por aquellos sectores doctrinales más reacios a reconocer la influencia del DIDH en el ámbito migratorio, destacadamente, Gary FREEMAN. "Can Liberal States Control Unwanted Migration?”, op. cit., pp. 19 y 20.

479 GUIRAUDON y LAHAV, op. cit., p. 189.

480 JOPPKE, C. “Why Liberal States Accept Unwanted Immigration?”, op. cit., p. 267.

481 PERRUCHOUD, Richard. “The Law of Migrants”; en International Migration, №. 24, 1986, pp. 699-715.

482 ARANGO, Joaquín. “Dificultades y dilemas de las políticas de migración”, op. cit., p. 58.

483 LAHAV y GUIRAUDON. “A Reappaisal of the State Sovereignty Debate...”, op. cit., p. 180. 
de esta tríada explica, a nuestro juicio, la modesta extensión ${ }^{484}$ de derechos de los migrantes en un clima político propicio a la restricción de flujos y el camino ascendente recorrido por la RF hasta lograr situarse en el campo de los derechos subjetivos protegidos a nivel interno en los Estados miembros de la UE.

\section{NUEVAS FACETAS PROBLEMÁTICAS VINCULADAS A LA RF}

Junto a las facetas ya analizadas, que han impregnado tradicionalmente la concepción y la regulación de esta materia, los cambios acaecidos últimamente en los patrones de la migración familiar han hecho aflorar nuevas dimensiones de la RF, destacadas por Elenore Kofman ${ }^{485}$ y Albert Kraler ${ }^{486}$. Muchas de ellas presentan una condición fuertemente problemática, circunstancia que está ocasionando cambios en percepción socio-política de la inmigración vinculada a la familia, así como nuevas estrategias normativas por parte de los países receptores.

\section{a. Incremento de la inmigración matrimonial y de los matrimonios de conveniencia}

Dentro de la inmigración vinculada a la familia, el matrimonio se ha erigido como el principal acto de la vida familiar, constituyendo a un tiempo tanto una causa como un efecto generador de inmigración ${ }^{487}$. En la actualidad, sin embargo, de todas las tipologías migratorias vinculadas a la familia, la formación familiar o inmigración matrimonial es la que ha experimentado un mayor crecimiento, no solamente como consecuencia de la globalización y la facilidad de los transportes, sino también impulsada por las nuevas tecnologías de la información que la han facilitado de forma extraordinaria, permitiendo incluso la sustitución del contacto personal durante el período de noviazgo ${ }^{488}$. En el ámbito académico, han surgido términos específicos, muchos de ellos de carácter peyorativo, que reflejan este fenómeno: "Mail-order brides" — novias por catálogo—, "transnational brokered marriages" 489 - matrimonios transnacionales concertados - o incluso se ha llegado a hablar de "mercado matrimonial" 490.

484 A este diagnóstico llega Freeman, quien afirma que "contrariamente a lo sostenido por las tesis restriccionistas, la principal corriente entre las políticas migratorias del mundo occidental es al menos modestamente expansionista". FREEMAN, G. "The decline of sovereignty?. Politics and immigration restriction in liberal states"; en JOPPKE, C. (ed.). Challenge to the nation-state: Immigration in Western Europe and the United States, op. cit., p. 88.

485 KRALER, Albert y KOFMAN, Eleonore. Civic Stratification, Gender and Family Migration Policies, op. cit., p. 6. 486 KRALER, Albert. Civic Stratification, Gender, and Family Migra-tion Policies in Europe. Final Report, Viena, BMWF/ ICMPD, 2009. Sobre la base de este reporte final, KRALER Y KOFMAN, en tanto que coordinador e investigadora, respectivamente, del proyecto de investigación titulado Civic Stratification, Gender and Family Migration Policies in Europe (2006-2009) emitieron el informe ejecutivo titulado "Family migration in Europe: policies vs. Reality", No. 16. Agosto 2009, p. 4.

487 KOFMAN, Eleanore. Civic Stratification, Gender and Family Migration Policies, op. cit., p. 4.

488 Meeto y Kofman señalan que "the majority of the couples are introduced with the prior intention of marriage and have either no or only a comparatively short period of courtship. Internet is increasingly replacing face to face contact (here the rather derogatory maill-order bride label) as a means of introducing potencial spouses". MEETO y KOFMAN. "Family Migration"; World Migration 2008, op. cit., p. 156.

489 Para una visión crítica de los análisis tradicionales en torno a este tema, resulta de interés ROBINSON, Kathryn. "Marriage Migration, Gender Transformations and Family Values in the <Global Ecumene>; en Gender, Place and Culture, vol. 14, No. 4, 2007, pp. 483-497.

490 En torno a esta expresión, Robinson ha afirmado que: “The market metaphor invokes a sense of women using their 'sexual capital' to achieve economic gains through marriage and migration to a wealthy country: a view that essentialises a Western conflation of sex with the highest form of intimacy, and ignores the differential constitution 
La importación de parejas no nacionales parece haber sido especialmente fructífera en Europa y Asia y, estadísticamente, involucra de forma mayoritaria a mujeres extranjeras procedentes de países pobres entablando relaciones sentimentales con varones de países desarrollados ${ }^{491}$. En el ámbito europeo, conviene matizar que el predominio de la migración familiar como canal principal de entradas regulares de inmigrantes se da en los países del Norte y Centro Europeo que son, simultáneamente, aquellos donde la inmigración matrimonial ha escalado porcentualmente en los últimos años hasta representar la vía mayoritaria de migración familiar. Por su parte, en los considerados todavía como nuevos países de inmigración —entre ellos España - resulta todavía predominante la RF en sentido estricto dentro de la inmigración familiar ${ }^{492}$.

Paralelamente al auge de la inmigración matrimonial, está emergiendo una nueva característica en sentido divergente: dentro de la formación familiar comienza a sobresalir su masculinización, esto es, la tendencia creciente a que varones extranjeros penetren en el Estado receptor como parejas ${ }^{493}$. Estos tipos de importación de parejas extranjeras de ambos sexos constituyen un fenómeno en aumento y de rápido crecimiento, tanto entre los nacionales del Estado receptor - que a su vez incluirían tanto a los nacionales de origen como a los extranjeros nacionalizados - como entre los no nacionales allí asentados. Dentro de este último colectivo, habría que contemplar tanto a los extranjeros recién llegados, como a los inmigrantes instalados de forma definitiva, y entre éstos, a su vez, incluiría también a las segundas y subsiguientes generaciones - que pueden o no estar naturalizados en dicho Estado.

Ya señalamos que entre las personas de origen inmigrante parece resultar común encontrar pareja entre individuos de su mismo bagaje cultural o procedentes del entorno étnico de las comunidades de origen de sus progenitores. Esta tendencia ha tenido ocasión de estudiarse en profundidad a raíz de los trabajadores extranjeros que llegaron invitados por el modelo migratorio del guest worker, pero que finalmente terminaron instalándose en dichos países, entre los que sobresale numéricamente el colectivo turco ${ }^{494}$. De esta tendencia presente entre los grupos étnicos minoritarios en Europa, los sociólogos han deducido que la existencia de matrimo-

of sexual subjectivities in differing social/cultural settings". ROBINSON, Kathryn. "Marriage Migration, Gender Transformations and Family Values in the <Global Ecumene>", op. cit., p. 484.

491 MEETOO, Veena y KOFMAN, Eleanore. "Family Migration"; World Migration 2008, IOM, op. cit., p. 156; ROBINSON, Kathryn. "Marriage Migration, Gender Transformations and Family Values in the <Global Ecumene>", op. cit., pp. 483 y 484.

492 GIL ARAUJO, Sandra. Las políticas de migración familiar en Europa. El control de la inmigración a través de las familias. X Congreso Nacional de Sociología Jurídica. Córdoba, noviembre de 2009, sp. http://www.sasju.org.ar/xcon/ Xarchivos/Xcongreso/Comision_7/GilAraujoSandra\%20(2).pdf

493 KOFMAN, Eleanore. "Family-Related Migration: A Critial Review of European Studies", op. cit., p. 251.

494 En referencia al colectivo turco asentado en Holanda, existe un interesante estudio que reflexiona en torno a la justificabilidad moral de la restricción de la inmigración matrimonial. El capítulo se abre así: "On 21 February 2003 an intriguing announcement appeared in the Lonely Hearts Column of my local Dutch newspaper: 'Athletic Turkish fireman is seeking clever girl. I am looking for a wife to make a future life and family together. It would be extra nice if she were from Emirdag (Turkey) or thereabouts. The Turkish fireman is no exception. That is to say, it is exceptional that he should advertise in the Lonely Hearts columns, but it is fairly common that he, as a Dutcht citizen of Turkish descent, should be seeking a Turkish wife, preferably from his own home town. A large majority of former guest workers and their descendants in West European countries marry a spouse with the same ethnic background. Moreover, many of them seem to prefer a spouse imported from Turkey or the Maghreb rather than a partner whose parents were born there but who grew up in Western Europe herself (or himself; the pattern seems to exist for brides and bridegrooms alike). Goverments in West European countries worry about this demographic development". TRAPPENBURG, Margo. "Restricting Family Rights: Philosophical Reflections on Transnational Marriages"; en HONOHAN, I; JENNINGS, J. (eds.). Republicanism in Theory and Practice. London, Routledge, p. 173. 
nios entre los inmigrantes y los nativos constituye un indicador de una integración exitosa ${ }^{495}$ - circunstancia que, para el caso español, apunta ya a un claro predominio de los matrimonios mixtos en la nupcialidad de los extranjeros afincados en nuestro país ${ }^{496}$.

Pero, junto a este aspecto positivo, el auge de la inmigración matrimonial ha destapado determinados aspectos controvertidos implícitos a la misma, algunos de los cuales parecen derivar de la apuntada tendencia "endogámica" 497 de las comunidades de origen extranjero afincadas en el país receptor. Recientes investigaciones en el marco europeo destacan que es el colectivo masculino de origen extranjero el que muestra una preferencia mayor a la importación de parejas procedentes del entorno étnico y cultural de sus comunidades de origen, en relación al colectivo de mujeres de origen extranjero residentes en países europeos ${ }^{498}$.

Trappenburg ha destacado que el principal problema que este modelo de comportamiento matrimonial implica para el Estado de acogida es que tiene que "afrontar generaciones de recién llegados una y otra vez" ${ }^{\prime 99}$ con dificultades lingüísticas que se perpetúan, pese a involucrar a individuos descendientes de inmigrantes que pertenecen ya a la tercera o cuarta generación y que han nacido en el país receptor. Además, los extranjeros recién llegados se ubican en la edad adulta, lo que supone "una retroalimentación permanente de la primera generación que en principio constituye el grupo

495 TRAPPENBURG, M. “Restricting Family Rights...”, op. cit., p. 174. IZQUIERDO, Antonio. “Terremoto en los cimientos del modelo migratorio”; en GARCÍA ROCA, Joaquín y LACOMBA, Joan (eds.). La inmigración en la sociedad española. Una radiografía multidisciplinar. Barcelona, ediciones Bellaterra, 2008, p. 81. SCOTT, Sam and CARTLEDGE, Kim H. “Migrant Assimilation in Europe: A Transnational Family Affair”, op. cit., p. 64.

496 De los matrimonios celebrados en España a lo largo del año 2005, un 14’2\% lo fue con un cónyuge extranjero. Antonio Izquierdo indica al respecto que mientras los matrimonios entre nativos registran un descenso suave (-8\%), los matrimonios mixtos representan un $75 \%$ del total de los matrimonios, tanto de los españoles varones celebrados con mujeres extranjeras (46\%) como los de mujeres españolas con hombres extranjeros (29\%). De esta circunstancia el autor concluye que, "de persistir el predominio de los matrimonios mixtos, el aumento de la tasa de nupcialidad (...) reflejará cierto éxito en el proceso de integración de la reciente inmigración extranjera”. IZQUIERDO, Antonio. “Terremoto en los cimientos del modelo migratorio", op. cit., p. 81. Según datos extraídos del Instituto Nacional de Estadística, entre los años 2005 al 2009, mientras la tasa de nupcialidad entre ciudadanos españoles descendía un total de un 15,5\%, los matrimonios mixtos en España aumentaron un 33,4\%. En el año 2009 se celebraron en España un total de 30.266 matrimonios mixtos, lo que suponía que los matrimonios celebrados con algún contrayente extranjero representaban en torno al 19\% del total de los contraídos en nuestro país. Comparando estas cifras con las registradas en 1989, se obtiene una visión panorámica más atinada del salto cualitativo producido en esta materia: en 1989, en España se contrajeron un total de 8.947 matrimonios con al menos un cónyuge extranjero, lo que suponía un $4 \%$ del total de matrimonios celebrados en territorio español. En sentido concordante a lo señalado por Antonio Izquierdo respecto a las uniones mixtas como indicadores de procesos exitosos de integración se pronuncian también ALBERT GUARDIOLA, María Carmen y MASANET RIPOLL Erika, para quienes esta situación posee dos efectos principales: "En primer lugar, los matrimonios mixtos disminuyen las distinciones culturales en las futuras generaciones porque los hijos de los matrimonios mixtos tienen menos probabilidad de identificarse con un solo grupo. Y, en segundo lugar, la relación íntima que se establece en el matrimonio o pareja puede debilitar las actitudes negativas, prejuicios y estereotipos hacia otros grupos". "Los matrimonios mixtos en España, ¿espacios de construcción intercultural?"; Revista OBETS n 1, 2008, p. 58.

497 Kofman puntualiza que esta tendencia resulta especialmente acusada entre las poblaciones procedentes del Norte de Africa y de Turquía, de modo que los ataques contra la misma resultan en "un intento de contener el crecimiento de comunidades islámicas”. KOFMAN, Eleonore. "Family-Related Migration: A Critial Review of European Studies”, op. cit., p. 254.

498 El estudio rastrea la propensión a los matrimonios inter-étnicos entre varios grupos de inmigrantes y sus descendientes instalados en Alemania, Francia, Inglaterra, Bálgica y Holanda, durante el período subsiguiente a la segunda guerra mundial. LUCASSEN, Leo and LAARMAN, Charlott. "Immigration, Intermarriage and the Changing Face of Europe in the Post War Period”; en History of the Family vol.14, No.1, 2009, pp. 52-68. Una versión de este estudio está disponible en http://www.law.buffalo.edu/baldycenter/pdfs/lucassenoct08.pdf

499 TRAPPENBURG, M. “Restricting Family Rights...”, p. 175. 
con mayores dificultades de incorporación a la sociedad de acogida"500. Trappenburg ha señalado que una causa habitual para este tipo de preferencias matrimoniales radica en los valores y normas a los que la pareja extranjera se adhiere, especialmente en torno a las relaciones de género, resultando éstas poco populares y mal aceptadas entre la población nativa mayoritaria ${ }^{501}$.

Para intentar reducir este fenómeno y romper a su vez esta cadena que, en la percepción de los gobiernos de los países receptores, perpetúa el vínculo de las personas de origen inmigrante con su pasado cultural, algunos de éstos países han introducido medidas normativas que están teniendo muy buena acogida en los foros internacionales, como la UE. Entre las prevenciones adoptadas para sortear la aludida tendencia, destaca la imposición de exigencias salariales altas como condición previa para poder importar a una pareja extranjera y el establecimiento de edades mínimas por debajo de las cuales no cabe dicha importación. Hasta el punto de que países tradicionalmente liberales en la concepción de sus sistemas migratorios, están imponiendo férreos controles a la inmigración matrimonial, incluso en presencia de nacionales del propio Estado, esto es, de parejas mixtas. Dinamarca ha encabezado el ranking de países que en un breve lapso de tiempo, han transmutado desde posturas muy garantistas del derecho a la RF hasta suponer las más restrictivas de las existentes en Europa $^{502}$, degradando la naturaleza jurídica de la RF a la condición de una mera decisión de carácter administrativo ${ }^{503}$.

De otro lado, el aumento de este fenómeno y las correlativas reacciones de suspicacia, rechazo y hasta incluso "pánico moral" ${ }^{04}$ suscitadas en las sociedades de acogida, ha terminado situando a los matrimonios o parejas que involucran a personas extranjeras bajo sospecha, "haciendo muy difícil el matrimonio y la vida familiar para muchas parejas genuinas" ${ }^{\prime 205}$. Esta circunstancia tiene su más claro reflejo normativo en la regulación de los matrimonios de conveniencia, cuya prevención contemplan todos los Estados receptores y cuyo tratamiento normativo a veces se asienta sobre genéricas presunciones de fraude ${ }^{506}$ contrarias al principio general de buena fe que ha de presidir el ordenamiento jurídico. Pero también está incidiendo en las normas que regulan la naturalización, provocando que algunos Estados dificulten el acceso a la nacionalidad como vía indirecta para limitar la inmigración matrimonial ${ }^{507}$.

En síntesis, las facetas problemáticas de la migración familiar se condensan especialmente sobre la formación familiar o inmigración matrimonial, precisamente la categoría que está experimentando últimamente un mayor crecimiento cuantitativo. Ya apuntamos en su momento que los efectos multiplicadores y la formación de cadenas migratorias parecían implicar consecuencias más inten-

500 CEBOLLA BOADO y GONZÁLEZ FERRER. La inmigración en España (2000-2007)..., op. cit., p. 87.

501 TRAPPENBURG, M. “Restricting Family Rights...”, p. 175.

502 Sobre el tema, puede consultarse, entre otros,THOMASSEN, Henrik. “The Danish Rules on Family Reunification”; en CARLIER, Jean-Yves and BRUYEKER, Philippe de. Immigration and Asylum Law of the EU: Current Debates. Academic Network for Legal Studies on Immigration and Asylum in Europe. Bruxelles, Bruylant, 2005, pp. 519-529.

503 GIL ARAUJO, Sandra. Las políticas de migración familiar en Europa. El control de la inmigración a través de las familias, op. cit., sp.

504 La expresión corresponde a Kathryn ROBINSON, op. cit., p. 484.

505 KRALER, Albert \& KOFMAN, Eleonore. Civic Stratification, Gender and Family Migration Policies in Europe, op. cit., p. 9.

506 En el mismo sentido se pronuncia GÓMEZ CAMPELO, quien las denomina "presunciones de culpabilidad”, activándose las mismas cuando uno de los cónyuges es nacional de un tercer Estado. Como ejemplo cita las legislaciones implementadas por los Países Bajos y Australia, donde es lícito que la policía de extranjería examine personalmente cada solicitud. "La compleja aplicación de la Directiva 2003/86/CE sobre el derecho a la reagrupación familiar", op. cit., p. 82.

507 Ídem, p. 7. 
sas y de mayor alcance temporal en este tipo específico de formación familiar, hasta el punto de señalarse que este subtipo "implica una fuente potencialmente infinita de nueva inmigración y, por tanto, un mayor reto para el control de flujos que la RF propiamente dicha que, por su propia naturaleza, se extinguirá a los pocos años de iniciarse el flujo de trabajadores" ${ }^{\prime 08}$. Además, también se presumen superiores las probabilidades de cierre étnico en lo que respecta a la migración matrimonial. Esta situación, unida a los problemas de fraude a través de la figura de los matrimonios de conveniencia, refuerza las resistencias ante la inmigración matrimonial, como un fenómeno que socava los controles migratorios y contra el que se alzan fuertes restricciones ${ }^{509}$.

No es de extrañar pues que las dificultades adjudicadas a este subtipo de migración familiar, en combinación con la consolidación del género familiar como principal vía de entradas regulares, hayan derivado en la implementación de políticas crecientemente restrictivas sobre estas figuras migratorias.

\section{b. RF y Dificultades para la integración en el Estado Receptor}

Junto a las ventajas de la RF en tanto que vehículo de integración ${ }^{510}$, que constituyen ya un tópico en las diferentes aproximaciones al fenómeno migratorio, y que analizamos al principio de este mismo epígrafe, últimamente comienzan también a señalarse las ambigüedades o contradicciones implícitas a la inmigración por causa familiar ${ }^{511}$. Se afirma que puede fomentar el aislamiento del inmigrante en el núcleo de origen, en sus valores y tradiciones, pudiendo exacerbar identidades y "repliegues culturales" ${ }^{12}$ que propicien cierta impermeabilización del inmigrante en sus entornos étnicos y familiares.

Conforme a esta reciente percepción, la RF, lejos de favorecer la integración de los extranjeros admitidos, puede contribuir a aislar y encerrar a los inmigrantes en enclaves étnicos poco porosos a los valores culturales propios de la sociedad de destino, que den lugar a las denominadas "socieda-

508 CEBOLLA BOADO y GONZÁLEZ FERRER. La inmigración en España (2000-2007)..., op. cit., p. 87.

509 KRALER, A y KOFMAN, E. Civic Stratification, Gender and Family Migration Policies in Europe, op. cit., p. 7.

510 El fundamento de la RF y su conexión inescindible con la integración aparece detallado en estos términos, en un informe de la Organización Internacional del Trabajo: "Uniting migrant workers with their families living in the countries of origin is recognised to be essentials for the migrants's well-being and their social adaptation to the host country. Prolonged separation and isolation lead to hardships and stress situations affecting both the migrants and the familias left behind and prevent them from leading a normal life. The large numbers of migrante workers cut off from social relations and living on the fringe of the receiving community create many well-known social and psychological problems that, in turn, largely determine community atttitudes towards migrant workers". ILO, Migrant workers, Report VII, International Labour Conference, 59th session. Genova, junio de 1974, p. 27.

511 Entre las voces que dan cuenta de estos cambios recientes en la percepción de la reunificación familiar, cabe destacar el estudio Civic Stratification, Gender and Family Migration Policy In Europe. International Center for Migration Policy Development, que bajo la coordinación de Veronika Bilger y Albert Kraler emprendió un estudio de las políticas de inmigración familiar en nueve Estados europeos y su impacto sobre la vida y estrategias adaptativas de los inmigrantes, durante los años 2006-2008. Sin embargo, el estudio advierte que la creciente problematización de la inmigración familiar y la subsiguiente introducción de mayores restricciones en su marco normativo y en las políticas públicas se basa en percepciones y no en evidencias, sin que las políticas hagan por el momento justicia a la complejidad implícita a la inmigración familiar. Los resultados de este proyecto están disponibles en http://research. icmpd.org/1282.html.

512 EZQUERRA UBERO, J.J. "El derecho a vivir en familia de los extranjeros en España: ensayo de valoración de la normativa aplicable"; en Migraciones, No. 1, 1997, pp 40-41; MOLINER NAVARRO, Rosa Ma . El concepto de familia nuclear en la Directiva europea 2003/86/CE sobre reagrupación familiar"; en ABRIL CAMPOY, Juan Manuel y AMAT LLARI, Ma Eulalia (coords.). Homenaje al profesor Lluis Puig I Ferriol, volumen II. Valencia, Tirant lo Blanch, 2006, p. 1789. 
des paralelas", dificultando la integración del inmigrante y, más allá, la cohesión social e incluso la propia identidad nacional ${ }^{513}$. Esta percepción se basa a su vez en la consideración de la familia como un agente socializador que desarrolla una función de primer orden para la transmisión de valores y normas culturales ${ }^{514}$ que, en el supuesto de familias extranjeras, pueden diferir sustancialmente respecto a las predominantes en las sociedades de acogida.

En síntesis, las supuestas dificultades integradoras achacables a la migración familiar se cimientan sobre la idea de que "las prácticas características de cada cultura se transmiten principalmente por endoculturación primaria, es decir, en el seno de un grupo familiar" ${ }^{15}$. En este contexto, la familia del inmigrante se percibe como una institución fundamentalmente patriarcal, sede del mantenimiento, transmisión y perpetuación de prácticas y valores que pueden chocar con las normas de género y los principios que constituyen la base de las sociedades de acogida ${ }^{516}$.

Esta nueva perspectiva de la RF, radicalmente contraria a la concepción tradicional de la misma como vía extraordinariamente benéfica para la inserción del inmigrante y para la propia sociedad de acogida, hunde sus raíces en la constatación del fracaso de algunos proyectos integradores vinculados a la RF, señaladamente los casos de la periferia de Francia, que vinieron a arrojar luz sobre las carencias en la integración entre los descendientes de origen inmigrante, muchos de ellos nacidos y/o naturalizados en dicho país. Además, esta percepción está nutrida de fuertes prejuicios - que abundan, por otro lado, en el ámbito migratorio-, y de visiones estereotipadas y estáticas de la inmigración familiar, como un "terreno caracterizado por relaciones patriarcales así como prácticas y tradiciones anti-liberales, como matrimonios forzosos y concertados, entre otras" ${ }^{\prime 17}$.

Las visiones temerosas de la inmigración familiar como fuente de reproducción y de perpetuación de patrones y prácticas culturales foráneas que pueden entrar en conflicto con las propias de la sociedad de acogida - matrimonios forzados, ablación de clítoris...- resultan ser especialmente fructíferas respecto a la inmigración matrimonial ${ }^{518}$. En otras palabras, los temores ante una interculturalidad supuestamente conflictiva que propicia y hasta perpetúa la migración familiar, se concentran especialmente sobre la formación familiar de carácter matrimonial, que es percibida como la categoría migratoria vinculada a la familia que puede suponer mayores obstáculos de cara a la integración de los inmigrantes. Y, dentro de ella, la práctica de importar esposas se alza como una

513 KRALER y KOFMAN. Civic Stratification..., op. cit., pp. 6-7.

514 BOYD, Monica. "Family and Personal Networks in International Migration: Recent Developments and New Agendas"; en International Migration Review, vol. 23, №. 3, 1989, p. 643.

$515 \mathrm{La}$ autora reflexiona muy críticamente sobre este punto, con el fin de desmontar la aceptación generalizada de la existencia de lo que denomina "identidades absolutas y sustanciales tanto en el plano colectivo como en el individual”, pues, a su juicio, esta concepción termina transformando la diferencia cultural propia de los colectivos de inmigrantes en un importante factor de segregación y exclusión de los mismos. MAQUIEIRA D’ANGELO, Virginia. "Cultura y derechos humanos de las mujeres"; en PÉREZ CANTO, Pilar (coord.). Las mujeres del Caribe en el umbral del 2000. Madrid, Dirección General de la Mujer, Comunidad Autónoma de Madrid, 1998, p. 182.

516 Para una visión crítica y sucinta de los aspectos problemáticos asignados a la inmigración familiar, vid. KRALER, Albert. "Family migration in Europe: policies vs. Reality". IMISCOE, Policy Brief, No. 16. August 2009, op. cit., p. 4.

517 KRALES, A. y KOFMAN, E. Civic Stratification, Gender..., op. cit., p. 6.

518 Para un estudio sociológico y estadístico de esta cuestión, vid. GONZÁLEZ FERRER, Amparo. Estrategias familiares y laborales en la emigración. RF, elección de parejas y empleo de los inmigrantes en el país de destino, op. cit., La autora concluye, entre otros aspectos, que "los análisis llevados a cabo en este libro sugieren que la importación de cónyuges de los países de origen es una forma de matrimonio generalmente asociada con formas de convivencia más tradicionales como vivir en hogares extensos”, op. cit., p. 198. 
subespecie potencialmente más proclive al cierre étnico que para el supuesto de que sean las mujeres quienes importen a varones extranjeros con fines matrimoniales ${ }^{519}$.

Esta nueva percepción está provocando la introducción en las legislaciones de extranjería de medidas preventivas dirigidas a promover la integración con carácter previo a la admisión del inmigrante y de su familia, o bien, la inclusión de la exigencia de integración a posteriori como una obligación jurídica - el denominado "contrato de integración" ${ }^{520}$. En definitiva, propicia la aparición de un concepto coactivo de integración, profundamente contradictorio con el tradicional, según el cual el extranjero debe dar muestras de su capacidad e interés para la integración, antes incluso de su llegada y establecimiento en el Estado de acogida y como requisito previo para obtener el permiso de entrada. Lo analizaremos con más calma a la luz del caso de una normativa concreta, la Directiva 2003/86/CE, en el tercer capítulo de nuestro trabajo.

En síntesis, esta nueva faceta de la RF está asociada al surgimiento de requisitos, directos u oblicuos, destinados a introducir filtros altamente selectivos en la admisión de los familiares de los residentes, especialmente sobre los cónyuges, en lo que constituye una de las características más señaladas de la RF en nuestros días ${ }^{521}$ y en la que están convergiendo tanto los países europeos como los Estados de larga tradición migratoria ${ }^{522}$.

\section{c. RF y Mercado de Trabajo}

La inmigración familiar se halla construida sobre bases humanitarias y sus características se han formulado por oposición a las de la migración laboral, lo que explica en parte su continuación e incremento a raíz de la política de cierre de fronteras de la década de los setenta del pasado siglo. Sin embargo, detrás de su aceptación más o menos renuente por parte de los países europeos, siempre latió la preocupación de que los familiares extranjeros dependientes admitidos por motivos de reagrupación se convirtiesen en "potenciales adiciones a la fuerza de trabajo extranjera ya residente en el país receptor y una carga sobre el Estado social de bienestar" ${ }^{\prime 23}$. El nuevo contexto social en que se desarrollan los flujos migratorios parece confirmar algunas de las inquietudes de los países receptores.

La feminización de los flujos, que la propia RF fomenta, junto a los cambios sociológicos que han promovido la incorporación de la mujer al mercado de trabajo, han convertido en anacrónicas

519 Sobre este aspecto, GONZÁLEZ FERRER apunta como uno de los “resultados más inesperados” de su estudio, que "mientras las práctica de importar esposas está claramente asociada con bajos niveles educativos entre los hombres, este no es el caso para las mujeres que importan a sus maridos", por razones que la propia autora reconoce no estar aún claras. A continuación señala que "lo que sí parece claro a la luz de los resultados obtenidos es que la práctica de importar esposas está fuertemente ligada a formas de comportamiento familiar tradicional" siendo a menudo "reflejo de la práctica de los matrimonios arreglados, muchas veces dentro de la propia familia, en los países de origen”. Estrategias familiares y laborales en la emigración, op. cit., p. 200.

520 Para una visión exhaustiva y crítica de la figura de los contratos de integración, vid. SOLANES CORELLA, Ángeles. "Integrando por ley?: De los contratos europeos de integración al compromiso de la Ley autonómica Valenciana 15/2008”; en Revista de derecho migratorio y extranjería, №. 20, 2009, pp. 47-75.

521 Así lo confirma el informe de carácter anual emitido por la OCDE International Migration Outlook, donde, a modo de ejemplo, en el correspondiente al año 2010 se constató la continuación de la tendencia gubernamental a la imposición creciente de requisitos más estrictos sobre la figura de la RF, citando a España, Noruega, Reino Unido y México, entre otros países, como ilustrativos de dicha tendencia. “Trends in International Migration”, International Migration Outlook: SOPEMI 2010, op. cit., p. 67.

522 KOFMAN, Eleanore. “Family-Related Migration: A Critial Review of European Studies”, op. cit., p. 250. LAHAV, G. "International versus National Constraints in Family-Reunification Migration Policy", op. cit., p. 363.

523 AVCI, Gamze. “Immigrant Categories: The Many Sides of One Coin?”, op. cit., p. 204. 
las consideraciones tradicionales en torno al predominio del inmigrante principal masculino y el supuesto escaso interés de los familiares dependientes para incorporarse al mercado laboral del país de acogida. De este modo, la habitual vinculación de la inmigración femenina con la dependencia, en contraposición al trabajo y a la autonomía ${ }^{524}$, sobre la cual se construyó dogmáticamente la RF, resulta obsoleta en la actualidad.

Un porcentaje creciente de reagrupantes está formado por mujeres laboralmente activas en el país de acogida. Además, con independencia del sexo del reagrupante, los familiares reagrupados suelen terminar formando parte de la fuerza laboral del Estado receptor pues, de hecho, la inmigración familiar suministra muchos de los trabajadores extranjeros ${ }^{525}$. En consecuencia, la RF se convierte "en una vía adicional de obtener inmigración laboral" ${ }^{526}$. Ello conduce al paradójico resultado de que en aquellos países que incorporan políticas migratorias más restrictivas, la obstaculización de la inmigración laboral convierte a la RF en una de las escasas avenidas legales para la migración - cuando no la única virtualmente factible para la admisión de extranjeros, dejando aparte el asilo y la inmigración de individuos altamente calificados ${ }^{527}$ - para, finalmente, la inmigración familiar terminar desembocando en un mecanismo perpendicular de incorporación de fuerza laboral extranjera. Parece ser pues que los efectos multiplicadores de la RF no se limitan al número de entradas y de autorizaciones de residencia, sino que se extienden sobre el mercado de trabajo del país de acogida.

Conscientes de las presiones oblicuas que la admisión de parientes del residente extranjero podría provocar sobre los por entonces deficitarios mercados laborales de los países receptores, la obstaculización —cuando no exclusión temporal- a la participación laboral de los familiares reagrupables constituyó una de las medidas más características de la regulación de la inmigración familiar tras el cierre de fronteras ${ }^{528}$.

La parte más trascendente de este proceso indirecto es que, como ya señalamos, la selección de los beneficiarios de la RF se realiza en virtud a la existencia de lazos familiares - genuinos y persistentes - pero sin tener en cuenta las capacidades o habilidades laborales o profesionales de sus integrantes, ni las correlativas necesidades de los mercados laborales y de las economías autóctonas. Y aquí es donde surge otra de las facetas más problemáticas de la RF pues, desde la perspectiva del mercado de trabajo del Estado receptor, puede producir efectos multiplicadores escasamente selectivos sobre la oferta laboral de dicho Estado, dando lugar a un tipo de mano de obra poco

524 KOFMAN, Eleanore. Civic Stratification, Gender...op. cit., p. 4.

525 ONG HING, Bill. Deporting Our Souls..., op. cit., p. 125.

526 BATTISTELLA, Graziano. "Family Reunification: Policies and Issues"; en Asian and Pacific Migration Journal, vol. 4, No. 2-3, 1995, p. 241.

527 KOFMAN, Eleanore. Civic Stratification, Gender...op. cit., p. 3.

528 El bloqueo del reclutamiento de trabajadores invitados en Alemania, si bien logró cifras negativas de migración laboral neta desde los años 1974 a 1978, no consiguió impedir la admisión de los familiares de los trabajadores extranjeros allí establecidos. Consciente de esta situación, el gobierno alemán emprendió duras medidas restrictivas contra la RF - lo que se ha dado en llamar "la guerra contra la familia extranjera"-. Entre ellas, se promulgó un decreto que establecía la denegación de permisos de trabajo a ciudadanos no comunitarios que lo solicitasen por primera vez - el denominado "Reglamento de las fechas claves" - que "perjudicaron especialmente las perspectivas laborales de las esposas e hijos en edad de trabajar que habían llegado a Alemania recientemente, bien como turistas o por las vías formales de RF. A estos extranjeros sólo les quedó la economía sumergida como opción para obtener un empleo" (...). El bloqueo del acceso al mercado de trabajo (formal) para los recién llegados estuvo acompañado por medidas complementarias que también pretendían disminuir la tasa de RF”. Posteriormente la autora advierte que pese a la importancia de estas medidas y los acusados efectos que provocaron, las mismas "han sido frecuentemente ignoradas por gran parte de la literatura especializada”. GONZÁLEZ FERRER, Amparo. Estrategias familiares y laborales de la emigración, op. cit., pp. 44-45. 
cualificada ${ }^{529}$. En consecuencia, aun cuando los flujos de inmigrantes comiencen a menudo de un modo selectivo con trabajadores cualificados, con el tiempo tienden a ampliarse, a hacerse menos selectivos y, finalmente, terminan dominados por parientes que hacen uso de las disposiciones de reagrupación familiar" 530 .

Esta circunstancia puede tener repercusiones en la creación y/o mantenimiento de los denominados nichos laborales ${ }^{531}$, donde se puede llegar a producir la sustitución de mano de obra nacional por la extranjera. Sin embargo, es justo recordar que los nichos laborales resultan ser bastante resistentes al sistema de preferencias laborales autóctonas que suelen incorporar las legislaciones migratorias, pues los nichos están conformados por trabajos habitualmente rechazados por la población local, de modo que finalmente la competencia laboral suele ser más ficticia que real.

Las medidas implementadas por las legislaciones internas para paliar en parte este efecto secundario que la RF puede provocar sobre sus mercados de trabajo, se han dirigido a la imposición de obstáculos a la incorporación laboral de los familiares reagrupados. Algunas legislaciones retrasan este proceso impidiendo el acceso al mercado de trabajo de los parientes admitidos durante un plazo inicial tras su entrada en el territorio de acogida. Esta exclusión puede llegar a ser incluso definitiva, especialmente para los familiares dependientes adultos, tales como hijos a partir de la mayoría de edad o ascendientes del reagrupante, pues estas categorías son admitidas en Europa de forma excepcional y en consideración casi exclusiva a la alta dependencia que mantienen con respecto del reagrupante o principal.

Sin embargo, estas medidas retardadoras o de exclusión, lejos de producir efectos realmente disuasorios, parecen haber terminado empujando a los familiares dependientes a buscar empleo en

529 En este sentido, la OIM ha afirmado que "la reunificación familiar puede ser una ruta de ingreso de personas poco calificadas o no calificadas, y existe una tendencia creciente por parte de los países tradicionales de inmigración y de nuevos países emergentes, de limitar el ingreso de miembros de la familia, a través de pruebas más difíciles de auto sustentabilidad (educación, habilidades, experiencia laboral, y edad), vínculos más cercanos al país huésped, y posibilidades de emplearse". Inmigración y Reunificación Familiar. Organización Internacional para las Migraciones, s.p. http://www.iom.int/jahia/Jahia/about-migration/managing-migration/immigration-systems/immigration-familyreunion/cache/offonce/lang/es

530 MASSEY, D; ARANGO, J.; GRAEME, H.; KOUAOCI, A; PELLEGRINO, A y TAYLOR, E. "Una evaluación de la teoría de la migración internacional: el caso de América del Norte”; MALGESINI, Graciela (comp..). Cruzando fronteras. Migraciones en el sistema mundial, op. cit., p. 235.

531 En un artículo referido al contexto de EEUU, Buchanan analiza de forma muy crítica los distintos mitos que rodean la concepción tradicional de la RF, con el ánimo de desmontarlos. Especialmente corrosivo se muestra respecto a la admisión de los familiares en sentido amplio. En torno al tema específico de la incorporación de los familiares admitidos con fines de RF al mercado de trabajo estadounidense, Buchanan se pronuncia en sentido muy negativo, señalando que "the impact on Black Americans has been devastating. Whole areas of unskilled Niche labour, once typically handled by black workers, are now performed by foreign workers". BUCHANAN, William. "Myths of Family Reunification. Immigrants disrupt familias to start process"; en The Social Contract, fall 1996, p. 34. En un sentido radicalmente contrario se manifiesta Ong Hing, para quien "a concern that the current system raises for some policymakers is based on their belief that the vast majority of immigrants who enter in kinship categories are working class or low skilled. They wonder whether this is good for the country. Interestingly enough, immigrants who enter in the sibling category actually are generally highly skilled", añadiendo que las necesidades del país en el corto y largo plazo instruyen sobre la falsedad de las críticas arrojadas contra la RF, en vista de que las proyecciones parecen apuntar al declive de la fuerza laboral autóctona en pocas décadas y a que EEUU necesitará trabajadores extranjeros de todos los niveles y categorías profesionales, incluyendo a los escasamente cualificados, muchos de los cuales - tanto cualificados como no- serán suministrados a través de la RF. ONG HING, Bill. Deporting Our Souls..., op. cit., pp. 125 y 126. 
el sector irregular ${ }^{532} y$ han sido especialmente negativas para el trabajo de las mujeres ${ }^{533}$. Esta última circunstancia debe examinarse a la luz de una conclusión presente desde los primeros trabajos doctrinales que estudiaron la inmigración familiar y que sigue siendo cierta en la actualidad: cuando la inmigración tiene lugar en pareja, tanto de forma simultánea o en fases sucesivas, las mujeres suelen representar casi siempre el colectivo más dañado económica y profesionalmente ${ }^{534}$. En definitiva, la restricción del acceso al trabajo para los familiares dependientes admitidos por causa de RF, debe considerarse dentro del esquema más amplio de una inmigración familiar que sigue reproduciendo las desigualdades que las mujeres enfrentan, con carácter general, en el ámbito laboral ${ }^{535}$, en cuyo contexto, las dificultades o la propia segregación laboral de la mujer vendría a fomentar aún más dichas discriminaciones. No en vano, la ONU ha señalado con rotundidad que la característica más notable de la migración femenina reside en estar "fundada sobre la reproducción continuada y la explotación de las desigualdades de género del capitalismo global”"536.

532 European Migration in the 1980s. Trends and Policies. Conference of European Ministers Responsible of Migration Affairs. Strasbourg, 6-8 May 1980. Strasbourg, Council of Europe, 1981, p 4. En torno a este aspecto, en las conclusiones finales se recomendaba "practical solutions should be found to remove obstacles to family reunion for migrant workers in the spirit of Article 12 of the European Convention on the Legal Status of Migrant Workers. In drawing up and applying regulations on family reunion or access to the labour market, the receiving countries should try to take into account their possible repercussions on the irregular work phenomenon”. Sobre este aspecto, Hollifield matiza que las debilidades en el estatuto jurídico que afrontan los extranjeros, en tanto que sujetos especialmente vulnerables, convierten a éstos en un colectivo empujado a buscar trabajo en el sector informal. HOLLIFIELD, James F. Immigrants, Markets and the State...op. cit., p. 12.

533 MEETO, V; KOFMAN, E. "Family Migration”. World Migration 2008, op. cit., p. 166. En la misma línea incide la Comunicación de la Comisión Europea al Consejo, al Parlamento Europeo, al Comité Económico y Social y al Comité de las Regiones sobre inmigración, integración y empleo, $\operatorname{COM}(2003)$ No. 336 final, de 3 de junio de 2003, p. 27. Para un estudio detallado de la relación entre migración, familia y empleo, con particular incidencia en las vicisitudes del empleo de las mujeres, tanto reagrupantes como reagrupadas, en el mercado de trabajo alemán, vid. GONZÁLEZ FERRER, A. Estrategias familiares y laborales de la emigración, op. cit., pp. 147-196.

534 En un interesante artículo que estudia la evolución doctrinal de la inmigración familiar desde el punto de vista económico, sociológico y demográfico, Thomas Cooke señala que desde los primeros estudios en esta materia, emprendidos en los años 70, la doctrina se ha centrado principalmente en estudiar el denominado "training wife effect": esto es, cómo influía la emigración en la vida y oportunidades laborales de las mujeres que seguían a sus parejas masculinas en la aventura migratoria. Todos los estudios coincidían, desde perspectivas distintas, en señalar que la mujer tenía menos iniciativa migratoria que el hombre pero que, en cualquier caso, salía perjudicada del proceso migratorio, al menos en lo que respecta a sus ganancias salariales y su estatus profesional en relación con su marido también inmigrante. En la actualidad, con parejas en las que ambos miembros suelen trabajar, los estudios siguen apuntando a que la mujer suele ser quien más pierde económicamente como consecuencia de la inmigración. En palabras del propio autor, “migration reduces women's earnings due to a drop in labour force participation, but those losses are compensated for by net gains in total family earnings". COOKE, Thomas J. "Migration in a Family Way"; en Population, Space and Place, No. 14, 2008, p. 256.

535 Boyle explica que esta situación de pérdida económica y de estatus profesional que experimentan las mujeres inmigrantes en el contexto de la migración familiar se produce incluso en aquellos supuestos de partida en que la mujer está mejor situada profesionalmente que el hombre. Para Boyle ello se debe más a las asunciones de género que hombres y mujeres interiorizan que a factores o decisiones puramente económicas. Para el autor, resulta esencial el hecho de que la mujer, en situaciones extremas, y por su bagaje cultural, está más dispuesta que el hombre a asumir retos que benefician a la familia, aun a costa de su sacrificio profesional. En otras palabras, la mujer puede optar por priorizar su vida personal sobre la profesional, sometida a decisiones críticas, como las que suponen la inmigración en el seno de una familia ya constituida. BOYLE, Paul. "Gender Inequality in Employment Status following Family Migration in GB and the US: The Effect of Relative Occupational Status"; en International Journal of Sociology and Social Policy, vol. 19, 1999, pp. 122-123.

$536 \mathrm{El}$ informe elaborado en el marco de la ONU, continúa afirmando: "For the most part, female labor migrants perform 'women's work' as nannies, maids and sex workers - the worst possible occupational niches in terms of remuneration, working conditions, legal protections and social recognition In this way, gender acts as a basic organizing principle of labor markets in destination countries, reproducing and reinforcing pre-existing gender patterns that oppress women. But it is not only women who perform these jobs, but women of a particular race, class, ethnicity 
Además, las restricciones al empleo impuestas a los familiares reagrupables refuerzan otro efecto controvertido que ha sido achacado a la RF en conexión con el mercado de trabajo: los familiares regularmente reagrupados gozan de residencia legal pero dado que, en muchas ocasiones penetran al mercado de trabajo, aun careciendo de autorización de trabajo para ello, la inmigración familiar se puede convertir en una fuente adicional de trabajo irregular en los Estados Europeos ${ }^{537}$. Con carácter general, se ha señalado abundantemente el vínculo existente entre las redes familiares asentadas en el país receptor y la inmigración irregular ${ }^{538}$, pues dichas redes sirven también para facilitar la entrada y el asentamiento irregular de parientes y conocidos, desafiando los obstáculos y políticas oficiales ${ }^{539}$. Este vínculo es tanto mayor cuanto más grandes sean las restricciones establecidas en los sistemas jurídicos de $\mathrm{RF}^{540}$. Dicho sin tapujos, los inmigrantes familiares pueden convertirse en trampolines para nuevas inmigraciones de trabajadores irregulares no cualificados.

Los efectos de la inmigración familiar sobre el mercado de trabajo del país receptor parecen ser particularmente intensos en aquellos sistemas que permiten la RF a los miembros de la familia en sentido extenso ${ }^{541}$, como EEUU - family sponsorship_, pues en ellos la inmigración familiar puede sustituir en efecto a la migración laboral ${ }^{542}$.

En síntesis, junto a la consideración de que la RF constituye un mecanismo de entrada poco selectivo, se añade la percepción de que la fuerza de trabajo adicional en la que se traduce constituye un sector laboral de escasas cualificaciones y que difícilmente hubiese logrado superar los requisitos de entrada establecidos para la migración laboral - por no mencionar sus supuestas vinculaciones con el mercado de trabajo informal-. Esta situación desmiente uno de los presupuestos teóricos que servían de base a la RF: su construcción se realizaba sobre la base del supuesto divorcio ${ }^{543}$ entre

and/or nationality -i.e., gender cross-cuts with other forms of oppression to facilitate the economic exploitation of women migrants and their relegation to a servile (maids) and/or despised (sex workers) status. Gender inequality in the source countries also plays an important role in the migratory decision, in a number of ways: for instance, women are often 'selected' to migrate by their families based on the expectation that they will sacrifice themselves to a greater degree than men for the welfare of their families -i.e., work harder, remit a higher proportion of their earnings, spend less on themselves, endure worse living conditions". UN-INSTRAW. Feminization of Migration 2007. Gender, Remittences and Development. Working Paper 1, op. cit, p. 3. Para un estudio en mayor profundidad de la desigualdad que sigue acompañando a la mujer en el contexto migratorio y, para el caso específico español, vid. Colectivo IOÉ. “Mujeres migrantes en España. Proyectos migratorios y trayectorias de género”; en Ofrim Suplementos. Oficina Regional para la Inmigración de la Comunidad de Madrid, 1998, pp. 11-38.

537 DELAET, Debra L. U.S. Immigration Policy in an Age of Rights, op. cit., p. 14; Sobre este punto, Kofman, añade la mayor probabilidad de que las mujeres inmigrantes se vean abocadas al mercado irregular de trabajo, afirmando que: Men and women enter in different proportions under specific categories: men have tended to be more visible in the formal sectors of the economy; women are more likely to obtain work in the informal sector, often because of their status as dependants in family migration". KOFMAN, Eleanore. Contemporary European Migrations, Civic Stratification and Citizenship, op. cit., p. 9.

538 BOYD, Monica. "Family and Personal Networks in International Migration: Recent Developments and New Agendas", op. cit., p. 649.

539 FAIST, Thomas. The volumen and Dynamics of International Migration and Transnational Social Spaces. Oxford, Oxford University Press, 2000, p. 158.

540 Paloma GÓMEZ CRESPO afirma que las normativas restrictivas fomentan las situaciones de irregularidad "porque los familiares, al no poder entrar en el país de manera 'legal', lo hacen como sea"; en "La aplicación de la normativa de <reagrupación familiar>: ¿Flexibilidad o arbitrariedad?; Ofrim Suplementos, No. 7, 2000, p. 96.

$541 \mathrm{KHOO}$, Siew-Ean. "Sponsorhip of relatives for migration and immigrant settlement intention"; International Migration, vol. 41, No. 5, 2003, p. 193.

542 Meetoo y Kofman ponen como ejemplo lo sucedido con los inmigrantes mexicanos y los procedentes de América Central y Suramérica "who have not been able to use the skilled routes for entry". MEETOO y KOFMAN. "Family Migration”. World Migration 2008, op. cit., p. 165.

543 KOFMAN, Eleonore. “Family-Related Migration: A Critial Review of European Studies”, op. cit., p. 243. 
la inmigración familiar y el mercado de trabajo del país de destino. Dado que la inmigración laboral es muy susceptible a contextos económicos negativos - también en la percepción política y social de las sociedades receptoras - en supuestos de recesión económica las suspicacias contra la inmigración laboral, por las conexiones apuntadas, también se extenderían sobre la RF. Surgiría aquí de forma cruda la cuestión de la legitimidad de las exenciones al régimen general que beneficia a los familiares más directos de los residentes extranjeros, en el marco de una inmigración familiar que termina convirtiéndose, al menos parcialmente, en inmigración laboral.

A modo de recapitulación, cabría destacar que las múltiples facetas problemáticas que se concentran en la inmigración familiar, tanto en sus visiones tradicionales como en las más contemporáneas, revelan la coexistencia en la RF de numerosos elementos sometidos a dinámicas frecuentemente contradictorias, que la han terminado situando en un compleja encrucijada de caminos: entre las exigencias de contención y seguridad derivadas de las políticas de control de flujos y las exigencias integradoras implícitas a las políticas de extranjería; entre las tensiones derivadas de la protección de los intereses nacionales y las que surgen de la necesidad de proteger a la persona humana. Estas diversas facetas de la RF vienen a subrayar la "constante interrelación entre los aspectos políticos y humanitarios del tema" ${ }^{444}$, convirtiendo a la inmigración de carácter familiar en una materia de altísima sensibilidad política sobre la que se multiplican los retos ya de por sí inherentes a la inmigración de nuestros días.

En la raíz de estas dificultades, subyace quizá la cuestión de que la RF incorpora al Estado receptor "migrantes no solicitados" ${ }^{445}$ que no resultan funcionales para los intereses nacionales que el país de destino pretender salvaguardar a través del control migratorio y la recepción selectiva de flujos. Cuestión que finalmente termina emplazando a la RF, desde el punto de vista del país de destino, en un tipo de "inmigración no deseada"

Para cerrar estas reflexiones en torno a las complejidades que presenta la migración familiar cabría señalar que las múltiples tensiones conflictivas y contradicciones que subyacen en ella vienen a ser un reflejo amplificado - como consecuencia de la índole intrínsecamente problemática de la propia RF- del carácter ambivalente en el que se desarrolla en nuestros días la relación entre la migración internacional y los Estados modernos, una relación que Joppke ha definido como "mutuamente condicionante y excluyente al mismo tiempo" ${ }^{547}$.

544 PERRUCHOUD, Richard. "Family Reunification”; en International Migration...op. cit., p. 510.

545 La expresión corresponde a LAHAV y GUIRAUDON. "A Reappraisal of the State Sovereignty Debate. The case of Migration Control", op. cit., p. 164.

546 Así la clasifica Christian Joppke, quien concibe la inmigración no deseada como aquella que no es activamente solicitada por los Estados, sino más bien "pasivamente aceptada por éstos, bien por motivos humanitarios y en reconocimiento de derechos individuales, como en el asilo y la RF de inmigrantes laborales, o bien a causa de la total incapacidad estatal para impedir la entrada de inmigrantes, como ocurre con la inmigración ilegal”. Más adelante, y a fin de evitar las críticas analíticas y normativas, el autor precisa que el término "no deseada" es usado en un sentido puramente descriptivo, para denotar aquella inmigración que tiene lugar a pesar y en contra de explícitas políticas estatales. El autor incluye en esta categoría a la inmigración de carácter familiar en Europa, como consecuencia de las políticas de inmigración cero establecidas desde principios de la década de los setenta en dicho continente. JOPPKE, C. "Why Liberal States Accept Unwanted Inmigration?"; en World Politics, vol. 50, No. 2, 1998 , p. 266 y nota a pie de página №. 2, de la p. 267.

547 JOPPKE, Christian. Immigration and the Nation-State: The United States, Germany and Great Britain. Oxford, Oxford University Press, 1999, p. 2. 


\section{RAZONES PARA EL ACTIVISMO JUDICIAL EN MATERIA DE RF: UNA PROPOSICIÓN TEÓRICA}

Al igual que otros destacados autores, Stephen Castles y Mark Miller han apuntado, como una de las características distintivas de los flujos migratorios de nuestros días, la creciente politización a que está sometida esta materia ${ }^{548}$. Este fenómeno es especialmente perceptible a partir de la década de los noventa, momento en que la inmigración en Europa "se ha convertido en un tema público de confrontación acalorada con fuertes grupos de presión a favor y en contra” ${ }^{349}$. Martinello señala que la politización de las migraciones "se manifiesta en una dramatización exagerada, y a veces en una inmensa mediatización de los problemas vinculados a las migraciones humanas. Tanto los flujos migratorios como la presencia de poblaciones de origen inmigrado se ven casi por doquier como fuentes de inseguridad, e incluso como amenazas reales" 550 .

Este "alarmismo social" 551 tiende a provocar en los Estados de acogida la acentuación de criterios de seguridad pública a fin de reducir al máximo el número de entradas de quienes se perciben como potenciales agresores del orden público y beneficiarios oportunistas del Estado de bienestar del país. La seguridad económica y ciudadana se hacen prevalecer sobre consideraciones de integración social. Ello a su vez legitima e intensifica la percepción negativa de la inmigración asociándola con la provocación de supuestos efectos negativos para los ciudadanos de los países receptores valoración que había cobrado fuerza a raíz de la política de restricción iniciada a mediados de los setenta del pasado siglo ${ }^{552}$.

548 MARTINELLO, Marco. La Europa de las migraciones. Por una política proactiva de la inmigración. Barcelona, Bellaterra, 2003, p. 7. Recientemente, a raíz de la toma de conciencia de la necesidad de reducir la animadversión hacia la población inmigrante por parte de los medios de comunicación, la televisión pública en España ha incluido en su primer manual de estilo la conveniencia de utilizar una visión profunda, cuidada y alejada de estereotipos en todas aquellas noticias que involucren a este colectivo. Concretamente, dentro del capítulo quinto, existe una sección -la décimo cuarta - que, bajo el título, "Inmigración, racismo y xenofobia" señala expresamente que "RTVE debe evitar la superficialidad y las visiones estereotipadas cuando se aborden asuntos referidos a la inmigración, el racismo y la xenofobia. Para ello, aunque se informe de la vertiente jurídico-policial de estos asuntos (sucesos, muertes, etc.), debe fomentarse la presencia de informaciones que incidan en las cuestiones de fondo. Los profesionales de RTVE deben adoptar una actitud responsable y activa en el fomento de la convivencia y la promoción de valores éticos". Manual de Estilo de RTVE. Directrices para los profesionales. Madrid, Instituto RTVE, Corporación de RTVE, catálogo de publicaciones, diciembre de 2010, sp. Disponible en http://manualdeestilo.rtve.es/cuestiones-sensibles/514-inmigracion-racismo-y-xenofobia/

549 BRYCESON, D y VUORELA, U. “Transnational Families in the Twenty-first Century”, op. cit., p. 37.

550 MARTINELLO, Marco. La Europa de las migraciones. Por una política proactiva de la inmigración. Barcelona, Bellaterra, 2003, p. 7. Recientemente, a raíz de la toma de conciencia de la necesidad de reducir la animadversión hacia la población inmigrante por parte de los medios de comunicación, la televisión pública en España ha incluido en su primer manual de estilo la conveniencia de utilizar una visión profunda, cuidada y alejada de estereotipos en todas aquellas noticias que involucren a este colectivo. Concretamente, dentro del capítulo quinto, existe una sección - la décimo cuarta - que, bajo el título, "Inmigración, racismo y xenofobia" señala expresamente que "RTVE debe evitar la superficialidad y las visiones estereotipadas cuando se aborden asuntos referidos a la inmigración, el racismo y la xenofobia. Para ello, aunque se informe de la vertiente jurídico-policial de estos asuntos (sucesos, muertes, etc.), debe fomentarse la presencia de informaciones que incidan en las cuestiones de fondo. Los profesionales de RTVE deben adoptar una actitud responsable y activa en el fomento de la convivencia y la promoción de valores éticos". Manual de Estilo de RTVE. Directrices para los profesionales. Madrid, Instituto RTVE, Corporación de RTVE, catálogo de publicaciones, diciembre de 2010, sp. Disponible en http://manualdeestilo.rtve.es/cuestiones-sensibles/514-inmigracion-racismo-y-xenofobia/

551 MARTINELLO, Marco. La Europa de las migraciones. Por una política proactiva de la inmigración, op.cit., p. 8.

552 En este aspecto Arango ha destacado el cambio profundo en la valoración de la inmigración característico de nuestros días, afirmando que "si bien a ésta nunca le han faltado enemigos, si en cualquier sociedad ha habido grupos sociales adversos, en el pasado tendía a prevalecer una valoración positiva de la misma. Basta analizar la mitología 
Los ataques terroristas contra las Torres Gemelas en Nueva York, así como los ocurridos posteriormente en Madrid y Londres, situaron en el punto de mira de la sospecha pública a los inmigrantes $^{53}$, especialmente a los de origen musulmán, exacerbando aún más el rigor del control de fronteras. En este contexto, no es de extrañar que la inmigración familiar se convirtiera en un tema políticamente muy candente y blanco constante de los objetivos de las reformas migratorias, al tiempo que se producía la "fortificación del Estado nacional" 554 a fin de mantener el control sobre esta materia. La reunificación familiar emergía como un tema de altísima sensibilidad política.

Sobre estos prejuicios planea en primer término el provocado por las inevitables crisis económicas que golpean cíclicamente a las economías de mercado, que en la actualidad se desarrolla con particular intensidad en España. Éstas dan paso a un discurso fácilmente digerible sobre la insuficiente capacidad del mercado laboral - real o ficticia - para absorber las demandas de trabajo procedentes de la fuerza laboral autóctona de los países de acogida que compite con la procedente del extranjero. En este fantasma de la inseguridad económica se encuentra un filón electoral para los partidos políticos. El rédito electoral se refuerza además mediante la explotación del argumento en torno al coste económico que para el Estado social suponen los inmigrantes y los agravios comparativos que se pueden producir en torno a la recepción de servicios públicos sociales - especialmente entre los inmigrantes y las capas más empobrecidas de la sociedad de acogida ${ }^{555}$. Como es natural, ello desemboca en un aumento de los temores y del rechazo al inmigrante y a sus familias por parte de las sociedades de acogida.

La inmigración en general y la RF en particular constituyen un campo especialmente fértil para los prejuicios ${ }^{556}$, que desde luego no se detiene en los ya apuntados. Gran parte de la politización que afecta al fenómeno migratorio se debe también a una exaltación interesada de supuestas identidades enfrentadas y hasta incluso al supuesto carácter "inintegrable" 557 de determinados inmigrantes

dominante en el imaginario colectivo de las viejas sociedades receptoras para confirmarlo. Aunque no sólo, la inmigración también era vista como una fuente de oportunidades, de vivificación económica, cultural y de todo orden, incluso como una bicoca o una bendición. Por el contrario, hoy en día la inmigración es vista ante todo como un problema que hay que gestionar, mitigar, adelgazar, cuando no combatir, como un riesgo y como un motivo de preocupación”. ARANGO, Joaquín. "Inmigración y diversidad humana. Una nueva era en las migraciones internacionales", op. cit., p. 14.

553 Asensi Sabater estima que la clave de la actual política migratoria reside en la sospecha y considera que el terrorismo internacional intensificó esta tendencia, afirmando al respecto que "el avance de las políticas de la sospecha se puede constatar con singular crudeza a raíz de los atentados terroristas del 11 de septiembre de 2001 en los Estados Unidos. A partir de esa fecha, por muchos motivos decisiva, se ha intensificado la criminalización fáctica y legal de categorías enteras de sospechosos, especialmente entre la población extranjera”. ASENSI SABATER, José. Políticas de la sospecha. Migraciones internacionales y principios constitucionales, op. cit., p. 61.

554 La expresión corresponde a LAHAV, Gallya. "International versus National Constraints in Family-Reunification Migration Policy"; en Global Governance No. 3, 1997, p. 368.

555 En los expresivos términos empleados por María Jesús Criado, la relación entre la emigración y el Estado Social, se establece sobre los siguientes cimientos: "la lógica económica en vigor apuesta por economías estatales <saneadas $>$ y el progresivo desarme del Estado benefactor y, como efecto inmediato, prima el rechazo y temor ante todo lo que pueda incrementar el <gasto público>. En coherencia con ello, visto que los recursos son escasos, intenta reducir la demanda. La figura que fragua como resultado de su proyección, es el inmigrante como extractor de rentas no merecidas, como <gorrón > de bienes públicos". CRIADO, María Jesús. "Vieja y nueva emigración”; CRIADO, M.J. La línea quebrada: historias de vida de migrantes. Madrid, CES, 2001, p. 16.

556 GROENENDIJK, Kees. "Legal Concepts of Integration in EU Migration Law"; en European Journal of Migration and Law, 2004, vol. 6, №. 2, p. 114.

557 SARTORI, Giovanni. La sociedad multiétnica. Pluralismo, multiculturalismo y extranjeros. Madrid, Taurus, 2001, p. 114. En palabras del autor, "la integración se produce sólo a condición de que los que se integran la acepten y la consideren deseable. Si no, No. La verdad banal es, entonces, que la integración se produce entre integrables y, por consiguiente, que la ciudadanía concedida a inmigrantes inintegrables no lleva a integración sino a desintegración”. 
-donde los musulmanes constituyen el colectivo que se percibe como el más refractario. A este respecto el profesor Sami Näir ha señalado insistentemente que el debate político actual frente a la inmigración suele centrarse en la relación, calificada como "problemática", entre la identidad de la sociedad de acogida y la identidad de los inmigrantes. Para este autor muchos discursos políticos explotan tales prejuicios identitarios con un nulo coste político y una altísima rentabilidad electoral ${ }^{558}$, pues mientras los extranjeros afectados no tienen derecho al voto, los trabajadores cuyos intereses pretende defender tal discurso sí son ciudadanos con derecho al sufragio.

Ahora bien, uno de los efectos más trascendentes que a largo plazo provoca la recepción y el establecimiento permanente de intensos flujos migratorios en las sociedades receptoras es la formación de minorías ${ }^{559}$. La característica más sobresaliente de estos colectivos de extranjeros asentados en el Estado receptor es que están compuestos por sujetos especialmente vulnerables de derechos humanos $^{560}$. Los inmigrantes - entendiendo por tales a los extranjeros que se desplazan a un tercer

558 Con base en la identidad como elemento clave en la relación con los inmigrantes, Sami Näir ha expuesto que se construye un argumento identitario que, llevado al extremo, puede incluso llegar a explicar el comportamiento individual de ciertos inmigrantes por su origen nacional. Estos argumentos no ayudan a resolver ninguno de los desafíos que plantea la inmigración; antes bien, crean condiciones de revolución permanente e impiden el camino a la integración en las sociedades de acogida. Para el prof. Sami Naïr en estos discursos lo que en realidad subyace es un problema identitario por parte de la sociedad receptora, cuyos efectos se encarnan en la mirada que esa sociedad dirige a los inmigrantes que recibe. No se cuestiona pues la identidad de los inmigrantes, sino la de la propia sociedad de acogida. Curso Magistral “Flujos Migratorios, Política de Integración e Identidad”. Universidad Internacional Menéndez Pelayo. Santander, 29 julio-2 agosto de 2002.

559 Castles y Miller distinguen al respecto entre la formación en la sociedad de destino de lo que denomina "minorías étnicas" y "comunidades étnicas". Los autores construyen el concepto de minoría étnica por oposición al más deseable de "comunidad étnica". Ambos conceptos se sitúan en dos extremos, si bien los autores puntualizan que "la mayoría de los países de inmigración han tendido a situarse en un punto intermedio entre estos dos extremos”. Ambas posibilidades extremas dependen de las concretas acciones emprendidas por las sociedades receptoras y de las políticas implementadas por los Estados de acogida. La formación de comunidades étnicas —que serán percibidas como parte de una sociedad multicultural — sería posible en aquellos casos en que las sociedades receptoras permitan "la apertura al establecimiento, la concesión de la ciudadanía y la aceptación gradual de la diversidad cultural". En el lado opuesto se sitúan aquellos Estados que fomentan políticas que niegan la realidad del establecimiento permanente de los inmigrantes en las sociedades de acogida, limitando sistemáticamente sus derechos y rechazando la diversidad cultural propia de la inmigración, determinando con ello la aparición de minorías étnicas "cuya presencia se considera en amplios sectores como indeseable y generadora de divisiones”. CASTLES y MILLER. La era de la migración..., op. cit., pp. 46 y 47.

560 Jorge Bustamante estima que la vulnerabilidad de los inmigrantes es de naturaleza social. En sus propias palabras, "vulnerability is understood here as a social condition of powerlessness ascribed to individuals with certain characteristics that are perceived to deviate from those ascribed to the prevailing definitions of a national. Vulnerability is a social condition associated with outcomes of impunity for those who violate the human rights of those migrants labeled as deviants". BUSTAMANTE, Jorge. "Immigrant's Vulnerability as Subjects of Human Rights"; en International Migration Review, vol. 36, №. 2, 2002, p. 340. En idéntico sentido, Perruchoud y otros destacados autores, han destacado que la OIT ha reconocido expresamente la debilidad de los migrantes, "expuestos a hostilidad y explotación, frecuentemente enfrentarán problemas mayores de asimilación o integración, así como para la preservación de su base nacional, étnica y lingüística”. PERRUCHOUD, Richard; JENNY, R.K. y GOODWIN-GILL, Guy S. "Basic Humanitarian Principles Applicable to Non-Nationals”; en International Migration Review, vol. 19, №. 3, 1985, p. 560. En torno a este tema se pronuncian, en la doctrina española, entre otros muchos, LÓPEZ SALA, A. M. Inmigrantes y Estados...op. cit., p. 142. BONET PEREZ, Jordi. Las políticas migratorias y la protección internacional de los derechos y libertades de los inmigrantes. Un análisis desde la perspectiva del ordenamiento jurídico español. Bilbao, Universidad de Deusto, 2003, pp. 10 y 11. CACHÓN RODRÍGUEZ, Lorenzo, quien afirma que "la vulnerabilidad de los inmigrantes en el mercado de trabajo, que tiene su fundamento último en la especificidad de su $<$ mancha inmigrante $>$, arranca en el hecho de su condición obrera y se manifiesta en mayores tasas de paro, mayores tasas de temporalidad en el empleo, mayores tasas de accidentabilidad, una extraordinaria concentración sectorial, salarios más bajos y peores condiciones de trabajo, mayor presencia en todo tipo de jornadas y horarios de trabajo especiales $y$, en definitiva, una alta proporción de empleos calificables como $<3 \mathrm{P}>$ : puestos de trabajo más Penosos, más 
país por motivos fundamentalmente económicos - son mucho más propensos que la población autóctona a sufrir violaciones sobre sus derechos más básicos. Jorge Bustamante estima que la vulnerabilidad del inmigrante constituye una condición endógena adscrita al inmigrante ya en su país de origen, pero que se intensifica en el país de destino ${ }^{561}$, donde pasarán a formar parte de los sustratos sociales más desfavorecidos ${ }^{562}$. Esta vulnerabilidad se ve acentuada y perpetuada por su exclusión del proceso político nacional puesto que los inmigrantes no son electores en el Estado de acogida, de ahí que Hollifield haya subrayado que los extranjeros se encuentran entre los miembros políticamente más vulnerables de las sociedades liberales ${ }^{563}$.

La ruta crítica de Bustamante y Hollifield había sido abierta años atrás por la Suprema Corte de Justicia de los Estados Unidos en el caso Carolene Products, en donde el alto tribunal estadounidense había identificado a los extranjeros como "minorías insulares" 564 que por esta consideración debían ser objeto de una intensa protección judicial. En torno a dicho concepto de "minoría insular" el profesor John Hart Ely ha elaborado una persuasiva teoría sobre la legitimidad del activismo judicial para protegerles. Ely define a las minorías insulares como aquellas minorías marginadas del proceso político a través del cual normalmente se hacen valer los derechos en una democracia representati$\mathrm{va}^{565}$. La explicación de esta inserción reposa en un obstáculo insalvable: los inmigrantes -continúa diciendo este autor-, conforman típicamente una de las minorías insulares en el proceso político democrático pues, en tanto que extranjeros, no gozan del derecho a votar y ser votados y, en consecuencia, no participan como sujetos en el proceso de formación de las políticas públicas del sistema representativo, sino únicamente como objeto de tales políticas.

Aplicado a nuestro objeto de estudio, el marco teórico y conceptual propuesto por John Hart Ely nos permite explicar y justificar la razón del protagonismo que los jueces han asumido en materia de reunificación familiar y adelantar ya la siguiente conclusión que será un punto de apoyo central para nuestra tesis: La resistencia inicial de los poderes legislativos internos al reconocimiento legal de la RF como derecho así como las subsiguientes obstaculizaciones por vía legislativa y administrativa, han sido subsanadas mediante la actuación pionera del poder judicial — tanto a nivel internacional como interno- a fin de extraer del espíritu liberal del constitucionalismo democrático un derecho de los extranjeros legalmente asentados en el Estado parte receptor a reunirse con sus familiares más

Peligrosos y más Precarios. (Equivalente a las $<3 \mathrm{D}>$ en inglés: dirty, dangerous, demanding o las $<3 \mathrm{~K}>$ en japonés: kitanai, kiken, kitsui. Y si señalamos estas variantes lingüísticas es para destacar la similar $<$ ley de hierro $>$ a que están sometidos los inmigrantes en los diferentes países y circunstancias.). Y, además, los inmigrantes tienen una notable mayor presencia en la economía sumergida"; en La <España inmigrante >: marco discriminatorio, mercado de trabajo y políticas de integración. Barcelona, Anthropos editorial, 2009, p. 246.

561 BUSTAMANTE, J. “Immigrant's Vulnerability as Subjects of Human Rights”, op. cit., pp. 340-341.

562 AJA FERNÁNDEZ, Eliseo. "Veinte años de doctrina del Tribunal Constitucional sobre los derechos de los inmigrantes"; en La democracia constitucional: estudios en homenaje al profesor Francisco Rubio Llorente, Vol. 1. Madrid, Congreso de los Diputados, 2002, p. 444.

563 HOLLIFIELD, James F. Immigrants, Martets and the State: The Political Economy of Postwar Europe. Cambridge, Harvard University Press, 1992, p. 12.

564 A través del Ministro Stone, la Corte Suprema de EEUU sostuvo en 1938, en el asunto United States v. Carolene Products Co.: "Es innecesario considerar siquiera que las leyes que restringen aquellos procesos políticos que ordinariamente son considerados los idóneos para reaccionar contra una legislación no deseada, deben ser sujetas a un escrutinio judicial más riguroso que otro tipos de leyes con fundamento en las prohibiciones establecidas en la Decimo cuarta Enmienda. (...) Tampoco es necesario entrar en la consideración de si (...) prejuicios contra minorías insulares constituyen una condición especial que tiende seriamente a obstruir la operación de los procesos políticos sobre los que ordinariamente se confía que protegerán a las minorías, y que por tanto pueden constituir un llamado para un escrutinio judicial más intenso", traducción propia.

565 ELY, John Hart. Democracy and Distrust. A Theory of Judicial Review. Cambridge, Harvard University Press, 1980, p. 148 . 
próximos. El mayor mérito de este modo de proceder es que actuó beneficiando a sujetos altamente vulnerables que resultaban particularmente invisibles a nivel jurídico — no así a nivel social—como consecuencia de su exclusión del ámbito de los derechos políticos. La intervención activista de los jueces tuvo lugar a pesar de la inexistencia de un reconocimiento expreso de la RF como derecho en las normas tanto internacionales como nacionales ${ }^{566}$ - al menos en lo que respecta a la primera época de desenvolvimiento en Europa de la RF, afincada mayoritariamente por entonces en el ámbito administrativo, cuando no a un nivel puramente fáctico en los Estados receptores. Probablemente, el activismo judicial se haya producido con el beneplácito - o, al menos, bajo la mirada aliviadade los poderes públicos dotados de legitimación democrática directa y, por ende, más idóneos para una primera intervención normativa, pues con ello se veían descargados de adoptar controvertidas decisiones $^{567}$ sobre una materia que, como señalamos, posee una alta carga política.

En este proceso de progresiva expansión judicial de los derechos de los inmigrantes, la labor del TEDH ha sido especialmente relevante y a su estudio consagraremos el siguiente capítulo de nuestro trabajo. Para facilitar su comprensión y motivar la justificación del activismo judicial en materia de RF, en el que el Tribunal de Estrasburgo ha desempeñado un notable y pionero papel, consideramos adecuada la exposición, siquiera sea en apretada síntesis, de la teoría del control constitucional de John Hart Ely para la protección de las "minorías insulares" a que hemos aludido, y que responde al problema de teoría democrática identificado por Luis López Guerra: “Qué esfera de actividad queda reservada al juez individual y qué esfera de actividad le queda por el contrario vedada, y similares preguntas sobre el poder judicial en su conjunto, son interrogantes típicos de la teoría y la práctica política en contextos muy distintos, incluyendo el español"568.

En su obra clásica, Democracy and Distrust. A Theory of Judicial Review, John Hart Ely esbozó una teoría sobre la tarea de construcción de derechos - y el margen de apreciación- que corresponde a los jueces constitucionales en el marco de una democracia representativa ${ }^{569}$. La tesis central del profesor estadounidense es que la función del poder judicial consiste en mantener abierto el proceso político para que sean las autoridades democráticamente elegidas por el pueblo las que tomen las decisiones políticas en representación de los gobernados. En cuanto a la configuración de los derechos en las leyes, los jueces - continúa diciendo Ely— sólo deben sustituir al poder legislativo para configurar derechos mediante el "proceso judicial" cuando el "proceso político" representativo es institucionalmente incapaz de hacerlo. Bajo esta idea, al interpretar derechos fundamentales la intensidad del escrutinio judicial que aplican los jueces debe ser progresiva - (1) bajo, (2) medio ó (3) intensa-, según el tipo de derechos individuales en juego y la posibilidad de que dichos derechos puedan ser defendidos a través del proceso político o no. En otras palabras, el nivel del escrutinio judicial viene determinado por la posibilidad de que la concreta norma legal o acto de autoridad impugnado ante el juez constitucional pueda o no ser efectivamente defendido por los ciudadanos a través del proceso político.

566 JOPPKE, Christian y MARZAL, Elia. "Courts, the new Constitutionalism and Immigrant Rights: The Case of the French Conseil Constitutionnel”; en European Journal of Political Research, №. 43, 2004, pp. 823-844.

567 John Hart Ely señala: "The problem seems more basic, and may lie not in a propensity to make politically controversial decisions without telling us why, but rather in a propensity not to make politically controversial decisions - to leave then instead to others, most often others who are not elected or effectively controlled by those who are". Democracy and Distrust.., op. cit., p. 134.

568 LÓPEZ GUERRA, Luis. "Democracia, división del poder y Poder Judicial”; en El Poder Judicial en el Estado Constitucional. Lima, Palestra, 2001, p. 21.

569 En su aplicación a nuestro objeto de estudio, la teoría será identificada como "grado de intensidad del escrutinio judicial" que debe otorgarse a los jueces en materia de RF. 
En la teoría que John Hart Ely propone sobre el control constitucional de las leyes enmarcado en un sistema representativo, las interpretaciones que los miembros del poder legislativo hacen sobre las normas configuradoras de los derechos y libertades civiles gozan por regla general del mayor grado de presunción de constitucionalidad. Ello se debe a que los legisladores democráticamente elegidos las han formulado transformando el mandato popular en normas jurídicas. En consecuencia Ely sugiere un escrutinio judicial bajo para estos asuntos que pertenecen al proceso político, porque dicho proceso es eficaz para defender y promover derechos e intereses sociales. Para dicho autor, si bien los protagonistas más visibles de una democracia representativa son el Parlamento y el Gobierno, en realidad quien define en última instancia la inclinación ideológica que se verterá en una ley es el cuerpo electoral: Son los electores quienes terminan delimitando con qué ideología habrá de interpretarse legislativamente un determinado derecho. Y son finalmente los electores los que defienden sus derechos a través de sus votos. Este es el llamado carácter abierto que ostentan las Constituciones y los derechos en ellas reconocidos, que a través del sufragio tendrán diferentes interpretaciones ideológicas, más o menos conservadoras o progresistas, con el paso del tiempo ${ }^{570}$.

Ahora bien, en la tarea de mantener abierto los conductos de la democracia representativa, hay normas que no están explícitamente dirigidas a estructurar el proceso político pero sin duda inciden en él como, por ejemplo, la libertad de conciencia.

Por ello, según Ely, los derechos configurados por las leyes que afectan indirectamente al proceso político merecen un escrutinio judicial medio. Dicho en otras palabras, en caso de ser impugnadas, a las normas de este tipo el juez les debe otorgar una presunción de constitucionalidad media. Por último, las normas que directamente regulan aspectos concernientes a los derechos políticos de los gobernados o que directamente inciden en el proceso político democrático, no gozan del mismo nivel de presunción de constitucionalidad que las anteriores: su presunción de constitucionalidad debe ser bajo. Ello se debe a que este tipo de normas regulan la distribución del poder político entre los poderes públicos y los gobernados o entre los poderes públicos entre sí, y por tanto suelen venir contaminadas por los intereses de los partidos políticos que al legislar se convierten en juez y parte. A juicio del profesor Ely son sobre todo las normas que estructuran el proceso político las que deben ser objeto de un escrutinio judicial muy intenso, el más intenso posible, pues sólo así se puede garantizar la apertura del proceso político para que la sociedad pueda defender sus derechos a través del juego democrático. En este elenco se pueden ubicar, por ejemplo, las normas electorales y las que rigen a los partidos políticos o el derecho de libertad de expresión y acceso a la información pública: como los medios de comunicación suelen evaluar la labor de los políticos, Ely sugiere que el legislador no está institucionalmente situado en un lugar en el que pueda configurar el derecho a la libertad de expresión y de acceso a la información pública de la mejor manera posible para elevar la calidad del proceso político, precisamente porque pueden llegar a tener interés en reducir la capacidad de investigación y difusión de información de sus agudos censores.

Los criterios anteriormente expuestos sobre la intensidad del escrutinio judicial aplicable a las leyes emanadas del Parlamento, se asientan en la idea de que el electorado influye de forma determinante a través de su voto en la interpretación de los derechos constitucionales que hacen los legisladores. Si, por ejemplo, la mayoría del cuerpo electoral no comparte la interpretación que los legisladores de un determinado partido político hicieron sobre el derecho a la vida al despenalizar ciertos supuestos del aborto, entonces el cuerpo electoral puede votar en la siguiente elección para

570 ZAGREBELSKY,Gustavo. El derecho dúctil. Madrid, Trotta, 1992, pp. 150-153. 
que llegue una mayoría parlamentaria de otro partido que revierta lo dispuesto en materia de aborto. Esta es la lógica del proceso político democrático basado en la regla de la mayoría para decidir ${ }^{571}$.

Sin embargo, Ely advierte que en una democracia representativa la regla de la mayoría no siempre opera con la misma coherencia ${ }^{572}$. Como explica John Hart Ely, existen en todas las sociedades políticas "minorías insulares" que por algún obstáculo insalvable no son capaces de influir de forma determinante o incluso de ninguna forma en el proceso político y, por tanto, dicho proceso no es capaz de proteger sus derechos. Para Ely es ahí donde se abre el espacio para el activismo judicial. Como acertadamente había destacado la Corte estadounidense en Carolene Products, un ejemplo claro de las "minorías insulares" está constituido por los inmigrantes, excluidos históricamente del derecho de sufragio $^{573}$. Su influencia en el proceso político a fin de defender sus derechos es irrelevante. Por ello estas "minorías insulares" deben ser protegidas por el proceso judicial mediante un escrutinio intenso por parte de los jueces. En palabras de Ely, "los extranjeros como clase son un ejemplo típico de una 'minoría insular' ...para la cual resulta apropiada una elevada consideración judicial"574.

Para nuestro objeto de estudio, la aplicación de la teoría de Ely desemboca en la necesidad de que los jueces que se enfrenten a controversias relacionadas con el derecho a la reunificación familiar de los extranjeros establecidos en un Estado, deban aplicar un test muy riguroso de escrutinio judicial, ya que estamos ante un derecho - en ocasiones inexistente - predicable de un colectivo que supone un ejemplo típico de "minoría insular" y que carece de medios alternativos para reivindicar y hacer valer sus derechos ante el Estado de acogida. Salvo la excepción representada por el ámbito municipal, el extranjero en España no tiene derecho al voto para reivindicar la protección de su derecho a la reunificación familiar, pero sí cuenta con el derecho a la tutela judicial efectiva. En adición, los jueces y tribunales no están sujetos a la presión que sobre los parlamentarios ejerce el cuerpo electoral — susceptible de ser preso del discurso xenófobo-, razón por la cual el poder judicial y el Tribunal Constitucional españoles están institucionalmente mejor situados que el Parlamento y el Gobierno para proteger el derecho a la reunificación familiar.

En el poder judicial confluyen elementos estructurales ${ }^{575}$ que favorecen su posicionamiento como líderes en el proceso de reconocimiento y consagración normativa expansiva de los derechos de los inmigrantes en general, y de la RF en particular. El aislamiento de los Tribunales respecto de las presiones electorales y de la opinión pública a las que sí se ven sometidos los Parlamentos, partidos políticos y ejecutivos que concurren en la configuración de las leyes y políticas migratorias, convierte estructuralmente a los jueces, de entre todas las instituciones del Estado, "en los más receptivos con los inmigrantes" ${ }^{\prime \prime 76}$. De otro lado, el principio de inamovilidad de los jueces en conjunción con el imperativo de neutralidad, actúa como escudo frente a las presiones anti-migratorias que a menudo calan en las sociedades receptoras, "estando solamente obligados a los imperativos abstractos del derecho legal y constitucional" ${ }^{777}$. Este cúmulo de circunstancias les sitúa en una postura

571 ELY, John Hart. Democracy and Distrust. A Theory of Judicial Review, op. cit., pp. 77-88.

572 Ídem, p. 98.

573 Nota atribuida al Magistrado Stone en el Asunto Carole Products. Citado por ELY, J. H. Democracy and Distrust..., op. cit., p. 151.

574 Ídem. ELY subraya que esta proposición, inicialmente atribuida al magistrado Stone en Carolene Products, ha sido parafraseada recientemente por la Corte Suprema en voz del ministro Blackmun.

575 JOPPKE, Christian y MARZAL, Elia. "Courts, the new Constitutionalism and Immigrant Rights: The Case of the French Conseil Constitutionnel”; en European Journal of Political Research, №. 43, 2004, p. 824.

576 Ídem.

577 JOPPKE, Christian. “Why Liberal States Accept Uwanted Immigration?”; op. cit., p. 271. 
inmejorable para poder servir de baluarte protector de las minorías en general, y en particular de las minorías insulares, en claro contraste al proceso político, "crónicamente vulnerable a los sentimientos populistas anti-inmigrantes" 578 .

El papel clave desarrollado por el poder judicial en la extensión —o, en el más prudente de los casos, a fin de evitar limitaciones excesivas o desacelerar el ritmo de restricción ${ }^{579}$ - de los derechos de los inmigrantes en el Estado receptor, puede explicar la paradoja ${ }^{580}$ que sacude a las democracias europeas occidentales desde mediados de los setenta: El creciente clima de animadversión hacia los inmigrantes y la puesta en práctica de políticas migratorias altamente restrictivas ha venido acompañado de un proceso lento, pero inexorable, de constante expansión del círculo de derechos predicables de los extranjeros ${ }^{581}$. Este proceso expansivo se ha producido "en contra de las preferencias de las mayorías democráticas" 582 que, pese a negar su condición de sociedades de inmigración, terminaron convirtiéndose en espacios multiétnicos con un porcentaje relativamente elevado de extranjeros residentes en su interior.

En sentido concurrente con la tesis expuesta en torno al papel de los jueces - tanto nacionales como del ámbito internacional- con respecto a los derechos de los inmigrantes, se encuentra Sassia Sassen, quien sostiene que "el régimen internacional de los derechos humanos ha sido un mecanismo clave para hacer aparecer sujetos que hasta ahora eran invisibles en el derecho internacional pueblos indígenas, inmigrantes y refugiados, mujeres-. Estos cambios, independientemente de su tamaño y especialización, han traído un número creciente de instancias donde un sector del Estado está en desacuerdo con otro. Quizá el más evidente es el papel estratégico que los jueces han asumido en los países altamente desarrollados cuando se trata de defender los derechos de los inmigrantes, refugiados y los que buscan asilo" 583 .

578 Ídem.

579 Sobre este punto, Lahav y Guiraudon aclaran que en materia migratoria “judicial rulings do not generally represent an expansion of immigrant rights but rather ar attempts to limit or perhaps to slow down a contraction of such rights”. LAHAV, G. y GUIRAUDON, V. “A Reappraisal of the State Sovereignty Debate. The Case of Migration Control", op. cit., pp. 170 y 175.

580 En torno a la misma, JOPPKE y MARZAL señalan que "a persistent puzzle across Western states is the disparity between mass publics that are generally opposed, if not hostile, to immigration and increased rights for immigrants, who in important respects have come to acquire a status close to that of citizenship"; en "Courts, the new Constitutionalism and Immigrant Rights...., op. cit., p. 823.

581 Desde múltiples frentes doctrinales se ha señalado la fractura existente entre la retórica oficial de control restrictivo de los flujos migratorios y una realidad migratoria expansionista. Vid. JOPPKE, C. "Why Liberal States Accept Unwanted Immigration?"; en World Politics vol. 50, 1998, p. 267. Por su parte, Freeman señala textualmente que "las políticas de inmigración en las democracias liberales exhiben fuertes similitudes que resultan, contrariamente al consenso académico, ampliamente expansionistas e inclusivas"; en FREEMAN, Gary. "Modes of Immigration Politics in Liberal Democratic States”; en International Migration Review, vol. 29, No. 4, 1995, p. 881. En idéntico sentido, Cornelius, Martin y Hollifield habían expuesto que existía una fractura creciente entre los objetivos buscados y los resultados obtenidos por las políticas migratorias de las democracias industrializadas. CORNELIUS, Wayne; MARTIN, Philip y HOLLIFIELD, James. Controlling Immigration... first edit, 1994, op. cit., p. 3.

582 JOPPKE, C. "Courts, the new Consitutionalism and Immigrant Rights: The Case of the French Conseil Constitutionnel”, op. cit., p. 824. Pese a todo lo dicho, Joppke puntualiza que existe un "límite inherente a la constitucionalización de los derechos de los inmigrantes, que deriva del hecho de que los extranjeros no son ciudadanos", Ídem.

583 SASSEN, Saskia. "La formación de las migraciones internacionales: implicaciones políticas"; en Revista internacional de filosofía política, No. 27, 20006, p. 32. 


\section{CAPÍTULO II}

\section{LA MIGRACIÓN FAMILIAR EN EL SISTEMA INTERNACIONAL DE DERECHOS HUMANOS Y EN EL ÁMBITO DEL CONSEJO DE EUROPA}

\section{LA RF EN EL SISTEMA INTERNACIONAL DE DERECHOS HUMANOS}

\subsection{La RF como derecho implícito: Búsqueda de un derecho matriz}

Si bien la configuración de la RF hunde sus raíces en el DIDH, no es posible encontrar en el nutrido cuerpo de normas de muy diversa naturaleza que lo constituyen un reconocimiento expreso de la $\mathrm{RF}$ - salvo en textos relativamente recientes. De ahí que tanto a nivel doctrinal como jurisprudencial, su construcción se encauzase mediante su vinculación a principios jurídicos y derechos humanos expresamente consagrados en el ámbito internacional, cuya titularidad no se restringía a los ciudadanos de un Estado Nacional.

En el ámbito doctrinal europeo, dos han sido los principios presentes en los instrumentos internacionales que han sido apuntados como soporte jurídico de la RF: la unidad familiar y, en menor medida, el principio de libertad de circulación derivado del derecho de salir de cualquier país, incluido del propio, y del derecho a regresar al país natal ${ }^{1}$. Los escritos más recientes han tendido a obviar la referencia a la libertad de circulación, concentrándose en la unidad de la familia ${ }^{2}$, en vista

1 Véase, a modo meramente ejemplificativo, PERROUCHOUD, R. "Family Reunifcation"; International Migration,op. cit., pp. 511 y 512; KOFMAN, Eleonore. "Family-Related Migration: A Critial Review of European Studies”, op. cit., p. 253. APAD, Joanna y SITAROPOULOS, Nicholas. The right to family unity and reunification of trird country migrants in host states: Aspects of International and European law. June 2001, pp. 7-9. Disponible en http://www.2008. december18.net/web/general/paper53EurFamilyReunification.pdf. En un punto intermedio se sitúa Mubanga quien, aún enfatizando la íntima conexión de la RF con el derecho de abandonar y regresar al propio Estado - la libre circulación de personas-, aboga por considerar la RF como un derecho independiente. Este último autor dotó de autonomía tempranamente al derecho a la reunificación familiar, cuando tal derecho en su aplicación a los extranjeros procedentes de terceros países comenzaba a escalar al ámbito de las preocupaciones internacionales en el ámbito europeo. MUBANGA-CHPOYA, C. L. C. “The Right of Everyone to Leave any Country, Including his Own and to Return to his Country. Analysis of the current trends and developments regarding the right to leave any country including one's own, and to return to one's own country, and some other rights or considerations arising therefrom". Document E/CN.4/Sub.2/1988/35, of 20 June 1988, p. 106. En el ámbito doctrinal español, la prof. VIDAL FUEYO tamibén ha apuntado la conexión existente entre la libertad circulatoria (art $19 \mathrm{CE}$ ), en su sentido de derecho de entrada y establecimiento, con el derecho la RF, apuntando asimismo a la protección de la familia que otorga el art. 39 CE. VIDAL FUEYO, M.C. "La jurisprudencia del TC en materia de derechos fundamentales de los extranjeros a la luz de la STC 236/2007”; en Revista Española de Derecho Constitucional, no 85, 2009, p. 374. LAHAV, Gallya. "International versus Nationals Constraints in Family-Reunification Migration Policy", op, cit. p. 355.

2 CHOLEWINSKI, Ryszard. “Family Reunification and Conditions Placed on Family Members...., op. cit., p. 275. KRALER, Albert. Civic Stratification, Gender and Family Migration Policies in Europe. Final Report, 2010, op. cit., p. 29. 
de que la libre circulación no implica en ningún momento un derecho a inmigrar, puesto que "mientras el derecho a abandonar un país es reconocido en varios instrumentos internacionales, no existe un correspondiente deber por parte de un Estado a permitir a las personas a entrar en su territorio"3.

Dado que la libertad de circulación no obliga jurídicamente a los Estados parte a admitir en su territorio a personas extranjeras, subsumir la inmigración de carácter familiar como un contenido de dicha libertad, se traduciría en una débil tutela de la RF. Por ello, la protección de la RF se afianzaría fundamentalmente en conexión con el principio de la unidad familiar, principio que a su vez desemboca en dos derechos que gozan de amplio reconocimiento en el $\mathrm{DIDH}^{4}$ : el derecho a contraer matrimonio y fundar una familia, y el derecho a la vida familiar. Sin embargo, el hecho de que muchos tratados vinculen la protección de la familia con el matrimonio, disminuía las garantías extraíbles de cara a la RF.

Por su parte, el derecho a la vida familiar presentaba un contenido más amplio, no quedando restringida su tutela a la existencia de un matrimonio previo, lo que suponía la protección de un haz mucho mayor de modelos familiares. El derecho a la vida familiar terminaría por ello consolidándose como el principal derecho matriz que daría pie a derivar cierto grado de tutela internacional sobre la inmigración de carácter familiar. El TEDH se apuntaría a esta corriente, encajando la posible protección que podía brindar a la RF de los extranjeros como un contenido implícito del derecho al respeto de la vida familiar, excluyendo su extracción de otras disposiciones alternativas del CEDH que también ofrecían una cobertura protectora a los extranjeros y a sus familias ${ }^{5}$. Desde la década de los ochenta, el derecho a la vida familiar consagrado en el art $8 \mathrm{CEDH}$ ha sido frecuentemente alegado por los tribunales internos para proteger el derecho a la RF de los extranjeros residentes en sus territorios. La UE, apoyándose en la jurisprudencia del TEDH, también ha vinculado la RF con el derecho a la vida familiar de los extranjeros. Esta forma de razonar ha dado lugar en Europa "a un entendimiento de la reunificación familiar como una versión del derecho a la vida familiar en contextos migratorios"6.

En consecuencia, en el entorno de familias de inmigrantes geográficamente dispersas como consecuencia de la emigración, la RF ha sido fundamentalmente concebida como una premisa o prerequisito $^{7}$ necesario del derecho a la vida familiar de los extranjeros o un medio de implementación

3 PERRUCHOUD, R. “Family Reunificaton”, op. cit., p. 511.

4 En sentido divergente se manifiesta Elspeth Guild, quien encaja directamente la RF como contenido del derecho humano a la vida familiar, señalando sin embargo que se trata de un derecho frecuentemente expresado de dos formas: de un lado, el derecho a casarse y fundar una familia y, de otro, la protección de la vida privada y familiar frente a interferencias derivadas del orden público y la seguridad nacional. GUILD, Elspeth (compilation and commentary). The Developing Immigration and Asylum Policies of the European Union. Adopted Conventions, Resolutions, Recommendations, Decisions and Conclusions. Kluwer Law International, The Haghe, 1996, p. 260.

5 STOREY estudió tempranamente aquellas disposiciones del Convenio de Roma que ofrecían potencial protector en contextos migratorios, destacando el derecho al respeto de la vida privada y del domicilio, -protegidos ambos también en el art. $8 \mathrm{CEDH}$-, así como el derecho a contraer matrimonio consagrado en su art. 12, e incluso el artículo 5 del Protocolo $n^{\circ} 7$ que protege la igualdad entre esposos. Sin embargo, matiza que la naturaleza de las garantías ofrecidas por la vida familiar del art. 8, de carácter más fuerte y más amplio, ha determinado la primacía de este último derecho como sede de reclamaciones migratorias. "The Right to Family Life and Immigration Case Law at Strasbourg", op. cit., pp. 341-344.

6 KRALER, Albert. Civic Stratification, Gender and Family Migration Policies in Europe. Final Report, 2010, op. cit., p. 30.

7 ARRIAGA IRABURU, Inés. El derecho a la vida familiar de los extranjeros en la jurisprudencia de Estrasburgo. Pamplona, Eunsa, $1^{\text {a }}$ ed., junio de 2003. p. 23. Como explica la propia autora, desde la década de los sesenta del pasado siglo, en el seno del Consejo de Europa, la Comisión comenzó a reconocer "el derecho a residir en otro país diferente al de la nacionalidad (...) como premisa del derecho al respeto de la vida familiar". De esta forma, y en base a una construcción judicial de los derechos derivados indirectos, la Comisión reconocía su competencia indirecta para 
de la unidad familiar ${ }^{8}$, pues actúa como un recurso para remediar su ruptura. Y ello en la medida en que la garantía plena del disfrute efectivo del derecho a la vida familiar,_ en su aplicación específica a parientes próximos no nacionales separados entre las fronteras de diversos Estados a causa de la emigración de alguno de sus miembros-, conlleva para los poderes públicos, en determinadas circunstancias, autorizar la RF de dichos extranjeros, pues lo contrario provocaría como resultado una afectación indirecta o derivada del derecho al respeto de su vida familiar.

En último término, la RF constituye una vía para la protección de la familia en tanto que célula social básica, por lo que conviene analizar el reconocimiento y la intensidad de la tutela que el DIDDH otorga a estos diversos conceptos.

\section{2 Anclaje normativo de la Reunificación Familiar en el Derecho Internacional de los derechos humanos}

Los dos principios que sirven de sustento a la RF — libertad de circulación y unidad familiarestán consagrados y protegidos de interferencias estatales en los textos integrantes de la Carta Internacional de los derechos humanos. Sin embargo, en este conjunto normativo - compuesto por la Declaración Universal de los Derechos Humanos, los dos Pactos Internacionales de 1966 y sus dos protocolos facultativos-, no se contienen referencias explícitas a la RF.

El sistema universal de derechos humanos fue auspiciado por la Organización de las Naciones Unidas. Su Carta fundacional —Carta de ONU de 1945- incluía referencias a los derechos humanos, cuyo respeto y promoción se convertía en uno de los propósitos esenciales de la nueva organización. El texto que inaugura el derecho internacional de los derechos humanos lo constituye la Declaración Universal de los Derechos Humanos —en adelante DUDH-, Resolución General adoptada por la Asamblea General de las Naciones Unidas el 10 de diciembre de $1948^{9}$. Si bien técnicamente la DUDH no es un Tratado internacional, sino una resolución ${ }^{10}$, constituye el documento internacional más universal y prestigioso en materia de derechos humanos. Los derechos en ella proclamados poseen un valor declarativo o recomendatorio - con excepción de aquellas de sus normas que consagran principios generales del derecho internacional o de derecho consuetudinario-, lo que implica en principio una baja densidad normativa ${ }^{11}$, a reserva de los efectos jurídicos concretos reconocidos por cada ordenamiento jurídico a nivel interno.

examinar la admisibilidad de un derecho que carecería de reconocimiento expreso en el CEDH — la RF-, al reconocerlo como contenido implícito o derivado del derecho al respeto a la vida familiar, consagrado en el art. $8 \mathrm{CEDH}$. La decisión de la Comisión que marcó el pistoletazo de salida a esta innovadora construcción jurisprudenciaf fue la decisión $312 / 57$, pese a que en ella la demanda fue declarada manifiestamente mal fundada y, por ello, no fue objeto de enjuiciamiento por parte del TEDH. Idem.

8 PERROUCHOUD, R. “Family Reunification”, op. cit., p. 511.

9 Resolución $217^{\mathrm{a}}$ (III), de 10 de diciembre de 1948.

10 Szabo ha señalado que la Declaración universal de derechos humanos constituye una especie de excepción: mientras las declaraciones carecen de vinculatoriedad jurídica y su valor es puramente moral, frente a ellas la Declaración goza de gran autoridad mundial y su peso jurídico es muy superior al que ostenta una mera recomendación. SZABO, Imre. "Historical Foundations of Human Rights and Subsequent Developments"; VASAK, Karel (ed.). The International Dimension of Human Rights, vol. I. Paris, Westport, Greenwood Press,1982, pp. 23-24.

11 Pese a que formalmente carezca de fuerza jurídica vinculante, la evolución posterior ha ido imprimiendo cierta densidad normativa a los derechos en ella reconocidos, que pueden ser oponibles a los Estados en ciertas circunstancias. En cualquier caso, la Declaración Universal de Derechos Humanos ha desempañado dos funciones básicas: de un lado, se ha convertido en el parámetro para valorar el compromiso real de los Estados con los derechos humanos y, de otro, ha cumplido una importantísima tarea pedagógica y moralizante pues, al definir el sistema general de los derechos humanos de la ONU, ha impregnado todos los textos posteriores en esta materia. ESCOBAR HERNÁN- 
Tras la DUDH, el siguiente paso en el progresivo proceso de codificación del derecho internacional de los derechos humanos lo representa la adopción, bajo el marco de la ONU, de los Pactos Internacionales de Derechos Civiles y Políticos — en adelante PIDCP - y de Derechos Económicos, Sociales y Culturales, aprobados simultáneamente el 16 de diciembre de 1966 ${ }^{12}$. Estos Pactos implican un cambio en la naturaleza jurídica de los derechos consagrados, pues constituyen Tratados internacionales de ámbito universal que hacen surgir obligaciones a los Estados partes que los han ratificado y están dotados de instrumentos de control para su cumplimiento. Al Pacto Internacional de Derechos Civiles y Políticos se le añadieron posteriormente dos Protocolos facultativos.

La libertad de circulación y residencia aparece consagrada en el artículo 13 de la DUDH, que proclama el derecho de todas las personas a salir de cualquier país, incluido el propio y a regresar a su país ${ }^{13}$. La redacción de este precepto constituye una excepción al tono general de equiparación de derechos entre nacionales y extranjeros que preside la $\mathrm{DUDH}^{14}$. Por su parte, el PIDCP recoge una formulación más amplia y acabada de este principio en su artículo 12, limitando el derecho de libre circulación a toda persona que se halle legalmente en el territorio de un Estado. El apartado cuarto de esta última disposición proclama que "nadie podrá ser arbitrariamente privado del derecho a entrar en su propio país". A su tenor, la titularidad activa del derecho de entrada al territorio de un Estado aparece restringida a los nacionales de dicho Estado ${ }^{15}$. La misma disposición del Pacto, en su apartado tercero, consagra el derecho que corresponde a toda persona de salir libremente de cualquier país, incluido del propio. Sin embargo no se reconoce un correlativo derecho general de entrada, con la consiguiente obligación estatal de permitir la admisión en su territorio de aquellas personas no nacionales interesadas en entrar en él por diversos motivos, entre los que cabría citar la reunión con sus parientes allí instalados. Idéntica conclusión se deriva del artículo 13 DUDH ${ }^{16}$.

DEZ, Concepción. La protección internacional de los derechos humanos (I); Capítulo XXVII; en DÍEZ DE VELASCO, Manuel (coord.). Instituciones de Derecho Internacional Público. Madrid, Tecnos, Decimotercera ed., 2001, pp. 543-549. En torno al valor de la DUDH vid. CARRILLO SALCEDO, Juan Antonio. "Algunas reflexiones sobre el valor jurídico de la Declaración Universal de Derechos Humanos”; en PÉREZ GONZÁLEZ, Manuel (cord.). Hacia un nuevo orden internacional y europeo. Estudios en Homenaje al profesor Manuel Díez de Velasco. Madrid, Tecnos, 1993, pp. 167-178.

12 Resolución 2200 A (XXI), de la Asamblea General de las Naciones Unidas.

13 Apartado segundo del artículo $13 \mathrm{DUDH}$. El apartado primero de esta disposición afirma que "toda persona tiene derecho a circular libremente y a elegir su residencia en el territorio de un Estado".

14 BONET PÉREZ, Jordi. Las políticas migratorias y la protección internacional de los derechos y libertades de los inmigrantes. Un análisis desde la perspectiva del ordenamiento jurídico español, op. cit., pp. 22-24. El autor especifica que junto con el artículo $13 \mathrm{DUDH}$, también el derecho a la participación política, formulado en el artículo $21 \mathrm{DUDH}$, así como la cláusula general de limitación de derechos prevista en su artículo 29.2, constituyen supuestos de distanciamiento de "la lógica de la igualdad formal y de la no discriminación, inherente a la base programática de la Declaración Universal”, lo que lleva al autor a calificar dicha equiparación como de signo restrictivo, y a afirmar que, bajo la misma, "se sigue observando un hondo respeto por la soberanía estatal en la fijación de su política migratoria”.

15 En este sentido, Frowein ha señalado que, en el derecho internacional, el derecho de entrada a un Estado está limitado, con carácter general, a los nacionales de dicho Estado. "Ello muestra la importancia del derecho de la nacionalidad, que crea un estatus de gran relevancia no solo en el derecho nacional, sino también en el derecho internacional público". FROWEIN, Jochen Abr. "Concluding Report to the Heildelberg Colloquium on the Legal Position of Aliens in National and International Law”; en FROWEIN, J.; TORSTEIN, S. (eds.). The Legal Position of Aliens in National and International Law. Springer-Verlag, Berlin-Heildelberg, New York-London-Paris-Tokyo, 1987, p. 2082.

16 Con respecto de dicho artículo, y en palabras de Jordi BONET, "la libertad de residencia que parece ampararse vendría restringida implícitamente por la facultad del Estado de rechazar la entrada de esa persona en su territorio y de no autorizar la permanencia de un extranjero dentro de las propias fronteras". Las políticas migratorias y la protección internacional de los derechos y libertades de los inmigrantes..., op. cit., p. 22. 
En síntesis, no cabe deducir la existencia de ningún derecho humano a inmigrar, tanto en su dimensión individual como colectiva ${ }^{17}$. La única protección que cabría extender, más allá de lo estrictamente proclamado por el artículo 12 PIDCP, ha sido deducida por el Comité de Derechos Humanos, quien entiende que el término "regresar" al propio país, debe entenderse también aplicable a los residentes permanentes o de larga duración que hayan establecido "vínculos próximos y duraderos" con el país de residencia ${ }^{18}$. La aplicación de este concepto amplio de regreso, supondría extender la protección del derecho de entrada a un país para abarcar, junto a los nacionales de dicho Estado, a los extranjeros residentes permanentes o de larga duración pero, con respecto a este último colectivo, amparando su derecho a entrar nuevamente al país de residencia tras haberlo abandonado por diversos motivos - turismo, visita de familiares en el país de origen, estudios, trabajo en un tercer Estado, etcétera. El artículo 12.3 PIDCP subraya el carácter limitado de los derechos vinculados a la libertad de circulación, que sólo podrán ser objeto de restricciones previstas en la ley, necesarias para proteger la seguridad nacional, el orden público, la salud o la moral públicas o los derechos y libertades de terceros, y siempre que las mismas sean compatibles con los demás derechos reconocidos en el PIDCP.

Con respecto a la protección de la unidad familiar, el carácter esencial que la institución familiar ostenta en la estructuración social constituye el punto de partida ineludible de su tutela internacional. Éste es precisamente el prisma adoptado por la Declaración Universal de los Derechos Humanos de la ONU. Su artículo 16, tras consagrar en su dos primeros apartados el derecho a contraer matrimonio y fundar una familia, así como la igualdad de derechos entre los esposos, afirma que "la familia es el elemento natural y fundamental de la sociedad y tiene derecho a la protección de la sociedad y del Estado"19. Además, el artículo 12 DUDH proclama que nadie será objeto de injerencias arbitrarias en su familia, reconociendo el derecho que asiste a todas las personas a la protección jurídica contra tales injerencias o ataques. Desde el ámbito doctrinal se ha señalado que, de esta disposición, al circunscribir las injerencias proscritas a aquellas consideradas "arbitrarias", cabría deducir la legitimidad de la imposición de determinadas restricciones sobre la admisión de personas en un Estado con fines de $\mathrm{RF}^{20}$.

En el reconocimiento del derecho a la protección de la familia y de la unidad familiar dispensado por la DUDH sobresalen dos características: Su carácter genérico y contundente ${ }^{21}$. La generali$\mathrm{dad}^{22}$ constituye una consecuencia inevitable del ámbito geográfico universal cubierto por la ONU. Su contundencia se desprende del propio carácter estructural de la familia en la sociedad, así como de su íntima conexión con la dignidad del ser humano. Sin embargo, de la formulación contenida conjuntamente en los artículos 12 y 16 de la DUDH no cabe deducir que la protección de la familia

17 SAGARRA TRÍAS, Eduard. "Artículo 13 Declaración Universal de los Derechos Humanos". Asociación para las Naciones Unidas en España. Barcelona, Icaria, Antrazyt, 1998, p. 2

18 Human Rights Committee, 67th Session, 1999, General Comment No. 27 on Article 12, para. 20. UN, International Human Rights Instruments. Compilation of General Comments and General Recommendations Adopted by Human Rights Treaty Bodies. UN, Doc. HRI/GEN/1/Rev.5 (26 April 2001).

19 Apartado tercero del artículo 16 de la Declaración Universal de Derechos Humanos.

20 PLENDER, Richard. International Migration Law. Martinus Nijhoff Publishers, revised second edition, Dordrecht, London, 1988, p. 367.

21 FERNÁNDEZ SÁNCHEZ, Pablo Antonio. El derecho de reagrupación familiar de los extranjeros; en Derecho y conocimiento, $\mathrm{N}^{\circ} .1,2001$, p. 375.

22 Adicionalmente, de la propia esencia de la familia en tanto que institución social —entre cuyos caracteres sobresalen su universalidad, variabilidad y diversidad - se extrae la necesidad de que una organización de dimensión universal como la ONU esté abocada a sostener un concepto amplio y de contornos difusos de familia, con el fin de que en él pueda contenerse la enorme variedad de estructuras familiares merecedoras de protección jurídica. 
se haya construido teniendo en mente el presupuesto de hecho de parientes próximos separados entre diversos Estados ${ }^{23}$.

Por su parte, el Pacto Internacional de Derechos Civiles y Políticos ${ }^{24}$, en materia de protección de la familia, contiene una norma prácticamente idéntica al artículo 16 de la DUDH, su artículo 23. Esta disposición fue redactada con el fin de proporcionar protección a aquellas familias que habían sido separadas como consecuencia de la segunda guerra mundial ${ }^{25}$, sin embargo la redacción no incluyó referencia alguna a esta cuestión a fin de no dificultar el consenso ${ }^{26}$.

De modo similar a como hiciera el art. 12 DUDH, el PIDCP, en su art. 17, prohíbe las injerencias sobre la vida privada, la familia, el domicilio y la correspondencia. La diferencia más importante respecto a la disposición correlativa de la DUDH, reside en que en el artículo 17 PIDCP las injerencias prohibidas en la vida familiar no son únicamente aquellas arbitrarias sino también las ilegales ${ }^{27}$. Richard Plender infiere que cabe la posibilidad de injerencias legales, pero arbitrarias y que, en consecuencia, serían legítimas las interferencias estatales en la vida familiar de forma legal, aun cuando fuesen arbitrarias, supuesto en el que se incluirían aquellas legislaciones migratorias que no protegiesen la reunificación familiar ${ }^{28}$. Sin embargo, a nuestro juicio, el matiz contenido en el artículo 17 PIDCP arrojaría un saldo más positivo de cara a sus implicaciones en el ámbito de la RF. Ello se derivaría del uso de la conjunción disyuntiva “ó" en el artículo 17 PIDC en conexión con la redacción en negativo de su titularidad activa. En virtud de estos dos elementos, el artículo 17 PIDCP prohibiría tanto las injerencias arbitrarias como las ilegales, lo que supone añadir un nivel de protección superior al implícito a la DUDH. En base a esta interpretación, los obstáculos a la RF derivados de las diversas leyes migratorias internas podrían ser arbitrarios a la luz del artículo 17 PIDCP, aun cuando estuviesen legalmente previstos, arbitrariedad proscrita también por dicha disposición. Si bien conviene subrayar que, pese a la amplísima ratificación con que cuenta el PIDCP, los mecanismos encargados de supervisar su aplicación —-destacadamente el Comité de Derechos Humanos- aún siendo vinculantes para los Estados Parte, carecen de eficacia jurídica directa dentro de los respectivos ordenamientos domésticos ${ }^{29}$, circunstancia que repercute finalmente sobre su cumplimiento efectivo, dependiendo éste enteramente de la buena voluntad de dichos Estados.

Junto al artículo 17, el PIDCP proclama en su artículo 23 el derecho de la familia a la protección social y estatal. La ubicación de esta última disposición ofrece pistas para descubrir su naturaleza

23 PLENDER, Richard. International Migration Law, op. cit., pp. 365-366.

24 El artículo 23 del Pacto Internacional de Derechos Civiles y Políticos dispone que "1. La familia es el elemento natural y fundamental de la sociedad y tiene derecho a la protección de la sociedad y del Estado. 2. Se reconoce el derecho del hombre y de la mujer a contraer matrimonio y a fundar una familia si tienen edad para ello. 3. El matrimonio no podrá celebrarse sin el libre y pleno consentimiento de los contrayentes. 4. Los Estados Partes en el presente Pacto tomarán las medidas apropiadas para asegurar la igualdad de derechos y de responsabilidades de ambos esposos en cuanto al matrimonio, durante el matrimonio y en caso de disolución del mismo. En caso de disolución, se adoptarán disposiciones que aseguren la protección necesaria a los hijos". La protección de la familia se incluye en términos similares en el artículo 10 del Pacto Internacional de Derechos Económicos, Sociales y Culturales.

25 HENKIN, Louise (ed.). The International Bill of Rights: The Covenant on Civil and Political Rights. Columbia University Press, November 1981, p. 205.

26 Por ello Plender afirma que "the framers of the Covenant were not oblivious of the dificulties presented by immigration control in this context”. PLENDER, Richard. International Migration Law, op. cit., p. 366.

27 El apartado primero del artículo 17 del PIDCP afirma literalmente que "nadie será objeto de injerencias arbitrarias o ilegales en su vida privada, su familia, su domicilio o su correspondencia, ni de ataques ilegales a su honra y reputación". Su apartado segundo añade que "toda persona tiene derecho a la protección de la ley contra esas injerencias o esos ataques".

28 BATTISTELLA, Graziano. "Family Reunification: Policies and Issues”, op. cit., p. 234.

29 DÍEZ-PICAZO, Luis María. Sistema de Derechos Fundamentales. Madrid, Civitas, 1ª edc., 2003, p. 151. 
jurídica: la protección de la familia no aparece incluida entre el grupo de derechos inderogables, recogidos en el artículo 4 PIDCP. Considerando el carácter inderogable de un derecho como característica que revela de forma indiciaria su naturaleza fundamental, la protección de la familia reconocida en el artículo 23 PIDCP está excluida del círculo de derechos humanos fundamentales, lo cual no obsta para que estemos ante un derecho internacionalmente protegible ${ }^{30}$.

En suma, las disposiciones dirigidas a la protección de la familia en los instrumentos internacionales multilaterales fundadores del DIDH en el marco de las Naciones Unidas, no fueron originariamente construidas con preocupaciones migratorias, de modo que "las condiciones y necesidades específicas de los migrantes son sólo marginalmente tocadas" ${ }^{31}$ por dichos instrumentos. Tampoco de su formulación amplia pueda derivarse un derecho específico de los extranjeros a la RF, en virtud del cual los Estados estén obligados a permitir la admisión en su territorio de no nacionales que pretendan reunirse y vivir allí con sus parientes más próximos ${ }^{32}$.

Sin embargo, de la conjunción de las normas que contemplan a la unidad familiar desde diversas perspectivas - prohibición de interferencias, derecho a la protección social y jurídica, derecho al matrimonio-, con aquellas relativas a la libertad de circulación, cabe extraer un nivel intenso de protección internacional, al menos en lo que respecta a la reunión de familias constituidas por nacionales de un determinado Estado. En este supuesto, el Estado no podría denegar la entrada de miembros de su comunidad política — ni tampoco en principio prohibir su salida-, mucho menos si el motivo de su admisión reside en reunirse con sus parientes, pues en este último supuesto se adicionaría la potencialidad plena de la libertad de circulación que corresponde a los nacionales, con el derecho a la tutela jurídica y social de la familia. "La denegación de la autorización de entrada en su país natal, situaría al nacional en la difícil disyuntiva de elegir entre la expatriación o la interrupción de la unidad de su familia"33. Lo mismo sería aplicable en el supuesto de que el nacional contase con parientes próximos que ostentasen la nacionalidad de un tercer Estado. De ahí que, en nuestra opinión, de la protección internacional de la familia, en conjunción con la libre circulación, cabría extraer la tutela de la reagrupación de familias íntegramente constituidas por nacionales de dicho Estado, como también, aunque con un nivel inferior de protección, la de familias mixtas formadas por parientes nacionales y extranjeros, - si bien cabe subrayar la protección superior de las primeras porque la nacionalidad otorga un derecho inherente de entrada y salida del país natal. En estos supuestos, la ruptura de los vínculos familiares y consiguiente separación familiar debida a injerencias de las autoridades internas del Estado parte, constituiría una violación del Derecho internacional.

30 Seguimos al respecto la argumentación de Pablo Antonio FERNÁNDEZ SÁNCHEZ en "El derecho de reagrupación familiar de los extranjeros", op. cit., p. 376.

31 BATTISTELLA, Graziano. "Family Reunification: Policies and Issues"; en Asian and Pacific Migration Journal, vol. 4, No. 2-3,1995, p. 234.

32 En el mismo sentido PLENDER, Richard. International Migration Law, p. 366 y nota a pie de página №. 13 de la p. 386; BATTISTELLA, Graziano. "Family Reunification: Policies and Issues”, op. cit., p. 234. En sentido contrario se manifiesta Karel VASAK, quien sugiere que de la protección internacional de la familia se deriva como consecuencia la necesidad de tutelar la RF, afirmando que "el respeto a la vida familiar significa en primer lugar y por encima de todo que la familia debe estar protegida como unidad, tanto respecto a los padres entre si como entre padres e hijos. De este modo, por ejemplo, los esposos están facultados para vivir en el mismo país, un requisito muy importante en el caso de trabajadores migrantes, y que el hijo está habilitado para vivir con su padre”, idem, traducción propia. VASAK, K. (ed.) The International Dimension of Human Rights. Westport, Greenwood Press, 1982, p. 154.

33 Plender afirma de forma contundente que "the strongest claim to enter a State's territory can often be advanced by members of the immediate family of a national of that State; for if they are denied admission, the national is confronted with a choice between expatriation and disruption of the unity of the family". PLENDER, Richard. International Migration Law, op. cit., p. 367. 
En el ámbito universal existen, además, diversos Convenios Internacionales que contemplan facetas concretas de la familia, otorgándole una protección parcial, con importantes repercusiones en materia de RF. En este sentido, destaca la Convención sobre los Derechos del $\mathrm{Niño}^{34}$, de 20 de noviembre de 1989, que recoge múltiples disposiciones con implicaciones familiares, todas ellas regidas por el principio de respeto al interés superior del menor y donde, además, se encuentra expresamente consagrada la RF. Su artículo 8 contempla el compromiso de los Estados partes de respetar el derecho del niño a preservar su identidad, considerando a las "relaciones familiares" como un elemento integrante de dicha identidad, y estipulando al respecto que las mismas han de desarrollarse "de conformidad con la ley y sin injerencias ilícitas"35. De tal modo que "cuando un niño sea privado ilegalmente de algunos de los elementos de su identidad o de todos ellos, los Estados Partes deberán prestar la asistencia y protección apropiadas con miras a restablecer rápidamente su identidad”36.

De forma más específica, el artículo 9 de la citada Convención resalta la importancia esencial de que los hijos convivan con sus padres o, cuando esto no sea posible en consideración al interés del menor, puedan mantener contactos regulares con ellos. A tal fin constituye una obligación que incumbe a los Estados partes "velar por que el niño no sea separado de sus padres contra la voluntad de éstos" ${ }^{\prime 37}$, para cuyo cumplimiento "toda solicitud hecha por un niño o por sus padres para entrar en un Estado Parte o para salir de él a los efectos de la reunión de la familia será atendida por los Estados Partes de manera positiva, humanitaria y expeditiva. Los Estados Partes garantizarán, además, que la presentación de tal petición no traerá consecuencias desfavorables para los peticionarios ni para sus familiares" 38 .

La preocupación por garantizar la protección de las familias desde el derecho internacional, constituye además una constante de los diversos sistemas regionales surgidos para la protección de los derechos, que se expresan en términos similares a los utilizados en el ámbito universal. En todos ellos la familia se considera el núcleo básico de la sociedad y se prohiben las injerencias en la vida familiar, sin contenerse referencias específicas a su protección en el contexto migratorio. Aquí se situarían los artículos 11 y 17 de la Convención Americana de Derechos Humanos y el artículo 18 de la Carta Africana de los derechos humanos y de las gentes. Consideración especial merece el Convenio Europeo de Derechos Humanos, tratado internacional que ha dado pie a la organización regional de mayor efectividad para la protección de los derechos humanos, el Consejo de Europa.

Tan sólo dos años después de la DUDH, el carácter programático o moral de esta Declaración llevó a plantearse la necesidad de crear mecanismos internacionales dotados de garantías más efectivas de los derechos. De esta pretensión nacerá el Convenio Europeo para la Protección de los Derechos Humanos y Libertades Fundamentales ${ }^{39}$, más conocido como Convenio de Roma, por la ciudad donde fue firmado el 4 de noviembre de 1950, y que entraría en vigor el 3 de septiembre de 1953.

El título I del Convenio Europeo de Derechos Humanos (en adelante CEDH), establece un elenco de derechos inspirado en la Declaración Universal de los Derechos Humanos. Y si bien durante los trabajos preparatorios del Convenio Europeo se planteó la remisión a los derechos tal y como

34 Convención sobre los Derechos del Niño, adoptada y abierta a la firma y ratificación por la Asamblea General en su resolución 44/25, de 20 de noviembre de 1989. Su entrada en vigor se produjo el 2 de septiembre de 1990.

35 Apartado primero del artículo 8 de la Convención sobre los Derechos del Niño.

36 Artículo 8.2 de la Convención sobre los Derechos del Niño.

37 Artículo 9.1 de la Convención sobre los Derechos del Niño.

38 Apartado primero del arículo 10 de la Convención sobre los Derechos del Niño.

39 El Estado Español no lo ratifica sino hasta el 26 de septiembre de 1979 (BOE del 10 de octubre de 1979), justo después de que finalizara la dictadura franquista y precisamente como parte de los esfuerzos por transitar a un sistema democrático basado en la concepción de los derechos humanos como fundamento y fin del Estado. 
estaban reconocidos en la Declaración Universal de la ONU, finalmente se optó por redactarlos de forma autónoma por ser ello más conforme con la naturaleza de un tratado internacional y, como tal, generador de efectos jurídicos vinculantes ${ }^{40}$.

El sistema regional de protección de derechos humanos instaurado por el Consejo de Europa presentó desde el principio características singulares que otorgan al mismo una naturaleza especial o sui generis dentro del sistema internacional de protección de derechos. Entre dichas características destacan las siguientes:

1. El establecimiento por primera vez de un mecanismo de protección jurisdiccional supranacional que no operaba exclusivamente en el ámbito interestatal, sino que admitía las reclamaciones de particulares contra las violaciones de los derechos consagrados en el Convenio ${ }^{41}$. El Tribunal Europeo de Derechos Humanos — en adelante TEDH - se situaba a la cabeza del sistema, encargándose de la interpretación y aplicación del Convenio Europeo de Derechos Humanos. Este órgano tendría competencia para entender de los casos de violación de los derechos garantizados en el CEDH y, a tal fin, la potestad de adoptar decisiones vinculantes para los Estados parte respecto al cumplimiento de las obligaciones asumidas por éstos en el Convenio.

Por lo que respecta al entramado institucional originario con competencias jurisdiccionales, el mecanismo de garantía se completaba con la Comisión Europea de Derechos Humanos, órgano competente para realizar el examen de admisibilidad de las demandas incoadas. Sin embargo, la reforma estructural llevada a cabo por el Protocolo Adicional № 11 al Convenio de Roma, cuya entrada en vigor tuvo lugar el 1 de noviembre de 1998, suprimió la Comisión Europea, reforzando con ello las competencias del Tribunal Europeo, convertido a partir del citado Protocolo en órgano de carácter permanente y de jurisdicción obligatoria ${ }^{42}$. Tras su entrada en vigor, los recursos formulados por particulares acceden directamente al TEDH, "culminando el proceso de acercamiento del individuo al TEDH ${ }^{43}$ ".

2. La legitimación activa ante el TEDH corresponde tanto a los Estados parte del Consejo de Europa (art. $33 \mathrm{CEDH}$ ), como a los particulares que se hallen sometidos a la jurisdicción de éstos (art. $34 \mathrm{CEDH}$ ), y en las mismas condiciones que los Estados ${ }^{44}$ (artículo $1 \mathrm{CEDH}$ ). Esta amplia legitimación no se circunscribe únicamente a los nacionales de los Estados parte, sino a toda persona, cualquiera que fuese su nacionalidad o incluso si carecía de ella, con el único requisito de que la misma se encuentre bajo la jurisdicción del Estado parte demandado ${ }^{45}$. Esta

40 CARRILlO SALCEDO, Juan Antonio. El Convenio Europeo de Derechos Humanos. Madrid, Tecnos, 2004, $1^{\text {a }}$ edic., reimp. p. 19.

41 El antiguo artículo 25 del CEDH, modificado por el Protocolo $\mathrm{N}^{\circ} .11$, tras cuya entrada en vigor ha pasado a constituir el actual artículo 34, disponía que: "la Comisión podrá conocer de cualquier demanda dirigida al Secretario general del Consejo de Europa por cualquier persona física, organización no gubernamental o grupo de particulares, que se considere víctima de una violación, por una de las Altas Partes Contratantes, de los derechos reconocidos en el presente Convenio, en el caso de que la Alta Parte Contratante acusada haya declarado reconocer la competencia de la Comisión en esta materia. Las Altas Partes Contratantes que hayan suscrito tal declaración se comprometen a no poner traba alguna al ejercicio eficaz de este derecho".

42 Ídem, p. 46.

43 ARRIAGA IRABURU, Inés. El derecho a la vida familiar de los extranjeros en la jurisprudencia de Estrasburgo. Pamplona, Eunsa, $1^{\text {a }}$ ed., junio de 2003. p. 14.

44 Ídem, p. 46.

45 QUERALT JIMÉNEZ, Argelia. La interpretación de los derechos: del Tribunal de Estrasburgo al Tribunal Constitucional. Madrid, CEPC, 2008, p. 89, por ello la mencionada autora destaca como uno de los elementos configuradores del sistema de protección establecido por el CEDH lo innecesario del vínculo de nacionalidad entre el Estado demandado y el particular afectado por la vulneración del derecho convencional. 
característica otorga al CEDH una dimensión universa ${ }^{46}$ con profundas implicaciones en el alcance de las obligaciones asumidas por las Altas Partes Contratantes del $\mathrm{CEDH}^{47}$.

3. El sistema del CEDH no está basado en el principio de reciprocidad, característica que lo diferencia de los tratados internacionales clásicos. El propio Tribunal ha señalado que "la Convención comprende mucho más que meros acuerdos recíprocos entre los Estados contratantes. Además de una red de compromisos mutuos y bilaterales, crea obligaciones objetivas que, en palabras del Preámbulo, disfrutan de una garantía colectiva (...) la Convención permite a los Estados partes requerir la observancia de dichas obligaciones sin tener que justificar un interés preciso y directo, por ejemplo, del hecho de que una medida de la que se quejan ha perjudicado a alguno de sus propios nacionales" Los beneficiarios de las obligaciones asumidas por los Estados partes son las personas físicas y jurídicas dependientes de su jurisdicción ${ }^{49}$, no los propios Estados miembros.

4. El Convenio opera, como establece su Preámbulo, entre "Estados europeos animados de un mismo espíritu y en posesión de un patrimonio común de ideales y de tradiciones políticas, de respeto a la libertad y de preeminencia del Derecho". Ello sugiere que, pese a las diferencias existentes entre los Estados miembros, existe una comunidad de valores compartidos que ha propiciado el surgimiento, - gracias a la obra interpretativa del TEDH—, de un orden público europeo de los derechos humanos ${ }^{50}$. De hecho, en la jurisprudencia del TEDH late una clara vocación armonizadora del sistema europeo de garantías de los derechos fundamentales ${ }^{51}$.

5. El sistema previsto por el CEDH reviste carácter subsidiario, lo que supone que el Derecho interno de los Estados parte sigue constituyendo la vía primera y principal de protección de los derechos y libertades fundamentales. El mecanismo del Convenio de Roma "tiene por función añadirse y superponerse a éste, completarlos si es preciso, remediar llegado el caso sus lagunas, carencias o flaquezas ${ }^{52 "}$.

6. El entramado institucional de carácter jurisdiccional previsto para la interpretación y aplicación del CEDH, convertía al TEDH en un órgano que, al tiempo que tutelaba los derechos previstos en el Convenio resolviendo conflictos en casos particulares que enfrentaban a los Estados partes entre sí o bien a particulares con un Estado parte, desarrollaba una función de desarrollo de los preceptos convencionales mediante su interpretación judicial ${ }^{53}$, reconocida expresamente por

46 ARRIAGA IRABURU, I. El derecho a la vida familiar de los extranjeros..., op. cit., p. 21.

47 En este sentido, la Comisión Europea de Derechos Humanos, en el caso Pfunders/Fundres, de 11 de enero de 1961 afirmaba que cuando un Estado decide obligarse por esta Convención, "reconoce, pues, los derechos y las libertades definidos en el Título I a toda persona dependiente de su jurisdicción, cualquiera que sea su nacionalidad o su estado; que, en resumen, reconoce esos derechos y libertades no solamente a sus propios nacionales y a los de los Estados partes sino incluso a los nacionales de los Estados no partes en la Convención y a los apátridas” (Causa 788/60), Austria/ Italia, Recueil des Décisions de la Comisión Européenne des Droits de l'Homme, Estrasburgo 1962, pp. 41-42). Citado por CHUECA SANCHO, Ángel G. La expulsión de extranjeros en la Convención Europea de Derechos Humanos. Egido Editorial, Zaragoza, 1998. p. 28.

48 Caso interestatal Irlanda contra Reino Unido de Gran Bretaña, sentencia de 18 de enero de 1978. Párrafo 239.

49 CARRILlO SAlCEDO, Juan Antonio. El Convenio Europeo de Derechos Humanos, op. cit., pp. 46.

50 CARRILlO SAlCEDO, Antonio. El Convenio Europeo de Derechos Humanos. Madrid, Tecnos, 2004, 1ª edic., reimp. p. 22.

51 La función armonizadora del nivel de garantías de los derechos es considerada por QUERALT JIMÉNEZ como una de las vías en las que, junto al desarrollo del $\mathrm{CEDH}$, se despliega la doble función jurisprudencial realizada por el TEDH. La interpretación de los derechos: del Tribunal de Estrasburgo al Tribunal Constitucional, op. cit., pp. 86 y 97.

52 EISSEN, Marc-André. El Tribunal Europeo de Derechos Humanos. Madrid, Civitas, 1ª ed., 1985. p. 82.

53 QUERALT JIMÉNEZ, sobre la base de la propia jurisprudencia del TEDH, subraya la doble función desempeñada por este tribunal: una función reactiva o de tutela de los derechos convencionales junto con una función de desarrollo del CEDH, que frecuentemente se realiza de forma combinada. La interpretación de los derechos: del Tribunal de Estrasburgo al Tribunal Constitucional, op. cit., pp. 86-88. 
el propio Tribunal de Estrasburgo ${ }^{54}$. La jurisprudencia emanada del TEDH en la interpretación de los preceptos convencionales constituye, junto con el propio $\mathrm{CEDH}$, fuente del derecho convencional de consulta inexcusable para conocer tanto el alcance de los preceptos y derechos consagrados en dicho Convenio ${ }^{55}$ como de las obligaciones convencionales que vinculan a los Estados miembros ${ }^{56}$.

El Convenio de Roma como mecanismo de protección de derechos humanos fue concebido desde su origen como un sistema dinámico y progresivo - como afirma el propio Preámbulo del CEDH. De este modo, sucesivos Protocolos adicionales, en número de catorce hasta la actualidad, han ido ampliando y perfeccionando el catálogo de derechos o bien modificado aspectos organizativos y estructurales del sistema. Como sugieren ciertos autores, el paso del tiempo y la labor realizada por el TEDH han sedimentado la naturaleza cuasi-constitucional del sistema de garantías rebasando así la naturaleza convencional original, hasta el punto de que el TEDH tiende en la actualidad a aproximarse a un Tribunal Constitucional Europeo ${ }^{57}$.

La consolidación de los rasgos apuntados, ha convertido al complejo mecanismo institucional creado en el marco del Consejo de Europa en el sistema internacional de protección de los derechos humanos más evolucionado y eficaz ${ }^{58}$ de los existentes hasta el momento.

En el sistema regional europeo, las referencias a la protección de la familia contenidas en el CEDH no están unificadas, sino que aparecen en dos disposiciones diferentes: de un lado, en el artículo $8^{59}$, que consagra el derecho al respeto de la vida privada y familiar y, de otro, en el artículo $12^{60}$, donde se reconoce el derecho a contraer matrimonio y a fundar una familia. Si embargo, es el artículo 8 el que otorga una protección más amplia y genérica a la estructura familiar ${ }^{61}$, sin vincularla

54 Sentencia caso Irlanda contra Reino Unido de 1978, párr. 154.

55 En este sentido Saiz Arnaiz ha señalado que "el Convenio se manifiesta como fuente del Derecho no sólo desde su texto escrito sino, de manera incluso más intensa, también desde la doctrina jurisprudencial emanada, en particular, del Tribunal de Estrasburgo, de modo que el estudioso o el aplicador del Derecho no puede prescindir de este segundo elemento, al que bien podríamos catalogar como parte del acquis conventionnel, para conocer los contenidos de los derechos enunciados en aquel Convenio". SAIZ ARNAIZ, Alejandro. La apertura constitucional al derecho internacional y europeo de los derechos humanos. El artículo 10.2 de la Constitución Española, op. cit., p. 138.

56 QUERALT JIMÉNEZ, A. La interpretación de los derechos..., op. cit., p. 88.

57 Entre, otros, SÁNCHEZ LEGIDO, Ángel. La reforma del mecanismo de protección del CEDH. Madrid, Colex, 1995. p. 97. En la misma línea, SAIZ ARNAIZ afirma que el TEDH “asume (...) en la práctica, el papel de una especie de TC que fiscaliza la actividad de los poderes públicos estatales en su sometimiento al Convenio". La apertura constitucional al derecho internacional y europeo..., op. cit., p. 144. LASAGABASTER HERRARTE, Iñaki (dir.). Convenio Europeo de Derechos Humanos. Comentario sistemático. Madrid, Thomson-Civitas, 2004, p. 24.

58 PASTOR PALOMAR, Antonio. "El Sistema Europeo: el Consejo de Europa"; en FERNÁNDEZ DE CASADEVANTE ROMANI, Carlos (coord.). Derecho Internacional de los Derechos Humanos. Madrid, Editorial Dilex, S.L., 2000. p. 130.

59 El artículo 8 del Convenio de Roma reconoce que: "1. Toda persona tiene derecho al respeto de su vida privada y familiar, de su domicilio y de su correspondencia. 2. № podrá haber injerencia de la autoridad pública en el ejercicio de este derecho, sino en tanto en cuanto esta injerencia esté prevista por la ley y constituya una medida que, en una sociedad democrática, sea necesaria para la seguridad nacional, la seguridad pública, el bienestar económico del país, la defensa del orden y la prevención del delito, la protección de la salud o de la moral, o la protección de los derechos y las libertades de los demás".

60 Por su parte, el artículo 12 consagra el derecho a contraer matrimonio, con la siguiente formulación literal: "A partir de la edad núbil, el hombre y la mujer tienen derecho a casarse y a fundar una familia según las leyes nacionales que rijan el ejercicio de este derecho".

61 En este sentido Heather SWINDELLS señala que "el principal artículo del CEDH que directamente afecta a la familia es el artículo 8 y este artículo tendrá una influencia fundamental sobre el derecho de familia”. SWINDELLS, Heather. The European Convention on Human Rights and its Impact on Family; en Speakers Presentations to the 2001 World Congress on Family Law and the Rights of Children and Youth, p. 1. Disponible en: www.lawrights.asn.au/ docs/swindells2001.pdf 
a la existencia de un matrimonio previo ni a la fundación de una familia, de ahí que haya sido esta disposición la que con el tiempo se haya revelado más eficaz. Junto a estos dos artículos mencionados, el CEDH incluía otra disposición destinada a prohibir la tortura, la pena y los tratos inhumanos o degradantes - el artículo $3^{62}$ - que terminaría adquiriendo una gran importancia en el ámbito de la inmigración y la extranjería, a fin de otorgar protección a aquellas personas cuya expulsión de un determinado Estado parte conllevase el riesgo de sufrir tales padecimientos en un país tercero.

$\mathrm{Al}$ igual que ocurría con la DUDH y el PIDCP, el CEDH no surgió con preocupaciones migratorias ni la protección de la familia se vinculaba originalmente a la migración internacional. Sería la actuación de sus órganos de aplicación e interpretación, tanto la ya extinta Comisión Europea de Derechos Humanos como el TEDH, quienes ostenten el mérito de amparar expresamente las situaciones surgidas de la colisión entre la protección de la unidad familiar y los controles desplegados por los Estados parte en el ámbito de las políticas migratorias internas, en el seno del derecho a la vida familiar reconocido por el artículo $8 \mathrm{CEDH}$. En base a esta disposición, los órganos encargados de su interpretación y aplicación han logrado trascender sus principios generales para extraer una protección específica de la familia en el contexto de la migración internacional ${ }^{63}$, en dos situaciones específicas: protección frente a las expulsiones y tutela de la reagrupación familiar —al estudio de éstas últimas dedicaremos el presente capítulo-.

En el mismo ámbito del Consejo de Europa, otro tratado internacional vendría a subsanar la escasez de derechos de contenido económico y social detectable en el Convenio de Roma. Se trata de la Carta Social Europea, firmada en Turín, el 18 de octubre de 1961. En ella se contempla tanto la protección con carácter general de la familia, como la protección específica de las familias de los trabajadores migrantes. Su artículo $16^{64}$, inspirándose en el artículo correlativo de la DUDH y partiendo de la misma consideración de la familia como "célula fundamental de la sociedad", consagra su protección social, jurídica y económica, comprometiendo a los Estados parte a su fomento. Adicionalmente, en el artículo 19 se proclama el derecho de los trabajadores migrantes y sus familias a la protección y asistencia, para cuya garantía los Estados parte se comprometen a "facilitar en lo posible el reagrupamiento de la familia del trabajador extranjero a quien se le haya autorizado para establecerse dentro del territorio" ${ }^{65}$. A estos efectos, por familia del trabajador extranjero se entiende, al menos, la esposa y los hijos a cargo cuya edad no supere los 21 años ${ }^{66}$. Sin embargo, en el contexto de la Carta Social Europea, las mayores limitaciones para la eficacia del derecho a la RF provienen del hecho de que sus disposiciones se aplican sobre la base del principio de reciprocidad, lo que supone la exclusión de la tutela de los extranjeros procedentes de terceros países asentados en territorio europeo.

Dentro del Consejo de Europa, el Convenio Europeo relativo al estatus jurídico de los trabajadores migrantes, de 24 de noviembre de 1977, en su artículo $12^{67}$, contiene una regulación expresa del

62 El artículo $3 \mathrm{CEDH}$ consagra la prohibición de la tortura, señalando literalmente que "nadie podrá ser sometido a torturas ni a penas o tratos inhumanos o degradantes".

63 BATTISTEllA, G. "Family Reunification”, op. cit., p. 235; PLENDER, R. International Migration Law, op. cit., p. 366.

64 El Artículo 16 de la Carta Social Europea establece que "con miras a lograr las condiciones de vida indispensables para un pleno desarrollo de la familia, célula fundamental de la sociedad, las partes contratantes se comprometen a fomentar la protección económica, jurídica y social de la familia, especialmente mediante prestaciones sociales y familiares, disposiciones fiscales, apoyo a la construcción de viviendas adaptadas a las necesidades de las familias, ayudas a los recién casados o por medio de cualesquiera otras medidas adecuadas".

65 Apartado sexto del artículo 19 de la Carta Social Europea.

66 Anexo, Parte II del Artículo 19, apartado sexto de la Carta Social Europea.

67 Dicha disposición proclama que: "El cónyuge del trabajador migrante, empleado legalmente en el territorio de una 
derecho a la RF. La reagrupación se reconoce a favor del cónyuge del trabajador migrante y de sus hijos no casados menores de edad, estando supeditada al empleo legal del residente extranjero en el territorio de una parte Contratante, a la disposición de una vivienda considerada normal para los trabajadores nacionales empleados en la misma región, estableciéndose la posibilidad adicional de imposición de un plazo de espera previo que no podrá exceder los 12 meses.

En el ámbito de la ONU, existen tratados internacionales que consagran expresamente el derecho a la reagrupación familiar. Destaca, en este sentido, la Convención Internacional sobre la protección de los derechos de todos los trabajadores migrantes y de los miembros de sus familias ${ }^{68}$, adoptada mediante Resolución General de la Asamblea General en diciembre de 1990. Su artículo 44 parte del derecho a la protección social de la familia, en tanto que grupo básico natural y fundamental de la sociedad. El apartado segundo de esta misma disposición contiene un reconocimiento expreso de la RF, si bien su formulación diluye la vinculatoriedad jurídica de la obligación correspondiente, al señalar que "los Estados Partes tomarán las medidas que estimen apropiadas y entren en la esfera de su competencia para facilitar la reunión de los trabajadores migratorios con sus cónyuges o con aquellas personas que mantengan con el trabajador migratorio una relación que, de conformidad con el derecho aplicable, produzca efectos equivalentes al matrimonio, al igual que con sus hijos solteros menores de edad que estén a su cargo"69.

Dentro de la Organización Internacional del Trabajo, cabría mencionar el Convenio 143 sobre las migraciones en condiciones abusivas y la promoción de la igualdad de oportunidades y de trato de los trabajadores migrantes ${ }^{70}$, de 1975. El artículo 13.1 de este Convenio señala en tono potestativo que "todo Miembro podrá adoptar todas las medidas necesarias, que dependan de su propia competencia, y colaborar con otros Miembros a fin de facilitar la reunión de familias de todos los trabajadores

Parte Contratante, y sus hijos no casados, mientras se les considere como menores por la legislación pertinente del Estado de acogida, y que dependan del trabajador migrante, están autorizados, en condiciones análogas a las estipuladas en el Convenio para la admisión por la legislación o por acuerdos internacionales, a unirse con el trabajador migrante en el territorio de una Parte Contratante, siempre que éste disponga para su familia de una vivienda considerada como normal para los trabajadores nacionales en la región donde esté empleado. Cada Parte Contratante podrá supeditar la autorización mencionada a un plazo de espera que no podrá exceder de 12 meses. 2. Cada Estado puede, en cualquier momento, en una declaración dirigida al Secretario General del Consejo de Europa que tendrá efecto un mes después de su recepción, supeditar, además, la reagrupación familiar mencionada en el párrafo 1 a la condición de que el trabajador migrante disponga de recursos estables suficientes para subvenir a las necesidades de su familia. 3. Cada Estado puede, en todo momento, en una declaración dirigida al Secretario General del Consejo de Europa, que tendrá efecto un mes después de su recepción, derogar temporalmente la obligación de conceder la autorización prevista en el párrafo 1 en una o varias partes de su territorio que designará en su declaración, siempre y cuando estas medidas no estén en contradicción con las obligaciones que se desprendan de otros instrumentos internacionales. En la declaración se indicarán los motivos particulares que justifiquen la derogación por la que se refiere a la capacidad de acogida. El Estado que recurra a esta facultad de derogación informará plenamente al Secretario General del Consejo de Europa de las medidas tomadas y velará para que sean publicadas en el plazo más breve posible. Deberá informar, asimismo, al Secretario General de la fecha en que estas medidas pierdan validez y entren de nuevo en vigor las disposiciones del Convenio. La declaración no afectará, en general, a las peticiones de reagrupación familiar sometidas a las autoridades competentes, antes de que la declaración sea dirigida al Secretario General, por trabajadores migrantes ya establecidos en la parte del territorio referida".

68 Adoptada por la Asamblea General de las Naciones Unidas, mediante Resolución 45/158, de 18 de diciembre de 1990.

69 El párrafo transcrito corresponde al apartado segundo del art. 44 de la citada Convención. El apartado tercero del artículo 44 de la Convención Internacional sobre la protección de los derechos de todos los trabajadores migrantes y de los miembros de sus familias, señala literalmente que "los Estados de empleo, por razones humanitarias, considerarán favorablemente conceder un trato igual al previsto en el párrafo 2 del presente artículo a otros familiares de los trabajadores migratorios".

70 Adoptado por la Conferencia General de la OIT el 23 de junio de 1975. 
migrantes que residan legalmente en su territorio". El apartado segundo circunscribe dicha reunión al cónyuge del trabajador migrante y, en la medida en que estén a su cargo, a los hijos, al padre y a la madre del migrante. En el seno de la OIT, destaca asimismo la Recomendación 151 relativa a los trabajadores migrantes ${ }^{71}$, de 1975, cuyo artículo 13 insta a los gobiernos de los países de empleo y de origen a adoptar todas las medidas posibles para facilitar la reunión de los trabajadores migrantes con sus familias lo más rápidamente posible y, a tal efecto, entiende por familia el cónyuge y, en la medida en que estén a su cargo, también los hijos — sin límite de edad—, el padre y la madre del trabajador migrante ${ }^{72}$.

En el DIDU es posible pues encontrar un nutrido cuerpo de instrumentos internacionales de consistencia normativa muy variable - recomendaciones, declaraciones, tratados - relacionados con la RF. La característica común a todos estos instrumentos internacionales es que, otorgando todos ellos protección a la institución familiar con diversas formulaciones, sin embargo, ninguno ofrece una definición de familia. Esta materia queda reservada a las legislaciones estatales, que cuentan para su definición con un considerable margen de apreciación, "de forma tal que su consideración variará atendiendo a la discrecionalidad del legislador"73. De otro lado, en materia específica de RF, casi todos estos instrumentos concurren en otra característica muy notable: la falta de proclamación expresa del derecho, circunstancia que determina que del principio de unidad familiar no quepa deducir sin más, un derecho correlativo a la RF de idéntica densidad normativa ${ }^{74}$. Y, en las ocasiones excepcionales en que la RF se nombra expresamente, los documentos internacionales coinciden en una redacción laxa ${ }^{75}$ que remarca su escasa vinculatoriedad jurídica.

71 Adoptada en Ginebra por la Conferencia General de la OIT el 24 de junio de 1975.

72 El artículo 13 de la Recomendación 151 relativa a los trabajadores migrantes, afirma que “1). Los gobiernos de los países de empleo y de los países de origen deberían adoptar todas las medidas posibles para facilitar la reunión de los trabajadores migrantes con sus familias lo más rápidamente posible. Esas medidas deberían incluir la legislación y los acuerdos bilaterales o multilaterales necesarios. 2) Antes de tal reunión, será menester que el trabajador pueda ofrecer a su familia un alojamiento adecuado, que responda a los criterios normalmente aplicables a los trabajadores nacionales del país de empleo". Por su parte, el artículo 15 contiene la definición concreta de familia a efectos de aplicación de la presente Recomendación.

73 ARRESE IRIONDO; Ma Nieves, Multiculturalidad y vida familiar en la jurisprudencia del Tribunal Europeo de Derechos Humanos: La reagrupación familiar; en LASAGABASTER, Iñaki (coord.). Multiculturalidad y laicidad: A propósito del Informe Stasi. Herrarte, 2004, p. 198. En el mismo sentido, Fernández Sánchez, quien va más allá, afirmando que el margen de apreciación del que disponen los Estados, junto a la "ausencia casi total de previsiones jurídicas respecto a la unidad familiar" en el ámbito internacional, "pueden llevar, incluso, de la apreciación a la propia negación del derecho". FERNÁNDEZ SÁNCHEZ, P. A. “El derecho de reagrupación familiar de los extranjeros”, op. cit., p. 375.

$74 \mathrm{Al}$ respecto, PERRUCHOUD estima que existe un salto cualitativo entre la RF y los principios internacionales en los que se basa, "a scale of values has to be established and respected between a fundamental principle and a mere means of implementation. The principles of family unity and of the free movement of persons are recognized, but their modalities of implementation with regard to family reunification are left to the competence of the individual States". PERRUCHOUD, R. "Family Reunification"; International Migration, op. cit., p. 512. En contra, CHOLEWINSKI califica la RF como un derecho humano fundamental, derivado de la unidad familiar, señalando que "consequently, to move from the protection of the family unit provided by International human rights treaty law to the recognition of a right to family reunification in the immigration field is not such a significant step to take. Nevertheless, no International human rights instrument has taken this step in explicit terms". "Family Reunification and Conditions Placed on Family Members...., op. cit., p. 275.

75 En esta línea, LAHAV ha destacado que las múltiples cláusulas de derecho internacional general de las que se podría derivar la protección internacional del derecho a la RF se hallan todas ellas sin excepción "débilmente enunciadas", limitándose a enunciar el derecho, pero dejando en manos de los Estados parte tomar libremente las medidas que considere necesarias para facilitar la vida familiar de los extranjeros. En consecuencia, la autora concluye que "a pesar de las convenciones internacionales, el Estado retiene un alto grado de soberanía y discreción en términos de formulación de las condiciones impuestas sobre las diferentes categorías de migrantes y refugiados". "Family-related Migration..., op. cit., p. 253. 
En consecuencia, si bien las bases jurídicas para el derecho a la RF están sólidamente asentadas en el ámbito internacional - e incluso ya se ha señalado la existencia de una "codificación parcial de los derechos a la RF en el derecho internacional"76 - en principio no cabría deducir una protección internacional sino deficitaria, en vista de que o bien no estamos ante un derecho expreso, o bien, cuando su reconocimiento está explícitamente formulado, la redacción potestativa y/o la falta de mecanismos de ejecución han determinado que su cumplimiento quede diferido a la buena disposición que manifiesten los Estados miembros ${ }^{77}$.

En definitiva, el reconocimiento de la RF a nivel internacional no se ha formulado como un auténtico derecho subjetivo que genere correlativas obligaciones jurídicas de admisión de la familia inmigrante para el Estado receptor. A lo sumo, podría hablarse de la existencia de una recomendación o de un fuerte imperativo moral internacional que actúan como condicionantes estatales, impeliendo a los Estados a facilitar en lo posible la RF de los extranjeros asentados en sus respectivos territorios ${ }^{78} \mathrm{o}$, más modestamente, impulsándoles a minimizar la incidencia estatal sobre su vida familiar. En palabras de Lahav, pese a que múltiples normas internacionales promueven la desiderabilidad de la $\mathrm{RF}^{79}$, no es posible extraer una vinculatoriedad que exija incorporar este principio en las políticas migratorias internas de los Estados, traducible en un correlativo derecho subjetivo para los inmigrantes. En una línea similar, Delaet ${ }^{80}$, tras examinar el régimen internacional, ha señalado que los Estados Nacionales retienen la capacidad de determinar los criterios de admisión de los familiares del extranjero residente en su territorio, configurando el concepto de familia aplicable así

76 STAVER, Anne. “Family Reunification: A Right for Forced Migrants?” Working Paper Series N. 51. Refugee Studies Centre, Oxford Department of International Development, University of Oxford, November 2008, p. 14.

77 Si bien conviene precisar que tales características no son privativas de la RF a nivel internacional, siendo, por el contrario, predicables del sistema de obligaciones internacionales derivadas para los Estados del DIDH. En palabras de Elisa Pérez Vera, "el Derecho internacional no ha logrado todavía plasmar en normas jurídicas obligatorias ese postulado de la igualdad entre los seres humanos que impulsa su desarrollo (...) de ahí tambien que las obligaciones internacionales impuestas al Estado por esta vía se configuren como simples condicionamientos que el legislador estatal debe tener en cuenta al fijar, en el ámbito de sus competencias, el régimen jurídico de los extranjeros". Pese a ello, a juicio de esta misma autora, la generalidad e imprecisión de las obligaciones internacionales que recaen sobre los Estados, se ve compensada con su posible invocación universal, tanto en lo que respecta a los beneficiarios del DIDH — todos los seres humanos, con independencia de su nacionalidad, e incluso aun cuando carezcan de ella-, como respecto de sus destinatarios — todos los sujetos del Derecho internacional, pero especialmente todos los Estados-. PÉREZ VERA, E. “Articulo 13. Extranjería”; en ALZAGA VILLAAMIL, Oscar. Comentarios a la Constitución Española de 1978. Tomo II. Madrid, Cortes Generales, Edersa, 1996, pp. 186 y 187.

78 En el mismo sentido, Azci ha señalado que "although there is no International document which guarantees the universal right of family reunification for migrants, existing documents establish moral standards to recognise migrant' rights to be joined by their families". AZCI, Gamze. "Immigrant Categories.., op, cit. pp. 203-204. Igualmente, BATTISTELLA afirma que sólo puede hablarse de la existencia de una recomendación de la que no es posible deducir una obligación jurídicamente exigible a los Estados. Battistella pone como ejemplo, junto a los documentos ya destacados en este espígrafe, el Acta final de Helsinki que sirvió de punto de partida la Organización para la Seguridad y la Cooperación en Europa (OSCE), donde se contienen disposiciones expresas relativas a la RF, pero su redacción no es imperativa. "Family Reunifcation", op. cit., p. 235.

79 Para LAHAV "the guiding principles of the liberal International order that emerged in the post-World War II period have secured the role of the State in defining and protecting its interests. The International system has granted states a considerable degree of latitude in navigating their migration interest. While International law has established a strong humanistic and moral basis for countries to allow family migration, International instruments have failed to appropriate the state's right and to establish as yet a universal right to family reunification, whether of citizens or foreigners. States retain strong rights that stem not only from the predominance of the sovereignty principie but also from legal ambiguity and from conditionality on states, which have varying territorial jurisdictions, definitions, and interests". LAHAV, Gallya. "International versus National Constraints in Family Reunification Migration Policies", op. cit., p. 354.

80 DELAET, Debra. U.S. Immigration Policy in an Age of Rithts, op. cit., p. 14. 
como los concretos miembros que serán elegibles a efectos de la reagrupación, conservando con ello un elevado margen de apreciación para afrontar libremente estas cuestiones.

En este sentido, un Informe de la Organización Internacional del Trabajo señalaba a finales del siglo XX que los Estados "no están obligados por ninguna disposición del derecho internacional a garantizar la reunificación familiar" ${ }^{\prime 1}$. Y en el año 2005, la ONU reconocía también que pese a la protección extensiva que tanto los instrumentos regionales como universales otorgan a la familia, "el reconocimiento de un específico derecho a la RF parece estar en una especie de limbo jurídico entre el deber estatal de reconocer y respetar los derechos humanos de todos los individuos situados dentro de su territorio vis-á-vis al derecho de los Estados a determinar libremente - dentro de ciertos límites- sus leyes migratorias y las políticas de control fronterizo"82.

La excepción a esta situación generalizada la representa el escenario europeo, en un doble sentido: de un lado, la UE, donde recientemente la RF de los extranjeros ha ascendido, por primera vez en el ámbito internacional, al estatus de derecho subjetivo; y, de otro, en el ámbito geográficamente más extenso del Consejo de Europa, donde la protección ofrecida por el TEDH ha logrado imponer límites crecientes sobre el poder discrecional de los Estados para determinar las admisiones de familiares de extranjeros en su territorio.

Con todo, en el ámbito del derecho internacional, aun en los supuestos de mayor protección regional — como es el caso de la UE y el Consejo de Europa-, sólo cabría concluir la existencia de un todavía muy precario, limitado y condicionado derecho subjetivo a la RF, sometido a un amplísimo margen de apreciación estatal.

\section{EL ARTÍCULO 8 DEL CONVENIO EUROPEO: DIFICULTADES Y POSIBILIDADES INTERPRETATIVAS INHERENTES A SU ESTRUCTURA Y CONTENIDO}

\section{1 La vida familiar como norma de principio}

Ya señalamos que, en el ámbito del Consejo de Europa, la protección de la RF de los extranjeros había sido canalizada mediante su encaje convencional en el derecho al respeto de la vida familiar, reconocido en el art. $8 \mathrm{CEDH}^{83}$. Esta norma no consagra expresamente un derecho a la RF, de modo tal que la temprana pero limitada protección de la RF en el seno del Consejo de Europa constituiría una construcción jurisprudencial pionera, debida a la labor conjunta del TEDH y de la extinta Comisión. Ambas instituciones, apoyándose en el carácter constitucional que la protección de la fami-

81 ILO Committee of Experts Report on Migrant Workers, 87th Session, Migrant Workers, Report III (1B), Geneve, June 1999, apartado 473.

82 "Family Reunification". Office of United Nations High Commissioner for Human Rights. November 2005, traducción propia. Disponible en http://www2.ohchr.org/english/issues/migration/taskforce/docs/familyreunification.pdf

83 El artículo 8 del Convenio de Roma establece literalmente: "1. Toda persona tiene derecho al respeto de su vida privada y familiar, de su domicilio y de su correspondencia. 2. No podrá haber injerencia de la autoridad pública en el ejercicio de este derecho, sino en tanto en cuanto esta injerencia esté prevista por la ley y constituya una medida que, en una sociedad democrática, sea necesaria para la seguridad nacional, la seguridad pública, el bienestar económico del país, la defensa del orden y la prevención del delito, la protección de la salud o de la moral, o la protección de los derechos y libertades de los demás". 
lia gozaba dentro de los Estados partes - y las prácticas judiciales internas de algunos de ellos ${ }^{84}$-, recurrieron al derecho al respeto de la vida familiar proclamado por el art. $8 \mathrm{CEDH}$ para proteger, en determinados supuestos, a la familia de los extranjeros. Esta forma de proceder sería posteriormente asimilada tanto por los poderes judiciales nacionales, como por las propias instituciones de la Unión Europa.

Sin embargo, la construcción del derecho a la RF de los extranjeros en el Consejo de Europa ha tenido que acometer importantes retos jurídicos por la complejidad de la norma convencional a la que fue anclada, empezando por el hecho de que tal disposición constituye una norma con estructura de principio. Pero además de las dificultades que en sí misma comporta una norma de principio, concurren tanto en el apartado primero como en el segundo de este mismo artículo 8 CEDH otras muchas variables añadidas - que iremos identificando a lo largo de este apartado- que, al tiempo que fomentan aún más los escollos interpretativos de este precepto, se convierten paradójicamente en el sustrato para la aplicación de una fértil jurisprudencia creativa por parte de los órganos de interpretación del Convenio de Roma. No en vano, la protección del medio ambiente, concebido en sentido amplio - tutela frente a ruidos, emanaciones u olores molestos y/o nocivos que interfieren en la vida privada y el domicilio - ha sido también derivada del artículo $8 \mathrm{CEDH}$. Trataremos de identificar los elementos distintivos de esta norma que han propiciado esta situación.

Siguiendo la doctrina elaborada por Ronald Dworkin en Norteamérica y Robert Alexy ${ }^{85}$ en Europa, en el derecho existen normas con estructura de reglas y normas con estructura de principios. Ambas tienen en común que se dirigen a indicar qué obligación jurídica corresponde a una cuestión concreta al aplicar el derecho a un caso particular, pero difieren en la forma en que orientan al operador jurídico en cómo deben hacer esta operación ${ }^{86}$.

Las normas con estructura de reglas se distinguen porque presentan una "disyuntiva" al operador jurídico, es decir, ofrecen una alternativa entre dos situaciones o intereses o, en palabras de DiezPicazo $^{87}$, las reglas responden a la estructura dual tradicional de las normas jurídicas, constituidas por un supuesto de hecho y una consecuencia jurídica. Éstas se aplican en términos de sí o no, ya que si se produce un hecho en la realidad que encaje en el supuesto de hecho de la norma jurídica, se le debe aplicar la consecuencia jurídica prevista ${ }^{88}$. Las normas con estructura de reglas se caracterizan por su mayor grado de concreción, por lo que, aunque no están exentas de dificultades ${ }^{89}$, en princi-

84 Cabría matizar el carácter pionero de la construcción jurisprudencial de Estrasburgo pues, siguiento a Joppke, el TEDH tiende a adoptar un punto de vista prudente y auto-limitador en sus decisiones, pronunciándose exclusivamente sobre aspectos en los que ya existe una fuerte protección nacional. En el caso de la RF de los extranjeros, la intervención del TEDH sobre la base del artículo $8 \mathrm{CEDH}$, se explica, a juicio de Joppke, porque "los derechos de familia ya disfrutaban de un estatus constitucional a través de los Estados Europeos, y antes de que la Corte de Estrasburgo entrara en escena, estos derechos de familia constitucionales ya habían sido aplicados por tribunales internos a los extranjeros". JOOPKE, C. "Courts, the new Constitutionalism and Immigrant Rights", op. cit.p. 837.

85 ALEXY, Robert. Teoría de los derechos fundamentales, (traducción de Ernesto Garzón Valdés). Madrid, Centro de Estudios Constitucionales, 1993.

86 DWORKIN, Ronald. Los derechos en serio, (traducción de Marta Guastavino). Barcelona, Ariel Derecho, 1977, 5a reimp. p. 75.

87 DÍEZ-PICAZO, Luis María. Sistema de Derechos Fundamentales, op. cit., p. 40.

88 En los términos de la didáctica fórmula kelseniana, si A es B debe ser B. KELSEN, Hans. Teoría general del Derecho y del Estado, (traducción de Eduardo García Máynez). México, UNAM, 1988, pp. 160-165.

89 Si bien Luis Díez Picazo matiza que, aunque en principio la operación de subsunción de los hechos en la norma se presenta como "un sencillo silogismo, en el cual la premisa mayor siempre estaría constituida por la norma jurídica y la premisa menor por los hechos fijados por el juez o intérprete, de suerte que la conclusión tiene que producirse automáticamente por el juego lógico de ambas premisas", sin embargo, la operación jurídica o judicial es siempre mucho más compleja. El autor explica que la solución de todo conflicto de intereses implica, en primer lugar, selec- 
pio suponen menores problemas de aplicación normativa. Para la aplicación de las reglas, hay que acudir a la técnica de la subsunción que, como antes indicamos, consiste en aplicar la consecuencia jurídica cuando se ha materializado la hipótesis o supuesto de hecho previsto en la norma.

Ahora bien, es habitual que los derechos fundamentales no suelan estar formulados como reglas sino como principios. Éstos se caracterizan por enunciar disposiciones generales dotadas de un menor grado de especificación ${ }^{90}$. De ahí que los principios hayan sido definidos como "prescripciones jurídicas generalísimas o fórmulas de derecho fuertemente condensadas que albergan en su seno indicios o gérmenes de reglas ${ }^{\prime 21}$. Los principios gozan de proyección normativa, esto es, a partir de ellos pueden extraerse reglas ${ }^{92}$ que dotarán de un contenido material más concreto a los principios. Pero para que de estos enunciados normativos condensados puedan evaporarse o extraerse reglas —reglas que están "indeterminadas" pero son "predictibles"93 - es necesario el recurso a la interpretación por parte de los operadores jurídicos, concretamente del legislador y del juez.

La interpretación de los principios constituye una tarea compleja. Como consecuencia de su alto nivel de abstracción, la aplicación de este tipo de disposiciones se caracteriza por la pluralidad de opciones ${ }^{94}$ en manos del intérprete. Si bien es cierto que esta pluralidad no es infinita, pues se circunscribe a una "variedad delimitada" 95 de elecciones, la interpretación del principio termina convirtiéndose en una difícil operación y sobre la que planea el riesgo del subjetivismo y la discrecionalidad jurídica ${ }^{96}$.

Siguiendo a Robert Alexy ${ }^{97}$, un principio constituye un mandato de optimización de un determinado bien jurídico. Persigue que el valor por él tutelado - en nuestro caso, el respeto a la vida

cionar la norma jurídica concreta sobre la cual la operación judicial se producirá; en segudo lugar, fijar los hechos concretos sobre los que se opera para, posteriormente, contrastar el caso y el supuesto general de la norma jurídica; y, finalmente, fijar el sentido y el alcance de la consecuencia establecida por la norma. DÍEZ-PICAZO. Luis. Experiencias jurídicas y teoría del derecho. Barcelona, Ariel, reimpresión de la $3^{\text {a }}$ ed., 1999, pp. 221-224.

90 Sobre este punto, Pérez Luño parte de la distinción entre valores, principios y normas, considerando que el criterio más adecuado para su diferenciación es el "diferente grado de concreción”, en vista de que la normatividad constituye una característica común a todos ellos. PÉREZ LUÑO, Antonio Enrique. Derechos humanos, Estado de derecho y Constitución. Madrid, Tecnos, 6a edic, 1999, pp. 291-292.

91 ARAGÓN, Manuel. Constitución y Democracia. Madrid, Tecnos, Temas clave de la Constitución Española, $1^{\text {a }}$ edic. $1^{\text {a }}$ reimp, 1990. p. 93.

92 Subrayando esta faceta de los principios, Freixes y Carbonell los definen como "instituciones con proyección normativa de las cuales se extraen reglas jurídicas”. FREIXES SANJUAN, Teresa y REMOTTI CARBONELL, J. Carlos. "Los valores y principios en la interpretación constitucional"; en Revista Española de Derecho Constitucional, $\mathrm{n}^{\circ}$ 33, mayo-agosto 1992, p. 102.

93 Ídem, p. 96.

94 FREIXES y REMOTTI. “Los valores y principios en la interpretación constitucional”, op. cit., p. 107.

95 ARAGÓN, M. Constitución y democracia, op. cit., p. 96.

96 ARAGÓN REYES ha destacado que "en la proyección normativa de los principios opera la categoría de la discrecionalidad jurídica y no sólo la discrecionalidad política que utiliza en éste como en otros casos el legislador”. Ídem. p. 96.

97 Sobre la cualidad distintiva de los principios, Robert Alexy aclara que: "El punto decisivo para la distinción entre reglas y principios es que los principios son normas que ordenan que algo sea realizado en la mayor medida posible, dentro de las posibilidades jurídicas y reales existentes. Por lo tanto, los principios son mandatos de optimización, que están caracterizados por el hecho de que pueden ser cumplidos en diferente grado y que la medida debida de su cumplimiento no sólo depende de las posibilidades reales sino también de las jurídicas. El ámbito de las posibilidades jurídicas es determinado por los principios y reglas opuestos. En cambio, las reglas son normas que sólo pueden ser cumplidas o no. Si una regla es válida, entonces debe hacerse exactamente lo que ella exige, ni más ni menos. Por lo tanto, las reglas contienen determinaciones en el ámbito de lo fáctica y jurídicamente posible. Esto significa que la diferencia entre regla y principios es cualitativa y no de grado. Toda norma es o bien una regla o un principio". ALEXY, R. Teoría de los derechos fundamentales, op. cit., pp. 86-87. 
familiar-, sea realizado en la mayor medida posible, esto es, que sea maximizado, convirtiéndose en un objetivo a perseguir por los poderes públicos al que habría que dotar del mayor grado posible de efectividad.

Conocer el grado concreto de maximización del bien jurídico protegido por el principio depende de múltiples circunstancias concurrentes: políticas públicas, condiciones económicas, sustrato cultural y sociológico, etc., lo que ya apunta las dificultades aplicativas que suscitan los principios ${ }^{98}$. Un principio no se aplica recurriendo a la técnica de la subsunción, sino a la técnica de la ponderación. La ponderación requiere sopesar los intereses concurrentes, lo que acaba exigiendo de los operadores jurídicos una tarea de difíciles equilibrios donde la solución no es clara. No se trata ya de la aplicación de una consecuencia jurídica en términos de sí o no, sino de equilibrar los intereses para protegerlos más o menos en función de su respectiva capacidad de resistencia, es decir, de priorizar un interés sobre el otro $u$ otros en función de las circunstancias concretas del caso ${ }^{99}$.

La ponderación encierra múltiples dificultades y riesgos. Entre ellos destacan la necesidad de recurrir al debate moral, el subjetivismo y la menor previsibilidad del resultado interpretativo, por tanto, tiende a cierta inseguridad jurídica que se intenta minimizar mediante la imposición de ciertos criterios en la utilización de las técnicas ponderativas. Entre los criterios exigibles a la ponderación resulta fundamental el principio de proporcionalidad. Este principio exige realizar un justo equilibrio entre los diversos intereses que compiten entre sí — de un lado, el interés particular que ostenta el/los titulares activos del derecho frente a los intereses generales invocados por las autoridades públicas para la limitación del mismo-, de forma tal que los intereses que resulten desplazados por el valor considerado como prioritario lo sean de la forma menos lesiva posible. Esto es, la proporcionalidad reclama que el desplazamiento de un interés sobre el otro no sea total, sino únicamente hasta donde sea estrictamente necesario para el logro de la finalidad perseguida por los poderes públicos.

No es casualidad que sea en el ámbito de los derechos fundamentales y del propio TEDH donde este principio ha tenido un claro reconocimiento jurisprudencial, y ello pese a que no estuviera expresamente consagrado en ninguno de los preceptos del Convenio. El principio de proporcionalidad es usado muy frecuentemente por el TEDH como fundamento jurídico de sus sentencias, circunstancia que resulta especialmente perceptible en aquellos pronunciamientos relativos a derechos en los que el propio Convenio prevé la posibilidad de limitaciones tasadas, como ocurre en el caso del respeto a la vida familiar consagrado por el artículo 8 del Convenio. Tal es la importancia de la proporcionalidad, que ha adquirido el estatus de principio general en el sistema del $\mathrm{CEDH}^{100}$. Si bien esta materia será analizada con mayor detenimiento en sede de interpretación del Convenio de Roma.

Habiendo precisado ya el concepto de principio como una de las variables que inciden en la complejidad de la interpretación jurídica, al tiempo que otorga sustrato para la riqueza de sus resul-

98 En torno a las divergencias aplicativas que suscitan las reglas y principios, Manuel Aragón afirma que "a diferencia de las reglas, que se aplican o no se aplican a un caso, los principios ofrecen argumentos para decidir, pero no obligan, por sí mismos, a la adopción de una única decisión”. ARAGÓN, M. Constitución y democracia, op. cit., p. 85.

99 Por ello, Ronald Dworkin afirma que "los principios tienen una dimensión que falta en las reglas jurídicas: la dimensión del peso o importancia. Cuando los principios se interfieren, quien debe resolver el conflicto tiene que tener en cuenta el peso relativo de cada uno. En esto no puede haber, por cierto, una mediación exacta, y el juicio respecto de si un principio o directriz particular es más importante que otro será con frecuencia motivo de controversia. Sin embargo, es parte esencial del concepto de principio el que tenga esta dimensión, que tenga sentido preguntar qué importancia o qué peso tiene". DWORKIN, R. Los derechos en serio, op. cit., pp. 77-78. En este apartado usamos una concepción técnica de principio, alejándonos de la distinción que este autor realiza entre directrices y principios,considerados éstos últimos como exigencias de la justicia- Ídem., p. 72.

100 VAN DIJK, Pieter and VAN HOOF, Fried (eds.). Theory and Practice of the European Convention on Human Rights. The Hague, Kluwer Law International, $3^{\text {a }}$ ed., 1998, p. 80. 
tados, conviene ahora centrar nuestra atención en otros elementos distintivos del precepto objeto de nuestro estudio, el artículo $8 \mathrm{CEDH}$.

\subsection{Los límites al respeto a la vida familiar (art. 8.2 CEDH): Conceptos Jurídicos Indeterminados}

El primer párrafo del articulo $8 \mathrm{CEDH}$ consagra una multiplicidad de derechos íntimamente conectados a la esfera de la personalidad ${ }^{101}$ — vida privada, vida familiar, respeto al domicilio y la correspondencia - formulados como principios y, por lo tanto, caracterizados por la imprecisión de su alcance. Usando las mismas palabras que Díez Picazo, el primer apartado del artículo 8 es una norma dotada de una "textura abierta" 102 a la interpretación. Por su parte, el segundo apartado del artículo 8, aparentemente de mayor concreción, establece los límites posibles a los derechos reconocidos en el párrafo anterior utilizando para ello una cláusula restrictiva "especialmente amplia"103.

La previsión expresa de limitaciones es una característica que comparten los derechos reconocidos en los artículos 8 a $11^{104}$ del Convenio de Roma. Estas disposiciones poseen una estructura idéntica: Todos ellos parten de un reconocimiento genérico de los derechos en el primer apartado del artículo respectivo para, a continuación, en el párrafo segundo, incluir una cláusula limitativa que prevé la posibilidad de restricciones a los mismos, restricciones que sólo serán admisibles si cumplen los requisitos establecidos en dicho apartado. Por estar sujetos a cláusulas limitativas, los derechos comprendidos en las citadas disposiciones del Convenio encajan en la categoría de los denominados "qualified rights", en contraposición a los absolute rights, que no admiten derogaciones $^{105}$.

101 VAN DIJK, Pieter; VAN HOOF, Fried; VAN RIJN, Arjen y ZWAAK, Leo (eds.). Theory and Practice of the European Convention of Human Rights, fourt Edition. Intersentia, Antwerpen-Oxford, 2006, p. 665. Estos autores consideran que resumir el amplio rango de derechos reconocidos en el artículo 8 dentro de la noción de vida privada o privacidad puede resultar erróneo, puntualizando que "the Court seems willing to accept that Article 8 is to be understood as containing various guarantees to personal autonomy, personal privacy, personal identity, personal integrity, personal development, personal identification and similar Concepts linked to the individual notion of personhood. Article 8, therefore, protects much more than a straightforward 'right to privacy"'. Idem. En una línea divergente se situarían SARMIENTO, Daniel; MIERES MIERES, Luis Javier y PRESNO LINERA, Miguel, quienes consideran los derechos convencionales al respeto de la vida familiar, del domicilio y de la correspondencia como proyecciones o manifestaciones concretas de la más amplia noción de la vida privada, derecho comprensivo que englobaría a los otros tres consagrados conjuntamente en el primer apartado del art. 8 CEDH. Las sentencias básicas del Tribunal Europeo de Derechos humanos. Estudio y jurisprudencia. Pamplona, Thomson-Civitas, editorial Aranzadi, 2007, $1^{\text {a }}$ edic., pp. 64-73.

102 DÍAZ-PICAZO, Luis María. Sistema de Derechos Fundamentales. 1a ed. Madrid, Civitas, 2003, p. 39.

103 SARMIENTO, Daniel; MIERES MIERES, Luis Javier y PRESNO LINERA, Miguel. Las sentencias básicas del Tribunal Europeo de Derechos humanos. Estudio y jurisprudencia, op. cit., p. 64.

104 Los artículos 8 a 11 del Convenio se caracterizan por la previsión de la posibilidad de restricciones a los derechos en ellos consagrados: vida privada y familiar, protección del domicilio y la correspondencia (artículo 8); libertad de pensamiento, conciencia y religión (artículo 9); libertad de expresión (artículo 10, donde se incluye el derecho a la información); libertad de reunión y asociación (artículo $11 \mathrm{CEDH}$ ). Lo mismo podría predicarse del artículo 2 del Protocolo no 4 (libertad de circulación) y del artículo 1 del Protocolo $n^{\circ} 7$ (garantías en el procedimiento de expulsión de extranjeros que residan legalmente en el territorio de un Estado miembro).

105 Los derechos considerados absolutos lo son por ser de carácter inderogable, incluso en aquellos supuestos extremos en que el Estado esté inmerso en una guerra u otro peligro público que amenace la vida de la nación, es decir, tales derechos escapan a la regla derogativa establecida en el artículo $15 \mathrm{CEDH}$, que prevé la derogación de ciertos derechos convencionales en situaciones de Estado de Excepción. Los derechos inderogables, absolutos o imperativos están recogidos en los artículos 2, 3, 4.1 y 7 del Convenio de Roma: derecho a la vida y a no ser privado arbitrariamente de la vida (artículo 2), derecho a no ser sometido a tortura ni a penas o tratos inhumanos o degradantes (artículo 3), 
Pero, junto a estas características compartidas, entre las peculiaridades que caracterizan la amplia redacción de las limitaciones contempladas en el artículo 8.2, destaca especialmente la inclusión, dentro de las restricciones al derecho al respeto a la vida familiar, de una de carácter inédito en todo el texto del Convenio: la protección del "bienestar económico del país" que, como tendremos ocasión de ver, concentra de forma monopolística las alegaciones formuladas por los Estados parte para justificar la negativa a admitir la entrada y residencia de los familiares de extranjeros, en el marco de las políticas migratorias. La inclusión de este objetivo constituye una de las particularidades del artículo 8, ya que "no aparece como causa legítima de restricción de ningún otro de los derechos del mismo tipo"106.

El artículo 8.1 no define en ningún momento los derechos consagrados, lo cual es perfectamente congruente con la técnica habitual de los catálogos de derechos, tanto en el ámbito internacional como constitucional. Por lo tanto, en el primer párrafo existen cuatro derechos con estructura de principio, mientras que en el segundo apartado de la misma disposición se definen los límites a estos derechos, recurriendo para ello a la enumeración de los siguientes conceptos jurídicos indeterminados: Seguridad nacional; Seguridad pública; Bienestar económico del país; Defensa del orden y la prevención del delito; Protección de la salud o de la moral; Protección de los derechos y las libertades de los demás.

Los límites a la vida familiar se enuncian pues como conceptos jurídicos indeterminados ${ }^{107}$. Con esta categoría jurídica se alude a aquellos supuestos en que la norma "se refiere a una esfera de realidad cuyos límites no aparecen bien precisados en su enunciado (...) se trata de conceptos que no admiten una cuantificación o determinación rigurosas (...) pero que, no obstante admiten ser precisados en el momento de la aplicación"108. La norma recurre a conceptos de esta naturaleza cuando ésta incluye realidades, conceptos y fenómenos que rechazan una delimitación diáfana. Sin embargo, la nota definitoria de los conceptos jurídicos indeterminados respecto de los supuestos de discrecionalidad administrativa reside en que la aplicación de tales conceptos sólo admite una solución o, en palabras de García de Enterría, "una unidad de solución justa"109. Es decir, el enunciado de un concepto jurídico es indeterminado, pero no así su aplicación, que sólo admite una solución justa en función de las concretas circunstancias que concurran, siempre susceptible de control judicial.

Todo concepto jurídico indeterminado está dotado de una estructura tripartita, en la cual se distinguen un núcleo de certeza caracterizado por datos ciertos y precisos; una zona intermedia o de incertidumbre; y, finalmente, una zona de "certeza negativa" donde se sabe con precisión el ámbito de aplicación excluido por la norma jurídica.

Fijar el alcance de los conceptos jurídicos indeterminados y, por lo tanto, determinar la solución justa en cada supuesto en que concurran, constituye una operación compleja de delimitar. Esta tarea

derecho a no ser sometido a esclavitud o servidumbre (artículo 4.1) y el derecho a la irretroactividad de la ley penal (artículo 7.1). Como se puede observar, son normas de ius cogens que constituyen el denominado standard mínimo internacional.

106 LEZERTUA, Manuel. "El derecho a la vida privada y familiar en la jurisprudencia del Tribunal Europeo de Derechos Humanos"; en LÓPEZ ORTEGA, Juan José (dir.). Perfiles del derecho constitucional a la vida privada y familiar. Madrid, Cuadernos de Derecho Judicial, 1996. pp. 58-59.

107 En el mismo sentido, llamando la atención sobre el amplio margen de apreciación estatal que suponen, GARCÍA VÁZQUEZ, Sonia. "Derechos y libertades de los extranjeros en España: el derecho a la reagrupación familiar"; en Anuario da Facultade de Dereito da Universidade da Coruña, No 7, 2003, p. 447.

108 GARCÍA DE ENTERRÍA, Eduardo y FERNÁNDEZ, Tomás-Ramón. Curso de Derecho Administrativo. Vol, I. Navarra, Aranzadi, 13a edic., 2006, p. 463.

109 Idem. 
"exige examinar cada supuesto concreto a la luz de determinadas circunstancias" 110 y se traduce en mayores dificultades de control o revisión jurisdiccional ${ }^{111}$. Las dificultades, sin embargo, no son predicables de las tres partes constitutivas del concepto jurídico indeterminado, se centran exclusivamente en la zona intermedia o de incertidumbre del concepto jurídico. Es precisamente en este ámbito de incertidumbre donde se ofrece al Estado un margen de apreciación, cuya misma concesión pone en evidencia las dificultades que conlleva la operación descrita a fin de arribar a la única solución justa en que se concreta la aplicación de esta categoría jurídica ${ }^{112}$.

En el ámbito de la interpretación del Convenio de Roma, el margen de apreciación constituye un criterio hermenéutico habitualmente utilizado por el TEDH, y de especial importancia para la interpretación y aplicación de la vida familiar recogida en el artículo $8 \mathrm{CEDH}$. A través del margen de apreciación se pretende ofrecer a los Estados signatarios un ámbito de actuación desde el que apreciar las concretas medidas que deberán implantar o de las que deberán abstenerse a fin de cumplir con las obligaciones derivadas del Convenio de Roma, siempre bajo la supervisión del TEDH. Pero esta es una cuestión que tendremos ocasión de abordar en el siguiente epígrafe, al estudiar el método interpretativo usado por el TEDH para precisar los derechos consagrados por el Convenio de Roma. Basta aquí apuntar que, nuevamente, los conceptos jurídicos indeterminados y la aplicación de la teoría del margen de apreciación en el artículo 8.2, constituyen factores que abren el campo interpretativo, propician el casuismo y, por ende, dificultan la sistematicidad de las decisiones del TEDH.

Si conjugamos ahora los elementos inherentes a la estructura del art. $8 \mathrm{CEDH}$, en sus dos apartados, el resultado redunda en un reforzamiento de las características y complejidades ya apuntadas. La interacción entre el carácter abierto de la formulación de los cuatro derechos proclamados en el art. 8.1 CE, en conjunción con la amplitud de las limitaciones tasadas en su apartado segundo, "constituye un incentivo interpretativo para mantener el ámbito de aplicación del artículo 8 CEDH con un carácter especialmente abierto"113. Ello determina la configuración del artículo 8 CEDH como una cláusula especialmente proclive al ensanchamiento de los derechos que consagra, fundamentalmente la vida privada y familiar, por medio de diversas técnicas jurídico-interpretativas, esto es, como una disposición caracterizada por la tendencia a la expansividad de las nociones jurídicas que consagra ${ }^{114}$.

En definitiva, la estructura normativa del artículo $8 \mathrm{CEDH}$ explicaría en gran parte el tipo de estrategia interpretativa acometida por el TEDH para la aplicación al caso concreto de esta disposición en aquellos supuestos relativos a la protección de la vida familiar de los extranjeros asentados en el territorio de alguno de sus Estados parte y, con carácter general, para la interpretación del elenco

110 STC 220/2004, de 29 de noviembre, F. J. $2^{\circ}$.

111 GARCÍA DE ENTERRÍA, Eduardo y FERNÁNDEZ, Tomás-Ramón. Curso de Derecho Administrativo, op. cit., p. 468.

112 Cuando el TC se ha enfrentado a esta figura recurre a una terminología idéntica. Los conceptos jurídicos indeterminados, ha afirmado, "ofrecen un margen de apreciación muy alto", STC 4/1981, de 2 de febrero., F. J. $1^{\circ}$.

113 SARMIENTO, Daniel; MIERES MIERES, Luis Javier y PRESNO LINERA, Miguel. Las sentencias básicas del Tribunal Europeo de Derechos humanos. Estudio y jurisprudencia, op. cit., p. 65.

114 Idem, pp. 64-66, si bien conviene reiterar que los autores citados insertan los derechos consagrados en el art. 8.1 CE como manifestaciones de la vida privada, a la que consideran en exclusiva como noción caracterizada por su expansividad. Además, los autores añaden un elemento adicional para explicar el carácter expansivo de la noción de vida privada: el hecho de que el CEDH no cuenta con una disposición general que proteja la libertad, permitiendo al TEDH crear nuevos derechos. Sin embargo, el TEDH ha declarado reiteradamente que el derecho a la vida privada del art. 8.1 CEDH ha de ser interpretado a la luz del principio de autonomía y autodeterminación individual, resultando en la práctica que dichos conceptos han quedado integrados dentro de las garantías ofrecidas por la vida privada. 
de derechos conjuntamente proclamados en el art. $8 \mathrm{CEDH}$. De hecho, se ha señalado que la propensión del TEDH a proteger nuevos derechos no consagrados explícitamente por el Convenio de Roma, haciéndolos derivar como contenidos implícitos de derechos expresos, "es mucho más acentuada en los derechos cuya cláusula de limitación es muy amplia, como en el caso del artículo 8"115.

A modo de recapitulación, es posible enfatizar en este momento las dificultades inherentes a la estructura y contenido del artículo 8 del Convenio de Roma que, sin embargo, han sido convertidos en oportunidades interpretativas en manos del TEDH gracias a una jurisprudencia altamente creativa. Tanto los derechos consagrados en esta disposición —apartado $1^{\circ}$ - como los límites a los mismos - apartado $2^{\circ}$ - se caracterizan por la apertura e imprecisión de su alcance y, por tanto, para su determinación hay que recurrir inevitablemente al uso de técnicas interpretativas. En la estructura del artículo 8 existe un reenvío circular, pues los límites que servirían en principio para concretar, si quiera de forma negativa, el contenido concreto de los derechos consagrados, suponen, en sí mismos, nociones abiertas a la interpretación, al igual que los propios derechos que a través de sus límites se intentan precisar. La sinergia de estas características refuerza el potencial expansivo de la cláusula del respeto a la vida familiar consagrada en el art. $8 \mathrm{CEDH}^{116}$.

\subsection{La Familia, concepto culturalmente condicionado}

Analizada ya la estructura del artículo y las dificultades interpretativas que implica, procederemos a identificar dos elementos adicionales que explican la complejidad de la tarea a la que se enfrenta el TEDH a la hora de aplicar el artículo 8 a casos concretos: El tiempo y el espacio.

Como pusimos de relieve al inicio de nuestro trabajo, el concepto de familia varía en el espacio, existiendo claras diferencias en la definición jurídica de lo que sea la familia entre los distintos Estados miembros del Consejo de Europa. Así en algunos la familia comprende tan sólo una unión entre hombre y mujer, mientras que en otros además de esta concepción tradicional, se incluye la unión entre personas del mismo sexo (coordenada espacial). Por otro lado, dentro un mismo Estado, el tiempo imprime profunda y aceleradamente su huella en la concepción de la familia, ya que "en el derecho de familia, más que en ningún otro, han actuado profundos cambios sociales; hasta el punto de que parece haberse roto el tenue hilo que liga al Derecho moderno con el antiguo"117. La evolución del concepto no solamente social de familia, sino jurídico, resulta claramente perceptible en España a raíz de la entrada en vigor de la Ley 13/2005, de 1 de julio ${ }^{118}$, que produjo la equiparación jurídica de los matrimonios homosexuales, frente al patrón secular previo que sólo reconocía como matrimonio a la unión exclusivamente heterosexual.

Por las razones apuntadas es posible a nuestro juicio afirmar que la familia es un concepto culturalmente condicionado, tanto temporal como geográficamente y, por ende, relativo, circunstancial y plurivalente. En este sentido, y desde el punto de vista sociológico, Anthony Giddens señala que "muchos sociólogos creen que no podemos hablar de <la familia $>$, como si sólo hubiera un modelo

115 Ibidem, p. 66.

116 En torno al potencial expansivo del CEDH y, concretamente, de la vida familiar protegida en su artículo octavo se pronuncia también SANZ CABALLERO, Susana. "El Tribunal Europeo de Derechos Humanos y las uniones de hecho"; en Repertorio Aranzadi del Tribunal Constitucional, № 2, 2003, p. 2481-2488, especialmente en pp. 2481-2486.

117 DE RUGGIERO, Roberto. Instituciones de Derecho Civil, traducción de la $4^{\mathrm{a}} \mathrm{ed}$. italiana anotada y concordada con la legislación española por Ramón Serrano Suñer y José Santa-Cruz Tejeiro, $4^{\text {a }}$ ed. Madrid, Instituto Editorial Reus, D.L. 1977-1979. Tomo II, vol. II, p. 6.

118 Se trata de la Ley 13/2005, por la que se modifica el Código Civil en materia de derecho a contraer matrimonio. 
de vida familiar más o menos universal (...) parece más adecuado hablar de $<$ familias $>$. La utilización del término en plural subraya la diversidad de sus manifestaciones. Aunque para abreviar puede que con frecuencia hablemos de $<$ la familia $>$, es vital la variedad que conlleva el concepto ${ }^{119 “}$. Y, desde el ámbito jurídico, la conclusión es idéntica. "No hay un concepto intemporal de familia. Más exacto que hablar de familia en singular, como institución universal y única, sería hablar de $<$ familias $>$ en plural para designar modelos con arreglo a los cuales los grupos humanos se han organizado históricamente" 120 .

La diversidad de la familia, en tanto que concepto culturalmente condicionado, influye directamente en su concepción jurídica dotando a ésta de una gran elasticidad y permeabilidad a las circunstancias culturales, religiosas, sociales e históricas concretas, vigentes en el momento de su regulación. "La familia no se haya regulada exclusivamente por el derecho. En ningún otro campo influyen como en éste la religión, la costumbre, la moral"121. A diferencia de lo que ocurre en otras ramas jurídicas, las normas del derecho de familia poseen un "marcado carácter ético"122. La noción jurídica de la familia se abre así al debate de la filosofía moral y, en definitiva, a la íntima conexión entre derecho, ética y moral. Idénticas conclusiones serían aplicables al derecho a la vida familiar consagrado en el artículo $8 \mathrm{CEDH}$, del que se ha afirmado que constituye "uno de los conceptos más permeables a los cambios morales y sociológicos de una comunidad"123, de ahí la resistencia del TEDH a ofrecer un concepto de familia.

Conviene en este punto precisar que si bien la variabilidad histórica ${ }^{124}$ es un fenómeno predicable, con carácter general, de los derechos subjetivos, en el caso de aquellos derechos que, como la vida familiar, se conectan con conceptos culturalmente condicionados, la intensidad de este fenómeno es considerablemente mayor. De este modo es perfectamente posible, y de hecho se da en el derecho objeto de nuestro análisis que, en espacios temporales relativamente cortos, puedan producirse variaciones de significado de la vida familiar de gran entidad que necesariamente conlleven implicaciones jurídicas.

La mutabilidad de la familia es especialmente perceptible en aquellos países que registran elevadas tasas de inmigración, donde es precisamente este factor el que ostenta un peso mayor en la acelerada transformación del mapa social que están experimentando ${ }^{125}$. El caso español es paradigmático al respecto.

Pero, además, conviene no perder de vista que la permeabilidad del concepto jurídico de familia en los últimos tiempos está también íntimamente conectado a los avances científicos, especialmente en el ámbito de la reproducción asistida. Podríamos por ello decir que, además de religiosa y culturalmente, la familia es un concepto biológica o científicamente supeditado. Los constantes avances

119 GIDDENS, Anthony. Sociología. Madrid, Alianza Editorial, primera reimpresión de la 4a ed., 2004. pp. $231-232$.

120 DÍEZ -PICAZO, Luis; GULlÓN, Antonio, Sistema de Derecho Civil., Volumen IV. Madrid, Tecnos, 6ª edic, 1992, p. 30.

121 DE RUGGIERO, Roberto. Instituciones de Derecho civil, op. cit., p. 7.

122 Ídem. En este orden de ideas, y subrayando el peso de las creencias religiosas sobre la configuración jurídica de la familia, Ruggiero señala que "la influencia más decisiva, al menos en orden a las instituciones más importantes, como el matrimonio, fue ejercida por la Iglesia, la cual mantuvo sujetas a su disciplina gran parte de las instituciones familiares”. P. 7. En el mismo sentido, Díez-Picazo destaca las consecuencias jurídicas que posee la existencia de lo que él denomina “factores de sacralización de la vida familiar". DÍEZ-PICAZO, Luis; GULLÓN, Antonio, Sistema de Derecho Civil., Volumen IV, op. cit., p. 32.

123 SANZ CABALLERO, Susana. “El TEDH y las uniones de hecho”, op. cit., p. 2482.

124 DÍEZ-PICAZO, Luis María. Sistema de derechos fundamentales, op. cit., p. 109.

125 En torno al enorme potencial de cambio social que suponen las migraciones, véase PORTES, Alejandro. "Migración y cambio social: algunas reflexiones conceptuales"; en RES, n 12, 2009, pp. 9-37. 
en materia médica están provocando la irrupción de nuevas e insólitas estructuras familiares, permitiendo el acceso a la paternidad de individuos hasta ahora excluidos por condicionantes biológicas que antes eran absolutamente impeditivas. Baste pensar en el fenómeno de las madres de alquiler, la fecundación in vitro, la donación anónima de óvulos, etc., que permiten desconectar la paternidad biológica de la social.

El panorama en la definición jurídica de lo que sea familia a efectos de su protección por el $\mathrm{CEDH}$, se complica para el TEDH si tenemos en cuenta que, en el último período, a raíz de la incorporación en el Consejo de Europa de Turquía y de los países procedentes de la desintegración de la Unión de Repúblicas Socialistas Soviéticas, el número de Estados miembros se ha incrementado de forma extraordinaria, para dar entrada a países que rompían con la relativa homogeneidad cultural que hasta entonces existía entre los países signatarios.

Si sumamos todas las variables apuntadas hasta ahora - derechos formulados como principios, límites configurados como conceptos jurídicos indeterminados para cuya precisión es necesario respetar un cierto margen de apreciación estatal, familia como concepto culturalmente condicionado por el tiempo y el espacio, Consejo de Europa como organización internacional protectora de derechos que se mueve en un ámbito geográfico cada vez mayor y culturalmente más heterogéneo- comprenderemos que nos enfrentamos ante un precepto de gran vaguedad, de estructura normativa muy abierta y para cuya delimitación resulta esencial la labor interpretativa de la jurisprudencia de Estrasburgo.

\subsection{La vida familiar, derecho de construcción jurisprudencial}

En la definición de la familia protegida por el Convenio de Roma, así como de las concretas obligaciones jurídicas que supongan para los Estados el respeto a la vida familiar, el artículo 8 actúa como un mero punto de partida. Será la actividad interpretativa del TEDH la que, de forma progresiva, vaya integrando la parquedad de la norma y perfilando las facultades concretas inherentes en el contenido del derecho al respeto de la vida familiar. Por lo tanto, si está claro que los derechos son una rama del ordenamiento, tanto interna como internacional — según la perspectiva que se adopte-, de configuración fundamentalmente jurisprudencial ${ }^{126}$, en el caso del artículo 8, los múltiples factores que en él concurren y que ya han sido explicados, hacen que esta afirmación sea doblemente cierta.

El derecho al respeto de la vida familiar es, como no puede ser de otro modo, un derecho jurisprudencial, lo que explica la necesidad de acudir al case law de Estrasburgo para conocer el contenido del mismo ${ }^{127}$. Pero antes de abordar el estudio de la jurisprudencia emanada del respeto a la vida familiar reconocido en el artículo 8, conviene detenernos en los criterios interpretativos utilizados

126 DÍEZ-PICAZO, Luis María. Sistema de Derechos Fundamentales, op. cit., p. 46. El autor prosigue señalando que "más que ningún otro sector del ordenamiento, los derechos fundamentales constituyen un auténtico 'derecho jurisprudencial': es precisamente la jurisprudencia la que completa el enunciado a menudo lapidario de las declaraciones de derechos, dotándolas de concreción y certidumbre”.

127 La configuración jurisprudencial de la RF por parte del TEDH está clara entre la doctrina que, sin embargo, discrepa en torno a si puede calificarse técnicamente como derecho o no. Vid, entre otros, IGLESIAS SÁNCHEZ, Sara. "El valor de la Directiva 86/2003 sobre reagrupación familiar a la luz de los derechos fundamentales y de la sentencia del TJCE en el asunto 540/03"; en Revista de Derecho Comunitario Europeo, No 26, 2007, especialmente pp. 129-134, si bien esta autora concluye que el TEDH no reconoce la existencia de un derecho a la RF, limitándose a establecer límites a las legislaciones y prácticas nacionales a fin de respetar el derecho a la vida familiar tal y como es consagrado por el CEDH, idem, p. 134. Como derecho de construcción pretoriana califica Arriaga Iraburu la configuración jurisprudencial que el TEDH ha dotado al derecho a la RF como obligación positiva derivada del derecho al respeto a la vida familiar, en tanto que derecho "derivado indirecto". ARRIAGA IRABURU, Inés. El derecho a la vida familiar de los extranjeros en la jurisprudencia de Estrasburgo, op. cit., pp. 23-32. 
para ello por el TEDH. Esto nos permitirá comprender que el casuismo no es un defecto del sistema, sino una necesidad inevitable derivada de la delicada tarea que asume el TEDH - especialmente en el ámbito de la vida familiar-, e incluso un mecanismo para reforzar la estabilidad del sistema regional y la propia respetabilidad del TEDH.

\section{LA INTERPRETACIÓN DEL CONVENIO EUROPEO DE DERECHOS HUMANOS}

El Convenio de Roma es un Tratado internacional suscrito en la actualidad por todos los Estados partes del Consejo de Europa, que suman cuarenta y siete países. Este extenso ámbito de aplicación territorial, con la variabilidad social, económica, histórica y política subyacente, constituye un elemento que condiciona su interpretación ${ }^{128}$.

Para su interpretación son de aplicación las reglas generales que, en esta materia, rigen para los Tratados internacionales, establecidas principalmente en la Convención de Viena sobre el Derecho de los Tratados ${ }^{129}$. Entre dichos criterios, destaca por su importancia la regla interpretativa general contenida en el primer apartado del artículo 31 de la Convención de Viena, conforme a la cual "un tratado deberá interpretarse de buena fe conforme al sentido corriente que haya de atribuirse a los términos del tratado en el contexto de éstos y teniendo en cuenta su objeto y fin".

Pero incluso ya antes de su codificación por la Convención de Viena, tanto la Comisión como el TEDH recurrieron al criterio del objeto y fin del Convenio de Roma como directriz interpretativa ${ }^{130}$. Este hecho es de notable significación si se considera que tuvo lugar en una época donde el principio esencial para la interpretación de normas internacionales establecía que "las limitaciones a la soberanía de los Estados no se presumen”, principio usado con frecuencia por los Estados para limitar unilateralmente sus compromisos convencionalmente asumidos ${ }^{131}$.

De forma pionera pues, los órganos de Estrasburgo han ido fraguando un instrumental jurídico especial para cumplir con el objeto y propósito particulares de la Convención de Roma, elaborando principios interpretativos propios así como conceptos jurídicos singulares para su aplicación. Todos ellos se encuentran en íntima conexión con la particular naturaleza jurídica del CEDH y las finalidades que éste estaba llamado a cumplir.

En tanto que Convenio cuyo objeto y propósito especial es el reconocimiento y protección de un elenco de derechos o, en palabras de Santiago Ripol, la "preeminencia de los derechos fundamentales"132, el CEDH es un Tratado con una naturaleza especial, sui generis, que desborda el ámbito de la reciprocidad ${ }^{133}$ entre los Estados signatarios. Esto es, el Tratado por su objeto y propósi-

128 LASAGABASTER HERRARTE, Iñaki (dir.). Convenio Europeo de Derechos Humanos. Comentario Sistemático, op. cit., p. 24

129 Artículos 31-33 de la Convención de Viena sobre el Derecho de los Tratados, suscrita en Viena el 23 de mayo de 1969.

130 El TEDH, en Wemjof contra República Federal Alemana, sentencia de 27 de junio de 1968, señaló que: “Dado que se trata de un Tratado normativo, es también necesario buscar la interpretación que sea más apropiada para realizar el propósito y alcanzar el objeto del tratado, no aquel que restringiría al máximo grado posible las obligaciones asumidas por las partes".

131 SÁNCHEZ LEGIDO, Ángel. La reforma del mecanismo de protección del CEDH, op. cit., pp. 97-98.

132 RIPOL CARULLA, Santiago. El sistema europeo de protección de los derechos humanos y el Derecho español. Barcelona, Atelier, 2007, p. 13.

133 CARRILlO SALCEDO, Juan Antonio. El Convenio Europeo de Derechos Humanos, op. cit., pp. 21-22. Insiste de 
to -reconocimiento y protección supranacional de derechos-, no está sujeto para su cumplimiento a la voluntad efectiva que manifieste un Estado frente a otro.

El CEDH ha sido definido por los propios órganos de Estrasburgo como "un instrumento constitucional del orden público europeo”, cuya finalidad específica es garantizar colectivamente los derechos humanos. La doctrina ha destacado abundanemente esta cualidad de la naturaleza cuasi constitucional del sistema del $\mathrm{CEDH}^{134}$. Quizá por ello si el estudio se aborda desde la perspectiva del Derecho Constitucional, al introducirse al marco teórico y conceptual de la Convención de Roma, tal y como ha sido desarrollado por los órganos de Estrasburgo, no se pueden evitar ciertos paralelismos con la teoría y el lenguaje constitucional: principios y conceptos usados en el sistema del CEDH y hasta problemas de interpretación tienen sus homólogos a nivel interno, en la dogmática constitucionalista, especialmente aquella desarrollada en el ámbito de los derechos fundamentales ${ }^{135}$.

La labor interpretativa, como ya apuntamos, es especialmente fructífera en lo que respecta a los derechos individuales, dado que éstos suelen estar formulados como normas de principio caracterizados por su alto nivel de indeterminación y por ello abiertos a la interpretación y ponderación. Con esta idea en mente, se comprenderá que el TEDH desarrolle una vital labor de delimitación y

nuevo en el mismo aspecto en la página 30, al estudiar los métodos interpretativos utilizados por el TEDH en sus razonamientos.

134 Vid, entre otros, Van Dijk y Van Hoof quienes afirman que "algunos de los principios generales que caracterizan el case law del Tribunal reflejan una aproximación constitucionalista a la Convención y a la función supervisora del Tribunal". VAN DIJK, P.; VAN HOOF, G.J.H. (coords.). Theory and Practice of the European Convention on Human Rights, op. cit, third edition, p. 95. Por su parte, Carrillo Salcedo habla insistentemente de la naturaleza y dimensión constitucional del Convenio como expresión de un orden público europeo de los derechos, a cuyo estudio dedica un epígrafe de su obra. CARRILLO SALCEDO, J. A. El Convenio Europeo de Derechos Humanos, op. cit., pp. 21-22.

135 De hecho, la declaración de derechos contenida en el Título I del Convenio es, por su contenido, equiparable a la parte dogmática de una Constitución de un Estado democrático políticamente descentralizado que hubiera sido elaborada en la segunda mitad del siglo XX, con la importante salvedad de la exclusión de los derechos sociales - explicable como consecuencia del carácter supranacional del sistema del Consejo de Europa, la época de su fundación y las dificultades garantistas que entrañan los derechos sociales. Además, se trata de derechos redactados de forma muy sucinta y abreviada, como también es propio de los textos constitucionales. Entre tales derechos existe una conexión obvia, de modo que, tanto el CEDH, como las Constituciones internas, han de ser contempladas como un conjunto coherente y sistemático, como una unidad, pues lo contrario mermaría la eficacia jurídica de sus disposiciones. Esta idea late detrás de una afirmación que, en materia de interpretación de los derechos del Convenio, constituye doctrina constante del TEDH. Este órgano ha afirmado repetidamente que el Convenio y sus Protocolos deben considerarse como un todo. Vid, entre otras, sentencia de 23 de julio de 1968, dictada en el caso "Régimen lingüístico en Bélgica”, apartado 7; Asunto Abdulaziz, Cabales y Balkandali contra el Reino Unido, STEDH de 28 de mayo de 1985, apartado 60.

Pero los paralelismos no acaban ahí. El Convenio, al igual que las Constituciones, tiene una vocación de permanencia y está también dotado de rigidez formal, lo que, en el ámbito interno, actúa como una garantía extraordinaria de la normatividad de los textos constitucionales. Ello determina que, dado que ambos son textos destinados a perdurar en el tiempo, se deban arbitrar mecanismos tendentes a su actualización. La puesta al día puede realizarse mediante dos vías, identificadas por la doctrina, que suelen darse de forma acumulativa. De un lado, mediante un mecanismo formal y expreso de reforma, especialmente gravoso, que dota de rigidez tanto a las Constituciones como a los Tratados internacionales; Y, por otro lado, un mecanismo informal, no expresamente reconocido en los textos normativos, sino derivado de la práctica jurisdiccional. Esta segunda vía de actualización, en el caso del texto del Convenio, y a raíz de la desaparición de la Comisión, tiene lugar a través de la interpretación constante del mismo llevada a cabo por un único órgano de carácter jurisdiccional, el TEDH; Mientras que en el derecho interno, la tarea interpretativa tiene lugar a través de una multiplicidad de órganos que, en materia constitucional, tienen a la cabeza a los Tribunales Constitucionales como intérpretes supremos de la Constitución, en aquellos países dotados de sistemas concentrados. 
precisión del contenido de los derechos establecidos en el Convenio de Roma ${ }^{136}$, cuya interpretación pasa a integrar el propio contenido normativo del $\mathrm{CEDH}^{137}$.

La tarea de actualización vía interpretación jurisprudencial no está exenta de riesgos. De ahí que, en el desarrollo de la misma, los Tribunales hayan de sujetarse a principios y límites expresos. Las especialidades del Convenio de Roma justifican que este tratado cuente con principios interpretativos propios. Junto a las reglas interpretativas de la Convención de Viena, son también de aplicación criterios interpretativos propios, que lo singularizan de los tratados multilaterales clásicos. Dichos criterios han ido progresivamente depurándose gracias a la labor de la Comisión Europea, ya desaparecida, y del TEDH, a lo largo de sus casi cinco décadas de actuación. A efectos de la claridad expositiva, los abordaremos de forma separada, insistiendo en que el orden usado para su exposición no supone una graduación en su importancia y que, por otro lado, el Tribunal suele utilizarlos de forma combinada.

\subsection{Principio de la efectividad o del efecto útil}

Constituye una doctrina reiteradamente utilizada en el razonamiento del TEDH considerar que los derechos y libertades de la Convención no son retóricos o ilusorios, sino concretos y efectivos ${ }^{138}$. El principio hermenéutico del efecto útil exige que los derechos del CEDH sean interpretados con la finalidad de dotarles de la mayor eficacia posible.

Esta forma de aproximarse a los derechos convencionales conduce, de un lado, a un principio interpretativo habitual en materia de derechos subjetivos, cual es la interpretación favorable de los derechos, es decir, interpretar de forma extensiva el contenido del derecho frente a la interpretación estricta o restrictiva de sus límites ${ }^{139}$. De otro, desemboca en el denominado "efecto útil" del $\mathrm{CEDH}$, que, en última instancia, implica que, con la finalidad de proteger el derecho consagrado, éste expande o amplía su ámbito de actuación, determinando obligaciones de mayor calado para los Estados parte.

136 Conforme al artículo 32 del Convenio de Roma "la competencia del Tribunal se extiende a todas las cuestiones relativas a la interpretación y la aplicación del Convenio y de sus Protocolos que le sean sometidas.." Para entender la percepción que el propio TEDH tiene sobre su labor interpretativa y supervisora del CEDH lo mejor es aproximarse a su jurisprudencia, donde queda claro el papel de este órgano para esclarecer y desarrollar por vía interpretativa las disposiciones contenidas en el Convenio de Roma. Constituye jurisprudencia reiterada la siguiente afirmación, "the Court's judgments in fact serve not only to decide those cases brought before the Court but, more generally, to elucidate, safeguard and develop the rules instituted by the Convention, thereby contributing to the observance by the States of the engagements undertaken by them as Contracting Parties". STEDH Ireland v. The United Kingdom, de 18 de enero de 1978, apartado 154. De otro lado, y continuando con los paralelismos entre el CEHD y las Constituciones internas, similares consideraciones cabría aplicar respecto de la tarea desarrollada en el derecho interno por los Tribunales Constitucionales, respecto a la concreción normativa de los derechos consagrados en las Constituciones respectivas. Esto es aún más obvio si tenemos en cuenta la aproximación con que el TEDH se enfrenta a su tarea interpretativa. El TEDH, en su actuación, parece aproximarse cada vez más a una jurisdicción constitucional de carácter supranacional, sin perjuicio de los límites obvios que se derivan de la eficacia de las sentencias del TEDH en el derecho interno.

137 LASAGABASTER HERRARTE, Iñaki. CEDH. Comentario sistemático, op. cit., p. 21.

138 Vid, entre otras, Airey c. Irlanda, sentencia de 9 de octubre de 1979, parr. 26; Artico c. Italia, sentencia de 13 de mayo de 1980, parr. 33; Soering c. Reino Unido de Gran Bretaña, sentencia de 7 de julio de 1989, parr. 87.

139 Vid, inter alia, Silver y otros contra el Reino Unido, de 25 de marzo de 1983, donde el TEDH sentó un principio que constituye doctrina asentada en torno a la interpretación de los límites de los derechos convencionales, en los siguientes términos: "Those paragraphs of Articles of the Convention which provide for an exception to a right guaranteed are to be narrowly interpreted”. Párrafo 97, apartado d) de la citada sentencia. 
El efecto útil es, a nuestro juicio, un criterio que refuerza la eficacia normativa de los derechos consagrados en el CEDH pues, como ya señalamos, entre los propósitos originales que animaron a la construcción del sistema de protección de derechos del Consejo de Europa se pretendía expresamente superar las limitaciones de la Declaración Universal de los Derechos Humanos. Este objetivo protector del individuo frente a las estructuras estatales fue y sigue siendo el motor principal del sistema instaurado por el Consejo de Europa.

De la utilización por parte de las instituciones de Estrasburgo del principio del efecto útil se derivan múltiples criterios hermeneúticos empleados habitualmente por el TEDH. Por su importancia para entender el origen y el desarrollo jurisprudencial del derecho a la reagrupación familiar en el ámbito del Convenio de Roma, dedicaremos un amplio análisis a esta materia. Si bien es habitual su estudio independiente, a nuestro entender tanto el reconocimiento de obligaciones positivas derivadas de la Convención de Roma como la protección de rebote y las nociones autónomas, constituyen manifestaciones derivadas de la potencialidad del principio del efecto útil en el marco del CEDH. Junto a tales principios, la doctrina del margen de apreciación posee una importancia vital en nuestro ámbito de estudio, como consecuencia de la inserción de la inmigración como una de las más relevantes potestades soberanas del Estado.

\section{a) Reconocimiento de obligaciones positivas}

La pretensión de dotar de la mayor efectividad posible a los derechos del Convenio ha permitido al TEDH extraer de sus normas obligaciones positivas para los Estados, con independencia de que éstas no aparezcan expresamente establecidas en el texto de la Convención. Dichas obligaciones vendrían a unirse a las obligaciones negativas que, en principio, se derivaban con carácter casi exclusivo para los Estados parte. El proceso que desembocó en la extracción de obligaciones convencionales de naturaleza positiva del texto del Convenio de Roma ilustra la potencialidad del principio del efecto útil.

El CEDH dedica su Título I a la consagración de un catálogo reducido de derechos de carácter fundamentalmente civil y político. Dentro de la tipología clásica corresponderían a derechos de primera generación, que otorgan a sus titulares un ámbito de autonomía de actuación que exige en principio la abstención de los poderes públicos. El cumplimiento de estos derechos supondría para los Estados parte el deber de no inmiscuirse en el perímetro de libertad individual o colectiva proyectado por el derecho.

Sin embargo, en la década de los cincuenta del pasado siglo, época a la que corresponde el $\mathrm{CEDH}$, ya habían surgido y se habían asentado en el ámbito interno los denominados derechos de segunda generación o de carácter social. Éstos últimos se traducen en exigencias de actuación positiva, en forma de prestaciones de diverso tipo - social, económica, educativa...etc. - que correspondería proveer a los poderes públicos en tanto que titulares pasivos de dichos derechos. El hecho de que esta segunda generación de derechos no se vertiese en el Convenio de Roma se explica por múltiples factores, entre los que destaca:

a) La naturaleza del CEDH en tanto que tratado internacional que establecía tempranamente un estándar mínimo ${ }^{140}$ de consenso interestatal en materia de protección de derechos humanos;

140 Su carácter de mínimo se desprende claramente del $53 \mathrm{CEDH}$, conforme al cual "ninguna de las disposiciones del presente Convenio será interpretada en el sentido de limitar o perjudicar aquellos derechos humanos y libertades fundamentales que podrían ser reconocidos conforme a las leyes de cualquier Alta Parte Contratante o en cualquier 
b) Las mayores dificultades de garantía que entrañan los derechos sociales y, por ende, las mayores resistencias que frente a ellos oponen los gobiernos signatarios;

c) El CEDH se concebía, como establece su Preámbulo, como un instrumento para garantizar la unidad entre los Estados parte en la confianza de que la dignidad humana, como fundamento de los derechos individuales, permitiría la consolidación de las democracias ahuyentado definitivamente el fantasma de la guerra y la dictadura, con sus consecuencias nefastas sobre los derechos humanos - fantasmas demasiado cercanos en la mente de los Estados signatarios originarios. A tal fin en el Preámbulo dichos Estados se declaraban "resueltos, en cuanto Gobiernos de Estados europeos animados de un mismo espíritu y en posesión de un patrimonio común de ideales y de tradiciones políticas, (...) a tomar las primeras medidas adecuadas para asegurar la garantía colectiva de algunos de los derechos enunciados en la Declaración Universal". Con la reciente guerra como trasfondo, se entendía que, obviamente, estas primeras actuaciones eran aquellas medidas de protección contra el Estado consideradas más esenciales por su mayor proximidad a la dignidad humana, de ahí que se consagrasen fundamentalmente derechos de primera generación, predicables de todos los individuos, tanto nacionales como no nacionales de los Estados parte ${ }^{141}$.

Acorde con la naturaleza de los derechos de primera generación reconocidos en el CEDH, se derivaban fundamentalmente para los Estados miembros obligaciones negativas, esto es, de inhibición de actuaciones que implicaran injerencias ilegítimas en el ejercicio de los derechos convencionales. Esta característica ha sido destacada, entre otros autores, por Merrils ${ }^{142}$, quien ha subrayado la naturaleza excepcional de aquellos artículos del CEDH que, por su redacción, obligaban a los Estados a tomar medidas positivas, entre ellos el artículo 6, que consagra el derecho a un proceso equitativo. Con todo, y como es bien sabido, los derechos de segunda generación serían finalmente consagrados a principios de la década de los sesenta, en un tratado específico, la Carta Social Europea ${ }^{143}$, también suscrito en el ámbito del Consejo de Europa.

Pero no obstante el entendimiento original del tipo de obligaciones que se derivaban de este instrumento supranacional de protección de derechos, la concepción de los derechos convencionales como derechos efectivos y no ilusorios permitió al TEDH extraer obligaciones positivas para los Estados parte. A lo largo del proceso de aplicación e interpretación del CEDH, los órganos de Estrasburgo fueron percibiendo claramente que la ausencia de ciertas obligaciones positivas mermaría sustancialmente la eficacia de los derechos. Como consecuencia de su origen jurisprudencial, -esto es, de interpretación del CEDH por parte de la Comisión y el TEDH en clave de eficacia-, muchas de estas obligaciones positivas son de carácter implícito, es decir, forman parte del contenido inherente del derecho garantizado, aunque no figuren literalmente en el texto del artículo.

Las obligaciones positivas para los Estados comenzaron a perfilarse en el Asunto de determinados aspectos relativos al régimen lingüístico belga, fallado en 1968. Al determinar el contenido del

otro Convenio en el que ésta sea parte”. Este artículo subraya la libertad que tienen los Estados parte para adoptar sistemas más garantistas para la protección interna de los derechos fundamentales, actuando pues el CEDH como un tope mínimo que puede rebasarse al alza, pero no a la baja.

141 Ya subrayamos que el artículo 1 del CEDH proclama una amplísima titularidad activa para los derechos consagrados, superando así, en palabras de CARRILLO SALCEDO, "la exigencia de la nacionalidad de la reclamación". El Convenio Europeo de Derechos Humanos, op. cit., p. 42.

142 MERRILLS, J.G. The Development of International Law by the European Court of Human Rights. Manchester, MUP, 1993, pp. 102-103.

143 La Carta Social Europea, fue aprobada en Turín el 18 de octubre de 1961. 
derecho a la instrucción garantizado en el artículo 2 del Protocolo adicional al CEDH, el TEDH tuvo ocasión de afirmar la existencia de obligaciones positivas. Para ello usó como recurso interpretativo y argumentativo la conjunción de la protección eficaz de los derechos como objeto y fin del CEDH, en conexión con el amplio alcance de la titularidad activa de tales derechos consagrada en su artículo 1. Esta doble técnica ${ }^{144}$ permitió al TEDH sacar la siguiente conclusión:

"La formulación negativa significa, y así lo confirman los trabajos preparatorios, que las Partes Contratantes no reconocen un derecho a la educación que les obligue a mantener a su costa o subvencionar un sistema de enseñanza de una forma o en una escala determinadas. De ello no cabe deducir, sin embargo, que el Estado carezca de toda obligación positiva para asegurar el respeto de este derecho, tal como el artículo 2 del Protocolo le protege. Puesto que un “derecho" existe, éste es garantizado, en virtud del artículo 1 del Convenio, a toda persona dependiente de la jurisdicción de un Estado contratante ${ }^{145}$.

Y en la misma sentencia, pero en el ámbito específico del derecho a la vida familiar consagrado en el artículo $8 \mathrm{CEDH}$, el TEDH señaló que "el objeto de tal artículo es esencialmente la protección del individuo frente a interferencias arbitrarias del poder público"146. Ahora bien, si el objeto esencial del artículo 8 es la garantía del individuo frente a injerencias estatales arbitrarias, cabría afirmar, a sensu contrario, la naturaleza no exclusivamente negativa de los deberes que derivan para los Estados de dicho precepto. Por ello, la doctrina ha destacado que con este pronunciamiento el TEDH estaba dando entrada, de forma implícita ${ }^{147}$ a las obligaciones positivas en el ámbito de los derechos recogidos en el artículo $8 \mathrm{CEDH}$.

Este aspecto es especialmente importante, porque analizaremos la reagrupación familiar de los extranjeros como un contenido potencialmente implícito derivado del derecho al respeto a la vida familiar, del cual se deducen obligaciones positivas para los Estados parte. En otras palabras, tanto la Comisión inicialmente como después el TEDH han asignada a la RF, en el ámbito del CEDH, el carácter de obligación positiva implícita o inherente al derecho a la vida familiar de los extranjeros recogido en el artículo 8.

Carrillo Salcedo ha destacado el enorme potencial e importancia de la obligación que recae sobre los Estados parte de asegurar los derechos reconocidos en el CEDH, establecida en el artículo $1 \mathrm{CEDH}^{148}$. La versión inglesa del texto del artículo 1 - shall secure-, mucho más imperativa que el original francés, sirvió de apoyo al TEDH para, aplicando el principio de efectividad, afirmar que la garantía de los derechos del Convenio no solamente supone que los Estados parte respeten tales derechos, sino que, además, exige de sus autoridades que impidan o sancionen la violación en niveles inferiores ${ }^{149}$. De esta forma, el artículo 1 ha servido para dar entrada en el CEDH de un lado, a las obligaciones positivas necesarias para asegurar el goce efectivo de los derechos convencionales

144 "El Tribunal estima que el propósito querido por las Partes Contratantes, con carácter general, mediante el Convenio Europeo de Derechos del Hombre, era el de una eficaz protección de los derechos fundamentales del hombre, y ello, sin duda, en razón no sólo de las circunstancias históricas en las que fue concluido el Convenio, sino también del desarrollo social y técnico de nuestra época que tantas posibilidades ofrece a los Estados de regular el ejercicio de estos derechos. Por ello, el Convenio supone un justo equilibrio entre la salvaguardia del interés general de la comunidad y el respeto de los derechos fundamentales del hombre, al tiempo que atribuye un valor particular a estos últimos". Caso lingüístico belga, STEDH de 23 de julio de 1968, apartado 5.

145 Caso lingüístico belga, STEDH de 23 de julio de 1968, apartado 3.

146 Ibidem, apartado 7.

147 CONNELLY, A.M. "Problems of interpretation of article 8 of the European Convention on Human Rights"; en International and Comparative Law Quarterly, 1986, vol. 35. p. 572. En el mismo sentido se pronuncia ARRIAGA IRABURU, Inés. El derecho a la vida familiar de los extranjeros en la jurisprudencia de Estrasburgo, op. cit., p. 224.

148 CARRILLO SALCEDO. El Convenio Europeo de Derechos Humanos, op. cit., p. 101.

149 Asunto interestatal Irlanda c. Reino Unido de Gran Bretaña, STEDH de 18 de enero de 1978, apartado 239. 
$y$, de otro, ha permitido dotar de eficacia horizontal o entre particulares a las disposiciones de dicho Tratado ${ }^{150}$.

Adicionalmente, vale la pena detenerse en un aspecto cuando menos curioso del artículo 8, cual es la extraña redacción de su primer párrafo: "toda persona tiene derecho al respeto de su vida privada y familiar, de su domicilio y de su correspondencia”. En lugar de la fórmula habitual en el Convenio de consagrar directamente el derecho, en este caso, a la vida familiar, lo reconoce de forma oblicua, recurriendo a una perífrasis — "el respeto a" - . El tenor literal del artículo 8.1, a nuestro juicio, parece apuntar a una cierta preeminencia de las obligaciones negativas derivadas para los Estados parte a fin de garantizar el derecho al respeto de la vida familiar. El artículo delimita un ámbito prioritario de esfera privada que incluiría bienes jurídicos variados, pero en íntima conexión —intimidad, familia, domicilio, correspondencia - que se pretenden poner al resguardo de interferencias arbitrarias por parte de los poderes públicos. Es decir, perfilaría fundamentalmente obligaciones negativas, al tiempo que permite extraer de forma derivada o con carácter secundario obligaciones positivas ${ }^{151}$.

Este aspecto quedó zanjado con la sentencia Marckx c. Bélgica, donde el TEDH extrajo obligaciones positivas de la cláusula de "respeto" efectivo a la vida familiar. Pero esto tendremos ocasión de analizarlo más adelante. Por el momento lo importante es subrayar que en la actualidad la responsabilidad internacional de los Estados parte del Convenio de Roma se deriva tanto por el incumplimiento de obligaciones negativas, como de obligaciones de carácter positivo.

El reconocimiento de ambos tipos de obligaciones convencionales tiene profundas consecuencias:

1. Implica, en primer lugar, que la tradicional distinción entre derechos de primera y segunda generación se desdibuja, lo cual es coherente con el carácter indivisible e interdependiente ${ }^{152} \mathrm{de}$ los derechos humanos. Es, además, una percepción más realista que toma en cuenta el carácter evolutivo de los derechos, cuyo contenido se va ensanchando y adaptando a la propia evolución histórica y a los nuevos retos y exigencias que ésta demanda. Las sucesivas generaciones de derechos producen una acumulación de facultades y, correlativas obligaciones, sobre un mismo derecho/s, cuyo contenido se va enriqueciendo ${ }^{153}$.

2. Supone una ampliación de las obligaciones que el CEDH genera para los Estados parte, sobre todo si se tiene en cuenta que las obligaciones positivas se desdoblan en múltiples facetas - reformas

150 CARRILlO SALCEDO. El Convenio Europeo de Derechos Humanos, op. cit., pp. 21-22; 99-102.

151 Como consecuencia de este enfoque predominantemente, y para mayor claridad, Connelly propone reformular el texto del artículo 8 uniendo sus dos apartados en un conjunto integrado que quedaría redactado de la siguiente forma: "Toda persona tiene el derecho de estar libre de interferencias de la autoridad pública en su vida privada y familiar, su casa y su correspondencia, excepto de acuerdo a la ley y en la medida que, en una sociedad democrática, sea necesaria para la seguridad nacional, la seguridad pública, el bienestar económico del país, la defensa del orden y la prevención del delito, la protección de la salud o de la moral, o la protección de los derechos y las libertades de los demás". Esta redacción es más explícita y clara respecto a la prioridad de obligaciones negativas. CONNELLY, A.M. "Problems of interpretation of article 8 of the European Convention on Human Rights", op. cit., p. 565, traducción propia.

152 En este sentido, el párrafo 5 de la Declaración y Programa de acción de la Conferencia de Viena de derechos humanos de mayo 1993 señala que "todos los derechos humanos son universales, indivisibles e interdependientes y están relacionados entre sí. La Comunidad internacional debe tratar los derechos humanos en forma global..”.

$153 \mathrm{Al}$ respecto, se ha señalado que "las denominadas generaciones de los derechos humanos permiten entender el desarrollo progresivo que tienen los derechos como reacciones de consenso de los sujetos de la comunidad internacional, frente a los nuevos problemas y realidades internacionales". PECES-BARBA, G.; FERNÁNDEZ LIESA, C.; LLAMAS CASCÓN, A., Textos Básicos de Derechos humanos, op. cit., p. 269. 
legislativas, correcciones de prácticas administrativas, puesta en marcha de políticas públicas, etc.-, que muchas veces exigen esfuerzos presupuestarios para los que quizá, los Estados no se encuentren preparados o, aun estando en condiciones, no estén dispuestos a realizar ${ }^{154}$. Entre estas medidas se encuentran incluso acciones de carácter preventivo ${ }^{155}$ destinadas a salvaguardar los derechos del Convenio.

3. De esta segunda consecuencia se deriva la cautela que ha de tener el TEDH al incrementar el monto de las obligaciones estatales, especialmente si consideramos que el Tribunal de Estrasburgo interpreta y aplica un Tratado internacional cuya eficacia jurídica está condicionada al consentimiento explícito por parte de los Estados contratantes - ius contrahendi-. Dado que ya apuntamos quela mayoría de las obligaciones positivas son de carácter implícito, la necesidad de autocontención es mayor, pues a través de ellas los Estados verían involucrada su responsabilidad internacional sin que mediara consentimiento expreso. Ello aboca a la controvertida cuestión de las reformas implícitas provocadas por la creación judicial del derecho, en una esfera si cabe más sensible como es el ámbito internacional, con sus consecuentes repercusiones en la soberanía de los Estados. Conviene no olvidar que la posibilidad de incluir nuevos derechos en el sistema del Convenio de Roma, con las consiguientes obligaciones que de ellos deriven para los Estados, está permanentemente abierta a través del recurso a los Protocolos adicionales.

4. Permite dotar de cierta eficacia horizontal a los derechos convencionales, posibilitando reaccionar frente a determinadas violaciones de estos derechos que tengan su origen en actos de los particulares.

5. En contrapartida, se refuerza la protección que el CEDH otorga a los individuos sujetos a la jurisdicción de los Estados parte, fortaleciéndose así la función propia de los derechos, entendidos como mecanismos de protección que se erigen frente al Estado.

\section{b) La protección de rebote: la RF como derecho indirecto derivado del derecho al respeto a la vida familiar}

El efecto útil conduce, además, a la llamada protección de rebote, de importancia vital para nuestro objeto de estudio. La protección de rebote permite dar entrada de forma indirecta a derechos no expresamente consagrados en el Convenio ni en sus Protocolos Adicionales, pero respecto de los cuales se estima que, su falta de protección, supondría una violación paralela de derechos explícitamente garantizados.

Para la aplicación de la protección de rebote es necesario que exista un nexo causal entre el derecho no reconocido, pero protegido de forma indirecta, y el derecho convencionalmente consagrado; Esto es, que el disfrute del derecho indirecto sea considerado como un requisito indispensable para la efectividad del derecho explícitamente reconocido en el sistema del CEDH, de forma tal que la denegación del primero desemboque, por extensión o por efecto rebote, en una lesión simultánea del segundo.

Como es obvio, no hubiera sido posible extraer una protección de este tipo si el TEDH no parte de una concepción sistemática e integradora de todos los derechos consagrados en el CEDH y en

154 MERRILLS, J.G. The Development of International Law by the European Court of Human Rights. Manchester, MUP, 1993, p. 106.

155 MOWBRAY, A. R. The development of Positive Obligations under The European Convention on Human Rights by The European Court of Human Rights. Oxford, Portland Oregon, 2004. p. 4. 
sus Protocolos Adicionales. Ya apuntamos anteriormente que, de forma muy temprana, el Tribunal partía de la consideración del Convenio y sus Protocolos como un todo, de forma que distintos aspectos de una misma materia, pese a estar regidos esencialmente por una disposición, pueden quedar también afectados por otras. Este criterio integrador o sistemático usado por el TEDH ha permitido establecer profundas correlaciones o conexiones recíprocas entre los derechos del Convenio, posibilitando el surgimiento de la protección de rebote. Las bases de esta construcción se deben a la extinta Comisión, en un caso relativo precisamente a la compatibilidad con el CEDH de las normas migratorias inglesas, donde señaló que "el rechazo de un derecho que no está en si mismo protegido por la Convención podría no obstante violar otro derecho ya incluido en este Tratado"156.

Esta argumentación tendría posteriormente una formulación más concreta ${ }^{157}$ en otro supuesto migratorio donde nuevamente se cuestionaba la legislación migratoria inglesa, el Asunto Abdulaziz, siendo éste el primer caso en materia de RF de los extranjeros fallado por el TEDH. En Abdulaziz tanto la Comisión como el Tribunal establecieron que "el derecho de un extranjero a entrar o permanencer en un país no está como tal garantizado por la Convención, pero los controles migratorios han de ser ejercidos en coherencia con las obligaciones del Convenio, y la exclusión de una persona de un Estado donde están viviendo miembros de su familia plantea una cuestión que atañe al art. 8 "158. Dando lugar, en la materia que nos ocupa, a la concepción de que, aunque los aspectos esenciales del derecho a entrar en un país miembro del Consejo de Europa se rigen por el Protocolo número 4 -en aquellos Estados que lo hayan ratificado- "no debe excluirse que medidas adoptadas en el campo de la inmigración puedan afectar al derecho al respeto a la vida familiar, garantizado por el artículo 8 "159.

Con esta forma de razonar el TEDH daba entrada en el CEDH al reconocimiento, bajo determinadas condiciones, de un derecho de permanencia de los extranjeros en el territorio de un Estado parte $^{160}$. Sin embargo, al sistema del CEDH le interesarán sólo los derechos migratorios — tanto el rechazo a su expulsión como la admisión de un no nacional obligando al Estado parte a autorizar su residencia - en la medida en que su rechazo pueda constituir una injerencia ilegítima o una falta de respeto en el derecho a la vida familiar de un extranjero cuyos lazos familiares se encuentran en el territorio del Estado contratante.

En el ámbito de la extranjería, entendiendo ésta en sentido amplio — no nacionales de los Estados partes, apátridas, asilados e incluso personas pendientes de un proceso de extradición, etc. - la protección de rebote ha conseguido una aplicación notable ${ }^{161}$, como consecuencia de la utilización del criterio de efectividad de los derechos en combinación con la interpretación evolutiva y teleológica. Pese a ello, la protección que el CEDH podía brindar a los derechos de los extranjeros - ausentes de su texto- se abriría paso lenta y accidentadamente, gracias fundamentalmente a la cons-

156 East African Asians case, App. №. 4403/70 etc (1981) EHRR 76. Informe adoptado por la Comisión Europea de Derechos Humanos, de 14 de diciembre de 1973.

157 CVETIC, Goran. "Immigration Cases in Strasbourg: The Right to Family Life Under Article 8 of the European Convention", en International and Comparative Law Quarterly, Vol. 36, N. 3, 1987, p. 648.

158 Asunto Abdulaziz, Cabales y Balkandali contra Reino Unido, de 28 de mayo de 1985, apartado 59.

159 Idem, apartado 60.

160 MARZAL YETANO, Elia. El proceso de constitucionalización del derecho de inmigración. Estudio comparado de la reformulación e los derechos de los extranjeros por os tribunales de Alemania, Francia y España. Derechos precarios y emergentes. Madrid, Dykinson, 2009, p. 251, la autora señala que el reconocimiento por parte del TEDH de un derecho de permanencia "en realidad modifica las estructuras básicas del Convenio. El Tribunal en efecto crea, a partir del marco general de su texto, y a pesar de la letra de su articulado, respuestas nuevas y específicas para el área de la inmigración", permitiendo "la emergencia de derechos inicialmente no previstos por los autores del Convenio".

161 MARZAL YETANO, Elia. La autora considera la extranjería y la inmigración como los ámbitos donde la protección de rebote o par ricocher ha conseguido una aplicación más amplia. 
trucción efectuada por la Comisión Europea de Derechos Humanos ${ }^{162}$, de la que será tributaria el TEDH, quien recogerá gran parte de las aportaciones de la Comisión.

Durante los primeros años de rodaje de la Comisión, eran consideradas inadmisibles ${ }^{163}$ las demandas que llegaban a ella alegando que una medida de política migratoria de un Estado parte orden de expulsión o devolución, prohibición de entrada o de residencia en el territorio de una Alta Parte Contratante - por suponer la ruptura simultánea de la vida familiar establecida en el territorio de dicho Estado, constituía una violación del derecho consagrado explícitamente en el artículo 8.1. La Comisión argumentaba que ni en el CEDH ni en sus Protocolos adicionales se otorgaba como tal ningún derecho a los extranjeros a entrar, permanecer o no ser expulsados del territorio de una Alta parte contratante del Convenio. Dicho derecho se examinaba aisladamente, con la finalidad de apreciar una apariencia de violación del mismo, como correspondía a esta fase inicial del procedimiento. En este punto, la Comisión recordaba que constituye un principio general del Derecho internacional sólidamente asentado, que el control de las fronteras es una materia ligada a la soberanía estatal y, por lo tanto, los Estados parte tienen derecho a regular y supervisar la entrada y permanencia de no nacionales en sus respectivos territorios, premisa que desde entonces ha permanecido inalterable en el ámbito de Estrasburgo ${ }^{164}$.

En consecuencia, la Comisión se declaraba incompetente para examinar la admisibilidad ${ }^{165}$ de las demandas que un particular incoaba ante este órgano por supuesta violación del derecho a la vida familiar como consecuencia de una medida de expulsión, de denegación de entrada o de residencia adoptada por un Estado miembro, en el cual vivían familiares cercanos al demandante. Dichas demandas eran consideradas incompatibles con las disposiciones del Convenio o manifiestamente mal fundadas $y$, por tanto, declaradas inadmisibles.

A finales de la década de la década de los cincuenta se produce un giro de importancia capital en la argumentación usada hasta el momento por la Comisión ${ }^{166}$. Tras repetir que la inmigración es una materia de soberanía estatal y que el Título I del Convenio no contempla ningún derecho de entrada o permanencia de no nacionales en el territorio de los Estados miembros, la Comisión afirmó por primera vez que:

"Sin embargo, en tanto que un Estado firma y ratifica el CEDH se entiende de acuerdo en restringir el libre ejercicio de los derechos que le corresponden conforme al derecho internacional, incluyendo el derecho a controlar la entrada y salida de extranjeros, con el alcance y dentro de los límites de las obligaciones que ha asumido bajo la Convención”167.

162 En el mismo sentido, ROGERS, Nicola. "Immigration and the European Convention on Human Rights: Are New Principles Emerging?"; en European Human Rights Law Review, No 1, 2003, p. 60.

163 ARRIAGA IRABURU, Inés. El derecho a la vida familiar de los extranjeros..., op. cit., p. 161.

164 MARZAL YETANO, Elia. El roceso de constitucionalización del derecho de inmigración..., op. cit. pp. 222-225.

$165 \mathrm{El}$ antiguo artículo $25 \mathrm{del} \mathrm{CEDH}$ delimitaba la competencia ratione materiae de la Comisión. Su párrafo $1^{\circ}$ establecía que "la Comisión podrá conocer de cualquier demanda dirigida al Secretario general del Consejo de Europa por cualquier persona física, organización no gubernamental o grupo de particulares, que se considere víctima de una violación, por una de las Altas Partes Contratantes, de los derechos reconocidos en el presente Convenio, en el caso de que la Alta Parte Contratante acusada haya declarado reconocer la competencia de la Comisión en esta materia. Las Altas Partes Contratantes que hayan suscrito tal declaración se comprometen a no poner traba alguna al ejercicio eficaz de este derecho".

166 Seguimos en este punto la argumentación de Inés ARRIAGA en la obra El derecho a la vida familiar de los extranjeros en la jurisprudencia de Estrasburgo. Pamplona, Eunsa, 2003, pp. 21-32.

167 Decisión sobre la admisibilidad X c/. Suecia. Traducción propia. Yearbook 1958-59, p. 335. 
Con ello la Comisión establecía la posibilidad de que el respeto a los derechos convencionales pueda desembocar en el establecimiento de ciertos condicionantes - indirectos - en las políticas migratorias internas que, en principio, forman parte de la soberanía estatal y, por tanto, de la discrecionalidad del Estado parte. De esta forma, el control estatal sobre sus fronteras no puede concebirse como un derecho absoluto, estando condicionado por los compromisos internacionales asumidos por el Estado y, de forma especial, por los límites derivados del respeto a los derechos consagrados en el CEDH.

Del tenor de esta decisión cabe afirmar que "del CEDH se derivaría para los Estados contratantes una restricción del derecho, reconocido por el Derecho internacional general, de controlar la entrada y salida de extranjeros. Por ello, una medida de control migratorio podrá, de este modo, ser considerada como violatoria de uno de los derechos proclamados en el CEDH, a pesar de la ausencia de proclamación explícita de derecho inmigratorio alguno. En otras palabras, con esta declaración la Comisión estableció un nexo entre los derechos inmigratorios y el derecho al respeto de la vida familiar protegido por el artículo 8 del CEDH"168.

La protección de rebote se afianza a lo largo de la década de los setenta en la argumentación de la Comisión, siendo admitida explícitamente en las Observaciones preliminares del informe emitido en el caso de los Asiáticos del Este Africano ${ }^{169}$. En él la Comisión estableció la conexión de causalidad entre la denegación de un derecho migratorio inexistente en la letra del Tratado de Roma y su efecto paralelo en la violación de un derecho explícito, al concluir que "aunque el derecho a entrar en un país no está protegido por la Convención, no obstante, el rechazo de este derecho puede, en ciertas circunstancias especiales, violar de forma independiente otro derecho ya cubierto por este tratado"170.

Con todo, la argumentación de la Comisión en el ambito de la migración durante esta época está marcada por la búsqueda de un lugar - cualquiera, pero distinto al Estado contratante - donde sea posible el establecimiento de la vida familiar de los extranjeros afectados, en cuya presencia se declara la inexistencia de violación del derecho consagrado en el artículo $8 \mathrm{CEDH}$-razonamiento que heredará el TEDH—; así como por "la posibilidad de la esposa de seguir a su marido"171, —incluso aunque ésta posea la nacionalidad de dicho Estado-, como un relevante factor para excluir la protección que la vida familiar pueda dispensar a los extranjeros.

Esta forma de razonar tenderá a repetirse desde entonces, hasta que el TEDH recoga el testigo y, en ausencia de la Comisión, se alce como instancia única para analizar los casos relativos a personas extranjeras que se hallan bajo la jurisdicción de los Estados parte y que alegan haber sido objeto de medidas restrictivas de su derecho al respeto de la vida privada y familiar y del domicilio, de medidas de expulsión o extradición que podían suponer un riesgo de torturas o tratos inhumanos o degradantes (artículo $3 \mathrm{CEDH}$ ) e incluso frente a injerencias medioambientales - todas ellas medidas estatales restrictivas, atentatorias de un derecho convencional, provocadas por la denegación

168 ARRIAGA IRABURU, Inés. El derecho a la vida familiar de los extranjeros..., op. cit., pp. 28-29.

169 En dicho Informe puede leerse que "la Comisión no ha discutido la cuestión general de si el rechazo de un derecho que no está en sí mismo protegido por el Convenio podría no obstante violar en ciertas circunstancias otro derecho ya incluido en este tratado. Sin embargo, admitiendo las presentes demandas al amparo del artículo 3 y otras disposiciones del Convenio, la Comisión implícitamente ha aceptado que la existencia de tal violación no queda excluida". Informe relativo al caso de los africanos del Este de Asia contra el Reino Unido, adoptado por la Comisión el 14 de diciembre de 1973 en aplicación de lo dispuesto en el antiguo artículo 31 del CEDH

170 Idem, párrafo 187. Citadto por ARRIAGA, I. El derecho a la vida familiar de los extranjeros..., op. cit., p. 54.

171 Aplicación N. 7816/77 X e Y c. Alemania. Citado por CVETIC, Goran. Immigration Cases in Strasbourg..., op. cit., p. 648. 
de un derecho que, en principio, no está contemplado en el Convenio y, pese a ello, potencialmente cubiertas por Estrasburgo.

De esta forma, a través de la protección de rebote, los derechos consagrados en el Convenio expanden su contenido, acogiendo "derechos indirectos derivados"172. Con la protección de rebote se da pues entrada en el texto de la Convención a los derechos implícitos. Éstos no están reconocidos expresamente en la letra de las disposiciones del Convenio, pero podrían considerarse derechos inherentes a su espíritu, ya que suponen un requisito o premisa indispensable para el disfrute del derecho explícitamente consagrado en el CEDH. Esta aproximación pone de relieve la íntima conexión existente entre el efecto útil, la protección de rebote y la interpretación teleológica o finalista del Convenio. De modo similar a lo que ocurre con el recurso a la protección de rebote, el criterio del efecto útil supone para los jueces integrantes del TEDH la exigencia de que intenten la maximización del derecho, pudiendo conducir a amplificar el contenido de éste y su ámbito de protección, esto es, a ampliar su "halo de incertidumbre".

\section{c) Las nociones autónomas}

El sistema regional de salvaguardia de los derechos humanos del Consejo de Europa se articula y superpone subsidiariamente sobre los sistemas nacionales de protección de los derechos fundamentales de los Estados miembros. Como su propio Preámbulo anuncia, la organización se basa en un patrimonio común de valores y tradiciones jurídicas, lo que indica que tanto los sistemas internos como el propio sistema del Consejo de Europa se basan en conceptos y categorías normativas relativamente comunes, pese a la heterogeneidad predicable de sus diversos sistemas jurídicos. De hecho, el propio entramado normativo del CEDH se inspira en los derechos internos y su articulado remite a la ley nacional en múltiples ocasiones ${ }^{173}$, por no mencionar que los métodos empleados por el TEDH reposan y son deudores de los empleados a su vez por los Tribunales Supremos y/o Constitucionales de los Estados parte ${ }^{174}$..

En su tarea de aplicación e interpretación de los términos, derechos, categorías e instituciones jurídicas recogidas en el Convenio de Roma ${ }^{175}$, el TEDH suele dotar a éstos de aquel sentido que resulte más conforme con el derecho interno de los Estados contratantes. Sin embargo, en aquellas circunstancias donde se enfrente a materias y categorías abiertas, en las que existen profundas divergencias entre los Estados miembros o donde la interpretación interna pueda excluir la aplicación de

172 ARRIAGA IRABURU, Inés. El derecho a la vida familiar de los extranjeros en la jurisprudencia de Estrasburgo, op. cit., p. 20.

$173 \mathrm{El}$ propio apartado segundo del artículo $8 \mathrm{CEDH}$ constituye un ejemplo de la remisión a la ley interna, al estipular que sólo cabe injerencia en el ejercicio del derecho reconocido en el apartado primero "en tanto en cuanto esta injerencia esté prevista por la ley”. Por otro lado, esta cláusula restrictiva es común a los derechos reconocidos en los artículos 8 a 11 del Convenio de Roma. Al respecto, Van Dijk y van Hoof han destacado que el reenvío a los requisitos fijados por las respectivas leyes internas de los Estados signatarios para la restricción de los derechos convencionales no es concebido por el TEDH como una remisión “completa y exhaustiva”, antes bien, el Estado de derecho exige que éstas cumplan con ciertos requisitos cualitativos - accesibilidad, previsibilidad, falta de arbitrariedad, entre otros-, lo que permite a los órganos de garantía del CEDH "ejercer un grado de control sobre el contenido de los estándares legales nacionales”. VAN DIJK, P.; VAN HOOF, G.J.H. Theory and Practice..., op. cit., 3ª ed., p. 77, traducción propia.

174 QUERALT JIMÉNEZ, Argelia. “Los usos del canon europeo en la jurisprudencia del Tribunal Constitucional: una muestra del proceso de armonización europea en materia de derechos fundamentales"; en Teoría y Realidad Constitucional, no 20, 2007, p. 454. GREWE, C. "Le Juge Constitutionnel et l'interprétation européenne”; en SUDRE, F (dir.). L'interprétation de la Convention Européenne des droits de l'homme. Bruselas, 1998, p. 200.

175 Artículo $32 \mathrm{CEDH}$. 
las garantías establecidas por el derecho convencional, poniendo en riesgo la eficacia del sistema del CEDH, el Tribunal de Estrasburgo dotará a dichos términos de un significado propio y autónomo y, por ende, independiente del que al mismo concepto se le atribuya en el derecho interno del Estado demandado. De este modo, la interpretación autónoma permite al TEDH — en caso de necesidadapartarse y desvincularse de las interpretaciones nacionales existentes sobre términos y derechos internos homólogos a los convencionales, "dotando de un contenido marcadamente europeo a su jurisprudencia"176.

Los criterios usados por los Estados signatarios para interpretar en sus respectivos ordenamientos nacionales aquellos derechos fundamentales que protegen valores equivalentes a los tutelados por los derechos consagrados por el Convenio de Roma no vinculan al TEDH, el cual puede y de hecho asigna a algunos de los derechos y términos convencionales significados propios. La calificación jurídica interna de los términos, instituciones y derechos convencionales constituye tan sólo un factor más a la hora de determinar la aplicabilidad del Convenio, un mero punto de partida, pero no es concluyente ${ }^{177}$, y por eso su valor ha sido calificado como formal o relativo por la jurisprudencia de Estrasburgo ${ }^{178}$. La utilización de conceptos autónomos abarca incluso aquellas cláusulas convencionales que remiten expresamente a la ley interna ${ }^{179}$ entre las que, como ya señalamos, se encuentra el artículo $8 \mathrm{CEDH}$.

Como consecuencia del juego de este principio interpretativo, las nociones autónomas construidas por la jurisprudencia del TEDH desalojan o desplazan la utilización de la noción interna equivalente, en la medida necesaria para el cumplimiento del CEDH, pasando a integrar el acquis conventionnel. De esta forma, cuando las autoridades internas apliquen el Convenio o lo utilicen a efectos interpretativos de sus derechos fundamentales internos, deberán utilizar la cláusula convencional con el alcance que autónomamente haya establecido el $\mathrm{TEDH}^{180}$, en el caso de que dicho alcance exista.

Una definición del criterio interpretativo autónomo puede encontrarse en la opinión disidente formulada por el juez Matscher en el Asunto König c. Alemania, de 28 de junio de 1978, para quien "la interpretación autónoma significa, sobre todo, que los preceptos de las convenciones internacionales no deben ser interpretados solamente por referencia al significado y alcance que poseen en el derecho interno del Estado parte, sino que deben referirse 'en primer término, a los objetivos y al esquema de la Convención y, en segundo lugar, a los principios generales que emanan del corpus de los sistemas legales nacionales'. Dicho en otras palabras, uno debe buscar el 'común denominador' que subyace a los preceptos en cuestión, ya que es legítimo suponer —en ausencia de una definición legal en la propia Convención- que ese es el significado que los Estados parte desearon que tuviesen las disposiciones. El 'común denominador' puede ser identificado mediante el análisis del derecho interno de los Estados parte. No obstante, el resultado de tal investigación nunca podrá llegar a ser un concepto que esté totalmente en asintonía con el sistema legal del Estado parte concernido".

De esta definición conviene resaltar dos aspectos importantes. De un lado, evidencia las dificultades implícitas a la interpretación autónoma, que sitúa al TEDH ante la necesidad de hallar una "in-

176 SAIZ ARNAIZ, A. La apertura constitucional...., op. cit., p. 142.

177 LEACH, Philip. Taking a case to the European Court of Human Rights. Oxford University Press, $2^{\mathrm{a}}$ edic., p. 165.

178 "In this connection, it is first necessary to know whether the provision(s) defining the offence charged belong, according to the legal system of the respondent State, to criminal law, disciplinary law or both concurrently. This however provides no more than a starting point. The indications so afforded have only a formal and relative value and must be examined in the light of the common denominator of the respective legislation of the various Contracting States". STEDH Engel and others v. The Netherlands, de 8 de junio de 1976, párrafo 82.

179 QUERALT JIMÉNEZ, Argelia. La interpretación de los derechos: del Tribunal de Estrasburgo al TC, op. cit., p. 112. 180 Idem, p. 114. 
terpretación de mayoría"181, esto es, de búsqueda del denominador común a las prácticas y legislaciones internas en la materia. Ello se traduce en una investigación de derecho comparado ${ }^{182}$, si quiera somera, para averiguar la realidad jurídica existente en el momento en que la norma convencional que reclama una interpretación autónoma ha de ser aplicada. Por otro lado, este concepto revela la íntima conexión existente entre el criterio interpretativo autónomo y la interpretación evolutiva y teleológica, abocadas a entenderse e interaccionar mutuamente.

La atribución de un significado propio a determinados términos y derechos convencionales no constituye una facultad explícitamente conferida al TEDH por las disposiciones del CEDH. El propio TEDH lo enmarca como un criterio derivado del objeto y finalidades específicas del Convenio de Roma ${ }^{183}$. A nuestro juicio, la naturaleza de este criterio puede descubrirse mejor atendiendo a los propósitos que viene a cumplir, entre ellos:

- Su finalidad principal es la protección de los derechos convencionales, evitando que la interpretación del concepto usada por el Estado nacional pueda ser utilizada como un subterfugio para eludir la aplicación del CEDH y marginar la protección que éste otorga. Por ello, cabría considerarlo como una manifestación o una consecuencia del principio de efectividad o del efecto útil ${ }^{184}$, encaje que parece congruente con la argumentación ofrecida por el $\mathrm{TEDH}^{185}$. En este sentido, Delmas-Marty afirma que cuando los órganos de Estrasburgo reivindican una interpretación autónoma "lo hacen expresamente para evitar una interpretación nacional restrictiva que podría eludir la aplicación de una u otra cláusula del CEDH"186, calificando este criterio interpretativo como una herramienta necesaria a fin de poder oponerse y "resistir a cualquier forma de fraude a la Convención”187.

$181 \mathrm{Al}$ respecto DELMAS-MARTY afirma que la búsqueda de una interpretación de mayoría determina, en sí misma, la aparición de un nuevo problema de determinar y valorar la voluntad mayoritaria, en particular de optar entre una "mayoría cuantitativa" - situación prevalente en la mayoría de los Estados miembros- o bien, una "mayoría cualitativa" -que tendría en cuenta "una mayoría ideal de Estados iluminados que presentan el standard más elevado de tutela de los derechos del hombre”. Op. cit., p. 312. Traducción propia.

182 Múltiples votos particulares a las sentencias del TEDH han puesto en evidencia que, en este ejercicio de derecho comparado, el Tribunal realiza una investigación insuficiente y excesivamente sumaria, llegando a calificar de peligroso el razonamiento. El juez Matscher, tras aportar la definición de interpretación autónoma analizada, afirma en el mismo voto disidente a la sentencia Öztürk c. Alemania, que "autonomous interpretation would call for comparative studies of a far more detailed nature than tose carried out so far by the Convention institutions". Similares consideraciones en torno a los problemas metodológicos derivados de la utilización del criterio interpretativo autónomo realiza el mismo juez en su voto particular a la sentencia König c. Alemania, de 28 de junio de 1978.

183 Vid, entre otras, STEDH Öztürk v. Germany, de 21 de febrero de 1984, apartado 49. En esta línea se inscriben autores como VAN DIJK y VAN HOOF. Theory and Practice..., op. cit., nota a pie de página $\mathrm{n}^{\circ} 17$.

184 VAN DIJK, P. VAN HOOF, G.J.H. Theory and Practice..., op. cit., 3a edic, p. 77. En el mismo sentido, Val Garijo, quien considera que "esta facultad del TEDH para elaborar conceptos jurídicos propios y autónomos respecto de los Derechos internos es esencial para que los magistrados de Estrasburgo puedan cumplir con eficacia su función de protección de los derechos humanos". VAL GARIJO, F. "Los conceptos autónomos en la jurisprudencia del Tribunal Europeo de Derechos Humanos como límites a la soberanía estatal. Comentario a la sentencia del TEDH de 21 de diciembre de 2006, asunto. Borisova c. Bulgaria"; en Revista General de Derecho Europeo, n 12, 2007, p. 1.

185 La vinculación de las nociones autónomas como recurso interpretativo que refuerza la efectividad del sistema del CEDH late detrás de algunas de las argumentaciones del TEDH. En palabras del propio Tribunal de Estrasburgo, "si los Estados contratantes pudieran discrecionalmente calificar una infracción de disciplinaria en lugar de criminal o perseguir al autor de una infracción 'mixta' disciplinariamente con preferencia a la vía penal, el juego de las cláusulas fundamentales de los artículos 6 y 7 se encontraría subordinado a su voluntad soberana. Una laxitud tan amplia conlleva el riesgo de llevar a resultados incompatibles con el fin y el objetivo del Convenio". STEDH Engel and others v The Netherlands, de 8 de junio de 1976, apartado 34.

186 DELMAS-MARTY, M. Verso un'Europa dei diritti dell'uomo. Ragione di Stato e diritti umani nel sistema della Convenzione europea. Padova, Cedam, 1994, p. 313.

187 Ídem. p. 324. 
- Adicionalmente, el recurso a la interpretación autónoma de determinados conceptos y derechos convencionales constituye un importante instrumento para reforzarla independencia funcional del TEDH ${ }^{188}$.

- Evita la excesiva heterogeneidad interpretativa, constituyendo una herramienta favorecedora de la igualdad de las obligaciones dimanantes del CEDH para los Estados miembros ${ }^{189}$.

- Es un factor que denota y simultáneamente refuerza el carácter supraestatal del TEDH ${ }^{190}$, permitiendo poner lindes a la soberanía estatal. Por ello, los conceptos autónomos, siguiendo a Val Garijo, se erigen en límites materiales, - y no meramente formales-, a la voluntad soberana de los Estados miembros del Consejo de Europa ${ }^{191}$.

- Constituye, además, una técnica que fomenta el carácter creativo de la jurisprudencia del TEDH, permitiéndole el desarrollo de los derechos convencionales por vía interpretativa, lo que sitúa esta directriz interpretativa dentro de aquellas que tienden a promocionar el activismo judicial ${ }^{192}$ del TEDH.

- La interpretación autónoma posee un efecto visible al mediano y largo plazo, y por lo tanto de carácter paulatino, pues, a nuestro juicio, puede actuar como un factor propulsor de la convergencia entre las prácticas y legislaciones internas de las Altas partes contratantes, promoviendo un entendimiento común en torno a los derechos fundamentales en el ámbito europeo, sin por ello llegar a la uniformidad ${ }^{193}$. Delmas-Marty ha resaltado que los contextos en que el TEDH invoca una lectura autónoma del texto del Convenio de Roma presuponen la

188 VAL GARIJO, F. “Los conceptos autónomos en la jurisprudencia del TEDH...”, Op. cit., pp. 11-13.

189 OST, François. Originalitá dei metodi di interpretazione della Corte Europea del Diritti dell'Uomo; en DELMASMARTY, Mireille (coord.). Verso un'Europa dei diritti dell'uomo..., op. cit., p. 312. QUERALT JIMÉNEZ, A. La interpretación de los derechos..., op. cit., p. 112.

190 "Privado del poder de forjar conceptos jurisprudenciales autónomos, el TEDH quedaría vinculado por los legisladores y tribunales internos, perdiendo una autonomía jurídico-funcional que es imprescindible, en la teoría y en la práctica, para ejercer con eficacia su tarea de protección y garantía de los derechos humanos y las libertades fundamentales proclamados en el CEDH". VAL GARIJO, F. "Los conceptos autónomos en la jurisprudencia del TEDH...", Op. cit., p. 11.

191 VAL GARIJO, Fernando. "Los conceptos autónomos...”, op. cit., pp. 13-14. A modo de ejemplo de esta funcionalidad de las nociones autónomas, este autor señala que "el concepto de acusación en materia penal, en particular, constituye un límite material al poder sancionador del Estado, que no puede configurarse autónomamente como penal, administrativo o disciplinario sin atender a los contenidos básicos del concepto de materia penal establecido por el TEDH". Este mismo autor destaca el carácter derivado o secundario de los conceptos autónomos, entendidos como límites a la soberanía estatal. Su carácter derivado se debe al hecho de que las nociones autónomas no derivan directamente del Convenio, sino que suponen una construcción del TEDH apoyándose en los preceptos de éste. Subraya así mismo este autor que no existe ninguna norma específica que atribuya al TEDH el poder de dotar a los términos convencionales de un significado autónomo, pero lo considera una facultad implícita a la función que el artículo 32 CEDH otorga al TEDH de interpretación y aplicación del mismo.

192 MAHONEY, Paul. "Judicial Activism and Judicial Self-Restraint in the European Court of Human Rights: Two Sides of the Same Coin”; en Human Rights Law Review, 1990, vol.11. pp. 57-88. A una conclusión similar parece llegar de forma indirecta Revenga Sánchez quien, al estudiar el margen de apreciación estatal, afirma que "el campo en el que el TEDH afianzó decididamente su activismo fue el del análisis de cuestiones relativas a las garantías del proceso legal (arts. 5 y 6 del Convenio)". En su estudio, el autor citado subraya la existencia de dos tendencias contradictorias en la jurisprudencia emanada del TEDH, de un lado aquella que tiende al activismo judicial, de otro aquella que, potenciando el margen de apreciación estatal, sitúa a este órgano en una postura respetuosa con la soberanía estatal, de autocontención judicial, de ahí que hable del "dilema activismo/autocontención”. REVENGA SÁNCHEZ, Miguel, Seguridad Nacional y Derechos Humanos. Estudios sobre la jurisprudencia del Tribunal de Estrasburgo. Navarra, Aranzadi, 2002, p. 60.

193 En esta línea se inscribe QUERALT JIMÉNEZ, quien sitúa los conceptos autónomos entre los criterios interpretativos tendentes a la armonización del estándar europeo. La interpretación de los derechos: del Tribunal de Estrasburgo al TC, op. cit., pp. 111-112. 
ausencia de un consenso europeo en dicho ámbito y, por lo tanto, el punto de partida consiste precisamente en materias sobre las que abunda la disparidad normativa, interpretativa y de prácticas entre los Estados miembros ${ }^{194}$. En estos supuestos, el TEDH no se verá atado por las diversas interpretaciones internas - de no ser así se correría el riesgo de privar de eficacia al sistema y a la labor efectuada por el TEDH- y acudirá a la fórmula autónoma para proveerse de cierta libertad de actuación. En la búsqueda de la interpretación más adecuada para la eficacia del Convenio, una libertad absoluta pondría en riesgo su propia autoridad moral y el cumplimiento estatal de las obligaciones estatales convencionales, de ahí que el Tribunal intentará hallar la fórmula interpretativa del término en cuestión que mejor aprehenda la existencia de un cierto denominador común a la disparidad existente. La introducción de la noción autónoma se irá convirtiendo gradualmente en el germen reductor de los contrastes internos, impulsando cierta convergencia normativa en la materia concreta sobre la que se despliega. De este modo, partiendo de una situación de disparidad inicial, la noción autónoma y su progresivo asentamiento a través del case-law estrasburgués, irán generando un diálogo interestatal que fraguará en un consenso normativo cada vez mayor. De hecho, ya se ha destacado que "la utilización por el TEDH de los conceptos autónomos ha favorecido determinantemente el fenómeno de la armonización del estándar europeo en este escenario heterogéneo ya que aquellos permiten dotar de un contenido y alcance propio a los elementos configuradores de los derechos y libertades convencionales, con independencia de cual sea su reconocimiento (en ocasiones, inexistencia) y alcance en los sistemas internos de garantía"195. Es importante resaltar que este efecto será observable especialmente con el paso del tiempo, ya que el TEDH, inserto en una difícil tensión de protección de derechos frente a la soberanía estatal, habrá de actuar con prudencia, sin incurrir en saltos al vacío que puedan erosionar la soberanía estatal y por ello provocar resistencias de los Estados parte.

Las dificultades inherentes a este principio interpretativo que sitúa al TEDH en una posición de búsqueda de un delicado equilibrio entre la protección de los derechos convencionales y el respeto a la soberanía estatal, reclamando prudencia en su actuación, explican que las nociones autónomas no abunden ${ }^{196}$ en el ámbito del CEDH. Pero junto a su relativa escasez, hay que resaltar la centralidad de las materias sobre las que recaen, esenciales para la protección del individuo frente a los poderes públicos ${ }^{197}$. Términos convencionales tales como derecho civil o acusación en materia penal incluidos en el artículo $6 \mathrm{CEDH}$, en el marco del derecho a un proceso equitativo, o el de asociación del artículo 11, así como la posesión reconocida en el artículo 1 del Protocolo no 1 del CEDH, han sido forjados por el TEDH como conceptos autónomos del Convenio.

El significado autónomo de estos términos supone una cierta alteración de la regla interpretativa general que, en materia de convenios internacionales, estipula que éstos han de interpretarse

194 A este presupuesto de heterogeneidad que actúa como detonante para la utilización de las nociones autónomas, QUERALT JIMÉNEZ añade también el supuesto de que las nociones convencionales sean ajenas a alguno de los sistemas internos. Idem, p. 112.

195 QUERALT JIMÉNEZ, Argelia. "Los usos del canon europeo en la jurisprudencia del Tribunal Consittucional.....”, op. cit., p. 468.

196 VAL GARIJO, F. “Los conceptos autónomos en la jurisprudencia del TEDH...”, op. cit., p. 11.

197 En este sentido, DELMAS-MARTY ha señalado que "la praxis de la interpretación autónoma permite la defensa de aquellos baluartes que el TEDH considera esenciales. De este modo vienen negociados, al sucederse las sentencias, la salvaguardia y el desarrollo de las libertades fundamentales". Verso un'Europa dei diritti dell'uomo. ..., op. cit., p. 320 , traducción propia. 
"conforme al sentido corriente que haya de atribuirse a los términos del tratado" —artículo 31.1 Convención de Viena sobre el Derecho de los Tratados- ${ }^{198}$.

Por su importancia para nuestro objeto de estudio, es obligado identificar dos de estos conceptos autónomos: la vida familiar y la noción de víctima en la Convención de Roma. De un lado, la Comisión Europea en su informe relativo al caso Marckx contra Bélgica, de 10 de diciembre de 1977, consideró que la vida familiar protegida por el artículo 8.1 constituye un concepto autónomo ${ }^{199}$ y, por ende, de interpretación independiente al derecho interno de los Estados miembros. Esta conclusión es perfectamente coherente con el carácter de la familia como una institución culturalmente condicionada y por ello variable histórica y geográficamente, lo que nos sitúa en un terreno propicio para la divergencia de prácticas y normativas internas, hipótesis que, como vimos, podía actuar como detonante de la interpretación autónoma.

Y, de otro, el concepto de víctima necesario para ostentar legitimación activa para entablar demandas ante el TEDH, es también una noción autónoma. El concepto de víctima designa a la persona directamente afectada por el acto o la omisión objeto del litigio ${ }^{200}$, siendo indiferente para el mismo la existencia o no de perjuicios o daños. Basta pues para ser víctima a efectos del CEDH una afectación directa y personal, lo que legitima incluso a que personas afectadas en sus derechos convencionales por la legislación interna de un Estado, aunque todavía no hayan sufrido actos concretos aplicativos de la misma, puedan dirigir sus demandas ante el TEDH. Como veremos más adelante, la noción de víctima legitimada para incoar demandas individuales en supuestos específicos donde se alegaba la violación estatal del derecho a la vida familiar ha sido interpretada de forma realista ${ }^{201}$ por la Comisión y el Tribunal, ampliando así el ámbito protector ofrecido por el artículo 8.1 CEDH.

Lo que interesa destacar en nuestro trabajo es la cuestión de si, en el ámbito del derecho al respeto de la vida familiar de los extranjeros asentados en el territorio de los Estados partes, la noción autónoma de familia actúa como límite material a la potestad soberana de los Estados de regular las cuestiones migratorias en dos aspectos: De un lado, como límite a la potestad disciplinaria estatal en materia de extranjería (protección frente a ciertas expulsiones de extranjeros, dentro del marco de la obligación negativa que asumen los Estados, al suscribir el Convenio, de no interferir en la vida familiar de las personas sometidas a su jurisdicción); de otro, como límite y condicionante —en sentido inverso al anterior, esto es, en sentido amplificador - de la potestad soberana de regular la admisión y entrada de no

198 Esta es la interpretación proporcionada por VAN DIJK y VAN HOOF. Theory and Practice... op. cit., $3^{\mathrm{a}}$ edic, p. 77. 199 Citado por VAN DIJK y VAN HOOF. Theory and Practice..., op. cit., Última ed., 2006, p. 690.

200 Asunto Paula y Alexandra Marckx c. Bélgica, STEDH, párr., 27. La peculiaridad de este supuesto es que las demandantes resultaban directamente afectadas por la legislación belga que denunciaban, pero todavía no se habían producido actos concretos de aplicación de la misma. Es decir, alegaban la incompatibilidad abstracta con el CEDH de la legislación belga reguladora de la filiación materna extramatrimonial y de la situación jurídica discriminatoria por ella creada, lo que supondría, de aceptarse, situar al TEDH en una posición muy próxima a una jurisdicción constitucional de ámbito supranacional. Por ello, una de las cuestiones preliminares que tuvo que abordar el Tribunal era si las demandantes ostentaban legitimación activa, esto es, si podían considerarse víctimas a la luz del CEDH, precisando al efecto dicho concepto. Frente a la alegación del gobierno demandado de que el Tribunal era incompetente para el conocimiento del asunto puesto que los problemas suscitados por las demandantes eran puramente teóricos, el TEDH afirma su competencia. El argumento usado por el TEDH es que en este asunto no se trataba de examinar en abstracto la legislación impugnada, sino de conocer las reclamaciones de particulares contra una ley que, por sí misma, vulneraba sus derechos, para lo cual bastaba con el hecho de que los particulares corriesen el riesgo de verse directa y personalmente afectados por esa ley, incluso aun cuando no hayan sufrido todavía perjuicios o daños, dado que todavía no se habían producido actos particulares de ejecución de la misma. En el caso en cuestión, el Tribunal de Estrasburgo concluyó que las demandantes ostentaban legitimación para presentarse como víctimas de las violaciones de derechos que alegaban.

201 ARRIAGA IRABURU, I. El derecho a la vida familiar de los extranjeros...., op. cit., p. 40. 
nacionales en su territorio, dentro del marco de la obligación positiva que pesa sobre los Estados parte de permitir el desarrollo de la vida familiar (dando así entrada, de forma colateral, a la reunificación familiar dentro del ámbito del artículo 8). De los dos aspectos mencionados, sólo el segundo será objeto de atención en el presente trabajo. Se tratará fundamentalmente de observar cómo y en qué medida la noción autónoma de familia elaborada por el TEDH actúa como límite material condicionante de la definición interna de un elemento integrante del núcleo básico de la soberanía estatal, como es la inmigración, estableciendo ciertos topes frente a la libertad de los poderes internos de regular la admisión de no nacionales a fin de que puedan reunirse con inmigrantes asentados en su territorio.

Pero para poder responder a esta cuestión, es obvio que ha de acudirse a la jurisprudencia emanada en aplicación del artículo $8 \mathrm{CEDH}$ y ello forma parte del último apartado de este Capítulo, a cuya lectura nos remitimos.

En síntesis, la plena efectividad de los derechos del Convenio exige dotar a alguno de los términos y derechos en él recogidos de un significado autónomo y, como tal, independiente al que en los respectivos derechos internos de las Altas partes contratantes se otorgue a nociones equivalentes, de ahí que hayamos optado por incluir su estudio como una manifestación del principio del efecto útil. En el ámbito de los derechos convencionales los conceptos autónomos sirven pues para evitar que el recurso a las nociones internas equivalentes pueda vaciar de contenido los derechos convencionales, potenciando la eficacia normativa del sistema del CEDH. El TEDH la reclamará en aquellas situaciones donde el término jurídico interno - que, como vimos forma parte integrante del margen de apreciación nacional - se constituya como una camisa de fuerza que evite el despliegue protector del Convenio de Roma. Por ello, y en esta misma medida, las nociones autónomas, - que no abundan en el ámbito del Convenio-, sirven para imponer restricciones a la potestad soberana de los Estados nacionales integrantes del Consejo de Europa en aquellas materias específicas sobre las que se despliegan. Para nuestro objeto de estudio, será de especial trascendencia descubrir la potencialidad de la noción autónoma de la familia para imponer, en determinadas circunstancias, ciertos límites materiales sobre la potestad soberana estatal de regular la entrada de familiares no nacionales de extranjeros asentados en su territorio.

\subsection{Principio de interpretación evolutiva}

Se trata de un principio interpretativo íntimamente ligado al criterio teleológico. Puede encontrarse cierto fundamento al uso de este principio en el propio Preámbulo del Convenio, donde se hace referencia expresa a la salvaguardia y desarrollo de los derechos del hombre como una de las finalidades del sistema protector. La palabra desarrollo imprime al sistema del Consejo de Europa de un dinamismo evolutivo, pues parece apuntar a una visión del Convenio como un punto de partida ${ }^{202}$.

Tanto la Comisión como el TEDH han considerado al CEDH como un instrumento vivo ${ }^{203}$, que ha de interpretarse a la luz de las circunstancias actuales y de las concepciones dominantes en

202 En el mismo sentido, CARRILLO SALCEDO, al comentar el Preámbulo del Convenio, considera que la referencia que allí hacen los gobiernos de los Estados signatarios, al declararse resueltos a "tomar las primeras medidas adecuadas para asegurar la garantía colectiva de algunos de los derechos enunciados en la Declaración Universal” desvela que "el Convenio no fue concebido como algo definitivo, sino por el contrario, como un primer paso y un punto de partida en el desarrollo progresivo del reconocimiento y protección internacionales de los derechos humanos". El Convenio Europeo ...., op. cit., p. 19.

203 En un caso donde se juzgaba si la pena de azotes que en los años setenta todavía se aplicaba en la Isla de Mann como castigo judicial, constituía un trato inhumano y degradante a la luz del artículo 3 del Convenio de Roma, el Tribunal afirmó que: "hay que señalar que una pena no deja de ser degradante por el mero hecho de que se considere que es 
nuestros días en los Estados democráticos. Con ella la Corte aplica a una impronta dinámica a los derechos del Convenio, más que histórica ${ }^{204}$. Esta aproximación a los derechos convencionales por parte del TEDH se observa en muchas de sus sentencias.

El criterio evolutivo, a nuestro juicio, resulta de particular relevancia en una materia como la vida familiar en la que, como vimos, los condicionantes culturales e históricos son muy poderosos. Esto explica que la interpretación evolutiva o dinámica sea habitualmente usada en el case law de Estrasburgo relativo a la interpretación del respeto a la vida familiar, siendo ello patente desde el principio. En la sentencia que marca el case-law en esta materia, Paula y Alexandra Marckx contra Bélgica ${ }^{205}$, el Tribunal, al examinar la posible violación del artículo 14 en relación con el artículo 8 CEH por parte de determinados artículos del Código Civil Belga que otorgaban un tratamiento más favorecedor a los hijos legítimos respecto a los naturales, resta importancia a las concepciones dominantes en la época de los redactores del Convenio, señalando:

\begin{abstract}
"Es cierto que en la época en que el Convenio de 4 de noviembre de 1950 se proyectó era frecuente y acorde al Derecho en muchos países europeos establecer distinciones de este tipo entre la familia ilegítima y la legítima. Sin embargo, el Tribunal recuerda que el Convenio debe ser interpretado a la luz de las circunstancias actuales. En el presente caso, el Tribunal no puede dejar de tener en cuenta que la gran mayoría de los ordenamientos jurídicos de los países miembros del Consejo de Europa han evolucionado y continúan haciéndolo, junto con los más importantes documentos internacionales, hacia el pleno reconocimiento jurídico de la máxima "mater semper certa est" ${ }^{206}$.
\end{abstract}

Uno de los criterios utilizados por el TEDH para interpretar sus disposiciones de forma dinámica y conforme a las concepciones existentes en el momento de su aplicación, es el estado de la materia en cuestión en la evolución de las legislaciones internas de los Estados parte, esto es, la evolución normativa y social de la cuestión de que se trate en el ámbito de los Estados miembros del CEDH. A través de la interpretación evolutiva, el TEDH hace evolucionar el Convenio al compás de los avances legislativos, sociales, científicos y de mentalidades que se van produciendo en los Estados miembros.

Del examen de la jurisprudencia emanada en la interpretación de la vida familiar cabría dar un paso más y afirmar que, en uso de la interpretación evolutiva, el Tribunal parece anticiparse a su época y situarse en una posición de vanguardia, alineándose con los países europeos que cuentan con legislaciones internas más progresistas en materia familiar ${ }^{207}$, aunque habitualmente los avances

un medio eficaz de disuasión o de lucha contra la delincuencia o de que realmente lo sea. Sobre todo, el Tribunal tiene que insistir en ello, no se puede nunca admitir que se impongan penas opuestas al artículo 3, cualesquiera que sean sus efectos disuasivos. El Tribunal recuerda además que el Convenio es un instrumento vivo que hay que interpretar -la Comisión lo ha puesto de manifiesto debidamente a la vista de las actuales condiciones de vida. En este caso, el Tribunal no puede dejar de estar influido por la evolución y las normas generalmente aceptadas de la política penal de los Estados miembros del Consejo de Europa en esta materia". Sentencia Tyrer contra el Reino Unido de Gran Bretaña e Irlanda del Norte, de 25 de abril de 1978, párrafo 31.

204 LEACH, Philip. Taking a Case to the European Court of Human Rights. New York, Oxford University Press, Blackstone's Human Rights Series, second sedition, 2005, p.164.

205 Esta sentencia es calificada por Miguel Revenga Sánchez como un notable ejemplo de jurisprudencia evolutiva, "apoyada en la (presunta) transformación de las concepciones morales a nivel transnacional". REVENGA SÁNCHEZ, M. Seguridad nacional y..., op. cit., p. 63.

206 Marckx c. Bélgica, STEDH de 13 de junio de 1979, párrafo 41.

207 Esta afirmación puede constatarse, a título de ejemplo, en la sentencia ya citada, Marckx c. Bélgica, donde el Tribunal declaró tajantemente que constituía una discriminación basada en el nacimiento y, por tanto, contraria al artículo 14 $\mathrm{CEDH}$, la distinción que la legislación belga efectuaba entre hijos legítimos e ilegítimos. En la sentencia el Tribunal expone las diferencias legislativas que, en la época de redacción de la sentencia, existían entre los Estados signatarios del Convenio respecto a la regulación de la filiación legítima e ilegítima. Pese a ser consciente de que los países Euro- 
jurisprudenciales del Tribunal de Estrasburgo se producen tras constatar éste la existencia de una opinión mayoritaria entre los Estados parte y el derecho internacional ${ }^{208}$.

La interpretación evolutiva relativiza criterios interpretativos tradicionales, tales como la interpretación histórica y determina que, conforme avance el tiempo, la importancia de conocer la ratio de los preceptos del CEDH y de sus trabajos preparatorios sea menor o, al menos, puramente anecdótica, sin olvidar que en muchas ocasiones acudir al criterio histórico no ofrece respuestas, debido fundamentalmente al laconismo de los trabajos preparatorios ${ }^{209}$.

Otro efecto del uso de este criterio hermenéutico reside en que provoca un ensanchamiento de las facultades que constituyen el contenido de los derechos convencionales. De hecho, tal ha sido la importancia de este criterio que el mismo constituye, "la segunda vía de expansión del contenido del catálogo de derechos y libertades recogidos en la Convención de Roma"210. En este sentido, el recurso habitual a esta técnica en la interpretación del artículo $8 \mathrm{CEDH}$ ha determinado que la vida familiar haya conocido una ampliación inesperada, sirviendo para proteger situaciones jurídicas y, por tanto, derechos implícitos, para los que en principio el precepto no fue concebido, de los que a título ejemplificativo cabe mencionar la protección de derechos vinculados al medio ambiente, como el ruido, y la propia RF de los extranjeros.

El uso por parte del TEDH del principio evolutivo denota de un lado un saludable pragmatismo que protege su propia respetabilidad. La variabilidad histórica de la vida familiar determinaría que, de no adoptar el Tribunal Europeo un criterio como éste, podría correr el riesgo de petrificar las disposiciones del Convenio como consecuencia del distanciamiento que el paso del tiempo habría impreso sobre los derechos proclamados. Por otro lado, la utilización de la interpretación evolutiva se erige en un mecanismo de supervivencia adaptativo usado para textos normativos con vocación de permanencia temporal, lo que de nuevo aboca a la dimensión constitucional del CEDH. De hecho, evoca la doctrina norteamericana sobre la living Constitution, de particular importancia en un texto constitucional caracterizado por su longevidad.

Pero, simultáneamente, el recurso al criterio evolutivo desemboca en una línea de activismo judicial $^{211}$ que no está exenta de problemas, especialmente cuando se aplica a una materia como la familia, cuya configuración jurídica depende en gran medida del derecho interno ${ }^{212}$. El carácter culturalmente condicionado de la familia eleva los riesgos ${ }^{213}$ inherentes al uso de la interpretación evolutiva.

peos que habían adoptado nuevas normativas tendentes a la equiparación total entre hijos matrimoniales y naturales no eran siquiera la mayoría, estadísticamente hablando, opta por la solución más progresista y protectora.

208 QUERALT JIMÈNEZ, Argelia. La interpretación de los derechos...., op. cit., p. 116.

209 EISSEN, Marc-André. El Tribunal Europeo de Derechos Humanos, op. cit., p. 94.

210 RIPOL CARULLA, Santiago. El sistema europeo de protección..., op. cit., p. 32.

211 MAHONEY, Paul. "Judicial Activism and Judicial Self-Restraint in the European Court of Human Rights: Two Sides of the Same Coin”; en Human Rights Law Review, 1990, vol.11, pp. 57-88.

212 Estos riesgos fueron señalados por el juez Morenilla en la opinión disidente que formuló a la sentencia Kroon c. Holanda, de 27 de octubre de 1994. En ella Morenilla afirmó que: “This principle of 'evolutive and creative' interpretation, which allows the Convention to be adapted to the changing circumstances of our democratic societies, thus making it 'a living instrument', means however that in practice the Court is confronted with a difficult dilemma: that 'of guarding against the risk of exceeding its given judicial role of interpretation by overruling policy decisions taken by elected, representative bodies who have the main responsibility in democratic societies for enacting important legislative changes, whilst not abdicating its own responsibility of independent review of governmental action".

213 En idéntico sentido se pronunció el juez Morenilla, en la opinión disidente formulada a la sentencia Kroon y otros contra Países Bajos, de 27 de octubre de 1994: “This dilemma is even greater in matters such as marriage, divorce, filiation or adoption, because they bring into play the existing religious, ideological or traditional conceptions of the 


\subsection{El margen de apreciación estatal}

La doctrina del margen estatal de apreciación constituye una técnica importada de los métodos internos de revisión judicial de la acción del gobierno, especialmente en el ámbito del Consejo de Estado Francés ${ }^{214}$. Su importancia en la jurisprudencia del TEDH es clave, hasta el punto de "desplegar un papel central en la mayor parte de los casos decididos por el Tribunal" 215 y es especialmente relevante para nuestro objeto de estudio.

$\mathrm{Al}$ igual que ocurría con las nociones autónomas, este criterio ordena las relaciones y distribuye el reparto de funciones entre los órganos del Consejo de Europa y los Estados signatarios. Sin embargo, a diferencia de los conceptos autónomos, el margen de apreciación estatal constituye una doctrina de autocontención judicial, que fue diseñada para hacer frente al problema de la relación entre la soberanía nacional de los Estados parte y los poderes de supervisión del Convenio, a fin de "inhibir a los órganos de Estrasburgo de intervenir en asuntos estatales con demasiada frecuencia y amplitud"216.

Bajo el esquema del CEDH, el Tribunal Europeo de Derechos Humanos tiene asignada la función de supervisar el cumplimiento por los Estados Parte de las obligaciones derivadas de los derechos humanos protegidos en dicho tratado. Ello en el entendido de que, como indican los artículos 1 y 19 de la Convención, los Estados Parte son los primeros obligados en hacer cumplir, —a través de sus instituciones internas y en sus respectivos territorios-, las obligaciones del Convenio con respecto a los derechos y libertades en éste consignados, pues el sistema del Consejo de Europa actúa sometido al principio de subsidiariedad. Como antes se dijo, cada Estado puede y debe, en uso de su soberanía, desplegar la protección del Convenio en el ámbito del Derecho e instituciones internas. Cada Estado Parte goza pues de un cierto margen de apreciación.

Como Van Dijk y Van Hoof han puesto de manifiesto, la percepción que los órganos de Estrasburgo tienen de sus poderes de supervisión parte de la constatación de la naturaleza subsidiaria ${ }^{217}$ del

family in each community. The majority of my colleagues have, however, considered there to be a "positive obligation" incumbent on the Netherlands to recognize the right of the natural father to challenge the presumption of the paternity of the legal father (the husband of the mother), thus giving priority to biological ties over the cohesion and harmony of the family and the paramount interest of the child. In my opinion, this conclusion involves a dangerous generalization of the special circumstances of the instant case and one which imposes on the Contracting States an obligation not included in the text of Article 8 (art. 8), based on changeable moral criteria or opinions on social values".

214 MACDONALD, Ronald St. John. "The Margin of Appreciation in the Jurisprudence of the European Court of Human Rights"; en International Law at the time of its Codification, Essays in honour of Judge Roberto Ago, vol. III. Milán, A. Giuffré, 1987, p.187. En el mismo sentido, REVENGA SÁNCHEZ, M. Seguridad nacional y..., op. cit., p. 57. Así mismo, en VAN DIJK y VAN HOOF, Theory and Practice...., op. cit, $3^{\text {a }}$ edic, p. 84, donde, al hablar de las raíces de esta doctrina, afirman que la misma refleja la distribución global de poderes dentro de un marco constitucional y la necesidad de respetar los poderes respectivos en un sistema donde existe una concurrencia de autoridades y competencias.

215 HUTCHINSON, Michael R. “The Margin of Appreciation Doctrine in the European Court of Human Rights"; en International and Comparative Law Quarterly, vol. 48, III, p. 638.

216 Idem, p. 647.

217 La subsidiariedad aparece contemplada en el artículo $35 \mathrm{CEDH}$, conforme al cual "al Tribunal no podrá recurrirse sino después de agotar las vías de recurso internas, tal como se entiende según los principios de derecho internacional generalmente reconocidos y en el plazo de seis meses a partir de la fecha de la resolución interna definitiva”. Como ha puesto de manifiesto Santiago RIPOL CARULLA, la subsidiariedad constituye, con carácter general, un principio estructural del Derecho internacional de los derechos humanos. El sistema europeo de protección de los derechos humanos y el Derecho español. La incidencia de las sentencias del Tribunal Europeo de Derechos Humanos en el ordenamiento jurídico Español. Barcelona, Atelier libros jurídicos, 2007, p. 40. 
sistema, de modo tal que el mecanismo del CEDH se activará una vez agotados los recursos ante las autoridades internas ${ }^{218}$. El punto de partida de la aplicación de esta doctrina reside pues en la tarea del TEDH de asegurar la observancia de los compromisos adquiridos por las Altas partes contratantes, tarea que es ejecutada de forma simultánea y paralela a las jurisdicciones nacionales de los Estados miembros que han consentido en ser partes del Consejo de Estado.

Pese a que, como vimos, el origen de esta doctrina se sitúa en las técnicas jurídicas internas, MacDonald ha destacado que su desarrollo por parte de los órganos del CEDH ha tenido lugar de forma independiente ${ }^{219}$ a los derechos nacionales, lo que permite desvincular su estudio de las incidencias que la misma haya suscitado en el ámbito doméstico. Como señala este mismo autor, la doctrina fue inicialmente recibida por la Comisión Europea de Derechos Humanos a mediados de la década de los cincuenta del pasado siglo, conectada a la aplicación del artículo $15 \mathrm{CEDH}^{220}$ que contempla la posibilidad de suspender las garantías del Convenio en tiempos de guerra u otras circunstancias extremas que amenacen la vida de la nación. Este precepto pretende facilitar la defensa de la democracia cuando ésta se haya amenazada por situaciones de emergencia pública, lo que ha permitido a Revenga Sánchez calificar los orígenes del uso de esta doctrina como "espectaculares"221.

Ante la concurrencia de las situaciones extremas contempladas en el art.15, la Comisión reconocía al Estado parte "discreción para apreciar el riesgo a la vida de la nación"222, así como para adoptar las medidas requeridas para hacer frente a la misma. A lo largo de la década de los sesenta la doctrina se había afianzado progresivamente en conexión con la aplicación del artículo $15^{223} \mathrm{y}$ comenzaba a ser tímidamente ${ }^{224}$ recibida por parte del TEDH, ampliando su ámbito de aplicación a

218 Como destacan estos autores, el reparto de roles respectivos entre los Estados parte y el TEDH, en cuya dinámica interna se sitúa la doctrina del margen de apreciación estatal, se encuentra formulado en los artículos 1 y 19 del CEDH, respectivamente. VAN DIJK; VAN HOOF. Theory and..., $3^{\text {a }}$ edic., p. 82.

219 MACDONALD, R. ST. The Margin of appreciation...., op. cit., p. 187.

$220 \mathrm{El}$ artículo 15.1 CEDH, bajo la rúbrica "Derogación en caso de estado de urgencia" dispone que "en caso de guerra o de otro peligro público que amenace la vida de la nación, cualquier Alta Parte Contratante podrá tomar medidas que deroguen las obligaciones previstas en el presente Convenio en la medida estricta en que lo exija la situación, y supuesto que tales medidas no estén en contradicción con las otras obligaciones que dimanan del Derecho internacional".

221 REVENGA SÁNCHEZ, M. Sociedad democrática...Op. cit., p. 58.

222 Informe emitido por la Comisión en el Asunto interestatal Grecia c. el Reino Unido, de 26 de septiembre de 1958 (Demanda no 176/56).

223 Vid, inter alia, Lawless c. Irlanda, de 1 de julio de 1961, para. 22, y 36-38. Este asunto es calificado por Macdonald como un hito en el afianzamiento de la doctrina del margen de apreciación en el ámbito del Consejo de Europa, especialmente gracias al discurso pronunciado por Sir. Humphrey Waldock, Presidente de la Comisión. “The Margin of Appreciation...., op. cit., p. 188. Así mismo, cabe mencionar también el informe emitido por la Comisión en el asunto de los Coroneles Griegos, en 1967. En el asunto Irlanda contra el Reino Unido, de 18 de enero de 1978, el TEDH en referencia a su propio papel, y en alusión al art. $15 \mathrm{CEDH}$, afirmó que “ The limits on the Court's powers of review are particularly apparent where Article 15 is concerned. It falls in the first place to each Contracting State, with its responsibility for 'the life of [its] nation', to determine whether that life is threatened by a 'public emergency' and, if so, how far it is necessary to go in attempting to overcome the emergency. By reason of their direct and continuous contact with the pressing needs of the moment, the national authorities are in principle in a better position than the international judge to decide both on the presence of such an emergency and on the nature and scope of derogations necessary to avert it. In this matter Article 15 para. 1 leaves those authorities a wide margin of appreciation. Nevertheless, the States do not enjoy an unlimited power in this respect. The Court, which, with the Commission, is responsible for ensuring the observance of the States' engagements (Article 19), is empowered to rule on whether the States have gone beyond the 'extent strictly required by the exigencies' of the crisis). The domestic margin of appreciation is thus accompanied by a European supervision”. Irlanda c. Reino Unido, 18 de enero de 1978, párrafo 207.

224 En el asunto relativo a ciertos aspectos del régimen lingüístico Belga, de 23 de julio de 1968, el TEDH enfatizó el carácter subsidiario del sistema regional europeo con las siguientes palabras: "In attempting to find out in a given case, whether or not there has been an arbitrary distinction, the Court cannot disregard those legal and factual 
la interpretación de la cláusula limitativa de derechos contenida en los artículos 8 a 11 del Convenio de Roma. De modo que si inicialmente este criterio interpretativo fue usado como una habilitación al Estado nacional para la defensa extraordinaria del orden constitucional democrático, posteriormente adquirió una nueva virtualidad en tiempos de normalidad democrática.

Bajo este nuevo escenario la doctrina del margen de apreciación tendrá que ver cada vez más con aspectos relacionados con la teoría democrática, encontrando "su campo natural de aplicación"225 en aquellas disposiciones del Convenio de Roma que consienten limitaciones a los derechos reconocidos en aras a la consecución de determinados intereses generales, esto es, en los artículos 8 a $11 \mathrm{CEDH}^{226}$. En esta concepción evolucionada, el margen de apreciación se traduce en la concesión de una esfera de actuación a los Estados parte para la interpretación, tratamiento y afectación de los derechos fundamentales con homólogos a los convencionales, a través de sus órganos internos y de sus procesos constitucionales ordinarios.

En 1976, en un asunto ${ }^{227}$ donde el TEDH debía juzgar el secuestro y requisamiento por parte de las autoridades inglesas de un libro danés sobre educación sexual dirigido a escolares menores de edad, este órgano tuvo la oportunidad de analizar detenidamente la doctrina del margen de apreciación, estableciendo una jurisprudencia que desde entonces se ha mantenido constante.

La cuestión central que debía resolver el TEDH en dicho asunto era la proporcionalidad de las medidas limitativas adoptadas sobre los derechos consagrados en los artículos 9 y 10 CEDH, fundamentalmente si las restricciones a la libertad de expresión eran necesarias en una sociedad democrática para la protección de la moral2 ${ }^{22}$, en vista de que el libro había sido considerado obsceno por las autoridades inglesas. Al respecto, el TEDH, tras subrayar el carácter subsidiario del mecanismo regional de protección de derechos del Consejo de Europa, señaló la inexistencia de un consenso entre las Altas partes contratantes en torno a las exigencias de la moralidad ${ }^{229}$, como detonante de la aplicación de la doctrina del margen de apreciación. En este pronunciamiento, el Tribunal hizo

features which characterise the life of the society in the State which, as a Contracting Party, has to answer for the measure in dispute. In so doing it cannot assume the rôle of the competent national authorities, for it would thereby lose sight of the subsidiary nature of the international machinery of collective enforcement established by the Convention. The national authorities remain free to choose the measures which they consider appropriate in those matters which are governed by the Convention. Review by the Court concerns only the conformity of these measures with the requirements of the Convention", párr. 10. MACDONALD califica el lenguaje usado en esta sentencia como ambivalente, lo que le impide considerarla como un ejemplo del uso por parte del TEDH de la técnica del margen de apreciación, a la cual en ningún momento hace referencia expresa este órgano. “The Margin of Appreciation...., op. cit., pp. 189-190.

225 REVENGA SÁNCHEZ, M. Sociedad democrática..., op. cit., p. 58.

226 Los derechos contenidos en estas disposiciones, que prevén la posibilidad de restricciones tasadas, constituyen, a juicio de MAcDONALD, el "más importante grupo de artículos a los que la doctrina -del margen de apreciaciónha sido aplicada”. Op. cit., p. 193.

227 Se trata del caso Handyside c. Reino Unido, al que se le conoce también como asunto del "Libro Rojo del Cole", de 7 de diciembre de 1976.

228 Artículo 10.2 CEDH.

229 "El Tribunal destaca que el mecanismo de protección instaurado por el Convenio reviste un carácter subsidiario en relación a los sistemas nacionales de garantía de los derechos. El Convenio confía, en primer lugar, a cada uno de los Estados Contratantes el cuidado de asegurar el goce de los derechos y libertades que consagra. Las instituciones creadas por él contribuyen a esa finalidad, pero no entran en juego sino por la vía contenciosa y después de haberse agotado las vías de recursos internos (art. 26). Este criterio es válido también para el artículo 10.2. En particular no se puede encontrar en el derecho interno de los Estados Contratantes una noción europea uniforme de la 'moral'. La idea que sus leyes respectivas se hace de las exigencias de la moral varía en el tiempo y en el espacio, especialmente en nuestra época, caracterizaba por una evolución rápida y profunda de las opiniones en la materia" Asunto Handyside c. Reino Unido, STEDH de 7 de diciembre de 1976, párr. 48. 
explícito el fundamento sobre el que reposa la concesión a los Estados parte de un margen de apreciación -especialmente en aquellas materias reguladas por el CEDH en las que no existe entre los Estados un common ground-, y precisó el alcance del adjetivo "necesario" a efectos de poder justificar la restricción de un derecho convencional, en los siguientes términos:

"Gracias a sus contactos directos y constantes con las fuerzas vivas de sus países, las autoridades del Estado se encuentran en principio mejor situadas que el juez internacional para pronunciarse sobre el contenido preciso de estas exigencias, así como sobre la 'necesidad' de una 'restricción o sanción' destinada a dar una respuesta a ello. El Tribunal señala en esta ocasión que el adjetivo 'necesario' en el sentido del artículo 10.2 no es sinónimo de 'indispensable’ y 'estrictamente necesario’ y en el artículo 15.1 la frase 'en la medida estricta en que lo exija la situación', no tiene tampoco la flexibilidad de términos tales como 'admisible, 'normal', 'útil', 'razonable' u 'oportuno'. Por ello, corresponde a las autoridades nacionales juzgar con carácter previo sobre la realidad de la necesidad social imperiosa que implica la noción de 'necesidad' en este contexto.En consecuencia, el artículo 10.2 reserva a los Estados Contratantes un margen de apreciación. Al tiempo se concede este margen de apreciación al legislador nacional ('previstas por la Ley’) y a los órganos, especialmente a los judiciales, llamados a interpretar y aplicar las leyes en vigor"230.

Finalmente, en la citada sentencia Handyside el Tribunal de Estrasburgo matizó el carácter limitado de la esfera de actuación que ofrece al Estado parte el margen de apreciación y su sometimiento a la supervisión final de los órganos de Estrasburgo ${ }^{231}$. Asimismo, en este pronunciamiento, el TEDH apuntó de forma indiciaria un criterio que la jurisprudencia posterior tenderá a remarcar: la importancia del derecho concreto en cuestión —en el caso Handyside se trataba de la libertad de expresión e información, esenciales para el mantenimiento de la democracia- y la consiguiente exigencia de proporcionalidad en su restricción ${ }^{232}$.

En este breve recorrido por la construcción jurisprudencial de la doctrina del margen de apreciación en el ámbito del Consejo de Europa, no puede dejar de mencionarse otro caso relacionado con las libertades de expresión e información, que constituye todo un hito en su desarrollo. Se trata del asunto Sunday Times ${ }^{233}$ - o caso de la talidomida-, donde el TEDH tuvo ocasión de enfatizar la importancia del derecho cuestionado, así como la existencia de un mayor consenso en Europa en

230 Ídem.

231 "El artículo 10.2 no atribuye, sin embargo, a los Estados Contratantes un poder ilimitado de apreciación. Encargado, junto con la Comisión, de asegurar el respeto de sus compromisos (art. 19), el Tribunal tiene competencia para adoptar la decisión final en torno a si una restricción o sanción se concilia con la libertad de expresión tal como la protege el artículo 10. El margen nacional de apreciación va íntimamente ligado a una supervisión europea. Tal supervisión afecta a la vez a la finalidad de la medida litigiosa y a su 'necesidad'. Cubre tanto a la ley en que se basa como a la decisión que la aplica, incluso cuando emane de una jurisdicción independiente”. Asunto Handyside, cit., parr. 49.

$232 \mathrm{Al}$ respecto, el TEDH señaló expresamente que: "Su función supervisora impone al Tribunal prestar una atención extrema a los principios propios de una "sociedad democrática". La libertad de expresión constituye uno de los fundamentos esenciales de tal sociedad, una de las condiciones primordiales para su progreso y para el desarrollo de los hombres. Al amparo del artículo 10.2 es válido no sólo para las informaciones o ideas que son favorablemente recibidas o consideradas como inofensivas o indiferentes, sino también para aquellas que chocan, inquietan u ofenden al Estado o a una fracción cualquiera de la población. Tales son las demandas del pluralismo, la tolerancia y el espíritu de apertura, sin las cuales no existen una "sociedad democrática". Esto significa especialmente que toda formalidad, condición, restricción o sanción impuesta en la materia debe ser proporcionada al objetivo legítimo que se persigue". Asunto Handyside, parra. 49.

233 Asunto Sunday Times c. el Reino Unido, de 26 de abril de 1979. En este asunto se trataba de juzgar la compatibilidad con el CEDH de las restricciones sobre el derecho a la información impuestas en virtud del contempt of court costumbre jurídica inglesa de imponer ciertas limitaciones a la libertad de información sobre los procedimientos en curso, con la finalidad de proteger el libre desenvolvimiento de la justicia- en relación a los procesos judiciales que, en torno al caso de los niños víctimas de la talidomida, estaban en la época pendientes de tramitación antes los Tribunales Ingleses. 
torno al significado de la autoridad e imparcialidad judicial - como límite a la libertad de expresión- para proceder a reducir la amplitud del ámbito del margen de apreciación ${ }^{234}$. Además, señaló un criterio de excepcional importancia que apunta a la variabilidad del margen estatal en función no solamente del grado de consenso europeo existente en la materia, sino también de cual sean los objetivos legítimos usados por el Estado para justificar la limitación del derecho impugnado ${ }^{235}$.

Pese al carácter lento y progresivo de la construcción jurisprudencial de esta importante doctrina, no resulta posible ofrecer una definición de la misma, ni tampoco determinar a priori con exactitud cuándo y en qué medida el TEDH recurrirá al uso de esta técnica, pues "su ámbito exacto y función está lejos de un desarrollo completo" ${ }^{236}$. Por ello, se ha apuntado al uso funcional que los órganos del CEDH hacen de la misma, desarrollándola sobre bases ad hoc ${ }^{237}$. Sin embargo, del abundante cuerpo jurisprudencial es posible identificar ciertas regularidades en su uso, que sugieren cuándo es posible recurrir y en qué supuestos no cabe acudir a ella, así como las variables que influyen en el espectro del margen de apreciación del Estado nacional.

MacDonald ha identificado cinco categorías de supuestos en los que se ha aplicado esta técnica, si bien en el entendido de que no se trata de una enumeración exhaustiva pues "en teoría no hay límite a los artículos del Convenio a los que puede ser aplicado el margen de apreciación, ya que el TEDH nunca ha impuesto tal límite"238. Algunas de ellas ya han sido mencionadas al exponer el desarrollo de la construcción jurisprudencial de esta doctrina.

- En primer lugar, se encuentran aquellos supuestos en los que se invoca el artículo 15, o bien los derechos consagrados en los artículos 8 a 11 -que representan el grupo de mayor importancia-, así como cuando se alega una discriminación contraria al artículo 14, y el TEDH debe determinar si dicha diferencia puede justificarse de forma objetiva y razonable.

- Las dos últimas categorías ${ }^{239}$ están representadas, de un lado, por aquellas disposiciones del CEDH que contienen términos vagos e imprecisos - como por ejemplo los fines legítimos enunciados en las cláusulas limitativas de los derechos, tales como la "protección de la moral" $y$, finalmente, cuando se presenta un caso ante el TEDH que exige equilibrar intereses, esto es, que requiere por parte del tribunal sopesar los intereses del individuo frente a los de la comunidad nacional. En conexión con esta última categoría, "en principio el margen de apreciación es relevante a los (numerosos) elementos del Convenio respecto de los cuales es aplicado el test de proporcionalidad"240.

234 STEDH Sunday Times, cit., párr. 59.

235 "The scope of the domestic power of appreciation is not identical as regards each of the aims listed in Article 10 (2). The Handyside case concerned the 'protection of morals'. The view taken by the Contracting States of the 'requirements of morals', observed the Court, 'varies from time to time and from place to place, especially in our era', and 'State authorities are in principle in a better position than the international judge to give an opinion on the exact content of these requirements'. Precisely the same cannot be said of the far more objective notion of the 'authority' of the judiciary. The domestic law and practice of the Contracting States reveal a fairly substantial measure of common ground in this area. This is reflected in a number of provisions of the Convention, including Article 6, which have no equivalent as far as 'morals' are concerned. Accordingly, here a more extensive European supervision corresponds to a less discretionary power of appreciation". Ídem.

236 MACDONALD. The Margin of Appreciation..., op. cit., p. 207.

237 Idem, p. 192.

238 Ibidem.

239 Estas dos últimas son las únicas identificadas por VAN DIJK y VAN HOOF, en el entendido de que las anteriores son de carácter obvio pues constituyeron las primeras objeto de aplicación por parte del TEDH. Theory and Practice... Op. cit., $3^{\text {a }}$ edic. p. 85

240 VAN DIJK; VAN HOOF. Theory and Practice..., op. cit., $3^{\text {a }}$ edic., p. 85. En la misma dirección apunta Fassbender cuando afirma que "el Tribunal, al enjuiciar si una medida es necesaria y proporcionada stricto sensu, ha reconocido 
- En contrapartida, el recurso al margen de apreciación no debería ser aplicado a aquellos supuestos donde la Convención señala reglas detalladas, o términos de carácter estricto y objetivo - como los artículos 2 y $3 \mathrm{CEDH}$-, ni tampoco en cuestiones de naturaleza puramente procesal e, incluso, en las cinco categorías antes señaladas, cuando la violación del derecho sea muy evidente.

La doctrina ha destacado como rasgo principal del margen de apreciación conferido a los Estados su carácter variable, del que se deduce su naturaleza cambiante ${ }^{241}$. La variabilidad del margen de apreciación depende de múltiples factores, para cuyo análisis seguiremos la exposición de Van Dijk $\mathrm{y}$ van $\mathrm{Hoof}^{242}$. Tras un repaso de la jurisprudencia pertinente, estos autores sugieren los siguientes elementos condicionantes de la mayor o menor amplitud del margen de apreciación:

1. La existencia de un entendimiento común europeo en la legislación y la práctica de los Estados Parte, esto es, en una materia sobre la que existe cierto consenso y cuya regulación muestre sincronías, se tiende a cerrar el ámbito del margen de apreciación concedido a los Estados. $\mathrm{E}$ inversamente, cuando la ley o práctica enjuiciada en la demanda difieran entre los Estados Parte, se ampliará la intensidad del ámbito de apreciación.

2. La naturaleza del derecho objeto de enjuiciamiento. De este modo, sobre ciertos derechos, como el de propiedad-, los Estados Parte gozan de un margen de apreciación más amplio que cuando se trate de otro tipo de derechos - por ejemplo el de libertad de expresión- más íntimamente conectados a la propia esencia y funciones de las sociedades democráticas o que formen parte del "núcleo esencial de la vida privada de un ciudadano"243.

3. Las diferentes actividades del individuo que se pretenden proteger bajo un mismo derecho concreto. Así, en el caso del ejemplo anterior, el margen de apreciación será más estrecho cuando lo que se trate de proteger sean cuestiones relacionadas con debates sobre asuntos de interés público, que aquellas relativas a publicidad comercial protegidas igualmente bajo el derecho a la libertad de expresión.

4. La naturaleza de la legítima finalidad perseguida por la medida estatal restrictiva impugnada y las circunstancias o el contexto de la misma.

5. Finalmente, un último factor que incide sobre el ámbito del margen de apreciación es si el asunto tiene que ver con las diversas políticas públicas generales del Estado. En estos casos, el Tribunal ha asumido que las legislaturas de los Estados Parte gozan de un amplio margen de apreciación. Esta variable es de especial importancia para el objeto de estudio de la presente tesis debido a que, como ya señalamos, dentro de las restricciones al derecho al respeto a la vida familiar del 8.2 se encuentra una de carácter inédito en todo el texto del Convenio: la protección del "bienestar económico del país" que suele alegarse para justificar limitaciones a derechos incardinados en el ámbito de las políticas migratorias y, para el supuesto específico de la RF, monopoliza dichas alegaciones.

que los Estados disponen de un cierto margen de apreciación”. FASSBENDER, Bardo. "El principio de proporcionalidad en la jurisprudencia del Tribunal Europeo de Derechos Humanos"; en Cuadernos de Derecho Público, n 5 septiembre-diciembre 1998, p. 57.

241 Vid, entre otros, CARRILLO SALCEDO, J.A. El Convenio Europeo..., op. cit., p. 92.; FASSBENDER, Bardo. El principio de proporcionalidad..., op. cit., p. 61. VAN DIJK; VAN HOOF. Theory and Practice..., op. cit.,p. 87.

242 VAN DIJK; VAN HOOF. Theory and practice..., op. cit., 3ª edic., 1998, pp. 84-91. En el mismo sentido, MAHONEY, Paul. "Marvellous Richness of Diversity or Invidious Cultural Relativism?"; en Human Rights Law Journal, vol. 19, nº1, 1998, pp. 1-6.

243 FASSBENDER, Bardo. "El principio de proporcionalidad...” op. cit, p. 60. 


\section{a) Efectos del margen de apreciación}

La intensidad del margen de apreciación concedido a los Estados parte despliega efectos directos sobre el nivel de escrutinio ejercitado por el TEDH en un caso concreto objeto de enjuiciamiento, esto es, sobre el poder de supervisión que ejerce el Tribunal de Estrasburgo en torno al cumplimiento estatal de las obligaciones convencionales. Si bien con el importante matiz de que la relación entre ambos conceptos, "en un caso dado, no siempre es tan clara como debiera" ${ }^{244}$, cabría afirmar que, a mayor margen de apreciación, menor será la intensidad del escrutinio realizado por el TEDH y, por tanto, mayor espacio para que entren en juego los intereses generales aducidos por los Estados para justificar la intervención limitativa sobre los derechos del Convenio.

El margen de apreciación concedido a los Estados partes otorga a éstos una esfera de maniobra por la que penetra la soberanía estatal ${ }^{245} \mathrm{y}$, por ende, cierta restricción en el ámbito de las obligaciones internacionales asumidas por los Estados en virtud de su condición de miembros del Consejo de Europa. Todo ello, repetimos, sin perjuicio de la competencia revisora que en última instancia compete al TEDH y conforme a la cual éste supervisa la conformidad de las decisiones internas de las autoridades estatales con los derechos consagrados por el CEDH. En este sentido, Carrillo Salcedo inscribe la doctrina del margen de apreciación dentro de las técnicas que cumplen una función conciliadora de intereses $^{246}$, pues si bien es cierto que el sistema del Convenio de Roma está destinado a la salvaguardia de los intereses individuales — derechos subjetivos - frente al Estado, la preeminencia de los derechos humanos tiene lugar sin por ello perder de vista la custodia de los intereses de la comunidad nacional, en cuyo respaldo actúa el margen de apreciación estatal.

Por ello, el uso del margen de apreciación, especialmente cuanto mayor sea la intensidad de su ámbito, tiende a inclinar la balanza a favor del Estado y a debilitar el test de proporcionalidad usado por el TEDH para examinar los límites a los derechos convencionales. Al respecto, François Ost ha afirmado que "muy a menudo, el reclamo al margen nacional aparece como preliminar a una solución favorable al Estado demandado y condiciona una interpretación más prudente de las disposiciones enjuiciadas" 247 .

Por lo que respecta a los Estados parte, la doctrina del margen de apreciación se corresponde con el diálogo democrático que bajo el marco constitucional, como expresión suprema de la soberanía, se establece entre los poderes públicos — políticos y jurisdiccionales. En este diálogo democrático las políticas públicas aprobadas por los respectivos Parlamentos expresan posiciones políticas ideológicamente estructuradas por los partidos políticos. De ahí que, con el tiempo, ciertos derechos y libertades así como los conceptos jurídicos indeterminados que la Constitución reconoce como condicionantes legítimos para su afectación, pueden variar según el partido o coalición de partidos en el gobierno. Todo ello, incluida la apreciación del Tribunal Constitucional sobre - los derechos y libertades-, entra dentro del margen de apreciación de que goza cada Estado Parte.

El reconocimiento a las Altas partes contratantes de un margen de apreciación actúa, a juicio del antiguo Secretario del TEDH, como "una especie de autolimitación judicial"248 que se basa en

244 VAN DIJK...(3 $3^{\text {a }}$ edic). Theory and Practice..., op. cit., p. 93.

245 EISSEN, Marc-André. El Tribunal Europeo..., op. cit., p. 87. FASSBENDER, B. "El principio de proporcionalidad en la jurisprudencia del TEDH", op. cit., p. 64.

246 CARRILLO SALCEDO, J.A. El Convenio Europeo..., op. cit., p. 91.

247 OST, F. El Tribunal Europeo de Derechos Humanos, op. cit., p. 320.

248 EISSEN, Marc-André. op. cit., p. 82. En la misma línea se inscribe CARRILLO SALCEDO, quien expresamente incluye a la doctrina del margen de apreciación estatal como una de las "manifestaciones de la tendencia al autocontrol judicial”. El Convenio Europeo..., op. cit., pp. 91-94. 
la consideración de que las autoridades nacionales están mejor situadas que el juez internacional para pronunciarse sobre cuestiones actuales atinentes a las realidades nacionales, sin perjuicio de la supervisión efectuada al respecto por el $\mathrm{TEDH}^{249}$. Cuando el TEDH maneja criterios deferentes con el margen nacional de apreciación el resultado es cierto repliegue o distanciamiento del caso, que provoca una jurisprudencia cautelosa y prudente por parte del Tribunal, de autocontención judicial y deferente hacia la soberanía estatal. Miguel Revenga denomina a este resultado jurispru-

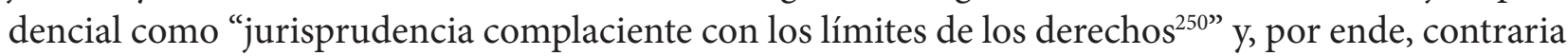
al activismo judicial que desplegaría una jurisprudencia, en palabras del mismo autor, "agresiva de derechos fundamentales", como aquella que provoca el uso por parte del TEDH del criterio de interpretación evolutiva.

El margen de apreciación opera en sentido inverso a los conceptos autónomos, y ello en una multiplicidad de niveles que, a modo de intento de sistematización, cabría resumir del siguiente modo:

a) El otorgamiento de un margen de maniobra estatal pretende dejar en la esfera de los Estados parte la protección de los derechos convencionales tal y como éstos son interpretados en las esferas nacionales, otorgándoles cierto grado de discrecionalidad. Sin embargo, los conceptos autónomos operan de forma contraria, detrayendo de los Estados la determinación de ciertos conceptos jurídicos homólogos a los convencionales.

b) A través del margen de apreciación se cuela la soberanía estatal; mientras que mediante la construcción jurisprudencial de los conceptos autónomos se establecen límites a la voluntad soberana de los Estados miembros del Consejo de Europa, reafirmándose con ello la supraestatalidad del sistema regional de protección de los derechos humanos.

c) La relación entre la intensidad del margen de apreciación y la probabilidad de que el TEDH acuda a una interpretación autónoma puede calificarse como inversamente proporcional ${ }^{251}$.

d) La concesión de un margen de apreciación fomenta el mantenimiento de los particularismos ${ }^{252}$

249 En palabras del propio Tribunal, sentando una jurisprudencia constantemente reiterada en decisiones posteriores:

“...It falls in the first place to each Contracting State, with its responsibility for 'the life of [its] nation', to determine whether that life is threatened by a 'public emergency' and, if so, how far it is necessary to go in attempting to overcome the emergency. By reason of their direct and continuous contact with the pressing needs of the moment, the national authorities are in principle in a better position than the international judge to decide both on the presence of such an emergency and on the nature and scope of derogations necessary to avert it. In this matter Article 15 Para. 1 (art. 15-1) leaves those authorities a wide margin of appreciation. Nevertheless, the States do not enjoy an unlimited power in this respect. The Court, which, with the Commission, is responsible for ensuring the observance of the States' engagements (art. 19), is empowered to rule on whether the States have gone beyond the 'extent strictly required by the exigencies' of the crisis (Lawless judgment of 1 July 1961, Series A №. 3, p. 55, para. 22, and pp. 57-59, paras. 36-38). The domestic margin of appreciation is thus accompanied by a European supervision. Asunto Irlanda c. Reino Unido, 18 de enero de 1978, aptdo. 207.

250 REVENGA SÁNCHEZ, M. Seguridad Nacional y Derechos Humanos..., op. cit., p. 55.

251 En este sentido, tal y como ha destacado François Ost, “cuanto más amplio sea el margen nacional de apreciación concedido, tanto menos estará tentado el TEDH de imponer una interpretación autónoma de los términos de las disposiciones tomados como referencia, en ausencia de un significativo consenso europeo. Al contrario, en el caso en que la Corte se considere autorizada a extrapolar una doctrina europea mayoritaria, o bien común, reducirá proporcionalmente el margen de apreciación y no dudará en adoptar una interpretación autónoma”. OST, François. Originalità dei metodi di interpretazione...; en DELMAS-MARTY, M. Verso un'Europa dei diritti dell'Uomo, op. cit, . p. 315.

252 FASSBENDER ha afirmado al respecto que "es muy posible que la protección de las diferencias y de las especialidades nacionales haya constituido uno de los principales objetivos de esta doctrina", que encierra "el peligro de la disolución de un espacio europeo unitario de protección de los derechos humanos". Este peligro constituye un reto de especial importancia en el nuevo contexto ampliado del Consejo de Europa. Al respecto este autor ha señalado que 
y tradiciones culturales de los distintos Estados signatarios, propiciando la disparidad legislativa ${ }^{253}$, en sentido inverso a la funcionalidad desplegada al respecto por la interpretación autónoma.

El margen de apreciación da oportunidad para que en los Estados se interprete la Constitución como una norma abierta, es decir, supone respetar los procesos políticos internos - que las cuestiones relevantes se ventilen y decidan en los parlamentos nacionales-. Lo contrario podría socavar las bases del propio Estado nacional. Por ello, cabría afirmar que el recurso al margen de apreciación por parte del TEDH denota una actitud pragmática por parte de este órgano que desarrolla la finalidad última de evitar y/o prevenir resistencias estatales ${ }^{254}$, preservando la autoridad moral y respetabilidad internacional del TEDH y del propio sistema Regional de cara a los Estados Parte $^{255}$.

La doctrina del margen de apreciación, con todas las críticas que suscite, refleja una actitud de prudencia y autocontención del tribunal, pudiendo considerarse como "un intento, aunque imperfecto, de hacer explícitas las consideraciones de política judicial que subyacen en su razonamiento y en las variaciones en el nivel de escrutinio desplegado por el TEDH"256.

El margen de apreciación no es un cheque en blanco para los Estados nacionales, a cuyo cobijo puedan afectar indiscriminadamente los derechos protegidos por el Convenio y debilitar sus obligaciones internacionales. Supone un ámbito - acotado- de maniobra estatal que pretende proteger la soberanía de las Altas partes Contratantes así como las particularidades propias de cada Estado. En esta línea, Carrillo Salcedo afirma que "si se desorbita, la doctrina del margen de apreciación puede llegar a poner en cuestión la esencia misma del $\mathrm{CEDH}^{257}$ diluyéndola "en una excesiva pluralidad de situaciones particulares" 258 . De ahí que la Corte reiteradamente señale que la doctrina del margen de apreciación va siempre de la mano de la supervisión europea - lo contrarío sería una abdicación de las obligaciones del TEDH—, lo que lleva a Van Dijk a afirmar que "cualquier libertad dejada a los Estados contratantes bajo esta figura es residual y provisional" 259 .

"es posible que el nuevo ámbito de actuación obligue en un futuro próximo al Tribunal a modificar una doctrina —el margen de apreciación - desarrollada para un círculo limitado de Estados relativamente homogéneos, con el fin de no permitir que aquella doctrina (...) se convierta en una figura jurídica que justifique unas diferencias demasiado grandes en los niveles de protección de los derechos humanos". "El principio de proporcionalidad...”, op. cit., p. 65.

253 VAN DIJK; VAN HOOF. Theory and Practice..., op. cit., p. 3, quienes afirman que "a través del margen de apreciación el Tribunal envía el mensaje de que no desatenderá las particularidades nacionales”. En sentido similar, MACDONALD. Op. cit., p. 208.

254 En este sentido, VAN Dijk y VAN HOOF afirman que esta doctrina "permite a la Corte desarrollar los estándares sustantivos del Convenio, sin chocar contra serias objeciones por parte de los Estados que pudieran comprometer la autoridad del TEDH". Theory and Practice...., $3^{\text {a }}$ edic. op. cit., p. 93, traducción propia.

255 VAN DIJK; VAN HOOF. Theory and practice..., op. cit., pp. 93-94.

256 VAN DIJK; VAN HOOF. Theory and Practice..., op. cit., p. 93. En un sentido opuesto, profundamente crítico con el uso del margen de apreciación estatal, al que califica expresamente como una teoría discrecional, vid. GARCÍA ROCA, Javier. "La muy discrecional doctrina del margen de apreciación nacional según el TEDH: Soberanía e Integración”; en Teoría y Realidad Constitucional, n 20, 2007, pp. 117-143. García Roca estima que esta doctrina constituye un problema estructural que explica las inconsistencias que existen en la jurisprudencia de Estrasburgo.

257 CARRILLO SALCEDO. El Convenio Europeo...., op. cit., p.

258 Idem.

259 VAN DIJK; VAN HOOF. Theory and Practice..., op. cit., p. 97. 


\section{b) El Artículo 8 CEDH y el Margen de Apreciación Estatal}

Entre la doctrina especializada destaca por su poder explicativo la aportación de Yourow, ${ }^{260}$ quien ha formulado una teoría que pone en conexión la amplitud del margen estatal concedido a los Estados con los distintos tipos de derechos consagrados en el CEDH. Para ello se basa en la existencia de cierta jerarquía ${ }^{261}$ o continuum entre los derechos convencionales protegidos. Conforme a la citada teoría, Yourow apunta que es posible establecer un vínculo entre el carácter de los derechos del Convenio de Roma y la tendencia mayor o menor del TEDH respecto a su uso, con especial consideración al margen de apreciación.

En este sentido, este autor traza un esquema o modelo que denomina "atómico o sistema solar" en forma circular, en cuyo núcleo se situarían aquellos derechos de carácter más inalienable prohibición de la tortura y de la esclavitud-. En este núcleo, la fuerza del margen de apreciación nacional es mínima. Yourow afirma que estos derechos nucleares están dominados por criterios de tendencia centrípeta, considerando como tales la interpretación evolutiva y creativa.

Los anillos o círculos situados a un nivel intermedio estarían constituidos, en primer lugar, por el derecho a un debido proceso y las libertades personales consagradas en los artículos 8 a 11. Estos círculos, que ocuparían una posición media, están sujetos a ambas fuerzas simultáneamente, centrípetas y centrífugas, de modo que en ellos existe una tensión entre criterios interpretativos de signo contrario, señaladamente el margen de apreciación y el criterio evolutivo.

El anillo que ocupa una posición más externa y por ende más distante del núcleo, estaría conformado por los poderes de derogación que el artículo 15 otorga a los Estados, donde las fuerzas centrífugas son mayores, y también mayor la amplitud del margen de apreciación, con la consecuente mayor propensión a la diversidad legislativa.

Conforme a este sistema atómico, el derecho a la vida familiar del art. 8 CEDH ocuparía una posición media-exterior, lo que lo convertiría en una disposición sometida a una tensión interna entre fuerzas de signo centrípeto -léase interpretación autónoma y criterio evolutivo- y fuerzas de signo centrífugo - mayor MA, mayor disparidad legislativa, mayor auto contención y repliegue judicial y, por lo tanto, menor escrutinio ejercitado por los órganos de Estrasburgo.

A esta misma conclusión podríamos llegar si, centramos nuestra atención en la materia objeto de regulación - vida familiar - que, como disciplina vinculada fundamentalmente al derecho interno, aboca a un mayor margen de apreciación estatal y, por consiguiente, a cierta tendencia a la autocontención judicial. Sin embargo, si nos concentramos en el carácter elástico y culturalmente condicionado de la familia, nos situaríamos ante un precepto propenso a la aplicación del criterio evolutivo y por ende al activismo judicial. En consecuencia, se trata de una disposición en la que conviven, simultáneamente, tendencias interpretativas de signo contradictorio y efectos contrapuestos.

260 YOUROW, H. The margin of appreciation doctrine in the dynamics of European Human Rights Jurisprudence. La Haya, Kluwer, 1996, pp. 86 y 188.

261 La doctrina de la disposición jerárquica de los derechos se extrae del case-law de Estrasburgo. Por ejemplo, en el Informe de la Comisión en el caso interestatal de Grecia contra Reino Unido, Vol. II, pp. 327 y 328 , los derechos se clasifican en función del grado en que el Estado pueda interferir sobre ellos. En el primer grupo de derechos más rigurosamente garantizados se incluye el derecho a la vida, la prohibición de la tortura o tratos inhumanos o degradantes, la prohibición de la esclavitud o servidumbre y el principio de nulla poena sine lege. El derecho a la vida familiar del artículo 8 se situaría en una segunda categoría de derechos dotados de garantías menos rígidas contra la interferencia estatal, como consecuencia de la cláusula limitativa del apartado segundo común a los artículos 8 a 11. Conforme a esta disposición jerárquica, los derechos se clasifican en función de la solidez de las garantías que prevean contra la intervención estatal. 
Aplicando la doctrina del margen de apreciación a nuestro campo de estudio, cabría sugerir, en una primera y sumaria aproximación general y abstracta - pendiente de ser contrastada con posterioridad al examinar el case-law de Estrasburgo - las siguientes premisas metodológicas, que actuarían a modo de marco teórico en el que posteriormente encajar el estudio práctico de la RF de los extranjeros, a fin de facilitar la comprensión del tratamiento que le viene otorgando el TEDH:

- El reconocimiento a los Estados de un "margen de apreciación" en algunas materias, destacadamente en la vida familiar, es una consecuencia que el TEDH ha extraído del carácter subsidiario del sistema de garantía establecido por el Consejo de Europa. La interpretación de los límites al derecho al respeto de la vida familiar de los extranjeros constituye, usando la terminología empleada por Sánchez Revenga, uno de los campos naturales de aplicación de esta doctrina. Este derecho se inserta en un artículo, el octavo del Convenio de Roma, "que ciertamente ha demostrado ser muy fructífero en lo que respecta al margen de apreciación"262.

- En materia de vida familiar, en cuanto que concepto culturalmente condicionado, entre los cuarenta y siete países integrantes del Consejo de Europa no existía inicialmente un "common ground" europeo suficientemente consolidado es decir, una concepción común sobre el contenido del núcleo de certeza del derecho al respeto a la vida familiar. No concurre pues la condición para que el margen de apreciación de los Estados sea más estrecho y el escrutinio del Tribunal Europeo más estricto en demandas cuyo eje principal implique despejar si las autoridades internas han respeto la vida familiar en un supuesto concreto en que se alegue su violación por parte de extranjeros asentados en el territorio de cualquiera de los Estados parte que hayan pretendido traer a sus familiares a dicho Estado, procedentes de un tercer país.

- Centrando nuestra atención en los distintos criterios que modulan la intensidad del margen de apreciación, en el derecho a la reunificación familiar como contenido implícito del derecho al respeto de la vida familiar de los extranjeros, se da una concurrencia de factores que apuntan hacia la amplitud del margen estatal.

1. El respeto a la vida familiar constituye un derecho que exige inevitablemente tanto del Estado parte como del TEDH sopesar los distintos intereses concurrentes: de un lado el interés del individuo de reunirse con su familia, de otro el interés estatal de controlar la entrada, permanencia y residencia de extranjeros en su territorio y preservar el bienestar económico del país, entre otras finalidades. Como se analizará en su momento, el test del justo balance de intereses constituye una parte esencial en el razonamiento del TEDH cuando se enfrenta a demandas relativas a reunificación familiar.

2. En el artículo $8 \mathrm{CEDH}$ concurren términos vagos y expresiones imprecisas, como por ejemplo la noción de "respeto" y los múltiples conceptos jurídicos indeterminados que actúan como justificativos de la restricción del derecho, que otorgan mayor amplitud a la discrecionalidad estatal;

3. Quizá como uno de los factores más importantes se sitúa el hecho de que la reunificación familiar constituye un aspecto particular de las diversas políticas migratorias implementadas por los Estados miembros, en íntima conexión con el núcleo más esencial de la soberanía estatal. Por ello, los casos que lleguen ante el TEDH alegando que una denegación de entrada de un extranjero por motivos de reunificación familiar constituye una violación del derecho al respeto de la vida familiar reconocido en el artículo $8 \mathrm{CEDH}$ afectarán a políticas generales internas, íntimamente vinculadas a la soberanía nacional y con fuertes implicaciones sociales

262 MACDONALD. The Margin of Appreciation..., op. cit., p. 190. 
y económicas - ya se destacó abundantemente la importancia de la RF como pilar estratégico para la integración social de los inmigrantes, así como su naturaleza jurídica híbrida o multifuncional-. Como parte de una política interna, en conexión directa con la soberanía estatal, la RF parece abocar, en principio, a la concesión de un intenso margen de apreciación a los Estados parte.

4. Tanto la ya desaparecida Comisión como el TEDH se aproximan a los supuestos de reunificación familiar de los extranjeros considerándolos como una obligación estatal positiva derivada del efectivo respeto a la vida familiar. Como vimos, los supuestos que involucran obligaciones positivas ${ }^{263}$ implícitas a las disposiciones del $\mathrm{CEDH}$, son casos especialmente propicios para el otorgamiento de un amplio margen estatal, a fin de respetar los procesos políticos internos, especialmente a los poderes legislativos nacionales.

5. Una noción cultural, histórica y geográficamente condicionada, como la familia, es rica en condicionantes éticos y culturales, dificultando la existencia de un bagaje común europeo. Ello propicia la concesión de un mayor margen de apreciación a los Estados, traduciéndose en una menor intensidad en el escrutinio efectuado por los órganos de Estrasburgo.

Por último, como un factor que actúa en sentido inverso a los anteriormente indicados, propiciando cierta restricción en la amplitud del margen de apreciación estatal, cabría mencionar que el derecho al respeto de la vida familiar, por su conexión directa con la dignidad humana, constituye un derecho con una importancia vital para el bienestar del individuo, especialmente cuando lo que se dilucida es la reunificación de hijos menores de edad. En este sentido, la naturaleza del derecho o las actividades del individuo amparadas por el derecho al respeto de la vida familiar, —en tanto que plataforma jurídica del derecho a la reunificación familiar de los extranjeros-, actúa como un factor que puede reducir la amplitud del margen de apreciación estatal al que, en principio, apuntan todos los restantes criterios mencionados.

Sin embargo, el elevado casuismo al que conducen los problemas interpretativos que se derivan del respeto a la vida familiar - ya identificados-, así como la propia aproximación empírica adoptada por el TEDH al aplicar e interpretar los distintos derechos convencionales ${ }^{264}$, - junto con la multiplicidad de criterios apuntados en este epígrafe-, determinan un espectro variable del margen de apreciación estatal, cuyo alcance exacto en abstracto es difícil de determinar en esta materia. La respuesta concreta exige el estudio detenido del case-law estrasburgués.

\subsection{El principio de proporcionalidad}

Ya señalamos en su momento que los derechos reconocidos en los artículos 8 a 11 del CEDH se caracterizan por la expresa previsión de restricciones a su contenido, limitaciones que serán legítimas siempre que respeten las finalidades y requisitos contemplados por el propio Convenio en

263 VAN DIJK y VAN HOOF han destacado que ciertos casos relativos a obligaciones positivas que representan un aspecto concreto de una política pública general más amplia perseguida por las legislaturas nacionales - como lo es la reunificación familiar-, abogan a favor del otorgamiento de un amplio margen de apreciación a las autoridades nacionales. Lo contrario, a nuestro juicio, supondría enjuiciar toda una política a partir de un caso concreto que representa tan sólo un segmento particular de la misma. Theory and Practice..., op. cit., p. 89.

264 MATSCHER, F. "Methods of Interpretation of the Convention"; en MACHDONALD, R. ST. J.; MATSCHER, F; PETZOLD, H. The European system for the protection of Human Rights. Dordrecht, Boston, 1993, p. 64. El autor señala que el método empírico y pragmático utilizado por el TEDH, centrado en resolver problemas concretos de derechos, eludiendo la formulación de teorías generales, resulta más fácil de comprender desde la perspectiva jurídica del common law que desde la típicamente continental. 
dichas disposiciones. Estas finalidades, como también vimos, se formulan recurriendo a conceptos jurídicos indeterminados y, por tanto, dotados de contornos vagos y abstractos ${ }^{265}$, esto es, de difícil determinación concreta.

Entre los requisitos exigidos a los límites posibles de los derechos consagrados en los artículos 8 a $11 \mathrm{CEDH}$, dos son constantes o comunes a todos ellos: la necesidad de que las limitaciones estén previstas legalmente, y sean necesarias en una sociedad democrática para la consecución de alguno o algunos de los fines legítimos que dichos preceptos prevén - la seguridad nacional, la seguridad pública, la defensa del orden y la prevención del delito, la protección de la salud o de la moral, o la protección de los derechos y libertades de terceros-.

En el examen de los casos de posibles violaciones a los derechos convencionales que reconocen limitaciones (artículos 8 a 11), la metodología ${ }^{266}$ más habitualmente utilizada por el case law —aunque no única- consiste en el examen secuencial de los parámetros señalados anteriormente. A saber, en primer lugar el TEDH constata que existe una violación del derecho para proceder, a continuación, a determinar si dicha interferencia es acorde a la ley o está prevista legalmente, tras lo cual evaluar si la medida limitativa persigue alguno de los fines legítimos exhaustivamente enumerados en el párrafo segundo de los artículos mencionados. Finalmente, la cuestión más problemática de dilucidar y la que, por ello, ocupa la parte más sustancial del razonamiento jurídico del TEDH, es la que se centra en determinar si la limitación del derecho es necesaria en una sociedad democrática, una vez constatada y justificada dicha limitación en la persecución de alguna de las finalidades legítimas.

Con el fin de controlar que las injerencias de las distintas autoridades estatales respeten el requisito de la necesidad en una sociedad democrática, el TEDH ha exigido expresamente que debe existir una proporcionalidad entre las medidas limitativas o restrictivas de los derechos y los fines que con dichas medidas se persiguen, ya que ello permite alcanzar un justo equilibrio entre los distintos intereses - generales y particulares - presentes en el litigio. Proporcionalidad y justo equilibrio aparecen así como conceptos gemelos ${ }^{267}$.

El principio de proporcionalidad no está expresamente consagrado en ningún precepto del Convenio de Roma ${ }^{268}$. Es una construcción cuyo origen se sitúa en el derecho interno alemán y posteriormente ha sido importada por el TEDH y el Tribunal de Justicia de las Comunidades Europeas. Su uso con carácter general es creciente en el ámbito de los derechos, tanto fundamentales como humanos, y se explica como consecuencia de la estructura principial que caracteriza a éstos y que determina la necesidad de acudir a la ponderación para la aplicación de los mismos.

El principio de proporcionalidad posee una estructura tripartita ${ }^{269}$. El punto de partida para su aplicación consiste en evaluar si la medida limitativa del derecho en cuestión persigue un fin legíti-

265 CARRILLO SALCEDO, J.A. El Convenio Europeo..., op. cit., p. 27.

266 VAN DIJK; VAN HOOF. Theory and Practice..., op. cit., p. 335.

267 CARRILLO SALCEDO, J.A. El Convenio Europeo..., op. cit., p. 110. La misma percepción tiene el TEDH; vid, entre otras, Asunto López Ostra c. España, STEDH de 9 de diciembre de 1994, párrafo 150.

268 Pese a no estar expresamente reconocido en el texto del Convenio, puede deducirse implícitamente de alguna de sus disposiciones, tales como de los requisitos establecidos para la limitación de los derechos individuales (artículos 8-11), especialmente de la "necesidad en una sociedad democrática". También puede entreverse en el artículo 15 el cual, al prever la posible limitación de los derechos convencionales en caso de guerra u otro peligro público, señala que sólo "en la medida en que resulte estrictamente indispensable a la vista de las circunstancias concretas". BARDO FASSBENDER. "El principio de proporcionalidad en la jurisprudencia del Tribunal Europeo de Derechos Humanos"; en Cuadernos de Derecho Público, no 5, septiembre-diciembre 1998, pp. 52-53.

269 Vid., entre otros, BRAGE CAMAZANO, Joaquín. Los límites a los derechos fundamentales. Madrid, Dykinson, 2004, pp. 364-386; DÍEZ PICAZO, Luis María. Sistema de derechos fundamentales, op. cit., pp. 109-112. BERNAL PULI- 
mo, - en nuestro caso, alguno de los objetivos taxativamente enumerados en el apartado segundo del artículo $8 \mathrm{CE}$ - Si la respuesta es afirmativa, y sólo en ese caso, entrarán en juego — de forma acumulativa y escalonada o sucesiva - tres exigencias o subprincipios inherentes a la proporcionalidad:

1. En primer lugar se procederá a analizar si la limitación del derecho constituye una medida adecuada para el logro de la finalidad legítima establecida (subprincipio de adecuadión o idoneidad).

2. Tan sólo cuando así sea, se pasará a examinar si la limitación del derecho es necesaria, en el sentido de que no es posible encontrar otra medida limitativa alternativa que sea menos gravosa para el particular (subprincipio de necesidad, imprescindibilidad o intervención mínima).

3. La última fase supone para el operador jurídico la exigencia de ponderar los distintos intereses en competición -individuales y estatales - a fin de determinar que la intervención limitativa sobre el derecho no constituya una restricción excesiva que desemboque en el vaciamiento del derecho en cuestión (subprincipio de proporcionalidad estricta, ponderabilidad o prohibición de exceso).

En el ámbito específico del Consejo de Europa, el principio de proporcionalidad ha sido usado de forma tanto expresa como tácita por la jurisprudencia del TEDH desde 1968, dejándose entrever por primera vez en la sentencia relativa a ciertos aspectos lingüísticos de la enseñanza en Bélgica. En dicha ocasión, a propósito de la existencia de un tratamiento discriminatorio contrario al artículo 14 del Convenio, la Corte Europea afirmó que "una diferencia de trato en el ejercicio de un derecho consagrado por el Convenio no sólo debe perseguir una finalidad legítima: el artículo 14 se ve también violado cuando resulta claramente que no existe una razonable relación de proporcionalidad entre los medios empleados y la finalidad perseguida" 270 .

Pero es especialmente a partir de la sentencia Handyside donde el uso del principio de proporcionalidad por parte del TEDH se hace explícito. En este asunto, donde se debatía si una limitación a la libertad de expresión era o no compatible con el Convenio (Art. 10), el TEDH recordó el carácter limitado del margen de apreciación estatal, desarrollando al respecto la Comisión y el TEDH una función supervisora. Posteriormente, y basándose en la importancia esencial de la libertad de expresión en una sociedad democrática, extrajo, como consecuencia de ello, que toda formalidad, condición, restricción o sanción impuesta en la materia debía ser proporcionada al objetivo legítimo que se persigue $^{271}$.

Desde entonces, la utilización del principio de proporcionalidad por parte de los jueces de Estrasburgo es habitual y especialmente intensa en aquellos preceptos que, como el artículo 8, prevén limitaciones expresas al ejercicio de los derechos.

La necesidad en una sociedad democrática "fortalece la posición de los particulares frente a los intereses de la comunidad"272, actuando así de contrapunto a la función desempeñada por las limitaciones estatales a los derechos del Convenio, precisamente la opuesta, la salvaguardia de los

DO, Carlos. El principio de proporcionalidad y los derechos fundamentales: el principio de proporcionalidad como criterio para determinar el contenido de los derechos fundamentales vinculante para el legislador. Madrid, CEPC, 2003, pp. 101.

270 Asunto relativo a ciertos aspectos lingüísticos de la enseñanza en Bélgica, sentencia de 23 de julio de 1968, párrafo 10.

271 Handyside c. Reino Unido de Inglaterra, STEDH de 7 de diciembre de 1976, párrafo 49.

272 FASSBENDER, B. "El principio de proporcionalidad...., op. cit., p. 57. 
intereses generales. De forma gráfica, podría decirse que en un caso donde se plantea si una limitación estatal constituye o no una violación a los derechos del Convenio, nos encontramos ante dos intereses contrapuestos y, en principio, dignos de protección, fluctuando en una báscula donde el papel de fiel de la balanza aparece representado por la actuación del principio de proporcionalidad. Este principio permitirá optar por uno de los intereses contrapuestos, pero con el menor sacrificio posible respecto al otro, es decir, permite la minimización de la restricción, que se extenderá tan sólo al ámbito estrictamente necesario.

En consecuencia, de la cláusula de la necesidad en una sociedad democrática el TEDH ha extraído los principios interpretativos más importantes ${ }^{273}$, incluido el principio de proporcionalidad. Esta cláusula ha servido pues al TEDH para "verificar la proporcionalidad de una concreta intervención" en los derechos consagrados en el Convenio. Sobre su base, el TEDH exige que "las injerencias en el goce de un derecho, esto es, sus limitaciones y restricciones, han de ser proporcionadas"274.

Por eso, en palabras de Luis Ma Díez-Picazo la proporcionalidad es una "técnica tendente a que la consecución de intereses públicos no se haga a costa de los derechos e intereses de los particulares, sino que busque un punto de equilibrio entre ambos"275, lo que permite un notable grado de tecnificación a la hora de buscar un punto de equilibrio entre principios en colisión, que encarnan respectivamente intereses públicos y derechos individuales.

De este modo, la operatividad del principio de proporcionalidad consiste en actuar como límite a las posibles restricciones de los derechos contemplados en el Convenio, lo que permite al Tribunal poder controlar, con criterios técnicos, las medidas limitativas que los Estados signatarios establezcan sobre los derechos convencionales - respecto a las cuales, como hemos visto, los Estados gozan de un margen de apreciación tanto mayor cuanto menor sea el grado de consenso europeo en la materia de que se trate-. Constituye por ello un "límite de los límites"276.

\section{LA VIDA FAMILIAR: EL CONCEPTO DE FAMILIA EN LA JURISPRUDENCIA DEL TEDH}

El CEDH en su artículo 8.1, con una redacción poco ortodoxa, reconoce que todos tienen derecho al "respeto" de la vida familiar. Esta formulación constituye una de las particularidades más destacables de esta disposición, pues los restantes derechos convencionales son consagrados de forma directa. Adicionalmente, de una primera aproximación gramatical al artículo 8.1CEDH podrían deducirse otras notas de utilidad para abordar el concepto y contenido de la vida familiar en el CEDH:

- La utilización del término "todos" en alusión a la amplia titularidad activa del derecho.

- El reconocimiento del derecho a la VF viene precedido por una conjunción copulativa respecto del derecho previo - la vida privada-, lo que sugiere la existencia de un vínculo de continuidad entre ambas. Y, de hecho, éste parece ser el punto de vista del TEDH ya que determinadas relaciones que son excluidas del ámbito de la vida familiar, pasan a ser consideradas como constitutivas del concepto más amplio de vida privada. Así ocurre, por ejemplo, en el ámbito de las relaciones homosexuales.

273 VAN DIJK; VAN HOOF. Theory and Practice...., op. cit., p. 340.

274 Ídem. p. 27.

275 DÍEZ-PICAZO, Luis María. Sistema de derechos fundamentales, op. cit., p. 110.

276 Idem. 
- A diferencia de su precedente- artículo 12 DUDH, donde se reconoce el derecho a casarse y fundar una familia-, el Convenio protege "la vida familiar", no la familia.

A fin de arrojar luz sobre el sentido original de una disposición dotada de una redacción poco ortodoxa o ambigua, suele ser útil el recurso a los trabajos preparatorios como método interpretativo auxiliar. Ya señalamos que, en la elaboración de este artículo, los redactores se inspiraron en el artículo 12 de la Declaración Universal de los Derechos Humanos. Sin embargo, en el Convenio de Roma el contenido del artículo 12 DUDH se vertió de forma separada en dos disposiciones: los arts. 8 y el $12^{277}$. Con ello se ponía en evidencia la concepción independiente de la protección de la vida familiar, que no quedaba condicionada a la existencia de un matrimonio previo ni a la fundación de una familia. Además de esta divergencia respecto a la disposición que sirvió de inspiración al artículo $8 \mathrm{CEDH}$, existen otras importantes. El Convenio ampara la "vida familiar", mientras que la Declaración de la ONU protege la familia; de otro lado, se consagra "el respeto" de la vida familiar, en lugar de la formulación directa del derecho contenida por el artículo 12 DUDH. La causa de este concreto cambio de redacción — como veremos, ha desplegado importantes consecuencias-, no resulta sin embargo disipada por los trabajos preparatorios.

De otro lado, la importancia de la interpretación evolutiva, usada frecuentemente en el ámbito del CEDH, determina que el recurso al método histórico a fin de descubrir la ratio de sus disposiciones despliegue una utilidad muy relativa. Pese a ello, el recurso a los trabajos preparatorios del Convenio, no puede ignorarse. En este sentido, es importante subrayar que el análisis de los trabajos preparatorios del art. $8 \mathrm{CEDH}$ revela cierto predominio de la familia en su concepción más tradicional ${ }^{278}$ que, sin embargo, la evolución jurisprudencial posterior se ha ocupado de desmentir.

\subsection{El método Escalonado de Enjuiciamiento: Sus particularidades en presencia de obligaciones positivas}

Una de las constantes de la jurisprudencia de Estrasburgo en torno al art. $8 \mathrm{CEDH}$ reside en la utilización, para el examen de los múltiples casos donde se alega la violación del respeto a la vida familiar, de un método escalonado o multifásico ${ }^{279}$ de enjuiciamiento, de raíz germánica. El uso de este método se aplica para evaluar la compatibilidad con el Convenio de medidas estatales posiblemente violatorias de aquellos derechos convencionales que contemplan límites expresos y que, como vimos, están consagrados entre los artículos 8 a 11 del Convenio. La técnica escalonada supone el análisis sistemático y progresivo de una serie de cuestiones, especificadas a continuación.

En primer lugar, el TEDH ha de determinar si el artículo 8.1 es aplicable al caso, esto es, establecer si la violación alegada encaja en el tipo normativo del derecho al respeto de la vida familiar, para lo cual es preciso delimitar previamente si la relación entre los demandantes constituye vida familiar en el sentido del CEDH.

277 BARTOLE, Sergio; CONFORTI, Benedetto; RAIMONDI, Guido. Commentario alla Convenzione Europea per la tutela dei diritti dell'uomo e delle libertà fondamentali, op. cit., p. 307.

$278 \mathrm{Al}$ respecto, ARRIAGA subraya que de la lectura de los trabajos preparatorios del Convenio de Roma se dedude "una preocupación particular por la familila considerada legítima, manifestada por el interés de proteger la institución del matrimonio y el rechazo a la proclamación del derecho al divorcio". Pese a ello, familia y matrimonio fueron objeto de reconocimiento independiente en disposiciones separadas "desde el primer momento" de su redacción. $E l$ derecho a la vida familiar..., op. cit., nota a pie $\mathrm{n}^{\circ} 1, \mathrm{p} .79$.

279 BRAGE CAMAZANO, Joaquín. "Aproximación a una teoría general de los derechos fundamentales en el CEDH", op. cit., pp. 121-123. El autor analiza este método, si bien no aparecen referencias a los supuestos en los que el TEDH adopta el prisma de las obligaciones positivas, reduciendo su análisis al primer párrafo del artículo en cuestión. 
Si el TEDH estima que el supuesto está incluido en la vida familiar protegida por el artículo 8, pasará a examinar —en segundo lugar-, el cumplimiento de dicha disposición, cumplimiento que se verifica de dos formas distintas según cual sea la naturaleza de la obligación a cargo del Estado parte:

- Lo más habitual es que se trate de supuestos de obligaciones negativas, en las que se dilucida si el Estado ha incumplido o no su obligación de abstenerse en el ámbito de la vida familiar. En estos casos los órganos de Estrasburgo han de determinar si la medida impugnada constituye una "injerencia" en el contenido del derecho. Tan sólo si la Corte concluye que ha existido una "interferencia", procederá a evaluar la posible justificación de la misma, mediante una operación que a su vez se divide en tres fases: evaluar que la injerencia sea legal — "conforme a la ley" —; legítima —esto es, que persiga alguna de las finalidades enunciadas a la acción estatal que el apartado segundo de los artículos mencionados contempla en forma de límites-, y proporcionada - es decir, "necesaria en una sociedad democrática" para el cumplimiento de las finalidades legítimas-. En este supuesto se encaja la protección frente a las expulsiones de extranjeros, siempre que las mismas no hayan respetado el justo equilibrio entre los intereses en presencia, canalizados habitualmente en el interés individual a la vida familiar, en conflicto con el interés estatal en la protección del orden público y la prevención de infracciones de naturaleza penal ${ }^{280}$.

- Si estamos ante obligaciones migratorias de carácter positivo, el análisis varía sustancialmente. El primer paso sigue siendo común, ya que el TEDH procederá a analizar la aplicabilidad del artículo al supuesto de hecho planteado en la demanda. Pero, si estima que el art. 8 CEDH es aplicable, a partir de aquí el método difiere respecto al enfoque que tiene lugar bajo el prisma de las obligaciones negativas.

- La primera diferencia es de carácter terminológico, ya que la posible evaluación del cumplimiento o no del derecho convencional se realizará en términos "de falta de respeto", lo que implica constatar si -debiendo intervenir a fin de permitir el normal desarrollo de la vida familiar-, el Estado se abstuvo. La explicación reside en la naturaleza positiva de la obligación, que exige del Estado la adopción de medidas para asegurar el desarrollo efectivo del derecho - precisamente el supuesto contrario a la obligación de no intromisión que generan las obligaciones negativas.

- La divergencia más sustancial reside en que cuando el TEDH adopta el enfoque de las obligaciones migratorias positivas, enjuicia su posible cumplimiento o incumplimiento por parte de las medidas estatales controvertidas sin entrar a evaluar el apartado segundo del artículo en cuestión, lo que "parece desechar el significado del segundo párrafo del artículo 8 "281. Esta forma de proceder resulta sorprendente, ya que es precisamente al amparo del

280 SANTOLAYA MACHETTI, P. El derecho a la vida familiar de los extranjeros, op. cit., p. 99. El leading case en esta materia lo constituye el asunto Berrehab contra Países Bajos, de 21 de junio de 1988, a partir del cual, en palabras del autor mencionado, el TEDH ha confeccionado "una línea jurisprudencia sobre las condiciones en las que el art. 8 $\mathrm{CEDH}$ puede actuar como límite a la posibilidad de aplicación de las causas legales de expulsión de los extranjeros"; idem, p. 98.

281 JOHNSON, Nancy. “The breath of Family Law Review under the European Convention on Human Rights"; en Harvard International Law Journal, vol. 36, 1995, p. 518. La autora prosigue más adelante afirmando que, "en lugar de buscar la interferencia, el Tribunal debe hacer una determinación subjetiva de qué mínima acción es requerida por parte del Estado miembro para asegurar respeto a la vida familiar". Referencias al método diferenciado de enjuiciamiento, según el carácter positivo o negativo de las obligaciones convencionales pueden encontrarse, entre otros, en CONNELLY, "Problems of interpretation...., op. cit., p. 593. LIDDY, Jane. “Curret Topic: The Concept of Family Life under the ECHR”; en European Human Rights Law Review, vol.1, 1998, p.16. 
párrafo segundo del artículo 8 donde el TEDH suele desplegar los mayores esfuerzos argumentativos y donde tiene lugar la aplicación exhaustiva del principio de proporcionalidad, bajo la cláusula de la necesidad en una sociedad democrática.

- En contrapartida, el enfoque adoptado para el análisis de las obligaciones convencionales positivas permite incluir en la demanda quejas relativas a violaciones de derechos cuyo origen proceda de un particular $-\mathrm{y}$ no necesariamente de las autoridades públicas-, dotando al $\mathrm{CEDH}$ de cierta eficacia horizontal.

El análisis efectuado por el TEDH mediante el método escalonado, se interrumpirá en cualquiera de las fases previas en el momento en que se constate que el derecho en cuestión no es aplicable, o bien que no ha habido injerencia en el contenido del mismo - en el caso de que estemos en presencia de obligaciones negativas - , o estime que no existe falta de respeto - cuando las obligaciones son de carácter positivo. Alternativamente, el TEDH puede determinar que el incumplimiento de los requisitos fijados para la limitación - o la falta de respeto- supone, en el caso concreto, que la medida estatal impugnada constituye una violación del Convenio.

\subsection{El Leading case: Asunto Marckx contra Bélgica, Sentencia de 13 de junio de 1979}

El estudio del contenido de la vida familiar, en su aplicación específica al ámbito de las obligaciones positivas, exige tomar como punto de partida el análisis de esta sentencia. En ella, el TEDH se enfrentó a la definición del concepto y del contenido de la vida familiar, siendo considerado el leading case en esta materia ${ }^{282}$. En este razonamiento se apuntan y anticipan, a nuestro juicio, características de la jurisprudencia del TEDH que serán una constante en la aproximación que los órganos de Estrasburgo realizan al derecho a la vida familiar. La tendencia jurisprudencial que se inicia en Marckx es de importancia trascendental para la construcción y el entendimiento del derecho a la reagrupación familiar en el ámbito del Consejo de Europa, si bien es importante precisar que este pronunciamiento no aborda la vida familiar en el contexto migratorio.

En el asunto Marckx contra Bélgica las demandantes, la señora Paula Marckx, madre soltera de nacionalidad belga, actuando en su nombre y en representación de su hija Paula, entablaron una demanda contra el Reino de Bélgica ante la Comisión. Alegaban que determinados preceptos del Código Civil Belga reguladores de la filiación materna extramatrimonial y de los derechos patrimoniales de los hijos ilegítimos eran incompatibles, entre otros, con los artículos 8, 14 del CEDH y el artículo 1 del Protocolo número $1^{283}$. Las recurrentes estimaban que los artículos del Código Civil belga relativos a las formas de establecimiento de la filiación materna de los hijos ilegítimos, suponían una violación de la vida familiar y eran discriminatorios respecto a los establecidos para los hijos matrimoniales ${ }^{284}$. Argumentaban que el reconocimiento de los hijos naturales

282 Sobre la trascendencia e influencia de esta sentencia en la jurisprudencia del TEDH, vid. SALZBERG, Marc. "The Marckx Case. The Impact on European Jurisprudence of the European Court of Human Rights' 1979 Marckx Decision Declaring Belgian Illegitimacy Statutes Violative of the European Convention on Human Rights"; en Denver Journal of International Law and Policy, 1984, vol. 13, p. 288.

283 El artículo 1 del Protocolo número 1 consagra el derecho a la propiedad en los siguientes términos: “Toda persona física o moral tiene derecho al respeto de sus bienes. Nadie podrá ser privado de su propiedad sino por causa de utilidad pública y en las condiciones previstas por la ley y los principios generales del Derecho Internacional".

284 En el momento en que este caso se sometió a la Comisión, la familia de la señora Marckx estaba constituida, además de por su hija menor, por su propia madre y su hermana, abuela y tía de la niña respectivamente. De acuerdo con la legislación belga vigente en la época en que se suscitó el caso, del mero hecho del nacimiento no se derivaban 
no producía efectos plenos respecto a las vinculaciones familiares legales del menor y perjudicaba sus derechos sucesorios y a recibir donaciones - efectos que, sin embargo, no existían para el caso de los hijos legítimos-.

Conforme al método escalonado ya descrito, el Tribunal analiza en primer lugar si procede la aplicabilidad del artículo 8.1 al vínculo natural existente entre las demandantes, considerando, como punto de partida, que "al garantizar el derecho al respeto a la vida familiar de cada uno, el artículo 8 presupone la existencia de una familia" ${ }^{\text {"25 }}$. El TEDH recuerda que, en virtud del artículo 14 , el goce de los derechos convencionales, entre ellos del derecho al respeto de la vida familiar garantizado por el artículo 8, debe asegurarse a toda persona sin distinción alguna. Por ello, el TEDH afirma que el artículo 8 no distingue entre familia legítima e ilegítima pues tal distinción carece de justificación objetiva y razonable, constituyendo una discriminación basada en el nacimiento contraria al artículo 14, e incompatible además con el término "todos". La conclusión es clara: "El artículo 8 debe aplicarse a la vida familiar de la familia ilegítima de igual forma que a la de la familia legítima"286.

En Marckx el TEDH ofrece, además, un concepto mínimo de familia que, a nuestro juicio, puede actuar a modo de contenido esencial aplicable también en los supuestos que involucren a inmigrantes, al señalar que: "La vida familiar según el significado del artículo 8 incluye al menos los vínculos con los parientes cercanos, tales como el de abuelos y nietos, en la medida en que aquellos pueden jugar un importante papel en la vida familiar de éstos"287.

La argumentación ofrecida a lo largo de toda la sentencia Marckx revela además uno de los rasgos del enfoque que las instituciones de Estrasburgo emplean al aproximarse al concepto de familia:

vínculos de filiación entre la madre soltera y su hijo. Dichos vínculos exigían, o bien el reconocimiento de la madre, o bien la investigación de la maternidad. Pero aún después de establecida la filiación materna de un hijo ilegítimo, el menor no se convertía en un miembro de la familia de la madre, dado que la filiación creaba vínculos jurídicos únicamente entre la madre soltera y su hijo. Además, los hijos ilegítimos reconocidos se situaban en una posición de desventaja respecto del disfrute de derechos patrimoniales, pues a partir del reconocimiento veían restringidos sus derechos en materia sucesoria y de donaciones. La alternativa que tenía una madre soltera en Bélgica sería retener su posibilidad de testar o donar a favor de su hijo, pero a costa de renunciar a establecer con él vínculos familiares reconocidos legalmente. De hecho, la señora Marckx tuvo que recurrir a la adopción de su propia hija para paliar en lo posible las consecuencias negativas apuntadas, dado que ésta era la única vía disponible conforme al código civil belga para mejorar el estatus jurídico del menor — aunque el menor adoptado por su propia madre biológica soltera seguía sin adquirir ningún derecho en la sucesión intestada de los parientes de la madre-.

285 Marckx. C. Bélgica, apdo. 31.

286 Idem, párrafo. 31. En el caso analizado, "el vínculo natural existente entre las demandantes da origen a una vida familiar protegida por el artículo 8”. Además, dicha vida familiar es calificada como auténtica, en consideración a los cuidados constantes que la madre dispensó a su hija desde su nacimiento y que revelan la asunción de responsabilidades maternas. "No es discutible que Paula Marckx asumió responsabilidades con respecto a su hija Alejandra desde el momento de su nacimiento en la medida en que cuidó constantemente de ella, de lo cual se deduce la existencia de una auténtica vida familiar entre ambas”. Marckx. C Bélgica, párr. 31.

287 Caso Paula y Alexandra Marckx c. Bélgica, 13 de junio de 1979. Párr. 45. A juicio de ARRIAGA, este concepto al que hemos calificado como mínimo o esencial de familia, peca de excesiva ambigüedad, e incluso estima que es "tautológico". El derecho a la vida familiar..., op. cit., p. 83.

De otro lado, en Marckx el Tribunal perfiló el contenido de la vida familiar, determinando el haz de derechos y relaciones incluidas dentro de la protección del artículo 8. Ante la alegación de las demandantes de que los derechos patrimoniales entre parientes se derivan del artículo 8, - formando parte de los derechos familiares-, el TEDH afirma que la vida familiar incluye las relaciones sociales, morales o culturales que tengan lugar en esta esfera. Además, comprende también otros factores que, pese a constituir intereses de carácter material —obligaciones de alimentos, derechos patrimoniales, especialmente los hereditarios y la libre disposición de bienes entre parientes-, están conectados de forma muy directa con la vida familiar. Sin embargo, los derechos patrimoniales derivados de los lazos familiares no constituyen un presupuesto indispensable para el disfrute de la vida familiar. Idem, parr. 52. 
Su actitud abierta y protectora, como consecuencia del uso combinado de criterios interpretativos diversos, fundamentalmente el efecto útil, la interpretación evolutiva ${ }^{288}$ y la noción autónoma de familia. Pese a ello, este enfoque no obsta para que el TEDH confirme la legitimidad de las medidas de apoyo y fomento de la familia tradicional, precisando al respecto que: "Sin embargo, ello no implica la necesidad de recurrir a medidas que, como en el caso que nos ocupa, sean al mismo tiempo lesivas para la familia ilegítima; Los miembros de una familia ilegítima han de disfrutar de las garantías consagradas por el artículo 8 del Convenio en el mismo plano que los de la familia tradicionap89".

Con este pronunciamiento, el TEDH estaba firmando el acta de defunción de una distinción hijos legítimos e ilegítimos, aludidos con la más amplia y peyorativa terminología-, profundamente arraigada en el derecho europeo ${ }^{290}$ desde su incorporación al Código Napoleónico. Los orígenes de la misma son remotos y de carácter marcadamente religioso, situándose en el Concilio de Trento de $1563^{291}$. Y aquí reside una de las notas más significativas de la sentencia Marckx, pues en ella por primera vez la Comisión, en su informe, otorgó carácter autónomo a la noción de familia. Siguiendo a este órgano, el TEDH hizo uso de la noción autónoma de familia, lo que le permite distanciarse de los derechos de familia internos, adoptando unos parámetros de enjuiciamiento potencialmente más protectores que desembocan en una comprensión amplia de la familia.

Se inicia de este modo una jurisprudencia caracterizada por su activismo judicial, con profundas implicaciones. Entre ellas, cabría destacar que da lugar al surgimiento de una tendencia en aumento desde entonces: la capacidad de influencia del Tribunal de Estrasburgo en la rápida transformación del derecho europeo de familia ${ }^{292}$, rama que tradicionalmente había sido inmune a la penetración del derecho internacional público. En este sentido, en la época inmediatamente posterior a la sentencia Marckx, se produjo un efecto en cadena en algunos Estados miembros donde el Convenio poseía efecto directo, derribando las distinciones discriminatorias entre hijos que aún subsistían ${ }^{293}$. Y, más allá aún, la estela iniciada en Marckx es claramente perceptible en una serie de pronunciamientos donde el propio Tribunal de Estrasburgo tendría ocasión de volver a enfrentarse a la cuestión de la diferencia de derechos entre hijos habidos fuera y dentro del matrimonio ${ }^{294}$.

$288 \mathrm{Al}$ estudiar el criterio evolutivo incluimos a la sentencia Marckx como un ejemplo más que notable del uso y de la potencialidad de este criterio. El TEDH recurrió a esta técnicas en múltiples apartados de la sentencia Marckx, fundamentalmente en el parr. 41, al afirmar que: "Es cierto que en la época en que el Convenio de 4 de noviembre de 1950 se proyectó era frecuente y acorde al Derecho en muchos países europeos establecer distinciones de este tipo entre la familia ilegítima y la legítima. Sin embargo, el Tribunal recuerda que el Convenio debe ser interpretado a la luz de las circunstancias actuales. En el presente caso, el Tribunal no puede dejar de tener en cuenta que la gran mayoría de los ordenamientos jurídicos de los países miembros del Consejo de Europa han evolucionado y continúan haciéndolo, junto con los más importantes documentos internacionales, hacia el pleno reconocimiento jurídico de la máxima "mater semper certa est".

289 Marckx c. Bélgica. Párr. 40.

290 SALZBERG, M. “The Marckx Case. The Impact on European Jurisprudence...”, op. cit., p. 299.

291 En el Concilio de Trento, la unión de hecho no matrimonial pasó a ser considerada inválida para el derecho canónico. Una prueba más del carácter condicionado de la familia, en este caso de la influencia de la religión en su configuración jurídica.

292 JOHNSON, Nancy. "The Breath of Family Law Review under the European Convention on Human Rights”; en Harvard International Law Journal, 1995, vol. 36, p. 513.

293 SALZBERG habla por ello de las secuelas de Marckx, citando tres ejemplos — uno en Alemania y dos en Bélgica-, donde los tribunales internos aplicaron directamente esta sentencia para dejar sin efecto normas internas discriminatorias con los hijos naturales. “The Marckx Case. The Impact on European Jurisprudence...”, op. cit., pp. $294-299$.

294 Johnston y otros c. Irlanda, sentencia de 18 de diciembre de 1986, parr. 75; Bermeire c. Bélgica, de 29 de noviembre de 1991; Camp y Bourimi c. Países Bajos, sentencia de 3 de octubre de 2000, parr. 38. 


\section{a) Vida familiar: Obligaciones positivas y negativas}

La sentencia Marckx ocupa un lugar preeminente en la jurisprudencia del TEDH por muchos motivos. Aparte de los ya apuntados, se trata de la primera vez que el TEDH extrajo deberes positivos a cargo de los Estados parte derivados del respeto al derecho a la vida familiar, despejando de este modo el alcance del derecho. Esta importante precisión se realizó en la primera fase de su análisis, al evaluar la aplicabilidad del artículo 8.1 CEDH, concretando el significado de la ambigua redacción de dicha disposición.

"Al proclamar en el párrafo primero el respeto a la vida familiar de cada uno, el artículo 8 supone en primer lugar que el Estado no puede interferir en el ejercicio de ese derecho más que de acuerdo con los términos que estrictamente establece el párrafo segundo del mismo artículo. Como sentenció el Tribunal en el caso "Lingüístico belga"295, el objeto de tal artículo es esencialmente la protección del individuo frente a interferencias arbitrarias del poder público".

Conforme a este razonamiento, el "respeto" a la vida familiar da origen, en primer lugar, a obligaciones negativas para los Estados parte del $\mathrm{CEDH}$, en base a las cuales éstos han de evitar intromisiones ilegítimas en la vida familiar de las personas que se hallen bajo su jurisdicción. Pero, - al afirmar que éste es el objeto esencial del artículo-, está abriendo la puerta a la posibilidad de contenidos accesorios que permiten la inclusión de otro tipo de deberes estatales en el contenido de la vida familiar. El Tribunal prosigue por ello afirmando que:

"No obstante, el Estado no sólo debe abstenerse de tales interferencias, sino que, junto a tal obligación de carácter negativo, existen asimismo aquellas obligaciones positivas que el respeto efectivo a la vida familiar implica"296.

La extracción de obligaciones positivas supone que un derecho de carácter predominantemente liberal adquiere un contenido prestacional, cuya garantía jurídica presenta mayores dificultades. A tenor del razonamiento seguido por el TEDH, las obligaciones positivas parecen ser de carácter secundario o accesorio respecto a las negativas, que ocupan una posición prioritaria. De este modo, el derecho al respeto de la vida familiar tendría una doble faceta - liberal y simultáneamente prestacional-, lo que vendría a convertirlo en un derecho de carácter híbrido, mixto o multifacético, en perfecta coherencia con la naturaleza jurídica del derecho a la RF. En cualquier caso, la introducción de obligaciones positivas ${ }^{297}$ en el derecho a la vida familiar constituye una expansión del contenido del derecho y, por ende, del propio Convenio de Roma.

A fin de concretar el alcance de las obligaciones estatales positivas implícitas al artículo 8, el Tribunal introduce el concepto de vida familiar normal, de relevancia para los supuestos migratorios: "Ello significa, entre otras cosas, que cuando el Estado establece en su ordenamiento jurídico interno el régimen aplicable a ciertos vínculos familiares,(...), debe actuar en todo caso de forma que los interesados puedan desarrollar una vida familiar normal ${ }^{298}$. La aplicación de esta argumenta-

295 Asunto relativo a ciertos aspectos del régimen lingüístico de la enseñanza en Bélgica, sentencia de 23 de julio de 1968, apartado 7.

296 SEDH Marckx. C. Bélgica. Párr. 31.

297 La inclusión de obligaciones positivas en el ámbito del derecho a la vida familiar fue en su momento objeto de duras críticas doctrinales. Salzberg califica el apartado 31 de la sentencia Marckx, donde se produjo dicha inclusión, como una "cláusula perturbadora" como consecuencia de su imprecisión y vaguedad. SALZBERG, M. “The Marckx Case. The Impact on European Jurisprudence...”, op. cit., p. 293.

298 STEDH Markx c. Belgica, párrafo 31. A renglón seguido, el TEDH afirma que "tal como se concibe en el artículo 8, el respeto a la vida familiar implica concretamente, según la opinión del Tribunal, la existencia en el ordenamiento jurídico interno de cada Estado de ciertas garantías legales que permitan la integración del menor en su familia desde el momento mismo de su nacimiento". 
ción al caso enjuiciado, lleva al TEDH a concluir que, del artículo 8 en conexión con el artículo 14, se derivaba para el Estado belga la obligación positiva de permitir la creación y el normal desarrollo de la vida familiar de una madre soltera y su hijo, evitando cualquier discriminación basada en el nacimiento"299.

Asimismo, el TEDH concreta la naturaleza de las obligaciones positivas, señalando:

Es cierto que el Estado puede satisfacer esta necesidad con los medios que juzgue más oportunos, pero en la medida en que ello no se realiza atenta contra el párrafo 1 del artículo 8, sin que siquiera haya lugar a contemplarlo desde la perspectiva del párrafo $2^{300}$.

En consecuencia, y conforme a la naturaleza supra-estatal del sistema establecido en el CEDH, las obligaciones positivas son obligaciones de resultado ${ }^{301}$ : otorgan libertad al Estado para la elección de los diversos medios - normas sustantivas, concesión de ayudas materiales, prácticas administrativas concretas...etc. - que considere más oportunos para la consecución del objetivo perseguido, a saber, permitir a los individuos el desenvolvimiento de una vida familiar normal. Si con todo, las obligaciones de resultado constituyen un rasgo habitual en el ámbito de las obligaciones internacionales.

De la argumentación empleada por el TEDH parece deducirse que las positivas, en tanto que obligaciones de resultado, se traducirían en la concesión a los Estados parte de una esfera mayor de discrecionalidad ${ }^{302}$. La especial naturaleza de este tipo de obligaciones incide pues en la existencia de un margen de apreciación más amplio que el concedido a los Estados para el cumplimiento de las obligaciones meramente negativas ${ }^{303}$. Esta característica es, a nuestro juicio, de vital importancia para comprender la reagrupación familiar en el ámbito del Consejo de Europa, especialmente en su primitiva configuración jurisprudencial.

299 Marckx contra Bélgica, parr. 34,

300 Marckx...apdo. 31.

301 Ibidem, párra. 31, in fine. En el apartado 52 de la sentencia Marckx, el Tribunal reitera la naturaleza de las obligaciones positivas emanadas del artículo 8, pero esta vez en relación al establecimiento de los derechos patrimoniales en materia familiar. El juez Matscher, en su opinión parcialmente disidente, se pronuncia en el mismo sentido, cuando afirma que "es cierto, además que los Estados disfrutan de una cierta discrecionalidad a la hora de elegir los medios con que conseguir ese objetivo, ya que el artículo 8 no impone en absoluto a los Estados contratantes el deber de asumir un código de la familia que comprenda las reglas que tal objetivo implica".

302 El juez Matscher se expresa en un sentido similar en la opinión parcialmente disidente que formula a la sentencia Marckx, si bien matizando el alcance relativo del margen de apreciación. De su argumentación se deduce, a sensu contrario, que en cualquier caso el margen de discreción estatal parece ser superior que el existente en el caso de las obligaciones de injerencia: "Coincido enteramente con el razonamiento básico que sustenta la decisión del Tribunal: 'el respeto a la vida familiar garantizado por el artículo 8, párrafo 1, CEDH no se limita a la obligación del Estado de evitar que las autoridades públicas interfieran en el normal desarrollo de lo que considera la vida familiar', sino que implica, además, una obligación del Estado de establecer en su ordenamiento jurídico interno normas que efectivamente permitan ese normal desarrollo. (...) Por otra parte, debe tenerse asimismo en cuenta que esta obligación positiva que deriva del artículo 8 del Convenio se limita a aquello que es necesario para la creación y desarrollo de una vida familiar conforme a la idea que las modernas sociedades europeas tienen de este sentido. Es cierto, además, que los Estados disfrutan de una cierta discrecionalidad a la hora de elegir los medios con que conseguir ese objetivo"

303 Subrayando el margen de apreciación del que debería disfrutar el Estado en esta materia, si bien en un sentido profundamente crítico con la mayoría del tribunal, el juez Gerald, en su opinión disidente, afirma que el estado civil y la vida familiar son campos conceptuales diferentes del ordenamiento, pero "incluso si suscribiera el punto de vista mantenido en esta cuestión por la sentencia, continuaría estimando que el Gobierno belga no debería ser condenado por la aplicación de una ley a la que, pese a que algunos la consideran defectuosa o poco equitativa, tiene en realidad 


\section{b) La exclusión del apartado segundo del artículo 8 CEDH:}

Marckx apunta otro rasgo que se convertirá en usual para el enjuiciamiento de los deberes estatales positivos: la eliminación del análisis del párrafo segundo del artículo 8, en el razonamiento secuencial empleado por el TEDH. En el apartado anteriormente trascrito, aparece la primera y hasta el momento única referencia explícita a este peculiar enfoque empleado por los órganos de Estrasburgo para evaluar la compatibilidad con el Convenio de medidas estatales de carácter positivo. En Marckx, el TEDH apreció la existencia de violación del artículo 8, pero sin pasar a examinar si la injerencia estaba justificada en los términos del apartado segundo de dicho artículo, cuando lo habitual es precisamente lo contrario.

Este método será desde entonces predominante para el enjuiciamiento de actos estatales que contravengan obligaciones convencionales positivas de carácter migratorio. La técnica escalonada de enjuiciamiento se detiene en la segunda de las fases apuntadas, esto es, se paraliza al concluir el análisis del posible incumplimiento del artículo 8.1 CEDH. La explicación ofrecida por el TEDH resulta insuficiente, declarando sin mayor detenimiento que el recurso al apartado segundo resulta innecesario. Un explicación alternativa puede encontrarse en uno de los votos particulares emitidos a la sentencia Marckx, el correspondiente al juez Fitzmaurice. A su juicio, la eliminación del párrafo segundo se explica porque en Marckx se cuestionaba la legislación belga sin que ninguna de las demandantes hubiese aún sufrido actos concretos de injerencia en su vida familiar por parte de las autoridades de dicho pais. Sin embargo, lamenta esta exclusión ya que "el párrafo $2^{\circ}$ puede asimismo ser trascendente para el caso; no porque se hayan producido injerencias concretas por parte de las autoridades, sino porque la referencia a esa posible interferencia que hace el párrafo $2^{\circ}$ ayuda a dilucidar el sentido del párrafo $1^{\prime 304}$. Fitzmaure recurre a la interpretación sistemática, para subrayar la importancia del apartado segundo en la delimitación de los perfiles del contenido de los distintos derechos proclamados en el artículo 8.1 CEDH.

\section{c) La trascendencia de la sentencia Marckx contra Bélgica}

Esta sentencia supone el punto de partida de una línea de activismo judicial en el ámbito de la vida familiar, cuyo desenvolvimiento es clave para entender la consolidación del derecho a la reunificación familiar ${ }^{305}$ en el ámbito del Consejo de Europa.

La línea jurisprudencial emprendida en Marckx conducirá a un progresiva ampliación de la institución familiar objeto de protección. Las dos características más sobresalientes de la vida familiar ,tal y como es concebida por la jurisprudencia de Estrasburgo — su amplitud y extensividad-, se explican por la profundización de la línea activista que, en el ámbito de la familia, el TEDH emprendió en Marckx.

En Marckx, la Comisión por primera vez otorgó a la familia un carácter autónomo. En nuestra opinión, no es casualidad que precisamente la primera vez que se recurre al concepto autónomo de familia es cuando el TEDH logra superar la barreras impuestas por los derechos internos de familia, imponiendo una interpretación cuyos efectos, en un corto plazo, se desplegaron en una armonización de las normativas internas reguladoras del régimen de filiación de los hijos naturales y los

304 Opinión disidente del juez Sir Gerald Fitzmaurice, parrafo 6.

305 En tanto que derecho implícito, se trata de una construcción enteramente jurisprudencial, que además se enclava en el ámbito de las obligaciones positivas derivadas del respeto a la vida familiar, cuyo pistoletazo de salida se produjo precisamente en Marckx c. Bélgica. 
derechos a ellos otorgados, en un rama - el derecho de familia-, caracterizada precisamente por su alto grado de divergencia. Como afirma Jane Liddy, "Marckx señala el comienzo de la expansión del TEDH en el área del derecho de familia ${ }^{306 " . ~ A ~ n u e s t r o ~ j u i c i o, ~ e x i s t e ~ u n a ~ i ́ n t i m a ~ c o n e x i o ́ n ~ e n t r e ~ e s t e ~}$ efecto y el uso en Marckx por primera vez de la noción autónoma de familia.

En otro orden de consideraciones, en Marckx el TEDH especificó y limitó los efectos temporales de sus sentencias, negando la eficacia retroactiva de las mismas, de forma similar a como suele ocurrir en las jurisdicciones constitucionales, a fin de preservar la seguridad jurídica. Este aspecto ha sido destacado por Marc-André ${ }^{307}$ como un ejemplo de moderación en la política judicial. De esta forma, Marckx nos suministra un ejemplo del uso combinado de criterios interpretativos con efectos contradictorios - autocontención y activismo judicial一, sin que ello reste coherencia al resultado final.

A lo largo del presente trabajo hemos tenido ocasión de hacer referencia en varias ocasiones a esta sentencia. Fue en su momento citada para ilustrar el uso y potencial aplicativo del criterio interpretativo evolutivo; así mismo, se abordó al hablar del concepto amplio de víctima, que permite amplificar la capacidad protectora del Convenio, reforzando el efecto útil. En virtud de esta noción, se admiten reclamaciones de particulares ante el TEDH sin que exista un perjuicio concreto, lo que supondría la posibilidad de impugnar normativas internas potencialmente violatorias de derechos siempre que sean incompatibles con el Convenio ${ }^{308}$, lo que aproxima al TEDH a una jurisdicción constitucional de carácter supranacional. De este modo, Markx c. Bélgica ilustra la aproximación del Tribunal de Estrasburgo a una jurisdicción constitucional -o "cuasiconstitucional" -, de carácter supranacional en el sentido kelseniano de legislador negativo, faceta ampliamente destacada por la doctrina. De hecho, tras el pronunciamiento del TEDH en Marckx, el Estado belga tuvo que reformar la legislación civil impugnada. Además, dado que el pronunciamiento del TEDH tiene su origen en una demanda formulada por un particular o grupo de particulares, ello sirve para subsanar la legitimación activa restrictiva que, en el ámbito del derecho interno de los Estados parte, algunos países contemplan en sus procesos internos de control de constitucionalidad de las normas ${ }^{309}$.

En definitiva, Marckx ejemplifica una línea jurisprudencial de decidido activismo judicial, - representando fundamental por el frecuente recurso al criterio evolutivo y el uso del concepto autónomo de familia-, que se convertirá en una constante en la aproximación del TEDH a casos donde se dilucida la vida familiar. Ilustra de forma notable la capacidad del Tribunal de Estrasburgo de emitir pronunciamientos creativos e innovadores que muchas veces anticipan reformas normativas internas en la materia con creta objeto de enjuiciamiento, propiciando una mayor aproximación normativa entre los Estados parte.

306 JOHNSON, Nancy. "Breadth of family law..." op. cit., p. 519.

307 EISSEN, MarcAndré. El Tribunal Europeo de Derechos Humanos, op. cit., p. 86.

308 En el origen de la demanda no existían actos concretos de las autoridades estatales violatorios de derechos convencionales, sino una queja de determinados artículos de la legislación civil belga, que aún no habían sido aplicados a las demandantes.

309 En el caso de España, el individuo está excluido de la legitimación activa para entablar un recurso de inconstitucionalidad ante el TC; la única vía para que el individuo penetre en dicha legitimación es de forma indirecta, a través de la figura del Defensor del Pueblo. Además, tampoco cabe un recurso de amparo contra leyes, es decir, si la contradicción con la Constitución deriva directamente de una norma de rango legal, el individuo no puede impugnar la norma. La única vía, también oblicua, de subsanar esto sería a través de la autocuestión de inconstitucionalidad que el TC puede plantearse a sí mismo cuando, tras resolver un recurso de amparo, determina que la violación de un derecho fundamental de la sección $2^{\text {a }}$ está provocada por la propia norma legal. 


\section{LA CONSTRUCCIÓN JURISPRUDENCIAL DEL DERECHO A LA RF DE LOS EXTRANJEROS POR EL TEDH:}

Los derechos de los inmigrantes en el seno del Consejo de Europa, ausentes en el texto del Convenio de Roma, constituyen un ámbito de construcción enteramente pretoriano, debido en sus inicios a la obra de la Comisión Europea de Derechos Humanos. Durante tres décadas la Comisión, al estudiar la admisibilidad de las demandas, se ocupó de establecer el case-law en esta materia, sobre la base del grado de incidencia que una medida migratoria adversa provocaba sobre la vida familiar de los extranjeros asentados en el territorio de los Estados parte. En este tipo de demandas se alegaba la violación de la vida familiar como consecuencia de una medida estatal que, al decretar la expulsión de un miembro de la familia o bien al denegar la entrada o permanencia de familiares de extranjeros asentados en el territorio de los Estados parte del CEDH, provocaba, respectivamente, o bien la ruptura de la vida en familia, o bien constituía una falta de respeto de dicho derecho ${ }^{310}$.

Los principios generales formulados por la Comisión en este ámbito, servirían al TEDH como punto de partida. Entre ellos, destaca la consolidación de la protección de rebote que, como señalamos, permitió la tutela de los inmigrantes y la entrada de algunos derechos migratorios en el ámbito del Convenio. Sin embargo, la intervención de la Comisión en este ámbito se caracterizó por un elevado índice de decisiones de inadmisibilidad ${ }^{311}$, lo que había impedido su análisis temprano por parte del TEDH.

$\mathrm{Al}$ analizar demandas con contenido migratorio, la Comisión partía de la constatación del derecho soberano que ostentan los Estados de controlar sus fronteras y regular los aspectos relativos a la entrada y establecimiento de los extranjeros en sus territorios, en tanto que principio general sólidamente asentado del Derecho Internacional. A continuación, recordaba que el derecho de un extranjero a entrar o permanecer en el territorio de un Estado miembro no está, como tal, garantizado por el Convenio de Roma. Al estudiar la evolución de la protección de rebote tuvimos ocasión de comprobar que la tesis primitiva sustentada por la Comisión al enfrentarse a asuntos de esta naturaleza, se basaba en la aplicación rígida de la doctrina de que el CEDH no contemplaba como tal - "no right as such" - ningún derecho migratorio. También subrayamos que esta doctrina fue progresivamente abandonada según iba consolidándose la técnica de la protección de rebote. El punto de inflexión estaba representado por la Decisión 434/58.

A partir de dicha Decisión, la Comisión considera que, no obstante la omisión en el Convenio de Roma de derechos migratorios, sin embargo, en ciertas circunstancias, la exclusión de una persona del territorio de un Estado en el que viven sus parientes puede plantear un problema en el que entre en juego el artículo $8^{312}$-admitiendo con ello la aplicabilidad de esta disposición para proteger ciertos derechos de los inmigrantes que, en principio, habían quedado excluidos por el tenor literal de dicha disposición.

310 Vid. al respecto ARRIAGA, I. El derecho a la vida familiar de los extranjeros..., op. cit., pp. 231-238. La autora periodifica las distintas etapas en el case-law desarrollado por la Comisión en materia de reagrupación familiar.

311 QUESADA POLO, Santiago. “La expulsión...”, op. cip., p. 320. ARRIAGA IRABURU, Inés. El derecho a la vida familiar..., op. cit., p. 233, la autora relaciona esta circunstancia con la aplicación del test de los obtáculos por parte de la Comisión. Si bien apunta algunos supuestos excepcionales en los que la Comisión declaró admisibles demandas relativas a supuestos de RF, mencionando el asunto Alam y Khan c. Reino Unido y el caso de los asiáticos del Este africano. En una línea similar se inscribe SANTOLAYA MACHETTI, P. El derecho a la vida familiar..., op. cit., p. 92.

312 Se trata de una fórmula repetida por la Comisión con escasas variaciones desde el año 1963 (Decisión 1855/63 X. C. Dinamarca, CD/RD 16, pp. 50-52). Citada por ARRIAGA IRABURI, I. El derecho a la vida familiar de los extranjeros..., op. cit., p. 29. 
Sobre la premisa de la deferencia hacia la soberanía y el respeto al derecho migratorio nacional - considerado éste como un asunto básicamente interno por su íntima conexión a la soberanía estatal-, la Comisión concedía un amplio margen de apreciación al Estado al revisar aquellas medidas migratorias potencialmente violatorias de la vida familiar de los extranjeros. En consecuencia, el punto de partida para abordar el estudio de esta cuestión reside en negar con carácter general la existencia de una obligación, tanto negativa como positiva, por parte del Estado parte del CEDH de admitir o no expulsar a los extranjeros. Tal obligación sólo será exigible en concurrencia de determinadas circunstancias particulares, que trataremos de identificar a lo largo del presente capítulo -en lo que respecta exclusivamente a la RF entendida como obligación de carácter negativo-.

El derecho a la RF, sobre la base del derecho al respeto a la vida familiar consagrado en el artículo $8 \mathrm{CEDH}$, constituye una rama jurisprudencial relativamente reciente, abordada por el TEDH desde inicios de la década de los ochenta del pasado siglo. Desde entonces hasta la actualidad, la Corte de Estrasburgo ha emitido diez sentencias sobre migración familiar — si bien las últimas constituyen asuntos más próximos al ámbito de las expulsiones que a la reagrupación de extranjeros, y nos servirán fundamentalmente como ejemplo ilustrativo de la sutileza de la distinción entre obligaciones positivas y negativas, así como de la inconsistencia del mantenimiento de los criterios de clasificación entre ellas y de la aplicación de un método diferenciado de evaluación-.

Del examen detallado de la jurisprudencia de Estrasburgo en materia de inmigración familiar, cabe establecer una clara línea divisoria entre dos líneas jurisprudenciales marcadamente separadas. De ahí que hablemos de dos etapas sucesivas en la construcción jurisprudencial de la RF, la primera de las cuales abarca las tres primeras sentencias dictadas en este ámbito - Abdulaziz, Cabales y Balkandali c. Reino Unido, Gül c. Suiza y Ahmut c. Países Bajos- y caracterizada por su tono marcadamente restrictivo. La segunda etapa está conformada por tres pronunciamientos-Tuquabo-Teckle c. Países Bajos, Rodrigues da Silva y Hoogkkamer c. Países Bajos, Konstatinov c. Holanda-. Esta segunda fase está precedida por una sentencia de importancia esencial -el asunto Sen c. Holanda-, emitida a finales del año 2001, que representa un radical y decidido viraje jurisprudencial respecto a los test empleados por el TEDH para abordar la reunificación familiar.

Entre ambas fases se sitúan dos Recomendaciones sobre reagrupación familiar emitidas por el Comité de Ministros y la Asamblea Parlamentaria del Consejo de Europa, próximas temporalmente al asunto Sen c. Holanda, que reflejan y anticipan el cambio de perspectiva al abordar la migración familiar en el ámbito de Estrasburgo.

Finalmente, cabría hablar de una tercera y última etapa en la jurisprudencia de Estrasburgo en torno a la migración familiar, integrada por tres sentencias muy recientes -Asuntos Nuñez contra Noruega, Agraw contra Suiza y Osman contra Noruega-. El tenor marcadamente progresista que el Tribunal adopta a fin de potenciar el efecto útil que el derecho a la vida familiar proyecta sobre la $\mathrm{RF}$, es de tal intensidad, que nos empuja a calificarla como una fase rupturista. Junto a su carácter garantista, en esta última etapa el TEDH oscurece los criterios de clasificación aplicables al contexto migratorio en el seno del artículo $8 \mathrm{CEDH}$, abordando como supuestos de RF casos con características más propias de las obligaciones migratorias negativas.

\subsection{La familia del extranjero en la jurisprudencia del TEDH}

Cuando el TEDH se enfrenta a un supuesto de una medida migratoria adversa dictada contra un extranjero que pueda suponer una ruptura, injerencia - obligación negativa- o falta de respe- 
to - obligación positiva - de su vida familiar, la primera tarea que debe realizar, en aplicación del método escalonado de enjuiciamiento, es evaluar la aplicabilidad del artículo 8 al caso concreto. Ello supone comprobar si, en el supuesto enjuiciado, existe VF protegida por el Convenio, analizando si el vínculo existente entre el/los demandantes merece tal consideración, conforme al significado otorgado a dicho concepto por la jurisprudencia de Estrasburgo. En consecuencia, la existencia de vida familiar delimita la titularidad activa del derecho proclamado en el art. $8 \mathrm{CEDH}$.

En vía de principio, los derechos proclamados en dicha disposición gozan de un amplia titularidad - "todos", reza textualmente el art. 8-, circunstancia que ha permitido el acceso de los extranjeros a reivindicar la protección de su vida familiar ante las autoridades de Estrasburgo. Resta pues identificar las relaciones familiares que quedan amparadas bajo la protección que otorga la vida familiar consagrada en el Convenio de Roma.

Constituye jurisprudencia constante del TEDH considerar que la vida familiar, en el sentido del art. $8 \mathrm{CEDH}$, presupone la existencia de una familia ${ }^{313}$, lo que exige despejar una primera cuestión: La definición jurídica de qué es la familia.

Sin embargo, no es posible encontrar una definición convencional de familia ${ }^{314}$, a efectos de la aplicación del artículo 8 del CEDH. El abundante corpus jurisprudencial existente en esta materia no ofrece en ningún momento una noción de lo que sea familia, es más, "el tribunal ha mantenido voluntariamente cierta aureola de indeterminación porque la vida familiar es quizá uno de los conceptos más permeables a los cambios morales y sociológicos de una comunidad. De su jurisprudencia se va deduciendo la progresiva ampliación de la que se ha beneficiado esta institución pero el TEDH se niega, en muy buena lógica, a limitar su protección a determinado concepto o idea de familia" 315 . Es precisamente tanto la indeterminación del Convenio de Roma como la opción de no proporcionar una definición de familia por parte de los órganos de Estrasburgo, lo que ha permitido, en opinión de Sanz Caballero, poder proteger múltiples situaciones familiares, "demostrando la plasticidad de este instrumento jurídico" ${ }^{316}$.

De otro lado, el hecho de que el artículo 8 garantice el derecho a la vida familiar - y no hable directamente de la familia, que constituye una garantía institucional, y no un derecho en sí mismo-, ha sido señalado por la doctrina ${ }^{317}$ como la causa que ha liberado al TEDH de la obligación de ofrecer una definición jurídica de familia, a efectos del CEDH.

El TEDH aborda esta cuestión adoptando un punto de vista muy pragmático, ya que "la existencia o no de vida familiar en el sentido del artículo 8 es esencialmente una cuestión de hecho que depen-

313 Cf. Marckx c. Bélgica, par. 31.

314 En idéntico sentido se sitúan STOREY, H. “The right ro family life and immigration case law at Strasbourg”, op. cit., p. 334; ARRIAGA, I. El derecho a la vida familiar..., op. cit., p. 83. VILLIGER, M.E. "Expulsion and the right to respect for private and family life (Article 8 of the Convention) - an introduction to the Commission's case law"; en MATSCHER, F; PETZOLD, H. (eds.). Protecting Human Rights: The European Dimension. Studies in Honour of G.J. Wiarda. Köln-Berlin-Bonn-München, C. Heymanns Verlag, 1988, p. 658.

315 SANZ CABALLERO, Susana. "El TEDH y las uniones de hecho”; en Repertorio Aranzadi del TC. № 2, 2003 , p. 2482. La autora prosigue relacionando la ausencia de una definición de familia por parte del TEDH con la concepción del $\mathrm{CEDH}$ como un instrumento vivo, "que debe ser interpretado siempre de acuerdo con el contexto social imperante en cada momento histórico en una sociedad democrática pluralista y tolerante".

316 SANZ CABALLERO, Susana. La familia en perspectiva internacional y europea. Valencia, Tirant lo Blanch, $2006, \mathrm{p}$. 86. En idéntico sentido se manifiesta ARRIAGA IRABURU, I. El derecho a la vida familiar..., op. cit, nota a pie. $\mathrm{n}^{\circ}$ 2, p. 79.

317 ARRIAGA IRABURU, I. El derecho a la vida familiar..., op. cit., p. 108. 
de de la existencia real en la práctica de vínculos personales estrechos"318. Esta aproximación revela el sentido generalmente amplio, liberal, fáctico y casuístico de la familia en la visión del TEDH. Con todo, pese al tenor liberal que domina la aproximación del Tribunal de Estrasburgo a la noción de familia, ésta sin embargo está imbuida por el peso de la noción occidental de familia nuclear, desembocando finalmente en un entendimiento más bien estrecho de los vínculos familiares tutelados bajo el concepto de vida familiar ${ }^{319}$. Además, los criterios utilizados para su apreciación resultan en ocasiones poco claros y subjetivos ${ }^{320}$.

Lo que pretendemos en este apartado es sentar las premisas con las que el TEDH se aproxima al análisis de la existencia de VF, haciendo incidencia en supuestos donde los demandantes son extranjeros asentados en el territorio de los Estados contratantes, a reserva de su verificación concreta cuando analicemos posteriormente las sentencias emitidas en materia de inmigración familiar. De forma simultánea a la determinación de los requisitos que las instituciones de Estrasburgo exigen para tomar en consideración la vida familiar de los extranjeros - test convencionales empleados al efecto-, identificaremos las relaciones familiares que quedan incluidas dentro de la vida familiar garantizada por el art. $8 \mathrm{CEDH}$.

En el contexto específicamente migratorio, los órganos de Estrasburgo suelen analizar directamente la existencia o no de vida familiar del extranjero, sin entrar a valorar previamente la presencia de una familia ${ }^{321}$-si bien éste constituye un rasgo procedimental diferencial, carente de implicaciones prácticas-.

Los criterios empleados por el TEDH - al menos en lo que respecta a su primera jurisprudencia-, para dilucidar la compatibilidad con el derecho a la VF de los extranjeros de los controles migratorios establecidos por las políticas internas de los Estados parte, fueron extraídos de los establecidos anteriormente por la Comisión, cuyos presupuestos serían retomados por el TEDH ${ }^{322}$. Sin embargo, de tales presupuestos se deduce la dificultad e incluso imposibilidad ${ }^{323}$ de ofrecer un concepto de vida familiar, en vista que, para los órganos de Estrasburgo, ésta constituye una cuestión de hecho, totalmente dependiente de las circunstancias concretas que concurran en el caso ${ }^{324}$.

318 Caso K. y T. contra Finlandia, 2001, apartado 150.

319 ARRIAGA IRUBURU, I. El derecho a la vida familiar..., op. cit., p. 102.

320 Idem, pp. 81-82, y nota a pie de página no 10 de la p. 82. ARRIAGA critica al respecto el "carácter subjetivo e inaprensible" de tales criterios.

321 ARRIAGA ha denunciado la oscuridad de la terminología empleada en el concepto de vida familiar de los extranjeros. Mientras que, con carácter general, la jurisprudencia de Estrasburgo emplea los términos de 'familia, 'relación familiar,' 'célula familiar' o 'vínculos familiares' en sentido intercambiable, sin embargo, en supuestos migratorios, "existe cierta confusión en torno a los conceptos de 'familia' y 'vida familiar', siendo la regla general que los órganos estrasburgueses se planteen directamente si existe 'vida familiar' en el caso en cuestión, sin un estudio previo sobre la existencia de 'familia”'. El derecho a la vida familiar..., op. cit., nota a pie de página n 10, p. 82.

322 Parcialmente en contra de esta apreciación se manifiesta STOREY. El autor señala que la aproximación del TEDH no es radicalmente diferente a la de la Comisión: ambos se basan en un método fáctico, exigiendo y analizando los vínculos familiares próximos que de hecho existan. Sin embargo, el TEDH muestra a su juicio un concepto de VF más dinámico, como un proceso con diferentes estadios. Storey insiste en la necesidad de no subestimar estas notas diferenciales, a fin de poder alcanzar un correcto entendimiento de supuestos migratorios en el ámbito de Estrasburgo. "The Right to Family Life and Immigration Case Law at Strasbourg”; op. cit., especialmente pp. 334-335. En un tono parecido, ARRIAGA ha destacado que, aun caminando sobre las premisas sentadas por la Comisión, el TEDH aplicó el doble test exigido a la vida familiar de los extranjeros, pero sentando desde el inicio un concepto más amplio de vida familiar que el sostenido por la Comisión. El derecho a la vida familiar..., op. cit., p. 106.

323 Así lo define ARRIAGA, I. El derecho a la vida familiar..., op. cit., p. 83.

324 STOREY, H. “The Right to Family Life and Immigration Case Law at Strasbourg”; op. cit., p. 334. 
Con todo, el espíritu con el que la Comisión concebía la existencia de vida familiar y los requisitos exigidos para estimar su concurrencia en casos relativos a inmigrantes queda reflejado sumariamente, a juicio de Storey ${ }^{325}$, en el siguiente extracto jurisprudencial:

"La Comisión recuerda (...) que aparte de vínculos de sangre, otro tipo de vínculos deben existir entre las personas implicadas para que su relación pueda constituir vida familiar dentro del significado del artículo 8 (...) Así, para decidir si la familia existe, la Comisión ha tenido en cuenta si, por ejemplo, las personas han vivido de hecho juntas y si eran financieramente dependientes".

De su jurisprudencia es posible deducir, en primer lugar, que los inmigrantes deben demostrar la cercanía de sus vínculos familiares - requisito que se traduce en la exigencia de que su vida familiar sea real $\boldsymbol{y}$ efectiva $\boldsymbol{a}^{326}$, para ser considerada existente y poder ser susceptible de protección convencional. Y, además, se requiere que la vida familiar preexista a la medida migratoria supuestamente violatoria.

Sobre este presupuesto, el TEDH iniciaría, a mediados de los ochenta, su jurisprudencia relativa a supuestos migratorios, encajándolos, como hacía también la Comisión, dentro del contexto del respeto a la vida familiar reconocida en el art. $8 \mathrm{CEDH}$. Cabe pues hablar de un doble test convencional $^{327}$ - de un lado, se exige una VF real y efectiva; y, de otro, que sea de carácter preexistente-, cuyo análisis se hará de forma separada.

\section{a) Vida Familiar Real y Efectiva}

1.1 - Carácter efectivo de la vida familiar: De ambas exigencias, la más habitual es demostrar la efectividad de la vida familiar, que corre a cargo del recurrente. Para ello suele ser necesario la existencia de vínculos biológicos acompañados, generalmente, de convivencia entre los integrantes del núcleo familiar ${ }^{328}$.

Sin embargo, el requisito de la convivencia o cohabitación no es indispensable cuando lo que se trata de evaluar son las relaciones entre padres y sus hijos menores. El TEDH llegó a esta conclusión en el asunto Berrehab, relativo a una expulsión de un extranjero - ciudadano marroquí-, a quien las autoridades internas habían denegado la renovación de su permiso de residencia, lo que le apartaría de la hija que había tenido con su exmujer, de nacionalidad holandesa. En el asunto Berrehab, el TEDH afirmó de forma contundente que "la vida en común no es una condición indispensable para la vida familiar entre los padres y los hijos menores ${ }^{329 "}$. Esta apreciación resulta fundamental para que el Convenio de Roma ofrezca cobertura al derecho a la RF, caracterizado por la separación física y, por ello, la falta de cohabitación durante un cierto tiempo, entre los miembros de la familia que desean reagruparse.

325 7229/75, D.R. 12, 32; cf. 5269/71 v. UK C.D. 39, 104, 108. STOREY, H. “The Right to Family Life and Immigration Case Law at Strasbourg”; op. cit., p. 329, traducción propia. De esta aproximación, el autor extrae los requisitos de existencia y efectivad, exigibles a la vida familiar en el sentido del art $8 \mathrm{CEDH}$, tal y como las concebía la Comisión.

326 ARRIAGA IRABURU, I. El derecho a la vida familiar..., op. cit., p. 84.

327 Seguimos en este ámbito fundamentalmente los planteamientos expuestos por ARRIAGA IRABURU, al estudiar la jurisprudencia de la Comisión relativa a la vida familiar de los extranjeros, en El derecho a la vida familiar de los extranjeros, op. cit., pp. 79-109.

$328 \mathrm{Al}$ respecto ARRIAGA ha precisado que "no es suficiente la existencia de un vínculo familiar, debiendo éste ser el fundamento de una efectiva 'vida familiar"'. Posteriormente puntualiza que los dos componentes principales en los que se desdobla la exigencia de efectividad de la VF, son la cohabitación y la dependencia económica, establecidos por la Comisión desde la década de los setenta. Idem, pp. 85 y 87, respectivamente.

329 Asunto Berrehab c. Holanda, sentencia de 21 de junio de 1988, parr. 21. 
En consecuencia, la existencia de una auténtica vida familiar entre padres e hijos no depende de la convivencia constante o permanente. Puede existir VF tras la ruptura de la convivencia entre los padres - cónyuges - por divorcio, como en el caso descrito o, con carácter general, tras el cese de la vida en común. En tales circunstancias, la cohabitación puede suplirse por la existencia de factores que permitan al TEDH poder deducir la intensidad y firmeza de las relaciones mantenidas entre ambos. De este modo, entre padres y sus hijos menores basta la voluntad del progenitor de establecer contactos personales con su hijo - visitas frecuentes ${ }^{330}$ - o, si éstos no han sido posibles, a través de cualquier otra vía que evidencie la asunción de responsabilidades por parte del progenitor, tales como la contribución a los gastos del menor, contactos telefónicos...etc.

Las relaciones paterno filiales constituyen el epicentro de la vida familiar objeto de protección por parte de Estrasburgo. Por ello, el TEDH estima que la relación que un matrimonio legal y real crea entre los cónyuges debe calificarse como vida familiar ${ }^{331}$. De este modo, el concepto de familia en que se apoya el artículo 8 tiene la consecuencia de que un niño nacido de dicha unión forma parte de pleno derecho de esta relación; por consiguiente, desde el momento, y por el mero hecho de su nacimiento, existe entre él y sus padres, incluso si éstos no conviven a la sazón, un lazo que supone $<$ vida familiar $>$ "332.

El vínculo constitutivo de vida familiar que existe entre padres e hijos desde el mismo momento del nacimiento es de tal naturaleza, que no podrá ser roto por acontecimientos posteriores, salvo en circunstancias excepcionales ${ }^{333}$. De modo que, en supuestos en los que los progenitores dejen a sus hijos en su país de origen y emigren en busca de una vida mejor, cabría suponer que la separación física no romperá el vínculo, -incluso aunque sea por períodos temporales largos y coincidentes con la infancia del menor-, siempre que existan factores que revelen la intensidad, estabilidad y permanencia del vínculo entre padres e hijos, pese a la distancia geográfica, así como indicativos de la existencia de dependencia entre ellos, fundamentalmente de carácter económico. Aplicando la anterior doctrina, también sería previsible entender que bastará la mera constancia de la voluntad de los padres de traer a sus hijos al país de acogida en cuanto regularicen su situación jurídica y/o las visitas realizadas ${ }^{334}$, como indicativo de subsistencia del vínculo familiar.

El principio de no distinción entre hijos legítimos y naturales sentado desde Marckx, es también de aplicación a éstos últimos en el contexto migratorio, sean hijos nacidos de una pareja de hecho no casada, procedentes de familias monoparentales o cualquier otra circunstancia asimilable. Y, más allá, la imposibilidad de distinción se extiende también a la propia familia, de modo que la protección del art. 8 no se restringe a las relaciones familiares basadas en el matrimonio, amparando "otros lazos familiares de facto ${ }^{335}$ " como la cohabitación extramatrimonial ${ }^{336}$, si bien en el apartado final

330 En el caso Berrehab, el TEDH afirmó que "sin duda, el señor Berrehab y la señora Koster, ya divorciados, no continuaban viviendo juntos al nacer Rebeca ni lo hicieron después. No es menos cierto que el primero, hasta su expulsión de los Países Bajos, vio a su hija cuatro veces por semana durante varias horas, la frecuencia y la regularidad de sus entrevistas demuestran lo mucho que representaban para él. Por tanto, no se puede sostener que los lazos de la «vida familiar» se habían roto entre ellos".

331 Asunto Abdulaziz, Cabales y Balkandali de 28 de mayo de 1985, apartado 62.

332 Berrehab contra Holanda, STEDH de 21 de junio de 1988, apartado 21. Sen c. Países Bajos, STEDH de 21 de diciembre de 2001, apdo. 28; Kosmopoulou c. Grecia, STEDH de 5 de febrero de 2004, apdo. 42.

333 Gül contra Suiza, apartado 32.

334 Idem, apartado 33.

335 Expresión habitualmente empleada por el TEDH desde la sentencia Kroon y otros c. Países Bajos, de 20 de septiembre de 1994, apartado 30.

336 En el asunto Keegan c Irlanda, de 26 de mayo de 1994, el TEDH estableció que "the notion of the 'family' in this provision is not confined solely to marriage-based relationships and may encompass other de facto 'family' ties 
de este capítulo se analizará la aplicación de este presupuesto general a las parejas migrantes que aspiran a la RF.

Esta doctrina fue llevada a sus últimas consecuencias en el caso Kroon ${ }^{337}$, donde el TEDH prosiguió la estela de activismo judicial y extensión del concepto de vida familiar iniciada en Marckx. En Kroon el TEDH aceptó la existencia de vida familiar entre personas que nunca habían convivido, si bien con el importante matiz de que había un hijo extramatrimonial de por medio y la pareja, pese a elegir vivir separados y no casarse, tenía en común cuatro hijos ${ }^{338}$.

Cuando lo que se trata de evaluar son las relaciones entre padres e hijos adultos, la vida familiar a efectos del artículo 8 exige la existencia de factores adicionales de dependencia ${ }^{339}$, no bastando los meros lazos afectivos considerados normales ${ }^{340}$. El requisito de dependencia suele ser interpretado de forma restrictiva por las instituciones de Estrasburgo, centrándose fundamentalmente en su carácter económico o material, no bastando únicamente una dependencia emocional ${ }^{341}$. Esta exigencia determina que la admisibilidad de vida familiar en tales circunstancias sea bastante excepcional,

where the parties are living together outside of marriage. A child born out of such a relationship is ipso iure part of that "family" unit from the moment of his birth and by the very fact of it. There thus exists between the child and his parents a bond amounting to family life even if at the time of his or her birth the parents are no longer co-habiting or if their relationship has then ended". Keegan c. Irlanda, apdo. 44. En el mismo sentido se pronunciaba el TEDH en Johnston c. Irlanda, de 1986, parr. 55. Haciendo referencia a la vida familiar existente entre un hombre separado, la mujer con quien convivía desde hacía quince años y el hijo común, recordó que Article 8 (art. 8) applies to the 'family life' of the 'illegitimate' family as well as to that of the 'legitimate' family". Tras lo cual afirmó que " in the present case, it is clear that the applicants, the first and second of whom have lived together for some fifteen years, constitute a "family" for the purposes of Article 8. They are thus entitled to its protection, notwithstanding the fact that their relationship exists outside marriage". Parr. 56. Adicionalmente, en esta sentencia el TEDH estimó que ni del artículo 8 ni del $12 \mathrm{CEDH}$ podia derivarse un derecho a divorciarse o a casarse de nuevo.

337 KROON y otros c. Holanda, de 24 de octubre de 1994. En Kroon se ventilaba el incumplimiento del artículo 8 como consecuencia de la denegación de la solicitud de reconocimiento de paternidad por parte de las autoridades holandesas al padre biológico de un niño nacido de una relación extramatrimonial estable, donde los padres no convivían. El problema estribaba en que la madre del menor permanecía aún casada con otro hombre, de quien posteriormente se divorció. Para el Estado holandés, pesaba más la presunción legal de paternidad (que se atribuía al marido de la madre) que la presunción biológica. Sin embargo, el TEDH afirmó que las autoridades estatales tienen la obligación positiva de permitir el establecimiento de los vínculos familiares completos y que no podía pesar más una presunción legal sobre la realidad biológica y social. Vid. al respecto JOHNSON, Nancy. "The breath of Family Law Review under the European Convention on Human Rights"..., op. cit., pp. 520-525. Para la autora esta sentencia ejemplifica el activismo judicial al que el TEDH tiende en materia de derecho de familia, al tiempo que constituye "una importante extensión del derecho de familia iniciado en el caso Marckx". Idem, p. 523.

338 "In any case, the Court recalls that the notion of 'family life' in Article 8 is not confined solely to marriage-based relationships and may encompass other de facto 'family ties' where parties are living together outside marriage. Although, as a rule, living together may be a requirement for such a relationship, exceptionally other factors may also serve to demonstrate that a relationship has sufficient constancy to create de facto 'family ties'; such is the case here, as since 1987 four children have been born to Mrs Kroon and Mr Zerrouk. A child born of such a relationship is ipso jure part of that 'family unit' from the moment of its birth and by the very fact of it (see the Keegan judgment, ibid.). There thus exists between Samir and Mr Zerrouk a bond amounting to family life, whatever the contribution of the latter to his son's care and upbringing". Kroon y otros c. Países Bajos, STEDH de 20 de septiembre de 1994. Apdo. 30.

339 Ezzouhdi v. France, No. 47160/99, STEDH 13 February 2001, APTO. 34.

340 En palabras de la Comisión, "generally, the protection of family life under Article 8 involves cohabiting dependents, such as parents and their dependant, minor children. Whether it extends to other relationships depends on the circumstances of the particular case. Relationships between adults (...) would not necessarily acquire the protection of Article 8 of the Convention without evidence of further elements of dependency involving more than the normal emotional ties". Demanda No 10375/83, C c. Reino Unido, decisión de 3 de julio de 1992.

341 ARRIAGA, I. El derecho a la vida familiar..., op. cit., p. 88. 
pues se exige la presencia de "vínculos particularmente estrechos" ${ }^{342}$. De este modo, se ha considerado como vida familiar en el sentido del artículo $8 \mathrm{CEDH}$ aquella existente entre hijos adultos discapacitados y sus padres ${ }^{343}$.

Para demostrar el carácter efectivo de la vida familiar — especialmente entre miembros adultos de la familia-, suele exigirse, junto a la dependencia emocional o afectiva, la existencia de dependencia material o financiera entre los integrantes de la unidad familiar. Y puede ser considerado como factor adicional a favor de dicha efectividad, la superposición de varias generaciones. Si bien cabe apuntar que, pese al tenor generalmente restrictivo del requisito de la dependencia, en la jurisprudencia del TEDH puede percibirse también cierta relajación de estas exigencias, y existen casos en los que la Corte de Estrasburgo parte del punto de vista contrario, apreciar la existencia de vida familiar en la relación entablada entre padres e hijos adultos, salvo que excepcionales circunstancias rompan tal vínculo ${ }^{344}$. Si bien, resta comprobar la aplicabilidad de esta doctrina al ámbito de la migración familiar, en vista de sus repercusiones y su afectación a cuestiones íntimamente conectadas a la soberanía nacional.

El requisito de la efectividad supone la exclusión de los contactos esporádicos entre miembros de la familia, que no tienen entidad suficiente para dar origen a vida familiar ${ }^{345}$ - si bien, por las circunstancias específicas que rodean a la migración familiar, tendremos ocasión de comprobar la elasticidad de esta exigencia en nuestro ámbito de estudio, que será sustituida por test adicionales.

1.2 - Autenticidad del vínculo familiar: Respecto a la exigencia del carácter real de la vida familiar, constituye una vía para luchar contra el fraude de ley con el fin de evitar atraer la protección del artículo 8 a relaciones que quedarían excluidas. Se ha usado poco, y casi siempre para evaluar que los vínculos existentes entre una pareja sean genuinos, excluyendo la simulación.

Su exigencia deriva del primitivo case law de la Comisión. En una ocasión este órgano rechazó la admisibilidad de una demanda presentada por una ciudadana de Zaire que alegaba que la denegación de las autoridades holandesas a permitir la entrada de su supuesta hija constituía una injerencia en su vida familiar - y, por lo tanto, en un contexto que encajaría en la RF-. Sin embargo, la demandante realmente era la tía de la menor. En la argumentación de los órganos de Estrasburgo, pesó mucho el recurso al engaño empleado por las recurrentes ${ }^{346}$.

342 LIDDY Jane. “Current Topic: The Concept of Family Life...”, op. cit., p. 17.

343 Nasri c. Francia, sentencia de 13 de julio de 1995, apdos. 38 y 44. Como afirmó el TEDH, este caso reunía una "acumulación de especiales circunstancias" - apdo. 46- ya que el demandante era un extranjero pendiente de una orden de deportación, sordo mudo, analfabeto y desconocía el lenguaje de los signos, de modo que se aceptó que sacarlo de su círculo familiar supondría una grave injerencia en el derecho reconocido en el artículo 8 CEDH. Lo más relevante, además de la inclusión de las relaciones entre hijos adultos en el ámbito de la vida familiar, es que también fueron consideradas como tales las relaciones entre hermanos adultos.

344 Boughanemi c. Francia, aptdo. 35. De esta sentencia no cabe deducir, a nuestro juicio, un principio de general aplicación a relaciones entre adultos. De su lectura queda clara la apreciación de vida familiar entre el sr. Boughanemi y su hijo, pero de los lazos entre el demandante y sus padres y diez hermanos, aunque fueron considerados para apreciar la existencia de injerencia en la vida familiar provocada por la orden de deportación, parece deducirse su inclusión en la vida privada, antes que en el concepto más estrecho y estricto de vida familiar.

345 Haas c. Países Bajos, SEDH de 13 de enero de 2004, párr. 42.

346 Nsona c Holanda, SEDH de 28 de noviembre de 1996. "The Commission confined itself to observing that when Francine arrived in the Netherlands, she was falsely claimed to be Bata Nsona's child. It also considered the allegation that Francine was in fact Bata Nsona's niece to be unsubstantiated. There had therefore, in its opinion, been no interference with the applicants' right to respect for their family life". Por su parte, el TEDH afirmó que las autoridades neerlandesas no podían ser responsables de rechazar alegaciones que carecían de sustento en la evidencia, insistiendo en que en tales circunstancias las autoridades neerlandesas no podía imputárseles injerencia en la vida familiar. "Upon arrival at Schiphol Airport the applicants presented a Zaïrean passport in the name of Bata Nsona, apparently issued 
Este requisito puede estar llamado a jugar un papel relevante en asuntos migratorios, a fin de evitar que los denominados matrimonios en blanco o de conveniencia puedan colarse en la protección dispensada por el artículo 8, burlando el espíritu de la norma y la propia normativa interna de extranjería. Sin embargo, hasta el momento no se ha presentado un caso de esta naturaleza ante el TEDH en el ámbito de la inmigración familiar.

Lo que si ha sido objeto de pronunciamiento, si bien tempranamente y por parte de la Comisión, ha sido la compatibilidad con el Convenio de aquellas medidas estatales destinadas a comprobar la autenticidad de los vínculos sanguíneos, en aquellos supuestos en los que existían dudas en torno a la misma ${ }^{347}$. Esta doctrina podría tener cierta relevancia en vista de la tendencia creciente en algunos Estados contratantes a la imposición de pruebas genéticas a fin de constatar el carácter real de los vínculos familiares alegados por los extranjeros para poder acceder a la $\mathrm{RF}^{348}-\mathrm{y}$, a un tiempo, luchar contra la falsedad documental-.

\section{b) Preexistencia de la vida familiar}

La vida familiar debe además preexistir a la medida estatal que interfiere o no respeta su normal desarrollo: Con carácter general, la vida familiar protegida por el artículo 8 es aquella cuya existencia es anterior a la medida estatal migratoria de carácter limitativo, tomándose este momento como referencia temporal.

Constituye doctrina reiterada del TEDH afirmar que, al garantizar el derecho al respeto de la vida familiar, el artículo 8 presupone la existencia de una familia. Es decir, el CEDH protege la vida familiar ya existente ${ }^{349}$, no la futura. Harris, O`Boyle y Warbrick extraen esta misma conclusión de la interpretación del término "respeto" que, en la redacción del artículo $8 \mathrm{CEDH}$, antecede a la vida familiar objeto de protección. A juicio de estos autores, el respeto a la vida familiar "no permite a las personas reclamar un derecho a establecer una vida familiar, por ejemplo, casándose o teniendo la oportunidad de tener hijos, ni un derecho general a establecer vida familiar en una jurisdicción particular $350 "$

De entrada, la aplicación rigurosa de este requisito supondría restringir la posible tutela que el art. 8 proyecta sobre la inmigración familiar de los extranjeros, a los supuestos calificados como RF en sentido estricto, excluyendo la protección de la creación ex novo de vida familiar que tiene lugar en la formación familiar o migración matrimonial.

Sin embargo, la exigencia de preexistencia de la vida familiar admite modulaciones, siendo interpretada de forma flexible por el TEDH. A modo de ejemplo, este órgano ha permitido la aplicabilidad del artículo 8.1 a parejas casadas que, en el momento de presentar ante el Estado demandado

the previous day, in which Francine had been entered as her child. When this entry was found by the Royal Military Constabulary to be apparently forged, the applicants admitted that Francine was in fact not Bata Nsona's daughter and claimed instead that she was her niece. Such has been their claim ever since".

347 Citado por ARRIAGA, quien señala la Decisión sobre la admisibilidad 8378/78 (Kamal c. Reino Unido). El derecho a la vida familiar..., op. cit., p. 85 y nota a pie de página n 20 de la misma página.

348 Para un análisis de esta cuestión, vid. LA SPINA, Encarnación. "Singularidades y retos normativos en el control genético de la inmigración familiar hacia España, Italia y Portugal”; en Cuadernos Electrónicos de Filosofía del Derecho, no 21, 2010, pp. 105-132.

349 En el mismo sentido, ARRIAGA, I. El derecho a la vida familiar..., op. cit., p. 88. La autora prosigue explicando que la Comisión señalaba repetidamente que "el art 8 garantiza el respeto de una VF existente, sin obligar a un Estado a dejar a un extranjero entrar en su territorio para crear vínculos familiares 'nuevos”. Idem, p. 89.

350 HARRIS, O`BOYLE, WARBRICK. Law of the European Convention on Human Rights, op. cit., p. 313. 
la solicitud de permiso de entrada o permanencia para sus maridos, no habían todavía establecido una vida familiar, pero tenían la legítima expectativa de mantenerla en el territorio de dicho Estado $^{351}$ - Asunto Abdulaziz, Cabales y Balkandali-, dando con ello entrada a la tutela de la VF no preexistente, sino meramente proyectada. Al analizar detenidamente la jurisprudencia emitida en materia de RF, tendremos ocasión de matizar más este aspecto.

A modo de panorámica recapitulatoria, la protección que otorga el derecho al respeto de la vida familiar a los vínculos familiares de los extranjeros puede ser vista como un círculo ${ }^{352}$ que incluye en su interior diversas relaciones interpersonales, en cuyo núcleo se sitúa el vínculo entre padres e hijos menores, con independencia del régimen de filiación de estos últimos. Por constituir el epicentro de la vida familiar objeto de protección, los test empleados para constatar el carácter efectivo, real y existente de la misma se aplican de forma notablemente diluida, ya que se parte de la presunción de su existencia ${ }^{353}$, salvo que extraordinarias circunstancias posteriores rompan esos vínculos.

La fortaleza del vínculo que se crea entre padres e hijos menores es independiente del estatus jurídico-formal existente entre los progenitores, de modo que la misma consideración se aplica para los hijos menores nacidos de una pareja de hecho o extramatrimoniales, e incluso aunque los padres no convivan ${ }^{354}$.

Conforme las distintas relaciones familiares se vayan alejando del epicentro, mayor será la carga de la prueba que recae sobre los demandantes para demostrar la preexistencia, autenticidad y efectividad de sus vínculos. De este modo, las relaciones entre padres e hijos adultos ${ }^{355}$ no son objeto auto-

351 En palabras del TEDH, y en uno asunto referido a la reunificación familiar: "El Tribunal recuerda que, al garantizar el derecho al respeto de la vida familiar, el artículo 8 'presupone la existencia de una familia'. Sin embargo, ello no implica que toda vida familiar proyectada quede enteramente excluida de su ámbito. Sea lo que fuere lo que la palabra 'familia' pueda además significar, debe en todo caso incluir la relación nacida de un matrimonio legal y no ficticio, (...), incluso si una vida familiar del tipo al que el Gobierno se refiere no ha sido todavía plenamente establecida. Deben considerarse tales uniones como suficientes para merecer el respeto debido en virtud del artículo 8". STEDH Abdulaziz, Cabales y Balkandali contra el Reino Unido, de 28 de mayo de 1985, apartado 62. En este supuesto, pesó en la argumentación del TEDH el hecho de que dos de las tres demandantes habían convivido con sus respectivas parejas, con anterioridad a la denegación estatal de la autorización para que sus maridos permaneciesen con ellas en el Reino Unido.

352 STOREY, H. “The Right to Family Life and Immigration Case Law..., op. cit., pp. 334-335.

353 En un sentido similar al propuesto, ARRIAGA subraya que, al analizar la VF, el TEDH, en comparación con lo que hiciera previamente la Comisión, adopta una definición más amplia de vida familiar, basando "su análisis en la presunción de que existe 'vida familiar' por la mera existencia de vínculos legales o sanguíneos, al menos entre padres-hijos, abuelos-nietos y, en ocasiones, entre hermanos". El derecho a la vida familiar..., op. cit., p. 106.

354 Keegan c. Irlanda, STEDH de 26 de mayo de 1994, pár. 44. El caso fue elevado ante la Comisión Europea por un ciudadano irlandés, padre de una hija natural que había sido dada en adopción sin contar con su conocimiento ni autorización. Estaba en juego además la legislación irlandesa que contemplaba procedimientos discriminatorios contra los hijos ilegítimos, suscitando así cuestiones de naturaleza idéntica a las resueltas por el TEDH en el asunto Marckx. Al examinar la aplicabilidad del artículo 8 al vínculo existente entre padre e hija el Tribunal desatendió los argumentos del gobierno demandado. Irlanda subrayaba el carácter esporádico e instable de la relación existente entre el demandante y la madre de la menor, cuya relación además había finalizado antes del nacimiento de la niña —con la que el demandante nunca había convivido-, para alegar que la mera relación sanguínea o el sincero deseo del padre de constituir vida familiar con su hija no era suficiente para ser considerada vida familiar en el sentido del artículo 8 CEDH. Sin embargo, el TEDH aplicó el mismo razonamiento que para los hijos matrimoniales, considerando que « the notion of the "family" in this provision is not confined solely to marriage-based relationships and may encompass other de facto "family" ties where the parties are living together outside of marriage. A child born out of such a relationship is ipso iure part of that "family" unit from the moment of his birth and by the very fact of it. There thus exists between the child and his parents a bond amounting to family life even if at the time of his or her birth the parents are no longer co-habiting or if their relationship has then ended».

355 "El Tribunal recuerda que «las relaciones entre adultos no gozan necesariamente de la protección del artículo 8 si no se demuestra la existencia de elementos complementarios de dependencia distintos a los vínculos afectivos norma- 
mático de protección, salvo que se demuestre la existencia de vínculos adicionales de dependencia, normalmente interdependencia económica junto a fuertes lazos emocionales.

En cuando a su cercanía con respecto al núcleo básico, las siguientes relaciones implicadas son las que se entablan entre los miembros de un pareja unida mediante un vínculo matrimonial. Por su parte, las uniones de hecho no matrimoniales ${ }^{356}$ entran dentro del círculo de protección, aunque no se sitúan en plano de igualdad con respecto a los matrimonios. El mayor problema respecto a ellas suele ser constatar su carácter estable, duradero y comprometido, bien sea mediante la vida en común, los años de convivencia, la existencia de dependencia económica y, especialmente, a través de la presencia de hijos comunes.

Han sido también incluidas dentro de la vida familiar en sentido general - no en el ámbito específico de la RF-, las relaciones familiares entre abuelos y sus nietos ${ }^{357}$; entre tíos y sobrinos ${ }^{358}$, así como entre hermanos ${ }^{359}$. El límite, al menos por el momento, lo constituyen las parejas homosexuales ${ }^{360}$, cuya relación no es considerada constitutiva de vida familiar aunque, sin embargo, ha sido insertada en el concepto más amplio de vínculos interpersonales constitutivos de vida privada, consagrada en el mismo artículo $8 \mathrm{CEDH}$.

En definitiva, de la jurisprudencia del TEDH en torno a la vida familiar, dos características emergen como definitorias de la familia: su carácter amplio y progresivamente expansivo, elástico a futuras incorporaciones de nuevos modelos familiares, según avance el consenso - social, jurídico, ético, científico, de mentalidades - en torno a su aceptación social. Ello ha permitido un salto sustancial desde la protección inicial de la familia en sentido tradicional, para dar cabida a una pluralidad de situaciones familiares de facto de carácter profundamente liberal y hasta alternativo ${ }^{361}$. Sin embargo, resta por comprobar si este mismo concepto resulta aplicable también al ámbito de la migración familiar, cuestión que abordaremos al estudiar la jurisprudencia emitida en dicha materia.

De otro lado, la amplitud del concepto convencional de familia es, a nuestro modo de ver, una consecuencia necesaria para mantener la estabilidad del sistema. Una organización como el Consejo de Europa, pese a tener un origen identitario realmente homogéneo -inicialmente compuesta por 10 Estados miembros con tradiciones comunes-, se caracteriza en la actualidad por la creciente disparidad y heterogeneidad de sus cuarenta y siete Estados miembros. Esta situación desemboca en la conveniencia de que el TEDH se muestre "tolerante" ${ }^{362}$ con el concepto de familia, a fin de que pueda encajar en él la enorme diversidad de modelos familiares existentes. Lo contrario supondría excluir de la tutela del CEDH múltiples estructuras familiares que, prima facie, son merecedoras de protección.

$\mathrm{Al}$ abordar el carácter relativo de la familia, apuntamos ya como características de la misma su diversidad, su elasticidad y el acelerado proceso de transformación al que se ve sometido. A todas

les». Ezzouhdi v. Francia, STEDH de 13 de febrero de 2001, par. 34. Kwakie-Nti y Dufie contra Países Bajos, Decisión de 7 de noviembre de 2000, S. y S. contra Reino Unido, Decisión de la Comisión de 10 de diciembre de 1984.

356 K y T c. Finlandia, STEDH de 12 de julio de 2001, apdo. 150; Haas c. Países Bajos, STEDH de 13 de enero de 2004 , apdo. 42.

357 Tras su inclusión en la sentencia Marckx. c. Bélgica, la relación entre abuelos y nietos fue considerada como constitutiva de vida familiar en la sentencia Bronda c. Italia, de 9 de junio de 1998; apdo. 27. Si bien se trata de asuntos que no tratan especialmente sobre la VF de los extranjeros.

358 Decisión de 15 de diciembre de 1977, X e Y c. Reino Unido, demanda 7229/75, parr. 32.

359 Decisión de la Comisión de 11 de marzo de 1981, demanda 8986/80.

360 Decisión de 14 de mayo de 1986 Simpson c. Reino Unido, demanda 11716/85.

361 SANTOLAYA MACHETTI, P. El derecho a la vida familiar..., op. cit., p. 80.

362 SANZ CABALLERO, Susana. La familia en perspectiva internacional y Europea. Valencia, Tirant monografías, 2006, p. 350 . 
ellas habría que agregarle su carácter crecientemente inestable. Este último rasgo es especialmente preocupante a la vista de las consecuencias que puede tener sobre la parte más débil de la familia, los hijos menores. Todo ello pone en la primera línea de atención los derechos del menor que, eventualmente, pueden chocar con los de sus progenitores, especialmente cuanto no existe coincidencia entre los lazos biológicos, de un lado, y los jurídicos o sociales, de otro.

Sobre la misma ha llamado la atención el juez Pettiti, en el primer caso sobre transexualidad que llegó al TEDH. Desde entonces hasta hoy, transcurrida más de una década, se ha producido un cambio radical en la jurisprudencia sobre el tema del TEDH, pero las observaciones de este magistrado no han perdido vigencia alguna:

"El creciente número de situaciones familiares precarias e inestables está creando nuevas dificultades para los hijos de primeras y segundas familias, tanto legítimos como naturales, sucesivos o superimpuestos - superimposed-, y en el futuro exigirá una atenta consideración sobre la identidad de la familia y el significado de la vida familiar que el art. 8 aspira a proteger, tomando en cuenta la prioridad que debe otorgarse al interés del menor y a su futuro"363.

Si a estas características, le sumamos ahora la rapidez y entidad de los avances científicos en materia médica y su repercusión sobre las estructuras familiares, así como la mayor aceptación social de formas de vida sexual alejadas de los parámetros convencionales, el resultado convierte a la vida familiar en un creciente desafío para los órganos encargados de su interpretación y aplicación. El ámbito migratorio y el derecho a la reagrupación familiar no hacen sino incrementar los retos que la vida familiar supone en sí misma para los órganos de Estrasburgo. Sin embargo, en este ámbito, el Estado, a fin de proteger sus intereses internos $-\mathrm{y}$, fundamentalmente, para contener los efectos multiplicadores que una definición amplia de familia provocaría sobre el stock de inmigrantes-, se muestra reacio a reconocer las nuevas estructuras familiares en que desemboca la evolución sociológica y los avances científicos, amparado para ello, de un lado, por el concepto autónomo de familia que rige el derecho migratorio y, de otro, en la noción de familia nuclear que subyace y domina el planteamiento de los órganos de Estrasburgo en torno a la vida familiar de los extranjeros amparada por el Convenio de Roma.

Todo ello ayuda a entender la aplicación de un doble test más riguroso para constatar la existencia de vida familiar de los extranjeros, que no rige en otros ámbitos de aplicación del artículo 8 $\mathrm{CECH}$, tales como cuando, por ejemplo, lo que se pretende ante las instituciones de Estrasburgo es el establecimiento del régimen de filiación entre padres solteros y sus hijos ${ }^{364}$.

En definitiva, cuando lo que se trata es de evaluar la vida familiar de los extranjeros en supuestos que involucran medidas migratorias - expulsión/denegación de autorización de entrada o residencia-, los test convencionales empleados para determinar la existencia de vida familiar y, por ello, la aplicabilidad inicial del art. $8 \mathrm{CEDH}$, registran una mayor opacidad y, lo que es más trascendente, se detecta en los órganos de Estrasburgo una aproximación al concepto de familia más exigente y

363 Opinión concurrente del juez Pettiti en X, Y y Z c./ Reino Unido, STEDH de 22 de abril de 1997. Las crecientes dificultades que encierra la noción jurídica de vida familiar en el nuevo contexto quedan de manifiesto en otro párrafo de la misma opinión concurrente: “ Did X, Y and Z form a family? A family, in general, cannot be a mere aggregate of the individuals living under one roof. The ethical and social dimension of a family cannot be ignored or underestimated. If there was a family, as there appears to have been in the case before the Court, can the object sought by $\mathrm{X}$ be imposed on Z?".

364 FORDER, C. “Article 8 ECHR: The Utter Limits of 'Family Life' and the Law of Parenthood”, en Maastricht Journal of European and Comparative Law, no 4, 1997, pp. 141-142. 
estricta $^{365} \mathrm{y}$, por ende, restrictiva ${ }^{366}$. De ahí que la doctrina haya denunciado la falta de homogeneidad $^{367}$ en la interpretación del concepto de vida familiar, variable en función del concreto contexto en que el TEDH vaya a aplicarlo. La aludida "diferenciación en el significado de la vida familiar" está permeando la jurisprudencia de los Estados parte ${ }^{368}$.

No obstante su carácter comparativamente más estrecho y estricto, el TEDH — estudiando con perspectiva evolutiva su jurisprudencia-, muestra también en los supuestos migratorios una tendencia a la progresiva ampliación del concepto de vida familiar, de la que determinados fallos dictados en materia de RF — destacadamente Abdulaziz y Rodrigues da Silva, que analizaremos posteriormente-, constituyen un claro referente.

\section{PRIMERA ETAPA EN LA CONSTRUCCIÓN JURISPRUDENCIAL DEL DERECHO A LA REUNIFICACIÓN FAMILIAR}

Analizada la titularidad activa del derecho a la vida familiar, tanto con carácter general como cuando éste es aplicable a extranjeros que luchan contra medidas estatales migratorias contrarias a sus intereses familiares, corresponde ahora abordar la construcción jurisprudencial del derecho a la RF. Simplificando al extremo, el punto de partida para comprender la aproximación de las instituciones de Estrasburgo y el alumbramiento de la RF sobre la base del derecho a la vida familiar del artículo 8, lo constituye doctrina reiterada de la Comisión y la Corte en torno al contenido de tal derecho, a saber, "el disfrute de la compañía mutua entre padres e hijos constituye un elemento fundamental de la vida familiar" 369 .

En el caso de familias separadas entre las fronteras de diversos países, siendo uno de ellos Estado parte del Consejo de Europa, la mutua compañía apuntada exige la reunión de sus miembros en el territorio de uno de los dos países implicados - al menos en lo que respecta a las relaciones paterno filiales que involucren a menores-. El extranjero que solicita la RF pretende que la reconstitución de su vida familiar se produzca en el Estado parte de acogida; el Estado parte demandado que ha rechazado la solicitud de RF, alega que la recomposición de la vida familiar debe tener lugar en un tercer país - habitual pero no necesariamente el Estado de origen de alguno de los parientes del

365 STOREY, H. “The Right to Family Life and Immigration Case Law at Strasbourg”; en International and Comparative Law Quarterly, 1990, vol. 39. p. 343.

366 ARRIAGA atribuye este carácter al doble test empleado por Estrasburgo para enjuiciar los casos relativos a la VF de los extranjeros: "efectividad y carácter real de la VF y preexistencia de la misma”. El derecho a la vida familiar...op. cit., p. 84 .

367 FORDER, Caroline. “The utter limits of 'Family Life' and the Law of Parenthood”; op. cit., pp. 141-142. Forder prosigue subrayando que el concepto de vida familiar, en su aplicación a los extranjeros en supuestos migratorios, -como cuando cuando lo que se ventila ante el TEDH es si un padre está habilitado a reclamar un derecho de residencia a favor de su hijo en un Estado parte-, es más estricto que el que rige con carácter general. La autora denuncia, con carácter más concreto, la obvia diferencia existente entre el flexible y laxo concepto de vida familiar que el TEDH aplicó en el asunto Kroon —donde estimó la existencia de vida familiar entre una padre y su hijo, pese a la falta de implicación del padre en la crianza del menor-, frente al mucho más exigente concepto exigido en el asunto Berrehab -donde constaba con certeza el interés e implicación del padre con respecto al cuidado de su hija, a la que, con anterioridad a su expulsión de Holanda, visitaba cuatro veces por semana durante varias horas cada vez, estimando el TEDH que los lazos constitutivos de vida familiar persistían tras la expulsión del padre del país donde residía su hija.

368 FORDER constata su asunción por parte de la Suprema Corte Holandesa, pero puntualiza que dicha aproximación todavía no ha sido asumida por el Tribunal de Luxemburgo. Idem, p. 142 y nota a pie $\mathrm{n}^{\circ} 48$ de la citada página.

369 Asunto McMichael v. Reino Unido, sentencia de 24 de febrero de 1995, apartado 86. 
extranjero-; lo que debe valorar el TEDH son las circunstancias que rodean la situación particular de los demandantes y el justo equilibrio entre los intereses en conflicto, para determinar si el Estado demandado ha violado sus obligaciones convencionales en el marco del derecho al respeto de la VF.

En esta perspectiva, la autorización de la entrada y/o residencia de los familiares del extranjero residente dentro del Estado parte no constituye un fin en si mismo, sino un medio instrumental necesario para evitar la violación indirecta o derivada que su denegación provocaría - a modo de efecto rebote-, sobre el derecho convencional al respeto de la vida familiar. Por eso se ha afirmado que el derecho a la RF constituiría una condición previa o pre-requisito ${ }^{370}$ necesario para dotar de efectividad a un derecho explícito del Convenio, como lo es el respeto a la vida familiar, en su aplicación a extranjeros asentados dentro del territorio de alguno de los Estados contratantes.

Desde que, a mediados de la década de los ochenta, el TEDH abordara por primera vez el derecho a la RF de los extranjeros, hasta el momento de cerrar estas páginas, se observa en los pronunciamientos emitidos sobre este tema una clara evolución, que marca al menos dos etapas claramente diferenciadas en la forma de abordar esta cuestión, separadas por la sentencia Sen, que actúa a modo de frontera divisoria entre ambas.

En la primera etapa se enmarcan tres sentencias emitidas por el TEDH en el lapso temporal de once años que media entre 1985 y el año 1996. Se trata del asunto Abdulaziz, Cabales y Balkandali; la sentencia Gül contra Suiza y, finalmente, Ahmut contra Holanda. Todas ellas se caracterizan por una aproximación a la migración familiar muy deferente con el interés general estatal de controlar la inmigración y el derecho soberano que ostenta el Estado parte de determinar la entrada y condiciones de permanencia de extranjeros en su territorio y, por ello, muy restrictiva hacia los intereses particulares. Retomando la perspectiva previa, en esta etapa el TEDH considera que la reconstitución de la vida familiar del extranjero ha de producirse, con carácter general, en cualquier Estado distinto al Estado parte de acogida del reagrupante, salvo que existan obstáculos de gran entidad o razones especiales que recomienden la reunión de la familia dentro del país receptor demandado. Sobre la base de esta construcción inicial, las posibilidades de extraer un derecho a la RF de la formulación contenida en el art. $8 \mathrm{CEDH}$ - si bien admitido expresamente por parte del TEDH como contenido potencial del derecho al respeto de la vida familiar-, resultan sin embargo extraordinariamente limitadas, casi nulas, desde el punto de vista material.

Los tres pronunciamientos correspondientes a esta primera etapa son de carácter desestimatorio, negando todos ellos la violación del derecho al respeto de la vida familiar. Y ello incluso en concurrencia de situaciones que, desde el punto de vista del derecho comunitario, ampararían la concesión del derecho - por ejemplo, en los asuntos Abdulaziz, Cabales y Balkandali contra Reino Unido, y Ahmut contra Holanda, algunos de los demandantes habían adquirido la nacionalidad del Estado parte receptor-, o ante circunstancias humanitarias particularmente difíciles, próximas al asilo - como testimonia el asunto Gül contra Suiza-. Con todo, en la postura del TEDH se observa una creciente fisura, oscilando desde la unanimidad en la primera de las sentencias emitidas - Abdulaziz—, hasta el grado máximo de discrepancia entre sus miembros — Ahmut—.

\subsection{Abdulaziz, Cabales y Balkandali contra Reino Unido}

Esta sentencia, fallada el 28 de mayo de 1985, constituye el leading case en materia de reunificación familiar. Es, además, la primera que sobre este tema dictaminó el TEDH — salvo el paréntesis 
representado por la brevísima referencia que la Corte realizó a esta cuestión en 1980, el asunto Guzzardi $^{371}$ - . Abdulaziz pone fin así a tres décadas en las que la Comisión había determinado en solitario el case law en asuntos migratorios. La trascendencia interpretativa de las cuestiones que planteaba este pronunciamiento, llevó al Tribunal de Estrasburgo, en base al antiguo artículo 50 del Reglamento interno del TEDH, a acometer su análisis en pleno ${ }^{372}$.

En el origen de esta sentencia se sitúan tres demandas formuladas ante la Comisión Europea por tres mujeres, residentes legales y permanentes en el Reino Unido, que habían contraído matrimonio con extranjeros. Las demandantes alegaban que el rechazo por parte de las autoridades inglesas a otorgar a sus maridos una autorización para permanecer - Señores Abdulaziz y Balkandali-, o entrar -Sr. Cabales-, en el Reino Unido constituía una violación, entre otros, del derecho al respeto de la vida familiar contraria, además, al artículo 14, por su carácter discriminatorio. La denuncia de discriminación se basaba fundamentalmente en dos motivos. De un lado, en razón del sexo, debido a las mayores dificultades que la legislación migratoria inglesa por entonces vigente establecía para la reunificación de los maridos, respecto de aquellas establecidas para que las mujeres extranjeras pudiesen reunirse con sus parejas masculinas; de otro, en razón del nacimiento, pues sólo permitía la reagrupación de parientes de quienes ostentasen la nacionalidad inglesa como consecuencia de su nacimiento.

De los tres supuestos ${ }^{373}$, en sentido estricto, sólo el relativo a la solicitud de entrada en el Reino Unido para el marido de la señora Cabales - quien vivía en Filipinas-, constituiría un caso típico de reunificación familiar, pues se trataba de la admisión por primera vez en territorio inglés de un no nacional a fin de reunirse con su cónyuge, implicando pues un movimiento migratorio de carácter transnacional. En los otros dos casos los maridos se encontraban residiendo de hecho en Inglaterra,

371 Caso Guzzardi contra Italia, STEDH de 6 noviembre 1980. El asunto Guzzardi como primer supuesto en que el TEDH penetra en materia migratoria, en relación con el derecho a la vida familiar reconocido por el art. $8 \mathrm{CEDH}$, es apuntado por STOREY, Hugo. “The Right to Family Life and Immigration Case Law at Strasbourg”, op. cit., p. 328.

La referencia a esta cuestión en la sentencia aludida, mínima por otro lado, aparece en el apartado 109, en sede de análisis del cumplimiento del art. $8 \mathrm{CEDH}$. La violación del derecho al respeto de su vida familiar había sido alegado por el demandante en un contexto migratorio - su familia se vio obligada a abandonar Italia como consecuencia de la falta de renovación del permiso de residencia del demandante-. Sobre esta cuestión, el TEDH se limitó a señalar, en conformidad con lo establecido en su informe por la Comisión, que "las razones dadas por el señor Guzzardi para explicar dicha omisión no revelan nada contrario al artículo 8 que pudiera ser atribuido al Estado italiano, y en esas circunstancias la necesidad de tal permiso es compatible con aquel precepto". La escasez de la referencia jurisprudencial explica que la doctrina suela eludir la cita a Guzzardi como antecedente de esta rama jurisprudencial.

372 Citado por ARRIAGA, I. El derecho a la vida familiar..., op. cit., nota a pie de p. no 39, p. 239.

373 La Señora Abdulaziz, nacida en Malawi, pero apátrida en aquel momento, había contraído matrimonio con un ciudadano portugués nacido en Damán — antiguo territorio perteneciente a Portugal situado en la India-. Su marido fue inicialmente admitido en calidad de visitante en el Reino Unido, pero después se le denegó la solicitud de estancia indefinida. Pese a ello, el Sr. Abdulaziz permaneció en territorio inglés sin autorización. Fruto de esta unión nació un hijo en el Reino Unido. Por su parte, la segunda demanda fue incoada por la Señora Cabales, nacida en Filipinas, donde conoció y se casó con el señor Ludovico. Tras su matrimonio, regresa para continuar su trabajo como enfermera en el Reino Unido y solicita del Ministerio de Interior una autorización de entrada a favor de su marido, que le es denegada. En 1984, con posterioridad al planteamiento de su demanda ante la Comisión Europea, la señora Cabales obtuvo la naturalización como ciudadana británica. Al Sr. Cabales se le otorga visado autorizándole a permanecer en el Reino Unido con el fin de casarse y posteriormente es autorizado a residir durante los doce meses siguientes en calidad de marido. El Gobierno inglés cuestionó la validez del matrimonio celebrado en Filipinas. Finalmente, la Señora Balkandali poseía la nacionalidad británica en virtud de un anterior matrimonio, ya disuelto, con un ciudadano inglés. Contrae posteriormente matrimonio en el Reino Unido con un nacional de Turquía, con quien ya convivía, que había entrado en el Reino Unido en calidad de estudiante y cuyo permiso ya había expirado. Tras el matrimonio se le deniega al marido un permiso de residencia. Del matrimonio nace un niño con derecho de residencia indefinida en el Reino Unido. 
si bien carecían de autorización legal para ello, por lo que encajarían en situaciones de RF de hecho que pretenden regularizarse en virtud del arraigo familiar. En cualquier caso, las tres demandas involucraban supuestos de reunificación de cónyuges y, ante la similitud de su contenido, fueron acumuladas por la Comisión, siendo analizadas desde el prisma de la reagrupación familiar y en el marco de la política migratoria inglesa vigente en la época en que se suscitaron los hechos.

Siguiendo el esquema establecido en esta materia por la Comisión, el TEDH analiza la compatibilidad con el Convenio de las medidas migratorias impugnadas, en dos etapas sucesivas: en primer lugar, revisa la existencia de vida familiar — esto es, si los lazos familiares constituyen vida familiar en el sentido del art. 8, sin hablar explícitamente de familia-, para, posteriormente, estudiar su cumplimiento o no por parte del Estado demandado. Pero, dado que es la primera ocasión en que el TEDH se enfrenta a la migración familiar, con carácter previo despeja las dudas en torno a la aplicabilidad del art. 8 CEDH en el ámbito de los derechos migratorios. Con todo, y sobre la base del respeto formal al esquema previamente establecido por la Comisión, la Corte introduce importantes novedades en el tratamiento de la RF, que establecerán la pauta a seguir en las futuras demandas con contenido migratorio.

\section{a) La aplicabilidad del artículo 8: vida familiar y derechos migratorios}

El TEDH despejó en primer lugar la cuestión de la aplicabilidad del artículo 8, cuestionada por el Gobierno demandado, quien afirmaba que las cuestiones relativas al control migratorio no quedaban comprendidas en el ámbito de aplicación ni de tal precepto ni de ningún otro del Convenio de Roma - que, como señalamos, había constituido la tesis primitiva de la Comisión en materia migratoria, denominada doctrina "no right as such"-. Argumentaba el gobierno inglés que, en este ámbito, el único texto relevante, si cabe, sería el Protocolo número 4 -no suscrito por el Reino Unido-, cuyo artículo cuarto prohíbe las expulsiones colectivas de extranjeros y garantiza el derecho exclusivo de los nacionales a entrar y a no ser expulsados de su propio Estado ${ }^{374}$, pero sin reconocer el derecho a la RF de los extranjeros. El Preámbulo del Protocolo número 4 afirma explícitamente que dicho Protocolo ampara derechos distintos a los consagrados en el CEDH, lo cual, a juicio del gobierno demandado, probaría la exclusión de los derechos migratorios respecto del Convenio de Roma.

Por su parte, la Comisión había despejado previamente esta cuestión, al decidir sobre la admisibilidad de las tres demandas, afirmando la aplicabilidad del artículo $8 \mathrm{CEDH}$ mediante la siguiente fórmula - que, como ya señalamos, constituía su jurisprudencia constante en las demandas con contenido migratorio-:

"Si, como tal, el derecho de un extranjero a entrar o permanecer en un país no está garantizado por el Convenio, el control de la inmigración debe ejercerse, no obstante, de forma compatible con las exigencias de éste, y la exclusión de una persona del territorio de un Estado en el que viven sus parientes puede plantear un problema en el que entre en juego el artículo $8^{3375}$.

374 Artículo 3 del Protocolo Adicional número 4 al CEDH que, bajo el encabezamiento de "prohibición de la expulsión de los nacionales", tiene el siguiente tenor literal: "1. Nadie puede ser expulsado, en virtud de una medida individual o colectiva, del territorio del Estado del cual sea ciudadano. 2. Nadie puede verse privado del derecho de entrar en el territorio del Estado del cual sea ciudadano".

375 En el apartado 59 de la sentencia Abdulaziz, Cabales y Balkandali c. Reino Unido, el TEDH transcribe así parte de la argumentación que la Comisión ofreció en el amplísimo Informe - consta de 48 páginas-, emitido a las tres demandas que se sitúan en el origen del presente pronunciamiento. En dicho Informe, la Comisión señaló además que "the right of a foreigner to enter or remain in the territory of a High Contracting Party is not guaranteed, as such, by 
La protección de rebote, eje central de la argumentación transcrita de la Comisión, está presente a lo largo de toda la fundamentación jurídica de la Corte de Estrasburgo destinada a despejar las dudas sobre la aplicabilidad del artículo 8, y puede incluso observarse en la forma indirecta en que las demandantes plantean su reclamación: se quejan de que la decisión del gobierno demandado les priva de la compañía de sus cónyuges, pero no expresamente de que el gobierno inglés impida la entrada o permanencia a sus maridos ${ }^{376}$. Esta forma oblicua de argumentar, pone el énfasis en el resultado que una medida interna adoptada en el ámbito de la política migratoria ha provocado sobre un derecho convencional: se obstruyen las condiciones para posibilitar la vida en familia, provocando su ruptura - Srs. Abdulaziz y Balkandali-, o imposibilitando su constitución — para el caso del Sr. Cabales - , enfatizando el nexo casual que conecta un derecho explícito - VF- a otro que no lo está - RF-.

El TEDH se aúna a los argumentos de la Comisión y rechaza las alegaciones del gobierno demandando, acudiendo a la interpretación sistemática de la Convención de Roma, que actúa de refuerzo argumentativo para consolidar la protección de rebote que el artículo 8 despliega en el ámbito migratorio. En palabras del TEDH:

"El Tribunal recuerda que el Convenio y sus Protocolos deben considerarse como un todo, de forma que una materia regida en lo esencial por una de sus disposiciones puede también en algunos de sus aspectos quedar sometida a otras. Así, aunque algunos aspectos del derecho a entrar en un país se rigen por el Protocolo número 4 en los Estados obligados por tal instrumento, no debe excluirse que medidas adoptadas en el campo de la inmigración puedan afectar al derecho al respeto a la vida familiar, garantizado por el artículo $8^{\prime 377}$.

En este pronunciamiento el Tribunal sigue la doctrina establecida por la Comisión en torno a la protección de rebote y la posibilidad de afectación del derecho a la VF — expresamente consagrado por el Convenio-, por parte de medidas estatales migratorias, que en ningún momento aparecen formuladas como derechos a favor de los extranjeros. La doctrina ${ }^{378}$ ha destacado que, en la exigencia de compatibilidad entre la ejecución de las políticas migratorias internas y los derechos del $\mathrm{CEDH}$, reside la aportación fundamental de la sentencia Abdulaziz. Con ello, el Tribunal de Estrasburgo estaba dando potencialmente entrada a la RF como contenido implícito del derecho a la VF - mientras que, por su parte, la protección contra expulsiones de extranjeros, por su afectación a la VF, sería poco tiempo después dictaminada por el TEDH en el asunto Berrehab ${ }^{379}$.

the Convention. However, in adhering to the Convention, the Contracting Parties agreed to restrict the free exercise of their powers under general international law including the aforementioned power, to the extent and within the Limits of the obligations which they assumed under this treaty. The Commission's task under Art 19 in the present applications is, thus, not to supervise the immigration policy of the United Kingdom Government, but to examine whether the applicants' right to respect for family life has been ensured without discrimination in the light of Arts 3, 8, 13 and 14 of the Convention". Apartados 94 y 96 del Informe de la Comisión, adoptado el 12 de mayo de 1983 , en relación a las demandas Nos. 9214/80, 9473/81 and 9474/81.

376 Abdulaziz, Cabales y Balkandali c. Reino Unido, apartado 59.

377 Idem, apartado 60.

378 CARRILLO SALCEDO, A. "Protección de derechos humanos en el Consejo de Europa: Hacia la superación de la dualidad entre derechos civiles y políticos y derechos económicos y sociales", op. cit., p. 445. Por su parte, Marina Vargas considera que esta declaración del TEDH -sin que la autora haga referencia expresa a la sentencia Abdulaziz-, "significa una protección indirecta del derecho a la reagrupación familiar". VARGAS GÓMEZ-URRUTIA, Marina. La reagrupación familiar de los extranjeros en España. Normas de extranjería y problemas de derecho aplicable. Madrid, Thomson-Aranzadi, 2006, p. 82.

379 Caso Berrehab v. Holanda, STEDH 21 de junio de 1988, Demanda 10730/84. 


\section{b) La extensión de la vida familiar}

Abdulaziz constituye un ejemplo ilustrativo de la tendencia expansiva del TEDH en torno al concepto de la vida familiar, inaugurada en la sentencia Marckx. Previamente a Abdulaziz, la vida familiar objeto de protección en contextos migratorios era aquella existente con anterioridad a la medida estatal limitativa - test de la preexistencia de la VF-. Con este pronunciamiento el TEDH da un paso más con respecto a la doctrina de la Comisión, admitiendo que la vida familiar proyectada o planificada, pero aun no plenamente existente, puede atraer también la protección del artículo 8.

"El Tribunal recuerda que, al garantizar el derecho al respeto de la vida familiar, el artículo 8 'presupone la existencia de una familia' Sin embargo, ello no implica que toda vida familiar proyectada quede enteramente excluida de su ámbito. Sea lo que fuere lo que la palabra 'familia' pueda además significar, debe en todo caso incluir la relación nacida de un matrimonio legal y no ficticio, (...), incluso si una vida familiar del tipo al que el Gobierno se refiere no ha sido todavía plenamente establecida" ${ }^{\text {"380 }}$.

De esta forma, la Corte desmontaba uno de los argumentos empleados por el gobierno inglés para sostener la inaplicabilidad del artículo 8, quien afirmaba que ninguna de las parejas tenía establecida una vida familiar en el momento en que presentaron la solicitud del permiso de entrada o permanencia, sino tan sólo la "legítima expectativa de mantenerla", para excluir la aplicabilidad del art. $8 \mathrm{CEDH}$.

Conforme al nuevo parámetro establecido en Abdulaziz, la vida familiar cubre tanto aquella preexistente como la proyectada. La exigencia de preexistencia de la VF, constante hasta este pronunciamiento en la doctrina de la Comisión, limitaba la posible protección que el art. $8 \mathrm{CEDH}$ pudiese proyectar sobre las relaciones familiares de los extranjeros, a aquellas establecidas con anterioridad al hecho migratorio. En materia de RF, ello se traducía en la potencialidad limitada del Convenio para amparar, bajo el manto del art. $8 \mathrm{CEDH}$, únicamente a la denominada $\mathrm{RF}$ en sentido estricto. Al extender la protección a la vida familiar proyectada - que no ha sido todavía plenamente establecida-, la Corte de Estrasburgo está simultáneamente amplificando la posible tutela sobre la migración familiar, para cubrir también potencialmente los supuestos de formación familiar o migración matrimonial, y ello tiene lugar en un caso en que se evaluaba precisamente la admisión a efectos de entrada del Sr. Cabales, así como la continuación de la residencia de las otras parejas de las demandantes. Por ello, la extensión del concepto de VF en el ámbito migratorio, ha sido también destacada como otra de las principales aportaciones del TEDH en la sentencia Abdulaziz ${ }^{381}$.

Con esta idea en mete, cabría suponer que, ante las instituciones de Estrasburgo, los recién casados pudiesen aspirar a la RF. Mayores dificultades representan los novios/as de inmigrantes legalmente asentados pues, en este caso, habría de probarse que se trata de una relación estable y con proyección de futuro, a fin de dar cumplimiento a la exigencia de VF real y efectiva. Si parecería legítimo poder incluir - al menos como posibilidad teórica-, a las parejas de hecho donde alguno de sus miembros sea extranjero, especialmente cuando haya hijos menores de por medio. Si bien estas cuestiones habrán de ser constatadas en los subsiguientes pronunciamientos emitidos por el TEDH en este ámbito.

380 STEDH Abdulaziz, Cabalesy Balkandali c. Reino Unido, apartado 62.

381 STOREY precisa que, con esta extensión, "la Corte estaba claramente favoreciendo una definición más amplia de la vida familiar que aquella normalmente empleada por la Comisión en este ámbito" "The Right to Family Life and Immigration Case Law at Strasbourg", op. cit., p. 335, traducción propia. 
Además el TEDH exige explícitamente que el matrimonio sea "legal" y "no ficticio", lo que supone la exclusión de los denominados matrimonios en blanco o de conveniencia, confirmando con ello la relevancia del test de la autenticidad de los vínculos ${ }^{382}$ - en su aplicación específica a parejas casadas-, en el contexto migratorio.

En este punto, el gobierno inglés había cuestionado la validez del matrimonio de una de las tres demandantes - la señora Cabales - , celebrado conforme a las leyes filipinas. El TEDH constata que había existido una ceremonia matrimonial en Filipinas, tras la cual la Señora Cabales y su marido se creían casados y que deseaban sinceramente convivir y llevar una vida familiar normal ${ }^{383}$. Pero no entra a valorar la controversia surgida en torno a la validez o nulidad del matrimonio en el derecho filipino, por considerar que el vínculo así establecido era lo suficientemente estrecho como para determinar la aplicación del artículo 8, afirmando que "en suma, todas las demandantes habían establecido una vida familiar suficiente a efectos del artículo $8^{\prime 384}$. La argumentación subraya la prioridad del elemento intencional o psicológico sobre el jurídico-formal en cuanto a la validez del matrimonio contraído en un tercer país, y apunta a que el umbral de exigencia no puede ser el máximo - basta la concurrencia de lo que el TEDH califica como una VF "suficiente"-.

\section{c) El cumplimiento del artículo 8: Criterios aplicables}

El TEDH aborda esta cuestión basándose en la doctrina que ya sentara en Marckx c. Bélgica, recordando que el artículo 8 engendra obligaciones tanto positivas como negativas para los Estados parte. Sin embargo, Abdulaziz constituye el primer supuesto en el que explícitamente se admite la invocación de "falta de respeto" como base para alegar la violación del derecho a la vida familiar, independientemente de la existencia de una interferencia ${ }^{385}$. La Comisión, en su doctrina previa, había analizado los supuestos de RF de extranjeros - tanto la denegación del permiso de entrada como la no renovación de la autorización de residencia a favor de familiares de extranjeros residentes-, desde la perspectiva del "respeto" a la VF concebido como obligación negativa, utilizando el concepto de "injerencia" o interferencia" sobre la VF ${ }^{386}$. Dado que Abdulaziz constituye además el primer asunto sobre RF ante el TEDH, lo importante a nuestros efectos será determinar si estamos ante una obligación positiva o negativa para, posteriormente, establecer su alcance.

$\mathrm{Al}$ respecto, de la argumentación del TEDH se deduce que enfoca el análisis del cumplimiento o no del Convenio por parte del Reino Unido, encajando la posible obligación estatal dentro de las obligaciones positivas que el Estado ha de desarrollar a fin de asegurar un efectivo "respeto" a la vida familiar. Por ello, el posible incumplimiento no se analiza como un injerencia o intromisión estatal, sino desde la perspectiva de la "falta de respeto".

382 Sobre este aspecto, STOREY ha señalado que, en Abdulaziz la Corte ha venido a confirmar la necesidad de evaluar los vínculos entre parejas "en términos de cuan establecidos, cuan genuinos y cuan comprometidos" están. "The Right to Family Life and Immigration...”, op. cit., p. 334, traducción propia.

383 Abdulaziz, Cabales y Balkandali. Apartado 62. Las alegaciones del gobierno inglés son examinadas en el apartado 48.

384 Idem. Apartado 65. En torno a las dudas sobre la validez del matrimonio de la señora Balkandali, el TEDH señala: "El Tribunal entiende que no debe entrar a resolver la controversia surgida en torno al Derecho filipino. El señor y la señora Cabales habían celebrado una ceremonia matrimonial y los documentos aportados ante el Tribunal prueban que se creían casados y deseaban sinceramente convivir y llevar una vida familiar normal, como hicieron a continuación. En estas circunstancias, el vínculo así establecido era lo suficientemente estrecho como para determinar la aplicación del artículo 8”. Ibidem, apartado 63.

385 STOREY, Hugo. “The Right to Family Life and Immigration Case Law at Strasbourg”, op. cit., p. 335.

386 ARRIAGA I. El derecho a la vida familiar de los extranjeros..., op. cit., p 236. 
"El Tribunal recuerda que, aunque el objeto esencial del artículo 8 es proteger al individuo contra injerencias arbitrarias de los poderes públicos, puede además generar obligaciones positivas inherentes a un efectivo "respeto" a la vida familiar. Sin embargo, la noción de "respeto", especialmente cuando se consideran tales obligaciones, no es clara; considerada la diversidad de las prácticas seguidas y las condiciones existentes en los Estados Partes, sus exigencias varían considerablemente de un caso a otro. Se trata, pues, de un ámbito en el que aquéllos gozan de un amplio margen de apreciación para determinar, en función de las necesidades y recursos de la comunidad y los individuos, las medidas a observar para asegurar el cumplimiento del Convenio"387.

De otro lado, el TEDH se pronuncia de forma explícita en torno al alcance del margen de apreciación en el ámbito de las obligaciones estatales positivas derivadas del CEDH. Si ya en la sentencia Marckx el TEDH había sugerido un margen de apreciación superior para este tipo de obligaciones convencionales, en Abdulaziz les adjudica con claridad un margen de apreciación que expresamente define como "amplio". Del apartado transcrito, se deducen pues dos notas de excepcional importancia en la configuración jurídica de la inmigración familiar ante los órganos de Estrasburgo:

- Su encuadre en el ámbito de las obligaciones estatales positivas que, a su vez, tienen su fuente ${ }^{388}$ en la noción de "respeto" que precede a la VF.

- La adjudicación al Estado parte de un "amplio" margen de apreciación a fin de determinar las concretas medidas que ha de implementar para el control de los flujos migratorios que llegan a su territorio, para asegurar el cumplimiento del Convenio. La amplitud del margen de apreciación es superior al existente en el ámbito de las obligaciones negativas, circunstancia que, desde el punto de vista del particular, supone una merma en la protección que del CEDH se puede derivar en materia de $\mathrm{RF}^{389}$.

Los factores que provocan esta mayor amplitud del margen estatal son la heterogeneidad de prácticas y condiciones existentes en los Estados parte - esto es, la inexistencia de un consenso básico en la materia-. Ello determina que la variabilidad del margen de apreciación juegue a favor de los Estados, concediéndoseles un vasto campo para la maniobra estatal, que redunda en un nivel inferior de escrutinio por parte del TEDH. La Corte de Estrasburgo sitúa el origen de dicha amplitud, en último extremo, en la poca claridad de la noción de "respeto", por lo que sus exigencias varían considerablemente de un caso a otro. Esta última circunstancia apunta a la importancia del casuismo en el ámbito de la RF, punto éste que será a continuación explícitamente confirmado por el TEDH:

"En particular, en la materia ahora considerada el alcance de la obligación de un Estado de admitir en su territorio a parientes de inmigrantes depende de las singulares circunstancias del interesado" ${ }^{390}$.

387 Abdulaiz, Cabales y Balkandali c. Reino Unido, apartado 67.

388 ARRIAGA IRABURU, I. El derecho a la vida familiar de los extranjeros..., op cit. p. 228. La autora puntualiza las dos opciones que, en el ámbito migratorio, se derivan del derecho al respeto a la VF. Si la óptica es la del respeto como obligación positiva, el TEDH analizará "si existe una obligación estatal de asegurar a los demandantes una vida familiar en su lugar de residencia"; mientras que, si la óptica adoptada parte de la visión del "respeto" como obligación negativa, se analizarán "los efectos del rechazo del permiso para los familiares de los demandantes de entrar o permanecer con ellos, viendo si estos efectos provocan una injerencia - al impedir al extranjero disfrutar de una VF manteniéndolo separado de su familia- que requiere justificación ex. art. 8.2 CEDH".

389 La amplitud del margen de apreciación para el mantenimiento de los controles migratorios y la consiguiente "limitada protección” que ello implica para los particulares, es expresamente confirmada por Nicola Rogers al estudiar la primera jurisprudencia del TEDH, donde se inscribe Abdulaziz. ROGERS, Nicola. "Immigration and the European Convention on Human Rights: Are new Principles Emerging?"; en European Human Rights Law Review, vol. 1, 2003, p. 53.

390 Sentencia Abdulaiz, Cabales y Balkandali c. Reino Unido, apartado 67. 
Además, aunque parece descartar la existencia de una obligación de alcance general de permitir la reagrupación familiar, el TEDH se abre a la posibilidad ${ }^{391}$ de que, en determinadas circunstancias particulares, el Estado esté obligado por el CEDH a admitir en su territorio a familiares de inmigrantes. Pero, en cualquier caso, dicha obligación no obsta para enervar el principio de Derecho internacional general que rige en el ámbito migratorio, basado en el respeto a la soberanía estatal, siempre que la misma se ejerza de forma compatible con los compromisos derivados de los Tratados internacionales.

"Además, el Tribunal no puede olvidar que el presente litigio se refiere no sólo a la vida familiar, sino también a la inmigración, y que, conforme a un principio de Derecho internacional firmemente establecido, los Estados tienen el derecho, sin perjuicio de los compromisos que deriven de los Tratados, de controlar la entrada de los no nacionales en su territorio" ${ }^{392}$.

$\mathrm{Al}$ establecer el respeto a la soberanía estatal como premisa de partida del derecho migratorio - reafirmando la línea jurisprudencial que sobre esta materia había venido dictaminando la Comisión-, el TEDH está reconociendo que las medidas migratorias son "esencialmente un asunto de derecho interno" ${ }^{393}$, lo que, implícitamente, presupone la existencia de un elevado margen estatal en este ámbito ${ }^{394}$ - circunstancia que la Corte había confirmado de forma expresa en párrafos previos-.

Tras sentar esta premisa, el TEDH distingue el caso de las demandantes - que habían contraído matrimonio tras su establecimiento legal en el Reino Unido y que, por lo tanto, carecían de una vida familiar previa-, diferenciándolo respecto del supuesto típico que da lugar a la RF en sentido estricto, esto es, de aquellos inmigrantes que abandonan su país de origen dejando tras de sí a su familia para instalarse en el Estado receptor y reconstruir allí la unidad familiar fracturada. En palabras del TEDH:

"Ha de subrayarse que el litigio no se refiere a inmigrantes que ya tuvieran una familia a la que hubieran dejado tras de sí en otro país hasta el reconocimiento de su derecho a permanecer en el Reino Unido: las demandantes no contrajeron matrimonio sino una vez establecidas en este país como solteras" ${ }^{395}$.

Esta distinción ha servido de fuente de inspiración para la formulación futura de relevantes votos discrepantes ${ }^{396}$, así como a esperanzadas opiniones doctrinales ${ }^{397}$, pues de la formulación en negativo realizaba por el Tribunal, cabría deducir, en positivo, la posibilidad de proclamar un derecho

391 MOWBRAY, Alastair. The Development of Positive Obligations under the European Convention of Human Rights by the European Court of Human Rights. Hart Publishing, Oxford, Portland-Oregon, 2004, p. 172. En el mismo sentido, ARRIAGA sostiene, en base a la afirmación transcrita, que "el TEDH reconoció que puede existir una obligación estatal de admitir extranjeros familiares de personas residentes en el país, la cual varía de acuerdo a las circunstancias del caso, puesto que el CEDH no impone una obligación general a los Estados de respetar la elección del lugar de residencia de un matrimonio". El derecho a la vida familiar..., op. cit., p. 240.

392 Abdulaiz, Cabales y Balkandali c. Reino Unido, STEDH, apartado 67.

393 ROGERS, Nicola. “Immigration and the European Convention on Human Rights...”, op. cit., p. 53.

394 Idem, p. 54.

395 Abdulaiz, Cabales y Balkandali, STEDH, apartado 68.

396 Esta distinción serviría casi una década después como punto de partida al juez Martens —en la opinión disidente que formuló a la sentencia Gül c. Suiza, de 19 de febrero de 1996-, para sostener que en los supuestos en los que el inmigrante deja atrás a su familia en su país de origen y adquiere la residencia legal en el Estado parte, podría inferirse una obligación por parte del Estado de acogida de admitir a los familiares de dicho inmigrante.

397 Sobre esta diferenciación, Inés ARRIAGA ha sostenido que "si bien prima facie pudiera inferirse de la doctrina Abdulaziz que el TEDH había dejado conscientemente la puerta abierta al reconocimiento de un derecho a la reagrupación familiar, esta posibilidad se desvaneció con la sentencia Gül, ratificada posteriormente en Ahmut”. ARRIAGA, cit, pp.. 250-251. 
a la RF a favor de los extranjeros que dejasen tras de sí a su familia en un tercer Estado, una vez que los mismos accedan a un estatus regular en el Estado parte de acogida. De la diferenciación realizada por la Corte de Estrasburgo en el párrafo transcrito, pueden deducirse tres aspectos importantes de cara a la construcción jurisprudencial del derecho a la RF:

- Parece entreverse que los supuestos constitutivos de reunificación familiar en sentido estricto -donde el demandante tiene una vida familiar previa en su Estado de origen que pretende después reconstruir tras su establecimiento legal en el país de acogida-, podrían dar pie a la protección vía artículo $8 \mathrm{CEDH}$.

- El Tribunal alude expresamente a que el requisito previo que activa el derecho a la RF, exige del extranjero/a que actúa como reagrupante adquirir el derecho de permanecer en el país de acogida. En consecuencia, el potencial derecho a la RF que pueda derivarse del art. $8 \mathrm{CEDH}$ para los parientes del extranjero, depende de que éste adquiera previamente un estatus legal que le habilite jurídicamente a permanecer en el Estado parte. Derecho a la RF y regularidad administrativa de la estancia, van pues de la mano en la doctrina inicial de Estrasburgo.

- De otro lado, esta distinción introduce un criterio de carácter temporal en el análisis del contenido tutelable de la vida familiar, en aquellas demandas relativas a migración de la familia, que puede contradecir el concepto extenso de vida familiar que el TEDH había apuntado en párrafos precedentes de esta misma sentencia: Pese a que el Tribunal declarase entonces que, a efectos de determinar la existencia de VF, dentro de tal concepto cabe también incluir la vida proyectada, pero no plenamente existente, sin embargo de la distinción apuntada se extrae que la protección de la RF en el ámbito del Convenio sólo ampararía la vida familiar preexistente a la medida estatal que presuntamente provoque su ruptura ${ }^{398}$. En este supuesto las demandantes habían contraído matrimonio una vez asentadas en el Reino Unido y, por lo tanto, la vida familiar había surgido con posterioridad al establecimiento en el Estado demandado. El criterio temporal juega aquí en contra de los intereses de las demandantes, en vista que no habían establecido una vida familiar en su país de origen que dejaran atrás al instalarse en el Reino Unido.

A tenor de lo expuesto, la protección deducible del art. 8 CEDH estaría restringida a los supuestos de RF en sentido estricto - exigiendo la previa existencia de lazos familiares fracturados como consecuencia de la emigración del reagrupante-, y ligada a la adquisición previa de residencia legal por parte del extranjero que actúa como sponsor. Quedarían excluidos los supuestos de formación familiar o inmigración matrimonial, que no encajarían dentro del marco de protección que del derecho al respeto a la vida familiar pudiera potencialmente derivarse a la RF de los extranjeros, así como los casos de RF de hecho.

La anterior distinción sirve de base al TEDH para desmontar el argumento de las demandantes, para quienes el respeto a la vida familiar que el Reino Unido les debía asegurar en su territorio implicaba el derecho a establecer su hogar en el Estado de su residencia habitual —o incluso en el Estado de su nacionalidad, dado que dos de ellas habían accedido a ella-, a reserva de lo previsto en el apartado segundo del artículo 8. Contrariamente a ello, el TEDH afirma que:

398 Por ello, SANTOLAYA MACHETTI afirma que el TEDH “parece adoptar una línea de razonamiento, utilizaba también en Frette contra Francia, de 26 de febrero de 2002, a tenor de la cual el derecho a la vida familiar presupone la existencia de una familia y no protege el derecho de fundarla". El derecho a la vida familiar de los extranjeros, op. cit., p. 93. 


\begin{abstract}
"No puede entenderse que el artículo 8 imponga a un Estado Parte la obligación general de respetar la elección por parejas casadas del país de su residencia matrimonial y de aceptar el establecimiento en tal Estado de los cónyuges no nacionales"399.
\end{abstract}

Esta doctrina será a partir de ahora constantemente reiterada por el TEDH en los casos que sobre RF lleguen a su conocimiento. Además, la sentencia Abdulaziz, siguiendo al respecto el case law de la Comisión, confirma dos parámetros esenciales para poder evaluar el cumplimiento o no del artículo 8 por parte del Estado demandado en el ámbito de la reagrupación familiar que, siguiendo las denominaciones habituales en la doctrina, asignaremos como el test convencional de los obstáculos y el test de la responsabilidad.

1. Test de los obstáculos: El TEDH exige probar la existencia de obstáculos que impidan el mantenimiento de la vida familiar en el Estado de origen de las demandantes o de sus familiares. La carga de la prueba de dichos obstáculos recae sobre los/as demandantes ${ }^{400}$. Parece ser que estos obstáculos han de ser de carácter jurídico, siendo irrelevantes los obstáculos puramente fácticos, a juzgar por lo que señala el TEDH:

"En el presente caso las demandantes no han probado la existencia de obstáculos que les impidieran mantener una vida familiar en su propio país o en el de sus maridos ni de razones especiales por las que tal solución no pudiera esperarse de ellas" ${ }^{401}$.

Este criterio, al que la doctrina ha denominado criterio "elsewhere ${ }^{402 "} \mathrm{o}$ "test de los obstáculos" 403 , presupone, a nuestro juicio, una concepción de la reagrupación familiar como una obligación de carácter excepcional para el Estado parte, cuya concesión tan sólo sería exigible ex artículo $8 \mathrm{CEDH}$ cuando existan obstáculos u razones especiales en las que no sea posible - jurídicamente hablando- la reconstitución de la vida familiar en cualquier otro Estado - distinto del Estado parte receptor-, con el que el demandante o sus familiares mantengan vínculos, preferentemente el país de origen de cualquiera de ellos ${ }^{404}$. En vista de la entidad que el TEDH exige a tales obstáculos, parecería apuntar a supuestos detonantes de la concesión del derecho de asilo, lo que, en la práctica, supondría la propia negación del derecho a la $\mathrm{RF}^{405}$ de aquellos extranjeros que, motivados por razones funda-

399 Abdulaziz, Cabales y Balkandali, STEDH, apartado 68.

400 En el mismo sentido se pronuncia SANTOLAYA MACHETTI, P. El derecho a la vida familiar de los extranjeros, op. cit., p. 93.

401 Abdulaziz, Cabales y Balkandali. Apartado 68.

402 STOREY, Hugo. “The Right to Family Life and Immigration Case Law at Strasbourg”, op. cit., pp. 331y 338. ARRIAGE, I. El derecho a la vida familiar, op. cit.

403 ARRIAGA IRABURU, I. El derecho a la vida familiar...op cit. pp. 111-279, en particular en pp. 232 y 250. STOREY, Hugo. "The Right to Family Life and Immigration Case Law at Strasbourg”, op. cit., pp. 331y 338. JOHN, A. "Family Reunification for Migrants and Refugees: A Forgotten Human Right? A Comparative Analysis of Family Reunification under Domestic Law and Jurisprudence, International and Regional Instruments, ECHR Caselaw and the EU 2003 Family Reunification Directive”. University of Coimbra Human Rights Center Working Paper, 2003 , p. 33. Disponible en http: //www.fd.uc.pt/hrc/hrc_investigacao_uk.html

404 A una conclusión similar llega AKANDIJ-KOMBE, Jean-François. Positive obligations under the European Convention on Human Rights. A guide to the implementation of the European Convention on Human Rights. Human rights handbooks, N. 7. Strasbourg, Council of Europe, 2007, p. 43.

405 En sentido igualmente crítico en torno a la aplicación del test de los obstáculos por parte del TEDH, se pronuncia ARRIAGA, quien considera que dicho test "vacía de contenido el derecho protegido por el artículo 8 CEDH". El derecho a la vida familiar..., op. cit., p. 233. También STOREY, quien denuncia que la utilización del test elsewhere conduce a un "inaceptablemente bajo nivel de protección de los derechos garantizados", señalando que resulta "insostenible" a la luz de la entidad de la unidad familiar, y subrayando asimismo las "inconsistencias internas" con los principios y valores básicos del CEDH a las que conduce su aplicación. "The Right to Family Life and Immigration Case Law at Strasbourg", op. cit, pp. 337 y 338. 
mentalmente económicas, abandonasen su país natal en busca de mejores condiciones de vida en un Estado parte del Consejo de Europa. En consecuencia, si previamente la Corte de Estrasburgo parecía alumbrar expresamente la posibilidad de proteger la RF sobre la base del respeto efectivo a la VF consagrado en el art. $8 \mathrm{CEDH}$, la exigencia del test de los obstáculos - cuyo origen se asienta en doctrina reiterada de la Comisión-, destruye dicha posibilidad, dejándola confinada, a lo sumo, a supuestos muy próximos al asilo.

2. Test de la responsabilidad individual: Con una importancia secundaria respecto al anterior criterio, en la sentencia el TEDH hace explícito, a fin de descargar al gobierno inglés, que no es atribuible al Estado demandado la situación jurídica en que se encontraban los maridos de las demandantes ${ }^{406}$. Según argumenta la Corte, en el momento de contraer matrimonio todas las demandantes eran conscientes de que con la normativa migratoria vigente en Inglaterra - normas que databan del año 1980-, no obtendrían una autorización para el establecimiento de sus cónyuges en el Reino Unido $^{407}$. Por ello, y siguiendo la terminología empleada por la doctrina, este criterio que atribuye la responsabilidad de la situación migratoria a los propios demandantes podría denominarse test de la responsabilidad individual ${ }^{408}$.

Los antecedentes de la exigencia del test convencional de la responsabilidad individual se sitúan también en la doctrina consolidada décadas previas por la Comisión Europea de derechos humanos. Llevado a sus últimos extremos, el test de la responsabilidad individual podría suponer la exclusión del derecho a la RF en la mayoría de los supuestos de migración económica, en la medida en que la decisión de emigrar se debe a motivaciones que, en último término, residen en la voluntad del migrante y su familia, sobre quienes caería la responsabilidad de las consecuencias que dicha decisión haya provocado sobre los miembros de la familia.

A modo de visión unitaria de la argumentación ofrecida por el TEDH en Abdulaziz, cabe señalar que, - habiendo partido su análisis de la óptica del carácter positivo de la obligación estatal derivada del artículo 8-, la Corte conjuga los distintos criterios apuntados priorizando, a nuestro entender, dos de ellos: de un lado, la inexistencia de obstáculos para mantener o reconstruir la vida familiar en el Estado de origen o en cualquier otro país distinto al Estado parte; De otro lado, el énfasis puesto en el amplio margen de apreciación que corresponde a los Estados en materia de RF. Ambos criterios sitúan el interés estatal - en este supuesto, cifrado expresamente en frenar la inmigración primaria en un contexto de fuerte desempleo, sin que el Tribunal lo subsuma dentro de alguna de las limi-

406 Sobre este punto, el TEDH señala: "al tiempo de su matrimonio: i) la señora Abdulaziz sabía que su marido, admitido en el Reino Unido como simple visitante y por un período limitado, debía presentar una solicitud para quedarse allí permanentemente $y$, tras la publicación de las normas proyectadas (apartado 20, supra), que probablemente sería rechazada; ii) la señora Balkandali no debía ignorar que, tras la expiración del permiso de residencia temporal obtenido por su marido a título de estudiante, éste se hallaba irregularmente en el Reino Unido y que, conforme a las Normas de 1980, entonces en vigor, no podía esperarse una decisión favorable a su establecimiento. Por su parte, la señora Cabales, quien nunca había convivido con el señor Cabales en el Reino Unido, habría debido saber que éste necesitaría un permiso de entrada y que, conforme a las normas vigentes, le sería denegado". STEDH Abdulaziz, Cabales y Balkandali, apartado 68.

$407 \mathrm{El}$ hecho de que en el momento de su matrimonio las parejas en cuestión supieran que no tenían derecho a vivir juntas en el Reino Unido, fue tenido en cuenta por el TEDH incluso a efectos de cálculo de la indemnización por daños morales, que fue finalmente rechazada (Apartado 95 STEDH Abdulaziz, Cabales y Balkandali).

408 Storey hace referencia a este test como "lack of individual responsability for any such immigration measure", situándolo entre los criterios habitualmente utilizados por la Comisión a fin de evaluar la existencia de "razones especiales" que puedan justificar la concesión de la RF. STOREY, Hugo. “The Right to Family Life and Immigration Case Law at Strasbourg”, op. cit., p. 332,. ARRIAGA, I. El derecho a la vida familiar..., op. cit., p. 250. 
taciones legítimas establecidas por el art. 8.2-, en una posición de clara ventaja respecto al interés individual de las demandantes de reunirse con sus maridos en el territorio del Estado de acogida.

La conjunción de estos criterios lleva al TEDH a concluir, por unanimidad, que no ha habido "falta de respeto" a la vida familiar, ni, por tanto, infracción del artículo 8. El Reino Unido no estaba obligado a autorizar el establecimiento en su territorio de los maridos de las demandantes.

La perspectiva de la "falta de respeto" usada por la Corte para el análisis del cumplimiento del art. $8 \mathrm{CEDH}$, parece condicionar de forma determinante el método secuencial empleado: al concluir que no ha habido tal "falta de respeto", el TEDH finaliza su análisis, sin adentrarse en la evaluación del apartado $2^{\circ}$ del artículo 8, - esto es, sin analizar si la medida estatal estaba legalmente prevista y si era necesaria para una sociedad democrática a fin de lograr alguna de las finalidades legítimas establecidas en el art. 8.2 CEDH-. Sin embargo, en su Informe previo, la Comisión si había examinado la justificabilidad de la injerencia al amparo del apartado segundo del art. $8 \mathrm{CEDH}$, como era su costumbre al examinar demandas con contenido migratorio ${ }^{409}$. En ningún momento, del razonamiento de la Corte de Estrasburgo, pueda extraerse explicación alguna en torno a esta forma novedosa de proceder.

La supresión del apartado segundo del art. 8 CEDH en el análisis efectuado por el TEDH fue criticada por dos de los cuatro votos concordantes formulados a esta sentencia ${ }^{410}$. El juez Bernhardt, en su opinión concordante, denunció explícitamente que "este razonamiento excluye la aplicación del apartado segundo del artículo y, de hecho, impone limitaciones implícitas a los derechos garantizados por el apartado primero"411. Asimismo, dicha omisión causó sorpresa entre la escasa doctrina especializada que estudió tempranamente el case law extraburgués en el ámbito de la RF de los extranjeros ${ }^{412}$, especialmente ante el contraste que supondrá frente al análisis que poco tiempo después emprendería el TEDH en el ámbito de las obligaciones negativas de carácter migratorio -léase protección frente a expulsiones-, donde si se evalúa la justificación de la injerencia al amparo del art. 8.2 CEH.

En conjunto, el razonamiento ofrecido en esta sentencia adolece, a nuestro juicio, de un defecto fundamental: el prisma adoptado parte de la consideración de la RF como una obligación potencial convencional de carácter positivo, a la que dota de características claramente diferenciadas respecto de las obligaciones negativas, señaladamente un margen de apreciación superior. Sin explicar la causa, el TEDH no analiza el apartado segundo del art. 8, eludiendo con ello el control de la justa ponderación entre los intereses en juego, lo que redunda en un examen menos exhaustivo de la cuestión de fondo. Ya señalamos que la conjunción del test de los obstáculos con la doctrina del elevado margen de apreciación, sitúa a los intereses individuales en una posición de partida de clara desventaja. Pero, adicionalmente, el análisis jurídico no entra a considerar los factores del apartado segundo del

409 STOREY, Hugo. “The Right to Family Life and Immigration Case Law at Strasbourg”, op. cit., p. 332.

410 En este sentido las opiniones particulares concordantes formuladas por el juez Thor Vilhjalmsson y, de forma mucho más explícita, por el juez Bernhardt, consideran, _ contrariamente a lo sostenido por la mayoría de los miembros del TEDH—, que sí hubo falta de respeto a la vida familiar, aunque la injerencia estaba justificada por el apartado $2^{\circ}$ del artículo 8, fundamentalmente en aras de la preservación del bienestar económico del Estado demandado.

411 Opinión Particular Concordante del juez Bernhardt, apartado1. Este magistrado concluía afirmando que "en mi opinión, por el contrario, las medidas en cuestión sólo pueden justificarse, y de hecho se justifican, por la aplicación del apartado 2".

412 Sobre este punto, STOREY señala que "en Abdulaziz la Corte pareció considerar que su fallo relativo a la cuestión de respeto volvía innecesario examinar separadamente si había alguna interferencia injustificable. Pero en Berrehab hizo precisamente lo contrario". "The Right to Family Life and Immigration Case Law at Strasbourg”, op. cit., p. 335, traducción propia. 
artículo 8, de cara a la posible justificación de la injerencia. Con ello se reducen las posibilidades de defensa de las demandantes ${ }^{413}$, fundamentalmente porque se obvia el juicio de proporcionalidad que suele realizarse en el seno de la cláusula de necesidad en una sociedad democrática.

La conjunción de los criterios y elementos procedimentales citados termina situando al interés estatal de "frenar la inmigración primaria" y salvaguardar el mercado nacional de empleo, en una posición de clara primacía frente al debilitado interés particular de las demandantes. Al amplio margen de apreciación se suma la aplicación del criterio de los obstáculos que, a nuestro entender, determina la existencia de una presunción en contra de la concesión de la reagrupación familiar ${ }^{414}$, como ya sucediera al ser aplicado por la Comisión. Por añadidura, la exclusión del apartado segundo supone la inaplicación del principio de proporcionalidad, que podría haber neutralizado, en cierta medida, el peso de los intereses aducidos por el gobierno demandado. En su conjunto, constituye por ello "un pronunciamiento frontalmente contrario al derecho de reagrupación familiar"

Otro aspecto a destacar de la sentencia Abdulaziz reside en la invocación del "bienestar económico del país" como causa legítima de intervención sobre el derecho al respeto a la vida familiar, que por primera vez encuentra aceptación en la jurisprudencia de Estrasburgo, tras haber sido poco reclamada y en la misma medida ignorada en contextos migratorios ${ }^{416}$. Con carácter previo, la Comisión, en su Informe a Abdulaziz, había confirmado esta limitación "como un título válido de restricción" ${ }^{17}$, — pese a haber rechazado las alegaciones formuladas por el gobierno inglés para justificar las medidas migratorias impugnadas en base a esta causa, y ello tras haber efectuado sobre la misma un examen tan inusualmente elevado, que fue calificado como un "escrutinio sin precedentes" ${ }^{18}$ —. Esta limitación, que en su momento fue tildada como "retrógrada" 419 por los re-

413 Colin Warbrick ha señalado en este sentido, que el enjuiciamiento realizado por el TEDH bajo el apartado primero del artículo 8 es más favorable para los intereses estatales, que el que tiene lugar sobre la base del apartado segundo de dicho artículo. La razón se debe a que bajo el apartado segundo los intereses individuales se sopesan solamente con los objetivos estatales taxativamente establecidos en dicho apartado, que además son evaluados bajo el prisma de la necesidad social imperiosa y el principio de proporcionalidad. Sin embargo, si el examen del caso se realiza solamente conforme al apartado primero del artículo 8, el balance entre los intereses del individuo y los intereses del Estado tiene lugar tomando en consideración cualquier interés estatal sin limitaciones ni determinaciones específicas. WARBRICK, Colin. “The Structure of Article 8”; en European Human Right Law Review, 1998, vol.1. Pág. 43.

414 Así se pronunciaba también STOREY al analizar las consecuencias de la aplicación del test de los obstáculos por parte de la Comisión. El autor señalaba que "la Comisión ha sido marcadamente reacia a aceptar que ha habido una interferencia real, excepto cuando la medida efectivamente impide a la vida familiar afectada de ser disfrutada "en cualquier otro lugar", fuera del territorio del Estado contratante implicado. Esta perspectiva global en torno al concepto de interferencia ha sido tratada como una presunción. Dicha presunción solamente puede ser refutada si el demandante puede mostrar que ha existido interferencia en la forma de obstáculos serios o prácticos a la reunificación en cualquier otro lugar - elsewhere- u otras especiales razones que puedan aplicar en el caso particular". “The Right to Family Life and Immigration Case Law at Strasbourg”, op. cit., p. 331, traducción propia.

415 SANTOLAYA MACHETTI, P. El derecho a la vida familiar de los extranjeros, op. cit., p. 93. El autor prosigue señalando que "admitido el principio de que las decisiones estatales en la materia pueden suponer una injerencia en la VF protegida por el Convenio, sin embargo parece poderse afirmar que sólo resultarán contrarias al Convenio en la medida en que exista una VF anterior que resulte imposible o sumamente gravoso desarrollar en ningún otro país, comenzando por el de origen del inmigrante o de su cónyuge".

416 STOREY cita como ejemplo de invocación del "bienestar económico del país" por parte del gobierno británico, la Demanda Alam Y.B., invocación que fue ignorada por la Comisión. "The Right to Family Life and Immigration...., op. cit., p. 333, nota a pie de página ${ }^{\circ} 41$.

417 STOREY, Hugo. “The Right to Family Life and Immigration Case Law at Strasbourg”, op. cit., p. 334.

418 Idem, p. 333. Posteriormente, el mismo autor añade que el "altamente empírico y detallado escrutinio", constituye uno de los más sorprendentes cambios en la aproximación que la Comisión ha efectuado en el ámbito de la migración, p. 338.

419 Citado por STOREY, Hugo. “The Right to Family Life and Immigration Case Law at Strasbourg”, op. cit., p. 333, nota al pie de página $n^{\circ} 41$. Explanatory Reports on the Second to the Fifth Protocols to the ECHR, H (71) 11, Strasbourg, pp. 32-35. 
dactores del Protocolo $\mathrm{n}^{\circ} 4$ al Convenio de Roma -en atención a la capacidad latente que conlleva para justificar políticas migratorias restrictivas-, adquirirá tal importancia en el ámbito de la RF que, como veremos, será a partir de ahora la causa que monopolizará la invocación de las intervenciones estatales acometidas en este ámbito ante los órganos de Estrasburgo.

En Abdulaziz se ventilaron también otras cuestiones de vital importancia, aunque de carácter más secundario para nuestro objeto de estudio. Las demandantes se consideraban víctimas de discriminaciones injustificadas en el ejercicio de su derecho a la vida familiar, fundadas en el sexo, la raza y el nacimiento - puesto que la señora Balkandali había adquirido la nacionalidad inglesa-. De ellas, sólo la relativa a la discriminación sexual fue aceptada por el TEDH. En la época en que se suscitaron los hechos, era más fácil para un hombre extranjero establecido en el Reino Unido, que para una mujer en la misma situación obtener para su cónyuge no nacional el permiso de entrada o permanencia en aquél país. Es decir, el gobierno dificultaba la reunión con los maridos y facilitaba la reunión de las mujeres de los hombres inmigrantes ${ }^{420}$.

El TEDH consideró que la diferencia entre el impacto de los hombres y el de las mujeres sobre el mercado nacional de trabajo, no era tan importante como para justificar la diferencia de trato respecto de la posibilidad para una persona establecida en el Reino Unido de que se reúna con ella su cónyuge. De ahí que apreciase la existencia de discriminación basada en el sexo derivada de las normas internas de inmigración, que en este punto serían incompatibles con el CEDH.

Sin embargo, este pronunciamiento tuvo un efecto colateral negativo. Santolaya ${ }^{421}$ identifica lo que se puede describir como un efecto boomerang ya que, tras Abdulaziz, Cabales y Balkandali, a fin de ejecutar esta sentencia del TEDH, y para evitar la carga de discriminación, la legislación británica se reformó en sentido restrictivo, suprimiendo el trato de favor que concedía a los inmigrantes de sexo masculino para reunirse con sus mujeres en territorio inglés.

\subsection{Gül contra Suiza, STEDH de 19 de febrero de 1996}

Una década después de Abdulaziz, el Tribunal de Estrasburgo tuvo ocasión de enfrentarse a otro supuesto sobre reagrupación familiar de no nacionales. Se trata del caso Gül contra Suiza, adoptado el 19 de febrero de 1996. En el origen de los hechos se sitúa una demanda que el señor Gül —nacional turco que gozaba de una autorización de estancia por razones humanitarias en Suiza一, dirigió a la extinta Comisión Europea alegando que el rechazo de las autoridades suizas a conceder a su

420 El TEDH examinó si esta distinción normativa poseía una justificación objetiva y razonable. El Gobierno inglés alegaba que la distinción pretendía limitar la inmigración y se justificaba por la necesidad de proteger el mercado nacional de trabajo en una época de elevado desempleo, como consecuencia del mayor impacto de los hombres sobre las mujeres en el mercado de trabajo por su tendencia mayor a buscar empleo. Para despejar esta cuestión, el TEDH recurre al principio de interpretación evolutiva, interpretando las normas a la luz de las condiciones existentes en el momento de interposición de las demandas, caracterizada por la progresión hacia la igualdad de los sexos. Ello supone que sólo razones muy poderosas podrían conducir a considerar compatible con el Convenio una distinción fundada en el sexo (Apartado 78). En este sentido, el Tribunal afirma que"el principio ya tradicional de reunión de las familias de los hombres inmigrantes, que el Gobierno alega como razón para excluir a los maridos y aceptar a las mujeres, no responde ya a las modernas exigencias de la igualdad de sexos". Abdulaiz, Cabales y Balkandali, apdo. 77.

421 SANTOLAYA MACHETTI, Pablo. El derecho a la vida familiar de los extranjeros, op. cit., p. 94 . El autor califica la ejecución de la sentencia Abdulaziz por parte del Reino Unido como “desalentadora”, señalando que finalmente la igualdad formal se consiguió a la baja, sin que fuera posible la RF. En el mismo sentido, véase KRALER, Albert \& KOFMAN, Eleonore. Civic Stratification, Gender and Family Migration Policies in Europe. Paper presented at Conference Euroean Dynamics of Citizenship. Public policies and migrante activities, op. cit., p. 2. 
hijo una autorización para residir en dicho país con sus padres, constituía una violación del derecho reconocido en el artículo $8 \mathrm{CEDH}$.

Gül había vivido en Turquía junto a su mujer y sus dos hijos hasta que en 1983 viajó a Suiza, donde solicitó asilo político por su condición de kurdo y antiguo miembro del Partido Social Demócrata turco. En Suiza trabajó hasta que una enfermedad le incapacitó laboralmente. Desde entonces recibía una pensión por invalidez parcial. Cuatro años después de la llegada de Gül a Suiza su mujer, quien hasta ese momento había permanecido en Turquía se quemó seriamente durante un ataque de epilepsia y viajó a Suiza, donde recibió tratamiento médico de urgencia. Al año siguiente nace en Suiza el tercer hijo del matrimonio, una niña llamada Nursal que pasa al cuidado público debido a que, por su enfermedad, la madre no podía hacerse cargo de ella. Por esa época un médico suizo especialista en medicina interna, declara que el regreso de la señora Gül a Turquía podría ser fatal, debido a su delicado estado de salud. En 1989, seis años después de su instalación en Suiza, el gobierno suizo rechaza la petición de asilo político del Sr. Gül, pero a la vista del largo tiempo de permanencia en el Estado y del precario estado de salud de su mujer, se les concede un permiso de residencia por razones humanitarias para él, su esposa y su hija. A partir de entonces, el demandante solicitó reiteradamente permiso a las autoridades suizas para traer a sus dos hijos, que permanecían en Turquía. Esta petición es sucesivamente rechazada por dos motivos: de un lado, porque de acuerdo a la legislación helvética el permiso de residencia por motivos humanitarios no facultaba a sus titulares para ejercer la RF. De otro lado, por incumplimiento de las condiciones que el derecho suizo establecía para la misma, entre ellas la inadecuación de la vivienda, la escasez de medios materiales y que el hijo mayor había superado ya la mayoría de edad.

Tras agotar los recursos internos, Gül alega ante la Comisión Europea que el rechazo de las autoridades suizas a permitir a sus dos hijos entrar en el país a fin de reunirse con él constituía una violación de su derecho al respeto de la vida familiar. La Comisión tan sólo declaró admisible la demanda con respecto al hijo menor de edad y, en su Informe ${ }^{422}$, consideró que había existido violación del artículo 8.

Al analizar la aplicabilidad del artículo 8.1, el TEDH constata que el vínculo existente entre Gül y su hijo menor de edad merece la consideración de vida familiar, por no concurrir en este supuesto las excepcionales circunstancias que pueden dar lugar a la ruptura del vínculo entre un padre y su hijo menor ${ }^{423}$. De esta forma el Tribunal rebate los argumentos utilizados por el gobierno demanda-

422 En su Informe, la Comisión aplicó sus principios habituales en materia migratoria, entre ellos la protección de rebote, al señalar que: "The Commission recalls that no right of an alien to enter, remain or reside in a particular country is as such guaranteed by the Convention. However, if a person is refused entry to a country where his close family resides, an issue may arise under Article 8 of the Convention" (apartado 38). La Comisión analizó la posible violación del derecho a la vida familiar en términos de "injerencia" o interferencia, y, tras evaluar su justificación al amparo del apartado segundo de dicha disposición — medida prevista por la ley, dirigida a proteger el "bienestar económico del país" en vista de que la familia dependía de los beneficios de la seguridad social, considerando sin embargo que la medida estatal no era necesaria en una sociedad democrática para la satisfacción de dicha finalidad—, estimó la violación del art. 8 CEDH.

423 Siguiendo la doctrina formulada por el TEDH en Berrehab sobre la fortaleza del vínculo existente entre padres e hijos menores, el apartado 32 de la sentencia Gül establece que "the Court reiterates that it follows from the concept of family on which Article 8 is based that a child born of a marital union is ipso jure part of that relationship; hence, from the moment of the child's birth and by the very fact of it, there exists between him and his parents a bond amounting to "family life" which subsequent events cannot break save in exceptional circumstances". Posteriormente, la Corte constata la permanencia de dicho vínculo al señalar que que: "Despite the distance, in geographical terms, between them, the applicant has made a number of visits to Turkey, the last of these being in July and August 1995. It cannot therefore be claimed that the bond of "family life" between them has been broken" (apartado 33). 
do, quien afirmaba la inexistencia del elemento intencional inherente a la vida familiar, sobre la base de que el demandante había dejado a su hijo en su país natal a muy corta edad — con tan sólo tres meses de edad-, y nunca había intentado desarrollar allí una vida familiar con él. Para el TEDH, el largo tiempo transcurrido -7 años-, y la distancia física, no rompen el vínculo familiar entre padres e hijos menores. Con ello, confirma, en el ámbito específico de la reagrupación familiar en sentido estricto, la vigencia de la presunción de existencia de vida familiar en relaciones paternofiliales caracterizadas por la separación física y temporal, que tan sólo pueden ser fracturadas en concurrencia de excepcionales circunstancias ${ }^{424}$.

Además, Gül proporciona dos elementos específicos ${ }^{425}$ que actúan como medios de prueba de la permanencia de la vida familiar en las relaciones entre padres e hijos menores, separados como consecuencia de la emigración del progenitor: De un lado, las peticiones reiteradas del padre para traerse a su hijo, formuladas desde el momento de regularización de su status legal —en este caso, desde la concesión del permiso de residencia por razones humanitarias-, constituyen una prueba de la constancia del vínculo familiar. De otro, las visitas del padre a su país natal para ver al hijo - sin especificar su número ni regularidad- actúan en el mismo sentido.

Constatada la existencia de vida familiar, el TEDH se centra entonces en verificar si las autoridades suizas, al denegar la entrada del hijo menor en el país, habían "interferido" en el derecho del demandante, esto es, el cumplimiento del artículo $8 \mathrm{CEDH}$. A primera vista, parecería que el TEDH adopta la óptica seguida por la Comisión de analizar la obligación estatal en términos de injerencia, esto es, como posible incumplimiento de la obligación negativa de no interferir en el ejercicio del derecho a la vida familiar. Sin embargo, se trata de una incoherencia terminológica - se emplea el término "interferencia" que habitualmente designa obligaciones negativas, en el contexto de las obligaciones positivas-, pues de la fundamentación jurídica se deduce una aproximación al análisis de la obligaciones concretas que del respeto efectivo a la vida familiar se derivan para las autoridades suizas como una exigencia de hacer, esto es, sobre la base de las obligaciones positivas.

A fin de enfocar la cuestión de la existencia o no de interferencia sobre el derecho del art. 8 $\mathrm{CEDH}$, el TEDH avanza una importante doctrina:

"El Tribunal reitera que el objeto esencial del artículo 8 es proteger al individuo contra acciones arbitrarias de las autoridades públicas. Puede haber, en adiciónn, obligaciones positivas inherentes al "respecto" efectivo de la vida familiar. Sin embargo, los límites entre las obligaciones estatales positivas y negativas derivadas de esta disposición no permiten una definición precisa. Los principios aplicables, no obstante, son similares. En ambos contextos ha de prestarse atención al justo balance entre los intereses contrapuestos del individuo y de la comunidad en su conjunto; y en ambos contextos el Estado disfruta de un cierto margen de apreciación".

El TEDH, en su función de concreción normativa de la norma principial contenida en el artículo 8 , subraya la dificultad de distinción entre obligaciones positivas y negativas, cuyos límites poseen contornos difusos y, por tanto, admitiendo que no cabe contemplarlas como compartimentos estancos. Señala, además, que ambos tipos de obligaciones se rigen por principios similares, exigiendo

424 En el mismo sentido se pronuncia SANZ CABALLERO. La familia en perspectiva..., op. cit., pp. 92-93.

425 Dichos elementos fueron valorados por el TEDH y aparecen con claridad en el apartado 33 de la sentencia, donde se afirma que "however, after obtaining a residence permit on humanitarian grounds in Switzerland in 1990, the applicant asked the Swiss authorities for permission to bring the boy, who was then six years old, to Switzerland. Subsequently, he repeatedly asked the Swiss courts to allow his son to join him, before bringing his case before the Convention institutions. Despite the distance, in geographical terms, between them, the applicant has made a number of visits to Turkey, the last of these being in July and August 1995. It cannot therefore be claimed that the bond of "family life" between them has been broken". 
un justo balance entre los intereses concurrentes, individuales y colectivos, para cuya apreciación el Estado disfruta de cierto margen de apreciación. Con ello, la Corte profundiza en la determinación del contenido material de las obligaciones positivas, extrayendo tres reglas de vital importancia, _lo que convierten a este concreto pronunciamiento en una de las aportaciones fundamentales de esta sentencia, junto con la constatación de la existencia de vida familiar entre padres e hijos menores en el contexto específico de la RF en sentido estricto-:

1. En primer término, el Tribunal aproxima el régimen jurídico de las obligaciones positivas y negativas, extrayendo cierta equiparación en el régimen de todas las obligaciones migratorias convencionales derivadas de la vida familiar, con independencia de su carácter positivo o negativo. Todas ellas se regirán por principios similares.

2. Consecuentemente, se reduce el margen de maniobra reconocido al Estado para determinar las concretas medidas - normativas, ayudas públicas..- - que ha de implementar para permitir el normal desarrollo de la vida familiar, en tanto que obligación positiva en el marco migratorio. En este punto el tribunal parece alejarse conscientemente de la doctrina sentada en Abdulaziz, donde el énfasis puesto en la mayor amplitud del margen de apreciación estatal para determinar el contenido de las obligaciones positivas, situaba al Estado en una clara postura de ventaja frente a los intereses individuales. Dado que ahora el régimen tiende a la equiparación, la consecuencia es que el margen de apreciación, en el ámbito de las obligaciones positivas, se comprime, pasando de "amplio" - Abdulaziz-, a "cierto" — en el sentido de relativo-.

3. La tercera regla extraíble de Gül reside en la introducción, en el contexto del enjuiciamiento de la RF en tanto que obligación positiva, del test del justo balance entre los intereses concurrentes. Con ella, el TEDH sigue la herencia de la Comisión, quien desde inicios de la década de los ochenta del pasado siglo había desarrollado una "fórmula especial de balance" 426 en el contexto migratorio, a fin de equilibrar los intereses individuales relativos al respeto de la vida familiar del los extranjeros, con el establecimiento de controles migratorios internacionalmente adecuados ${ }^{427}$.

El test del justo balance supone la irrupción del principio de proporcionalidad en el enjuiciamiento empleado por el TEDH ante supuestos de reunificación, si bien, a nuestro juicio, constituye su versión más atenuada o rebajada. Como ya señalamos, el principio de proporcionalidad constituye un elemento inherente en la estimación de si una medida estatal limitativa de un derecho convencional cumple con el requisito de la necesidad en una sociedad democrática (art. 8.2). Cuando se utiliza en conjunción con esta cláusula, sus exigencias son mayores pues implica la aplicación de los tres subprincipios de la proporcionalidad - adecuación, necesidad y proporcionalidad en sentido estricto. Frente a ella, el test del justo balance obvia dos de esos elementos, reduciéndose a la proporcionalidad en sentido estricto ${ }^{428}$, - y ello resulta tanto más evidente si esta circunstancia se analiza a la luz de la exclusión del análisis del apartado segundo del art $8 \mathrm{CEDH}$, que caracteriza el enfoque jurisprudencial del TEDH en el ámbito de la RF de los extranjeros.

426 STOREY, Hugo. “The Right to Family Life and Immigration Case Law at Strasbourg”, op. cit., p. 332, el autor explica que esta fórmula fue "presumiblemente introducida para alinear su case law migratorio en coherencia con los históricos juicios emitidos por la Corte en los asuntos Sunday Times y Handyside", traducción propia.

427 Idem.

428 En este sentido, Presno Rivera afirma que “a la hora de establecer si del artículo 8, en el caso concreto, se deriva una obligación positiva para el Estado, el Tribunal emplea el test del <justo equilibrio $>$, que funciona en la práctica como trasunto del principio de proporcionalidad en sentido estricto". SARMIENTO, Daniel; MIERES MIERES, Luis Javier; PRESNO RIVERA, Miguel. Las sentencias básicas del Tribunal Europeo de Derechos Humanos. Estudio y Jurisprudencia. Pamplona, Thomson Cívitas, editorial Aranzadi, 2007, p. 67 
En consecuencia, la compatibilidad con el Convenio de Roma de las medidas estatales restrictivas del derecho a la reagrupación familiar serán enjuiciadas conforme a este último subprincipio, mientras que las interferencias sobre la vida familiar de los extranjeros - supuestos de protección frente a expulsiones-, se evaluarán utilizando los parámetros más estrictos incluidos en el apartado segundo del artículo 8. Comparando ambos tipos de test, la posición del individuo frente al interés estatal de controlar la inmigración, se encuentra, en términos globales, más robustecida cuando el TEDH enjuicie medidas estatales migratorias que se inscriban en el ámbito de las obligaciones negativas. Puede que, en ambos supuestos, el TEDH hubiese llegado a idénticas conclusiones respecto al supuesto concreto que debe juzgar pero, comparativamente hablando, resulta más exhaustivo el escrutinio que la Corte realiza al evaluar la compatibilidad con el Convenio de las medidas de expulsión potencialmente violatorias del derecho a la vida familiar de los extranjeros.

Comparando esta doctrina con la establecida en Abdulaziz, en Gül se detecta un distanciamiento en materia del régimen aplicable a las obligaciones positivas, especialmente relevante por la reducción del margen de apreciación estatal. Sin embargo, el alejamiento se produce solamente en este punto, porque en Gül contra Suiza el TEDH aplica, con mayor rigor si cabe, todos los principios sentados en Abdulaziz ${ }^{429}$.

Tras reiterar que el artículo 8 no impone una obligación general a los Estados de autorizar la reunificación familiar en su territorio, y que la extensión concreta de las obligaciones derivadas de dicho artículo depende de las circunstancias particulares de las personas involucradas y del interés general, el Tribunal concluye la necesidad de valorar los hechos que concurren en este caso.

A fin de valorar tales circunstancias, acude en primer lugar al test de los obstáculos, pero llevándolo a sus extremos de máxima exigencia. Si en Abdulaziz, este criterio implicaba que sólo cabría deducir una obligación estatal de admitir la entrada de familiares de no nacionales asentados en el territorio de un Estado contratante cuando los demandantes demostrasen la existencia de obstáculos que impidiesen mantener la vida familiar en un tercer Estado, la aplicación de este test en Gül es mucho más rigurosa. A juicio del TEDH:

"La tarea en este caso consiste en determinar en qué medida es cierto que el traslado de Ersin - hijo menor del recurrente- a Suiza sería la única forma para que el demandante pudiese desarrollar una vida familiar con su hijo" ${ }^{\text {"30. }}$.

En consecuencia, los obstáculos deben ser ahora de tal relevancia que supongan en la práctica que sólo es posible para el demandante disfrutar de la vida familiar en el territorio del Estado contratante, como única vía factible después de haber descartado la posibilidad de vida familiar en cualquier otro Estado. Ello supone un aumento de la rigidez del criterio elsewhere, elevando las exigencias que para el particular derivan del test de los obstáculos, neutralizando en cierto modo el efecto que la introducción del test del "justo equilibrio" podría operar a efectos de equilibrar los

429 A juicio del TEDH, "The present case concerns not only family life but also immigration, and the extent of a State's obligation to admit to its territory relatives of settled immigrants will vary according to the particular circumstances of the persons involved and the general interest. As a matter of well-established international law and subject to its treaty obligations, a State has the right to control the entry of non-nationals into its territory. Moreover, where immigration is concerned, Article 8 cannot be considered to impose on a State a general obligation to respect the choice by married couples of the country of their matrimonial residence and to authorise family reunion in its territory. In order to establish the scope of the State's obligations, the facts of the case must be considered". Gül v. Suiza, apartado 38.

430 Ibidem, apartado 39, traducción propia. 
intereses concurrentes: frente al interés individual del demandante de disfrutar de su vida familiar en Suiza, el test de los obstáculos, —en esta nueva concepción más rigurosa-, otorga una situación de clara superioridad al interés de la Federación Suiza de controlar la inmigración.

En el análisis de las circunstancias concretas del caso, el TEDH acude también al test de la responsabilidad, aplicando también este criterio con mayor rigor que en Abdulaziz. El TEDH centra su atención en la causa que dio origen a la separación del demandante respecto de su hijo menor, esto es, el hecho de que el Sr. Gül abandonase su país natal en 1983- "al dejar Turquía, el demandante causó la separación de su hijo" ${ }^{31}$ - . El resultado del test sería descargar al Estado demandado, que no es en modo alguno responsable de la situación en la que se encuentra la familia del demandante.

En la aplicación concreta del test de los obstáculos a las circunstancias que rodean al Sr. Gül, - quien podría regresar a su país natal y seguir percibiendo la pensión de invalidez que recibe en Suiza一, y a la señora Gül — cuyo retorno "sería más problemático"332 debido a su delicado estado de salud-, el Tribunal reconoce que no sería fácil para ellos regresar al país de origen. Sin embargo concluye que no hay, estrictamente hablando, obstáculos que les impidan desarrollar su vida familiar en Turquía. Se confirma que los obstáculos exigidos son de carácter jurídico ${ }^{433}$, y no meramente fácticos - pues al proclamar las dificultades prácticas que los demandantes afrontarán para retornar a su tierra natal a fin de reconstruir allí la unidad familiar, la Corte simultáneamente reconoce que éstas carecen de entidad para estimar la violación del derecho.

A favor de esta conclusión pesan dos factores más. De un lado, el derecho interno suizo, que ha concedido un permiso por razones humanitarias a los demandantes, permiso que nos les habilita para ejercitar el derecho a la reunificación familiar. De otro, un elemento de más relieve, y donde el TEDH acude al recurso comparativo con anteriores sentencias. Ésta es una técnica habitualmente usada por el Tribunal de Estrasburgo en su argumentación jurídica, confrontando el caso actual con asuntos anteriormente fallados, donde se da un concurrencia de circunstancias similares a las planteadas en el asunto objeto de enjuiciamiento. En este supuesto, el TEDH recurre al asunto Berrebah, para introducir un elemento comparativo a considerar dentro del test de los obstáculos que refuerza la postura del Estado demandado. A diferencia de Berread - donde el demandante, ciudadano marroquí pendiente de expulsión, tenía una hija de nacionalidad holandesa que siempre había vivido en dicho país y cuya vida familiar se veía amenazada por la orden de expulsión de su padre-, en el presente caso, el demandante tiene un hijo nacido y criado en su país natal, Turquía, y por lo tanto, con fuertes vínculos culturales y lingüísticos allí.

De este modo, y por vía comparativa, el TEDH introduce el test de la integración, que supone evaluar la fortaleza de los vínculos que los particulares - en este caso el hijo menor del demandante-, conservan con su Estado de origen. En el test de la integración se toman en cuenta, pero con una importancia infinitamente menor, el nivel de integración de los demandantes en el Estado de

431 Idem, apartado 41. Además, el TEDH parece poner en entredicho las auténticas razones que motivaron la salida del demandante de Turquía, dudando de la veracidad de los motivos de su petición de asilo — "fue incapaz de probar a las autoridades suizas, que rechazaron concederle el status de refugiado político, que él personalmente había sido víctima de persecución en su Estado de origen", señala la Corte en el mismo apartado-. En cualquier caso, las posteriores visitas a su hijo menor, que residía en Turquía desde su nacimiento, confirman, a juicio del TEDH, que las razones para la petición de asilo ya no son válidas, dado que no existe riesgo para el demandante en entrar en tal país.

432 Gül v. Suiza, STEDH apdo. 41.

433 En el mismo sentido se pronuncia STOREY, Hugo. “The Right to Family Life and Immigration Case Law at Strasbourg", op. cit., p. 331. 
acogida deducida de la duración temporal de su estancia en Suiza ${ }^{434}$. Esto es, en la aplicación del test de integración, pesan más los vínculos que las personas afectadas mantengan con su país natal que aquellos que haya creado en el Estado receptor ${ }^{435}$.

El resultado de la combinación de estos tres criterios —obstáculos, responsabilidad e integración, con predominio absoluto del criterio de los obstáculos-, lleva a concluir al Tribunal que, pese a que la situación de la familia demandante es muy difícil desde el punto de vista humanitario, sin embargo el Estado demandado, desde el punto de vista estrictamente jurídico ${ }^{436}$, no ha violado las obligaciones dimanantes del artículo 8.1 al no conceder un permiso de residencia para el hijo menor del demandante. La terminología es confusa, ya que se habla reiteradamente de la inexistencia de "interferencia ${ }^{437 ", ~ t e ́ r m i n o ~ q u e ~ s u e l e ~ u s a r s e ~ p a r a ~ r e f e r i r s e ~ a ~ o b l i g a c i o n e s ~ n e g a t i v a s ~ c u a n d o, ~ s i n ~ e m-~}$ bargo, el prisma adoptado en este caso fue el carácter positivo de las obligaciones estatales derivadas del respeto a la vida familiar.

Dado que el TEDH no aprecia interferencia en el derecho convencional, paraliza su análisis en este momento, sin entrar a evaluar el apartado segundo del artículo 8, al igual que ocurría en Abdulaziz. Sin embargo, conviene precisar que la Comisión, en su Informe relativo al caso Gül, mantuvo un punto de vista radicalmente opuesto, ya que estimó violación del artículo 8 -por 14 votos contra 10 en contra- y examinó la demanda sometiéndola a los parámetros justificativos del artículo 8.2 CEDH.

A nuestro juicio, son aplicables nuevamente aquí las consideraciones críticas apuntadas en Abdulaziz al obviar el análisis exhaustivo de proporcionalidad que se efectúa a partir del apartado segundo del precepto analizado. Pero esta crítica podría formularse con mayor contundencia, a la vista de que en Gül el TEDH ha endurecido los criterios aplicables, especialmente el test de los obstáculos. Los efectos respectivos de los criterios aplicados por el TEDH, de carácter contradictorio - mayor rigor del test de los obstáculos y de la responsabilidad versus disminución del margen de apreciación estatal - se contrarrestan y el resultado es similar al producido en la primera sentencia: a efectos del justo balance entre los intereses concurrentes, el Estado demandado y el particular demandante ocupan posturas que distan de ser igualitarias, siendo superior y preferente el interés estatal.

Sin embargo, en Gül el TEDH parece obviar la distinción formulada en Abdulaziz, que parecía apuntar a una apertura al reconocimiento de la reagrupación familiar vía artículo 8 en los supuestos en que el extranjero que la reclama haya dejado tras de sí una vida familiar preexistente en su Estado

434 Gül c. Suiza, apdo. 42.

435 En nuestra opinión existe un factor importante en este caso, - al que el TEDH no otorgó apenas relevancia-, y que hubiera actúado al otro lado de la balanza del test de la integración: la hija nacida en Suiza estaba, desde su nacimiento, a cargo del Estado como consecuencia de la incapacidad y enfermedad de sus progenitores. En estas circunstancias resulta un poco incoherente que los padres, pese a su deseo, puedan hacerse cargo del hijo que dejaron en Turquía al cuidado de la familia del padre. Considerando que el demandante recibía una pensión por invalidez y el tratamiento médico de la madre, conceder un permiso de entrada al otro hijo en territorio suizo se traduciría en una elevación de la carga estatal. El TEDH pasa por alto esta circunstancia, señalada repetidamente en las alegaciones del Estado demandado.

436 "Having regard to all these considerations, and while acknowledging that the Gul family's situation is very difficult from the human point of view, the Court finds that Switzerland has not failed to fulfill the obligations arising under Article 8 para. 1, and there has therefore been no interference in the applicant's family life within the meaning of that Article", apartado 44 sentencia Gül. La distinción, en la argumentación del TEDH, entre consideraciones humanitarias y jurídicas, ha sida puesta de relieve por el Alto Comisionado de Derechos Humanos de las Naciones Unidas en "Family Reunification", OHCHR Migration Papers, november 2005, p. 12. Disponible en http://www2.ohchr.org/ english/issues/migration/taskforce/docs/familyreunification.pdf

437 Idem, apdos. 39 y 43. 
de origen. Cuando se encuentra, como en Gül, ante un supuesto típico de reagrupación familiar que, adicionalmente, reunía consideraciones humanitarias excepcionalmente difíciles y próximas al asilo en concurrencia con la situación regular del reagrupante, elude aplicar la doctrina que había dejado entrever en Abdulaziz, y opta por endurecer el test de los obstáculos ${ }^{438}$. Las expectativas levantadas en torno al posible alumbramiento de un derecho de reunificación familiar bajo la cobertura del artículo $8 \mathrm{CEDH}$, se vienen abajo en Gül. De hecho, la lectura de Abdulaziz llevaría incluso a concluir que no cabría deducir del art. $8 \mathrm{CEDH}$ la protección de carácter indirecto a un derecho a la RF de los extranjeros, ni siquiera en presencia de inmigrantes que afronten circunstancias excepcionalmente difíciles.

Pese a ello, a partir de la sentencia Gül comienza a percibirse de forma patente una fisura cada vez mayor entre los jueces integrantes del TEDH. Abdulaziz se falló por unanimidad, mientras que en esta segunda sentencia la Corte comienza a dividirse y el fallo se emite con 7 votos a favor y dos en contra. La división, como veremos, no ha hecho más que empezar.

\section{a) Opinión disidente del Juez Martens a Gül contra Suiza}

La sentencia Gül contra Suiza viene acompañada de la opinión disidente del juez Martens, suscrita por el juez Russo. En ella se apuntan argumentos de gran relevancia que anticipan el futuro giro jurisprudencial en esta materia, lo que justifica la conveniencia de analizarla con cierto detenimiento.

Antes de entrar a considerar las circunstancias que concurren en el caso Gül, el juez Martens constata la evolución que, en una década — desde Abdulaziz—, se ha producido en la doctrina jurisprudencial general en torno al artículo $8 \mathrm{CEDH}$, evolución que no ha afectado al ámbito de la inmigración, donde siguen rigiendo los mismos principios sentados en Abdulaziz. De otro lado, reflexiona en torno a la distinción jurisprudencial entre obligaciones convenciones positivas y negativas $^{439}$, considerándola una cuestión artificial y de carácter puramente semántico. A su juicio, el caso Gül ilustra la inconsistencia del mantenimiento de dicha distinción, pues una misma medida puede considerarse simultáneamente como la violación de una obligación negativa -las autoridades suizas deberían haberse abstenido de adoptar la medida denegatoria de la reunión entre Gul y su hijoo de una obligación positiva -el Estado demandado comprometió su responsabilidad internacional ya que, debiéndolo, no posibilitó la reunión entre el demandante y su hijo.

Dado que el TEDH, en este pronunciamiento, hizo explícita la necesidad de aplicar principios similares tanto a las obligaciones positivas como a las negativas, Martens estima irrelevante el esfuer-

438 A la misma conclusión llega Anne STAVER, señalando explícitamente a Gül como ejemplo de aplicación "estricta” del test de los obstáculos. "Family Reunification: A Right for Forced Migrants?", op. cit., p. 14.

439 "Negative obligations require member States to refrain from action, positive to take action. The Court has repeatedly stressed that the boundaries between the two types "do not lend themselves to precise definition". The present case well illustrates the truth of this proposition since the question whether the Swiss decision violated a positive or a negative obligation, if either, seems hardly more than one of semantics: the refusal of the Swiss authorities to let Ersin and his parents be reunited may be considered as an action from which they should have refrained, whereas it could arguably also be viewed as failing to take an action which they were required to take, namely making a reunion possible by granting the authorisation. If one takes the view that, if there is a violation at all, it must be of a positive obligation -a view that finds support in the aforementioned Abdulaziz, Cabales and Balkandali judgment- then one has to put up with the rather awkward systematic inconsistency that exclusion of a person from a state where his family lives does not fall into the same category of breaches as expulsion of a person from a state where his family lives: the former decision may be in breach of a positive obligation under Article 8 (art. 8), whereas the latter may be in breach of a negative obligation". Opinión disidente del juez Martens, apartado $7^{\circ}$. 
zo conducente a encajar el posible incumplimiento de un Estado parte en una de las dos tipologías, porque en ambas debe examinarse el justo equilibrio entre los intereses involucrados.

Para Martens, la consecuencia más llamativa de la diferenciación apuntada, "es que en el contexto de las obligaciones positivas, el margen de apreciación entraría en juego en la fase de determinación de la existencia de la obligación, mientras que en el contexto de las obligaciones negativas, sólo juega un papel, si acaso, en la fase de determinación de si la violación de la obligación está justificada ${ }^{440}$. Martens viene así a subrayar que el enfoque diferenciado desemboca en la existencia de un margen de apreciación superior en el ámbito de las obligaciones positivas.

Respecto a las circunstancias que concurren en el caso Gül, para el juez Martens, contrariamente a lo sostenido por el TEDH, la decisión de las autoridades suizas de denegar al hijo del demandante una autorización para residir con él, en principio compromete la responsabilidad el Estado bajo el artículo 8, constituyendo una violación del mismo, salvo que merezca justificación en virtud de algunas de las causas establecidas en el apartado segundo de dicho precepto ${ }^{441}$. Para Martens, la decisión de las autoridades suizas estaba justificaba en virtud de los dos primeros parámetros establecidos en el artículo 8.2 CEDH: fue tomada de acuerdo a la ley interna y perseguía un fin legítimo - aunque, en este segundo aspecto, el juez Martens califica de "hipócrita" ${ }^{42}$ el intento de las autoridades helvéticas de maquillar los auténticos objetivos de la medida estatal, alegando que ésta pretendía servir a los intereses del menor, a quien, supuestamente le convendría más permanecer en Turquía que reunirse con su familia en Suiza, cuando la legítima finalidad perseguida, si no la única, era el bienestar económico del país.

Del caso Gül, restaría para Martens abordar la cuestión esencial, esto es, la proporcionalidad o no de la medida: examinar si era necesario en una sociedad democrática rechazar la autorización para que el hijo de 7 años del demandante pudiese vivir en Suiza con sus padres, analizando si la misma tuvo en cuenta el justo balance entre los intereses contradictorios concurrentes. Al respecto, el juez Martens examina ambos platillos de la balanza. De un lado, el interés de la comunidad Suiza en un contexto con tasas migratorias muy elevadas, que habían convertido a la inmigración en un tema particularmente sensible. En este panorama, resulta comprensible el temor del Estado receptor de crear un precedente, de ahí que apele a su derecho de controlar las fronteras, exigiendo un elevado margen de apreciación en esta materia ${ }^{443}$. En el otro lado de la balanza, se sitúa un elemento fundamental de un elemental derecho humano, el derecho de cuidar de los propios hijos ${ }^{444}$, de tal modo que, en cuanto el demandante regularizó su situación legal en Suiza, solicitó traer a su hijo a dicho país. Martens menciona aquí uno de los criterios señalados al estudiar el margen de apreciación estatal, como variable que condicionaba cierta restricción en su amplitud - la naturaleza del derecho y su importancia para el titular-.

440 Opinión disidente del Juez Martens. Apartado 8. Traducción propia.

441 Idem, apartados 6 y 9.

442 "On the other hand I cannot help saying that I consider the Government's attempt to embellish the harsh, political objectives of their decision by pleading that in the first place it was designed to serve Ersin's interests rather hypocritical. The stress laid on financial considerations makes it clear that the legitimate aim pursued was, if not only then mainly, 'the interests of the economic well-being of the country', Apartado 9 de la opinión disidente del juez Martens.

443 Al examinar el interés del gobierno suizo, Martens recuerda asimismo que éste alegaba haber concedido al demandante un permiso por razones humanitarias, el cual otorgaba un estatus legal transitorio que no permite el ejercicio de la reunificación familiar. Como consecuencia de dicha concesión, el gobierno hubo de soportar los costes de subsistencia del demandante, su mujer e hija en Suiza, de ahí que, a juicio de Martens, sería demasiado esperar que hiciera lo mismo por el hijo residente en Turquía.

444 Opinión disidente del juez Martens a Gül c. Suiza, apdo. 12. 
El gobierno suizo es consciente del peso de este elemento, pero intenta minimizarlo apoyándose en el test de los obstáculos tal como fue establecido en Abdulaziz, alegando que el demandante no había demostrado la existencia de obstáculos para el restablecimiento de la familia en Turquía. Sin embargo, para eljuez Martens, la alegación del gobierno demandado desconoce que, bajo la distinción que la sentencia Abdulaziz, Cabales y Balkandali estableció entre el caso allí presente y la situación de los inmigrantes que tienen una familia a la que dejan detrás en otro país hasta obtener un status legal en el Estado receptor, se encuentra una importante cláusula que sugiere que, en este último supuesto, deberían aplicarse normas distintas a Abdulaziz ${ }^{445}$. En otras palabras, el caso Abdulaziz no constituye autoridad para que el gobierno demandado pueda rechazar la petición de entrada del hijo menor del demandante en base a que si el demandante y su esposa quieren la reunión de la familia deberían regresar a Turquía. Para Martens:

"Al contrario, la sentencia Abdulaziz, Cabales y Balkandali sugiere que, en casos donde un padre y una madre han alcanzado un estatus estable en un país y desean reunirse con su hijo, al que dejaron mientras en su país de origen, es per se irrazonable, cuando no inhumano, darles a elegir entre renunciar a la posición que han adquirido en el país de destino o renunciar a disfrutar de su mutua compañía, que constituye un elemento fundamental de la vida familiar" ${ }^{346}$.

En consecuencia, la proposición que el TEDH anunció en el caso Abdulaziz, debe entenderse, a juicio de Martens, como la obligación estatal de conceder la RF a aquellos inmigrantes que, después de dejar una vida familiar tras de si en el país de origen, hayan adquirido un estatus legal en el Estado parte receptor ${ }^{447}$, considerando no sólo irrazonable, sino inhumano, la aplicación del test de los obstáculos en tales circunstancias.

De otro lado, Martens destaca un elemento que fue tenido en cuenta por el Estado demandado para otorgar al Sr. Gül el permiso de estancia por razones humanitarias: el elemento temporal. El Sr. Gül vivió en Suiza durante 7 años, lo que ha provocado que tanto él como su mujer y su hija allí nacida estén integrados en dicho país. Si se evalúa el carácter humanitario de la elección que tenían ante sí las autoridades suizas, debería pesar más la integración en el Estado de acogida que un elemento puramente formal como es el estatus legal de su permiso de estancia en dicho país. En refuerzo de su postura, Martens tiene en cuenta la concurrencia de múltiples factores en este caso, que también deberían haber sido tenidos en cuenta por el Tribunal y que, en su conjunto, sitúan al demandante y a su familia en una postura que merece compasión ${ }^{448}$. En definitiva, para el juez Martens el rechazo

445 Martens prosigue argumentando: "Which norms? The Court does not answer that question, but it is natural to infer that it intended to make it clear that in respect of such cases it might possibly hold that, in the context of the issue of family reunion, the State of settlement should respect the choice of the immigrants who have achieved settled status there and, accordingly, must accept members of their family which they had left behind for settlement". Opinión disidente del juez Martens, apdo. 14.

446 Apdtdo. 14 de la opinión disidente del juez Martens a STEDH Gül c. Suiza, traducción propia.

447 VAN WALSUM, Sarah. "Comment on the Sen Case. How Wide is the Margin of Appreciation Regarding the Admission of Children for Purposes of Family Reunification"; en European Journal of Migration and Law, n4, 2003, p. 516.

448 Entre los factores humanitarios que deberían haber merecido reflexión, Martens señala explícitamente la existencia de una hija de la pareja nacida y criada en el Estado receptor, de modo que la negativa de las autoridades suizas obligaría al demandante no solamente a elegir entre renunciar a su hijo establecido en Turquía o renunciar a la posición ya adquirida en Suiza, sino que, adicionalmente, el regreso a Turquía implicaría la necesidad de renunciar también a su hija, cuyo interés superior aconseja que permanezca en el Estado contratante. Además existen motivos de carácter humanitario, como la discapacidad del demandante y la enfermedad de su esposa, dependiente de tratamiento médico - que con certeza puede obtener en Suiza, mientras que se debate si podría obtenerlo en Turquía- e, incluso la situación del demandante en Turquía, dado que no ha podido probarse la existencia o no de persecución política en dicho país. Apartado 15, opinión disidente del juez Martens. 
de las autoridades suizas a permitir la entrada en el país al hijo del demandante, no ha tenido en cuenta el justo equilibrio entre los intereses, de modo que se trata de una decisión desproporcionada y violatoria del artículo $8 \mathrm{CEDH}$.

En síntesis, la trascendencia de esta opinión disidente reside en que el juez Martens deduce de la jurisprudencia emitida por el TEDH en el caso Abdulaziz, la existencia de la obligación estatal de conceder la RF para aquellos inmigrantes que han adquirido un estatus legal en el país receptor, siempre que cuenten con una vida familiar preexistente en un tercer país, esto es, la necesidad de proteger la denominada RF en sentido estricto como contenido del derecho al respeto de la vida familiar. Llega incluso a sugerir que esta obligación se incrementa para las autoridades en supuestos de altas tasas migratorias ${ }^{449}$, donde las presiones políticas y sociales suelen desembocar en la adopción de decisiones políticas restrictivas en el país receptor.

Antecedentes de la línea de razonamiento avanzada por Martens, se pueden encontrar en dos decisiones de admisibilidad emitidas por la Comisión en casos relativos a la RF en el año 2001 -los asuntos Lahnifi ${ }^{450}$ y Adnane $e^{451}$-, donde el TEDH distinguió los supuestos de reagrupación, existiendo una vida familiar previa, de los casos de establecimiento de una vida familiar ex novo, señalando que, en casos migratorios donde la vida familiar era preexistente, resultaba irrazonable la aplicación del test de los obstáculos ${ }^{452}$.

El razonamiento de Martens saldrá reiteradamente a la luz en la jurisprudencia posterior del TEDH, sirviendo de inspiración y antecedente remoto para el futuro giro jurisprudencial que se producirá en este ámbito.

\subsection{Ahmut contra Holanda, STEDH de 28 de noviembre de 1996}

El siguiente conflicto ante el TEDH relativo a la migración familiar no se hizo esperar. Se trata del caso Ahmut contra Holanda, fallado el mismo año en que la Corte resolvió el asunto Gül y que, al igual que éste, hacía referencia a relaciones paterno-filiales. Sin embargo, Ahmut es un caso controvertido y de difícil encaje dentro de la vida familiar de los extranjeros ya que el demandante, -el señor Salah Ahmut-, era un nacional marroquí establecido legalmente en Holanda, donde había adquirido la nacionalidad holandesa, conservando al mismo tiempo la natal.

El señor Ahmut había emigrado a Holanda en 1986, dejando en Marruecos cinco hijos fruto de un matrimonio ya disuelto con una mujer marroquí, a cuyo cargo quedaron los hijos. Poco después

449 Frente a la alegación del gobierno demandado de que el estatus legal del Sr. Gül — permiso de residencia por razones humanitarias - era de carácter temporal y le otorgaba una protección menor que la autorización de residencia, el juez Martens recordó la necesidad de conciliar intereses, necesidad especialmente relevante en un contexto migratorio difícil, señalando textualmente que: "The European Court of Human Rights has to ensure, in particular, that State interests do not crush those of an individual, especially in situations where political pressure -such as the growing dislike of immigrants in most member States - may inspire State authorities to harsh decisions. .(...) the Court must examine cases like this not only from the point of view of immigration and residence, but also with regard to the mutual interests of the applicant, his wife and Ersin". Apartado 15, opinión disidente del juez Martens a la STEDH Gül contra Suiza.

450 CEDH, 13 de febrero de 2001, nr. 39329/98.

451 CEDH, 6 de noviembre de 2001, nr. 50568/99.

452 Estos asuntos son citados por VAN WALSUN como antecedentes de la opinión disidente del juez Martens, si bien la autora se refiere a la opinión que Martens formula a Ahmut donde, como veremos, se exponen los mismos argumentos que le llevan a disentir respecto a la mayoría de los jueces que dictaminaron Gül. "Comment on the Sen Case”, op. cit., p. 516, notas a pie de página números 12 y 13. 
de su llegada a Holanda, la ex mujer del demandante fallece en un accidente de tráfico y los hijos pasan al cuidado de la madre del demandante, con la ayuda financiera de éste. Conforme al derecho marroquí, el señor Ahmut es el tutor de los niños. En Holanda el demandante rehace su vida y contrae matrimonio. El hijo menor del demandante le visita varias veces en Holanda, hasta que en 1990, contando con nueve años, se instala allí con su hermana que por entonces ya era mayor de edad. Ambos habían entrado en Holanda con un visado de carácter provisional, de modo que solicitan de las autoridades holandesas un permiso para poder residir con su padre, quien en esa época ya había adquirido la nacionalidad holandesa. La solicitud les es denegada y se ordena su expulsión, si bien se decide la suspensión de sus efectos mientras el gobierno holandés resuelve el recurso planteado por el demandante.

Tras agotar los recursos internos, los tres elevan una demanda ante la Comisión Europea de Derechos humanos, alegando que la denegación del permiso de residencia a los dos hijos del demandante constituía una violación del derecho al respeto de su vida familiar. La Comisión declaró admisible la demanda tan sólo con respecto al señor Ahmut y su hijo menor, no respecto a la hija mayor de edad. En su Informe, este órgano estimó que la medida migratoria impugnada perseguía como fin legítimo el bienestar económico del país, pero en atención a las específicas circunstancias del menor - huérfano de madre y a cargo de su abuela paterna, ya anciana y enferma-, estimó que era desproporcionada por no considerarla necesaria para una sociedad democrática, declarando la existencia de violación del artículo 8 por parte del Estado holandés.

El caso Ahmut constituye un supuesto típico de RF en sentido estricto, sobre la base de la distinción que el TEDH apuntara en el apartado 68 de la sentencia Abdulaziz — persona que deja atrás a su familia en su país natal hasta que legaliza su situación en el Estado receptor, momento a partir del cual solicita un permiso de residencia inicial para sus hijos a fin de reunirse con ellos en el territorio de dicho Estado. Además este caso cuenta con una peculiaridad importante, ya que el reagrupante ostentaba la doble nacionalidad, siendo una de ellas la holandesa. Llama la atención que el TEDH se enfrente a este caso sin otorgar relevancia alguna al hecho de que el demandante poseyera la nacionalidad de un Estado parte ${ }^{453}$, factor que tampoco había sido tenido en cuenta por la Comisión ${ }^{454}$, si bien éste órgano había estimado la violación del derecho a la vida familiar.

A lo largo de todo el razonamiento desplegado para evaluar el cumplimiento del artículo 8 CEDH, el TEDH se apoya explícitamente en la doctrina sentada en el caso Gül, tanto respecto a los principios aplicables - a cuya sistematización procede ${ }^{455}$-, como a la sutil distinción entre obligaciones positivas y negativas y la equiparación en su tratamiento. De este modo, tras constatar la

453 Por pasar por alto el hecho de que el reagrupante había adquirido la nacionalidad del Estado parte demandado, - "elemento del que se hubieran podido deducir consecuencias relevantes, al menos desde la óptica de la normativa comunitaria"-, SANTOLAYA MACCHETI califica el caso Ahmut como un supuesto "controvertido". El derecho a la vida familiar de los extranjeros..., op. cit., p. 95.

454 Apartados 45 a 54 del Informe de la Comisión Europea de Derechos Humanos, 17 de mayo de 1995. Application N. 21702/93, Salah Ahmut and Souffiane Ahmut against the Netherlands. Por su parte, en el apartado 65 de la sentencia, el TEDH recopila los argumentos vertidos por la Comisión.

455 "The applicable principles have been stated by the Court in its Gul judgment as follows (loc. cit., para. 38): (a) The extent of a State's obligation to admit to its territory relatives of settled immigrants will vary according to the particular circumstances of the persons involved and the general interest. (b) As a matter of well-established international law and subject to its treaty obligations, a State has the right to control the entry of non-nationals into its territory. (c) Where immigration is concerned, Article 8 (art. 8) cannot be considered to impose on a State a general obligation to respect immigrants' choice of the country of their matrimonial residence and to authorise family reunion in its territory". STEDH Ahmut contra Holanda, apartado 67. 
existencia de vida familiar entre los demandantes ${ }^{456}$, indaga la naturaleza de la obligación que está en juego, determinando que se trata del posible incumplimiento de una obligación de carácter positivo $^{457}$ - el deber que compete al Estado parte de permitir el desarrollo de la vida familiar en su territorio- - Sin embargo, la Comisión había enjuiciado la medida estatal limitativa considerándola desde la perspectiva de un "interferencia" y, por tanto, aplicando el método correspondiente a las obligaciones negativas, que involucra en su análisis al apartado segundo del artículo 8 CEDH.

El alcance de la obligación estatal está determinado por las circunstancias del caso, para cuyo análisis el TEDH aplica los test habituales —obstáculos, responsabilidad individual, integración-, si bien cabe deducir una alteración en el orden de su importancia:

1. Test de la integración: El Tribunal subraya que, con la breve excepción del tiempo que el hijo menor pasó en Holanda con su padre, toda su vida ha vivido en Marruecos, donde ha sido criado por la familia de su padre y donde tiene "fuertes vínculos con el ambiente lingüístico y cultural de su país" 458 . En la apreciación del TEDH, un elemento adicional a tener en cuenta es que el menor conserva múltiples parientes en su país natal, en respuesta a la alegación de los demandantes de que la avanzada edad y la enfermedad de la madre del señor Ahmut, —que hasta el momento se había hecho cargo del niño-, le impedían continuar con esa tarea.

Sin embargo, en la aplicación de este criterio, la circunstancia de que el señor Ahmut estuviese plenamente integrado en Holanda, donde en el momento de incoación de la demanda ante la Comisión llevaba viviendo siete años, y en donde además había vuelto a casarse, mantenía un negocio propio y había logrado el status legal más beneficioso posible ${ }^{459}$ - la nacionalidad del Estado parte-, no fue tenida en cuenta. En suma, el test de la integración, tal y como es aplicado en Ahmut por el TEDH, es unidireccional, siendo empleado en exclusiva para valorar la fortaleza de los vínculos del demandante con el Estado de origen —en este caso, del hijo menor del señor Ahmut—, sin tener en cuenta a efectos de su neutralización, la correlativa integración en el país de acogida del otro demandante, el señor Ahmut.

2. La aplicación del test de la responsabilidad individual se produce con una severidad mayor que en previos pronunciamientos:

456 La aplicabilidad del artículo 8 no constituye una cuestión controvertida y es despejada rápidamente por el TEDH. Aplicando la doctrina Berrehab - también seguida en Gül-, confirma que el vínculo entre el demandante y su hijo es constitutivo de vida familiar, constatando que la distancia física y temporal que la migración supone para los miembros de la familia no constituye una de las circunstancias excepcionales que pueden provocar la ruptura de tal vínculo. En palabras del TEDH, "As the Court has frequently held, it follows from the concept of family on which Article 8 is based that a child born of a marital union is ipso iure part of that relationship; hence, from the moment of the child's birth and by the very fact of it, there exists between him and his parents a bond amounting to 'family life', which subsequent events cannot break save in exceptional circumstances. It was not suggested that any such exceptional circumstances were present in this case. The existence of 'family life' between the applicants is therefore established". Idem, apdo. 60.

457 "The present case hinges on the question whether the Netherlands authorities were under a duty to allow Souffiane to reside with his father in the Netherlands, thus enabling the applicants to maintain and develop family life in its territory. For this reason the Court will view the case as one involving an allegation of failure on the part of the respondent State to comply with a positive obligation”. Apartado 63, STEDH Ahmut contra Holanda.

458 Ídem. Apartado 68.

459 Estas circunstancias, conjunta o aisladamente consideradas, fueron tenidas en cuenta por los cuatro jueces que formularon opiniones disidentes a la sentencia Ahmut. 
"El hecho de que los demandantes vivan separados es el resultado de la decisión consciente de Salah Ahmut de asentarse en Holanda en vez de permanecer en Marruecos. Por lo tanto, Salah Ahmut no está impedido de mantener el grado de vida familiar por el que él mismo ha optado al trasladarse a Holanda" ${ }^{\text {"60 }}$.

En conexión con esta circunstancia el TEDH señala que, pese a gozar de la nacionalidad holandesa, "el demandante ha conservado su nacionalidad marroquí originaria"461, como un factor adicional que refuerza el test de la responsabilidad individual en descargo de Holanda. El encaje de este factor dentro del examen del test de la responsabilidad, así como la propia formulación empleada por la Corte, parece sugerir cierta penalización del demandante por el hecho de haber mantenido su nacionalidad natal, junto a la holandesa. A mayor abundamiento, esta es la única ocasión en que el Tribunal de Estrasburgo saca a relucir la nacionalidad holandesa del demandante a lo largo de toda su argumentación.

De otro lado, en el momento en que se elevo la demanda a la Comisión, el hijo del señor Ahmut contaba 14 años de edad y estaba internado en un colegio marroquí. Es precisamente en la consideración de este último factor, donde se observa la aplicación más rigurosa del test de la responsabilidad individual. El TEDH imputa al señor Ahmut la responsabilidad de la decisión de que su hijo sea criado en Marruecos como consecuencia de haber optado por su escolarización en ese país ${ }^{462}$, -decisión que, sin embargo, se produjo después de y como consecuencia de la denegación de su permiso de residencia, lo que provocó el retorno del menor a Marruecos y su consiguiente escolarización allí-. Con ello, el test de la responsabilidad individual, llevado a sus extremos, juega un papel esencial en el razonamiento del TEDH, en perjuicio de los intereses particulares.

3. Test de los obstáculos, en conexión con el test de la responsabilidad, y reduciendo notablemente su peso respecto al desempeñado en previos pronunciamientos. A juicio del TEDH, la decisión de las autoridades holandesas "no impide el mantenimiento del grado de vida familiar por el

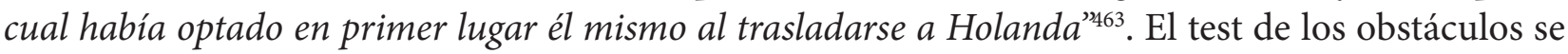
ventila de forma expeditiva, señalando someramente la inexistencia de obstáculos para el regreso de Ahmut a su país natal ,como demuestra el hecho de las visitas que padre e hijo han realizado, desde el regreso de éste último a Marruecos.

El endurecimiento en la aplicación del test de la responsabilidad individual es claro; el TEDH enfatiza el hecho de que el demandante ha causado la separación familiar de la cual se queja ya que, con su decisión de emigrar a Holanda, optó conscientemente por una rebaja o degradación en la intensidad de su vida familiar. Las autoridades holandesas, al denegar el permiso de residencia a su hijo, no han imposibilitado que el demandante continuara desarrollando el tipo de vida familiar por él elegida al abandonar Marruecos. El TEDH parece seguir en este punto la argumentación esgrimida en su momento por el gobierno demandado ${ }^{464}$, para quien el grado de vida familiar protegible

460 Ídem, apartado 70, traducción propia.

461 "In addition to having had Netherlands nationality since February 1990, Salah Ahmut has retained his original Moroccan nationality. Souffiane has Moroccan nationality only". Ahmut, apartado 70.

462 "By sending Souffiane to boarding-school, Salah Ahmut has arranged for him to be cared for in Morocco. The Court therefore need not go into the question whether Souffiane's relatives living in Morocco are willing and able to take care of him". Idem, apartado. 72.

463 Ibidem, apartado 70.

464 Holanda se había apoyado en la sentencia Gül y en Berrehab, para introducir una distinción en el tratamiento de los casos. A juicio de las autoridades holandesas, si lo que se juzga es el rechazo a la concesión de un permiso inicial de residencia para los familiares de inmigrantes asentados - que hasta entonces han permanecido en su Estado de origen-, dicho rechazo no constituiría una violación del artículo $8 \mathrm{CEDH}$, pues no impediría la continuación de los lazos familiares en el mismo grado que eran ejercidos hasta el momento de la decisión estatal. Sin embargo, si se trata de la retirada del status de residente - como ocurre en los supuestos de expulsión, como el supuesto Berrehab, 
es el establecido por el propio demandante cuando decidió dejar su país natal, decisión que parece considerar irreversible e irrevocable ${ }^{465}$. La rigidez con que se aplica el test de la responsabilidad individual implica, en último extremo, la propia anulación del derecho a la RF, al menos en lo que respecta a inmigrantes económicos - dado que solamente sería posible para el extranjero superar este test cuando la decisión de emigrar fuera forzada por motivos próximos a la persecución política $\mathrm{u}$ otros o existiera riesgo sobre la vida, que encajarían en los supuestos de asilo y refugio.

A continuación - y continuando con la doctrina sentada en Abdulaziz y ratificada e n Gül一, el TEDH establece que, aunque el demandante prefiera mantener e intensificar su vida familiar con su hijo en Holanda, "sin embargo, el artículo 8 no garantiza el derecho a elegir el lugar más adecuado para desarrollar la vida familiar" ${ }^{\prime 66}$. La introducción del matiz más adecuado, deja entrever la actitud cautelosa del TEDH ante la intensidad del fenómeno migratorio en Holanda y la alta densidad de su población.

Tras evaluar las circunstancias concretas que concurren en Ahmut a la luz de los tres criterios vistos, el TEDH concluye, por una exigua minoría -5 votos a favor contra cuatro-, que el rechazo de Holanda a la petición de residencia del hijo menor marroquí del señor Ahmut no constituye una violación del artículo 8. El análisis de la Corte se detiene en este momento, sin tomar en consideración las circunstancias justificadoras del apartado segundo del artículo 8.

La emisión del fallo por una "pequeña mayoría" ${ }^{467}$, es un síntoma revelador no solamente de la profunda división interna entre los jueces integrantes de la Sala sino, fundamentalmente del carácter problemático del tema, en un contexto migratorio cada vez más difícil, fundamentalmente porque el fallo tiene implicaciones sobre una materia en conexión directa con la soberanía estatal. De hecho, la sentencia produce la impresión de que el Tribunal se repliega cautelosamente ante esta realidad, en un ejercicio de autocontención judicial, y tiende a sobredimensionar el interés de los Estados de controlar la inmigración, reduciendo el efecto útil que podría extraerse del artículo $8 \mathrm{CEDH}$.

Ahmut constituye un fallo polémico que viene acompañado de opiniones disidentes, suscritas por los tres de los cuatro jueces en minoría, alarmados ante la escasa protección que el derecho a la vida familiar está otorgando en asuntos migratorios relativos a la $\mathrm{RF}^{468}$. Para el juez Válticos, el elemento decisivo en este caso es la trascendencia del derecho que ostentan padre e hijo a vivir juntos - "pocos derechos humanos son tan importantes" -, al que habría que añadir, en apoyo de las pretensiones de los demandantes, la nacionalidad holandesa adquirida por el padre. El hecho de que al señor Ahmut se le deniegue un derecho que ostentaría un nacional en cualquier país, lleva a este juez a denunciar lo que considera una sospecha de discriminación. De hecho, la interpretación efectuada

donde se cuestionaba la expulsión de una marroquí residente en Holanda, país donde había nacido su hija, fruto de su matrimonio con una mujer holandesa-, entonces la decisión estatal constituiría una interferencia en el ejercicio del derecho a la vida familiar del extranjero, ya que imposibilitaría la continuación de ésta en la forma en la que el demandante estaba acostumbrado. De este modo, el gobierno demandado viene a sugerir que la actuación del artículo 8 como vía de protección de la vida familiar de los extranjeros se active casi exclusivamente en supuestos de retirada del permiso de residencia - fundamentalmente en casos de expulsión-, pero sería muy excepcional en los supuestos típicos de reunificación familiar. STEDH Ahmut contra Holanda, apartado 62.

465 Ahmut contra Holanda, apartado 70.

466 Idem, apartado 71.

467 Expresión tomada de la opinión disidente del juez Válticos a la sentencia Ahmut.

468 VAN WALSUM, Sarah. "Comment on the Sen Case. How Wide is the Margin of Appreciation Regarding the Admission of Children for Purposes of Family Reunification"; en European Journal of Migration and Law, n4, 2003 , p. 515. 
por la mayoría del Tribunal, a su juicio, "refleja un espíritu restrictivo incompatible con el verdadero significado del CEDH y con el concepto de derechos humanos".

El juez Martens formula un voto particular, al cual se adhiere el juez Lohmus, lamentando que en Ahmut se haya seguido la doctrina sentada en Gül, a la que califica como "desafortunado precedente" ${ }^{\prime 69}$. Martens reitera los argumentos esgrimidos en el voto particular emitido en su día con ocasión de la sentencia Gül. A su juicio, la medida estatal denegatoria del permiso de residencia al hijo menor del señor Ahmut, es una decisión desproporcionada que viola ambos apartados del artículo 8. En su opinión, el presente caso reúne todos los factores para que se aplique sin excepciones la regla que en su día infirió del caso Abdulaziz: Obligación del Estado parte de admitir a miembros de la familia que el inmigrante legalmente asentado dejó tras de sí en su país natal —Marruecos-. Aunque reconoce que esta obligación admite excepciones, "sin embargo cuando lo que está en juego es la reunión con hijos pequeños del inmigrante —en este caso, un niño extranjero de 9 años y huérfano de madre - es muy difícil admitir que la regla no debería ser seguida"470. Martens enfatiza el hecho de que el demandante ha alcanzado el status legal más beneficioso posible - la nacionalidad del Estado de acogida-, de modo que si desea reunirse y vivir en Holanda con su hijo, "el principio de igualdad exige que la Corte aplique los mismos standards que aplicaría para aquellos cuya nacionalidad holandesa es irreprochable"471. Los restantes elementos que fueron tenidos en cuenta por la mayoría del tribunal -existencia de familiares en Marruecos que podían hacerse cargo del menor, el hecho de que el hijo careciese de la nacionalidad holandesa, el largo tiempo que padre e hijo vivieron separados, la decisión del padre de internar a su hijo en un colegio marroquí-, son insustanciales y carecen de entidad para poder justificar una excepción a la regla general que el juez Martens deduce del caso Abdulaziz.

Se suma a estas dos opiniones disidentes la que formula el juez Morenilla. Este magistrado considera que son dos los elementos clave para estimar la violación del derecho a la vida familiar por parte del Estado Holandés: la corta edad del hijo y la nacionalidad holandesa del padre. Acusa al TEDH de excesivo formalismo y de olvidar el espíritu humanitario que late detrás de los derechos humanos. Por ello, estima que la decisión estatal impugnada no solamente no es ni necesaria ni proporcionada, y por tanto contraria al CEDH, "sino también contraria a profundas razones de naturaleza humanitaria" ${ }^{\prime 72}$.

De la lectura de la sentencia queda la impresión de estar ante un tribunal aún más restrictivo ante la RF que en casos precedentes, en un claro ejemplo de contención judicial y respeto al margen de apreciación estatal en materia migratoria. Sin embargo, este supuesto reunía múltiples factores que inclinaban la balanza a favor de los intereses individuales para la concesión de la reagrupación familiar: la corta edad del hijo del demandante y su necesidad y mayor dependencia respecto de su único progenitor vivo; la integración del demandante en el Estado receptor; pero, fundamentalmente, la nacionalidad del señor Ahmut. De otro lado, el derecho comunitario reconocía con carácter

469 Apartado segundo de la opinión disidente del juez Martens a la sentencia Ahmut contra Holanda.

470 Apartado 5 de la opinión disidente del juez Martens a la STEDH Ahmut contra Holanda. Traducción propia.

471 Ídem. Apartado 6. Traducción propia.

472 "To deny a father and son their right to be together when the son is at an age at which he needs his father's care and guidance, particularly since his mother has died, and to deny a national of the Netherlands the right to have his son begin an education in the adopted country of which he is a national according to the law, is in my opinion contrary not only to the European Convention of Human Rights but also to "cogent reasons of a humanitarian nature" as set forth in the national legislation (1982 Aliens Circular, Chapter B19, paras. 1.1 and 2.5)”. Opinión disidente del juez Morenilla a la Sentencia Ahmut contra Holanda. 
fundamental el derecho a la RF para quienes ostentasen la nacionalidad de un EM, requisito cumplido por el demandante.

Del caso Ahmut se deduce una configuración jurisprudencial muy restrictiva del derecho a la reagrupación familiar ${ }^{473}$. Como tal, se traduciría en una limitada obligación para los Estados parte del CEDH -deducible del artículo 8- de permitir la entrada de familiares de inmigrantes legalmente asentados tan sólo en circunstancias extremadamente excepcionales. Además, de la lectura de la sentencia Ahmut se entrevé una influencia mayor del contexto migratorio en el razonamiento de la Corte ${ }^{474}$, - este órgano hace referencia expresa a la política migratoria restrictiva del Estado holandés derivada de la alta densidad de población extranjera y de los elevados porcentajes de desempleo- que, paradójicamente, se traduce en un paralelo endurecimiento de los requisitos jurisprudenciales. Desde nuestro punto de vista, son más poderosos los argumentos sustentados por los jueces en minoría en la Sentencia Ahmut.

\section{EL VIRAJE JURISPRUDENCIAL PRODUCIDO CON LA SENTENCIA SEN: LA RF COMO CONTENIDO MATERIAL DEL DERECHO AL RESPETO A LA VIDA FAMILIAR}

El siguiente supuesto en que un particular vuelve a plantear ante el TEDH una reclamación relativa a la reagrupación familiar basada en el artículo $8 \mathrm{CEDH}$, es el caso Sen contra los Países Bajos, fallado el 21 de diciembre de 2001. Esta sentencia marca un claro giro jurisprudencial producido en un lapso temporal relativamente corto con respecto al acervo anterior ${ }^{475}$. Hasta este momento, la línea jurisprudencial en materia de RF se había caracterizado por ser claramente restrictiva y había continuado in crescendo a lo largo de una década hasta llegar a su punto álgido en 1996, con la sentencia Ahmut. De otro lado, Sen constituye el primer caso sobre migración familiar conocido enteramente por el TEDH, desaparecida ya la Comisión como consecuencia de la entrada en vigor del Protocolo $n^{\circ} 11$.

En esta ocasión los demandantes son tres ciudadanos turcos - un matrimonio de residentes legales en Holanda y su hija-, que acuden a la Comisión Europea reclamando que la denegación de las autoridades holandesas del permiso de residencia a la hija menor de edad para reunirse con sus padres en Holanda, constituía una violación del derecho al respeto de su vida familiar.

El señor Sen llegó a Holanda en 1977, contando con 12 años de edad, para reunirse con su padre y, por lo tanto, en el marco de una reagrupación familiar. Desde entonces reside legalmente en este

473 En el mismo sentido se pronuncia SANTOLAYA MACHETTI, quien señala que en Ahmut el TEDH sienta "una doctrina aún más restrictiva si cabe de las posibilidades de utilización del Convenio para definir este derecho". El derecho a la vida familiar de los extranjeros..., op. cit., p. 95. También VAN DIJK, Pieter; VAN HOOF, Fried; VAN RIJN, Arjen and ZWAAK, Leo (eds.). Theory and Practice of the European Convention on Human Rights, $4^{\mathrm{a}}$ edic, 2006, op. cit., p. 704. Estos últimos autores citan las sentencias Gül y Ahmut, como ejemplos de aplicación más severa de los test convencionales —especialmente el test de los obstáculos—, en materia de admisión de extranjeros por parte del TEDH.

474 SANTOLAYA HACHETTI. El derecho a la vida familiar..., op. cit., p. 95.

475 En sentido similar en torno al cambio jurisprudencial que se produce con el asunto Sen, se pronuncia VAN WALSUM, Sarah, en un exhaustivo análisis de esta sentencia. "Comment on the Sen Case. How Wide is the Margin of Appreciation Regarding the Admission of Children for Purposes of Family Reunification"; en European Journal of Migration and Law, no 4, 2003, pp. 511-520. Sin embargo, el giro producido en materia de RF con el asunto Sen ha pasado desadvertido para un sector doctrinal, quizá como consecuencia de que el TEDH parece jugar al despiste: afirma apoyarse en previos pronunciamientos para, de forma paradójica, alejarse significativamente de ellos. 
país. Se casa en Turquía con una mujer de nacionalidad turca, tras lo cual él regresa a Holanda y la esposa permanece en Turquía, donde da a luz a una niña. Cuando la primogénita tiene tres años, la madre se une con su esposo en Holanda, dejando a la pequeña al cuidado de su hermana. En Holanda la esposa obtiene el permiso de residencia y allí nacen otros dos hijos del matrimonio. Cuando la niña contaba con nueve años de edad, los padres solicitan un permiso de residencia provisional para la menor. Justifican la tardanza en dicha solicitud - habían transcurrido seis años desde que la madre se reuniera con su marido en Holanda-, alegando que fue consecuencia de problemas de pareja que ya han sido resueltos. Además, señalan que nadie podía hacerse cargo de la pequeña en Turquía porque su tía - que hasta el momento se había hecho cargo de la menor-, tenía depresiones, insistiendo en que jamás habían tenido la intención de confiarle definitivamente el cuidado de su hija, sino tan sólo con carácter temporal ${ }^{476}$.

El gobierno holandés rechazó repetidamente la solicitud de los señores Sen, apoyándose en la política migratoria restrictiva implantada en ese país, justificada por la elevada densidad de su población. El Estado demandado afirmó también que en el presente caso no concurrían razones imperiosas de carácter humanitario que justificasen la concesión del permiso de residencia a la hija de los señores Sen, dado que existían más familiares en Turquía que podían ocuparse de la menor. Además, el gobierno argumentaba distinguiendo los casos de reunificación familiar - y por tanto de concesión inicial de un permiso de residencia- que reclamarían, a su juicio, un tratamiento más exigente, de aquellos en los que se cuestiona la continuación o revocación de un permiso ya concedido. Respecto de estos últimos el gobierno holandés deduce la existencia de una obligación positiva de facilitar la vida familiar en su territorio, pero no respecto de los supuestos de reunión con familiares en el Estado de acogida.

El propio gobierno demandado había reconocido que el vínculo entre los demandantes constituía vida familiar a efectos del artículo $8 \mathrm{CEDH}^{477}$, ratificando el TEDH que, en este supuesto, pese a haber transcurrido seis años de separación entre padres e hija, no se dan las circunstancias excepcionales que provocan la ruptura de dicho vínculo. Tras determinar así la aplicabilidad del artículo 8 , el Tribunal sitúa el análisis de la reclamación de los demandantes como un posible incumplimiento de una obligación de carácter positivo, si bien empleando para ello una terminología confusa -el TEDH utiliza el término de "injerencia"478, pese a situar el conflicto en el marco de las obligaciones positivas-. Para la Corte, la cuestión de fondo a resolver reside en determinar si las autoridades holandesas tenían la obligación positiva de autorizar a la menor a residir con sus padres, a fin de permitirles mantener y desarrollar una vida familiar en su territorio.

$\mathrm{Al}$ enmarcar de esta forma el asunto central objeto de análisis, el Tribunal de Estrasburgo está ampliando el ámbito de las obligaciones dimanantes para los Estados partes en materia de VF de los

476 Un dato llamativo de la sentencia Sen es que el gobierno turco participó en el proceso ante el TEDH, ejerciendo su derecho a intervenir mediante la presentación de alegaciones con argumentos en apoyo de las pretensiones de los demandantes. En consecuencia, el país de origen de los demandantes apoyaba los argumentos de éstos en favor de la reagrupación familiar, mientras que el Estado de acogida se amparaba en el test de los obstáculos, para sostener que la reunión de la familia debía producirse en el país natal.

477 Sen c. Holanda, apdo. 27.

$478 \mathrm{El}$ uso terminológico confuso queda patente cuando el TEDH centra su análisis a fin de delimitar la cuestión de fondo que ha de dirimir en este asunto, afirmando que "sobre la cuestión de si el asunto supone una «injerencia» en el ejercicio por los demandantes de su derecho al respeto de su «vida familiar» o, dicho de otra manera, la alegación del incumplimiento por el Estado demandado de una «obligación positiva»". Sin embargo, a renglón seguido señala que: "el Tribunal debe, por tanto, determinar si las autoridades holandesas tenían la obligación positiva de autorizar a Sinem a residir con sus padres en los Países Bajos, permitiendo así a los interesados mantener y desarrolar una vida familiar en su territorio". Apartado 31 de la sentencia Sen contra Holanda. 
extranjeros: a diferencia de lo expuesto en Ahmut, dichas obligaciones no se restringen a permitir el mantenimiento de los lazos familiares de los extranjeros asentados en el territorio de los Estados parte -lo que supondría un mero mantenimiento del status quo familiar precedente al hecho migratorio-, sino que van más allá, exigiendo del Estado que facilite el desarrollo de la vida familiar de los extranjeros ${ }^{479}$, al menos cuando se trata de relaciones paterno-filiales que involucran a menores de edad. Antecedentes de esta línea argumental progresiva se encuentran, de forma remota, en la sentencia Marckx y, más recientemente, en un supuesto migratorio relativo a la protección frente a expulsiones que fue dictado escasos meses antes de Sen, el asunto Ciliz contra Holanda, de 11 de julio de $2000^{480}$. La trascendencia de Sen, reside en que el TEDH confirma esta misma línea argumental progresiva, basada en un entendimiento dinámico de la VF, también en el marco de la RF ${ }^{481}$.

En consecuencia, con Sen se asienta una concepción más profunda de las obligaciones convencionales positivas derivadas del respeto a la vida familiar de los extranjeros, conforme a la cual el Estado parte de acogida no solamente ha de permitir el mantenimiento de los vínculos familiares considerados normales entre los parientes próximos de aquellos no nacionales regularmente asentados en sus territorios, sino más allá, está obligado a permitir el desarrollo de tales vínculos. Ello aludiría a la superación del concepto previo de familia del inmigrante manejado en Estrasburgo - asentado sobre la concepción estricta del test de los obstáculos y de la responsabilidad-, en base al cual los parientes próximos se mantenían largo tiempo separados transnacionalmente, lo que llevó a la doctrina a hablar de familia "peripatética o ambulante" 482 - concepción que no resistiría el prisma de desarrollo de vínculos familiares bajo la perspectiva de "normalidad", adoptado ahora por la Corte.

A fin de emprender el análisis de la cuestión de fondo, ya delimitada, el Tribunal reitera que el alcance de las concretas obligaciones estatales depende de las circunstancias que concurran en el caso. Apoyándose expresamente en la doctrina establecida en Gül y Ahmut, el TEDH ofrece en esta sentencia una sistematización de los principios aplicables en el análisis jurídico de los supuestos que involucran obligaciones positivas de carácter migratorio, a saber:

1. "El alcance de la obligación por parte de un Estado de admitir en su territorio a los familiares de inmigrantes depende de la situación de los interesados y del interés general. 2. Según un principio de derecho internacional, los Estados tienen el derecho, sin perjuicio de los compromisos que se derivan para ellos de los tratados, a controlar la entrada de no nacionales en su territorio. 3. En materia de inmigración, el artículo $8 \mathrm{CEDH}$ no podría interpretarse como una imposición a un Estado de la obligación general de

479 A la misma conclusión llega VAN WALSUN, indicando que esta ampliación del ámbito de las obligaciones esenciales derivadas del respeto a la vida familiar constituye una de las aportaciones fundamentales de la sentencia Sen. La autora argumenta dicha ampliación, basándose no solamente en el parágrafo 32 de esta sentencia, sino en lo establecido más adelante por el TEDH en el apartado 40, donde señala que la admisión de la entrada de la hija menor en Holanda constituye la opción más apropiada para el desarrollo de la VF de los demandantes. "Comment on the Sen Case...", op. cit., p. 519.

480 VAN WALSUN deduce del razonamiento empleado por el TEDH en Ciliz y en Sen, que las obligación nucleares derivadas del art. $8 \mathrm{CEDH}$ en materia migratoria, "exigen del Estado permitir e incluso facilitar el desarrollo de vínculos familiares normales entre miembros asentados dentro de la comunidad del Estado demandado y sus familiares extranjeros". Tales obligaciones centrales actúan como límite del margen de apreciación estatal en materia de política migratoria. "Comment on the Sen Case", op. cit., p. 520, traducción propia.

481 Idem.

482 STOREY, Hugo. “The Right to Family Life and Immigration Case Law at Strasbourg”, op. cit., p. 337. El autor, criticando ferozmente la aplicación del criterio elsewhere por considerarlo insostenible con los valores y principios que sirven de base al Convenio de Roma, señaló en su momento que dicho test presuponía una vida familiar entendida como un "abstracción atómica. Ignora el hecho que las familias reales raramente viven peripatéticamente, incluso en nuestras móviles sociedades europeas de hoy”, traducción propia. 
respetar la elección, por parejas casadas, de su residencia común y de permitir el reagrupamiento familiar en su territorio" 483 .

Si bien en la sistematización de estos principios el TEDH manifiesta una clara continuidad, el viraje jurisprudencial se aprecia a partir de este momento, pues la interpretación que les imprime el Tribunal comienza a diferir. En este sentido, el TEDH explicita y clarifica por primera vez los criterios que han de tenerse en cuenta para modular las circunstancias del caso $^{484}$, a fin de extraer el alcance de las obligaciones que incumben al Estado parte en la admisión de parientes del residente ${ }^{485}$ :

"En su análisis, el Tribunal tiene en consideración la edad de los niños afectados, su situación en su país de origen y su grado de dependencia con respecto a sus padres. No se podría analizar la cuestión solamente desde el punto de vista de la inmigración, comparando esta situación con la de las personas que han creado vínculos familiares una vez que se han establecido en su país anfitrión”486.

El TEDH, apoyándose expresamente en la doctrina que en su momento avanzó en Abdulaziz - tal y como había sido interpretada por el juez Martens-, parece respaldar el alumbramiento de la RF en el seno del derecho al respeto de la vida familiar en aquellos supuestos donde el extranjero cuente con una vida familiar previa, que dejó atrás para emigrar, descartando la protección de los vínculos familiares creados a partir del establecimiento en el país receptor - lo que supondría la exclusión de la formación familiar-.

Resulta de singular importancia la referencia explícita a Abdulaziz, y precisamente al apartado en el que el Tribunal había distinguido la situación de las demandantes, —que habían creado su vida familiar ex novo tras su establecimiento legal en el Reino Unido-, de la de aquellos inmigrantes que ya tuvieran una familia a la que hubieran dejado tras de sí en otro país hasta el reconocimiento de su derecho a permanecer en el Estado de acogida. Fue precisamente este apartado de la sentencia Abdulaziz el que sirvió al juez Martens para inferir que, en esta última situación, cabría deducir la obligación general del Estado parte de admitir a los familiares de los inmigrantes que cumplieran con la condición establecida - preexistencia de una vida familiar dejada atrás para emigrar-, y a la formulación de sendas opiniones disidentes en Gül y Ahmut. Pero también habíamos destacado que, pese a las expectativas levantadas por Abdulaziz, en los casos posteriores relativos a la RF nunca se aplicó la regla inferida, aunque en ellos la situación de los recurrentes encajaba en el supuesto de hecho apuntado por el Tribunal en Abdulaziz. Ahora, el TEDH, ante un supuesto similar a los casos anteriores ya analizados, retoma y explota las posibilidades de esta distinción. De hecho, en este específico apartado - y también a lo largo de todo el razonamiento desplegado por el TEDH—, se

483 Sentencia Sen contra los Países Bajos, de 21 de diciembre de 2001, apartado 35.

484 VAN DIJK, Pieter; VAN HOOF, Fried; VAN RIJN, Arjen and ZWAAK, Leo (eds.). Theory and Practice of the European Convention on Human Rights, $4^{\text {a }}$ edic, 2006, op. cit., p. 704.

485 Algunas de estas pautas se habían aplicado ya rigurosamente en los antecedentes analizados —especialmente la situación en el Estado de origen de las personas implicadas y, en menor medida, el grado de dependencia de los menores respecto a sus progenitores, que solía traducirse en determinar si existían familiares cercanos que pudieran quedarse a su cargo- . Otros criterios, sin embargo, habían sido subestimados por el TEDH, pese a la insistencia de los demandantes -la edad de los niños afectados-, lo que incluso había servido de base a varios jueces disidentes a acusar al TEDH de aplicar, en los casos de reunión de niños de corta edad con sus padres inmigrantes, un tratamiento jurídico poco humanitario.

486 Sentencia Sen contra los Países Bajos, de 21 de diciembre de 2001, apartado 36, remitiéndose el Tribunal explícitamente al apartado 68 de la sentencia Abdulaziz, Cabales y Balkandali de 1985, donde el TEDH señaló que "ha de subrayarse que el litigio no se refiere a inmigrantes que ya tuvieran una familia a la que hubieran dejado tras de sí en otro país hasta el reconocimiento de su derecho a permanecer en el Reino Unido: las demandantes no contrajeron matrimonio sino una vez establecidas en este país como solteras". 
percibe la influencia constante de los argumentos expuestos en su momento por el juez Martens en sus opiniones disidentes ${ }^{487}$, aunque en ningún momento el Tribunal lo haga explícito.

A partir de este momento, el alejamiento respecto de sus precedentes jurisprudenciales será constante. Llama la atención el esfuerzo del TEDH en disimular este alejamiento, usando para ello un razonamiento progresivo y de carácter comparativo en el que la equiparación con anteriores casos - especialmente con las circunstancias que dieron lugar a la sentencia Ahmut-, es usada como trampolín para, paradójicamente, apartarse de sus antecedentes, bajo la excusa de que en Sen concurren circunstancias distintas que justificarían por ello conclusiones también diferentes.

1. Test de la responsabilidad individual ${ }^{488}$ : El TEDH imputa a los padres la responsabilidad de la degradación en su vida familiar, de la que ahora se quejan, pues ésta es la consecuencia de la decisión de la madre de emigrar a Holanda para reunirse con su marido, dejando a su hija en su país de origen. Subraya el elemento intencional — “decisión adoptada deliberadamente por los padres”-, de modo que la decisión estatal no privaría, en principio, a los padres de su derecho a disfrutar del tipo de vida familiar por el que ellos mismos optaron al dejar a la niña en su país natal. Dada la similitud de los hechos, el test de la responsabilidad se aplica inicialmente con la misma contundencia que en la sentencia Ahmut.

2. Test de la integración o el mantenimiento de vínculos con el Estado de origen ${ }^{489}$ : El TEDH analiza la situación de la menor en su país de origen, destacando sus fuertes vínculos con ese país, en cuyo entorno ha permanecido toda su vida.

3. Test de los obstáculos, examinado en conexión con el test de la integración en el Estado de acogida, hasta ahora inédito en el razonamiento del TEDH: Esta es la parte más trascendental de esta sentencia y la que sienta una doctrina novedosa que abre la vía al reconocimiento del derecho a la RF como contenido material implícito del derecho al respeto de la vida familiar, capaz de desplegar efectos jurídicos reales y no meramente formales. En ella el TEDH, tomando como punto de partida la aplicación del criterio de los obstáculos, hace un uso combinado de todos los test aplicables a la materia, dándoles un enfoque diferente.

\footnotetext{
"Sin embargo, contrariamente a lo que consideró en el asunto Ahmut, el Tribunal señala que en el caso presente existe un obstáculo más grande para que la familia Sen regrese a Turquía. Titulares de un permiso de establecimiento y de otro de residencia por el hecho de haberse casado con una persona autorizada para establecerse en los Países Bajos, los dos primeros demandantes han establecido su vida allí, donde viven legalmente desde hace varios años y donde en 1990 nació su segundo hijo, y en 1994 el tercero. Estos dos niños han vivido siempre en los Países Bajos, en el entorno cultural de este país donde están escolarizados. Por ello, el único vínculo con su país de origen es la nacionalidad y, por tanto, existían obstáculos para trasladar su vida familiar a Turquía. En estas condiciones, la llegada de Sinem a los Países Bajos constituía el medio más adecuado para desarrollar una vida familiar con ésta, ya que, teniendo en cuenta su edad, había que favorecer su integración en la célula familiar de sus padres”490.
}

487 VAN WALSUN destaca también la influencia del juez Martens detrás del pronunciamiento emitido por el TEDH en el apartado 37 de la sentencia Sen. "Comment on the Sen Case..., op. cit., p. 517.

488 Para el TEDH, "al igual que en el asunto Ahmut, la residencia separada de los demandantes es el resultado de la decisión, adoptada deliberadamente por los padres cuando la segunda demandante se reunió con su marido en los Países Bajos y, por tanto, nada impide que los demandantes mantengan el grado de vida familiar que los propios padres eligieron en 1986". Apartado 38 de la sentencia Sen contra Países Bajos.

489 "Después de que su madre se fuera a los Países Bajos en 1986, Sinem — la hija menor — se quedó a cargo de su tía y de su tío. Ha vivido toda su vida en Turquía y tiene, por tanto, vínculos sólidos con el entorno lingüístico y cultural de su país en el que tiene familiares, a saber, dos tíos, dos tías, sus primos y su abuelo que reside habitualmente en este país". Apartado 39, de la STEDH Sen c. Países Bajos.

490 Sen contra Países Bajos, STEDH, apartado 39. 
Frente a la alegación del gobierno demandado que, apoyándose en Gül, consideraba que no existían obstáculos para la reconstitución de la vida familiar en Turquía y que no tenía entidad como tal el nacimiento de una hija en suelo holandés, el TEDH se apoya en Ahmut -obviando deliberadamente las múltiples semejanzas que este caso presentaba con Gül, especialmente hijos nacidos en territorio del Estado parte-. En su argumentación, aplica conjuntamente el test de los obstáculos con el test de la integración, pero concebido aquí de forma inédita, ya que se examinan simultáneamente los vínculos tanto con el Estado de origen, como con el Estado de acogida. Esta segunda faceta del test de la integración había sido conscientemente desconocida por el Tribunal en anteriores sentencias.

La trascendencia del asunto Sen reside no solamente en la aplicación del test de integración en sus dos facetas sino, sobre todo, en el hecho de que el TEDH, a efectos de la justa ponderación entre los intereses afectados, otorga una importancia mucho mayor a los vínculos creados en el país de residencia que a los mantenidos con el Estado de origen. Este cambio en la priorización de las circunstancias inclina la balanza del lado de los intereses individuales, y puede por ello tener repercusiones importantes en el tratamiento jurisprudencial de futuros casos sobre reagrupación familiar que se ventilen ante el TEDH.

La combinación de criterios consolidados —obstáculos e integración en el Estado de origen-, junto a la dotación de nuevos efectos a test ya habituales - integración en el Estado de acogida-, lleva al TEDH a valorar positivamente el carácter legal del asentamiento en Holanda de los padres y, fundamentalmente, el nacimiento allí de dos hijos más de la pareja. Esta última circunstancia es vital para poder concluir la existencia de un obstáculo - más grande que en Ahmut, afirma el TEDH, pero sin embargo idéntico al también existente, pero no valorado en la sentencia Gül-, para el retorno de los demandantes a su país natal. La atención prestada a las condiciones de estos dos menores y a la búsqueda de su bienestar, trae a la mente el criterio del interés superior del menor ${ }^{491}$, -reiterado abundantemente por dos Recomendaciones que analizaremos a continuación-, y ahora por primera vez ostentando un considerable peso en la argumentación del TEDH ${ }^{492}$. La Corte subraya que estos dos niños han crecido y se han criado enteramente en Holanda, careciendo de vínculo alguno con su país de origen, con la salvedad de su nacionalidad. En estas circunstancias la solución más adecuada es permitir la entrada de la niña en el país receptor, en vez de la hasta ahora habitual de exigir a los demandantes el regreso a su país natal a fin de poder disfrutar allí del grado de vida familiar reclamado ante el TEDH. La corta edad de la menor -9 años en el momento del primer rechazo de la solicitud de residencia, y donde nuevamente gravita la influencia de los argumentos de Martens ${ }^{493}$ - es un elemento que juega a favor tanto de su integración en Holanda como en la unidad familiar a la que pertenece, recomendando que ésta sea particularmente urgente.

491 Morano-Foadi y Andreadakis señalan expresamente la sentencia Sen, junto con Tuquabo-Tekle, como pronunciamientos donde se observa la penetración del criterio del interés superior del menor y su bienestar en el case law Estrasburgués relativo a la migración familiar. En su aplicación concreta en el derecho migratorio - y especialmente en materia de protección frente a expulsiones, que es el ámbito preferente de atención de los citados autores- "el TEDH examinará la seriedad de las dificultades que probablemente enfrenten los hijos del demandante en el país al cual éste será expulsado". MORANO-FOADI, Sonia y ANDREADAKIS, Stelios. "The convergence of the European Legal System in the treatment of Third Country Nationals in Europe: the CJEU and ECtHR jurisprudente", Oxford Brookes University, 2010, p. 20. Disponible en http://ssrn.com/abstract=1729139

492 A la misma conclusión llega el Comité de Expertos en Migración Internacional, Refugio y Derecho Penal -Meijers Committee - en "Memorandum on immigration and asylum in the VVD-CDA Coalition Agreement of 30 September 2010", Utrecht, Holanda, p. 4.

493 En idéntico sentido se manifiesta VAN WALSUN, Sarah. “Comment on the Sen Case...”, op. cit., p. 518. 
En comparación con anteriores sentencias, en Sen el TEDH realiza una aplicación del test de los obstáculos notablemente dulcificada. En sentido exactamente opuesto a la aplicación tradicional del test de los obstáculos, en Sen la Corte de Estrasburgo analiza si la reunión de la familia en el Estado de acogida —en vez de en el país de origen de alguno de los demandantes_-, es la vía más adecuada para el desarrollo de la vida familiar. Con ello, si antes el criterio elsewhere desempeñaba un lugar prioritario para negar la violación del derecho a la vida familiar, ahora es usado en un sentido totalmente inverso: Sigue ocupando un lugar preferente en la fundamentación jurídica, pero sirve para sustentar la protección del derecho, pues ahora el nacimiento de otros hijos en el país receptor actúa como obstáculo en contra del retorno al país de origen, y a favor del establecimiento de la vida familiar de todos sus integrantes en Holanda. Este resultado ha sido posible gracias a la consideración de los vínculos de todas las personas afectadas $-\mathrm{y}$ no solamente de los tres demandantes - con el Estado de acogida, inédito hasta ahora.

A partir de aquí, el razonamiento del TEDH desmonta dos de los argumentos más repetidos a lo largo del escaso acervo jurisprudencial referente a la inmigración familiar.

a) El TEDH cambia su concepción respecto a la decisión de emigrar y sus consecuencias sobre las relaciones paternofiliales, perdiendo su anterior carácter fijo e irrevocable. Antes se incluía siempre como un elemento vital del test de la responsabilidad individual, usado para atribuir a los demandantes la responsabilidad de la separación respecto de sus hijos y la consiguiente merma del grado tutelable de su vida familiar. De este modo, la separación de la familia provocada por la emigración se percibía como una decisión deliberada de apartarse definitivamente de los hijos, siendo precisamente ese elemento consciente e intencional el subrayado por el TEDH para la imputación de la responsabilidad a los demandantes. En su momento hicimos hincapié en la frialdad y poco realismo de un razonamiento de este tipo, que obviaba la faceta traumática de la decisión de emigrar dejando atrás a los hijos, circunstancia habitual en múltiples países del tercer mundo ${ }^{494}$, al que ahora el Tribunal otorga un peso muy inferior.

"Es cierto que éstos - los padres - eligieron, después de que Sinem pasara los tres primeros años de su vida con su madre, dejar a su hija mayor en Turquía cuando la segunda demandante se reunió con su marido en los Países Bajos en 1986. Sin embargo, esta circunstancia que tuvo lugar en la infancia de Sinem no puede considerarse como una decisión irrevocable de fijar, para siempre, su lugar de residencia en este país y sólo guardar con ella vínculos esporádicos y distendidos, de renunciar definitivamente a su compañía y de abandonar así toda idea de reunir a su familia" ${ }^{395}$.

Esta nueva percepción, - mucho más realista y, desde luego, más humanitaria-, implica un aligeramiento considerable del test de la responsabilidad individual, en beneficio de los intereses de los particulares, y un alejamiento de la doctrina dictada en Ahmut ${ }^{496}$, en la que el TEDH, de forma confusa, declara apoyarse. De hecho, la insistencia en apoyarse en precedentes jurisprudenciales previos para, sin embargo, apartarse de ellos llegando a conclusiones diferentes, dotan a Sen de una gran ambigüedad ${ }^{497}$.

494 En la misma línea se sitúa la opinión de VAN WALSUM, Sarah. “Comment on the Sen Case....; op. cit., p. 513.

495 Sen c. Países Bajos, apartado 39.

496 VAN WALSUN subraya el hecho de que dos argumentos que habían jugado un rol decisivo en Ahmut —la decisión consciente de los progenitores de dejar a un hijo detrás, así como la existencia de parientes en el país de origen-, son ahora abandonados, pese a la declaración del TEDH de estar apoyándose en la doctrina sentada en Ahmut. "Comment on the Sen Case", op. cit., p. 518.

497 VAN WALSUN incide en esta misma característica: la Corte se conduce con gran ambigüedad pues, aunque alude constantemente a la doctrina sentada en Gül y fundamentalmente en la sentencia Ahmut, sin embargo, llega a conclusiones contradictorias con dicha doctrina. Idem, p. 517. 
b) La Corte subraya la falta de proporcionalidad inherente a las alternativas planteadas al emigrante para hacer valer el derecho a la reunificación familiar, como consecuencia de la aplicación del test de los obstáculos - que desde Abdulaziz hasta Sen, había sido estricta y sistemáticamente empleado por el TEDH para constatar la proporcionalidad de las medidas estatales denegatorias de la RF-:

"Al dejar a los dos primeros demandantes únicamente la elección de abandonar la situación que obtuvieron en los Países Bajos o renunciar a la compañía de su hija mayor, el Estado demandado ignoró el equilibrio justo que debe reinar entre, por un lado, los intereses de los demandantes y, por otro, su propio interés por controlar la inmigración" ${ }^{\prime 498}$.

La influencia de los argumentos del juez Martens - expuestos en sus dos opiniones disidentes a Gül y Ahmut-, planea por toda la sentencia, siendo especialmente clara y contundente en el último fundamento jurídico de la sentencia, reproducido anteriormente casi en su totalidad. Constituye una prueba palpable de la trascendencia de los votos particulares, que muchas veces actúan a modo de guía que anticipa y orienta futuros cambios jurisprudenciales. El TEDH repite casi literalmente la crítica al test de los obstáculos reiteradamente formulada por Martens, como argumento para deducir la desproporcionalidad de la medida estatal denegatoria de la residencia a la hija menor de los señores. La Corte de Estrasburgo concluye que la decisión de las autoridades holandesas es desproporcionada porque, junto a todos los factores ya examinados, al impedir la reunión de los señores Sen con su hija menor, les sitúa ante una difícil opción: renunciar al estatus y la vida establecida en el país de acogida, regresando a su país de origen para desarrollar allí su vida familiar; o bien permanecer en el Estado de acogida pero a costa de renunciar a la compañía de su propia hija.

$\mathrm{Al}$ acoger el argumento del juez Martens, señalando que la disyuntiva que plantea a los demandantes el test de los obstáculos ${ }^{499}$ es desproporcionada, cabría deducir que toda su anterior jurisprudencia $^{500}$ — caracterizada por la aplicación constante y rigurosa de dicho test-, había pecado también de cierta falta de proporcionalidad ${ }^{501}$. A partir de Sen cabe presuponer que ya no podrá mante-

498 Sen c. Países Bajos, apdo. 40.

499 En este sentido, Cvetic despliega un interesante argumento conectando el derecho de un individuo a dejar cualquier país, incluido el propio, con el correlativo derecho del nacional a permanecer en su propio país, como facultad que forma parte del contenido del derecho a la vida privada -por el hecho de que dicha persona no puede ser expulsada de su propio país. El supuesto de hecho que analiza Cvetic son matrimonios mixtos, donde el nacional pretende traerse a su país a la persona extranjera con quien ha contraido o pretender contraer matrimonio. Para Cvetic, el uso del criterio elsewhere, al poner a un nacional ante la difícil elección de permanecer en su país, pero renunciando a su vida familiar, o bien ser obligado a dejar su país para poder ejercer su derecho a la vida familiar y seguir a su esposo/a un país donde éste ultimo tenga vínculos (normalmente el Estado de origen del miembro de la pareja -esposo/a - extranjero) constituye un "choque o colisión encubierta" entre los derechos a la vida privada y a la vida familiar. Es decir, el autor subraya que la consecuencia a la que conduce el uso del criterio elsewhere en casos donde se ventilan asuntos migratorios ante Estrasburgo, conduce a una colisión velada entre dos derechos — vida privada y vida familiar-, ambos igualmente protegidos por el artículo 8 CEDH. CVETIC, GORAN. "Immigration Cases in Strasbourg: The Right to Family Life under Article 8 of the European Convention"; en International and Comparative Law Quarterly, vol, 36, № 3, Julio 1987, p. 650.

500 Señalamos en su momento que la jurisprudencia inicial en materia de reunificación familiar se caracterizaba por la prioridad que en el razonamiento del TEDH ocupaba el test de los obstáculos o criterio elsewhere, considerado rígidamente. En ella la severidad del test de los obstáculos ponía a los demandantes ante la difícil encrucijada de optar entre la compañía de sus familiares o la situación en la que disfrutaba en el país de residencia.

501 La alternativa que planteaba a los demandantes el test de los obstáculos, en su concepción inicial, no minimizaba el impacto sobre la vida familiar del extranjero, pues no exploraba si cabía una solución alternativa menos restrictiva para los titulares del derecho, contraviniendo de este modo el subprincipio de necesidad o intervención mínima implícito a la exigencia de proporcionalidad en sentido lato. Además, el criterio elsewhere era en sí mismo desproporcionado en sentido estricto, pues conduía al vaciamiento del derecho. 
nerse que el Estado parte sólo está obligado a otorgar la residencia a los familiares del inmigrante a efectos de facilitar la reunificación familiar en su territorio, cuando existan obstáculos insuperables que impidan el retorno del inmigrante a su país natal o a un tercer país en el que desarrollar su vida familiar, lo que supone un enorme paso adelante para la configuración jurisprudencial del derecho a la RF como derecho implícito al CEDH. El test de los obstáculos, cuyos antecedentes se sitúan en la doctrina de Comisión y que había sido aplicado sin fisuras durante toda la primera década en que el TEDH lidió con asuntos migratorios, se viene abajo.

Con ello, en la sentencia Sen el TEDH introduce una doctrina novedosa y radicalmente opuesta a la sentada hasta el momento, sin hacer explícito ni la novedad del planteamiento ni el alejamiento de sus propios precedentes. Muy al contrario, el TEDH se apoya expresamente en Gül y fundamentalmente en Ahmut, para realizar un giro jurisprudencial de gran calibre respecto de la doctrina vertida en dichas sentencias, de ahí que Sen haya sido considerado un pronunciamiento muy ambiguo $^{502}$. El resultado final es que en Sen el TEDH desmonta casi por completo su anterior doctrina jurisprudencial relativa a la RF, al declarar la desproporcionalidad de la disyuntiva a la que conduce el test de los obstáculos, tal y como era previamente concebido, constatando por primera vez la violación del derecho al respeto a la vida familiar. Estas consideraciones suponen que, en el justo balance entre los intereses concurrentes, los intereses individuales ya no ocupan una posición de inevitable desventaja frente a la intensidad del interés estatal de controlar la inmigración —interés este último que venía respaldado por el reconocimiento de cierto margen de apreciación a los Estados. Y ello porque, entre otras razones, a partir de Sen la reunificación familiar ya no se podrá analizar (...) solamente desde el punto de vista de la inmigración ${ }^{503}$. Lo que permite tomar en consideración elementos trascendentales en el razonamiento jurisprudencial, entre ellos el interés supremo del menor.

En Sen es palpable la flexibilización y humanización de todos los criterios jurisprudenciales aplicables por el TEDH para evaluar los supuestos de RF en el marco del artículo 8 CEDH: el test de los obstáculos fundamentalmente, pero también resultan notablemente aligerados el test de la responsabilidad individual y de la integración en el Estado de origen. Hasta esta sentencia, dichos criterios habían ido evolucionando en la línea contraria, de progresivo endurecimiento. Además, en este pronunciamiento el TEDH introduce un nuevo test convencional, examinando el nivel de integración o la creación de vínculos en el Estado de acogida por parte de todas las personas implicadas, y no únicamente de los demandantes. En Sen jugó un papel decisivo en la consideración del TEDH los dos hijos nacidos y crecidos en Holanda, quienes no ostentaban la cualidad de demandantes. A tenor de esta consideración, cabe concluir que los vínculos con el país receptor serán especialmente merecedores de protección cuando en el mismo hayan nacido otros hijos del reagrupante extranjero - además de los que éste dejó en su país natal-. Si la vida de estos menores se ha desarrollado enteramente en el país de residencia, careciendo de referentes con el Estado de su propia nacionalidad, es muy probable que el test de los obstáculos juegue a favor del inmigrante, estimándose que el desarrollo de la vida familiar en el país receptor constituye la opción más adecuada.

Especialmente destacable resulta la inversión del papel desarrollado por el test de los obstáculos. Antes su concepción rígida vaciaba de contenido la RF, situando al extranjero en una posición de desventaja frente a los intereses estatales. En su nueva dimensión, el test de los obstáculos se analiza conjuntamente con los vínculos desarrollados en el Estado de acogida, de modo tal que

502 VAN WALSUM, Sarah. "Comment on the Sen Case. How Wide is the Margin of Appreciation Regarding the Admission of Children for Purposes of Family Reunification”, op. cit., p. 512.

503 Sen c. Países Bajos, STEDH apartado 36. 
si el TEDH constata la existencia de vínculos de gran fortaleza con el país de residencia $-\mathrm{y}$, a juzgar por el presente caso, los vínculos de mayor entidad serían el nacimiento en dicho territorio de hijos de los inmigrantes legalmente asentados-, dicha conexión desemboca en erigir tales vínculos como obstáculos para la reconstitución de la familia en el país natal, posibilitando así la reagrupación familiar en el Estado de acogida, objetivo perseguido por los demandantes que se amparan en el artículo $8 \mathrm{CEDH}$.

La trascendencia de este razonamiento reside en que de Sen cabe extraer por primera vez la obligación positiva ${ }^{504}$, deducible del artículo $8 \mathrm{CEDH}$, de que el Estado parte receptor admita las pretensiones de entrada y residencia a favor de los hijos menores de los inmigrantes legalmente establecidos en su territorio - aquellos a quienes el reagrupante dejó en su país natal al emigrar-, predicable al menos en aquellos supuestos donde existan también hijos menores de edad nacidos y criados enteramente en el país de residencia. En consecuencia, por primera vez la protección de rebote que el derecho al respeto de la vida familiar despliega sobre la inmigración familiar se traduce en un derecho con contenido material real y efectivo que se activaría, como mínimo, en los supuestos de RF en sentido estricto, donde los inmigrantes legalmente asentados cuenten además con hijos nacidos en el país de residencia y deseen reunirse con los hijos menores de edad que dejaron en su momento en un tercer país antes de emigrar. Curiosamente, esta circunstancia parece situar a la Corte de Estrasburgo en una posición de promotor de la natalidad en el Estado de acogida, pues en tales supuestos parecen elevarse las posibilidades de concesión de la reunificación familiar, chocando con las alegaciones del Estado demandado, quien se amparaba en la alta densidad poblacional, para justificar la implementación de políticas migratorias restrictivas. Se trata de una configuración muy limitada de la $\mathrm{RF}^{505}$ pero, con todo, constituye el primer caso de protección de tal derecho ante Estrasburgo.

Hay algunos elementos llamativos en el asunto Sen que conviene destacar. En primer lugar, la sentencia Sen, pese al calado de sus argumentos, se emite por unanimidad, circunstancia que en esta materia no había tenido lugar desde Abdulaziz. La unanimidad es especialmente sorprendente si tenemos en cuenta que el giro jurisprudencial que en ella se realiza, podría haber precipitado las discrepancias entre los jueces integrantes de la Sala. Las causas que explican esta unanimidad son difíciles de despejar, dado que no se explicitan a lo largo de la fundamentación jurídica. A modo de mera hipótesis, es posible sugerir que quizá en ello haya influido la reflexión de los jueces del Tribunal, conscientes de la rigidez de su anterior postura, que había convertido en inviable en la práctica la protección del derecho a la reunificación familiar. Pero, sobre todo, es posible inferir el efecto ejercido en el viraje jurisprudencial por un elemento ajeno a la sentencia, pero cuya gestación próxima en el tiempo a Sen, es reveladora de su influencia. Se trata de la Recomendación del Comité de Ministros a los Estados Miembros relativa al estatus legal de las personas admitidas por reunifi-

504 A la misma interpretación llega CHOLEWINSKI, Ryszard, reconociendo la mayor valentía mostrada por el TEDH en la sentencia Sen, señalando que "los Estados partes están constreñidos bajo una obligación positiva de admitir a un miembro de la familia en una situación donde no pueda esperarse razonablemente que la unidad familiar sea reubicada al país de origen". "Family Reunification as a Constitutional Right?"; APAD, Joanna (ed.). Justice and Home Affairs in the EU. Liberty and Security Issues alter Enlargement. Edward Elgar Publishing, Ceps, CheltenhamNorthampton, 2004, p. 263, traducción propia.

505 Espina define el alcance del derecho a la RF derivado del art. 8 CEDH en la interpretación efectuada por el TEDH como "extremadamente limitado". LA ESPINA, Encarnación. "Singularidades y retos normativos en el control genético de la inmigración familiar hacia España, Italia y Portugal”, en Cuadernos Electrónicos de Filosofía del Derecho, nº 21, 2010, p. 115. 
cación familiar, que ya fue objeto de análisis. Sea como fuere, se ha apuntado que la unanimidad se gestó al precio de sacrificar la claridad de este pronunciamiento ${ }^{506}$.

A la sentencia Sen se le formuló una opinión concordante por parte del juez Türmen, quien votó en el mismo sentido que sus colegas, pero se apartó de ellos respecto del razonamiento adoptado. Türmen lamenta que en este caso el Tribunal sólo haya seguido parcialmente el argumento del juez Martens. A juicio de Türmen, el fallo se ha basado fundamentalmente en una circunstancia de hecho: el nacimiento de los dos hijos menores del matrimonio en Holanda, donde han vivido siempre, de modo que el único vínculo que les une con el país de origen es la nacionalidad. A su juicio, la reunificación familiar debería concederse en los casos en que un padre y una madre han conseguido establecerse de forma permanente en un país y desean que se reúnan con ellos los hijos que, provisionalmente, dejaron en su país de origen, es decir, con independencia de que haya o no hijos nacidos en el Estado de acogida. Si en Sen no se hubiera producido la circunstancia de la existencia de estos dos hijos, Türman presume que el TEDH, siguiendo a Ahmut, no habría apreciado la existencia de violación del artículo ${ }^{507}$. Considera inadmisibles tales limitaciones al reagrupamiento familiar, pues testimonian un espíritu restrictivo incompatible con el sentido del Convenio y la noción de derechos humanos.

Cabe finalmente destacar que, pese a que se trata del primer asunto en el que el TEDH estima la existencia de violación del derecho a la vida familiar ante la negativa del Estado demandado de permitir la reunificación familiar de la hija de los señores Sen, sin embargo sigue sin analizarse el apartado segundo del artículo 8. Este análisis se había obviado durante la anterior jurisprudencia, pero quizá podría justificarse porque en ella el TEDH no había apreciado la violación del derecho. Esta circunstancia es especialmente llamativa si se tiene en cuenta que, en casos similares incluidos en el contexto de las obligaciones positivas derivadas del artículo 8.1 - por ejemplo en materia de protección medioambiental y contra el ruido-, el TEDH tras constatar la violación derecho, continúa su análisis evaluando la posible justificación de la medida estatal limitativa conforme a los parámetros establecidos en el párrafo segundo de dicho artículo.

En definitiva, la sentencia Sen contra Holanda marca un punto de inflexión en la jurisprudencia relativa a la vida familiar de los extranjeros, en su faceta específica de protección de la migración familiar. Con este pronunciamiento, el Tribunal de Estrasburgo sienta las bases para la consolidación del derecho a la reagrupación familiar en sentido estricto como ámbito material implícito al derecho al respeto de la vida familiar, que hasta el momento poseía un carácter meramente formal. Se trata del primer pronunciamiento donde el TEDH dota de efectividad jurídica al derecho a la reunificación familiar, apartándose de su anterior línea marcada por la autocontención judicial y el repliegue ante la solidez del interés estatal de controlar la inmigración. Sen marca el inicio de una línea de mo-

506 VAN WALSUN subraya como ejemplos especialmente ambiguos las afirmaciones vertidas por el TEDH en los apartados 36 a 40, donde el Tribunal incurre en contradicciones y, pese a apartarse de su razonamiento en previos pronunciamientos, afirma expresamente apoyarse en ellos. “Comment on the Sen Case..., op. cit., p. 517.

507 En contra de esta opinión del juez Türmen se declara VAN WALSUN. La autora niega que Sen no suponga un alejamiento significativo de la línea jurisprudencial establecida en Gül y en Ahmul. "Si este fuera el caso, cómo explicar que virtualmente todos los puntos críticos del juez Martens relativos a Gül y Ahmut hayan sido integrados en la decisión del Tribunal Europeo en Sen", se cuestiona críticamente la citada autora. Posteriormente añade que, tras un examen cuidadoso de los hechos de Sen, resulta bastante improbable que la situación de los dos niños nacidos y criados en Holanda explique, por sí misma, por qué el TEDH decide de forma distinta que en Ahmut. A su juicio, el nacimiento de estos dos niños en Holanda no es relevante en el razonamiento del TEDH, estimando que para Estrasburgo tales circunstancias son consideradas "como uno de los indicadores del firme grado de asentamiento de los padres en Holanda, y no como el único obstáculo que impide la reunificación en Turquía”. "Comment on the Sen Case", op. cit., p. 517. 
desta protección de la migración familiar, pero de clara tendencia expansiva y progresiva en pos del asentamiento de un derecho a la RF de los extranjeros en el marco del $\mathrm{CEDH}$, aunque excluyendo de su ámbito de protección los supuestos de formación familiar.

Con Sen el TEDH aplica el principio del efecto útil sobre el derecho consagrado en el artículo 8 para potenciar la cobertura jurídica que este derecho ofrece a la reagrupación familiar de los extranjeros - entendida únicamente en su sentido estricto-, en el ámbito del CEDH. Por esta vía, cabría presuponer que el artículo 8 puede erigirse en límite a la soberanía estatal de los países contratantes en el establecimiento de sus políticas relativas a la reagrupación familiar, exigiendo la admisión de los hijos menores de edad del extranjero legalmente asentado dentro del territorio del Estado parte. Resta por ver si la condición de que el reagrupante posea también hijos nacidos dentro del país receptor es una circunstancia aislada de la sentencia Sen, o, por el contrario, se erige en requisito fundamental para atraer al país de residencia a los hijos menores que quedaron en el país de origen. Sea como fuere, por primera vez de una sentencia del TEDH pueden extraerse condicionantes concretos de las políticas migratorias implementadas por los Estados parte del Consejo de Europa en el ámbito de la RF, cuya inobservancia puede activar la protección real y efectiva de los extranjeros afectados ante el TEDH. El examen de su trascendencia concreta en futuros desarrollos jurisprudenciales, exige continuar con el análisis del case-law de Estrasburgo.

\section{RECOMENDACIÓN DEL COMITÉ DE MINISTROS SOBRE EL ESTATUS LEGAL DE LAS PERSONAS ADMITIDAS POR MOTIVOS DE RF ${ }^{508}$}

Próximas en el tiempo a la sentencia Sen, tanto el Comité de Ministros como, posteriormente, la Asamblea Parlamentaria del Consejo de Europa emitieron dos importantes Recomendaciones que traslucen el cambio de perspectiva que, en torno a la concepción de la RF, quedó patente con la sentencia Sen. A su estudio dedicaremos los dos próximos epígrafes.

El 26 de marzo de 2002 el Comité de Ministros —órgano de decisión política del Consejo de Estado- adoptó una Recomendación, dirigida a los Estados miembros, relativa al estatus legal de las personas admitidas por motivos de reunificación familiar. En ella sugiere a los gobiernos el seguimiento de una serie de principios comunes para su aplicación, tanto a nivel legislativo interno como de las prácticas administrativas, carentes de eficacia jurídica vinculante. Dichos principios pretenden constituir un tope mínimo que permita un cierto nivel de armonización entre las políticas de reagrupación familiar aplicables en los distintos Estados parte, sin perjuicio de la posibilidad que tienen éstos de incrementar los niveles de protección estableciendo principios más beneficiosos para el inmigrante ${ }^{509}$.

La Recomendación alude expresamente al derecho al respeto de la vida privada y familiar consagrado por el artículo $8 \mathrm{CEDH}$ - dando por sentado el encaje de la reunificación familiar en su seno-, en consonancia con el case law desarrollado al respecto por el TEDH. Esta Recomendación pone en evidencia la asunción institucional de la relevancia de la vida familiar como enclave jurídico de la protección de la migración familiar en el ámbito del Convenio de Roma. Así mismo, toma en

508 Recommendation (2002) 4 of the Committee of Mnisters to Member States on the Legal Status of Persons Admitted for Family Reunification. Adopted by the Committee of Ministers on 26 March 2002 at the 790th meeting of the Ministers' Deputies. Disponible en http://wcd.coe.int/wcd/ViewDoc.jsp?id=271943\&Site=CM

509 La disposición IX, bajo la rúbrica de "Final clauses", señala literalmente "this recommendation is without prejudice to the option open to a member state to grant a more favorable legal status to family members". 
cuenta el principio de no discriminación con respecto a los derechos convencionales, reconocido en el artículo $14 \mathrm{CEDH}$ - que en la primera jurisprudencia solía alegarse conjuntamente con la violación del artículo 8-. De la Recomendación cabe deducir dos pilares fundamentales que convergen, junto al respeto a la vida familiar, como fundamento del derecho a la reunificación de los extranjeros: de un lado, la salvaguardia de la unidad familiar como derecho universalmente consagrado en la Declaración Universal de los derechos humanos; de otro, la defensa del interés superior y bienestar del menor, y su particular necesidad de protección y asistencia.

La Recomendación está imbuida por una saludable dosis de realismo y humanismo. Se percibe en ella un espíritu abierto y humanitario - similar al que late por detrás del viraje jurisprudencial que, en este ámbito, el TEDH emprenderá con la sentencia Sen, fallada apenas tres meses antes de la adopción de la presente Recomendación-, por lo que no resulta descabellado apuntar que los órganos institucionales integrantes del Consejo de Europa eran conscientes de la importancia de la migración familiar y la necesidad de apostar por su salvaguardia dentro de los Estados parte de dicha organización regional. En consecuencia, esta Recomendación bien puede tenerse, sino como detonante del giro jurisprudencial que en materia de migración familiar la Corte de Estrasburgo acababa de emprender con la sentencia Sen, al menos como notable símbolo del cambio de conciencia que, en torno a este ámbito, estaba teniendo lugar en el seno del Consejo de Europa.

La Recomendación sobre el estatus legal de las personas admitidas por motivos de RF se rinde a la evidencia fáctica de que la migración familiar constituye una de las mayores fuentes de flujos migratorios en la mayoría de los Estados Europeos, así como un importante elemento auxiliar para la integración de los nuevos inmigrantes en la sociedad de acogida ${ }^{510}$. De ahí la conveniencia de que su régimen jurídico en los distintos Estados miembros - como "parte integral de una coherente política de inmigración e integración”-, esté guiado por principios comunes.

En el análisis de este documento, nos detendremos tan sólo en aquellos aspectos más trascendentes, bien por introducir novedades o porque se apartan de la doctrina sostenida por el TEDH en las sentencias sobre RF hasta el momento analizadas.

1. Ámbito de aplicación: "Para los efectos de esta recomendación, el término 'miembros de la familia' cubre a todas las personas admitidas en el territorio de un Estado miembro para residir con un nacional o un extranjero residente legal, a fin de formar o preservar la unidad familiar" 511 .

Si tomamos como punto de referencia comparativo el ámbito de protección de la migración familiar derivado del case law emitido hasta el momento por el $\mathrm{TEDH}^{512}$, de este primer inciso de la Recomendación se desprende una notable ampliación de la cobertura ofrecida por la RF en el

510 Sobre este punto, en los Considerandos de la Recomendación se establece literalmente: "Bearing in mind that family reunification is one of the major sources of immigration in most European states and that the residence status and other rights granted to the admitted family members are important elements in assisting the integration of the new migrants in the host society".

511 Transcripción literal del apartado I de la Recomendación. Traducción propia.

512 Como vimos en su momento, hasta la fecha de esta Recomendación, del case law se desprendía que el TEDH, al analizar la aplicabilidad del artículo 8.1, manejaba un concepto amplio de familia, pero al que imponía como condicionante la preexistencia de la vida familiar. Dicha preexistencia se traducía en la exigencia de que los lazos familiares hubieran sido establecidos con anterioridad a la medida estatal que causaba su injerencia. En el ámbito específico de la reunificación familiar, suponía que la protección se activaría solamente para aquellos familiares a los que el inmigrante hubiera dejado tras de sí en su Estado de origen. Aunque si bien es cierto que el TEDH, al examinar el concepto de familia, interpretaba de forma flexible el requisito de la preexistencia, sin embargo, en materia de reagrupación familiar, este requisito actuaba siempre como tope para la protección, incluso en aquellos supuestos más favorables (véase la distinción apuntada en el apartado 68 de la sentencia Abdulaziz, así como la sentencia Sen). 
ámbito de Estrasburgo. Y ello porque, según esta disposición, se protegería tanto la continuación de una vida familiar ya existente - "preservar" - , como, lo que es mucho más relevante, su iniciación o creación ex novo - “formar”- La inclusión del término formar supone la posibilidad de una importante vía de extensión de la vida familiar objeto de protección y, por tanto, de la tutela que puede ofrecer a los inmigrantes el derecho a la reunificación familiar. De ser seguida esta recomendación, implicaría que la RF objeto de protección ante el TEDH, sería tanto la RF en sentido estricto - la única potencialmente tutelada ante Estrasburgo hasta el momento de la aprobación de la presente Recomendación, y con un estatus muy precario-, como la migración matrimonial o formación de familias a través de la migración - que fue expresamente rechazada en Abdulaziz, pese a que esta sentencia extendió a la "vida familiar proyectada" la aplicabilidad del concepto de vida familiar-.

Esta ampliación, puesta en conexión con el case law de Estrasburgo, supondría que la Recomendación podría superar la distinción apuntada en Abdulaziz, en la que se apoyara reiteradamente el Juez Martens para inferir y proponer la protección del derecho a la reunificación familiar como regla general aplicable al supuesto típico de inmigrantes que dejaron atrás a los miembros de su familia, o RF en sentido estricto. Ahora la regla general se amplificaría para amparar cualquier tipo de vida familiar, con independencia del momento cronológico de su constitución, dando cabida tanto a la vida familiar preexistente a la adquisición de un estatus legal en el Estado de acogida, como a la que se hubiera iniciado tras dicha adquisición. El Comité de Ministros aconseja pues a los Estados parte no restringir la RF a los supuestos de lazos familiares preexistentes, amparando bajo el paraguas protector del derecho al respeto de la vida familiar de los extranjeros, tanto la RF en sentido estricto, como la formación familiar.

De otro lado, la recomendación del Comité de Ministros establece la mayoría de edad a los dieciocho años, salvo que, conforme al derecho aplicable al joven, se alcance antes. Se estará a lo que establezca la ley personal del menor, a efectos exclusivos de respetar una mayoría de edad más temprana. Esta excepcional consideración al derecho personal del menor - cuando es siempre el derecho interno del Estado miembro el aplicable-, es unidireccional: sólo se tendrá en cuenta cuando la ley personal del menor establezca la mayoría de edad antes de los dieciocho, no cuando exija una edad superior.

2. Estatus legal de los miembros de la familia: El Comité de Ministros aconseja a los Estados miembros que, tras admitir a los familiares del residente por motivos de RF, les conceda un estatus legal que encaje en una de estas tres modalidades: un permiso de establecimiento; un permiso de residencia renovable; o bien un permiso de residencia dotado de la misma duración que aquel que posea el principal. Si los destinatarios son niños, en la determinación de la duración del permiso de residencia, los Estados deberán priorizar el interés superior y el bienestar del menor.

3. Autonomía del estatus legal de los miembros de la familia del residente: El Comité de Ministros aboga por que los familiares reagrupables puedan obtener un estatus legal autónomo - esto es, concederles un permiso de carácter independiente del que posee el reagrupante-, tras un período temporal general de cuatro años de residencia legal. En caso de divorcio, separación o muerte del sponsor, debería ser suficiente un período de residencia legal de un año para que los familiares del residente pudieran solicitar un permiso autónomo, en cuya resolución los Estados han considerar de forma prioritaria el interés del menor.

4. Protección efectiva contra la expulsión de los miembros de la familia: El Comité de Ministros establece los criterios que los Estados deberían tener en cuenta cuando decidan retirar el permiso de residencia, denegar su renovación o expulsar a los familiares admitidos por reagrupación 
familiar. Estos criterios-a título no exhaustivo-, son los siguientes: el lugar de nacimiento de la persona afectada, su edad al entrar en el territorio del Estado parte, la duración de su residencia, sus relaciones familiares, la existencia de lazos familiares en el país de origen, así como la solidez de los vínculos sociales y culturales que mantiene con dicho país. En su enumeración llama la atención la preeminencia del criterio de integración con el país de origen, sin mencionar el nivel de arraigo alcanzado en el Estado de acogida, como hiciera en su primera jurisprudencia el TEDH.

Por la importancia de este tema, conviene detenernos en su análisis, contemplándolo desde una perspectiva más amplia. La presente Recomendación, centrada en el estatus legal adquirido por los familiares reagrupables, a efectos de su posible expulsión tan sólo contempla la protección de los parientes admitidos al Estado parte en virtud de la RF. Sin embargo, con carácter general, la expulsión de extranjeros asentados en el territorio de los Estados miembros está contemplada en la Recomendación 1504 relativa a la no expulsión de inmigrantes de larga duración ${ }^{513}$, que la Asamblea Parlamentaria del Consejo de Europa había aprobado un año antes. En esta última, la Asamblea Parlamentaria sugería a los Estados miembros no expulsar a los extranjeros residentes legales de larga duración que conservaban su nacionalidad original, haciendo hincapié en los denominados inmigrantes de segunda generación, esto es, los extranjeros nacidos o criados en el Estado de acogida, para quienes el país de sus padres es a menudo un territorio desconocido.

Para la definición de inmigrantes de larga duración debemos remitirnos a un texto cronológicamente anterior: la Recomendación (2000) 15 del Comité de Ministros relativa a la seguridad de la residencia de los inmigrantes de larga duración ${ }^{514}$, conforme a la cual, por tal ha de entenderse a todo extranjero que haya residido legal y habitualmente en el territorio de un Estado parte durante un período de al menos cinco años y un máximo de diez años, excluyendo a quienes hubiesen pasado dicho período en calidad de estudiantes.

La adopción de procedimientos de expulsión, habitualmente dictada sobre la base de motivos de orden público, es considerada por la Asamblea Parlamentaria en la Recomendación 1504 de 2001 ya citada como una medida estatal desproporcionada y discriminatoria ${ }^{515}$ cuando se dirige tanto contra inmigrantes de segunda generación como a inmigrantes de larga duración, y como un doble castigo si se aplica a personas que ya hayan cumplido sentencia en prisión. Este aspecto es de gran relevancia, habida cuenta del abundante acervo jurisprudencial a que ha dado lugar ante el TEDH la protección frente a expulsiones, encajada como una obligación estatal negativa derivada del derecho al respeto a la vida familiar. Sobre este punto, resulta llamativo que en el apartado quinto de esta recomendación, la Asamblea Parlamentaria lamentase que el TEDH no haya adoptado una postura clara respecto a la expulsión de inmigrantes de larga duración ${ }^{516}$, lo que redunda en insegu-

513 Recommendation 1504 (2001) de 14 de marzo de 2001. Non-expulsion of long-term immigrants. Text adopted by the Standing Committee, acting on behalf of the Assembly, on 14 March 2001.

514 Recommendation (2000) 15 of the Committee of Ministres concerning the security of residence of long-term migrants. Fue adoptada el 13 de septiembre de 2000. La definición de inmigrante de larga duración está contenida en el punto i) del apartado a) de la cláusula 1.

515 En el Apartado tercero de la Recomendación 1504 (2001), la Asamblea Parlamentaria señala: "the application of expulsion measures against them seems both disproportionate and discriminatory: disproportionate because it has lifelong consequences for the person concerned, often entailing separation from his/her family and enforced uprooting from his/her environment, and discriminatory because the state cannot use this procedure against its own nationals who have committed the same breach of the law".

516 "The Assembly notes with concern that legal rules on expulsion without a time frame are being misused and regrets the fact that the European Court of Human Rights has not adopted any clear stance on the expulsion of long-term immigrants. This deprives them of the certainty of the law to which they are entitled in a law-based state", apartado quinto de la Recomendación 1504 (2001). 
ridad jurídica. Esta circunstancia resulta agravada por el abuso que los Estados hacen de la figura de la expulsión, sin enmarcarla en unas coordenadas temporales a partir de las cuales no pueda ser ejercida. Así mismo, la Asamblea Parlamentaria señalaba con rotundidad que, bajo ninguna circunstancia, la expulsión no debería ser aplicada a gente nacida o criada en el Estado de acogida o a sus hijos menores de edad ${ }^{517}$. En cualquier caso, la expulsión debería dictarse sólo en circunstancias verdaderamente excepcionales ${ }^{518}$, y cuando se hubiese probado que la persona afectada representa un peligro real para el Estado ${ }^{519}$. Finalmente, recomendaba a los Estados asegurar a las personas sujetas a procedimientos de expulsión el derecho a un juicio justo asistido por abogado y, dadas sus consecuencias a menudo irreversibles, el derecho a un recurso dotado de efectos suspensivos. Todas estas orientaciones serían también aplicables a los familiares reagrupables.

5. Derechos de los miembros de la familia admitidos por causa de RF: El último bloque de la Recomendación (2002) 4 está dedicado a aquellos derechos que, a juicio del Comité de Ministros, los Estados parte habrían de otorgar a los parientes admitidos por motivos de reagrupación familiar. Este órgano aconseja a los Estados parte ofrecer a los familiares un tratamiento igual al que disfrute el reagrupante, respecto a las condiciones de acceso al trabajo (V.1) y derechos sociales - específicamente en el ámbito sanitario y de la seguridad social (V.2)—.

En materia de acceso al trabajo, se introduce una de las precisiones más importantes de la Recomendación ${ }^{520}$. Tras señalar que los familiares deben disfrutar de un tratamiento igualitario al concedido al reagrupante en lo relativo a las condiciones de acceso al empleo en el país de acogida (V.1), el Comité de Ministros sugiere que el período de espera introducido por los Estados a fin de preservar el mercado de trabajo autóctono no debe exceder los dos años, tras los cuales los familiares de residentes de corta duración ${ }^{521}$ deberían ser admitidos por motivos de RF (V.1). Esta importante consideración - establecimiento de un período máximo de dos años de residencia legal, tras los cuales el inmigrante de corta duración podría reunirse con sus familiares en el territorio del Estado parte-, se introduce casi de forma perpendicular y, por la importancia de la misma de cara a las condiciones de ejercicio de la RF y del estatus de los familiares reagrupables, su encaje hubiera resultado más adecuado en la primera parte de la Recomendación.

Así mismo, se recomienda a los Estados establecer el mismo régimen que el aplicable a los nacionales respecto a las condiciones laborales y la participación en sindicatos (V.3), en materia educativa -incluyendo la educación universitaria y la educación profesional (V.4) - , y respecto a las libertades de reunión, asociación y expresión (V.4). Los familiares del residente deberían también gozar del derecho a la libertad de movimiento en el territorio del Estado parte (VI) y, tras cinco años de residencia legal, acceder al derecho de sufragio activo y pasivo en las elecciones locales, siempre que cumplan con los mismos requisitos legales exigidos al efecto a los nacionales (VII).

517 Apartado 7 de la Recomendación 1504(2001). En el mismo sentido, la recomendación final h). Traducción propia. 518 La recomendación final g) explicitaba este extremo. Serían circunstancias realmente excepcionales las que permitirían proceder a la expulsión de un inmigrante de larga duración, tan sólo los delitos particularmente graves contra la seguridad del Estado, y cuando la persona ya hubiera sido declarada culpable.

519 Ídem, cláusula 10.

520 El apartado V.1 in fine de la Recomendación (2002) 4, señala que "waiting periods for family members of short-term residents introduced by member states due to labour market considerations should not exceed two years".

$521 \mathrm{El}$ concepto habría que deducirlo, a sensu contrario, del establecido para los inmigrantes de larga duración en la Recommendation (2000) 15 of the Committee of Ministres concerning the security of residence of long-term migrants, de 13 de septiembre de 2000. Conforme al mismo, serían considerados inmigrantes de corta duración aquellos extranjeros con menos de cinco años de residencia habitual y legal en el territorio del Estado parte. 
En suma, el conjunto de sugerencias del Comité de Ministros, ofrece un tratamiento bastante generoso para los familiares reagrupados, a fin de favorecer su integración en el Estado de acogida. En cualquier caso, cabría afirmar que el cambio jurisprudencial que el TEDH efectuaría a partir de la sentencia de Sen, ha tenido una buena acogida en los restantes órganos integrantes del Consejo de Europa. La Recomendación profundiza en la línea de flexibilidad en el tratamiento de la reagrupación familiar que se había iniciado con el asunto Sen: Amplía el concepto de vida familiar para amparar tanto la RF en sentido estricto como la migración matrimonial; Así mismo propone un período de espera máximo de dos años - único aspecto que peca de prudencia de la Recomendación-, tras los cuales el residente legal podría solicitar la reagrupación con sus familiares, quienes además deberían poder obtener un permiso independiente tras cuatro años de residencia legal en el territorio del Estado parte.

Pero la importancia de la Recomendación, dejando a un lado su más que limitada eficacia jurídica sobre los Estados parte, reside en que requiere unanimidad en su votación ${ }^{522}$. Esta circunstancia revela, tras su adopción, la existencia de un notable grado de consenso entre los ministros de asuntos exteriores - o sus representantes diplomáticos permanentes- de los Estados parte, sobre lo que debe entenderse como deseable en la regulación de estas materias en el ámbito del Consejo de Europa, ante un tema que representa un importante reto para los países europeos de acogida y que, por ello, suele ser fuente de discrepancias. De otro lado, dado que el Comité de Ministros es el órgano encargado de vigilar la ejecución de las sentencias del Tribunal de Estrasburgo, cabe suponer cierto grado de adecuación entre las recomendaciones emitidas por el Comité de Ministros y la propia jurisprudencia del TEDH. La adopción de esta recomendación suministra cierto fundamento para una línea jurisprudencial más progresista y creativa por parte de la Corte de Estrasburgo, basada en la aplicación del principio del efecto útil, a fin de favorecer y ablandar los requisitos exigibles para el ejercicio de la migración familiar.

Justo dos años después de esta Recomendación, la Asamblea Parlamentaria adoptó otra sobre el mismo tema, con la rúbrica Movilidad humana y derecho a la reunión familiar ${ }^{52}$, que adopta un punto de vista más general que la Recomendación del Comité de Ministros, pues contempla la totalidad de facetas del derecho de reunificación familiar, y no únicamente la protección de los familiares extranjeros reagrupados.

\section{RECOMENDACIÓN 1686 (2004) DE LA ASAMBLEA PARLAMENTARIA. MOVILIDAD HUMANA Y DERECHO A LA REUNIFICACIÓN FAMILIAR}

En esta ocasión, la Asamblea Parlamentaria del Consejo de Europa se dirige al Comité de Ministros formulándole tres sugerencias principales:

1. Que incremente su labor de vigilancia en torno al acatamiento por parte de los Estados miembros de los instrumentos legales internacionales relativos a la reunificación familiar, en particular del cumplimiento del Convenio de Roma y de las recomendaciones promulgadas en este ámbito por el Comité de Ministros ${ }^{524}$. Dado que en el CEDH no existe ningún derecho que como tal consagre el derecho a la RF, se hace evidente nuevamente que la reagrupación familiar es un derecho asumido a nivel institucional en el ámbito del Consejo de Europa, como derecho implícito al CEDH.

522 DÍEZ DE VELASCO, M. Las organizaciones internacionales, op. cit., p. 392.

523 Recomendación 1686 (2004), on 23 November 2004. Human mobility and the right to family reunion.

524 Idem, punto i) del apartado 11. 
2. Que formule propuestas para la armonización e implementación de políticas relativas a la reagrupación familiar en los Estados miembros, estableciendo una definición común de la unidad familiar y de los requisitos exigibles, basándose para ello en las indicaciones que le formula la Asamblea Parlamentaria en el presente documento ${ }^{525}$.

3. Que, en el tiempo intermedio, redacte una Recomendación a los Estados miembros que contenga las sugerencias de la Asamblea, como es propio de la naturaleza no ejecutiva de este órgano. El tenor literal parece apuntar a que esta labor debe ser afrontada por el Comité de Ministros con cierta premura ${ }^{526}$.

En base a este último punto, estaríamos ante una Recomendación de carácter indirecto, emitida en un intervalo temporal escaso - no han transcurrido dos años desde la Recomendación del Comité de Ministros relativa al status legal de las personas admitidas por motivos de reunificación familiar-, y donde se le plantea una labor urgente al Comité de Ministros. Las causas que pueden estar detrás de esta premura temporal se apuntan tímidamente en la propia Recomendación y, de forma más explícita, en el memorándum explicativo redactado por Mrs. Zapfl-Helbling ${ }^{527}$, que acompaña al informe previo emitido por el Comité de Migración, Refugio y Población. Detrás de esta Recomendación subyace la preocupación de la Asamblea Parlamentaria ante el fenómeno cada vez más habitual en ciertos Estados miembros — aquellos que sufren mayor presión migratoria-, de revisar sus políticas migratorias en un sentido crecientemente restrictivo, limitando la migración de carácter laboral y recortando las concesiones de asilo. Las consecuencias de esta tendencia, que ha dado lugar a la denominada "Europa fortaleza", son especialmente visibles en el endurecimiento de los requisitos exigidos para el ejercicio de la reunificación familiar que, sin embargo, constituye a veces la única vía legal de inmigración en tales países. Esta consideración se trasluce del apartado noveno ${ }^{528}$ de la Recomendación, donde queda patente la fragilidad la RF en el contexto de políticas migratorias restrictivas.

En el texto de la Recomendación se perciben dos partes claramente diferenciadas:

1. La primera parte contiene una serie de observaciones generales, a modo de consideraciones previas en torno al derecho a la reagrupación familiar: naturaleza jurídica, titularidad, finalidades y su enclave en el contexto internacional.

525 Ibidem, punto ii) del apartado 11.

526 Punto iii) del Apartado 12 de la Recomendación 1686 (2004): “Consequently, the Assembly recommends that the Committee of Ministers address, in the meantime, a recommendation to member states, urging them to apply, where possible and appropriate, a broad interpretation of the concepto f family and include in that definition members of the natural family, non-married Partners, including same-sex Partners, children born out of wedlock, children in joint custody, dependent adult children and dependent parents".

527 Explanatory memorandum by Mrs Zapfl-Helbling. Report Committee on Migration, Refugees and Population. Rapporteur: Mrs Rosmarie Zapfl-Helbling, Switzerland, Group of the European People's Party. Doc. 10123, 1 April 2004.

528 El tenor literal del apartado noveno de la Recomendación de la Asamblea Parlamentaria es el siguiente: “The Assembly notes with some concern that certain member states have shown a tendency to revise their immigration policy and impose tighter restrictions on the right to family reunion". En el mismo sentido apunta el punto 3 del Apartado II del Memorandum explicativo anexo al Informe emitido el 1 de abril de 2004 por el Comité de Migración, Refugio y Población, donde se afirma: "Family reunion must be analysed within the context of both migratory flows and European migration and asylum policies. Today, economic and social difficulties encourage certain European countries to reconsider their immigration policies and impose tighter restrictions. As labour migration has become extremely limited, refugee status, granted increasingly less easily, and family reunion are now the only legal avenues of immigration in European countries". 
2. En la segunda parte la Asamblea Parlamentaria formula las tres sugerencias genéricas al Comité de Ministros, que han sido objeto de atención al inicio de este apartado.

Las consideraciones preliminares se inician ${ }^{529}$ destacando el carácter fundamental del derecho que actúa como soporte jurídico de la reunificación familiar, esto es, del respeto a la vida familiar - artículos $8 \mathrm{CEDH}$ y $16 \mathrm{DUDH}$ - que, como tal, está dotado de una titularidad activa universal. A continuación, la Recomendación ofrece la siguiente definición jurídica de la reunificación familiar: "situación en la que miembros de una familia vienen a reunirse con uno de sus miembros - el sponsor o principal- que está residiendo legalmente en otro país" ${ }^{530}$.

De esta noción cabría destacar que, en consonancia con la jurisprudencia emitida hasta la fecha por el TEDH, supedita la reunificación familiar al carácter legal de la residencia ostentada por el extranjero reagrupante. Este condicionante guarda sintonía con lo dispuesto en la Recomendación ya analizada del Comité de Ministros $^{531}$ en la que, al delimitar el ámbito de aplicación de la misma y la extensión de la noción "miembros de la familia" reagrupables, se subrayaba también la condición de residente legal del principal o sponsor, a quien, además, se añadía la mención a los nacionales de los Estados parte. La Asamblea Parlamentaria, con buena técnica jurídica, y haciendo mención expresa al régimen jurídico comunitario más beneficioso del que gozan los nacionales de los Estados miembros, elude conscientemente la mención de éstos como sujetos activos de la RF, encuadrando este derecho en el ámbito de la extranjería.

La correcta comprensión de esta definición exige ser analizada conjuntamente con lo dispuesto en el apartado cuarto de la presente Recomendación ${ }^{532}$, donde se precisa con mayor claridad la titularidad del derecho a la RF, señalando que en la Unión Europea el mismo es predicable de los nacionales de terceros países y puede ser ejercicio, en principio, por inmigrantes legalmente residentes en un Estado miembro, así como por los refugiados y las personas que gozan de protección subsidiaria. Como ya hemos señalado, la titularidad activa del derecho a la reagrupación familiar se desdobla en dos tipos de destinatarios, por lo que se analizarán separadamente a la luz de lo establecido en el párrafo anterior:

a) El sujeto facultado para ejercer el derecho, desencadenando con ello el proceso transnacional de reunificación — reagrupante, principal o sponsor-: La Asamblea Parlamentaria considera como titulares activos del derecho a los inmigrantes que estén residiendo legalmente en un Estado miembro, así como a los refugiados y los beneficiarios de protección subsidiaria o complementaria —estas dos últimas categorías, por sus características específicas, quedan fuera de nuestro estudio. Quedarían excluidos de forma definitiva los nacionales de dichos Estados. Respecto de los extranjeros procedentes de terceros países que estén residiendo de forma irregular en los Estados partes, si bien están excluidos de la titularidad activa, sin

529 El apartado 1 de la Recomendación 1686 (2004) tiene el siguiente tenor literal: "El derecho al respeto de la vida familiar es un derecho fundamental perteneciente a todas las personas y está asegurado por varios instrumentos legales internacionales, tales como la Declaración Universal de los derechos humanos (art. 16) y el Convenio Europeo de Derechos Humanos (art. 8)". Traducción propia.

530 Apartado 2 de la Recomendación 1686 (2004). Traducción propia.

531 Punto 1 del apartado I de dicha Recomendación, bajo la rúbrica “ámbito de aplicación”.

532 El punto cuarto de la presente Recomendación señala literalmente: “The right to family reunion in the European Union is one which applies to nationals of non-European Union member states and may be exercised, in principle, by migrants lawfully resident in a member state, persons having obtained refugee status according to the 1951 Geneva Convention relating to the Status of Refugees, as well as persons having been granted complementary or subsidiary protection". 
embargo la Recomendación establece un importante matiz —en principio ${ }^{53}$ - que parece indicar la posibilidad de excepciones que amparen la concesión del derecho a extranjeros que se hallen en situación de irregularidad administrativa dentro del país receptor.

b) Los destinatarios finales quienes, como consecuencia del ejercicio del derecho por parte del reagrupante, adquirirán un permiso de entrada y residencia a fin de poder convivir en el Estado parte receptor con su familiar — sujetos reagrupables-: Tienen tal carácter los nacionales de terceros países, no pertenecientes a la Unión Europea ${ }^{534}$. Quedan pues excluidos los ciudadanos comunitarios, quienes gozan de un régimen más beneficioso. Respecto de los beneficiarios de este derecho, la Recomendación subraya la indefinición del concepto de familia y la falta de homogeneidad de las regulaciones internas - "el concepto de familia subyacente a la RF no ha sido definido a nivel europeo y varía en particular de acuerdo al valor y la importancia otorgadas al principio de dependencia" ${ }^{335}$-.

La Asamblea Parlamentaria recuerda que diversas Convenciones internacionales — entre ellas la Carta Social Europea, la Convención Europea sobre el estatus legal de los trabajadores migrantes y la Convención de la ONU sobre los derechos de los niños-, alientan a los Estados miembros a promover el derecho a la reunificación familiar. Y este órgano se une al Comité de Ministros al reiterar el deber que incumbe a los Estados parte, de acuerdo con los principios declarados en el Consejo Europeo de Tampere (1999), de propugnar políticas migratorias basadas en el principio de equiparación entre los nacionales de terceros Estados que cuenten con residencia legal en el Estado parte y los ciudadanos comunitarios.

La importancia del derecho a la reagrupación familiar queda patente tras las finalidades que persigue: Permite la reconstitución de las familias de los inmigrantes residentes legales, fortaleciendo la integración de éstos en la sociedad de acogida y la cohesión social"536. La inclusión del término "reconstitución" parece circunscribir la protección de la vida familiar a aquella de carácter preexistente a la adquisición del estatus legal por parte del inmigrante principal - o RF en sentido estricto- . Parece quedar al margen de la cobertura ofrecida por el derecho a la reunión familiar la vida familiar surgida con posterioridad, alejándose con ello la Asamblea Parlamentaria del carácter más amplio

533 Idem.

534 Esta consideración puede ser algo restrictiva si se tiene en cuenta que, como consecuencia de la considerable ampliación geográfica del Consejo de Europa, existen países que tienen la condición de Estados parte de dicha organización internacional y que, sin embargo, no son simultáneamente miembros de la Unión Europea. Las personas no nacionales de estos últimos países, pero que residan legalmente en su territorio o a quienes tales Estados hayan concedido el estatuto de refugiado o la protección internacional subsidiaria, también ostentarían la titularidad activa del derecho a la reagrupación familiar, como consecuencia de hallarse sometidos a la jurisdicción de un Estado parte (art $1 \mathrm{CEDH}$ ) y, por ende, podrían en último término incoar demanda al TEDH tras el agotamiento de las instancias internas.

535 Punto VII de la Recomendación. El principio de dependencia, en cuanto condicionante de la extensión de la familia objeto de protección, podría abrir el abanico de sujetos reagrupables, dando entrada a situaciones tan habituales como las de los hijos mayores de edad pero aún a cargo de sus progenitores tales como los estudiantes, ancianos, familiares enfermos o discapacitados a cargo del principal, así como cualquier otro tipo de relación familiar cercana que quepa calificar de dependiente. De hecho, la propia Asamblea Parlamentaria, en su apartado 8, sugiere a los Estados miembros interpretar en este sentido amplio el concepto de familia en su aplicación a los solicitantes de asilo, de forma que, respecto a dichos sujetos, los familiares reagrupables incluirían de facto a miembros de la familia natural, tales como la pareja no casada del solicitante, sus hijos naturales, personas de la tercera edad, enfermos u otras relaciones dependientes.

536 Apartado 6: "The reconstitution of the families of lawfully resident migrants and refugees by means of family reunion strengthens the policy of integration into the host society and is in the interests of social cohesion". 
que, en este sentido, ofrecía la Recomendación del Comité de Ministros sobre el estatus legal de las personas admitidas por motivos de RF previamente analizada.

El último apartado de esta primera parte está dedicado a los requisitos -económicos, de alojamiento, de integración y límites de edad-, de cuyo cumplimiento suele depender la concesión de la reunificación familiar. La Asamblea estima que su aplicación estricta constituye una amenaza al derecho al respeto de la vida familiar, especialmente respecto de los derechos de los niños, fomentando el riesgo de exclusión social de ciertos nacionales de terceros países ${ }^{537}$.

Los aspectos más relevantes de la segunda parte se centran en la exposición articulada y detallada de sugerencias concretas que habrán de ser tenidas en cuenta por el Comité de Ministros, a fin de que este órgano dirija una Recomendación a los Estados miembros ${ }^{538}$ :

a) De forma específica, la Asamblea Parlamentaria propone un interpretación amplia y extremadamente generosa del concepto de familia ${ }^{539}$, que incluya miembros de la familia natural, parejas no casadas - abarcando también aquellas formadas por miembros del mismo sexo-, niños nacidos fuera del matrimonio, niños con custodia compartida, e incluso hijos adultos dependientes y padres dependientes. Esta sugerencia se formula de forma sutil, recomendando su aplicación cuando ello sea posible y apropiado. Pese a ello, representa un avance radical que, aun estando en perfecta sintonía con la concepción amplia y profundamente liberal de la familia mantenida por la jurisprudencia del TEDH, sin embargo no ha sido aplicada aún al ámbito migratorio.

b) En conexión con lo establecido en el apartado 11, la Asamblea recomienda imponer condiciones menos estrictas a los solicitantes de reunificación familiar en materia de garantías financieras, seguro de enfermedad y alojamiento, evitando la discriminación contra las mujeres inmigrantes y refugiadas que podría resultar de su imposición. Con ello, se asume implícitamente que el colectivo femenino sigue siendo el beneficiario principal de este derecho.

c) Una sugerencia fundamental que apunta el carácter avanzado de esta Recomendación, en comparación con la anterior del Comité de Ministros-, es la relativa a los períodos de espera establecidos a nivel interno para que el reagrupante pueda ejercer el derecho a la RF. La Asamblea propone el establecimiento de procedimientos administrativos más simples y transparentes y la armonización de los períodos de espera, que han de limitarse a un máximo de doce meses ${ }^{540}$-el Comité de Ministros había sugerido un plazo de dos años como tope temporal- . De otro lado, la Asamblea especifica que el rechazo de la solicitud de reagrupación no debería producirse si el solicitante no facilita documentos que no sean instrumentales para el cumplimiento de las condiciones para la misma. El examen interno de las solicitudes debería realizarse con un espíritu positivo y humanitario, ofreciendo apoyo a los grupos vulnerables.

d) Amparándose en el case-law del TEDH relativo al artículo $8 \mathrm{CEDH}$, recomienda no retornar a los inmigrantes ilegales o solicitantes de asilo cuya petición haya sido rechazada, si ello constituye una amenaza a la unidad familiar. En su lugar, la Asamblea promueve la regularización del sujeto por motivos humanitarios, antes que imponerle el retorno forzoso a su país de origen. Lo sorprendente de la generosidad que esta disposición destila, es que la Asamblea no establezca

537 Apartado 11 de la Recomendación 1686(2004). Movilidad Humana y Dº a la RF.

538 Idem, apartado 12. III.

539 Inciso a) del punto III del apartado 12 de la Recomendación 1686(2004) de la Asamblea Parlamentaria del Consejo de Europa.

540 Idem, apartado 12.III.e). 
condicionantes, tales como períodos largos de estancia - ilegal - en el territorio del Estado parte o vínculos especialmente sólidos con el país receptor, a fin de constatar la severidad de la ruptura de la unidad familiar producida por el retorno forzoso del inmigrante. En esta materia, la postura de la Asamblea Parlamentaria es más abierta que la que subyace a las Recomendaciones relativas a la no expulsión de inmigrantes asentados dictadas en el marco del Consejo de Europa, que se circunscriben a los inmigrantes de segunda generación y a los de larga duración. Nuevamente, cabe subrayar las referencias explícitas al artículo $8 \mathrm{CEDH}$, evidenciando la consolidación del derecho al respeto de la vida familiar como plataforma convencional para la protección de los inmigrantes en el ámbito del CEDH.

e) En un sentido similar, la Asamblea propone la no-devolución forzosa de los extranjeros residentes legales a sus países de origen tras el cumplimiento de sentencias por comisión de delitos, imponiendo como condición que los lazos familiares principales estén en el país de acogida. Asimismo, las autoridades estatales no deberían rechazar las solicitudes de reunificación basándose exclusivamente en los antecedentes penales del peticionario.

f) Y, como consecuencia lógica de la visión profundamente progresista con que esta Recomendación contempla la migración familiar, la Asamblea introduce prevenciones a fin de evitar situaciones de abuso del derecho. En este sentido, propone que los Estados se aseguren de detectar casos de relaciones abusivas dentro de las familias reunidas, tratándolas de una forma justa y humana y, en particular, que las mujeres víctimas de violencia doméstica o matrimonios forzosos no sean devueltas a sus países de origen contra su voluntad ${ }^{541}$.

g) Las restantes propuestas - incentivar la concesión de permisos autónomos a los familiares reagrupados, autorizándoles para trabajar tan pronto como les sean emitido un permiso de residencia, entre otras-, son del mismo cariz que las analizadas en su momento al examinar la Recomendación 2002 (4) del Comité de Ministros.

En síntesis, la Recomendación de la Asamblea Parlamentaria destaca por un tenor progresista y humanitario, tanto en la contemplación de la RF, como en las prevenciones contra la expulsión de inmigrantes -incluidos los irregulares-, que pongan en peligro su vida familiar. De este espíritu general, sólo habría que excepcionar dos aspectos: De un lado, la protección de la RF en sentido estricto, dado que la exigencia del carácter previo de la vida familiar excluiría la tutela de la formación familiar a través de la migración — si bien esta consideración está incluida en la parte dedicada a las consideraciones preliminares, resultando dudoso su contenido sustantivo—; De otro lado, la inclusión de prevenciones contra el abuso del derecho, necesarias en vista del cariz liberal de la Recomendación. En comparación con la jurisprudencia del TEDH - incluso teniendo en cuenta el viraje producido en Sen-, así como con la Recomendación previa del Comité de Ministros, casi todos los elementos constitutivos del derecho a la reunificación familiar han resultado notablemente suavizados.

Parece ser que el carácter crecientemente restrictivo detectado en las políticas migratorias internas ha desencadenado una reacción en sentido totalmente inverso por parte de los órganos del Consejo de Europa encargados, desde distintas perspectivas, de la defensa de los derechos humanos. Éstos han reforzado la protección ofrecida a la migración familiar, conscientes de la importancia que tiene tanto para los sujetos que se benefician de ella como para la sociedad de acogida, asícomo de su desprotección en un contexto adverso. Resta por ver las reacciones estatales, especialmente ante disposiciones como las relativas a la ampliación de los familiares reagrupables dando cabida incluso

541 Apartado 12.III, inciso K, de la Recomendación 1686(2004) de la Asamblea Parlamentaria. Movilidad Humana y Derecho a la RF. 
a parejas del mismo sexo, cuestión cuya regulación difiere entre los distintos países miembros y no deja de ser una cuestión social controvertida.

Sea como fuere, resulta obvio que, frente a la línea dura de los Estados parte, la tendencia en el seno de los órganos integrantes del Consejo de Europa va en dirección contraria, favoreciendo el ejercicio del derecho a la RF, suavizando sus exigencias y abordando su examen desde consideraciones humanitarias.

\section{LA CONFIRMACIÓN DE LA LÍNEA JURISPRUDENCIAL PROGRESISTA}

\subsection{Sentencia Tuquabo-Tekle y otros contra Holanda}

Apenas cuatro años después de la sentencia Sen, el 1 de diciembre de 2005 el TEDH falló otra reclamación relativa al derecho a la reunificación familiar, sobre la base del derecho reconocido en el artículo $8 \mathrm{CEDH}$. Al haber sido emitido con posterioridad a la aprobación de las dos Recomendaciones analizadas y de la sentencia Sen, este pronunciamiento sirve como banco de prueba para comprobar hasta qué punto el viraje producido en Sen da inicio a una nueva línea jurisprudencial, así como el grado en que el TEDH ha tenido en cuenta el tenor progresista y humanitario de las sugerencias tanto del Comité de Ministros como de la Asamblea Parlamentaria del Consejo de Europa.

En el origen del caso se sitúa una demanda que presentan ante el TEDH los miembros de una familia compuesta por cinco ciudadanos holandeses - los padres y tres hijos - y una ciudadana eritrea, Mehret Ghedlay Subhatu. Los recurrentes alegaban que la negativa de las autoridades holandesas a permitir la residencia de Mehret a fin de que se reuniera en Holanda con su madre, su padrastro y sus hermanos, constituía una violación de su derecho al respeto de la vida familiar.

La señora Tuquabo - madre de Mehret- nació en Eritrea cuando este país pertenecía aún a Etiopía, y allí tuvo tres hijos. En 1989, tras la muerte de su primer marido y durante la guerra civil, huyó a Noruega, donde solicitó asilo político alegando que había sufrido persecución debido a las actividades de su marido para el Frente de Liberación del Pueblo de Eritrea. Las autoridades noruegas no le conceden el asilo, pero le expiden un permiso de residencia por motivos humanitarios y le otorgan permiso para traer a sus dos hijos. Su hijo mayor se reunió con ella, pero los otros dos niños, entre ellos Mehret, no logran salir de Eritrea debido a la difícil situación política del país, quedándose allí al cuidado de un tío y de su abuela. Posteriormente, la señora Tuquabo contrae matrimonio con el señor Tuquabo, que vivía en Holanda donde había sido admitido como refugiado. Se le concede un permiso de residencia para poder vivir con su marido y se traslada con su hijo a vivir a Holanda, donde nacen dos hijos de la pareja. En septiembre de 1997 — cuatro años después de que la señora Tuquabo hubiese obtenido su residencia legal en Holanda-, el matrimonio solicita un visado provisional de residencia a fin de que la hija que permanecía en Eritrea se pudiese reunir con ellos en Holanda. Por entonces ésta estaba a punto de cumplir 16 años y desde hacía ocho que vivía separada de su madre.

Las autoridades holandesas rechazan la solicitud alegando que la señora Tuquabo ha formado una nueva unidad familiar en Holanda, a la que nunca ha pertenecido Mehret, quien está integrada en la familia de su tío y de su abuela y nunca ha tenido vínculos familiares con su padrastro; Subrayan además el retraso de la pareja en solicitar la residencia para su hija, la edad de la menor - 15 años -, y su correlativo menor grado de dependencia, así como la inexistencia de obstáculos para que la familia, si lo deseaba, se reuniese con la hija retornando a Eritrea. 
Por su parte, los demandantes alegan que la demora en la presentación de solicitud de residencia para su hija es debida a la situación política de Eritrea, que imposibilitaba los contactos con ese país a efectos de la expedición de un pasaporte que permitiese la salida de la menor, así como a los posteriores problemas de alojamiento que tuvieron en Holanda, que ellos percibían como un impedimento legal de cara a su concesión. Además, señalan que, contrariamente a lo que afirmaba el gobierno, la edad de la hija representa un problema para la continuación de su existencia normal en Eritrea, debido a que ya había alcanzado la edad núbil y, por ello, su abuela había decidido que dejara la escuela, aun con la oposición expresa de los señores Tuquabo, pero no podían hacer nada mientras su hija no viviera con ellos en Holanda.

Como también sucedía en el caso Ahmut, se trata de un supuesto de difícil encaje en la vida familiar de los extranjeros ya que todos los demandantes - con la excepción de la hija menor para quien se solicita la reagrupación familiar-, habían adquirido la nacionalidad holandesa. Sin embargo, esta circunstancia vuelve a desempeñar una escasísima relevancia en la argumentación del TEDH, al igual que ocurriera en la Sentencia Ahmut.

El gobierno holandés ${ }^{542}$ no había cuestionado la existencia de vida familiar entre la señora Tuquabo y su hija Mehret, por ello la cuestión de la aplicabilidad del artículo 8 queda fuera de discusión y el Tribunal se centra desde el principio en concretar la cuestión esencial que ha de dirimirse en el presente caso: el TEDH ha de determinar si el artículo $8 \mathrm{CEDH}$ impone al Estado demandado la "obligación positiva" de permitir a la hija de la señora Tuquabo residir en Holanda con su madre, padrastro y hermanos, permitiendo así a los demandantes desarrollar una vida familiar alli ${ }^{543}$.

Con ello, el TEDH confirma la extensión del ámbito de las obligaciones convencionales positivas derivadas del respeto a la vida familiar, que había realizado en el asunto Sen: Hace referencia única y expresamente, no al mantenimiento de una vida familiar, sino a su desarrollo dentro del ámbito territorial del Estado parte. De otro lado, la evolución en la asunción del derecho a la reunificación familiar como contenido del artículo 8, patente a nivel institucional en las dos Recomendaciones analizadas, se aprecia con claridad tanto en la terminología adoptada por las partes, especialmente en los demandantes ${ }^{544}$, como, lo que es más trascendente, en el propio razonamiento del TEDH.

Este órgano, - tras reiterar doctrina consolidada respecto a los principios aplicables en el ámbito de la $\mathrm{RF}^{545}$ y la necesidad de valorar las circunstancias que rodean al caso a fin de determinar el

542 El gobierno demandando planteó una alegación de inadmisibilidad al TEDH, por considerar la demanda incompatible ratione personae con las disposiciones del $\mathrm{CEDH}$, ya que uno de los demandantes -la hija menor Mehret-, se encontraba en Eritrea y no pertenecía a la jurisdicción del Estado en el sentido del artículo 1 CEDH. Esta objeción preliminar fue rechazada por el TEDH, sin proceder a su estudio, por no haber sido planteada en el momento procesal oportuno - debía haber sido expuesta antes de que el TEDH decidiese sobre la admisibilidad de la demanda-.

543 Apartado 44 de la sentencia Tuquabo-Tekle.

544 Los demandantes reclamaban a las autoridades holandesas el incumplimiento de su obligación positiva, inherente al artículo $8 \mathrm{CEDH}$, de permitir a la hija residir en Holanda para gozar de una vida familiar en ese país. Apartado 33, STEDH Tuquabo-Teckle y otros contra Holanda.

545 Los principios aplicables para establecer el alcance de las obligaciones estatales en el ámbito de la RF, son los siguientes: "(a) El alcance de la obligación de un Estado de admitir en su territorio a familiares de emigrantes establecidos variará según las circunstancias particulares de las personas afectadas y el interés general; (b) Como cuestión de legislación internacional arraigada y sujeta a sus obligaciones en función de los tratados firmados, un Estado tiene derecho a controlar la entrada de extranjeros en su territorio; (c) En lo que respecta a inmigración, no se puede considerar que el artículo $8 \mathrm{CEDH}$ imponga a un Estado una obligación general de respetar la opción de los matrimonios del país de fijar su residencia matrimonial y de autorizar la reagrupación familiar en su territorio". STED Tuquabo-Tekle, apartado 43. 
alcance concreto de las obligaciones derivadas del artículo $8 \mathrm{CEDH}^{546}$-, despliega una argumentación en la que resulta patente la aplicación constante de la doctrina Sen: el TEDH repite literalmente los criterios que fueron explicitados en Sen, a fin de ponderar los intereses concurrentes -la edad de los menores afectados, su situación en su país de origen y el punto hasta el que son dependientes de sus padres ${ }^{547}$ - Y, nuevamente siguiendo a Sen, se apoya en la distinción apuntada en el apartado 68 de Abdulaziz, pero de una forma mucho más clara y explícita, apostando por la protección de la RF en sentido estricto - es decir, por los supuestos en los que los extranjeros cuentan con una vida familiar preexistente-, al señalar que:

"En este contexto, no se debe perder de vista que este caso se refiere no sólo a inmigración, sino también a vida familiar y que incluye a un extranjero, la señora Tuquabo-Tekle, que ya tenía una familia que dejó atrás en otro país hasta que consiguió una situación estable en los respectivos países de acogida, esto es, Noruega y Holanda" ${ }^{348}$.

En la valoración concreta de las circunstancias del caso, - a fin de examinar si el gobierno demandado ha mantenido un justo equilibrio entre su interés de controlar la inmigración y el interés particular de los demandantes de reunirse con su hija menor en el territorio del Estado parte de acogida-, el Tribunal sigue el mismo orden que el mantenido por el gobierno demandado en sus alegaciones: test de la responsabilidad individual; y test de los obstáculos en conjunción con el test de la integración.

Acude en primer lugar al test de la responsabilidad individual, a fin de examinar hasta qué punto es cierto que del retraso en la presentación de la solicitud de residencia para la hija de los demandantes, se pueda deducir que la estancia de ésta en Eritrea al cuidado de su abuela y su tío constituya una decisión permanente. En este punto, el TEDH sigue literalmente la doctrina formulada en Sen, para aliviar notablemente el test de la responsabilidad individual:

"El Tribunal ya ha sostenido que no se puede asumir que los padres que dejan atrás a sus hijos mientras consiguen una situación estable en el extranjero hayan irrevocablemente decidido que dichos hijos se queden en el país de origen permanentemente y hayan abandonado toda idea de una futura reagrupación familiar" ${ }^{\prime \prime}$.

En esta sede, el Tribunal valora positivamente la intención que siempre tuvo la señora Tuquabo de que su hija se reuniera con ella primero en Noruega y posteriormente en Holanda, admitiendo que el retraso no se debió a su negligencia o dejadez, sino, en primer lugar a circunstancias que escapaban a su control -en referencia a la situación política de Eritrea-, y con posterioridad a la sincera creencia de los demandantes de que no era posible solicitar la reagrupación familiar en Holanda, hasta obtener una vivienda que cumpliera determinados requisitos ${ }^{550}$.

546 STEDH Tuquabo-Tekle y otros contra Holanda, de 1 de diciembre 2005, apartado 42. En este apartado el TEDH, al sentar los principios aplicables al régimen de las obligaciones positivas, remite expresamente a Ahmut, pero el cambio jurisprudencial en la determinación del grado del margen de apreciación del que gozan los Estados Parte en el ámbito de las obligaciones positivas de carácter migratorio, había sido fijado con carácter definitivo en el asunto Gül. Como vimos, en Gül el TEDH rebajó el margen de apreciación estatal de "elevado" a relativo, estimando que los Estados gozan de cierto margen de apreciación en esta materia.

547 Apartado 44 de la sentencia Tuquabo-Tekle y otros contra Holanda.

548 Idem.

549 Ibidem, apartado 45.

550 Apartados 46 y 47 de la sentencia Tuquabo-Tekle. El aligeramiento en el test de la responsabilidad lleva incluso a afirmar al TEDH, - en justificación de los demandantes-, que el hecho de que, según el gobierno, no se exigiera a la señora Tuquabo y a su marido tomar dichas medidas no quita mérito al objetivo que anima sus esfuerzos: reunirse con su hija en Holanda. 
A lo largo de la aplicación del test de la responsabilidad individual se percibe un cambio de actitud muy notable por parte del Tribunal, mostrándose favorable a encontrar resquicios que descarguen de responsabilidad a los demandantes. Si se toman en cuenta los criterios apuntados en Sen, que el Tribunal sigue aquí al pie de la letra — tanto la edad de la hija, próxima a la mayoría de edad, como el criterio del grado de dependencia con los padres, como el grado de integración en el país natal—, su aplicación estricta podría haber jugado en contra de los intereses de los demandantes.

La ponderación de los intereses en juego, lleva a continuación al TEDH a aplicar el test de los obstáculos, usado en conexión con el test de la integración en el Estado de acogida, haciendo uso en ambos casos del método comparativo. Es precisamente en este punto donde se observa un cambio sustancial en la apreciación del TEDH: el test de los obstáculos o criterio elsewhere ya no radica en apreciar la existencia o no de obstáculos para el retorno de los demandantes al país natal o a cualquier otro tercer país distinto al Estado receptor donde reconstuir la vida familiar, sino en determinar "hasta qué punto es cierto que el que Mehret se instalara en Holanda sería el medio más adecuado para que los demandantes desarrollaran una vida familiar juntos" ${ }^{351}$.

En el análisis de esta cuestión, el TEDH enfatiza las simulitudes que este caso presenta con Sen: la señora Tuquabo-Tekle y su marido - como el señor y la señora Sen-, han estado viviendo legalmente en Holanda durante una serie de años e incluso solicitado, y obtenido, la nacionalidad holandesa. Además, y también como en el caso Sen, han nacido dos niños del matrimonio en Holanda, que siempre han vivido en dicho país, en su entorno lingüístico y cultural y que, por tanto, solo pueden tener lazos mínimos, si los tienen, con el país de origen de sus padres ${ }^{52}$.

En la argumentación del Tribunal de Estrasburgo se observa claramente que el aligerado test de los obstáculos interactúa con el test de la integración, siguiendo la perspectiva igualmente más dulcificada que ya había sido introducida en Sen, esto es, enfatizando los vínculos en el Estado de acogida: el TEDH tiene en cuenta la situación estable que cinco de los miembros de la familia Tuquabo han obtenido en el país de residencia -incluida su nacionalidad, circunstancia que se menciona de pasada como un elemento muy auxiliar a favor de los intereses de los demandantes, sin concederle el peso prioritario que, a nuestro juicio, debería tener-. Fundamentalmente valora el hecho de que, al igual que ocurría en Sen, en Holanda han nacido y vivido dos de los hijos del matrimonio, sin apenas vínculos con el país natal de sus padres. Esta perspectiva del test de la integración hace que el test de los obstáculos desempeñe un papel contrario al que jugaba en la primera jurisprudencia sobre esta materia, permitiendo el surgimiento de obstáculos que impidan el retorno de la familia al país de origen.

En esta sede, el TEDH introduce una referencia al test de la responsabilidad individual ${ }^{553}$, poniendo en duda que la señora Tuquabo dejase intencionalmente a su hija en Eritrea, señalando que huyó de aquel país en plena guerra civil buscando asilo, sin éxito, en el extranjero. Con ello, desmonta el argumento reiterado por el gobierno holandés, y encuentra motivos - la situación de refugiado del marido y el permiso de residencia por motivos humanitarios que Noruega había concedido en su momento a la señora Tuquabo-, que se erigen en obstáculos para el regreso de la familia al país de origen. En supuestos anteriores ya estudiados — concretamente el caso Gül_, circunstancias simi-

551 Idem, apartado 47.

552 Ibidem.

553 En el apartado 47, el TEDH señala que "es cuestionable hasta qué punto se puede mantener en este caso, como hizo el Gobierno, que la señora Tuquabo-Tekle dejó a Mehret «por su propia voluntad», teniendo en cuenta que huyó de Eritrea en el transcurso de una guerra civil para buscar asilo en el extranjero tras la muerte de su marido". STEDH Tuquabo-Tekle y otros contra Holanda. 
lares habían sido desconocidas por el Tribunal a la hora de ponderar el equilibrio entre los intereses lo que, en ausencia de otra explicación alternativa, nos lleva a intuir la influencia ejercida por las Recomendaciones ya analizadas de los órganos del Consejo de Europa en el cambio de perspectiva del TEDH, más liberal que la mostrada en el asunto Sen.

Finalmente, la comparación con Sen - a la que el TEDH acude reiteradamente en su análisis del test de los obstáculos-, recala en un elemento distintivo entre ambos casos: la edad de la hija -9 años en Sen y 15 en Tuquabo-. La Corte de Estrasburgo entra a valorar si la edad del menor afectado constituye un factor diferencial, con entidad suficiente como para determinar que el presente caso conduzca a un resultado distinto al alcanzado en Sen ${ }^{554}$, advirtiendo expresamente que:

"El Tribunal ya ha rechazado con anterioridad demandas de reagrupación familiar y quejas en virtud del artículo 8 en las que los menores afectados habían alcanzado mientras tanto una edad en la que presumiblemente no necesitaban demasiados cuidados como niños y eran cada vez más capaces de valerse por sí mismos. En casos de esta naturaleza, el Tribunal también ha examinado si el menor había crecido en el contexto lingüístico y cultural de su país de origen, si tenía allí otros familiares y si se podía esperar que los padres volvieran a ese país" ${ }^{355}$.

A juzgar por la anterior advertencia de la Corte de Estrasburgo, la edad de Mehrit jugaría en este supuesto en contra de las pretensiones de los demandantes pues, a tenor de su propia jurisprudencia, cabría extraer la regla general según la cual los hijos extranjeros menores de edad que permanecieron fuera del país receptor de su progenitor, verán disminuidas las posibilidades de serles concedido un permiso de entrada y residencia por motivos de RF, según su edad se vaya aproximando a la mayoría de edad. En tales supuestos, se presumiría su menor dependencia con respecto de sus padres y una mayor capacidad para valerse por sí mismos.

Sin embargo, en este caso, los demandantes habían propuesto que la edad jugase un papel inverso al habitual, ya que la edad de la hija — casi dieciséis años en el momento de rechazo de su primera solicitud-, recomendaba la unión con su familia en Holanda pues, siguiendo las costumbres eritreas, su abuela había sacado a la menor de la escuela y podría enfrentarse a un matrimonio concertado.

"El Tribunal coincide con el Gobierno en que los argumentos de los demandantes en este contexto, por sí mismos, no justifican la conclusión de que el Estado tenga la obligación positiva de permitir a Mehret residir en Holanda. Aún así, y teniendo en cuenta que era, después de todo, todavía una menor, el Tribunal acepta, en las particulares circunstancias de este caso, que la edad de Mehret en el momento en que se presentó la solicitud de la reagrupación familiar, no es un elemento que deba llevarle a valorar el caso de manera diferente a lo que hizo en el caso Şen" 556 .

Es en este punto, donde se observa cierta inconsistencia en la argumentación del TEDH, siendo patente el cambio de actitud de este órgano. En su razonamiento se percibe una búsqueda intencionada para encontrar elementos de apoyo sobre los que poder sustentar la concesión del derecho reclamado por los demandantes. Y ello pese a que, como el TEDH subraya, concurría en este caso un importante elemento diferencial que, de haber sido aplicado estrictamente, podría haber llevado a la denegación del derecho: la edad de la hija y su altísimo grado de integración en el Estado de acogida.

554 Apartado 48 de la sentencia Tuquabo-Tekle y otros contra Holanda.

555 Apartado 49 de la sentencia Tuquabo-Tekle, donde el propio TEDH hace referencia a su jurisprudencia previa, emitida en los asuntos Benamar contra Holanda, de 5 de abril dee 2005, I.M. contra Holanda, de 25 de marzo de 2003 y Chandra y otros contra Holanda, de 13 de mayo de 2003.

556 Apartado 50 de la sentencia Tuquabo-Tekle y otros contra Holanda. 
El mismo ánimo de búsqueda consciente de argumentos que amparen la protección del derecho, puede percibirse en el siguiente párrafo de la sentencia, que lleva al Tribunal a valorar un elemento hasta ahora inédito en su argumentación.

\footnotetext{
"Por otra parte, el Tribunal añade que, aunque no es en sí mismo decisivo, es digno de mención que cuando la señora Tuquabo-Tekle solicitó el permiso de las autoridades noruegas para que su hija se reuniera con ella en Noruega, Mehret tenía la misma edad que tenía Sinem - la hija menor en el caso Senen cuanto sus padres presentaron la solicitud a las autoridades holandesas ${ }^{3557}$.
}

Por primera vez el TEDH tiene en cuenta un hecho que cronológicamente quedaría fuera del ámbito de su atención - la edad de la menor en el momento en que su madre intentó reunirse con ella en Noruega-, como también desde el punto de vista territorial - Noruega no es en este asunto el Estado demandado-, para establecer un punto de equiparación con el asunto Sen, que otorgue una justificación adicional a la aplicación de las mismas consecuencias. En consecuencia, el TEDH aplica idéntica conclusión que en Sen, sosteniendo la existencia de violación del artículo $8 \mathrm{CEDH}$ por parte del Estado demandado, por no haber mantenido un justo equilibrio entre los intereses de los demandantes, por un lado, y su propio interés en controlar la inmigración, por otro.

Los aspectos señalados denotan una notable predisposición por parte del Tribunal de Estrasburgo para encontrar recovecos argumentativos que sirvan de asidero para la protección de la RF, argumentos que, en otro tiempo, hubieran sido totalmente irrelevantes y endebles. En TuquaboTekle es pues claramente perceptible en el TEDH una actitud de decidido activismo a favor de las pretensiones a la RF de los inmigrantes legalmente asentados en el territorio de los Estados parte del CEDH. La explicación más lógica a este cambio de actitud puede residir, al menos parcialmente, en la influencia ejercida por las sugerencias propuestas tanto por el Comité de Ministros como por la Asamblea Parlamentaria del Consejo de Europa y, entre todas ellas, es clara la recepción del interés superior del menor como sólido criterio jurisprudencial capaz de neutralizar el interés general del Estado de controlar la inmigración.

En suma, la sentencia Tuquabo-Tekle constituye no solamente la confirmación del viraje jurisprudencial acaecido en Sen sino, mucho más allá, su profundización en un sentido acusadamente más liberal. Este pronunciamiento parece dar pie para anunciar, con fundado optimismo, que se aproximan tiempos favorables para la protección del derecho a la reunificación familiar de los extranjeros en el ámbito del CEDH. Los miembros del Tribunal se muestran muy propicios a impulsar el efecto útil del derecho al respeto de la vida familiar sobre la inmigración familiar, todavía reducida a supuestos de RF en sentido estricto, a favor de hijos menores y sobre el presupuesto de la estancia legal de los reagrupantes ${ }^{558}$. Todo ello, sin cuestionar el derecho que, conforme a un principio internacional arraigado, compete al Estado parte en el control sobre la entrada de extranjeros en su territorio - premisa hasta el momento constante en la aproximación efectuada por Estrasburgo al ámbito migratorio ${ }^{559}$.

A nuestro juicio, Tuquabo-Tekle constituye la confirmación de una aproximación liberal a la migración familiar, que otorga bases para poder extraer un todavía precario derecho a la RF de los

557 Idem, apartado 51.

558 De modo similar, Cathryn COSTELLO cita a las sentencias Sen y Tuquabo como ejemplos indicativos de que, junto a la protección de la residencia de nacionales de terceros países arraigados en el Estado parte receptor, el TEDH está también dispuesto a reconocer un derecho de entrada a favor de menores extranjeros de edad, hijos de residentes legales, aunque matiza que este último derecho se garantiza tan sólo en "casos excepcionales". "Metock: Free movement and 'normal family life' in the Union”; en Common market law review, Vol. 46, № 2, 2009, p. 590.

559 Idem. 
extranjeros como contenido implícito al derecho al respeto de la vida familiar, si bien con un alcance muy limitado. En apoyo de esta idea podría además tenerse en cuenta que Tuquabo, al igual que Sen, es una decisión adoptada por unanimidad, pese a que en ella se encuentran puntos argumentativos más flojos y alguna inconsistencia admitida por el propio Tribunal ${ }^{560}$.

\subsection{STEDH Rodrigues da Silva and Hoogkamer contra Holanda, de 31 de enero 2006}

El caso Rodrigues da Silva, fallado escasos dos meses después que Tuquabo-Tekle, reúne particularidades importantes que lo hacen merecedor de un análisis detallado: Se trata del primer supuesto sobre RF relativo a relaciones paterno-filiales, donde el hijo es fruto de una relación extramatrimonial; de otro lado, el vínculo familiar ha sido creado con posterioridad a la entrada del extranjero en el Estado parte, encajando por ello en un supuesto de formación familiar; además, se solicita la residencia por motivos de RF, no para la hija de la demandante - como viene siendo frecuente-, sino para la madre. Finalmente, como aspecto más destacable, es la primera ocasión en la que el TEDH debe examinar a la luz del Convenio de Roma la denegación por parte de las autoridades holandesas, de una solicitud de residencia planteada por una persona que ha estado en situación de irregularidad administrativa durante toda su estancia en el Estado contratante. Constituye por ello un relevante ejemplo de la amplitud de la legitimación activa de los particulares ante el TEDH, que el artículo $1 \mathrm{CEDH}$ permite.

Dado que es la primera vez que el TEDH tiene la ocasión de enfrentarse a un supuesto de migración familiar basado en la estancia irregular, constituye un caso fronterizo, en el que confluyen elementos tanto de la expulsión como de la reunificación familiar - los dos aspectos que han erigido al artículo $8 \mathrm{CEDH}$ en una norma de protección convencional de los extranjeros-. Por ello, Rodrigues da Silva permite extraer criterios de distinción entre los supuestos de obligaciones positivas y negativas derivadas del respeto a la vida familiar de los no nacionales dentro del ámbito del Convenio de Roma. Y, simultáneamente, confirma la acusada línea protectora emprendida por la Corte de Estrasburgo con la sentencia Sen puesto que, aun enfrentado a supuestos extremos que implican el incumplimiento de las normas migratorias internas, el TEDH se muestra favorable a la tutela de la RF.

Las demandantes son una mujer de nacionalidad brasileña y su hija, Ráchael Hoogkamer, nacida en Holanda como consecuencia de la relación de su madre con un nacional holandés. La madre llegó a Holanda en 1994, con veintidós años de edad y dejando a dos hijos de una previa relación en su país natal, Brasil, al cuidado de sus padres. En Holanda vivió con su pareja, Mr. Hoogkamer, nacional holandés, pero durante todo el tiempo que duró la relación —en total tres años-, no solicitó un permiso de residencia, al que hubiera tenido derecho, alegando que carecían de documentos justificativos del salario de Mr Hoogkamer. Un año después de su llegada a Holanda, se trae a su hijo menor a este país, permaneciendo el mayor en Brasil con sus abuelos y, al poco tiempo, da a luz a una niña en Holanda, la segunda demandante. Ésta obtiene la nacionalidad holandesa al ser reconocida por su padre.

La pareja se separa a principios de 1997, permaneciendo la hija con su padre y a partir de entonces inician una batalla legal por la tutela sobre la menor. Finalmente los tribunales holandeses conceden la custodia de la hija al Sr. Hoogkamer, teniendo en cuenta un informe emitido por el

560 Vid. Apartado 50 de la sentencia Tuquabo-Tekle y otros contra Holanda, ya comentado. 
Departamento holandés de Cuidado y Protección Infantil, en el que se aconseja que, en interés de la menor, ésta se quede con su padre en vista de la probabilidad de que la madre regrese a Brasil - lo que provocaría la ruptura de contactos entre la menor y su madre, así como con sus abuelos paternos, a quienes la niña estaba muy unida-, de ahí que se estime traumático para la menor abandonar Holanda. La madre llega a un acuerdo con los abuelos paternos de Rachael, considerado satisfactorio para ambas partes, en virtud del cual éstos atienden a la menor durante la semana, mientras que los fines de semana la niña permanece al cuidado de su madre, desempeñando el padre un papel menos significativo en su crianza. En dicho acuerdo, los propios abuelos paternos habían reconocido explícitamente que los contactos regulares con la madre tenían un efecto muy benéfico sobre la niña.

Tras la ruptura de su relación de pareja $-\mathrm{y}$ habiendo transcurrido tres años de estancia irregular en Holanda-, la madre solicita por primera vez un permiso de residencia, denegado por el gobierno holandés, quien informa a la madre que debe abandonar el país. Pese a ello, la mujer permanece en Holanda y consigue traerse a su hijo mayor, que hasta entonces había estado viviendo en Brasil, a fin de que conviva con ella y su nueva pareja holandesa.

Ante el TEDH las recurrentes alegan que el rechazo de las autoridades holandesas a conceder un permiso de residencia a la primera demandante, constituye una violación de su derecho al respeto de la vida familiar. Subrayan que si se le concede la máxima importancia al hecho de la estancia ilegal de la primera demandante, el balance entre los intereses que ha de mantener las autoridades internas, se vería reducido a proporciones inaceptables. Las demandantes establecen una equiparación entre este supuesto y las circunstancias concurrentes en el caso Sen. Al igual que en Sen, proponen que el Tribunal tome en consideración los fuertes vínculos que la menor mantiene con el Estado contratante pero, adicionalmente, afirman que en este supuesto existe un obstáculo mayor que en Sen para el desarrollo de la vida familiar en el país de origen: la madre no ostenta la custodia sobre su hija, lo que le impide tomar decisiones relativas al lugar de residencia de la menor. El padre de la niña siempre sostuvo que no permitiría que su hija se fuera a vivir a Brasil, de modo que si la madre es forzada a abandonar Holanda, su hija se vería privada de la proximidad y los cuidados de su madre, elementos de vital importancia para una niña que contaba tan sólo con tres años de edad en el momento del rechazo de las autoridades holandesas. Fue precisamente evitar que la menor tuviera que abandonar Holanda y perder los contactos regulares con sus abuelos paternos, lo que determinó que las autoridades holandesas concediesen la tutela al padre, aún a sabiendas del escaso papel que éste desempeñaba en el cuidado de la menor.

Por su parte, el gobierno holandés subraya que la vida familiar invocada se ha desarrollado mientras la primera demandante estaba viviendo ilegalmente en Holanda, elemento que, a su juicio, es vital. Enfatiza además que esta circunstancia se debe enteramente a la propia demandante, quien nunca se esforzó en legalizar su situación, pese a que durante el período que convivió con el padre de su hija, podía haber optado a un permiso de residencia en este país.

El Tribunal resuelve rápidamente la cuestión de la aplicabilidad del artículo 8 a la relación existente entre la madre y su hija extramatrimonial:

"No hay duda que hay vida familiar, dentro del significado del art. 8 CEDH entre la primera demandante y su hija Rachael, la segunda demandante: Rachael ha nacido de una relación genuina, en la que sus padres cohabitaron como si estuvieran casados" 561 .

561 Apartado 37, sentencia Rodrigues da Silva and Hoogkamer c. Holanda. 
Como es bien sabido, la igualdad entre los hijos habidos fuera y dentro del matrimonio constituye jurisprudencia consolidada desde la sentencia Marckx c. Bélgica, pero es la primera vez que tenemos ocasión de observar su aplicación en un supuesto migratorio relativo a la RF. La rapidez con que se ventila esta cuestión revela que estamos ante una doctrina sin fisuras, ni siquiera ante supuestos potencialmente más problemáticos en vista de la importancia cualitativa que ostenta la migración familias. En consecuencia, el respeto a la vida familiar de los extranjeros como base para la protección de la inmigración familiar, resulta predicable tanto a hijos habidos dentro como fuera del matrimonio. De especial relevancia para ello resulta constatar, como hace la Corte, que la niña es fruto de una relación de pareja "genuina".

\title{
a) RF, Expulsión y casos fronterizos: Criterios de Clasificación
}

El propio Tribunal de Estrasburgo enmarca este caso como un supuesto relativo a la reunificación familiar, encajando la medida impugnada en el ámbito de las obligaciones positivas. Sin embargo - a diferencia de anteriores ocasiones donde esta cuestión siempre permaneció inexplicada y algo confusa-, el Tribunal hace explícitos por primera vez los criterios de distinción que le permiten asignar una naturaleza positiva a la medida estatal objeto de impugnación, haciendo suyos argumentos que venían siendo esgrimidos repetidamente por los gobiernos demandados ante el $\mathrm{TEDH}^{562}$.

\begin{abstract}
"El presente caso incumbe el rechazo de las autoridades internas a permitir residir en Holanda a la primera demandante; aunque ésta ha estado viviendo en dicho país desde 1994, su estancia no fue legal en ningún momento. Por lo tanto, la decisión impugnada no constituyó una interferencia en el ejercicio del derecho de las demandantes al respeto de su vida familiar, donde le fuese retirado el estatus de residente que autorizaba a la primera demandante a permanecer en Holanda. La cuestión a examinar en el presente caso es más bien si las autoridades holandesas estaban obligadas a permitir la residencia en Holanda a la primera demandante, habilitando así a las demandantes a mantener y desarrollar la vida familiar en su territorio. Por esta razón la Corte acuerda que este caso ha de ser considerado como un supuesto que involucra una alegación del fallo por parte del Estado demandado del cumplimiento de una obligación positiva"s63.
\end{abstract}

Este apartado de la sentencia, transcrito en su integridad, supone un intento de sistematización de una línea jurisprudencial hasta el momento confusa. Por ello resulta muy bienvenido el propósito del TEDH de asentar criterios generales que permitan cierta anticipación de los resultados jurisprudenciales, en una materia que ha sido blanco frecuente de críticas por su inconsistencia y arbitrariedad ${ }^{564}$. Conforme al TEDH, para diferenciar los casos de reagrupación familiar al amparo del artículo 8.1 CEDH, de otros supuestos colindantes también insertados en este enclave, en los que extranjeros asentados en el Estado parte alegan ante el TEDH la ruptura de su vida familiar como

562 De hecho, en este apartado el TEDH remite expresamente al párrafo 63 de la sentencia Ahmut, donde el Tribunal situó la medida estatal impugnada por los particulares - el rechazo a conceder un permiso de residencia a la hija del demandante-, en el ámbito de las obligaciones positivas estatales, pero sin incluir criterios de distinción que permitieran justificar el carácter positivo de la misma. Realmente en la sentencia Ahmut es el gobierno holandés demandado quien, en el párrafo 62, explicita los criterios de distinción en los que ahora se ampara el tribunal para justificar el encaje de la medida impugnada en el seno de las obligaciones positivas.

563 Apartado 38, sentencia Rodrigues da Silva and Hoogkamer c. Holanda.

564 Vid, a modo meramente ejemplificativo de las críticas doctrinales vertidas sobre esta rama jurisprudencial, a Costello, quien sostiene que se trata de una jurisprudencia "pegada al caso, impredecible y algo incoherente", adjudicando fundamentalmente al elevado margen de apreciación existente la causa de tales fallos. COSTELLO, Cathryn. "Metock: Free Movement and 'Normal Family Life' in The Union”, op. cit., p. 590. 
consecuencia de una medida migratoria adversa, el criterio de clasificación se basaría en el carácter o la naturaleza de la medida estatal impugnada:

a) Si la decisión estatal consiste en la retirada del estatus de residente a un extranjero - que hasta ese momento se hallaba regularmente asentado en el territorio del Estado parte donde disfrutaba de sus vínculos familiares-, es calificada como una interferencia o injerencia en el derecho consagrado en el artículo 8.1 CEDH. Dicha injerencia, al suponer la negación del derecho a permanecer en el país receptor, provoca una ruptura directa e inmediata de la vida familiar del extranjero afectado, imposibilitando la continuación de su residencia en el Estado parte y de su vida familiar allí. En estos supuestos, el TEDH encaja la decisión estatal impugnada en el ámbito de las obligaciones negativas derivadas del derecho al respeto de la vida familiar ${ }^{565}$, evaluando en primer lugar si la injerencia constituye una medida de la que el Estado debió abstenerse. Posteriormente, examinará su posible justificación determinando si se trata de una medida prevista en la ley y si está amparada por alguna de las restricciones contempladas en el apartado segundo del Convenio de Roma - habitualmente en relación con el orden público interno-, aplicando para ello el análisis secuencial que permite la aplicación explícita del principio de proporcionalidad mediante la vía de la cláusula de la necesidad en una sociedad democrática.

Las interferencias sobre la vida familiar de los extranjeros comprenderían tanto los casos de la revocación del permiso de residencia como del rechazo de su renovación, así como los supuestos de expulsión de extranjeros - en los que, en último término, desembocarían estos casos-. Por ello con carácter general, estos supuestos son catalogados como casos de protección frente a expulsiones, pues finalmente ésta es la consecuencia directa o indirecta de la decisión estatal.

b) Si la medida estatal impugnada consiste en la denegación de entrada o el rechazo de la concesión inicial de un permiso de residencia en el territorio del Estado contratante, el TEDH la encajará en el seno de una obligación de carácter positivo derivada del efectivo respeto al derecho de la vida familiar de los extranjeros.

Hasta el asunto Rodrigues da Silva, se presuponía que la medida estatal denegatoria había sido dictada contra un extranjero que se hallaba fuera del territorio del país receptor - al que pretendía entrar a fin de convivir con sus familiares más cercanos para, con ello, tanto mantener como desarrollar su vida familiar en dicho país-. Sin embargo, este caso supone la ampliación de la cobertura de la RF en el seno de Estrasburgo permitiendo, al menos en vía de principio, el planteamiento de demandas ante el TEDH por supuesta violación de la RF, también en supuestos en los que el extranjero se encuentra dentro del territorio del Estado parte demandado, si bien de forma irregular. Estas últimas situaciones incluirían múltiples supuestos tanto de irregularidad sobrevenida - extranjeros que entran en el país receptor con visado de turista, sin regresar a su país de origen al finalizar su autorización de estancia en dicha calidad, supuestos de denegación de renovaciones de autorizaciones previas de residencia, etc.- como aquellos casos en que el extranjero entró al país receptor

565 La expulsión constituye una medida disciplinaria típica en el ámbito de la extranjería. En el ámbito del Consejo de Europa, ha dado lugar a una abundante jurisprudencia sobre la base de múltiples alegaciones que se amparan en el derecho al respeto de la vida familiar de los extranjeros. Dichas demandas reclaman que la medida de expulsión dictada contra un no nacional constituye una injerencia en el derecho al respeto de la vida familiar del extranjero afectado. La vida familiar como límite material a la ejecución de expulsiones de extranjeros, se inició en Estrasburgo con la sentencia Berrehab contra Países Bajos, de 21 de junio de 1988, que constituye el leading case en esta materia. Dentro de esta línea jurisprudencial se insertan, entre otras, Moustaquim contra Bélgica de 18 de febrero de 1991; Nsona contra Países Bajos, de 28 de noviembre de 1996; Mehemi contra Francia, de 26 de septiembre de 1997; Boulifa contra Francia, de 21 de octubre de 1997; Dalia contra Francia, de 19 de febrero de 1998; Ciliz contra Países Bajos, de 11 de julio de 2000. 
contraviniendo desde el principio la normativa interna de extranjería. En tales supuestos, faltaría el movimiento trasnacional que caracteriza a la RF.

Si el inmigrante está fuera del territorio, la medida interna impugnada supondría la denegación de la entrada y residencia en el Estado parte; Si, por el contrario, el extranjero se halla irregularmente en el territorio del país contratante, la decisión estatal desembocaría indirectamente en su expulsión -en el caso de que éste no abandonara voluntariamente el territorio del Estado parte-. Esta última situación nos sitúa ante supuestos fronterizos o limítrofes entre la RF y la expulsión, de contornos difusos y difícil distinción en la práctica, por dos motivos principales: De un lado, porque la RF típicamente se predica para la admisión de no nacionales que están fuera del Estado de acogida; De otro lado, porque la ejecución de la medida estatal impugnada provocaría, como efecto mediato, la exclusión o expulsión del inmigrante irregular — mientras que dicho efecto es directo e inmediato en los casos típicos calificados genéricamente como supuestos de expulsión.

Que estamos ante figuras próximas, cuya distinción en ocasiones es más formal que real, se observa tanto en la confusión existente al respecto entre la doctrina -que en ocasiones ha tipificado y analizado como supuestos de protección frente a expulsiones frente al TEDH lo que, estrictamente, no son sino casos típicos de $\mathrm{RF}^{566}$ - , como por parte del propio TEDH —el caso Agraw, que analizaremos a continuación, es calificado expresamente por esta institución como un supuesto de RF, aun consistiendo en una obligación negativa-. Por eso, desde estas páginas, aun alabando el esfuerzo de sistematización desplegado por la Corte en este pronunciamiento, lo consideramos aún insuficiente, a la vista de la oscuridad que sigue dominando en esta materia.

La clave pues en los supuestos de migración familiar considerados como obligaciones positivas, reside en que la medida estatal impugnada deniega la entrada inicial o bien un primer permiso de residencia. Por eso se entiende la inclusión de los supuestos de RF en casos de irregularidad dentro del ámbito de las obligaciones positivas: en tales casos, se trata del primer permiso de residencia del que disfrutaría el hasta entonces extranjero irregular — en el caso de que el Tribunal acceda a sus peticiones por estimar la violación de su derecho al respeto de la VF. En este ámbito, el Tribunal de Estrasburgo deberá determinar si, en el supuesto específico y examinando las circunstancias concretas concurrentes, el Estado incumplió con su obligación positiva de permitir la entrada o la residencia - en ambos casos, con carácter inicial- del extranjero en su territorio. En la valoración de tales circunstancias, el TEDH declara aplicar principios similares a los que rigen en el ámbito de las obligaciones negativas, concediendo en ambos supuestos "cierto" margen de apreciación al Estado parte, así como la necesidad de mantener un justo equilibrio entre los intereses concurrentes: de un lado el interés individual de desarrollar la vida familiar en el Estado parte, de otro el interés estatal de controlar la inmigración, que queda circunscrito dentro del bienestar económico del país en los supuestos clasificados como migración familiar.

Sin embargo, en el enjuiciamiento de los supuestos de RF en tanto que obligación positiva derivada del artículo 8.1 CEDH, existe una diferencia que consideramos esencial respecto al tratamiento

566 Vid, a modo de ejemplo, el análisis que realizan MORANO, Sonia y ANDREADAKI, Stelios, citando a las sentencias Sen contra Países Bajos y Tuquabo-Tekle, a fin de evaluar la aplicabilidad de los criterios sentados por el TEDH en el asunto Boutlif, en materia de expulsión y deportación de extranjeros. En concreto se evalúa el criterio de la seriedad de las dificultades que afrontarán los hijos extranjeros del demandante, también extranjero, si este último llega a ser expulsado del Estado parte receptor, en su aplicación a dos supuestos de - RF, concebidos sin embargo como formando parte de la rama de obligaciones migratorias de carácter negativo-. "The convergence of the European Legal System in the treatment of Third Country Nationals in Europe: the CJEU and ECtHR jurisprudente", op. cit., p. 20, nota a pie de página $\mathrm{n}^{\circ} 89$. 
jurídico que el TEDH despliega en el análisis de los supuestos de protección fente a expulsiones, en tanto que obligación negativa depurada del mismo precepto: A saber, en la RF, el examen jurídico se restringe al apartado primero del artículo 8, sin entrar a considerar las circunstancias justificadoras del apartado segundo, lo que puede traducirse en un papel menos significativo del principio de proporcionalidad y, por ende, cierto desequilibrio a favor de los intereses estatales y menores posibilidades de defensa para los extranjeros — que, sin embargo, puede ser compensado a través de los diversos test que emplea el TEDH en el enjuiciamiento de las circunstancias concretas del caso. El examen secuencial seguido por el TEDH en materia de RF es, cuantitativa y cualitativamente, inferior al desplegado en el ámbito de las obligaciones negativas, de lo que, consecuentemente, se deduce un menor grado de escrutinio.

Siguiendo al propio TEDH, la RF incluye pues tanto los supuestos habituales de transnacionalidad -familiares extranjeros del residente legal que viven fuera del Estado parte y pretenden entrar en él a fin de reunirse con el reagrupante-, como los casos atípicos o fronterizos, en los que el derecho al respeto de la vida familiar se usa como plataforma para reclamar la concesión de un permiso inicial de residencia que regularice la situación de extranjeros que ya están viviendo en el Estado de acogida y cuentan con lazos familiares sólidos en el territorio de dicho Estado. A la vista de las altas tasas de irregularidad en algunos de los Estados parte, cabría deducir la importancia futura de este tipo de demandas ante el TEDH.

Por lo tanto, lo fundamental a efectos de esta distinción no es la permanencia del extranjero fuera o dentro del Estado parte, sino el carácter inicial de la autorización administrativa - bien sea un permiso de entrada o de residencia, previamente solicitado y denegado por las autoridades internas-, que habilitaría al extranjero para el desarrollo o mantenimiento de su vida familiar en el territorio del Estado contratante. Si el extranjero disfrutaba ya de un status de residente que le habilitaba para permanecer en el territorio del Estado miembro pero, por distintas circunstancias, éste es revocado por las autoridades estatales — con la consiguiente incidencia sobre su vida familiar-, los casos serán genéricamente calificados en atención a sus efectos como supuestos de expulsión, siendo examinados por el TEDH bajo la perspectiva de las obligaciones negativas emanadas del derecho al respeto de la vida familiar del artículo 8.1 CEDH. Estos últimos casos quedan fuera del análisis del presente trabajo.

Retomando el hilo de la sentencia Rodrigues da Silva, otra de sus aportaciones - tras dejar entrever los criterios de distinción entre obligaciones positivas y negativas en el contexto de la VF-, reside en la inclusión de nuevos factores jurisprudenciales que han de ser tenidos en cuenta en la valoración de las circunstancias concurrentes en supuestos de RF, a fin de extraer, en conjunción con el interés general, el alcance concreto de las obligaciones estatales. Junto a los criterios habituales -edad del menor y su situación en el país de origen, así como su dependencia respecto de sus progenitores-, el TEDH apunta otros, en directa relación con la irregularidad de la estancia de una de las demandantes:

"Los factores que han de ser tenidos en cuenta en este contexto son el grado de ruptura efectiva de la vida familiar, la extensión de los vínculos con el Estado contratante, si hay obstáculos insuperables para la reconstitución de la vida familiar en el país de origen de uno o más de los demandantes, si hay en juego factores de control migratorio (por ejemplo, un historial de incumplimientos del derecho migratorio), o consideraciones de orden público que apoyen la exclusión”"567.

567 Apartado 39 de la sentencia Rodrigues da Silva and and Hoogkamer c. Holanda, traducción propia. 
Algunos de estos criterios es la primera vez que ven la luz — pese a que su influencia se podía percibir en el razonamiento del TEDH - , tales como el grado en que la vida familiar es efectivamente fracturada como consecuencia de la medida estatal denegatoria de la residencia, cuyo origen se sitúa en la jurisprudencia emitida por este mismo Tribunal en materia de protección frente a expulsiones. También llama la atención la inclusión del test de la integración en el país de residencia - evaluar la extensión de los vínculos con el Estado contratante - sin que, paralelamente, se mencionen los lazos con el Estado de origen que, como vimos, constituía la doctrina dominante, junto con el test de los obstáculos, en la primera línea jurisprudencial relativa a la RF.

La tendencia parece apuntar, al menos por el momento, a un constante asentamiento de la línea jurisprudencial progresista iniciada en Sen. Sin embargo, el TEDH incluye expresamente factores de contrapeso a favor de los intereses estatales - control migratorio y consideraciones de orden público-, así como una concepción estricta del test de los obstáculos — que ahora exige la concurrencia de obstáculos de carácter insuperable para la vida familiar en el país de origen de alguno de los demandantes-. Estos últimos criterios, dirigidos a la protección del interés general del Estado demandado, están íntimamente relacionados con la contravención de las normas holandesas de extranjería por parte de una de las demandantes durante su larga estancia en dicho país.

Junto a ellos, el TEDH incluye por primera vez en el ámbito de la migración familiar un nuevo criterio de aplicación específica en los supuestos de RF de hecho, esto es, de peticiones de residencia por causa familiar formuladas por inmigrantes irregulares que están ya de hecho viviendo en el país de acogida.

"Además, otra importante consideración será si la vida familiar fue creada en una época en que las personas involucradas eran conscientes que el estatus migratorio de cualquiera de ellas era tal, que la persistencia de la vida familiar dentro del Estado de acogida era precaria desde el principio. La Corte ha sostenido previamente que, en tales casos, es probable que sólo en las más excepcionales circunstancias el rechazo del familiar extranjero constituya una violación del artículo 8 "568.

Dada la naturaleza de este tipo de supuestos, en los que subyace un incumplimiento del derecho migratorio, el TEDH sitúa este test en íntima conexión al test de la responsabilidad individual: a saber, si la creación de la vida familiar se produjo en una época en la que las personas afectadas eran conscientes del carácter irregular de su estatus migratorio, desembocando en la precariedad de la persistencia de su vida familiar en el Estado de acogida y, por ende, dando lugar a una muy baja probabilidad de que el TEDH declare la violación del art. $8 \mathrm{CEDH}$ en tales supuestos.

A tenor de esta doctrina, ante supuestos de RF de hecho, el principio general aplicable será su denegación jurisprudencial y la consiguiente emisión y/o ejecución de la orden de expulsión o exclusión del demandante en situación irregular — pues la misma tan sólo será constitutiva de violación del artículo 8 en las más excepcionales circunstancias. A sensu contrario, cabría afirmar que, si bien desde la sentencia Sen parecen discurrir buenos tiempos para la reunificación familiar de los extranjeros en el ámbito del Consejo de Europa, la excepción vendría representada cuando tal derecho sea solicitado para amparar la residencia de inmigrantes que se encuentran viviendo irregularmente en el territorio del Estado parte, sin que en principio quepa considerar que la elevada extensión temporal de dicha estancia pueda ser considerada como una circunstancia o factor atenuante.

La cuestión esencial que plantea este pronunciamiento es intentar descubrir indicios que nos permitan vislumbrar, pese al elevado casuismo que impregna las sentencias del TEDH, cuales sean

568 Idem, traducción propia. 
esas extraordinarias o excepcionales circunstancias que autorizan la protección del derecho a la reunificación familiar incluso de los inmigrantes irregulares, en cuyo caso la RF actuaría como vía para su regularización administrativa. Ello exige evaluar el enjuiciamiento que la Corte de Estrasburgo realiza sobre las concretas circunstancias que convergen en este supuesto.

En el análisis de las mismas, el Tribunal aplica en primer lugar el test de los vínculos de la primera demandante con su país de origen: A la vista de la edad a la que se trasladó a Holanda -22 años- deduce que incluso ahora, tras cinco años de estancia en el Estado parte, conserva fuertes lazos con Brasil. Posteriormente analiza las consecuencias que se producirían si se viera obligada a regresar a su país natal bajo la óptica del test de los obstáculos, con la novedad de que parecen equipararse los impedimentos de carácter puramente fáctico a los jurídicos. Para ello el TEDH se apoya expresamente en el razonamiento que llevó a los tribunales internos holandeses a denegar la tutela a la madre de la niña — un informe emitido por el Departamento de Cuidado y Protección Infantil, en el que se recomendaba que la menor permaneciese en Holanda, donde tenía lazos muy sólidos con sus abuelos paternos-.

Para evaluar las consecuencias del retorno de la madre a Brasil — dejando tras de sí en Holanda a su hija Rachael, a quien no puede llevarse por carecer de tutela sobre ella-, el Tribunal aplica los criterios habituales: la edad del menor afectado -3 años, la edad más baja hasta el momento de un menor implicado en un caso de reagrupación familiar ante el TEDH - y el consiguiente elevado grado de dependencia con su madre, así como sus fuertes vínculos con el Estado parte, especialmente con sus abuelos paternos. En aplicación del criterio del grado en que la vida familiar es efectivamente fracturada por la medida estatal, el TEDH concluye que la expulsión de la demandante a Brasil rompería los lazos con su hija, quien necesita a su madre, situación considerada insostenible ${ }^{569}$ en atención al interés primordial de la menor.

Tras observar que la primera demandante no ha incurrido en ningún delito y, pese a que no intentó en ningún momento regularizar su estancia en el Estado parte hasta después de tres años de su llegada al país, - elementos ambos que ocuparían un lugar destacado en la valoración de test de la responsabilidad individual, aunque con efectos simétricamente opuestos-, el Tribunal emite una importante doctrina de aplicación en supuestos que involucren a extranjeros ilegalmente asentados.

"El Tribunal reitera que aquellas personas que, sin cumplir con el derecho vigente, confrontan a las autoridades de un Estado parte con su presencia como un hecho consumado en dicho territorio, en general no tienen ningún derecho a esperar que les sea concedido un permiso de residencia" ${ }^{270}$.

Esta doctrina había sido avanzada por el propio TEDH con ocasión de una demanda en materia de RF —Chandra y otros v. Holanda ${ }^{571}$ —, planteada en 1999 por una mujer holandesa de origen indonesio y sus cuatro hijos también indonesios, en la que alegaban que el rechazo de las autoridades holandesas a conceder a los niños un permiso de residencia a fin de vivir con su madre en dicho país,

569 "The refusal of a residence permit and the expulsion of the first applicant to Brazil would in effect break those ties as it would be impossible for them to maintain regular contacts, which would be the more serious given that Rachael, who was only three years old at the time of the final decisión, needed to remain in contact with her mother". Apartado 41 de la sentencia Rodrigues da Silva and Hoogkamer c. Holanda.

570 STEDH Rodrigues da Silva, apartado 43, traducción propia.

571 En aquella ocasión, en un caso relativo a la admisión de una demanda de RF en circunstancias de irregularidad o RF de hecho, el TEDH afirmó que: "Having chosen not to apply for a provisional residence visa from Indonesia prior to travelling to the Netherlands, the applicants were not entitled to expect that, by confronting the Netherlands authorities with their presence in the country as a fait accompli, any right of residence would be conferred on them". Decision as to the Admissibility of Application No. 53102/99 by Roslina Chandra and Others v. the Netherlands, 13 May 2003. 
constituía una interferencia en su derecho al respeto a la vida familiar. Dicha demanda fue inadmitida por el TEDH, atendiendo a que los hijos fueron en principio introducidos en Holanda por su madre con el fin de visitarla y finalmente permanecieron allí de forma ilegal tras la expiración del visado de turista.

Con ello, el TEDH reafirma el principio general que había adelantado en párrafos precedentes de esta sentencia, de aplicación en los supuestos de RF de hecho: su concesión tan sólo será obligatoria para el Estado parte en las más excepcionales circunstancias ${ }^{572}$.

En vista de la contundencia de esta doctrina, cabría prever un desventurado pero lógico final para la historia de Rachael y su madre en Holanda. Sin embargo, el previsible peso de las Recomendaciones previamente analizadas y del viraje jurisprudencial en el que el TEDH se haya inmerso, es de tal calibre que, sorprendentemente, la Corte concluye la existencia de violación del artículo 8 por parte del Estado holandés. Para que ello sea posible, introduce una serie de consideraciones de importancia capital para nuestra tesis, pues será en ellas donde descubriremos resquicios favorables a la reagrupación familiar que actúen a modo de excepciones al principio general aplicable en esta materia.

\begin{abstract}
"Sin embargo, la Corte encuentra relevante que, en el presente caso, el gobierno indicó que la residencia legal en Holanda habría sido posible sobre la base de la relación duradera que la primera demandante y Mr. Hoogkamer mantuvieron entre junio de 1994 y enero de 1997. Aunque no hay duda que puede ser hecho un serio reproche a la actitud indolente de la primera demandante hacia las normas migratorias holandesas, este caso debe distinguirse de otros en los que la Corte estimó que las personas involucradas no habrían podido esperar razonablemente en ningún momento haber podido continuar su vida familiar en el Estado de acogida" ${ }^{573}$.
\end{abstract}

A tenor de lo anterior, en supuestos de estancia irregular en el territorio de un Estado parte, será un elemento relevante a favor de los intereses del extranjero demandante que, en cualquier momento a lo largo de su permanencia en el Estado miembro, haya podido acceder a un estatus regular —en este caso, como consecuencia de la relación estable que la madre de Rachael mantenía por entonces con un ciudadano holandés. La posibilidad de haber podido solicitar la residencia por encajar en alguno de los motivos habilitantes reconocidos al efecto por las legislaciones migratorias internas - aun cuando dicha solicitud nunca haya llegado a formalizarse-, daría lugar al surgimiento de una expectativa razonable para el extranjero irregular de poder continuar con su vida familiar en el territorio del Estado de acogida, al serle reconocido su derecho a la RF. Habría que distinguir pues este caso, de aquellos en los que el extranjero entra o permanece de forma irregular en el Estado receptor sin en ningún momento encajar en tales supuestos.

De hecho, tal y como afirma el TEDH, conceder una importancia suprema al hecho de la estancia irregular del demandante, sin más consideraciones, supondría, por parte de las autoridades estatales, incurrir en un excesivo formalismo ${ }^{574}$.

572 Vid. Apartado 39 STEDH Rodrigues da Silva.

573 Ídem, traducción propia.

574 THYM ha señalado la incorrección en que incurre el TEDH en este apartado. El autor explica que con esta argumentación, la Corte de Estrasburgo está haciendo referencia implícita al case law del Tribunal Europeo de Justicia, en torno al ejercicio de la libre circulación bajo el Tratado de la Unión Europea — argumento al cual el TEDH había explícitamente acudido en una sentencia emitida tres semanas antes a Rodrigues da Silva, el asunto Ariztimuno Mendizabal. Sin embargo, dado que en Rodrigues da Silva la primera demandante es una ciudadana de un tercer Estado en situación irregular y que no disfrutaría de las libertades comunitarias, Thym denuncia que en este razonamiento el TEDH "confunde la diferencia fundamental existente entre ambas situaciones. Mientras los ciudadanos comunitarios ostentan una libertad fundamental directamente ejercitable a asentarse en otro Estado miembro, 


\begin{abstract}
"En vista de las consecuencias de largo alcance que una expulsión provocaría sobre las responsabilidades que la primera demandante tiene como madre, así como sobre su vida familiar con su joven hija, y teniendo en cuenta que, en atención al interés superior de Rachael, lo mejor es que la primera demandante permanezca en Holanda, la Corte considera que, en las particulares circunstancias del caso, el bienestar económico del país no está por encima de los derechos de las demandantes bajo el artículo $8 \mathrm{CEDH}$, a pesar del hecho de que la primera demandante estuvo residiendo ilegalmente en Holanda en la epoca en que nació Rachael. De hecho, puede considerarse que, al otorgar suma importancia a este último elemento, las autoridades han incurrido en un excesivo formalismo"s75.
\end{abstract}

Todo ello lleva al TEDH a estimar que las autoridades holandesas no han mantenido un justo equilibrio entre los intereses en juego y, por consiguiente, a apreciar la violación del artículo 8, incluso en un supuesto donde la situación irregular de una de las demandantes reclamaba un actitud muy prudente y respetuosa hacia la soberanía estatal por parte del Tribunal de Estrasburgo.

A la vista de la doctrina pionera formulada en esta sentencia, cabe extraer, si quiera de forma provisional, las siguientes conclusiones:

1. Consolidación a nivel jurisprudencial del derecho a la reagrupación familiar de los extranjeros, incluso en concurrencia de una circunstancia agravante y hasta el momento inédita -el carácter irregular de la estancia de una de las demandantes-, que podría haber llevado al TEDH a su denegación, en aplicación de su propia jurisprudencia previa — donde la condición regular de la estancia en el reagrupante había sido un requisito esencial para poder optar a la $\mathrm{RF}-$.

Para valorar en su justo extremo la importancia de este avance jurisprudencial, debe tenerse en cuenta que, a nivel interno, la exigencia de regularidad administrativa en el reagrupante constituye una exigencia constante. En consecuencia, aunque formalmente el TEDH sigue aproximándose a la migración familiar sobre el presupuesto del respeto a la soberanía estatal y al margen de apreciación que rige estas cuestiones, del examen detenido de su jurisprudencia se extrae una más que notable contención del margen de apreciación existente a la hora de regular las condiciones de entrada y permanencia de extranjeros por motivos de RF. Además, el mero hecho de que la jurisprudencia de Estrasburgo contemple la posibilidad de excepcionar en supuestos muy tasados la exigencia de residencia legal — derrumbando con ello un pilar incuestionable del derecho migratorio interno-, constituye, a nuestro juicio, la prueba más evidente del nivel de consolidación conseguido por esta rama jurisprudencial. Sin embargo, esta circunstancia no ha llamado apenas la atención de la doctrina mayoritaria, que sigue negando la posibilidad de deducir un derecho a la RF de la vida familiar consagrada en el art. $8 \mathrm{CEDH}$.

2. En este supuesto se aprecia la concurrencia de dos factores esenciales que han determinado la protección de los intereses del individuo frente al Estado.

a. Por primera vez de forma explícita, el Tribunal se basa en el interés superior del menor como factor primordial a la hora de evaluar las circunstancias del caso y el justo equilibrio entre los intereses mantenido por el Estado demandado - si bien en ello influyó, y mucho, que esta circunstancia hubiera sido tenida en cuenta por las propias autoridades internas holandesas, tanto judiciales como administrativas, a la hora de conceder la tutela sobre la menor al padre, a fin de posibilitar la permanencia de la niña en Holanda-. Este criterio,

Ms Rodrigues da Silva nuna había sido autorizada a residir en Holanda y es el propio TEDH quien le concede tal derecho. Es obvio que la conclusión del TEDH no es satisfactoria desde el punto de vista de la política migratoria”. THYM, Daniel. "Respect for Private and Family Life under Article 8 ECHR in Immigration cases: A Human Right to Regularize Illegal Stay?", op. cit., p. 102, traducción propia.

575 STEDH Rodrigues da Silva c. Holanda. Apartado 44. 
subyacente en el razonamiento desplegado por el TEDH desde la sentencia Sen, había sido contundentemente proclamado por las Recomendaciones del Comité de Ministros y de la Asamblea Parlamentaria. Ahora se cuela $-\mathrm{y}$, a juzgar por la importancia que se le concede en este caso, parece que con carácter definitivo y explícito-, en los casos relativos a la reunificación familiar de los extranjeros que involucren a menores. En esta sentencia el criterio del interés superior del menor constituye un elemento muy relevante que ha de considerarse al evaluar el test de los obstáculos. Cabe señalar el avance que ello supone pues se trata de un criterio que desempeña un papel esencial en todos los procesos que afecten a menores, tanto a nivel interno como internacional.

b. En descarga de la primera demandante, inmigrante irregular en Holanda, influyó de forma decisiva la circunstancia de que, al inicio de su estancia en el Estado de acogida, habría podido optar a la residencia legal - si bien en ese momento no la solicitó y, cuando lo hizo, ya no encajaba en el supuesto de hecho habilitante, por haber finalizado su relación sentimental con un ciudadano holandés.

3. Pese a todo lo dicho, sigue vigente como principio general aplicable a inmigrantes irregulares la no concesión de la residencia solicitada a efectos de reunificación familiar, salvo que concurran circunstancias excepcionales. Si bien, cabría cuestionar su contundencia, en vista de que el propio TEDH afirma que no debe concederse una suprema importancia al hecho de la estancia ilegal de uno de los demandantes ${ }^{576}$, de lo que cabría deducir que es un elemento más, dentro de los que deben ser tomados en consideración en el análisis del justo balance entre los intereses concurrentes.

4. Como circunstancias excepcionales que podrían llevar a determinar la protección del derecho a la RF, incluso en situaciones de irregularidad administrativa -o RF de hecho-, cabría considerar las siguientes:

a. Inexistencia de incumplimientos previos de las normas de extranjería e inmigración por parte del inmigrante irregular - así como de un historial delictivo en el Estado de acogida, pues de ser así, se encuadraría en principio como un supuesto de obligación negativa-;

b. Existencia de hijos nacidos y criados enteramente en el Estado parte, carentes de vínculos con el país de origen de sus padres;

c. Interés superior del menor: Si éste tiene fuertes vínculos con el Estado de acogida, mayor será la probabilidad de que el TEDH aprecie violación del derecho, a fin de permitir el desarrollo de su vida familiar en el territorio del Estado parte. En la valoración de este factor cabe suponer que pesen los informes y decisiones adoptadas al efecto con carácter previo por las autoridades estatales internas;

d. Edad del menor y su grado de dependencia con respecto a sus padres, en relación inversamente proporcional a las posibilidades de concesión de la reunificación familiar.

e. Finalmente, si el inmigrante pudo optar en algún momento a un estatus legal en el Estado de acogida - pese a que no lo llegara a solicitar-, será un elemento relevante que puede inclinar la balanza, en conjunción con alguno/s de los anteriores, a favor de los intereses particulares, frente al interés estatal de controlar sus fronteras y luchar contra la inmigración irregular.

5. Tales circunstancias excepcionales son de carácter relativo y su peso específico resulta difícil de anticipar en abstracto, pues dependerá de la ponderación efectuada por el TEDH en función de 
las particularidades fácticas del caso. Por lógica, cabe conjeturar que cuantas más concurran, mayor será su eficacia para enervar el principio general aplicable a los supuestos de inmigración familiar sobre la base de la irregularidad de la estancia de alguno de los miembros de la familia.

Si este pronunciamiento se sitúa en perspectiva, dentro del conjunto del acervo jurisprudencial emitido por el TEDH en el ámbito de migración familiar, no cabe sino concluir que la Corte de Estrasburgo está embarcada en una línea de decidido y valiente activismo judicial ${ }^{577}$ en pro de la familia de los inmigrantes, incluyendo los supuestos de irregularidad. Conviene recordar que, hasta la emisión de Rodrigues da Silva, una condición esencial e incuestionada esgrimida por el TEDH para que se activara la protección que la vida familiar dispensaba sobre la reagrupación familiar de los extranjeros, había sido el carácter legal del asentamiento del inmigrante en el territorio del Estado parte. Ello nos da idea del descomunal avance que supone esta sentencia, pues "ilustra el potencial del artículo 8 para efectivamente conceder a inmigrantes ilegales un derecho a regularizar su estancia ilegal" 578 . Por ello, desde la doctrina se ha subrayado que este pronunciamiento, al indicar las condiciones que habilitan para conceder permisos de residencia a fin de regularizar la situación de inmigrantes irregulares que han permanecido en el Estado parte de acogida durante largos períodos en dicha situación, "representa la última frontera que la Corte explora al tratar con las implicaciones prácticas del artículo 8 en su aplicación a inmigrantes ${ }^{579 "}$.

De otro lado, resulta patente en esta sentencia la voluntad de la Corte de Estrasburgo de sistematizar y clarificar los criterios que rigen la naturaleza de las obligaciones convencionales en el ámbito migratorio, aportando luz sobre una materia que, desde sus inicios, ha estado dotada de un alto grado de confusión y ambigüedad. Al mismo tiempo que la Corte emprendía avances decididos en su aproximación al ámbito de la migración familiar, hacía lo propio en materia de protección contra expulsiones ${ }^{580}$, por lo que se ha destacado que ambas ramas jurisprudenciales "ilustran la voluntad de la Corte de construir un case law coherente, que facilite la aplicación autónoma del art. 8 CEDH por parte de los tribunales internos" 581 .

577 En la misma línea se sitúa Daniel THYM, quien subraya la existencia de "un renovado activismo de la Corte en el campo de la inmigración", que "reaviva la tensión inherente entre la efectiva protección de los derechos humanos y el legítimo objetivo de los Estados partes de controlar la inmigración 'como un asunto de bien establecido derecho internacional"', recurriendo a las propia argumentación secularmente empleada por el TEDH para abordar los casos migratorios. "Respect for Private and Family Life under Article 8 ECHR in Immigration cases: A Human Right to Regularize Illegal Stay?”, op. cit., p. 102, traducción propia.

578 THYM, Daniel. “Respect for Private and Family Life under Article 8 ECHR in Immigration cases..., op. cit., p. 101. En esta misma línea - y subrayando asimismo la entidad del avance jurisprudencial que supone la doctrina emitida por el TEDH en esta sentencia-, Roagna ha señalado que "el potencial del artículo 8 para asegurar a residentes ilegales de larga duración el derecho a regularizar su posición, fue puesto de relieve en Rodrigues da Silva y Hoogkamer" ROAGNA, Yvana. Protecting the Right to respect for Private and Family LIfe under the European Court of Human Rights. Strasbourg, Council of Europe Human Rights Handbooks, 2012, p. 90.

579 ROAGNA, Yvana. Protecting the Right to respect for Private and Family LIfe under the European Court of Human Rights, op. cit., p. 90.

580 Vid. Asunto Boutlif, y el amplio comentario que en torno a la sistematización de los ocho criterios jurisprudenciales que rigen las expulsiones y deportaciones de extranjeros acometida por esta sentencia, en MORANO, Sonia y ANDREADAKI, Stelios. "The convergence of the European Legal System in the treatment of Third Country Nationals in Europe: the CJEU and ECtHR jurisprudente”, op, cit., pp. 17-20. En idéntico sentido se expresa Roagna, al indicar que "the potential of Article 8 in securing long-term illegal residents the right to regularise their position was highlighted in Rodrigues da Silva and Hoogkamer". ROAGNA, Yvana. Protecting the Right to respect for Private and Family LIfe under the European Court of Human Rights, op. cit., p. 91.

581 Idem, p. 20. 


\subsection{Sentencia Konstatinov contra Holanda, de 26 de abril de 2007}

Poco después de un año tras la sentencia Rodrigues da Silva, el TEDH vuelve a enfrentarse a un supuesto que conjuga la migración familiar con la irregularidad de la estancia. De forma más acusada que en Rodrigues da Silva, nos encontramos ante un caso limítrofe entre la RF y la expulsión, sobre la base del derecho al respeto de la VF de los extranjeros.

Los hechos que dieron lugar a la demanda son los siguientes: La demandante, Ms. Jadranka Konstatinov, nació en Serbia en la época en que este país formaba parte de la ex República Federal Socialista de Yugoslavia, de donde era ciudadana. Tras la muerte de su madre, siendo todavía una niña, dejó Serbia junto a su padre y, a la edad de 22 años, contrajo matrimonio con Mr. G., ciudadano de nacionalidad desconocida que había nacido en Roma pero vivía en Holanda con un permiso de residencia. Un año después de su matrimonio, la demandante es expulsada de Holanda a Alemania por razones sin especificar y, al poco tiempo, a Mr. G se le concede un permiso de residencia permanente, tras lo cual la demandante solicita a las autoridades holandesas un permiso de residencia a fin de poder permanecer con su pareja en Holanda. La petición es rechazada debido a que el marido no llegaba al ingreso mínimo requerido al efecto por las normas migratorias.

En 1989 la pareja tiene un niño en Holanda y al año siguiente la madre se ve obligada a salir del país, regresando poco después para casarse nuevamente con su pareja, pero esta vez conforme a las normas civiles holandesas. Tras la boda, y portando un pasaporte serbio, solicita nuevamente un permiso de residencia para permanecer en Holanda con su esposo, pero su petición es extraviada y no es atendida sino hasta siete años después de haber sido formulada. Durante dicho período la demandante es condenada en seis ocasiones por delitos de robo y hurto, cumpliendo distintas penas de prisión.

Su solicitud de residencia es finalmente rechazada en base a tres motivos principales: la demandante carecía desde el principio del visado de residencia provisional emitido por las autoridades diplomáticas o consulares holandesas en su país de origen, esto es, había residido irregularmente en Holanda; la insuficiencia de ingresos de su marido; y por consideraciones de orden público, como consecuencia del historial delictivo de la demandante. Aunque lo intentó, la demandante no pudo acogerse a la denominada política de tres años, en virtud de la cual si un permiso de residencia no era resuelto en dicho período por causas no imputables al peticionario, el gobierno holandés procedería a su concesión, siempre que no existieran razones en contra, tales como antecedentes criminales. En la misma decisión, las autoridades holandesas declaran a la demandante extranjera indeseable, declaración que conllevaba una orden de exclusión del país por un período de cinco años. Ante la petición de la demandante, se adopta como medida provisional el aplazamiento de la expulsión hasta la decisión final del recurso. Durante ese período, la demandante acumula varias condenas más por robo. El agotamiento de las vías internas concluye con el rechazo de la petición de residencia y la declaración de Ms. Jadranka como extranjera indeseable. Pese a ello, la recurrente continúa viviendo en Holanda, aunque en paradero desconocido, mientras que a su hijo se le concede un permiso de residencia a fin de que pueda quedarse en Holanda con su padre.

Que estamos ante un caso de difícil clasificación queda patente en la forma en que la demandante se dirige ante el TEDH, alegando que su expulsión de Holanda constituye una interferencia injustificada en su derecho al respeto de su vida privada y familiar ${ }^{582}$, reconocido en el artículo 8

582 STEDH Konstatinov v. The Netherlands, 26 April 2007. Apartado 34. 
CEDH. La demanda se plantea pues en términos de obligación negativa, contemplando la medida estatal impugnada - la expulsión, a juicio de los demandantes-, como una injerencia de la que el Estado parte debería haberse inhibido.

El TEDH, tras reiterar que los principios aplicables a las obligaciones positivas y negativas derivadas del respeto a la VF son similares, estima innecesario situar la medida impugnada en una de dichas rúbricas ${ }^{583}$. Y aquí reside un tímido avance jurisprudencial pues, por primera vez, el Tribunal se rinde a la evidencia y rehúsa calificar la medida impugnada como una obligación negativa - injerencia - o positiva - incumplimiento del deber positivo de admitir a un no nacional-. Como habíamos apuntado en varias ocasiones, esta clasificación producía escasos resultados y era más bien origen de múltiples confusiones terminológicas.

Sin embargo - y en clara contradicción con lo expuesto-, en cuanto tiene ocasión, la Corte sitúa implícitamente este caso dentro de los supuestos de reunificación familiar y cambia la terminología usada por la demandante, ya que la medida impugnada no es la expulsión, sino el rechazo de su permiso de residencia ${ }^{584}$. A partir de este momento, el Tribunal aplicará al análisis del caso el tratamiento propio de las obligaciones positivas, reduciendo su examen al apartado primero del artículo 8, sin entrar a considerar la posible justificación de la injerencia desde la perspectiva del apartado segundo de dicho precepto.

Pese a ello, la inserción de este caso dentro del ámbito de la RF, supone una confirmación de la doctrina en torno al deslinde entre obligaciones positivas y negativas en el ámbito migratorio, que el TEDH estableciera previamente, en el apartado 38 de la sentencia Rodrigues da Silva: La medida impugnada para el Tribunal es la denegación de un permiso de residencia en la que simultáneamente se declaraba a la recurrente extranjera indeseable y que, por ello, implicaba una orden de exclusión del país. De haberle sido concedido dicho permiso por las autoridades holandesas, hubiera sido el primero disfrutado hasta el momento por la demandante. El carácter inicial del mismo determina pues su inclusión dentro de la RF, pese a que la demandante estuviese ya dentro del territorio del Estado parte receptor.

A lo largo de esta sentencia tenemos ocasión de asistir a una aplicación sin fisuras de la doctrina formulada por el TEDH en el caso Rodrigues da Silva. De este modo, se repiten literalmente los prin-

583 "As the applicable principles are similar, the Court does not find it necessary to determine whether in the present case the impugned decisions, namely the refusal to grant the applicant - who has never lawfully resided in the Netherlands- a residence permit and to declare her an undesirable alien, constitutes an interference with her exercise of the right to respect for her family life or is to be seen as one involving an allegation of failure on the part of the respondent State to comply with a positive obligation". Apartado 47 de la sentencia konstatinov contra Holanda.

584 Respecto a las alegaciones de las partes implicadas, la demandante se basa, en primer lugar, en la existencia de fuertes vínculos con el Estado de acogida — donde lleva 21 años viviendo y donde se casó, nació y ha criado a su hijo, hablando la lengua holandesa. Tanto su hijo como su marido ostentan permisos de residencia holandeses. Adicionalmente, declara que carece de vínculos con su Estado de origen, del que salió con sólo siete años de edad y ni siquiera habla la lengua de la ex Yugoslavia. Para descargar el test de la responsabilidad individual, justifica su historial delictivo en Holanda aduciendo que la familia pasaba por graves dificultades financieras. Así mismo, subraya las gravosas consecuencias que la expulsión tendría sobre su vida familiar, que se desarrolla enteramente en Holanda, donde además residen la madre y los seis hermanos de su marido, vínculos que son de particular importancia para la cultura romaní de la que procede. Finalmente, considera que existen obstáculos para regresar a su país de origen con su familia, debido a que su nacionalidad es incierta y a que su hijo padece asma desde su nacimiento. Por su parte, el gobierno demandado se basa fundamentalmente en el test de la responsabilidad individual -esto es, en la estancia ilegal de la demandante en Holanda, donde en ningún momento ha reunido las condiciones para poder acceder a un estatus legal y donde, además, ha acumulado varios delitos que la inhabilitan aún más para su consecución-, y en la inexistencia de obstáculos para la reconstitución de la familia en Serbia, ya que considera la alegación de apatridia de la recurrente como una mera conjetura que no ha quedado en ningún momento demostrada. 
cipios aplicables a esta materia, así como los factores ${ }^{55}$ que deben ser tenidos en cuenta por el Estado a la hora de mantener un balance entre los intereses en juego, junto con el principio general ${ }^{586}$ que ha de regir cuando están en juego situaciones de extranjería irregular. Todos ellos son una extracción literal de la doctrina sentada en Rodrigues da Silva ${ }^{587}$. Primero son enunciados en abstracto para, posteriormente, ser aplicados a las circunstancias concretas que concurren en Konstatinov.

De este modo, en la evaluación de las circunstancias del caso, dos son los test convencionales usados por el TEDH, en aplicación directa de los criterios introducidos en Rodrigues da Silva:

1. Test de la Responsabilidad individual, enfatizando el carácter irregular de la estancia de la demandante en Holanda y la consiguiente fragilidad del mantenimiento de su vida familiar en dicho país.

"La Corte señala que la demandante nunca ha disfrutado de una autorización provisional de entrada o de residencia y que las relaciones en las que se basa fueron creadas en una época y desarrolladas durante un período en que las personas involucradas eran conscientes de que el estatus migratorio de la demandante era precario y que (...) la persistencia de la vida familiar dentro de Holanda se volvería precaria”s88.

El retraso en que incurrieron las autoridades holandesas al resolver la solicitud de residencia no descarga a la demandante de su responsabilidad, dado que ésta nunca reunió los requisitos exigidos para su concesión, fundamentalmente debido a la insuficiencia de salario del marido. Al hilo de esta observación, el TEDH realiza por primera vez una importante reflexión sobre las exigencias económicas establecidas tanto por los Estados parte como a nivel comunitario, como condicionante para el ejercicio de la reagrupación familiar.

"En principio, la Corte no considera irrazonable el requisito de que un extranjero que haya adquirido un estatus estable en un Estado contratante y que busque la reunificación familiar, tenga que demostrar poseer ingresos suficientes, independientes y duraderos, no considerados beneficios sociales, para proveer a los costos básicos de subsistencia de los miembros de su familia con quienes pretende reunirse" 589 .

Como principio general, la Corte avala la razonabilidad de la exigencia interna de supeditar la concesión de la RF al cumplimiento de ciertos requisitos económicos, siempre que éstos sean de carácter básico - en el sentido de no excesivamente gravosos-, y garanticen que el extranjero podrá afrontar — de forma independiente a los beneficios concedidos por la asistencia pública—, los gastos de mantenimiento de su familia.

Con la referencia explícita a la razonabilidad ${ }^{590}$ de este tipo de medidas, el Tribunal está evaluando la legitimidad de un límite muy habitual —en este caso de carácter material o económico-,

585 "Factors to be taken into account in this context are the extent to which family life is effectively ruptured, the extent of the ties in the Contracting State, whether there are insurmountable obstacles in the way of the family living in the country of origin of one or more of them and whether there are factors of immigration control (for example, a history of breaches of immigration law) or considerations of public order weighing in favour of exclusion". Apartado 48, STEDH Konstatinov contra Holanda.

586 "Another important consideration will also be whether family life was created at a time when the persons involved were aware that the immigration status of one of them was such that the persistence of that family life within the host State would be precarious from the outset. The Court has previously held that where this is the case it is likely only to be in the most exceptional circumstances that the removal of the non-national family member will constitute a violation of Article 8". Idem.

587 El apartado 48 en su integridad es idéntico al apartado 39 de la STEDH Rodrigues da Silva.

588 Apartado 49 de la sentencia Konstatinov contra Holanda, traducción propia.

589 Ídem, apartado 50, traducción propia.

590 Cabe señalar que la razonabilidad supone, para el Tribunal que la aplique, menores exigencias que el principio de proporcionalidad, ya que para que un acto de los poderes públicos restrictivo de un derecho fundamental se estime razonable se requiere que "se ajuste a los cánones de sentido común generalmente admitidos, no que dichos actos 
impuesto al ejercicio de un derecho que la propia Corte entiende como fundamental - el respeto a la vida familiar - en cuyo contenido se inserta implícitamente la reagrupación familiar. Sobre esta materia ya se había pronunciado en el mismo sentido la Recomendación de la Asamblea Parlamentaria ${ }^{591}$, sugiriendo que los requisitos económicos exigidos no fueran excesivos, a fin de evitar el vaciamiento del derecho. En su aplicación concreta al caso Konstatinov, el TEDH estima razonable la exigencia contenida en la normativa migratoria holandesa, dado que el marido de la demandante “nunca alcanzó ni se esforzó por alcanzar" ${ }^{592}$ el salario mínimo exigido por la legislación holandesa, para hacer frente a los costes básicos de subsistencia de su familia.

De otro lado - y en sede de valoración del canon de responsabilidad individual—, el Tribunal tiene en cuenta el historial delictivo en Holanda de la recurrente, que otorga aún mayor inestabilidad a su estatus migratorio y a la continuidad de su vida familiar en el Estado parte. El TEDH formula una doctrina de aplicación específica a casos fronterizos - cuyas raíces se remontan a la jurisprudencia emitida en materia de obligaciones negativas migratorias-, reconociendo, como principio general que rige la admisión de extranjeros, el derecho de los Estados parte a expulsar a un extranjero condenado por delitos penales ${ }^{593}$. Cita la sentencia Üner contra Holanda, ya señalamos que, de forma similar a Rodrigues da Silva, había sistematizado los criterios jurisprudenciales que rigen en materia de protección frente a actos de expulsión que amenazan la vida familiar de los extranjeros.

Dado que el TEDH se refiere explícitamente a los casos en que el Estado ha de valorar si admite a dicho extranjero, parece encuadrar la aplicación de este principio en los que hemos considerado casos fronterizos entre la RF y la expulsión - de lo contrario no cabría la expulsión y se hablaría simplemente de denegación de entrada. Esta doctrina parece supeditarse por ello a casos de concesión inicial de un permiso de residencia que involucre a extranjeros irregulares que cuenten con antecedentes penales, supuesto en donde sería legítima su expulsión. O, más concisamente, a supuestos en los que se valore conceder la RF de hecho a un extranjero que haya delinquido dentro del territorio del Estado parte. Pero, en los casos típicos de expulsión, -que exigen la previa retirada del estatus legal de residente-, el Estado habrá de tener en cuenta factores adicionales tales como el tiempo de residencia, la gravedad del delito, el grado de consolidación de la vida familiar del afectado en el país de acogida... etc, que rigen las obligaciones negativas en el ámbito migratorio.

1. Test de los Obstáculos, aplicado según la concepción estrita establecida en Rodrigues da Silva: el TEDH ha de evaluar la inexistencia de obstáculos "insuperables" - incluyendo tanto los de

sean gravosos para el particular en el menor grado posible". DÍEZ PICAZO, L. M. Sistema de derechos fundamentales, op. cit., p. 110.

591 Inciso a) del punto III del apartado 12 de la Recomendación 1868 (2004) de la Asamblea Parlamentaria. Movilidad humana y derecho a la RF.

592 "As to the question whether such a requirement was reasonable in the instant case, the Court considers that it has not been demonstrated that, between 1990 and 1998, Mr G. has in fact ever complied with the minimum income requirement or at least made any efforts to comply with this requirement whereas the applicant's claim that he is incapacitated for work has remained wholly unsubstantiated". Apartado 50 in fine, STEDH Konstatinov contra Holanda.

593 Sobre este punto, la Corte de Estrasburgo afirma: "The Court further notes that, (...), the applicant has amassed various convictions of criminal offences attracting a prison sentence of three years or more, thus rendering her immigration status in the Netherlands even more precarious as this entailed the risk of an exclusion order being imposed, which risk eventually materialised. On this point the Court reiterates that, where the admission of aliens is concerned, Contracting States are in principle entitled to expel an alien convicted of criminal offences". Idem, apartado 51 . 
carácter fáctico como jurídicos—, para el ejercicio de la vida familiar fuera del Estado de acogida demandado ${ }^{594}$.

En este punto, el TEDH considera relevante la proximidad a la mayoría de edad del hijo de la demandante. En estas circunstancias, para acceder a la protección que dispensa el artículo 8.1, el TEDH recurre a la aplicación de la doctrina sentada para proteger a extranjeros objeto de medidas de expulsión, exigiendo elementos adicionales de dependencia respecto de sus progenitores, que vayan más allá de los vínculos emocionales normales.

"La Corte apunta que el hijo de la demandante alcanzará pronto la mayoría de edad, en abril de 2007, de modo que, conforme a case law consolidado en materia del art. $8 \mathrm{CEDH}$, las relaciones entre parientes adultos no necesariamente atraen la protección del artículo 8, exigiendo elementos adicionales de dependencia que vayan más allá de los lazos emocionales normales" ${ }^{395}$.

El asma que el hijo padece y que fue alegada por su madre como un obstáculo para la reconstitución de la vida familiar en el Estado de origen, no es considerado como tal elemento adicional de dependencia. Además, el Tribunal no otorga credibilidad a la supuesta apatridia de la recurrente, lo que se traduce en la ausencia de impedimentos para continuar con su vida familiar en el país de origen $^{596}$.

Todas las consideraciones apuntadas, llevan al Tribunal a determinar por unanimidad la inexistencia de violación del artículo $8 \mathrm{CEDH}$. A modo de resumen, y en vista de las conexiones que existen entre este caso y el asunto Rodrigues da Silva, conviene no perder de vista que en el asunto Konstatinov confluyen dos circunstancias agravantes para la reunificación - de carácter totalmente opuesto a las que habíamos analizado en Rodrigues da Silva como condiciones extraordinarias que podrían dar lugar a la protección del derecho-:

1. De un lado, la demandante ha residido todo el tiempo en situación irregular — casi veintiún años en Holanda en total desde su entrada en el país, hasta el agotamiento de las instancias internas - y nunca a lo largo de todo ese tiempo ha podido optar a un estatus legal: su marido no cumplía los requisitos exigidos por la normas internas y la única vía posible de regularización - la denominada política de tres años-, había quedado excluida como consecuencia de su historial delictivo.

2. De otro lado, la acumulación de delitos en el Estado parte, que sitúan a este caso en una zona muy próxima a los supuestos de expulsión, en los que el interés individual no se enfrenta únicamente al interés estatal de controlar la inmigración y el gasto público - genéricamente subsumido en el "bienestar económico del país" - , sino también al interés general de protección del orden público y prevención del delito. Esta situación provoca un punto de partida de claro escoramiento en favor de los intereses estatales, como corresponde al principio general vigente en los supuestos de RF de hecho.

594 En palabras del propio Tribunal, el test de los obstáculos consiste en resolver la cuestión de "Si hay obstáculos insuperables para el ejercicio de la vida familiar fuera de Holanda"

595 Apartado 52 sentencia Konstatinov, traducción propia.

596 Antes de emitir su fallo, el TEDH precisa la naturaleza temporal de la orden de exclusión implícita a la declaración de la demandante como extranjera indeseable que las autoridades holandesas emitieron simultáneamente a la denegación de su residencia, especificando que no constituye una exclusión permanente del país: "In any event, the decision to declare the applicant an undesirable alien does not entail a permanent exclusion order, but an exclusion order of a temporary validity in the sense that — at the applicant's request - it can be lifted after a limited number of years of residency outside of the Netherlands". Idem, apartado 52. 
Cabría pues extraer una conclusión clara: En aquellas situaciones en las que a la situación de irregularidad de un inmigrante se aúne un comportamiento delictivo por parte de éste, las posibilidades de concesión del derecho a la reunificación familiar amparándose en su vida familiar ya constituida dentro del Estado parte receptor, son extraordinariamente limitadas, casi nulas. En tales supuestos el principio general aplicable será el derecho legítimo que asiste al Estado de acogida a denegar el ejercicio del derecho a la RF en su territorio, expulsando del mismo a dicho inmigrante.

Cabría destacar, a modo de cierre que los intereses en conflicto, tal y como quedan delimitados por el propio $\mathrm{TEDH}^{597}$, confirman la delgada línea que separa la $\mathrm{RF}$ - en estos supuestos limítrofes-, respecto de los casos de expulsión: Ya no está en juego únicamente el bienestar económico del país y el control migratorio (subsumido siempre dentro del anterior); junto a éste, respaldan al Estado demandando la protección del orden público y la prevención del delito (art. 8.2). La oscuridad terminológica que habíamos denunciado en sentencias previas, es aquí más aguda, dado que este supuesto, al aunar irregularidad junto con comisión de delitos, incrementa las dificultades de deslinde entre las tipologías tradicionales - positiva/negativa-. Todo ello es especialmente oportuno si además se tiene en cuenta que, aunque el propio TEDH considera innecesaria la clasificación de la medida estatal impugnada, sin embargo en la práctica ha enfocado su análisis dentro de las obligaciones positivas y, como tal, ha vuelto a eludir el análisis del apartado segundo del artículo octavo. Dada la coincidencia existente entre las restricciones legítimas que este supuesto guarda con las obligaciones negativas, no se entiende que el Tribunal haya obviado el examen del artículo 8.2 $\mathrm{CEDH}$ - aun cuando dicho análisis no hubiera cambiado en nada el atinado juicio al que llegó la Corte en este caso-.

En consecuencia, las críticas que en su momento adelantamos en torno a la menor intensidad del escrutinio desplegado por la Corte de Estrasburgo en materia de migración familiar, se vuelven más pertinentes en aquellos supuestos que, por su gran proximidad al ámbito de las obligaciones migratorias negativas, merecerían la aplicación de idénticos parámetros de enjuiciamiento. La explicación parece residir en el íntimo convencimiento de que, cuando está en juego un permiso de residencia de carácter inicial, las obligaciones del Estado parte con respecto a dicho extranjero aun cuando éste ya se encuentre dentro de su territorio-, son de menor entidad, que cuando el no nacional ya ha disfrutado de una autorización administrativa previa concedida por tal Estado.

\section{EL TALANTE RUPTURISTA DE LA ÚLTIMA LÍNEA JURISPRUDENCIAL}

\subsection{Sentencia Nuñez contra Noruega, de 28 de junio de 2011}

El asunto Nuñez contra Noruega ${ }^{598}$, fallado el 28 de junio de 2011, revela nuevamente la superposición existente entre los supuestos de migración familiar en condiciones de irregularidad y

597 Los intereses enfrentados en el presente litigio, a juicio del TEDH, se deducen del último apartado de la sentencia: "The foregoing considerations are sufficient to enable the Court to conclude that it cannot be said that the Netherlands authorities have failed to strike a fair balance between the applicant's interests on the one hand and its own interest in controlling immigration and public expenditure and in the prevention of disorder or crime on the other. Consequently, there has been no violation of the applicant's right to respect for her rights guaranteed by Article 8 of the Convention" Apartado 53, STEDH Konstatinov contra Holanda.

598 Nuñez v. Norway, Appl. No 55597/09; Judment of 28 June 2011. Conforme a lo establecido en el artículo 44.2 CEDH, este pronunciamiento adquirió carácter definitivo el 29 de septiembre de 2011, al cumplirse tres meses desde su emisión, y no haber solicitado ninguna de las partes implicadas su revisión por parte de la Gran Cámara. 
la protección frente a expulsiones. En tales casos existe un altísimo grado de imbricación entre las obligaciones migratorias positivas y negativas, pues en ambos suele mediar una orden de expulsión. De otro lado, sirve como confirmación de algunos de los principios extraídos de la doctrina jurisprudencial previa, al tiempo que avanza una nueva línea de talante decididamente rupturista.

Este pronunciamiento tiene su origen en una demanda formulada por una mujer dominicana, quien alegaba que la orden de expulsarla de Noruega la separaría de sus dos hijas de corta edad — de 7 y 9 años-, nacidas y criadas en dicho país. La demandante estimaba que las infracciones del derecho migratorio noruego cometidas y que habían determinado su orgen de expulsión — ratificada por la Corte Suprema Noruega-, no podían justificar la separación entre ella y sus dos hijas menores.

La demandante - Mirtha Ley de León Nuñez-, de nacionalidad dominicana, había llegado a Noruega en 1996. Dos meses después de su llegada, fue deportada del país como consecuencia de una multa impuesta a causa de un robo cometido en una tienda. La deportación conllevaba una prohibición de entrada en Noruega durante dos años; pese a ello, la demandante regresó al país cuatro meses después de su deportación, portando un pasaporte con una identidad falsa. Poco después, contrae matrimonio con un noruego, tras lo cual solicita un permiso de residencia, alegando que nunca antes había visitado Noruega y que carecía de antecedentes penales, concediéndosele en base a ello un permiso de trabajo y una autorización de asentamiento.

Tras separarse de su marido, emprende una relación con un nacional dominicano, fruto de la cual nacen dos niñas en Noruega, cuya custodia es adjudicada a la demandante tras la ruptura de su relación sentimental con el padre de las menores. Durante este tiempo, es arrestada por la policía, quien la acusa de haber estado en Noruega con una identidad falsa. El Departamento de Inmigración decide revocarle sus permisos migratorios y emite una orden de expulsión del país, que llevaba adjunta una prohibición de entrada durante dos años en calidad de sanción administrativa a fin de agilizar los procedimientos administrativos para la ejecución de la misma. La demandante recurrió su deportación, llegando hasta el Tribunal Supremo, quien estimó que las autoridades noruegas habían respetado el principio de proporcionalidad, ratificando la orden de expulsión. Durante dicho período, la custodia legal sobre sus dos hijas es adjudicada en solitario al padre de las menores, en previsión de la posible salida del país de la madre como consecuencia de la expulsión dictada en su contra.

El enjuiciamiento del TEDH parte de la constatación de la existencia de VF entre la demandante y sus hijas. La rapidez con que se ventila esta cuestión, en la que la Corte se limita a señalar escuetamente qu el artículo 8 es aplicable al caso ${ }^{599}$, confirma la consolidación de otro importante aspecto: La formación familiar es objeto de tutela $-\mathrm{y}$ en condiciones de paridad respecto de los supuestos de RF en sentido estricto-, dentro del ámbito de protección otorgado por el artículo 8 a la migración familiar. En Nuñez v. Noruega, los vínculos familiares se habían constituido tras la entrada de la demandante en el Estado parte y en condiciones de irregularidad.

Seguidamente, la Corte procede a enunciar, — de forma más sistemática que en anteriores ocasiones-, la aplicación de los principios vigentes en materia migratoria, recordando enfáticamente el derecho soberano que ostentan los Estados a fin de controlar la entrada y residencia de los extranjeros en sus territorios ${ }^{600}$. Asimismo, el TEDH precisa que la residencia en Noruega de la demandante

599 Apartado 65 de la sentencia Nunez v. Noruega, donde el TEDH se limita a señalar literalmente: "At the outset the Court finds it clear that the relationship between the applicant and her daughters constituted 'family life' for the purposes of Article 8 of the Convention, which provision is therefore applicable to the instant case".

600 Idem, apartado 66. 
ha sido ilegal en todo momento, pues aunque ostentaba permisos de trabajo y residencia, los mismos habían sido conseguidos en base a la información falsa que había proporcionado al Departamento de Inmigración, y recuerda que su inserción en el país había tenido lugar con documentos de viaje falsos y contraviniendo la prohibición de entrada que inicialmente se le emitió.

El carácter ilegal de toda la estancia de la demandante en Noruega - aunque portase permisos migratorios, éstos fueron obtenidos ilegítimamente - ratifica la vigencia de la doctrina que, en torno a la clasificaciónn de obligaciones migratorias, habíamos extraído en su momento de la sentencia Rodrigues da Silva. Aunque en esta circunstancia la Corte de Estrasburgo no califica expresamente la medida impugnada - una orden de expulsión que conlleva una prohibición de entrada - como una obligación positiva, de su enjuiciamiento se deriva con claridad que le asigna un estatus positivo, eludiendo el análisis del apartado segundo del artículo $8 \mathrm{CEDH}$. Por tanto, el carácter inicial de la autorización de residencia en Noruega que la demandante conseguiría, — de ser admitidas sus pretensiones ante Estrasburgo-, dota a la obligación estatal de un carácter positivo.

Nuñez contra Noruega constituye un supuesto en el que se aúna la violación del derecho migratorio interno - agravada por la emisión de información fraudulenta-, junto a la comisión de un delito dentro del territorio del Estado parte. Ello suministra al TEDH una oportunidad a fin de avanzar doctrina aplicable en estos casos. En la parte inicial de la sentencia, el análisis de la Corte gira en torno a la aplicación del test de la responsabilidad individual a las circunstancias que rodean la estancia en Noruega de la demandante, con un tenor estricto. Para la Corte de Estrasburgo, resulta especialmente relevante tomar en consideración la información falsa proporcionada por la demandante, enfatizando la importancia de la confianza como base del sistema migratorio interno.

\footnotetext{
"Dado que sería imposible para las autoridades ejercer un control efectivo de la entrada y permanencia en Noruega de todos los inmigrantes, el sistema tendrá que basarse en gran medida en la confianza de que el derecho migratorio será respetado por sus destinatarios, fundamentalmente en la expectativa de que los extranjeros suministren información correcta cuando solicitan su residencia. Si serias y repetidas violaciones del derecho migratorio diesen lugar a la impunidad, el interés público del respeto a la ley quedaría minado" ${ }^{\prime \prime}$.
}

En consecuencia, si resulta legítimo para el Estado rechazar peticiones de residencia que no reúnan los requisitos exigidos, cuando en dicha solicitud el extranjero ha proporcionado una información falsa existen mayores razones para considerar que "el rechazo de tal solicitud no constituiría en sí misma una sanción".

"Por lo tanto, la posibilidad de que las autoridades reaccionen con una expulsión constituiría un importante mecanismo general de disuasión contra graves o repetidas violaciones del derecho migratorio"602.

Con estas premisas - enunciadas en un tono contundente-, el TEDH entiende que "un esquema de implementación nacional del derecho migratorio que, como en este supuesto, está basado en la imposición de sanciones administrativas en forma de expulsión no constituye una violación del artículo $8 \mathrm{CEDH}^{\prime \prime 63}$. La Corte rechaza la argumentación de la demandanda, para quien solamente cabría considerar prioritario el interés público de expulsar a extranjeros en aquellos supuestos donde la persona implicada ha cometido delitos penales, sean éstos serios o no. Con ello, la Corte avala la

601 El TEDH continúa precisando que "since an application for a residence permit would be rejected in the event of failure to meet the conditions for residence, a refusal of such an application would not in itself constitute a sanction for the provision of false information". STEDH Nuñez v. Noruega, apartado 71, traducción propia.

602 Idem.

603 Ibidem. 
procedencia estatal de imposición de sanciones administrativas de expulsión tanto en concurrencia como en ausencia de comisión de delitos penales.

En aplicación de las premisas apuntadas, y prestando especial consideración al carácter agravado de las infracciones del derecho migratorio por parte de la demandante, el TEDH confirma la proporcionalidad de la medida de expulsión que en su contra dictaron las autoridades migratorias noruegas, y posteriormente ratificaron los tribunales de dicho país ${ }^{604}$.

Cabría con ello pensar que el enjuiciamiento ha concluido y las autoridades noruegas pueden proceder a ejecutar la orden de expulsión. Sin embargo, a continuación el TEDH aplica minuciosamente algunos test convencionales, otorgando una absoluta preponderancia al interés superior del menor. Ello permite a la Corte llegar a una conclusión que resulta contradictoria con la apreciación anterior, a saber que "no está satisfecha con la forma en que las autoridades del Estado demandado actuaron dentro de su margen de apreciación al buscar un justo balance de un lado entre el interés público en asegurar la eficacia del control migratorio, y de otro la necesidad de la demandante de permanecer en Noruega a fin de mantener contactos con sus hijas en el mejor interés de éstas ${ }^{2605}$. El TEDH sentencia que la expulsión de la demandante, junto con la prohibición de entrada durante dos años, constituyen una violación del artículo $8 \mathrm{CEDH}$.

Entre los aspectos más sobresalientes de la aplicación de los test convencionales que rigen la migración familiar en condiciones de irregularidad, cabe subrayar los siguientes — cuya interacción permite a la Corte declararar que la expulsión es contraria al artículo $8 \mathrm{CEDH}-$ :

- Test de la integración en el Estado de origen: La demandante penetró en Noruega siendo adulta — con 31 años - y allí cohabitó con una persona de su misma nacionalidad. La Corte estima que los vínculos más sólidos son los que mantiene con su país natal y que, "en cualquier caso, los mismos habian sido constituidos estando residiendo ilegalmente y sin ninguna legítima expectativa de poder permanecer en el país' ${ }^{3606}$.

- Test de la responsabilidad individual: El TEDH, que previamente había subrayado las reiteradas y graves infracciones al derecho migratorio interno cometidas por la demandante, se centra ahora en evaluar el otro lado de la balanza, aquí representado por el retraso en el que incurrieron las autoridades holandesas. Éstas tardaron cuatro años desde la revocación del permiso de trabajo y residencia hasta la emisión de la orden de expulsión, pues su tramitación era, por imperativo legal, de carácter independiente. La Corte estima inicialmente que dicha tardanza es de escasa importancia desde la perspectiva del art. 8 $C E D H^{607}$. Pero, posteriormente, y de forma algo contradictoria con lo aquí proclamado, la Corte afirma que su tramitación por separado justifica sólo parcialmente dicha demora, indicando que "no parece que la medida impugnada cumpliese en ningún grado apreciable con el interés de prontitud y eficiencia del control migratorio, que constituyen los propósitos declarados que persiguen tales medidas administrativas" ${ }^{608}$. Este aspecto vuelve a mencionarse

$604 \mathrm{Al}$ respecto, afirma expresamente que "in these circumstances, the Court considers that the public interest in favour of ordering the applicant's expulsion weighed heavily in the balance when assessing the issue of proportionality under Article 8 of the Convention". STEDH Nuñez v. Noruega, apartado 73.

605 STEDH Nuñez v. Noruega, apartado 84, traducción propia.

606 Apartado 76, STEDH Nuñez v. Noruega, traducción propia.

607 Apartado 77, STEDH Nuñez v. Noruega.

608 Para el TEDH, "although this state of affairs could to some extent be explained by the immigration authorities' choice to process the revocation of her work and settlement permit not in parallel but separately, it does not appear to the Court that the impugned measure to any appreciable degree fulfilled the interests of swiftness and efficiency of immigration control that was the intended purpose of such administrative measures". Apartado 82, STEDH Nuñez v. Noruega. 
cuando la Corte emite su juicio sobre este caso, indicando con ello su influencia en la postura final ${ }^{609}$.

- Criterio del interés superior del menor, a cuyo examen el TEDH decider prestar especial consideración ${ }^{610}$, a fin de determinar si el mismo es capaz de alterar el justo balance de intereses conforme al artículo 8: En su seno, valora que las niñas han nacido y vivido permanentemente con la demandante, quien ha sido su principal cuidadora hasta que los tribunales noruegos otorgaron la custodia al padre. Por ello, - y en consonancia con lo establecido por la minoría de magistrados integrantes del Tribunal Supremo de Noruega que juzgaron el caso-, señala que "la demandante es la persona más importante en la vida de las niñas ${ }^{611 " ~ y ~ e n f a t i z a ~ e l ~}$ estrés al que fueron sometidas éstas al ser trasladadas a vivir con su padre y ante el riesgo de que su madre fuera expulsada del país, tras lo cual, por añadidura — dada la prohibición de entrada - resulta incierto el régimen de visitas que podrían mantener.

En esta sede, el TEDH analiza las consecuencias que la ejecución de la expulsión tendría sobre las menores, subrayando "la probabilidad de ser separadas de su madre durante prácticamente dos años, un período muy largo para menores de la edad en cuestión ${ }^{\text {'612 }}$, lo que revela su vulnerabilidad. Aunque los contactos con la madre se presumen posibles - el progenitor manifestó su voluntad de facilitar las visitas entre ellas-, el TEDH señala que no existe garantía de que, al finalizar los dos años de prohibición de entrada, la madre pueda regresar a Noruega. Por ello, la Corte estima que la expulsión junto con la prohibición de entrada durante dos años, "constituye sin ninguna duda una medida de muy largo alcance vis-á-vis las menores"613. Este factor desempeñará un peso decisivo en la decisión finalmente adoptada por la Corte de Estrasburgo.

Un aspecto muy destacado de este pronunciamiento reside en que el TEDH, por primera vez en un supuesto relativo a migración familiar, se apoya de forma explícita en el artículo 3 de la Convención de los derechos del niño, "conforme al cual el interés superior del niño será una consideración pri-

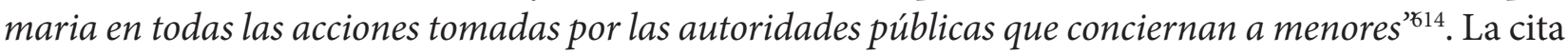
a este Tratado internacional - que ya había tenido lugar en el ámbito de las obligaciones migratorias negativas ${ }^{615}$ - , refuerza el grado de penetración que, desde Sen, ha tenido el criterio del bienestar de los menores implicados, cuya aplicación desde entonces ha sido constante y crecientemente intensa. Desde dentro del propio TEDH, el magistrado Jebens, valoró esta nueva aproximación de la Corte, calificándola como un "diálogo constructivo entre jueces (...) que constituye un importante paso adelante y debería ser bienvenido en una Corte de Derechos Humanos del siglo XXI”616. Con todo,

609 En contra de la importancia del retraso en que incurrieron las autoridades migratorias noruegas al emitir la orden de expulsión, se pronunció el juez Jebens en la opinión concurrente formulada en esta sentencia. En opinión de este juez, lo relevante en este supuesto es la dependencia y la situación de vulnerabilidad en que quedarían las menores de ejecutarse la orden de expulsión contra su madre, así como la larga separación temporal que ello provocaría, -no tanto la tardanza de las autoridades noruegas, circunstancia que vino a añadir mayor presión a la situación de las menores-. Por ello, aun estando de acuerdo en que la expulsión de la demandante viola el artículo 8 CEDH, el único argumento relevante para ello "ha de referirse en exclusiva al mejor interés de los niños".

610 En el apartado 78 de la sentencia, la Corte anuncia el examen detenido que prestará a la aplicación de este criterio, señalando literalmente: "However, the Court will examine whether particular regard to the children's best interest would nonetheless upset the fair balance under Article 8".

611 STEDH Nunez contra Noruega, apartado 79.

612 Idem, apartado 81.

613 Ibidem, apartado 83.

614 STEDH Nuñez v. Noruega, apartado 84.

615 Vid, al respecto, Neulinger and Shurukv. Switzerland, (Application No. 41615/07), STEDH de 6 de julio de 2010, donde el TEDH también cita expresamente el artículo 3 de la Convención de los Derechos del niño.

616 Opinión concurrente del juez Jebens. Nuñez v. Norway, traducción propia. 
advirtió también que con la prioridad dada al interés y protección de los menores, "inevitablemente se reduce el margen de apreciación estatal en tales casos" ${ }^{\prime 617}$.

La sentencia está impregnada de un tono poco claro ${ }^{618}$ y contradictorio. Parece haber un abismo entre las premisas de partida a las que el TEDH declara someterse al inicio de su enjuiciamiento, y las conclusiones a las que finalmente llega, una vez aplicados los diversos test convencionales - fundamentalmente el interés superior del menor-. Podría pues establecerse una línea divisoria entre dos partes de esta sentencia: una primera, de tenor contundente y tajante, donde la aplicación del test de la responsabilidad individual a las circunstancias que rodean la solicitud de la demandante, conducen de forma clara a declarar proporcional la medida de expulsión dictada en su contra. Un segunda, donde la aplicación del criterio del interés supremo del menor, consigue neutralizar los efectos de todos los restantes test, convencionales permitiendo que la demandante, pese a las circunstancias agravadas de irregularidad que concurrían en el caso, permanezca en Noruega a fin de que sus hijas no queden privadas del vínculo con su madre, a una edad en que la presencia materna resulta esencial para la vida de las menores.

El carácter incoherente que desprende este pronunciamiento, se deja entrever en un aspecto que, a partir de ahora, se convertirá en una frase repetida por el TEDH en el momento de emitir su sentencia. Antes de declarar las medidas estatales impugnadas contrarias al derecho a la vida familiar, el TEDH puntualiza no estar convencido de que "en las concretas y excepcionales circunstancias del caso, haya sido otorgado suficiente peso al interés primordial de los niños para los propósitos del artículo $8 \mathrm{CEDH}^{\prime \prime 19}$. Pero la pregunta que puede surgirle a todo lector atento es si realmente en este caso confluyen las concretas y excepcionales circunstancias que hubieran podido contrarrestar los sólidos argumentos que apoyaban el interés estatal de controlar la migración, dada la información fraudulenta proporcionada por la demandante, y que inclinaban la balanza hacia una actitud judicial respetuosa del margen de apreciación estatal ${ }^{620}$. De lo contrario, cabría concluir que el nacimiento de hijos menores en el Estado parte de acogida podrá neutralizar, en atención al interés primordial de éstos, cualquier consideración adversa — por sólida que ésta sea-, que pese a favor del interés estatal de controlar la inmigración y expulsar a inmigrantes que hayan cometido serias y repetidas violaciones del derecho migratorio - usando la misma expresión utlilizada por la Corte al iniciar su análisis de este caso.

En esta misma línea, los magistrados Mijovi'c y De Gaetano formularon una amplia opinión conjunta disidente, enfatizando la importancia de respetar el "legítimo interés público en asegurar un efectivo -y no meramente cosmético o ilusorio - control migratorio ${ }^{621}$ ", en concurrencia de situaciones de hecho como las presentes en Nuñez v. Noruega. Por ello manifiestan su preocupación de que el TEDH esté enviando "una señal equivocada, a saber que las personas que están ilegalmente en un país puedan de algún modo arreglárselas para legitimar su residencia a través de la vía del matrimonio o del nacimiento de hijos" ${ }^{22}$ en dicho Estado.

617 Idem.

618 Reclamando también una mayor claridad en el razonamiento de la Corte de Estrasburgo, se pronuncia el juez Begens en la opinión concurrente que acompaña a la sentencia Nuñez v. Noruega.

619 STEDH Nuñez v. Noruega, apartado 84.

620 Así lo declara expresamente el magistrado .... En su voto disidente...

621 Opinión conjunta disidente de los jueces Mijovi—c y De Gaetano, apartado primero.

622 Apartado 1. Opinión conjunta disidente de los jueces Mijovi'c y De Gaetano. STEDH Nuñez v. Noruega, traducción propia. 
Ambos magistrados enfatizan la importancia del subterfugio y el engaño al que recurrió la demandante para conseguir su permiso de residencia en Noruega - "que en sí mismo constituye una muy seria infracción en términos del derecho migratorio" 623 - Asimismo, subrayan el exhaustivo examen que los Tribunales de dicho país realizaron de los sucesivos recursos interpuestos contra la orden de expulsión. En base a ello, estiman que el TEDH debería haber aplicado los principios que rigen esta materia - reiteradamente citados en esta sentencia-, esto es, considerar que la vida familiar se creó en un momento en que los demandantes eran conscientes que la persistencia de la vida familiar sería precaria y que, por tanto, "el rechazo del miembro de la familia no nacional sería incompatible con el artículo 8 sólo en excepcionales circunstancias", que a su juicio no concurren en Nuñez v. Noruega. Por ello advierten que:

"Encontramos difícil de entender cómo y porqué, dado el considerable margen de apreciación dado a los Estados en conexión con la política migratoria, y el hecho de que los tribunales internos están mejor situados para apreciar, de un lado, las exigencias particulares locales y, de otro, la situación de las personas afectadas por la decisión estatal, la Corte de Estrasburgo encontró necesario en este caso interferir en la decisión final de la Suprema Corte Noruega e ir contra ella ${ }^{624}$.

En esta misma línea, ambos jueces disidentes consideran que el criterio del interés superior de los menores ha de suponer "un peso significativo" dentro del juicio de proporcionalidad, otorgándole una importancia primaria, "pero no es necesariamente decisivo". Adicionalmente, "teniendo en cuenta el margen de apreciación del Estado demandado que consideramos debe ser más amplio en el contexto de la inmigración ilegal que el que correspondería en el contexto de la inmigración o residencia legal”'25. Por todo ello, están conformes con lo decidido en su momento por el TS Noruego, extrayendo como "regla que, cuando un nacional extranjero ha cometido una infracción criminal particularmente seria, su expulsión sólo será desproporcionada si entraña una extraordinaria carga para los menores ${ }^{626 "}$.

En vista de que el padre de las hijas de la demandante tenía la custodia, había demostrado una paternidad responsable y había manifestado su cooperación a fin de facilitar las visitas con la madre, los magistrados disidentes consideran que, "bajo un objetivo y desapasionado examen de los hechos $y$ de los principios jurídicos aplicables ${ }^{627}$, la expulsión de la demandante constituye una medida proporcionada, pues no impone una carga extraordinaria sobre la vida familiar de las personas implicadas. A su juicio, Noruega actuó dentro del margen de apreciación que le compete, realizando un justo balance entre los diversos intereses concurrentes.

El voto disidente conjunto — sólidamente argumentado y dotado de una profunda coherencia-, ofrece motivos de reflexión sobre dónde situar la delgada línea que en ocasiones separa la protección de los derechos humanos y el respeto al margen de apreciación estatal en los supuestos de migración familiar que hemos calificado como fronterizos, sin caer en desequilibrios hacia uno u otro lado. Quizá el TEDH la sentencia Nuñez v. Noruega —en su afán de no desproteger a las hijas menores de la demandante-, haya incurrido en un excesiva intromisión en delicadas cuestiones internas, cuya difícil regulación - y aun más compleja implementación—, constituye en la actualidad uno de los

623 Idem, apartado 4.

624 Opinión conjunta disidente de los magistrados Mijovi-c y De Gaetano, apartado tercero.

625 Apartado 5 de la opinión conjunta disidente de los magistrados Mijovic y De Gaetano a la STEDH Nuñez v. Noruega, traducción propia.

626 Idem.

627 Ibidem 
mayores retos del derecho migratorio. Por ello, hubiera merecido un acercamiento más contenido y cauteloso por parte del TEDH y, en cualquier caso, un razonamiento más claro y sistemático.

\subsection{Casos Agraw contra Suiza y Osman contra Dinamarca: Las dificultades de deslinde entre obligaciones migratorias positivas y negativas ante supuestos fronterizos}

Los Asuntos Agraw contra Suiza y Osman contra Dinamarca —fallados respectivamente durante el verano de 2010 y 2011-, ejemplifican el incremento de las dificultades que entraña aplicar los vaporosos criterios de distinción entre obligaciones positivas y negativas de carácter migratorio, especialmente en presencia de supuestos fronterizos poco nítidos.

La demanda que dio origen a la sentencia Agraw contra Suiza ${ }^{628}$ fue formulada ante Estrasburgo por una ciudadana etíope a quien Suiza había denegado su petición de asilo, permaneciendo desde entonces en dicho país sin cobertura legal. La demandante se quejaba de que las autoridades suizas rehusaron modificar su asignación cantonal para permitirle reunirse con su esposo, un ciudadano etíope que también había visto rechazada su solicitud de asilo y residía en el cantón suizo de Vaud, a hora y media de donde vivía la demandante. Esta situación les impidió vivir en pareja durante un período de más de cinco años.

Poco antes de la recepción de la demanda ante el TEDH, las autoridades suizas otorgaron un permiso de residencia al esposo de la demandante, quien con ello obtuvo también una autorización para residir en el cantón donde éste habitaba. Precisamente la obtención de dicho permiso de residencia llevó al gobierno suizo a solicitar del TEDH que se archivara la presente demanda, por estimar resuelto el litigio de fondo que había llevado a la demandante a quejarse ante la Corte de Estrasburgo. Sobre esta cuestión, la demandante expresó formalmente ante el TEDH el mantenimiento de la demanda en todos sus extremos. La cuestión de inadmisibilidad presentada por el gobierno suizo fue rechazada de forma expeditiva por el TEDH, recordando su doctrina asentada en torno al concepto de víctima ${ }^{629}$.

La demandante estimaba que las autoridades suizas, al haber rechazado la reasignación del cantón a fin de poder vivir junto a su marido, le habían provocado una injerencia en el ejercicio de su derecho al respeto de su vida familiar. Por su parte, el gobierno suizo alegaba que, al haberle sido rechazada definitivamente su petición de asilo — tanto a ella como a su esposo-, no cabía la posibilidad de cambio en la asignación cantonal, siendo definitivas y ejecutorias las decisiones denegatorias de asilo y de devolución al país de origen. Adicionalmente, estimaba que la boda había tenido lugar cuando los interesados ya habían sido objeto de una decisión de retorno.

La sutileza de las fronteras divisorias entre las obligaciones migratorias positivas y negativas queda patente en el asunto Agraw, tanto en la argumentación del gobierno demandado ${ }^{630}$, como del propio TEDH. El caso presentaba aristas singulares. De un lado, aunque la demandante había sido objeto en su momento de una orden de expulsión, su comportamiento no había sido en ningún momento contrario al orden público, pues la expulsión era la consecuencia derivada del rechazo de

628 Agraw contra Suiza, STEDH de 29 de julio de 2010. Demanda número 24404/05.

629 Agraw contra Suiza, STEDH, apartados 29-32.

630 El gobierno suizo concluyó su argumentación señalando que: "Por estos motivos, no habría habido injerencia en el ejercicio, por la demandante, de su derecho al respeto de su vida familiar, en el sentido del artículo 8. El Gobierno estima, asimismo, que Suiza no ha incumplido las obligaciones positivas que le impone el párrafo 1 de esta disposición”. Ídem, apartado 42. 
su petición de asilo. De otro lado, durante su estancia en el Estado parte demandado no fue factible la ejecución de la orden de expulsión, de modo que a lo largo de su permanencia en territorio suizo, la demandante no disfrutó en ningún momento de una autorización migratoria que dotase de respaldo legal a su permanencia en Suiza - condición esencial para asignar una naturaleza positiva a la obligación convencional-.

Siguiendo esta misma línea de razonamiento, la Corte de Estrasburgo parece encajar inicialmente la medida estatal dentro del ámbito de las obligaciones positivas, señalando que:

"El Tribunal recuerda que a la demandante, que no formula queja sobre la decisión negativa que pronunciaba su alejamiento del territorio suizo, se le impidió formalmente llevar una vida en común con su esposo durante más de cinco años. A la luz del principio según el cual la vida en pareja constituye, para los cónyuges, uno de los atributos esenciales del derecho al respeto de la vida familiar, estima que la demandante, en cualquier caso a partir de la fecha de su matrimonio, podía aprovecharse de las garantías que se derivan del artículo $8^{\prime 631}$.

Sin embargo, a renglón seguido, y de forma bastante contradictoria, el TEDH asigna a la medida estatal controvertida una naturaleza expresamente negativa - calificándola como una "injerencia"y, como tal, enfoca el enjuiciamiento del asunto aplicándole el método secuencial de razonamiento en tres fases, esto es, analizando si la medida estatal estaba justificada a la luz del Convenio de Roma en base a los tres siguientes parámetros de enjuiciamiento: si poseía un fundamento legal, si perseguía un fin legítimo y, finalmente, si la misma era necesaria en una sociedad democrática. En palabras del propio TEDH:

"Por este hecho, la negativa a asignarle al cantón en el que residía su esposo constituyó, para la demandante, una injerencia en el ejercicio de su derecho al respeto de la vida familiar. Tal injerencia vulnera el artículo 8 salvo si cumple las exigencias del apartado 2 de dicha disposición. Por tanto, queda por saber si la injerencia estaba "prevista por la Ley», perseguía uno o más de los fines legítimos que enuncia este apartado y era «necesaria en una sociedad democrática» para alcanzarlos" 632 .

A nuestro juicio, este caso confirma la debilidad de los criterios de distinción entre obligaciones positivas y negativas derivadas del respeto a la vida familiar de los extranjeros, que el propio TEDH había anteriormente clarificado y parecía haber querido abandonar en el asunto Konstatinov. Si se aplica la propia doctrina de Estrasburgo formulada en el asunto Rodrigues da Silva, este caso encajaría dentro del ámbito de la RF como obligación positiva, pues incumbe la concesión inicial de un permiso de residencia a una extranjera que llevaba tiempo habitando en el país receptor sin contar con un estatus legal — tras el rechazo de su solicitud de asilo, la ejecución de la expulsión no fue posible por el rechazo de Etiopía a la repatriación, país natal de la demandante-. Por lo tanto, no estamos ante un caso típico de irregularidad por contravención de las normas migratorias internas, sino por la imposibilidad de cumplimiento de la orden de expulsión - aspecto en el que incide el TEDH al reflexionar sobre la situación de la demandante y de su esposo, cuya situación legal era idéntica a la de la demandante. A mayor abundamiento, el comportamiento de la demandante había sido irreprochable en territorio suizo - cuestión que varias veces sale a relucir a lo largo de la argumentación expuesta en la demanda y en el análisis efectuado por el TEDH—, de modo que no existían argumentos de orden público que pudieran arropar el carácter negativo de la medida estatal impugnada.

Pese a ello, la Corte de Estrasburgo le aplica el tratamiento secuencial propio de las obligaciones migratorias negativas, analizando la justificación de la injerencia bajo el prisma del apartado

631 Ibídem, apartado 45.

632 Agraw contra Suiza, STEDH, apartado 46. 
segundo del artículo $8 \mathrm{CEDH}$. Como aspecto destacable, al evaluar el fin legítimo perseguido por la medida estatal impugnada, el TEDH estima que dicho propósito "puede incorporarse a la noción de < bienestar económico del país > 333 — otro motivo más, en nuestra opinión, que indica el carácter positivo de la obligación estatal. Con todo, dado lo reciente del asunto, la escasa doctrina que se ha ocupado de su estudio ${ }^{634}$ —en sentido similar a la opinión aquí sustentada-, ha otorgado una naturaleza positiva a la obligación estatal.

El talante protector de la línea jurisprudencial emprendida en Sen está bien presente a lo largo de este pronunciamiento. El TEDH estima que la medida impugnada no era necesaria en una sociedad democrática, en atención a las circunstancias excepcionales que rodean este caso, así como al número considerable de años durante los cuales la demandante estuvo separada de su esposo. En la ponderación de intereses contrapuestos, la Corte otorga un peso superior a los intereses privados de la demandante en poder vivir con su esposo, que a los intereses públicos del gobierno suizo. En torno a éstos últimos, la Corte considera que la reasignación cantonal solicitada por la demandante "no habría incidido de forma notable en el número de extranjeros destinados a ese cantón ni alterado la repartición equitativa entre los cantones de los solicitantes de asilo, ni perjudicado el orden público" ${ }^{\prime 35}$. En consecuencia, declara la existencia de violación del artículo 8 CEDH.

Por su parte, el asunto Osman v. Dinamarca ${ }^{636}$ incurre en el mismo tratamiento confuso de la distinción entre obligaciones migratorias, adjudicando carácter negativo a un caso que, de forma aún más diáfana que en la sentencia Agraw, reunía caracteres propios de las obligaciones positivas ${ }^{637}$.

La demanda ante Estrasburgo en el asunto Osman tenía su origen en la denegación por parte del gobierno danés de la rehabilitación de un permiso de residencia, que caducó al estar su titular más de un año fuera del país de acogida.

La demandante era una ciudadana somalí a quien, con siete años de edad, Dinamarca había concedido un permiso de residencia a fin de que se reuniese en su territorio con su padre refugiado en dicho país-, madre y hermanos. Su escolarización había transcurrido en Dinamarca, cuya lengua hablaba a la perfección y en cuyo país tenía sus vínculos familiares más fuertes. Con 15 años de edad, sus padres decidieron que la demandante regresara a Kenia, en contra de su voluntad, a fin de que cuidada de su abuela, que residía en un campo de refugiados en dicho país. A la edad de 17 años, y por lo tanto siendo todavía una menor, solicitó a las autoridades danesas el restablecimiento de su permiso de residencia, a fin de volver a reunirse con su familia en Dinamarca. Su permiso previo había expirado por haber permanecido fuera del territorio danés durante más de un año.

En la época en que la demandante formuló su petición, había cambiado la regulación migratoria en Dinamarca, y el país exigía que las solicitudes de RF para hijos menores fueran formuladas antes de que éstos cumplieran 15 años - una buena muestra de la función protectora que puede desplegar la Directiva 2003/86 sobre el derecho a la RF como cláusula implícita de stand still, pues Dinamarca pudo realizar dicho cambio normativo por haber quedado fuera del

633 Asunto Agraw contra Suiza, apartado 49.

634 DÍAZ GREGO, María. "Derecho de extranjería y jurisprudencias del Tribunal Constitucional, del TEDDH y del

TJUE”. Anuario MIG. La hora de la integración. Legislación y Jurisprudencia, 2011, p. 422.

635 Agraw contra Suiza, STEDH, apartado 53.

636 Case of Osman v. Denmark, STEDH, Estrasburgo, 14 junio de 2011. Application nº 38058/09.

637 Como un supuesto de RF y, por lo tanto, como obligación positiva, también califica al asunto Osman DÍAZ GREGO, María. "Derecho de extranjería y jurisprudencias del Tribunal Constitucional, del TEDDH y del TJUE”, op. cit., p. 427. 
ámbito de aplicación de la citada norma comunitaria. El gobierno danés estimó que, en el presente caso, no concurrían las circunstancias excepcionales que justificasen la obtención de un permiso de residencia a favor de la demandante, quien agotó todas las instancias hasta llegar al Tribunal de Estrasburgo. La causa principal que latía detrás de la denegación era la edad de la demandante, que había cumplido la mayoría de edad y, en cualquier caso, había rebasado los 15 años en el momento de su solicitud inicial — cuándo ésta fue formulada, la menor contaba por entonces con 17 años y 9 meses-.

Osman v. Dinamarca ${ }^{638}$ constituye, hasta el momento de cerrar la redacción de estas páginas, el último caso que sobre migración familiar ha fallado el TEDH. Aporta avances doctrinales de extrema importancia que, al tiempo que confirma principios extraídos en sentencias previas, introduce novedades importantes. De entre ellas, destaca por su importancia la alegación de la vida privada, en conjunción con la vida familiar, como derecho convencional afectado por la medida migratoria adversa contra la cual se quejan los demandantes extranjeros. Es obvio que en los supuestos limítrofes entre RF y expulsión, donde las solicitudes residencia vienen acompañadas de órdenes de exclusión del territorio del Estado receptor, la medida migratoria adversa —además de separar al extranjero afectado de sus vínculos familiares-, le desvincula y aparta del entorno vital, social y profesional en que ha desarrollado su vida en el período previo a la emisión de la orden de exclusión. En Osman, el TEDH siguiendo la senda abierta por la sentencia Slivenko y otros contra Latvia ${ }^{639}$-emitida en octubre de 2003 y relativa a la tutela de una amplia minoría de rusohablantes en Latvia y Estonia-, extiende a la RF una concepción ampliada del ámbito de protección del artículo 8, para incluir el amplio abanico de relaciones sociales, culturales, económicas, profesionales y personales que constituyen la vida privada de los inmigrantes ${ }^{640}$.

A diferencia del caso Agraw - donde mediaba una orden de expulsión de imposible cumplimiento ante la negativa de las autoridades del país de origen a repatriar a sus conciudadanos-, en este último asunto no media tal orden. En Osman contra Dinamarca la negativa a restablecer el permiso de residencia de la demandante, ya caducado, impide la reconstitución de su vida familiar - y más allá, de todo el complejo ámbito de relaciones de diverso cariz que abarca la vida privada-. En sentido estricto, de serle éste restablecido, no supondría un permiso inicial, dado que la demandante había vivido gran parte de su vida en dicho país. En consecuencia, Osman constituye un supuesto de RF más diáfano que el asunto Agraw. Pese a ello, en el asunto Osman confluyen dos características singulares: la demandante trata de rehabilitar un permiso previo de residencia por causa familiar que, salvadas las distancias, podría equivaler a los supuestos tradicionales de renovación de permisos en vigor- $y$, más importante, tras serle rechazada su solicitud, la demandante entró en Dinamarca de forma ilegal, aspecto que la hace merecedora de ser catalogada como un supuesto fronterizo - si bien algo atípico-.

El Tribunal de Estrasburgo inicia su evaluación del caso rehusando expresamente catalogar la decisión impugnada como una obligación negativa o positiva — pues en ambos supuestos rigen principios similares y el Estado disfruta de "cierto" margen de apreciación, debiendo de realizar en ambos supuestos un justo balance entre los intereses concurrentes-. Pese a esta declaración inicial - que sigue doctrina previa-, el propio TEDH cataloga implícitamente la solicitud como un supuesto de RF. Con todo, al examinar el supuesto, le otorga el tratamiento de las obligaciones negativas, analizando la justificación de la injerencia estatal a la luz de los parámetros del artículo

638 Case of Osman v. Denmark, SETEH de 14 de junio de 2011, (Application no 38058/09).

639 Case of Slivenko et a. Versus Latvia, STEDH de 9 de octubre de 2003.

640 THYM, Daniel. “Respect for Private and Family Life under Article 8 ECHR...”, op. cit., p. 88. 
8.2 CE, y evaluando con bastante detenimiento la proporcionalidad de la medida estatal a la luz de su necesidad en una sociedad democrática. Este aspecto procedimental, idéntico a lo sucedido en el asunto Agraw, parece indicar que el TEDH está iniciando un nuevo rumbo más coherente, aplicando a las obligaciones migratorias positivas - sin calificarlas expresamente como tales- un tratamiento idéntico al utilizado para analizar las de carácter negativo. De ser ello cierto, resulta elogiable, en cuanto eleva el rigor del escrutinio judicial empleado. Desde estas páginas, lamentamos únicamente que este importante avance haya quedado oscurecido pues, en nuestro punto de vista, hubiera merecido cierta justificación por parte del TEDH asícomo la aplicación de criterios más diáfanos.

Dado que la edad de la demandante se erige como uno factor fundamental desencadenante de la denegación de su solicitud migratoria, el TEDH puntualiza que ésta era todavía menor cuando solicitó reunirse con su familia, alcanzando la mayoría cuando le fue denegada de forma definitiva dicha solicitud. En adición, el TEDH señala que existe vida familiar entre "adultos jóvenes" que aún no han formado su propio núcleo familiar y sus padres, otorgando sustento para ampliar la cobertura protectora del artículo 8 a hijos que hayan rebasado la mayoría de edad. En palabras del TEDH:

\begin{abstract}
"La Corte ha aceptado en un número de casos relativos a adultos jóvenes que todavía no han fundado su propia familia, que su relación con sus padres y otros parientes próximos también constituye 'vida familiar. Además, el artículo 8 también protege el derecho a establecer y desarrollar relaciones con otros seres humanos y con el mundo exterior y puede en ocasiones abarcar aspectos de la identidad social de un individuo; debe aceptarse que la totalidad de los vínculos sociales entre inmigrantes establecidos y la comunidad en la que viven, constituye parte del concepto de 'vida privada' en el sentido del artículo 8. A pesar de la existencia de 'vida familiar', la expulsión de un inmigrante asentado constituye una interferencia con su derecho al respeto de la vida privada. Dependerá de las circunstancias del caso particular, si es apropiado para la Corte centrarse en la 'vida familiar' antes que en los aspectos de la 'vida privada'"641.
\end{abstract}

En base a esta consideración ampliada del derecho afectado por la medida migratoria adversa, la Corte estima que la denegación de la renovación del permiso de residencia a la demandante interfirió tanto con su vida privada como con su vida familiar. Para determinar si la misma constituye una violación de tales derechos, aplica el método secuencial de evaluación, conforme a los parámetros del artículo 8.2 - encajando genéricamente la medida impugnada dentro del fin legítimo del "control migratorio" ${ }^{642}$ - . Como es habitual, el mayor despliegue argumentativo tiene lugar para despejar si la medida estatal era necesaria en una sociedad democrática. A tal fin, aplica fundamentalmente el test de la integración en el Estado de acogida - la demandante pasó en Dinamarca sus años de escolarización, donde viven en la actualidad sus padres y hermanos, contando allí con sólidos vínculos sociales, culturales y familiares-. Frente a la fortaleza de los vínculos establecidos con Dinamarca, los vínculos con Kenya son de entidad muy inferior, llegando a afirmar el TEDH que:

"Para poder justificar la expulsión de un inmigrante arraigado que ha pasado la mayor parte de su infancia y juventud viviendo regularmente en el país de acogida, se exigen muy serias razones" ${ }^{643}$.

Aplicando idéntico razonamiento, la Corte señala que "muy serias razones son requeridas para justificar el rechazo de las autoridades a restaurar el permiso de residencia de la demandante"644,

641 Osman contra Dinamarca, STEDH, apartado 55, traducción propia.

642 Idem, apartado 58.

643 Osman contra Dinamarca, STEDH, apartado 65, traducción propia.

644 Idem. 
considerando que las mismas no concurren en el presente supuesto. Por ello, estima que el gobierno demandando no realizó un justo balance de los intereses en conflicto, concluyendo que "el interés de la demandante no fue tenido suficientemente en cuenta cuando las autoridades rechazaron rehabilitar su permiso de residencia en Dinamarca" ${ }^{645}$, y estimando la violación del artículo 8 CEDH.

Osman está impregnada del mismo talante marcadamente protector que, desde la sentencia Sen, ha ido in crescendo en la forma de aproximarse del TEDH a la migración familiar. Su mayor trascendencia reside en admitir la violación del derecho a la vida privada en un asunto propio de la $\mathrm{RF}$, a fin de ampliar la cobertura protectora y poder amparar las relaciones sociales no exclusivamente familiares $-\mathrm{y}$, con ello, que los hijos jóvenes adultos puedan obtener la tutela del artículo $8 \mathrm{CEDH}$. Este avance, de llegar a inaugurar una nueva tendencia jurisprudencial, se antoja cargado de implicaciones prácticas frente a unos Estados parte cada vez más tentados a imponer restricciones normativas sobre la RF, especialmente sobre las figuras de los hijos adultos y los ascendentes.

En consecuencia, si enfocamos el tratamiento jurisprudencial del la inmigración familiar en el ámbito de Estrasburgo desde una perspectiva evolutiva, la línea liberal emprendida en Sen y ratificada en las sentencias dictadas durante la primera década del presente siglo, nos llevan a concluir que el razonamiento jurídico empleado por la Corte de Estrasburgo descansa sobre premisas contrarias a las empleadas en sus primeros pronunciamientos en esta materia. Si al inicio de esta rama jurisprudencial el Tribunal partía de la existencia de una presunción contraria al reconocimiento del derecho a la vida familiar — susceptible de ser destruida por una argumentación muy sólida por parte de los demandantes extranjeros-, en la actualidad el TEDH se muestra muy proclive a la concesión del derecho, correspondiendo al Estado parte demandado la tarea de justificar con argumentos muy poderos la necesidad de la injerencia o falta de respeto en el derecho a la RF, recurriendo a una justificación que podríamos calificar como apodíctica ${ }^{646}$.

\subsection{Informe de la Asamblea Parlamentaria en torno a la Reunificación Familiar}

En febrero de 2012, y como respuesta a la consulta lanzada por la Comisión Europea ${ }^{647}$ en torno a la Directiva comunitaria 2003/86/CE sobre el derecho a la RF — que analizaremos en el siguiente capítulo-, la Asamblea Parlamentaria del Consejo de Europa emitió un informe $e^{648}$ que pretende fijar

645 Osman contra Dinamarca, STEDH, apartado 76.

646 En torno al cambio en modo de razonar del TEDH para enjuiciar supuestos migratorios en el contexto del art. 8 $\mathrm{CEDH}$, se expresa también Marat Kengerlinsky, quien indica que del énfasis en la necesidad del demandante de probar la existencia de obstáculos insuperables se ha pasado a una situación contraria, en la que es el Estado parte demandado el que debe justificar de forma sólida la necesidad de la interferencia, en el ámbito del cumplimiento de sus obligaciones migratorias positivas derivadas del derecho al respeto de la VF. En palabras de la autora señalada: "The emerging picture was the following. Whilst the Contracting States were not prohibited from exercising immigration control by Article 8, and would be afforded a margin of appreciation in so doing, the legal reasoning changed its form. The emphasis had moved from applicants having to prove 'insurmountable' obstacles to overcoming various immigration measures in order to demonstrate that their rights had been interfered with, to the State having to justify the interference and to demonstrate that it had proper procedures in place to ensure the respect for family life, giving effect to its positive obligations under Article 8.2". KENGERLINSKY, Marat. "Restrictions in EU Immigration and Asylum Policies in the light of International Human Rights Standards"; Essex Human Rights Review, vol. 4, No 2, September 2007, pp. 5.

647 European Commission, Consultation on the right to family reunification of third-country nationals living in the EU, 15 November 2011.

648 Position paper on family reunification. Committee on Migration, Refugees and Displaced Persons of the Parliamentary Assembly of the Council of Europe. Aprobado por el Comité sobre Migración, Refugio y Personas Desplazadas, el 24 de enero de 2012. AS/mig (2012) 01. 2 February 2012. 
su posición sobre este tema. La consulta pública abierta por la Comisión Europea pretendía recopilar información de los distintos entes y organismos vinculados a la aplicación nacional de la Directiva mencionada, con vistas a planificar la estrategia de actuación más adecuada en un futuro próximo, dadas las múltiples dificultades y trabas que han lastrado la implementación interna de dicha norma comunitaria. En su informe, la Asamblea Parlamentaria se reafirma en el tenor progresista con el que previamente había abordado esta cuestión en la Recomendación sobre Movilidad humana y derecho a la $R F$ —emitida en el año 2004, y a la que constantemente se remite-.

La premisa básica de la que parte la Asamblea Parlamentaria reside en celebrar la existencia de la Directiva reguladora de la migración familiar de los extranjeros procedentes de terceros países, a la que considera como "una sólida base para clarificar y promover la RF” ${ }^{649}$ y un estándar mínimo para los Estados miembros de la UE. Pese a ello, lamenta la escasa armonización que la Directiva ha producido en esta materia, como consecuencia de los amplios márgenes de apreciación que muchas de sus disposiciones otorgan a los Estados.

La concepción liberal de la RF mantenida por la Asamblea Parlamentaria lleva incluso a este órgano - como propuesta central de su informe-, a recomendar a la Comisión Europea reformar la Directiva comunitaria a fin de que pueda convertirse en un auténtico instrumento de armonización ${ }^{650}$, basándose en una definición más amplia de familia, condiciones de ejercicio menos estrictas, procedimientos más simplificados y la concesión de derechos igualitarios a los familiares reagrupados. A fin de evitar la reformatio in peius, la Asamblea parlamentaria puntualiza que "cualquier reforma de la Directiva no debería conducir a una disminución de los estándares ya establecidos" ${ }^{\prime 651}$ en ella, _advertencia especialmente procedente, dada la tendencia predominante en algunos Estados parte al endurecimiento del ejercicio de la RF, denunciada tempranamente por la propia Asamblea Parlamentaria en el año 2004 y confirmada en el presente Informe. Asimismo, insiste en la necesidad de asegurar un pleno cumplimiento de la Directiva por parte de los EEMM, especialmente con respecto a las obligaciones internacionales que les incumben en materia de derechos humanos y, específicamente, en el ámbito de la RF.

Con un tenor más concreto, la Asamblea sugiere que las disposiciones de la Directiva que contienen derogaciones y cláusulas opcionales concediendo una gran libertad a los EEMM en su aplicación, sean eliminadas en la versión modificada de dicha norma, en caso de que la misma llegue a producirse -incluyendo preceptivamente en tal derogación las restricciones relativas a la edad del cónyuge y los hijos menores-. En coherencia con la interpretación abierta del concepto de vida familiar sostenida por la jurisprudencia de Estrasburgo, propone una definición común y amplia de familia, que abarque "a miembros de la familia natural, parejas no casadas, incluyendo las del mismo sexo, hijos nacidos fuera del matrimonio, hijos en régimen de custodia compartida, así como hijos adultos dependientes y ascendientes dependientes"652. Respecto a las condiciones para el ejercicio del derecho a la RF establecidas en la Directiva 2003/86, la Asamblea Parlamentaria apuesta abiertamente por la imposición de condiciones menos severas, pues "es preferible mantener en mínimos las condiciones que los Estados puedan imponer, y centrarse mejor en la armonización, a fin de impedir la existencia de distintos niveles entre los Estados" ${ }^{253}$. Se muestra especialmente crítica en torno a la posibilidad de establecer condiciones de integración,

649 Apartado tercero del Informe de la Asamblea Parlamentaria en torno a la RF.

650 Punto número 20. Position Paper on Family Reunification.

651 Punto tercero. Positon paper of Family Reunification.

652 Idem, punto 11, traducción propia.

653 Informe de la Asamblea Parlamentaria en torno a la RF, apartado 14. 
pues las mismas propician la discriminación y perjudican especialmente a los miembros más vulnerables de la familia.

A lo largo del presente Informe, queda patente en la postura de la Asamblea Parlamentaria -en sintonía con la última línea jurisprudencial del TEDH—, la voluntad firme de facilitar y promover la migración familiar en el seno del Consejo de Europa. Por ello, podemos aventurar que el espíritu dominante actualmente en esta organización regional está enfocado en potenciar el efecto útil que la protección al respeto de la vida familiar de los extranjeros proyecta sobre el derecho a la RF en el ámbito de Estrasburgo y, a su través, en los Estados partes y en la propia Unión Europea -donde es perceptible también un rumbo progresista, al menos en lo que concierne exclusivamente a la postura del Tribunal de Justicia de la Unión Europea-.

Parece pues definitivamente cancelado el talante restrictivo que impregnó el tratamiento de esta materia en Estrasburgo hasta la llegada del nuevo siglo, y quellevó a la doctrina, de forma prácticamente unánime, a negar la posibilidad de extraer un derecho a la RF dentro de la cobertura del artículo 8 del Convenio de Roma. El nuevo rumbo que ha tomado la migración familiar resulta especialmente bienvenido en el actual contexto recesivo, donde la voluntad de muchos Estados nacionales apunta en sentido exactamente inverso, situando a los órganos jurisdiccionales internacionales -tanto al TEDH como al TJUE- en la posición de neutralizar las aludidas resistencias estatales. 



\section{CAPÍTULO III}

\section{LA REAGRUPACIÓN FAMILIAR EN EL DERECHO COMUNITARIO}

\section{DE LA INTERNACIONALIZACIÓN A LA ASUNCIÓN DE COMPETENCIAS MIGRATORIAS EN LA UE}

La regulación de las cuestiones relativas a la extranjería y la inmigración —entendidas éstas como la entrada, permanencia, circulación de no nacionales ${ }^{1}$, así como el estatuto jurídico que a éstos corresponde-, constituyó tradicionalmente una materia incluida dentro del núcleo duro de la soberanía estatal, dotada de una fundamental impronta política, cuya regulación constituía por ello una competencia exclusiva del Estado-nación. El único intersticio permitido provenía del cumplimiento de los compromisos internacionales que vinculaban al Estado en materia de derechos humanos. Estos compromisos se traducían en la imposición de ciertos límites al ejercicio de la soberanía estatal en el control de sus fronteras territoriales, y en la admisión y condiciones de residencia de los extranjeros dentro de su territorio. El surgimiento de las Comunidades Europeas, en tanto que organización dotada de objetivos fundamentalmente económicos, no alteró este panorama competencial.

Sin embargo, pese al silencio de los Tratados originarios en el ámbito migratorio, éstos otorgaban a los nacionales de los Estados miembros - en adelante EEMM - un derecho de libre circulación a fin de desarrollar determinadas actividades económicas, que contenía el germen del futuro derecho migratorio comunitario ${ }^{2}$. La libre circulación de trabajadores se traducía en la facultad de los individuos de desplazarse más allá de las fronteras nacionales con fines laborales, limitando la hasta entonces casi absoluta discrecionalidad estatal en un área fuertemente vinculada a la soberanía nacional ${ }^{3}$. Esta libertad, que iría sucesivamente ampliándose hasta terminar desvinculándose

1 La nacionalidad, en tanto que pertenencia de una persona a una comunidad política determinada, se define como el vínculo jurídico que une a un individuo con un Estado. Por exclusión, quienes no participan de dicho vínculo son definidos en negativo como extranjeros.

2 En torno a la fuerte vinculación existente entre la libre circulación, la inmigración y el asilo, vid., entre otros, GEDDES, Andrew. Immigration and European integration. Towards fortress Europe?. Manchester University Press, United Kingdom, 2000, especialmente pp. 43-66.

3 En palabras de Elspeth Guild, "the principle of free movement embodies a right to the limitation of Member State discretion". GUILD, Elspeth. "Discretion, Competence and Migration in the European Union"; European Journal of Migration and Law, No 1, 1999, p. 61. En el mismo sentido se expresa Andrew Geddes, quien afirma que "el establecimiento de un marco jurídico y politico que garantizase la libre circulación requería también la asignación de competencias jurídicas y políticas supranacionales a fin de asegurar que los acuerdos en materia de libre circulación fueran plenamente eficaces. El corolario de ello fue que las competencias discrecionales de los EEMM fueron limitadas por el surgimiento de la autoridad supranacional, desarrollada para la consecución de los objetivos comunitarios del mercado común. Los EEMM no podían controlar de forma absoluta la inmigración porque 
del ejercicio de actividades económicas, revelará con el paso del tiempo su extraordinario potencial expansivo $^{4}$ en el ámbito migratorio ${ }^{5}$. No sólo propiciaría la instauración de "los cimientos de la europeización de la política migratoria"6, sino que también actuaría como motor del reconocimiento del derecho a la reunificación familiar, primero predicándose en exclusiva de los ciudadanos de los países miembros para terminar desembocando en un derecho paralelo, aunque de menor densidad normativa, para los nacionales procedentes de terceros países.

Los antecedentes más remotos del derecho comunitario de la inmigración se sitúan a mediados de la década de los setenta del pasado siglo. Los Estados Europeos empiezan a recurrir a la cooperación gubernamental para hacer frente a algunas parcelas concretas del ámbito migratorio. La extranjería comienza entonces, si quiera de forma muy modesta e informal, a iniciar su lenta ascensión al ámbito de las preocupaciones internacionales europeas, superando así su tradicional tratamiento como asunto propio del ámbito de las políticas internas. Se trataba de una cooperación que se producía al margen de las Comunidades Europeas, en adelante CCEE y que pretendía mejorar la eficacia de la respuesta estatal ante el terrorismo, la delincuencia organizada y la inmigración ilegal, fenómenos que comenzaban a poner de manifiesto la insuficiencia de los mecanismos del Estado nación ante los retos que planteaba un mundo crecientemente globalizado e interdependiente ${ }^{7}$.

En esta misma época se crea el denominado Grupo de Trevi ${ }^{8}$, en forma de reuniones periódicas entre los ministros encargados de los asuntos de justicia e interior de nueve EEMM, con el fin de intercambiar información en materia de terrorismo, criminalidad transnacional e inmigración ilegal. Se trataba de una cooperación no institucionalizada y esporádica, aquejada de múltiples deficiencias, entre las que destacaba la opacidad e incluso secretismo de sus reuniones, lo que impide a día de hoy conocer el origen de determinados actos que constituyen el antecedente más lejano de la cooperación en los ámbitos de justicia e interior en la UE?.

los nacionales de otros EEMM que circulasen por motivos de trabajo podían moverse libremente (y reclamar este derecho ante los tribunales)". GEDDES, Andrew. Immigration and European Integration, op. cit., pp. 43-44, traducción propia.

4 El potencial expansivo de la libre circulación de personas en la UE no se circunscribe únicamente al ámbito migratorio. Va mucho más allá, puesto que esta libertad constituye la piedra angular para la consecución de la integración europea, incluyendo su dimensión política, cuya manifestación más expresiva es el proyecto constitucional. GEDDES, Andrew. Immigration and European Integration, op. cit., pp. 43 y 65. BALDACCINI, Anneliese; TONER (Helen). "From Amsterdam and Tampere to the Hague: An Overview of Five Years of EC Immigration and Asylum Law”; BALDACCINI, Anneliese; GUILD, Elspeth and TONER, Helen (eds.). Whose Freedom, Security and Justice?. EU Immigration and Asylum Law and Policy. Hart Publishing, Oxford and Pórtland, Oregon, 2007, p. 6.

5 Una perspectiva diferente la aporta González Vega, para quien, dado que los flujos migratorios se reconducen a la libre circulación de personas en tanto que elemento esencial del proceso de integración europea, el tratamiento de la inmigración en la UE conduce a una auténtica paradoja, ya que "los intentos por regular — o más bien yugular- la inmigración nos enfrentan a la postre a lo que constituye una negación de las libertades que la UE aspira a regular”. GONZÁLEZ VEGA, Javier. “¿Pero realmente existe una política euroepa de inmigración? Dificultades y retos para su concreción”. Eikasia. Revista de Filosofía, año II, 10, mayo 2007, p. 51.

6 BALDACCINI y TONER. "From Amsterdam and Tampere...”, op. cit., p.6.

7 En torno a la crisis del Estado-Nación ante el fenómeno de la globalización y la necesidad de recurrir a la cooperación multilateral para afrontar los retos que ésta plantea, vid. VALLESPÍN OÑA, Fernando "Globalización y política: la crisis del Estado"; en ARTETA AISA, Aurelio (coord.). Teoría política: poder, moral, democracia. Madrid, Alianza editorial, 2003, pp. 402-423.

8 El Grupo de Trevi fue constituido en el año 1975. En su seno se gestaría la futura creación de Europol.

9 ARGEREY VILAR, Patricia y ESTÉVEZ MENDOZA, Lucana. "El triángulo Ampliación-Inmigración-Terrorismo. Los grandes retos actuales de Europa”. Documento de Trabajo de la cátedra Jean Monnet de Integración económica. Universidad Complutense, Facultad de Ciencias Económicas, nota a pié de página nº 12, p. 7. 
Eventualmente el nacimiento de un embrionario régimen jurídico de la extranjería en el ámbito de la Unión se tornaría inevitable ${ }^{10}$ a raíz de la inserción del mercado interior como objetivo comunitario en el Acta Única Europea ${ }^{11}$ —en adelante AUE-. La realización de este objetivo exigía la libre circulación de personas, mercancías, servicios y capitales dentro del territorio comunitario, lo cual implicaba a su vez la paulatina desaparición de controles en las fronteras internas. Esta supresión colocaba en primer plano la situación de la seguridad de las fronteras exteriores comunes a la Unión, exigiendo medidas de refuerzo así como una cierta regulación común del régimen de entrada y permanencia a través de las mismas. Ante la ausencia de atribución competencial de las CEE para emprender esta tarea de cierta aproximación normativa de las medidas relativas a la admisión y residencia de los extranjeros, los Estados siguieron recurriendo a fórmulas de colaboración intergubernamental ${ }^{12}$, "a fin de atemperar los riesgos presentados por las diferencias entre políticas estatales respecto a la inmigración no comunitaria y las dificultades de su control en condiciones de libre tránsito intracomunitario"13. Además, el concepto de mercado interior introducido en el AUE actuaría como prólogo del surgimiento de una cierta idea de la Europa de los ciudadanos ${ }^{14}$, que no tardaría en hacer su aparición formal en el ámbito comunitario.

Paralelamente al recurso voluntario de los Estados miembros a la colaboración intergubernamental en el ámbito migratorio, éstos desarrollarían una actitud ambivalente de fuerte resistencia a la pérdida progresiva de control en este sensible ámbito material ${ }^{15}$. Esta postura será desde

10 GEDDES, Andrew. Immigration and European Integration..., op. cit., p. 67.

11 El AUE fue firmada en Luxemburgo el 17 de febrero de 1986 por nueve Estados miembros y el 28 de febrero de 1986 por Dinamarca, Italia y Grecia. Su entrada en vigor se produjo el 1 de julio de 1987. El artículo 13 del AUE establecía que el TCEE sería completado con una disposición —el artículo $8 \mathrm{~A}$-, cuyo párrafo segundo establecía literalmente que: "El mercado interior implicará un espacio sin fronteras interiores, en el que la libre circulación de mercancías, personas, servicios y capitales estará garantizada de acuerdo con las disposiciones del presente Tratado". El primer párrafo de dicha disposición fijaba como fecha tope para el establecimiento progresivo del mercado interior el 31 de diciembre de 1992. En torno a la reglamentación comunitaria de la extranjería en el período inmediatamente interior y posterior al AUE, resulta de especial utilidad el estudio de ORTIZ-ARCE DE LA FUENTE, Antonio. "La extranjería no comunitaria en el marco de la Comunidad Económica Europea. Hacia la configuración de una política migratoria comunitaria y el reforzamiento de los controles exteriores"; Revista del Centro de Estudios Constitucionales, №. 12, mayo-agosto 1992, pp. 207-231.

12 En esta línea, la Declaración Política de los gobiernos de los EEMM sobre la libre circulación de personas, añadida al Acta Final del AUE, afirmaba que "con objeto de promover la libre circulación de personas, los EEMM cooperarán, sin perjuicio de las competencias de la Comunidad, en particular en lo que respecta a la entrada, circulación y residencia de los nacionales de terceros países". Tratados Constitutivos de las Comunidades Europeas. Luxemburgo, Oficina de Publicaciones Oficiales de las CCEE, 1987, p. 595.

13 ORTIZ-ARCE DE LA FUENTE, Antonio. "La extranjería no comunitaria en el marco de la Comunidad Económica Europea. Hacia la configuración de una política migratoria comunitaria y el reforzamiento de los controles exteriores", op. cit., p. 231.

14 ESCOBAR HERNÁNDEZ, Concepción. “Extranjería y ciudadanía de la Unión Europea”; en ESCOBAR HERNÁNDEZ, C. (coord.), Extranjería, Inmigración en España y en la Unión Europea. Colección Escuela Diplomática, No. 3, Madrid, 1998, p. 105.

15 GEDDES, A. Immigration and European Integration..., op. cit., p. 44. BALDWIN-EDWARDS, Martin. “The Emerging European Immigration Regime: Some Reflections on Implications for Southern Europe”; en Journal of Common Market Studies, vol. 35, № 4, diciembre 1997, p. 498. La ambivalencia es tal que Livi-Baci ha descrito de forma expresiva el fuerte contraste existente entre la consideración positiva de los EEMM hacia el proceso de integración frente a sus renuencias a la cesión competencial en el ámbito migratorio, afirmando la existencia de una "ideología positiva" en torno a la integración frente a la "ideología negativa" que mantienen respecto al tratamiento de la extranjería y la inmigración en el ámbito comunitario. LIVI-BACCI, M. "South-North Migration: A comparative approach to North American and European Experiences"; en The Changing Course of International Migration. Paris, OECD, 1993, pp. 37-46. 
entonces una constante ${ }^{16}$ en la aproximación de los Estados y condicionará todo el lento proceso de construcción normativa del régimen jurídico de la extranjería y la inmigración en la UE. Como ejemplo paradigmático de esta temprana actitud, ya en 1985 cinco Estados miembros recurrieron ante el TJUE ${ }^{17}$ una decisión de la Comisión Europea en la que este órgano establecía un "procedimiento de comunicación previa y de concertación sobre las políticas migratorias respecto a terceros Estados"18. En la misma línea, el AUE incorporó en su apéndice, a iniciativa del Reino Unido, una declaración general dirigida a "negar cualquier transferencia implícita de soberanía en esta área"19.

Sin embargo, el fracaso en la consecución de la libre circulación de personas durante esta fase de la integración europea lastrará paralelamente el régimen de extranjería destinado a surgir a su amparo, reforzando que el tratamiento de la inmigración se mantuviera en escenarios intergubernamentales. De esta forma, las decisiones que afectan a la extranjería en la Comunidad Europea, son tomadas desde fuera de la Unión en variados foros de cooperación paracomunitarios ${ }^{20}$, "aunque constituidos para lograr finalidades y objetivos netamente comunitarios"21. Ello desembocó en el progresivo establecimiento, a lo largo de la década de los noventa, de un régimen europeo de internacionalización parcial de los controles migratorios que, como consecuencia de su distorsionada e inconsistente forma de elaboración, arrastraba serios problemas de aplicación ${ }^{22}$. El cuerpo normativo resultante era de lo más heterogéneo y fragmentario, lo que incrementaba su complejidad, y fue en su momento definido como un auténtico rompecabezas europeo ${ }^{23}$. Esta diversidad venía además acentuada porque a cada categoría jurídica de extranjero - refugiados, solicitantes de asilo, extranjeros no comunitarios, miembros de la familia del residente legal etc.- se le aplicaba un régimen jurídico propio y diferenciado.

16 Esta actitud sigue definiendo hoy en día la aproximación de los EEMM a la regulación comunitaria de la inmigración. En palabras de Nanclares "pervive, en el fondo, la misma dialéctica entre los polos de una conveniencia de actuación europea y una resistencia de los Estados a perder su control sobre la materia de inmigración que ha existido desde que se empezó a construir el Mercado único sin fronteras interiores". MARTÍN PÉREZ DE NANCLARES, J. "El reto de la inmigración. Sobre la conveniencia de una política común europea al estilo de la prevista en la Constitución Europea”; RGDE, No. 11, octubre 2006, s.p.

17 Alemania y otros EEMM c. Comisión, C281/85, 1987, ECR, p. 3245.

18 Decisión 85/381 de 8 de julio de 1985. El asunto fue resuelto mediante sentencia de 9 de julio de 1987, en la que el TJUE estimó que la política migratoria estaba vinculada la política social del artículo 118, con la relevante excepción de lo relativo a la integración cultural de los extranjeros procedentes de terceros países. Sobre la misma pueden consultarse, MANCA, Luigino. L'inmigrazione nel Diritto dell'Unione Europea. Milán, Giuffré Editore, Milán, pp. 27-35; MANZINI, F. "Política comunitaria e nazionale delle migrazioni nella prospectiva dell'Europa sociale"; en Rivista di Diritto Europeo, 1989, pp. 309-319.

19 Se trata de la Declaración General sobre los artículos 13 a 19 del AUE que afirma literalmente: "Ninguna de estas disposiciones afectará al derecho de los EEMM de adoptar aquellas medidas que estimen necesarias en materia de control de la inmigración de terceros países, así como con respecto a la lucha contra el terrorismo, la criminalidad, el tráfico de drogas y el tráfico de obras de arte y de antigüedades”. BALDWIN-EDWARDS, Martin. “The Sociopolitical Rights of Migrants in the European Community"; ROOM, Graham. (ed.) Towards a European Welfare State?. Saus Publisher, 1991, p. 207. BALDWIN-EDWARDS, Martin. “The Emerging European Immigration Regime: Some Reflections on Implications for Southern Europe”; en Journal of Common Market Studies, vol. 35, No 4, diciembre 1997, p. 498.

20 Continuó sus reuniones periódicas el Grupo de Trevi. En 1986 se creó el Grupo Ad Hoc de Inmigración, formado por los ministros responsables de inmigración de los por entonces 12 EEMM, y supervisado por el Grupo de Coordinadores, y en 1985 se constituyó el Grupo de Schengen. PEERS, Steve. "Building Fortress Europen: The development of EU Migration Law”; en Common Market Law Review, No. 35, 1998, pp. 1235- 1272.

21 ESCOBAR HERNÁNDEZ, C. “Extranjería y ciudadanía de la Unión Europea”, op.cit. p. 106.

22 BALDWIN-EDWARDS, Martín. “The Emergin European Immigration Regime..., op.cit. pp. 497-498.

23 Idem, p. 498. 
Esta anómala situación se prolongará hasta el año 1992, momento a partir del cual las decisiones en materia de extranjería e inmigración empezarán a ser tomadas dentro del ámbito comunitario, si bien no con carácter exclusivo, pues continuarán en funcionamiento los foros de cooperación al margen de las CCEE, especialmente en el ámbito Schengen ${ }^{24}$.

Sin embargo, a medida que la Unión iba dotándose de un progresiva dimensión política y, fundamentalmente, al hilo del desarrollo de objetivos económicos comunitarios - el anhelado establecimiento de un mercado común en el que los nacionales de los EEMM disfrutasen de las libertades comunitarias y de un régimen común del que quedaban excluidos los no comunitarios-, la Unión Europea irá reclamando ámbitos competenciales en la definición de un régimen jurídico de los extranjeros de la Unión que goce de las características de común y compartido entre sus EEMM, con independencia de los tratamientos normativos particulares que recibe el extranjero dentro de cada Estado. Por lo tanto, el nacimiento, desarrollo y profundización de una competencia comunitaria que absorbe ciertas parcelas al Estado-nación en la regulación de la extranjería y la inmigración seguirá las vicisitudes de la integración económica y política de la Unión, en relación directamente proporcional: A mayor integración, mayor necesidad paralela de construir un régimen normativo común para el tratamiento de los nacionales de terceros países.

En el lento y paulatino proceso de construcción de un derecho comunitario de la inmigración, el Tratado de Maastricht constituye un hito fundamental. En su seno emerge por primera vez la inmigración como "un área política explícita"25. Con este Tratado, las CCEE comienzan a trascender sus objetivos económicos para incorporar cierta vocación de integración política ${ }^{26}$. Los indicadores de este giro son significativos y bien conocidos. A nivel terminológico, hace su primera aparición la denominación "Unión Europea”, revelando el inicio de esta nueva dimensión de mayor calado político de las Comunidades. Con ello, la Unión se dota de "un elemental componente político que permite incorporar la categoría, aunque sea precaria, de ciudadanía de la Unión”27. La libre circulación de los

24 El Acuerdo de Schengen fue firmado en esta localidad de Luxemburgo el 14 de junio de 1985 por cinco países integrantes de las por entonces Comunidades Económicas Europeas: Francia, Alemania, Bélgica, Países Bajos y Luxemburgo. Pretendía lograr la libre circulación de personas entre los países firmantes, mediante la supresión gradual de los controles en las fronteras internas comunes de dichos Estados y el consiguiente reforzamiento de las fronteras exteriores. Fue perfeccionado por el Convenio de Aplicación de Schengen, de 19 de junio de 1990, y por la Convención de Dublín de 15 de junio de 1990 y la Convención de Luxemburgo de 15 de julio de 1991. Su implantación se inició una década después de la firma del Acuerdo Schengen, acuerdo al que se irían uniendo sucesivamente más Estados miembros hasta alcanzar en la actualidad a todos los EEMM, con la excepción de Reino Unido e Irlanda. El sistema Schengen ha sido considerado como una "cooperación sui generis de naturaleza convencional (...), que supuso un período previo y útil de concertación de las políticas nacionales de la gran mayoría de los Estados miembros en estas materias". JIMÉNEZ PIERNAS, Carlos. "La Comunitarización de las políticas de inmigración y extranjería: Especial referencia a España”; en Revista de Derecho Comunitario Europeo, № 13, 2000, p. 870. La influencia del sistema Schengen sobre el posterior derecho comunitario de la inmigración ha sido definida como "muy relevante". ESCOBAR HERNÁNDEZ, C. "Extranjería y ciudadanía de la Unión”, op. cit., p. 113. $\mathrm{Su}$ acervo sería incorporado y, por ende, comunitarizado en virtud del "Protocolo por el que se integra el acervo Schengen en el marco de la Unión Europea”, anejo al Tratado de Ámsterdam.

25 BALDWIN-EDWARDS, M. “The emerging..., op. cit., p. 498.

26 En este sentido, el artículo A 2e del Tratado de la Unión Europea afirma que "el presente Tratado constituye una nueva etapa en el proceso creador de una Unión cada vez más estrecha entre los pueblos de Europa...”.

27 ESCOBAR HERNÁNDEZ, C. "Extranjería y ciudadanía de la Unión”, op. cit., p. 107. En palabras de esta misma autora, "el concepto de ciudadanía de la Unión se convierte en el irrenunciable punto de referencia para definir al 'extranjero en la Unión'. Si bien en el entendido de que ambas nociones no son identificables por mera oposición o contraste, ya que determinados derechos predicables de los ciudadanos de la Unión — derecho de petición al Parlamento Europeo y el derecho a dirigirse al Defensor del Pueblo Europeo- también son ejercitables por los nacionales de terceros países que residan o tengan su domicilio social en un Estado miembro, a tenor de los artículos 138 D y 138 E TCE. 
trabajadores, en conexión con esta nueva categoría jurídica, determinó que a partir de ese momento "la inmigración intra-Europea para los ciudadanos comunitarios fuese supranacionalizada" 28 . El surgimiento del status de ciudadano de la Unión, dotado de un corpus de derechos y deberes unificados en el territorio comunitario, impide la aplicación de la categoría de extranjeros a los nacionales de cualquier Estado miembro ${ }^{29}$, tanto desde la perspectiva del derecho estatal interno como comunitario. De este modo la ciudadanía de la Unión llevaba implícita la reserva de la categoría de extranjero para los nacionales de terceros países o extracomunitarios, permitiendo el desenvolvimiento con mayor propiedad de cierta extranjería en la Unión.

Maastricht dotó a la recién bautizada Unión Europea de una estructura tripartita, al estilo de los templos griegos de la época clásica, de donde se tomó la metáfora. Al pilar o estructura básica, de carácter comunitario y en el que rigen los métodos decisorios y de funcionamiento institucional propios del derecho comunitario supranacional, se le añadieron dos contrafuertes extracomunitarios. El segundo pilar estaba destinado a la cooperación entre los EEMM en materias de política exterior y seguridad común - PESC-, mientras que el tercero recogía disposiciones relativas a la cooperación en los ámbitos de justicia y asuntos de interior - CAJI- . Estos dos pilares anexos estaban regidos por los métodos propios de la cooperación intergubernamental, esto es, el requisito del consenso o unanimidad entre todos los EEMM y el limitado papel desempeñado por las instituciones comunitarias, con una exclusión total en dicho ámbito de la jurisdicción del Tribunal de Justicia de las Comunidades Europeas. La estructuración en pilares constituía un ingenio jurídico a fin de "preservar la naturaleza intergubernamental de áreas políticas sensibles, al tiempo que permite incorporar dichas áreas dentro del marco de la Unión" ${ }^{30}$.

Dentro del tercer pilar — construido en base a la adición de un nuevo título VI al TUE-, se insertó el asilo, la extranjería, la inmigración y el cruce de fronteras exteriores como materias de interés común ${ }^{31}$, y de nuevo vinculándolas a la realización de la libre circulación de personas como fin de la Unión. Se trataba con ello de favorecer la coordinación y colaboración entre los EEMM, actores principales del proceso, poniendo a su disposición las instituciones comunitarias. De este modo la extranjería, situada todavía de lleno dentro del ámbito de las competencias del Estado, pasó a ser objeto de atención en el ámbito de la UE, si bien a través de los mecanismos propios de una "tímida"32 cooperación intergubernamental.

La toma de decisiones dentro del tercer pilar ${ }^{33}$ seguía un modelo intergubernamental propio de los mecanismos del derecho internacional público, esto es, a extramuros del derecho comunitario.

28 GEDDES, Andrew. "International Migration and State Sovereignty in an Integrating Europe"; en International Migration, vol. 39, n 6, 2001, p. 23.

29 MANGAS MARTÍN, Araceli y LIÑÁN NOGUERAS, Diego J. Instituciones y Derecho de la Unión Europea, Madrid, 1996, p. 617. Lo que determina que el extranjero ya no haga referencia al nacional de un EM que no ha nacido en otro EM en el que reside de forma temporal o permanente sino, de forma mucho más restringida, a los nacionales extracomunitarios.

30 BALDWIN-EDWARDS, M. “The emerging...., op cit., p. 499, traducción propia.

31 Para un estudio más detallado del régimen de extranjería durante la vigencia del Tratado de Maastricht, vid. ESCOBAR HERNÁNDEZ, Concepción. “Extranjería y ciudadanía de la Unión Europea”, op. cit., pp. 103-126.

32 JIMÉNEZ PIERNAS, Carlos. "La comunitarización de las políticas de inmigración y extranjería: Especial referencia a España”; op. cit., p. 870.

33 En noviembre de 1993 se creó el tercer pilar de la Unión Europea, a partir de entonces los encuentros hasta ese momento mantenidos entre los ministros responsables de inmigración de los Estados miembros fueron integrados en el Consejo de Justicia y Asuntos Interiores (el grupo ad hoc de inmigración se convierte en Steering Grupo I y el Grupo de coordinadores pasa a convertirse en el Comité K4). En 1994 se unió el Grupo de Trabajo Eurodac. PEERS, Steve. “Building Fortress Europe: The Development of EU Migration Law”, op. cit., pp. 1238-1239. 
A estos efectos, la disposición central del Tratado de Maastricht era el artículo K.1 TUE, conforme al cual la política de asilo, las normas relativas al cruce de personas por las fronteras exteriores y la práctica de controles sobre dichas personas, así como la política de inmigración y la política relativa a los nacionales extracomunitarios, con particular referencia a "las condiciones de estancia de los nacionales de terceros Estados en el territorio de los EEMM, incluidos el acceso al empleo y la reagrupación familiar" ${ }^{34}$ pasaban a ser considerados ámbitos de interés común para la consecución de los fines comunitarios.

Durante la vigencia del Tratado de Maastricht los distintos instrumentos aprobados en el ámbito de la extranjería y la inmigración sobre la base del artículo K.1 TUE - posiciones comunes, acciones comunes y convenios internacionales ${ }^{35}$ - se caracterizaron por su escasa eficacia jurídica ${ }^{36}$. Muchos de ellos eran meras declaraciones políticas carentes de fuerza vinculante en los EEMM. Junto a su debilidad jurídica, las medidas adoptadas en el marco del tercer pilar destacaron por su abundancia, dando lugar a una auténtica "plétora" ${ }^{37}$ de resoluciones, recomendaciones y conclusiones dirigidas a aproximar las políticas internas, muchas de ellas no publicadas oficialmente. Dentro de éstas, fueron especialmente prolíficas las referidas al marco del asilo y de la inmigración ilegal. Los escasos Convenios que fueron aprobados en este período constituyen la excepción en este escenario de marcada debilidad jurídica, si bien como tales se insertaban en el ámbito del derecho internacional público y su eficacia concreta dependía de la que le asignasen las normas constitucionales internas de cada Estado miembro. Por ello, la situación creada por el Tratado de Maastricht en materia de extranjería e inmigración ha llegado a ser definida como "una semi-comunitarización" que a pocos satisfizo ${ }^{38}$.

Sin embargo, una materia paradigmática en el ámbito de la inmigración sí que sería comunitarizada por el Tratado de Maastricht, constituyendo una marcada excepción al panorama intergubernamental dominante durante su vigencia ${ }^{39}$. Se trataba de la concesión de visados para estancias infe-

34 Artículo K.1. apartado 3, punto b) del Tratado de Ámsterdam, incluido en el Título IV.

35 El artículo K.3 señalaba los instrumentos jurídicos que el Consejo podría adoptar. Este artículo habilitaba al Consejo para dictar posiciones comunes - carentes de eficacia jurídica-, acciones comunes - podían tenerla, pero no era claro-; y convenciones de derecho internacional, cuya concreta eficacia interna dependía del sistema particular de cada EM.

36 En palabras de Kay Hailbronner, "los EEMM de la UE han sido muy reticentes a atribuir eficacia vinculante a los instrumentos de inmigración y asilo basados en el artículo K.1 TUE". HAILBRONNER, Kay. "European Immigration and Asylum Law under the Amsterdam Treaty"; en Common Market Law Review, n 35, 1998, p. 1047, traducción propia.

37 BALDWIN-EDWARDS, Martin. “The Emergin European Immigration Regime..”, op. cit., p. 501. Las resoluciones adoptadas en materia de extranjería e inmigración, formuladas en el ámbito del tercer pilar intergubernamental y por ello constitutivas de soft law, fueron las siguientes: Resolución sobre Reunificación Familiar; Resolution on admisión for employment, junio 1994 (OJ 1996, C 247/.); Resolution on admisión of the self-employed, diciembre de 1994 (OJ 1996, C 247/7) y Resolution on admission on students (OJ 1996, C 247/10); Joint action on integration of legal residents, formalmente después una Resolución adoptada en marzo de 1996 (OJ 1996, C 80/2); Joint Position governing admisión of persons entering on other grounds, pero nunca se produjo un acuerdo sobre ésta última debido a la oposición de Alemania, Dinamarca, Holanda y Austria (documento 8630/95, de 30 de junio). Resolución relativa a matrimonios de conveniencia, adoptada en diciembre de 1997 sobre una propuesta de Luxemburgo (OJ 1997, C 382/1).

38 GORTÁZAR ROTAECHE, Cristina J. "De las políticas de 'Inmigración 0' a la Inmigración selectiva”; en La inmigración en la Unión Europea: Situación y perspectivas para Euskadi. Bilbao, Consejo Vasco del Movimiento Europeo, 2003, p. 189.

39 Esta circunstancia ha permitido a un sector doctrinal señalar el año 1993 como la fecha que marca el inicio de la lenta cesión de soberanía por parte de los EEMM a las instituciones comunitarias en materia migratoria. Constituye por ello el antecedente más inmediato de la comunitarización, que más adelante llevaría a cabo el Tratado de Ámsterdam. JIMÉNEZ PIERNAS, Carlos. "La comunitarización de las políticas...", op. cit., p. 870. Sin embargo es posible encontrar referencias doctrinales que sitúan este inicio en un momento algo anterior. Así por 
riores a tres meses en el territorio comunitario, concretamente, de la lista de ciudadanos de terceros países cuyos nacionales debían estar en posesión de visados para cruzar las fronteras exteriores de la Unión, cuya elaboración sería objeto de regulación comunitaria conforme al artículo 100C TCE ${ }^{40}$.

Esta circunstancia suponía que, en esta fase embrionaria de construcción del derecho comunitario de la inmigración, coexistían dos planos normativos en el seno de la Unión. De un lado, aquellas medidas relativas al tránsito por las fronteras y visados, insertadas en el primer pilar y adoptadas sobre la base jurídica del artículo 100 C TCE. Éstas constituían normas plenamente comunitarias, dotadas de la eficacia supranacional propia de este derecho. De otro lado, aquellos instrumentos normativos basados en el artículo K.3 e incluidos en el tercer pilar, sometidos a la dinámica y efectos propios del derecho internacional público. Esta coexistencia de planos, - comunitario y extracomunitario-, dio lugar a un régimen normativo disperso y a veces contradictorio. Sin embargo, para contrarrestar en parte esta falta de unidad normativa, cabe señalar que tanto las medidas basadas en el pilar comunitario como las derivadas de la CAJI, se adoptaban en el Consejo de Justicia e Interior.

La dispersión y cierta incoherencia que definían al incipiente régimen de extranjería, se veían acentuadas por una circunstancia adicional: Junto a la duplicidad de planos normativos dentro de la propia Unión, el Tratado de Maastricht permitió la continuación de los foros de cooperación intergubernamentales existentes con anterioridad a su entrada en vigor, en particular el sistema Schengen. Éste había sido constituido en 1986, pero comenzó a implantarse de forma escalonada a inicios de los noventa, haciendo realidad entre algunos de los países firmantes la supresión de las fronteras interiores. Schengen constituirá la fuente de una importante producción de normas en el ámbito de la extranjería, el asilo y la inmigración ${ }^{41}$. Algunas materias - concretamente los visados y controles fronterizos-, se superponían y solapaban entre el primer y el tercer pilar y el ámbito Schengen ${ }^{42}$. El problema residía en que las estrategias migratorias desarrolladas en Schengen, a menudo aparecían desconectadas ${ }^{43}$ de aquellas establecidas en base al Tratado de Maastricht.

En resumen, las políticas públicas establecidas en el marco del tercer pilar fueron objeto de numerosas críticas por tres motivos principales: falta de transparencia, escasa efectividad y nula rendi-

ejemplo, Peers considera que, con anterioridad a la transferencia de competencia a la Comunidad en materia de inmigración, "la substancia del derecho de migración se movió firmemente a la agencia comunitaria en 1991, tras el acuerdo alcanzado en la Convención de Dublín y el casi acuerdo sobre la Convención sobre Fronteras Exteriores". El incremento de la presión migratoria y la necesidad de cooperación que venía aparejada a la Convención sobre Fronteras Exteriores, explican a juicio de este autor la conveniencia de que la Comunidad adoptara un enfoque común en materia migratoria y emprendiese la tarea de armonizar las diferentes políticas internas en la materia. PEERS, Steve. "Building Fortress Europen: The development of EU Migration Law"; en Common Market Law Review, no 35, 1998, pp. 1235- 1272 .

40 Sobre la base de esta disposición se adoptaron el Reglamento (CE) no 1683/95 del Consejo, de 29 de mayo de 1995 , por el que se establece un modelo uniforme de visado (DOCE n ${ }^{\circ}$ L 164, de 14 de julio de 1995); Reglamento (CE) 2317/95, de 25 de septiembre de 1995, por el que se determinan los terceros países cuyos nacionales deben estar provistos de un visado al cruzar las fronteras exteriores (DOCE no L 234, de 3 de octubre de 1995).

41 Estas medidas serían posteriormente consideradas por el Tratado de Ámsterdam como expresamente compatibles con las establecida por la Unión en dicha área, tanto en el plano comunitario del primer pilar (artículo 100 C, párrafo 7 TCE) como del ámbito CAJI (artículo K.7).

42 BALDWIN-EDWARDS, M. “The emerging..., op. cit.,, p. 506.

43 Idem, p. 508. Un ejemplo ilustrativo de las incoherencias resultantes de la desconexión entre los planos Schengen y Maastricht, viene dado por dos importantes reglamentos establecidos en ambos foros. El Reglamento (CE) 2317/95, de 25 de septiembre de 1995, establecía 101 países que necesitaban visado para entrar en la UE, mientras que el Grupo de Schengen exigía por entonces a 129 países el requisito previo de visado. Este Reglamento fue finalmente anulado por el Tribunal de Justicia de Luxemburgo en la decisión emitida el 10 de junio de 1997. 
ción de cuentas en torno a su proceso de gestación ${ }^{44}$. Las políticas migratorias no escaparon a estas debilidades y sobre las mismas planeaba de forma especialmente aguda el fantasma de la incoheren$\mathrm{cia}^{45}$, cierta indefinición en sus objetivos ${ }^{46} \mathrm{y}$ unas estructuras de trabajo excesivamente complejas ${ }^{47}$ que dificultaban aún más la toma de decisiones. Por si fuera poco, el ámbito intergubernamental en que se desenvolvían, determinaba que estas políticas se caracterizasen por retener un muy alto grado de discrecionalidad estatal ${ }^{48}$ que proyectaba aún más problemas a su implementación práctica.

Se trataba, por otro lado, de una visión del asilo y la inmigración basada en la idea de amenaza que representaba el aumento de la presión migratoria, de las peticiones de asilo, la inmigración irregular y el crimen internacional ${ }^{49}$ y por ello destinada tan sólo a hacer frente a los aspectos de control más urgentes, vinculados al incremento en la seguridad que venía exigido por el logro progresivo del mercado interior. El sistema se asentaba en una concepción defensiva, enfatizando los elementos de seguridad y policiales de los flujos en las fronteras, sin que, paralelamente, preocupasen los derechos de los extranjeros procedentes de terceros países. Esta tendencia restrictiva se hizo particularmente visible a raíz de la laboriosa implantación del sistema $S_{\text {chengen }}{ }^{50}$, siendo identificada con la descriptiva expresión de "Europa fortaleza"s1. Esta visión se veía reforzada por la yuxtaposición ${ }^{52}$ de materias - el asilo y la inmigración se mezclaban con los asuntos criminales-como consecuencia de su tratamiento intergubernamental, provocando cierta criminalización de los asuntos migratorios ${ }^{53}$.

44 BALDWIN-EDWARDS, M. “The emerging...., op. cit., p. 503.

45 Idem, p. 502.

46 MARTÍN Y PÉREZ DE NANCLARES, J. La inmigración y el asilo en la UE. Colex, Madrid, 2002, pp. 46 y ss, donde se explican con mayor detenimiendo las deficiencias del modelo intergubernamental que aconsejaban su sustitución por mecanismos propiamente comunitarios.

47 BALDWIN-EDWARDS, M. “The emerging...., op. cit, pp. 503-504.

48 GUILD. Elspeth. “Discretion, Competence and Migration in the European Union..., op. cit., p. 62.

49 BALDWIN-EDWARDS, Martin. “The Emergin...”, op. cit., p. 498.

50 ARANGO, Joaquín. "Dificultades y dilemas de las políticas de inmigración”; Anuario de la Facultad de Derecho de la Universidad Autónoma de Madrid, No 7, 2003, p. 59. Al respecto, este autor ha destacado que junto a su finalidad principal -la supresión de las fronteras internas entre los Estados firmantes-, Schengen era "portador de una segunda finalidad, de naturaleza eminentemente restrictiva y policial, cual es el fortalecimiento de las fronteras exteriores". Este autor ha destacado asimismo un efecto paradójico producido por el sistema Schengen pues, lejos de su objetivo de control principal, ha podido acarrear la "contrapartida imprevista de incrementar las dificultades que afligen al control de las fronteras comunes y, consiguientemente, de ampliar las oportunidades de los candidatos a la inmigración irregular".

51 Una visión más matizada en torno a la Europa Fortaleza en la que, junto a los aspectos de control y seguridad propios de esta oscura "zona de exclusión”, se destacan también las luces que la integración europea ha conllevado en materia de liberalización, libre circulación y transnacionalización de ciertos derechos, se encuentra en GEDDES, Andrew. Immigration and European Integration... op. cit., pp. 15-21. Este autor considera que la noción de Europa fortaleza responde más bien a un juego político de simbolismos, más relacionado con el temor europeo a la pérdida de formas de vida, identidades nacionales y culturales, supuestamente amenazadas por el fenómeno migratorio, que a la capacidad de los EEMM para controlar la inmigración, capacidad sobre la cual el autor considera que ha sido "exagerada". Pese a estas consideraciones, su estudio, realizado en el año 2000, concluye considerando que de forma inequívoca la inmigración en la UE se encuentra escorada en la dirección de la priorización de los aspectos de control y seguridad. Idem, pp. 16 y 171.

52 BALDACCINI, A; TONER, H. From Amsterdan and Tampere to the Hague..., op. cit., p. 11.

53 Como ejemplo de esta corriente que tiende a criminalizar la inmigraciónn, múltiples autores han denunciado la inclusión y proliferación en el lenguaje coloquial de términos aparentemente neutrales, que sin embargo están cargados de prejuicios y en sí mismos incorporan una fuerte carga ideológica peyorativa contra la inmigración. Entre dichos vocablos coloquiales, resulta paradigmática la utilización del término de "extranjero ilegal", en lugar del más correcto jurídicamente de "extranjero irregular". Para Marina Gascón o Sami Naïr el término de ilegal "estigmatiza a quien lo porta”. GASCÓN ABELLÁN, Marina. Nosotros y los otros: el desafío de la inmigración. Lección inaugural del curso académico 2000-2001. Gabinete del Rector de la Universidad de Castilla-la Mancha, Ciudad Real, 2001, p. 19. Su uso constituye una buena muestra de la corriente que tiene a vincular extranjería con delincuencia, con 
De modo que el tradicional trípode ${ }^{54}$ sobre el que debían reposar las políticas migratorias —control de admisiones de extranjeros, regulación de las peticiones de asilo y lucha contra la inmigración ilegal; políticas de integración, incluyendo la lucha contra el racismo, la discriminación y la xenofobia; y cooperación al desarrollo, a fin de intentar paliar las causas productoras de emigración en los países de origen - se encontraba profundamente desequilibrado, siendo claramente prioritario el eje del control de flujos. Adicionalmente, este sistema, lejos de constituir un sistema completo, se circunscribía a la regulación de las cuestiones de interés común más elementales, dando lugar a un régimen "parcial y embrionario" 55.

Consciente de las deficiencias que lastraban la construcción de un auténtico régimen de la extranjería y la inmigración bajo la vigencia del Tratado de Maastricht, el propio Tratado preveía cauces a fin de poder completar el traspaso de las materias comprendidas en la CAJI al ámbito comunitario. Se trataba de la denominada "pasarela" prevista en el artículo K.9, bajo la exigencia de la unanimidad del Consejo y la ratificación de la misma por parte de los EEMM, según sus respectivas disposiciones constitucionales. Pero el proceso de traspaso era tan extremadamente difícil ${ }^{56}$ que nunca fue utilizado.

La aprobación y entrada en vigor del Tratado de Ámsterdam ${ }^{57}$ supuso un cambio sustantivo en el tratamiento de la inmigración, hasta el punto de ser calificado como un "giro histórico" ${ }^{8}$ en la política europea. Ámsterdam asignaba a la Unión Europea la consecución de un nuevo objetivo: el establecimiento progresivo de un "espacio de libertad, seguridad y justicia, en el que esté garantizada la libre circulación de personas conjuntamente con medidas adecuadas respecto al control de las

efectos muy perniciosos sobre la percepción social que las sociedades receptoras pueden tener sobre los flujos que acogen. En los textos jurídicos, la tendencia al uso del término “ilegal”, iniciado y profundamente propagado en la década de los noventa del pasado siglo, ha ido en descenso con la llegada del nuevo siglo. Sin embargo, la UE parece mantenerse al margen de la creciente influencia del maquillaje lingüistíco que afecta a los asuntos migratorios y continúa utilizando con profusión el término de extranjero ilegal o de lucha contra la inmigración ilegal, en los más modernos textos comunitarios consensuados. Baldacini y Toner también han subrayado esta tendencia antisistema de la UE, y consideran además que la cuestión de la lucha contra la inmigración ilegal está recibiendo un tratamiento comunitario preferente, hasta el punto de estimar que la UE está prestando "una desproporcionada atención al retorno de los inmigrantes irregulares". Ambas autoras observan además con preocupación que todas las iniciativas comunitarias dirigidas a facilitar el retorno presentan una preocupante "falta de garantías legales adecuadas". BALDACCINI y TONER. From Amsterdan and Tampere to the Hague..., op. cit., p. 12. La tristemente célebre Directiva sobre el retorno de inmigrantes irregulares, aprobada el 18 de junio de 2008, constituye un buen ejemplo de las tendencias apuntadas a nivel comunitario.

54 Paradójicamente la expresión "tres ejes de la política migratoria” se convirtió en un clásico en esta época, coincidiendo con la emergencia de la Europa fortaleza y las políticas de restricción de flujos. Su fama deriva de una Comunicación de la Comisión sobre Políticas de Inmigración y Asilo de 23 de febrero de 1994. Sami Naïr ha ido más allá, y ha denunciado que los términos de "emigración", "inmigrante" y "extranjero" se han convertido en un prejuicio y su mera pronunciación genera efectos. Para este autor, tales términos constituyen términos "performativos", "palabras que llevan en sí el infortunio, que evocan conflictos, miedos, sufrimientos. Palabras malditas, preñadas de significados". NAIR, Sami. Y vendrán... las migraciones en tiempos hostiles. Barcelona, editorial Planeta, 2006, p. 13.

55 ESCOBAR HERNÁNDEZ, Concepción. “Extranjería y ciudadanía de la UE”, op. cit., p. 110.

56 BALDWIN-EDWARDS, M. “The emerging...”, op. cit., p. 504.

57 El Tratado de Ámsterdam de 2 de octubre de 1997, entró en vigor el 1 de mayo de 1999. BOE de 7 de mayo de 1999. Sobre su incidencia en el ámbito del asilo, la extranjería y la inmigración vid., entre otros, HAILBRONNER, KAY. "European Immigration and Asylum Law under the Amsterdam Treaty"; en Common Market Law Review, no 35, 1998, pp. 1047-1067. VALLE GÁLVEZ, A. “La refundación de la libre circulación de personas, tercer pilar y Schengen: el espacio europeo de libertad, seguridad y justicia”; en Revista de Derecho Comunitario Europeo, $\mathrm{n}^{\circ} 3$, 1998, pp. 41-78.

NAÏR, Sami. Y vendrán... las migraciones en tiempos hostiles, op. cit., p. 140. 
fronteras exteriores, el asilo, la inmigración y la prevención y la lucha contra la delincuencia"59. A tal fin, la inmigración y la extranjería se erigían en un objetivo directamente vinculado a la consecución de la UE como un espacio de libertad, seguridad y justicia ${ }^{60}$.

El Tratado de Ámsterdam establecía un nuevo título, el Título IV, que situaba bajo el paraguas competencial de la UE - esto es, en el primer pilar comunitario ${ }^{61}$-, muchas de las materias que hasta ese momento habían sido objeto de cooperación intergubernamental bajo el Tercer Pilar. En el pilar intergubernamental se residenciaban ahora la cooperación policial y judicial en materia penal, separándose de este modo las materias propias de la emigración y el asilo de los asuntos criminales, cuyo tratamiento se venía entremezclando durante el largo período previo de colaboración intergubernamental. El calado de este cambio es de tal magnitud que entrañaba profundas implicaciones sobre la soberanía estatal, pasando la inmigración de una potestad típicamente estatal a convertirse en una competencia comunitaria compartida ${ }^{62}$ con los EEMM, sobre la base del principio de subsidiariedad.

El traspaso de parte de las materias del tercer al primer pilar suponía transformaciones sustanciales en el tratamiento jurídico de la extranjería a nivel comunitario, con profundas implicaciones en el ámbito interno de los EEMM. A los Estados, en tanto que sujetos hasta ahora primordiales en la formulación de las políticas migratorias, se añadían las instituciones comunitarias en aquellos ámbitos materiales atribuidos a la UE que producirán al efecto normas dotadas de los efectos propios del derecho comunitario, señaladamente efecto directo y supremacía sobre los derechos internos. Si la ausencia de una base jurídica expresa había imposibilitado el logro de "resultados tangibles"63 en materia migratoria, el Tratado de Ámsterdam venía a poner punto final a esta situación, comunitarizando parcialmente la extranjería e inmigración.

Muchos fueron los factores que propiciaron este hecho. Entre ellos, la creciente presión migratoria que recibían los Estados europeos; la mayor eficiencia en su gestión si se planteaba con un enfoque común y coordinado; y, especialmente, el impulso de la realización del viejo objetivo de la libre circulación de personas en el ámbito comunitario. La reactivación de este objetivo - introducido en el Acta Única Europea y desde entonces sucesivamente profundizado-, convirtió en necesidad la anterior conveniencia de regular conforme a parámetros comunes las cuestiones relativas a los nacionales de terceros Estados que entran, residen y circulan por el espacio comunitario. La gestión de la inmigración a nivel casi exclusivamente nacional, como venía ocurriendo hasta ahora - con la excepción de la cooperación intergubernamental entre los EEMM, muchas veces carente de efectividad - tornó inviable, por ineficaz ${ }^{64}$, el objetivo comunitario de supresión de las fronteras

59 Artículo 2 TUE.

60 Artículo 61. a TUE. Para ESCOBAR HERNÁNDEZ, el espacio de libertad, seguridad y justicia vendría a reforzar el vínculo funcional ya existente entre la inmigración y la libre circulación de personas: las medidas a adoptar en el ámbito migratorio constituyen un medio necesario para el logro de la libre circulación intracomunitaria y, por ende, para el establecimiento de la Unión como un espacio de libertad, seguridad y justicia. "Extranjería y ciudadanía de la UE”, op. cit., p. 120.

61 En el pilar comunitario, la Unión Europea - y no los EEMM - constituye el intérprete fundamental, cuyos actos, fruto de la potestad legislativa otorgada ahora por el Tratado, poseerán la eficacia supranacional propia del derecho comunitario.

62 Para ESCOBAR HERNÁNDEZ se trata de una "competencia necesariamente compartida, centrada esencialmente en la definición de normas básicas”. "Extranjería y Ciudadanía de la UE”, op. cit, p. 123.

63 BUlTerman, M. “Case C-540/03, Parliament v. Council, Judment of the Grand Chamber of 27 june 2006 ”; en Common Market Law Review, no 45, 2008, p. 245.

$64 \mathrm{Al}$ respecto Nanclares ha afirmado que "la desaparición de las fronteras interiores entre los Estados miembros supone que las fronteras exteriores de cada Estado son a la vez fronteras exteriores de toda la Unión Europea. Desde 
interiores, elemento éste indispensable a su vez para el logro de la libre circulación de personas por el espacio comunitario. En este sentido, el tratamiento de la inmigración ha sido considerado como un "objetivo primario" ${ }^{65}$ de la Unión.

Pero en el Tratado de Ámsterdam la comunitarización de la inmigración distaba de ser plena. Los Estados seguían conservando poderes esenciales de actuación, ya que el ámbito material cubierto por el nuevo Título IV, aún siendo amplio, estaba lejos de abarcar todo el vasto espectro que engloba la extranjería y la inmigración ${ }^{66}$. Quedaban fuera importantes aspectos, tales como la expulsión y deportación o la prevención de inmigración incontrolada ${ }^{67}$. Se trataba pues de una comunitarización parcial y gradual ${ }^{68}$; si bien cabría señalar que Ámsterdam parecía haber dado el paso del Rubicón, de modo que el futuro apunta a una sucesiva ampliación de las competencias comunitarias en esta materia, en detrimento de la soberanía estatal. Además, del análisis de las materias enumeradas y comunitarizadas por el Tratado de Ámsterdam, se desprende una importante conclusión respecto al cambio en el tratamiento jurídico de la inmigración: de la anterior visión de control, propia de la denominada Europa Fortaleza, pasan a contemplarse además materias propias del estatuto jurídico de los nacionales de terceros países, así como medidas encaminadas a lograr su integración en el territorio del EM, tendiéndose a equilibrar los dos polos — seguridad y concesión de derechos - entre los que ha de desenvolverse de forma armónica el tratamiento de esta materia. Si bien, el predominio de los factores de control y seguridad seguía siendo un elemento destacado del diseño comunitario de las políticas de extranjería e inmigración.

Tres grupos de materias fueron exentas del plazo general de cinco años otorgado al Consejo para que adoptase legislación en las materias concretas del asilo y la inmigración, que habían pasado a ser competencia normativa de la UE ${ }^{69}$. Esta exclusión reflejaba claramente el carácter altamente controvertido de las materias incluidas, entre las que figura, como no podía ser de otro modo, la reagrupación familiar. Se trata de las medidas a fin de fomentar el esfuerzo equitativo entre los EEMM para la acogida de refugiados y personas desplazadas, así como la asunción de las consecuencias de

que un inmigrante traspasa ilegalmente la frontera en Ceuta o en Catania se convierte en un inmigrante ilegal de toda la Unión”. MARTÍN Y PÉREZ DE NANCLARES, José. "El reto de la inmigración: sobre la conveniencia de una política común europea al estilo de la prevista en la Constitución Europea"; en Revista General de Derecho Europeo, No. 11, 2006, p. 2.

65 HAILBRONNER, KAY. "European Immigration and Asylum Law under the Amsterdam Treaty"; en Common Market Law Review, n 35, 1998, p. 1048.

66 La competencia material genérica está delimitada en el artículo 61, conforme al cual "a fin de establecer progresivamente un espacio de libertad, seguridad y justicia, el Consejo adoptará: a) en un plazo de cinco años a partir de la entrada en vigor del Tratado de Amsterdam, medidas destinadas a garantizar la libre circulación de personas de conformidad con el artículo 14, conjuntamente con las medidas de acompañamiento directamente vinculadas con aquella y relativas a los controles en las fronteras exteriores, el asilo y la inmigración (...); b) otras medidas en los ámbitos del asilo, la inmigración y la protección de los derechos de los nacionales de terceros países (...)". Éstas últimas se especifican con carácter más concreto en el artículo 63. Junto a las medidas en materia de asilo, y aquellas relativas a los refugiados y personas desplazadas (artículo 63.1, apartados 1 y 2), el apartado tercero del artículo 63 establece que el Consejo ha de adoptar medidas sobre política de inmigración en los siguientes ámbitos: a) condiciones de entrada y de residencia, y normas sobre procedimientos de expedición por los EEMM de visados de larga duración y de permisos de residencia, incluidos los destinados a la reagrupación familiar; b) la inmigración y la residencia ilegales, incluida la repatriación de residentes ilegales; El apartado cuarto añade competencias normativas para adoptar "medidas que definan los derechos y las condiciones con arreglo a los cuales los nacionales de terceros países que residan legalmente en un EM puedan residir en otros EEMM”.

67 HAILBRONNER, Kay. “European Immigration...” op. cit., p. 1049.

68 ESCOBAR HERNÁNDEZ. “Extranjería y ciudadanía de la UE”, op. cit., p. 120. HAILBRONNER, KAY. “European Immigration..., op. cit., p. 1053.

69 Artículo 63 in fine. 
dicha acogida ${ }^{70}$; las medidas sobre política de inmigración relativas a las condiciones de entrada y de residencia y las normas sobre procedimientos de expedición por los EEMM de visados de larga duración y de permisos de residencia, incluidos los destinados a la reagrupación familiar ${ }^{71}$. En este grupo también se incluyen las medidas que definen los derechos y las condiciones con arreglo a los cuales los nacionales de terceros países residentes legales en un EM pueden residir en otros EEMM.

La inserción de determinadas materias migratorias en el "redil comunitario"72 estaba caracterizada por algunas particularidades que venían a contaminar de cierta intergubernamentalidad ${ }^{73}$ el proceso de Comunitarización emprendido en Ámsterdam. Estos elementos contaminantes o "fragmentadores"74 reflejan las dificultades políticas y los consiguientes recelos estatales ante tal delicado paso, constituyendo todas ellas concesiones a los EEMM y cautelas ${ }^{75}$ necesarias a fin de llevar a buen término la indicada comunitarización. El Tratado de Ámsterdam fijaba un período transitorio de cinco años a contar desde su entrada en vigor, durante el cual el régimen comunitario estaba empañado de múltiples elementos intergubernamentales que afectaban tanto al procedimiento legislativo como al funcionamiento y atribuciones de las propias instituciones comunitarias, e incluso al ámbito de aplicación territorial de dicho régimen. Constituyen por ello "limitaciones materiales, temporales y territoriales" ${ }^{\prime 6}$ al nuevo derecho comunitario del asilo y la inmigración, traduciéndose en "significativas restricciones sobre la acción de las instituciones comunitarias" que señalamos a continuación.

1. El proceso para la adopción de normas relativas a las materias establecidas en el nuevo Título IV escapaba al régimen comunitario general del artículo 251, caracterizado por la exigencia de mayoría cualificada en el Consejo. En el ámbito migratorio la toma de decisiones se condicionaba al requisito de la unanimidad en el Consejo ${ }^{78}$, si bien tan sólo durante el período transitorio de cinco años. Tras el mismo, el Consejo, por unanimidad y previa consulta al Parlamento Europeo, decidirá si todos o parte de los ámbitos del Titulo IV se regirán por el procedimiento general ${ }^{79}$.

El requisito de la unanimidad ejercerá una influencia de primer orden tanto en el contenido como en el propio procedimiento de adopción de las medidas comunitarias relativas al asilo y la inmigración, pues implicaba otorgar un derecho de veto a cada uno de los EEMM. Sus efectos se disparan si tenemos en cuenta que la inmigración constituye en la actualidad, tanto a nivel comunitario como en los EEMM individualmente considerados, una materia altamente politizada ${ }^{80}$ y por ello muy sensible a los vaivenes de la opinión pública, sobre todo en ciclos electorales. La unanimi-

$70 \quad$ Letra b) del artículo 63.2.

71 Letra a) del artículo 63.3.

72 MARTÍN Y PÉREZ DE NANCLARES, José Manuel. "La inmigración y el asilo en la Unión Europea: Presente y futuro"; REMIRO BROTONS, A; MARTÍNEZ CAPDEVILA, C. (eds). Anuario de la Facultad de Derecho de la Universidad Autónoma de Madrid, vol. 7, 2003, p. 93.

73 JIMÉNEZ PIERNAS, C. “La comunitarización...”, op. cit., p. 874.

74 MARTÍN Y PÉREZ DE NANCLARES, J.M. El reto de la inmigración..., op. cit., s.p.

75 JIMÉNEZ PIERNAS, C. “La comunitarización...”, op.cit. p. 872.

76 Idem, p. 874.

77 GEDDES, Andrew. Immigration and European Integration...., op. cit., p. 129.

78 Artículo 67.

79 Existe una propuesta de la Comisión sobre la adaptación de las disposiciones del Título IV del TCE relativas a la jurisdicción del Tribunal de Justicia con vistas a asegurar una mayor protección judicial efectiva, COM (2006) 346 final, 28 de junio 2006.

BALDACCINI, A; TONER, H. "From Amsterdam and Tampere to the Hague”..., op. cit., p. 21. 
dad constituye pues un elemento ${ }^{81}$ que dificultará la toma de decisiones en aspectos especialmente conflictivos, pudiéndose traducir en la preponderancia de los intereses nacionales sobre el interés común europeo, y aumentando las probabilidades de que las medidas legislativas emprendidas bajo el Título IV se adopten bajo el prisma del mínimo común denominador ${ }^{82}$ —esto es, reproduciendo a nivel comunitario el estándar de protección más bajo de entre los ya existentes en las políticas migratorias internas de los EEMM.

Adicionalmente, el requisito de la unanimidad tiene un enorme potencial para actuar como un elemento dilatorio que disminuya la eficacia del procedimiento legislativo comunitario, siendo asimismo "insostenible en una Unión ampliada" ${ }^{3}$. En suma, condicionar la adopción de normas comunitarias en el ámbito de la extranjería y la inmigración al logro de la unanimidad de los EEMM, puede "poner en cuestión el logro de visiones de largo plazo que han sido formuladas por varios Consejos Europeos" ${ }^{34}$, señaladamente por el Consejo Europeo de Tampere, como tendremos ocasión de señalar más adelante.

2. Durante el período transitorio el Parlamento Europeo desempeñó un papel de mera consulta. Este rol constituye en sí mismo una mejora respecto al que ostentaba el Parlamento en el tercer pilar, pero era insuficiente ante la calidad jurídica que tienen las normas emanadas en el pilar comunitario, situando al Parlamento Europeo en una débil posición ${ }^{85}$ que contrasta con el procedimiento general de codecisión. La debilidad institucional del Parlamento Europeo en el ámbito migratorio ha provocado una "carencia de rendición de cuentas y transparencia en el proceso legislativo" ${ }^{\prime \prime}$.

La función de mera consulta del PE, en conjunción con el requisito de la unanimidad, exacerba ${ }^{87}$ las dificultades ya apuntadas implícitas a la toma de decisiones en materia migratoria, aumentando por ello los riesgos de primacía del interés nacional en el resultado y el contenido de las medidas legislativas adoptadas.

81 Junto a la posibilidad de que un EM pueda bloquear una medida legislativa deseable, las autoras Baldaccini y Toner han destacado tamicén la parte positiva de este poder de veto en que se traduce el requisito de la unanimidad. "Allowing one Member State to hold out against measures being agreed in an undesirable state and enabling it to press more effectively for adequate standards to be maintained”. BALDACCINI, A. Y TONER, H. "From Amsterdam" ..., op. cit., p. 5.

82 FLETCHER, Maria. "EU Governance Techniques in the Creation of a Common European Policy on Immigration and Asylum; European Public Law, vol. 9, n 4, p. 541.

83 Ídem, p. 541.

84 Ibidem, p. 542.

85 Sobre el papel de mera consulta atribuido al Parlamento Europeo en el ámbito del asilo y la inmigración, BALDACCINI y TONER han afirmado que "significa que los puntos de vista expresados por el Parlamento podrían fácilmente ser dejados al margen e ignorados por el Consejo"; en "From Amsterdam and Tampere to the Hague: An Overview of Five Years of EC Immigration and Asylum Law”, op. cit., p. 5. De hecho, la elaboración de la Directiva 2003/86/CE sobre reunificación familiar 2003/86 ofrece una importante lección sobre las consecuencias prácticas que las particularidades institucionales y del procedimiento de decisión en materia migratoria tendrán sobre el contenido de las normas emanadas en dicho ámbito. La elaboración de dicha directiva revela la debilidad institucional del PE y la facilidad con la que sus opiniones, expresadas en dictámenes vinculantes en torno a la elaboración de medidas legislativas, pueden ser desatendidas. Incluso en la fase final de elaboración de dicha directiva se llegó a obviar el trámite preceptivo de volver a consultar al PE, omisión que fue denunciada en su momento sin que el TJUE se pronunciara sobre este asunto en la sentencia C-540 que puso fin al recurso de anulación presentado contra dicha Directiva.

86 BALDACCINI, A. Y TONER, H. “From Amsterdam and Tempere to the Hague...”, op. cit., p. 5.

87 Idem, p. 21. 
3. Ante situaciones de emergencia "caracterizadas por la llegada repentina de nacionales de terceros países" a un EM, el Consejo podría adoptar por mayoría cualificada y a propuesta de la Comisión, medidas provisionales por un período máximo de seis meses, que quedaban exceptuadas de la necesidad de consulta previa al Parlamento Europeo ${ }^{88}$.

4. El monopolio de la iniciativa legislativa que con carácter general incumbe a la Comisión, se rompía en el ámbito migratorio. En las materias comprendidas dentro del Título IV la Comisión compartía la iniciativa legislativa con los $\mathrm{EEMM}^{89}$, característica propia del antiguo tercer pilar. La iniciativa legislativa de la Comisión sí se extendería a la concesión de visados, ámbito regulado por el antiguo artículo 100 c, y que ya había sido comunitarizado desde el Tratado de Maastricht.

5. Existían también peculiaridades relativas al control jurisdiccional ejercido por el Tribunal de Justicia de las CCEE —en adelante TJUE - en el ámbito del Título IV. Tomando como punto de partida la situación anteriormente existente bajo el tercer pilar, la posición del TJUE salía robustecida en el nuevo Título IV de Ámsterdam. Sin embargo, existían dos disposiciones que limitaban ${ }^{90}$ sustancialmente los poderes de control de la Corte de Luxemburgo en el ámbito del asilo y la inmigración.

a) Los juzgados y tribunales inferiores quedaban excluidos de la formulación de cuestiones prejudiciales ante el TJUE ${ }^{91}$, limitando el artículo 68.1 su planteamiento tan sólo a aquellos Tribunales internos contra cuyas resoluciones no cabía ulterior recurso ${ }^{92}$. Con ello se trataría de impedir que las resoluciones emitidas por tribunales internos en aplicación de las normas comunitarias sobre extranjería e inmigración, fueran recurridas con la única intención de impedir su ejecución. A modo de compensación a esta limitación en la formulación

88 Artículo 64.2.

89 Artículo 67. 1.

90 Para Hailbronner ambas restricciones, especialmente la que afecta a la formulación de cuestiones prejudiciales, pueden tener consecuencias sobre la protección efectiva que el Tribunal de Luxemburgo otorga a los particulares. Estas limitaciones jurisdiccionales se tornan especialmente preocupantes si se tiene en cuenta la profunda conexión del derecho migratorio con los derechos del individuo, poniendo en evidencia las insuficiencias del sistema comunitario de protección judicial, especialmente ante la posibilidad de normas comunitarias que entren en contradicción con los derechos fundamentales. HAILBRONNER, K. "European Immigration and Asylum..., op. cit., p. 1057. En el mismo sentido inciden Baldaccini y Toner, para quienes el hecho de que en estas materias el TJUE no disfrute de una jurisdicción plena ha determinado que en este ámbito los nacionales de terceros países están sujetos a "un régimen legal subdesarrollado", privando a estos sujetos de una protección judicial efectiva. Lamentan especialmente este sistema anómalo, en particular respecto a la limitación que afecta a las cuestiones prejudiciales, en un ámbito que es especialmente sensible en términos de derechos fundamentales. En sus palabras, "it is an anomaly that an area that is particulary sensitive in terms of fundamental rights does not benefit from the same jurisdiccional control or uniform application throughout Europe as other areas of EC law". Ambas autoras han destacado con respecto a la limitación de las cuestiones prejudiciales a los tribunales internos contra los que no quepa recurso, que la práctica comunitaria desde 1999 revela que tales limitaciones "has substantially restricted access to the ECJ in practice". BALDACCINI y TONER. “From Amsterdam and Tampere..., op. cit., pp. 7 y 20, respectivamente.

91 Apartado primero del artículo 68.

92 El objetivo último perseguido por esta restricción parecía ser evitar una litigiosidad que podría llegar a ser "inmanejable", así como la dilación indebida de los procedimientos mediante el recurso a las cuestiones preliminares. PEERS, Steve. "The Jurisdiction of the Court of Justice Over EC Immigration and Asylum Law: Time For a Change?”; BALDACCINI, A; GUILD, E.; TONER, H. (eds.). Whose Freedom, Security and Justice?, op. cit., pp. 85-108. El temor ante un aluvión de casos como causa para impedir la normalización de la jurisdicción del TJUE, es criticado por BALDACINI y TONER, afirmando que dichos temores se podrían haber conjurado mediante reformas en la arquitectura judicial comunitaria, sin necesidad de disminuir el grado de protección judicial conferido al asilo y la inmigración en la UE, como finalmente sucedió en el Tratado de Ámsterdam; en "From Amsterdam and Tampere to the Hague..., op. cit., p. 7. 
de cuestiones prejudiciales, el artículo 68.3 establecía la posibilidad de que el Consejo, la Comisión o un Estado miembro solicitasen al Tribunal de Justicia un pronunciamiento sobre una cuestión interpretativa del Título IV o sobre actos de las instituciones comunitarias basados en dicho Título. Se trataba de una "fórmula paralela" ${ }^{93}$ al recurso prejudicial establecido en el artículo 68.1.

b) Las medidas relativas al mantenimiento del orden público y la salvaguardia de la seguridad interior, contenidas en la cláusula de salvaguardia del artículo 62, quedaban totalmente excluidas de la jurisdicción del TJUE ${ }^{94}$. La virtualidad de esta exclusión puede ser restringida, habida cuenta de que corresponde al TJUE establecer los límites de su propia jurisdicción ${ }^{95}$.

Estas particularidades del sistema de control jurisdiccional se tradujeron en la práctica en una limitación de las facultades que el TJUE ostentaba sobre la interpretación uniforme, sobre el control de la legalidad del derecho comunitario de la inmigración y sobre la eficacia de su aplicación ${ }^{96}$. Por ello la doctrina reclamó tempranamente la necesidad de normalización ${ }^{97}$ de la jurisdicción del Tribunal de Luxemburgo.

6. En adición a lo expuesto, el sistema comunitario de inmigración y asilo no regirá por igual en todo el territorio de la Unión Europea, pues ha nacido aquejado de asimetrías geográficas. Dos Estados se reservan la posibilidad de su no aplicación - Inglaterra e Irlanda ${ }^{98}$ (opt-in) - y Dinamarca ${ }^{99}$ queda excluida de su ámbito de aplicación (opt-out). Este sistema opcional fue, en palabras de Kay Hailbronner, "el precio necesario para el logro de la comunitarización”"100 en un ámbito especialmente sensible como es la inmigración, la extranjería y el asilo. Sin embargo, se prevé la posibilidad de que estos países puedan quedar sujetos al régimen general mediante la manifestación de voluntad de dichos Estados ${ }^{101}$.

Estos "malos hábitos intergubernamentales de su pasado102", de los que no ha logrado desprenderse el ámbito migratorio, singularizaron al Título IV CE, llevando a matizar las calificaciones vertidas en torno al proceso llevado a cabo por el Tratado de Ámsterdam, con el más suavizado término de "cuasi-comunitarización ${ }^{103 "}$ y a definir el Título IV como un auténtico "ghetto"104 dentro de dicho Tratado.

93 ESCOBAR HERNÁNDEZ, C. “Extranjería y ciudadanía...”, op. cit., p. 125.

94 Apartado segundo del artículo 68.

95 HAILBRONNER, K. "European Immigration and Asylum...”, op.cit, p.1057.

96 BALDACCINI, A; TONER, H. “From Amsterdam and Tampere to the Hague..., op. cit., p. 7.

97 Dicha normalización fue propuesta por la Comisión en la Comunicación de la Comisión al Parlamento Europeo, al Consejo, al Comité Económico y Social Europeo, al Comité de las Regiones y al Tribunal de Justicia de las Comunidades Europeas relativa a la adaptación de las disposiciones del título IV del Tratado constitutivo de la Comunidad Europea referentes a las competencias del Tribunal de Justicia, con el fin de garantizar una protección jurisdiccional más efectiva. COM (2006) 346 final, de 28 de junio de 2006, cuyos efectos se producen a partir del 1 de enero de 2007.

98 Protocolo no 4 sobre la posición del Reino Unido e Irlanda, anexo al Tratado de Ámsterdam (1997) DOCE C 340/03.

99 Protocolo no 5 sobre la posición de Dinamarca, anexo al Tratado de Amsterdam (1997) DOCE C340/03.

100 HAILBRONNER, K. “European Immigration and Asylum..”, op. cit., p. ¿?

101 Arts. 3.4 y 8 del Protocolo sobre la posición del Reino Unido y de Irlanda; arts. 5 y 7 del Protocolo sobre la posición de Dinamarca y arts. 4 y 5 del Protocolo sobre la integración del acervo Schengen.

102 FLETCHER, Maria. "EU Governance Techniques in the Creation of a Common European Policy on Immigration and Asylum”, op. cit., p. 533.

103 Ídem, p. 534.

104 Ibidem, p. 533. 
En el Tratado de Ámsterdam existen además otras cautelas destinadas a que los EEMM puedan seguir reteniendo sus poderes de control sobre los asuntos migratorios. A las ya analizadas limitaciones materiales y territoriales, se unen dos disposiciones reveladoras de las resistencias estatales a renunciar a ceder parcelas de poder a la UE:

a) El segundo párrafo del artículo 63.4 contienía una cláusula de salvaguardia ${ }^{105}$ destinada a amparar la facultad que asiste a los EEMM de mantener o introducir ex novo "disposiciones nacionales que sean compatibles con el presente Tratado y con los acuerdos nacionales" en tres ámbitos específicos de la política migratoria: medidas que establezcan las condiciones de entrada y de residencia así como las relativas a la expedición de visados de larga duración y permisos de residencia, incluidos los destinados a la reagrupación familiar; medidas sobre inmigración y residencia ilegales, incluida la repatriación de residentes ilegales; así como medidas definitorias de los derechos y condiciones en las cuales los nacionales de terceros países residentes legales en un EM puedan residir en otros EEMM.

Se trata de una disposición ambigua y de difícil interpretación. La doctrina coincide en considerarla una concesión a aquellos EEMM más reacios a ceder parte de sus competencias soberanas en asuntos migratorios, que viene a subrayar el carácter no exclusivo de la competencia comunitaria en este ámbito ${ }^{106}$. En el mismo sentido, y al hilo de la interpretación de esta cláusula, se ha concluido que la extranjería y la inmigración constituyen "un ámbito de competencia compartida cuya parte principal la siguen detentando por ahora los EEMM"107. En cualquier caso, la cláusula de salvaguardia indica la necesidad de que las medidas nacionales introducidas por los EEMM respeten el requisito de la compatibilidad con el derecho comunitario en la materia - tanto originario como derivado. De ahí que esta disposición no pueda ser considerada como una exención que autorice a los Estados a introducir medidas internas que se desvíen de las medidas comunitarias.

b) La cláusula de mantenimiento del orden público establecida en el artículo 64, a cuyo resguardo la competencia comunitaria en el ámbito migratorio se entenderá sin perjuicio de las responsabilidades que incumben a los espacios grandes en materia de orden público y seguridad interior. Esta disposición queda exenta del control del TJUE ${ }^{108}$ y está dotada de una ambigüedad superior a la cláusula de salvaguardia examinada anteriormente. Esta cláusula restrictiva, que habilitaba a los EEMM a limitar o incluso eliminar ${ }^{109}$ en su espacio territorial la aplicación de las normas generales del espacio de libertad, seguridad y justicia, ha llegado a ser definida como una auténtica "carta blanca"110 para los Estados, cuya concreción dependerá enteramente de su voluntad política. De forma más matizada, Hailbronner propone su interpretación en sentido restrictivo, entendiendo que la responsabilidad de los EEMM se circunscribe al ejercicio de poderes de policía, esto es, "sólo a la prevención de

105 Conforme a esta cláusula, "las medidas adoptadas por el Consejo en virtud de los puntos 3 y 4 no impedirán a cualquier Estado miembro mantener o introducir en los ámbitos de que se trate disposiciones nacionales que sean compatibles con el presente Tratado y con los acuerdos internacionales".

106 HAILBRONNER. “European Immigration..., op. cit., p. 1051.

107 JIMÉNEZ PIERNAS, C. “La comunitarización...”, op. cit., p. 875.

108 El apartado segundo del artículo 68 TCE afirmaba rotundamente que "el Tribunal de Justicia no tendrá en ningún caso competencia alguna sobre las medidas o deicisiones adoptadas con arreglo al punto 1 del artículo 64 relativas al mantenimiento del orden público y a la salvaguardia de la seguridad interior".

109 MARTÍN Y PÉREZ DE NANCLARES. J. La inmigración y el asilo en la UE. Hacia un Nuevo espacio de libertad, seguridad y justicia, op. cit., p. 102. Este autor señala que esta cláusula de salvaguardia constituye una limitación horizontal que rige tanto en el marco del tercer pilar (art. 33 TUE) como en el acervo Schenguen, que ha sido integrado en el marco de la Unión —art. 2.1 Protocolo núm. 2-.

110 Ídem, p. 102. 
daños inminentes para el mantenimiento de la ley, el orden y la seguridad interiores" ${ }^{111}$, ya que, de lo contrario, la cláusula desembocaría en un entendimiento amplio que otorgaría a los EEMM la responsabilidad principal en el control de la inmigración y en la formulación de políticas públicas en la materia. Este autor considera que dicha cláusula puede concebirse como una disposición limitadora de la acción comunitaria en el ámbito migratorio, en el sentido de que "no incumbe a la UE emitir normas que restrinjan el ejercicio del poder policial relativo al mantenimiento de la ley y el orden"112.

Junto a estas limitaciones, el sistema migratorio de la UE seguía arrastrando cierta disparidad normativa. Dado que el Tratado de Ámsterdam ha permitió la subsistencia de la cooperación intergubernamental en forma del segundo pilar extracomunitario - dedicado a la cooperación policial y judicial en materia penal—, la coexistencia de planos normativos provocó una dispersión de instrumentos jurídicos reguladores de la extranjería e inmigración. Si las actuaciones comunitarias están amparadas por las competencias del pilar comunitario, el panorama normativo estará constituido por reglamentos, directivas y decisiones. Sin embargo, si la intervención comunitaria se produce en materias incluidas dentro del segundo pilar, dará lugar al despliegue de posiciones comunes, decisiones marco, decisiones o convenios.

Para amortiguar en parte este panorama dispar, Ámsterdam dio otro paso fundamental: las decisiones, declaraciones y actos adoptados en el ámbito de cooperación Schengen - el denominado acervo Schengen - quedaban incorporados al ámbito comunitario en virtud del Protocolo por el que se integra el acervo de Schengen en el marco de la Unión Europea. Con ello, la cooperación que antes se operaba en el foro Schengen pasaba a realizarse dentro del "marco jurídico e institucional de la UE y respetando las disposiciones pertinentes del Tratado de la Unión Europea y del Tratado constitutivo de la Comunidad Europea"113. Esta incorporación venía a cancelar en parte ${ }^{114}$ la disparidad de fuentes productoras de disposiciones en este ámbito, "unificando el régimen de extranjería en la Unión" ${ }^{115}$. Sin embargo, la recepción de Schengen en el Tratado de Ámsterdam no implicaba su comunitarización inmediata, ya que conforme al artículo 2.1 del citado Protocolo, el Consejo decidirá por unanimidad a fin de establecer la base jurídica de cada una de las disposiciones o decisiones que constituyan el acervo Schengen. A partir de esa decisión, las competencias del TJUE sobre estas disposiciones serán plenas, a excepción de aquellas relativas al orden público y a la salvaguardia de la seguridad interior ${ }^{116}$.

Pese a las particularidades descritas, todo el conjunto de novedades introducidas por el Tratado de Amsterdam posibilitaban por primera vez el surgimiento de un régimen comunitario de extranjería e inmigración, calificado por la doctrina como "emergente" "distinto y separable de los regímenes de extranjería de los EEMM"117.

Hasta el momento, la razón oficialmente esgrimida para justificar la escasez de resultados habidos en el terreno de la inmigración había sido la ausencia de atribución competencial de la UE. Con Ámsterdam se superaba por fin este escollo, permitiendo emerger normas en materia de asilo

111 HAILBRONNER. K. “European Immigration and Asylum”, op. cit., p. 1052.

112 Ídem, p. 1053.

113 Artículo 1 del Protocolo por el que se integra el acervo de Schengen en el marco de la Unión Europea.

114 Se trata de una cancelación parcial o cierta amortiguación de la disparidad de fuentes normativas, pues ya destacamos que en Ámsterdam subsiste todavía un segundo pilar intergubernamental.

115 ESCOBAR HERNÁNDEZ, C. “Extranjería y ciudadanía...”, op. cit., p. 123.

116 Artículo 2.1, párrafo tercero, in fine, del Protocolo sobre la integración del acervo Schengen.

117 ESCOBAR HERNÁNDEZ, C. “Extranjería y ciudadanía de la Unión”, op. cit., p. 126. 
e inmigración dotadas de la eficacia jurídica supranacional propia del derecho comunitario ${ }^{118}$. Sin embargo, $-\mathrm{y}$ con la salvedad de las peculiaridades institucionales y geográficas ya analizadas-, la mayor dificultad para la consecución de una auténtica política migratoria común continúa residiendo, a juicio de Nanclares, en la escasa atribución material de competencias a la UE ${ }^{119}$. Por ello, este mismo autor concluye que pese a los notables avances conseguidos con el Tratado de Ámsterdam, en esta materia sigue latiendo la paradoja entre la insuficiencia de la actuación estatal, la necesidad de recurrir a la acción comunitaria y la resistencia de los EEMM a ceder competencias migratorias. "En las cuestiones básicas, la verdadera política de inmigración (estancias de larga duración) sigue en manos de los Estados y aun en lo relativo a las estancias breves la mayor parte de la actuación comunitaria se limita a la adopción de «normas mínimas» y, en modo alguno, a la posibilidad de adoptar una verdadera política común en la materia"120. En definitiva, se trataba de un régimen de "dejación de soberanía en régimen de gananciales"121, cuya dinámica jurídica estaba preñada de problemas para las legislaciones nacionales"122.

Poco tiempo después de la entrada en vigor del Tratado de Ámsterdam, el Consejo Europeo de Tampere ${ }^{123}$, reunido los días 15 y 16 de octubre de 1999, supuso el "pistoletazo de salida para la creación del espacio de libertad, seguridad y justicia" ${ }^{124}$, dando con ello un apoyo decisivo a la puesta en marcha de una política migratoria a nivel comunitario, dotada además de un enfoque novedoso. La Cumbre de Tampere tomaba su inspiración en el Plan de acción establecido por el Consejo de Viena de $1998^{125}$. En Tampere se fijó la necesidad de establecer una política migratoria común para la UE, basada en un enfoque global del fenómeno migratorio. Para ello partió de un reforzamiento del vínculo existente entre el espacio de libertad, seguridad y justicia con el respeto de los derechos humanos ${ }^{126}$. Sus principales novedades residían en un tratamiento integrador del asilo y la inmigración, y la necesidad de abordar el estatuto jurídico del extranjero que reside legalmente en un EM sobre la base de la garantía de un "trato justo" y la concesión de derechos y obligaciones comparables a los de los ciudadanos de la Unión ${ }^{127}$. Todo parecía indicar que la nueva política común partía de

118 A tal fin, el Consejo y la Comisión emitieron el 3 de diciembre de 1998 un Plan de acción sobre la mejor manera de aplicar las disposiciones del Tratado de Ámsterdam relativas a la creación de un espacio de libertad, seguridad y justicia. En él se establecía que en un plazo de dos años tras la entrada en vigor del Tratado debía adoptarse un instrumento sobre el estatuto jurídico de los inmigrantes legales. Asimismo se fijaba un plazo de cinco años, para establecer una normativa sobre las condiciones de entrada y residencia y las normas relativas a los procedimientos de expedición de visados y permisos de residencia de larga duración, incluido los destinados a la reagrupación familiar.

119 MARTÍN Y PÉREZ DE NANCLARES. "El reto de la inmigración..., op. cit., s.p.

120 Idem.

121 NAÏR, Sami. Y vendrán... las migraciones en tiempos hostiles, pp. cit., p. 140.

122 Idem.

123 Sobre el tema pueden consultarse, entre otros, ESCOBAR HERNÁNDEZ, Concepción. "La reciente evolución de la problemática del asilo y la inmigración en la UE: Algunas notas sobre la Cumbre de Tampere"; en Tiempo de Paz, n 41, vol. 25, 1999, 99. 229-247. AAVV. "Cumbre de Tampere"; en Europa Junta, no 75, octubre 1999, pp. 2-12. “The Tampere summit: The ties that bind or the Policemen's Ball”. (Editorial Comments); en Common Market Law Review, n 36, 1999, pp. 1119-1126. VALLE GARAGORRI, Rafael. "La Cumbre Europea Extraordinaria de Tampere"; El Espacio Europeo de Libertad, Seguridad y Justicia. Ministerio del Interior, 2000, pp. 147-154.

124 FONSECA MORILLO, Francisco J. "Los derechos de los nacionales de terceros países en la Unión Europea. Situación jurídico-política tras la proclamación de la Carta de los Derechos Fundamentales de la Unión”; en Revista CIDOB de Afers Internacionals, No 53, 2001, p. 79.

125 DOCE C 19, de 23 de enero de 1999.

126 ESCOBAR HERNÁNDEZ, C. “La reciente evolución de la problemática...”, op. cit., p. 42.

127 Tampere proponía literalmente que "una política de integración más decidida debería encaminarse a concederles derechos y obligaciones comparables a los de los ciudadanos de la Unión” así como "la necesidad de aproximar las legislaciones nacionales sobre las condiciones de admission y de residencia de los nacionales de terceros países, 
un enfoque mucho más equilibrado del trípode migratorio: el establecimiento de un sistema europeo común de asilo; la definición de una política migratoria que pretendía gestionar con eficacia los flujos y la erradicación de la inmigración clandestina; sin por ello descuidar la integración de los residentes, a quienes había de dotarles de un corpus de derechos comunes, integrador del régimen europeo de extranjería ${ }^{128}$.

Para su consecución, Tampere instaba al Consejo a tomar decisiones con rapidez, teniendo en cuenta tanto la capacidad de recepción de los EEMM, como sus vínculos históricos y culturales con los países de origen. Posteriormente, la Comunicación de la Comisión al Consejo y al Parlamento Europeo sobre una política comunitaria de migración ${ }^{129}$ vino a incidir en la misma línea de cambio de enfoque en el ámbito migratorio.

Durante este proceso la Carta de los Derechos Fundamentales de la Unión ${ }^{130}$ fue aprobada el 7 de diciembre de 2000. Su propia elaboración suponía un importante paso simbólico, indicativo de que la UE había entrado en una fase de mayor envergadura política ${ }^{131}$. La Carta no confería nuevos derechos, sino que procedía a codificar y clarificar los ya existentes en el ámbito europeo, tomando como fuente de inspiración las convenciones internacionales, las tradiciones constitucionales comunes de los EEMM y la jurisprudencia comunitaria ${ }^{132}$. Con ello, la Carta venía a dotar de mayor visibilidad a los derechos fundamentales en el ámbito comunitario, reforzando su posición frente a las instituciones comunitarias y los EEMM encargados de la aplicación del derecho de la Unión. Especialmente relevante fue la influencia ejercida por el Convenio de Roma en el articulado de la

basadas en una evaluación conjunta de la evolución económica y demográfica de la Unión, así como de la situación en los países de origen".

128 En el mismo sentido, ESCOBAR HERNÁNDEZ, C. “La reciente problemática...”, op. cit p. 43. Si bien, tras analizar las conclusiones de Tampere, la autora se lamenta de que la política migratoria continuase partiendo de una concepción restringida respecto a la admisión de nacionales de terceros países y siguiera optando "por una solución minimalista, que continúa dejando un amplio poder en manos de los Estados para definir sus política inmigratorias (...) sin que, en ningún caso, se plantee el problema del establecimiento de un procedimiento común de adminisón, ni la definición de criterios únicos de admisión”. Por lo que la autora concluye que, en materia de admisiones, el progreso de Tampere ha sido "nulo". Idem, p. 46. El balance general es sin embargo positivo, ya que la autora valora la voluntad que subyace en Tampere de "organizar en forma sistemática e integrada todas las cuestiones referentes a la presencia del elemento extranjero en el nuevo espacio de libertad, seguridad y justicia”, ibidem p. 49.

129 Documento COM (2000) 757 final.

130 DOCE, serie C no 364 del 18.12.2000. La idea de redactar en un único documento todos los derechos garantizados en el espacio comunitario surgió en el Consejo Europeo de Colonia, celebrado en diciembre de 1999, a cuyo efecto se nombró una Convención encargada de su elaboración. La Carta de Derechos Fundamentales de la UE fue proclamada al año siguiente, durante la Cumbre Europea de Niza, en diciembre de 2000. Su naturaleza jurídica quedó abierta, de modo que hasta que fuese formalmente incorporada en los tratados constitutivos y adquiriese vinculatoriedad, sería una declaración política solemne. Sobre la Carta pueden consultarse, entre otros, CARRILLO, Marc. "La Carta de Derechos Fundamentales de la Unión Europea"; en Revista Vasca de Administración Pública, n 65, 2003, pp. 145-165. ALONSO GARCÍA, R. "La Carta de los Derechos Fundamentales de la UE”; en Gaceta Jurídica, no 209, septiembre-octubre 2000. RUBIO LLORENTE, Francisco. "La Carta Europea de los Derechos"; en Claves de la Razón Práctica, no 122, mayo 2002, pp. 4-11.

131 Así se expresaba la Comisión en su Comunicación de 13 de septiembre del 2000, en donde analizaba el anteproyecto de la Carta de los DDFF que había sido presentada por la Convención ad hoc encargada de su redacción. En su comunicación, la Comisión enfatizó la función de legitimidad política que la Carta estaba destinada a cumplir.

132 De ahí que SAIZ ARNAIZ señale que la Carta de DDFF de la UE se emplaza "en un terreno de juego situado a tres bandas: los Derechos nacionales (...), el Derecho Comunitario y el Derecho Internacional de los Derechos Humanos"; en "La Carta de los Derechos Fundamentales de la Unión Europea: entre el Derecho Comunitario y el Derecho Internacional de los Derechos Humanos"; en Azpilcueta. Cuadernos de Derecho, No 17, 2002, p. 42. 
Carta, hasta el punto de determinar un "paralelismo de contenidos entre la Carta y el Convenio"133, palpable sobre todo en las disposiciones incluidas bajo el epígrafe "libertades", que incorporaba derechos fundamentales universales.

La Carta se basaba en un filosofía integradora de los derechos, de modo que junto a los clásicos derechos de libertad, incorporaba los derechos económicos y sociales e incluso incluía derechos de solidaridad sistematizados en torno a seis epígrafes: dignidad, libertad, igualdad, solidaridad social, ciudadanía y justicia. Por ello ha sido considerada profundamente respetuosa con los principios de indivisibilidad e incluso de universalidad de los derechos. Y, si bien es cierto que algunas de las facultades se reservan a los ciudadanos de la Unión, con carácter general los derechos reconocidos son predicables de todas las personas, con independencia de su nacionalidad, hasta el punto que se ha destacado que "la Carta suprime, en gran medida, la diferencia de estatuto entre ciudadanos de la Unión y nacionales de los terceros países" ${ }^{\text {"134. }}$.

En el ámbito específico de la extranjería, la Carta Europea de $\mathrm{DDFF}^{135}$ fue especialmente bienvenida, siendo considerada por algunos como un instrumento que podría profundizar la dimensión integradora ${ }^{136}$ que, desde Tampere, estaba imprimiéndose a las políticas comunitarias en materia de extranjería, asilo e inmigración.

No obstante el optimismo generado por la aprobación de la Carta de Derechos fundamentales de la UE y su posible proyección sobre las cuestiones migratorias de los ciudadanos extracomunitarios, el Tratado de Niza de 26 de febrero de $2001^{137}$ no estableció cambios relevantes en el tratamiento

133 Ídem, p. 47. El paralelismo entre la Carta y el CEDH es tal que, con respecto de muchas de las disposiciones de la Carta, existe una auténtica identidad terminológica. Dicha identidad constituyó, a juicio de SAIZ ARNAIZ, una opción consciente por parte de los redactores de la Carta de DDFF. "La Carta de los Derechos fundamentals de la UE...", op. cit., p. 43.

134 El optimismo de Fonseca Morillo es tal que le lleva a concluir su estudio cuestionándose si “ ¿cabe, por tanto hablar de una ciudadanía civil paneuropea basada en la residencia y no en la nacionalidad?, afirmando al especto que lo único claro por el momento es que la diferencia entre los derechos del ciudadano europeo y los derechos del nacional extracomunitario "es cada vez menor y se concentra, esencialmente, en los derechos políticos". FONSECA MORILLO, J. “Los derechos de los nacionales de terceros países...”, op. cit., pp. 81 y 93.

135 Sobre las implicaciones migratorias de la Carta Europea de Derechos Fundamentales vid. PEERS, Steve. "Immigration, Asylum and The European Union Charter of Fundamental Rights”; en European Migration Law Journal, 2001, pp. 141-169.

136 Por su potencial integrador, Fonseca Morillo destaca en particular la importancia de seis disposiciones de la Carta Europea de DDFF de la UE: El derecho a la educación, que la Carta confiere a toda persona en su artículo 14 y que, a juicio de este autor, "significa que en el marco de sus políticas de formación, la Unión debe respetar la gratuidad de la enseñanza obligatoria, incluso para los nacionales de terceros países"; La libertad profesional y el derecho al trabajo, reconocidos en el artículo 15.1 de la Carta y predicables de todas las personas; El derecho reconocido en el apartado tercero del artículo 15, que establece que los nacionales de terceros países autorizados a trabajar en el territorio de los EEMM tendrán derecho a unas condiciones laborales equivalentes a aquellas que disfrutan los ciudadanos de la Unión, siempre que disfruten de una autorización para trabajar en dicho EM. Especialmente relevantes para la integración social de los extranjeros resultan otras dos disposiciones de la Carta de DDFF: la prohibición de las discriminaciones, recogida en el articulo 21 e inspirada en el artículo 14 del CEDH, que incluye entre los motivos prohibidos la raza, el color, los orígenes étnicos, la lengua, la religión o la pertenencia a una minoría nacional, ampliando con ello el listado de causas del artículo 14 del CEDH; y, finalmente, la obligación de la Unión de respetar la diversidad cultural, religiosa y lingüística, establecida en el artículo 22 de la Carta. FONSECA MORILLO, J. “Los derechos de los nacionales...”, op. cit., pp. 81; 83-84.

137 El Tratado de Niza por el que se modificaba el TUE y los Tratados constitutivos de las Comunidades Europeas, fue firmado el 26 de febrero de 2001, entrando en vigor el 1 de febrero de 2003 tras su ratificación por los entonces 15 EEMM. España lo ratificó el 27 de diciembre de 2001, entrando en vigor el 1 de febrero de 2003 (BOE n 24, de 28 de enero de 2003). 
jurídico de esta materia ${ }^{138}$, lo que de nuevo subrayaba las resistencias de los Estados a profundizar en el proceso de cesión competencial en este terreno.

Contra estas resistencias ${ }^{139}$ se pronunciarían diversos Consejos Europeos ${ }^{140}$, denunciando la omisión de los EEMM respecto al cumplimiento de los compromisos e incluso - lo que resultaba más grave-, la reducción de los niveles de protección en las medidas que se estaban negociando.

A la vista del "indolente"141 proceso de negociación de propuestas en el ámbito del asilo y la inmigración, el Consejo Europeo de Sevilla — los días 21 y 22 de junio de 2002-, volvió a situar en el primer plano de la agenda comunitaria la extranjería y la inmigración. El Consejo de Sevilla fijó términos para que las propuestas más destacadas en este ámbito fueran acordadas para finales del año 2003, y concretamente dos de ellas que estaban retrasándose como consecuencia de su azaroso proceso de negociación: la propuesta de Directiva sobre RF y la propuesta de Directiva sobre residentes de larga duración.

Sin embargo, el Consejo Europeo de Sevilla vino también a imprimir una visión alejada de los amplios objetivos enunciados en Tampere, quizá explicable como consecuencia de los actos terroristas contra las torres gemelas de Nueva York de septiembre de $2001^{142}$. En Sevilla se volvió a enfatizar la lucha contra la inmigración ilegal, otorgándole "máxima prioridad"143, en dirección nuevamente hacia la Europa Fortaleza, volviendo a emerger vigorosamente la prioridad del enfoque securitario y restrictivo de la inmigración ${ }^{144}$. En este contexto, los ideales de trato justo y derechos comparables de Tampere se configuraban como una retórica alejada de la realidad.

138 El Tratado de Niza añadió un nuevo párrafo en el artículo 67 TCE, extendiendo el ámbito de las materias que se decidirían por mayoría cualificada y por el procedimiento de codecisión. Sobre el tema puede consultarse MOREIRO GONZÁLEZ, C. J. (coord.) Tratado de Niza. Análisis, comentarios y texto. Madrid, Colex, 2002. BACIGALUPO SAGGESE, Mariano. "Visados, asilo, inmigración y otras políticas relacionadas con la libre circulación de personas (el Espacio de Libertad, Seguridad y Justicia)”; en LINDE PANIAGUA, E (coord,). Políticas Comunitarias. Madrid, Colex, 2001, pp. 183-220.

139 Pese a la rapidez con que debían acometerse las medidas legislativas en las materias que habían sido transferidas por Amsterdam a la UE, el proceso de negociación de algunas de las propuestas más importantes reveló las complejidades y dificultades implícitas a un proceso teñido de elementos intergubernamentales. Ello otorgaba un papel protagónico a los EEMM, cuyas reticencias bloqueaban la elaboración de estas normas, introduciendo demoras en el proceso legislativo. Ante esta situación, el Consejo Europeo de Sevilla urgió a sacar adelante las normas que estaban bloqueadas. De ahí que con respecto a las propuestas de directiva sobre reunificación familiar y sobre residentes de larga duración, Steve PEERS afirmara con optimismo, "will likely be boosted by the urging of the Seville European Council. "Key Legislative Developments on Migration in the European Union”; European Journal of Migration and Law, vol. 5, n' 1, 2003, p. 126.

140 Consejo Europeo de Laeken, celebrado el 14 y 15 de diciembre de 2001; Consejo Europeo de Sevilla, el 21 y 22 de junio de 2002; Consejo Europeo de Salónica, de 19 y 20 de junio de 2003. Para Muñoz Aunión, existen sólidos motivos que convierten a los Consejos Europeos en el órgano más apropiado para impulsar el establecimiento de una política comunitaria migratoria común. Entre ellos, la perspectiva existente por entonces de la Ampliación, la prioridad que los Estados Europeos asignan a las cuestiones de seguridad interior, el fracaso del tercer pilar, e incluso por razones de transparencia y legitimidad democrática. Pese a ello, el autor destaca que una característica común y recurrente de todos ellos consiste en que los acuerdos adoptados en dichos Consejos son siempre mucho más modestos que las pretensiones con que han sido iniciados por las respectivas Presidencias. MUÑOZ AUNIÓN, Antonio. Política migratoria de la Unión Europea. Valencia, Tirant lo blanch, 2008, pp. 345 y 357.

141 PEERS, Steve. "Key Legislative Developments on Migration in the European Union", op. cit., p. 107.

142 Sobre el impacto del 11S en la política migratoria europea, vid. LUCAS MARTÍN, Francisco Javier de. "Sobre las políticas de inmigración en la Unión Europea un año después del 11 de septiembre de 2001: Inmigración, derechos, ciudadanía”; en Cuadernos electrónicos de Filosofía del Derecho, nº. 6, 2002.

143 ARANGO, Joaquín. “Dificultades y dilemas...”, op. cit., p. 60.

144 En el mismo sentido, CHOLEWINSKI, R. “Family Reunification as a Constitutional Right?”, op. cit., p. 259. 
Con posterioridad al Consejo de Sevilla, el fallido Tratado por el que se establecía una Constitución para Europa $a^{145}$ sí que contenía novedades sustanciales en el ámbito de la extranjería y la inmigración. En primer lugar, proponía suprimir los restos de intergubernamentalidad, comunitarizando la cooperación policial y judicial en materia penal. El espacio de libertad, seguridad y justicia - que se encontraba enunciado nuevamente como objetivo comunitario- ${ }^{146}$, pasaba a constituir en bloque una competencia comunitaria compartida y se regulaba de forma unificada dentro del título relativo a las políticas y acciones internas de la Unión ${ }^{147}$. Para su consecución, la sección $2^{\text {a }}$ del Capítulo IV se dedicaba en exclusiva a la regulación de las políticas sobre controles en las fronteras, asilo e inmigración ${ }^{148}$.

La regulación contenida en el capítulo IV se presentaba con un cambio terminológico nada desdeñable en la materia objeto de estudio: Se abandonaban las cláusulas con atribuciones materiales concretas a base de normas mínimas, para afirmar con rotundidad, —en vinculación con el establecimiento del Espacio Europeo de Libertad, Seguridad y Justicia-, que la Unión "desarrollará una política común de asilo, inmigración y control de las fronteras exteriores que esté basada en la solidaridad entre Estados miembros y sea equitativa respecto de los nacionales de terceros países"149. Con esta disposición se dotaba a la Unión de una cláusula general de competencia en materia migratoria ${ }^{150}$, que constituía una de las mejoras más trascendentales del nuevo tratado.

Dejando aparte el carácter imperativo de la redacción, la nueva regulación del Espacio de Libertad, Seguridad y Justicia hubiese permitido superar muchas de las rémoras que venían lastrando el despliegue de una política común integral en los ámbitos analizados. En este sentido, se suprimían las peculiaridades intergubernamentales que contaminaban el régimen jurídico de la extranjería y la inmigración. Así, las relativas a las deficiencias en el funcionamiento de las instituciones comunitarias, tanto en el procedimiento legislativo - que pasaba a regirse por el criterio común de la codecisión y mayoría cualificada-, como las relativas al control jurisdiccional ejercido por el TJUE — que recuperaba la plenitud de su potestad-. Las limitaciones territoriales también quedaban abolidas, acabando así con las asimetrías geográficas y la consiguiente mayor complejidad del sistema, de forma que el tratamiento jurídico de la inmigración se uniformaría a nivel territorial, incluyendo al Reino Unido, Irlanda y Dinamarca. Además, la Constitución Europea diseñaba un panorama de técnica legislativa más simplificado (distinguiendo por ejemplo entre actos legislativos -ley y ley marco-y actos no legislativos), que venía a poner fin a la dispersión de instrumentos jurídicos que caracterizara al régimen migratorio comunitario, consecuencia, de otro lado, de la multiplicidad de ámbitos de actuación: pilar comunitario, extracomunitario y subsistencia de instrumentos anteriores a Ámsterdam.

145 En torno a las novedades que en el tratamiento de la inmigración implicaba la Constitución Europea vid., entre otros, GARCÍA MURCIA, Joaquín. "La política comunitaria de inmigración en la Constitución Europea”; Revista del Ministerio de Trabajo y Asuntos Sociales, no 57, 2005, pp. 217-240. BORRAJO INIESTA, Ignacio. "El desafío de la inmigración”; en RODRÍGUEZ IGLESIAS G.C. y TORREBLANCA, J.I. (coords.). Superar la crisis constitucional profundizando en la integración europea: cuatro propuestas. IX Informe Elcano, junio 2007, pp. 53-67.

146 Artículo I-14.2j en conexión con el apartado $2^{\circ}$ del art. III-257.

147 Título III.

148 Artículos III-265 a III-268.

149 Apartado segundo del artículo III-257.

150 BORRAJO INIESTA, Ignacio. “El desafío de la inmigración”, op. cit., p. 55. PÉREZ Y NANCLARES, Francisco Javier. "El reto de la inmigración: sobre la conveniencia de una política común europea al estilo de la prevista en la Constitución Europea”; en Revista General de Derecho Europeo (iustel), nº 11, 2006, s. p. 
En el ámbito de los controles en fronteras, la Constitución Europea profundizaba la trayectoria iniciada en Schengen, aunque sobre la base de la plena comunitarización. En este sentido, el Tratado enunciaba el desarrollo de una política común cuyos objetivos serían la total ausencia de controles ejercidos sobre las personas - con independencia de su nacionalidad-, cuando éstas transitasen las fronteras interiores, así como garantizar los controles y la vigilancia eficaz en el cruce de fronteras exteriores y la instauración paulatina de un sistema integrado de gestión de las fronteras exteriores $^{151}$. A fin de alcanzar dichos objetivos, la Unión sería competente para establecer, mediante leyes o leyes marco, medidas en torno a la política común de visados y otros permisos de corta duración, las condiciones en las que los nacionales extracomunitarios podrán circular libremente por el territorio de la Unión durante períodos cortos, el establecimiento de controles sobre las personas en las fronteras exteriores, la ausencia de controles en las fronteras interiores y las medidas necesarias a fin de lograr la instauración progresiva de un sistema integrado de gestión en las fronteras exteriores ${ }^{152}$. Dado el carácter políticamente delicado de las fronteras, el texto del Tratado contenía la salvaguardia de explicitar que dichas medidas "no afectarán a la competencia de los Estados miembros respecto de la delimitación geográfica de sus fronteras, de conformidad con el Derecho internacional"153.

Las novedades de mayor relevancia se concentraban en materia de asilo e inmigración, hasta el punto de posibilitar ${ }^{154}$ una auténtica política común comunitaria en los mencionados ámbitos ${ }^{155}$. En el ámbito del asilo, el objetivo comunitario establecido en la Constitución Europea consistía en desarrollar una política común de asilo, protección subsidiaria y protección temporal, respetuosa de la Convención de Ginebra de 1951 así como del Protocolo sobre el Estatuto de los Refugiados de 1967 y del principio de no devolución, que ofrecería un estatuto apropiado a todo nacional extracomunitario necesitado de protección internacional ${ }^{156}$. Para que ello fuese posible, el Tratado atribuía amplias competencias para que la Unión dictase leyes o leyes marcos que establezcan "las medidas relativas a un sistema común de asilo" — nótese que la redacción es mucho más amplia que la contenida en Ámsterdam. Dicho sistema habría de incluir un estatuto uniforme de asilo válido en toda la Unión, un estatuto uniforme de protección subsidiaria, un sistema común para la protección temporal de los desplazados en caso de afluencia masiva, un apartado novedoso como son las normas relativas a la asociación y cooperación con terceros países a fin de gestionar los flujos de solicitantes de asilo o de protección subsidiaria o temporal, y los habituales rótulos de competencia respecto a los criterios para la determinación del Estado miembro responsable del examen de la solicitud de asilo o de protección subsidiaria y las normas en torno a las condiciones de acogida de los mismos.

Al igual que se preveía en Ámsterdam, la Constitución europea establecía la posibilidad de que el Consejo adoptase, a propuesta de la Comisión, reglamentos o decisiones europeos que establezciesen medidas provisionales - pero ahora no sujetas a límite temporal concreto- en beneficio de Estados miembros que se enfrenten a la afluencia repentina de nacionales de terceros países ${ }^{157}$.

151 Artículo III- 265.

152 Artículo III-265, apartado segundo.

153 Apartado tercero del artículo III-265.

154 PÉREZ Y NANCLARES, F. J. “El reto de la inmigración...”, op. cit., pp. 4-5.

155 Una visión más crítica se encuentra en GARCÍA MURCIA, para quien los avances más sustanciales del Tratado Constitucional se concentraban en el ámbito del asilo, mientras que, en materia de inmigración eran mucho más modestas, limitándose a contemplar "una acción de apoyo a a la política de los EEMM, con objeto únicamente de atender de manera adecuada las exigencias de control de las fronteras exteriores y de preservación del espación común de libertad, seguridad y justicia”; en “La política comunitaria de inmigración...”, op. cit., p. 235.

156 Artículo III-266.1.

157 Apartado tercero del artículo III-266. 
En el ámbito específico de la inmigración, los objetivos de la política comunitaria común aparecían especificados en el apartado primero del artículo III-267: "gestión eficaz de los flujos migratorios, un trato equitativo de los nacionales de terceros países que residan legalmente en los Estados miembros, así como una prevención de la inmigración ilegal y la trata de seres humanos y una lucha reforzada contra ambas". Sobresale por encima de todo la redacción imperativa con que se formulaba -la Unión "desarrollará una política común" - y que se enunciaba con la misma rotundidad e idéntica terminología en los tres ámbitos de actuación para el despliegue de la misma -control de fronteras exteriores, asilo e inmigración-. De otro lado, también destacaba la aparente recuperación, aunque de forma atenuada, de los principios emanados de Tampere en torno al trato que ha de dispensarse a los nacionales extracomunitarios - trato "equitativo" para todos los nacionales extracomunitarios, en sustitución del anterior principio de trato comparable o equiparable al de los ciudadanos comunitarios, aplicable tan sólo a los residentes de larga duración-. Y también es de subrayar la incorporación, como competencia comunitaria, de la lucha contra la trata de seres humanos, que en Ámsterdam formaba parte del pilar extracomunitario.

Para la consecución de estos objetivos ampliados, la Constitución Europea otorgaba a la Unión competencias para dictar leyes o leyes marco europeas que establecerían medidas relativas a las condiciones de entrada y residencia y a la expedición de visados y permisos de residencia de larga duración, incluidos los de reagrupación familiar ${ }^{158}$, con una redacción idéntica a la de Ámsterdam. Junto a ella se incluía una competencia más amplia para definir los derechos de los residentes extracomunitarios en un Estado miembro, así como las condiciones para la libertad de circulación y residencia en los demás Estados miembros; la inmigración y residencia ilegales, incluyendo la expulsión y repatriación; y la lucha contra la trata de seres humanos, en particular de mujeres y niños.

La Constitución Europea mantenía la competencia habitual de la Unión para celebrar convenios de readmisión con terceros países ${ }^{159}$ y se adicionaba como competencia comunitaria el establecimiento de medidas de apoyo a aquellos EEMM que propiciasen la integración de los nacionales de terceros países que residiesen legalmente en su territorio, pero incorporando una cláusula de salvaguardia que excluía "toda armonización de las disposiciones legales y reglamentarias de los EEMM"160; esta última competencia se formulaba con carácter optativo para los EEMM, desprovista del carácter imperativo que poseían los restantes títulos competenciales, lo que lleva a Nanclares a calificarla como una "atribución competencial de inferior rango"161.

En materia de integración - y a diferencia del Tratado CE que no proporcionaba una base legal expresa para una política comunitaria en dicho ámbito-, el proyecto de tratado constitucional sí ofrecía una base explícita ${ }^{162}$ para la legislación comunitaria, si bien, como señalamos, acotándola ${ }^{163}$ al fomento y apoyo a los EEMM que promoviesen la integración de los residentes legales de terceros

158 Apartado 2.a) del Artículo III-267. En torno a los acuerdos de readmisión, GARCÍA MURCIA critica su carácter parcial, dado que tan sólo contemplan la fase final del proceso, a la que denomina "hipótesis patológica", sin prever simultáneamente la posibilidad de acuerdos de regulación de los flujos o de fijación de contingentes o preferencias. "La política comunitaria de inmigración ...", op. cit., p. 228. BORRAJO INIESTA se manifiesta igual de crítico respecto a la limitación "de esta manifestación específica del ius contrahendi de la Unión a la readmisión de inmigrantes en situación ilegal"; en "El desafío de la inmigración”, op. cit., p. 57.

159 Apartado tercero del artículo III-267.

160 Apartado cuarto del artículo III-267.

161 PÉREZ Y NANCLARES, J. “El reto de la inmigración...”, op. cit., sp.

162 Respecto a la política comunitaria de integración, se ha advertido de su carácter necesariamente limitado afirmando que "the cultural and idelogical diversity within the Union will set rather strict limits on the scope of a Euroepan integration policy". GROENENDIJK. "Legal Concepts on integration..., op. cit., p. 126.

163 BORRAJO INIESTA, I. "El desafío de la inmigración", op. cit., p. 56. 
países. Se mantenía, sin embargo, como competencia estatal la decisión respeto de los volúmenes de admisión en su territorio, con fines laborales, de nacionales extracomunitarios. Esta reserva suponía que las migraciones laborales seguirían perteneciendo de forma íntegra a los EEMM ${ }^{164}$, traduciéndose en el carácter incompleto de la política común migratoria de la Unión. "En el fondo, pues, los EEMM seguirán manteniendo tras la Constitución Europea un importante ámbito de actuación propia incluso en la parte del espacio de libertad, seguridad y justicia más intensamente regulada por la Unión"165.

Como consecuencia de la negativa a su ratificación por parte de Francia y Holanda, el proyecto de Tratado por el que se establecía una Constitución para Europa fracasó. Sin embargo, la ampliación de la UE con la incorporación de diez nuevos EEMM en 2004, convertía en inviable el procedimiento legislativo trazado por el Tratado de Ámsterdam para adoptar medidas en el ámbito del asilo y la inmigración durante los cinco primeros años de su vigencia ${ }^{166}$. El propio Tratado de Ámsterdam había previsto el traslado automático de determinadas materias del requisito de la unanimidad y la consulta previa del PE, al procedimiento de mayoría cualificada y de codecisión. Las que no fueron trasferidas de forma automática siguiendo las prescripciones de Ámsterdam, lo fueron mediante la decisión del Consejo.

Con el propósito de gestionar jurídica y políticamente los problemas que ya no pudieron abordarse con la fallida Constitución Europea, el Tratado de Lisboa ${ }^{167}$ fue firmado el 13 de diciembre de 2007 y, tras múltiples dificultades, entró finalmente en vigor el 1 de diciembre de $2009^{168}$. Su Título IV contempla la regulación del Espacio de Libertad, Seguridad y Justicia, en cuya sede ocupa un lugar central la inmigración ${ }^{169}$. Su regulación parte de principios idénticos a los contenidos en el Tratado Constitucional, hasta el punto que la definición de los objetivos que ha de perseguir la UE ${ }^{170}$ en el desarrollo de la política migratoria común es de tenor literal idéntico al artículo equivalente de

164 GARCÍA MURCIA, J. “La política comunitaria de inmigración en la Constitución Europea”, op. cit., p. 228. Sobre este punto BORRAJO INIESTA mantiene una opinión divergente, considerando que la reserva estatal de la fijación de los volúmenes de admisión de extranjeros, prevista en el apartado 4 del artículo III-267 de la Constitución Europea, resulta razonable. "El desafío de la inmigración", op. cit., p. 56.

165 PÉREZ Y NANCLARES, J. "El reto de la inmigración”, op. cit., p. 6.

166 El período transitorio de cinco años previsto por el Tratado de Amsterdam concluyó el 1 de mayo de 2004. Tampere había establecido directrices de actuación para los primeros cinco años de desarrollo del espacio de libertad, seguridad y justicia. Al concluirse dicho período, la agenda de trabajo para el siguiente período de profundización de dicho espacio fue establecida por el Programa de la Haya, acordado en el Consejo Europeo de 4 y 5 de noviembre de 2004. La puesta en marcha del Programa de la Haya tendría lugar mediante el Plan de Acción del Consejo y de la Comisión de junio de 2005 DOCE C 198/1.

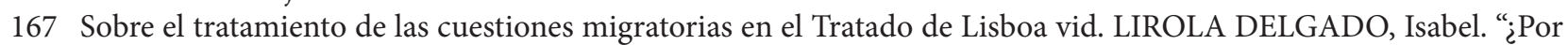
fin una política de inmigración de la Unión en el Tratado de Lisboa?”; MARTÍN Y PÉREZ DE NANCLARES, José (coord.). El Tratado de Lisboa: la salida de la crisis constitucional. Madrid, Portal Derecho, iustel, 2008, pp. 539-548.

168 Para su entrada en vigor hubieron de superarse fuertes escollos. El Tratado de Lisboa no superó el referéndum de aprobación celebrado en Irlanda el 12 de junio de 2008. El gobierno irlandés se comprometió a convocar un nuevo referéndum, que tendría lugar el 2 de octubre de 2009, y que concluiría esta vez con un resultado positivo —se manifestó a su favor el 67,1\%, registrándose una participación del 58\%-. El último de los obstáculos vendría de la mano del primer ministro checo Václav Klaus, contrario a su ratificación a fin de no restar soberanía a la República Checa. Tras pronunciarse a favor del Tratado de Lisboa tanto el Parlamento como el TC de dicho país, finalmente el presidente checo firmó el texto del Tratado en noviembre de 2009 — cuando ya había sido ratificado por todos los restantes EEMM-, clausurando con ello una etapa de interminables negociaciones.

169 Capítulo II: "Políticas sobre controles en las fronteras, asilo e inmigración".

170 Articulo 63 bis del Tratado de Lisboa, conforme al cual "la Unión desarrollará una política común de inmigración destinada a garantizar, en todo momento, una gestión eficaz de los flujos migratorios, un trato equitativo de los nacionales de terceros países que residan legalmente en los EEMM, así como una prevención de la inmigración ilegal y de la trata de seres humanos y una lucha reforzada contra ambas". 
dicho Tratado ${ }^{171}$. Ello es revelador de que, en este punto, existe un consenso ${ }^{172}$ en torno a cómo ha de desenvolverse este aspecto emblemático del ELSJ.

La regulación concreta sigue en lo sustancial el Tratado Constitucional: adopción de normas mediante el procedimiento legislativo ordinario; incremento del rol del Parlamento Europeo al devenir colegislador en dicho procedimiento; normalización del funcionamiento de las instituciones comunitarias incluyendo la recuperación de las potestades interpretativas plenas del TJUE; ampliación competencial de la Unión en materia migratoria - si bien con la importante reserva a favor de los EEMM del establecimiento de volúmenes de admisión en su territorio de extranjeros procedentes de terceros países, con el fin de buscar trabajo por cuenta ajena o por cuenta propia— ${ }^{173}$; e idéntica cláusula de salvaguardia respecto a la competencia de fomento y apoyo a los Estados en el ámbito de la integración. Se mantiene también la inclusión del principio de solidaridad y reparto equitativo de la responsabilidad entre los EEMM -incluido en el aspecto financiero-, que habrá de regir las políticas de la Unión en el ámbito de la asilo y la inmigración ${ }^{174}$.

La entrada en vigor del Tratado de Lisboa ha producido cambios de relevancia en nuestro ámbito de estudio. Señaladamente, al normalizarse el procedimiento legislativo, la anterior exigencia de unanimidad es sustituida por la regla de mayoría que rige el procedimiento de co-decisión. Con ello queda extinguido el poder de veto que obstruyó la aprobación de la Directiva comunitaria sobre $\mathrm{RF}$ - pero, simultáneamente, se allana el camino para su futura reforma ${ }^{175}$, en el caso de que esta posibilidad llegara a presentarse-. Además, el Tratado de Lisboa otorga rango de derecho primario a la Carta Europea de Derechos Fundamentales, otorgándole vinculatoriedad jurídica, y reforzando el papel de los derechos en el ámbito comunitario, - circunstancia que puede estar llamada a cumplir un significativo papel en materia de $\mathrm{RF}^{176}$ dada su fuerte vinculación con los derechos humanos-.

Pese a ello, ni el Tratado de Lisboa ni el proyecto de Constitución Europa han logrado dotar a la Unión de la facultad más emblemática de la política migratoria, a saber, el establecimiento del número y condiciones en que los trabajadores procedentes de terceros países podrán establecerse en el territorio de la Unión. Por ello, cabría apuntar que el lento camino hacia la comunitarización está lejos de consumarse. Sigue todavía en fase incipiente la política migratoria común a nivel comunita-

171 Artículo III-267 del Tratado por el que se establece una Constitución para Europa.

172 LIROLA DELGADO, I. “¿Por fin una política de inmigración de la Unión...”, op. cit., p. 541. La autora precisa que, pese a la identidad de contenidos respecto a los objetivos y medidas que han de adoptarse en el ámbito migratorio, el Tratado de Lisboa ha dotado de mayor importancia y sistematicidad a esta materia que la que presentaba en la Constitución Europea, al situarla inmediatamente después de la regulación de las libertades del Mercado interior.

173 Artículo 63 bis apartado 5. En torno a las consecuencias de esta reserva, Lirola Delgado señala que "limita así enormemente la capacidad de la Unión para regular ad extra una auténtica política común de inmigración en la que posiblemente debería incluirse el ofrecimiento (...) de una cuota o contingente de entrada de inmigrantes en la Unión que después podría ser repartida entre los EEMM conforme a sus necesidades laborales". LIROLA DELGADO “¿Por fin una política de inmigración de la Unión...”, op. cit., p. 544. La sugerente propuesta de la profesora Lirola está en plena coherencia con lo señalado por la Comisión en su Comunicación COM (2006) 735, de 30 de noviembre de 2006, bajo el título "El planteamiento global sobre la migración un año después", donde se señala que "la experiencia ha demostrado que para alcanzar un acuerdo, la UE necesita ofrecer algo a cambio". Citado por BORRAJO INIESTA. "El desafío de la inmigración”, op. cit., nota al pie n 2, p. 57. Este autor proponía una línea de actuación similar a la de la profesora Lirola, al criticar la limitación establecida por el Tratado Constitucional, el cual restringía los acuerdos de la UE con terceros países en materia migratoria, a la formulación de acuerdos de readmisión de inmigrantes irregulares.

174 El artículo 63 ter del Tratado de Lisboa es idéntico al artículo III-268 del Tratado Constitucional.

175 PASCOUAU, Yves y LABAYLE, Henri. Conditions for Family Reunification under Strain..., op. cit., p. 6.

176 Idem, p. 7. 
rio - aunque hay quienes aseguran que tal política está aún del todo ausente ${ }^{177}$, pese a la profusión legislativa ${ }^{178}$ existente a fin de regular aspectos concretos de la extranjería y la inmigración.

En muchos aspectos, las cosas parecen no haber variado mucho: se suceden los Consejos Europeos tratando de impulsar políticamente una política comunitaria migratoria que tenga en cuenta los aspectos de la integración en la gestión de los flujos. Pero los últimos suelen asemejarse bastante a sus precedentes, y las conclusiones se reiteran sin llegar a materializarse, en lo que parece constituir un "mito del eterno retorno"179.

En esta línea continuista se inscribe el Pacto Europeo sobre Inmigración y Asilo, documento de carácter político que, a iniciativa de la presidencia francesa $-\mathrm{y}$ destacadamente, de su mentor, Nicolás Sarkozy - fue aprobado por el Consejo de Justicia e Interior y finalmente refrendado por los 27 jefes de Estado y de Gobierno 16 de octubre de 2008. El Pacto Europeo sobre Inmigración y Asilo propone una estrategia migratoria común, sistematizada en cinco rúbricas de actuación, cuya característica más señalada reside en la recuperación del espíritu de control migratorio que presidió la época de la Europa fortaleza ${ }^{180}$. A tal fin, el Pacto pretende reforzar la lucha contra la inmigración legal, una mejor organización de los flujos legales, aumentar la eficacia de los controles en las fronteras exteriores de la Unión, construir un sistema común de Asilo para el año 2012 y establecer acuerdos con los países emisores de flujos.

El Pacto Europeo sobre Inmigración y Asilo es relevante para nuestro objeto de estudio porque ilustra tanto la propensión estatal al endurecimiento de la inmigración familiar como vía recurrente para la contención de flujos, como sus resonancias a nivel comunitario ${ }^{181}$. Como ha destacado Aran-

177 En el mismo sentido se pronuncia González Vega, para quien "difícilmente puede merecer el calificativo de política común una política que (...) establece unas competencias de naturaleza compartida entre la UE y sus EEMM y es esencialmente una política de mínimos orientada en la práctica a favorecer la coordinación con aquéllos (...) y algunas de cuyas medidas sólo buscan incentivar concretas actuaciones de los EEMM, cuya competencia exclusiva para regular aspectos centrales en materia de política migratoria no es cuestionada en modo alguno”. GONZÁLEZ VEGA, Javier A. “Pero realmente existe una política europea de inmigración? Dificultades y retos para su concreción”; Eikasia, Revista de Filosofía, año II, 10, mayo 2007, p. 50. En esta línea se inscribe también Martín Martínez al afirmar que "de hecho, aunque se habla de la existencia de un 'Derecho comunitario de la inmigración', de existir, tal derecho presenta a nuestro juicio unos contornos difusos y un carácter incipiente y heterogéneo”. MARTÍN MARTÍNEZ, Magdalena. "Ordenando el desorden. El estatuto jurídico de los inmigrantes en la Unión Europea”; SALINAS DE FRÍAS, Ana (dir.). Inmigración e integración: Aspectos sociales y legales. Madrid, ediciones Sequitur, 2008, p. 158.

178 "Las dificultades que entraña la definición de una política europea de inmigración no provienen de la falta de instrumentos normativos en manos de la UE, sino de la falta de voluntad política y de la insolidaridad que frente a estas cuestiones demuestran sus Estados miembros”. GONZÁLEZ VEGA, Javier A. “¿Pero realmente existe una política europea de inmigración?”, op. cit., p. 75.

179 La expresion corresponde a González Vega, quien sostiene muy acertadamente que la pretendida política comunitaria de inmigración es más un mito que una realidad. El autor encuentra multiples dificultades a la hora de poder inscribir bajo la rúbrica de política europea a los desarrollos logrados por la UE en el ámbito de la inmigración. Afirma además que la política migratoria comunitaria revela dos mitos fundamentales, de un lado "el mito del eterno retornor", esto es, de unos compromisos politicos constantemente reiterados en las sucesivas Cumbres Europeas pero sin lograr materializarse en desarrollos de envergadura y, de otro lado, "el mito de la completud", esto es de normativas que se acumulan pero que en el fondo son de carácter fragmentario y relevan la auténtica falta de completud de dicha política. GONZÁLEZ VEGA, Javier A. “¿Pero realmente existe un política europea de inmigración?”, op. cit., pp 53-58, espec. p. 56.

180 ARANGO, Joaquín. "Del boom a la crisis: La inmigración en España a finales de la primera década del siglo XXI”; MATIA PORTILLA, Francisco Javier (Dir.). Crisis e Inmigración. Reflexiones interdisciplinares sobre la inmigración en España. Valencia, Tyrant lo Blanch monografías, 2012, p. 45. En idéntico sentido se pronuncian PASCOUAU, Yves y LABAYLE, Henri. Conditions for Family Reunification under Strain. A Comparative Study in nine EU Member States, op. cit., p. 5

181 PASCOUAU, Yves y LABAYLE, Henri. Conditions for Family Reunification under Strain..., op. cit., p. 5 
go ${ }^{182}$, subyace a este propósito la distinción entre inmigración escogida y los flujos no queridos o sufridos - propia de la política francesa vigente en el momento de su proposición-, con la finalidad de promover selectivamente la primera y tratar de minimizar la inmigración que el Estado ha de tolerar o sufrir, donde se emplazan los flujos migratorios familiares.

A tal fin, insertado dentro del Compromiso primero, dedicado a la mejor organización de la migración legal, el Pacto aspira a una mayor eficacia en la regulación de la inmigración familiar señalando textualmente que "debe estar mejor organizada" - léase "limitada"183. La mejora en su organización normativa se centra sobre sus condiciones de ejercicio y, tal como proclama el Pacto, ha de llevarse a cabo "en el respeto del Convenio Europeo de protección de los Derechos Humanos y de las libertades fundamentales y en función de la capacidad de acogida de los Estados miembros y de la capacidad de integración de las familias". Como medidas concretas, el Pacto propone que los Estados implementen políticas de integración "ambiciosas" sustentadas sobre el equilibrio entre la concesión de derechos y las obligaciones de los migrantes, considerando como factores esenciales de integración "el aprendizaje del idioma del país de acogida" - y, con ello, dando a entender la posibilidad de condicionar la RF al logro de tal aprendizaje ${ }^{184}$ -

Contemplando esta materia en perspectiva, cabría señalar que continúan todavía operantes algunas de las características que han venido dominando el derecho migratorio comunitario. Sigue siendo claramente prioritaria la política migratoria ${ }^{185}$, y continúa más desatendida la política de extranjería ${ }^{186}$. Pues, con independencia de la voluntad formalmente expresada, persiste en el fondo una falta de voluntad política estatal que provoca desajustes ${ }^{187}$ con respecto a las materializaciones prácticas de los objetivos declarados. La resistencia estatal con que se inauguró la cooperación entre los Estados europeos en el ámbito migratorio, allá por los setenta, sigue bien presente hoy, e incluso, en presencia de una severa crisis económica, parece haberse agudizado - como lo demuestra la voluntad manifestada por algunos países comunitarios, partidarios de reintroducir temporalmente controles fronterizos internos ante situaciones excepcionales de afluencia masiva de inmigrantes-. Mientras, la inmigración ha escalado en las preocupaciones de la población europea ${ }^{188}$, convirtiéndose en un desafío para los Estados y haciendo inevitable el recurso a fórmulas de cooperación o, en el caso de la UE, de supranacionalidad.

182 ARANGO, Joaquín. "Del boom a la crisis: La inmigración en España a finales de la primera década del siglo XXI", op. cit., p. 45.

183 PASCOUAU, Y y LABAYLE, H. Conditions for Family Reunification under Strain..., op. cit., p. 5.

184 ARANGO, Joaquín. "Del boom a la crisis: La inmigración en España a finales de la primera década del siglo XXI", op. cit., p. 45.

185 En este punto, estamos siguiendo la distinción establecida por Jiménez Piernas entre política pública de inmigración frente a la política pública de extranjería, ya apuntada en el capitulo anterior del presente trabajo. El mismo autor subraya que el balance entre ambas ramas se presenta profundamente descompensado. JIMÉNEZ PIERNAS, C. "La comunitarización de las políticas de inmigración y extranjería: especial referencia a España"; Revista de Derecho Comunitario Europeo, n 13, 2002, pp. 864 y 875.

186 En el mismo sentido, BALDACCINI y TONER, quienes afirman que: "In sharp contrast to the pletora of legislative measures and policies adopted and developed to prevente and control migration and achieve 'border security' far less political attention has been paid to legal migration and measures related to the status of third country nacional migrants within the EU." En el ámbito de la inmigración legal, las dos directivas más importantes son las de RF y la de residentes de larga duración. BALDACCINI y HONER. "From Amsterdam and Tampere to the Hague"..., op. cit., p. 25. PEERS, Steve. Ilpa-Memorandum on EC immigration and asylum legislation, enero de 2004. GROENENDIJK, Kees. "Legal Concepts of Integration in EU Migration Law”, op. cit., p. 117.

187 GONZÁLEZ SÁNCHEZ, Enrique. “Asilo e inmigración en la Unión Europea”; en Revista de Derecho Comunitario Europeo, no 13, 2002, p. 849. El autor explica con cierto detenimiento los complejos componentes sociales, políticos e institucionales de la inmigración que provocan el desajuste apuntado, especialmente pp. 848-850.

188 Meter datos del Eurobarómetro, Public Opinion Analysis sector of the European Commission 
Sin embargo, es justo reconocer que el carácter incompleto de la política migratoria comunitaria no ha sido óbice para que la Unión experimente una creciente y parece que hasta imparable influencia condicionante sobre la formulación y el desarrollo de las políticas migratorias de los EEMM ${ }^{189}$, sometidas a un lento proceso de acercamiento, que se antoja sin retorno. Con todo, el progresivo acercamiento y comunitarización del derecho migratorio se está desenvolviendo sin eludir a los EEMM, muy al contrario, nutrido y orquestado bajo su atenta batuta, en lo que ha sido calificado como un constante movimiento de abajo a arriba — "bottom-up movement"190_.

\section{LA MIGRACIÓN FAMILIAR EN EL DERECHO COMUNITARIO: BREVE PANORAMA NORMATIVO}

La regulación de la migración familiar en el ámbito del derecho comunitario dista de constituir un régimen unificado y en el que rijan parámetros homogéneos. Su creación se produce también en épocas cronológicamente diferenciadas. En este sistema es posible diferenciar tres grandes cuerpos normativos ${ }^{191}$, según cual sea la nacionalidad que ostenten sus destinatarios:

1. El derecho a la reunificación familiar de los nacionales de los EEMM y de los miembros de sus familias, con independencia de cual sea la nacionalidad de éstos últimos.

Éste es el bloque normativo que cuenta con mayor antigüedad y con una cobertura de protección más intensa. La reunificación familiar surgió para este colectivo de forma muy temprana, como un derecho derivado de la libre circulación de los trabajadores comunitarios, con el fin de que esta libertad comunitaria pudiera ser ejercida en condiciones de dignidad e igualdad ${ }^{192}$. Si los nacionales de cualquier EM se trasladaban e instalaban en otro EM por motivos laborales, ya desde $1961^{193}$ se reconoció el derecho que correspondían tanto a ellos, como a sus esposas/os e hijos menores de 21 años, a reunirse en el territorio del segundo Estado miembro. Así mismo, a los familiares del trabajador se les garantizaba también el acceso al empleo y a la educación en el Estado de acogida en condiciones de igualdad ${ }^{194}$. La reunificación familiar se concebía como un requisito fundamental para la integración del trabajador y de su familia en su nuevo Estado de residencia ${ }^{195}$. Esta primera

189 GARCÍA MURCIA, J. “La política comunitaria de inmigración en la Constitución Europea”, op. cit., p. 57,

190 PASCOUAU, Y y LABAYLE, H. Conditions for Family Reunification under Strain..., op. cit., p. 5.

191 GROENENDIJK, Kees. "Family Reunification as a Right under Community Law"; en European Journal of Migration and Law, n 8, 2006, pp. 215-230.

192 Sobre la reagrupación familiar de los ciudadanos comunitarios pueden consultarse, entre otros FERRER I GÓMEZ, Albert. Libre circulación de nacionales de terceros estados y miembros de la familia en la Unión Europea. Barcelona, Institut Universitari d'Estudis Europeus, Quaderns de treball nº 27, D.L. 2001. GARRIDO GÓMEZ, Ma Isabel. "El derecho de reagrupación familiar en el ámbito de la Unión Europea”; en La Constitución Española en el ordenamiento comunitario: XVIII Jornadas de Estudio. Volumen 3, 1999, pp. 1107-1147. PEERS, Steve. "Family Reunion and Community Law"; WALKER, Neil (ed.). Europe's Area of Freedom, Security and Justice. Oxford University Press, 2004, pp. 143-197.

193 Regulación 15/61 del Consejo, DOCE 26 de agosto de 1961, cuyo Preámbulo abogaba por el establecimiento progresivo de la libertad de circulación de los trajadadores que gozasen de la nacionalidad de alguno de los Estados miembros, tomando en consideración las prioridades de los mercados laborales autóctonos.

194 Artículos 11-15 del Reglamento n. 15 de 12 de junio de 1961, DOCE 26 de agosto de 1961.

195 En la nota explicativa de la propuesta relativa al Reglamento de 1961 relativo a la libre circulación de trabajadores en el espacio comunitario, la Comisión Europea justificaba en estos términos la importancia de la RF para la integración de los trabajadores migrantes procedentes de los EEMM que se instalaban en el territorio de otro EM: "However serious the problems of family migration, resulting from the demographical or housing situation may be, they are certainly less serious than the disadvantages resulting from the separation of the family members". Citado por GROENENDIJK, Kees. "Family Reunification as a Right under Community Law”, op. cit p. 215. Este autor 
normativa fue objeto de sucesivas reformas, en 1965, y en $1968^{196}$, que vinieron a ampliar los derechos reconocidos a los trabajadores, incluyendo en la definición de miembros de la familia también a los ciudadanos procedentes de terceros países que mantuviesen vínculos de parentesco con un trabajador comunitario.

Desde entonces, este bloque normativo ha ido engrosando progresivamente, como consecuencia tanto de sucesivas modificaciones normativas, como de la interpretación extensiva y activista efectuada al respecto por el Tribunal de Justicia de las Comunidades Europeas ${ }^{197}$. El derecho se extendió, ganando autonomía al desprenderse de la exigencia de vinculación laboral del reagrupante ${ }^{198}$. En la actualidad la reunificación familiar de los ciudadanos comunitarios y de los miembros de sus familias aparece contemplada en la Directiva 2004/38/CE ${ }^{199}$ relativa al derecho de los ciudadanos de la Unión y de los miembros de sus familias a circular y residir libremente en el territorio de los Estados miembros, que ha venido a codificar y sistematizar las normas anteriormente dispersas, profundizando en la línea de extensión de derechos. El plazo de transposición finalizó el 30 de abril de 2006, momento a partir del cual los derechos establecidos en la Directiva son directamente aplicables y ejercitables por sus titulares.

De forma muy simplificada podría afirmarse que, con respecto a este primer grupo, la conexión inmediata de su derecho a la RF con una libertad comunitaria originaria ${ }^{200}$, de la que deriva, junto al nexo comunitario exigido para su aplicación - la familia ha de contar entre sus miembros con algún ciudadano comunitario, por lo que ampararía tanto a familias mixtas o a aquellas íntegramente constituidas por nacionales de los EEMM - explican que estemos ante un auténtico derecho subjetivo que desde sus inicios fue ganando en densidad normativa y que actualmente posee la naturaleza jurídica de un derecho fundamental, íntimamente vinculado a la ciudadanía de la Unión e incluso al mercado único ${ }^{201}$. Constituye por ello el bloque normativo dotado de mayores garantías y de condiciones más ventajosas de aplicación.

considera que las condiciones básicas para la integración eran tres: reagrupación familiar, principio de igualdad y asegurar el status de residencia tanto del trabajador como de los miembros de su familia.

196 Reglamento (CEE) no 1612/68 del Consejo, de 15 de octubre de 1968, relativo a la libre circulación de los trabajadores dentro de la comunidad, Diario Oficial n ${ }^{\circ}$ L 257 de 19/10/1968. A su vez, este Reglamento fue modificado por los Reglamentos (CEE) no 312/76 y 2434/92. Sobre la evolución de la regulación relativa a la libre circulación de trabajadores, vid. GOEDINGS, S. Labour Migration in a Integrating Europe. National Migration Policies and the Free Movement of Workers 1950-1968. Diss. Amsterdam, The Hague: Sdu, 2006.

197 Reciente jurisprudencia del TJUE en materia de RF resulta especialmente activista en torno a esta cuestión, hasta el punto de extender la ciudadanía de la Unión a supuestos muy próximos al ámbito de la extranjería. Vid, Asunto C-127/08 Blaise Baheten Metock y otros contra Minister for Justice, Equality and Law Reform, sentencia de 25 de Julio de 2008 y resulta muy evidente en el asunto C-34/09, Gerardo Ruiz Zambrano contra Office national de l'emploi (ONEm), sentencia de 8 de marzo 2011.

198 El TJUE en la sentencia Baumbast y R, de 17 de septiembre de 2002, reconoció explícitamente el carácter autónomo de la libertad de circulación, con independencia del ejercicio o no de actividades económicas por parte de sus titulares.

199 Directiva relativa al derecho de los ciudadanos de la Unión y de los miembros de sus familias a circular y residir libremente en el territorio de los Estados miembros, por la que se modifica el Reglamento (CEE) $n^{\circ} 1612 / 68$ y se derogan las Directivas 64/221/CEE, 68/360/CEE, 72/194/CEE, 73/148/CEE, 75/34/CEE, 75/35/CEE, 90/364/CEE, 90/365/CEE y 93/96/CEE.

200 La vinculación entre el derecho fundamental al respeto a la vida familiar y el derecho a la RF de los ciudadanos comunitarios y los miembros de sus familias, con independencia de la nacionalidad de estos últimos, con el derecho originario de los Tratados,

201 Así lo ha reconocido expresamente el TJUE en el asunto Metock, de 25 de Julio de 2008, apartado 68, indicando que "el establecimiento de un mercado interior implica que los requisitos de entrada y de residencia de un ciudadano de la Unión en un Estado miembro del que no tiene la nacionalidad sean los mismos en todos los Estados miembros. Por lo tanto, la libertad de circulación de los ciudadanos de la Unión debe interpretarse como el derecho 
2. El segundo conjunto normativo está constituido por las disposiciones específicas relativas a la reunificación familiar contenidas en los múltiples acuerdos de asociación entre la Comunidad Económica Europea y terceros Estados, concluidos al amparo del artículo 310 TCE.

Entre ellos destaca por su importancia el Acuerdo de Asociación entre Turquía y la Comunidad Europea $^{202}$, que ha sido objeto de una amplia interpretación jurisprudencial por parte del Tribunal de Luxemburgo ${ }^{203}$. El mismo contiene una cláusula de stand still que protege a sus destinatarios frente a regímenes más restrictivos que los EEMM introduzcan en sus políticas migratorias.

3. El tercer grupo normativo está constituido por las normas que regulan las condiciones en que los nacionales procedentes de terceros países, legalmente instalados en algún EM, pueden ejercer la reunificación familiar. En la actualidad este bloque está contemplado en la Directiva sobre el derecho a la reunificación familiar 2003/86/CE. Aunque su enunciado general pueda generar confusión, sus normas se aplican exclusivamente a aquellas familias compuestas íntegramente por ciudadanos de terceros países.

La reunificación familiar de los nacionales de terceros países surge también a remolque de la libre circulación —como, en general, todo el régimen comunitario de extranjería, asilo e inmigración- pero carece de vinculación con esta libertad comunitaria, de la que obviamente están excluidos los extranjeros que ingresan por primera vez en algún EM. Su surgimiento está íntimamente ligado a consideraciones fácticas y humanitarias en cuya raíz se encuentra el derecho a la vida familiar consagrado a nivel internacional, especialmente en el ámbito del Consejo de Europa.

A diferencia del primer bloque, la RF de los nacionales extracomunitarios no está contemplada en los Tratados originarios, siendo objeto de un reconocimiento jurídico mucho más tardío y limitado, por parte del derecho comunitario derivado ${ }^{204}$ - la Directiva 2003/86 ya mencionada-, de ahí

de abandonar cualquier Estado miembro, y en particular el Estado miembro del que el ciudadano de la Unión tenga la nacionalidad, para establecerse, en las mismas condiciones, en cualquier Estado miembro, distinto del Estado miembro del que el ciudadano de la Unión tenga la nacionalidad".

202 Acuerdo de asociación suscrito entre la CEE y Turquía, mediante la Decisión 1/80 del Consejo de 23 de diciembre de 1963 (DOCE L 217) y su Protocolo Adicional de 23 de noviembre de 1970 DOCE L293, de 29 de diciembre de 1973. Este acuerdo constituye el más favorable de los múltiples acuerdos de asociación suscritos entre las CEE y terceros países, entre los que destacamos los siguientes: Acuerdo de Cooperación entre la CEE y la República de Túnez, firmado el 25 de abril de 1976, DOCE L265, de 27 de septiembre de 1978; en la actualidad ha sido sustituido por el Acuerdo Euromediterráneo deAsociación, DOCE L 97, de 30 de marzo de 1998; Acuerdo de Cooperación entre la CEE y la República Democrática y Popular de Argelia, firmado el 26 de abril de 1976, DOCE L 263, de 27 de septiembre de 1978. Acuerdo de Cooperación entre la CEE y el Reino de Marruecos, firmado el 27 de abril de 1976, DOCE L 264, de 27 de septiembre de 1978, también sustituido por el Acuerdo Euromediterráneo de Asociación, DOCE L 70, de 18 de marzo de 2000. Acuerdo Euromediterráneo de Asociación con Israel, DOCE L 147, de 21 de junio de 2000. Acuerdo de Cotonú, concluido con los países ACO. de 23 de junio de 2000, DOCE L 317, de 15 de diciembre de 2000. Acuerdos con los PECOs (países de Europa Central y Oriental) concluidos entre los años 1993 y 1994, con los por entonces países candidatos a la adhesion y ya miembros de la UE. En torno a las particularidades migratorias incluidas en los diversos Acuerdos y su tipología, vid. FERNÁNDEZ SÁNCHEZ, Pablo. Derecho comunitario de la inmigración. Atelier, Barcelona, 2006, pp. 289-313.

203 Se cuentan más de treinta sentencias que giran en torno a la interpretación de este acuerdo de asociación. Por su importancia conviene subrayar dos de ellas - Cetinyaka y Torum-, donde el Tribunal de Justicia vino a dotar de mayor seguridad al estatus de los familiares de trabajadores turcos admitidos por motivos de reunificación familiar en un EM, estableciendo que tras un período de residencia de tres años o tras haber finalizado su educación secundaria en el EM, sólo podían ser expulsados o bien sobre la base de motivos de orden público estrictamente delimitados o por abandonar el país durante un período largo de tiempo sin una razón legítima que les avalase. Estas consideraciones serían aplicables no sólo los familiares reagrupados, sino también los hijos nacidos en el Estado de acogida. GROENENDIJK, Kee. "Family Reunification as a Right..., op. cit., p. 216

204 En torno a las menores garantías del derecho a la vida familiar y su corolario, la RF, de los nacionales de terceros países en el ambito comunitario, como consecuencia de no derivar del derecho originario, vid. Standing Commit- 
que su densidad normativa sea también muy inferior. En palabras de Daniel Thym, "la ciudadanía de la Unión como fuente última de los derechos de movilidad en Europa distingue con claridad el estatus del ciudadano de la Unión del de los nacionales de terceros países"205, otorgando a estos últimos un estatus migratorio que no resulta predicable de los nacionales comunitarios.

Estos tres cuerpos contienen normas de carácter complementario ${ }^{206}$, al menos en lo que respecta a los ciudadanos procedentes de terceros países. El objeto de nuestro trabajo se centrará con carácter exclusivo en el estudio del tercer cuerpo normativo, esto es, en la evolución, estado actual y contenido de la reunificación familiar de los nacionales procedentes de terceros países instalados en algún EM.

\section{LA REGULACIÓN DE LA INMIGRACIÓN FAMILIAR CON ANTERIORIDAD AL TRATADO DE AMSTERDAM}

\subsection{Resolución sobre la armonización de Políticas Nacionales relativas a la Reunificación Familiar}

La resolución sobre la armonización de políticas nacionales relativas a la reunificación familiar ${ }^{207}$ es un acto fruto de la colaboración intergubernamental entre los ministros responsables de inmigración de las por entonces Comunidades Europeas, adoptado en el encuentro mantenido en Copenhague el 1 de junio de 1993. La idea original de su elaboración se remonta a diciembre de 1991, cuando el Grupo Ad Hoc de Inmigración emitió un Informe sobre política de inmigración y $a s i l{ }^{208}$ en respuesta a la petición formulada por el Consejo Europeo de Luxemburgo para presentar reflexiones y propuestas de armonización en materia de asilo e inmigración ${ }^{209}$.

tee of Experts on International Immigration, Refugee and Criminal Law (Meijers Committee). Memorandum on Immigration and Asylum in the VVD-CDA. Coalition Agreement of 30 September 2010, Utrecht, 2010, p. 2.

205 THYM, Daniel. Respect for Private and Family Life. The European Perspective. University of Konstanz, TEAM Workshop, 2011, p. 9. El autor señala además que "European Union migration law is characterised by the fundamental distinction between the free movement of union citizens and the immigration status of third-country nationals. Union citizens are covered by the fundamental freedoms which abolish national restrictions to free movement, residence and employment across the European Union". Idem, p. 8.

206 GROENENDIJK ha señalado al respecto que los extranjeros de terceros países, según cual sea su nacionalidad, pueden beneficiarse de los dos últimos cuerpos normativos de forma simultánea, o bien sucesiva. Por ejemplo el Acuerdo de Asociación con Turquía no contempla el derecho de los familiares del trabajador turco asentado en un EM a ser autorizados para residir con el trabajador, derecho que sin embargo constituye la regulación central de la Directiva comunitaria sobre reunificación familiar. De este modo, los trabajadores turcos y sus familiares se benefician del segundo y tercer cuerpo normativo. Adicionalmente, otras normas pueden afectarles, como las contempladas en la Directiva relativa al estatus de los residentes de terceros países de larga duración, en el caso de que su residencia en el EM sobrepase los cinco años. “Family Reunification as. A Right...", op. cit., p. 216.

207 SN 2828/1/93 WGI 1497. REV 1. Grupo Ad Hoc de Inmigración, Copenhague, 1 de junio de 1993.

208 Report from the Ministers responsible for immigration to the European Council meeting in Maastricht on immigration and asylum policy. Bruselas, 3 de diciembre de 1991. SN 4038/91 (WGI 930). El texto de este informe puede consultarse en GUILD, Elspeth (compilation and commentary). The Developing Immigration and Asylum Policies of the European Unión. Adopted Conventions, Resolutions, Recommendations, Decisions and Conclusions. Kluwer Law International, The Haghe, 1996, pp. 449-491. También es possible encontrarlo en HANDOLL, J. Free Movement of Persons in the EU: Towards European Citizenship. Chichester, John Wiley \& Sons Canada, Lt., 1995, pp. 646-648.

209 El origen de dicha petición procede a su vez de una propuesta formulada por Alemania en el Consejo Europeo de Luxemburgo, en junio de 1991, a fin de proceder a la armonización de las normas y prácticas nacionales en el ámbito del asilo, la inmigración y la normativa sobre extranjeros de terceros países. El ambicioso carácter de la propuesta alemana, que aspiraba a una armonización tanto formal como sustancial de las legislaciones internas, da 
En el citado informe sobre política de inmigración y asilo ${ }^{210}$, antecedente de esta Resolución, los ministros europeos responsables de inmigración establecieron un programa ${ }^{211}$ concreto de trabajo ${ }^{212}$ en el que a la armonización de las políticas de reagrupación familiar se le dotaba de la máxima prioridad $^{213}$, dentro de las líneas de actuación establecidas a fin de aproximar las políticas de admisión de extranjeros. En dicho Informe, el Grupo ad hoc de inmigración acordó exceptuar las políticas de reunificación familiar del carácter restrictivo que debía caracterizar a las políticas europeas de extranjería e inmigración, reiterando su compromiso con el respeto a los derechos humanos tal y como son definidos por el Convenio Europeo de Derechos Humanos ${ }^{214}$.

La aprobación de la resolución sobre armonización de las políticas nacionales relativas a la RF tuvo lugar tras la firma del Tratado de Maastricht, pero antes de su entrada en vigor. Esta situación explica su adopción por parte de los Ministros encargados de las respectivas carteras de inmigración de los EEMM, en vez de por el Consejo de la Unión ${ }^{215}$. Con su aprobación se trataba de poner en práctica de forma urgente una de las acciones establecidas en el programa armonizador, consideradas todas ellas como medidas transitorias que prepararían la posterior política migratoria, de largo plazo, que habría de ser implementada de forma progresiva a partir de la entrada en vigor del TUE

pie a Callovi a definirla como una "posición maximalista" que finalmente no triunfaría. CALLOVI, Giuseppe. "Il Ricongiungimento delle Famiglie Straniere nella Comunita Europea"; en SCABINI, Eugenia y DONATI, Pierpaolo (dirs.). La Famiglia in una Società Multietnica. Milano, Vita e Pensiero, 1997, pp. 118-119.

210 El Informe fue aprobado en la reunión de Ministros de inmigración, mantenida en la ciudad holandesa de La Haya el 3 de diciembre de 1991, tras lo cual fue remitido al Consejo Europeo de Maastricht que tuvo lugar la semana siguiente a su aprobación. El Consejo Europeo de Maastricht ratificó y recomendó la adopción del programa de trabajo propuesto por los ministros en el mencionado informe. Dado que el Tratado de Maastricht aún no había entrado en vigor, se acordó proceder de forma inmediata a la puesta en marcha del programa de trabajo, "como transición y en preparación de la política que sería ejecutada gradualmente a partir de la entrada en vigor del Tratado de la Unión Europea”. CALLOVI, G. “Il Ricongiungimento delle famiglie....”, op. cit., p. 120.

211 Párrafo $2^{\circ}$ del Preámbulo.

212 Report from the Ministers responsable for immigration ....; GUILD, E. The Developing..., op. cit., p. 451.

213 El programa de trabajo, según reza el propio informe, fue establecido de forma muy pragmática, de modo que la armonización no se consideró como un fin en sí misma, sino como un medio para reorientar políticas donde tal actuación ofrecía mayor eficiencia y velocidad de intervención. GUILD, E. The Developing Immigration..., op. cit., pp. 451 y 459. Las líneas del programa de trabajo fueron enumeradas en función al criterio de su prioridad. El apartado primero corresponde a la actuación en materia de armonización de políticas de admisión de extranjeros (A) y, de las tres actuaciones que comprende, también la primera de ellas es precisamente la relativa a la armonización de las políticas nacionales de admisión con el propósito de reunión familiar y formación y admisión de estudiantes, seguidas por la armonización de las políticas de admisión por otros motivos, —-tales como por razones humanitarias y de empleo-, y la armonización de las disposiciones legales que rigen a las personas autorizadas para residir. Idem, p. 452. Dicha prioridad vuelve a subrayarse en el Párrafo $2^{\circ}$ del Preámbulo de la Resolución sobre la armonización de políticas nacionales relativas a la reunificación familiar.

$214 \mathrm{Al}$ respecto, el Informe establecía literalmente que "si el proceso de armonización se iniciara sin definir principios básicos, la armonización sería llevada al más bajo nivel. Asumiendo que la inmigración en los Estados Miembros debe permanecer limitada, sobre todas las posibilidades, se impondrían las opciones restrictivas. Está claro que una política migratoria europea debe ser necesariamente restrictiva, con la excepción de las políticas relativas a los refugiados y a la reunificación familiar, así como las políticas para la admisión por motivos humanitarios. Sin embargo, debe tenerse en cuenta que la tradición europea está basada en principios de justicia social y respeto a los derechos humanos, tal y como son definidos en la Convención Europea de derechos humanos". Citado por GUILD, E. The Developing..., op. cit., p. 460, traducción propia. De la redacción del Informe de 1991 parece pues desprenderse la necesidad de que la armonización de las políticas migratorias, con la RF a la cabeza, se realizase a un nivel alto de protección a fin de evitar el riesgo de que ésta tuviese lugar tomando como base las políticas internas más reaccias a la admisión de extranjeros procedentes de terceros países.

215 PEERS, Steve. "Raising Minimum Standards, o Racing for the Bottom? The Commission's Proposed Migration Convention"; en GUILD, Elspeth (ed.) The Legal Framework and Social Consequences of Free Movement of Persons in the European Union. Boston, Kluwer Law International, 1998, p. 149, nota al pie nº 3. 
reformado por Maastricht ${ }^{216}$. La resolución en materia de reunificación familiar constituía pues tan sólo una de las piezas del programa global de armonización establecido en el Informe sobre política de inmigración y asilo de 1991. Múltiples instrumentos similares vieron la luz en la misma época a fin de materializar dicho Programa ${ }^{217}$. Pero es significativo que la primera medida acordada sea precisamente la relativa a la reunificación familiar ${ }^{218}$, en coherencia con la máxima prioridad que le asignó el Informe.

Sin embargo, los problemas suscitados por la disposición referente a la posibilidad de que los familiares reagrupables obtuviesen un permiso de trabajo en un Estado Miembro, obstruyeron su negociación ${ }^{219}$. Además, el proceso de elaboración y aprobación de esta resolución se caracterizó por su opacidad y elevado secretismo, por lo que resulta imposible conocer la evolución del proyecto, que fue declarado confidencial y tan sólo fue publicado tras su aprobación. Finalmente, su aprobación tuvo lugar en un período de tiempo relativamente corto - 18 meses en total一, pero con retraso respecto a los planes originales. Esta dilación se perfilará como una característica que a partir de entonces será constante en el proceso de adopción de normas relativas a políticas de reagrupación familiar - reflejo de las enormes dificultades que reviste llegar a un consenso europeo a fin de adoptar directrices comunes en una materia de tan alta sensibilidad política.

Concurrían dos razones que venían a dificultar aún más el proceso de consenso: La primera de ellas consistía en el alto grado de disparidad ${ }^{220}$ que caracterizaba a las legislaciones y prácticas internas de los EEMM relativas a la RF, en la época en que fue finalmente aprobada esta resolución; en segundo lugar porque por entonces la Comunidad carecía de competencia material en materia migratoria, considerada un asunto de interés común y situada dentro del Tercer Pilar intergubernamental.

Con independencia de la ampulosidad de la terminología ${ }^{221}$ usada — armonización - la resolución constituía mucho más modestamente un compromiso mediante el cual el grupo ad hoc de

216 CALLOVI, Giuseppe. “Il Ricongiungimento delle Famiglie....”, op.cit. p. 120.

217 Un exposición detallada de los múltiples instrumentos que fueron adoptados por los ministros de inmigración en el seno del Pilar destinado a la cooperación en asuntos de justicia e interior, se encuentra en BALDWIN-EDWARDS, Martin. “The Emerging European Immigration Regime: Some Reflections on Implications for Southern Europe"; en Journal of Common Market Studies, vol. 35, No 4, diciembre 1997, p. 501. Todos ellos venían a materializar el ambicioso Programa para la armonización de políticas de diciembre de 1991. Su abundancia es tal, que este mismo autor afirma que las reuniones sostenidas por los ministros de interior dieron lugar a una auténtica "plétora" de resoluciones, recomendaciones y conclusiones cuya finalidad era la aproximación progresiva de las legislaciones y prácticas migratorias de los EEMM.

218 Esta es, de otro lado, una característica compartida con la Directiva actualmente vigente sobre RF que también ha sido la primera norma, esta vez de derecho comunitario derivado, acordada en materia migratoria dentro del elenco de medidas tomadas a raíz de la atribución competencial efectuada por el Tratado de Amsterdam.

219 Como apuntan BOELES y KUIJER, inicialmente se preveía que el borrador de la resolución fuera aprobado en la Conferencia Ministerial que tuvo lugar en Londres en noviembre de 1992. Las reticencias en el proceso de adopción de la resolución procedieron fundamentalmente de Irlanda y, en menor medida, de Francia. "Harmonization of family reunification"; A New Immigration Law for Europe? The 1992 London and 1993 Copenhaguen Rules on Immigration. Nederlands centrum buitenlanders, Utrecht, 1993, p. 25.

220 La enorme divergencia entre los EEMM fue constatada por la Comisión Europea en la Inspección del documento de trabajo que sirvió de base a la resolución, y cuyos resultados aparecen en el Informe - no publicado- de dicho órgano, fechado el 13 de mayo de 1992, bajo el título Inspection of the Working Document of the European Comisión of 12 May $1992(\mathrm{~V} / 384 / 92)$.

221 Esta terminología grandilocuente es, por otro lado, común a las medidas adoptadas en la época en el marco del tercer pilar. Todas ellas destacan por su carácter ambicioso, y más considerando que por entonces la Comunidad carecía de competencias en materia migratoria. En este sentido, BALDWIN-EDWARDS señaló "Although the concepts of coordination or approximation may seem to be more appropriate in this general area, frequently in the actual texts the 
inmigración acordó un conjunto de principios destinados a "orientar"222 sus políticas migratorias internas, especialmente a efectos de la reforma de las mismas. Tales principios habían de ser incorporados en los ordenamientos internos de los EEMM con el fin de actuar como pautas que, al aproximar los criterios, sujetos y condiciones en que habían de desarrollarse las políticas de RF en el ámbito comunitario, lograsen cierta convergencia entre las regulaciones nacionales.

Esta medida puede considerarse como el antecedente comunitario más remoto de la actual Directiva sobre reagrupación familiar, si bien su naturaleza jurídica es muy diferente. La Directiva supone un acto normativo de derecho comunitario derivado, enmarcado en el seno de la competencia sobre asuntos de inmigración que a partir del Tratado de Ámsterdam se otorga a la comunidad. Por su parte, la resolución constituyó un acto de naturaleza intergubernamental, por lo que se situaba fuera del ámbito del derecho comunitario, integrando el denominado soft law, y también quedaba excluida de la jurisdicción del Tribunal de Luxemburgo.

La resolución presentaba una naturaleza jurídica incierta ${ }^{223}$. De un lado, declaraba abiertamente que era un acto jurídicamente no vinculante ${ }^{224}$, de lo cual deduciríamos estar ante un compromiso político puramente programático, que no daría origen a derechos subjetivos reclamables por los particulares ni, correlativamente, a obligaciones jurídicamente exigibles a los EEMM. Sin embargo, la redacción de muchos de sus principios era marcadamente imperativa. Junto a ello, en su preámbulo los ministros establecieron una fecha tope - el 1 de enero de 1995, esto es, un año y medio después de su adopción - para que las legislaciones y prácticas internas de los EEMM se adaptasen a los principios en ella contenidos. Esta aparente contradicción entre su vinculación meramente política junto con su tono imperativo y el establecimiento de un plazo para la adaptación de las legislaciones internas, llevó a la doctrina a calificar abiertamente su naturaleza jurídica como "ambigua"225, "incomprensible"226 y a cuestionarse sobre el tipo de obligaciones que la resolución engendraba ${ }^{227}$.

La resolución constaba de una estructura en dos partes claramente diferenciadas: la primera compuesta por nueve párrafos a modo de preámbulo; y una segunda parte, o cuerpo principal, formada por 17 principios sustantivos que habrían de regir las políticas sobre RF de los Estados miembros. En el Preámbulo se reconocía la doble influencia - internacional e interna - a la que estaba sometida la regulación de la reagrupación familiar, proclamándose explícitamente que en la

term harmonization is used. This is quite remarkable, given the difficulty even of the least onerous - co-ordination". The emerging..., op. cit., p. 499.

222 MOLINER NAVARRO, Rosa María. "El concepto de <familia nuclear > en la Directiva europea 2003786/CE sobre reagrupación familiar;” en ABRIL CAMPOY, Juan Manuel y AMAT LLARI, Ma Eulalia (coords.). Homenaje al Profesor Lluis Puig I Ferriol, Vol. II. Valencia, Tirant lo Blanch, 2006, p. 1792.

223 PEERS, S. Building Fortress..., op. cit., p. 1242, quien señala además el débil efecto jurídico de la Resolución; También BALDWIN-EDWARDS, Martin. The emerging..., op. cit., p. 500.

224 La naturaleza jurídica de la Resolución queda perfilada de forma algo ambigua en el párrafo $5^{\circ}$ de su Preámbulo, que establecía literalmente que "los principios no son legalmente vinculantes para los Estados miembros y no constituyen un fundamento legal para la acción de los individuos", (traducción propia). En consonancia con el carácter intergubernamental de la resolución, en el artículo primero se afirmaba que los principios contenidos en la misma "no afectan al derecho comunitario".

225 PEERS, Steve. "Raising Minimum Standars or Racing for the Bottom?. The Commission's Proposed Migration Convention"; GUILD, E. (ed.). The Legal Framework and Social Consequences of Free Movement of Persons in the European Union. Kluwer Law International, Centre of European Law, 1993, p. 151.

226 BOELES y KUIJER. “Harmonization..., op. cit., p. 28.

227 BOELES Y KUIJER, miembros ambos del Comité de Expertos que analizó en su momento el texto de la Resolución, se interrogan sobre la cualidad juridica de las obligaciones dimanantes de este instrumento: ¿Es una obligación o una intención que no puede ser exigida?. Idem, p. 28. 
adopción de la resolución se habían tenido en cuenta las obligaciones derivadas de ambas fuentes ${ }^{228}$. A renglón seguido se precisaba que ni las obligaciones internacionales ni las nacionales se verían afectadas por la presente resolución, incidiendo con ello nuevamente en el laxo carácter jurídico de este instrumento. Asimismo, en esta parte de la Resolución se remarcaba la importancia de la reunificación familiar como mecanismo de integración - "uno de los factores para el éxito de la integración de los inmigrantes que residen legalmente dentro de los territorios de los EEMM"229.

El cuerpo sustantivo se iniciaba especificando el ámbito de aplicación personal de la resolución, sobre el que también incidía el preámbulo. La primera disposición aclaraba que los principios serían de aplicación a los miembros de la familia de nacionales de terceros Estados que residiesen legalmente en el territorio de un Estado miembro sobre una base que les permitiera una expectativa de residencia permanente o de larga duración ${ }^{230}$. Contar con dicha expectativa era de extraordinaria importancia a efectos de la determinación del contenido de la RF pero, sin embargo, tal concepto permanecía indefinido, correspondiendo su determinación a los ordenamientos jurídicos y políticas internas ${ }^{231}$. Con ello la resolución anticipaba una de sus características más notorias: una redacción constantemente abierta, cargada de indefiniciones, incluso en los aspectos más básicos definitorios de la RF, lo que favorecía muy poco el programa armonizador establecido en el informe de 1991 del que la resolución traía causa.

La estabilidad que la resolución exigía a la residencia legal del reagrupante implicaba la exclusión de aquellos extranjeros no comunitarios presentes en el territorio de un EM para estancias temporales de corta duración, tales como los estudiantes y los titulares de permisos de trabajo por un período fijo y determinado ${ }^{232}$. Quedaban también fuera de su ámbito de aplicación los familiares extracomunitarios de nacionales de los Estados miembros que ejercitasen su derecho a la libre circulación $^{233}$, cuestión que estaba regida por el derecho comunitario. Los principios de la resolución tampoco afectaban a los refugiados ${ }^{234}$, a quienes los Estados miembros aplicaban políticas de reagrupación más favorables.

La consecuencia del restringido ámbito de aplicación personal de la resolución de 1991 fue que, tras su aprobación, la RF seguía adoleciendo de la misma dispersión e incoherencia que eran predicables, con carácter general ${ }^{235}$, de los derechos disfrutados por los ciudadanos procedentes de terceros países en el ámbito europeo de la época. Ante la carencia de una norma que contemplase de forma sistemática y global la reunificación familiar de dicho colectivo, la regulación de esta materia

228 En el apartado tercero del preámbulo se afirma literalmente: “The question of family reunification is already to some extent governed by International Conventions to which some or all of the Member States are parties, as well as by Basic provisions of their nacional laws. The obligations flowing from these Conventions and from Basic nacional laws have been taken into account in the process of seeking further harmonization between the Member States, which does not affect those obligations".

229 Apartado cuarto del Preámbulo.

230 Artículo 1.1 del cuerpo normativo de la Resolución. El carácter restringido de su ámbito de aplicación había sido anticipado por el propio preámbulo de la resolución, cuyo apartado sexto establecía que los principios armonizadores se limitaban a las personas que no fuesen nacionales de un EM, pero que residiesen legalmente en el territorio de dicho Estado.

$231 \mathrm{Al}$ respecto el artículo 1 in fine establecía que "the question of what constitutes an expectation of permanent or long-term residence is for determination by referente to national law and policies".

232 Apartado $9^{\circ}$ del Preámbulo y párrafo $1^{\circ}$ del cuerpo de la resolución. El apartado antes citado del preámbulo explicaba la exclusión de estas categorías en base a la corta duración de sus respectivas estancias en el territorio de los EEMM, así como la existencia de prácticas y políticas internas muy divergentes entre los EEMM.

233 Apartado $8^{\circ}$ del Preámbulo.

234 Aparado $9^{\circ}$, párrafo $2^{\circ}$ del Preámbulo.

235 PEERS, Steve. “Towards Equality. Actual and Potential Rights..., op. cit., pp. 25. 
debía rastrearse en diversas normas, en función de la concreta categoría del extranjero implicado ${ }^{236}$. Con todo, pese a su limitado ámbito de aplicación personal, en la resolución se contenían elementos que parecían apuntar ${ }^{237}$ el carácter progresivo del proceso armonizador que con ella se iniciaba. En base a esta construcción progresiva, la convergencia normativa anhelada en materia de reunificación familiar se iría profundizando cada vez más con el paso del tiempo, para dar cobertura a las categorías de personas que por el momento habían quedado excluidas del ámbito de aplicación personal de la resolución.

La resolución dibujaba a grandes rasgos el concepto de reagrupante, pero sin perfilarlo completamente. El tercer principio ${ }^{238}$, siguiendo las prácticas internas, concedía a los EEMM la posibilidad de reservarse el derecho de exigir a los nacionales de terceros países que residiesen legalmente en sus respectivos territorios durante "ciertos períodos de tiempo" antes de poder proceder al ejercicio de la reunificación familiar, sin fijar un tope temporal máximo a fin de evitar extralimitaciones en las legislaciones internas. La definición de dicho período de espera, que la resolución no cerraba, resultaba vital para la viabilidad de la reunificación familiar, pues la imposición de plazos excesivos podía en la práctica vaciar de contenido a dicho derecho. No obstante ello, el artículo 3 se caracterizaba por la indeterminación, traduciéndose en la concesión de una amplísima libertad a los EEMM sobre un elemento que formaba parte del contenido esencial de la RF. Su vaguedad casaba mal con el objetivo armonizador, permitiendo la convivencia simultánea de plazos temporales muy diversos entre los EEMM, e incluso la posibilidad de que éstos introdujesen plazos más restrictivos a los existentes antes de la aprobación de esta Resolución. Esta permisividad a favor de los Estados levantó duras críticas entre la doctrina ${ }^{239}$, que denunció además su incompatibilidad con los Tratados internacionales y la incoherencia con el autoproclamado respeto a los compromisos internacionales que solemnemente establecía el preámbulo de la presente resolución.

El contenido principal de la RF aparecía descrito en el artículo segundo con una formulación tan ambigua que ponía sobre la pista de la precariedad del derecho contemplado: "Los EEMM concederán normalmente la admisión, bajo las condiciones establecidas en el resto de la Resolución...”; A continuación proporcionaba un listado de los familiares reagrupables. A tenor de dicha disposición, la definición de los miembros de la familia habilitados para entrar y residir en un Estado miembro incluía solamente a los integrantes de la familia nuclear, pero en su concepción más restrictiva posible. Tan sólo el esposo/a del residente - entendiendo por tal a la persona unida mediante un vínculo jurídico matrimonial reconocido por el Estado receptor-, los hijos dependientes comunes de la

236 Como norma general se perfilaba la presente resolución pero, dado su limitado ámbito de aplicación, la reunificación familiar de los múltiples colectivos excluidos - estudiantes, refugiados, beneficiarios de formas de protección subsidiaria o temporal, ciudadanos comunitarios que no hubiesen hecho uso de su derecho a la libre circulación, etc - se contemplaba en múltiples normas y resoluciones que contenían apartados específicos sobre este derecho.

237 Este carácter progresivo se desprende de lo establecido en el apartado sexto del Preámbulo de la resolución. En él se afirma literalmente que "The harmonization principles are confined at this stage to family reunification in respect of persons who are not nationals of a Member State but who are lawfully resident within the territory of a Member State on a basis which affords them an expectation of permanent or long-term residence". En coherencia con el carácter progresivo del proceso de armonización, el último apartado del preámbulo declaraba que la armonización de las políticas de RF con respecto a las categorías de personas no cubiertas por la resolución —-familiares de nacionales de los EEMM, residentes no europeos pero que no contasen con una expectativa de residencia permanente o de larga duración, así como los refugiados- "will be further examined in the course of considering admissions policies in respect of them”. (Apartado 9 in fine del preámbulo).

238 Dicho principio establecía que "Member States reserve the right to require non-EC nationals to be lawfully present in their territory for certain periods of time before family members may be reunited with them under the terms of these principles".

239 BOELES, P y KUIJER, A. “Harmonization...., p. cit., p. 30. GUILD, E. The Developing..., op. cit., p. 271. 
pareja y los hijos por ambos adoptados. Respecto de los hijos adoptados, la resolución imponía una seria de requisitos acumulativos ${ }^{240}$ a fin de evitar los fraudes a la ley.

Pero aún incluso para estos familiares a quienes la resolución contemplaba como destinatarios principales, la RF no podía predicarse de forma inequívoca, como consecuencia de la ambigüedad de la redacción de esta disposición ${ }^{241}$. La inclusión del adverbio "normalmente" para definir la "obligación" que pesaba sobre los EEMM de autorizar la entrada en su territorio a determinados familiares del reagrupante alertaba del carácter discrecional de la misma, abriendo la puerta a restricciones ulteriores en las legislaciones y prácticas internas, y negando de esta forma cualquier derecho subjetivo a la reunificación familiar de los extranjeros no comunitarios amparados por la resolución. Suponía asimismo un duro lastre a efectos del proceso de armonización perseguido por este instrumento comunitario. Sin embargo, ello resultaba perfectamente coherente con el carácter no vinculante de sus principios. En otras palabras, la RF tal y como estaba regulada en la resolución de armonización de 1993, no constituía un derecho subjetivo reclamable por sus destinatarios ante las autoridades públicas de cualquier EM, sino una prerrogativa estatal caracterizada por su alta discrecionalidad y por ello de muy difícil armonización, en vista del amplísimo margen de maniobra concedido a los EEMM.

Si respecto a los tres destinatarios principales no cabía hablar de un auténtico derecho subjetivo a la reagrupación familiar, la admisión de las restantes categorías de parientes, aún formando parte de la familia nuclear, dependía enteramente de la voluntad discrecional de los EEMM. La reserva más criticable, a nuestro juicio, es aquella que dejaba en manos de los EEMM la admisión de los hijos de uno sólo de los cónyuges, incluidos los adoptados por uno sólo de los progenitores; si bien la Resolución precisaba que, a efectos de determinar la admisión de estos hijos, el Estado miembro debía tomar en consideración si el reagrupante o su esposa/o poseía la patria potestad, la custodia o tenía efectivamente a su cargo al menor ${ }^{242}$. En este supuesto encajarían los hijos habidos de anteriores matrimonios o hijos naturales de una previa pareja, así como los menores adoptados por uno de los cónyuges cuando formaba parte de otra unidad familiar. El hecho de que la admisión de estos menores en el EM dependiese enteramente de la discrecionalidad estatal suponía negar la existencia de un derecho a la reagrupación familiar respecto de un miembro de la familia - los hijos menores-, a quien el derecho internacional de los derechos humanos hacía acreedor de los niveles más altos de protección. Además esta disposición no tenía en cuenta la enorme evolución social a la que las familias estaban sometidas, obviando fenómenos tan habituales como la inestabilidad y la reconstitución familiar. Por ello, esta reserva fue criticada por su incompatibilidad con respecto a la jurisprudencia de Estrasburgo en torno a la interpretación del concepto de vida familiar, para la

240 En este sentido, se exigía que la adopción hubiese tenido lugar cuando ambos progenitores residían juntos en un tercer país y conforme a una decisión adoptada por la autoridad administrativa o tribunal competente de dicho Estado, que fuera reconocida y aceptada por el EM de residencia y, como consecuencia de la cual, el menor adoptado hubiera adquirido los mismos derechos y obligaciones que los restantes hijos naturales y se hubieran cortado de forma definitiva los vínculos con la familia de origen de dicho menor.

241 Pese a las destacadas deficiencias en el contenido del derecho, establecido en el artículo 2 de la resolución, esta norma es considerada por BOELES y KUIJER como "la única disposición que puede ser leída como una descripción positiva de un derecho a la reunificación familiar”. Frente a ella, las restantes disposiciones que integran el cuerpo de la Resolución, constituyen "disposiciones restrictivas o bien reservas, bajo las cuales o bien cabe la posibilidad de que el EM establezca una mayor restricción o bien que introduzca una política más generosa”; "Harmonization of Family Reunification...., op. cit., p. 26.

242 Principio $6^{\circ}$, Resolución sobre la armonización de políticas nacionales relativas a la RF 
cual la falta de cohabitación entre padres e hijos no tenía la suficiente entidad como para romper la fortaleza del vínculo constitutivo de vida familiar entre ambos ${ }^{243}$.

Se formulaba también como una reserva estatal la admisión de los hijos adoptados por ambos cónyuges, en el supuesto de que la adopción hubiera tenido lugar cuando uno de ellos o la pareja residía ya legalmente en el Estado Miembro ${ }^{244}$. Por su formulación, esta reserva constituía una prevención contra el fraude a fin de evitar la posibilidad de que, estando ya en el Estado receptor, la pareja o uno de sus miembros adoptase a un niño con la única intención de permitir la entrada del menor en el Estado miembro. Sin embargo esta reserva podía dar lugar a una discriminación injustificada entre hijos biológicos y adoptados, contraria a la doctrina de la prohibición de discriminación entre hijos, ya consolidada por la jurisprudencia de Estrasburgo en la época en que se elaboró esta Resolución.

Los matrimonios poligámicos y los hijos habidos de los mismos quedaban excluidos de la RF, como se desprendía con claridad de la contundencia de la redacción del artículo $5^{245}$. La resolución sólo permitía autorizar la entrada de una esposa en el territorio de los EEMM - y, aunque no se explicitaba en su texto, cabe pensar por extensión que también a los hijos habidos de dicha esposa-. Ello en sí mismo constituía un tema polémico. Sin embargo, la exclusión total de los hijos de la otra esposa, sin prever matices que permitiesen su admisión en circunstancias excepcionales - como podría ser la muerte del progenitor que residía fuera del EM, lo que dejaba a sus hijos huérfanos de madre y con el padre residiendo en la UE - abría una brecha de discriminación entre hijos, esta vez nacidos del mismo progenitor, que suscitaba dudas a efectos de su encaje en la jurisprudencia de Estrasburgo.

Con independencia de cual fuese su condición, la admisión de los hijos por motivos de reunificación familiar estaba sometida al cumplimiento de una controvertido requisito general: éstos debían estar por debajo de una edad máxima que oscilaba entre 16 y 18 años $^{246}$. Siempre que se respetasen ambos topes, los EEMM gozaban de libertad para fijar con precisión la edad concreta máxima que regiría, dentro de su territorio, para la admisión de los hijos de inmigrantes procedentes de terceros Estados. El límite de edad por debajo de los 18 años fue en su momento duramente criticado por la doctrina ${ }^{247}$ que analizó la Resolución, subrayando su incompatibilidad con los compromisos internacionales a que estaban sujetos los EEMM, especialmente con el artículo 19 de la Carta Social Europea, donde se fijaba la edad de 21 años como límite para la admisión de los hijos dependientes. Además del cuestionado requisito de la edad, se exigía para su admisión que los hijos no estuviesen casados ni hubieran formado su propia unidad familiar independiente o estar viviendo de forma independiente.

243 En el mismo sentido, BOELES y KUIJER. “Harmonization of Family Reunification...., op. cit., p. 30.

244 Principio $7^{\circ}$.

245 Dicho artículo afirmaba de forma rotunda que "una esposa y sus hijos no serán admitidos con fines de reunificación familiar si el matrimonio es polígamo y el residente ya tiene a una esposa residiendo en el territorio de un Estado miembro", traducción propia.

246 Este requisito estaba contemplado en el principio octavo, dentro de la rúbrica general de "Further conditions concerning children". Su formulación literal establecía que "in orden to qualify for admisión for the purpose of family reunification children must be below a maximum age, which the Member States agree should be between 16 and 18 years, and must not have married or have formed and independent family unito $r$ be leading an independent life".

247 GUILD, Elspeth. The developing Immigration and Asylum Policies...., op. cit., pp. 270 y 271. BOELES, P y KUIJER, A. "Harmonization of Family Reunification..., op. cit., p. 30; 
La autorización de la entrada y residencia de otros miembros de la familia, distintos de los expresamente contemplados ${ }^{248}$, dependía por completo de la decisión discrecional de las autoridades internas del Estado miembro. La situación de éstos aparecía formulada mediante una cláusula altamente restrictiva que condicionaba su admisión a la existencia de "razones imperiosas que justificasen su presencia" ${ }^{49}$ en el EM. Esta restricción suponía que, para los restantes miembros de la familia - por ejemplo, para padres del residente legal, nietos, sobrinos, etc.-, regía una presunción iuris tantum en contra de su admisión ${ }^{250}$. Dicha cláusula podría tropezar con dificultades para encajar dentro de la definición abierta de familia manejada en la jurisprudencia de Estrasburgo a partir de la sentencia Marckx c. Bélgica, conforme a la cual hijos, padres y abuelos formaban en principio parte del núcleo familiar digno de protección ${ }^{251}$.

La admisión en el territorio del Estado miembro de los familiares reagrupables estaba condicionada al cumplimiento de numerosos requisitos que redundaban en una severa limitación del contenido de la reagrupación familiar:

1. Los familiares reagrupables serían admitidos con el propósito exclusivo de vivir junto al residente, lo que excluía la posibilidad de que, al menos inicialmente, dichas personas pudiesen llevar una vida laboral en el Estado receptor ${ }^{252}$.

2. La autorización para permanecer en el Estado miembro quedaba sometida al "cumplimiento continuado de los criterios de admisión"253, de modo que los mismos no regían únicamente la admisión inicial, extendiéndose a lo largo de todo el período de residencia dependiente de los miembros de la familia admitidos por motivos de RF, pudiéndose exigir en las sucesivas renovaciones de sus permisos de residencia. Esta exigencia continuada colocaba a la reunificación familiar en una situación de permanente vulnerabilidad.

3. El Estado miembro se reservaba el derecho de determinar y, en su caso, rechazar la admisión y residencia del cónyuge e hijos adoptivos ${ }^{254}$, si el matrimonio o la adopción habían sido

248 Los familiares expresamente contemplados por la Resolución en sus artículos 2, 6 y 7, si bien con distintos grados de protección, eran el cónyuge del residente, hijos comunes, incluidos los adoptivos, hijos adoptados por ambos miembros de la pareja cuando residían en un tercer país, junto a los hijos de uno sólo de los cónyuges, hijos adoptados por uno sólo de los cónyuges e hijos adoptados por ambos cuando residían en el EM receptor.

249 El principio décimo establecía al respecto que "Member States reserve the possibility of permitting the entry and stay of family members, other than those envisaged in paragraphs 2, 6 and 7 of this Resoluciton, for compelling reaznos which justify the presence of the person concernid".

250 En el mismo sentido, GUILD, E. The Developing Immigration...., op.cit., p. 266. Esta regulación es analizada por la autora en contraste con aquella vigente en la época para los familiares extranjeros de los ciudadanos comunitarios. Las enormes diferencias entre ambos estatutos de derechos son calificadas como "alarmantes", por lo que concluye la incompatibilidad de la Resolución con los instrumentos internacionales que vinculan a los EEMM. Adicionalmente, Guild afirma que "la resolución tiene la consecuencia de crear o enfatizar diferentes standards aplicables a los diferentes extranjeros sobre el territorio en un área de derechos fundamentales protegida por muchos instrumentos internacionales de derechos humanos". Idem, p. 267, traducción propia.

251 Sin embargo, conviene puntualizar que la sentencia Marckx no constituye jurisprudencia sobre vida familiar de los extranjeros y que, en materia migratoria, no cabe extrapolar el concepto amplio de familia, y menos aún en el ámbito específico de la reunificación familiar como obligación positiva emanada del derecho a la vida familiar. La prudencia debe ser aún mayor si se tiene en mente que, en la época en que vió la luz esta Resolución, la jurisprudencia del TEDH en torno a la RF estaba muy poco desarrollada y tenía un carácter marcadamente restrictivo.

252 Apartado $2^{\circ}$ del principio $2^{\circ}$.

253 Principio $11^{\text {a }}$ de la Resolución, conforme al cual "an authorization to stay on the basis of family reunification may, for such a period as the Member State concernid determines, be condicional upon the continued fulfilment of the criteria for admissión".

254 Artículo 4, en relación a los matrimonios en blanco o de conveniencia, y el artículo 9 con respecto a las adopciones fraudulentas. Resolución sobre la armonización de Políticas Nacionales relavitas a la RF, op. cit. 
realizados con el único objetivo de entrar en el Estado miembro - matrimonios y adopciones de conveniencia. Sobre la RF, tal y como quedaba configurada en la presente Resolución, parecía planear constantemente la sospecha de fraude.

4. Los familiares admitidos adquirirían un status independiente al del reagrupante tras un "período razonable de tiempo"255 — no determinado en la Resolución —, por lo que su concreción se dejaba en manos del EM. A partir de dicho momento indefinido, los familiares reagrupables podrían trabajar - “if appropriate”, aclaraba la resolución - en el Estado receptor. Para comprender esta indeterminación, conviene echar un rápido vistazo a los antecedentes legislativos de la resolución. El acceso al mercado laboral para los familiares admitidos se convirtió en un auténtico escollo, constituyendo con mucho la cuestión más controvertida ${ }^{256}$ para lograr un acuerdo entre los ministros de inmigración y el germen del bloqueo en el proceso negociador. Francia e Irlanda fueron los países más reticentes a la concesión de derechos laborales a los familiares reagrupables. Sería Francia quien finalmente destapase el bloqueo, proponiendo el que se convertiría en el actual artículo 12 de la Resolución y que incluía la frase de la discordia - "if appropriate, be authorized to work"$^{257}$ - . Este bloqueo explica el carácter altamente impreciso de la disposición finalmente consensuada.

5. Los Estados miembros se reservaban así mismo el derecho de exigir requisitos relativos a la suficiencia de recursos económicos, adecuado alojamiento y la existencia de un seguro de enfermedad, a fin de que los familiares admitidos no constituyesen una carga a las arcas públicas $^{258}$.

6. Como era habitual en el ámbito interno, la resolución contemplaba la seguridad nacional y el orden público como causas que fundamentaban la denegación de las solicitudes de reagrupación familiar. En este sentido, establecía que los EEMM "normalmente" rechazarían la entrada y estancia de un familiar si su presencia constituía una amenaza a la seguridad nacional o al orden público $^{259}$; en materia de salud pública los Estados miembros se reservaban el derecho de aceptar o no al familiar. En este apartado dedicado a las cláusulas que permitían la negación del derecho, llamaba la atención - y esta vez por su carácter permisivo - la no inclusión expresa del bienestar económico del país como causa que podía fundamentar el rechazo de la reunificación familiar. Esta exclusión contrastaba con el artículo 8.2 del CEDH, que contemplaba expresamente el bienestar económico estatal como injerencia legítima que justificaba la limitación del derecho a la vida familiar de los extranjeros, siendo precisamente esta causa la que ha amparado en régimen de monopolio todas las reclamaciones de RF presentadas ante las autoridades de Estrasburgo.

Por contraste a las múltiples cláusulas restrictivas, reservas e indeterminaciones presentes constantemente a lo largo de la Resolución objeto de análisis, sobresalía la inclusión de un principio de carácter progresista en su apartado $14^{260}$. A tenor del mismo, la petición de RF debía ser formulada "normalmente" mientras el familiar reagrupable se encontrase fuera del territorio del Estado receptor. Esta disposición, a sensu contrario, permitía — aunque de forma limitada—, la posibilidad de

255 Idem. Principio 12.

256 PEERS, Steve. "Building Fortress..., op. cit., p. 1240. BRINKMANN, Gisbert. "Family Reunion, Third Country Nationals and the Community's New Powers"..., op. cit., p. 261.

257 BOELES y KUIJER. "Harmonization of Family Reunification..., op. cit., p. 25; PEERS, Steve. "Building Fortress Europe...”, op. cit., p. 1240.

258 Principio 16.

259 Principio 17.

$260 \mathrm{El}$ artículo 24 in fine afirmaba que "the application must normally be made whilst the family member concernid is outsider the territory of the Member State concernid". 
admitir solicitudes de familiares reagrupables que se hallasen ya en el territorio del Estado miembro. A juzgar por la cantidad de prevenciones contra la mera posibilidad de fraude a las normas de inmigración que se recogían en la resolución, llamaba la atención una previsión de estas características, especialmente por el pragmatismo que implicaba, rindiéndose a la evidencia de la presencia de miembros de la familia que residían con el reagrupante en virtud de títulos habilitantes diversos, e incluso contraviniendo las normas de extranjería. En el contexto restrictivo que la Resolución dibujaba, la disposición contenida en el apartado 14 de la Resolución era de un alto sentido humanitario.

Como se derivaba del propio título de la resolución y del programa que con ella se pretendía implementar a fin de dar cumplimiento al Informe sobre política de inmigración y asilo de 1991, intentar limar las divergencias más sustanciales entre las políticas y legislaciones nacionales relativas a la RF constituía el objetivo principal de la resolución que venimos comentando. El presupuesto de partida de la Resolución tenía una lógica aplastante, basado en la consideración de que el primer paso imprescindible para la existencia de una auténtica política europea de extranjería e inmigración consistía en lograr cierto acercamiento entre las legislaciones nacionales, a fin de poder sentar las bases de una política común de la UE en esta materia. Y para ello se abordaría en primer lugar la regulación de la inmigración de carácter familiar por constituir ésta una de las más importantes vías legales de entrada de inmigrantes no comunitarios en la CE. Se trataba en sí mismo de un objetivo arduo y de gran complejidad ${ }^{261}$.

Con este punto de partida en mente, se puede en primer lugar analizar la adecuación de la resolución para el logro del objetivo armonizador, para posteriormente comprobar sus resultados prácticos en dicho ámbito. Respecto a la primera cuestión, es de advertir que la Resolución no contemplaba ningún mecanismo que permitiera asegurar el cumplimiento ${ }^{262}$ de la adaptación de las legislaciones de los EEMM antes del 1 de enero de 1995, término fijado en su preámbulo. Además tampoco contenía una cláusula de emplazamiento a fin de señalar futuras revisiones de los principios contemplados en ella. Este cúmulo de circunstancias, junto con su ambigua naturaleza jurídica, su vinculación puramente política y la enorme profusión de reservas e indeterminaciones a lo largo de su articulado, nos permite llegados a este punto afirmar que las metas armonizadoras eran de carácter totalmente opcional ${ }^{263}$. El carácter potestativo de la armonización era en sí mismo contradictorio al propio objetivo armonizador. Por ello, tras la aprobación de la resolución, desde el ámbito doctrinal se advirtió que "sus reglas armonizadoras serán complementarias a los sistemas legales internos, que permanecen invariables"264, y que más que ante un instrumento de armonización, la resolución constituía "una colección de opciones que harán posible una política de reunificación familiar al nivel más restrictivo posible"265.

261 Las características propias del ámbito intergubernamental en que se forjó la resolución no hacían sino incrementar las dificultades de armonización. El panorama se dificultaba aún más como consecuencia de la alta sensibilidad política de la materia, la enorme disparidad normativa y de prácticas administrativas internas existente en esta materia a principios de la década de los noventa del pasado siglo y la inexistencia en dicha época de una competencia comunitaria migratoria que legitimase y dotara de eficacia jurídica a las normas comunitarias dictadas a fin de conseguir su materialización.

262 Lo más parecido a cierto control del cumplimiento de la resolución se produjo en el año 1998, a través de una decisión del Consejo que creó un mecanismo para monitorizar la implementación de esta resolución, a fin de "reveal the practical effect ot the Council's work in this matter and provide useful lessons for its future work". OJ 1996 C11/1; cf. Analysis of replies to the questionnaire on family reunification, Council Documents 8491/98 of 12 May 1998, and 8491/98 ADD 1 of 8 June 1998. Citado por BRINKMANN, Gisbert. “Family Reunion, Third Country Nationals, and the Community's New Powers", op. cit., p. 251.

263 BOELES y KUIJER. "Harmonization of Family Reunification...., op. cit., p. 27.

264 Idem.

265 Ibidem, p. 25. 
En definitiva, múltiples elementos presentes en la resolución obstruían el logro del objetivo armonizador perseguido. Se trataba de una medida de muy escasa vinculación jurídica y cuyo objetivo primordial - la armonización de la RF en el ámbito europeo- nacía asimismo afectado por la propia naturaleza jurídica del instrumento adoptado. La resolución constituía una herramienta muy poco adecuada para el logro del objetivo armonizador, pues a lo largo de su articulado "ni se obligaba ni se presionaba" 266 a su consecución, con el resultado que la armonización perseguida adolecía del mismo vicio que la Resolución que pretendía llevarla a cabo: su carácter puramente optativo. Los principios acordados por los ministros a cargo de la cartera de inmigración, lejos de la armonización perseguida, se diluyeron en un compromiso político de muy baja intensidad, del que parecían ser conscientes desde el principio sus artífices, a juzgar por la gran cantidad de ambigüedades ${ }^{267}$, vaguedades, reservas e indeterminaciones que diseminaron a lo largo de la Resolución. Tal laxitud, por otro lado resultó inevitable para poder lograr el consenso necesario para su aprobación. Como en su momento se advirtió, "el acuerdo se logró en un período de tiempo relativamente corto, pero ello fue claramente al precio de la armonización"268.

Si pasamos ahora a considerar los resultados de la Resolución en los sistemas migratorios internos, la conclusión resulta ser consistente con la característica de alta discrecionalidad estatal que hemos venido apuntado. Ello explica que la Resolución no lograse acuerdos precisamente en aquellos puntos donde las divergencias regulatorias entre los EEMM eran más fuertes ${ }^{269}$, tales como las condiciones en que debía ejercerse la reagrupación familiar, la exigencia de plazos previos de residencia legal, qué otros familiares distintos al esposo/a e hijos dependientes podrían ser autorizados a entrar en base a ella o la definición concreta de hijos a efectos de reunificación. En todos estos puntos decisivos, la Resolución no ofrecía reglas concretas, sino un conjunto de reservas que se traducían en un amplio elenco de "opciones" 270 abiertas a los EEMM.

Todo este cúmulo de circunstancias llevó a la doctrina a manifestar sus temores sobre la posibilidad de que, con el texto de la Resolución en la mano, la única armonización posible fuera a la baja, es decir, que los EEMM usasen este instrumento como excusa para rebajar los estándares protectores que sus legislaciones internas ofrecían a los extranjeros residentes a efectos de reunificación familiar. Y, en cumplimiento de los pronósticos doctrinales, la temida carrera a la baja - "race to the bottom"- de hecho tuvo lugar en dos EEMM: Holanda y Luxemburgo introdujeron mayores restricciones en la RF tras la aprobación de la presente Resolución ${ }^{271}$. De esta forma la Resolución constituyó no sólo un instrumento al parecer inadecuado para el logro de sus objetivos, sino incluso "técnicamente contraproducente"272.

266 BOELES y KUIJER. “Harmonization..., p. 27, citando a R.H. LATRWAARS.

$267 \mathrm{Al}$ respecto BRINKMANN afirma que "since Member States were unable to agree on a common policy, most of the provisions are vague and Member States are free to give their own interpretation to them"; en "Family Reunion, Third Country Nationals and the Community's New Powers", op. cit., p. 251.

268 PEERS, Steve. “Building Fortress Europe...., op. cit., p. 1240. Este autor se pregunta: “ ¿How did twelve Member States reach agreement on this important and complex issue within eighteen months, and indeed almost reach agreement within one year?". Y la respuesta es clara: "It was simple; they did not really reach agreement at all; (...) but although an agreement was reached within a relatively short period, this was clearly at the cost of harmonization".

269 De hecho la Comisión emitió un Paper en 1992 donde llegó precisamente a esta conclusión.

270 PEERS, Steve. “Building Fortress Europe...”, op. cit., p. 1241.

271 BOELES, P y KUIJER, A. "Harmonization..., op. cit., p. 27. Ambos autores señalan que "en su forma presente la resolución puede ser fácilmente interpretada como una invitación a los EEMM para incluir todas las restricciones, incluso las optativas, en sus respectivas legislaciones". Para Bolees y Kuijer esta vía es la única a través de la cual la Resolución podría cumplir su objetivo armonizador, esto es, permitir una "legislación uniforme que reduciría a un deterioro draconiano las posibilidades de reunificación familiar en los EEMM”. Idem, p. 28.

272 Ibidem, p. 33. 
En conclusión, la resolución se situó muy lejos de los objetivos del programa de trabajo establecido en el Informe de 1991 - que la presente Resolución pretendía materializar en el ámbito específico de la RF-, donde los ministros de inmigración habían dejado claro la necesidad de que la armonización se realizase estableciendo una serie de principios básicos a fin de evitar que ésta tuviera lugar al nivel más bajo posible de protección ${ }^{273}$. Así mismo, el descenso en el nivel de garantías resultaba contradictorio con la adhesión explícita al principio de respeto de los derechos humanos y al CEDH que figuraba en el mencionado Informe, y con el autoproclamado respeto a los compromisos internacionales vigentes sobre la materia, contenido en el apartado tercero del preámbulo de la Resolución. Tras analizar el contenido de la resolución, la doctrina había denunciado que sus principios establecían estándares de protección que se situaban muy por debajo de los mínimos fijados por el derecho internacional de los derechos humanos — señaladamente el $\mathrm{CEDH}^{274}$ 一, produciendo un incremento en la brecha, ya existente, entre los ciudadanos europeos y los procedentes de terceros países $^{275}$.

La resolución era pródiga en la concesión de reservas a los Estados miembros, era igualmente generosa en el establecimiento de múltiples prevenciones contra el fraude a las normas migratorias y el abuso del derecho, manteniendo a la institución objeto de nuestro estudio dentro del rango de las facultades discrecionales del Estado miembro sobre la que planeaban constantemente - y no solamente en el momento inicial de su concesión - las dudas en torno a su carácter genuino. Además, abundaban en ella las indeterminaciones y ambigüedades, dejando sin respuesta cuestiones básicas para la configuración de la reagrupación familiar ${ }^{276}$. La resolución ofrecía pues un grado muy bajo de protección a la reunificación familiar, sin configurarla como un derecho subjetivo, sino como una prerrogativa cuya concesión o no seguía dependiendo casi enteramente de la libre voluntad del Estado miembro, situación idéntica a la existente antes de su aprobación. Incluso se detectaban a lo largo de su escaso articulado algunas contradicciones ${ }^{277}$. En esta resolución era pues particularmente visible una de las características comunes a las múltiples medidas de soft law sobre inmigración que fueron dictadas en aquella época: su incoherencia ${ }^{278}$.

273 Report from the Ministers responsible for immigration to the European Council meeting in Maastricht on immigration and asylum policy, p. 460 —dentro del apartado 3, relativo a los Principios básicos para el nivel de armonización一. En él se afirmaba explícitamente la adhesión a la "tradición europea, basada sobre principios de justicia social y respeto a los derechos humanos, tal y como son definidos en la Convención Europea de Derechos Humanos".

274 Concretamente, la noción de familia contemplada por la Resolución resultaba más restrictiva que la contemplada por el TEDH. CLELIA CICIRIELLO, Maria. "Ricongiungimento familiare como diritto Fondamentale del migrante"; La Comunitá Internazionale, no 1, 2006, p. 113.

275 GUILD, Elspeth. The Developing Immigration..., op. cit., pp. 259-273. Al analizar el texto de la resolución, la autora denuncia múltiples incumplimientos del estándar mínimo internacional de protección, concluyendo que "it is deeply unsatisfactory that states establish new policies in a field regulated by International obligations which exclude existing obligations and indeed may result in their breach", op. cit., p. 273. En el mismo sentido, CLELIA CICIRIELLO, M. "Ricongiungimento familiare...", op. cit., pp. 113-114.

276 Tales como el tiempo previo de residencia legal del reagrupante en el Estado receptor antes de poder solicitar reunirse con sus familiares, o el período de tiempo tras el cual el familiar reunificado podrá acceder a un status independiente.

277 Entre las contradicciones cabría destacar la que representaba reconocer que en la adopción de la Resolución se ha tenido en cuenta la doble influencia - internacional e interna - a la que está sometida la regulación de la reagrupación familiar, al tiempo que se afirma que las obligaciones derivadas de ambas fuentes normativas no se verán afectadas por el contenido de la resolución (apartado $3^{\circ}$ del Preámbulo); o la que implicaba sostener que la presente resolución no afecta a las divergencias legislativas existentes entre los distintos Estados miembros respecto a la cuestión del tratamiento igualitario o no de sus propios nacionales y los extranjeros extracomunitarios a efectos de la reagrupación familiar (apartado $9^{\circ}$ del Preámbulo).

278 BALDWIN-EDWARDS. “The Emerging European Regimen...”, op. cit., p. 502. Las incoherencias de la resolución quedan más al descubierto si tratamos de proporcionar una definición de la reagrupación familiar derivada de los 
Las características apuntadas de la Resolución determinaron que fuera considerada un instrumento muy controvertido, siendo objeto de fuertes críticas. Se señaló la imposibilidad del logro de su objetivo armonizador ${ }^{279}$; se cuestionó su utilidad ${ }^{280}$ debido a la gran flexibilidad que ofrecía a los EEMM; se destacó la enorme libertad en su implementación ${ }^{281}$ y el mantenimiento de un elevadísimo margen de apreciación estatal que, nuevamente, mermaba la eficacia armonizadora. La doctrina indicó en su momento la inadecuación tanto de la elección de la forma de una Resolución a fin de poder llevar a cabo el objetivo armonizador de las políticas internas perseguido, como del ámbito intergubernamental en el que se forjó. Así mismo, denunció el incumplimiento ${ }^{282}$ de los compromisos internacionales que vinculaban a los EEMM, así como la profundización de la discriminación entre los diferentes estatutos de extranjeros. Tras analizar detenidamente su texto, el Comité de expertos permanentes en materia de inmigración aconsejó a los EEMM su no implementación ${ }^{283}$. Se advirtió que, lejos de incrementar la protección del derecho, la Resolución contenía un número elevadísimo de cláusulas restrictivas que venían a reproducir las ya existentes en algunos de los países con legislaciones de reunificación más estrictas, permitiendo que éstas fueran a su vez insertadas en países más liberales ${ }^{284}$. En conjunto fue calificada como un instrumento "decepcionante y deslucido"285.

Con todo, la resolución marcó el pistoletazo de salida de la intención de empezar a configurar de forma compartida y común en el ámbito europeo un derecho de reagrupación para los extranjeros no comunitarios, que con el tiempo habría de ganar en densidad normativa ${ }^{286}$. Por ello, puede apuntarse que la resolución constituyó la simiente a nivel comunitario de un precario derecho a la reunificación familiar o "protoderecho" de configuración fundamentalmente interna, caracterizado por la existencia de un elevado margen de apreciación estatal y poco permeable a la influencia internacional que declaraba respetar en su preámbulo.

En cualquier caso, precisamente en este contexto era de apreciar el esfuerzo por aproximar normativas y prácticas estatales en una materia respecto a la que todos los artífices coincidían en su complejidad e importancia, tanto para la integración de los inmigrantes establecidos en el territorio de los Estados miembros - declarado en su preámbulo - como para la viabilidad de las propias políticas internas, presionadas por una inmigración creciente y por la necesidad de convergencia que implicaba la realización del mercado único —establecida explícitamente en el Informe de 1991.

principios en ella contenidos, fundamentalmente si la construimos sobre la conjunción de sus tres primeros artículos. De acuerdo a los mismos, la RF consistiría en la facultad que "normalmente" asiste al reagrupante — definido como el residente legal en un EM durante "cierto período de tiempo" y que además contase con la "expectativa de una residencia permanente o de larga duración", ambos conceptos sin especificar-, para reunirse en el territorio del EM en el que estuviese residiendo con algunos de sus familiares — los especificados en la resolución- quienes podrían entrar y permanecer en el territorio de dicho Estado en condiciones más ventajosas que las establecidas con carácter general en los respectivos regímenes nacionales de extranjería.

279 BOELES y KUIJER. “Harmonization...”, op. cit., p. 25.

280 Al respecto, BALDWIN-EDWARDS afirmó que en la Resolución "the rules on family reunification are so flexible - to allow for substantial national variation - that one can question their utility. Furthermore, much of this area is governed by existing international law.- again restricting the options open"; The Emerging..., op. cit., p. 502.

281 BOELES y KUIJER. “Harmonization...”, op. cit., p. 26.

282 GUILD, E. The Developing Immigration..., op. cit., pp. 271. BOELES y KUIJER. “Harmonization...”, op. cit., p. 31.

283 BOELES y KUIJER. "Harmonization...., op. cit., pp. BATTISTELLA, Graziano. Family Reunification: Policies and Issues; en Asian and Pacific Migration Journal, vol. 4, No 2-3, 1995, p. 242.

284 Idem. Este autor califica la Resolución como "controvertida".

285 CHOLEWINSKY, Ryszard. "Family Reunification as a Constitutional Right?”; APAP, Joanna (ed.). Justice and Home Affairs in the EU. Liberty and Security Issues after Enlargement. Cheltenham (UK) y Northampton (USA), CEPS, 2004, p. 265.

286 Así se deduce del último párrafo del preámbulo, que invita a ahondar en la futura armonización de la RF, especialmente para aquellos colectivos que habían quedado por el momento excluidos de su ámbito de aplicación. 
Pero, con independencia de sus múltiples carencias, la Resolución estaba llamada a cumplir una función que trascendía su exigua eficacia jurídica: Servir a modo de guía que debía orientar las prácticas y políticas relativas a la RF de los distintos EEMM, especialmente relevante a efectos de la reforma futura de las legislaciones internas ${ }^{287}$. Esta función de guía constituía en sí misma un arma de doble filo: De un lado, dado que la resolución no incluía ninguna cláusula de stand still, existía el riesgo de una posible merma de las garantías de la migración familiar en aquellos EEMM -la mayoría- que ya contaban con regulaciones internas de RF; pero de otro, para aquellos EEMM que no habían procedido todavía a configurar legislativamente la reunificación familiar y ésta se incardinaba en el conjunto de meras prácticas administrativas, esta función de brújula era de vital importancia pues actuaría en sentido contrario al antes mencionado, esto es, promoviendo e impulsando la regulación expresa de la reagrupación familiar y con ello incrementando sus garantías jurídicas.

Ambos aspectos se materializaron en la práctica. Ya señalamos que algunos EEMM habían procedido a rebajar las garantías que rodeaban a la RF de los extranjeros de terceros países justo tras la aprobación de la Resolución de 1991. De otro lado, entre los países cuyas legislaciones internas no preveían un derecho a la reunificación familiar para los extranjeros no comunitarios, en la época en que esta resolución vio la luz, se encontraba España. Fue precisamente la aprobación por España de la Resolución de armonización lo que desencadenó la reforma del Reglamento de extranjería a fin de colmar esta laguna, dando entrada al derecho a la reunificación familiar para ajustar las normas y prácticas españolas a los principios en ella acordados. Así el acuerdo del Consejo de Ministros de 12 de noviembre de $1993^{288}$ sobre tramitación de visados para la reagrupación de familiares de extranjeros no nacionales de EEMM de la Unión Europea fijó los criterios a seguir para resolver las solicitudes de visados de RF de ciudadanos de terceros países.

Pese a los intentos posteriores de adoptar medidas comunitarias en este ámbito, la Resolución constituyó el único instrumento vigente en materia de migración familiar de nacionales extracomunitarios que los EEMM fueron capaces de acordar dentro del ámbito del tercer pilar. Precisamente esta ausencia de medidas alternativas, no vino sino a incrementar la importancia de la Resolución que, con el paso del tiempo, pasaría a formar parte del aquis comunitario sobre inmigración y asilo. En este sentido, casi una década después de su entrada en vigor, la Resolución reveló la trascendencia de su función orientadora: En 2002, los por entonces países candidatos a la adhesión —ante el retraso en la aprobación de la Directiva sobre RF que había comenzado a negociarse casi tres años antes-, tuvieron que actuar en conformidad con el texto de la Resolución y adaptar sus legislaciones internas a los tenues principios armonizadores sobre reunificación familiar en ella establecidos ${ }^{289}$.

287 CALLOVI, Giuseppe. "Il Ricongiungimento delle famiglie straniere nella Comunita Europea"; en SCABINI, Eugenia y DONATI, Pierpaolo (dirs.). La Famiglia in una Società Multiétnica. Milano, Vita e Pensiero, 1997, p. 118; BOLEES y KUIJER. "Harmonization of Family Reunification..., op. cit., p. 28. De otro lado esta función estaba perfilada en el apartado quinto del Preámbulo de la Resolución, del siguiente modo: “They —en referencia a los ministros de inmigración de los EEMM, firmantes de la Resolución - agreed to have regard to these principles in any proposals for the revisión of national legislation".

288 Resolución de 18 de febrero de 1994, de la Subsecretaría, por la que se dispone la publicación del Acuerdo de Consejo de Ministros mencionado. BOE n 47, de 24 de febrero de 1994, p. 6117. Su justificación residía en la necesidad de que España se adaptase a los compromisos internacionales suscritos en la materia, en especial a la Resolución de Ministros de la UE responsables de inmigración de 1 de junio de 1993. La exposición de motivos del Reglamento de extranjería reformado, hacía referencia explícita al texto de la Resolución y a la necesidad de adaptar al mismo la normativa española.

289 VAN KRIEKEN, P.J. (ed.). The Asylum Acquis Handbook. The Hague, T.M.C. Asser Press, 2000, pp. 83 y 104. CHOLEWINSKI, Ryszard. "Family Reunification as a Constitutional Right?": APAP, Joanna (ed.). Justice and Home Affairs in the EU. Liberty and Security Issues after Enlargement. $\mathrm{E}_{\mathrm{i}}$ Cheltenham, UK y Northamplton, USA, CEPS, Edward Elgard, 2004, pp. 259-273. 


\subsection{Propuesta de convenio relativo a las normas de admisión de nacionales de terceros países en los EEMM}

Un mes después de la aprobación del Tratado de Ámsterdam ${ }^{290}$, que confería competencias a la UE en materia migratoria, la Comisión propuso una Convención sobre Migración ${ }^{291}$, en la que se venía trabajando desde tiempo atrás a fin de superar el déficit normativo de las diversas resoluciones emitidas sobre temas migratorios. Dado que Ámsterdam todavía no había entrado en vigor y los EEMM eran conscientes de las pocas probabilidades de que la propuesta de convenio fuese aprobada antes de ese momento ${ }^{292}$, la propuesta fue adoptada sobre la base jurídica del antiguo artículo K.3 apartado 2.c $)^{293}$, esto es, en un ámbito intergubernamental, en el contexto de tránsito hacia un nuevo arreglo competencial. Su adopción se hizo con la perspectiva en mente de que, una vez entrado en vigor el Tratado de Ámsterdam, la Comisión presentaría un borrador sobre la nueva atribución competencial conferida por el artículo 63, pero aprovechando las deliberaciones y reflexiones desarrolladas al hilo de esta propuesta.

El proceso de gestación de la propuesta de Convenio adoleció de la misma opacidad y falta de transparencia que venían caracterizando a las medidas sobre inmigración dictadas por aquella época a fin de dar cumplimiento al programa de trabajo de 1991. Asimismo, la Propuesta se inspiraba claramente en seis de dichos instrumentos ${ }^{294}$, si bien con notables mejoras en su redacción y en la sistematización de normas antes dispersas en variadas regulaciones.

290 El Tratado de Ámsterdam fue aprobado en el Consejo Europeo de Ámsterdam, celebrado los días 16 y 17 de junio de 1997, siendo firmado por los ministros de asuntos exteriores de los por entonces 15 EEMM el 2 de octubre de 1997. Su entrada en vigor se produjo el 1 de mayo de 1998.

291 Se trata de la Propuesta de la Comisión por la que se establece el Convenio relativo a las normas de admisión de nacionales de terceros países en los Estados miembros (COM/97/0387) de 30 de julio de 1997; COM(97) 387, final, de 30 de julio; OJ 1997, C337/9. Sobre la misma véase, entre otros, GUILD, Elspeth. "Comisión Initiative: Proposal for a Decisión on Establishing a Convention on Rules for the Admisión of Tirad-Country Nationals to the Member States of the EU". Immigration Law Practitioners Association Memorandum, European Update: September 1997. HEDEMANNROBINSON, M. "From Object to Subject? Non-EC Nationals and the Draft Proposal of the Comisión for a Council Act Establishing the Rules for Admisión of Third-Country Nationals to the Member States"; en Yearbook of European Law, No 18, 1998, pp. 317-326. PEERS, S. "Raising Minimum Standards or Racing to the Bottom? The Commissions's Proposed Migration Convención”; en GUILD, E (ed.). The Legal Framework and Social Consequences of Free Movement of Persons in the European Unión. Boston, Kluwer Law International, 1998, pp. 159-164.

292 Esta consideración se desprende con claridad de la Declaración Introductoria que precede a la Exposición de Motivos de la propuesta de Convenio. Allí se establece que: "The Comission has always wanted the immigration rules to be within the Community ambit. It's accordingly welcomes the results to the Intergovernmental Conference and the prospects oponed up by the Amsterdam Treaty. That Treaty has not yet been signed, letf alone ratified, but it would be a mistake to postpone consideration to the subject-matter of this proposal until it has entered into force. In the current situation the Commission can make proposals only on the legal bases available in Title VI of the Treaty on European Union. Once the new Treaty has entered into force, however, the Commission will obviously present a new draft in the form of a Directive". Y a continuación subrayaba el propósito que se perseguía con la presente propuesta de Convenio en los siguientes términos: "This will preserve the fruits of the previous deliberations on the substance but in the context of the new legal basis".

293 Esta disposición establecía que "el Consejo podrá, sin perjuicio de lo dispuesto en el artículo 220 del Tratado constitutivo de la Comunidad Europea, celebrar convenios recomendando su adopción a los Estados miembros según sus respectivas normas constitucionales. Salvo disposiciones en contrario establecidas en estos convenios, las posibles medidas de aplicación de los mismos se aprobarán en el seno del Consejo por mayoría de dos tercios de las Altas Partes Contratantes. Tales convenios podrán disponer que el Tribunal de Justicia será competente para interpretar las disposiciones de los mismos y dictar sentencia en los litigios relativos a su aplicación, de conformidad con las modalidades que puedan haber establecido".

294 La inspiración fundamental procedía de las siguientes normas: Resolution on family reunification de 1993; Resolution on admisión for employment 1994; Resolution on admisión for self-employment 1994; Resolution on admisión for study 1994; Resolution on third-country nationals with long-term residence 1996; así como de una Joint 
Con esta propuesta la Comisión pretendía superar las deficiencias que todas las medidas comunitarias migratorias arrastraban respecto a su débil naturaleza jurídica, optando para ello por un instrumento - una convención- que representaba el máximo rango legal dentro de las posibles medidas a adoptar en el ámbito del tercer pilar $^{295}$. Elevar su rango jurídico suponía al mismo tiempo incrementar las garantías de los derechos reconocidos a los extranjeros no comunitarios ${ }^{296}$. Además la Comisión aspiraba a sobrepasar el carácter fragmentario e incoherente de las medidas comunitarias relativas a nacionales de terceros países hasta el momento vigentes. La situación respecto a los derechos reconocidos a este colectivo en el derecho comunitario de la época, había sido descrita gráficamente como un "potpurrí de derechos actuales y potenciales"297, desarrollados de forma descoordinada, ad hoc, casual "e insatisfactoria en relación con las oportunidades que presentaba el mercado interno ${ }^{298}$ ". Esta situación contrastaba vivamente con la existente respecto a los nacionales comunitarios, quienes disfrutaban de un conjunto "estandard de derechos en todos los EEMM de la UE”299 que se había ido engrosando al compás del desarrollo de la Comunidad ${ }^{300}$.

Para evitar esta dispersión e incoherencia normativa, la Comisión proyectaba diseñar una norma de carácter integral que regulase de forma unificada todos los aspectos relativos tanto al ingreso para estancias superiores a tres meses, como los referentes a la integración de los extranjeros extracomunitarios en el territorio comunitario. Pretendía así emprender una labor de refundición de las normas relativas a nacionales de terceros países reguladoras de las condiciones de admisión por razones de empleo asalariado o autónomo, los estudiantes, la RF, los derechos de los residentes de larga duración y otras categorías. Adoptaba con ello la Comisión un papel de "líder" ${ }^{301}$ en el diseño y formulación de las políticas migratorias comunitarias.

El destino original de esta propuesta era bastante incierto, habida cuenta de que su adopción por los Estados miembros conforme a sus respectivas normas constitucionales ${ }^{302}$ - como cabría esperar de un convenio-, se tornaba casi imposible ante la perspectiva de la futura entrada en vigor del Tratado de Ámsterdam y el nuevo panorama competencial por éste establecido ${ }^{303}$. Además, el carácter

Action on visas for school parties, que nunca llegó a entrar en vigor. PEERS, S. “Raising Minimum Standars...”, op. cit., p. 155.

295 Tras la lectura de esta propuesta persisten las dudas respecto a la naturaleza jurídica de sus normas, aún en el hipotético supuesto de que hubieran llegado a ser ratificadas como un Tratado internacional. Estas dudas se desprenden del considerando noveno, conforme al cual las normas comunes de admisión de nacionales de terceros países "no confieren ningún derecho de residencia", conservando intacto los Estados miembros su poder discrecional en cuanto a las decisiones efectivas de admisión de los nacionales de terceros países". Esta ambigüedad de la propuesta fue en su momento duramente criticada por el Parlamento Europeo en su Dictamen de 21 de enero de 1998. Proyecto de Resolución Legislativa que contiene el dictamen del Parlamento Europeo sobre la propuesta de acto del Consejo por el que se establece el Convenio relativo a las normas de admisión de nacionales de terceros países en los EEMM y sobre el proyecto de Convenio relativo a las normas de admisión de nacionales de terceros países en los EEMM. COM(97)0387 —C4-0681/97-97/0227 (CNS).

296 PEERS, Steve. “Towards Equality: Actual and Potential Rights of Third-Country Nationals in the European Union”; en Common Market Law Review, no 33, 1996, p. 49.

297 Idem, p. 7.

298 Ibidem

299 Ibidem, p. 13.

300 HEDEMANN-ROBINSON, Martin. "Third-Country Nationals, European Union Citizenship, and Free Movement of Persons: a Time for Bridges rather than Divisions"; en Yearbook of Euroepan Law, No 16, 1996, p. 323.

301 HAILBRONNER. "European Immigration and Asylum Law under the Amsterdam Treaty", op. cit., p. 1050.

302 En este sentido, el Consejo de la Unión Europea recomendaba a los Estados su adopción en las disposiciones previas a los considerandos de la Propuesta.

303 En torno al tema de la aprobación de esta propuesta, BRINKMANN afirma que tanto los EEMM como la Comisión eran conscientes de que la Convención no sería adoptada con anterioridad a la entrada en vigor del Tratado de 
global y prematuro de este instrumento venía a complicar aún más las cosas. Todo ello, unido a la falta de interés de los $\mathrm{EEMM}^{304}$ en profundizar la agenda armonizadora, determinó que finalmente la propuesta no cuajase.

No obstante, su importancia para nuestro objeto de estudio no es menor ya que, si bien no logró trascender la fase de mero borrador, contiene una regulación expresa del derecho a la RF en su capítulo VII ${ }^{305}$, bajo la rúbrica "admisión con fines de reagrupación familiar" 306 , que posteriormente serviría como marco para la reflexión y redacción de la futura Directiva reguladora de esta materia. Dicho convenio pretendía determinar el marco en el que había de organizarse la migración familiar en el ámbito comunitario ${ }^{307}$, continuando la estela de la Recomendación ya estudiada de fijar normas comunes para el desarrollo armonizado del derecho. Y, lo que es más destacable, las normas relativas a la RF parecían escapar de la naturaleza no vinculante de la Propuesta, para conferir derechos reales y no meramente programáticos a sus titulares. Esta conclusión se extrae del considerando noveno, conforme al cual las "normas comunes de admisión, con excepción de las relativas a la reagrupación familiar y de las aplicables a las personas reconocidas como instaladas con carácter duradero, no confieren ningún derecho de residencia y (...) los Estados miembros conservan su poder discrecional en cuanto a las decisiones efectivas de admisión de los nacionales de terceros países".

En esta Propuesta de Convenio la titularidad activa ${ }^{308}$ del derecho a la reunificación familiar se confiere a los nacionales extracomunitarios que cuenten con residencia legal en el territorio de un Estado miembro desde al menos un año y que, en la fecha de presentación de la solicitud de reagrupación familiar, tengan derecho de residencia en dicho Estado durante al menos otro año más. Como excepción a la regla general, los estudiantes extracomunitarios también podrán ejercer el derecho a la RF, pero en este supuesto los plazos de residencia legal se incrementan, exigiéndoseles haber residido legalmente durante al menos dos años y tener derecho a residir otro año más. Estamos pues ante un ámbito de aplicación personal que, a diferencia de la Resolución de armonización, delimitaba con precisión el período previo mínimo de residencia legal exigido para que el reagrupante se pudiera reunir con sus familiares en el territorio del Estado receptor - el denominado período de espera. El problema residía en que no existía la misma delimitación con respecto a la duración máxima de dicho período, por lo que se presentaba el riesgo de que los EEMM pudiesen establecer con absoluta libertad plazos excesivos sin la existencia de límites comunitarios que actuaran como tope para evitar el vaciamiento del derecho. De nuevo, la Propuesta caía en la indeterminación con respecto a un elemento básico del contenido de la reagrupación familiar.

De otro lado, destaca la inclusión de la concepción tradicional de la reagrupación familiar como derecho cuya titularidad corresponde en exclusiva al familiar reagrupante ${ }^{309}$, y su ampliación a los

Amsterdam. "Family Reunion, Third Country nationals and the Community's New Powers", op. cit., p. 252, Nota a pie de página número 36.

304 PEERS, Steve. “Raising Minimum Standards..., op. cit., p. 151.

305 Artítculos 24 a 31 de la Propuesta de Convenio relativo a las normas de admisión de nacionales de terceros países en los EEMM.

306 Las discusiones habidas entre los EEMM en torno a las disposiciones relativas a la reunificación familiar contenidas en dicho capítulo se encuentran transcritas en el Documento del Consejo 6488/98 ADD 1, de 1 de septiembre de 1998.

307 Así se afirma expresamente en el considerando sexto de la Propuesta de Convenio.

308 Artículo $24 \mathrm{COM} / 97 / 0387$.

309 Al respecto, el Parlamento Europeo, al ser consultado por el Consejo, de conformidad con el párrafo segundo del artítculo K.6 del Tratado de la Unión Europea se había manifestado en contra. En su dictamen de 21 de enero de 1998 el Parlamento declaró que, con respecto al apartado 1 del artículo 28, "el derecho subjetivo debería corresponder al nacional que vive fuera del país de acogida y desea residir en el Estado miembro” (PE 225.459). Proyecto de Resolución Legislativa 
nacionales extracomunitarios admitidos con fines de estudio en el territorio de un Estado miembro $^{310}$ en un establecimiento de enseñanza superior público u homologado, ampliando en este último supuesto el plazo de residencia legal previa en el EM. Esta previsión resultaba ser positiva, especialmente si se tiene en cuenta que los estudiantes habían sido excluidos del ámbito de aplicación personal de la Resolución de 1993, por lo que el ejercicio del derecho a la reagrupación familiar constituía un asunto enteramente dependiente de las distintas legislaciones internas de los respectivos EEMM. Sin embargo, la exigencia de un plazo superior al general fue en su momento objeto de críticas sobre la base de que ello "reduciría dramáticamente los derechos de los estudiantes a estar con sus familias en aquellos EEMM que actualmente cuentan con disposiciones más generosas"311.

Uno de los méritos más destacables de esta propuesta es que por primera vez venía a colmar la laguna y la discriminación inversa que el derecho comunitario arrastraba en esta materia, contemplando la situación de los ciudadanos comunitarios que no hayan ejercido su derecho a la libre circulación y residan en el Estado miembro de su nacionalidad y equiparándola con los comunitarios que sí han hecho uso de tal derecho ${ }^{312}$. Para ellos se señala expresamente ${ }^{313}$ que gozarán del derecho a la reagrupación familiar - con respecto a sus familiares no comunitarios - en las mismas condiciones que el régimen establecido para los ciudadanos comunitarios que han ejercido su derecho a la libre circulación, previsto por entonces en los artículos 10 a 12 del Reglamento (CEE) n 1612/68 del Consejo, de 15 de octubre de 1968.

La inserción de este colectivo constituía pues una excepción al ámbito general de aplicación del presente convenio, ya que el mismo, tal como reza su artículo segundo, "se aplicará a los nacionales de terceros países". Sin embargo, la redacción de la disposición salva la excepcionalidad invirtiendo los términos del derecho ${ }^{314}$ : al contemplar la situación de los ciudadanos comunitarios que residen en el Estado de su nacionalidad, la enunciación del derecho se altera poniendo en primer término a los familiares no comunitarios del ciudadano comunitario, esto es, a los beneficiarios del derecho a quienes, no obstante, tal y como se desprende del artículo 24, no les corresponde la titularidad activa - a tenor de dicha disposición sólo los reagrupantes podrán ejercer su derecho a la reagrupación familiar y, consecuentemente, la solicitud se presenta y decide en el territorio del Estado miembro implicado.

La definición de los familiares reagrupables aparece contenida en el artículo 26 con una fórmula que supone una notable mejora respecto a los familiares contemplados en la Resolución de 1993. Conforme a dicha disposición, los destinatarios de la reagrupación familiar serán el cónyuge

que contiene el dictamen del Parlamento Europeo sobre la propuesta de acto del Consejo por el que se establece el Convenio relativo a las normas de admisión de nacionales de terceros países en los EEMM y sobre el proyecto de Convenio relativo a las normas de admisión de nacionales de terceros países en los EEMM. (COM(97)0387 - C4-0681/97- 97/0227 (CNS)), p. 27.

310 Artículo 15 de la propuesta de Convenio.

311 PEERS, Steve. “Raising Minimum...., op. cit., p. 163.

312 Por ello el artículo 25 fue considerado por Steve PEERS como la norma "más radical” de todas las contenidas en la propuesta de Convenio. Su alta consideración tan solo se veía ensombrecida, a juicio de este autor, por la falta de claridad de que adolece la última parte de esta disposición. “Raising Minimum..., op. cit., p. 160.

313 Artículo 25 COM/97/0387.

$314 \mathrm{Al}$ respecto el artículo 25 de la Propuesta de Convenio comentada señalaría que "no obstante lo dispuesto en el presente capítulo, la RF de los nacionales de terceros países que sean miembros de la familia de un ciudadano de la Unión que resida en el Estado miembro cuya nacionalidad posea, estará sujeta a las mismas condiciones que las que establecen los artículos 10 a 12 del Reglamento (CEE) no 1612/68 del Consejo, de 15 de octubre de 1968, relativo a la libre circulación de los trabajadores dentro de la Comunidad y las demás disposiciones pertinentes del Derecho comunitario". 
- "siempre que el matrimonio sea compatible con los principios fundamentales del ordenamiento jurídico del Estado miembro", exigencia que parece estar destinada a la exclusión de los matrimonios poligámicos-; también lo serán los hijos menores, tanto comunes como de uno solo de los miembros de la pareja, incluyendo a los adoptados. Se observa un importante avance en la definición de los hijos, desterrando las anteriores prevenciones en torno a las adopciones para dar entrada tanto a los hijos adoptados por ambos cónyuges, como por sólo uno de ellos. Para los hijos se exige que no estén casados y que tengan una edad inferior a la mayoría legal establecida por el Estado miembro de que se trate. Se contempla también la posibilidad de admitir a los ascendientes y otros descendientes a cargo del ciudadano comunitario, pero en este caso se trata de una posibilidad dejada al arbitrio del Estado miembro, si bien con la exigencia de que éste ha de examinar la solicitud de forma favorable ${ }^{315}$.

En coherencia con el otorgamiento de la titularidad activa en exclusiva al reagrupante o sponsor, la solicitud de reagrupación familiar ha de presentarse en el Estado miembro en que éste resida y podrá hacerse a los seis meses de la entrada en el mismo. El ejercicio del derecho está condicionado a la posesión de un alojamiento adecuado y medios de subsistencia suficientes - sin mayor especificación - para hacer frente a las necesidades de la familia tras la reagrupación. En este último aspecto, el condicionamiento material del derecho - alojamiento y medios económicos- estaba redactado en términos claramente imperativos, mientras que en la anterior Resolución se planteaba en términos opcionales, permitiendo así tanto la posibilidad de su exigencia como su exoneración ${ }^{316}$.

Como observamos en su momento, en la Resolución armonizadora de 1993 la cuestión del empleo de los familiares admitidos por razones de reagrupación familiar había sido una de las más controvertidas, hasta el punto de bloquear el proceso de negociación. En este aspecto la propuesta de Convenio es altamente liberal y flexible, pues permite a los familiares reagrupables el ejercicio de actividades tanto por cuenta ajena como propia tras el transcurso de seis meses desde su llegada ${ }^{317}$. Además se establece que el plazo de seis meses pueda incumplirse si "un cambio imprevisto en la composición de la familia o en los ingresos de la misma" exige ofrecerles acceso a una actividad laboral. Esta última previsión supera con creces a la disposición correlativa de la Resolución sobre armonización, reconociendo un supuesto de hecho que podría dar entrada a situaciones tan habituales como por ejemplo nacimiento de un nuevo hijo, disminución en los ingresos familiares u otras situaciones imponderables ante las cuales se permite un acceso laboral más temprano aún -y seis meses es en sí mismo un plazo razonable- de los familiares admitidos por causa de reunificación familiar.

El carácter derivado del derecho a la RF se desprende con claridad de la disposición que contempla la duración de la autorización de residencia expedida a favor de los familiares reagrupables: ésta corresponderá a la que reste al período de validez del permiso de residencia del principal o reagrupante. Sin embargo, en los supuestos de viudedad, divorcio, separación, fallecimiento de los

315 El párrafo $3^{\circ}$ del artículo 26 establece que "los EEMM examinarán favorablemente la reagrupación de los ascendientes y otros descendientes a cargo, siempre que se reúnan las condiciones del artículo 28 ”.

316 Contrástese el artículo 28 de la Propuesta de convenio sobre normas de admisión de nacionales de terceros países con la reserva contenida en el principio 16 de la Resolución sobre armonización de políticas nacionales relativas a la reunificación familiar de 1993. En el mismo sentido, PEERS, S. “Raising Minimum...”, op. cit., p. 163.

317 Esta disposición es contemplada muy críticamente por Steve PEERS, señalando que la imposición de un período mínimo no viene acompañada por el establecimiento de un plazo máximo. Al respecto, señala este autor que "como las normas relativas a los períodos de espera antes de la entrada inicial, la anterior regla reduciría los derechos de los miembros de la familia en algunos EEMM sin mejorar sus derechos en otros" (Traducción propia). PEERS, S. "Raising Minimum Standars..., op. cit., p. 164, traducción propia. 
padres o mayoría de edad, se prevé que los familiares admitidos por razones de RF accedan a un estatuto autónomo - o, en palabras de la propuesta, "podrán solicitar una autorización de residencia por otro concepto" - contemplándose que, de ser necesario, y mientras se examina su solicitud, el Estado miembro expedirá una autorización provisional de residencia. En este punto la Propuesta de Convenio adolece de una previsión concreta donde se prevea el tiempo de residencia exigido a los familiares reagrupados, como causa autónoma que otorgue derecho a la adquisición de una residencia independiente a la del principal o sponsor. En este aspecto la Resolución de armonización se caracterizó por su imprecisión y vaguedad - léase concesión de un margen elevadísimo de apreciación a los EEMM - exigiendo tan sólo que tras un plazo "razonable" los reagrupados conseguirían una residencia autónoma. Había llegado pues el momento de cerrar un elemento tan básico del derecho a la reagrupación familiar. Sin embargo, la Propuesta de Convenio dejó pasar esta oportunidad, haciendo depender la adquisición de un estatuto autónomo por parte de los familiares admitidos de la concurrencia de una serie de causas tasadas - viudedad, divorcio, separación, fallecimiento de los padres o alcanzar la mayoría de edad—, que nuevamente vienen a subrayar el carácter dependiente del derecho, sin prever la posibilidad de adquisición de autonomía simplemente por la residencia continuada en el EM durante un determinado número de años.

Las prevenciones contra el uso fraudulento del derecho están nuevamente presentes a lo largo de la propuesta del Convenio, pero de forma ostensiblemente inferior que en la anterior Resolución. En este sentido, se contemplaba tan sólo la posibilidad de que el Estado miembro deniegue o retire la autorización de residencia con fines de reagrupación familiar cuando "se demuestre" -importante elemento de seguridad jurídica para los titulares del derecho, ya que no se parte del principio general de presunción de fraude- la existencia de fraude, falsificación o que el matrimonio o la adopción se realizaron con la exclusiva finalidad de obtener la admisión en el Estado miembro.

En definitiva, pese a contener una definición muy tradicional de la familia objeto de reagrupación $^{318}$, estamos ante una Propuesta que en algunos aspectos es bastante progresista, especialmente si se compara con la previa Resolución de 1993. En este sentido, contempla y equipara la situación de los familiares extracomunitarios de ciudadanos comunitarios que no hayan ejercido su derecho a la libre circulación, amplía el concepto de familiares reagrupables ${ }^{319}$ mejorando la definición de los hijos objeto de reagrupación y dejando incluso abierta la posibilidad de reunir a ascendientes y descendientes a cargo del reagrupante. Frente a la vaguedad de la Resolución, esta norma define con mayor precisión cuestiones básicas para el ejercicio del derecho a la reagrupación familiar. En este sentido, la reunificación familiar queda sujeta al cumplimiento del requisito temporal de un año de residencia legal en el Estado miembro — dos para el caso de estudiantes de enseñanza superior-, plazo más que razonable, especialmente si tenemos en cuenta las salvedades temporales establecidas en la actual Directiva comunitaria (que tendremos ocasión de examinar posteriormente)—; prevé el acceso al mercado laboral de los familiares reagrupados siempre que hayan transcurrido seis meses desde su llegada autorizada al Estado miembro. Existen asimismo mejoras en materia de seguridad jurídica en las disposiciones que contienen prevenciones contra el fraude a las normas de extranjería.

318 En su momento el Parlamento Europeo propuso una enmienda al artículo relativo a las categorías de personas que pueden reagruparse, a fin de que incluyese, junto a los matrimonios, a las parejas de hecho y a los hijos comunes o no del conviviente. Enmienda no 27 al artículo 26, apartado 1. Finalmente la disposición solo contempló al cónyuge del residente y a los hijos, tanto comunes o de uno solo de los cónyuges.

319 La ampliación del círculo de familiares reagrupables no pareció contentar suficientemente a algunos. En este sentido, es calificada como “modesta” por Steve PEERS. "Raising Minimum..., op. cit., p. 162. 
Con carácter general, la Propuesta fue bien acogida en el ámbito doctrinal. Se valoraba positivamente la introducción de un corpus garantista de derechos para los extranjeros extracomunitarios residentes en los EEMM, especialmente para los de larga duración, pues con ello se venían a eliminar algunas de las más flagrantes discriminaciones que venían aquejando el status de los extracomunitarios. Así mismo, la remoción parcial de la discriminación inversa que padecían los nacionales comunitarios que no hubiesen ejercido su derecho a la libre circulación y continuasen residiendo en el mismo Estado de su nacionalidad, fue altamente valorada. Estas innovaciones eran especialmente bienvenidas tras un período de continuas restricciones en el status de los nacionales de terceros países — que la Resolución de armonización de 1993 venía a ejemplificar en el ámbito de la RF. Además, la labor de clarificación y sistematización del corpus normativo atinente a los extranjeros extracomunitarios, venía a simplificar el panorama normativo disperso constituido por las cinco resoluciones en vigor. Esta labor de sistematización fue especialmente relevante en materia de reunificación familiar.

Sin embargo, junto a estas luces se señalaron también las sombras que cobijaba el texto de la Propuesta: el riesgo todavía presente de que, con determinadas provisiones, los EEMM estuviesen tentados a reducir el nivel de protección interna conferido a los extranjeros de terceros países - por ejemplo el implícito a las normas sobre RF que exigían un año como mínimo de residencia legal antes de poder proceder al ejercicio del derecho sin correlativamente imponer un plazo máximo ${ }^{320}$-, o las disposiciones relativas a la adquisición de un status autónomo por parte de los familiares ya reunidos en el EM, calificadas como "una gran decepción" ${ }^{321}$. Nuevamente la Propuesta de Convención adolecía de una cláusula de stand still que permitiese conjurar el temido riesgo a una carrera a la baja en los EEM, carencia que venía siendo denunciada desde la aprobación de la Resolución y que continuaba sin ser enmendada.

Pese a las expectativas levantadas, la Propuesta de Convenio de la Comisión nunca llegó a entrar en vigor ${ }^{322}$. Con todo, su utilidad residía en que vendría a servir "como base para la discusión a fin de preparar la acción legislativa de la comunidad bajo el artículo 63 EC una vez que el Tratado de Ámsterdam entre en vigor" 323 , al tiempo que reflejaba la actitud hacia la inmigración y la integración de los extranjeros de terceros países ${ }^{324}$ a finales de los noventa del pasado siglo. Más allá de su regulación específica en materia de RF, en sentido claramente más progresista que la Resolución de 1993, parecía desprenderse la intención de los EEMM de incorporar la normativa ya existente en

320 PEERS, Steve. “Raising Minimum Standards..., op.cit. p. 162.

321 Idem, p. 163.

322 A ello contribuyó quizá de forma significativa, junto a los motivos ya apuntados al inicio de este epígrafe, el hecho de que mientras la Comisión formulaba formalmente esta propuesta, se había producido ya la aprobación del Tratado de Amsterdam que comunitarizaba esta materia. Ante la parálisis de la Propuesta de Convenio sobre Migración, la Comisión había anunciado su intención de convertirlo en una directiva comunitaria en cuanto dicho Tratado entrase en vigor. Así se desprende de las observaciones generales formuladas por el Parlamento Europeo en el Dictamen que contiene su opinion consultiva sobre el texto de la Propuesta de Convenio. En él puede leerse que "la Comisión concibe la propuesta de convenio como un instrumento previo a la armonización de legislaciones en materia de admisión de inmigrantes que permitirá, vía Directiva, el Tratado de Amsterdam cuando entre en vigor. Mientras tanto, se impone un enfoque global en materia de inmigración para adoptar en el futuro una estrategia común”, p. 28 del Dictamen. Esta perspectiva pudo paralizar el ya de por sí escaso interés de los EEMM.

323 HAILBRONNER, K. “European Immigration and Asylum Law under the Amsterdam Treaty...”, op. cit., p. 1050. En un sentido similar se manifiesta Rosa Ma Moliner Navarro, al afirmar que la Propuesta de Convenio estableció "el marco de reflexión con carácter previo a la adopción de instrumentos jurídicos en materia de inmigración”. MOLINER NAVARRO, Rosa Ma. “El concepto de familia nuclear...”; op. cit., p. 1792.

324 PEERS, Steve. “Raising Minimum Standards or Raising from the Bottom...” op. cit., p. 152. 
este ámbito - la resolución precedente- como un estándar mínimo ${ }^{325}$ sobre el cual ir avanzando y, con ello, mejorando progresivamente la situación de los ciudadanos procedentes de terceros países en la UE. Con ello los EEMM parecían querer embarcarse en lo que podría concebirse como un lenta, pero sin retorno, dinámica ascendente virtuosa —o, si se nos permite la expresión, de "carrera al alza": "race to the top"-.

\subsection{Resolución sobre medidas en materia de lucha contra los matrimonios fraudulentos ${ }^{326}$}

Como es bien sabido, el recurso a la migración familiar es una de las causas que explica la intensificación de los flujos migratorios con destino a la Unión Europea, pese a las restricciones que las políticas internas de extranjería de los EEMM introdujeron a partir de $1973^{327}$. Desde la década de los noventa del pasado siglo la inmigración familiar se ha consolidado como el principal canal de entrada legal en la UE y, de entre todos los subtipos que engloba, la migración de carácter matrimonial revela un potencial mayor de engrosamiento en las admisiones de extranjeros, tanto cuantitativa como temporalmente, así como una superior capacidad de fraude. Si además se tiene en cuenta que, con independencia del régimen jurídico aplicable, la reunificación familiar - entendida en sentido amplio- exonera de las trabas generales a que ha de enfrentarse la inmigración económica bajo el régimen general, podrá comprenderse la entidad del fenómeno y la preocupación estatal ante los intentos crecientes de burlar las trabas migratorias mediante el recurso a matrimonios ficticios. El problema se intensifica con la aparición de redes altamente organizadas que, con fines lucrativos, se dedican a promover la celebración de este tipo de matrimonios.

En las sociedades receptoras de inmigración el número de matrimonios mixtos y de matrimonios constituidos íntegramente por extranjeros está en constante crecimiento, hasta el punto de ser definido como "un fenómeno en auge" ${ }^{328}$. Las tasas de inmigración que reciben los países de la UE y la dureza de sus legislaciones de extranjería, unido al crecimiento exponencial de los matrimonios en los que al menos uno de los contrayentes es extranjero, abonan el terreno para un incremento simultáneo en el número de matrimonios simulados. Especialmente rentables resultan aquellos matrimonios concertados con ciudadanos comunitarios porque, en este caso, junto al permiso de entrada y residencia se obtiene el permiso de trabajo y ventajas añadidas, como el acceso a vías privilegiadas de adquisición de la nacionalidad ${ }^{329}$ del EM que ostenta el contrayente comunitario y en

325 PEERS, Steve. “Towards equality...”, op. cit.,p. 49.

326 Resolución del Consejo 97/C 382/01, de 4 de diciembre de 1997, sobre medidas que deberán adoptarse en materia de lucha contra los matrimonios fraudulentos (DOCE C n 382, de 16 de diciembre de 1997; 397Y1216(01)). Una versión reducida de esta resolución está disponible en la página web de la UE http://europa.eu/scadplus/leg/en/lvb/ 133063.htm. El texto también puede consultarse en VAN KRIEKEN, Peter J. (ed.). The Migration Acquis Handbook. The Foundation for a Common European Migration Policy. The Hague, TMC Asser Press, 2001, pp. $219-220$.

327 Sobre este punto, Näir señala que una de las principales consecuencias del "nefasto papel de la política de cierre de fronteras implantada desde mediados de los año setenta del siglo XX (...) ha sido precisamente favorecer las inmigraciones definitivas. Al cerrar abruptamente las fronteras, al bloquear la lógica de ir y volver, se obligaba al inmigrante a llevar consigo a su familia al país de acogida y se favorecía la inmigración definitiva”. NAÏR, Sami. $Y$ vendrán... las migraciones en tiempos hostiles. Barcelona, Planeta, 2006, p. 199.

328 El País, Domingo 10 de agosto de 2003, sobre datos proporcionados por el experto en migraciones Joaquín Arango, director del Centro de Estudios sobre Ciudadanía y Migraciones del Instituto Universitario de Investigación Ortega y Gasset.

329 En esta línea, García Rodríguez apunta la revalorización que ha cobrado el matrimonio con un nacional "como consecuencia de las contraprestaciones que pueden obtenerse (visado, permiso de residencia y, con el tiempo, 
el que ambos esposos residen. No en vano se ha afirmado que, al preverse un régimen más favorable para aquellos extranjeros que han contraído matrimonio con un nacional del Estado de acogida, la propia institución matrimonial queda afectada por dichas normas, "convirtiéndose en objeto de deseo aunque no en sí mismo considerada, sino por lo que a través suyo se puede conseguir"330. De ahí que tanto los EEMM como la UE hayan incrementado la vigilancia sobre este tipo de matrimonios fraudulentos, aún conscientes de las dificultades de prueba que entrañan y las colisiones que implican con derechos fundamentales tan esenciales como la intimidad personal y familiar.

En este contexto, sobre la base del párrafo tercero del artículo K.1 del TUE, y en un ámbito puramente intergubernamental, la Resolución sobre matrimonios de conveniencia fue adoptada en diciembre de 1997 por los representantes de los EEMM. Como explicita su breve preámbulo, su elaboración tuvo muy en cuenta la Resolución sobre armonización de las políticas nacionales relativas a la reunificación familiar acordada cuatro años antes - con la que comparte su escasa eficacia jurídica ${ }^{331}$ y el establecimiento de una fecha tope para que las legislaciones internas se adapten a sus disposiciones ${ }^{332}$-, si bien el alto grado de imprecisión que caracterizó a la primera no se encuentra presente en la resolución de 1997. Su importancia no es puramente anecdótica pues, para el caso específico de España, esta resolución continúa siendo una norma abundantemente citada por la Dirección General de Registros y Notariados.

La necesidad de abordar y combatir conjuntamente el fenómeno de fraude a la ley parte de la constatación de que los "matrimonios de conveniencia constituyen una forma de evadir las normas relativas a la entrada y residencia de los nacionales procedentes de terceros países". Las ventajas para el extranjero que accede a la residencia por vía matrimonial no sólo se cifran en las mayores facilidades para la obtención de un permiso de residencia, sino también en el hecho de que el propio extranjero reagrupado podrá acceder posteriormente a la reagrupación de sus familiares más próximos y disfrutar además de una protección superior frente a las expulsiones. Sin embargo, se aclara, el objetivo de esta resolución no es la introducción de controles sistemáticos sobre todos los matrimonios que se contraigan con nacionales extracomunitarios, ya que los controles sólo se efectuarán cuando haya "sospechas bien fundadas" de matrimonios en blanco ${ }^{333}$.

nacionalidad); de ahí que entre las dos opciones existentes para entrar en España, matrimonio con un extranjero residente legal y matrimonio con un español, ésta última es la vía más utilizada"; en GARCÍA RODRIGUEZ, Isabel. Matrimonio e Inmigración. El control del consentimiento matrimonial en la reagrupación familiar. Madrid, Colex, 2008, pp. 21-22. Una explicación del fundamento que subyace a este mecanismo de acceso privilegiado a la nacionalidad puede encontrarse, para el caso español, en CARRASCOSA GONZÁLEZ, Javier. "Matrimonios de conveniencia y nacionalidad española"; Anales de Derecho, Universidad de Murcia, No 20, 2002, pp. 7-34, fundamentalmente en las pp. 8-11.

330 GARCÍA RODRIGUEZ, Isabel. Matrimonio e Inmigración. El control del consentimiento matrimonial en la reagrupación familiar, op. cit, p. 65.

331 La Resolución de matrimonios de conveniencia afirma al respecto en su preámbulo "whereas this resolution is without prejudice to Community law".

332 Al respecto la redacción de la Resolución sobre matrimonios de conveniencia se presenta de una forma más modesta, estableciendo en su apartado final que los EEMM deben esforzarse en acomodar sus legislaciones nacionales a esta resolución. El apartado $6^{\circ}$ dispone literalmente: "Member States shall have regard to this resolution in any proposals to amend their nacional legislation. They shall furthermore endeavour to bring their nacional legislation into line Whit this resolution by 1 January 1999. The Council whall review the implementation of this resolution once a year, starting from 1 January 1999", (énfasis añadido).

333 La terminología para referirse a los matrimonios de conveniencia es extraordinariamente rica: desde el afrancesado "matrimonios blancos" a matrimonios simulados, matrimonios de complacencia, ficticios, fraudulentos o "compraventas de matrimonios". Este último término hace específica referencia a la situación en la que el cónyuge comunitario o residente en un EM acepta casarse con un nacional de un tercer país pactando previamente recibir una determinada 
La regulación de los matrimonios de conveniencia ${ }^{334}$ viene precedida por el recordatorio de los derechos a casarse y fundar una familia, reconocidos respectivamente en los artículos 12 del CEDH y 16 DUDH, así como por el derecho al respeto de la vida familiar consagrado en el artículo 8 del CEDH. La resolución deja a salvo la posibilidad de los EEMM de controlar, con carácter previo a la celebración de un matrimonio, si éste es de carácter fraudulento.

El cuerpo sustantivo de esta norma está integrado por seis disposiciones. La primera de ellas define los matrimonios de conveniencia para los propósitos de la resolución. Por matrimonios de conveniencia ha de entenderse aquellos concluidos entre un ciudadano comunitario o un nacional de un tercer país que reside legalmente en un EM y un nacional procedente de un tercer Estado, con el único propósito de evadir las normas que rigen la entrada y residencia de nacionales procedentes de terceros países ${ }^{335}$ y obtener para el nacional no comunitario un permiso de residencia o una autorización para residir en un EM.

Si bien no se trata de una resolución que contemple la RF como objeto principal de su regulación, sin embargo su contenido guarda una estrecha relación con la materia objeto de nuestro estudio. Al contraer matrimonio con un residente legal en un EM o con un ciudadano comunitario - supuesto de hecho previsto en la resolución de 1997-, el cónyuge extranjero pasa a formar parte de la familia nuclear del reagrupante, encajando por ello en la categoría de familiar reagrupable.

El régimen aplicable al cónyuge extranjero dependerá a su vez de la nacionalidad que ostente el reagrupante. La determinación del régimen de reunificación familiar se realizaría, obviamente, teniendo en cuenta la normativa comunitaria vigente en la época en que se aprobó la resolución sobre matrimonios de conveniencia. A tenor de la misma, si el reagrupante era nacional de algún EM el régimen aplicable para poder reunirse con su cónyuge extranjero dependía por completo de la legislación interna de cada EM. El panorama cambiaba si el reagrupante comunitario estuviese instalado en otro EM, en cuyo caso su esposo/a se beneficiaría del régimen de reagrupación más favorable previsto para la libre circulación de trabajadores. En el supuesto de que el contrayente reagrupante fuese un extranjero procedente de un tercer país que gozase de residencia legal en algún EM, a su esposo/a le sería de aplicación la resolución armonizadora de 1997. Sin embargo dada la escasa eficacia jurídica y la alta discrecionalidad que ofrecía a los EEMM este instrumento comunitario, el concreto régimen de reunificación familiar aplicable a los supuestos de matrimonios íntegramente constituidos por extranjeros de terceros países dependía casi enteramente de las legislaciones internas de extranjería previstas por los distintos EEMM.

cantidad de dinero, solicitando posteriormente la separación o el divorcio, tras el transcurso del tiempo marcado por la legislación interna del EM para poder acceder a la ventaja que persiga el contrayente extranjero.

334 En torno a los matrimonios de conveniencia, vid, entre otros, DIAGO DIAGO, María del Pilar. "Matrimonios por conveniencia”; en Actualidad Civil, n 2, 1996, pp. 329-347. GRIEDER MACHADO, Hilda y AGUILAR BENÍTEZ DE LUGO, Mariano. "El matrimonio de conveniencia"; en Boletín de información del Ministerio de Justicia, No 1879, 2000, pp. 3213-3234. AZNAR GIL, Federico. "Matrimonio de conveniencia y fenómeno migratorio: anotaciones canónicas"; Iuri Canonico quo sit Christi ecclesia felix : estudios canónicos en homenaje al prof. dr. d. Julio Manzanares Marijuán. Universidad Pontificia de Salamanca, Servicio de Publicaciones, 2002, pp. 389-418. GRUYON-RENARD, "El fraude en materia de estado civil en los Estados miembros de la CIEC"; en Boletín de Información del Ministerio de Justicia, $\mathrm{n}^{\circ}$ 1803-1804, pp. 1779-1813; HONDIUS, F.W. “Civil Status Fraud”, en G.D. Korella \& Twomwy (Eds.). Towards a European Inmigration Policy, College of Europe, 1993, pp. 79-84. Report on the Situation of Fundamental Rights in the European Union and its Member States in 2002. EU Network of Independent Experts of Fundamental Rigthts (CFR-CDF). March 2003, pp. 107-108. Disponible en: http://ec.europa.eu/justice_home/cfr_cdf/doc/rapport_2002_en.pdf

$335 \mathrm{Al}$ mencionar con carácter exclusivo la finalidad de evadir las normas relativas a la entrada y residencia de nacionales de terceros países, la Resolución está considerando únicamente como fraudulentos aquellos matrimonios celebrados defraudando la legislación de extranjería, excluyendo a los matrimonios contraídos en fraude a la legislación de nacionalidad. CARRASCOSA GONZÁLEZ, J. “Matrimonios de conveniencia y nacionalidad española”, op. cit., p. 18. 
La situación de los nacionales extracomunitarios cambiaría sustancialmente a raíz de la entrada en vigor del Tratado de Ámsterdam y la adopción en el año 2003 de la Directiva sobre reunificación familiar que examinaremos a continuación.

El artículo 2 de la resolución sobre matrimonios de conveniencia especifica aquellos factores que pueden suministrar motivos para creer que un matrimonio es de conveniencia. El hecho de que la cohabitación matrimonial no se mantenga; la falta de una contribución apropiada a las responsabilidades derivadas del matrimonio; el hecho de que los esposos nunca se hayan conocido antes de su boda; la inconsistencia de los esposos respecto a sus respectivos detalles personales (nombre, dirección, nacionalidad y trabajo), sobre las circunstancias de su primer encuentro o sobre otra información personal importante que les concierna; el hecho de que los esposos no hablen una lengua entendida por ambos; si para contraer matrimonio se entregó una suma de dinero, con la excepción del dinero entregado en forma de dote en el caso de nacionales procedentes de países donde pagar una dote constituya una práctica común; si el historial pasado de uno o de ambos contrayentes contiene evidencias de previos matrimonios de conveniencia o de residencias anómalas. Se trata de factores presuntivos de carácter no exhaustivo ${ }^{336}$, especificándose que la información relativa a los mismos puede resultar tanto de declaraciones emitidas por los esposos afectados o por terceras partes, de documentación escrita o de las indagaciones llevadas a cabo.

En el caso de que concurran factores que permitan presumir la existencia de un matrimonio fraudulento, la resolución prescribe que los EEMM deberán emitir un permiso de residencia o autorización de estancia al nacional del tercer país sólo después de que las autoridades internas competentes hayan verificado que el matrimonio no es de conveniencia y que las restantes condiciones relativas a la entrada y residencia se han cumplido. Tales controles pueden involucrar entrevistas mantenidas por separado a cada uno de los esposos.

El artículo cuarto contempla la sanción ${ }^{337}$ aplicable en caso de matrimonios de conveniencia, con una disposición redactada en tono contundente e imperativo. Si las autoridades nacionales competentes encontraran que el matrimonio celebrado es de conveniencia, el permiso de residencia o la autorización para residir concedida al nacional de un tercer país sobre la base del matrimonio será, como regla general, retirada, revocada o no renovada. La resolución garantiza que el extranjero procedente de un tercer Estado tendrá la oportunidad de oponerse a una decisión de denegación, retirada, revocación o no renovación del permiso de residencia, o bien de solicitar su revisión "ante un Tribunal o ante una autoridad administrativa competente" conforme a lo establecido al respecto por el derecho nacional.

\section{LA DIRECTIVA 2003/86/CE SOBRE EL DERECHO A LA REAGRUPACIÓN FAMILIAR: SU AZAROSO PROCESO DE GESTACIÓN}

Sobre la base de la nueva atribución competencial conferida por el Título IV del Tratado de Ámsterdam, el Consejo debía de adoptar numerosas medidas en los ámbitos del asilo y la inmigra-

336 CARRASCOSA GONZÁLEZ, J. “Matrimonios de conveniencia y nacionalidad española”, op. cit., p. 19.

337 Entre las sanciones, no se contemplan medidas como la nulidad del propio matrimonio de conveniencia, cuestión sobre la que la Resolución no se pronuncia, quedando en manos de los EEMM. CABRIA PALMÓN, Miriam. "Matrimonio de conveniencia"; en Noticias Jurídicas, mayo 2007, sp. Disponible en http://noticias.juridicas.com/ articulos/45-Derecho\%20Civil/200705-41412321412789896.html En el mismo sentido, CARRASCOSA GONZÁLEZ, J. "Matrimonios de conveniencia y nacionalidad española”, op. cit., p. 19. 
ción, dentro del plazo de cinco años a partir de la entrada en vigor de dicho tratado. El Tratado de Ámsterdam no prefijaba qué instrumentos concretos debían ser destinados para poner en marcha las nuevas medidas en las materias mencionadas, dejando esta decisión en manos del legislador comunitario, bajo la indicación de que las normas que se adoptaran estuviesen guiadas por el principio de proporcionalidad del artículo $5 \mathrm{TCE}^{338}$. Las medidas debían ser vinculantes dentro del marco del artículo $249 \mathrm{TCE}^{339}$, lo que excluía los dictámenes y recomendaciones, cerrando el círculo de alternativas en torno a los reglamentos y directivas comunitarias.

De otro lado, el Tratado de Ámsterdam otorgaba competencias en el ámbito migratorio, pero sin paralelamente definir con claridad un objetivo a cumplir por las medidas a adoptar en ese terre$\mathrm{no}^{340}$, lo que propiciaba que no estuviese determinado con cierta precisión el radio de decisión de los EEMM. Esta indefinición de objetivos en los que ejercitar las nuevas atribuciones competenciales migratorias, era más evidente si la situación se confrontaba con las competencias mucho más definidas relativas a la libre circulación de trabajadores ${ }^{341}$, a cuyo amparo había surgido el derecho a la RF de los ciudadanos comunitarios y de los miembros de sus familias, con independencia de cuál fuera la nacionalidad ostentada por éstos últimos.

En ausencia de un marco cerrado de posibilidades proveído por un objetivo comunitario claro y preciso, a modo de guía, planeaban intensamente las directrices políticas fijadas en Tampere. En octubre de 1999, poco después de la entrada en vigor del Tratado de Ámsterdam ${ }^{342}$, se convocó un Consejo extraordinario en la ciudad finlandesa de Tampere a fin de abordar de forma monotemática la puesta en marcha del nuevo objetivo comunitario de establecer un espacio de libertad, seguridad y justicia. En las conclusiones de la presidencia se subrayó la necesidad de aproximar las legislaciones nacionales sobre condiciones de admisión y residencia de los nacionales de terceros países ${ }^{343}$, adoptando para ello un enfoque global del fenómeno migratorio que además debía orientarse a garantizar un trato justo a los ciudadanos extracomunitarios que residiesen legalmente en el territorio de sus EEMM ${ }^{344}$. A tal fin, se pedía al Consejo que adoptase decisiones con rapidez, basándose para ello en propuestas formuladas por la Comisión ${ }^{345}$. En definitiva, el Consejo de Tampere vino a imprimir un sesgo muy diferenciado a las nuevas políticas migratorias que debían adoptarse para conformar el nuevo objetivo del espacio de libertad, seguridad y justicia.

338 FLETCHER, Maria. "EU Governance Tecniques in the Creation of a Common European Policy on Immigration and Asylum”, op. cit., p. 540.

339 El artículo 249 TCE establecía que "para el cumplimiento de su misión, el Parlamento Europeo y el Consejo conjuntamente, el Consejo y la Comisión adoptarán reglamentos y directivas, tomarán decisiones y dictámenes, y formularán recomendaciones y dictámenes, en las condiciones previstas en el presente Tratado".

340 La autora afirma literalmente al respecto que "as long as there is no clear Treaty objective which can inform the content of exercise of the competente, then it is nuclear to which extent nacional discretion must be excluded". GUILD, Elspeth. "Discretion, Competence and Migration in the European Union”, op. cit., p. 385

341 Idem, p. 84. Esta indefinición de objetivos concretos de las medidas a adoptar en el ámbito del asilo y la inmigración bajo el nuevo Título IV, lleva a GUILD a destacar "la distancia entre objetivos y competencias relativas a la inmigración en el Tratado de Amsterdam"

342 El Tratado de Ámsterdam entró en vigor el 1 de mayo de 1999.

343 Apartado 20 de las Conclusiones de la Presidencia del Consejo de Tampere.

344 Idem, Apartado 18.

345 Idem, Apartado 20. La rapidez en la toma de decisiones dentro del ámbito migratorio venía impuesta por el propio tratado de Amsterdam, cuyo nuevo título IV fijaba un período de plazo de cinco años, - a contar desde la entrada en vigor del Tratado-, para la adopción de las primeras medidas. El plazo de cinco años concedido finalizaba el 1 de mayo de 2004 lo que, unido a la propia complejidad intrínseca de la materia, explica la premura con que el Consejo Europeo de Tampere pretendía que el Consejo afrontase la construcción del espacio europeo de Libertad, seguridad y justicia en materia migratoria, sobre la base de propuestas formuladas por la Comisión. 
De modo que el punto de partida de la seminal Directiva sobre reunificación familiar - que venía a inaugurar el paquete de las medidas a adoptar bajo el nuevo Título IV CE- era la libertad ${ }^{346}$ de los Estados tanto para optar en torno al específico instrumento legislativo ${ }^{347}$ para regular esta fundamental vía de inmigración legal, así como para el concreto contenido normativo que había de otorgarse al derecho a la reagrupación familiar que se regularía en dicho instrumento, siguiendo para ello las directrices políticas fijadas en el Consejo de Tampere.

Haciéndose eco de lo establecido en Tampere, y sobre la base de la nueva atribución competencial contenida en el artículo 63.3 letra a) del Tratado de Ámsterdam, apenas un mes y medio después de esta Cumbre, la Comisión presentó al Consejo una Propuesta de Directiva sobre el derecho a la reagrupación familiar, el 1 de diciembre de $1999^{348}$. La Comisión parecía haber aprendido bien las lecciones de Tampere, a juzgar por lo que proclamó abiertamente en la exposición de motivos de esta propuesta original de Directiva. En ella insistía en la necesidad de apartarse del paradigma de la inmigración cero que había planeado por la UE a lo largo de las décadas previas de colaboración intergubernamental en materia migratoria. Dicho paradigma era ahora considerado inviable y poco realista, en coherencia con los principios de trato justo, integración más decidida y derechos comparables para los nacionales de terceros países, que habían sido establecidos en la Cumbre de Tampere.

Por otro lado, la opción de la Comisión por un instrumento comunitario como la Directiva, excluyendo la alternativa más precisa y detallada del reglamento, sin apenas margen para los EEMM, ponía de manifiesto la cautela ${ }^{349}$ de la actuación de esta institución y su respeto al principio de proporcionalidad $^{350}$. La Directiva constituye una norma jurídica vinculante para los EEMM respecto a

346 Quizá la explicación de esta libertad se encuentre en el hecho de que la Directiva sobre RF se empezó a gestar al inicio mismo del período de los cinco años establecido por el Tratado de Ámsterdam. Paradójicamente, la reunificación familiar había sido una materia exenta del plazo de cinco años otorgado al Consejo para dictar normas a fin de establecer el espacio de libertad, seguridad y justicia, sin embargo fue la primera medida legislativa adoptada. Ello da una idea de la importancia crucial de la RF como factor clave para la instauración y el éxito de una auténtica política migratoria comunitaria. La prioridad con que se acometió la directiva sobre RF constituye asímismo un reconocimiento implícito de las dificultades que debía afrontar, derivadas principalmente de las exigencias intergubernamentales que impregnaban dicho período, fundamentalmente el requisito de su adopción mediante la unanimidad de todos los EEMM representados en el Consejo.

347 Si bien es cierto que el punto de partida era la no imposición de un específico instrumento normativo comunitario por parte del Tratado de Amsterdam, sin embargo las propias características de las normas comunitarias en opción Directiva y Reglamento - matizaban extraordinariamente esta libertad inicial. La propia finalidad de la regulación que se pretendía acometer - armonización de las políticas y normas relativas a la RF en los EEMM, no su sustitución-, cerraba el círculo de opciones en favor de una Directiva, en tanto que instrumento comunitario que "sin sustituir al poder legislativo nacional, permita la armonización de las legislaciones nacionales”. MANGAS MARTÍN, Araceli y LIÑÁN NOGUERAS, Diego. Instituciones y Derecho de la Unión Europea, Madrid, Tecnos, quinta edición, 2008. p. 365.

348 COM (1999) 638 final- 1999/0258 (CNS).

349 En el mismo sentido, CANEDO ARRILLAGA, María Pilar. "La Propuesta de la Directiva Comunitaria sobre Reagrupación Familiar: Algunos comentarios desde el Derecho Internacional Privado”; en CALVO CARAVACA, A. L. y IRIARTE ÁNGEL, J. L. Mundialización y Familia. Editorial Colex, 2001, pp. 127-128. VELÁZQUEZ SÁNCHEZ, Ma del Mar. “¿La regulación del derecho a la reagrupación familiar o defensa de una política restrictiva de la inmigración?. Comentario a la Sentencia del Tribunal de Justicia de las Comunidades Europeas de 27 de junio de 2006, C-540/2003; en Revista General de Derecho Europeo. № 12, enero de 2007, p. 4. Esta última autora justifica esta opción en virtud del principio de proporcionalidad, por la flexibilidad en la consecución de los objetivos fijados que permite una norma como la directiva. Considera que la elección de una directiva constituye una "medida equilibrada", pero se lamenta de la excesiva duración del proceso de negociación de la directiva sobre reunificación familiar.

350 Sobre este aspecto, la propuesta original de Directiva 2003/86 aclaraba que la opción por un instrumento jurídico como la Directiva constituía aquella más respetuosa al principio de proporcionalidad, ya que "la forma de la acción comunitaria debe ser la más simple posible para que se pueda cumplir el objetivo de la propuesta y llevar a cabo eficazmente su ejecución. Con este espíritu, el instrumento jurídico elegido es la Directiva, que permite establecer unos principios marco, al tiempo que deja a los EEMM destinatarios de la misma la elección de la forma y los medios más convenientes 
los fines en ella establecidos, pero a la vez otorga a los Estados un grado de flexibilidad -léase margen de apreciación - en la elección de la forma y de los medios que estimen más adecuados a fin de lograr dichos resultados comunes, lo que podría atemperar de algún modo las más que previsibles reticencias estatales a fin de lograr el consenso requerido para su aprobación ${ }^{351}$. En torno al acierto en la elección del instrumento normativo, se pronunciaría posteriormente la Comisión de Asuntos Jurídicos y Mercado Interior del Parlamento, en la opinión emitida en torno a la propuesta original de Directiva. En dicho dictamen, este órgano recalcó que, en el ámbito de la reagrupación familiar, existía la necesidad de unificar las normas, "algo que se puede hacer de la mejor manera mediante la adopción de una Directiva (que deja determinado margen de maniobra a los EEMM)”.

Conforme al artículo 67 del Tratado de Ámsterdam, esta medida exigía para su adopción la decisión unánime del Consejo, previa consulta al Parlamento Europeo. El Comité Económico y Social emitió su dictamen el 25 de mayo de $2000^{352}$. En febrero de 2000 el Consejo consultó al Parlamento y en la sesión del 6 de septiembre del mismo año, el Parlamento Europeo aprobó su dictamen ${ }^{353}$ en torno a la propuesta de Directiva, una vez vistos el Informe de la Comisión de Libertades y Derechos de los Ciudadanos, Justicia y Asuntos Interiores y la opinión de la Comisión de Asuntos Jurídicos y Mercado Interior. En su dictamen, el Parlamento solicitó a la Comisión algunas modificaciones.

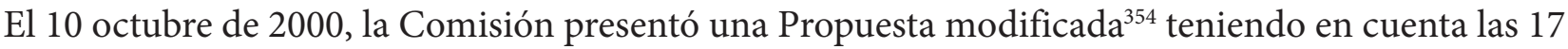
enmiendas formuladas por el Parlamento. La propuesta modificada de Directiva fue entonces enviada al Consejo de la Unión, donde encontraría fuertes resistencias. Las negociaciones en el seno del Consejo - mayo 2000, mayo 2001 y septiembre 2001 - revelaron las enormes dificultades políticas para la aprobación de esta norma ${ }^{355}$.

Ante el retraso y estancamiento con que la Directiva se había topado durante su laborioso proceso de negociación ${ }^{356}$, el Consejo Europeo de Laeken (Bélgica), desarrollado el 14 y 15 de diciembre 2001, invitó a la Comisión a presentar una nueva propuesta modificada, como muy tarde el 30 de abril de $2002^{357}$. Siguiendo esta proposición, la Comisión formuló una nueva propuesta el 2 de mayo de $2002^{358}$, que incluía numerosas disposiciones novedosas que suponían un cambio sustancial respecto del borrador inicial. El acuerdo político en el Consejo de Ministros sobre este nuevo texto se

para aplicar estos principios en su sistema jurídico y en su contexto nacional”. Apartado 9.4 de la Exposición de Motivos de la Propuesta de Directiva del Consejo sobre el derecho a la RF. Bruselas 1.12.1999, COM (1999) 638 final.

351 Y ello porque "mientras el reglamento es la más clara expresión del poder legislativo comunitario, podríamos decir que la directiva es la expression más neta de los límites de ese poder legislativo". MANGAS MARTÍN, Araceli y LIÑÁN NOGUERAS, Diego. Instituciones y Derecho de la Unión Europea, 2008, op. cit., p. 367.

352 CES 58872000, ponente Sr. Cassina, publicado en el DOCE C 204, de 18 de julio de 2000.

353 A5-0201/2000.

354 COM (2000) 624 final. DOCE C 62 E, 27.2.2001. Sobre esta segunda propuesta, vid. CHOLEWINSKI, R. "Family Reunion and Conditions Placed on Family Members: Dismantling a Fundamental Human Right"; en European Journal of Migration and Law, 2002, no 4, pp. 271-290.

355 Las previsiones iniciales estimaban que a finales de noviembre de 2000 sería adoptada la propuesta de directiva, en su segunda versión. Sin embargo, la realidad reveló un tortuoso proceso de negociación que se prolongó, contra todo pronóstico, por más de tres años.

356 De las enormes dificultades que encontraría la directiva durante su proceso de negociación, dando lugar a un considerable retraso en su adopción, da cuenta de forma muy expresiva la terminología empleada por Steve Peers — “with the Buck passed to the Commission by the Laeken European Council”- para denotar el punto de estancamiento al que había llegado su negociación al convocarse el Consejo Europeo de Laeken. PEERS, Steve. "Key Legislative Developments on MIgration in the European Union"; European Journal of Migration and Law, vol. 5, No 1, 2003, p. 127.

357 Conclusiones de la Presidencia, Consejo Europeo de Laeken, 14-15 de diciembre de 2001, números 38 a 41, especialmente el apartado 41.

358 COM (2002) 225. DOCE C 203 E. 2.5.2002. 
alcanzó el 27 febrero de 2003, siendo así la Directiva finalmente aprobada por el Consejo el 22 de septiembre de 2003, entrando en vigor el 3 de octubre de dicho año.

\subsection{La Propuesta inicial de Directiva}

Recogiendo el mandato de Tampere, la Comisión presentó una propuesta de Directiva sobre el derecho a la reagrupación familiar en diciembre de $1999^{359}$ —esto es, siete meses después de la entrada en vigor del Tratado de Ámsterdam y apenas mes y medio tras la celebración de la cumbre de Tampere-.

La Comisión se proponía acometer con diligencia la tarea de definir los principios rectores sobre los que fundar una política de inmigración ${ }^{360}$, empezando con las normas sobre RF, para proseguir de forma sucesiva con todos los aspectos relativos a la entrada y residencia de nacionales de terceros países - estudios, empleo asalariado e independiente, actividades no remuneradas, así como otorgar un estatuto a los residentes de larga duración y garantizar los derechos del artículo 63.4. Para ello pretendía adoptar un enfoque holístico y flexible, que tuviese en cuenta las múltiples dimensiones de los flujos migratorios tanto en los países de origen como de destino ${ }^{361}$. Afirmaba la Comisión que la política de inmigración cero - a la que aspiraba Europa tras el cierre de fronteras de mediados de los setenta- no ha sido "realista ni oportuna", alejándose explícitamente del espíritu restrictivo y coercitivo que impregnó la visión de la inmigración durante la etapa anterior - ya que determinadas vías de inmigración, como la representada por la RF "no podían ni debían interrumpirse", añadía este órgano-. Además necesidades económicas de mano de obra, causas demográficas como el envejecimiento de la población europea y el mantenimiento de relaciones privilegiadas con terceros países empujaban en esta nueva dirección de la política sobre inmigración; si bien ello no significaba retornar a las políticas migratorias abiertas de mediados del siglo pasado, porque las tasas de desempleo en Europa eran elevadas en ese momento.

Esta primera propuesta de Directiva presentada por la Comisión ${ }^{362}$ constituye, con mucho, la más intensamente fundamentada de todas y la más imbuida tanto por los compromisos internacionales que vinculan a los EEMM en la materia ${ }^{363}$, como por el objetivo pro-integrador y de trato justo concebido en Tampere. Con carácter general, destaca por su carácter liberal y espíritu humanitario,

359 COM (1999) 638 final, 1999/0258 (CNS), Bruselas, 1.12.1999.

360 Apartado 1.3 de la Exposición de Motivos de la propuesta original de directiva sobre reunificación familiar.

361 Idem, apartado 1.4.

362 COM (1999) 638 final, 1999/0258 (CNS). Sobre el texto de la propuesta inicial pueden consultarse, entre otros, BOELES, P. "Directive on Family Reunion: Are the Dilemmas Resolved?"; en European Journal on Migration and Law, 2001, no 3, pp. 61-71; BRINKMANN, G. "Family Reunion, Third Country Nationals and the Community's New Powers". GUILD, E y HARLOW, C. (eds.). Implementing Amsterdam: Immigration and Asylum Rights in EC Law. Oxford, Hart Publishing, 2001. CANEDO ARRILLAGA, María Pilar. "La Propuesta de la Directiva Comunitaria sobre Reagrupación Familiar: Algunos comentarios desde el Derecho Internacional Privado"; CALVO CARAVACA, A. L. y IRIARTE ÁNGEL, J. L. Mundialización y Familia. Editorial Colex, 2001, pp. 121-142. LÁZARO GONZÁLEZ, Isabel. "La reagrupación familiar de los extranjeros en España. Previsible incidencia de la futura directiva sobre el derecho a la reagrupación familiar"; en Migraciones, Universidad Pontificia de Comillas de Madrid, No 12, 2002, pp. 43-79.

363 En este aspecto, el Dictamen del Comité Económico y Social sobre esta propuesta, la acogió muy favorablemente, destacando que la misma "se inspira en un profundo respeto de los derechos humanos, la familia y los menores, como prescriben importantes actos y convenios internacionales" - apartado 2.1 del citado dictamen - y valorando que por fin la Comisión siguiese las peticiones formuladas por este órgano desde comienzos de los años noventa "relativas a la necesidad de definir un marco jurídico común para las condiciones de entrada y estancia de nacionales de terceros países y garantizar de manera clara y uniforme el derecho a la RF, entendido no sólo como un de- 
marcando lo que parecía ser un giro radical respecto a las directrices previas que guiaban la política migratoria comunitaria y que habían dado pie a la denominada Europa fortaleza ${ }^{364}$. De hecho, muchas de sus normas se inspiraban en los derechos disfrutados por las familias integradas por nacionales comunitarios en el ámbito del derecho a la libre circulación ${ }^{365}$. Incluso algunas disposiciones iban más allá, estableciendo una discriminación positiva a favor de los nacionales extracomunitarios, otorgándoles un trato más ventajoso que el comparable a los ciudadanos de la Unión a fin de compensar su mayor vulnerabilidad ${ }^{366}$. Constituye además, de las tres propuestas elaboradas, la más técnica y ambiciosa desde el punto de vista jurídico ${ }^{367}$. Sin embargo, justamente ello constituiría su talón de Aquiles: es patente en la propuesta original el establecimiento de un elevado estándar de protección que, en la medida en que situaba esta propuesta en sintonía con los derechos humanos, la distanciaba de la exigencia de unanimidad necesaria para su aprobación.

recho, sino también como un instrumento social, humano y cultural que favorece la integración de los nacionales de terceros países" (apartado 2.3 del Dictamen). 2000/C 240/09. DOCE de 18.7.2000.

364 El cambio de enfoque en el planteamiento global respecto a la política migratoria en la UE resulta patente en el considerando 1.3 que figura en la Exposición de Motivos de esta propuesta inicial. Ahí se afirma: "La definición de los principios rectores sobre los que fundar una política común de inmigración constituye, en efecto, una tarea esencial a la que la Comisión se propone prestar atención. La Comisión considera que la política de 'inmigración cero', mencionada en el pasado en el debate europeo sobre la inmigración, nunca ha sido ni realista ni oportuna ni nunca, por otra parte, se ha aplicado íntegramente como tal, por diversas razones: no solo porque, a corto y medio plazo, no podían, ni debian, interrumpirse ciertos canales de inmigración, como, por ejemplo, los de la reagrupación familiar, sino también porque determinados sectores de actividad económica son deficitarios de mano de obra. Además, los Estados no desean prescindir de su apertura al mundo, en particular, a través del mantenimiento de relaciones privilegiadas con determinados terceros países. A más largo plazo, intervienen factores demográficos como el envejecimiento de la población y sus consecuencias en el ámbito de la protección social y la financiación de las jubilaciones", (énfasis añadido).

365 Como filosofía general que impregna el articulado de esta propuesta, queda explícitamente establecido en el apartado 7.2 de la exposición de motivos, dentro del epígrafe dedicado a establecer el "objetivo de la propuesta de la Comisión". Tras recordar el seguimiento de los principios de Tampere de trato justo y política de integración más firme a través del reconocimiento a los nacionales no comunitarios de derechos comparables a los otorgados a los ciudadanos de la UE, en dicho apartado se afirma que "con el fin de garantizar a estas personas un trato comparable al de los ciudadanos de la Unión Europea, la propuesta de Directiva se inspira en algunas disposiciones del Derecho comunitario en vigor sobre RF de los ciudadanos de la Unión que ejercen su derecho a la libre circulación".

366 Así sucede en materia de adquisición de un permiso autónomo de residencia por parte de los familiares reagrupables (artículo 13.1) o con respecto a los derechos de acceso al mercado de trabajo, - tanto en forma asalariada como autónoma-, que se reconocen a los integrantes de la familia nuclear que han sido admitidos en un EM por motivos de reagrupación, en el artículo 12, apartados b y c. BRINKMANN, Gisbert. "Family Reunion, Third Country Nationals...", op. cit., pp. 264 y 265. Se trata asimismo del instrumento donde figuran más referencias, tanto explícitas como no, a la jurisprudencia del TEDH en aplicación del artículo $8 \mathrm{CEDH}$. Explícitamente en el artículo 15, al establecer la proporcionalidad entre el perjuicio a la vida de familia que ocasionen las medidas sancionatorias y los hechos reprochados, tendiendo en cuenta como criterios aplicables los "vínculos familiares, la duración de la residencia y la existencia de vínculos en el país de origen", que después se transplantarían en el artículo 17 de la Directiva, en su redacción final. Implícitamente en el considerando 2.2 de la exposición de motivos, que incorpora el concepto de "vida familiar normal" para explicar la importancia cualitativa de la RF como vía necesaria para el éxito de la integración de los inmigrantes, en los siguientes términos: "en efecto, la presencia de los familiares contribuye a una mayor estabilidad y a una mejor inserción de estas personas, al permitirles llevar una vida familiar normal".

367 A modo de ejemplo de su mayor perfección jurídica, puede citarse el artículo segundo, cuyo apartado e) especifica que el concepto de reagrupación comprende dos situaciones diferenciadas: de un lado, la reagrupación familiar en sentido estricto - reconstitución de la familia producida a raíz del hecho migratorio, cuando el reagrupante tuvo que dejar a los miembros de su familia para instalarse en un EM y desea que se unan a él-, como la formación de la familia - supuesto que incluye aquellos vínculos familiares producidos tras la instalación del reagrupante en el Estado receptor. 
Tras una década de intentos frustrados los EEMM se embarcaban con esta propuesta en un esfuerzo de aproximación de las normas sobre reagrupación familiar que, según rezaba su exposición de $\operatorname{motivos}^{368}$, perseguía dos objetivos: de un lado, garantizar la seguridad jurídica de los nacionales procedentes de terceros países que, de este modo, disfrutarían de condiciones de reagrupación familiar muy similares con independencia del EM en el que residiesen; de otro, pretendía reducir el riesgo del temido forum shopping, esto es, que la elección del EM se fundase en las condiciones más favorables que este país pudiera ofrecerle al extranjero, con las consecuencias añadidas de falta de solidaridad y distribución poco homogénea de las cifras migratorias.

La propuesta se concebía como la primera de un ambicioso conjunto de medidas en el ámbito de la inmigración legal, a fin de dar cumplimiento a las conclusiones del Consejo de Tampere y de “explotar todas las posibilidades que le ofrece el Título IV del TCE”369.

La propuesta original señalaba con claridad que su objetivo consistía en establecer un derecho a la reagrupación familiar ${ }^{370}$, cuya titularidad correspondía tanto a los nacionales de terceros países que residían legalmente en el Estado miembro - siempre que contasen con un permiso de residencia de un período de validez de, como mínimo, un año-, como a los ciudadanos de la Unión que no hubiesen ejercido su derecho a la libre circulación (art. 1). Su ámbito de aplicación era muy amplio, pues el concepto de reagrupante abarcaba, junto a las dos categorías citadas, a los refugiados, a los apátridas y a las personas beneficiarias de protección subsidiaria ${ }^{371}$. Asimismo, de lo dispuesto en esta disposición junto con la relativa a la regulación del procedimiento a seguir para el ejercicio del derecho a la reagrupación familiar ${ }^{372}$, se derivaba la titularidad activa de este derecho a favor del reagrupante con carácter exclusivo, conforme al concepto tradicional que en este ámbito se venía manejando desde los primeros intentos normativos acometidos a inicios de los noventa. La propia propuesta incluía una noción de reagrupante en coherencia con el monopolio de la titularidad activa, conforme a la cual se entendía por tal al "nacional de un tercer país que, residiendo legalmente en un EM o ciudadano de la Unión, solicita que los miembros de su familia se reúnan con él”373.

368 Considerando 7.4 de la Propuesta inicial de Directiva.

369 Apartado 1.5 de la Exposición de Motivos de la Propuesta. En palabras de la Comisión, su tarea se planteaba en los siguientes términos: "A medio plazo irá sucesivamente abordando todos los aspectos relativos a la entrada y residencia de los nacionales de terceros países, en particular, la entrada y residencia con fines de estudios, a los efectos de empleo asalariado e independiente y con el fin de realizar actividades no remuneradas. Asimismo, la Comisión se propone abordar la cuestión de la situación jurídica de los nacionales de terceros países titulares de un permiso de residencia de larga duración y garantizar igualmente la aplicación del apartado 4 del artículo 63, que se refiere a los derechos de los nacionales de terceros países que residan legalmente en un EM a residir en otro EM".

370 Así consta expresamente en el artículo 1 y en el primer párrafo del artículo 16, donde se afirma que "si bien la propuesta de directiva tiene por objeto crear un derecho a la reagrupación familiar...

371 Conforme a lo establecido en el apartado c) del artículo 2, el concepto de "persona beneficiaria de protección subsidiaria" abarca todos los casos en los que una persona que no puede beneficiarse de la protección de la Convención de Ginebra de 1951, recibe protección de un EM sobre la base de obligaciones humanitarias derivadas de la práctica o legislación nacionales de dicho Estado o de obligaciones internacionales(en particular, la prohibición de expulsar a una persona hacia un país donde corre el riesgo de ser condenada a la pena de muerte o a penas o tratos crueles, inhumanos o degradantes, derivada del artículo 3 del CEDH y de los artículos1 y 3 de la Convención de las Naciones Unidas contra la tortura y otros tratos o penas crueles, inhumanos o degradantes). Este concepto ampararía así supuestos de carácter humanitario, tales como guerras o otros acontecimientos que hayan provocado el exilio de la persona necesitada de protección internacional.

372 El artículo 7 de la propuesta establecía al respecto que "el reagrupante es quien presenta la solicitud de reagrupación de los miembros de su familia ya que, en efecto, es el titular del derecho".

373 Apartado d) del artículo segundo. 
De especial relevancia resultaba la inclusión, en su ámbito de aplicación, de los ciudadanos comunitarios que residiesen en el EM de su nacionalidad sin haber hecho uso de su derecho a la libre circulación. Con ello se procedía a garantizar la igualdad de trato a los nacionales comunitarios, clausurando así una situación ya casi crónica de discriminación inversa ${ }^{374}$ que venía siendo reiteradamente denunciada por la doctrina. Sin embargo, esta previsión no suponía la aplicación a dicho colectivo del régimen previsto en la propia propuesta. Para los familiares - cualquiera que fuese su estatuto jurídico ${ }^{375}$ - de ciudadanos de la Unión que no hubiesen ejercido su derecho a la libre circulación ${ }^{376}$, se preveía su sujeción a las disposiciones pertinentes del Derecho comunitario en materia de reagrupación familiar, como en su momento había dispuesto también la propuesta de convenio de 1997. Y si bien su previsión dentro de la propuesta fue unánimemente aplaudida, sin embargo no faltó quien destacase que la remisión a normas ya vigentes constituía un "uso desviado de la Directiva como instrumento jurídico"377, al no permitir a los EEMM la elección de los medios más adecuados para el logro de los fines previstos, como corresponde a este tipo de normas. En este sentido, se señaló que hubiese sido más correcto contemplar el régimen jurídico aplicable a estas personas a través de la adopción de un Reglamento comunitario ${ }^{378}$.

La propuesta contemplaba una definición amplia y de carácter netamente liberal de los familiares que podían optar a la reagrupación ${ }^{379}$ - hasta el momento la más extensa de las presentadas en esta materia. En dicha definición se incluía la familia nuclear, entendiendo por tal al cónyuge del reagrupante y los hijos menores no casados, tanto nacidos dentro como fuera del matrimonio, o fruto de matrimonios anteriores y, por supuesto, abarcando a los adoptivos. Para el caso de hijos adoptados se exigía que la adopción hubiese sido autorizada o en su defecto reconocida por la autoridad competente del EM. Sobre esta cuestión, la exposición de motivos que acompañaba al articulado de la propuesta, establecía una importante aclaración a fin de evitar malentendidos con instituciones consuetudinarias similares a la adopción, propias de algunos Estados emisores que, sin

374 La propuesta se hace eco de esta injusta situación en la exposición de motivos, donde respecto al artículo cuatro se afirmaba que:" La reagrupación familiar de los ciudadanos de la Unión que no ejercen su derecho a la libre circulación de personas hasta la fecha solo estaba regulada por las normas nacionales. Esta situación crea una diferencia de trato injustificada entre la familia de los ciudadanos de la Unión que no han ejercido su derecho a la libre circulación y han permanecido en el país de su nacionalidad y la de los que han ejercido su derecho a la libre circulación. En algunos casos, el Derecho nacional regula la reagrupación familiar de sus propios nacionales de manera más restrictiva que las normas del Derecho Comunitario. Al ser única la ciudadanía de la Unión, conviene colmar esta laguna jurídica. Por consiguiente, en virtud de este artículo, los miembros de la familia de los ciudadanos de la Unión quedan sujetos a las disposiciones pertinentes del Derecho comunitario en materia de reagrupación familiar". En el mismo sentido, BOELES, P. "Propuesta de Directiva sobre la reagrupación familiar y otras propuestas en el campo de la ley de la inmigración”, op.cit. p. 129.

375 Artículo 3.1.c).

376 Artículo 4 in fine. Ello suponía que a los miembros de la familia de ciudadanos de la Unión que no hubiesen ejercido su derecho a la libre circulación, les sería aplicable, fundamentalmente, el régimen previsto en los artículos 10-12 del Reglamento 1612/68, vigente en el momento de redacción de la propuesta inicial de directiva. Dicho reglamento preveía el tratamiento en materia de reagrupación familiar para los familiares de ciudadanos comunitarios que hubiesen ejercido su derecho a la libre circulación. En la actualidad el Reglamento 1612/68 ha sido derogado por la Directiva 2004/38/CE relativa al derecho de los ciudadanos de la Unión y de los miembros de sus familias a circular y residir libremente en el territorio de los Estados miembros.

377 CANEDO ARRILLAGA, María Pilar. "La propuesta de directiva comunitaria sobre reagrupación familiar: Algunos comentarios desde el derecho internacional privado”, op. cit., p. 129.

378 Idem.

379 Capítulo II, titulado "miembros de la familia" e integrado por los artículos 5 y 6 . Pese a ello, en términos comparativos, el tratamiento otorgado seguía situándose por debajo del establecido en el ámbito de la libre circulación de trabajadores comunitarios, conforme al cual se permitía la entrada de los hijos menores de 21 años así como de los hijos mayores y ascendientes que estuviesen a cargo del trabajador (artículo 10.1 del Reglamento 1612/68). 
embargo, son inexistentes en los EEMM ${ }^{380}$. La exposición de motivos clarificaba que "en consecuencia, la entrada de niños "confiados», según algunas costumbres, no es posible, salvo si la autoridad competente del EM reconoce que estas costumbres producen los mismos efectos que la adopción"381.

Pero, y aquí radica uno de sus rasgos más meritorios y por ello más conflictivos, esta primera propuesta reconocía a la pareja de hecho del reagrupante, incluyendo también la pareja del mismo sexo - y a los hijos menores de ésta, comunes o no- como familiar que podía optar a la reagrupación, en línea con la evolución social producida en la materia. Se exigía para ellos que la relación fuese duradera y con el importante matiz de que la inclusión de la pareja de hecho tendría lugar solamente en aquellos EEMM cuyo sistema jurídico asimilase la situación de las parejas de hecho a la de las casadas. En el concepto de familiares reagrupables se contemplaba también a los ascendientes ${ }^{382}$, cuando estas personas careciesen de apoyo familiar en su país de origen y estuviesen a cargo del reagrupante, y a los hijos mayores de edad, en el supuesto de que no pudiesen subvenir objetivamente a sus necesidades debido a su estado de salud ${ }^{383}$. En el caso de que el reagrupante fuese un estudiante, su derecho a la reagrupación familiar estaba limitado al cónyuge o pareja de hecho, los hijos menores de edad y a los hijos mayores dependientes.

Sin embargo, entre las ausencias, cabría destacar la exclusión de la categoría de futuro cónyuge dentro de los familiares reagrupables ${ }^{384}$. Esta omisión resulta especialmente llamativa si tenemos en cuenta que la propia exposición de motivos incluía la protección de la formación de la familia, dentro del concepto de reagrupación familiar. Dado que una de las formas más relevantes de formación de familias es precisamente a través del matrimonio, no incluir al prometido/a procedente de un ter-

380 Se trata, entre otras, de la costumbre de la "kafala", con repercusiones importantes en países miembros que, como España, reciben importantes cotas migratorias de Marruecos, donde esta institución goza de amplia implantación. La kafala es una institución de origen árabe que permite el acogimiento de menores por parte de familiares que, de este modo, se convierten en representantes legales del menor. En España se permite siempre que para su constitución en Marruecos haya intervenido un juez. Sobre esta institución pueden consultarse, entre otros, a RODRÍGUEZ BENOT, Andrés. "El reconocimiento de las medidas de protección del menor en un entorno multicultural: Un estudio comparado de la eficacia extraterritorial de la adopción y de la 'Kafala", en Revista general de derecho, No 667, 2000, pp. 4419-4448. ORLANDI, M. "La 'Kafala' islámica e la sua riconoscibilità quale adozione"; en $D i$ ritto di famiglia e delle persone, Vol. 34, No 2, 2005, pp. 635-665; LÓPEZ AZCONA, María Aurora. "La institución musulmana de la kafala y el Derecho de Extranjería: breve noticia de algunas resoluciones judiciales"; en Revista de derecho migratorio y extranjería, No. 11, 2006, pp. 223-227; ARCE JIMÉNEZ, Elena. "La kafala marroquí y la legislación de extranjería"; en Revista de derecho migratorio y extranjería, No. 13, 2006, pp. 265-278.

381 Comentario al artículo 5.1.b).

382 La inclusión de la reagrupación de los ascendientes seguía las directrices de trato justo establecidas en la Cumbre de Tampere. En palabras de la propia propuesta "esta disposición permite progresar en el sentido de unos derechos comparables entre nacionales de terceros países y ciudadanos de la Unión que ejercen su derecho a la libre circulación: en efecto, las normas de Derecho comunitario prevén la reagrupación familiar de los ascendientes a cargo del trabajador que emigra y de las personas inactivas" (artículo 5.1.d).

383 Artículo 5.1.e). Al respecto la exposición de motivos hablaba de "situaciones especialmente difíciles", explicando que "no sería oportuno prohibir la reagrupación familiar de un hijo que carece de medios de subsistencia independientes y necesita los cuidados y el apoyo material y emocional de su familia, por ejemplo, debido a una minusvalía grave" (párrafo e) del artículo 5).

384 BOELES, P. "Propuesta de Directiva sobre la reagrupación familiar y otras propuestas en el campo de la ley de la inmigración”, op.cit. p. 134. El Artículo 5, apartado a) de la propuesta inicial de directiva no contiene ninguna referencia a esta categoría de personas, de lo que se deduce su exclusión del concepto de familiares reagrupables. La única referencia explícita a esta exclusión se encuentra en el apartado e) del artículo 2, al establecer las definiciones generales de los términos incluidos en la propuesta de directiva, donde se afirma que "la propuesta de Directiva no regula la situación jurídica de las personas que desean entrar en el territorio de un EM con el fin de casarse con un nacional de un tercer país que ya reside en el mismo. Esta situación sigue perteneciendo al ámbito del Derecho nacional”. 
cer país que desea entrar al EM a fin de contraer matrimonio con el reagrupante, puede entorpecer el derecho a contraer matrimonio en supuestos de religiones muy conservadoras ${ }^{385} \mathrm{y}$ en cualquier caso, desemboca en cierto agravio comparativo, ya que los vínculos familiares preexistentes gozan de mayor protección que aquellos creados ex novo tras el asentamiento del reagrupante en el EM.

La propuesta contenía una regulación del procedimiento a seguir para la obtención de la reagrupación familiar. Dicho procedimiento se iniciaba mediante la presentación de la solicitud de reagrupación por parte del reagrupante quien, como vimos, era el único titular del derecho ${ }^{386}$. Este debía presentar la solicitud cuando sus familiares se encontrasen fuera del territorio del EM, pero se permitía flexibilizar esta norma en casos particulares o por consideraciones de carácter humanitario, en los que el miembro de la familia estuviese ya en el territorio del Estado receptor ${ }^{387}$. A fin de garantizar la seguridad jurídica, se establecía un plazo máximo de seis meses para la tramitación de la solicitud, exigiéndose que la respuesta negativa estuviese debidamente motivada para así facilitar su impugnación mediante los correspondientes recursos.

El proyecto de Directiva preveía la competencia discrecional de los EEMM para denegar la entrada y residencia cuando estuviesen en juego razones de orden público, seguridad interior y salud pública que debían fundamentarse, exclusivamente, en el comportamiento personal del familiar al que se aplicasen ${ }^{388}$. Se permitía asimismo a los EEMM condicionar ${ }^{389}$ el ejercicio del derecho a la reagrupación familiar a la prueba de que el reagrupante dispusiera de una vivienda considerada adecuada ${ }^{390}$, un seguro de enfermedad que cubriese todos los riesgos y a la existencia de recursos estables y suficientes ${ }^{391}$. Si el Estado decidía imponer dichas condiciones materiales facultativas en su legislación interna, éstas solamente podrían exigirse en el momento de presentación de la solicitud. Además dichas condiciones debían servir al objetivo exclusivo de asegurar que el reagrupante podría cubrir las necesidades de los miembros de su familia sin acudir a la financiación pública, y no podían implicar discriminación entre los nacionales comunitarios y los extracomunitarios ${ }^{392}$. El plazo de espera previo de residencia legal que podían fijar los EEMM a fin de garantizar la estabilidad de la residencia del reagrupante - redactado en términos potestativos, luego cabía que los EEMM ni siquiera impusiesen dicha exigencia- no podía ser superior a un año "para no vaciar de contenido el ejercicio de este derecho" ${ }^{393}$. Si el reagrupado necesitaba un visado para poder entrar

385 BOELES pone como ejemplo el caso de Ahmadiyya en Pakistán, donde está prohibida la cohabitación fuera del matrimonio y donde éste sólo puede celebrarse conforme a las leyes religiosas predominantes en el país. "Propuesta de Directiva sobre la reagrupación familiar y otras propuestas en el campo de la ley de la inmigración”, op.cit. p. 134.

386 La titularidad exclusiva del derecho a favor del reagrupante se afirma explícitamente en la exposición de motivos, al explicar el sentido del apartado primero del artículo 4 de la propuesta.

387 Artículo 7.

388 Artículo 8.

389 En la tarea de determinar el cumplimiento de los posibles condicionantes materiales que los EEMM podían exigir para el ejercicio del derecho a la reagrupación familiar, la propuesta exigía que los criterios de evaluación estuviesen estrictamente delimitados para no anular el derecho (art. 9.1) y, en el ámbito específico de los requisitos exigidos a la vivienda, se especificaba que los criterios establecidos al respecto no debían ser discriminatorios (apartado a del artículo 9).

390 Entendiendo por adecuada aquella vivienda considerada normal para una familia comparable que viviese en la mima región del EM en cuestión (artículo 9.1.a).

391 Por recursos estables y suficientes se debía interpretar aquellos que fuesen superiores o, como mínimo, iguales al salario mínimo garantizado por el Estado o, en su defecto, que no superasen el importe de la pensión mínima de jubilación pagada por el EM (artículo 9.1.c).

392 Artículo 9.2.

393 Comentario al artículo 10.1. Propuesta de Directiva del Consejo sobre el derecho a la RF. Bruselas 1.12.1999, COM (1999) 638 final. 
en el EM donde residía el reagrupante, la propuesta exigía al EM que facilitase su expedición en un plazo breve de tiempo, sin poder cobrar gastos por su emisión ${ }^{394}$.

Una vez autorizada su entrada en el territorio del EM, los familiares reagrupados disfrutarían de un permiso de residencia de validez idéntica a la del reagrupante. En el caso de que el permiso de residencia del reagrupante fuese permanente o de duración ilimitada, los EEMM podrían limitar la duración del primer permiso de residencia de los familiares reagrupados a un año.

La propuesta era especialmente generosa respecto a dos temas claves; de un lado, los derechos que corresponderían a los familiares reagrupados tras la autorización de su entrada y residencia en el $\mathrm{EM}^{395}$ - cuyo reconocimiento partía del principio de igualdad con respecto a los derechos disfrutados por los nacionales del EM donde residían los familiares ${ }^{396}-$, y, de otro, respecto a la adquisición por parte de dichas personas de un permiso autónomo de residencia, a fin de dotarles de una amplia seguridad jurídica ${ }^{397}$. En el primero de los aspectos citados, se reconocía el derecho a la educación de todos los familiares reagrupados. Además, el cónyuge e hijos menores tendrían acceso inmediato 398 a las actividades asalariadas o independientes y a la formación profesional, de las que se excluía a los hijos adultos y a los ascendientes debido su dependencia respecto del reagrupante ${ }^{399}$. El acceso al mercado de trabajo para los familiares reagrupados, en el pasado se había revelado como un elemen-

394 Artículo 11.1.

395 Artículo 12. BRINKMANN señala que el artículo 12 se diseñó con la idea de conceder a los miembros de la familia los mismos derechos que a los ciudadanos de la Unión, en las áreas mencionadas - educación y acceso al trabajo ( $\mathrm{P}$. 261). Además ha revelado que tales derechos eran incluso superiores que aquellos que disfrutaban los reagrupantes, conforme a la legislación comunitaria vigente en la época de redacción de esta primera propuesta. El autor enfatiza que esta diferencia se profundizaba en el caso de los estudiantes. Así, mientras que los estudiantes no están autorizados a desarrollar actividades lucrativas, los miembros de la familia que se reuniesen con él en el EM, podrían ostentar derechos laborales. BRINKMANN, G. “Family Reunion, Third Country Nationals and...”, op. cit., pp. 264-265. Además, tal y como estaba redactado el artículo 12, no contemplaba restricciones para el acceso al mercado laboral a los familiares admitidos. Por ello, el autor concluye que "this right cannot be construed as conferring on third country nationals a more favourable treatment than EU citizens enjoy. Article 39 (4) EC excludes from the right to free movement employment in the public service. In doing so, EC law takes account of the legitimate interest which Member States have in reserving for their own nationals a range of posts connected with the exercise of powers conferred by public law and with the protection of general interest". Idem, p. 261.

396 Artículo 12.1

397 Artículo 13.

398 Dado que la propuesta de directiva no establecía nada al respecto, se deduce que el acceso al mercado de trabajo para los familiares reagrupados podía producirse de forma inmediata, salvo para el caso de los hijos adultos y ascendientes, quienes quedaban excluidos. A la misma interpretación en torno al acceso inmediato al trabajo llega el Comité Económico y Social, en el dictamen emitido en torno a esta primera propuesta de directiva (apartado 1.8 in fine de dicho Dictamen). 2000/ C 204/09, DOCE, de 18 de julio de 2000.

399 El comentario a los apartados b y c del artículo 12 establecía que "'los miembros de la familia nuclear (cónyuge e hijos) tienen acceso a las actividades asalariadas o independientes y a la formación profesional. No se autoriza a los otros miembros de la familia, en particular, los hijos mayores de edad y los ascendientes dependientes, a ejercer actividad lucrativa alguna o a recibir una formación profesional ya que estas personas se benefician de la reagrupación sólo debido a su dependencia exclusiva del reagrupante". Esta exclusión fue criticada por el Comité Económico y Social. Para este órgano resultaba difícil de entender cómo, si a los ascendientes e hijos adultos el EM les podía conceder un permiso autónomo tras cuatro años de residencia en el EM — autonomía que implicaba la posibilidad de acceder al mercado de trabajo- por qué dichos derechos vinculados a la estancia autónoma no podían ser ejercidos directamente en el momento de la entrada en dicho Estado. (Apartado 3.3 in fine del Dictamen del Comité Económico y Social). Para posteriormente considerar, respecto a los hijos mayores que tuvieran enfermedades o fueran discapacitados, "deplorable que, para estas personas, la reagrupación se resumiera a una asistencia en la familia, sin ninguna posibilidad de vivir una vida humana y socialmente integrada” (apartado 3.3.1.b del Dictamen), y lo mismo respecto a "los ascendientes que viven en una situación de extrema pobreza y profunda miseria (a quienes no se permite trabajar”). Aapartado 3.3.1.c) del Dictamen del Comité Económico y Social. 
to de difícil aceptación por algunos EEMM que incluso había llegado a trabar el proceso de negociación, como ocurrió con la Resolución armonizadora de 1993. Ahora este derecho se proclamaba de forma muy amplia, aparentemente sin restricciones y sin establecer períodos de tiempo previos. Existía pues la posibilidad de que estas dificultades se reprodujesen nuevamente, especialmente ante la perspectiva de un instrumento jurídico vinculante, como lo es la Directiva que, además, permitía acceder automáticamente al mercado laboral. Ante la misma, hubo voces que recomendaban la introducción optativa de un período mínimo de residencia legal en el EM antes de conceder a los familiares derechos laborales ${ }^{400}$, especialmente porque en este específico aspecto existían fuertes divergencias entre las legislaciones de los EEMM.

En materia de acceso a un estatuto autónomo, la propuesta llegaba a estipular un tratamiento para los ciudadanos extracomunitarios más favorable que el previsto con respecto a los extranjeros de terceros países integrantes de la familia de ciudadanos comunitarios que ejerciesen su derecho a la libre circulación ${ }^{401}$. Los familiares reagrupables tendrían así acceso a un permiso de residencia autónomo, a más tardar, después de cuatro años de residencia, siempre que subsistiesen los vínculos familiares. Este período general de cuatro años podría adelantarse a un año en situaciones de muerte, separación o divorcio, y se concedería preceptivamente la residencia autónoma tras ese único año de residencia "cuando el solicitante se encontrase en una situación especialmente difícil"

Al final de su articulado, la propuesta contemplaba la posibilidad de sanciones ante el incumplimiento de las normas - fraude, falsificación de documentos, matrimonio o adopción fraudulentos. Las sanciones debían ser efectivas, proporcionales y disuasorias, estableciéndose la prohibición de controles sistemáticos, de modo que los controles para luchar contra los abusos de las normas sólo podrían efectuarse ante "presunciones fundadas de ilegalidad" 403 . Siguiendo la estela marcada por la Resolución de 1997 sobre medidas para combatir los matrimonios de conveniencia, la propuesta contemplaba la posibilidad de negar la expedición del permiso de residencia, o incluso su retirada o la denegación de su renovación, en caso de que hubiera pruebas de fraude y en supuestos de matrimonios o adopciones fraudulentos ${ }^{404}$. Asimismo se garantizaba el derecho de acceso a las "vías de recurso jurisdiccionales" ${ }^{405}$ para impugnar decisiones denegatorias de solicitudes de reagrupación familiar, de retirada o no renovación del permiso de residencia de los familiares ${ }^{406}$.

400 BRINKMANN, G. “Family Reunion, Third Country Nationals and...”, op. cit., p. 261. Con la importante precisión de que dicho período de espera no debía anular el derecho.

401 La justificación a esta discriminación positiva en favor de los extranjeros extracomunitarios reagrupados se encuentra en los comentarios al apartado primero in fine del artículo 13, donde se señala: "ello se explica por la particular situación de las personas a las que se dirige la disposición: se trata de nacionales de terceros países que, como tales, están más expuestos a un empeoramiento de su estatuto en caso de expulsión del reagrupante o en caso de ruptura de los vínculos familiares con el mismo".

402 Artículo 13. En el comentario que la exposición de motivos efectúa a esta disposición, puede leerse que estas situaciones especialmente difíciles ampararían supuestos de mujeres víctimas de violencia doméstica, así como viudas, divorciadas o repudiadas.

403 Artículo 14.2.

404 Brinkmann llegó a cuestionar la utilidad de esta posibilidad, contemplada en el artículo 14 de la propuesta. Argumentaba para ello que, conforme a la jurisprudencia consolidada del TJUE, "no rights can be claimed it abuse is involved". Conforme a dicha jurisprudencia, el matrimonio o la adopción de conveniencia constituyen un abuso del derecho a la reunificación familiar. BRINKMANN, G. "Family Reunion, Third Country Nationals and..., op. cit., p. 263.

405 Artículo 16.

406 Artículo 16. De esta disposición BOELES criticó la falta de referencia a un proceso justo y adecuado, y la conveniencia, - a fin de evitar daños irreparables-, de incluir que el recurso tuviese efectos suspensivos frente a la expulsión en los casos de denegación de la renovación, pues en dichos supuestos los miembros de la familia ya habían sido residentes legales en el EM en cuestión durante el período anterior a la impugnación de la medida estatal. 
Con carácter general, esta propuesta fue bien valorada por la doctrina. Fue calificada en su momento como una propuesta "loable" 407 y como "un medida detallada y equilibrada" 408 , en vista del nivel adecuado de tutela otorgado a sus titulares al "ofrecer una gama completa y equilibrada de normas destinadas a garantizar la protección de la vida familiar de los nacionales de terceros países" ${ }^{409}$. Y aunque se apreciaba el serio esfuerzo desplegado por la Comisión para llevar a cabo los objetivos de Tampere ${ }^{410}$, sin embargo, si el punto de vista se situaba en el otorgamiento a los nacionales extracomunitarios de derechos comparables a los disfrutados por los ciudadanos europeos, el estándar seguía situándose muy por debajo, confiriendo a sus titulares un estatuto mucho más débil ${ }^{411}$.

Dentro de un panorama general bastante plausible, la propuesta de Directiva contenía también disposiciones muy controvertidas. Entre ellas destacaba por su ambigüedad y por sus importantes implicaciones, la contenida en el artículo 3.4. Conforme a lo establecido en esta disposición, el estándar ofrecido por la propuesta se entendía "sin perjuicio de las disposiciones más favorables existentes al respecto en los acuerdos comunitarios o mixtos celebrados con terceros Estados y en la Carta Social Europea de 1961 y el Convenio Europeo relativo al estatuto jurídico del trabajador migrante de $1977^{\prime \prime} 412$. Sin embargo, esta cláusula no contenía referencia alguna a las disposiciones nacionales en vigor que fuesen más beneficiosas, o a otros tratados internacionales vinculantes para los EEMM. Esta omisión parecía anular tanto la posibilidad de regímenes internos más favorables, como de regímenes convencionales más beneficiosos establecidos por otros tratados distintos a los dos específicamente mencionados. Esta situación levantó duras críticas ${ }^{413}$ porque abría la puerta a reformas a la baja para aquellos países que contasen con regulaciones más generosas, así como por

"Propuesta de Directiva sobre la RF y otras propuestas...", op. cit., p. 136. En una posición radicalmente distinta se situaba BRINKMANN, para quien las garantías legales del artículo 16 iban más allá de los derechos concedidos a los ciudadanos de la Unión quienes, en ausencia de un derecho a recurrir a los tribunales, sólo cuentan con el derecho a la revisión del procedimiento (art. 9 de la directiva 64/221/EEC)"; en "Family Reunion, Third Country Nationals and..., op. cit., p. 263.

407 BOELES, Pieter. “Directive on Family Reunification: Are the Dilemas Resolved?”; en European Journal of Migration and Law, No 3, 2001, p. 71. Una version en castellano de este documento puede localizarse en BOELES, Pieter. "Propuesta de Directiva sobre la reagrupación familiar y otras propuestas en el campo de la ley de inmigración"; en Revista CIDOB d'Afers Internacionals, No 53, 2001, p.136.

408 BOELES, P. “Propuesta de Directiva sobre la RF...”, op. cit., p. 131.

409 FONSECA MORILLO, Francisco J. "Los derechos de los nacionales de terceros países en la Unión Europea. Situación jurídico-política tras la proclamación de la Carta de los Derechos Fundamentales de la Unión”; en Revista CIDOB de Afers Internacionals, No 53, 2001, p. 88. Este autor analizó la compatibilidad de esta primera propuesta con la Carta de Derechos Fundamentales de la UE, concluyendo que formaban "un conjunto coherente y homogéneo". Tanto esta propuesta, como la propuesta de Directiva relativa al estatuto de residentes de larga duración, "respetan y aclaran, en el contexto específico de las situaciones que pretenden regular, los derechos y libertades de la Carta". Idem, p. 93. Si bien Fonseca Morillo aclaraba a reglón seguido que dicha coherencia debería mantenerse a lo largo del futuro procedimiento legislativo. Ahí radicaría precisamente el problema, dado que el arduo procedimiento legislativo derivaría en una crónica corrosión del derecho a la reagrupación familiar.

410 GROENENDIJK, Kees. "Legal Concepts of Integration in EU Migration Law"; European Journal of Migration and Law, no 6, 2004, p. 118.

411 ILPA/MPG. Proposed Directive on Family Reunion. ILPA/MPG Explanatory Memorandum. Immigration Law Practitioners'Association and Migration Policy Group. Febrero de 2000, p. 126. Disponible en: http://www.migpolgroup.com/multiattachments/2544/DocumentName/apfamily.pdf. BRINKMANN, G. "Family reunion..., op. cit., p. 263.

412 Ambos instrumentos internacionales se situan en el marco del Consejo de Europa. Como el propio considerando 3.6 de la Exposición de Motivos se encarga de recordar, el Convenio europeo de 1977 contiene importantes limitaciones respecto a su ámbito de aplicación: sólo se refiere a los trabajadores asalariados y sólo se aplica a los trabajadores nacionales de los Estados que son Partes Contratantes de dicho Convenio.

413 BOELES. "La propuesta de Directiva...., op. cit., p. 132. CANEDO ARRILLAGA, M. P. "La propuesta de directiva comunitaria sobre reagrupación familiar...., op. cit., p. 142. 
acortar el campo a dos tratados internacionales, excluyendo otros también relevantes en la materia. Especialmente controvertida resultaba la ausencia de referencias al $\mathrm{CEDH}^{414}$, precisamente el convenio más trascendente en este ámbito.

Otro aspecto censurable residía en que la propuesta resultaba incongruente con la noción amplia de reunificación familiar que propugnaba. Expresamente, y con buena técnica jurídica, declara$\mathrm{ba}^{415}$ proteger tanto los vínculos familiares establecidos con anterioridad a la entrada del reagrupante - reagrupación familiar propiamente dicha - como aquellos constituidos posteriormente - formación de la familia-. Sin embargo, a lo largo de su articulado obviaba este concepto amplio, centrándose exclusivamente en la reagrupación en sentido estricto ${ }^{416}$. Es más, cuando aparecía alguna referencia a la reunificación dirigida a la formación ex novo de una familia, éstas eran de carácter excluyente $^{417}$.

El otorgamiento en exclusiva de la titularidad activa del derecho a la reunificación a favor del reagrupante, residente legal en un EM, se desprendía de lo establecido conjuntamente en los artículos 3 y 7 de la propuesta. Esta cuestión constituye, a nuestro juicio, otro aspecto controvertido de la propuesta. La Comisión justificaba esta atribución por la mayor facilidad que supone para el reagrupante afrontar los trámites administrativos en el EM en el que ya reside y a cuyas costumbres y lengua está familiarizado ${ }^{418}$. Sin embargo, el monopolio de la titularidad activa a favor del reagrupante podría suscitar dudas en torno a su compatibilidad con el concepto amplio que, en materia de titularidad activa, sostiene la jurisprudencia de Estrasburgo. Además contrastaba profundamente con el régimen vigente en materia de libre circulación de trabajadores ${ }^{419}$. En éste último, se preveía expresamente que, con independencia de su nacionalidad, los familiares del trabajador comunitario empleado en el territorio de otro EM tenían derecho a instalarse con el nacional comunitario ${ }^{420}$.

414 BOELES consideró muy lamentable esta ausencia, especialmente si se consideraba que la referencia explícita al CEDH aparecía en la exposición de motivos de la propuesta, al recordar que las medidas en este ámbito debían adoptarse conforme a la obligación de protección de la familia y al respeto de la vida familiar. En sus palabras "no se puede descartar que el CEDH, como lo interpreta el TEDH, será más favorable al derecho a la preagrupación familiar que el derecho que se establece en la propuesta de Directiva"; en "Propuesta de Directiva sobre la RF...", op. cit., p. 133.

415 Así consta tanto en el apartado e) del artículo segundo de la propuesta, como en el apartado 2.2 de la exposición de motivos de la misma. COM (1999) 638 final.

416 En el mismo sentido, CANEDO ARRILlaGA, M. P. “La Propuesta de Directiva comunitaria...”, op.cit. p. 128.

417 A título de ejemplo, cabe citar lo establecido en el artículo 2.e), que figura justo a renglón seguido del concepto amplio de reagrupación familiar al que nos hemos referido. Dicha disposición establecía que "la propuesta de directiva no regula la situación jurídica de las personas que desean entrar en el territorio de un Estado miembro con el fin de casarse con un nacional de un tercer país que ya reside en el mismo”.

418 Comentario al artículo 7.

419 BRINKMANN, G. "Family Reunion, Third Country Nationals and the Community's New Powers...", op. cit., pp. 254-255. El autor considera que la cuestión de la titularidad activa del derecho debería dejarse en manos de los EEMM, asegurándose que si la titularidad también se otorga a los familiares reagrupables, se garantice el derecho a la tutela judicial efectiva a fin de no vaciar de contenido el derecho a la reagrupación familiar.

420 Artículo 10.1 del Reglamento 1612/68. En torno a esta disposición Guild ha manifestado que "although third country nacional family members only enjoy a right because of the presence of their principal family member as a Member State nacional exercising a free movement right, the Article states that the family members 'have the right to install themselves with a worker' etc., not that the worker has the right to be joined by the family members". Por ello, concluye esta autora, que aunque los derechos de los nacionales extracomunitarios que forman parte de la familia de un ciudadano comunitario que ha hecho uso de su derecho a la libre circulación, son de carácter derivado respecto del derecho ostentado por el principal, sin embargo están redactados en términos de ejercicio individual. GUILD, Elspeth. "Discretion, Competence and Migration in the European Union”, op. cit., p. 66. En un sentido similar se pronuncia Richard Perrouchoud, quien señala que el derecho comunitario protege el derecho del esposo/a, hijos y otros familiares dependientes a vivir con el trabajador comunitario, si bien matiza que el artículo 10.1 del 
Pese a que la propuesta constituía en general una clara mejora respecto a los estándares pre$\operatorname{vios}^{421}$ y "una buena base para la creación y el desarrollo de una política comunitaria" 422 en materia de reagrupación familiar, nacía sin embargo destinada a enfrentar obstáculos formidables, en algunos puntos insuperables. La rigidez exigida — unanimidad - , y la generosidad de muchas de sus disposiciones, eran casi mutuamente excluyentes; ello hizo que la doctrina apuntase anticipadamente sus escasas posibilidades de éxito ${ }^{423}$ y la alta probabilidad de que el proceso de negociación que debía abrirse se saldase finalmente con el sacrificio de sus elementos principales ${ }^{424}$.

Ante esta incierta situación en torno al futuro de la propuesta, Boeles destacó tres elementos, a su juicio esenciales, que debían por ello sobrevivir a la negociación para asegurar que el resultado final fuese adecuado. En su opinión, resultaba fundamental en primer lugar establecer sin equívocos el carácter mínimo de la Directiva, de modo que quedase clara la posibilidad de los EEMM de introducir o mantener disposiciones más ventajosas en la materia; en segundo lugar, la introducción de una cláusula de stand still ${ }^{425}$ para evitar descensos en los niveles de protección y, finalmente, la inclusión de una referencia más amplia en el artículo 3.4 a fin de salvar las disposiciones más favorables establecidas en los tratados internacionales, con especial referencia al CEDH y la Convención sobre los derechos del niño, entre otros.

La Comisión tenía pues ante sí una dura tarea. Como apuntó Boeles, esta institución se enfrentaba a unos cuantos dilemas de difícil resolución. "Uno de ellos es la elección entre unas medidas correctas para las que no se conseguirá la unanimidad y unas medidas menos satisfactorias que tienen mayor posibilidad de ser aceptadas. Otro dilema es la elección entre una protección óptima del individuo y un control óptimo de la inmigración. Asimismo será difícil elegir entre preservar los criterios o sistemas nacionales o sacrificarlos en pro de un objetivo común" ${ }^{\text {\26. }}$.

Cumpliéndose los oscuros presagios que tempranamente adelantó la doctrina, la primera propuesta fue considerada excesivamente liberal por los EEMM ${ }^{427}$, cuyas presiones abrieron un largo y tortuoso proceso de negociación en el seno del Consejo, a lo largo del cual la configuración del derecho a la reunificación familiar fue degradándose en un proceso de devaluación creciente del derecho, según se iban sucediendo nuevas propuestas. Tan es así, que algunos estudiosos consideran que el derecho a la reunificación familiar, convenientemente garantizado por la primera propuesta, acabó siendo desmantelado ${ }^{428}$ en un texto final de compromiso que nada tenía que ver con la proposición original.

Reglamento 1612/68 tutela este derecho "de forma oblicua" y sólo para familiares dependientes de un nacional de un EM de la UE que esté trabajando en otro EM. PLENDER, Richard. International Migration Law. Martinus Nijhoff Publishers, revised second Edition, Dordrecht, London, 1988, p. 368.

421 En el mismo sentido ILPA/MPG. Proposed Directive on Family Reunion..., op. cit., p. 126.

422 BOLEES, P. “La propuesta de directiva sobre la RF...”, op.cit. p. 131.

423 Idem, p. 136. CANEDO ARRILLAGA, M.P. “La propuesta de la directiva comunitaria...”, op. cit., p. 142. BRINKMANN, Gisbert. "Family Reunion, Third Country Nationals and the Community's New Powers...”, op. cit., p. 264. Brinkman señala que aquellas disposiciones de la propuesta que concedían a los nacionales procedentes de terceros países derechos que los propios ciudadanos europeos no disfrutaban, no hacían sino empeorar las posibilidades de éxito de esta propuesta, pues en ellas serían más que previsible que las reticencias estatales, ya de por sí exacerbadas por el contexto de desempleo en todos los EEMM, tornasen imposible el logro de la unanimidad.

424 BOELES, P. “La propuesta de Directiva sobre la RF..., op. cit., p. 132.

425 Idem, p. 132. Boeles consideraba especialmente relevante la cláusula de stand stil para aquellos asuntos no cubiertos por la directiva, que de este modo gozarían de cierta protección.

426 BOELES, P. “Propuesta de Directiva sobre la reagrupación familiar...”, op. cit., p. 127.

427 GROENENDIJK, K.. “Legal Concepts on Integration...”, op. cit., p. 118.

428 CHOLEWINSKI, R. "Family Reunification and Conditions Placed on Family Members: Dismantling a Fundamental Right"; en European Journal of Migration and Law, no 4, 2002, pp. 271-290. 
Conforme a lo dispuesto en el artículo 262 TCE, el Consejo decidió consultar al Comité Económico y Social ${ }^{429}$ sobre la propuesta de Directiva presentada por la Comisión. El Comité acogió muy favorablemente esta propuesta, a la que consideró inspirada "en un profundo respeto de los derechos humanos, la familia y los menores, como prescriben importantes actos y convenios internacionales". Incluso estimó que mucho de los tratados internacionales citados por la Comisión en la Exposición de Motivos de la Propuesta no habían sido ratificados por los EEMM, añadiendo que "el hecho de que la propuesta de la Comisión tenga en cuenta estos textos (...) permite suponer que se procederá a una ratificación y una aplicación más general y rigurosa de estas normas internacionales por parte de los EEMM" ${ }^{330}$. Así mismo valoró muy positivamente el hecho de que la propuesta, en cumplimiento estricto del principio de subsidiariedad, definiese un marco jurídico común para las condiciones de entrada y estancia de nacionales de terceros países y garantizara de manera clara y uniforme el derecho a la reagrupación familiar, "entendido no sólo como un derecho, sino también como instrumento social, humano y cultural que favorece la integración de los nacionales de terceros países" ${ }^{431}$.

El Consejo, en cumplimiento del requisito establecido en el artículo 67 TCE, debía consultar al Parlamento Europeo ${ }^{432}$ sobre el texto de la propuesta. En el dictamen emitido por el Parlamento, este órgano declaraba apoyar el enfoque general y las principales orientaciones de la propuesta de la Comisión, especialmente la instauración de un derecho a la reagrupación familiar a favor de los nacionales de terceros países ya residentes. Pese a ello, el Parlamento adoptó 17 enmiendas, invitando a la Comisión a modificar su propuesta original.

Una de ellas ${ }^{433}$ pretendía subrayar el carácter mínimo de la Directiva, salvaguardando el derecho de los EEMM a otorgar mejores condiciones que las ofrecidas en la propuesta. Así mismo, en lo que constituía una de las más importantes enmiendas propuestas por el Parlamento, este órgano introdujo una cláusula de stand stil o mantenimiento del status $q u o^{434}$, que preveía la protección de las disposiciones nacionales más favorables, bajo la premisa de que "en el ámbito social varios EEMM disponen de enfoques de alcance más amplio incluso en materia de reagrupación familiar", por lo que "una

429 La consulta al Comité Económico y Social era de carácter facultativo y fue efectuada el 10 de febrero de 2000. El dictamen del Comité Económico y Social, preparado por su sección de Empleo, Asuntos Sociales y Ciudadanía, fue emitido el 5 de mayo del mismo año y finalmente aprobado en la sesión del 25 de mayo, por 81 votos a favor, 3 en contra y 8 abstenciones.

430 Apartado 2.1 del Dictamen del Comité Económico y Social C204/41, 18.7.2000.

431 Ídem, apartado 2.3.

432 La consulta se realizó mediante carta fechada el 11 de febrero de 2000. En contraste con el trámite facultativo de consulta al Comité Económico y Social, el procedimiento de consulta al Parlamento Europeo era de carácter preceptivo. El examen de fondo de la propuesta correspondió a la Comisión de Libertades y Derechos de los Ciudadanos, Justicia y Asuntos Interiores, tras la opinión formulada por la Comisión de Asuntos Jurídicos y Mercado Interior. El Parlamento aprobó su dictamen en la sesión plenaria de 6 de septiembre de 2000. En el dictamen figura asimismo la opinión emitida por la Comisión de Asuntos Jurídicos y Mercado Interior. Esta comisión del Parlamento, al igual que en su momento hiciera el Comité Económico y social, acogió con satisfacción y valoró positivamente la propuesta de la Comisión. A su entender, la directiva tendría repercusiones distintas según los distintos EEMM puesto que entre ellos el número de nacionales de terceros países variaba considerablemente, implicando para algunos de ellos "el replanteamiento, en parte, de las normativas actuales. El sistema propuesto, basado en criterios objetivos, significará, por ejemplo, el final de las disposiciones sobre cuotas y cifras objetivo".

433 Enmienda número 9.

434 La cláusula de stand still, propuesta por la enmienda número cuatro, tenía el siguiente tenor literal: "La transposición de la presente Directiva no deberá, en ningún caso, servir de pretexto para reducir el nivel de protección que garantizan los EEMM en relación con la reagrupación familiar en los ámbitos cubiertos por la presente Directiva” (Nuevo artículo 3.bis, apartado segundo, propuesto por la enmienda novena del Parlamento Europeo). 
Directiva comunitaria no debe contemplar una reducción del nivel de protección alcanzado en los diferentes EEMM". Y este era precisamente uno de los mayores peligros subyacentes a la aprobación de una norma comunitaria en esta materia, riesgo que en décadas precedentes había sido claramente señalado en el Informe sobre política de inmigración y asilo presentado en 1991 y que abriría paso a los intentos de acordar regulaciones comunes en un marco puramente intergubernamental.

El Parlamento también pretendía aclarar que el proyecto de Directiva no se limitaba a la reagrupación de un solo familiar, de modo que proponía incluir en varias disposiciones que las solicitudes de entrada y residencia serían de "uno o varios miembros de la familia" del reagrupante. Proponía además reducir el ámbito de aplicación de la Directiva, excluyendo a las personas beneficiarias de una forma subsidiaria de protección, quienes debían ser objeto de un tratamiento autónomo por parte de otra propuesta de la Comisión. De otro lado, la falta de armonización a nivel comunitario de la regulación de este colectivo, constituía un obstáculo para incluir el concepto de protección subsidiaria en la propuesta de Directiva. El Parlamento consideraba también que las decisiones denegatorias de las solicitudes de reagrupación debían justificarse detalladamente, lo cual permitiría al solicitante entender la razón de la desestimación para no volver a presentar otra solicitud similar o para aportar elementos de evaluación adicionales a su expediente. Mejoraba además la situación de los ascendientes e hijos adultos, a favor de quienes proponía la eliminación de su exclusión respecto del mercado laboral, por considerarlo "un factor útil de integración".

Tras este período de consultas, el texto de la propuesta volvió a la Comisión ${ }^{435}$ a fin de que este órgano reformulase su propuesta original sobre la base de las 17 enmiendas formuladas por el Parlamento Europeo. Por su parte, la Comisión consideró que la mayoría de las enmiendas propuestas por el Parlamento se inscribían plenamente en el marco del enfoque de la Comisión, constituyendo complementos que venían a enriquecer el texto original. Por ello, la Comisión aceptó la mayoría de dichas enmiendas, formulando una propuesta modificada de Directiva que fue aprobada en octubre del año 2000. Se trataba así del segundo proyecto de Directiva presentado en el plazo de un año desde la iniciación de los trabajos preparatorios.

\subsection{La propuesta modificada de Directiva}

La propuesta modificada de Directiva ${ }^{436}$, recogiendo las sugerencias del Parlamento Europeo, excluía a los beneficiarios de una forma de protección subsidiaria de su ámbito personal de aplicación ${ }^{437}$, solicitando así mismo la rápida adopción de una Directiva que abordase de forma independiente la acogida de estas personas. Se preveía expresamente que el reagrupante podía presentar simultáneamente varias solicitudes para varios miembros de su familia. Además la Comisión alteró el texto original para mejorar el estatus legal de los hijos adultos y los ascendientes reagrupados. Para ellos la redacción de la propuesta modificada introducía una mayor flexibilidad, a fin de dejar en manos de los EEMM su acceso al mercado laboral, tanto en forma de actividad asalariada como independiente - que la propuesta original excluía —, garantizándoles el derecho a acceder a la orien-

435 En cumplimiento a lo establecido en el artículo 250.2 TCE.

436 COM (2000) 624 final, 1999/0258 (CNS). Bruselas, 10.10.2000. En torno a esta propuesta modificada de Directiva del Consejo sobre le derecho a la reagrupación familiar vid. CHOLEWINSKI, Ryszard. "Family Reunification and Conditions Placed on Family Members: Dismantling a Fundamental Human Right"; en European Journal of Migration and Law, No 4, 2002, pp. 271-291.

437 Apartado 2.c) del artículo segundo. 
tación y formación profesional ${ }^{438}$. Pero, en contrapartida, desaparecía la referencia a las parejas no casadas del mismo sexo ${ }^{439}$ dentro de la categoría de familiares que podían optar a la reagrupación.

Sin embargo, y pese a que constituía una de las enmiendas más necesarias, la Comisión no aceptó la introducción de una cláusula de stand still por considerarla incompatible con el objetivo de aproximación de las legislaciones nacionales y porque, a su juicio, "varias de las disposiciones de la propuesta ofrecen ya importantes elementos de flexibilidad" motivar las decisiones de rechazo de solicitudes de reagrupación familiar, por considerarla redundante - ya estaba contemplada en el artículo 7.3 de la propuesta original—, ni la ampliación del concepto de dependencia para los ascendientes ${ }^{441}$. Aunque, con buen criterio, no cedió a la propuesta del Parlamento de eliminar la obligación de conceder un permiso de residencia renovable para los miembros de la familia admitidos, ya que ello les otorgaba cierta seguridad jurídica y su supresión "conduciría a una precarización de su estatuto" $"$ "

La propuesta modificada persistía en su primitiva cláusula de salvaguardia de las disposiciones más favorables ${ }^{443}$, sin contener referencias ni a las disposiciones del derecho nacional ni a otros convenios internacionales, salvo los dos expresamente mencionados ${ }^{444}$, y de nuevo sin aludir al CEDH.

Respecto a las condiciones materiales que los EEMM podían fijar para el ejercicio del derecho a la reunificación, el cambio de redacción provocó mayor ambigüedad en una cuestión clave. Si antes quedaba claro que las condiciones materiales sólo podrían exigirse en la primera petición, la propuesta modificada establecía que cabía su exigencia "con ocasión de la presentación de la solicitud de reagrupación" ${ }^{45}$, lo que abría la posibilidad a que las condiciones fuesen reclamadas en las sucesivas renovaciones. Pese a que el Parlamento había propuesto su supresión, la Comisión mantuvo el mandato general de que los requisitos relativos a las condiciones de vivienda, seguro de enfermedad y recursos económicos no implicasen ninguna discriminación entre los nacionales y los

438 Para los ascendientes e hijos mayores de edad, el Parlamento Europeo propuso la supresión total de la prohibición de acceso al mercado de trabajo y a la formación profesional, pero la Comisión aceptó tan sólo parcialmente esta enmienda. El resultado final es que con respecto a este concreto requisito, se mejoró la situación de dicho colectivo, cuya exclusión del mercado laboral pasó de ser preceptiva a optativa, constituyendo pues una opción en manos de los EEMM. El artículo 12.2 establecía al respecto que "los EEMM podrán limitar el acceso a un empleo asalariado o a una actividad independiente de los hijos mayores y los ascendientes".

439 Frente a su primitiva redacción, el artículo 5.1.1 determinaba que los EEMM autorizarán la entrada y la residencia "del cónyuge del reagrupante o la pareja de hecho que tenga una relación duradera con el reagrupante, si la legislación del EM en cuestión asimila la situación de las parejas no casadas a la de las casadas”.

440 Enmienda novena. Propuesta modificada de Directiva del Consejo sobre el derecho a la RF. Bruselas, 10.10.2000 COM (2000) 624 final.

441 La Comisión justificó su rechazo a ampliar el concepto de dependencia para los ascendientes afirmando que "no podía aceptarla, ya que desea que la admisión de los ascendientes en el marco de la reagrupación familiar esté estrictamente regulada”. (Enmienda 25). En coherencia con ello, la definición de los ascendientes del reagrupante - o de su cónyuge, o de la pareja de hecho- quedó exactamente igual que su precedente, en el artículo 5.1.d) de la propuesta modificada.

442 Enmienda 50 (2 $2^{\text {a }}$ parte).

443 Artículo 3.4.

444 Como señalamos en su momento, los dos únicos tratados internacionales mencionados en la primera propuesta eran la Carta Social Europea de 1961 y el Convenio europeo relativo al estatuto jurídico del trabajador migrante de 1977. Especialmente llamativa resultaba la exclusión del CEDH, lo que fue objeto de duras críticas doctrinales.

445 Apartado primero del artículo 9. 
ciudadanos extracomunitarios ${ }^{446}$. Se simplificaba y mejoraba, sin embargo, la exigencia potestativa de recursos económicos, que pasaban de ser "estables y suficientes" a "estables" ${ }^{47}$.

Tras su paso por la Comisión, la propuesta modificada de Directiva se enfrentaba a la dura prueba de lograr la unanimidad en el Consejo. Las deliberaciones habidas en el Consejo en septiembre de $2001^{448}$, desvelaron la existencia de numerosos puntos problemáticos sobre los que no era posible el consenso unánime entre los EEMM. Entre ellos destacaba la posición de las parejas no casadas, también se suscitaron problemas en torno a la edad de los hijos menores a fin de beneficiarse del derecho a la reunificación familiar, así como en torno a los límites temporales o períodos de espera que podían imponerse tanto al reagrupante como a sus familiares antes de poder beneficiarse de los derechos concedidos por la Directiva. Los bloqueos interpuestos en el Consejo eran de tal intensidad, que exigían buscar soluciones pragmáticas ${ }^{449}$, quizá al coste de renunciar parcialmente a los objetivos integradores fijados por las directrices de Tampere con que se había iniciado el proceso de elaboración de la Directiva y al precio obligado de adelgazar el contenido del derecho a la reunificación familiar.

\subsection{Tercera Propuesta de Directiva: Las claves para comprender la actual Directiva}

Como consecuencia de las dificultades políticas que afloraron en su proceso de negociación ${ }^{450}$ - que se prolongaba ya por espacio de dos largos años-, la Directiva sobre RF arrastraba un serio retraso. Esta situación llevó al Consejo Europeo de Laeken, celebrado los días 14 y 15 de diciembre de 2001, a solicitar a la Comisión la presentación de una nueva propuesta modificada, a más tardar el 30 de abril de $2002^{451}$. Laeken vino a reafirmar su compromiso con respecto a las orientaciones políticas y a los objetivos de la política migratoria comunitaria definidos en Tampere ${ }^{452}$. Consideraba que el establecimiento de normas comunes en materia de migración familiar era un elemento vital de una auténtica política común migratoria. Sin embargo, la necesidad de superar el retraso obligaba a que los nuevos impulsos en este ámbito se adoptasen bajo "un nuevo enfoque"

446 Artículo 9.2.

447 La suficiencia de los ingresos se consideraba acreditaba si éstos alcanzaban el nivel de recursos por debajo del cual el EM concediese una asistencia social.

448 2370th Council Meeting, Justice, Home Affairs and Civil Protection. C/01/334, Bruselas 27 y 28 de septiembre de 2001. 12204/01 (Presse 334-G), pp. 7 y 8.

449 Algunas de estas soluciones pragmáticas fueron propuestas por el Comisario Vitorino, quien señaló repetidamente que dado que la reunificación era un factor de integración, ésta debía ser la perspectiva que predominase al abordar dichas soluciones. Añadía que la directiva, dado su carácter pionero en el ámbito de la política comunitaria de inmigración, estaba llamada a servir de ejemplo y abrir camino a las restantes medidas que se adoptaran en dicho ámbito. Sesión no 2370 del Consejo —Justicia, Asuntos de Interior y Protección Civil—. Bruselas, 27 y 28 de septiembre de 2001. 12204/01 (Presse 334).

450 Particularmente difíciles resultaron las negociaciones en el Consejo sostenidas a lo largo de las sesiones de mayo de 2000, mayo de 2001 y septiembre de 2001.

451 Conclusiones de la Presidencia, Consejo Europeo de Laeken, 14 y 15 de diciembre de 2001. Apartados 41 y 38.

452 Ídem, apartado 37. En esta línea, el apartado 39 de las conclusiones de la Presidencia del Consejo Europeo de Laeken establecía que la política común en materia de asilo e inmigración había de respetar "el equilibrio necesario entre la protección de los refugiados, con arreglo a los principios del Convenio de Ginebra de 1951, la aspiración legítima a una vida mejor y la capacidad de acogida de la Unión y de sus Estados Miembros".

453 Ibidem, apartado 38. 
Siguiendo las recomendaciones formuladas en Laeken, la Comisión presentó un nuevo proyecto de Directiva el 2 de mayo de $2002^{454}$. El punto de partida era la consideración de que una verdadera política común de inmigración exigía la instauración de normas comunes sobre reagrupación familiar, habida cuenta de que la inmigración familiar constituía uno de los canales principales de entradas legales en la UE. La nueva propuesta se basaba en las negociaciones desarrolladas en el Consejo en torno a la propuesta anterior, de 10 de octubre, pero aportaba un prisma diferente a fin de lograr el éxito de las negociaciones.

La solución adoptaba pasaba por recurrir a un texto de compromiso dotado de mayor flexibilidad que permitiese superar las reticencias de los EEMM, especialmente de Alemania, Austria y Holanda, países cuyas presiones políticas durante la elaboración de la Directiva fueron especialmente fuertes. Esta mayor flexibilidad se vertía precisamente en aquellas cuestiones políticamente cargadas -o hot issues - donde persistía el bloqueo, permitiendo que sobre las mismas los EEMM conservaran un margen más amplio de maniobra y, adicionalmente, en la previsión de excepciones en casos limitados, a fin de posibilitar la "adaptación de la norma comunitaria a determinadas especificidades de las legislaciones nacionales vigentes" ${ }^{\prime 25}$.

El cambio de enfoque se traducía en la tendencia a utilizar la Directiva para reflejar a nivel comunitario las normativas internas más conservadoras, justo las correspondientes a los tres EEMM que más presiones políticas ejercieron durante su proceso de negociación -cuya posición fue descrita gráficamente por Groenendijk como la "troika" ${ }^{56}$ - El texto de compromiso se proyectaba, pues, con un enfoque eminentemente pragmático, con el fin de permitir desatascar las negociaciones y lograr el consenso, aun a costa de sacrificar parte de los ideales originales que impregnaron la primera propuesta. Dicho texto se basaba en dos premisas fundamentales:

a) De un lado, en la consideración de que la armonización de las legislaciones nacionales en materia de migración familiar debía concebirse como un proceso que se desarrollaría en varias etapas, de las cuales la Directiva vendría a constituir tan sólo la primera de ellas. Este proceso de construcción progresiva se tradujo en la inserción de una cláusula de emplazamiento ${ }^{457}$ que permitía fijar la próxima cita a fin de examinar la siguiente fase de la aproximación de las legislaciones internas sobre admisión a efectos de reagrupación familiar. Conforme a lo establecido en la cláusula de emplazamiento, precisamente aquellas disposiciones que ofrecían la máxima flexibilidad, serían objeto de revisión prioritaria - familiares reagrupables, concepto de reagrupante, condiciones de entrada, período de espera previo, acceso a un estatuto autónomo ${ }^{458}$. De esta forma se permitirían progresos paulatinos en el proceso de armonización del derecho dado que, como es lógico, las disposiciones más flexibles eran simultáneamente las que permitían mayores divergencias internas en la conformación normativa de la reagrupación familiar.

454 COM (2002) 225 final. Bruselas, 2.5.2002. 1999/0258 (CNS).

455 Apartado 2.1 de la Exposición de Motivos de la nueva Propuesta modificada de Directiva sobre reagrupación familiar. Bruselas 2.5.2002 COM (2002) 225 final.

456 GROENENDIJK, Kees. "Legal Concepts of Integration in EU Migration Law"; en European Journal of Migration and Law, 2004, vol. 6, no 2, p. 123.

457 La cláusula de emplazamiento reflejaba la flexibilidad temporal, mientras que la cláusula de stand still venía a plasmar la flexibilidad en la sustancia, a fin de evitar que los EEMM hicieran uso de las excepciones introducidas en el texto de compromiso si no estuvieran previstas por su legislación vigente en el momento de la aprobación de la directiva. Boletín UE 5-2002. Espacio de Libertad, Seguridad y Justicia (2/18).

458 Respecto de la cláusula de emplazamiento, Peers señaló que si bien indicaba las disposiciones que debían ser objeto de revisión prioritaria, en contrapartida "there is no indication of what the detailed content of such amendments would be". PEERS, Steve. "Key Legislative Developments on Migration in the European Union"; en European Journal of Migration and Law, № 5, 2003, p. 130. 
Asimismo, la propuesta incluía una cláusula de stand still o de mantenimiento del status quo para conjurar el riesgo de que los EEMM hicieran uso de las excepciones permitidas, sin que las mismas estuvieran previstas por su legislación vigente en el momento de la aprobación de la Directiva. Dicha cláusula no era de alcance general, sino que se aplicaba a determinadas disposiciones de la Directiva ${ }^{459}$. Esta cláusula vendría a evitar que los EEMM modificasen en sentido restrictivo sus legislaciones en la materia, incurriendo así en una "carrera a la baja" en la configuración interna del derecho a la reagrupación familiar, — carrera que, además, incrementaría las diferencias normativas entre los EEMM- Sin embargo, la formulación de dicha cláusula ponía en evidencia un peligro evidente: la carrera a la baja podía producirse durante el período que mediaba desde la negociación hasta la aprobación de la propuesta de Directiva ${ }^{460}$, al menos en lo que se refería a las disposiciones cubiertas por la cláusula de stand still. Steve Peers, al estudiar la tercera propuesta de Directiva, criticó también las limitaciones de esta cláusula de stand still, señalando que su efecto sería más bien similar a una "cláusula de no regresión" propia de las legislaciones sociales, "que simplemente exhorta a los EEMM a no bajar sus estándares de protección a los niveles de las cotas mínimas de la legislación de la Comunidad Europea" ${ }^{361}$.

b) La segunda premisa en la que se basaba el texto de compromiso consistía en la identificación de tres categorías diferentes de miembros de la familia, según la proximidad e intensidad de sus vínculos familiares con el sponsor, a saber: la familia nuclear - hijos menores y esposo/a-; ascendientes directos e hijos mayores de edad; y, por último, las parejas no casadas. La propuesta de compromiso partía de la obligación de concesión del derecho a la reunificación a los miembros de la familia nuclear, dotando de libertad a los EEMM a fin de que autorizar o no la entrada en su territorio a las otras dos restantes categorías de familiares. Además, la propuesta establecía una diferenciación en los derechos concedidos así como en las condiciones a las que sujetar su ejercicio, en función de las distintas categorías aludidas.

Como consecuencia del nuevo enfoque, la nueva propuesta de Directiva introducía múltiples modificaciones dando lugar a un texto que difería sustancialmente del borrador inicial presentado por la Comisión. Entre las principales modificaciones, cabe mencionar las siguientes:

1. Objetivo: Un cambio importante operado por la propuesta, que algunos estudiosos consideraron el más esencial ${ }^{462}$, y del que, sin embargo, no daba cuenta la exposición de motivos, residía en la modificación del objetivo de la Directiva. Los anteriores borradores establecían que su objeto era "instaurar" ó "establecer" un derecho a la reagrupación familiar para los nacionales procedentes de terceros países. Ahora la propuesta afirmaba, mucho más modestamente, que su objetivo era fijar las condiciones para el ejercicio de dicho derecho ${ }^{463}$. En el comentario a esta disposición que antecedía al articulado, podía leerse que con esta nueva formulación se pretendía "precisar mejor el objeto, a

459 Concretamente la cláusula de stand still se proyectaba sobre los apartados 1, 2 y 3 del artículo cuatro, el punto c) del apartado primero del artículo 7, y sobre el artículo 8 de la propuesta de directiva para impedir que estas concretas disposiciones tuvieran por efecto "la introducción de requisitos menos favorables que los existentes en cada EM en la fecha de adopción de esta Directiva”. En las disposiciones afectadas por la cláusula de stand still se contemplaba a los miembros de la familia reagrupables, el requisito de los recursos estables y el período de espera exigido al reagrupante antes de poder ejercer la reunificación familiar.

460 Este riesgo fue denunciado por el Comité Económico y Social, en el Dictamen emitido sobre la propuesta modificada de Directiva (Apartado 2.1 in fine de dicho dictamen). C 241/108, de 7.10.2002.

461 PEERS, Steve. “Key Legislative Developments..., op. cit., Vol.5, no 1, 2003, p. 128.

462 Vid, entre otros, BOELES, Pieter. "Directive on Family Reunification: Are the Dilemas Resolved?"; en European Journal of Migration and Law, No 3, 2001, pp. 61-71.

463 Artículo 1 de la tercera propuesta de directiva. 
saber, definir las condiciones en las cuales se ejerce a nivel europeo el derecho a la reagrupación familiar reconocido, por otra parte, en las legislaciones nacionales y los instrumentos internacionales existentes" ${ }^{\prime \prime}$. Sin embargo, cuesta creer que el objeto de una Directiva que pretende una armonización del derecho a la reagrupación familiar a nivel europeo quede mejor precisado a través de una formulación más restrictiva que, de entrada, puede suscitar dudas sobre el tipo de facultad subjetiva introducida por la propia Directiva ${ }^{465}$.

2. Ámbito de Aplicación: El ámbito de aplicación de la Directiva sufría una considerable restricción. Del concepto de reagrupante se amputaba a los ciudadanos de la Unión que no hubieran ejercido su derecho a la libre circulación ${ }^{466}$. Esta exclusión fue calificada como una "enorme reducción de los niveles de protección del derecho a la reagrupación familiar, en comparación con la versión del proyecto de Directiva elaborado por la Comisión en el año 2000; y también si se compara con los estándares de protección establecidos en cualquier otro texto del Consejo" ${ }^{\text {"467. }}$. La justificación para eliminar del ámbito de aplicación personal de la Directiva a los ciudadanos comunitarios que residiesen en el EM de su misma nacionalidad, se amparaba en la iniciación de un proceso de refundición del derecho comunitario relativo a la libre circulación de personas, de modo que "el ajuste de los derechos de todos los ciudadanos de la UE a la reagrupación familiar se reexaminará posteriormente una vez adoptada la refundición" ${ }^{\prime 468}$.

3. Concepto y requisitos exigidos al Reagrupante: El concepto de reagrupante se tornaba mucho más impreciso, quedando sujeto a un "novedoso" ${ }^{369}$ requisito adicional cargado de ambigüedad

464 Comentario al artículo primero del tercer proyecto de Directiva sobre RF. COM (2002) 225 final, p. 5. Disponible en http://eur-lex.europa.eu/LexUriServ/LexUriServ.do?uri=COM:2002:0225:FIN:ES:PDF

465 Sobre este aspecto, el Comité Económico y Social señaló, en su dictamen de octubre de 2002, que pese a que la nueva propuesta "afirma formalmente el derecho a la reagrupación familiar, lo circunscribe en una serie de procedimientos más restrictivos que los previstos en la propuesta de Directiva de 1999. La propia formulación del artículo 1 de la propuesta resulta indicativa, ya que mientras en el propuesta inicial el objetivo era instituir un derecho a la reagrupación, en el texto actual pasa a ser fijar las condiciones en las cuales se ejerce el derecho a la reagrupación”. (Apartado 1.3 del Dictamen del Comité Económico y Social sobre la «Propuesta modificada de Directiva del Consejo sobre el derecho a la reagrupación familiar»"). C241/108, de 7.10.2002. Por su parte, el Comité de las Regiones, en el dictamen que en torno a esta nueva propuesta emitió el 26 de marzo de 2003, expresó su preocupación por el cambio de enfoque de la propuesta, "que pasa de basarse en los derechos a basarse en los procedimientos; lamenta que el objetivo inicial —el reconocimiento de la reagrupación familiar - tal como se mencionaba en la primera propuesta de la Comisión de 1999, se vea limitado a la mera definición de una base común mínima de condiciones en las que se ejerce el derecho a la reagrupación familiar”. Apartado 1.2 del Dictamen del Comité de las Regiones sobre la Propuesta modificada de Directiva del Consejo sobre el derecho a la reagrupación familiar, C 73/16 (2003/C73/05).

466 El status de este colectivo seguía pues estando sometido a lo establecido por las legislaciones internas que, en ocasiones, contemplaban regulaciones más restrictivas que la normativa comunitaria aplicable a aquellos comunitarios que se hubiesen trasladado a un EM distinto al de su nacionalidad. Se planteaba así la paradójica e injustificable situación de que algunos ciudadanos comunitarios que vivían en el EM de su nacionalidad eran titulares de un derecho a la reagrupación familiar en condiciones mucho más limitadas, que cuando el mismo derecho era ejercido por aquellos ciudadanos comunitarios que se habían instalado ese mismo Estado miembro, sin ser nacionales del mismo. Algunas normas internas de los EEMM sometían pues a sus nacionales a un régimen de reunificación familiar discriminatorio respecto al establecido por el derecho comunitario relativo a la libre circulación, situación que fue calificada como "discriminación inversa”.

467 PEERS, Steve. "Key Legislative Developments on Migration in the European Union”, op. cit., vol. 5, nº 1, 2003, p. 127.

468 Apartado 2.4 de la Exposición de Motivos que antecede al texto de la tercera propuesta de directiva sobre reunificación familiar.

469 La novedad no era tal si el análisis se sitúa justo una década atrás. El texto de la Resolución relativa a la armonización de políticas familiares sobre reunificación familiar contenía una disposición casi idéntica, y dotada del mismo alto grado de indeterminación, que la que finalmente vino a colarse en la tercera propuesta de directiva. Se trataba del principio 1.1 de dicha Resolución de 1993. 
jurídica. Al reagrupante se le exigía ser "un nacional de un país tercero que resida legalmente en un EM, titular de un permiso de residencia expedido por ese EM de un período de validez superior o igual a un año". Hasta aquí poca novedad, si no fuera porque a renglón seguido se añadía como requisito suplementario que el reagrupante debía tener "una perspectiva fundada de obtener un derecho a la residencia duradera". Esta inclusión redundaba de nuevo en "una sustancial reducción de estándares" 470 comparado con la segunda propuesta emitida en el año 2000. Además, esta nueva exigencia recordaba peligrosamente la Resolución de 1993 de armonización de políticas nacionales relativas a la reagrupación familiar ${ }^{471}$, donde se exigía la residencia legal del reagrupante "sobre una base que le permitiese una expectativa de residencia permanente o de larga duración” ${ }^{372}$.

Sobre su origen ${ }^{473}$, en las versiones del Consejo se incluía una referencia similar, pero no idéntica, ya que en los textos del Consejo se hacía referencia al requisito de tener una perspectiva razonable de obtener el derecho de residencia de larga duración. El concepto de residente de larga duración goza de precisión y claridad, y es un "umbral más fácil de superar" ${ }^{774}$ que el indeterminado de residencia permanente. Sobre este cambio, no es posible encontrar justificación alguna en el texto de la Exposición de Motivos que antecede a la tercera propuesta de Directiva. La única explicación aparece en el comentario de los artículos, donde puede leerse que está "destinada a no conceder el derecho a la reagrupación familiar a las personas que sólo residan temporalmente, sin posibilidad de renovación. Esta exclusión contempla, en particular, a las personas au pair, becarios, etc." ${ }^{475}$. Además la disposición aclaraba que los miembros de la familia del reagrupante deben ser nacionales de países terceros, independientemente del estatuto jurídico de éstos ${ }^{476}$. Dado que los ciudadanos comunitarios que residían en el Estado de su nacionalidad habían quedado excluidos del ámbito de aplicación de esta propuesta, resultaba que la Directiva no contemplaba una regulación genérica del derecho a la RF, sino tan sólo de aquellas familias íntegramente constituidas por nacionales de terceros países.

4. Período de espera: El período previo de residencia legal que los EEMM podrán exigir al reagrupante antes de poder reunirse con los miembros de su familia se elevaba a dos años ${ }^{477}$. Pero, además, se preveía la posibilidad excepcional de introducir un período de espera de hasta tres años como máximo que tan sólo podría aplicarse en aquellos EEMM cuya legislación existente en la fecha de adopción de la Directiva tuviera en cuenta su capacidad de recepción ${ }^{478}$. La exposición de motivos aclaraba que se trataba de una excepción muy limitada, y que servía para permitir "escalonar las autorizaciones de entrada por reagrupación familiar a lo largo de varios años, según la capacidad de recepción del Estado miembro en cuestión" y con el límite máximo de no superar los tres años ${ }^{479}$.

470 PEERS, Steve. “Key Legislative...”, op. cit., Vol. 5, nº 1, 2003, p. 127.

471 En el mismo sentido, Steve PEERS afirma que "the proponed revised wording is very similar to the threshold in the 1993 Ministers' resolution on family reunion, and violates principles of clear and precise drafting agreed by the institutions". "Key Legislative...", op. cit., p. 128.

472 El principio número 1 de dicha Resolución establecía expresamente que: “These principles, which do not affect Community law, will be applied in respecto $f$ the family members of non-EC nationals who are lawfully resident within the territory of a Member State on a basis which affords them an expectation of permanent or long-term residence".

473 Vid. Council Document 8209/01.

474 PEERS, Steve. “Key Legislative Developments.., op. cit., p. 127.

475 Comentario al artículo 3.1 de la tercera propuesta de directiva. Bruselas, 2.5.2002. COM(2002) 225 final, p. 5.

476 Artículo 3.1 de la tercera propuesta de Directiva. Bruselas, 2.5.2002, COM(2002) 225 final.

477 Idem, Artículo 8.1.

478 Artículo 8.2 de la tercera propuesta de directiva.

479 Apartado 2.4 de la Exposición de Motivos de la propuesta modificada de directiva. 
5. La admisión de familiares: La autorización de entrada y residencia con fines de reagrupación de aquellos familiares distintos a los miembros de la familia nuclear - parejas no casadas y los hijos menores de éstas, así como hijos adultos y ascendientes - pasaba de ser preceptiva, a depender de la voluntad de los distintos EEMM. Respecto a dichos sujetos, la reunificación familiar a nivel comunitario continuaba constituyendo una facultad discrecional enteramente dependiente de la voluntad de los distintos EEMM, manteniéndose, en consecuencia, las disparidades internas.

Ni siquiera los miembros de la familia nuclear pudieron escapar a la entidad de las reformas que fueron introducidas por la Comisión a partir del tercer proyecto, a fin de plegarse a las crecientes exigencias de aquellos EEMM que estaban entorpeciendo el proceso de negociación. Y ello pese a que una premisa básica sobre la que se construyó este texto de compromiso era el otorgamiento preceptivo de la autorización de entrada y residencia a los miembros de la familia nuclear del extranjero residente legal en un EM. Contrariando dicha premisa, el tercer proyecto de Directiva convirtió en opcional la autorización para que los hijos menores, cuya custodia era compartida, pudiesen entrar al EM a fin de reunirse con el progenitor legalmente instalado allí. Además, el tercer proyecto de Directiva introdujo límites de edad que entorpecían e incluso podían llegar a anular la RF de aquellos miembros de la familia nuclear que el EM tenía la obligación de admitir, tanto a los hijos menores como al cónyuge.

\section{Establecimiento de límites de edad adicionales para el ejercicio de la reagrupación fami-} liar por parte de los miembros integrantes de la familia nuclear:

a) Topes de edad para los hijos menores de inmigrantes instalados legalmente en un EM: La propuesta modificada revisó la edad hasta la cual los niños podían ser reagrupados ${ }^{480}$, "con el fin de prever una excepción que autorice el mantenimiento de las legislaciones nacionales específicas. Esta excepción está estrictamente regulada" ${ }^{481}$. En este sentido, respecto a los hijos menores de inmigrantes, - junto al tope genérico de la mayoría de edad que siempre había gravitado sobre la legislación de extranjería-, se introdujeron topes de edad adicionales, de carácter facultativo para los EEMM. Dos eran los topes impuestos a los menores: Uno de ellos se situaba a partir de los doce años de edad del menor, en cuyo supuesto el EM podría exigirle cumplir con algún criterio de integración con carácter previo a admitir su entrada a efectos de reunificación familiar. El segundo tope fijaba los quince años como fecha máxima para presentar las solicitudes de reagrupación familiar; a partir de dicha edad, las solicitudes se concederían por motivos distintos a la RF. Con ambos topes se producía la paradójica situación de que la edad establecida con carácter general en el ámbito internacional para alcanzar la mayoría de edad, no se respetaba con respecto a los niños inmigrantes procedentes de terceros Estados.

b) Introducción de topes de edad para que los cónyuges pudieran reagruparse: El tercer proyecto concedía a los EEMM la posibilidad de exigir que tanto el reagrupante como su cónyuge hubieran alcanzado una edad mínima, que no podía superar la mayoría legal, antes de que el cónyuge pudiese reunirse con el reagrupante. Esta disposición sobreviviría a la propuesta, e incluso se endurecería más en la versión finalmente adoptada.

7. Condiciones económicas que cabía imponer al ejercicio de la reagrupación familiar: Las condiciones económicas materiales que gravaban facultativamente el ejercicio del derecho, podrían ahora exigirse al reagrupante no sólo al presentar la solicitud inicial de reagrupación familiar, sino también posteriormente, cuando solicitase la primera renovación del permiso de residencia de sus

480 Artículo 5.1 del tercer proyecto de directiva.

481 Apartado 2.4 de la Exposición de Motivos de la tercera propuesta de directiva. 
familiares ${ }^{482}$. Como vimos, esta posibilidad se introdujo de forma encubierta en el segundo proyecto, pero ahora se explicitaba la posibilidad de su exigencia con el tope fijado en la primera renovación. Esta modificación introducía mayor vulnerabilidad en la situación del reagrupante y, por derivación, en la de los familiares reagrupados, cuya continuación en el EM se veía amenazada por situaciones laborales y económicas adversas de carácter sobrevenido tras la autorización inicial de entrada al territorio de dicho Estado. De nuevo la justificación apelaba a la necesidad de evitar que los residentes recurriesen a los sistemas públicos de asistencia social, con el consiguiente incremento del gasto público.

8. Modificaciones en la duración de los permisos de residencia de los familiares y en el período temporal exigido para poder acceder a una residencia autónoma: Se revisó la duración de la validez del permiso de residencia de los familiares de aquellos reagrupantes que ya hubieran obtenido la residencia permanente ${ }^{483}$. En dicho supuesto, el plazo temporal para que los familiares reagrupados obtuvieran el estatuto de residente de larga duración se elevaba de cuatro a cinco años ${ }^{484}$, igualándolo a los criterios exigidos al reagrupante. La justificación oficial ${ }^{485}$ apelaba a razones de coherencia con el estatuto de los residentes de larga duración, - cuya regulación corría a cargo de una Directiva ${ }^{486}$ cuya tramitación resultó simultánea a la Directiva de reagrupación familiar, como consecuencia del largo proceso de gestación de esta última-. Las mismas razones de coherencia con el estatuto de residente de larga duración se aducían ${ }^{487}$ para justificar la elevación del límite máximo para la concesión del estatuto autónomo por los miembros de la familia reagrupados, que pasó de cuatro a cinco años de residencia. Sin embargo, "se suprimió el período de espera para un permiso autónomo en "casos de emergencia»" 488 .

9. Inclusión de la definición de apátridas dentro del concepto de nacionales procedentes de terceros países: La definición de nacionales de terceros países incluía ahora de forma explícita a los apátridas, si bien se afirmaba que en las anteriores propuestas "estaba subentendido" 489 .

10. Procedimiento para el ejercicio del derecho a la reagrupación familiar: Las normas relativas a la presentación, análisis y resolución del expediente de RF experimentaron un notable endurecimiento:

a) Así ocurrió con respecto a la presentación de solicitudes ${ }^{490}$, pues la tercera propuesta convertía en discrecional para el EM el examen de aquellas solicitudes presentadas cuando el familiar

482 Artículo 7.1.

483 Mientras se negociaba la directiva de reagrupación familiar, se iniciaron los debates relativos a la elaboración de la directiva de residentes de larga duración (propuesta de directiva de 13 de marzo de 2001). La Exposición de motivos de la propuesta modificada de directiva de reagrupación familiar alude por ello a la necesidad de dotar de coherencia a las normas previstas por ambas directivas, lo que se reflejó especialmente en las disposiciones relativas a la duración de la validez de los permisos de residencia de los miembros de la familia de un reagrupante que cuente con un derecho de residencia permanente (Apartado 2.4 de la Exposición de Motivos de la nueva propuesta modificada de Directiva).

484 Artículo 13.2.

485 Apartado 2.4 de la Exposición de Motivos de la tercera propuesta de directiva.

486 Se trata de la Directiva 2003/109/CE del Consejo, de 25 de noviembre de 2003, relativa al estatuto de los nacionales de terceros países residentes de larga duración.

487 "Este nuevo límite armonizará entre ellos los plazos de obtención del permiso de residencia permanente y del estatuto autónomo, y concederá suficiente flexibilidad para tener en cuenta las distintas situaciones nacionales", rezaba la Exposición de motivos de la propuesta modificada.

488 PEERS, Steve. “Key legislative developments...", op. cit., vol. 5, nº 1, 2003, p. 130.

489 Comentario al artículo 2. Bruselas, 2.5.2002. COM(2002) 225 final.1999/0258 (CNS)

$490 \mathrm{Al}$ menos ésta es la interpretación de Steve Peers, quien considera que en el tercer proyecto "the consideration of in-country applications is now only optional, a lower standard adopting the wording from Council text". PEERS, Steve. "Key legislative...", op. cit., vol. 5, n 1, 2003, p. 129. 
reagrupable estuviese ya dentro del territorio del $\mathrm{EM}^{491}$ — supuesto que, como es bien sabido, cubre la denominada RF de hecho-.

b) Elevación del plazo concedido a los EEMM para la resolución de los expedientes de RF: El plazo otorgado al Estado para responder a la solicitud de reagrupación se elevó de seis a nueve meses $^{492}$, añadiéndose incluso la posibilidad de que llegara a durar un año en circunstancias excepcionales. El texto discutido en el Consejo con carácter previo ${ }^{493}$ permitía extender el tiempo sin fijar un tope máximo, por lo que aún con carácter general, suponiendo una rebaja de protección, la redacción de la tercera propuesta, como ha señalado Peers, constituía una mejora respecto a las discusiones previas mantenidas en el Consejo ${ }^{494}$.

c) Ampliación de los motivos para rechazar o retirar un permiso de residencia por razones de reagrupación familiar ${ }^{495}$. La tercera propuesta catalogaba como motivos para rechazar o retirar un permiso, el hecho de que las condiciones establecidas en la Directiva no fueran ya satisfechas, o que la información presentada al efecto fuera falsa o fraudulenta. Tales disposiciones otorgan un poder discrecional enorme a las autoridades para negar la entrada o expulsar a miembros de la familia, e igualmente parecían desdibujar las limitaciones establecidas para volver a revisar las renovaciones en un momento posterior, si se mantenían en el tiempo las condiciones por las que se otorgó el permiso ${ }^{496}$.

Tal era el rigor y la intensidad de las modificaciones que incorporaba el tercer proyecto de Directiva presentado por la Comisión el 2 de mayo que, como era previsible, las críticas no se hicieron esperar. La Coordinadora Europea por el Derecho de los Extranjeros a Vivir en Familia, una red de ONG's que posteriormente se encargaría de promover el recurso de anulación contra la Directiva 2003/86, consideraba que esta proposición constituía un "inquietantísimo retroceso comparado con las orientaciones que el Consejo europeo de Tampere ha dado en el año 1999 en materia de inmigración. En efecto, mientras que en el espíritu del Tratado de Ámsterdam, todos los esfuerzos debían estar puestos al servicio de la armonización de las legislaciones de los Estados miembros para llegar a una base legislativa común, la nueva proposición de Directiva sobre el reagrupamiento familiar consiste en una superposición de compromisos concedidos a los Estados que utilizan una reglamentación interna de lo más restrictiva" ${ }^{\$ 97}$.

La propuesta modificada de Directiva volvió a someterse a los mismos trámites procedimentales establecidos en el artículo 262 TCE. De este modo, el 23 de mayo de 2002, el Consejo consultó al Comité Económico y Social sobre el tercer proyecto $^{498}$. En su dictamen, el Comité Económico y Social

491 Al respecto, el artículo 7.2 de la propuesta establecía que "no obstante lo dispuesto en el apartado 1, el EM en cuestión, en casos particulares o por consideraciones de carácter humanitario, examinará una solicitud presentada cuando el miembro de la familia ya residiere en su territorio". Como se puede observar, la redacción es imperativa - "examinará"-, en concurrencia de dos circunstancias imprecisas: "casos particulares o consideraciones humanitarias".

492 Artículo 5.4 de la tercera propuesta.

493 Council Document 8209/01.

494 En palabras de Steve Peers, "de hecho, ésta es una mejora con respecto al último texto que había sugerido una posible extensión al período de respuesta sin fijar un tiempo límite”. PEERS, Steve. “Key Legislative...”, op. cit. Vol. 5, no 1, 2003, p. 129.

495 La ampliación era de tal calibre, que Peers declaró que las razones que podía aducir el EM para no conceder o revocar un permiso de residencia por causa de RF habían sido “dramáticamente expandidas”. Ídem, p. 130.

496 Ibidem.

497 El texto citado se encuentra disponible http://www.coordeurop.org/sito/es/10arch/activ/10es_2002.html

498 Fue la Sección de Empleo, Asuntos Sociales y Ciudadanía la encargada de elaborar el dictamen, que sería finalmente aprobado en Pleno, en la sesión celebrada el 17 de julio, por 118 votos a favor, 7 en contra y dos abstenciones. 
alertó de las modificaciones que consideraba más conflictivas para la configuración del derecho a la reunificación familiar ${ }^{499}$.. Entre éstas era considerada especialmente grave la excepción contemplada en el artículo 4.1, conforme a la cual un EM podía examinar si un menor que ya hubiera cumplido los doce años cumplía un criterio de integración, siempre que el mismo estuviera previsto por su legislación interna en la fecha de adopción de la Directiva. Se criticaba la indeterminación de dicho criterio de integración: "No está absolutamente claro cuáles podrían ser los «criterios de integración», pero sí parece claro que esta excepción responde a las exigencias de unos EEMM que desean realizar una selección cada vez mayor de las potencialidades de los inmigrantes más jóvenes en relación con sus necesidades productivas" ${ }^{\prime 500}$.

Otra modificación denunciada por el Comité Económico y Social residía en el plazo otorgado al Estado para responder a la solicitud de reagrupación, que se elevó de seis a nueve meses ${ }^{501}$ con la posibilidad excepcional de prolongarlo hasta un año $\mathrm{o}^{502}$. Asimismo este órgano alertó del endurecimiento del período previo de residencia, que se incrementó de un año a dos, con la posibilidad excepcional de llegar a tres años de espera en el caso de que el EM en cuestión tenga en cuenta su capacidad de recepción en su legislación interna ${ }^{503}$. Este plazo otorgaba a los Estados una "fuerte discrecionalidad" y se prestaba "a la aplicación de importantes criterios de elasticidad política" ${ }^{504}$.

El Comité Económico y Social finalizaba su dictamen con una consideración general, ya que la propuesta introducía un buen número de "pequeñas modificaciones con efectos potencialmente perjudiciales para la dignidad de las personas". A modo de ejemplo señalaban dos situaciones incluidas en el artículo 16, que permitían al EM denegar la solicitud, retirarla o negarse a su renovación cuando el reagrupante o los miembros de su familia no hagan o hayan dejado de hacer vida conyugal o familiar efectiva, y cuando se constatase que el reagrupante o el compañero no casado ha contraído matrimonio o mantiene una relación estable con otra persona. Estos dos casos constituían para el Comité ejemplos "en los que se considera normal exigir que el ciudadano de un tercer país tenga un comportamiento moral irreprochable en el marco de sus relaciones familiares, lo que supone una clara discriminación respecto a lo que normalmente se pide a los ciudadanos comunitarios" 505 .

Respecto de la cláusula de mantenimiento del status quo ${ }^{506}$ incluida por la propuesta, el Comité Económico y Social alertó del riesgo de reducción a la baja de las legislaciones internas antes de la aprobación de la propuesta de Directiva, momento temporal señalado en la cláusula de stand still

(COM (2002) 225 final -199/0258 (CNS)). (2002/C 241/21).

499 El apartado 2.2 del Dictamen del Comité Económico y Social incluye un listado pormenorizado de las modfiicaciones propuestas consideradas más graves, así como una justificación de los riesgos que las mismas representan para el "derecho" a la reagrupación familiar. El entrecomillado del derecho corresponde al utilizado por el Comité Económico y Social, subrayando con ello los peligros obvios que dichas modificaciones entrañaban para la propia consideración de la facultad otorgada a los individuos y la correspondiente obligación que incumbía a los EEMM de concederles la reagrupación familiar bajo las condiciones agravadas establecidas en la propuesta de directiva.

500 Punto segundo del apartado 2.2 del Dictamen del Comité Económico y Social.

501 Artículo 5.4.

502 Sobre la misma, el Comité Económico y Social señaló que "seis meses ya eran más que suficientes y, por consiguiente, la ampliación de los plazos a nueve meses le produce perplejidad”. Punto 3 del apartado 2.2 del Dictamen del CESE.

503 Artículo 8.1.

504 Punto 4 del apartado 2.2 del Dictamen del Comité Económico y Social.

505 Punto 5 del apartado 2.2 del Dictamen del CESE.

506 La claúsula de stand still aparecía contenida en el artículo 3.6 y establecía que "los apartados 1, 2 y 3 del artículo 4, el párrafo segundo de la letra c) del apartado 1 del artículo 7 y el artículo 8 de esta Directiva no tendrán por efecto la introducción de requisitos menos favorables que los existentes en cada Estado miembro en la fecha de adopción de esta Directiva”. 
para impedir dicha modificación restrictiva. Asimismo, añadía que aunque la cláusula de stand still "pone un límite al uso de la Directiva para revisar en sentido restrictivo algunas normas nacionales, denuncia también el hecho de que una serie de artículos de la propuesta modificada (los citados en el artículo 3.6) son bastante más restrictivos que las normas vigentes en diversos Estados miembros sobre los mismos temas" ${ }^{507}$. Las disposiciones cubiertas por la cláusula de stand still ${ }^{508}$ revelaban pues los puntos más conflictivos y peligrosos de la Directiva, en donde las legislaciones de los EEMM podían superar el bajo estándar ofrecido por tales disposiciones. Las mismas constituían el fruto de la presión política desplegada por los EEMM más reacios a la adopción de una Directiva que ofreciese un zócalo elevado de protección al derecho a la RF. Es precisamente en estos puntos de mayor riesgo, donde más convenía introducir mecanismos protectores. Sin embargo no quedaba incluida dentro de la protección parcial dispensada por la cláusula de stand still la posibilidad de exigir límites de edad a los cónyuges antes de poder reunirse en el EM, disposición de carácter igualmente controvertido a las cubiertas por dicha cláusula.

En su dictamen, el Comité Económico y Social observó que el nuevo texto "se resentía mucho de las dificultades surgidas durante dos años de debate entre los EEMM"509, mostrándose profundamente preocupado por la entidad de las modificaciones y la orientación restrictiva que emanaba de ellas. Reconocía asimismo que "los problemas abordados en la propuesta de Directiva son muy delicados y la especial sensibilidad de los ciudadanos europeos sobre estos temas" 510 . Sin embargo, pese a manifestar su "decidida contrariedad frente a las importantes modificaciones introducidas en el texto de 1999"511, este órgano no emitió un dictamen formalmente negativo sobre la nueva propuesta. De esta forma, el Comité Económico y Social venía a hacer gala del mismo pragmatismo que rodeó la aprobación por la Comisión de la nueva propuesta modificada de Directiva, a fin de no entorpecer ${ }^{512}$ aún más el accidentado proceso de adopción de esta norma comunitaria.

La propuesta se sometió también al dictamen del Comité de las Regiones ${ }^{513}$. Este órgano acogió favorablemente el establecimiento de un sistema de normas procedimentales que habría de regir el examen de las solicitudes de reagrupación y que debía ser efectivo, gestionable —en relación con la carga normal de trabajo de las administraciones públicas de los EEMM-, transparente y equitativo $^{514}$. Sin embargo manifestó su preocupación en torno a múltiples elementos de la Directiva, tales

507 Apartado 2.1 del Dictamen emitido por el Comité Económico y Social el 7.10.2002. C 241/108.

508 Las disposiciones aludidas son los apartados 1, 2 y 3 del artículo 4 (esto es, los miembros de la familia que el Estado deberá preceptivamente reagrupar, así como los de carácter potestativo), el párrafo segundo de la letra c) del apartado 1 del artículo 7 (posibilidad de que el EM exija al reagrupante el cumplimiento de las condiciones materiales para poder ejercer el derecho a la reagrupación familiar no sólo al presentar la solicitud inicial de reunificación, sino también en el momento de requerir la primera renovación del permiso de residencia de los miembros de su familia) y el artículo 8 de la propuesta (establecimiento potestativo para los EEMM de un período de espera previo de dos años que puede llevar a elevarse a tres en aquellos Estados que cuenten con una legislación en la fecha de adopción de la directiva, que tenga en cuenta su capacidad de recepción).

509 Artículo 3.1.

510 Apartado 3.4 del Dictamen, constituye el último del cuerpo del dictamen emitido por el CESE.

511 Apartado 3.2 del Dictamen del Comité Económico y Social. C 241/108, de 7.10.2002.

512 Según afirmaba este órgano, "con la esperanza, más que con la convicción, de que esta última lectura lleve rápidamente a una conclusión de la tramitación de la propuesta y a la aprobación definitiva del documento", (apartado 3.2 del Dictamen del Comité Económico y Social).

513 Dictamen del Comité de las Regiones sobre la «Propuesta modificada de Directiva del Consejo sobre el derecho a la reagrupación familiar», (2003/C73/05), de 2 de noviembre de 2003. D.O.C.E. 26.3.2003. La decisión del Consejo de consultar al Comité de las Regiones se produjo el 23 de mayo de 2002. Dicha consulta, de carácter potestativo, está recogida en el primer párrafo del artículo 265 TCE. La Mesa del Comité de Regiones asignó la elaboración del dictamen de iniciativa a la Comisión de Relaciones Exteriores, con fecha de 12 de marzo de 2002.

514 Apartado 1.1 del Dictamen del Comité de las Regiones. 
como la exclusiva obligatoriedad de admitir a los miembros de la familia nuclear o tradicional, lo cual implicaba diferencias de trato con respecto a los compañeros no casados y los hijos ilegítimos de éstos y, además, acarreaba como consecuencia la aplicación de diferentes normas en los distintos EEMM a otro tipo de familias, distintas a las nucleares. Esa situación, a juicio del Comité de las Regiones, podría dar lugar a confusión y al incremento de la litigiosidad judicial ${ }^{515}$.. Otros focos de preocupación residían en la ausencia de referencias al coste de los visados para los miembros de la familia de los ciudadanos de terceros países, o la omisión de las parejas del mismo sexo que mantienen una relación estable y duradera así como los derechos de los hijos de estas parejas.

El Comité de las Regiones alertaba de los problemas potenciales que la ausencia de un sistema de normas comunes de reagrupación familiar provocaría, especialmente ante la inminente ampliación de la UE: Habría una diversidad aún mayor de sistemas de reagrupación variando de un Estado miembro a otro, provocando confusión, retrasos en la resolución de los expedientes y la posible interposición de recursos invocando los derechos humanos o los derechos de la infancia ${ }^{516}$. Ante esta situación, el Comité recomendaba ${ }^{517}$, entre otras sugerencias, ampliar la definición obligatoria de familia para incluir a los compañeros no casados — incluyendo a las parejas del mismo sexo-, los hijos ilegítimos y los adultos a cargo del reagrupante, aproximar los derechos de acceso a la educación, el empleo y la formación profesional a los disfrutados por los ciudadanos europeos; incluir expresamente el carácter positivo del silencio administrativo en expedientes de reagrupación familiar, y dotar de recursos apropiados y suficientes a los entes locales ${ }^{518}$ y regionales - en tanto que instancias principalmente responsables de prestar servicios de apoyo a los inmigrantes allí asentados y por ello, las más afectadas por el coste de esos servicios de asistencia-, a fin de que pudiesen cumplir sus funciones adecuadamente.

El Parlamento Europeo fue consultado de nuevo a raíz de las modificaciones de la propuesta de Directiva introducidas por la Comisión, emitiendo su dictamen el 9 de abril de $2003^{519}$. El Parlamento, consciente de las "dificultades de conseguir acuerdos en asuntos tan sensibles como los relacionados con la inmigración", consideró no obstante que "la actual propuesta ha perdido toda su ambición originaria, reduce su ámbito de aplicación y en lugar de aproximar las legislaciones nacionales por arriba, lo que hace es aproximarlas por abajo, con vistas a conseguir un mínimo común denominador de las legislaciones en vigor en la materia en los distintos EEMM"520".

Las enmiendas formuladas por el Parlamento se centraban en los beneficiarios de la RF, insistiendo en la inclusión de las parejas no casadas o vinculadas por una unión inscrita —con indepen-

515 Ídem, puntos 4 y 5 del primer apartado.

516 Íbidem, apartados $1.1 .3 ; 1.1 .4 ; 1.1 .7$.

517 Apartados 2.2; $2.3 ; 2.5 ; 2.6$ y 2.10 del Dictamen del Comité de las Migraciones.

518 Sobre el papel que cumplen los entes locales en la integración de los extranjeros vid., entre otros, SCHIBEL, Yongmi. "Integration and the Role of Local Autorities"; European Journal of Migration and Law, Vol. 5, No 1, 2003, pp. 99-106.

519 El examen de fondo de la propuesta modificada de Directiva correspondió a la Comisión de Libertades y Derechos de los Ciudadanos, Justicia y Asuntos Interiores, adjuntándose al informe elaborado por dicho organismo, la opinión emitida por la Comisión de Asuntos Jurídicos y Mercado Interior. El informe fue aprobado en la sesión del 19 de marzo de 2003 por 26 votos a favor, 18 votos en contra y ninguna abstención, presentándose el 24 de marzo de 2003. El mismo constaba de dos partes claramente diferenciadas; la primera de ellas contenía el Proyecto de Resolución Legislativa del PE sobre la propuesta modificada de Directiva, a la que se habían adicionado 72 enmiendas; la segunda consistía en la opinión emitida por la Comisión de Asuntos Jurídicos y Mercado Interior en torno a la propuesta modificada de Directiva del Consejo sobre el derecho a la reunificación familiar. Informe sobre la propuesta modificada de Directiva del Consejo sobre el derecho a la reagrupación familiar. A5-0086/2003. PE 319.245.

520 Idem, Exposición de Motivos, p. 50. 
dencia del sexo- ${ }^{521}$, los hijos de dichas parejas, así como a los hijos adultos y los ascendientes en el caso de que carecieran de otros apoyos y dependiesen del reagrupante. Sugería la ampliación del ámbito de aplicación de la Directiva para cubrir a los refugiados y a las personas que gozaran de formas de protección subsidiaria, tal y como se preveía en la propuesta original de la Comisión. Introducía una cláusula de no discriminación ${ }^{522}$, a fin de asegurar el respeto de este principio al adoptar las decisiones de concesión del reagrupamiento familiar. Proponía la supresión de la posibilidad de aplicar criterios de integración a los hijos mayores de 12 años, por considerarla "una grave derogación del principio general que podría amparar injustificables diferencias de trato a los menores de edad entre los EEMM"523, así como bajar el tiempo de residencia previo legal exigido-, de dos a un año de residencia continua, como máximo - para que el reagrupante pudiese hacer venir a sus familiares, a fin de "no privar de sentido el ejercicio del derecho" ${ }^{24}$. También proponía modificaciones en los procedimientos administrativos, ampliando las garantías procesales y fijando el sistema de sanciones aplicables en caso de vulneración de las normas nacionales de aplicación, así como controlar el seguimiento de la aplicación de la Directiva por parte de los EEMM a través de la exigencia de la presentación de informes a la Comisión.

El Parlamento Europeo aprobó la propuesta modificada de la Comisión en la que proponía 72 enmiendas ${ }^{525}$. Solicitaba por ello a la Comisión que modificase en consecuencia su propuesta, conforme a lo establecido por el artículo 250.2 TCE.

Aunque esta propuesta suponía con carácter general una considerable reducción de los estándares de protección respecto de las propuestas previas, para los EEMM más conservadores todavía no era suficiente ${ }^{526}$. La estrategia adoptada por la Comisión, consistente en plegarse a las presiones de

521 El Parlamento aclaraba, sin embargo, que la disposición relativa a las parejas de hecho sería solamente aplicable en los EEMM donde tales relaciones se tratasen de forma similar a las parejas casadas. Su inclusión quedaba así sujeta a un importante matiz "en aquellos casos en que la legislación o la práctica del EM de acogida conceda a los compañeros inscritos o no casados un trato similar al que conceden a las parejas casadas". El objetivo de esta enmienda era "reflejar y respetar los distintos tipos de relaciones familiares existentes en la sociedad actual". Enmienda 10, Considerando 11; Enmienda 22, Artículo 4, apartado 1, letra a, respectivamente.

522 Enmienda 21, Artículo 3 ter (nuevo) del Proyecto de Resolución Legislativa propuesto por el Parlamento Europeo en su Informe.

523 Justificación de la Enmienda 26 (Artículo 4, apartado 1, párrafo tercero de la letra c).

524 Justificación a la Enmienda 47 (Artículo 8, párrafo 1).

525 El Parlamento propuso tantas enmiendas como artículos tenía la propuesta legislativa, "a fin de poner un título a cada uno de ellos. A través de los títulos de cada artículo se visualiza y se comprende de una forma rápida el contenido del mismo, facilitando de esta forma su estudio y acceso". Justificación a la enmienda 14.

526 PEERS, Steve. “Key Legislative..., op. cit., vol. 5, no 1, 2003, pp. 130-132. En torno a la cláusula stand still surgieron discrepancias, manifestando Alemania, España y Grecia objeciones porque esta disposición podía limitar la discrecionalidad de los EEMM. Grecia formuló una reserva contra el carácter preceptivo de la obligación de admitir a los miembros de la familia nuclear. Alemania, por su parte, deseaba restringir aún más la formación de la familia, estableciendo un período de espera de cinco años para poder proceder a reunirse con el cónyuge en dichos supuestos. Grecia, España y Portugal objetaban la autorización de entrada —aún siendo facultativa-, para las parejas no casadas, intentando introducir restricciones para impedir que tras su admisión pudiesen circular libremente dentro de la UE. Austria se unía a dichas objeciones, pero además este país propuso introducir la amenaza a la seguridad internacional como causa que habilitase para rechazar solicitudes de RF, junto a la exigencia de un certificado de salud y un test de conocimiento de la lengua con carácter previo a la entrada de los miembros de la familia, así como elevar el período de espera antes de la admisión a cinco años. Tan sólo un país, Suecia, proponía un tratamiento más beneficioso para las parejas de hecho registradas, sugiriendo que en estos casos la admisión debía ser obligatoria y criticando el establecimiento del límite opcional de 12 años para los hijos menores de edad de los inmigrantes legalmente establecidos en un EM, a quienes el tercer proyecto permitía, bajo ciertas condiciones, aplicar un criterio de integración con carácter previo a la autorización de su entrada. Alemania, en contra de su habitual postura restrictiva, proponía introducir a los parientes colaterales dentro de la definición de familiares 
los Estados más conservadores, ni siquiera funcionó. El texto resultante, caracterizado por una dramática devaluación de las garantías ofrecidas y de los estándares de protección, no había contentado a los Estados que siguieron presionando en sentido aún más restrictivo, formulando sus objeciones y expresando reservas incluso a algunas de las disposiciones más controvertidas ya introducidas y que, no obstante ello, seguían siendo consideradas demasiado generosas por algunos Estados miembros.

El ansiado logro del acuerdo político se logró en los debates habidos en la sesión del 27 de febrero de 2003 del Consejo de Justicia y Asuntos de Interior ${ }^{527}$. El consenso se pagó a un altísimo precio. En las negociaciones de última hora habidas en dicho Consejo, los EEMM habían acordado un texto que no solamente desoía las propuestas del Parlamento en el dictamen emitido en torno al tercer proyecto - y en el cual el Parlamento había formulado 72 enmiendas ${ }^{528}$-, sino que endurecía aún más el rigor del derecho a la reunificación familiar. Con carácter general, la versión final de la Directiva es aún más restrictiva que la ya de por sí rigurosa tercera propuesta de Directiva, que constituyó su antecedente más inmediato en el proceso de su elaboración.

Ante la entidad de las reformas habidas en las negociaciones finales, el procedimiento protocolario exigía que el Consejo hubiera informado nuevamente al Parlamento del nuevo texto y hubiera esperado a la emisión de su dictamen, antes de proceder a la aprobación definitiva de la Directiva. Sin embargo, la adopción formal de la Directiva por el Consejo, en la versión más restrictiva de todas cuantas habían visto la luz, tuvo lugar el 22 de septiembre de $2003^{529}$, sin tomar en consideración la opinión del Parlamento Europeo ${ }^{530}$. De modo que tras un dilatadísimo proceso de elaboración en el que el borrador de la Directiva había cumplido con todos los trámites establecidos en el artículo 262 TCE - incluso aquellos estipulados con carácter meramente facultativo- ${ }^{531}$, el texto final no observó el mismo rigor precisamente respecto a un trámite de carácter preceptivo. Ello constituía una grave omisión procedimental que sin embargo el Parlamento Europeo no denunciós32 ante el TJUE en el recurso de anulación que se interpuso posteriormente contra la Directiva de reunificación familiar.

Las negociaciones subsiguientes a la tercera propuesta de Directiva se habían traducido en un estrechamiento aún mayor del derecho a la reagrupación familiar de los nacionales de terceros países. Ante esta situación, no tardaron en alzarse voces de alarma procedentes de distintos sectores,

reagrupables con carácter facultativo, en circunstancias especialmente difíciles. Este país, junto con Italia y Austria, consideraban demasiado rígida la prohibición de entrada que pesaba sobre los hijos de matrimonios poligámicos cuando ya había una esposa con sus respectivos hijos menores establecida en el territorio del EM.

527 Sesión no 2489 del Consejo -Justicia y Asuntos de Interior-. Bruselas, 27 y 28 de febrero de 2003. C/03/42, 6162/03 (Presse 42).

528 El Parlamento Europeo había emitido su dictamen el 9 de abril de 2003. Las enmiendas introducidas por esta institución fueron rechazadas el mismo día en que fueron presentadas.

529 Sesión no 2525 del Consejo —Competitividad- Mercado Interior, Industria e Investigación-. Bruselas, 22 de septiembre de 2003. 12339/03 (Presse 259) C/03/259.

530 Para Walter esta omisión del Consejo subraya la "débil posición del Parlamento en este procedimiento legislativo". WALTER, Anne. "The New EU Directive on the Right to Family Unification"; BÖCKER, Anita, HART, Betty de (eds.) Migration and The Regulation of Social Integration. Institud für Migrationsforschung und INterkulturelle Studien (IMIS). IMIA_ BEITRÄGE. Universität Osnäbrück. Dinamarca, Julio 2004, pp. 111-118, Nota a pie de página, n. 2, p. 111. Disponible: http://www.imis.uni-osnabrueck.de/pdffiles/imis24.pdf

531 Entre los trámites no preceptivos figuraban la consulta al CESE y al Comité de las Regiones, que habían sido consultados en todos los sucesivos proyectos de directiva presentados.

532 Sin embargo, dicho vicio sí fue denunciado por la Coordinadora Europea para el Derecho de los extranjeros a vivir en familia, en el recurso que está en la base de la acción formulada por el PE. El texto del recurso de la Coordinadora Europea se encuentra disponible en www.coordeurop.org. Este vicio procedimental fue estudiado en profundidad por la Abogada General en el recurso de anulación parcial contra la Directiva, pero el TJUE no se pronunció al respecto en la sentencia que puso fin a dicho recurso. 
coincidentes todos ellos en argumentar que la propuesta de Directiva se situaba muy por debajo de los estándares mínimos fijados por el derecho internacional de los derechos humanos, concretamente por el artículo $8 \mathrm{CEDH}$.

Una red $^{533}$ de organizaciones cristianas activas en los ámbitos de la inmigración y el asilo, asesoradas al respecto por Pieter Boeles - académico experto en temas de migración de la Universidad de Leiden (Holanda) - , emitieron un comunicado conjunto ${ }^{534}$ poco después del acuerdo político alcanzado el 27 de febrero de 2003 en el Consejo de Justicia y Asuntos Interiores, reprobando el texto de la Directiva. Dichas organizaciones denunciaron múltiples disposiciones de la Directiva ${ }^{535}$, lamentando que, pese a que a lo largo de su elaboración habían alertado que el proyecto estaba por debajo de los estándares básicos de protección de los derechos humanos, ésta se hubiese aprobado en dichos términos, olvidando los ideales de Tampere ${ }^{536}$.

El 20 de febrero de 2003 el Prof. Groenendijk, —en su calidad de presidente del Comité Permanente de Expertos sobre Inmigración Internacional, Refugio y Derecho penal一, envió una carta $^{537}$ al por entonces Comisario Europeo de Justicia e Interior, Antonio Vitorino, solicitando que la Comisión Europea retirase la propuesta de Directiva. Tan sólo una semana después de que esta carta fuera enviada, el Consejo de Justicia y Asuntos Interiores, en su sesión de 27 de febrero de 2003, alcanzó el acuerdo político definitivo para la aprobación de la Directiva, en una versión

533 La red de organizaciones estaba constituida por Caritas Europa, International Catholic Migration Comission, Jesuit Refugee Service-Europe, Comission of the Bishops' Conferences of the EC Secretariat, Quaker Council for European Affairs, Churche's Comisión for Migrants in Europe.

534 El Comunicado tenía el expresivo título de "The New EU Directive on Family Reunification: Right for Families to Live Together or Right for EU Member States to Derogate From Human Rights?". Press Statement, Brussels, 4 de marzo de 2003. Disponible: http://www.cec-kek.org/English/Pressstatementfamreunfina20020304.pdf

535 Dichas organizaciones centraron sus preocupaciones en las siguientes cláusulas de la Directiva: a) Estimaban que la posibilidad de derogar el derecho a la RF a niños de más de 12 años, contenida en la Directiva y que procedía de la tercera propuesta, era una "clara violación de estándares internacionales". Argumentaban que el derecho de los niños a vivir o reunirse con sus padres está garantizado en la Convención de los derechos del niño "y el derecho internacional debe tener prioridad sobre la legislación nacional y consideraciones de control migratorio". b) Consideraban asimismo que el establecimiento de largos períodos de espera (de 2 a 3 años) sometían los lazos familiares a una tensión extrema y criticaban el establecimiento de un período de 9 meses e incluso más, para solventar las solicitudes de RF, ya que tales expedientes debían ser resueltos tan pronto como fuera posible. c) La garantía legal concedida por la Directiva era consideraba "muy débil, casi vacía", hasta el punto de situarla no sólo por debajo del nivel de protección exigido por los artículos 8 y 13 del CEDH, sino también por debajo del umbral de garantías exigido por el artículo 47 de la Carta Europea de Derechos Fundamentales.

536 Estas organizaciones apostillaban su elenco de agravios a la configuración comunitaria del derecho a la reunificación familiar de los nacionales procedentes de terceros países, reiterando sus dudas en torno al cumplimiento de los estándares internacionales de derechos humanos, en particular los establecidos por el artículo 8 CEDH. Concluían su argumentación con una contundente conclusión: "Con la adopción de esta Directiva, los EEMM no cumplen plenamente con su responsabilidad de implementar los estándares internacionales de derechos humanos en el proceso de armonización de la legislación comunitaria. Esta responsabilidad es aún mayor si se considera el rol de líder que corresponde a la UE en el marco de una unión con mayor número de Estados. La Directiva manda una señal equivocada a los países que accederán a la Unión Europea y a todos los demás países europeos"; “The New EU Directive on Family Reunification: Right for Families to live together or Right for EU Member States to derogate from Human Rights?", op. cit., sp.

537 El texto de esta carta se encuentra disponible en la siguiente dirección: http://europapoort.eerstekamer. nl/9345000/1/j9vvgy6i0ydh7th/vgbwr4k8ocw2/f=/vgeslffblyxz.pdf. Sin embargo, en sus escritos posteriores, el prof. GROENENDIJK cambiaría su postura inicial, manifiestando su alivio porque su sugerencia de retirar la propuesta no fuese atendida. Estima Groenendijk que con todas las críticas de las que sin duda es merecedora la Directiva 2003/86, como consecuencia de su bajo zócalo de protección, sin embargo ésta tiene la gran virtualidad de fijar un mínimo que no podrá ser infringido por los EEMM. 
aun más restrictiva que el tercer borrador ya analizado, precisamente la que había sido duramente criticada por Groenendijk.

Pese a ello, la respuesta del Comisario Vitorino no se hizo esperar, y el 20 de marzo de 2003 contestó a la carta enviada por el Prof. Kees Groenendijk ${ }^{538}$. En ella, Vitorino niega que la Directiva viole los estándares fijados por la jurisprudencia de Estrasburgo; frente al argumento reiterado del incumplimiento de los estándares internacionales por parte de la Directiva, Vitorino replica que el texto acordado respeta el balance entre el derecho a la unidad familiar y la responsabilidad estatal de controlar la inmigración, tal y como exige la jurisprudencia del TEDH emanada en torno al artículo $8 \mathrm{CEDH}$. La carta de Vitorino ${ }^{539}$ refleja el espíritu pragmático con que tuvieron que acometerse las fases finales de elaboración de la Directiva, ante la disyuntiva de que el proceso se viese eternamente paralizado por los EEMM - "un primer paso era mejor que ninguno" afirmaba Vitorino-. El texto señala abiertamente que los ambiciosos objetivos iniciales de Tampere no se han alcanzado. Ante esta situación, Vitorino postergaba para un futuro próximo la esperanza de que dichos objetivos se lograsen con mayor facilidad tras la aprobación de esta Directiva, en vista de que la misma establecía los cimientos en la materia, sobre los que poder profundizar en el futuro.

\section{LA DIRECTIVA 2003/86 DEL CONSEJO SOBRE EL DERECHO A LA REUNIFICACIÓN FAMILIAR: VERSIÓN FINAL}

Como hemos indicado, la versión definitivamente acordada de la Directiva vino precedida por tres propuestas, cada una de las cuales suponía un recorte mayor del derecho a la reunificación familiar. La última de éstas fue sustancialmente ${ }^{540}$ modificada por el Consejo sin considerar siquiera las observaciones del Parlamento Europeo. Finalmente la Directiva 2003/86 fue aprobada, no solamente eludiendo esperar al dictamen que esta institución debía haber emitido como consecuencia de las alteraciones de última hora que sufrió su texto, sino que tampoco incorporó las modificaciones que el Parlamento había propuesto en el informe previo elaborado en torno al tercer proyecto. Parecía que a los EEMM les urgía que el texto viera la luz, como también lo sugiere la premura que denota

538 El texto de la carta de respuesta enviada por Vitorino a Groenendijk se encuentra disponible en Internet: http:// www.commissiemeijers.nl/assets/commissiemeijers/Commentaren/gerelateerde_documenten/gerelateerde documenten 2003 /Antwoord van eurocommissaris Vitorino op Commissie Meijers brief aangaande gezinsherenignig, 20 maart 2003.pdf

539 En ella el comisario Vitorino afirmaba literalmente: "Negotiations on this directive were very long and very difficult (...).The bottom line was that the Member States were not able to agree on the Commission's original proposal and therefore considered that the best course of action was to try to at least reach agreement on a number of common principles (....). It must be clear that the first piece of legislation in the field of legal migration is nothing but a first steep (...). Therefore, although all our inicial ambitious goals have not yet been met, I do relieve, that there is real hope that further progress can and will be made and that the process in the future will be easier, given that the foundations have now been laid (...). It was with the above considerations in mind that I decided that it was not appropriate to withdraw the Commission's proposal. I considered that a first step was better than no step at all and that the adoption of this proposal would constitute a foundation on which to build in the future. I do hope for your support for this future work in the area of legal migration".

540 Las modificaciones introducidas son de tal calado, que la versión de la Directiva finalmentte aprobada el 22 de septiembre de 2003, en la Sesión no 2525, puede considerarse como "una cuarta versión definitiva pendiente de ulterior aprobación”. QUIRÓS FONS, A. “Derecho comunitario de extranjería: Directiva 2003/86/CE sobre reagrupación familiar y reforma del derecho interno español"; en Anales de Derecho, n² 21, 2003, Universidad de Murcia, p. 400 . 
la fecha prevista para su entrada en vigor, que se hizo coincidir con el mismo día de su publicación en el D.O.C.E. ${ }^{541}$.

A lo largo del azaroso y largo proceso de gestación de la Directiva se produciría un profundo distanciamiento entre las visiones de la inmigración correspondientes al Parlamento y la Comisión. Si bien el punto de partida para ambos órganos fue muy similar ${ }^{542}$, la Comisión terminaría plegándose y transigiendo a las exigencias crecientes de los $\mathrm{EEMM}^{543}$. De manera que, finalmente, la Comisión sería portadora de un concepto restrictivo de la migración familiar, frente al Parlamento Europeo, firme en su decisión de mantener el nivel de respeto a los derechos humanos de la Directiva. El hecho de que la Comisión desistiera de su primer proyecto - inspirado por los ideales de Tampere-, debe mucho al requisito de la unanimidad, que ejerció un efecto corrosivo sobre la configuración final de la RF al otorgar derecho de veto a cualquier Estado insatisfecho con los sucesivos proyectos de Directiva. El cambio de orientación se trasladó de la mesa de negociación al texto, afectando finalmente a todo el contenido del cuerpo definitivo de la Directiva.

Sin embargo, existían factores adicionales que, en conjunción con el requisito de la unanimidad, confluían en detrimento de la capacidad negociadora de los representantes de los EEMM ${ }^{544}$.

a) La inmigración en general, y la reunificación familiar en particular, constituye una materia extraordinariamente dinámica ${ }^{545}$, afectada por un altísimo grado de inestabilidad legislativa, fenómeno compartido por todos los Estados nacionales miembros de la UE. Los representantes de los EEMM acudían al proceso negociador comunitario con restricciones impuestas por una legislación nacional vigente o que se encontraba en proceso de aprobación

541 La directiva venía marcada por el apremio en su entrada en vigor, muy superior a sus precedentes durante el laborioso proceso de gestación. La fecha de entrada en vigor de la directiva fue adelantándose en los proyectos sucesivos, incurriendo así en un baile de fechas bastante revelador de las prisas con las que en parte se pretendía, si no contrarrestar el enorme retraso con el que esta norma veía la luz — casi cuatro años—, sí al menos no seguir contribuyendo a su dilación. Si la propuesta original fijaba para la entrada en vigor de la directiva el vigésimo día siguiente al de su publicación en el DOCE (artículo 20 de la propuesta original), en la tercera propuesta la fecha se había anticipado, pasando a ser "el día siguiente de su publicación en el DOCE “ (artículo 21 de la tercera propuesta), para, finalmente, hacerse coincidir la entrada en vigor con el mismo día de su publicación en el DOCE (artículo 21 de la directiva en su versión definitiva). En consecuencia, su entrada en vigor se produjo el día 3 de octubre de 2003, cuando el texto oficial de la Directiva fue publicado en el DOCE.

542 Una interpretación distinta la sostiene Moliner Navarro, para quien durante la elaboración de esta norma comunitaria se habría revelado un conflicto subyacente entre el Parlamento y la Comisión. El primero partidario de una visión liberal y extensiva del derecho, frente a la Comisión preocupada por aspectos de seguridad y por el incremento numérico en las entradas y, por ello, proclive a una visión restrictiva del derecho. Para esta autora, "el texto final de la Directiva revela sin paliativos que ha vencido sustancialmente el planteamiento de la Comisión: la familia nuclear como sujeto básico del derecho y la discrecionalidad de los Estados como regla general en la regulación del derecho". MOLINER NAVARRO, Rosa Ma. "El concepto de familia nuclear..., op. cit., p. 1795.

543 En el mismo sentido, Cicirello afirma que la directiva "risente dei compromessi che la Commissione Europea è stata costretta ad accettare per evitare che la sua proposta fosse respinta e certamente del fatto che la Comunitá non ha competenza esclusiva nell'ambito dei settori che rientrano nel Titolo IV TCE”. CLELIA CICIRIELLO, Maria. "Ricongiungimento Familiare come diritto fondamentale del migrante"; en Comunità internazionale, Vol. 61, №. 1, 2006, pp. 115-116.

544 GONZÁLEZ SÁNCHEZ, Enrique. "Asilo e inmigración en la Unión Europea”; Revista de Derecho Comunitario Europeo, No 13, septiembre/diciembre 2002, p. 849.

545 En esta línea, se ha señalado que "EU Asylum and immigration law is a Fast-moving field". BALDACCINI, Anneliese; TONER (Helen). "From Amsterdam and Tampere to the Hague: An Overview of Five Years of EC Immigration and Asylum Law"; BALDACCINI, Anneliese; GUILD, Elspeth and TONER, Helen (eds.). Whose Freedom, Security and Justice?. EU Immigration and Asylum Law and Policy. Hart Publishing, Oxford and Pórtland, Oregon, 2007, p. 1. 
en sus respectivos Parlamentos nacionales ${ }^{546}$.

b) La visión negativa que del fenómeno migratorio calaba en la opinión pública de las sociedades receptoras ${ }^{547}$ - y que fomentaban los medios de comunicación-, no hacía sino incrementar las presiones de los representantes de los EEMM ante propuestas liberales.

c) Cabría señalar una circunstancia añadida que nos remonta al panorama jurídico que, en materia de RF, existía en el momento previo a la aprobación de la Directiva 2003/86. Tras más de una década de intentos, a principios del siglo XXI la RF en el ámbito comunitario emergía como un ámbito en el que las escasas normas consensuadas carecían de eficacia jurídica, dificultando la existencia de un régimen homogéneo. Pese a ello, las regulaciones internas no eran tan divergentes ${ }^{548}$. En los EEMM se había logrado un grado notable de aproximación respecto a los presupuestos que regían la regulación de la reunificación familiar de los ciudadanos procedentes de terceros países ${ }^{549}$ como consecuencia de las influencias recíprocas de las políticas migratorias ${ }^{550}$, propiciadas asimismo por la Resolución armonizadora de 1993.

546 En palabras de González Sánchez "La flexibilidad negociadora de los representantes de los Estados miembros en el marco del Consejo viene muy limitada por el hecho de que todos ellos acaban de adoptar sus propias normas nacionales en materia de asilo e inmmigración o bien la adopción de nuevas disposiciones legislativas es objeto de discusión en sus parlamentos nacionales. En estas circunstancias, los representantes nacionales en el marco del Consejo tienden o bien a bloquear las negociaciones para el desarrollo de la legislación comunitaria a la espera de que se proceda a la adopción de la propia legislación nacional, o bien, una vez esta última aprobada, a tratar que el contenido de las nuevas normas comunitarias en discusión coincida con el de las normas nacionales recientemente aprobadas, manifestando con ello escasísima flexilidad en la búsqueda de un compromiso. Si se tiene en cuenta que la generalidad de los Estados miembros se encuentran en una situación similar y que incluso habiendo adoptado legislaciones nacionales muy recientes se prevén ya nuevas modificaciones de las mismas a efecto de adaptarse a las situaciones cambiantes que van produciéndose en estos ámbitos, se comprende la dificultad para llegar a compromisos en el marco del Consejo para el desarrollo de la política europea”. GONZÁLEZ SÁNCHEZ, Enrique. "Asilo e inmigración en la Unión Europea”, op. cit., pp. 849-850.

547 ARANGO, Joaquín. “Tampere 2: Nuevos retos y perspectivas para la política de inmigración europea”; Cinco años después de Tampere. II Seminario Inmigración y Europa. Cidob, 2005, p. 151.

548 Una vision distinta, que subraya las diferencias entre los EEMM se encuentra en VELÁZQUEZ SÁNCHEZ, Ma del Mar. "La reagrupación familiar en la Unión Europea: comentario a la directiva 2003/86"; en Revista General de Derecho Europeo, № 4, 2004, p. 2; ABARCA JUNCO, A.P. y VARGAS GÓMEZ-URRUTIA, M. "Artículo 16 y artículo 17"; op. cit., p. 421. Para un estudio de las particularidades internas en la regulación de la RF en algunos países comunitarios vid. FERÁNDEZ SÁNCHEZ, Pablo Antonio. Derecho comunitario de la inmigración. op. cit., pp. 233-239.

549 En el año 2000 se publicó un estudio emprendido bajo los auspicios del Consejo de Europa que analizaba la legislación vigente sobre RF en diez Estados miembros. El estudio concluía con lo que calificaba como "sorprendentes similitudes" entre los derechos internos de los EEMM relativos a la RF de la mayoría de los Estados analizados. En temas esenciales, las disposiciones nacionales eran similares, pese a ello, las concretas condiciones de ejercicio de la RF diferían entre los EEMM. PEERS, Steve; BARZILAY, Robin; GROENENDIJK, Kees; GUILD, Elspeth. The Legal Status of Persons admitted for Family Reunion. Council of Europe Publishing, Centre for Migration Law, University of Nijmegen, The Netherlands, January 2000. http://www.coe.int/t/dg3/migration/documentation/Legal_texts/Family\%20Reunion_report_en.pdf; GOENENDIJK, Kees; GUILD, Elspeth. “Converging Criteria: Creating an Area of Security of Residence for Europe's Third Country Nationals"; European Journal of Migration and Law, no 3 , 2001, p. 40; VELÁZQUEZ SÁNCHEZ, Ma del Mar. “¿La regulación del derecho a la reagrupación familiar o defensa de una política restrictiva de la inmigración? Comentario a la Sentencia del TJUE de 27 de junio de 2006, C-540/2003"; en Revista General de Derecho Europeo, No 12, 2007, s.p.

550 Brinkmann señalaba en este sentido: "Member States' legislation in this field used to vary greatly. National interest and attitudes, however, have become increasingly compatible. Immigration policies of one country have echoes in other Europen countries. Both with regard to policy developments, and policy outcomes, or numbers, nacional disparities appear to be narrowing. The process could be best described as approximation rather than harmonisation of immigration policy in the field of family reunification". BRINKMANN, Gisbert. "Family Reunion, Third Country Nationals and the Community' New Powers", op. cit., p. 250 
d) Persistían sin embargo algunas divergencias ${ }^{51}$ respecto a determinados elementos integrantes del contenido del derecho, especialmente en materia de la regulación de las concretas condiciones de ejercicio y el estatuto de los familiares admitidos por motivos de RF. Precisamente sobre dichos aspectos diferenciados surgiría el bloqueo, convirtiéndose así en puntos de fricción a lo largo de la elaboración de la Directiva. La persistencia de estas divergencias entre las regulaciones nacionales se explica por una circunstancia que afecta especialmente a la migración familiar, en tanto que instrumento de control de entradas. Las políticas de admisión están vigorosamente influidas por cuestiones económicas, culturales y demográficas, así como por lazos históricos y por la situación geográfica del Estado receptor ${ }^{552}$. En el ámbito migratorio, las mayores dificultades para el consenso entre los EEMM afectan pues a las condiciones establecidas para la admisión de no nacionales por primera vez en el Estado receptor, donde se insertan las políticas de RF.

e) Los temores de los Estados ante los efectos multiplicadores de la reunificación y sus consecuencias tanto sobre los mercados laborales autóctonos - los familiares reagrupados terminan, más pronto o más tarde, integrándose en el mercado de trabajo-, como sobre sus sistemas públicos de bienestar social.

Estas circunstancias explican las diferencias existentes entre la propuesta original y la redacción final de la Directiva. El resultado de la negociación nos sitúa ante un texto sucesiva y crecientemente debilitado ${ }^{553}$ o, recogiendo la poética y descriptiva analogía de Arango, la propuesta terminaría encallando en los "formidables arrecifes que suponen las fuertes reticencias de algunos EEMM"554. En el trayecto, el derecho a la RF sufrió un constante y significativo proceso de devaluación ${ }^{555}$, conforme al cual múltiples elementos del derecho se vieron considerablemente mermados o del todo amputados: la lista de familiares reagrupables se redujo; se eliminó el derecho a la libre circulación que se había otorgado inicialmente a los familiares reagrupados; el margen de apreciación estatal resultó considerablemente incrementado mediante la introducción de cláusulas que confieren flexibilidad a los EEMM y la incorporación de disposiciones excepcionales que permiten derogaciones al régimen general; se endurecieron los requisitos a que se somete el ejercicio del derecho, entre ellos, significativamente, el incremento de los períodos de residencia legal previa - períodos de espera- para el ejercicio del derecho a la RF. En definitiva, la Directiva opta por un nivel de protección que privilegia la "prevalencia del status quo"556.

La Directiva está afectada por las mismas asimetrías geográficas que lastran el derecho comunitario de la inmigración. Según se hace explícito en sus considerandos 18 y 19, Reino Unido, Irlanda y Dinamarca no participan en su adopción ni están obligados ni sujetos por su aplicación. Para los

551 GOENENDIJK, Kees; GUILD, Elspeth. "Converging Criteria: Creating an Area of Security of Residence for Europe's Third Country Nationals”, op. cit., p. 43. Estos autores destacan que las diferencias eran especialmente acusadas respecto al estatus de los miembros de la familia admitidos por motivos de reagrupación familiar. Idem, p. 45.

552 Ibidem, p. 53.

553 PEERS, Steve. “Key Legislative...”, op. cit., p. 402. Alvarez Rodríguez califica el largo proceso como "un verdadero vía crucis, con múltiples estaciones, que cada vez que se iniciaba una nueva estación, el texto propuesto se levantaba —elevaba- mucho más debilitado”. ÁLVAREZ RODRÍGUEZ, A. “Algunas reflexiones urgentes...”, op. cit., p. 4.

554 ARANGO, Joaquín. "Dificultades y dilemas de las políticas de inmigración”, op. cit., p. 66. ARANGO, Joaquín. “Tampere 2: Nuevos retos y perspectivas para la política de inmigración europea”; en AAVV. Cinco años después de Tampere. II Seminario inmigración y Europa. Madrid, CIDOB, 2005, p. 151.

555 ARANGO, Joaquín. “Tampere 2: Nuevos retos y perspectivas para la política de inmigración europea”, op. cit., p. 151.

556 MOLINER NAVARO, R. "El concepto de familia nuclear..., op. cit., p. 1794. 
restantes EEMM, la Directiva, - en cuanto acto de derecho comunitario derivado-, es una norma vinculante respecto a sus resultados, dejando en manos de los EEMM la opción de los medios que estimen más convenientes para su logro. Conforme a lo establecido en el artículo $20^{557}$ de la Directiva, la fecha tope para su transposición en los EEMM se cumplió el 3 de octubre de 2005. Este plazo rige también para los diez Estados que accedieron a la UE en mayo de 2004, en vista de que a todos ellos se les exigió aceptar el acquis comunitario ${ }^{558}$.

\subsection{Principios inspiradores: Preámbulo}

La Directiva sobre el derecho a la RF se estructura en dos partes perfectamente delimitadas. La primera de ellas está integrada por un preámbulo, a modo de exposición de motivos, que consta de 18 considerandos; la segunda consiste en el cuerpo sustantivo de la norma, constituido por 22 disposiciones. La importancia del preámbulo no debe subestimarse, pues aunque carece de eficacia jurídica en sentido propio, constituye una herramienta interpretativa de primer orden $^{559}$ para arrojar luz sobre el sentido de las disposiciones que integran la Directiva, especialmente útil si éstas tienen puntos oscuros o ciertas contradicciones. Así ha quedado demostrado por la actitud del Tribunal de Justicia de las Comunidades Europeas en los recursos a que esta norma ha dado origen, que serán estudiados con posterioridad. En el Preámbulo, la Directiva recuerda que la norma se integra dentro del cumplimiento del objetivo político, _-introducido por el Tratado de Ámsterdam-, de instauración progresiva de un espacio de libertad, seguridad y justicia, encajándola en el nuevo panorama competencial trazado por el mismo Tratado ${ }^{560}$.

Conscientes de que la reciente atribución competencial no se producía en el vacío, sino en un panorama fuertemente condicionado por derechos procedentes del ámbito internacional ${ }^{561}$ la Directiva, desde sus primeros borradores, tuvo muy presente la necesidad de acoplarse a los compromisos internacionales en el ámbito de los derechos humanos, haciéndolo explícito en las diversas exposiciones de motivos que precedieron a dichos textos. En esta línea, la Directiva, en su considerando segundo, $-\mathrm{y}$ al igual que sus precedentes - , enuncia la obligación de proteger la familia y el respeto de la vida familiar como bases jurídicas internacionales que han de respetarse en el establecimiento de medidas sobre reagrupación familiar. A renglón seguido se autoproclama respetuosa con los derechos fundamentales y principios del ámbito internacional en los siguientes términos: "La presente Directiva respeta los derechos fundamentales y observa los principios reconocidos en particular por el artículo 8 del Convenio Europeo para la Protección de los Derechos Humanos y de las Libertades

557 El artículo 20 de la Directiva 2003/86 prevé que los distintos EEMM vayan informando de la transposición de la presente Directiva a la Comisión, según dichos procesos vayan teniendo lugar.

558 ECRE Information Note on the Council Directive 2003/86/EC of 22 September 2003 on the right to family reunification. European Council on Refugees and Exiles. Disponible en: http:// www.proasyl.de/texte/europe/union/2003/ ECRE\%20on\%20family\%20reunification.pdf

559 Kees GROENENDIJK señala el valor interpretativo del preámbulo de la Directiva tanto para el TJUE como para los tribunales internos al implementar la Directiva. En este aspecto, considera de especial importancia el apartado segundo del preámbulo.

560 Apartado primero del Preámbulo de la Directiva 2003/86.

561 Osterom-Staples, al analizar el texto de la directiva, afirmó que "aunque la reciente transferencia de poder a la Comunidad para regular la reunificación familiar sugiera un lienzo en blanco, este no es el caso. La realidad era que numerosas obligaciones internacionales de los EEMM relativas al respeto de la vida familiar tenían que ser acomodadas". OOSTEROM-STAPLES, Helen. "The Family Reunification Directive: A Tool Preserving Member State Interest or Conducive to Family Unity?"; en BALDACINI, Anneliese, GUILD, Elspeth and TONER, Helen (eds.). Whose Freedom, Security and Justice?. EU Immigration and Asylum Law and Policy. Oxford and Pórtland, Oregon, Hart Publishing, 2007, p. 452, traducción propia 
Fundamentales y por la Carta de los Derechos Fundamentales de la Unión Europea"562. Con esta proclamación, la Directiva viene a subrayar la importancia para la configuración de la reunificación familiar en la UE del CEDH y la Carta de DDFFUE, "destinados a ser el contexto interpretativo del derecho a la vida familiar en el ordenamiento comunitario"563.

Siguiendo también a los proyectos previos, el preámbulo de la Directiva contempla una concepción amplia de la reunificación familiar ${ }^{564}$. Conforme a ella, las finalidades que persigue el reconocimiento del derecho a la reunificación familiar serían tres: (a) garantizar la protección de la familia, (b) el mantenimiento de la vida familiar y (c) la creación de la vida familiar. En estas finalidades se apunta ya la noción extensa de RF, que abarcaría tanto a la reagrupación en sentido estricto - dirigida a proteger el "mantenimiento de la vida familiar", amparando los vínculos familiares que preceden a la entrada del inmigrante en el EM-, como a la denominada formación de la familia — que pretende tutelar la "creación de la vida familiar", protegiendo aquellos vínculos familiares que se han constituido con posterioridad a la entrada y residencia del reagrupante en el Estado receptor.

En coherencia con esta visión amplia, la definición de la reagrupación familiar aparece contenida en el apartado c) del artículo 2 en los siguientes términos: "la entrada y residencia en un EM de los miembros de la familia de un nacional de un tercer país que resida legalmente en dicho EM con el fin de mantener la unidad familiar, con independencia de que los vínculos familiares sean anteriores o posteriores a la entrada del reagrupante" ${ }^{565}$.

El preámbulo contiene además una innovadora cláusula antidiscriminatoria ${ }^{566}$. A tenor de la misma, "los EEMM deben aplicar las disposiciones de la presente Directiva sin ningún tipo de discriminación por razón de sexo, raza, color, origen étnico o social, características genéticas, lengua, religión o ideología, opiniones políticas o de otro tipo, pertenencia a minoría nacional, fortuna, nacimiento, minusvalía, edad u orientación sexual'567. La inclusión de la nacionalidad como causa expresa de discriminación ha sido convenientemente sustituida por la referencia a "pertenencia a minoría nacional".

Asimismo, el preámbulo constata la insuficiencia de los Estados para hacer frente en solitario a un fenómeno global como es la inmigración y la mejor posición de la UE, "debido a las dimensiones

562 Así, de forma explícita, ambas fuentes se alzan como parámetros de validez de la presente directiva; función que el artículo $8 \mathrm{CEDH}$ venía ya desarrollando desde que la comunidad empezó a coquetear tímidamente con la extranjería, pero que, respecto de la Carta de DDFF de la UE, constituye toda una novedad, especialmente si se considera su naturaleza jurídica en el momento en que fue aprobada la Directiva 2003/86/CE.

563 SANTOLAYA MACHETTI, Pablo. El derecho a la vida familiar de los extranjeros. Valencia, Tirant lo blach, 2004, p. 129.

564 El apartado noveno afirma al respecto que "con el fin de garantizar la protección de la familia, así como el mantenimiento o la creación de la vida familiar, es importante fijar, según criterios comunes, las condiciones materiales para el ejercicio del derecho a la reagrupación familiar".

565 La terminología usada resulta, algo inexacta ya que si la finalidad de la RF es el mantenimiento de la unidad familiar tal y como reza este artículo, lo lógico sería permitir y/o fomentar únicamente la reagrupación de aquellos parientes o miembros de la familia cuyos vínculos preexistían a la entrada del extranjero en el territorio del Estado receptor. Sin embargo, con buen criterio jurídico, - aunque no terminológico-, la definición de RF contenida en la Directiva ampara un concepto amplio de RF, que incluiría tanto la RF en sentido estricto como la denominada formación de la familia o inmigración matrimonial.

566 Los proyectos previos contenían prohibiciones concretas de discriminación tomando como referencia a los ciudadanos comunitarios. Así, al regular las condiciones económicas y materiales que los EEMM podían establecer al ejercicio del derecho, se establecía una concreta cláusula antidiscriminatoria. Esa referencia finalmente se eliminó y, en su lugar, se incluyó una disposición de carácter general en el preámbulo de la directiva en su versión definitiva.

567 Apartado quinto del Preámbulo. 
o a los efectos de la acción ${ }^{568}$, para adoptar medidas en este ámbito. Sin embargo, la acción comunitaria - el establecimiento del derecho a la reagrupación familiar según modalidades comunesdebe estar regida por dos principios, el principio de subsidiariedad y el principio de proporcionalidad, ambos establecidos en el artículo 5 TCE. Acorde a este último principio, "la presente Directiva no excede de lo necesario para alcanzar dichos objetivos" - afirma el apartado 16 del preámbulo, anticipando así tempranamente el carácter mínimo de la Directiva-.

Conforme se establece en el cuerpo sustantivo de la Directiva, sus disposiciones son de carácter mínimo. Así se deriva con claridad de lo dispuesto en los apartados 4 y 5 del artículo $3^{\circ}$, conforme a los cuales los EEMM pueden adoptar o conservar disposiciones más favorables a las establecidas en la presente Directiva, contenidas en acuerdos bilaterales y multilaterales entre la Comunidad o la Comunidad y sus EEMM, por una parte, y terceros países. Esto supone tanto acuerdos previos como los que se adopten con posterioridad ${ }^{569}$ a la presente Directiva, lo que implica una ampliación respecto a lo establecido en propuestas previas ${ }^{570}$. Especificar el carácter mínimo de la Directiva constituye una importante precisión a fin de evitar las ambigüedades que sobre esta cuestión pendían en la etapa in-

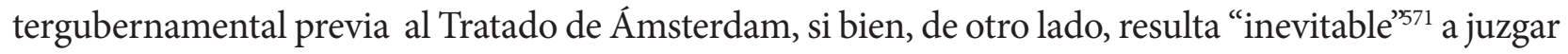
por los estándares tan bajos fijados por la Directiva a partir de su tercera versión. Es de destacar la ausencia de referencias expresas al CEDH que, aunque aparece mencionado en el preámbulo - apartado segundo-, continúa ausente en esta disposición que pretende salvaguardar el poder de los EEMM de fijar estándares de protección más elevados a los establecidos en la Directiva. Esta omisión fue criticada por la doctrina desde el primer borrador de Directiva presentado, y continuó invariable desde entonces hasta llegar a la versión final. Las referencias a convenios internacionales se limitan a la Carta Social Europea de 18 de octubre de 1961, la Carta Social Europea modificada de 3 de mayo de 1987, y al Convenio Europeo relativo al estatuto jurídico del trabajador migrante de 24 de noviembre de $1977^{572}$.

\subsection{Los objetivos expresos de la Directiva}

En conjunción con el artículo primero de la Directiva 2003/86 - que aborda explícitamente el objetivo que persigue esta norma-, el Preámbulo resulta de especial utilidad para extraer los obje-

568 Al respecto, el apartado 16 afirma textualmente: "Dado que los objetivos de la acción pretendida, a saber, el establecimiento de un derecho a la reagrupación familiar de los nacionales de terceros países que se ejerza según modalidades comunes, no pueden ser alcanzados de manera suficiente por los EEMM y, por consiguiente, pueden lograrse mejor, debido a las dimensiones o los efectos de la acción, a nivel comunitario, la Comunidad puede adoptar medidas, de acuerdo con el principio de subsidiariedad consagrado en el artículo 5 del Tratado. De conformidad con el principio de proporcionalidad enunciado en dicho artículo, la presente Directiva no excede de lo necesario para alcanzar dichos objetivos".

569 En el mismo sentido, PEERS, Steve. "Family Reunion and Community Law". WALKER, Neil (ed.). Europe's Area of Freedom, Security and Justice. Oxford, New York, Oxford University Press, 2004, p. 179.

570 Los dos primeros borradores de la Directiva acotaban el ámbito a aquellos acuerdos internacionales que hubiesen entrado en vigor antes de la fecha de entrada en vigor de la Directiva, limitación que se eliminó en la tercera versión, continuando intacta desde entonces.

571 En palabras de Steve Peers, al interpretar la tercera propuesta, — de dónde se deriva la presente disposición de la Directiva en su actual redacción-: "It will be possible for the EC or Member States to apply higher standards following conclusion of later International treaties, not just earlier International treaties, and also permit Member States to apply higher standards in their internal law. While these changes raise standards compared to the 2000 version, the minimum standards set by the Directive are now so low that granting the power to set higher standards was inevitable". PEERS, S. Key "Legislative Developments on Migration in the European Union"; European Journal of Migration and Law, vol. 5, No 1, 2003, p. 128.

572 Apartado b) del artículo 3.4 de la Directiva 2003/86/CE sobre el derecho a la RF. 
tivos que, al menos formalmente, persigue la comunidad con la presente Directiva. Sin embargo, del estudio detallado de las disposiciones de la Directiva quizá sea posible deducir otros objetivos implícitos, políticamente no tan correctos como para ser declarados expresamente, y a cuya consecución contribuyen las disposiciones consensuadas en esta norma comunitaria.

El análisis tanto de los objetivos declarados como de los no tan abiertamente proclamados, así como de la concreta regulación establecida para su ejecución, nos ofrecerá un marco idóneo para ilustrar las facetas problemáticas que conviven en la inmigraciones familiar y que la convierten simultáneamente en un derecho irrenunciable pero también en un dilema difícil de encarar para los Estados democráticos ${ }^{573}$. Empezaremos por los expresamente confesados, pues deducir los objetivos implícitos exige analizar con detenimiento el contenido de la Directiva.

En el conjunto del preámbulo se identifican con claridad tres finalidades de la Directiva conectadas de forma inmediata al objetivo expresamente mencionado en el primer artículo de esta norma ${ }^{574}$ :

\section{La Directiva y la concesión de un derecho a la reunificación familiar a los extranjeros procedentes de terceros países}

El objetivo de la Directiva, tal y como establece su artículo primero, "es fijar las condiciones en las cuales se ejerce el derecho a la reagrupación familiar de que disponen los nacionales de terceros países que residen legalmente en el territorio de los EEMM".

De este objetivo cabe hacer un par de observaciones de importancia capital para aproximarnos a la regulación de la RF: En primer lugar, _ pese a que la generalidad de su título podría inducir a pensar otra cosa-, la Directiva no contempla un genérico derecho a la reagrupación familiar para las personas que residen en territorio comunitario, sino tan sólo para aquellas familias íntegramente constituidas por ciudadanos de terceros paíse ${ }^{575}$. En segundo lugar, la redacción de esta disposición contrasta con la establecida en el artículo equivalente del texto de la primera propuesta, donde se afirmaba que su objetivo era "establecer un derecho a la reagrupación familiar". De ahí que el cambio operado en la redacción suscite dudas en torno a la cuestión de si la Directiva genera un auténtico derecho subjetivo reclamable ante las autoridades internas de los EEMM.

La respuesta a esta última cuestión dependerá de dos aspectos: de un lado, de la naturaleza jurídica vinculante de la norma que sirve de soporte a la regulación comunitaria de la RF; de otro, del concreto contenido sustantivo de dicha norma. Desde ahora mismo es posible cerrar la primera de las cuestiones: la Directiva, en tanto que norma de derecho comunitario derivado, constituye una norma vinculante para los EEMM, si bien no con la exhaustividad que es predicable de los Reglamentos $^{576}$. Esta situación es más patente si la contrastamos con la situación preexistente a la Directi-

573 Sobre las contradicciones inherentes a la RF, y las dificultades para aunar las exigencias derivadas de los derechos humanos con los intereses estatales en el control de los flujos migratorios, resulta de especial interés; LAHAV, Gallya. "International versus National Constraints in Family-reunification Migration Policy"; en Global Governance, No 3 (3), Sept-Dec 1997, pp. 349-372.

574 El artículo primero afirma que "el objetivo de la presente Directiva es fijar las condiciones en las cuales se ejrce el derecho a la RF de que disponen los nacionales de terceros países que residen legalmente en el territorio de los Estados miembros".

575 La definición de nacional de un tercer país está establecida en el párrafo a) del artículo 2, por referencia a la ciudadanía de la Unión, incluyendo a "cualquier persona que no sea ciudadana de la Unión en los términos del apartado 1 del artículo 17 del Tratado".

576 MANGAS MARTÍN, Araceli y LIÑÁN NOGUERAS, Diego. Instituciones y Derecho de la Unión Europea, op.cit. p. 366. 
va, caracterizada por la existencia de normas carentes de vinculatoriedad jurídica que impedían a su vez el despliegue normativo de la RF de los ciudadanos extracomunitarios en la UE.

En auxilio de esta primera conclusión concurre además el propio título de la Directiva, donde se califica a la reunificación familiar que se pretende regular como "derecho". El título de esta norma permaneció invariable a lo largo de la elaboración de la Directiva, pese a los numerosos cambios en sentido restrictivo que afectaron a su contenido sustantivo, lo que prima facie aboga por una concepción de la RF como derecho subjetivo ${ }^{577}$.

En principio, cabría pues concluir con carácter preliminar que el cambio operado en la redacción del objetivo de la Directiva no afecta en principio a la naturaleza jurídica del derecho que regula. Ahora bien, como explicaremos en las siguientes páginas, el problema estriba en el concreto contenido sustantivo de la Directiva. Por las circunstancias en que se desarrolló su gestación, podemos adelantar ya que dicho derecho se halla limitado por condiciones onerosas ${ }^{578}$ y sometido a un umbral bajo de protección, lo que le dota de un estatuto precario. De ahí que la respuesta definitiva en torno a la naturaleza jurídica del derecho a la RF de los nacionales procedentes de terceros países deba por ahora aplazarse, pues sólo podrá ofrecerse tras un estudio de la regulación contenida en la Directiva 2003/86.

\section{La Directiva como instrumento armonizador de la RF en el ámbito comunitario}

La Directiva pretende aproximar las regulaciones nacionales en la materia, estableciendo condiciones comunes para el ejercicio del derecho a la reagrupación familiar. Los apartados 3, 6 y 16 del Preámbulo son particularmente relevantes en este aspecto. Este objetivo guarda estrecha coherencia con la "necesidad de armonizar las legislaciones nacionales sobre las condiciones de admisión y de residencia de los nacionales de terceros países", fijado en el Consejo Europeo de Tampere de 1999, y que se reitera en el considerando tercero del preámbulo.

Especialmente explícito es el apartado 16, conforme al cual "los objetivos de la acción pretendida son (...) el establecimiento de un derecho a la reagrupación familiar de los nacionales de terceros países que se ejerza según modalidades comunes". En similar sentido se manifiesta el apartado 6, donde se afirma que "con el fin de garantizar la protección de la familia (...) es importante fijar, según criterios comunes, las condiciones materiales para el ejercicio del derecho a la reagrupación familiar".

Para comprobar la adecuación de la Directiva para el establecimiento de un marco armonizado para el ejercicio de la reagrupación familiar, es imprescindible observar la intensidad del margen de apreciación otorgado por la Directiva a los Estados, ya que elevados márgenes de apreciación estatal actúan en detrimento del objetivo armonizador.

Sin embargo, la valoración en sus justos términos de este objetivo requiere previamente recordar la naturaleza jurídica del instrumento jurídico en que se regula la RF y que servirá de soporte a la armonización, pues éste influirá a su vez sobre su consecución. Es consustancial a toda Directiva la concesión de cierto margen de maniobra a los EEMM ${ }^{579}$. Obviamente, la intensidad de dicho mar-

577 En el mismo sentido, SCHAFFRIN, Dora. "Which Standard for Family Reunification of third-country nationals in the European Union?”. op. cit., p. 99.

578 CHOLEWINSKI, R. "Family Reunion and Conditions Placed on Family Members: Dismantling a Fundamental Human Right"; en European Journal of Migration and Law, 2002, no 4, pp. 271-290.

579 MANGAS MARTÍN, Araceli y LIÑÁN NOGUERAS, Diego. Instituciones y Derecho de la Unión Europea, op. cit., p. 367. 
gen será inversamente proporcional al grado de armonización posible. En consecuencia, la opción por una Directiva condiciona en parte el objetivo armonizador en diversos sentidos: por un lado, concede cierto grado de flexibilidad a los EEMM encargados de su transposición, quienes han de elegir los medios más aptos para el logro de los resultados prescritos por la Directiva; por ello, las normas de la Directiva son una especie de "disposiciones marco en las que los Estados deberán fijarse en el futuro para regular la RF en su ordenamiento interno"s80. Esta circunstancia otorga a su vez un enorme protagonismo a los Estados parte y a las características peculiares de sus regímenes nacionales, durante el proceso de transposición y aplicación interna ${ }^{581}$ de la Directiva.

\section{La armonización ha de llevarse a cabo conforme a los principios fijados en el Consejo Europeo de Tampere y posteriormente reafirmados en Laeken}

Los principios establecidos tanto en Tampere como en Laeken, son reiterados casi literalmente por el apartado tercero del preámbulo. De dicha disposición se extrae que la armonización de las normas relativas a la RF de los nacionales procedentes de terceros países que residan legalmente en el territorio de los EEMM, debe construirse en torno a dos pilares básicos: trato justo e integración más decidida, - entendida esta última como la concesión de derechos a los nacionales extracomunitarios comparables a los disfrutados por los ciudadanos comunitarios- En una línea similar, la Directiva afirma que "debe fomentarse la integración de los miembros de la familia" ${ }^{82}$.

Cabría pues afirmar que la Directiva se concibió, al menos inicialmente, como un instrumento para fomentar la integración de los inmigrantes residentes legales en algún país de la UE ${ }^{583}$. En apoyo de esta concepción, se encuentra el apartado cuarto del preámbulo. En él la Directiva se acoge explícitamente a una concepción muy positiva de la migración familiar como instrumento necesario no solamente para el desarrollo de la vida familiar, sino fundamentalmente para promover la integración de los nacionales procedentes de terceros países en el EM de acogida. Además la reagrupación familiar desarrolla funciones adicionales de enorme importancia, al contribuir, en palabras de la Directiva, a la "creación de una estabilidad sociocultural (...) que permite, por otra parte, promover la cohesión económica y social, objetivo fundamental de la Comunidad, tal como se declara en el Tratado" 584 .

Una visión en dirección opuesta sobre potenciales consecuencias negativas de la reagrupación familiar se encuentra implícita en el apartado 11, donde se justifican las medidas restrictivas a las

580 ÁLVAREZ RODRÍGUEZ, Aurelia. Algunas reflexiones urgentes relativas a la reagrupación familiar en el Derecho Comunitario (A propósito de la publicación de la Directiva 2003/86/CE del Consejo, de 22 de septiembre de 2003, sobre el derecho a la reagrupación familiar. León, 5 de octubre de 2003, p. 2. Publicación electrónica, disponible en: http://www.icam.es/docs/ficheros/200407190008_6_4.pdf.

581 La peculiar naturaleza jurídica de las directivas se desprende del artículo 249 TCE. Si bien se trata de una norma jurídica dotada de vinculatoriedad, sin embargo, no es vinculante en todo su contenido, sino tan sólo parcialmente, respecto al resultado a alcanzar. De ahí se deriva la gran influencia que durante el proceso de transposición de las directivas ejercerán las características particulares de los concretos sistemas jurídicos de los EEMM. En palabras de Yongmi Schibel, "thus transposition is affected greatly by legal features, administrative procedures, and political processes within each of the Member States". SCHIBEL, Y. Monitoring and influencing the transposition of EU immigration law.The family reunion and long term residents Directives. Grupo de Política de Inmigración (MPG). Issue Paper prepared for the European Migration Dialogue, September 2004, p. 1. Disponible en: http://www.migrant. at/EMD-issue-paper\%201.pdf

582 Apartado 15 del Preámbulo.

583 SCHIBEL, Yongmi. Los derechos de movilidad en Europa. Grupo de Política de Inmigración (MPG). Bruselas, enero de 2006, p. 3. Disponible en: http://www.ciudad-derechos.org/espanol/pdf/eeg.pdf

584 Apartado cuarto del preámbulo de la Directiva 2003/86. 
solicitudes de reagrupación formuladas por familias poligámicas, que posteriormente se regulan con detalle en el cuerpo de la Directiva. Conforme al mismo "el derecho a la reagrupación familiar debe ejercerse en el debido respeto a los valores y principios reconocidos por los EEMM, especialmente en lo que respecta a los derechos de las mujeres y los niños". En este apartado hay ciertas reminiscencias a una integración con cierto carácter asimilacionista que contrastan vivamente con los proyectos previos, donde las instituciones comunitarias insistían en que la integración debía hacerse en el respeto a los valores y culturas de origen de los inmigrantes.

En cuanto instrumento de integración, la Directiva proclama solemnemente en su preámbulo que "la reagrupación familiar debe aplicarse en todo caso a los miembros de la familia nuclear, es decir, al cónyuge y a los hijos menores de edad" ${ }^{585}$. De esta declaración, en consonancia con el carácter mínimo de la Directiva, cabría extraer al menos la exigencia de que la RF de la familia nuclear estuviese considerada como parte del núcleo esencial del derecho a la reunificación familiar y, por tanto, excluida del margen de apreciación de los Estados. Pero tal entendimiento es desvirtuado posteriormente en el cuerpo de la Directiva. Sin necesidad de profundizar en el análisis de su contenido, podrían ya adelantarse las deficiencias y contradicciones inherentes al cumplimiento del objetivo integrador de la Directiva: Del análisis de su proceso de elaboración, ya deducimos un saldo bastante negativo en este aspecto, pues aunque una de las bases del texto de compromiso que desbloqueó la negociación de la Directiva fue garantizar al menos la obligación estatal de autorizar la entrada y residencia de los miembros de la familia nuclear del residente legal en territorio comunitario, posteriormente se adicionaron condiciones potestativas incluso sobre dichos miembros, que contradecían abiertamente este objetivo. Especialmente preocupantes resultan las exigibles a los hijos menores del inmigrante - esto es, sobre el sector más vulnerable y necesitado de protección del núcleo familiar.

Dos son los aspectos claves para poder valorar en su justa medida la fortaleza de la Directiva en tanto que instrumento comunitario de integración. De un lado, el análisis de su ámbito de aplicación personal, con especial incidencia en el concepto de familia que se maneje y en la extensión de los familiares reagrupables; De otro, el estatus legal concedido a dichos familiares tras su reagrupación en el EM. El haz de derechos y libertades que la Directiva les otorgue desarrollará un papel clave para fomentar su adaptación e inserción en el Estado de acogida. Sin olvidar que los principios de trato justo y derechos equiparables deben impregnar la regulación del derecho a la RF, tal y como abiertamente proclama el apartado tercero del preámbulo de la Directiva.

Nuevamente la respuesta a estas cuestiones debe dejarse abierta hasta que finalice el análisis en profundidad de la regulación contenida en la versión final de la Directiva 2003/86.

\section{3 Ámbito personal de aplicación de la Directiva}

El ámbito de aplicación personal del derecho a la RF, tal y como queda configurado en la Directiva 2003/86/CE, está definido por dos aspectos: De un lado, por los sujetos extranjeros que pueden optar a traer a sus familiares al EM en el que residen y, de otro, por los no nacionales susceptibles de entrar en el territorio de dicho Estado en condiciones más ventajosas que las establecidas por los regímenes generales nacionales de extranjería, a fin de poder llevar una vida familiar con el extranjero allí residente.

585 El apartado noveno del preámbulo establece que "la reagrupación familiar debe aplicarse en todo caso a los miembros de la familia nuclear, es decir, al cónyuge y a los hijos menores de edad". 


\section{a) El concepto de reagrupante: la doble titularidad activa del derecho}

Su definición aparece en el apartado c) del artículo segundo. El reagrupante ${ }^{586}$ es considerado como "la persona nacional de un tercer país que, residiendo legalmente en un Estado miembro, solicita la reagrupación familiar o los miembros de cuya familia la solicitan”.

La definición de reagrupante contenida en la disposición transcrita fue extendida, para cubrir también a los "miembros de la familia que solicitan" la reagrupación. Esta ampliación constituye uno de los escasísimos cambios de última hora en sentido progresista que cabe registrar en la Directiva, si comparamos ésta con la tercera propuesta inmediatamente anterior a su aprobación ${ }^{587}$. La noción de reagrupante incluida finalmente en la versión definitiva de la Directiva es más progresista que el existente en todos los borradores previos. Asimismo esta extensión rompe con la tradición comunitaria en esta materia que, para los nacionales procedentes de terceros países apostó siempre por un concepto tradicional ${ }^{588}$ de reagrupante, entendiendo por tal exclusivamente al extranjero residente legal que desencadena el proceso de reagrupación, con exclusión de los familiares reagrupables.

La ampliación del concepto de reagrupante se traduce en una extensión correlativa del radio de protección del derecho. Todos los miembros de la familia son titulares de dicho derecho y, en consecuencia, cualquiera de ellos debería poder presentar la solicitud - al menos la Directiva deja esta posibilidad en manos de los EEMM ${ }^{589}$ - y plantear un recurso administrativo o jurisdiccional en caso de denegación. Esta extensión resulta pues muy bienvenida ${ }^{590}$. Sin embargo, tendremos ocasión de analizar si la titularidad del derecho la otorga la Directiva en plano de igualdad o, más bien, el hecho de que el principal desencadene el proceso de reagrupación al ostentar un permiso de residencia en el EM tendrá implicaciones que redunden y subrayen la situación de dependencia y mayor vulnerabilidad de los familiares reagrupables ${ }^{591}$.

Sea como fuere, en este aspecto concreto parece que sí se tuvieron en cuenta los ideales de Tampere, pues la amplia titularidad activa del derecho a la RF reconocida por la Directiva 2003/86 sitúa a esta materia en sintonía con lo establecido en el ámbito de la libre circulación

586 La primera propuesta lo denominaba “solicitante", pero finalmente se adoptó la terminología de "reagrupante" —o sponsor en la versión inglesa-, técnicamente más correcta, en vista de que la directiva permite que los EEMM decidan si permiten también a los miembros de la familia reagrupables presentar la solicitud de reunificación (artículo 5.1).

587 El reagrupante aparecía definido en la tercera propuesta (artículo 2.c) en los siguientes términos: "el nacional de un tercer país que, residiendo legalmente en un EM, solicite que los miembros de su familia se reúnan con él”. La directiva, en su versión final, incluye literalmente la misma definición, a la cual le añade "o los miembros de cuya familia la solicitan".

588 El concepto tradicional de reagrupante había sido constantemente mantenido a lo largo de todo el proceso de elaboración de la directiva desde su fase inicial, en perfecta sintonía con el existente también con carácter previo, en la etapa intergubernamental anterior al Tratado de Ámsterdam.

589 El Artículo 5.1 de la Directiva 2003/86 establece al respecto que "los EEMM determinarán si, con el fin de ejercer el derecho a la reagrupación familiar, la solicitud de entrada y de residencia debe ser presentada ante las autoridades competentes del EM de que se trate, ya sea por el reagrupante ya sea por el miembro o miembros de la familia”.

590 En la concepción predominantemente restrictiva que impregna la Directiva, esta doble titularidad fue recibida positivamente por la doctrina. Rosa María Moliner la considera como "una concesión a la lógica”. MOLINER NAVARRO, R. M. "El concepto de familia nuclear en la Directiva...., op. cit., p. 1796. Una interpretación totalmente divergente se encuentra en Gómez Campello, quien deduce del artículo 1 de la Directiva que "el derecho a la RF lo ostenta sólo el extranjero residente en el Estado miembro". GÓMEZ CAMPELLO, Esther. "La compleja aplicación de la Directiva 2003/86/CE sobre el derecho a la reagrupación familiar", op. cit., p. 88.

591 Sin ánimo de adelantar acontecimientos, baste por ahora dejar señalado que la igualdad o su ausencia en materia de titularidad activa es especialmente detectable en el modo en que se regule el acceso a un estatuto autónomo por parte de dichos familiares y en los derechos que el EM receptor les conceda tras autorizar su entrada. 
de los ciudadanos comunitarios ${ }^{592}$, y es acorde al concepto igualmente extenso que ha venido contemplando, desde sus inicios, la jurisprudencia de Estrasburgo relativa a reunificación familiar de extranjeros ${ }^{593}$.

Sin embargo, en la cuenta de pasivos del balance sobre la ampliación del concepto de reagrupante es justo destacar que ésta se ha realizado con falta de técnica jurídica, generando múltiples equívocos terminológicos y confusión a lo largo del cuerpo de la Directiva. En buena lógica, la titularidad doble del derecho supondría eliminar la identificación del reagrupante con el sujeto titular del permiso de residencia en el EM, dado que también ostentan y pueden reclamar dicho derecho los familiares que optan a reunirse con él. Sin embargo, a lo largo del texto de la Directiva abundan los ejemplos de inconsistencia en la terminología utilizada, empleándose con demasiada frecuencia el término habitual o tradicional de reagrupante para designar únicamente al sponsor, excluyendo a los familiares reagrupables o ya reagrupados ${ }^{594}$.

A fin de evitar profundizar en este equívoco, reservaremos el término de principal o sponsor para hacer referencia al extranjero no comunitario que disfruta de un título legal que le habilita para residir en un EM por un período de tiempo determinado, en vista de que, en sentido estricto, y a tenor de lo prescrito por la Directiva, también son reagrupantes los familiares que optan a la reunificación.

\section{b) Requisitos que debe reunir el Principal o sponsor}

Para solicitar la reunificación con sus familiares, el principal debe ser titular de un permiso de residencia por un periodo de validez superior o igual a un año y tener una perspectiva fundada de obtener un derecho a la residencia permanente - art. 3.1- Como señalamos, esta redacción trae a la mente la contenida en el primer instrumento comunitario sobre RF formulado en el ámbito del tercer pilar -la Resolución sobre armonización de 1993-, precisamente en uno de sus puntos más criticados por carecer de una definición de lo que había de entenderse por perspectiva fundada. La Directiva persiste en la misma característica, ya que, ni a lo largo de su articulado, ni en los borradores previos, puede encontrarse ninguna definición de lo que deba entenderse por "perspectiva

592 Desde sus tempranos inicios, la regulación de la libre circulación de los trabajadores nacionales de algún EM contempló el derecho a la RF de dichos trabajadores y de los miembros de su familia — con independencia de la nacionalidad de estos últimos-, como un derecho derivado, pero de ejercicio individual. De ahí que el artículo 10.1 del Reglamento 1612/68 reconociese el derecho de los miembros de la familia del nacional de un EM a instalarse con dicho nacional, en clara referencia a la titularidad activa doble del derecho a la RF de este colectivo.

593 SCHAFFRIN, Dora. "Which Standard for Family Reunification of Third-Country Nationals in the European Unión?"; CARLIER, Jean-Yves and BRUYEKER, Philippe de. Immigration and Asylum Law of the EU: Current Debates. Academic Network for Legal Studies on Immigration and Asylum in Europe, Bruxelles, Bruylant, 2005, p. 100.

594 Los ejemplos del uso incorrecto del término de reagrupante a lo largo de la Directiva son abundantes. Así, en el artículo 13.3, se utiliza el concepto tradicional de reagrupante identificado en exclusiva con el titular del permiso de residencia en el EM de acogida, para establecer que la duración de los permisos de residencia otorgados a los familiares reagrupados no puede superar, en principio, la fecha de caducidad del permiso de residencia que posea el "reagrupante", — afirma dicha disposición—, olvidando que también los miembros de la familia son reagrupantes, conforme al concepto introducido en el artículo 2.c de la Directiva. El propio artículo 3.1, —al establecer los requisitos que debe reunir el principal o sponsor-, usa el término de "reagrupante" para aludir en exclusiva al titular de un permiso de residencia expedido por un EM. 
fundada" 595 ni tampoco residencia permanente ${ }^{596}$, pese a que dichos conceptos constituyen elementos esenciales para la correcta delimitación del derecho a la reunificación familiar.

Sin embargo, una ligera aproximación a estos términos puede extraerse de los Comentarios a la propuesta enmendada de $2002^{597}$, donde se explicaba que con estos requisitos se pretendía evitar que el derecho a la reunificación familiar quede abierto a personas que permanecen sobre una base meramente temporal en el territorio de un EM, tales como au-pairs - canguros-, estudiantes de intercambio y estudiantes en prácticas ${ }^{598}$. A tenor de este requisito, resulta esencial que el reagrupante cuente con un "proyecto personal de permanencia" ${ }^{599}$ en el EM receptor. Incidiendo en la misma idea, la redacción imperativa del artículo 3.1 permite concluir que la reagrupación familiar queda excluida a nivel comunitario para aquellos nacionales de terceros países que residen de forma temporal, esto es, con títulos que habilitan para estancias inferiores a un año en el EM ${ }^{600}$. Para estos sujetos, su régimen jurídico dependerá de lo que establezcan al respecto los regímenes de extranjería nacionales.

La perspectiva fundada de obtener un derecho a la residencia permanente se introdujo en el tercer proyecto de Directiva. El Comité Económico y Social consideró en su momento -en el dictamen emitido en torno a dicho proyecto-, que este requisito constituía una de las modificaciones más graves de la tercera propuesta. Para el Comité, con la adición de esta exigencia, "el derecho a la

595 A fin de determinar la noción de perspectiva fundada, Peers parte de una interpretación a sensu contrario de la directiva, dado que el artículo 3 no contiene referencia alguna al derecho nacional, a diferencia de lo que sucede con otras disposiciones de la Directiva 2003/86. De dicha ausencia extrae este autor la conclusión de que tanto el concepto de perspectiva fundada como de residencia permanente pretende tener un significado comunitario. Así mismo, del establecimiento de la RF como derecho, deriva la consecuencia de que las autoridades nacionales carecen de discreción para la interpretación de ambos conceptos. Respecto a la perspectiva fundada, el autor considera que la carga de la prueba de la inexistencia de dicha perspectiva y de su carácter infundado debe recaer sobre el EM que niegue su existencia, dado que estamos hablando de un derecho subjetivo a la RF. Peers excluye la aplicación de la ley nacional, a fin de propiciar una interpretación uniforme del concepto de perspectiva fundada. PEERS, Steve. "Family Reunion and Community Law"; WALKER, N. (ed.). Europe's Area of Freedom, Security and Justice, op. cit., p. 180.

596 Peers propone una interpretación muy coherente del concepto de residencia permanente. "Surely we can assume, (in the absence of evidence to the contrary) that different EC immigration directives are intended to be applied coherently. Therefore the best definition of "permanent residence" is that the concept includes the acquisition of either long-term resident status under the Directive on long-term resident third-country nationals, or the acquisition of status under a more generous national regime for long-term residence, which that Directive will permit (article 13 of Directive 2003/109)". PEERS, Steve. "Family Reunion and Community Law", op. cit., p. 179. Este mismo autor, junto con Helen Oosterom, precisan que el concepto de permanent residence "is not to be defined unilaterally by Member States". Para Staples una definición comunitaria cumpliría dos importantes objetivos, de un lado hacer uniforme la aplicación y de otro impedir que los EEMM reformen sus legislaciones en materia de derecho de residencia permanente restringiendo el ámbito personal de la directiva. PEERS, S. "Family reunion and Community Law, op. cit., p 180 PEERS, S. y OOSTEROMSTAPLES, Helen. "The family reunification directive..., op. cit., p. 457. De interés para profundizar en torno al origen de esta disposición resulta el artículo PEERS, Steve. "Key Legislative Developments on Migration in the European Union"; en European Journal of Migration and Law, n 5, 2003, pp. 387-410, especialmente p. 402.

597 Comentario al artículo 3.1 de la Propuesta de Directiva de 2 de mayo de 2002.

598 Exclusión y explicación de nuevo idénticas a la contenida en el preámbulo de la Resolución armonizadora de 1993.

599 QUIRÓS FONS, A. Derecho comunitario de extranjería..., op cit. p. 408.

600 Esta exclusión es considerada por Schaffrin como la más llamativa desventaja que padecen los miembros de la familia de ciudadanos de terceros países, en comparación con las familias mixtas que cuentan con algún ciudadano comunitario. SCHAFFRIN, Dora. "Which standard for family reunification...., op. cit., p. 142. Gómez Campello va más allá en la interpretación de este requisito, extrayendo de la exigencia de estabilidad o permanencia del principal, la conclusion de que "por vía interpretativa, haya que dejar fuera a quienes ostentan una autorización de residencia prolongada más allá de un año pero considerada temporal por las autoridades de concesión: es el caso de los estudiantes". GÓMEZ CAMPELLO, Esther. "La compleja aplicación de la Directiva 2003/86/CE sobre el derecho a la reagrupación familiar", op. cit., p. 88. 
reagrupación corría el riesgo de no poder ser ejercido nunca" ${ }^{601}$, especialmente en aquellos Estados miembros en los que el permiso de residencia estuviese vinculado al contrato de trabajo, ya que, como consecuencia de la duración habitualmente breve de dichos contratos, el permiso de residencia del reagrupante no llegaría a adquirir una perspectiva duradera. Además, se trata de una condición cumulativa, junto con la exigencia de contar con un permiso de residencia de un año o más de validez, esto es, el principal "ha de ser titular - que no mero solicitante- de una autorización de residencia" 602 - Ambos requisitos "no permiten ningún margen de maniobra cuando se trata de permisos de validez inferior a un año y de contratos todavía más cortos" ${ }^{\circ 03}$.

La estabilidad que se pretende dotar a la residencia del principal es tal, que la tercera propuesta introdujo otra controvertida disposición al respecto que permaneció intacta en la versión final de la Directiva. El artículo 8 otorga a los EEMM la facultad potestativa de requerir que el reagrupante haya residido legalmente en su territorio durante un periodo de tiempo máximo de hasta dos años, antes de reagrupar con él a los miembros de su familia ${ }^{604}$. El establecimiento de dos años constituye una considerable elevación del plazo establecido en los primeros proyectos, - que nunca pasó de un año-, mismo que se fijó en la propuesta de convenio de 1997. Además a esta disposición no se le adicionó ninguna cláusula parcial de mantenimiento del status quo a fin de limitar temporalmente la introducción de esta exigencia en los EEMM que contasen con períodos inferiores ${ }^{605}$. En consecuencia, $-\mathrm{y}$ siguiendo con ello las técnicas habituales de las políticas migratorias internas-, la Directiva impone la exigencia de un período de espera previo que oscila entre uno y dos años antes de que el principal pueda reunirse con sus familiares.

Sin embargo, el apartado segundo del mismo artículo octavo incorpora una condición adicional para el principal, que constituye una derogación potestativa al ya de por sí estricto régimen general. Esta derogación podrá ser aplicable en aquellos EEMM cuya legislación existente en la fecha de adopción de la presente Directiva tenga en cuenta su capacidad de acogida. Dichos países podrán requerir al principal un período de espera de hasta tres años como máximo - entre la presentación de la solicitud de reagrupación familiar y la expedición de un permiso de residencia. La prolongada espera que esta exigencia supone tiene su origen en las presiones de Austria, que pretendía con su incorporación poder continuar con su sistema interno de cuotas. Sin embargo, pocas semanas después de que el gobierno austriaco consiguiera su introducción en la Directiva, el TC de este país declaró inconstitucional el sistema de cuotas ${ }^{606}$ por su incompatibilidad con el artículo $8 \mathrm{CEDH}$. La historia de esta disposición muestra de forma irónica la paradoja a la que en ocasiones está abocado el derecho comunitario de la inmigración ante la propensión de los EEMM a convertirlo en un espejo de la legislación interna, llegando a veces no sólo a resultados absurdos sino, lo que es más grave, potencialmente violatorios de derechos humanos ${ }^{607}$.

601 Primer punto del apartado 2.2 del Dictamen del Comité Económico y Social de 7.10.2002.(2002/C 241/21).

602 GÓMEZ CAMPELLO, Esther. “La compleja aplicación de la Directiva...”, op. cit., p. 88.

603 Primer punto del apartado 2.2 del Dictamen del Comité Económico y Social de 7.10.2002.(2002/C 241/21).

604 Artículo 8.1 de la Directiva 2003/86, conforme al cual "los EEMM podrán requerir que el reagrupante haya residido legalmente en su territorio durante un período de tiempo, que no podrá superar dos años, antes de reagrupar a los miembros de su familia con él".

605 La inexistencia de dicha cláusula lleva a QUIRÓS FONS a señalar que "este requisito facultativo puede animar el endurecimiento del plazo básico en los EEMM”. Derecho comunitario de extranjería..., op. cit., p. 408, nota a pie n. 119.

606 Austrian Verfassungsgerichtshof 8 October 2003, nª G119/03. Citado por GROENENDIJK, K. "Legal Concepts on Integration..., op. cit., p. 120.

607 Elspeth GUILD, al comentar en su momento la Resolución de armonización del año 1993, contrastó su contenido con las obligaciones internacionales que vinculaban a los EEMM. Respecto a los períodos de espera, analizó el contenido de la Carta Social Europea concluyendo al respecto que "a legally imposed waiting period of three years is contrary to article 19.6 of the Social Charter”. El artículo 19.6 de la Carta Social Europea establece el compro- 
Esta derogación suscitó desde su introducción ${ }^{608}$ serias dudas y críticas ${ }^{609}$ en torno a su compatibilidad con los estándares internacionales de derechos humanos — como, por ejemplo, al art. 19.6 de la Carta Social Europea ${ }^{610}$ - . Si se contrasta con la jurisprudencia de Estrasburgo, deberá poder superar el test de la proporcionalidad y no convertir en inviable el ejercicio del derecho a la vida familiar ${ }^{611}$. Los tres años suponen en cualquier caso un período temporal que contrasta profundamente con el plazo de espera máximo de doce meses estipulado en el artículo 12 del Convenio Europeo relativo al estatuto jurídico del trabajador migrante, de 24 de noviembre de $1977^{612}$.

Conviene destacar que, al plazo de tres años del articulo 8.2, se le adicionó una cláusula de stand still parcial a fin de contrarrestar las posibles tentativas de algunos EEMM a rebajar sus legislaciones internas para posibilitar su aplicación. Esta cláusula fija como tope temporal la fecha de adopción de la Directiva, plazo temporal considerablemente más riguroso y, por ende más protector para los particulares, que las restantes cláusulas de stand still incluidas en la Directiva - dichas cláusulas están a su vez incorporadas a las dos derogaciones establecidas en el artículo 4, y ambas fijan como tope temporal la fecha de la aplicación de la Directiva, esto es, la de su implementación, plazo posterior al establecido en el artículo 8.2613 -

\section{A.2) Inclusiones y exclusiones: la extensión del concepto de principal}

El concepto de principal o sponsor incluye a los refugiados, quienes están sometidos a un régimen más beneficioso que el contemplado con carácter general para los restantes ciudadanos de

miso de las partes contratantes "a facilitar en lo posible el reagrupamiento de la familia del trabajador extranjero a quien se le haya autorizado para establecerse dentro del territorio". Sus conclusiones resultan ahora si cabe más procedentes, en vista de que dicho período ha sido introducido en la Directiva 2003/86 una década después de que la autora criticase la Resolución armonizadora de 1993. "Resolution on the Harmonization of national policies on family reunification", op. cit., p. 271

608 El período de espera excepcional de hasta 3 años antes de que el reagrupante pueda reunirse con sus familiares más próximos, con la cláusula de stand still también prevista para la fecha de adopción de la Directiva, fue introducida por la tercera propuesta de directiva, siendo incorporada con tenor idéntico por el texto final de la Directiva (artículo 8 en ambos textos).

609 Las críticas se multiplicaron desde múltiples frentes. En el ámbito doctrinal se ha considerado como un plazo "claramente desproporcionado cuando, ante la falta de posibilidad de que la vida familiar sea continuada en cualquier otro lugar, la ausencia de reunificación familiar constituye una violación del derecho al respeto a la vida familiar a ser continuada elsewhere". SCHUTTER, Olivier De. Report of the Situation of Fundamental Rigths in the European Union in 2003. EU Network of Independent Experts of Fundamental Rigthts (CFR-CDF). Enero de 2004, p. 54. En el ámbito doctrinal español, cabe citar a Campello, quien señala que el plazo de espera de tres años, junto con los dos años de residencia que como tope máximo cabe exigir al reagrupante, suponen que "éste puede ver cómo transcurren 5 años en la práctica, sin que el derecho a la vida familiar legalmente reconocido pueda ser efectivamente ejercitado. Mas aún, transcurrido ese largo plazo no existen garantías por parte del Estado de que su respuesta sea favorable si su capacidad de acogida es limitada". GÓMEZ CAMPELLO, E. "La compleja aplicación de la Directiva 2003/86/CE sobre el derecho a la RF", op. cit., p. 93.

610 El Comité Europeo de Derechos Sociales, encargado de supervisar el cumplimiento de la Carta Social Europea, había señalado en su momento que era válido el establecimiento de plazos de residencia legal antes de poder proceder al ejercicio de la reagrupación familiar, siempre que fuesen estrictamente limitados en el tiempo. Con carácter más concreto, señaló que períodos temporales superiores a un año violaban la Carta Social Europea. Conclusiones II y XI-2 del Comité de Expertos. En el mismo sentido, GUILD, Elspeth. "Resolution on the Harmonization of national policies on family reunification", op. cit., p. 271.

611 SCHAFFRIN, Dora. “Family Reunification of Third-Country Nationals..., op. cit., p. 101.

612 El artículo 12 del mencionado Convenio, que aborda la RF de los trabajadores migrantes, señala al final de su apartado primero que "cada Parte Contratante podrá supeditar la autorización mencionada a un plazo de espera que no podrá exceder de 12 meses".

613 En el mismo sentido, PEERS, Steve. "Key Legislative Developments on Migration in the EU”; European Journal of Migration and Law, n 5, 2003, nota a pie de página $n^{\circ} 65$, p. 404. 
terceros países, no siendo objeto de estudio en el presente trabajo. La regulación de su régimen específico de reunificación familiar se ha unificado en un capítulo aparte ${ }^{614}$, sistematización que tiene su origen en el tercer proyecto de Directiva.

Las exclusiones al concepto de principal están recogidas en los apartados segundo y tercero del artículo 3 de la Directiva. La primera disposición citada descarta del ámbito de su aplicación a los solicitantes de asilo cuya petición todavía no ha sido objeto de resolución definitiva, así como aquellas personas autorizadas a residir en virtud de una protección temporal o en virtud de formas subsidiarias de protección, o los que soliciten autorización de residencia por ambos motivos. Si el reagrupante encaja en alguna de estas categorías, no será aplicable la presente Directiva.

Por otro lado, el artículo 3.3 contempla la inaplicación de la Directiva a los miembros de la familia de ciudadanos de la Unión. Esta exclusión venía implícita en el objetivo de la Directiva ${ }^{615}$ así como en la definición del reagrupante ${ }^{616}$. El derecho de los ciudadanos de la Unión y de sus familiares - con independencia de cual sea la nacionalidad de éstos últimos-, a la reagrupación familiar en la actualidad está regulado en la Directiva 2004/38/CE de 29 de abril de $2004^{617}$. Sin embargo, su ámbito de aplicación se restringe a los ciudadanos comunitarios que ejerciten derechos de libre circulación ${ }^{618}$.

La versión final de Directiva 2003/86 sobre el derecho a la RF, tampoco contempla la reagrupación de ciudadanos de la Unión que no hayan hecho uso del derecho a la libre circulación en la UE ${ }^{619}$. Ello supone que aquellos ciudadanos de la Unión que residan en el mismo país del que son nacionales, no quedan cubiertos por el paraguas comunitario, situando a este colectivo en la "desfavorable posición de que sus solicitudes de reagrupación familiar sean procesadas bajo las leyes de extranjería del Estado miembro en cuestión" ${ }^{620}$. Esta situación genera un agravio comparativo entre ciudadanos de la Unión difícilmente compatible con el principio de igualdad de trato y no discriminación, que ha sido por ello calificada como un claro supuesto en el que la Directiva mantiene intacta la "discriminación inversa" ${ }^{21}$.

Recientemente, el Tribunal de Justicia de la Unión Europea, en adelante TJUE ha confirmado la aplicación del derecho interno a los ciudadanos de la Unión que no han hecho uso de la libertad

614 Capítulo V, bajo la rúbrica "Reagrupación familiar de refugiados" (artículos 9-12 de la Directiva).

615 Como ya señalamos, el objetivo declarado por el artículo $1^{\circ}$ de la Directiva consiste en fijar las condiciones de ejercicio del derecho a la reagrupación familiar "de que disponen los nacionales de terceros países que residen legalmente en el territorio de los EEMM".

616 Al respecto, el artículo 3.1 in fine de la Directiva 2003/86 sobre el derecho a la RF, establece la condición de que los miembros de la familia del reagrupante sean "nacionales de terceros países, independientemente de su estatuto jurídico".

617 Directiva 2004/38 del Parlamento Europeo y del Consejo, de 29 de abril de 2004 relativa al derecho de los ciudadanos de la Unión y de los miembros de sus familias a circular y residir libremente en el territorio de los Estados miembros, por la que se modifica el Reglamento (CEE) No 1612/68 y se derogan las Directivas 64/221/CEE, 68/360/CEE, 72/194/CEE, 73/148/CEE, 75/34/CEE, 75/35/CEE, 90/364/CEE, 90/365/CEE y 93/96/CEE.

618 Artículo 3.1 de la Directiva 2004/38 relativa al derecho de los ciudadanos de la Unión y de los miembros de sus familias a circular y residir libremente en el territorio de los Estados miembros.

619 El hecho de que la directiva contemple expresamente la exclusión de los miembros de la familia de ciudadanos comunitarios (art. 3.3) viene a despejar cualquier duda sobre su posible aplicación a lagunas como ésta. Esta laguna trató de ser suplida en la primera propuesta de directiva (art. 3.1), así como en la Propuesta de Convenio sobre Migración del año 1997.

620 BALDACCINI, A; TONER, H. "From Amsterdam and Tampere to the Hague...”, op. cit., p. 16.

621 APAP, Joanna; CARRERA, Sergio. Towards a Proactive Immigration Policy for the EU?. Center for European Policy Studies. Working Document No 198, December 2003, p. 9. Disponible en http://www.ceps.be 
circulatoria y siempre han residido en el mismo Estado de su nacionalidad ${ }^{622}$. Sin embargo, también ha eliminado parcialmente la discriminación inversa denunciada - en un supuesto de progenitores extranjeros de un menor que gozaba de la nacionalidad de un EM, y que no había ejercido nunca la libertad circulatoria por el territorio de la Unión-, como releva la novedosa doctrina sentada en el también reciente asunto Ruiz Zambrano ${ }^{623}$.

\section{c) Miembros de la familia a efectos de RF: Familiares reagrupables}

La definición de los sujetos habilitados a reunirse en el país receptor con el titular del permiso de residencia, - a cuyo fin el EM les expedirá una autorización- de entrada y residencia en condiciones más ventajosas que las exigidas para el régimen general, constituye uno de los elementos medulares del contenido del derecho a la RF. Este es un punto neurálgico de la Directiva, donde se puede comprobar el cumplimiento o no de los ideales de Tampere que le sirvieron de guía - parte de los cuales se reproducen en la propia exposición de motivos de la Directiva. La regulación de los beneficiarios del derecho constituye el aspecto más sacrificado durante la elaboración de esta norma, donde se observa con mayor nitidez que "el texto surgido al final del trayecto dista más de ciento ochenta grados de la idea original"624.

La Directiva establece una clara línea divisoria entre los beneficiarios directos ${ }^{625}$, esto es, aquellos extranjeros a quienes el EM está obligado imperativamente a autorizar su entrada y permanencia -siempre que cumplan con los requisitos de la Directiva-, respecto de aquellos sujetos cuya admisión o no es potestativa ${ }^{626}$. Esta materia está regulada en el Capítulo II, en una única disposición, el art. cuatro.

622 STJUE (Sala Tercera) de 5 de mayo de 2011. Asunto C-434/09, Shirley McCarthy y Secretary of State for the Home Department.

623 Caso Gerardo Ruiz Zambrano c. Office National de l'emploil, Asunto C-34/09, sentencia TJUE de 8 de marzo de 20011, cuya doctrina posee implicaciones de largo alcance en torno al concepto y al estatuto de la ciudadanía de la Unión. En ella, el TJUE ha señalado que la ciudadanía de la Unión exige que un Estado miembro autorice a los nacionales de un país tercero - progenitores de un menor que tiene la nacionalidad de dicho Estado miembro-, a residir y trabajar en él. La causa reside en el principio de efectividad, de modo que la denegación a los progenitores de la autorización de residencia privaría a dicho menor del disfrute efectivo de la esencia de los derechos vinculados al estatuto de ciudadano de la Unión. Esta exigencia es igualmente válida cuando el menor no ha ejercido nunca su derecho de libre circulación en territorio de los Estados miembros. Sobre el tema vid. IGLESIAS VARA, Sara. "El asunto Ruiz Zambrano una nueva aproximación del Tribunal de Justicia de la Unión Europea a la ciudadanía de la Unión"; en Revista General de Derecho Europeo, №. 24, 2011. APARICIO CHOFRÉ, Lucía. "Novedades en la reagrupación de los progenitores extranjeros por parte de un menor comunitario. El caso Zambrano"; en Revista sobre la infancia y la adolescencia, no 1, Septiembre 2011, pp. 112-120. JUÁREZ PÉREZ, Pilar. "La inevitable extensión de la ciudadanía de la Unión: A propósito de la STJUE de 8 de marzo de 2011 (Asunto Ruiz Zambrano)"; en Cuadernos de Derecho Transnacional, vol. 3, n 2, octubre 2011, pp. 249-266.

624 ALVAREZ RODRÍGUEZ, A. Algunas reflexiones urgentes relativas a la reagrupación familiar en el derecho comunitario. A propósito de la publicación de la Directiva 2003/86/CE del Consejo, de 22 de septiembre de 2003, sobre derecho el derecho a la reagrupación familiar, p. 4. Disponible en http://www.icam.es/docs/ficheros/200407190008_6_4. pdf

625 Apartado primero del artículo 4. Ambos tipos de beneficiarios vienen distinguidos con una dirección imperativa para los primeros, - beneficiarios indiscutibles del derecho a la RF (art. 4.1)-, y con una formulación potestativa para el segundo tipo de sujetos, los beneficiarios potenciales del derecho.

626 Apartados segundo y tercero del artículo 4 de la Directiva 2003/86. Esta disposición afirma - con respecto a los beneficiarios potenciales del derecho, en función de lo que decidan libremente los distintos EEMM-, que "los EEMM podrán, por vía legislativa o reglamentaria, autorizar la entrada y residencia...." 


\section{BENEFICIARIOS DIRECTOS}

Los beneficiarios directos aparecen contemplados en el primer apartado del artículo cuatro. Del tono imperativo de esta disposición se extrae una obligación a cargo de los EEMM de autorizar la entrada y residencia para los familiares allí estipulados, pues respecto de ellos su admisión resulta preceptiva ${ }^{627}$, siempre que dichos sujetos cumplan los requisitos establecidos en esta Directiva. Estamos pues ante un auténtico derecho subjetivo para las personas contempladas en el apartado primero del artículo $4^{628}$. El TJUE ya ha tenido ocasión de confirmar tan importante aspecto ${ }^{629}$.

Conforme al artículo 4.1 de la Directiva, los miembros de la familia titulares del derecho son los integrantes de la familia nuclear, esto es, cónyuges e hijos, quienes disfrutan del derecho a la reagrupación familiar sin que la Directiva les exija un requisito general de dependencia para su admisión en el $\mathrm{EM}^{630}$.

a) Respecto del cónyuge del reagrupante, se entiende por tal a la persona unida al residente legal en el EM mediante un vínculo jurídico matrimonial no disuelto, válido y auténtico.

El matrimonio reconocido en la Directiva es el monogámico ${ }^{631}$, como se deduce del apartado $4^{\circ}$ del artículo. Esta disposición establece que en caso de matrimonios poligámicos, sólo se admitirá un cónyuge - el que ya estuviera viviendo con el reagrupante en el territorio del EM-, lo que significa que se permitirá la entrada a la primera esposa que llegue o que ya esté viviendo con el titular del permiso de residencia, con independencia del orden que ocupe, esto es, tanto si corresponde o no al primer matrimonio contraído por el reagrupante poligámico. La reunificación del otro cónyuge está expresamente prohibida, por lo que a las características comentadas podríamos añadir que la Directiva recoge un concepto de familia típicamente occidental ${ }^{632}$.

Los hijos menores comunes del cónyuge que ya vive con el reagrupante se admiten, pero con respecto a los hijos del otro cónyuge, los EEMM conservan su poder discrecional de autorizar su

627 Iglesias Sánchez señala que "en efecto, el apartado primero del artículo 4 constituye la disposición básica a los efectos de la configuración jurídica del derecho a la reagrupación familiar". IGLESIAS SÁNCHEZ, Sara. "El valor de la Directiva 2003/86/CE sobre Reagrupación Familiar a la luz de los derechos fundamentals y de la Sentencia del TJUE en el asunto 540/03"; Revista de Derecho Comunitario Europeo, n 26, 2007, pp. 141-142.

628 De idéntico parecer es SALES i JARDÍ, quien señala que "con la redacción de esta Directiva se incorpora plenamente en el Derecho comunitario el derecho a la reagrupación familiar. Por primera vez se otorga un derecho subjetivo a la reagrupación familiar a los nacionales de terceros países en el seno de la Unión aunque para algunos la Directiva adolezca de algunas limitaciones permitiendo un cierto grado de discrecionalidad a los Estados miembros". SALES I JARDÍ, Mercè. "La protección de la vida familiar de los inmigrantes en el Ordenamiento Comunitario: el derecho a la reagrupación familiar”. Madrid, Asociación de Estudios comunitarios Europeos, 2010, p. 12. Disponible en: www.ucm.es/info/audesco/dt/wp0801.pdf

629 Asunto C-540, al resolver el recurso de anulación planteado contra la Directiva 2003/86; y, más recientemente, en el asunto Chakroun. Ambos seran estudiados posteriormente.

630 En el mismo sentido, PEERS, Steve. “Key Legislative Developments..., op. cit., No 5, p. 403.

631 Alvarez Rodríguez afirma, no sin cierta ironía, que "evidentemente, la aceptación de la poligamia para la vieja y conservadora Europea, por ahora, no está en la mente de ninguno de los Estados (cdo. 11 y art. 4.4 Directiva). Ciertamente supondría una gran revolución aceptar varios cónyuges simultáneos puesto que el vetusto Continente es excesivamente coherente al solo admitir la poligamia sucesiva, uno se casa y se divorcia cuantas veces quiera pero el matrimonio siempre debe responder a la monogamia”. ALVAREZ RODRÍGUEZ, A. Algunas reflexiones urgentes..., op. cit., p. 8. Para García Rodríguez, "la laxitud mostrada con las relaciones de pareja distintas a la matrimonial no abarca a los matrimonios poligámicos, por respeto a la cultura europea que defiende la no discriminación por razón de sexo y los derechos de la mujer”. GARCÍA RODRIGUEZ, Isabel. Matrimonio e Inmigración. El control del consentimiento matrimonial en la reagrupación familiar. Madrid, Colex, 2008, p. 60.

632 En este sentido, Moliner Navarro afirma que la Directiva consagra un "concepto europeo de familia nuclear" al que algunas de sus disposiciones otorgan un marcado carácter asimilacionista. MOLINER NAVARRO, Rosa Ma "El concepto de familia nuclear en la Directiva..., op. cit., pp. 1798 y 1806. 
entrada o no ${ }^{633}$. Esta conclusión está reforzada por lo establecido en el considerando décimo de la Directiva, que otorga un margen de apreciación a los EEMM a fin de que decidan en torno a la admisión o no, entre otros sujetos, "de los hijos menores de otro cónyuge y del reagrupante". El problema mayor de esta disposición estriba en que tal determinación redunda en una discriminación entre hijos, en este supuesto habidos dentro del matrimonio - si bien, de un matrimonio poligámico, y como tal, todos ellos hijos legítimos a la luz de la ley personal de los progenitores-, contraria a la jurisprudencia de Estrasburgo.

Con todo, la situación final de los hijos menores del otro cónyuge, en el supuesto de matrimonios poligámicos, ofrece una leve mejoría respecto a la regulación contemplada en el borrador de la Directiva precedente. En la tercera propuesta no se preveía la posibilidad de autorizar la entrada ni residencia de los hijos del otro cónyuge, en el caso de que el reagrupante tuviera ya un cónyuge viviendo con él en el territorio de un $\mathrm{EM}^{634}$. En la versión definitiva de la Directiva también se prohíbe autorizar la entrada de un segundo cónyuge, sin embargo se ha introducido una disposición que flexibiliza la situación de los hijos de este segundo cónyuge. Dicha disposición establece que "los EEMM podrán limitar la RF de los hijos menores de otro cónyuge y del reagrupante"635. Leyendo esta norma en sentido inverso, cabe concluir que, aunque con carácter limitativo, la directiva permite cierto resquicio para que los EEMM autoricen la entrada de los hijos del otro cónyuge a fin de vivir con el progenitor extranjero ya legalmente instalado en su territorio, en determinadas circunstancias, como podrían ser la muerte del segundo cónyuge. Si un EM autoriza la admisión de los hijos del segundo cónyuge, ello será sin perjuicio de que otros EEMM no reconozcan la existencia de lazos familiares en ese supuesto; en otras palabras, se permiten regímenes divergentes con respecto a la admisión de estos menores, como consecuencia de la inaplicación del principio de reconocimiento mutuo en esta materia ${ }^{636}$.

Ahora bien, respecto de los cónyuges, la protección que ofrece la Directiva dista de ser completa. Ésta incluye una cláusula adicional que permite a los EEMM exigir que el reagrupante y su esposo/a hayan alcanzado una edad mínima, que no podrá exceder de los 21 años, antes de que el cónyuge pueda reunirse con el reagrupante ${ }^{637}$. La disposición que contempla esta exigencia establece que la finalidad de la misma es "garantizar un mayor grado de integración y evitar los matrimonios forzados" ${ }^{38}$. La introducción o no de este polémico ${ }^{639}$ requisito queda enteramente a la voluntad de

633 Apartado cuarto del artículo 4, in fine. La redacción no deja lugar a dudas: "los Estados miembros podrán limitar la reagrupación familiar de los hijos menores de otro cónyuge y del reagrupante"

634 Artículo 4.4 del tercer proyecto de Directiva sobre reunificación familiar.

635 Apartado cuarto del artículo 4, in fine.

636 SCHAFFRIN, Dora. "Which Standard for Family Reunification?...., op. cit., p. 96.

637 Las críticas a esta disposición son muy abundantes. Alvarez Rodríguez considera que constituye una norma material imperativa que aumenta la edad para beneficiarse de la reagrupación que choca con los ordenamientos internos, donde está estipulado otorgar el consentimiento matrimonial de forma válida a una edad muy inferior. RODRÍGUEZ ALVAREZ, A. Algunas reflexiones urgentes..., op. cit., p. 9. Moliner Navarro estima que "establecer un límite mínimo de edad para ejercer el derecho, más bien parece responder a un deseo minimizador de las solicitudes o a una inaceptable general presunción de fraude en los solicitantes, que a un deseo de proteger la libertad de los contrayentes; aspecto éste, por cierto, bastante complicado de garantizar fuera del entorno occidental, sea cual sea la edad de los esposos". MOLINER NAVARRO, Rosa Ma. "El concepto de familia nuclear en la Directiva..., op. cit., pp. 1799-1800.

638 Apartado quinto del artículo cuarto de la Directiva 2003/86.

639 Una visión positiva respecto a esta opción se encuentra en SCHUTER. Para este autor, que realizó el Informe sobre derechos humanos del años 2003, la posible restricción al derecho a la reunificación contemplada en el artículo 4.5, "parece justificable por legítimas razones de orden público, y en consideración a la protección de los derechos de otras personas". Report on the situation of Fundamental Rights in the European Union in 2003, op. cit., p. 55. 
los EEMM, sin que la Directiva imponga precauciones adicionales, tales como que dicha exigencia rija ya en la legislación interna en la época en que entre en vigor la Directiva, - esto es, sin incluir una cláusula de stand still parcial, adicionada a esta disposición-.

Esta restricción no atenta directamente contra el derecho a contraer matrimonio, puesto que no impide su celebración, sino que posterga la vida en común de las personas casadas en el EM de acogida hasta que ambos no hayan cumplido los 21 años $^{640}$. En cualquier caso, tal exigencia constituye una elevación sustancial respecto al límite de edad que los EEMM podían requerir al reagrupante y a su cónyuge antes de poder reunirse en el EM, tal y como había sido establecido en la tercera propues$\mathrm{ta}^{641}$. Su origen se remonta a la fase final del proceso de negociación, siendo introducida a iniciativa de Alemania en el Consejo de Justicia y Asuntos internos de 27 de febrero de $2003^{642}$.

Junto a dicha restricción facultativa, es posible encontrar en la Directiva otras disposiciones que sitúan a los cónyuges en situación de vulnerabilidad. Es el caso de la condición establecida en el apartado primero del artículo 16, conforme al cual los EMM podrán rechazar la renovación del permiso de residencia del cónyuge - o de otros miembros de la familia que han sido admitidos con el propósito de la reunificación familiar-, si el reagrupante ya no vive o no mantiene una relación marital o familiar. En este artículo la vida marital emerge como una condición necesaria para la continuación de la residencia del esposo/a, no solo penalizando las rupturas conyugales, sino situando a la esposa - que estadísticamente supone la mayoría de los casos-, en una posición especialmente vulnerable ${ }^{643}$.

Otro aspecto problemático reside en la situación de las parejas de hecho. Señalamos en su momento que la primera propuesta contemplaba expresamente la reagrupación preceptiva de las parejas de hecho, - tanto heterosexuales como homosexuales-, siempre que la legislación del EM contemplase su equiparación. La Directiva en su versión final deja enteramente la admisión de las parejas no casadas a la decisión de los EEMM, que podrán —o no- autorizar su entrada y residencia, por vía legislativa o reglamentaria ${ }^{644}$. En esta materia, la Directiva distingue según se trate de la pareja no casada que mantenga con el reagrupante una relación estable debidamente probaba, respecto de la pareja registrada.

640 RODRÍGUEZ ALVAREZ. A. Algunas reflexiones urgentes..., op. cit., p. 9.

641 La tercera propuesta había introducido ex novo la posibilidad de que los Estados miembros exigiesen al reagrupante y a su cónyuge haber alcanzado una edad mínima, que no podía superar la mayoría legal, para poder reunirse en su territorio. La directiva mantiene esta opción de los Estados, pero ha elevado el tope máximo a los 21 años (antiguo artículo 4.5 y nuevo artículo 4.6).

642 GROENENDIJK ha destacado que el objetivo que se pretendía con su inserción, era permitir a su vez que dicha limitación pudiese ser introducida en el derecho interno alemán, pues el gobierno que incluía al Partido de Pim Fortuyn había acordado dicho cambio durante su formación. "Legal Concepts..., op. cit., p. 119; PEERS, S. "Key Legislative Developtment...”, op. cit., vol. 5, p. 403.

643 SCHUTTER, Olivier D. Report on the situation of fundamental rights in the European Union in 2003, op. cit., p. 56. Por ello este autor propone que la directiva debería haber previsto que el derecho de reunificación no cesase en el supuesto de que la ruptura de la relación matrimonial se debiera únicamente a la culpa del sponsor.

644 Artículo 4.3 de la Directiva sobre Reunificación familiar, conforme al cual “los Estados miembros podrán, por vía legislativa o reglamentaria, autorizar la entrada y la residencia, de conformidad con la presente Directiva y siempre que se cumplan las condiciones establecidas en el capítulo IV, de la pareja no casada nacional de un tercer país que mantenga con el reagrupante una relación estable debidamente probada, o del nacional de un tercer país que constituya con el reagrupante una pareja registrada, de conformidad con lo dispuesto en el apartado 2 del artículo 5, y de los hijos menores no casados, incluidos los adoptivos, de estas personas, así como de los hijos mayores solteros de estas personas, cuando no sean objetivamente capaces de proveer a sus propias necesidades debido a su estado de salud". 
La Directiva parece privilegiar la situación de las parejas registradas respecto de las no inscritas, pues sólo respecto a las primeras prevé expresamente que "los EEMM podrán decidir que las parejas registradas reciban el mismo trato que los cónyuges respecto de la reagrupación familiar" ${ }^{645}$. Para el examen de la solicitud de reagrupación de las parejas inscritas, el registro actúa como medio fiable de prueba ${ }^{646}$; Las parejas no registradas presentan mayores problemas a fin de demostrar la existencia y veracidad de los vínculos familiares. A estos efectos, el EM debe tener en cuenta elementos tales como los hijos comunes, la cohabitación previa y cualquier otro medio de prueba fiable ${ }^{647}$. Se trata pues de beneficiarios potenciales de la reagrupación familiar, dependiendo del régimen interno que al respecto establezca el $\mathrm{EM}^{648}$.

El mismo régimen potestativo establecido para las parejas de hecho, se fija también para los hijos menores no casados de estas personas, incluyendo los adoptivos, así como para sus hijos mayores solteros que no sean objetivamente capaces de proveer a sus propias necesidades como consecuencia de su estado de salud ${ }^{649}$.

Dada la evolución social que se ha producido en este ámbito — de la que da cumplida cuenta la avanzada jurisprudencia del TEDH - , no incluir a las parejas de hecho, al menos a las heterosexuales ${ }^{650}$, dentro del concepto de parientes reagrupables de forma imperativa $-\mathrm{y}$, lo que es aún más grave, a los hijos habidos de este tipo de parejas-, constituye una adhesión a un concepto rebasado de familia, de espaldas al principio de interpretación evolutiva. Es obvio que, a efectos civiles, la equiparación de las parejas de hecho con respecto a los matrimonios no es completa ni tampoco existe en las legislaciones de todos los EEMM. Sin embargo, su inclusión dentro de los miembros de la familia a fin de permitir su acceso al país receptor para convivir con el reagrupante, parecía ser el corolario obligado a la insistencia de la Comunidad en calificar el derecho a vivir en familia como fundamental ${ }^{651}$. Estas razones son más pertinentes respecto a los hijos de las parejas de hecho ${ }^{652}$ pues, en este caso, el establecimiento de un régimen menos favorable que el previsto para los hijos

645 Artículo 4.3 in fine.

646 Artículo 5.2.

647 Ídem.

648 Sobre este punto Schutter ha destacado la inexistencia de obligación para los EEMM de reconocer a la pareja de hecho, incluso registrada, del extranjero no comunitario residente legal en un EM, incluso en aquellas siutaciones donde el derecho a la reunificación se reconoce a las parejas de hecho estables extranjeras de los nacionales de dicho Estado y a los ciudadanos comunitarios. Este mismo autor considera que si un EM opta por reconocer el derecho a la reunificación para nacionales no comunitarios que forman parte de una pareja de hecho con el sponsor, pero a la vez niega este mismo derecho a las parejas constituidas por personas del mismo sexo, "would be guilty of discrimination directly based on sexual orientation, contrary to Article 21 of the Charter of Fundamental Rights". SCHUTTER, Olivier D. Report on the situation of Fundamental Rights in the European Union in 2003, op. cit., p. 53.

649 Artículo 4.3 in fine.

650 El carácter aún problemático que representan las parejas homosexuales, que no gozan del mismo grado de aceptación social que las heterosexuales — ni tampoco de un reconocimiento jurídico en todos los EEMM-, podría quizá justificar su exclusión en función del respeto al principio de subsidiariedad. Con todo, las razones subyacentes a su exclusión parecen vincularse a los efectos multiplicadores de la RF.

651 Así aparece calificado expresamente en la sentencia que pone fin al recurso de anulación contra la presente Directiva, que analizaremos en el siguiente apartado de nuestro trabajo.

652 Es obvio que detrás de la exclusión de las parejas de hecho quizá latan temores ante la mayor facilidad de fraude a las normas de extranjería, pero los mismos temores no son aplicables para el caso de los hijos habidos de dichas parejas. En cualquier caso, dichos temores se pueden conjurar a través del establecimiento de medios de prueba, como de hecho prevé el artículo 5 de la Directiva. Detrás de esta opción de la Directiva se encuentran los formidables obstáculos estatales habidos en el proceso de negociación, ante una cuestión que a buen seguro no está predeterminada por cuestiones ideológicas o éticas, sino más bien por un espíritu numérico restrictivo, a fin de intentar recortar la entrada al mayor número posible de miembros de la familia. 
legítimos constituye una diferenciación carente de justificación objetiva y razonable. La jurisprudencia del TEDH, de forma muy temprana — desde la sentencia Marck—, estableció con rotundidad el principio de igualdad absoluta entre los hijos habidos tanto dentro como fuera del matrimonio.

En contrapartida, es justo mencionar que una de las escasas reformas en sentido progresista que introdujo la versión final de la Directiva afecta a los hijos adultos solteros de la pareja de hecho del reagrupante. Su situación mejoró ligeramente, ya que este colectivo no aparecía contemplado - ni siquiera potestativamente-, en el artículo 4 de la tercera propuesta. La versión final de la Directiva los incorpora expresamente en el apartado tercero del artículo 4, junto a las parejas no casadas y sus hijos menores, incluyendo a los adoptivos, otorgando libertad a los EEMM a fin de que éstos decidan autorizar su entrada y residencia a los efectos de reagrupación familiar.

b) Los hijos, sometidos al requisito general de que sean solteros y con una edad inferior a la de la mayoría legal establecida por el EM en cuestión ${ }^{653}$.

Respecto a los hijos ${ }^{654}$, la Directiva establece que el EM debe autorizar la entrada en su territorio de los hijos comunes del principal y de su cónyuge, incluidos los hijos adoptivos de ambos. Para los hijos adoptivos se exige, a efectos de seguridad jurídica, que la adopción haya sido dictada por una resolución emitida por la autoridad competente del EM de que se trate o bien por una resolución ejecutiva en virtud de obligaciones internacionales. También es preceptiva la autorización de entrada de los hijos menores no comunes, tanto del reagrupante como de su cónyuge, incluidos los hijos adoptivos, siempre que en todos estos supuestos el progenitor tenga el derecho de custodia y los tenga a su cargo. Si se trata de hijos de un solo miembro de la pareja, pero cuya custodia sea compartida con un tercero, la autorización de entrada del menor dependerá de la decisión del EM, siempre que el otro titular del derecho de custodia haya otorgado su consentimiento.

Tratándose de hijos menores que encajen en las categorías mencionadas, la Directiva impone dos requisitos adicionales de carácter altamente controvertido, pues implican la posibilidad de negación del derecho incluso para estos sujetos, quienes, por su condición de menores, deberían ser objeto de una protección reforzada, conforme a lo establecido en los estándares fijados por el DIDH. Contradice además lo establecido en el preámbulo, conforme al cual la familia nuclear, "en todo caso" $^{655}$, ha de estar amparada por el derecho a la reunificación.

El primero de los requisitos controvertidos está establecido en el artículo 4.1 in fine de la Directiva, y viene redactado con carácter excepcional, remarcando con ello que se trata de una posibilidad restrictiva que se otorga a los EEMM. Conforme a esta disposición, para los hijos mayores de 12 años que lleguen al EM de forma independiente del resto de su familia, las autoridades nacionales podrán verificar si cumple algún criterio de integración antes de proceder a autorizar su entrada y residencia, siempre que dicho criterio se halle previsto por la legislación nacional existente en la fecha de la aplicación de la presente Directiva ${ }^{656}$.

653 Artítulo 1.1 in fine de la Directiva 2003/86/CE sobre el derecho a la RF.

654 Idem, párrafos b), c) y d) del artículo 1.

655 Considerando noveno del preámbulo de la Directiva sobre el derecho a la RF.

656 Las excepciones al régimen general relativas a los niños de edades superiores a 12 y 15 años proceden de propuestas planteadas por Alemania. El gobierno alemán pretendía incluir estas dos excepciones en su legislación interna. Finalmente, la German Immigration Act, aprobada en 2004, no incluyó estas limitaciones y la posibilidad de introducirlas posteriormente se vino abajo al cumplirse la fecha para la transposición de la directiva, el 3 de octubre de 2005. GROENENDIKJ, Kees. "Family Reunification as a Right under Community Law"; European Journal of Migration and Law, Volume 8, Number 2, 2006, p. 218. 
La justificación oficial a la introducción de esta polémica limitación, aparece contemplada en el preámbulo de la Directiva. Ahí se afirma que con esta exigencia se "pretende reflejar la capacidad de integración de los niños en edad temprana, garantizando que adquieran en el colegio la educación y los conocimientos lingüísticos necesarios"657.

La posibilidad de aplicar un criterio de integración con carácter previo a la entrada de los hijos menores que sobrepasen los doce años, se había introducido por primera vez en la tercera propuesta de Directiva ${ }^{658}$. En la versión finalmente aprobada de la Directiva se mantiene con ligeras variaciones. La propuesta hablaba sólo de hijos que tuvieran más de 12 años; la Directiva añade la exigencia acumulativa - precedida por la conjunción copulativa - de que el niño "llegue independientemente del resto de la familia”. Esta adición no fue incorporada sin embargo al considerando duodécimo del preámbulo, dando lugar a redacciones divergentes y provocando cierta oscuridad en su interpretación ${ }^{659}$.

En cualquier caso, el añadido del artículo 4.1 in fine determina que la situación de estos niños pueda llegar a encajar en el concepto de menor no acompañado ${ }^{660}$, cuya inclusión constituye también otra novedad del texto final de la Directiva. Como consecuencia de ello, se disparan las contradicciones que esta derogación provoca desde el punto de vista del estándar de los derechos humanos de los menores. Ya que, por un lado, si se trata de un menor acompañado, debería ser objeto de una protección superior. De otro, la exigencia añadida de que el niño llegue de forma independiente al resto de su familia parece cerrar el círculo de alternativas estatales: la imposición de criterios de integración al niño inmigrante que sobrepase los doce años de edad, sólo será posible para el EM en el caso de que el menor llegue independientemente de su familia; si llega con ellos no sería lícita su imposición. Cabe pues suponer que esta pequeña adición dota al artículo 4.1 in fine de un tenor algo menos restrictivo que la disposición similar contenida en la tercera propuesta y de la que trae causa. En contrapartida a esta sutil mejoría, la versión final de la Directiva endureció el requisito temporal incluido en la cláusula de stand still incorporada a esta disposición. La Directiva establece al respecto que el criterio de integración debe estar previsto en la legislación existente en el EM en cuestión, en

657 Párrafo duodécimo del Preámbulo.

658 Antiguo artículo 4.1.c de la tercera propuesta de Directiva sobre RF, y actual artículo 4.1 in fine de la Directiva 2003/86.

659 Si se comparan ambos textos, la regulación de esta concreta derogación —contenida en el artículo 4.1 in fine-, con su justificación -localizada en el duodécimo considerando del preámbulo—, se observa una importante diferencia en la redacción. A tenor del artículo 4.1 in fine, los Estados podrán aplicar algún criterio de integración cuando el hijo menor del inmigrante tenga más de doce años y llegue "independientemente del resto de su familia". Por su parte, el preámbulo está redactado de forma mucho más abierta, haciendo referencia a niños mayores de doce años "cuya residencia principal no es la misma que la del reagrupante", esto es, que no vivan con el progenitor reagrupante en el momento de solicitar el permiso de entrada en el EM. En caso de duda, parece que debería ostentar prioridad el artículo 4.1 in fine, que forma parte del cuerpo principal de la Directiva. El TJUE, en la sentencia que resolvió el recurso de anulación contra la Directiva 2003/86, no se pronunció sobre esta cuestión específica. La diferencia en las expresiones utilizadas en ambas partes de la directiva, también ha sido puesta de relieve por Cebada Romero. CEBADA ROMERO, Alicia. "La Directiva de la Comunidad Europea sobre Reagrupación Familiar: la sentencia del TJUE en el asunto C-540/03"; en ALDECOA LUZÁRRAGA, Francisco y SOBRINO HEREDIA, José Manuel (coords.). Migraciones y desarrollo: II Jornadas Iberoamericanas de Estudios Internacionales. Montevideo, 25, 26 y 27 de octubre de 2006, 2007, p. 547.

660 El apartado f) del artículo 2 contiene la definición de menor no acompañado a efectos de esta directiva. Se entiende por tal, "el nacional de un tercer país o el apátrida menor de 18 años que llegue al territorio de los EEMM sin ir acompañado de un adulto responsable de él, ya sea legalmente o con arreglo a la costumbre, mientras tal adulto responsable no se haya hecho cargo efectivamente del menor, o cualquier menor al que se deje solo tras su entrada en el territorio de los EEMM". 
la fecha de la aplicación de la Directiva ${ }^{661}$. Si bien se trata de una referencia temporal confusa, los antecedentes legislativos de esta disposición nos permiten concluir que por "fecha de aplicación" ha de entenderse la fecha de implementación ${ }^{62}$ —esto es, a partir del momento en que es obligatorio transponer la Directiva 2003/86 en los EEMM, a partir del 3 de octubre de 2005-.

Con independencia de sus perniciosos efectos sobre el tratamiento de los hijos menores de los inmigrantes y su más que dudosa compatibilidad con los estándares internacionales, esta disposición resulta ser una cláusula vaga, que no define en ningún momento qué ha de entenderse por "criterio de integración" - concepto del que, por otro lado, no es posible encontrar más referencias a lo largo del texto de la Directiva ${ }^{663}$. En definitiva, se trata de un concepto jurídico indeterminado, lo que no hace sino incrementar los riesgos de cara a la aplicación interna de esta disposición.

La segunda excepción al régimen general previsto para los hijos menores aparece contemplada en el apartado $6^{\circ}$ del artículo 4. Conforme a ella, los EEMM tienen la potestad libre de exigir que las solicitudes relativas a la reagrupación de los hijos menores se presenten antes de que éstos cumplan los 15 años de edad, siempre que así lo establezcan sus legislaciones en vigor en la fecha de aplicación de la presente Directiva ${ }^{664}$. Para los EEMM que decidan aplicar esta excepción, la Directiva prescribe que las solicitudes presentadas después de los 15 años de edad del hijo menor, deberán ser autorizadas "por motivos distintos de la reagrupación familiar", sin especificar cuáles pueden ser éstos.

Esta derogación potestativa al régimen general previsto por la Directiva obedece a una reforma de última hora, por lo que constituye una de las novedades en sentido restrictivo más trascendentes que aporta la versión final de la Directiva, en detrimento de la infancia inmigrante. La interpretación de esta traba a la RF puede estar en conexión con el prolongado e incluso ilimitado plazo que la Directiva otorga a los EEMM para resolver las solicitudes de $\mathrm{RF}^{665}$, a fin de evitar que los expedientes presentados cuando el menor ya ha cumplido los quince años sean resueltos cuando éste ha entrado ya en la edad adulta y carece, con carácter general, del derecho a la reagrupación.

De ambas excepciones se extrae una protección muy baja de los hijos menores de los inmigrantes en lo que, a nuestro juicio, constituye la parte más criticable de toda la Directiva y de muy difícil encaje en los estándares internacionales de protección de los niños ${ }^{666}$. Resulta especialmente

661 Sin embargo, la tercera propuesta exigía que lo fuera en la fecha de la adopción de la directiva, esto es, con carácter temporalmente previo al de su aplicación, acortando así la posibilidad excepcional de que los EEMM pudiesen aplicar esta exigencia a los hijos menores de los inmigrantes legalmente asentados en su territorio, que lleguen de forma independiente al resto de su familia.

662 PEERS, Steve. “Key Legislative..., op. cit., no 5, p. 403.

663 Una referencia similar, pero no idéntica, se encuentra en el párrafo segundo del artículo 7 de la Directiva. Ya señalamos que dicha disposición permite a los EEMM la posibilidad de requerir a los extranjeros el cumplimiento de "medidas de integración". La Directiva no aclara en ningún momento qué deba entenderse ni por medidas de integración ni por criterios de integración, ni si se trata de conceptos distintos o idénticos.

664 La conclusion es idéntica a la ya expuesta con ocasión de la cláusula de stand still incorporada al artículo 4.1 in fine de la Directiva. Por fecha de aplicación, entendemos la de la implementación. PEERS, Steve. "Key Legislative..., op. cit., no 5, p. 403.

665 ÁLVAREZ RODRÍGUEZ, Aurelia. Algunas reflexiones urgentes..., op. cit., p. 11. La misma conexión causal establece Moliiner Mavarro, quien afirma que "cabe intuir una razón de índole técnica: es posible que si no se solicita con esa edad, los complejos vericuetos administrativos del procedimiento ocasionen que se conceda el derecho cuando ya el hijo haya cumplido los 18 y no pueda ser ya sujeto del derecho a la reagrupación. Pero tal razonamiento no hace sino agravar todavía más negativamente el sentido del precepto. Resulta completamente inaceptable someter el ejercicio de un derecho a las posibles deficiencias y dilaciones que puedan producirse a lo largo de un proceso administrativo". MOLINER NAVARRO, R. M. “El concepto de familia nuclear...”, op. cit., p. 1806.

666 En la misma línea, ALVAREZ RODRÍGUEZ considera que las disposiciones relativas a los hijos son "incoherentes y contradictorias con las normas internacionalmente vigentes para los países miembros”. Algunas reflexiones urgentes..., op. cit., p. 10. 
censurable que los esfuerzos de contención de los flujos migratorios se desplieguen desprotegiendo al sector más vulnerable, la infancia inmigrante, bajo la excusa, bien de la aplicación de un concepto excluyente y desproporcionado de integración —artículo 4.1.in fine-, o bien amparando la inexcusable lentitud de los procedimientos administrativos de resolución de expedientes de RF- artículo 4.6. Ambas derogaciones resultan incoherentes con el establecimiento de un mayoría de edad aceptada por todos los EEMM, al fijar umbrales variables muy anteriores donde parece justificable que la protección del menor decaiga, pese a que éste continúe siendo oficialmente un menor ${ }^{667}$. De ahí que ambas disposiciones fueran impugnadas por el Parlamento Europeo argumentando, entre otros motivos, que constituían discriminaciones en razón de la edad. Examinaremos más adelante la respuesta ofrecida por el TJUE a dicha alegación.

En definitiva, con respecto a los miembros de la familia nuclear, ya señalamos que la Directiva proclama ampulosamente que deben gozar del derecho a la reagrupación familiar "en todo caso" en lo que, por otro lado, constituyó la base del compromiso que permitió sacar adelante la presente Directiva. Sin embargo, el análisis detenido de la regulación ofrecida por este instrumento nos permite concluir, mucho más matizadamente, que el cónyuge y los hijos menores de edad del sponsor gozan "en principio" 668 del derecho a la reunificación familiar, dado que las excepciones previstas en la Directiva permiten retrasar su ejercicio - para los cónyuges_, e incluso su misma negación - para los hijos quienes, a partir de los doce años, entran en una edad considerada como de difícil integración- ${ }^{669}$.

\section{FAMILIARES CUYA ADMISIÓN RESULTA POTESTATIVA PARA EL EM}

Los parientes no integrados en el concepto de familia nuclear se convierten en beneficiarios potenciales del derecho a la reagrupación familiar, sobre quienes el EM podrá decidir libremente la autorización de entrada y residencia en su territorio. Su concepción obedece nuevamente a parámetros restrictivos. En esta categoría encajarían los ascendientes del principal o su cónyuge - si bien sólo en línea directa y en primer grado (progenitores exclusivamente), lo que supone la eliminación de los colaterales-, los hijos mayores de edad y solteros del reagrupante o de su cónyuge, así como la pareja no casada nacional de un tercer país que mantenga con el sponsor una relación estable debidamente probada o que constituya con éste una pareja registrada y los hijos de dichas parejas -tanto los hijos menores no casados, incluyendo a los adoptivos, como los hijos solteros mayores de edad cuando no sean capaces de satisfacer sus propias necesidades como consecuencia de su estado de salud ${ }^{670}$.

667 En esta línea, Alvarez Rodríguez se pregunta: “El menor hasta cuándo es menor? (...) ¿Se deja de ser menor en una fecha anterior al cumplimiento de los dieciocho años por no gozar de una de las nacionalidades de los países de la UE?. ¿Vamos hacia la pluralidad de acepción 'miembros de la familia' en razón de la nacionalidad?, ¿y la protección del derecho a avivir en familia previsto en el art. 8 del Convenio de Roma, difiere según la nacionalidad de los cónyuges y de la nacionalidad de los hijos?”. ALVAREZ RODRÍGUEZ. A. Algunas reflexiones urgentes..., op cit. p. 13.

668 SCHUTTER, Olivier De. Report of the Situation of Fundamental Rights in the European Union in 2003. EU Network of Independent Experts of Fundamental Rigthts (CFR-CDF). Enero de 2004, p. 53. El informe se encuentra disponible en: http://ec.europa.eu/justice_home/cfr_cdf/doc/report_eu_2003_en.pdf

669 Moliner Navarro ha denunciado al respecto la concepción asimilacionista que subyace en estas dos limitaciones que pesan sobre los menores, a quienes se considera difícilmente integrables y sobre quienes "se proyecta (...) la consideración negativa de presunto delincuente o marginado". MOLINER NAVARRO, R.M. "El concepto de familia nuclear...", op. cit., p. 1806.

670 Junto a ellos, habría que añadir algunos sujetos ya mencionados que, pese a formar parte de la familia nuclear, no disfrutan de un auténtico derecho a la reagrupación familiar, resultando su entrada y residencia potestativa: los hijos menores no comunes tanto del reagrupante como de su cónyuge; los hijos cuya custodia se comparta siempre que, en 
La admisión de los ascendientes en línea directa y en primer grado, tanto del reagrupante como de su cónyuge ${ }^{671}$, se formula como una reserva. Para estos parientes se exige además que "no sean objetivamente capaces de proveer a sus propias necesidades debido a su estado de salud". La misma potestad libre rige respecto de los hijos mayores solteros del reagrupante o de su cónyuge, a quienes se exige idéntico requisito - que "no sean objetivamente capaces de proveer a sus propias necesidades debido a su estado de salud".

La autorización para entrar y residir en el territorio del EM en cuestión de estos dos grupos dependerá de lo que las autoridades internas libremente estipulen por vía legislativa o reglamentaria. Por tanto, su condición de miembros de la familia a efectos del ejercicio del derecho a la reagrupación familiar variará entre los EEMM, permitiendo la existencia de regímenes de migración familiar dispares.

A fin de prevenir los problemas adicionales que estas disparidades podrían suponer, el apartado décimo del preámbulo establece que, respecto de los beneficiarios potenciales del derecho, si un EM autoriza la reagrupación familiar de estas personas, "tal autorización se entenderá sin perjuicio de la posibilidad de que los EEM que no reconozcan la existencia de vínculos familiares en los casos cubiertos por esta disposición no concedan a dichas personas la consideración de miembros de familia por lo que respecta al derecho a residir en otro EM, con arreglo a la legislación comunitaria pertinente". Sin embargo, el artículo 16 de la Directiva relativa al estatus de los nacionales de terceros países residentes de larga duración ${ }^{672}$ permite a los miembros de la familia reunirse con el principal que se ha trasladado a un segundo EM como residente de larga duración, sometiéndolo a la condición de que la familia ya estuviera constituida en el primer EM. En consecuencia, del preámbulo de la Directiva 2003/86 cabe deducir una excepción al régimen aplicable a los residentes de larga duración y, además, que el principio de reconocimiento mutuo queda excluido en este ámbito ${ }^{673}$, lo que constituye "una forma más sutil de flexibilidad"674. En este aspecto, la Directiva no sirve al propósito armonizador, ya que respecto de estas personas se permite la existencia de múltiples disparidades entre los distintos EEMM, que podrán mantener e incluso introducir en sus respectivas prácticas y legislaciones nacionales, tratamientos diferenciados.

\subsection{El procedimiento para el ejercicio del derecho a la RF}

Esta materia está regulada en el Capítulo III de la Directiva, integrado por una única disposición, el artículo 5. El procedimiento para el ejercicio del derecho a la reagrupación familiar se inicia con la presentación de la solicitud. En coherencia con la amplia y dual titularidad activa del derecho ${ }^{675}$,

este último supuesto, se cumpla la condición de que el otro progenitor con quien el reagrupante o su cónyuge comparte la custodia, haya otorgado el consentimiento; así como los hijos menores del otro cónyuge y del reagrupante en el caso de matrimonios poligámicos. La admisión de estos familiares resulta optativa para el EM

671 Apartado 2. a) del artículo 4, cuyo tenor literal señala que los EEMM podrán autorizar la entrada y residencia de "los ascendientes en línea directa y en primer grado del reagrupante o de su cónyuge, cuando estén a su cargo y carezcan del apoyo familiar adecuado en su país de origen".

672 Directiva 2003/109/CE del Consejo, de 25 de noviembre 2003, relativa al estatuto de los nacionales de terceros países residentes de larga duración.

673 SCHAFFRIN, Dora. "Which Standard for Family...?", op. cit., p. 96.

674 Para Schaffrin esta inaplicación persigue la finalidad de evitar que la decisión de un EM en torno a la transposición y aplicación de la Directiva sobre RF extienda sus consecuencias a otro EM, que quizá no decida implementar la Directiva en el mismo sentido. SCHAFFRIN, Dora. "Which standard...?", op. cit., p. 96.

675 La evolución en la titularidad activa del derecho a la RF a lo largo del proceso de negociación de la Directiva, escapa al carácter general de escalada precipitada a la baja que se produjo durante el mismo. Contrariamente a lo que cabía 
la Directiva concede a los EEMM la facultad de decidir si la solicitud de entrada y de residencia por causa de RF debe ser presentada por el reagrupante, o bien por el miembro o miembros de su familia, "ante las autoridades competentes del EM de que se trate"676.

El cambio que experimentó la redacción de la parte final de este artículo permite la presentación de solicitudes de reagrupación no solamente ante el EM de acogida, sino también ante las autoridades consulares del EM situadas en los países de origen de los familiares del sponsor. Esta ampliación constituye un arma de doble filo. Si bien formalmente es cierto que garantiza mayores posibilidades de actuación, reafirmando la situación de los reagrupables como titulares activos del derecho, no está exenta de problemas de cara a su aplicación práctica. Muchos de estos problemas están íntimamente conectados a la precariedad del Estado de derecho existente en algunos países emisores, otros se derivan de la excesiva carga de trabajo que pesa sobre las representaciones diplomáticas, sin obviar que en ocasiones se generan redes de corrupción alrededor de los consulados - frecuentemente denunciadas por las ONG's-, y que pueden redundar finalmente en una obstaculización del derecho a la RF. Los inconvenientes que puede acarrear esta apertura fueron en su momento señalados por el propio Parlamento Europeo, quien había propuesto modificar la redacción del artículo 5 para que la presentación de solicitudes tuviera lugar ante "las autoridades competentes del EM en el que resida el reagrupante" ${ }^{777}$ y por las mismas personas — reagrupante o familiares-.

La solicitud deberá acompañarse de los elementos de prueba pertinentes, -en particular de los documentos acreditativos de los vínculos familiares y del cumplimiento de las condiciones previstas en los artículos 4, 6 y, en su caso, en los artículos 7 y 8 -, así como copias certificadas de los documentos de viaje del miembro o miembros de la familia ${ }^{678}$. A fin de certificar la existencia de los vínculos familiares, la Directiva permite que los EEMM realicen entrevistas con el reagrupante y los miembros de su familia, así como "cualquier otra investigación que estimen necesaria"679. Aquí encajarían las pruebas de ADN que ya están implantadas en algunos EEMM a fin de verificar la autenticidad de los vínculos familiares. En principio, su exigencia parece compatible con la jurisprudencia de Estrasburgo, al menos con la doctrina que en su momento sentara la Comisión Europea de Derechos Humanos. Sin embargo, las indagaciones toleradas por la Directiva sobre RF pueden

de esperar, en el primer proyecto presentado por la Comisión el titular del derecho era el reagrupante en régimen de monopolio, de modo que a él en exclusiva le correspondía presentar la solicitud de reagrupación de los miembros de su familia. Al respecto, el artículo 7 de la primera propuesta, al regular el procedimiento de presentación y examen de la solicitud de reagrupación, establecía literalmente que "el reagrupante es quien presenta la solicitud de reagrupación de los miembros de su familia ya que, en efecto, es el titular del derecho". La concesión en exclusiva de la titularidad activa del derecho a favor del sponsor, y la consiguiente presentación de la solicitud a su cargo en exclusiva, se justificaba en la mayor desenvoltura que tendría el reagrupante —al ser ya residente-, para realizar las gestiones administrativas, por estar familiarizado con las prácticas de la Administración nacional y poder desenvolverse en la lengua del país. Respecto a la ampliación de la titularidad activa cabe presumir, sin que en ningún momento sea explícita, la influencia de la jurisprudencia del TEDH que mantiene al respecto un concepto amplio de titularidad activa para incluir tanto al reagrupante en sí como a los miembros de la familia que se pretenden reagrupar.

676 Apartado 1 del artículo 5 de la Directiva 2003/86.

677 Enmienda número 35 del Parlamento Europeo. Esta institución justificaba esta enmienda añadiendo que "además, el reagrupante, que ya es residente, tendrá más facilidades para realizar los trámites administrativos gracias a sus conocimientos de la lengua del país y de las costumbres de las administraciones nacionales. En muchas regiones del mundo, las representaciones consulares de los EEMM se encuentran a cientos de kilómetros de los lugares de residencia de los familiares y frecuentemente están sobrecargadas con las solicitudes de visado de los países en cuestión. Trasladar la responsabilidad en relación con la adopción de la decisión a las representaciones en el extranjero puede dificultar la reagrupación familiar innecesariamente".

678 Párrafo segundo del artículo 5.

679 Idem. 
dar lugar a conflictos con el derecho a la intimidad y, por su finalidad, es obvio que afectarán con especial intensidad a las parejas de hecho así como a aquellos matrimonios sobre los que existan sospechas de fraude. De estos potenciales problemas alertó en su momento el Comité Económico y Social, quien consideraba especialmente grave la posibilidad de investigaciones permitida por el artículo 5.2.2 de la Directiva, y cuyo origen se sitúa en la tercera propuesta ${ }^{680}$.

Con carácter general, la solicitud será presentada y examinada cuando los miembros de la familia residan fuera del territorio del EM en el que reside el principal. Sin embargo - y esto es una característica presente desde el primer proyecto de Directiva ${ }^{681}$ - , se permite la posibilidad excepcional de que los EEMM puedan aceptar de forma potestativa que, en determinados casos, la solicitud se presente estando ya los miembros de la familia dentro de su territorio ${ }^{682}$. Las posibilidades de que los parientes que pretenden ser reagrupados se encuentren ya en el territorio del EM antes de que se haya procedido a su reunificación pueden ser muy variadas: junto a la habitual posibilidad de que se hallen de forma irregular, existen otras de difícil catalogación, como que se encuentren en virtud de otro título - como estudiantes-.

Sea como fuere, la posibilidad excepcional permitida por la Directiva de presentar la solicitud cuando los familiares están dentro del EM, otorga mayor flexibilidad a las diversas situaciones que puedan llegar a presentarse, permitiendo que el familiar afectado pueda cambiar de estatus sin tener que abandonar el territorio del EM en el que ya se encuentra, a fin de poder ejercer el derecho a la reunificación familiar. Dado que, estadísticamente, la situación más frecuente corresponde a los familiares que se encuentran en el territorio de acogida de forma irregular, la disposición estudiada - artículo 5.3 - puede ser considerada como una cláusula pasarela que otorga "cobertura legal a la conversión de la RF de hecho en una situación de derecho" ${ }^{\text {683 }}$.

La resolución del procedimiento deberá ser, según reza la Directiva, “cuanto antes y, a más tardar a los nueve meses" ${ }^{\prime \prime 84}$, momento en el que las autoridades internas deberán notificar por escrito la resolución adoptada a quien presentó la solicitud. Sin embargo, la Directiva vuelve a contradecir los objetivos de eficacia y equidad fijados en el preámbulo de este texto — que señalaba la importancia

680 A juicio del Comité Económico y Social, dado que la solicitud de reagrupación debía ir acompañada de los documentos acreditativos de los vínculos familiares, suscitaba perplejidad esta posible exigencia adicional que, además, podía prolongar el curso del procedimiento o servir para fundamentar una respuesta negativa. "Por consiguiente, pueden convertirse en auténticas vejaciones que acaben por lesionar la privacidad, sobre todo en el caso (art. 5.2 último párrafo) de que en vez de tratarse del cónyuge legalmente casado se trate de la pareja de hecho". Punto 5 del apartado 2.2 del Dictamen del CESE. C 241/108. DOCE 7.10.2002.

681 El primer proyecto de Directiva sobre RF ofrecía ciertas indicaciones en torno a las diversas posibilidades que pueden dar lugar a que el familiar reagrupable se encuentre ya en el territorio del EM con carácter previo a que se produzca su reunificación. El proyecto exponía situaciones a título meramente ejemplificativo, insistiendo en la necesidad de flexibilizar la norma para permitir la presentación de solicitudes estando ya los miembros de la familia del sponsor dentro del territorio del EM. De forma más concreta, el artículo 7.2 de la primera propuesta establecía que "esta norma debe flexibilizarse en casos particulares, en particular, cuando el miembro de la familia se encuentra ya en el territorio en virtud de otro título y no tiene más que cambiar de estatuto o por consideraciones de carácter humanitario, lo que puede cubrir el caso, por ejemplo, de un niño que tenga como único progenitor al reagrupante y, por lo tanto, no pueda ser devuelto a su país de origen".

682 El tono de la redacción es concluyente respecto al carácter facultativo que esta posibilidad representa para el EM. La formulación literal del artículo 5.3 señala que "excepcionalmente, los EEMM podrán aceptar, en determinados casos, que la solicitud se presente cuando los miembros de la familia ya estén en su territorio".

683 SERRANO VILLAMANTA, J.; ALONSO HEDROSA, G; LORA-TAMAYO, G; HERNÁNDEZ DE LA ORDEN, M.J y MARTÍNEZ RODRIGO, A. "La reagrupación familiar”; en Informe sobre la situación social de los inmigrantes y refugiados en 2008. Foro para la integración social de los inmigrantes, Monografías Foro, Ministerio de Trabajo e Inmigración, 2009, p. 10.

684 Artículo 4 de la directiva. 
de fijar un sistema de normas de procedimiento por las que se rija el examen de las solicitudes de reagrupación familiar ${ }^{65}$ con el fin de ofrecer un nivel adecuado de seguridad jurídica a los interesados.

Pese a contener tal proclamación, la Directiva establece la posibilidad, —eso sí "en circunstancias excepcionales relacionadas con la complejidad del examen de la solicitud"- ${ }^{686}$, de que los EEMM puedan ampliar el plazo general de nueve meses ${ }^{687}$. El mayor problema reside aquí en que esta alternativa excepcional no fija un período temporal máximo, que actúe como tope dentro del cual el EM esté obligado a resolver solicitudes de reagrupación especialmente complejas ${ }^{688}$. Esta posibilidad, en conjunción con los prolongados períodos de espera que cabe exigir al reagrupante, pueden rendir ineficaz ${ }^{699}$ el derecho formalmente proclamado. El margen de apreciación se diluye así en un período inexistente, cuando resulta probado que resoluciones dilatas en el tiempo - en el presente caso, por encima de los nueve meses-, unidas a los amplios períodos de espera que pueden exigir los EEMM para el ejercicio del derecho - de hasta tres años-, amenazan la subsistencia de los lazos familiares. Esta situación resulta especialmente grave cuando hay niños de por medio que, mientras tanto, puedan haber alcanzado la mayoría de edad o que corran el riesgo de verse privados de la compañía de sus padres en tempranas etapas de su vida, donde ésta es más necesaria. Posibilidades de este tipo, al no estar limitadas mediante el establecimiento de períodos temporales máximos, ya hemos señalado que amenazan seriamente la viabilidad del derecho, poniendo en peligro la perdurabilidad de los vínculos familiares.

La Directiva exige que las resoluciones denegatorias sean motivadas, añadiendo que "las consecuencias que pueda tener la ausencia de una resolución al expirar el plazo contemplado en el primer párrafo deberán ser reguladas por la legislación nacional del EM de que se trate" ${ }^{\prime 90}$. Ello significa que las consecuencias del silencio administrativo serán determinadas por los EEMM ${ }^{691}$, _circunstancia

685 Considerando décimo tercero del Preámbulo.

686 Apartado segundo del artículo quinto de la Directiva 2003/86/CE.

687 La disposición relativa a la ampliación, en circunstancias excepcionales, del plazo para tramitar y resolver la solicitud de RF, fue otra de las novedades destacadas de la Directiva, en su versión final. La tercera propuesta ya había elevado el plazo general de seis a nueve meses — ampliación que había provocado críticas por parte del Comité Económico y Social y del Comité de las Regiones, en sus respectivos dictámenes-, estableciendo que la resolución del expediente no podría sobrepasar los 12 meses como tope máximo (artículo 5.4 de la tercera propuesta). La directiva mantiene el plazo máximo general de nueve meses, pero permite la posibilidad excepcional de su ampliación sin establecer ningún límite temporal máximo. Con ello la posibilidad de sobrepasar el período de nueve meses queda abierta indefinidamente, recordando al respecto la Resolución de Armonización de 1993, que era pródiga en la imposición de límites temporales mínimos, sin fijar plazos máximos correlativos.

688 PEERS, Steve. “Key Legislative Developments..., op. cit., pp. 403-404. QUIRÓS FONS, A. Derecho comunitairo de extranjería..., op. cit., p. 410. Ambos autores critican duramente este requisito por permtir una ampliación sine die del plazo para la resolución de las solicitudes de RF. Esta situación deriva, en palabras de Steve Peers, en "an indefinite extensión of this period and it is up to Member States to determine the consequence of a failure too observe time limits, although there is an obligation to give reasons if the application is rejected". "Key Legislative Developments..., op. cit., pp. 403-404.

689 Dora SCHAFFRIN, señala contundentemente al respecto: "Also, as the rule of law requires that everyone has to be able to exercise the rights atributed to him/her in an effective manner, it should be ensured that the right to family reunification cannot be stripped of its effectiveness through the back door by requiring the sponsor to have lived in a Member State for two or even three years while granting the administration unlimited time for deciding on an application". "Which standard for family reunification..., op. cit., p. 141.

690 Artículo 5.4 in fine de la Directiva 2003/86/CE sobre el derecho a la RF.

691 Esta circunstancia fue observada con especial preocupación por el Comité de las Regiones. En su dictamen señaló que, dado que se dejaba en manos de las legislaciones nacionales la determinación de las consecuencias de no haber tomado ninguna decision al fnal del plazo otorgado al EM para resolver las solicitudes de RF, "esto puede entrañar una denegación de la solicitud por vía de un retraso administrativo”. Así mismo advirtió que ello podía dar lugar 
no exenta de riesgos de cara a la eficacia práctica del derecho a la RF y la a seguridad jurídica de los extranjeros afectados.

Finalmente, como criterio general que los EEMM deberán tener en cuenta al examinar una solicitud de reagrupación familiar, se establece el interés mejor del menor ${ }^{692}$, del que ha desaparecido la referencia expresa a su fuente de procedencia, la Convención Internacional sobre los Derechos del Niño.

\subsection{Condiciones para ejercer el derecho e la RF}

Las condiciones a las que se puede someter el ejercicio del derecho están contenidas en el Capítulo IV de la Directiva - artículos 6 a 8-. Como viene siendo habitual en esta materia, $-\mathrm{y}$ también en el ámbito de la libre circulación de trabajadores-, se indican razones de orden público, seguridad pública o salud pública como causas que pueden justificar la denegación de una solicitud de entrada y de residencia para los miembros de la familia ${ }^{693}$. Los mismos motivos se contemplan para poder retirar un permiso de residencia de un miembro de la familia o denegar su renovación - la inclusión aquí de la salud pública como causa de retirada de un permiso o de denegación de una renovación de residencia constituye otra novedad, en sentido restrictivo, de la versión definitiva de la Directiva ${ }^{694}$ -

Los motivos mencionados son conceptos jurídicos indeterminados ${ }^{695}$. Para clarificar estos conceptos, el apartado 14 del preámbulo afirma que la denegación de la RF sólo puede producirse por "motivos debidamente justificados". En particular, la persona que desee se le conceda la reagrupación familiar no debe constituir una amenaza para el orden público o la seguridad pública. La noción de orden público podrá incluir una condena por la comisión de un delito grave. En este

a que, en casos similares se produjeran diversos resultados, aumentando la litigiosidad ante el Tribunal de Justicia Europeo. Punto 1.8 del Dictamen del Comité de las Regiones emitido a la tercera propuesta de Directiva. (2003/ C73/05) DOCE 26.03.2003.

692 Apartado quinto del artículo 5 de la Directiva sobre el derecho a la RF. El criterio del interés mejor del menor, que los EEMM deben velar al examinar las solicitudes de RF, es idéntico a lo establecido previamente en la tercera propuesta. La única salvedad es que, en dicha propuesta, se hacía referencia a la Convención sobre los Derechos del Niño de 1989, de donde se había extraído dicho criterio. La directiva ha suprimido la referencia expresa a esta Convención, manteniéndose intacto el criterio del interés superior del menor, lo cual no supone una novedad de gran entidad, debido a la notoriedad tanto del criterio en cuestión como de su fuente de procedencia.

693 Apartado primero del artículo 6.

694 Los motivos establecidos como causas de denegación de una solicitud de entrada y de residencia de los miembros de la familia son idénticos tanto en la tercera propuesta de Directiva, como en su versión final; los tres clásicos: orden público, seguridad pública — antes seguridad interior- y salud pública. Sin embargo, los tres se mencionan en la versión definitiva de la Directiva sobre RF también como causas para retirar un permiso de residencia o denegar su renovación a un miembro de la familia, mientras que en la tercera propuesta no aparecía la salud pública. La exigencia de que las razones de orden público o seguridad interior debían basarse exclusivamente en el comportamiento personal del miembro de la familia en cuestión desapareció en la versión final, nuevamente recortando las escasas garantías ofrecidas a los familiares reagrupados ya en el EM. En su lugar, se ha incluido una disposición que recuerda la jurisprudencia de Estrasburgo emanada en casos de expulsión, que afirma que "para adoptar la resolución pertinente, el EM, además del artículo 17 —el cual incluye criterios jurisprudenciales del TEDH—, tendrá en cuenta la gravedad o el tipo de infracción contra el orden público o la seguridad pública cometida por el miembro de la familia, o el peligro que implique dicha persona" (artículo 6.2 in fine).

695 ALVAREZ RODRÍGUEZ se manifiesta en sentido crítico en torno a esta disposición, estimando que constituyen "cláusulas abiertas, de difícil comprensión, por la amplitud de su eventual discrecionalidad a la hora de proceder a la interpretación por parte de las autoridades estatales, están plagadas, como de costumbre, de los términos jurídicos indeterminados ya conocidos". Algunas reflexiones urgentes..., op. cit., p. 12. 
contexto se debe señalar que los conceptos de orden público y seguridad pública incluyen asimismo los "casos en que un nacional de un tercer país pertenece a una asociación que apoya el terrorismo, apoya una asociación de este tipo o tiene objetivos extremistas"696.

En la adopción de este tipo de resoluciones denegatorias o de retirada de permisos ya concedidos, el apartado segundo del artículo $6^{697}$ contempla una serie de criterios que están literalmente extraídos de la jurisprudencia de Estrasburgo emitida en el ámbito de las obligaciones negativas derivadas de la VF de los extranjeros - protección frente a expulsiones-. A estos criterios - la gravedad o el tipo de infracción contra el orden público o la seguridad pública cometida por el miembro de la familia o el peligro que implique dicha persona-, habría que unir los establecidos en el artículo $17^{698}$, que también se derivan de la jurisprudencia del TEDH en materia tanto de obligaciones positivas como negativas aplicables en el contexto migratorio, si bien constituye una penetración parcial de tales criterios: el artículo 17 incluye la naturaleza y solidez de los vínculos familiares de la persona y la duración de su residencia en el EM, así como la existencia de lazos familiares, culturales o sociales con su país de origen ${ }^{699}$.

Cuando se trata de motivos de salud sobrevenidos a la entrada de los miembros de la familia, el apartado tercero del artículo seis contempla una importante limitación que ya estaba incluida en las primeras versiones de la Directiva. Conforme a lo establecido en dicha disposición, las enfermedades o minusvalías que surjan con posterioridad a la expedición del permiso de residencia no pueden justificar la denegación de la renovación del permiso de residencia ni la decisión de devolución del familiar del territorio de aquel EM en que había sido admitido por motivos de RF.

Las condiciones materiales que pueden gravar el ejercicio del derecho a la reunificación familiar también han experimentado cierto endurecimiento ${ }^{700}$ en la versión definitivamente con-

696 Pese a que se intentó durante las negociaciones, finalmente no cuajó la propuesta de incluir entre los motivos denegatorios la amenaza a las relaciones internacionales“. PEERS, S. “Key legislative developments...”, op. cit., n 5, p. 404.

697 El artículo 6.2 de la Directiva 2003/86 afirma textualmente que "para adoptar la resolución pertinente, el EM, además del artículo 17, tendrá en cuenta la gravedad o el tipo de infracción contra el orden público o la seguridad pública cometida por el miembro de la familia, o el peligro que implique dicha persona”.

698 El artículo 17 proclama que "al denegar un solicitud, al retirar el permiso de residencia o denegar su renovación, así como al dictar una decision de devolver al reagrupante o un miembro de su familia, los EEMM tendrán debidamente en cuenta la naturaleza y la solidez de los vínculos familiars de la persona y la duración de su residencia en el Estado miembro, así como la existencia de lazos familiares, culturales o sociales con su país de origen". Los criterios establecidos en el artículo 17 a fin de efectuar la ponderación entre el interés individual y el estatal, están extraídos literalmente de la jurisprudencia de Estrasburgo, si bien de forma parcial. Se echan en falta otros criterios también consolidados por el TEDH que, sin embargo, no han penetrado en el artículo 17. Destacadamente, la existencia de lazos familiares, culturales o sociales en el país de acogida que, junto con la evaluación del tiempo de estancia en el país receptor - mencionado éste último en el art. 17- conformarían el test de la integración (desde la perspectiva de su realización en el país de acogida). En torno a la exclusion de importantes criterios de la jurisprudencia de Estrasburgo en la Directiva sobre RF también se pronuncia QUIRÓS FONS, A. "Derecho comunitario de extranjería...," op.cit., nota a pie de pág. n. 155, p. 411.

699 Una interpretación crítica a esta disposición se encuentra en GÓMEZ CAMPELLO. Sin hacer referencia a su procedencia de Estrasburgo, la autora considera, respecto del artículo 17 de la Directiva, que "tal norma permite entrever una voluntad de dotar a los órganos estatales competentes de un mayor margen de maniobra en su toma de decisiones valorando, mediante premisas de naturaleza transversal una multiplicidad de circunstancias que pueden influir favorable o desfavorablemente en la resolución y que se fijan en el interés familiar a tutelar por cada Estado"; en "La compleja aplicación de la Directiva 2003/86/CE sobre el derecho a la RF”, op. cit., p. 93.

700 El establecimiento de condiciones excesivamente onerosas para el ejercicio del derecho puede amenazar su efectividad práctica, vaciándolo de contenido. Bajo esta perspectiva, Cholewinski, al analizar los dos primeros proyectos de Directiva - los cuales establecían un umbral de protección considerablemente más alto que el finalmente aprobado-, señalaba proféticamente que: “The right to family reunification for third-country is in danger of being 
sensuada de la Directiva. Como viene siendo la norma en esta materia desde los primeros intentos reguladores, la Directiva otorga a los EEMM libertad para decidir gravar el ejercicio de este derecho con la imposición de requisitos materiales relativos a una vivienda considerada normal, un seguro de enfermedad que cubra todos los riesgos normalmente asegurados para los propios nacionales, así como recursos fijos y regulares suficientes ${ }^{701}$ para su propia manutención y la de los miembros de su familia, sin recurrir al sistema de asistencia social del EM ${ }^{702}$. La exigencia de recursos fijos se antoja más dura que su precedente - "recursos estables"-, especialmente en un contexto europeo de crisis económica y alta precariedad laboral, donde uno de los sectores más afectados son precisamente los inmigrantes.

La tercera propuesta de Directiva imponía a los EEMM que decidiesen subordinar el ejercicio del derecho a la reagrupación familiar al cumplimiento de estas condiciones materiales - vivienda, recursos, seguro de enfermedad- una obligación doble: De un lado, estos requisitos sólo podrían fijarse con el fin de garantizar que el reagrupante estuviese en condiciones de subvenir a las necesidades de los miembros de su familia sin recurrir a la financiación pública; De otro, la obligación de que estos requisitos no implicasen discriminación alguna entre los nacionales y los ciudadanos de terceros países. Ambas exigencias venían a arrojar cierta seguridad al estatus de los nacionales extracomunitarios. Para agravar aún más la situación de vulnerabilidad del reagrupante y de su familia, en la versión final de la Directiva ha desaparecido esta doble exigencia.

En la misma línea de endurecimiento se sitúa la regulación del momento en que el Estado podrá requerir el cumplimiento de las condiciones materiales facultativas. Tal y como dispone el artículo séptimo, las mismas podrán exigirse "al presentarse la solicitud de reagrupación familiar", lo que parece excluir la posibilidad de imponerlas con posterioridad. Sin embargo, la última parte de la Directiva - en sede de sanciones y recursos-, establece como causa de denegación tanto de una solicitud de RF como de su renovación, así como de la retirada de un permiso de residencia, que el reagrupante carezca de los recursos suficientes sin recurrir al sistema de asistencia social del EM "al renovar el permiso de residencia" ${ }^{03}$. Con esta redacción se permite hacer depender la residencia por RF de la suficiencia de recursos económicos no solamente al solicitar ésta inicialmente, sino en cualquiera de las renovaciones subsiguientes del permiso de residencia ${ }^{704}$ - cuyo número dependerá del período previo de residencia legal con que cuente el reagrupante en el EM-, circunstancia que dota de gran vulnerabilidad a la familia del extranjero, en contextos de recesión económica como el actual.

effectively rendered redundant by the conditions imposed upon this right". CHOLEWINSKI, Rychard. "Family reunion and conditions placed on family members..., op. cit., nota a pie n. 13, p. 273.

701 Frente a esta redacción, la tercera propuesta hablaba de "recursos estables y superiores o iguales al nivel de recursos por debajo del cual pueda concederse una asistencia social en el EM en cuestión".

702 Conforme a lo establecido en el artículo 7.1.c de la Directiva sobre el derecho a la RF, para la evaluación de los recursos económicos, los EEMM deberán tener en cuenta la naturaleza y regularidad de los mismos, así como la cuantía de los salarios y pensiones mínimos y el número de miembros que integran la familia.

703 Artículo 16 apartado a) de la Directiva 2003/86/CE.

704 El enduredicimiento de esta exigencia hace depender no sólo la propia concesión de la RF, sino también su continuación una vez ya concedida, de la suficiencia de recursos económicos. Por ello, cabría concluir que, a través del requisito establecido en el artículo 16. a) de la Directiva, el "bienestar económico del país" que domina esta materia en el ámbito de Estrasburgo, penetra en esta norma comunitaria, siquiera de forma indirecta. Como ya tuvimos ocasión de señalar, el bienestar económico del país constituye la causa más alegada para justificar restricciones legítimas al derecho a la RF en el ámbito de la jurisprudencia de Estrasburgo y, sin embargo, no fue contemplado como causa autónoma para retirar o denegar permisos de residencia por motivos de RF. 
La posibilidad del EM de verificar la suficiencia económica en las diversas renovaciones de los permisos de residencia de los miembros de la familia que ya han sido admitidos ${ }^{705}$ - que en la tercera propuesta de Directiva se circunscribía únicamente a la primera renovación-, convierte la existencia de recursos económicos en una espada de Damocles que pende sobre el sponsor y su familia durante toda su estancia dependiente en el EM $-\mathrm{O}$, para el caso del principal, hasta que éste adquiera el estatus de residente de larga duración. Para amortiguar en parte la rigidez de este requisito, la Directiva establece que cuando se trate de comprobar la suficiencia de recursos al renovar el permiso de residencia, "el EM tendrá en cuenta las contribuciones de los miembros de la familia a los ingresos familiares"706.

Junto a la exigencia facultativa de requisitos materiales, es posible también para los EEMM requerir que los nacionales de terceros países cumplan con las medidas de integración "de conformidad con la legislación nacional"707. Esta disposición constituye una de las novedades más trascendentes incorporadas por la versión final de la Directiva ${ }^{708}$, de la que no existe ni rastro en las propuestas previas. Su redacción destaca por su imprecisión y por la inexistencia de una cláusula de mantenimiento del status quo que fije una fecha tope que actúe como límite temporal para la posibilidad de los EEMM de recurrir a la aplicación de dichas medidas de integración. Dado que no se especifica qué ha de entenderse por tales medidas, las mismas constituyen un campo abierto para la discrecionalidad de los EEMM que opten por aplicarlas ${ }^{709}$.

705 La extensión de la exigencia de poder comprobar las condiciones materiales al solicitar la renovación de los permisos de residencia por RF - junto con la posibilidad de retirar y consiguientemente expulsar a los familiares admitidos en el caso de que el salario familiar no fuese considerado ya suficiente-, fue percibida en su momento como una de las medidas más preocupantes de la Directiva por parte de una red de organizaciones no gubernamentales de raíz cristiana, que habían seguido muy de cerca la elaboración de esta norma durante todo el largo proceso de negociación de la misma. Dichas organizaciones estimaban que estas condiciones eran contrarias al estándar internacional fijado, fundamentalmente, por el CEDH. Afirmaban al respecto: "deeply regret that material conditions are put forward for the renewal of residence permits for family members. The European Convention on Human Rights as well as the International Convention on the Rights of the Child regard it as an obligation of the state to safeguard and protect family especially with regard to children. Respect for family unity is found in most European Union Member States' constitutions as well'. The New EU Directive on Family Reunification: Right for Families to Live Together or Right for EU Member States to Derogate from Human Rights. Press Statement, Brussels, 4 march 2003, sp. http://www.cec-kek.org/English/Pressstatementfamreunfina20020304.pdf

706 Artículo 16.a) in fine. El criterio de tomar en consideración los ingresos totales de la familia - y no exclusivamente los del sponsor-, aminora en parte la onerosidad de esta posibilidad. Este criterio deriva de la tercera propuesta de directiva que, a diferencia de la regulación actual, exigía tomar en cuenta con carácter general las contribuciones a los ingresos familiares de los miembros de la familia reagrupados. En consecuencia, en la tercera propuesta este criterio resultaba de aplicación preceptiva en todos aquellos casos en que el reagrupante no cumpliese alguna de las condiciones generales - una vivienda normal, seguro de enfermedad y recursos estables y superiores o iguales al nivel de recursos por debajo del cual puede concederse una asistencia social en el EM en cuestión (artículo 7.1 in fine de la tercera propuesta de directiva).

707 Apartado segundo del artículo 7 de la Directiva sobre RF.

708 La posibilidad de exigir medidas de integración, contemplada en el artículo 7. 2, fue introducida a iniciativa de Austria en noviembre de 2002. Posteriormente Alemania y Holanda también respaldarían esta disposición. Tan sólo Bélgica y Suecia se opusieron explícitamente a ella en el Consejo de Ministros (Council Documents 1085/02 of 9 August 2002, 13053/02 of 23 October 2002 and 14272/02 of 26 November 2002). Sin embargo, pocos meses después, la oposición desapareció a raíz de la inserción de una segunda frase en dicha cláusula que endurecía aún más las condiciones establecidas al régimen general al establecer que, con respecto a la reunificación de los refugiados, la posibilidad de imponer medidas de integración sólo cabría con posterioridad a la concesión de la reunificación.

709 Por la discrecionalidad que otorga al EM, junto a la ambigüedad de su tenor, Quirós Fons considera este requisito como el más controvertido y criticado de la Directiva, del cual se extrae un claro tono asimilacionista, señalando que "de hecho, en el derecho interno español no se concibe, de momento, una medida de integración cumplida por el inmigrante en clave claramente asimilacionista sino cumplida por el Estado con carácter prestacional”. QUIRÓS FONS, A. "Derecho comunitario de extranjería”..., op. cit., nota al pie núm. 124, p. 408. 
De su formulación se deriva que las medidas de integración podrán ser exigidas tanto al sponsor como a los familiares reagrupados. Sin embargo, para los refugiados y sus familiares, la Directiva especifica que sólo puedan aplicarse una vez que se haya concedido la RF a las personas de que se trate ${ }^{710}$. De la excepción establecida para el régimen de la reunificación familiar aplicable a los refugiados y a los miembros de sus familias, cabe deducir, a sensu contrario, que las medidas potestativas de integración podrán ser impuestas a los extranjeros del régimen general - que no encajen en la categoría de refugiados-, tanto con carácter previo como posteriormente $\mathrm{e}^{71}$ a la autorización de su entrada en el EM que decida exigirlas. En consecuencia, no existe límite temporal para la posibilidad de exigir el cumplimiento de medidas de integración a los inmigrantes. La única posible excepción sería aplicable a los residentes de larga duración, a quienes la Directiva 2003/109/CE concede un estatuto más seguro.

Las características apuntadas convierten, a nuestro juicio, a las posibles medidas de integración previstas en el apartado segundo del artículo siete en una de las disposiciones con más riesgos en el proceso de transposición y aplicación interna de la Directiva 2003/86 $6^{712}$. Sin embargo, su potencial conflictivo no fue considerado excesivo, a juzgar por el hecho de que el Parlamento Europeo no incluyó al artículo 7. 2 entre las disposiciones recurridas ante el TJUE.

\subsection{Estatus de los familiares admitidos por causa de RF}

El estatus que corresponde a los familiares reagrupados se deriva de lo establecido en el Capítulo VI de la Directiva, bajo el epígrafe "entrada y residencia de miembros de la familia" ${ }^{\prime 3}$. Se trata de una materia de especial importancia, de cuya regulación puede depender la integración real de los familiares admitidos en el Estado de acogida.

La primera disposición dedicada a reglamentar la situación legal de las personas admitidas por motivos de reunificación, obliga al EM a autorizar la entrada del familiar o familiares "tan pronto como se acepte la solicitud de reagrupación familiar", a cuyo fin "dará a estas personas toda clase de facilidades para la obtención de los visados necesarios" ${ }^{714}$. Su formulación imperativa — "autorizará" - no deja lugar a dudas sobre el carácter prescriptivo de la obligación que pesa sobre los EEMM, viniendo con ello a confirmar el derecho subjetivo que la Directiva establece a favor de los nacionales procedentes de terceros países - que, como vimos, se derivaba principalmente de lo establecido en el artículo cuarto de este instrumento normativo. Desde la tercera propuesta se eliminó

710 Artículo 7.2 in fine.

711 En el mismo sentido se pronuncia Groenendijk, para quien "This exception made things worse for all other family members. According to the Directive, they may (not: must) be required to comply with integration measures while they are still abroad". GROENENDIJK. "Legal concepts on integration.... Op. cit., p. 120.

712 Holanda, Alemania y los Países Bajos, en base a la cláusula opcional del art. 7.2 de la Directiva, han introducido en sus legislaciones la exigencia de una medida de integración como condición previa para la admission en sus territorios -evaluación de conocimiento del francés, conocimiento básico de la lengua alemana y prueba previa de que los familiares conocen la lengua y la sociedad holandesa, que tendrá lugar en el país de origen, respectivamente-. Comisión de las Comunidades Europeas. Informe de la Comisión al Conseho y al PE relativo a la aplicación de la Directiva 2003/86/CE sobre el derecho a la RF, op. cit., pp. 7-8. La misma Comisión ha especificado que la admisibilidad de las medidas de integración que pueden introducir los EEMM, depende de que las mismas sirvan al objetivo de facilitar la integración y, acumulativamente, que respeten los principios de proporcionalidad y de subsidiariedad. Comisión Europea. Libro Verde sobre el derecho a la RF de los nacionales de terceros países que residen en la UE, op. cit., p. 5.

713 El capítulo VI incluye los artículos 13, 14 y 15.

714 Apartado primero del artículo 13 de la Directiva sobre el derecho a la RF. 
la referencia a la obligación de emitir visados de RF de forma gratuita. En consecuencia, la gratuidad o el coste de los mismos se establecerá libremente por los EEMM, aunque con el límite genérico de que su coste no sea excesivamente gravoso, a fin de respetar el principio de proporcionalidad y la jurisprudencia de Estrasburgo.

La duración de los permisos de residencia concedidos a los familiares se ha recortado $-\mathrm{y}$, por ende, endurecido-, con respecto a lo establecido en la versión inmediatamente anterior ${ }^{715}$. La Directiva señala la obligación del EM de expedir a los miembros de la familia admitidos un primer permiso de residencia renovable, cuya duración mínima inicial será de un año ${ }^{716}$, en claro contraste con la anterior obligación general de otorgarles un permiso de residencia de duración idéntica al que poseyera el reagrupante. Además, la Directiva aclara que la duración de los permisos de residencia concedidos a los familiares, "en principio" no podrá superar la fecha de caducidad del permiso de residencia que posea el sponsor ${ }^{717}$.

Especialmente trascendente a fin de evaluar la adecuación de la Directiva como instrumento de integración de los extranjeros lo constituye el artículo décimo cuarto, que establece los derechos que corresponden a los miembros de la familia del reagrupante tras su entrada autorizada en el EM. Conforme a dicho artículo, los familiares admitidos tendrán derecho a acceder a la educación, a un empleo por cuenta ajena o por cuenta propia, y acceso a la orientación, formación, perfeccionamiento y reciclaje profesionales. De tales derechos, los miembros de la familia serán titulares, según reza esta disposición, "de la misma manera que el reagrupante". Parece sentarse pues un principio general de equiparación con respecto al reagrupante en materia de derechos otorgados a los parientes admitidos por motivos de reagrupación familiar.

El acceso al mercado laboral de los familiares reagrupados se erige en un aspecto clave para su adaptación en el Estado receptor, al tiempo que una de las cuestiones más polémicas en la regulación de la migración por causas familiares. Este tema ha constituido habitualmente un punto sobre el cual se multiplicaban las discrepancias entre los EEMM, preocupados por la protección de sus mercados laborales autóctonos, especialmente en contextos recesivos como el actual.

En la regulación de este difícil aspecto, la Directiva, en su versión definitiva, contiene importantes novedades que contradicen parcialmente tanto el objetivo integrador, como la igualdad de derechos entre el reagrupante y los familiares reagrupados ${ }^{718}$. En esta línea, el apartado segundo del

715 En la tercera propuesta se establecía que el EM debía expedir a los familiares un permiso de residencia renovable "de idéntica duración a la del permiso de residencia del reagrupante". Como excepción preveía que, si el reagrupante ya era titular de un estatuto de residente de larga duración, el EM expediría a sus familiares un permiso de residencia de una duración limitada de, al menos, un año renovable, hasta que se cumpliesen las condiciones para que los familiares a su vez pudiesen vez obtener el estatuto de residente de larga duración (art. 13, apartados 2 y 3 de la tercera propuesta de Directiva).

716 Apartado segundo del artículo 13 de la Directiva 2003/86/CE.

717 Idem. Nuevamente esta disposición, que usa el término "reagrupante", constituye un ejemplo de uso terminológico confuso de este término. El artículo segundo de la Directiva contempla una definición amplia de reagrupante que incluye también a los familiares que se reúnen con éste en el EM de acogida. El artículo 13.3, sin embargo, está usando el concepto tradicional de reagrupante — restringiéndolo al sponsor-, del que explícitamente se aparta la versión definitiva de la Directiva.

718 La Directiva 2003/86 ha recortado el derecho al trabajo de los miembros de la familia del reagrupante, con respecto a la regulación contenida en la tercera propuesta. La formulación en ambos documentos es idéntica, ya que parten del reconocimiento del derecho de los familiares a acceder a la educación, al empleo por cuenta ajena o propia y a la orientación, formación, perfeccionamiento y reciclaje profesionales. Sin embargo, en la tercera propuesta de Directiva se establecía la posibilidad de que los EEMM limitasen el acceso al mercado laboral tan sólo con respecto a los ascendientes y a los hijos mayores. Ahora la Directiva otorga la misma posibilidad (art. 14.3), pero además 
artículo 14 faculta a los EEMM para el establecimiento de las condiciones que los miembros de la familia deben cumplir para poder ejercer una actividad laboral, tanto por cuenta propia como por cuenta ajena. Entre dichas condiciones, cabe la imposición de un período de espera máximo de 12 meses $^{719}$ "durante el cual los EEMM podrán estudiar la situación de sus mercados laborales antes de autorizar a los miembros de la familia a ejercer una actividad por cuenta ajena o por cuenta propia".

En definitiva, el acceso al mercado de trabajo puede estar trabado temporalmente - con el límite máximo de un año- para todos los familiares que han sido admitidos por motivos de RF, pero solamente en base a la verificación de la situación nacional del mercado de trabajo. Esta concesión a los EEMM puede dificultar la integración de los familiares, al tiempo que agravar la situación económica de la familia, cuyos gastos han sido incrementados a raíz de la llegada de nuevos miembros al territorio del país receptor ${ }^{720}$. Pese a los riesgos que conlleva la cláusula opcional establecida en el art. 14.2, su transposición en los EEMM — salvo marcadas excepciones ${ }^{721}$ —, ha dado lugar a normativas que generalmente facilitan el acceso de los familiares reagrupados al mercado nacional de empleo.

Mayores problemas se derivan de la regulación prevista con respecto al derecho al trabajo de los ascendientes en línea directa y en primer grado y de los hijos mayores solteros, tanto del reagrupante como de su cónyuge. Para estas dos categorías de familiares, la Directiva permite que los EEMM puedan limitar su acceso a una actividad por cuenta ajena o por cuenta propia, sin más especificaciones $^{722}$. Dado que no se contempla ningún límite temporal expreso al que sujetar esta posibilidad, cabe que los EEMM limiten el derecho al trabajo de ascendientes e hijos adultos de forma indefinida, lo cual supondría la negación del derecho formalmente proclamado - al menos hasta que tales sujetos adquieran un estatuto autónomo- - Si bien es cierto que estos familiares han sido admitidos en consideración casi exclusiva a la dependencia que mantienen con respecto del sponsor, la regulación de esta materia no hace sino promover de forma indefinida su situación de vulnerabilidad y dependencia, sin permitirles que dejen de suponer una carga económica familiar, para la frecuentemente debilitada economía de los inmigrantes.

permite a los EEMM fijar las condiciones que deben cumplir los familiares para ejercer una actividad por cuenta ajena o por cuenta propia - las cuales pueden llegar a convertir en superfluo el derecho formalmente proclamado. Además, la Directiva permite el establecimiento de un período máximo de espera de un año antes de que los familiares pueden tener acceso al mercado laboral.

719 El establecimiento opcional de un período de espera de un año como máximo, antes de que los familiares reagrupados puedan acceder al mercado de trabajo, se debe a las presiones ejercidas por Austria y Alemania durante la negociación de la Directiva sobre el derecho a la RF.

720 Schibel ha identificado aquellas disposiciones de la Directiva que resultan más problemáticas de cara a su trasposición en las regulaciones internas de los EEMM y que, por ello, merecen mayor vigilancia. El criterio que ha usado para identificarlas son los artículos que fueron impugnados ante el TJUE en el recurso de anulación promovido contra la directiva, a los que suma algunas otras disposiciones de esta norma. Entre ellas destaca el artículo 14, en materia de derechos otorgados a los familiares reagrupados. En palabras de Schibel, "prolonged exclusion from the labour market is likely to have a negative effect on the integration of family members and contravenes the integration goals set by Member States themselves". SCHIBEL. Yongmi. Monitoring and Influencing the transposition of EU immigration law. The family reunion and long term residents Directives. Issue Paper prepared for the European Migration Dialogue. September 200, p. 7. Disponible en la dirección: http://www.migpolgroup.com/multiattachments/2487/DocumentName/emd1.pdf

721 Alemana, Eslovenia y Hungría - tal y como subraya la Comisión-, permiten la exclusion completa del mercado de trabajo de ciertos familiares del sponsor durante el primer año siguiente a su admisión, con lo cual sus legislaciones están excediendo lo permitido por la cláusula opcional del art. 14.2, al no tener en cuenta que sólo cabe tal exclusión "sobre la base de una verificació n de la situación del mercado de trabajo". Infomre de la Comisión al Consejo y al PE relativo a la aplicación de la Directiva 2003/86/CE sobre el derecho a la RF, op. cit, p. 14.

722 Apartado tercero del artículo 14. 
Especialmente entorpecedora resulta la posible exclusión laboral de los hijos adultos —en vista de que no resulta descabellado prever mejoras en su salud que aconsejen su acceso al mercado laboral- y respecto de quienes, por su edad, su plena inserción en el Estado de acogida resulta, si cabe, aún más pertinente que respecto a los ascendientes. En cualquier caso, una limitación de este tipo desmiente la igualdad anteriormente proclamada, obstaculiza las posibilidades reales de que estas personas se inserten en la sociedad de acogida e impone cargas a la economía familiar, cuestión que puede tener consecuencias graves sobre la continuación de la residencia del reagrupante y su familia en el EM - en vista de que la suficiencia de recursos económicos constituye una condición necesaria no sólo para la concesión de la RF, sino para su renovación y, por tanto, para la propia permanencia del principal y de su familia en el $\mathrm{EM}^{723}$.

Otra de las cuestiones clave, integrante del estatus legal de los familiares admitidos, la constituye la regulación del acceso a un estatuto autónomo. La adquisición de un permiso de residencia independiente por parte de los miembros de la familia aparece regulada en el artículo 15. Tras cinco años de residencia como máximo, los cónyuges o parejas no casadas y los hijos que hubieran alcanzado la mayoría de edad, tendrán derecho - previa solicitud-, a un permiso de residencia autónomo. Para obtenerlo, se exige como condición que al miembro de la familia en cuestión no se le haya concedido ya un permiso de residencia por motivos distintos de la reagrupación familiar. Sin embargo, la versión final de la Directiva incorpora como novedad la posibilidad de que, con respecto al cónyuge o pareja no casada, los EEMM limiten su acceso a un estatuto autónomo en los casos de ruptura del vínculo familiar ${ }^{724}$. Esta limitación facultativa constituye una adición de última hora, que viene a subrayar la situación de vulnerabilidad del cónyuge o pareja del reagrupante, especialmente crítica en supuestos extremos como pueden ser de violencia doméstica — pues, de forma indirecta, la regulación puede llegar a promover la continuación de la relación de pareja a fin de no entorpecer el acceso a un estatuto autónomo y, en consecuencia, la propia prolongación e impunidad de la violencia intrafamiliar.

Nuevamente, la situación más crítica recae sobre los hijos adultos y los ascendientes en línea directa. La adquisición de una residencia independiente por parte de estas personas depende por completo de las decisiones que adopte cada EM. Al respecto, el apartado segundo del artículo 15 señala sucintamente que "los EEMM podrán conceder un permiso de residencia autónomo" a dichos sujetos, de lo que se deduce con claridad que los EEMM gozan también de la misma libertad para su denegación. La concesión de permisos independientes a los hijos adultos y ascendientes del reagrupante resulta pues totalmente discrecional para el $\mathrm{EM}^{725}$.

En el caso de viudedad, divorcio, separación o muerte de ascendientes o descendientes, los EEMM podrán libremente decidir sobre la concesión de permisos de residencia autónomos a las personas que hubieran entrado al país con fines de reagrupación familiar, "previa solicitud y si fuera necesario"726. Para estos supuestos, la protección que ofrece la Directiva es muy baja. Sin embargo, en concurrencia de "circunstancias especialmente difíciles" la expedición de dichos permisos autónomos resultará preceptiva para el EM, tal y como señala el párrafo tercero in fine

723 Así se deriva de lo establecido en el artículo 16. a) de la Directiva, conforme al cual los EEMM podrán retirar un permiso de residencia otorgado con fines de reagrupación familiar o denegar su renovación cuando, al renovar el permiso de residencia, el reagrupante carezca de los recursos suficientes sin recurrir al sistema de asistencia social del EM.

724 Artículo 15. 1 in fine de la Directiva sobre el derecho a la RF.

725 PEERS. S. “Key Legislative Developments..., op. cit., no 5, 2003, p. 405.

726 Apartado tercero in fine del artículo 15, conforme al cual "los EEMM establecerán disposiciones que garanticen la concesión de un permiso de residencia autónomo si concurren circunstancias especialmente difíciles”. 
del artículo 15. Se deduce pues que ni la muerte de familiares ni la separación ni la viudedad o el divorcio constituyen circunstancias especialmente difíciles que otorguen derecho a la adquisición de autonomía al familiar reagrupado. La Directiva establece que compete a la legislación nacional la fijación de las condiciones relativas a la concesión y duración de los permisos de residencia autónomos ${ }^{727}$.

En conexión con esta materia, la Directiva especifica como causa de retirada o de denegación de la renovación del permiso de residencia de un miembro de la familia "cuando la residencia del reagrupante llegue a su fin y el miembro de la familia aún no tenga el derecho al permiso de residencia autónomo con arreglo al artículo 15”728. Esta disposición deja claramente al descubierto la inestabilidad y vulnerabilidad implícita al estatuto dependiente que ostentan los familiares reagrupados, y de las que sólo podrán librarse al acceder a un permiso autónomo. Al mismo tiempo, arroja una luz muy reveladora de la importancia que adquiere la adquisición de un estatuto autónomo para los familiares admitidos ${ }^{729}$. Una visión más completa de esta materia exige además tener en cuenta la Directiva de residentes de larga duración, conforme a la cual los miembros de la familia accederán a un estatus autónomo tras cinco años de residencia legal en el EM.

El artículo 16 de la Directiva sobre RF regula los motivos para denegar solicitudes de entrada y residencia con fines de reagrupación familiar, o de retirada de permisos concedidos con dichos fines. Se incluyen como tales "cuando no se cumplan o hayan dejado de cumplirse las condiciones establecidas en la presente Directiva" ${ }^{730}$, motivo del que se deduce con claridad que la exigencia de las condiciones materiales fijadas por la Directiva es de carácter continuado - se entiende que hasta el reagrupante haya logrado un estatus más seguro, como el que se obtiene al convertirse en un residente de larga duración. Se prevé también como causa de denegación o retirada del permiso de residencia con fines de RF, que el reagrupante y el miembro o miembros de su familia no hagan o haya dejado de hacer vida conyugal o familiar efectiva ${ }^{731}$ - concepto que trae ecos de Estrasburgo, si bien aquí aplicado de forma algo distorsionada-, y cuando se constate que el reagrupante o la pareja no casada ha contraído matrimonio o que mantiene una relación estable con otra persona.

Y se adicionan los motivos clásicos, esto es, en caso de utilización de información o documentación falsa o engañosa, fraude o medios ilícitos, o en supuestos de matrimonio o relaciones de pareja de conveniencia o adopciones formalizadas únicamente para que el interesado pueda entrar en un $\mathrm{EM}^{732}$. Al respecto, en las negociaciones de última hora de la Directiva se incluyó una cláusula ${ }^{733}$ que permite a los EEMM - al evaluar este tipo de situaciones-, tener en cuenta de forma particular el hecho de que el matrimonio o la relación de pareja o la adopción se hayan formalizado después de que el reagrupante haya obtenido el permiso de residencia. Esta disposición viene nuevamente

727 Steve PEERS puntualiza al respecto que, "logically such conditions cannot negate Member States' obligations under the directive". "Key Legislative Developments...", op. cit., 2003, p. 405.

728 Apartado tercero del artículo 16.

729 En el mismo sentido, PEERS, Steve. “Key Legislative Developments...”, op. cit., n 5, 2003, p. 405.

730 Artículo 16.1.a) de la Directiva 2003/86/CE.

731 Apartado b) del primer párrafo del artículo 16 de la Directiva. Schibel considera que esta cláusula es especialmente problemática y, por ello, es merecedora de mayor vigilancia durante el proceso de transposición de la Directiva. Para el autor "this provision puts the spouse — statistically, this is in most cases the wife - in a particularly vulnerable position. Member States should use a broad definition when assessing the 'particularly difficult circumstances' which justify the grant of an autonomous residence permit (article 15.3), including for instance cases of domestic violence". SCHIBEL, Yongmi. Monitoring and influencing the transposition of EU ..., op. cit., p. 7.

732 Apartados a) y b) del párrafo segundo del artículo 16.

733 Artículo 16.2.a) de la Directiva sobre RF. 
a gravar más la formación familiar frente a la RF en sentido estricto, contradiciendo la concepción amplia de la reunificación familiar que se proclama tanto en el apartado sexto del preámbulo como en el artículo 2.d) de la Directiva.

Las prevenciones contra el fraude en materia de RF llevan a otorgar a los EEMM la posibilidad de proceder a controles e inspecciones específicos cuando existan sospechas fundadas de fraude o de matrimonio, relación en pareja o adopción de conveniencia. Con ocasión de la renovación del permiso de residencia de miembros de la familia, se establece que también podrán realizarse controles específicos ${ }^{734}$.

La Directiva otorga a sus beneficiarios cierta protección frente a las expulsiones, confiriendo por esta vía una mayor seguridad al estatuto de residente en un EM, y dando acogida - aunque sin hacerlo explícito- a los parámetros jurisprudenciales de Estrasburgo. Esta protección aparece especificada en los artículos 6.2 in fine - criterios aplicables en caso de retirada o denegación de renovación de un permiso de residencia-, y el artículo 17-cláusula transversal que constituye una recepción expresa de la jurisprudencia del TEDH en materia de VF de los extranjeros-. De otro lado, sólo cabe la expulsión de los familiares reagrupados por las causas tasadas en los artículo 6, 7 y 16 de la Directiva, lo que excluiría preceptivamente la expulsión por motivos distintos a los especificados en dichas disposiciones ${ }^{735}$.

En los supuestos de denegación de la solicitud, o de retirada o no renovación del permiso de residencia ya concedido para fines de reagrupación familiar, la Directiva consagra un débil derecho a la interposición "de los recursos jurisdiccionales o administrativos legalmente previstos" ejercicio de este derecho se regulará por las legislaciones internas de los Estados miembros. Si bien la formulación de este derecho ganó en precisión jurídica en la versión final de la Directiva ${ }^{737}$, su configuración ha seguido suscitando críticas ${ }^{738}$ ante el riesgo de que la desprotección del derecho a la tutela judicial puede convertir en ilusorio ${ }^{739}$ el propio derecho a la reunificación familiar. La fortaleza del derecho a la tutela jurídica se antojaba, si cabe, más pertinente como consecuencia de la ampliación de la titularidad activa del derecho a la reagrupación ${ }^{740}$.

734 Apartado cuarto del artículo 16.

735 GROENENDIJK, K. "Family Reunification as a Right...”, op. cit., p. 218. GROENENDIJK, Kees. “Legal Concepts of Integration in EU Migration Law..., op.cit., p. 118.

736 Artículo 18 de la Directiva 2033/86.

737 El derecho a acceder a vías de recurso jurisdiccionales mejoró en precisión, ya que en la versión correspondiente a la tercera propuesta se garantizaba el acceso "a las vías de recurso jurisdiccionales, de hecho y de derecho".

738 Para Schibel el derecho a la interposición de recursos constituye una cláusula controvertida de la Directiva, sobre la que es necesario incrementar su nivel de vigilancia durante la transposición y aplicación interna de esta norma comunitaria. En palabras de este autor, "the precise limits of the expression 'legal challenge' are not fully clarified within the directive. In transposition, it should be applied to mean 'right of appeal'. SCHIBEL, Yongmi, Monitoring and influencing...., op. cit., p. 7.

739 Elspeth Guild señala que la referencia a los remedios legales puede y debería estar infundida de substancia real a fin de que los individuos puedan realizar de forma práctica sus derechos, entre ellos el derecho a la reagrupación familiar. La autora advierte que el derecho a la RF puede convertirse en ilusorio si no se dota de una garantía jurídica efectiva a fin de remediar, ante las instancias jurisdiccionales, los incumplimientos de las autoridades públicas a dicho derecho. GUILD, E. "From Amsterdam and Tampere to the Hague...", op. cit., p. 7.

740 En el mismo sentido, BRINKMANN, Gisbert. "Family Reunion, Third Country Nationals and the Community's New Powers..., op. cit., pp. 254-255. 


\subsection{Valoración de la Directiva 2003/86: La adecuación de la Directiva para el logro de sus objetivos explícitos}

Tras haber analizado detenidamente tanto los antecedentes legislativos como el contenido final de la Directiva 2003/86, estamos en condiciones de responder a los interrogantes que dejamos abiertos al estudiar los objetivos que inspiran a este instrumento comunitario.

Ya señalamos que la Directiva persigue expresamente tres objetivos principales: Fijar las condiciones de ejercicio del derecho a la RF de que disponen los nacionales de terceros países residentes legales en el territorio de los EEMM - art. 1-y, por esta vía, armonizar la regulación del derecho a la reagrupación de los extranjeros en el ámbito comunitario, cuyo ejercicio se llevará a cabo según modalidades comunes - párrafo 16 del preámbulo—, así como también fomentar la integración de los extranjeros — párrafo 15 del preámbulo.

\section{a) La concesión de un derecho a la RF para los ciudadanos extracomunitarios}

Esta cuestión ya ha sido despejada, de modo que no nos detendremos en ella. Del tono imperativo del artículo 4.1 se deduce que la Directiva impone obligaciones preceptivas a cargo de los EEMM, a fin de autorizar la entrada y residencia de los familiares del extranjero residente. Este carácter preceptivo se deduce también de su artículo 13.1 y ya ha sido reiteradamente confirmado por la jurisprudencia del TJUE, quien ha ido incluso más allá del tenor literal de la norma para profundizar en su efecto útil, concluyendo que, -en concurrencia de los requisitos previstos por la Directiva 2003/86 - , la regla general aplicable para los EEMM por ella vinculados será la obligación de conceder la $\mathrm{RF}^{741}$. Esta perspectiva refuerza notablemente el derecho subjetivo que corresponde a los nacionales extracomunitarios en materia de migración familiar, en base a la norma comunitaria analizada.

En conclusión, la Directiva 2003/86 otorga por primera vez en el ámbito comunitario un derecho subjetivo autónomo y general a la RF para los nacionales procedentes de terceros países que cumplan con las condiciones exigidas. Si bien con el importante matiz de que tal derecho resulta predicable solamente a favor de los miembros de la familia nuclear —entendiendo ésta en su concepción más estrecha posible, cónyuge e hijos-, y aún contemplando ciertas restricciones excepcionales para ambas categorías. Con todo, el derecho a la RF de los nacionales extracomunitarios instaurado por dicha norma se erige como un umbral mínimo aplicable en todo el territorio de la Unión — con la excepción de los tres EEMM excluidos de su ámbito de aplicación-.

\section{b) La Directiva ante la armonización de las políticas nacionales sobre RF}

\section{b.1 Una norma respetuosa con el derecho interno y que tiende a reflejar las legislaciones nacionales más restrictivas en materia de RF}

El cambio de orientación impreso a partir de la tercera propuesta ${ }^{742}$, reveló en su momento el triunfo de una tendencia en la cual la Directiva se fraguaría sobre la base de trastocar lo menos po-

741 Sentencia del TJUE de 27 de junio de 2006, Parlamento v. Consejo, C-540/03, apartado 60; Sentencia del TJUE (Sala Segunda) Caso Rhimou Chakroun c. Minister van Buitenlandse Zaken C-578/08, de 4 de marzo 2010, apartados 41 y 43 .

742 La Exposición de Motivos de la Propuesta de Directiva de 2 de mayo de 2002 justificaba las excepciones al régimen general introducidas en su texto, afirmando que la directiva prevé "en casos muy limitados, excepciones para adap- 
sible las legislaciones y políticas internas existentes en los EEMM en materia de reunificación fami$\operatorname{liar}^{743}$, -especialmente de los países que habían mostrado más reticencias durante la negociación, cuyos regímenes de reagrupación eran precisamente los más restrictivos-.

El resultado nos sitúa ante una Directiva que, mediante una formulación dúctil y en ocasiones altamente imprecisa ${ }^{744}$, se caracteriza por conceder a los EEMM una amplia libertad y flexibilidad $^{745}$ - que ha llegado a calificarse como máxima ${ }^{746}$. Esta situación se traduce en elevadísimos margen de apreciación estatal que anticipan ya la débil efectividad de esta norma, donde escasean las disposiciones vinculantes ${ }^{747}$ - hasta el punto de haber sido tildada como una norma "de soft law derivado"748_, y la correlativa baja intensidad de su objetivo armonizador. Siguiendo a Staples, podría decirse que la Directiva no ha convertido en superfluo el derecho nacional ${ }^{749}$. Muy al contrario, permitirá la continuación de 24 políticas de reagrupación nacionales diversas, que podrán desenvolverse con bastante desenvoltura, si bien bajo un amplio marco general común.

La Directiva es por ello un instrumento que tiende a favorecer el mantenimiento del status quo y que terminaría proyectando las prácticas y legislaciones nacionales más conservadoras $\mathrm{s}^{750} \mathrm{en}$ materia de RF. Si se le aplicase el test del justo equilibrio exigido por Estrasburgo, la conclusión sería obvia: entre los dos polos sobre los que debe moverse el derecho a la reunificación familiar, la Directiva se

tarse a determinadas especificidades de las legislaciones nacionales vigentes" (apartado 2.1 EM. COM (2002) 225 final).

743 En este sentido, Groenendijk ha señalado que: "Firstly, the principle aim of most of the national civil servants participating in the negotiations was to secure minimal interference from the Directive in existing national law. This also applies for the few politicians who, at the time took a serious interest in these negotiations. They focussed primarily on the proposal and on their national immigration rules. Some actors, national civil servants, NGOs and the Commission, however, kept on recalling the principles set by the European Council in Tampere." GROENENDIJK, Kees. "Family Reunification as a Right under Community Law", op. cit., p. 220.

744 En idéntico sentido se expresa Schibel, quien prosigue afirmando que estas características provocan riesgos: “Un riesgo es que los Estados la 'interpreten de forma restrictiva si los gobiernos deciden aprovecharse de las derogaciones y de la redacción flexible' SCHIBEL. Yongmi. Monitoring and Influencing the transposition of EU immigration law. The family reunion and long term residents Directives, op. cit., p. 1, traducción propia..

745 La flexibilidad se traduce en mayores facilidades para los EEMM en el proceso de transposición de la Directiva. Sobre esta cuestión Schibel ha declarado que: "Already during the negotiation process, governments typically seek to insert a degree of flexibility into the wording of a directive to help it fit with existing national mechanisms and reduce the costs of implementation”. SCHIBEL, Y. Monitoring and influencing the transposition of EU...., op. cit., p. 2.

746 SCHAFFRIN, Dora. “Which Standard for Family Reunification...”, op. cit., p. 97.

747 WIESBROCK, Anja. "Court of Justice of the European Union. The Right to Family Reunification to Third-Country Nationals under EU Law; Decision of 4 March 2010, Case C-578/08, Rhimou Chkaroun V. Minister van Buitenlandse Zake"; European Constitutional Law Review, n 6, 2010, p. 479.

748 QUIRÓS FONS, A. “Derecho comunitario de extranjería...., op. cit., p. 398. En la misma línea, Gómez Campello considera que la Directiva 2003/86/CE tiene un carácter "escasamente vinculante”, provocando que los países adapten su normativa con excesiva flexibilidad; en "La compleja aplicación de la Directiva 2003/86/CE sobre el derecho a la RF", op. cit., p. 97.

749 OOSTEROM-STAPLES, Helen. “The Family Reunification Directive: A Tool Preserving Member State Interest or Conducive to Family Unity?”; en BALDACINI, Anneliese, GUILD, Elspeth and TONER, Helen (eds.). Whose Freedom, Security and Justice?. EU Immigration and Asylum Law and Policy. Oxford and Pórtland, Oregon, Hart Publishing, 2007, p. 487.

750 Resulta muy expresiva la opinión al respecto de Alvarez Rodríguez quien, tras calificar de excesivamente lenta la gestación de la Directiva, observa que "aunque los progenitores son muchos (...) sin embargo, a la vista de la criatura no nos queda más remedio que apuntar que los espermatozoides predominantes pertenecen a los Estados más conservadores de la UE". ÁLVAREZ RODRÍGUEZ, Aurelia. Algunas reflexiones urgentes relativas a la reagrupación familiar en el Derecho Comunitario..., op. cit., p. 2. 
ha inclinado hacia la priorización de los intereses estatales ${ }^{751}$. Ello se ha realizado con el consiguiente costo en la disminución del nivel de protección de los intereses individuales amparados por el derecho de reagrupación familiar.

En definitiva, la Directiva 2003/86, en su actual configuración, resulta poco adecuada para el logro del objetivo armonizador que proclama perseguir ${ }^{752}$. Sin embargo, sí permite cierta convergencia, limando las diferencias más sustanciales que persistan entre las políticas internas, preparando con ello el terreno para una futura armonización ${ }^{753}$. Esta circunstancia tiene una lectura positiva: de un lado, desde el punto de vista de su eficacia, ya que si la Directiva hubiese pretendido de golpe la homogeneidad, obviando las diferencias reguladoras que preexistían entre los EEMM, su grado de eficacia podría haberse visto comprometida ${ }^{754}$-por no hablar de las dificultades insalvables que hubiera afrontado su proceso de negociación-; de otro, la Directiva ha nacido marcada por la transitoriedad ${ }^{755}$, lo que permite un margen para el optimismo ante futuras reformas — aun cuando ya se ha advertido que, de emprenderse éstas en la actualidad, cabría el riesgo de que el texto modificado dificultara aún más el ejercicio del derecho a la $\mathrm{RF}^{756}$.

Que la Directiva sobre el derecho a la RF se ha previsto como una primera etapa de un proceso más largo que implicará evoluciones más profundas, se desprende con claridad de la cláusula de emplazamiento contenida en su artículo $19^{757}$. En ella se establece la obligación periódica de la

751 En el mismo sentido, OOSTEROM-STAPLES, Helen. “The Family Reunification Directive: A Tool Preserving Member State Interest or Conducive to Family Unity?”, op. cit., pp. 451-488. La Asamblea Parlamentaria del Consejo de Europa, en la Recomendación 1686 (2004) sobre Movilidad humana y derecho a la Reunificación familiar, lamentaba expresamente en su apartado X que la Directiva comunitaria sobre el derecho a la RF no estableciese disposiciones armonizadas en relación a las condiciones, procedimientos y plazos para la concesión del estatuto de residente y los derechos asociados.

752 Ferraiolo ofrece al respecto una visión muy pesimista del logro del objetivo armonizador propuesto por la Directiva. En sus palabras: "Il risultato è abbastanza sconsolante. Più che una armonizzazione delle normative, la Direttiva è l'insieme delle normative nazionali in materia corredate da un numero veramente notevoli di clausole facoltative che, se adottate tute da uno stesso Stato membro, renderebbero praticamente impossibile l'attuazione di quello che il titolo della Direttiva continua chiamare 'diritto' al ricongiungimento familiare”. FERRAIOLO, Stefano. "Immigrazione, asilo, accoglienza: gli effetti pratici del 'vento di Tampere'. Direttive, regolamenti e applicazioni nei diritti nazionali”; en Diritto e Giustizia, n 20, 22 mayo de 2004, p. 1. Por su parte, MOLINER NAVARRO califica la armonización de la Directiva 2003/86 como “exigua”. “El concepto de familia nuclear en la Directiva..., op. cit., p. 1801.

753 SCHAFFRIN, Dora. "Which standard for Family Reunification...?”, op. cit., p. 98.

754 Groenendijk and Guild son claros sobre este punto: "If common rules do not take into account those differences, it will restrict the effectiveness of those rules in practice (e.g. the problems with the implemention of the Dublin Convention). The relevance of those differences diminishes with the duration of the residence of admitted immigrants. After long legal residence the need to integrate immigrants and ensure the social stability and coherente of the society prevails over other considerations that dominate decisions on first admission. This development occurs sooner or later in all Member States. This common experience explains the surprising similarities and the convergente of the national law we noted in our study". "Converging Criteria ...." op. cit., p. 53.

755 QUIRÓS FONS, Antonio. “Derecho comunitario de extranjería: Directiva 2003/86/CE sobre reagrupación familiar y reforma del derecho interno español”, op. cit., p. 399. El autor considera que la transitoriedad, junto con la flexibilidad que caracterizan a la Directiva, constituyen "mecanismos técnico-jurídicos (....) necesarios fundamentalmente debido a la diversidad de los ordenamientos nacionales".

756 En una audiencia pública mantenida en el Parlamento Europeo el 10 de noviembre de 2011, la Red de Asociaciones de Mujeres Europeas - European Women's Lobby-, advertía en contra de la renegociación de la normativa europea sobre RF, ante el temor de que la misma fuera en detrimento de los extranjeros, especialmente del colectivo de mujeres migrantes, que constituye uno de los sectores más vulnerables.

757 El artículo 19 de la Directiva establece que "periódicamente, y por primera vez a más tardar el 3 de octubre de 2007, la Comisión informará al Parlamento Europeo y al Consejo sobre la aplicación de la presente Directiva en los Estados miembros, proponiendo, en su caso, las modificaciones necesarias. Estas propuestas de modificación se referirán prioritariamente a los artículos $3,4,7,8$ y 13 ”. 
Comisión de informar al Parlamento y al Consejo Europeo sobre la aplicación de esta norma en los EEMM, proponiendo las modificaciones necesarias y fijando una fecha tope ya rebasada -el 3 de octubre de 2007, cuando se cumplían dos años desde la fecha prevista para su transposición- para la emisión de dicho informe. La propia Directiva prescribe además las disposiciones que deben ser objeto de revisión prioritaria - los artículos 3, 4, 7, 8 y 13- revelando así cuales son los puntos más débiles y problemáticos de su regulación.

En cumplimiento de la obligación de informar que pesa sobre la Comisión, este órgano emitió un Informe en octubre del año $2008^{758}$, con un año de retraso respecto a las previsiones. En su descargo quizá sea justo recordar que la inmigración en el ámbito comunitario constituye con carácter general una materia que, debido a las múltiples dificultades que afronta y las constantes renuencias estatales, es propicia a los retrasos ${ }^{759}$ respecto a las previsiones establecidas en los calendarios oficiales. En dicho Informe, la Comisión presenta sintéticamente el estado de la transposición de la Directiva 2003/86/CE en los EEMM, confirmando el limitado alcance que la armonización por ella perseguida ha tenido en el ámbito de las políticas nacionales de $\mathrm{RF}^{760}$, y alertando de las deficiencias que lastraban su aplicación ${ }^{761}$.

Las múltiples debilidades detectadas por la Comisión en torno a la Directiva 2003/86 se encuentran en la base de una propuesta que lanzó en junio del mismo año de emisión de su informe de transposición de esta norma. En dicha propuesta, la Comisión señaló la conveniencia de "evaluar la aplicación y la necesidad de modificar la Directiva 2003/86/CE del Consejo relativa al derecho a la reunificación familiar"762, a fin de mejorar las oportunidades de integración de los inmigrantes asentados en territorio comunitario.

758 Informe de la Comisión al Consejo y al Parlamento Europeo relativo a la aplicación de la Directiva 2003/86/CE sobre el derecho a la reagrupación familiar. Bruselas, 8.10.2008. COM(2008) 610 final.

759 MARTÍN PÉREZ DE NANCLARES, J. “La inmigración y la Unión Europea”; MARTÍNEZ DE PISÓN, J. y GIRÓ MIRANDA, J. (cords.). Inmigración y Ciudadanía. Perspectivas sociojurídicas. Logroño, Universidad de la Rioja, Servicio de Publicaciones, 2003, p. 84.

760 Sobre este aspecto particular, el informe afirma textualmente que "el impacto de la Directiva en la armonización en el ámbito de la reagrupación familiar sigue siendo limitado. El carácter poco vinculante de la Directiva deja a los Estados miembros un margen de apreciación demasiado amplio, y en algunos Estados miembros los resultados incluso han rebajado las normas al aplicar disposiciones «opcionales» de la Directiva sobre ciertos requisitos para el ejercicio del derecho a la reagrupación familiar de una forma demasiado amplia o excesiva”. Informe de la Comisión al Consejo y al PE relativo a la aplicación de la Directiva 2003/86 sobre el derecho a la reagrupación familiar, p. 15.

761 Entre ellas, resumidamente, la Comisión advertía de la transposición incorrecta de las normas dirigidas a facilitar los visados, de aquellas sobre la concesión de permisos de residencia autónomos, también en el ámbito de la tutela jurídica, así como las dificultades que afrontaba la aplicación práctica del criterio transversal de tener en cuenta el interés superior del niño que permea todo el texto de la Directiva 2003/86. También denunciaba el margen de apreciación excesivo que las cláusulas opcionales otorgaban a los EEMM, concretamente las relativas al plazo de espera, el requisito de disponer de ingresos y la imposición de medidas de integración facultativas. Idem.

762 Comunicación de la Comisión al Parlamento Europeo, al Consejo, al Comité Económico y Social y al Comité de las Regiones, "Una política común de emigración para Europa: principios, medidas e instrumentos", COM (2008) 359 final. Bruselas 17.6.2008. La recomendación se inscribe dentro del apartado titulado "Prosperidad e inmigración: la integración es la clave del éxito de la inmigración". La propuesta de revisar y reformar la Directiva sobre RF constituye una de las medidas concretas sugeridas por la Comisión a fin mejorar el objetivo integrador. En palabras de la propia Comisión, "la integración de inmigrantes legales debe mejorarse mediante el incremento de los esfuerzos de los Estados miembros de acogida y la contribución de los propios inmigrantes ("proceso recíproco») de conformidad con los principios básicos comunes de la política de integración adoptados en 2004. Deben proporcionarse a los inmigrantes oportunidades de participar y desarrollar al máximo sus capacidades. Las sociedades europeas deben mejorar su capacidad de gestionar la diversidad inherente a la inmigración y aumentar la cohesión social”. 
Por su parte, el Consejo Europeo adoptó en 2009 un Programa estratégico plurianual para el período 2010-2014, -conocido como el Programa de Estocolmo, una Europa abierta y segura que sirva y proteja al ciudadano-. Consciente de los avances conseguidos, - pero también de los múltiples retos que quedan pendientes a la UE a fin de lograr el objetivo comunitario del Espacio de Seguridad, Libertad y Justicia-, el Consejo Europeo estableció un programa de trabajo en cuyo seno la inmigración se perfila como uno de los principales objetivos, junto con el reforzamiento de los derechos humanos y la seguridad. En materia migratoria, el Programa de Estocolmo recupera el espíritu que inspiró a los Programa plurianuales predecesores - Tampere y la Haya-, insistiendo en la necesidad de un trato justo a los residentes legales y derechos equiparables, y subrayando que el objetivo de la integración ha de impregnar e incorporarse en todos los ámbitos de las políticas relacionadas con los extranjeros. En esta línea, el Consejo subrayó su aspiración a "la consolidación de toda la legislación en el ámbito de la inmigración, comenzando por la migración legal, que se basaría en una evaluación del acervo vigente e incluiría las modificaciones necesarias para simplificar y/o, en su caso, ampliar la normativa existente y mejorar su aplicación y coherencia”.

En el ámbito específico de la $\mathrm{RF}^{763}$, el Consejo Europeo, en el seno del Programa de Estocolmo, invitó a la Comisión a que le presentase propuestas para la evaluación y, en caso necesario, la revisión de la Directiva 2003/86/CE sobre el derecho a la reagrupación familiar, teniendo en cuenta la importancia de las medidas de integración.

En este contexto, la Comisión — de forma más matizada a la propuesta que había emitido en junio de 2008, y en respuesta a la invitación lanzada por el Consejo- abrió un debate público entre los EEMM en torno al contenido de la Directiva sobre el derecho a la RF, bajo el título de "Libro Verde sobre el derecho a la RF de los nacionales de terceros países que residen en la UE" ${ }^{\text {"64 }}$. El objetivo del debate residía en conocer de primera mano las dificultades que lastran su aplicación interna, con vistas a definir la estrategia comunitaria más adecuada para simplificar y mejorar la regulación de esta materia.

En el Libro Verde —abierto en noviembre de 2011 y concluido en marzo de 2012-, la Comisión invita a los EEMM y a todas las instituciones, asociaciones y entidades vinculadas con la migración familiar, a que respondan a diversas preguntas en torno a la aplicación de la Directiva sobre RF, con la idea de recoger información factual y precisa sobre los problemas que afronta esta materia. En función del resultado que arroje la consulta, la Comisión habrá de decidir sobre el rumbo a seguir en este ámbito, adoptando la política concreta que se estime más acertada —a saber, "la modificación de la Directiva, la adopción de directrices de interpretación o el mantenimiento del status quo"765_. En consecuencia, el terreno está abierto en este ámbito.

\section{b.2 La Directiva ante el riesgo de reformas in Peius}

La Directiva no cuenta con ninguna disposición general destinada a mantener el status quo ${ }^{766}$, esto es, a impedir reformas a la baja en aquellas legislaciones internas que contasen con regulaciones

763 Bajo la rúbrica "Políticas anticipatorias respecto de los migrantes y sus derechos" - punto 6.1.4 del Programa de Estocolmo- el Consejo señala textualmente que "la Unión debe garantizar un trato justo a los nacionales de terceros países que residen legalmente en el territorio de sus Estados miembros. Una política de integración más enérgica debería ir encaminada a conferir a los migrantes derechos y obligaciones comparables a los de los ciudadanos de la Unión. Esto debería seguir siendo un objetivo de la política de inmigración común y debería ponerse en práctica cuanto antes, a más tardar en 2014".

764 Comisión Europea. Bruselas, 15.11. 2011. COM (2011) 735 final.

765 Libro verde sobre el derecho a la RF..., op. cit., p. 2.

766 La cláusula de stand still establecida en el párrafo 6 del artículo 3 de la tercera propuesta fue finalmente suprimida en la versión definitiva de la Directiva 203/86. 
más garantistas de la inmigración familiar al tiempo de su aprobación. Y, si bien es cierto que esta norma incorpora cláusulas parciales de stand still en las disposiciones más problemáticas, justo es señalar que su laxitud es tal que han sido descriptivamente calificadas como "desdentadas"

Desde las primeras propuestas en esta materia, los expertos habían subrayado la importancia de incluir una cláusula de estas características a fin de impedir que la entrada en vigor de la Directiva fuese aprovechada como una oportunidad para rebajar los estándares de protección existentes, en el período que mediaba entre la aprobación y el inicio de la fecha de transposición de la Directiva en los EEMM.

Sin embargo, la circunstancia de que la Directiva constituya un espejo de las legislaciones más conservadoras, unido al hecho de que realmente confiere un auténtico derecho subjetivo a la RF, arroja un saldo final positivo: Pese a no contar con una cláusula de stand still, el riesgo de reformas a la baja está conjurado por la propia existencia de la Directiva, que establece un tope mínimo infranqueable para los EEMM. En este sentido, en sí misma la Directiva "actuará como una cláusula implícita de stand still contra los esfuerzos para hacer más restrictivas las normas nacionales"768. En consecuencia, de producirse tales restricciones, éstas serán a costa de la Directiva, esto es, contraviniendo sus disposiciones - eventualidad que también se ha producido durante su proceso de transposición, como ha destacado la propia Comisión Europea.

El riesgo de reformas a la baja sólo existiría frente a aquellos países que contaran con legislaciones previas más generosas en el momento de su adopción. Pero este riesgo es menor, en vista de que eran sólo dos países los que se encontraban en dicha situación ${ }^{769}$ - Francia y España-. Será sobre dichos países sobre los que habrá que incrementar la vigilancia durante el proceso de aplicación de la Directiva ${ }^{770}$. El objeto de nuestro trabajo en el siguiente capítulo, se centrará en el seguimiento de

767 Cfr. SCHAFFRIN, Dora. "Which standard for family reunification..., op. cit., p. 140.

768 GROENENDIJK, Kees. "Legal Concepts of Integration...”, op. cit., p. 118. Un ejemplo ilustrativo de la eficacia de la Directiva como tope mínimo lo ofrece la legislación danesa sobre reunificación familiar, esto es, precisamente un país que no está vinculado por la Directiva 2003/86 como consecuencia de las técnicas de opting-out que han provocado un diseño de geometría variable en la política comunitaria de la inmigración. Las actuales restricciones que contempla la legislación interna danesa en este ámbito - que en poco tiempo ha pasado de ser el país europeo más generoso al más restrictivo en materia de $\mathrm{RF}$-, sin duda con mucho las más gravosas de toda la UE, no serían posibles si Dinamarca estuviese vinculado por la aplicación de la Directiva. Aunque sea un ejemplo excluyente, da buena cuenta del potencial protector de la Directiva frente a EEMM con aspiraciones excesivamente restrictivas de cara a la RF.

769 SCHNEIDER, H. y WIESBROCK, A. “The Council Directive on Family Reunification: Establishing Proper Rights for Third Country Nationals?”, en SCHNEIDER, H. (ed.). Migration, Integration and Citizenship. A challenge for Europe's Future. Vol II. Forum Maastricht, Maastricht, 2005, p. 35-69. El impacto real de la Directiva sobre RF sobre el estatus de los nacionales de terceros Estados residentes en los distintos EEMM, ha sido estudiado por Schneider y Wiesbrock. Sus autores parten de un análisis individualizado de los regímenes internos que existían en el momento inmediatamente anterior a la adopción de la Directiva, respecto a los que consideran los puntos más vitales de esta norma -a saber, los contenidos en el los artículos 4, 6, 7, 8, 13, 14 y 15 de la Directiva 2003/86-. El análisis restringe su ámbito geográfico a seis Estados europeos: España, Francia, Luxemburgo, Alemania, Bélgica y Austria. Su estudio viene a responder a dos preguntas claves en esta materia: De un lado, ¿la Directiva comunitaria ha supuesto una mejora real en el status de los nacionales de terceros países residentes legales en la UE en el ámbito de la reagrupación familiar, respecto a la situación que ya existía en los EEMM?; de otro, ¿cuáles son sus implicaciones en términos de armonización del derecho en los distintos Estados?.

770 En torno a la transposición e impacto real de la Directiva 2003/86, pueden consultarse los siguientes estudios: GROENENDIJK, Kees; FERNHOUT, Roel. The Family Reunification Directive in EU Member States, the first year of implementation. Center for Migration Law, 2007; International Federation for European Law, Migration and Asylum Law and Policy in the European Union, FIDE 2004 National Reports. HIGGINS, Imelda (edit.). General Rapporteur Kay Hailbronner, CUP, 2004; La Red Europea de Migración, organismo creado a partir del Consejo Europeo de Laeken y bajo la responsabilidad de la Comisión Europea, concluyó en enero de 2008 un estudio sobre 
la normativa española a fin de dar cuenta de su evolución, y determinar su compatibilidad con los umbrales establecidos en el ámbito tanto del Consejo de Europa como de la UE.

\section{c) La Directiva ante el objetivo integrador}

De los tres objetivos explícitos de la Directiva éste es el más difícil de evaluar, por la complejidad inherente a la finalidad integradora, y porque se trata, además, de un campo fértil para los prejuicios y los temores de la sociedad de acogida.

A fin de abordar de forma sistemática este apartado, en primer lugar asentaremos algunos conceptos jurídicos de integración ${ }^{771}$. Después los aplicaremos a la Directiva 2003/86/CE, para evaluar posteriormente los dos aspectos más trascendentes en esta materia -ámbito personal de aplicación y derechos concedidos a los familiares reagrupables-, lo que nos permitirá aportar una conclusión fundamentada, pero meramente tentativa.

Para rastrear qué concepción de la integración permea la regulación de la Directiva, tomaremos como punto de partida el estudio realizado por Groenendij $\mathrm{k}^{772}$. Este autor destaca la existencia de tres perspectivas distintas en torno a la relación existente entre la ley y la integración ${ }^{773}$.

La primera de ellas se basa en considerar que el otorgamiento de un estatus legal seguro al inmigrante mejorará su integración en la sociedad de acogida, concepción que goza de una larga tradición en el derecho comunitario - especialmente en el ámbito de la libre circulación de trabajadores $^{774}$-, siendo de muy reciente aplicación a los extranjeros procedentes de terceros países. La segunda perspectiva considera que la adquisición de la nacionalidad o, en su defecto, la concesión de un estatus de residencia permanente al inmigrante, constituye la compensación por haber completado el proceso de integración. Esta segunda visión contempla la integración como un proceso gradual, que ha de concluirse en algún momento, y ha estado ausente del derecho comunitario hasta

este tema disponible en la web. European Migration Network. "Family Reunification", http://ec.europa.eu/justice_home/doc_centre/immigration/studies/docs/emn_family_reunification_synthesis_report_jan08.pdf. GÓMEZ CAMPELO, Esther. "La compleja aplicación de la Directiva 2003/86/CE sobre el derecho a la reagrupación familiar”; en Revista Española del Tercer Sector, n 12, 2009, pp. 73-99. LABAYLE, H; PASCOUAU, Y. Directive 2003/86/ EC on the Right to Family Reunification. Study on the Conformity cheking of the Transposition by Member States of 10 Directives in the Sector of Asylum annd Immigration. DGJLS of the European Commission, 2007.

771 Para una visión más completa del controvertido concepto de integración y su evolución y significado diversos en Europa y América Latina, resulta de utilidad la lectura de dicha entrada en MALGESINI, Graciela y GIMÉNEZ, Carlos. Guía de conceptos sobre migraciones, racismo e interculturalidad. Madrid, Catarata, 2000, pp. 245-252.

772 GROENENDIJK, Kees. "Legal Concepts of Integration in EU Migration Law”; en European Journal of Migration and Law, 2004, vol. 6, n 2, pp. 11-126. En este ensayo, el autor trata de estudiar en qué medida estas tres perspectivas están presentes en el viejo y el nuevo derecho comunitario de la inmigración — tomando el año 2002 como fecha que separa ambos tipos de derechos- para, posteriormente, analizar cual de las tres perspectivas es dominante. Para ello centra su trabajo en el estudio de tres Directivas que habían sido recién publicadas en el momento en que el autor escribió su ensayo: La Directiva 2003/86 sobre RF; la Directiva relativa al estatus de los nacionales de terceros países residentes de larga duración; y la Directiva sobre el derecho de los ciudadanos europeos a trasladarse y residir dentro de la UE.

773 Idem, pp. 113-117.

774 GROENENDIJK subraya que tras la concesión del derecho a la RF tanto al trabajador comunitario como a sus familiares, con independencia de la nacionalidad de estos últimos, latían consideraciones de integración, que precisamente eran las que justificaban el otorgamiento a los familiares del derecho a acceder al mercado laboral, a la educación y a la vivienda (artículos 9-12 del Reglamento 1612/68, promocionado también por la jurisprudencia del TJUE que, además, adoptó la misma postura al interpretar la decisión 1/80 del Acuerdo de Asociación con Turquía). "Legal Concepts of Integration...." 
noviembre de 2003, en coherencia con la ausencia competencial comunitaria en materia de nacionalidad. La tercera visión considera que la falta de integración - o la percepción de la incapacidad o supuesta inadecuación del inmigrante para integrarse en la sociedad de acogida-, constituyen causas para rechazar la admisión al país. En esta tercera perspectiva, la integración llega a convertirse en una auténtica barrera para la admisión o la adquisición de un estatus de residente más seguro. Se trata nuevamente de una perspectiva desconocida en el derecho comunitario ${ }^{775}$ hasta septiembre de 2003 que, - por restringir el principio de libre circulación de personas-, no puede ser aplicada a los ciudadanos comunitarios ni a sus familiares. Además, esta visión excluyente de la integración entra en conflicto con la primera de las perspectivas apuntadas, a juicio de Groenendijk. Sobra decir que, de las tres visiones, la más cuestionable es la tercera.

Del análisis del texto de la Directiva sobre el derecho a la RF - y ciñendo su estudio tan sólo a las referencias explícitas-, Groenendijk concluye que en esta norma existen siete menciones a la integración. Cuatro de ellas están en el preámbulo - considerandos 3, 4, 12 y 15-, tres de las cuales se incluyeron desde la propuesta original - los apartados 3, 4 y 15 del preámbulo—, y corresponden a la primera perspectiva sobre integración. En ellas se reitera la necesidad de una política de integración más decidida ${ }^{776}$, encaminada a la concesión de derechos y obligaciones comparables a los que disfrutan los ciudadanos de la Unión; se contempla la RF como un mecanismo necesario para la vida en familia que facilita la integración; ${ }^{777}$ y se establece el objetivo de fomentar la integración de los miembros de la familia ${ }^{778}$. La única mención a la integración que fue incluida en el preámbulo con posterioridad, durante el proceso de negociación y a instancias de los EEMM, la constituye el apartado 12 del Preámbulo. En él la Directiva justifica el límite de doce años a partir del cual cabe la imposición de un criterio de integración previo a los hijos del residente, a fin de "reflejar la capacidad de integración de los niños en edad temprana". Las otras tres referencias expresas contenidas en la Directiva 2003/86 son fruto de la fase final de su negociación, y corresponden al artículo 4.1 in fine - posibilidad de imponer un criterio de integración a los hijos de inmigrantes a partir de los doce años-, al artículo 4.5 -exigencia potestativa de una edad mínima de 21 años al reagrupante y a su cónyuge con el fin de garantizar un mayor grado de integración-, y el artículo 7.2, relativo al cumplimiento también facultativo para el EM de medidas de integración a los extranjeros que, para el caso de los refugiados y sus familias, sólo podrán fijarse tras la concesión de la reagrupación a la persona de que se trate.

Resumidamente, Groenendijk finaliza su estudio concluyendo que la primera perspectiva de la integración domina claramente tanto en el nuevo como en el viejo derecho migratorio comunitario —considerando al año 2002, como el punto temporal de delimitación entre ambos-; la segunda perspectiva está ausente en materia de libre circulación y tan sólo la Directiva relativa al estatus de los nacionales de terceros países residentes de larga duración contiene una cláusula que la contempla; la tercera perspectiva ha sido introducida en la Directiva 2003/86, así como en la Directiva sobre el estatus de residentes de larga duración, a iniciativa de tres EEMM - Austria, Alemania y Holan$\mathrm{da}-$, si bien el autor declara que "no está claro si se trata de una victoria pírrica o del comienzo de

775 GROENENDIJK señala que en el derecho comunitario sobre libre circulación de trabajadores, el artículo 3.1 del Reglamento 1612/68 no exigía ningún conocimiento del lenguaje ni tampoco se imponía ningún requisito de integración con carácter previo al traslado de un nacional comunitario con su familia a otro EM. "Legal Concepts of Integration..., op. cit., p. 116.

776 Apartado tercero del Preámbulo de la Directiva 2003/86.

777 Idem, apartado cuarto.

778 Ibidem, apartado décimo quinto. 
una nueva tendencia"779. Además añade que la tercera perspectiva topa con importantes límites legales, políticos y administrativos, y "su uso como un instrumento para restringir la RF está limitado por el derecho a la vida familiar" 780 , añadiendo que la "idea de integración antes de la inmigración es aparentemente ineficaz y entraña altos costes tanto para los inmigrantes como para las Administraciones públicas. La integración desde el exterior es un concepto bastante contradictorio"781.

Asumiendo las conclusiones del estudio de Groenendijk, ceñiremos nuestro análisis a la primera y tercera perspectivas de la integración, para determinar su peso en la Directiva 2003/86, en vista de que esta norma las ha incorporado de forma implícita a su articulado.

Ya señalamos al comienzo de nuestro estudio cómo la unidad familiar y el disfrute de la vida en familia constituye una de las dimensiones esenciales para el éxito de los procesos de integración de los inmigrantes en el país de destino. También apuntamos entonces que el proceso integrador estaba gobernado por la importancia condicionante que en el mismo ostentaban la integración jurídica y laboral de los extranjeros. Dicho de forma más sencilla, otorgar un haz de derechos que permita al inmigrante y a su familia disfrutar de una condición jurídica más segura, junto con su inserción en el mercado laboral del Estado receptor, son los factores en principio claves para facilitar su integración en la nueva sociedad. Este es el punto de partida al que explícitamente se adhiere la Directiva en los apartados cuatro y quince de su preámbulo - la RF desempeña funciones de vital importancia al dotar al inmigrante de una estabilidad sociocultural que facilita su integración y promover simultáneamente la cohesión social; por lo que esta norma asume el objetivo expreso de fomentar la integración de los miembros de la familia mediante su acceso a un estatuto independiente al del reagrupante, así como a la educación, al empleo y a la formación profesional en las mismas condiciones que éste ${ }^{782}$ -

Junto a estas ventajas obvias de la RF, que constituyen ya un tópico en las diferentes aproximaciones al fenómeno migratorio, también advertimos en su momento que a raíz de la constatación de ciertos fracasos en los procesos de integración, últimamente han surgido nuevas facetas de la migración familiar que advierten de los peligros que ésta puede suponer para la inserción del inmigrante en la sociedad de acogida, — peligros todos ellos "poco fundados en información fiable"783 —. Se señala que la RF puede propiciar el encerramiento cultural de los inmigrantes, perpetuando roles $\mathrm{y}$ valores tradicionales que pueden chocar con algunos principios de las sociedades receptoras.

Detrás de esta concepción laten los temores de la sociedad de acogida ante los potenciales riesgos que de cara a la cohesión social puede tener la RF y la interculturalidad que lleva aparejada, así como a sus efectos multiplicadores sobre el número de admisiones de extranjeros. Pero en vista de los imperativos internacionales que condicionan la RF, no cabe sin más su restricción especialmente en el contexto europeo de respeto a los derechos humanos. De ahí que, por un lado, se conceda el

779 GROENENDIJK. “Legal concepts of Integration...”, op. cit., p. 125.

780 Idem.

781 Groenendijk afirma además que "the organisation of language courses within the country of immigration is far cheaper and easier than abroad." Ibidem, p. 126.

782 El Parlamento Europeo se adhirió expresamente a esta visión de la RF, considerando que los derechos que se otorgan a los familiares reagrupados constituyen mecanismos que facilitan extraordinariamente su integración en el país miembro de acogida. Exposición de motivos al Informe elaborado al tercer proyecto de Directiva sobre RF, op. cit., p. 48, de donde se han extraído las siguientes observaciones: "El derecho a la reagrupación familiar es, de por sí, un instrumento imprescindible para la integración” (p. 5); "el acceso al Mercado laboral es crucial para la integración de los nacionales de terceros países en la sociedad” (p. 19). En idéntica línea se sitúa la Comunicación de la Comisión de junio de 2003 sobre inmigración, integración y empleo. COM (2003) 336, de 3 de junio de 2003.

783 GONZÁLEZ-FERRER, Amparo. La inmigración de origen familiar (II): el control de flujos y el proceso de integración en España. Real Instituto Elcano, junio de 2011, p. 1. 
derecho sometiéndolo con carácter general a condiciones onerosas con fines de contención y restricción numérica y, por otro, se introduzcan disposiciones que permiten exigir la integración como condición previa para la autorización de entrada de los familiares del residente $e^{784}$ - tanto respecto a los hijos a partir de los doce años ${ }^{785}$ como al resto de los integrantes de la familia ${ }^{786}$ - e incluso para el propio mantenimiento de la residencia por causa familiar en el EM, tanto del reagrupante como de los familiares admitidos por tal motivo ${ }^{787}$.

Entre estos dos polos de difícil por no decir imposible reconciliación, se mueve la Directiva sobre RF. Esta norma se asienta sobre el presupuesto de que promover la integración exige la concesión de derechos al inmigrante, lo que redunda en un refuerzo de su seguridad jurídica. Esta noción subyacente de integración fue ya señalada en España por Javier de Lucas, y concibe los derechos como una condición previa para la integración. El problema que en este punto plantea la Directiva 2003/86 es el carácter altamente restrictivo de la noción de familia que maneja y la debilidad del estatuto de los familiares reagrupados, que las disposiciones abiertas de la Directiva permiten a los EEMM. La limitación de un año para el acceso al mercado laboral, e incluso la posibilidad de su supresión permanente para los hijos adultos y los ascendientes, constituyen un serio obstáculo para la participación de estas personas, pudiendo potenciar su exclusión no sólo laboral, sino también social ${ }^{788}$. Además pone en riesgo la continuación de la residencia, en la medida en que ésta se hace depender de la suficiencia económica del sponsor ${ }^{789}$. Las mismas consideraciones son aplicables respecto al acceso de los familiares a un estatuto autónomo, en vista de que la efectividad de su vínculo familiar o conyugal constituye una condición necesaria para la continuación de su residencia ${ }^{790}$. En este punto la situación más vulnerable corresponde al cónyuge o pareja de hecho, y a los ascendientes e hijos adultos. Para este último colectivo la concesión de un permiso de residencia autónomo resulta totalmente discrecional para el $\mathrm{EM}^{791}$, pero se da la paradoja de que cabe denegar la renovación de la residencia de dichos familiares, si la residencia del principal llega a su fin y el miembro de la familia aún no ha adquirido un estatuto autónomo ${ }^{792}$. Esta regulación fomenta la dependencia de los familiares respecto del sponsor, contradiciendo parcialmente la doble titularidad activa del derecho a la reagrupación familiar.

Adicionalmente, la tesis inversa a la de Javier de Lucas - la integración como condición previa para la concesión de derechos, incluyendo en algunos supuestos la propia autorización de entrada del familiar extranjero-, encuentra también acomodo en la Directiva. Esta tesis destila ciertas consideraciones asimilacionistas - que habían sido expresamente descartadas por las instituciones comunitarias $^{793}$ al emprenderse la elaboración de esta norma-, así como de contención y selec-

784 El artículo 4.1. in fine, para los hijos del residente que hayan cumplido ya los doce años de edad; y el artículo 7.2, que contempla la posibilidad de la imposición del cumplimiento de medidas de integración tanto al sponsor como a sus familiares, siendo las mismas aplicables tanto con carácter previo como una vez que ya se haya concedido la RF a los extranjeros.

785 Artículo 4.1 in fine de la Directiva sobre el derecho a la RF.

786 Idem, artículo 7.2.

787 Artículo 7.2 en conjunción con el artículo 16.1 a), ambos de la Directiva sobre el derecho a la RF.

788 Apartados segundo y tercero del artículo 14.

789 Artículo 16.1.a) de la Directiva 2003/86.

790 Idem, artículo 16.1.b).

791 Así se desprende con claridad de la redacción potestativa contenida en el apartado segundo del artículo 15 de la Directiva sobre el derecho a la RF.

792 Artículo 16.3

793 El Parlamento Europeo, en el Dictamen emitido en torno al primer proyecto presentado de Directiva sobre reunificación familiar, se declaró expresamente en contra de una integración asimilacionista. En este sentido, el considerando sexto de dicho dictamen justificaba la importancia de la reagrupación familiar por ser un mecanismo 
ción ${ }^{794}$ migratoria. Sin obviar que este concepto excluye la responsabilidad que, en el proceso de integración, también atañe a la sociedad receptora. Con su inclusión en la Directiva, ésta se aleja de las directrices de Tampere, bajo las cuales subyacía el concepto tradicional e incluyente de integración. Los principios de trato justo y derechos comparables no resisten la aplicación de criterios previos de integración.

El problema fundamental, a nuestro juicio, es que ambas tesis son profundamente contradictorias $-\mathrm{y}$ puede que hasta mutuamente excluyentes para aquellos extranjeros en situación económica más desfavorable-, y más si se observan desde la óptica actual de un contexto de fuerte recesión económica. Las lógicas contradictorias que laten detrás de estos dos conceptos de integración quedan al descubierto en el propio articulado de la Directiva 2003/86. La discordancia más sonora resulta de la conjunción del artículo 4.5 con el artículo 4.1 in fine. Mientras que con respecto a los hijos menores se asume que su integración se dificultará según aumente su edad, sin embargo, con respecto a los cónyuges, las edades bajas son vistas con cautela extrema, no solamente respecto a la posibilidad de fraudes, sino también por dificultar su integración en el Estado receptor ${ }^{795}$. En este punto, la Directiva no ha logrado librarse de una característica inmanente a las normas comunitarias sobre extranjería e inmigración: su carácter profundamente contradictorio ${ }^{796}$.

Pese a todo lo dicho, para valorar en sus justos términos este aspecto, caben dos alternativas que conducen a resultados distintos. O bien, situar el punto de comparación en el derecho equivalente, en su aplicación a los ciudadanos comunitarios; o bien, excluir expresamente tal comparación, y situarse más modestamente en la situación en que se encontraban los nacionales de terceros países en el momento inmediatamente anterior a la aprobación de esta Directiva. Descartamos la primera op-

necesario para la vida en familia, contribuyendo a la creación de una estabilidad sociocultural que, en opinión del Parlamento, facilitaba la integración del inmigrante "en el respeto de las culturas y tradiciones propias de los ciudadanos de terceros países". Con estos ajustes terminológicos, el Parlamento pretendía hacer más riguroso el texto de la Comisión, ya que — afirmaba el PE_, "la integración no debe tender a convertirse en una especie de asimilación de los ciudadanos de terceros países ni a destruir su identidad nacional".

794 Como Groenendijk ha subrayado, esta concepción de la integración es elitista y promueve la selección de aquellos inmigrantes que cuenten con recursos económicos altos, en vista de que son ellos los que afrontarán el coste del proceso de integración — cursos de idioma o de la cultura del Estado receptor-. Para el caso alemán, este autor ha señalado que en febrero de 2004, se introdujo en Alemania la exigencia de que los cónyuges extranjeros que residiesen fuera de la UE, debían superar un examen de lengua alemana que tendría lugar en su país de residencia, a fin de la obtención de un visado por RF. El autor concluye afirmando que "if knowledge of the Dutch language is made a condition for admission to the Netherlands, this will create an effective and highly selective barrier: only the well-educated or rich and some returning migrants will be able to fulfil this requirement"; "Legal concepts of Integration...., op. cit., pp. 116 y 117.

795 Respecto a esta contradicción, Groenedijk ha evidenciado que "the paternalistic reasoning behind this provision is exactly opposed to one used to justify the 12 years age limit: children are supposed to integrate more easily when they are young; spouses, on the other hand, apparently integrate better if they are older at the time of immigration". Y prosigue afirmando: "Recently, the EC Court of Justice has been rather critical of a restrictive national rule, justified by a Member State with its purported contribution to the integration of immigrants". La sentencia a la que se refiere este autor es ECJ October 2003, C-148/02 (Avello), concretamente en su párrafo 43. GROENENDIJK, Kees. "Legal concepts of integration..." op. cit., p. 119. En torno a la misma contradicción se pronuncia irónicamente Peers, afirmando: "It appears that while 20-year-olds could be considered too immature to get married, 15 year-olds could be considered too mature to enter as children". PEERS, Steve. "Key Legislative Developments on Migration in the EU”; European Journal of Migration and Law, no 5, 2003, p. 403.

796 GARCÍA COSO, Emiliano. "Los progresos en el diseño de una regulación europea común en materia de inmigración extracomunitaria”; en RUIZ DE HUIDOBRO DE CARLOS, J. M. (coord.). Regulación legal de la extranjería e inmigración en España. Madrid, Publicaciones de la Universidad Pontificia de Comillas, 2006, p. 51. El autor puntualiza que esta característica de las normas comunitarias en materia de inmigración y extranjería se encuentra presente desde los inicios del derecho comunitario migratorio. 
ción - la reunificación familiar de los residentes extracomunitarios está presidida por un estándar claramente inferior que desmiente el principio de Tampere de concesión de derechos "comparables" y que, por ello, no resiste el análisis comparativo con dicho colectivo-.

Excluyendo la comparación con el derecho equivalente en su aplicación a los ciudadanos comunitarios, y centrando nuestro punto de vista en la situación existente con carácter previo a la aprobación de la Directiva 2003/86, se obtiene una visión más armónica. La Directiva consagra un auténtico derecho a la RF, lo cual constituye una auténtica primicia en el derecho comunitario de la inmigración. Dado que la RF supone "la piedra angular para la integración de los inmigrantes"797, es claro que la Directiva ha sido formulada con una visión en mente inclusiva y positiva de la integración, que resulta dominante. La concesión del derecho es en sí misma un avance de tal entidad - pese a haberse producido en condiciones altamente restrictivas- que este hecho por sí sólo convierte a la Directiva en merecedora, a nuestro juicio, de ser considerada como un instrumento básico para la integración ${ }^{798}$.

Sin embargo, se trata de un instrumento temeroso que pretende abrir pero no demasiado, conceder el derecho, pero endureciendo los requisitos, a fin de contener los flujos y tratar de minimizar tanto los efectos multiplicadores de la migración familiar como sus potenciales consecuencias sobre los mercados laborales autóctonos y los respectivos Estados del bienestar ${ }^{799}$. En definitiva, la Directiva 2003/86 no renuncia a los objetivos de contención que parecen dominar el planteamiento comunitario de la inmigración pero, simultáneamente, tampoco renuncia a la integración —siquiera en su aspecto más básico de conceder la RF al núcleo más reducido e inevitable de la unidad familiar-. La Directiva se mueve pues en un contexto de difícil equilibro - explicable por el carácter intrínsecamente problemático de la RF- entre concesión de un derecho que, desde el punto de vista de los derechos humanos, resulta irrenunciable, y consideraciones de contención numérica de entradas y prevención de los riesgos que la interculturalidad pudiera provocar sobre la cohesión social y la convivencia armoniosa de la sociedad receptora. De ahí las contradicciones que afloran a lo largo de su articulado y que, como señalamos, subyacen también a la propia construcción jurídica de la migración familiar.

797 The New EU Directive on Family Reunification. Right for Families to Live Together or Right for EU Member States to Derogate From Human Rights?. Press Statement. Brussels, 4 de marzo de 2003, sp. Disponible en internet: http:// www.cec-kek.org/English/Pressstatementfamreunfina20020304.pdf

798 En contra de la opinión fijada en el texto se pronuncia CICIRIELLO. La autora estima que si se analiza la Directiva 2003/86 desde la perspectiva de su concepción como un instrumento destinado a facilitar la integración de los residentes legales, los aspectos dirigidos a la integración real son marginales y demasiado "descuidados". La autora prosigue afirmando que "se la politica di immigrazione deve fare il salto di qualità, passando da una politica di contenimento ad un politica di integrazione, sempre con riferimento all'immigrazione legale, il rispetto pieno del diritto al ricongiungimento familiare costituisce la condizione fondamentale per la realizzazione di tale svolta". CICIRIELLO, Maria Clelia. Il "Ricongiungimento Familiare come Diritto Fondamentale del Migrante"; Comunitá Internazionale, vol. 61, n 1, 2006, pp. 109-119 (pp. 116, 109 y 117).

799 La supuesta carga que la llegada de inmigrantes supone sobre el Estado de bienestar de los países receptores percepción altamente arraigada en las sociedades de acogida-, se basa en una concepción prejuiciada, más que en datos empíricamente constatados. De hecho, recientes estudios aparecidos en este ámbito apuntan, para el caso español, a un efecto en sentido exactamente opuesto a los temores de las sociedades receptoras: se señala explícitamente que la aportación de los inmigrantes a las arcas públicas es tres veces superior al gasto que éstos representan, al tiempo que se subrayan otros efectos económicos positivos, tales como facilitar la incorporación de la mujer al mercado laboral — gracias a la ayuda representada por las empleadas domésticas, sector mayoritariamente ocupado por mujeres extranjeras-, e incluso permitiendo la contención salarial. Vid. MORENO FUENTES, Francisco Javier y BRUQUETAS CALLEJO, María. Inmigración y Estado de bienestar en España. Barcelona, Fundación La Caixa, colección de Estudios Sociales, vol. 31, 2011. 


\section{d) ¿Qué tipo de derecho subjetivo configura la Directiva?}

Un repaso a la situación anterior a la existente antes de la adopción de la Directiva 2003/86/CE aporta una luz clarificadora sobre la naturaleza jurídica del derecho a la RF que ésta establece y las aportaciones de esta norma en el ámbito de la migración vinculada a la familia.

Antes de la aprobación de esta norma comunitaria, la RF de los extranjeros procedentes de terceros países constituía una prerrogativa estatal y, como tal, sujeta casi enteramente a la discrecionalidad del Estado nacional, - salvo por lo que respecta a los compromisos internacionales en materia de derechos humanos vinculantes para el Estado interno, señaladamente el CEDH y la jurisprudencia de Estrasburgo protectora de los inmigrantes sobre la base del derecho a la vida familiar-. Los múltiples esfuerzos desplegados en aquella época por armonizar esta materia resultaron vanos, como consecuencia de la endeble vinculación jurídica que tenían los instrumentos comunitarios acordados en el seno del tercer pilar.

Aún ahora, pasado un largo período tras la aprobación de la Directiva comunitaria, la RF sigue en nuestra opinión estando muy lejos de constituir un derecho fundamental. Sin embargo, su estatus jurídico se ha visto notablemente reforzado gracias a esta norma comunitaria. Es justo pues reconocer que el salto cualitativo producido por la Directiva 2003/86 es de gran envergadura, en vista de la resistencia de los tratados internacionales a consagrar con carácter autónomo y efectivo el derecho a la RF - que permanece, en el mejor de los casos, a la sombra del derecho a la vida familiar gracias a construcciones jurisprudenciales progresistas, como la efectuada por el TEDH-.

Partiremos de la identificación de los siguientes dos elementos, como identificativos de los derechos fundamentales, a saber: 1 . Su nivel de resistencia frente a la manipulación del poder legislativo; 2. La universalidad del sujeto, con independencia tanto de condicionantes de nacionalidad como requisitos administrativos. La pregunta que emerge entonces es clara, ¿estos dos elementos se encuentran presentes en el derecho a la reagrupación familiar?. La respuesta también es bastante clara, pese a la insistencia - retórica, a nuestro juicio- en el ámbito internacional a hablar de la RF como un derecho fundamental: los elevados márgenes de apreciación estatal y las restricciones que operan de forma omnipresente sobre el sujeto activo impiden hablar de la RF como un derecho fundamental.

¿Ante qué tipo de derecho estamos entonces?. La Directiva 2003/86/CE nos sitúa ante un derecho de configuración legal ${ }^{800}$. El carácter de mínimos de la Directiva determina que muchos elementos integrantes del derecho sigan dependiendo del legislador interno y que - aún sobre muchos de los aspectos prediseñados por la normativa comunitaria-, las políticas internas de los EEMM puedan desenvolverse muy cómodamente, actuando con elevados márgenes de apreciación. En consecuencia, aunque los perfiles básicos del derecho a la RF en el espacio comunitario europeo han sido configurados por la normativa comunitaria en virtud de la presente Directiva de 2003, en el reparto competencial continúa predominando la figura del legislador nacional. De ahí que, a modo de conclusión, podríamos completar la clasificación jurídica de la reagrupación familiar de ciudadanos no comunitarios en la UE encuadrándolo dentro de los derechos de configuración legal ${ }^{801}$, todavía predominantemente interna.

800 Así lo califican también — si bien en referencia al ordenamiento interno español— SERRANO VILLAMANTA, J.; ALONSO HEDROSA, G; LORA-TAMAYO, G; HERNÁNDEZ DE LA ORDEN, M.J y MARTÍNEZ RODRIGO, A. "La reagrupación familiar"; Informe sobre la situación de la integración social de los inmigrantes y refugiados en 2008. Madrid, Foro para la Integración Social de los Inmigrantes, 2009, p. 2.

801 A favor de la RF como derecho fundamental se manifiestan, entre otros representantes de la doctrina, MOLINER NAVARRO, Rosa Ma: "El concepto de familia nuclear en la Directiva europea 2003/86/CE sobre reagrupación 
Con todo, la propia aprobación de la Directiva arroja un balance muy positivo para la propia existencia del derecho a la RF en el ámbito comunitario y, por ende, en todos y cada uno de los Estados miembros integrantes: con ella, el derecho a la reagrupación familiar de los extranjeros procedentes de terceros países ha pasado a constituir un derecho reconocido en todo el territorio de la Unión $^{802}$ - con las salvedades ya señaladas como consecuencia de la técnica del opting out-. Pese a las deficiencias que lastran la configuración jurídica de la migración familiar en el espacio comunitario y los problemas que se detectan en la aplicación interna de la Directiva 2003/86, esta norma ha otorgado carácter irreversible ${ }^{803}$ al derecho a la RF. En palabras de la Comisión, la RF de los extranjeros no comunitarios "constituye actualmente una garantía legal mínima en toda la UE”804, gozando con ello de una cobertura geográfica sin precedentes en el derecho migratorio.

\section{EL RECURSO DE ANULACIÓN CONTRA LA DIRECTIVA SOBRE EL DERECHO A LA RF: LA SENTENCIA DEL TJUE EN EL ASUNTO C-540/03}

El Parlamento Europeo, haciendo uso de la nueva atribución competencial conferida por el artículo 230 TCE, interpuso el 22 de septiembre de 2003 un recurso de anulación contra determinadas disposiciones de la Directiva 2003/86/CE sobre el derecho a la RF. Dicho instrumento procesal es el equivalente funcional, en el ámbito comunitario, al recurso de inconstitucionalidad que se ventila ante los Tribunales Constitucionales nacionales ${ }^{805}$.

familiar”; en ABRIL CAMPOY, Joan Manuel y AMAT LLARI, Ma Eulalia (coords.). Homenaje al Profesor Lluis Puig I Ferriol, volumen II, 2006, p. 1789; QUIRÓS FONS, Antonio. "Derecho comunitario de extranjería: Directiva 2003/86/CE sobre Reagrupación familiar y reforma del derecho interno español”; en Anales de Derecho, n 21, 2003, Universidad de Murcia, p. 396. CICIRIELLO, Maria Clelia. "Il Ricongiungimento Familiare come Diritto Fondamentale del Migrante”; Comunitá Internazionale, vol. 61, no 1, 2006, pp. 109-119. Esta autora considera que el derecho a la RF constituye un "derecho fundamental del ser humano" (p. 118) y propone por ello "la completa asimilación entre ciudadanos europeos y extracomunitarios residentes legales de larga duración” (p. 119), finalizando con una frase que trasluce las esperanzas depositadas en el TJUE para el logro de dicha igualdad, afirmando que "in tale processo di completa assimilazione tra cittadini europei e extracomunitari residenti legali di lungo periodo un ruolo fondamentale spetta alla Corte di Giustizia dell'Unione, la quale, nell'affrontare le questioni connesse al ricongiungimento familiare, ha già dato segnali significativi circa l'esigenza di ricondurre tale tematica al piú generale problema della tutela dei diritti e delle libertá fondamentali dellùomo, realizando in tal modo un superacento dei pregiudizi culturali nei confronti deglie extracomunitari e le profonde diversità delle legislazioni nazionali in materia di immigrazione che fino ad oggi hanno ricevuto un'armonizzazione comunitaria al livello più basso rappresentato da condizioni minime”. Idem, p. 119.

802 PARRA ALBERCA, Sandra. "Reagrupación familiar: ¿Derecho de quién?; en Otrosí.net. Revista online del Ilustre Colegio de Abogados de Madrid, p. 1. http://www.otrosi.net/index.php?option=com_content\&task=view\&id=502

803 NAÏR, Sami. Y vendrán... las migraciones en tiempos hostiles. Barcelona, Planeta, 2006, p. 144. En palabras de este autor, con la presente Directiva "la Unión ha tenido, sin embargo, el mérito de hacer irreversible el derecho a la reagrupación familiar. Hay que apuntarlo en su haber”. Si bien, el autor prosigue matizando, —en relación a las sucesivas restricciones introducidas en la Directiva-, que "al darse cuenta de que debido precisamente a las limitaciones de la libre circulación, se estaba convirtiendo en el medio más seguro para aumentar la inmigración, en 2002 se propusieron una serie de importantes modificaciones que lo moderan mucho".

804 Comisión Europea. Libro Verde sobre el derecho a la RF de los nacionales de terceros países que residen en la Unión Europea, 2011, op. cit., nota a pie de p. n 4, p. 1.

805 Con el recurso de anulación se pretende lograr la intervención del TJUE a fin de controlar la legalidad de la normativa comunitaria. A través de esta vía procesal, el Tribunal de Luxemburgo ejerce una función de depuración del ordenamiento jurídico y, por lo tanto, de "contrapeso contra-mayoritario" similar a la que realizan los TC internos. ESTELLA DE NORIEGA, Antonio. El dilema de Luxemburgo. El Tribunal de Justicia de las Comunidades Europeas ante el principio de subsidiariedad. Madrid, Centro de Estudios Ramón Areces, 2000, p. 131. Al igual que con el recurso de inconstitucionalidad interno, con el recurso de anulación comunitario se trata de enjuiciar en 
La iniciativa del Parlamento se produjo a instancia de dos organizaciones no gubernamentales de defensa de los derechos de los inmigrantes ${ }^{806}$, que habían manifestado repetidamente su oposición al proyecto de Directiva durante el proceso de gestación de la misma.

Mediante el recurso de anulación el Parlamento impugnaba tres disposiciones de la Directiva sobre el derecho a la RF — concretamente el apartado 1 in fine del artículo 4, el apartado sexto del artículo 4, y el artículo 8-, solicitando su anulación al TJUE por su presunta vulneración de derechos fundamentales. Dichas disposiciones tenían en común permitir establecer a los EEMM derogaciones al régimen general fijado en la Directiva ${ }^{807}$, habiendo sido objeto de una gran controversia durante su proceso de negociación y levantado la voz de alarma entre la doctrina especializada y las asociaciones de defensa de los derechos humanos ${ }^{808}$. Los motivos de la impugnación se centraban en la alegación de que las disposiciones impugnadas permitían a los EEMM el mantenimiento o la adopción ex novo de disposiciones nacionales incompatibles con el respeto de los derechos fundamentales, - concretamente con el derecho al respeto de la vida familiar, el principio de no discriminación por razón de la edad y el criterio del interés superior del menor-. En definitiva, se trataba de

abstracto la validez de una norma. Para su planteamiento, el artículo 230 concede un plazo de dos meses a contar desde la publicación del acto comunitario objeto de impugnación. De tal modo que el recurso fue interpuesto por el Parlamento Europeo precisamente el día que finalizaba dicho plazo. Sobre las equivalencias entre el TJUE y los TC internos, puede consultarse SAIZ ARNAIZ, Alejandro. "El Tribunal de Justicia de las Comunidades Europeas como Tribunal Constitucional"; en MORODO, Raúl y DE VEGA, Pedro. Estudios de Teoría del Estado y de Derecho Constitucional en honor de Pablo Lucas Verdú. Madrid, Instituto de Investigaciones Jurídicas de la UNAM y Facultad de Derecho de la Universidad Complutense, 2000. Tomo IV, pp. 2425 - 2460. En torno al recurso de anulación en el derecho comunitario vid, entre otros, MANGAS MARTÍN, Araceli y LIÑÁN NOGUERAS, Diego J. Instituciones y derecho de la Unión Europea. Madrid, Tecnos, quinta edición, 3a reimpresión, 2008, pp. 459-470.

806 Se trata de la red europea de ONG's, Coordination européenne pour le droit des étrangers à vivre en famille, con sede en Bruselas y del Groupe d'Information et de soutien des travailleurs inmigrés (GISTI), con sede en París. El recurso de impugnación fue redactado conjuntamente por un grupo de expertos legales de ambas organizaciones y se encuentra disponible en la dirección http://www.gisti.org/doc/actions/2003/regroupement/. En el mismo se condensan los principales argumentos tanto relativos a la forma - violación del procedimiento de adopción establecido en el artículo 67.1 TCE por eludir el trámite obligatorio de consulta al PE-, como de fondo —violación del principio del respeto a los derechos fundamentales por parte del derecho comunitario, concretamente la violación del derecho al respeto de la vida privada y familiar y el concepto restrictivo de familia- que después se reiterarían en el cuerpo de la demanda. Ante la aprobación de la tercera y casi definitiva versión del borrador de Directiva sobre el derecho a la RF, la propuesta al Parlamento Europeo de la interposición del recurso de anulación era concebida por estas organizaciones no gubernamentales "como la última esperanza". Las gestiones realizadas por la Coordinadora Europea para el derecho de los extranjeros a vivir en familia a fin de conseguir la anulación de la directiva, pueden consultarse en la página web de dicha asociación — cartas al presidente del PE y a múltiples asociaciones y redes a fin de conseguir su apoyo, la carta enviada a los miembros de la Comisión de Asuntos Jurídicos y Mercado Interior, así como a la Comisión de libertades y derechos de los ciudadanos, justicia y asuntos internos. Ambas Comisiones del Parlamento Europeo apoyaron de forma unánime la iniciativa, siendo la Comisión de libertades el órgano que recomendaría la formulación del recurso que, finalmente, fue aprobado por el presidente del Parlamento Europeo.

807 Schneider y Wiesbrock han destacado que las tres disposiciones recurridas se caracterizan por compartir un singular encabezado en su redacción. Los tres artículos comienzan afirmando "excepcionalmente" o, en la redacción en la versión inglesa, con la expresión equivalente pero más ilustrativa, de "by way of derogation". Por ello ambos autores concluyen que dichas disposiciones "allows Member States to introduce or to maintain - as far as they already have such restrictive conditions - far reaching exceptions to the right of family reunion". SCHNEIDER, Hildegard, WIESBROCK, Anja. “The Council Directive on Family Reunification: Establishing Proper Rights for Third Country Nationals?...,” op. cit., p. 39.

808 Además de las dos ONG’s que se hallan en la base de la propuesta del recurso de anulación, otras seis organizaciones se adhirieron al proceso de protesta contra el contenido de la Directiva 2003/86/CE. 
juzgar en abstracto la compatibilidad de las disposiciones recurridas con los derechos fundamentales del ordenamiento jurídico comunitario ${ }^{809}$.

El Parlamento no atacaba la totalidad de la Directiva, sino que promovía únicamente un recurso de anulación parcial dirigido contra el Consejo, como parte demandada. El Consejo estuvo apoyado en sus pretensiones por la Comisión de las Comunidades Europeas y por la República Federal de Alemania, actuando como coadyuvantes. El asunto fue resuelto por el TJUE, constituido en Gran Sala, mediante sentencia dictada el 27 de junio de $2006^{810}$, tras oir en audiencia pública las conclusiones de la Abogado General ${ }^{811}$.

Por varias razones se trata de un recurso de singular importancia. En primer lugar, porque en él se plantean temas de especial trascendencia, tanto en el ámbito migratorio como en el más amplio de los derechos fundamentales. En segundo lugar, por su carácter pionero, ya que constituye el primer recurso planteado en el marco del Título IV - insertado por el Tratado de Ámsterdam-, abriendo camino $^{812}$ en un ámbito, la extranjería y la inmigración, que promete ser muy prolífico desde el punto de vista jurisprudencial ${ }^{813}$. Es, además, la primera ocasión en la que el procedimiento establecido por el artículo 230 del Tratado de Niza se plantea en un asunto que toca de lleno los derechos fundamentales -no en vano levantó por ello muchas expectativas entre la doctrina especializada ${ }^{814}$. En el análisis de los argumentos de fondo, tendremos ocasión de señalar que es también la primera vez que el TJUE se refiere explícitamente a la Carta de Derechos Fundamentales de la UE, como norma de referencia a cuya luz se puede examinar la validez de disposiciones comunitarias. Con ello el TJUE adoptaba una visión profundamente innovadora, - cuasi revolucionaria para algunos sectores ${ }^{815}$ - , que ha suscitado un enorme interés, determinando la trascendencia de este pronunciamiento mucho más allá del estricto ámbito migratorio. Por último, el recurso, - en la medida en que fue promovido a instancias de

809 El nivel de protección de los derechos fundamentales en el ordenamiento comunitario está determinado por el que resulte de los compromisos internacionales asumidos por los EEMM —especialmente el CEDH-, y de las tradiciones constitucionales comunes a dichos Estados (artículo 6 TUE). De ahí que en este asunto, el derecho internacional de los derechos humanos, con el CEDH a la cabeza, cobre una importancia esencial como parámetro de referencia con el que el TJUE contrasta la validez de las disposiciones de la Directiva sobre RF que habían sido impugnadas por el PE. En este sentido, el artículo $8 \mathrm{CEDH}$, en la interpretación efectuada por el TEDH, ejercerá una función clave en el razonamiento desarrollado por el Tribunal de Luxemburgo.

810 Sentencia del TJUE, de 27 de junio de 2006, asunto C-540/03.

811 Conclusiones de la Abogada General, Sra. Juliane Kokott, de 8 de septiembre de 2005.

812 LAWSON, Rick. "Family Reunification and the Union's Charter of Fundamental Rights, Judgment of 27 June 2006 , Case C-540/03, Parliament v. Council”; European Constitutional Law Review 2007, Vol. 3, p 329.

$813 \mathrm{Al}$ respecto Bulterman ha destacado el rol vital que el TJUE está potencialmente llamado a realizar en la interpretación y revisión de los diversos instrumentos relativos al asilo y la inmigración adoptados y por adoptar bajo el nuevo título IV TCE con respecto a los derechos fundamentales del sistema comunitario. Las razones que aduce para ello son, de un lado, que este título introduce nuevos conceptos en el ámbito comunitario que habrán de ser interpretados a fin de hacer homogénea su aplicación en la UE y, de otro, se trata de normativas que afectan al estatus individual de los ciudadanos de terceros países y, por ello, se insertan en un ámbito íntimamente conectado con los derechos fundamentales, cuya compatibilidad con el ordenamiento comunitario el TJUE habrá de controlar. BULTERMAN, Mielle. "Case C-540/03, Parliament v. Council, Judment of the Grand Chamber of 27 june 2006”; en Common Market Law Review, n 45, 2008, p. 245.

814 Como ejemplo de las mismas, quizá sea de utilidad transcribir las palabras de Apap y Carrera, para quienes: "Member states must not forget that, as signatories to the ECHR, they have undertaken to fully respect it while developing a proactive immigration policy for the EU. Taking the Council Directive on the right to family reunification to Court may represent a key opportunity to officially refresh some State' memories on their human rights obligations". APAP, Joanna y CARRERA, Sergio. Family Reunification - A case for annulment before the ECJ?. Enero de 2004. Disponible en: http://www.ceps.be/Article.php?article_id=256\&.

815 LAWSON, Rick. "Family Reunification and the Union's Charter of Fundamental Rights, Judgment of 27 June 2006, Case C-540/03, Parliament v. Council”, op. cit., p. 334. 
varias organizaciones no gubernamentales-, "ilustra del papel vital que ciudadanos, ONG's y miembros del parlamento pueden jugar en el proceso de construcción del nuevo derecho comunitario de la inmigración" ${ }^{\$ 16}$, al tiempo que pone de manifiesto la creciente importancia que sujetos atípicos distintos al Estado están adquiriendo en la sociedad internacional de nuestros días ${ }^{817}$.

Ahora bien, junto a los motivos señalados, este pronunciamiento jurisprudencial permite perfilar con mayor nitidez el contenido sustantivo del derecho a la reunificación familiar, cuyos límites son despejados por el TJUE, concretando $-\mathrm{y}$, como analizaremos, estrechando también- el concepto del margen de apreciación estatal, tal y como éste quedaba establecido en la Directiva. Con ello, - y aquí reside uno de sus principales logros-, el Tribunal de Luxemburgo ha depurado las limitaciones que atañen tanto al legislador comunitario como a los poderes legislativos y administrativos nacionales - cuya implicación es necesaria a lo largo del proceso de transposición y aplicación interna de la Directiva - en la configuración y desarrollo del derecho a la reunificación familiar. Sin embargo, como cualquier logro, este desarrollo jurisprudencial no ha estado exento de sombras, pues en esta sentencia el TJUE ha desplegado ciertas funciones cuasi legislativas - si bien de una forma no del todo explícita—, que han determinado su inclusión dentro de la controvertida categoría de las sentencias interpretativas ${ }^{818}$. Este aspecto, sin embargo, apenas ha sido destacado por los comentaristas de la sentencia, a excepción de la doctrina italiana, quizá más familiarizada con este tipo de pronunciamientos “aditivos" pronunciamiento, el TJUE ha iniciado una redefinición del escenario en el que se desenvuelven las normas de la Directiva 2003/86/CE ${ }^{820}$.

\section{1 La admisibilidad del recurso de anulación}

Con carácter previo al examen del fondo del asunto, el Tribunal revisó la procedencia de dos excepciones de inadmisibilidad que habían sido planteadas por el Consejo. Este es el orden del análisis

816 GROENENDIJK, K. "Legal Concepts about Integration...”, op. cit., p. 126. El autor prosigue advirtiendo que "si los ciudadanos se abstienen de participar en dicho proceso, tienen menos derecho a quejarse de los resultados", traducción propia.

817 A juicio de Celestino del Arenal, se trata de una característica sobresaliente de la "nueva" sociedad internacional, que este autor califica como "sociedad mundial". ARENAL MOYÚA, Celestino del. "Cambios en la Sociedad Internacional y Organización de las Naciones Unidas"; en Jornadas sobre el Cincuenta Aniversario de las Naciones Unidas. Madrid, Colección Escuela Diplomática, no 2, 1995, p. 10. En el mismo sentido se pronuncia este autor en "La nueva sociedad mundial y las nuevas realidades internacionales: un reto para la teoría y para la política". Cursos de Derecho Internacional y Relaciones Internacionales de Vitoria Gasteiz. № 21, 2001-2002, p. 25. El creciente protagonismo de las ONG's en materia de derechos humanos representa una faceta de las nuevas realidades internacionales propias de la sociedad mundial actual. Como muestra de su importancia para nuestro objeto específico de estudio, cabe señalar que durante el proceso inicial de elaboración de la Directiva 2003/86 sobre RF la propia Comisión había procedido a consultar a organizaciones no gubernamentales y al Alto Comisionado de los Refugiados a fin de redactar el primer proyecto, si bien posteriormente los EEMM se encargarían de recortar drásticamente sus sugerencias.

818 En el mismo sentido, calificándola expresamente como una sentencia interpretativa, se sitúa PISAPIA, Alice. "Una sentenza additiva in punto di attuazione della Direttiva sul ricongiungimento familiare"; en Giustizia civile, 2007, vol. I, pp.543-546.

819 Sobre este tipo de sentencias, vid. MARTÍN DE LA VEGA, Augusto. La sentencia constitucional en Italia: tipología $y$ efectos de las sentencias en la jurisdicción constitucional italiana, medio siglo de debate doctrinal. Madrid, Centro de Estudios Políticos y Constitucionales, 2003.

820 PASCOUAU, Yves; LABAYLE, Henri. Conditions for Family Reunification under Strain..., op. cit., p. 8. Los autores se refieren tanto a la doctrina emitida por el TJUE en el asunto C-540/03, como la que posteriormente dictó el mismo tribunal en el asunto Chakroun, relativos ambos a la interpretación de la Directiva sobre RF. 
que seguiremos en este apartado. Posteriormente - en el examen del fondo del asunto-, abordaremos los tres motivos de impugnación, para finalizar realizando una valoración general y destacando algunas cuestiones que consideramos de especial relevancia de esta sentencia.

\section{a) ¿Se dirige realmente el recurso contra un acto de las instituciones comunitarias?}

El TJUE analizó en primer lugar la admisibilidad del propio recurso de anulación como consecuencia de la formulación de dos excepciones preliminares. La primera de ellas fue planteada por el Consejo, basándose en que el recurso de anulación no se dirigía realmente contra un acto de las instituciones comunitarias - requisito exigido por el artículo $230 \mathrm{TCE}^{821}$ para poder plantear este tipo de recursos-, sino contra disposiciones nacionales.

A juicio del Consejo, las disposiciones impugnadas constituían excepciones a las obligaciones impuestas a los EEMM por la Directiva sobre el derecho a la RF. Todas ellas se caracterizaban por conceder a los Estados un margen de maniobra, permitiéndoles el mantenimiento o la introducción de normas nacionales plenamente compatibles con el respeto de los derechos fundamentales. Para este órgano, las disposiciones controvertidas constituían simples remisiones a normas nacionales existentes, permitiendo su vigencia, sin obligar ${ }^{822}$ a los EEMM a adoptar normas o acciones concretas. La aplicación de las disposiciones nacionales mantenidas o adoptadas de acuerdo con la Directiva, sería pues el único acto controlable por el TJUE y en sí no constituía una acción de las instituciones comunitarias en el sentido del artículo 46, letra d) TUE. Sobre la base de esta argumentación, el Consejo cuestionaba cómo era posible que el TJUE pudiese controlar en abstracto la legalidad de disposiciones comunitarias que se limitaban a remitirse a legislaciones nacionales futuribles, esto es, de las que no se conocía ni el contenido ni la forma en que serían aplicadas ${ }^{823}$.

En este punto el Parlamento, la Comisión ${ }^{824}$ y las conclusiones de la propia Abogada General ${ }^{825}$ coincidían en oponerse a las objeciones del Consejo. Los tres sostenían, si bien con diversos argu-

821 Conforme a lo establecido en el artículo 230 TCE, sólo cabe interponer un recurso de anulación contra los actos de las instituciones europeas, excluyéndose las recomendaciones y los dictámenes. También pueden ser objeto de un recurso de anulación algunos actos del Banco Europeo de Inversiones.

822 La libertad de los EEMM a la hora de aplicar o no el régimen excepcional previsto en las tres disposiciones recurridas de la Directiva 2003/86 y sus implicaciones de cara a la consideración de si se trata de un acto comunitario o un acto nacional, había sido en su momento destacada en el Informe sobre la Situación de los Derechos fundamentales en la UE correspondiente al año 2003. Dicho informe señalaba literalmente que "the most problematical provisions of Directive 2003/86/EC have in common that they allow certain exceptions to the Member States, which remain free to rely upon them or not". Sin embargo, y a diferencia de lo argumentado por el Consejo a lo largo del recurso, este informe advertía a renglón seguido que el establecimiento de dichas excepciones no implicaba en sí mismo que las mismas fueran admisibles desde el punto de vista de las exigencias de los derechos humanos, cuestionando de esta forma la legalidad de las disposiciones que finalmente fueron recurridas por el Parlamento. SCHUTTER, Olivier De. Report of the Situation of Fundamental Rights in the European Union in 2003..., op.cit., p. 56.

823 Apartado 16 de la STJUE, asunto C-540/03.

824 La Comisión señalaba que el control del respeto de los derechos fundamentales por parte del TJUE debía abarcar tanto los supuestos en que una norma comunitaria obligaba a los EEMM a adoptar medidas violatorias de derechos fundamentales, como aquellos casos en que simplemente lo permitía. Es decir, no cabía descartar la supervisión del TJUE por el hecho de que las disposiciones recurridas se limitaran a remitirse a los derechos nacionales. En su argumentación, la Comisión recordaba al TJUE que sólo cabría anular las disposiciones controvertidas si no era posible efectuar una interpretación de las mismas conforme con los derechos fundamentales. Apartados 18 y 19 de la STJUE, Asunto C-5440/03.

825 La Abogado General, en sus conclusiones, también se manifestó a favor de la admisibilidad del recurso. En su argumentación, señaló que las opciones abiertas a los EEMM por las disposiciones impugnadas limitaban potencialmente el alcance del derecho a la reagrupación familiar, siendo por ello necesario un pronunciamiento 
mentos, que las disposiciones impugnadas formaban parte integrante del derecho comunitario. En consecuencia, dichas normas estaban sometidas al control jurisdiccional del Tribunal de Justicia de la UE, a fin de que este órgano supervisase su compatibilidad con los derechos fundamentales del ordenamiento comunitario.

Esta primera excepción sacaba a la luz una de las cuestiones, a nuestro juicio, más importantes y problemáticas que planteaba la Directiva, ofreciendo con ello al TJUE la oportunidad de clarificar un aspecto básico íntimamente conectado a los derechos fundamentales. Como consecuencia de su carácter potestativo, las derogaciones recurridas de la Directiva sobre RF constituían meras opciones y no obligaciones a cargo de los EEMM, de modo que los regímenes excepcionales que permitían, no prescribían una actuación concreta de los EEMM que pudiera suscitar dudas sobre su compatibilidad con los derechos fundamentales. Además, la Directiva establecía con claridad su carácter de estándar mínimo, dejando a salvo la posibilidad de los Estados de adoptar disposiciones más favorables ${ }^{826}$. Como consecuencia de esta doble circunstancia, la posible violación de derechos fundamentales no derivaría en sí misma de la propia Directiva, sino de las diversas elecciones que efectuasen los EEMM al aplicar el régimen opcional por ella permitido, las cuales se instrumentalizarían mediante la introducción o el mero mantenimiento de normas nacionales internas. En definitiva, "la dificultad no derivaba de las obligaciones impuestas por la Directiva a los EEMM, sino del margen de apreciación que otorgaba a éstos" ${ }^{\prime 27}$. De modo que las controvertidas derogaciones opcionales desembocaban en el familiar y no menos controvertido concepto de margen de apreciación que, como vimos en el capítulo precedente, resulta vital en el ámbito del Consejo de Europa y desarrollará el mismo papel protagónico en el razonamiento que desplegará el TJUE a fin de resolver el recurso de anulación contra la Directiva.

En contra de los argumentos del Consejo, el Parlamento Europeo ${ }^{828}$ alegaba que las disposiciones recurridas constituían excepciones a las obligaciones impuestas por la Directiva a los EEMM, que permitían a éstos aplicar disposiciones nacionales contrarias a los derechos fundamentales. De modo que - al autorizar normas nacionales que no respetaban los derechos fundamentales-, era la propia Directiva 2003/86/CE la que violaba tales derechos.

El punto esencial residía pues en dilucidar si una norma comunitaria que no impone una obligación a los EEMM, sino que otorga un margen de apreciación que les permite aplicar normas internas potencialmente incompatibles con los derechos fundamentales, es en sí misma responsable de violar un derecho fundamental y, como tal, puede ser controlada por el TJUE. Sobre esta cuestión, el TJUE se pronunció de forma tajante desestimando esta primera excepción de inadmisibilidad. Señaló que el control efectuado por el TJUE se extiende también a aquellas disposiciones de derecho comunitario que establecen remisiones a normas nacionales y que las disposiciones comunitarias pueden violar derechos fundamentales, tanto si obligan, como si simplemente autorizan a los EEMM a adoptar o mantener normas nacionales no respetuosas con los derechos fundamentales ${ }^{829}$. Su razonamiento sobre el tema finalizó señalando de forma contundente que:

jurisprudencial expreso sobre su compatibilidad o no con el derecho comunitario. De lo contrario, advertía, "la Comunidad pierde la posibilidad de actuar por iniciativa propia contra medidas nacionales que se limiten a hacer uso de las opciones conferidas". Conclusiones de la Abogada General, sra. Kokott, apartado 45 de la sentencia.

826 Artículo 3.5 de la Directiva 2003/86 sobre el derecho a la Reunificación Famliar.

827 Report on the Situation of Fundamental Rights in the European Union in 2003, presentado por el Prof. Olivier DE SCHUTTER. EU Network of Independent Experts on Fundamental Rights, op. cit., p. 55.

828 Apartado 15 de la sentencia.

829 En palabras del propio Tribunal de Luxemburgo, "el hecho de que las disposiciones de la Directiva impugnadas reconozcan a los Estados miembros cierto margen de apreciación y les permitan aplicar, en determinadas circuns- 


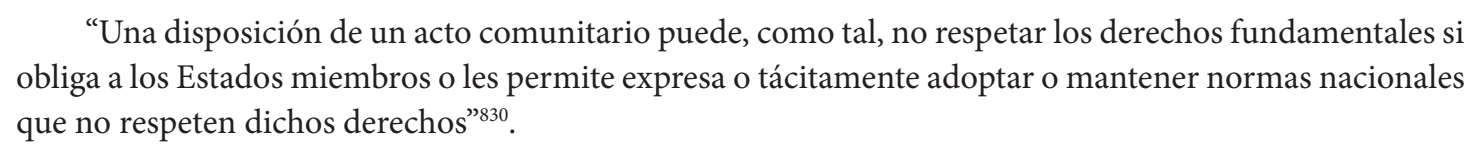

Con este pronunciamiento, - que ha sido considerado como uno de los puntos centrales de esta sentencia ${ }^{831}$ - el TJUE aclaraba el principio general de respeto a los derechos fundamentales en el ámbito comunitario y su eficacia tanto sobre las instituciones comunitarias como sobre los EEMM $^{832}$.

\section{b) ¿Las disposiciones recurridas pueden ser separadas del resto de la Directiva sin alterar su esencia?: El carácter separable de las disposiciones recurridas}

La segunda excepción fue alegada por el Consejo y el gobierno alemán. Ambos afirmaban el carácter esencial de una de las disposiciones recurridas, concretamente de la norma contenida en el artículo 4.1 in fine de la Directiva ${ }^{833}$. Los demandantes consideraban que la citada disposición contenía uno de los puntos centrales del compromiso gracias al cual fue posible desbloquear el proceso de negociación y proceder a la adopción de la Directiva 2003/86 sobre RF. Argumentaban que, dado su carácter esencial, la limitación contenida en el artículo 4.1 in fine resultaba inseparable del resto de la Directiva, de modo que una eventual anulación parcial por parte del TJUE equivaldría a una anulación de la totalidad de la Directiva. Siendo así las cosas - a juicio tanto del Consejo como de la República Federal de Alemania-, "la eventual sentencia de anulación parcial invadiría las competencias del legislador comunitario" $"$ ".

Con este argumento, el Consejo y el gobierno alemán invocaban la teoría de la inseparabilidad de los actos como causa de inadmisión de un recurso de anulación parcial. Conforme a dicha tesis, sólo es posible la anulación parcial de un acto cuando éste consta de varios elementos separables, y sólo están viciados de nulidad uno o varios de esos elementos susceptibles de ser escindidos.

La teoría de la inseparabilidad ha sido empleada en contadas ocasiones por parte del TJUE ${ }^{835}$. En este asunto concurrían algunas características con efectos contradictorios de cara a la aplicación de esta teoría. De un lado, se trataba de un caso relativo a la protección de los derechos humanos, y que tocaba de lleno a un colectivo particularmente digno de protección, como son los menores inmigrantes, circunstancia que obstaculizaba ${ }^{836}$ la consideración del carácter inseparable del artículo

tancias, una norma nacional que establezca excepciones a las reglas de principio impuestas por la Directiva no puede producir el efecto de sustraer estas disposiciones al control de legalidad por el Tribunal de Justicia previsto en el artículo 230 CE”. Apartado 22, STJUE, asunto C-540/03.

830 Apartado 23 STJUE, asunto C-540/03.

831 Cfr. ARNULL, A. "Family Reunification and Fundamental Rights"; en European Law Review, Editorial, n 31, 2006, p. 611.

832 Îdem.

833 El artículo 4.1 in fine de la Directiva 2003/86 permite a los EEMM la aplicación de un criterio previo de integración a los hijos de inmigrantes legalmente asentados, cuando los menores tengan más de doce años y lleguen independientemente del resto de la familia.

834 Apartado 25, STJUE en el asunto C-540/03.

835 CEBADA ROMERO, Alicia. "La directiva de la Comunidad Europea sobre reagrupación familiar: la sentencia del TJUE en el asunto C-540/03”; en ALDECOA LUZÁRRAGA, Francisco y SOBRINO HEREDIA, José Manuel (coords.). Migraciones y desarrollo: II Jornadas Iberoamericanas de Estudios Internacionales. Montevideo, 25, 26 y 27 de octubre de 2006, 2007, p. 540.

836 Idem, p. 538. Por todo ello, CEBADA ROMERO termina señalando que "se podría pensar que si el TJUE había sido particularmente restrictivo a la hora de aplicar la doctrina de la no separabilidad, probablemente lo sería —con mayor razón-, en este caso en el que la protección de los derechos humanos estaba en juego". 
4.1. in fine, y la consiguiente inadmisión del recurso, pues ello dejaría sin resolver tan importante cuestión. Por otro lado, el recurso había sido interpuesto por el propio Parlamento Europeo, con lo cual la abstención del TJUE con vistas a no invadir competencias legislativas resultaba, poco justificada en vista de que la promoción del caso había partido de un miembro del poder legislativo comunitario ${ }^{837}$.

El Parlamento ${ }^{838}$ se oponía a la tesis de la inseparabilidad, considerando que el último párrafo del apartado 1 del artículo 4 era perfectamente separable del resto de la Directiva. Que dicha norma hubiese permitido la adopción de la Directiva no decía nada sobre su supuesta inseparabilidad. Para este órgano, lo determinante era que la separación de un elemento de la Directiva fuera jurídicamente posible. La anulación de la disposición recurrida era jurídicamente posible, en la medida en que constituía una excepción a las reglas generales fijadas en la Directiva y su anulación no ponía en entredicho la eficacia de esta norma en su conjunto.

En contra del criterio adoptado por el Consejo y el Gobierno Alemán, la Abogada General consideraba que el recurso era inadmisible pues las normas impugnadas contenían una limitación esencial al régimen general establecido en la Directiva 2003/86. La anulación de dichas disposiciones supondría una alteración de la esencia de la Directiva, incurriendo de este modo el Tribunal de Justicia en una invasión en las competencias del legislador comunitario ${ }^{839}$. Pese a proponer la inadmisibilidad de este recurso, la Abogada General continuó con el examen del fondo del asunto, si bien advirtiendo que "únicamente con carácter subsidiario" 840.

Al enjuiciar esta excepción, el TJUE reiteró su jurisprudencia en torno a que la posibilidad de anulación parcial de un acto comunitario sólo cabe cuando los elementos cuya anulación se solicita, pueden separarse del resto del acto ${ }^{841}$. Si la anulación parcial de un acto modifica la esencia del mismo, entonces no se cumple la exigencia de separabilidad.

837 CEBADA ROMERO, Alicia. "La directiva de la Comunidad Europea sobre reagrupación familiar: la sentencia del TJUE en el asunto C-540/03”, op. cit., p. 540.

838 Apartado 26 de la presente sentencia del TJUE.

839 Apartado 47 de las conclusiones generales presentadas por la Abogada General, Sra. Kokott. A su juicio, el TJUE se encontraba en un callejón sin salida. Dado el carácter inseparable que la abogada otorgaba a las disposiciones recurridas de la Directiva, la anulación parcial de las mismas modificaría la esencia de la Directiva sobre el derecho a la RF, siendo "el legislador comunitario el único competente para llevar a cabo modificaciones de esas características". Pero, de otro lado, una anulación completa de la Directiva tampoco sería posible, porque con ella se rebasarían las peticiones de la demanda - ultra petita. (Apartado 46 de las conclusiones generales presentadas por la Abogada General, Sra. Kokott). De ahí que concluyera la inadmisibilidad del recurso de anulación parcial propuesto por el PE. Sin embargo, para Cebada Romero, la postura de la Abogada General resulta poco justificada, pues no tenía en cuenta elementos importantes que el TJUE considera a la hora de aplicar la restrictiva teoría de la inseparabiliadad. CEBADA ROMERO, Alicia. "La directiva de la Comunidad Europea sobre reagrupación familiar: la sentencia...", op. cit., p. 538.

840 Apartado 50 de las Conclusiones generales presentadas por la Abogada General. Sobre este punto, CEBADA ROMERO subraya la incongruencia de la postura de la Abogada General, quien continuó con el examen del asunto, - pese a haber propuesto su desestimación-. Lo más sorprendente de su actitud estriba en el hecho de que, tras examinar el fondo del asunto, la Abogada General concluyó que una de las disposiciones controvertidas —concretamente el artículo 8 de la Directiva - podía ser incompatible con el sistema internacional de los derechos humanos. De manera "que si el TJUE hubiera seguido en su integridad los pasos de la Abogado General, el resultado habría sido que una Directiva, una de cuyas disposiciones habría sido considerada incompatible con el Derecho Internacional, hubiera permanecido en vigor"; en "La directiva de la Comunidad Europea sobre reagrupación familiar: la sentencia del TJUE en el asunto C-540/03", op. cit., p. 540.

841 En el apartado 27 de esta sentencia, el TJUE se remite a su jurisprudencia sobre el tema, citando las sentencias de 10 de diciembre de 2002, Comisión/Consejo, C-29/99, Rec. P. I- 11221, apartados 45 y 46; de 21 de enero de 2003; Comisión/Parlamento y Consejo, C-378/00, Rec. P. I-937, apartado 30; de 30 de septiembre de 2003, Alemania/Co- 
Con estas premisas, el TJUE concluyó que la comprobación del carácter separable de las disposiciones recurridas exigía previamente entrar a conocer del fondo del asunto, a fin de poder determinar el alcance de las mismas. Para Cebada Romero, esta actitud del TJUE, en conjunción con el carácter restrictivo de su jurisprudencia en torno a la inseparabilidad del acto, "equivale a un reconocimiento de que las disposiciones controvertidas no conforman el corazón ni son uno de los principales ejes de la Directiva" ${ }^{\prime 42}$. Con ello el TJUE no sólo se alejaba de la propuesta de la Abogada General, sino que dejaba abierta la cuestión de la separabilidad o no de las disposiciones impugnadas, que finalmente quedaría irresoluta ${ }^{843}$ como consecuencia de la desestimación del presente recurso de anulación.

\section{2 Fondo del asunto}

\section{a) El test internacional aplicado por el TJUE}

El recurso giraba en torno a la alegación de la violación de determinados derechos fundamentales por parte de las disposiciones recurridas. De ahí que la primera operación que realiza el TJUE sea despejar o clarificar las normas jurídicas a cuya luz examinará la validez de la Directiva, a fin de poder supervisar su compatibilidad con los derechos fundamentales. Estas normas se erigirán en parámetros de legalidad de la Directiva comunitaria.

La característica más sobresaliente de esta sentencia es que el TJUE apela al sistema internacional de los derechos humanos a fin de identificar en su seno las fuentes normativas reguladoras de las obligaciones de los Estados en materia de migración familiar, fuentes que actuarán como criterios de validez de la propia Directiva sobre reunificación familiar.

El recurso al estándar internacional para contrastar la legalidad de las tres disposiciones recurridas no sólo venía exigido por el propio sistema comunitario de derechos fundamentales, a su favor concurrían otros factores. En primer término, la propia alegación del Parlamento Europeo de que las disposiciones controvertidas de la Directiva conculcaban los derechos fundamentales tal y cómo éstos se extraían del ámbito internacional —-fundamentalmente del CEDH—, orillando al Tribunal de Luxemburgo a efectuar un enjuiciamiento sobre la base del DIDH. En segundo lugar, el recurso al estándar internacional también se manifestaba como referencia obligada por la propia Directiva, que contenía en su preámbulo un apartado de singular trascendencia sobre el particular: El considerando segundo de la Directiva reafirmaba su vinculación con el sistema internacional de los derechos humanos, donde brillaba con luz propia el artículo $8 \mathrm{CEDH}$ - única referencia explícita de la

misión, C-239/01, Rec. P. I-10333, apartado 33; de 24 de mayo de 2005, Francia/Parlamento y Consejo, C-244/03, Rec. P I-4021, apartado 12, y de 30 de marzo de 2006, España/Consejo, C-36/04, Rec. P. I-000, apartado 9. STJUE, asunto C-540/03, apartados 27 y 28.

842 CEBADA ROMERO, Alicia. "La Directiva de la Comunidad Europea sobre Reagrupación Familiar: La Sentencia del TJUE en el Asunto C-540/03”, op. cit., p. 538. Frente a esta opinion, Pérez Martín, señala la procedencia de esta actitud, argumentando que "el TJUE en su Sentencia, de forma lógica y en absoluto criticable, condiciona su declaración de inadmisión o admisión del recurso basada en el carácter separable o no de las disposiciones controvertidas, al examen previo de su contenido y su posible contradicción con el derecho a vivir en familia”. Pérez Martín, Elena. "El derecho al respeto de la vida familiar y la reagrupación familiar de los hijos menores de extranjeros en la Unión Europea (STJUE de 26 de junio de 2006, C-540/03)”, p. 26. Disponible en http://www.funciva.org/uploads/ ficheros_documentos/1216117825_elena_perez_martin.pdf

843 Por ello CEBADO ROMERO se lamenta de que el TJUE haya "perdido una espléndida oportunidad para arrojar alguna luz sobre los contornos borrosos del argumento de la indivisibilidad"; "La Directiva de la Comunidad Europea sobre reagrupación familiar...., op. cit., p. 539. 
Directiva a un artículo concreto de un tratado internacional. Además, esta disposición del preámbulo calificaba la relación entre el contenido de la Directiva y los compromisos internacionales de los EEMM en materia de derechos humanos con el término de "respetuosa" ${ }^{444}$. La comprobación de la veracidad de esta afirmación será precisamente el objetivo central que tendrá que acometer el TJUE en este recurso, a raíz de la denuncia de falta de respeto formulada por el Parlamento.

$\mathrm{Al}$ abordar esta tarea inicial de identificación de las fuentes normativas internacionales que actuarán como parámetros de legalidad de la Directiva, el TJUE no hace sino aplicar la doctrina que, en torno a los derechos fundamentales, rige en el ámbito comunitario. Esta doctrina constituye una construcción jurisprudencial de la Corte de Luxemburgo y está cristalizada en el artículo 6 TUE ${ }^{845}$. De ahí que lo primero que haga el $\mathrm{TJUE}^{846}$ sea remitirse al contenido de dicha disposición, recordando que en el sistema comunitario los derechos fundamentales forman parte integrante de los principios generales del derecho, cuyo respeto garantiza dicho órgano. Para extraer los derechos fundamentales que rigen en el ámbito comunitario, el TJUE ha de recurrir a dos fuentes inspiradoras: las tradiciones constitucionales comunes a los EEMM, junto con los compromisos internacionales que incumben a los EEMM en materia de protección de los derechos humanos ${ }^{847}$.

Sobre la base de las dos fuentes citadas - tradiciones constitucionales y compromisos internacionales comunes-, el TJUE tiene ante sí la labor de despejar los derechos y correspondientes obligaciones que atañen a los EEMM en materia de reunificación familiar de los extranjeros no comunitarios, como si se tratase de una ecuación algebraica. Cabría entonces pensar que el esfuerzo del TJUE se centraría en rastrear, entre estas dos fuentes, las que contengan normas de mayor importancia en el marco de la inmigración familiar.

Sin embargo, la Corte de Luxemburgo no indaga en ningún momento en las tradiciones constitucionales de los EEMM - y ello pese a que el Parlamento había hecho referencia de forma muy somera a varias Constituciones nacionales ${ }^{84}-$. El TJUE se centra exclusivamente en el examen de los instrumentos internacionales protectores de derechos humanos más relevantes en el ámbito de la reagrupación familiar. Dichos instrumentos actuarán como fuentes normativas de las que emerge el derecho a la vida familiar como principio general del derecho comunitario del cual, a su vez, se deriva la protección del derecho a la reunificación familiar.

844 La dicción literal del considerando segundo de la Directiva sobre RF afirma que "la presente directiva respeta los derechos fundamentales y observa los principios reconocidos en particular por el artículo 8 del CEDH y por la Carta de los Derechos fundamentales de la Unión Europea”.

845 El apartado segundo del artículo 6 TUE establece que "la Unión respetará los derechos fundamentales tal y como se garantizan en el CEDH y tal y como resultan de las tradiciones constitucionales comunes a los Estados miembros como principios generales del Derecho comunitario". Esta disposición es reproducida literalmente en el apartado 36 de la presente sentencia. El artículo 6 TUE vino a codificar una doctrina que había sido construida tempranamente por el TJUE, a fin de suplir la laguna existente al respecto en el derecho comunitario, que en sus inicios se construyó con fines de carácter exclusivamente económico, careciendo de un sistema propio de derechos fundamentales y de competencias expresas en esta materia. De ello da buena cuenta la ausencia de referencias a los derechos fundamentales en los tratados constitutivos. En torno a los derechos fundamentales y a la progresiva construcción de un sistema comunitario propio y autónomo de derechos fundamentales gracias a la obra jurisprudencial del TJUE pueden consultarse, entre otros, DÍEZ BARRADO, Cástor. "Reconocimiento y protección de los derechos fundamentales en la Unión Europea”; MARIÑO MENÉNDEZ y otros. Derecho de Extranjería, Asilo y Refugio. Madrid, Ministerio de Asuntos Sociales, INSERSO, 1995, pp. 129-153.

846 Apartado 35, STJUE en el asunto C-540/03.

847 Artículo 6.2 TUE, transcrito literalmente en el apartado 36 de esta sentencia.

848 El apartado 33 in fine de la presente sentencia, señala literalmente: "Por último el Parlamento invoca varias constituciones de los Estados miembros de la UE", sin que en dicho apartado se especifiquen cuáles hayan sido los concretos textos consitucionales alegados por el PE. 
El test internacional juega un papel esencial en esta sentencia. Todo el razonamiento del Tribunal de Luxemburgo gravitará en torno a la aplicación de dicho test a fin de contrastarlo con las disposiciones recurridas de la Directiva para valorar la validez de las mismas. La cuestión principal que debía afrontar el TJUE era determinar si el legislador comunitario, al incluir las derogaciones recurridas de la Directiva sobre RF, se había excedido de los límites impuestos por los derechos fundamentales. Se trata, por lo tanto, de descubrir el estándar internacional existente en materia de reunificación familiar y aplicarlo a la Directiva, a fin de contrastar si las tres disposiciones controvertidas son respetuosas con dicho estándar.

El íter seguido por el TJUE en el empleo del test internacional es el siguiente: En primer lugar, identifica cuales son las fuentes internacionales de las que puede deducir los principios generales del derecho comunitario en materia de reunificación familiar; en segundo lugar, explora cada una de ellas de forma individualizada para extraer y analizar sus artículos más significativos a fin de determinar el nivel de protección que otorgan a la reagrupación familiar; en tercer lugar, deduce el estándar internacional aplicable con carácter general a dicho derecho, tal y como se desprende globalmente de las fuentes internacionales identificadas — dicho estándar actuará como tope mínimo que podrá ser superado por la Directiva pero, en ningún caso, reducido—; en cuarto lugar, contrasta el estándar internacional con el nivel de protección global que ofrece la Directiva sobre reunificación familiar, para, finalmente, confrontar de forma individualizada cada una de las disposiciones recurridas con el estándar internacional, centrándose fundamentalmente en la comparación entre los márgenes de apreciación respectivos existentes en el ámbito internacional y, por su parte, los que ofrecen las tres disposiciones controvertidas.

Los pasos segundo y tercero los realiza el Tribunal de Luxemburgo dentro del epígrafe destinado a evaluar la validez de la primera de las disposiciones impugnadas. Por una cuestión de sistemática, consideramos adecuado exponer conjuntamente las tres primeras operaciones señaladas, porque en ellas reside la parte más importante del test internacional que después utilizará de forma individualizada, pero casi idéntica, con cada una de las disposiciones recurridas. Creemos que exponerlo de una vez facilitará la comprensión de la parte sustantiva de esta sentencia, al tiempo que resulta esencial para nuestro trabajo de investigación que incluye un análisis del DIDH, especialmente del CEDH y la jurisprudencia emitida por el TEDH en materia de reunificación familiar.

\section{a.1) Identificación de los parámetros de validez de la Directiva}

Como resultado de su indagación en el panorama normativo internacional que vincula a los EEMM en materia de inmigración familiar, el TJUE identifica cinco parámetros internacionales sobre los que poder contrastar la legalidad de la Directiva comunitaria ${ }^{849}$, en el siguiente orden: El Convenio Europeo de Derechos Humanos de 1950, el Pacto Internacional de Derechos Civiles y Políticos (PIDCP), la Convención sobre los Derechos del Niños — "que, como el citado Pacto, vincula a todos los EEMM" ${ }^{850}$ - , la Carta de Derechos Fundamentales de la UE y la Carta Social Europea.

849 En el apartado 37 de esta sentencia, el TJUE señala: "El Tribunal de Justicia ya ha tenido ocasión de recordar que el Pacto Internacional de Derechos Civiles y Políticos figura entre los instrumentos internacionales relativos a la protección de los derechos humanos que el Tribunal de Justicia tiene en cuenta para la aplicación de principios generales del Derecho comunitario (véanse, en particular, las sentencias de 18 de octubre de 1989, Orkem/Comisión, 374/87, Rec. p. 3283, apartado 31; de 18 de octubre de 1990, Dzodzi C-297/88 y C-197/89, Rec. p. I-3763, apartado 68, y de 17 de febrero de 1998, Grant, C-249/96, Rec. P. I-621, apartado 44). Lo mismo sucede en el caso de la Convención sobre los Derechos del Niño antes mencionado, que, como el citado Pacto, vincula a todos los Estados Miembros". 
Según el razonamiento empleado por el TJUE, la característica esencial de las cinco fuentes identificadas consiste en contener disposiciones relativas a la reunificación familiar dotadas de los umbrales más altos de protección ${ }^{851}$. En consecuencia $-\mathrm{y}$ tras haber realizado una labor de depuración de entre los múltiples convenios y recomendaciones que habían sido invocados por el Parlamento Europeo ${ }^{852}$ - la conclusión es que el CEDH, el PIDCP, la Convención sobre los derechos del niño, el CEDH, la Carta de Derechos Fundamentales de la UE y la Carta Social Europea conforman, a juicio del Tribunal de Luxemburgo, el estándar de protección más garantista en el ámbito de la inmigración familiar dentro del sistema internacional de los derechos humanos.

Los cinco parámetros internacionales enunciados están dotados de una importancia desigual. Si como criterio para valorar su peso relativo en el ámbito de la reunificación familiar, adoptamos a su vez el peso que el TJUE les otorga a lo largo de su razonamiento, la conclusión es bastante obvia. De entre ellos, el CEDH, - tal y como es interpretado por el TEDH—, ostenta la mayor prioridad, hasta el punto de que a lo largo de todo su enjuiciamiento el Tribunal de Luxemburgo acude de forma reiterada y absolutamente prioritaria a la jurisprudencia de Estrasburgo derivada del artículo $8 \mathrm{CEDH}$ para confrontar la validez de la Directiva. Sobre esta misma base, el Parlamento Europeo había sustentado sus pretensiones de anulación de las disposiciones de la Directiva comunitaria invocando fundamentalmente el derecho a la vida familiar del artículo $8 \mathrm{CEDH}$, tal y como ha sido interpretado por la jurisprudencia del TEDH y, en segundo lugar, el principio de no discriminación consagrado en el artículo 14 del mismo instrumento internacional ${ }^{853}$. El propio Tribunal de Luxemburgo otorga expresamente al CEDH una posición claramente privilegiada en el ámbito de la reunificación familiar proclamando que "reviste un significado particular"

Tras el CEDH, emergen la Convención de los Derechos del Niño y la Carta de los Derechos Fundamentales - con una importancia aparentemente muy superior al PICDP y la Carta Social Europea, al menos, insistimos, desde el punto de vista de las referencias jurisprudenciales realizadas a dichos instrumentos a lo largo de esta sentencia-, pues a partir de ahora el PICDP y la Carta Social Europea brillarán por su ausencia en el razonamiento del TJUE. Por otro lado, las referencias autónomas que el Tribunal de Luxemburgo realiza a la Convención sobre los Derechos del Niño y espe-

851 Así parece deducirse de lo señalado por el TJUE en el apartado 39. En esta parte de la sentencia, la Corte, tras enunciar los cinco instrumentos internacionales más importantes en materia de RF de los extranjeros, afirma que: "En cuanto a los demás instrumentos internacionales invocados por el Parlamento, aparte de la Carta Social Europea, de la que se tratará en el apartado 107 de esta sentencia, no contienen, en cualquier caso, disposiciones más protectoras de los derechos del niño que las contenidas en los instrumentos ya citados". El TJUE parece indagar entre las distintas fuentes internacionales con el propósito último de poder entresacar, de entre los diversos tratados y recomendaciones internacionales que rigen el derecho de los extranjeros a la RF, los instrumentos más protectores y, por ende, más favorables al ejercicio del derecho.

852 El Parlamento Europeo había invocado, además, la Convención Internacional sobre la protección de los derechos de todos los trabajadores migratorios y de sus familiares, de 1990, la Declaración de los Derechos del Niño, proclamada por la Asamblea General en su resolución 1386 (XIV), de 20 de noviembre de 1959, e incluso llegó a apelar a dos recomendaciones sin eficacia jurídica dentro del ambito del Consejo de Europa (apartado 33 de la sentencia). Sin embargo, el listado más amplio de todos los proporcionados en la argumentaión del recurso corresponde a la Abogada General. En sus conclusiones, se contiene la referencia más extensa y profunda en torno a las fuentes internacionalmente relevantes para juzgar la validez del derecho a la reunificación familiar tal y como era garantizado por la Directiva comunitaria 2003/86. Bajo el epígrafe general "protección de la familia en la normativa sobre derechos humanos", los apartados 59 a 78 de la sentencia contienen información bastante detallada en torno al nivel de protección de la migración familiar en el DIDH.

853 Apartados 30 a 32 de la sentencia del TJUE en el asunto C-540/03.

854 Apartado 35, STJUE, asunto C-540/03. 
cialmente a la Carta de DDFF de la Unión, constituyen una auténtica innovación de esta sentencia y merecen por ello un comentario destacado.

Al mencionar la Convención de los Derechos del Niño, el TJUE parece querer reforzar su eficacia, lo que podría tener consecuencias positivas desde el punto de vista de la fortaleza de los derechos de los menores inmigrantes en el espacio comunitario. Para evaluar su posible trascendencia, conviene retener que la comunidad carece de competencias directas respecto a los derechos de los menores, ámbito que constituye un auténtico "territorio inexplorado" 855 , en el que la mencionada Convención de la ONU podría asentar las bases de un futuro derecho comunitario de los menores.

De mayor trascendencia resulta la referencia a la Carta de Derechos Fundamentales de la $\mathrm{UE}^{856}$, cuya inclusión entre los parámetros de validez de la Directiva despertó un enorme interés entre la doctrina internacionalista. La Carta, además de ser mencionada de forma autónoma, es objeto de un apartado íntegro de la sentencia, del siguiente tenor literal:

"Respecto a la Carta, fue proclamada solemnemente por el Parlamento, el Consejo y la Comisión en Niza el 7 de diciembre de 2000. Aunque esta Carta no constituye un instrumento jurídico vinculante, el legislador comunitario ha querido reconocer su importancia al afirmar, en el segundo considerando de la Directiva, que ésta observa los principios reconocidos no sólo por el artículo 8 del CEDH, sino también por la Carta. Por otra parte, el objetivo principal de la Carta, como se desprende de su preámbulo, es reafirmar «los derechos que emanan en particular de las tradiciones constitucionales y las obligaciones internacionales comunes a los Estados miembros, del [CEDH], de las Cartas Sociales adoptadas por la Unión y por el Consejo de Europa, así como de la jurisprudencia del Tribunal de Justicia [...] y del Tribunal Europeo de Derechos Humanos" $\$ 57$.

En este apartado reside, para algunos autores, una de las claves explicativas de la importancia de este pronunciamiento jurisprudencial. De hecho, la referencia a la Carta ha sido calificada como la "principal novedad" 858 de esta sentencia, hasta el punto de atribuirle el carácter de una "pequeña revolución” $"$.

Los comentarios sobre la trascendencia de esta referencia son muy variados. Hay quienes interpretan que, por esta vía, el TJUE estaría abriendo la puerta trasera o aplicando de soslayo el Tratado por el que se establece la Constitución Europea ${ }^{860}$ - que incorporaba a la Carta en su parte II, dotándola por fin de la ansiada eficacia jurídica de la que carecía en el momento de emisión de este pronunciamiento-, especialmente ante el fracaso del proyecto de Constitución Europea. Otros autores

855 DRYWOOD, Eleanor. "Giving with one hand, taking with the other: Fundamental Rights, Children and the Family Reunification Decision”; en European Law Review, n o 32, 2007, p. 397.

856 Si bien existen referencias en anteriores sentencias del TJUE a la Carta de Derechos Fundamentales de la UE, en ellas la Corte de Luxemburgo se limitaba a extractar a su vez los argumentos ofrecidos por las distintas partes implicadas, habiéndose mostrado reacio este órgano a invocar de forma autónoma la Carta de derechos fundamentales, en vista de su ambigua naturaleza jurídica y su incierto futuro. Como es bien sabido, el Tratado de Lisboa, vigente actualmente, ha dotado de eficacia jurídica a la Carta de DDFF de la UE.

857 Apartado 38 de la sentencia.

858 DRYWOOD, Eleanor. “Giving with one hand, taking with the other..., op. cit., p. 400.

859 LAWSON, Rick. "Family Reunification and the Union's Charter of Fundamental Rights, Judgment of 27 June 2006 , Case C-540/03, Parliament v. Council”, op. cit., p. 334.

860 ARNULL, Anthony. "Family Reunification and Fundamental Rights"; en European Law Review, No 5, 2006, p. 662. En torno a este aspecto, Cortés Martín estima "exagerada” la percepción de Arnull. CORTÉS MARTÍN, José Manuel. “TJUE — Sentencia de 27.06.2006, Parlamento Europeo/Consejo, C-540/03. ¿Restricciones al reagrupamiento familiar de nacionales de terceros países versus respeto de los derechos fundamentales"; en Revista de Derecho Comunitario Europeo, № 26, 2007, p. 226. 
consideran que con esta referencia se produce la "emancipación de la Carta de DDFF de la UE",661 mientras que algunos otros restan importancia a su mención ${ }^{862}$. Otros más subrayan el riesgo de que, a partir de ahora, con la mera referencia a este documento, el Tribunal se vea liberado ${ }^{863}$ de la tarea de rastrear los derechos fundamentales que rigen en el ámbito comunitario de entre las fuentes habituales -esto es, entre las tradiciones constitucionales comunes y los compromisos internacionales en materia de derechos humanos que vinculan a los EEMM, conforme a lo prescrito en el art. 6 TUE.

La referencia del TJUE a la Carta venía asimismo alentada por la mención expresa a la misma que contenía la Directiva sobre el derecho a la RF, en el considerando segundo de su preámbulo. El hecho de que la mención de la Carta figure fuera del cuerpo principal de la Directiva empaña en parte su trascendencia ${ }^{864}$, dado que el preámbulo carece de eficacia jurídica vinculante, siendo de importancia a efectos meramente interpretativos. De otro lado, hace surgir la cuestión de si esta referencia jurisprudencial expresa a la Carta hubiera tenido lugar de no existir ninguna alusión a este instrumento por parte de la Directiva sobre reagrupación familiar objeto de enjuiciamiento ${ }^{865}$. Las dudas en torno a esta última cuestión ya han sido despejadas a raíz de una sentencia posterior del TJUE ${ }^{866}$, donde vuelve a mencionar la Carta como parámetro del cual extraer los derechos fundamentales y, —esta vez-, sin que la legislación comunitaria ofreciese bases para ello, dado que el

861 LAWSON, Rick. "Family Reunification and the Union's Charter of Fundamental Rights, Judgment of 27 June 2006 , Case C-540/03, Parliament v. Council”, op. cit., p. 325.

862 CORTÉS MARTÍN, José Manuel. “TJUE-Sentencia de 20.06.2006, Parlamento...., op. cit., p. 227. El autor afirma al respecto: "nos parece erróneo considerar que esta primera aplicación de la Carta constituye un paso decisivo hacia la cristalización de los Derechos fundamentales garantizados en el orden jurídico comunitario, reconociéndoseles por esta vía un valor jurídico del que carecían".

863 LAWSON, Rick. "Family Reunification and the Union's Charter of Fundamental Rights...”, op. cit., p. 337. En este sentido, la Carta vendría a actuar como una fuente independiente de derechos fundamentales, esto es, a modo de un "free rider: it merely served to confirm the existence of rights which are already recognized in the more established sources". Además, el autor sugiere una interpretación adicional, dando a entender que la importancia que esta sentencia ha otorgado a la Carta de DDFF de la UE quizá se deba a un cambio de composición del Tribunal de Luxemburgo: "it is tempting to note that the Grand Chamber in this case included Judges Koen Lenaerts and Alan Rosas, who in their academic writings did not hide their enthusiasm for the Charter".

864 En esta línea, Cebada Romero interpreta la mención a la Carta de Derechos Fundamentales en el preámbulo de la Directiva sobre RF afirmando que "si el compromiso expreso de respetar y observar los principios y derechos consagrados en la Carta, hubiese sido incluido en el cuerpo principal de la Directiva, la Carta se habría convertido en un parámetro idóneo para medir la validez de ésta. En este caso, no obstante, el compromiso de acatar la Carta tiene menor valor, puesto que se incluye tan sólo en el Préambulo (que, como ha declarado recientemente el TPI, «has no inherent legal signficance»), Sentencia caso T-367/03, 30 de marzo de 2006)". CEBADA ROMERO, A. "La Directiva de la Comunidad Europea sobre Reagrupación Familiar: La Sentencia del TJUE en el Asunto C-540/03", op. cit., p. 542.

865 Cortés Martín no otorga una excesiva importancia al hecho de que la mención expresa a la Carta contenida en la Directiva sobre el derecho a la RF actúe como detonante de su referencia autónoma en la sentencia, pues "la misma referencia aparece en otros actos de Derecho derivado sin que el TJUE se hubiera sentido obligado hasta ahora a seguir esta vía”. CORTÉS MARTÍN, José Manuel. “TJUE - Sentencia de 27.06.2006, Parlamento Europeo/ Consejo, C-540/03...., op. cit., p. 226. En un sentido radicalmente opuesto se sitúa Lawson, para quien el hecho de que la Carta apareciese mencionada en el Preámbulo constituye un "factor decisivo" para que el TJUE se decidiese a mencionarla en esta sentencia. LAWSON, Rick. "Family Reunification and the Union's Charter of Fundamental Rights, Judgment of 27 June 2006, Case C-540/03, Parliament v. Council”, op. cit., p. 335.

866 Se trata de la sentencia emitida por el TEDH en el asunto Advocaten voor de Wereld, relativo a la validez de una Propuesta de Decisión Marco del Consejo sobre 13 de junio de 2002 relativa a la orden de detención europea y a los procedimientos de entrega entre Estados Miembros (2002/584/JHA), STJUE, 3 de mayo de 2007, Caso C-303/05, especialmente sus apartados 46 y 47. LAWSON, Rick. "Case Note. Family Reunification Directive. Court of Justice of the European Communities. Family Reunification and the Union's Charter of Fundamental Rights..., op. cit., p. 336, y nota a pie de p. no 16, p. 337. 
texto de referencia a aplicar e interpretar por la Corte de Luxemburgo no contenía ninguna alusión a dicho instrumento.

En todo caso, la inclusión de la Carta en el preámbulo de la Directiva 2003/88/CE podría interpretarse como una clara señal de la importancia que este instrumento está llamado a tener en materia migratoria ${ }^{867}$. Más aún si se tiene en cuenta que las dos únicas referencias expresas, hechas en plano de igualdad-, son al artículo 8 CEDH y a la Carta ${ }^{868}$. Por su parte, el Parlamento Europeo había invocado y ampliado el listado de los tratados internacionales que podían servir como parámetros de validez de la Directiva, incluyendo también a la Carta DDFF ${ }^{869}$. Sobre la función a desempeñar por la Carta, el PE indicaba que, pese a su falta de eficacia jurídica, "proporciona criterios útiles para interpretar las disposiciones del $\mathrm{CEDH}^{\text {" }}{ }^{870}$. En sentido contrario se había manifestado el Consejo, argumentando que la Comunidad como tal no era parte contratante en los diversos instrumentos de derecho internacional público sobre derechos humanos que habían sido invocados por el Parlamento y que, en cualquier caso, dichas normas no consagraban un derecho absoluto a la reagrupación familiar, sino "únicamente exigen que se respete y se tenga en cuenta el interés del niño" ${ }^{871}$. En consonancia con su postura, el Consejo había señalado la improcedencia de examinar este recurso desde el punto de vista de la Carta, ya que "ésta no es fuente del Derecho Comunitario" 872 .

La interpretación auténtica que efectúa el TJUE sobre este punto señala que la mención expresa de la Carta de derechos fundamentales en la Directiva viene a evidenciar la relevancia de este documento cuya función, - lejos de consistir en la creación ex novo de facultades subjetivas en el ámbito comunitario-, consiste más limitadamente en "reafirmar los derechos que emanan en particular de las tradiciones constitucionales y las obligaciones internacionales comunes a los Estados miembros ${ }^{\text {'873 }}$. La Carta vendría así a consolidar derechos ya existentes en la UE, confiriendo con ello mayor visibilidad a aquellas facultades subjetivas individuales que ya están presentes en el ámbito comunitario, por ser representativas de las tradiciones constitucionales y las obligaciones internacionales comunes a los EEMM. Al desarrollar este rol, la Carta estaría asimismo facilitando la función —que el propio TJUE está llamado a desempeñar-, de destilación de derechos procedentes de las dos fuentes "inspiradoras" antes mencionadas, — de ahí el riesgo, ya apuntado, de que la Corte de Luxemburgo se viera tentada a liberarse de esta tarea mediante una rápida y expeditiva mención al artículo correspondiente de la Carta de Derechos Fundamentales de la UE-.

En definitiva, la referencia a la Carta parece finalmente confirmar los pronósticos apuntados desde ciertos sectores doctrinales en torno a la tendencia emergente, por parte del TJUE, a considerar este instrumento "como el elemento central de interpretación de los derechos fundamentales

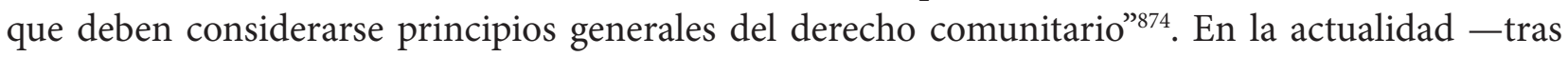

867 En el mismo sentido se manifiestan Baldaccini y Toner, para quienes la referencia a la Carta por parte del TJUE "proves that it is a crucial tool in the armoury of those concerned with rights protection in relation to EU migration law. This, together with the possibility of essentially normalised jurisdiction of the Court of Justice, holds out some hope for stemming the worst of the effects of the legislation that has thus far been adopted and now awaits full implementation". BALDACCINI, A; TONER, H. (eds.) "From Amsterdam and Tampere to the Hague”..., op. cit., p. 21.

868 Ambas están contenidas en el considerando segundo del preámbulo de la Directiva 2003/86.

869 Apartados 31-33 de la STJUE, asunto C-540/03, especialmente su apartado 33.

870 Apartado 31 de la presente sentencia, caso C-540/03.

871 Idem, apartado 34.

872 Ibidem, apartado 34 in fine.

873 Apartado 38, STJUE, asunto C-540/03.

874 FONSECA MORILLO, Francisco J. "Los derechos de los nacionales de terceros países en la Unión Europea. Situación jurídico-política tras la proclamación de la Carta de los Derechos Fundamentales de la Unión”, op. cit., p. 87. 
su entrada en vigor en diciembre de 2009-, las disquisiciones en torno al sentido concreto de las referencias jurisprudenciales a la Carta de derechos fundamentales de la UE han pasado a segundo término, a raíz de la eficacia jurídica adquirida por dicho documento, cuyo valor se sitúa en el mismo plano que los tratados originarios.

\section{a.2) La Reunificación familiar en el CEDH, la Convención de los Derechos del Niño y la Carta de Derechos Fundamentales de la UE}

La aplicación del test internacional se inicia con la indagación del nivel aislado de protección que las fuentes internacionales identificadas proporcionan al principio de respeto a la vida familiar y a la reunificación familiar de los extranjeros. La Corte de Luxemburgo recurre tan sólo a tres de los cinco parámetros internacionales de validez de la Directiva 2003/86, que había identificado anteriormente, -omitiendo el PIDCP y la Carta Social Europea-.

El test internacional parte del artículo $8 \mathrm{CEDH}$ y de un repaso a la jurisprudencia emanada del TEDH en torno a su aplicación ${ }^{875}$, recordando que el respeto efectivo de la vida familiar puede engendrar obligaciones positivas sobre las que rigen principios aplicables comparables a los vigentes en las obligaciones de no hacer y que, en ambos casos, es preciso establecer un justo equilibrio entre los intereses en liza, disponiendo en ellos el Estado de "cierto margen de apreciación". El artículo 8 del CEDH, en la interpretación dada por el Tribunal de Estrasburgo, constituye la fuente a la que el TJUE dedica la mayor parte de su argumentación. Por ello, cabría desde ahora concluir que el test internacional empleado por el Tribunal de Luxemburgo en este pronunciamiento es básica y prioritariamente el test convencional de Estrasburgo.

De la Convención sobre los Derechos del Niño — en adelante CDN— el TJUE rescata tres de sus disposiciones: El sexto considerando del preámbulo, el artículo 9.1 y el artículo 10. El primero de ellos establece que el niño, para el pleno y armonioso desarrollo de su personalidad debe crecer en el seno de la familia, - reconocimiento que para el TJUE constituye la base del "principio del respeto de la vida familiar" ${ }^{786}$ - . Además, el TJUE cita el artículo 9.1 CDN, que impone a los Estados partes la obligación de velar por que el niño no sea separado de sus padres contra la voluntad de éstos. Y, finalmente, se refiere al artículo 10. 1 de la Convención mencionada, que establece que toda solicitud hecha por un niño o sus padres para entrar en un Estado Parte o para salir de él, a los efectos de la reunión de la familia, debe ser atendida por los Estados Partes de manera positiva, humanitaria y expeditiva. El TJUE señala que esta última disposición establece una exigencia que se deduce a su vez de la obligación consagrada en el artículo 9.1 de la Convención.

Del contenido de la Carta de Derechos Fundamentales de la UE ${ }^{877}$ el Tribunal de Luxemburgo saca a la luz el derecho consagrado en su artículo 7, el cual "reconoce el mismo derecho al respeto de

875 En su repaso por la jurisprudencia del TEDH - apartados 52-56 de esta sentencia - la Corte de Luxemburgo se apoya fundamentalmente en la sentencia Sen, de la que extrae literalmente los principios aplicables en la materia (apartado 55), pero también se contiene una referencia a la sentencia Rodrigues da Silva contra Países Bajos, que fue dictada el 31 de enero de 2006, esto es, el mismo año en que el TJUE pronunció esta sentencia. Esto indica que las referencias a la jurisprudencia de Estrasburgo están muy actualizadas. Pese a ello, el TJUE hace una aplicación parcial de los criterios jurisprudenciales del Triunal de Estrasburgo, ya que, al mencionar los criterios que los Estados parte han de tener en cuenta para el examen de las solicitudes de RF, tan sólo establece "la edad de los menores afectados, su situación en el país de origen y su grado de dependencia de los padres”. Apartado 56, STJUE, asunto C-540/03.

876 Apartado 57, STJUE, asunto C-540/03.

877 Idem. Habida cuenta de que, como el propio TJUE reconoce, el artículo 7 de la Carta es una réplica casi exacta del artículo $8 \mathrm{CEDH}$, resulta adecuado concluir que la referencia a la Carta contenida en la Directiva comunitaria 
la vida privada o familiar". El TJUE subraya la necesidad de poner en conexión este derecho con dos obligaciones establecidas en el artículo 24 del mismo instrumento, de un lado con la obligación de tener en cuenta el interés superior del niño - artículo 24. 2 de la Carta- y, de otro, con la necesidad del menor de mantener de forma periódica relaciones personales y contactos directos con su padre y con su madre - artículo 24.3 de la Carta-.

\section{a.3) El estándar de protección internacional aplicable a la $R F$ de los extranjeros en el ámbito de la UE}

Con carácter preliminar, el TJUE indaga en la jurisprudencia de Estrasburgo y sus implicaciones para el derecho comunitario. En este sentido, recuerda que "el derecho al respeto de la vida familiar en el sentido del artículo 8 del CEDH forma parte de los derechos fundamentales que, según jurisprudencia reiterada del Tribunal de Justicia, están protegidos en el ordenamiento comunitario" ${ }^{\text {"878. }}$. Y que el contenido de tal derecho, - en lo que a efectos migratorios se refiere-, supone el "derecho a vivir con sus parientes próximos" implicando obligaciones para los EEMM, "que pueden ser negativas, por ejemplo cuando se les obliga a no expulsar a una personas, o positivas, cuando se les obliga a autorizar a una persona a entrar y residir en su territorio". El TJUE subraya la existencia de un vínculo entre la RF y el CEDH, afirmando que "aunque el CEDH no garantiza como tal ningún derecho en favor de un extranjero a entrar o residir en el territorio de un país determinado, excluir a una persona de un país en el que viven sus parientes próximos puede constituir una injerencia en el derecho al respeto de la vida familiar protegido por el artículo 8, apartado 1, del Convenio" 879 .

Tras analizar de forma aislada las fuentes internacionales más garantistas en materia de RF con preponderancia en el sistema del Consejo de Europa-, el TJUE las pone en correlación y concluye con una visión general clara, pero no muy halagüeña, del panorama internacional vigente: pese a que estas fuentes remarcan la importancia de la vida familiar para el niño, de ellas no es posible extraer un derecho subjetivo a la RF:

\footnotetext{
“Todas estas normas hacen hincapié en la importancia que tiene para el niño la vida familiar y recomiendan a los Estados tener en cuenta el interés del menor, pero no confieren a los miembros de una familia un derecho subjetivo a ser admitidos en el territorio de un Estado y no pueden interpretarse en el sentido de que privan a los Estados miembros de cierto margen de apreciación al examinar las solicitudes de reagrupación familiar" ${ }^{\$ 80}$.
}

En definitiva, el DIDH no otorga a las personas extranjeras ningún derecho a entrar y residir en un territorio del que no sean nacionales, a fin de reunirse con sus parientes allí instalados. Lo más que ofrece es cierta protección contra injerencias estatales ilegítimas, pues en este ámbito el EstadoNación sigue conservando el poder de determinar aquellos sujetos no nacionales a quienes admitirá en su territorio.

sobre RF desemboca nuevamente en un recordatorio de la importancia excepcional del artículo 8 CEDH para la protección del derecho a la RF de los extranjeros en la UE.

878 Apartado 53, STJUE, asunto C-540/03.

879 Dicha referencia aparece en el apartado 53 de esta sentencia donde el TJUE, además de repetir doctrina consolidada en el ámbito de Estrasburgo, cita su propia jurisprudencia, concretamente las sentencias Carpenter —apartado 42-, y Akrich —apartado 59-.

880 Apartado 59 de la STJUE, asunto C-540/03. 


\section{a.4) El estándar deducible de la Directiva 2003/86 sobre el derecho a la Reunificación familiar}

En claro contraste con el panorama que ofrece el sistema internacional de los derechos humanos vinculante para los EEMM, la visión del TJUE en torno al nivel de protección ofrecido por la Directiva comunitaria 2003/86 es frontalmente distinta: frente a la inexistencia de un derecho a la RF en el ámbito internacional - y no olvidemos que el TJUE había examinado las fuentes más protectoras-, la Directiva otorga un auténtico derecho subjetivo a la reunificación familiar. Ello da lugar claramente a un estándar de protección mucho más elevado que el estándar internacional. Por lo tanto, conforme al test internacional utilizado por el TJUE - esencialmente el test convencional de Estrasburgo-, la Directiva sobre el derecho a la RF en general se sitúa muy por encima de los estándares internacionales de protección; la Directiva en su conjunto aprueba - y con nota alta-, el test internacional. En palabras del TEDH:

"Al margen de estas disposiciones, el artículo 4, apartado 1, de la Directiva impone a los Estados miembros obligaciones positivas precisas, que se corresponden con derechos subjetivos claramente definidos, puesto que, en los supuestos determinados por la Directiva, les obligan a autorizar la reagrupación familiar de algunos miembros de la familia del reagrupante, sin que puedan ejercer su facultad discrecional" 881 .

Este apartado de la sentencia resulta de vital importancia. De un lado, viene a confirmar que la Directiva 2003/86 otorga a sus titulares un auténtico derecho subjetivo a la reunificación familiar, disipando con ello las dudas que habían originado tanto el cambio en la redacción del objetivo ${ }^{882}$ de esta norma comunitaria como las onerosas condiciones de ejercicio del derecho, que el tortuoso proceso de negociación había ido adicionando a la Directiva. Para extraer esta conclusión inequívoca en torno a la naturaleza del derecho, el TJUE se basa exclusivamente en el artículo 4.1 de la Directiva comunitaria.

Se trata además de un derecho subjetivo claramente formulado, esto es, del cual se derivan "obligaciones positivas precisas para los Estados" y "derechos subjetivos claramente definidos". Ello podría tener consecuencias prácticas de cara a la eficacia directa ${ }^{883}$ de esta disposición en aquellos Estados donde la Directiva no sea transpuesta a tiempo, o sea, incorrectamente transpuesta.

Y, finalmente, el TJUE contrasta directamente el estándar internacional con el estándar derivado de la Directiva comunitaria, especialmente el que trasluce la obligación impuesta en el artículo 4.1, queriendo con ello subrayar "el valor añadido de la Directiva"

En suma, tras más de una década de intentos fallidos, $-\mathrm{y}$ frente a la naturaleza puramente recomendatoria de los anteriores intentos de regular a nivel comunitario la reunificación familiar de nacionales procedentes de terceros países-, la Directiva consagra por primera vez un auténtico derecho subjetivo autónomo a la RF para aquellos extranjeros procedentes de terceros países que cumplan con los requisitos por ella establecidos. Sin embargo, el tipo de razonamiento empleado por el TJUE para juzgar la validez de este instrumento no recurre a parámetros autónomos ${ }^{885}$, esto

881 Apartado 60, STJUE, asunto C-540/03

882 Como señalamos en su momento, el objetivo de la Directiva 2003/86 pasó de ser el establecimiento de lo que calificaba expresa y abiertamente como "derecho" a la reunificación familiar a, mucho más modestamente, establecer condiciones para su ejercicio armonizado.

883 IGLESIAS SÁNCHEZ, Sara. "El valor de la Directiva 86/2003 sobre reagrupación familiar a la luz de los derechos fundamentales y de la sentencia del TJUE en el asunto 540/03"; en Revista de Derecho Comunitario Europeo, No 26, 2007, p. 147.

884 Idem.

885 De hecho el único momento en que el TJUE se apoya en su propia jurisprudencia tiene lugar con carácter previo a la aplicación del test internacional: en los apartados 52 y 53 de esta sentencia. En dichos apartados, el TJUE acude al 
es, a su propia jurisprudencia emitida en la materia con ocasión de aquellas familias integradas por extranjeros pero que cuentan con algún miembro comunitario. Con esta actitud el TJUE parece no querer otorgar un valor autónomo per se, a la Directiva ${ }^{886}$.

\section{b) El TJUE ante los derechos de los menores inmigrantes}

En la primera parte de esta sentencia el TJUE tuvo la valentía de romper barreras, mencionando de forma autónoma la Carta de DDFF de la UE y rastreando, entre los instrumentos constitutivos del sistema internacional de los derechos humanos, aquellos que ofrecían estándares más garantistas a la RF de los extranjeros. Sin embargo, no hizo gala del mismo arrojo a la hora de enfrentarse en la práctica con los derechos de los menores extranjeros a reunirse con sus progenitores legalmente instalados en algún EM.

Dos eran las disposiciones recurridas que afrontaban el tema del derecho a la vida familiar de los hijos menores de edad de los inmigrantes. De un lado, el último párrafo del apartado primero del artículo 4 de la Directiva ${ }^{887}$, donde se contemplaba la limitación que los EEMM podían establecer a los hijos mayores de 12 años del extranjero residente legal en su territorio, que llegasen de forma independiente del resto de su familia. En este supuesto, la Directiva permite aplicar un criterio potestativo de integración con carácter previo a la autorización de la entrada de dichos menores. De otro lado, el apartado sexto del mismo artículo 4, que permite a los EEMM exigir que las solicitudes relativas a la reagrupación de los hijos menores se presenten antes de que éstos hayan cumplido quince años de edad, estableciendo que, a partir de dicha edad, dichas solicitudes serán examinadas por los Estados que apliquen dicha excepción por "motivos distintos" de la reagrupación familiar.

Ambas disposiciones habían sido denunciadas por el PE invocando similares argumentos. Frente a ellas, el TJUE debía dilucidar si las limitaciones permitidas por ambos artículos en torno a los derechos de los menores inmigrantes autorizaban a los EEMM - expresa o tácitamente- a no tener en cuenta el derecho al respeto a la vida familiar, así como la obligación de considerar el interés mejor del menor y el principio de no discriminación por razón de la edad.

El razonamiento que desplegará el TJUE a fin de comprobar la compatibilidad con los derechos fundamentales de estas dos disposiciones, sigue una línea casi idéntica, de ahí que los analicemos

derecho al respeto de la vida familiar en el sentido del artículo $8 \mathrm{CEDH}$, a fin de afirmar su naturaleza fundamental, en tanto que soporte de la reunificación familiar. No obstante, incluso estas escasas incursiones del TJUE en su propia jurisprudencia, constituyen una recepción de la jurisprudencia del TEDH.

886 MARTIN, D. "Comments on N.v. Inspecteur van de Belastingdienst Osst/kantoor Almelo (Case C-470/04 of 7 September 2006), European Parliament v. Council (Case C-540/03 of 27 June 2006) and Tas-Hagen and Tas (Case C-192/05 of 26 October 2006"; en European Journal of Migration and Law, Vol. 9, No 1, 2007, pp. 148-149. Para este autor, "the choice made by the Court of Justice means that the legal value of a fundamental right of Community law, in other words of a grounding value of the European Union, is, to a quite large extent, left to the European Court which is not part of the Community legal order, and consequently the Court of Justice Could be obliged to review its meaning in the lights of an evolution of the jurisprudente of the European Court".

887 La formulación literal del último párrafo del apartado primero del artículo 4 de la Directiva 2003/86 establece que "excepcionalmente, cuando un hijo tenga más de 12 años y llegue independientemente del resto de su familia, el Estado miembro, antes de autorizar su entrada y su residencia de conformidad con la presente Directiva, podrá verificar si cumple algún criterio de integración previsto por su legislación existente en la fecha de la aplicación de la presente Directiva”. La justificación a esta derogación del régimen general previsto en la Directiva se contiene en el duodécimo considerando del preámbulo de ésta. Conforme a dicho considerando, "la posibilidad de limitar el derecho a la reagrupación familiar a los niños de edad superior a 12 años cuya residencia principal no es la misma que la del reagrupante, pretende reflejar la capacidad de integración de los niños en edad temprana, garantizando que adquieran en el colegio la educación y los conocimientos lingüísticos necesarios”. 
conjuntamente. De otro lado, se trata, a nuestro juicio, de la parte menos consistente de la sentencia, donde los esfuerzos argumentativos del Tribunal de Luxemburgo resultan insuficientes y poco fundamentados, como para lograr despejar de una vez las múltiples dudas de violación de los derechos fundamentales que habían arrojado ambas disposiciones.

En un esfuerzo de simplificación, la línea argumental desarrollada por el TJUE podría resumirse del siguiente modo. Tras haber identificado el estándar internacional aplicable a la reunificación familiar de los extranjeros, la cuestión central ahora residirá en comprobar si las restricciones impuestas al derecho a la RF por las disposiciones recurridas sobrepasan los límites fijados por el sistema internacional de los derechos humanos. Y es aquí donde emerge con toda su fuerza el concepto de margen de apreciación, cuyo alcance determina a su vez la intensidad de los límites al derecho a la reunificación familiar en el ámbito internacional.

La pregunta clave a la que ha de responder el Tribunal de Luxemburgo será pues la siguiente: ¿las limitaciones que contemplan las disposiciones impugnadas van más allá del margen de apreciación que cabe derivar de la jurisprudencia de Estrasburgo al aplicar e interpretar el derecho al respeto de la vida familiar del artículo $8 \mathrm{CEDH}$, en conjunción con los artículos relevantes de la Convención sobre los Derechos del Niño y de la Carta de DDFF de la UE?. Esta cuestión es abordada por el TJUE de forma sucesiva, comenzando por el artículo 4.1. in fine para después pasar al análisis del apartado sexto del mismo artículo 4.

\section{b.1) La limitación incluida en el artículo 4.1 in fine de la directiva}

El TJUE responde a la anterior pregunta de forma categórica. El artículo 4.1 in fine de la Directiva, lejos de superar el margen de apreciación existente en el sistema internacional de los derechos humanos - determinado por el case law de Estrasburgo-, lo mantiene de forma parcial ${ }^{888}$. La disposición recurrida otorga a los EEMM un margen de apreciación para ponderar las circunstancias concretas que concurren en las solicitudes de RF, similar al admitido por el TEDH.

"No puede considerarse que, con este tenor, el artículo 4, apartado 1, último párrafo, de la Directiva viole el derecho al respeto de la vida familiar. En el contexto de una Directiva que impone a los Estados miembros obligaciones positivas precisas, mantiene a favor de estos Estados un margen de apreciación limitado que no difiere del que les reconoce el Tribunal Europeo de Derechos Humanos en su jurisprudencia relativa a este derecho para ponderar, en las circunstancias de cada caso, los intereses en conflicto" ${ }^{\text {889. }}$.

Sin embargo, constatar que el margen de apreciación otorgado por el artículo 4.1. in fine no sobrepasaba el estándar internacional, solventaba sólo en parte la validez de esta disposición. En torno a la misma, el Parlamento Europeo había desplegado una abundante argumentación, señalando los múltiples incumplimientos de esta norma respecto a las exigencias impuestas por el CEDH y la jurisprudencia de Estrasburgo, que tendrá que ir desmontando el TJUE. Y, es precisamente en este punto, donde comienzan a aflorar las mayores debilidades en el razonamiento del TJUE.

888 Apartado 61, STJUE, asunto C-540/03. El tenor literal de este apartado, es el siguiente: "Por su parte, el artículo 4, apartado 1, último párrafo, de la Directiva tiene por efecto, en circunstancias definidas estrictamente, en concreto en el supuesto de que un hijo mayor de 12 años llegue independientemente del resto de su familia, mantener parcialmente el margen de apreciación de los Estados miembros permitiéndoles, antes de autorizar la entrada y la residencia del menor al amparo de la Directiva, examinar si cumple un criterio de integración previsto por las disposiciones nacionales vigentes en la fecha de aplicación de ésta”.

Apartado 62, STJUE, asunto C-540/03. 
Para hacer frente a la objeción que había planteado el Parlamento ${ }^{890}$ en torno a que el artículo 4.1 in fine de la Directiva no exigía ninguna ponderación de los respectivos intereses en conflicto y, por esta vía, conculcaba el artículo $8 \mathrm{CEDH}$ tal y como es interpretado por el TEDH, el TJUE acude a una interpretación sistemática del texto de la Directiva. Conforme a esta interpretación, la disposición recurrida, al ser aplicada por los EEMM, tiene que ser puesta en conexión con los artículos 5.5 y 17 de la Directiva ${ }^{891}$. El artículo 5.5 consagra el criterio del interés mejor del menor, que ha de ser tenido en cuenta preceptivamente ${ }^{892}$ por los Estados al examinar las solicitudes de RF. Por su parte, el artículo 17 obliga a los EEMM, - antes de emitir resoluciones denegatorias-, a tener en cuenta la naturaleza y la solidez de los vínculos familiares de la persona y la duración de su residencia en el EM, así como la existencia de lazos familiares, culturales o sociales con su país de origen.

En ambas disposiciones se observa la influencia del DIDH, pues constituyen artículos que vienen a codificar en el ámbito comunitario criterios extraídos literalmente de la Convención de los derechos del niño - artículo 5.5 de la Directiva一, y del case-law estrasburgués ${ }^{893}$ en la interpretación del artículo $8 \mathrm{CEDH}$-artículo 17 de la Directiva.

La lectura conjunta de estas disposiciones salvaría la legalidad del artículo 4.1 in fine, pues al verter los criterios establecidos por los artículos 5.5 y 17 de la Directiva, quedaría debidamente salvaguardada la preceptiva ponderación de los intereses en conflicto, exigida por la jurisprudencia del TEDH. Al recurrir al criterio interpretativo sistemático, el TJUE está siguiendo a su vez la argumentación ofrecida por el Consejo ${ }^{894}$ quien afirmaba que el artículo 4.1. in fine ni impedía ni prejuzgaba la ponderación de los diversos intereses en conflicto. En apoyo de este argumento sistemático, el TJUE acude nuevamente a la jurisprudencia de Estrasburgo, afirmando que "la edad de un menor y el hecho de que éste llegue independientemente de su familia también son elementos que tiene en cuenta el TEDH al tomar en consideración los vínculos del menor con los miembros de su familia en su país de origen, pero también los vínculos que tiene con el entorno cultural y lingüístico de este país' ${ }^{895}$.

Respecto al criterio de integración que el artículo 4.1. in fine permite aplicar a los menores antes de autorizar su entrada en el EM, el Parlamento había denunciado que su indefinición permitía restringir sensiblemente el derecho a la reagrupación familiar ${ }^{896}$. Esta institución señalaba asimismo que se trataba de una exigencia incongruente ${ }^{897}$ y desproporcionada ${ }^{898}$, porque el objetivo de la integración podría alcanzarse mediante medios menos radicales — tales como medidas impuestas al menor destinadas a facilitar su integración tras su entrada en el EM-.

890 Apartado 42, STJUE, asunto C-540/03.

891 Apartados 63 y 64, STJUE, asunto C-540/03.

892 La redacción imperativa del artículo 5.5 de la Directiva 2003/86 no ofrece dudas en torno al carácter preceptivo de la obligación que corresponde a los EEMM de velar por el interés mejor del menor.

893 El artículo 17 de la Directiva, tal y como afirma expresamente el TJUE, "contiene criterios que se corresponden con los que tiene en cuenta el TEDH al comprobar si un Estado que ha denegado una solicitud de reagrupación familiar ha ponderado correctamente los intereses en conflicto" (Apartado 64 de la sentencia).

894 El Consejo había desmontado la argumentación ofrecida por el Parlamento afirmando que la Directiva no prejuzgaba el resultado de la ponderación de los intereses individuales y colectivos en liza, recordando la obligación que pesaba sobre los EEMM de aplicar los criterios establecidos por los artículos 17 y 5.5 de la Directiva (Apartado 50, STJUE, asunto C-540/03).

895 Apartado 65, STJUE, asunto C-540/03. En él, el Tribunal de Luxemburgo se remite al apartado 69 de la sentencia Ahmut c. Países Bajos y al apartado 42 de la sentencia TEDH Gül c. Suiza.

896 Apartado 41, STJUE en el asunto C-540/03.

897 Idem, apartado 40.

898 Apartado 44, STJUE en el asunto C-540/03. 
Frente a la argumentación del Parlamento, el Tribunal de Luxemburgo afirma que el criterio de integración previsto por el último apartado del artículo 4.1 de la Directiva es plenamente compatible con el derecho al respeto de la vida familiar del artículo $8 \mathrm{CEDH}$. La argumentación ofrecida por el TJUE sigue una línea idéntica a la establecida anteriormente: negar que de la jurisprudencia de Estrasburgo pueda derivarse la obligación para los EEMM de permitir la reunificación familiar en su territorio; acudir al concepto de margen de apreciación, que esta disposición se limita a "mantener" conforme a los estándares internacionales; $y$, finalmente, recurrir de nuevo a la interpretación sistemática del texto de la directiva, aplicando los principios establecidos en los artículos 5.5 y 17 de la Directiva, como exigencia que los EEMM deben tener en cuenta al examinar si un menor cumple con un criterio de integración.

En refuerzo de esta tesis, el TJUE concluye su argumentación señalando vagamente que "la necesidad de integración puede estar amparada por varios de los fines legítimos contemplados en el apartado segundo del artículo $8 \mathrm{CEDH}^{\prime 399}$, pero sin especificar en ningún momento cuáles serían concretamente dichos fines dentro del amplio listado contemplado en dicha disposición. Desde nuestro punto de vista, el TJUE perdió aquí una oportunidad de sustentar con mayor profundidad y con un razonamiento técnicamente más correcto la compatibilidad de la Directiva con el CEDH. Se echa en falta una explicación más pausada ${ }^{900}$ en un punto que, en materia de respeto al CEDH, resultaba vital y que había sido señalado acertadamente por el Parlamento Europeo ${ }^{901}$.

El Parlamento ${ }^{902}$ también había alegado que el artículo 4.1 in fine constituía una discriminación basada exclusivamente en la edad y carente de justificación objetiva, por lo que incurría en una violación del principio de igualdad consagrado en el artículo $14 \mathrm{CEDH}$. En torno a esta cuestión, el TJUE sigue la argumentación ofrecida por el Consejo, considerando que la elección del umbral de los 12 años no es arbitraria, "puesto que corresponde a una fase de la vida del menor en la que éste ya

899 El apartado 66 de la sentencia en el asunto C-540/03.

900 Las insuficiencias argumentativas son habituales en esta parte de la sentencia. A modo de ejemplo, en contra de lo señalado por el Parlamento Europeo, el TJUE afirma que el legislador no confundió el criterio de integración del artículo 4 con el objetivo de integración — apartado 67-, pero sin explicar en ningún momento por qué y cuál es la diferencia conceptual entre ambos términos, por lo que tras la lectura de esta parte de la sentencia, no quedan despejadas las dudas suscitadas en su momento por el Parlamento. La argumentación también resulta escasa cuando el TJUE estima que la cláusula de stand still que figura al final del artículo 4.1 in fine es compatible con el derecho al respeto de la vida familiar, en contra de lo señalado por el PE. Esta institución denunciaba que la cláusula de stand still era menos estricta que las habituales, ya que únicamente exige que la ley nacional que incluya el criterio de integración, esté vigente en la fecha de aplicación de la Directiva, permitiendo con ello un lapso temporal elevado que contradecía el objetivo armonizador de esta norma comunitaria — apartado 45-. El TJUE afirma al respecto que el Parlamento no ha demostrado que dicha cláusula sea contraria a una norma jurídica de rango superior. Dado que el establecimiento de un criterio integrador es plenamente compatible con el derecho al respeto de la vida familiar, el Tribunal resta importancia al hecho de que la norma nacional pueda introducir el criterio de integración, tanto en la fecha de entrada en vigor, como en la fecha de aplicación de la directiva, respaldando así la opinión del Consejo, quien consideraba que ello constituía una opción política legítima del legislador comunitario. Aapartado 72, STJUE, asunto C-540/03.

901 Respecto a este punto, el Parlamento había alegado que "un criterio de integración previsto por una normativa nacional no forma parte de uno de los objetivos que puede justificar una injerencia como los contemplados en el artículo 8, apartado 2, del CEDH, en concreto, la seguridad nacional, la seguridad pública, el bienestar económico del país, la defensa del orden y la prevención del delito, la protección de la salud o de la moral, o la protección de los derechos y las libertades de los demás". (Apartado 42).

902 A juicio de esta institución, el objetivo de incitar a los padres a traer a sus hijos antes de que cumplan 12 años no tenía en cuenta los imperativos económicos y sociales que impiden a una familia acoger a un hijo durante un período más o menos largo. (Apartado 44). 
ha vivido durante un período relativamente largo en un país tercero sin los miembros de su familia, de manera que la integración en otro ambiente puede resultarle más difícip'903.

Las afirmaciones vertidas por el TJUE en torno al incremento de las dificultades adaptativas del menor a partir de los doce años de edad, constituyen un punto cuestionable por su escasa argumentación. El TJUE incurre en un razonamiento endeble y más instintivo que fundamentado, dando por válidas determinadas asunciones en torno a los supuestos mayores problemas para la integración de un niño inmigrante que haya cumplido los doce años de edad, sin ofrecer a cambio ningún argumento sustancial que lo apoye ${ }^{904}$. La fragilidad argumentativa del TJUE ha recibido duras críticas doctrinales ${ }^{905}$. Esta superficialidad resulta especialmente grave por aplicarse a los derechos de los menores sobre los que, en consonancia con el principio del efecto útil, el Tribunal de Luxemburgo debería haber elevado sus exigencias argumentativas a la hora de justificar limitaciones a sus derechos. Dado que en este asunto estaban en juego los derechos de los menores inmigrantes y su vulnerabilidad es doble - como menor y como inmigrante-, hubiese sido necesaria una elaboración mucho mayor por parte del TJUE.

Finalmente, el Parlamento había denunciado que la exigencia de un criterio de integración era contradictoria y discriminatoria, en vista de que la Directiva no exigía limitaciones similares basadas

903 Apartado 74 de la sentencia. Las supuestas mayores dificultades de integración que afrontará un menor inmigrante para adaptarse a un ambiente diverso al que ha desarrollado su vida a partir de los doce años de edad, constituye un argumento acogido también por el TJUE en el apartado 68 de la sentencia, cuando avaló la validez del criterio de integración incluido en el artículo 4.1. in fine de la directiva. En ese momento el TJUE insistió en la misma idea, afirmando que "así, el legislador comunitario consideró que, después de los 12 años de dad, el objetivo de integración no puede alcanzarse tan fácilmente y, consiguientemente, ha conferido al EM la facultad de tener en cuenta un nivel mínimo de capacidad de integración cuando decide autorizar la entrada y residencia con arreglo a la Directiva”.

904 En contra de la periodificación rígida de las edades que trasluce la argumentación del TJUE y la propia Directiva 2003/86, se manifiesta la Psicología Evolutiva, rama que subraya la importancia de las variaciones interindividuales que se producen en cada persona y la inexistencia un paralelismo absoluto entre la edad cronológica y la madurez biológica, especialmente a partir de la adolescencia. Según la psicología evolutiva, la maduración sigue una secuencia más o menos fija en la infancia, pero a medida que el niño crece y especialmente a partir de la pubertad, su desarrollo va siendo cada vez menos predecible, estando menos influido por la edad cronológica y más por las circunstancias históricas y culturales. En palabras de Jesús Palacios, "llega un momento en que lo fundamental de la maduración biológica ya ha sucedido, como sucede una vez que se completan todos los cambios de la pubertad, que transforman el cuerpo infantil en cuerpo adulto. A partir de ese momento la maduración impone muy poco al desarrollo psicológico. Esta es la razón por la que hasta la llegada de la pubertad en torno a una edad promedio de doce-trece años podemos asignar cada etapa del desarrollo a unos márgenes de edad concretos y reducidos, como ocurre en la primera década de la vida humana. A partir de ahí, como hemos visto que ocurría para la adolescencia, la adultez y la vejez, la adscripción a márgenes de edad muy concretos se hace más y más complicada, pues son factores diferentes a la maduración los que deben tenerse en cuenta, entre esos factores debe mencionarse en primer lugar la cultura a la que se pertenece". PALACIOS, Jesús. "Psicología evolutiva: conceptos, enfoques, controversias y métodos”; MARCHESI, Álvaro; COLL, César; PALACIOS, Jesús. Desarrollo psicológico y educación. Vol. I. Psicología evolutiva. Madrid, Alianza, 1990, p. 26.

905 Vid. entre otros, MARTIN, D. "Comments on N.v. Inspecteur van de Belastingdienst Osst/kantoor Almelo (Case C-470/04 of 7 September 2006), European Parliament v. Council (Case C-540/03 of 27 June 2006)...”, op. cit., pp. 146-147. DRYWOOD, Eleanor. "Giving with one hand, taking with the other...", op. cit., p. 406. Drywood señala además que las asunciones del TJUE no se corresponden con la realidad y las presiones que experimentan las familias migrantes, que en la práctica carecen del grado de libertad y elección como para periodificar el proceso migratorio de forma racional y decidir el momento idóneo para presentar la solicitud de RF, ni tampoco poseen el conocimiento del sistema legal del país receptor como para poder prever con anticipación los problemas jurídicos que puedan presentarse en tal proceso. Por ello, la autora señalada concluye subrayando que es falsa la asunción de la Corte en torno a los niños migrantes "thay they are the children of legally aware, economically empowered, choice (not forced) migrants". Idem. 
en un criterio de integración para el cónyuge del reagrupante ${ }^{906}$. Para desmontar esta alegación, el TJUE argumenta que el tratamiento diferenciado a los hijos respecto al cónyuge se justifica porque corresponde a dos situaciones distintas y no identificables. La argumentación señalada se despliega a través de una de las afirmaciones más controvertidas y criticadas ${ }^{907}$ de esta sentencia:

"Asimismo, el hecho de no tratar de la misma forma al cónyuge y al hijo mayor de 12 años no puede ser considerado una discriminación injustificada del hijo menor de edad. En efecto, el propio objetivo de un matrimonio es constituir una comunidad de vida duradera entre los cónyuges, mientras que un hijo mayor de 12 años no permanecerá necesariamente mucho tiempo con sus padres. Por tanto, puede estar justificado que el legislador comunitario tenga en cuenta estas situaciones diferentes y éste no se contradice cuando adopta normas diferentes para cada uno de ellos"908.

En este apartado el TJUE parece haber dado la espalda al principio de interpretación evolutiva que tanta influencia ha tenido en el ámbito de Estrasburgo, y cuya importancia para el derecho a la vida familiar es, si cabe, más acusada. El vínculo matrimonial puede ser disuelto civilmente -y de hecho lo es en proporciones crecientes-, mientras que el vínculo de consanguinidad es imperecedero. De hecho, la propia realidad sociológica imperante en muchos de los EEMM contradice abiertamente lo establecido por el Tribunal de Luxemburgo. Frente a la creciente inestabilidad que amenaza a las relaciones matrimoniales, la relación de los hijos con sus progenitores en los últimos tiempos es mucho más duradera, hasta el punto de que en algunos países los hijos adultos continúan viviendo con sus padres hasta edades cada vez más avanzadas ${ }^{909}$. España parece situarse, junto a Italia, a la cabeza de esta tendencia y la crisis económica mundial quizá la dinamice aún más.

Del conjunto de los argumentos ofrecidos, el TJUE concluye que el artículo 4, apartado 1, último párrafo de la Directiva, no viola el derecho fundamental al respeto de la vida familiar, ni la obligación de tener en cuenta el interés mejor del menor, ni el principio de no discriminación por razón

906 Apartado 43.

907 Las críticas han llovido en torno al pronunciamiento contenido en el párrafo transcrito. Así, se ha considerado que el argumento del TJUE resulta “absurdo, trasnochado y anacrónico”. VELÁZQUEZ SÁNCHEZ, Ma del Mar. “¿La regulación del derecho a la reagrupación familiar o defensa de una política restrictiva de la inmigración?. Comentario a la Sentencia del Tribunal de Justicia de las Comunidades Europeas de 27 de junio de 2006, C-540/2003"; en Revista General de Derecho Europeo. No 12, enero de 2007, s.p. Drywood señala que, con esta argumentación, "the Court is concerned with minimising the effect of migration on the population on the host state", además de subrayar su inadecuación a los cambios demográficos y sociales acaecidos en Europa. La autora concluye por ello que este enjuiciamiento ha tenido lugar en lo que considera un sistema jurídico que carece de infraestructura en torno a los derechos de los menores, evidenciando un "poorly engendered children's Rights model". DRYWOOD, Eleanor. "Giving with one hand, taking with the other...", op. cit., p. 406. Por su parte, MARTIN, ha subrayado que este apartado de la sentencia transluce un razonamiento "frágil y jurídicamente cuestionable", de modo que revela la actitud de la Corte de Luxemburgo de "no querer alcanzar una conclusión de incompatibilidad de una Directiva comunitaria con la Convención Europea”. MARTIN, D. “Comments on N.v. Inspecteur van de Belastingdienst Osst/kantoor Almelo (Case C-470/04 of 7 September 2006), European Parliament v. Council (Case C-540/03 of 27 June 2006) and Tas-Hagen and Tas (Case C-192/05 of 26 October 2006"; en European Journal of Migration and Law, Vol. 9, No 1, 2007, p. 147

908 Apartado 75, STJUE en el asunto C-540/03.

909 En el mismo sentido, VELÁZQUEZ SÁNCHEZ, Ma del Mar. “¿La regulación del derecho a la reagrupación familiar o defensa de una política restrictiva de la inmigración?...”, op. cit., sp. DRYWOOD, Eleanor. “Giving with one hand, taking with the other: fundamental rights, children and the family reunification decision”, op. cit., p. 406. Sobre este punto, la última autora subraya la "ironía” subyacente al punto de vista expuesto por la Corte de Luxemburgo, especialmente si se contrastan las estadísticas de divorcios a lo largo de Europa con las edades cada vez más elevadas en que los hijos adultos siguen conviviendo con sus padres. 
de la edad "ni como tal ni en la medida en que autoriza expresa o tácitamente a los Estados miembros a actuar de esa forma"

\section{b2) La limitación incluida en el apartado $6^{\circ}$ del artículo 4 de la directiva}

El Parlamento ${ }^{911}$ sostenía que esta disposición — al permitir a los EEMM exigir que las solicitudes de reagrupación de los hijos menores se presenten antes de que éstos cumplan los 15 años de edad-, constituía una violación el derecho al respeto de la vida familiar y de la prohibición de discriminación por razón de la edad. Los motivos invocados eran muy similares a los alegados en torno al artículo 4.1 in fine de la Directiva. Señalaba esta institución que el artículo 4.6, al establecer que los Estados Miembros que decidan aplicar esta excepción deben autorizar la entrada y residencia de dichos hijos por "motivos distintos" de la reagrupación familiar — sin definir en ningún momento tales motivos-, concedía un margen discrecional muy amplio a las autoridades internas, siendo fuente de incertidumbre jurídica. Asimismo, el Parlamento alegaba que el objetivo de integración se podía alcanzar mediante la aplicación de medidas menos radicales que una discriminación arbitraria por razón de la edad ${ }^{912}$.

El análisis de esta disposición es ventilado de forma más expeditiva por el Tribunal de Luxemburgo, pues para ello se apoya en parte de los argumentos ofrecidos para determinar la compatibilidad del artículo 4.1 in fine con los derechos fundamentales. De forma que la escasez argumentativa que denunciamos en el epígrafe anterior se reproduce, si cabe, con mayor crudeza en esta parte de la sentencia, especialmente cuando resuelve en torno a la ausencia de discriminación por razón de la edad y en torno a la validez de la cláusula de stand still que figura al final del articulo 4.6 - puntos en los que se limita a recurrir a los párrafos precedentes de la sentencia, donde esta cuestión fue ya resuelta respecto a la primera disposición recurrida ${ }^{913}$.

El TJUE no encuentra en el artículo 4.6 de la Directiva ningún atentado al derecho al respeto de la vida familiar del artículo $8 \mathrm{CEDH}$, tal y como es interpretado por el TEDH. Dicha disposición permite a los EEMM reservar la aplicación de los requisitos generales de la reagrupación familiar - establecidos en el artículo 4.1 de la Directiva-, a las solicitudes presentadas antes de que los hijos alcancen los 15 años de edad. Pero ello no puede interpretarse en el sentido de que prohíba a los EEMM tener en cuenta una solicitud relativa a un hijo mayor de 15 años o les autorice a no hacer-

910 Apartado 76, STJUE en el asunto C-540/03.

911 Apartados 77 y 78, STJUE en el asunto C-540/03.

912 En contra de la argumentación desplegada por el Parlamento Europeo, se manifestaron el Consejo y la Comisión. El Consejo por su parte, consideraba que el objetivo que se pretendía con esta disposición — facilitar la integración de los menores, incitando a las familias inmigrantes a hacer venir a sus hijos a la edad más temprana posibleconstituía una finalidad legítima de la política de integración, amparada por el artículo 8.2 CEDH. La fórmula "motivos distintos", precisamente por su amplitud, tiene como fin favorecer una decisión positiva en la mayor parte de las solicitudes. Añadía que la edad de 15 años se escogió para englobar el mayor número de casos, pero sin impedir la escolarización del menor en el EM de acogida, rechazando de esta forma el argumento de la discriminación arbitraria. La Comisión consideraba que el artículo 4.6 era plenamente compatible con el artículo 8 CEDH, ya que preservaba los derechos que dicho Convenio reconoce. En apoyo de dicha compatibilidad, la Comisión aducía un argumento que, a nuestro juicio, puede resultar especialmente peligroso. Señalaba la Comisión que el límite de 15 años era razonable y obedecía "al nexo existente entre el artículo 4.6 de la Directiva y el período de espera de tres años que figura en el artículo 8 de la misma directiva. Se trata, en efecto, de no expedir permisos de residencia a personas que, entre tanto hayan alcanzado la mayoría de edad" (apartado 83). Este último argumento fundamenta una restricción a un derecho autoproclamado fundamental por el TJUE sobre la base de demoras administrativas.

913 En el apartado 89 de esta sentencia, el TJUE resuelve sobre estos dos extremos acudiendo directamente a los motivos expuestos previamente en los apartados 74 y 72, cuando el TJUE dictaminó sobre la ausencia de discriminación y la validez de la cláusula de stand still contenida al final del artículo 4.1 in fine de la Directiva. 
$10^{914}$. Para el Tribunal carece de relevancia que la última frase de la disposición impugnada establezca que los EEMM que decidan hacer uso de esta excepción, deben autorizar la entrada de los hijos cuya solicitud se presente después de que éstos hayan cumplido 15 años "por motivos distintos de la reagrupación familiar". El Tribunal clarifica de forma un tanto críptica el sentido de esta expresión afirmando que "en efecto, en el contexto de la Directiva la expresión «reagrupación familiar» debe interpretarse en el sentido de que se refiere a la reagrupación familiar en los supuestos en que la Directiva obliga a permitirla. No puede ser interpretada en el sentido de que prohíbe a un Estado miembro que ha aplicado la excepción a autorizar la entrada y la residencia de un hijo para permitirle reunirse con sus padres"

Para reforzar la compatibilidad de la disposición recurrida con los derechos fundamentales, el Tribunal de Luxemburgo recurre nuevamente a la interpretación sistemática de la Directiva:

"El artículo 4, apartado 6 de la Directiva debe interpretarse a la luz de los principios que figuran en los artículos 5, apartado 5, de la misma Directiva, que obliga a los EEMM a tener debidamente en cuenta el interés mejor del menor, y 17 de dicha Directiva, que les obliga a tener en cuenta un conjunto de elementos, entre los que figuran los vínculos familiares de la persona" 916.

La interpretación sistemática permite al Tribunal de Luxemburgo concluir que el EM que aplique la excepción establecida en el apartado 6 del artículo 4 "sigue obligado a examinar la solicitud en interés del menor y procurando favorecer la vida familiar" "117, de modo que esta disposición es plenamente respetuosa con el derecho al respeto de la vida familiar, la obligación de tener en cuenta el interés mejor del menor y el principio de no discriminación por razón de la edad.

En definitiva, la posición del TJUE ante los derechos de los menores inmigrantes trasluce, para la mayoría de la doctrina, cierta "falta de habilidad“" ${ }^{\text {“18 }}$ en este ámbito. La Corte de Luxemburgo parece no sentirse cómoda al afrontar esta delicada temática, decantándose por un razonamiento débil y en la mayoría de las ocasiones expeditivamente argumentado ${ }^{919}$. Esta forma de proceder resulta especialmente censurable si tenemos en cuenta que afecta a un sector doblemente vulnerable - menores de edad extranjeros y, por ello, encajables en la categoría ya analizada de "minorías insulares"-, y más teniendo en mente que recae sobre un derecho autocalificado como fundamental por la propia Corte de Luxemburgo ${ }^{920}$. Aplicando las consideraciones expuestas en el primer capítulo del presente trabajo, habría sido de esperar un escrutinio muy riguroso $\mathrm{y}$, consecuentemente, una argumentación especialmente robusta por parte de la Corte de Luxemburgo a la hora de descartar una posible violación sobre derechos fundamentales de este colectivo.

914 Apartado 85, STJUE en el asunto C-540/03.

915 Apartado 86, STJUE en el asunto C-540/03.

916 Apartado 87, STJUE, asunto C-540/03.

917 Apartado 88, STJUE, asunto C-540/03.

918 DRYWOOD, Eleanor. "Giving with one hand, taking with the other: fundamental Rights, children and the family reunification decision", op. cit., p. 405. La autora prosigue afirmando "indeed, aspects of the decision in Parliament v. Council reveal a lack of expertise in addressing children".

919 En el mismo sentido, MARTIN, D. quien ha subrayado la limitada aproximación que el TJUE tiene en la resolución de este caso, calificándola expresamente como un enfoque minimalista, y afirmando que "the level of scrutiny exercised by the Court is a very low one if it is kept in mind that it relates to a derogation to what the Court calls a fundamental right”. Posteriormente el autor considera que la brevedad del razonamiento empleado por la Corte de Luxemburgo resulta "bastante insatisfactoria"; en "Coments on N.v. Inspecteur van de Belastingdienst Oost/ kantoor Alemo (Case C-470/04 of 7 September 2006), European Parliament v. Council (Case C-540/03 of 27 June If 2006)..., op. cit., p. 149.

920 Idem. 


\section{c) La validez de la imposición de prolongados períodos de espera}

La última de las disposiciones recurridas por el Parlamento era el artículo octavo ${ }^{921}$ de la Directiva. Este precepto otorga a los EEMM la posibilidad de exigir un período previo de residencia legal de dos años al reagrupante antes poder reunir con él a los miembros de su familia. Con carácter excepcional, dicho período previo puede llegar a tres años como máximo - a contar entre la solicitud y la expedición del permiso de residencia a los familiares-, si la legislación existente en un EM en la fecha de adopción de la Directiva tuviera en cuenta su capacidad de acogida.

Como ya señalamos, esta disposición obedece a negociaciones de última hora, de modo que, sobre la misma, el PE no tuvo oportunidad de pronunciarse antes de la aprobación de la Directiva 2003/86/CE. Sin embargo, este órgano no había denunciado este vicio procesal sobre el que, paradójicamente, la Abogada General se había pronunciado extensamente, llegando a proponer la inadmisión del recurso como consecuencia de la omisión de este trámite preceptivo del procedimiento legislativo.

Sobre la limitación al derecho, constituida por los períodos de dos y tres años previstos en el artículo 8, el Parlamento Europeo ${ }^{922}$ había señalado que no obligaba a un examen individualizado de las solicitudes, autorizando con ello a los EEMM a mantener medidas desproporcionadas que no guardaban el justo equilibrio entre los intereses en conflicto, al tiempo que permitía diferencias de trato entre los EEMM. Señalaba además que el criterio basado en la capacidad de acogida del EM equivalía a un régimen de cuotas incompatible con el artículo $8 \mathrm{CEDH}$. Sobre esta última cuestión, el Consejo ${ }^{923}$ contra argumentaba afirmando que la capacidad de acogida simplemente servía para identificar los EEMM que podían alargar a tres años el período de espera, sin equivaler en absoluto a un régimen de cuotas. Y, en torno a los tratamientos divergentes entre EEMM permitidos por el artículo 8 de la Directiva, el Consejo estimaba que se trataba de la consecuencia natural del proceso de aproximación progresiva de las legislaciones emprendido por la Directiva, señalando además que el carácter estricto de la cláusula de stand still contenida en el artículo 8, permitía "una aproximación considerable de las legislaciones de los EEMM“924.

La Comisión ${ }^{925}$, por su parte, estimaba que el período de espera del artículo 8 constituía una mera norma de procedimiento administrativo, que no excluía el derecho a la reagrupación y se unía al Consejo al considerar que esta norma perseguía un fin legítimo, a saber, la integración eficaz de los miembros de la familia en la sociedad de acogida.

El razonamiento del TJUE revela nuevamente la centralidad del concepto del margen de apreciación en el escrutinio de la validez de las disposiciones controvertidas de la Directiva, contrarrestadas con el art. 8 CEDH. A juicio de la Corte de Luxemburgo, esta disposición no menoscaba el derecho al respeto de la vida familiar del artículo $8 \mathrm{CEDH}$, tal y como lo interpreta el TEDH, puesto que "no impide toda reagrupación familiar, sino que mantiene a favor de los EEMM un margen de

921 La formulación literal del artículo 8 de la Directiva sobre el derecho a RF establece que "los EEMM podrán requerir que el reagrupante haya residido legalmente en su territorio durante un período de tiempo, que no podrá superar dos años, antes de reagrupar los miembros de su familia con él. Excepcionalmente, cuando en materia de reagrupación familiar la legislación existente en un EM tenga en cuenta su capacidad de acogida, este EM podrá establecer un período de espera de tres años como máximo entre la presentación de la solicitud de reagrupación familiar y la expedición de un permiso de residencia a los miembros de la familia”.

922 Apartados 91 y 92, STJUE, asunto C-540/03.

923 Apartados 93-95, STJUE, asunto C-540/03.

924 Apartado 94, STJUE, asunto C-540/03.

925 Apartado 96, STJUE, asunto C-540/03. 
apreciación limitado al permitirles cerciorarse de que la reagrupación familiar se producirá en buenas condiciones, después de que el reagrupante haya residido en el Estado de acogida durante un período suficientemente prolongado para presumir una instalación estable y cierto grado de integración ${ }^{2026}$.

En refuerzo de su argumentación, el Tribunal acude al artículo 17 de la Directiva, de donde deduce que tanto la duración de la residencia en el EM como el criterio de acogida, constituyen tan sólo uno de los elementos que el Estado receptor ha de tener en cuenta al examinar una solicitud de reagrupación familiar. De tal suerte que, a modo de conclusión, - en claro recordatorio de la exigencia del examen individualizado de las solicitudes derivada de la jurisprudencia de Estrasburgo-, el Tribunal afirma que el EM "no puede imponer un período de espera sin tener en cuenta, en casos específicos, el conjunto de los elementos pertinentes" "927, ni tampoco puede interpretarse el criterio de acogida "en el sentido de que autoriza cualquier sistema de cuotas o un plazo de espera de tres años impuesto sin tomar en consideración las circunstancias particulares de cada caso" ${ }^{228}$.

Afrontando las alegaciones del Parlamento en torno a que la existencia de variados plazos de espera - dos o tres años-, provocaría tratamientos diferenciados entre los EEMM, el TJUE aporta una interesante argumentación de la cual se desprende un saludable pragmatismo. Considera el Tribunal que la coexistencia de situaciones diferentes "es sólo la expresión de la dificultad de proceder a una aproximación de las legislaciones en un ámbito que, hasta ese momento, era competencia exclusiva de los EEM"929. Para finalizar afirmando que:

"En el presente asunto, el legislador comunitario no se ha excedido de los límites impuestos por los derechos fundamentales al permitir a los EEMM que tenían o deseaban adoptar una legislación específica, modular ciertos aspectos del derecho de reagrupación" ${ }^{\prime 930}$.

En definitiva, el Tribunal se rinde a la evidencia de que, ante una materia que hasta hace poco tiempo era coto privado de la soberanía nacional, no es prudente que la UE adopte pasos abruptos, siendo preferible la confluencia lenta pero progresiva de las legislaciones nacionales, en virtud de los ajustes que a esta Directiva se hagan en el futuro. De hecho, el carácter progresivo de la armonización fue una de las bases que permitió desbloquear el proceso de negociación. El Tribunal de Justicia viene así a confirmar que la armonización completa no sólo no sería posible, sino incluso contraproducente, pues habría podido provocar recelos e incumplimientos en los EEMM. De ahí la necesidad de que la Directiva respetase los procesos internos, permitiendo a los legisladores nacionales cierta modulación en la regulación de algunos aspectos del derecho a la reagrupación familiar, aun al precio de mantener o incluso provocar ciertas disparidades entre las políticas internas de reunificación familiar en la UE. En otras palabras, el mantenimiento del status quo - que, como vimos, constituía una característica definidora de la Directiva 2003/86, dando lugar a elevados márgenes de apreciación nacional-, es además una característica necesaria e incluso inevitable como consecuencia de la dificultades inherentes al objetivo armonizador perseguido por esta norma, - dificultades que aconsejaban la moderación comunitaria en la regulación de un marco jurídico de la inmigración familiar sobre bases comunes-.

El TJUE cierra su argumentación recordando a los EEMM que las exigencias derivadas de la protección de los principios generales reconocidos en el ordenamiento comunitario, les vinculan

926 Apartado 98, STJUE, asunto C-540/03

927 Apartado 99, STJUE, asunto C-540/03.

928 Apartado 100, STJUE, asunto C-540/03.

929 Apartado 102, STJUE, asunto C-540/03.

930 Idem. 
también cuando aplican la normativa de la UE ${ }^{931}$. De modo que los EEMM están obligados a transponer y aplicar las normas de la Directiva sobre el derecho a la RF de forma compatible con los derechos fundamentales. Sin embargo, este recordatorio se realiza de una forma quizá excesivamente optimista ${ }^{932}$ y recurriendo a un concepto algo contradictorio, pues el TJUE afirma literalmente que el margen de apreciación que la Directiva otorga a los EEMM "es lo suficientemente amplio para permitirles aplicar las normas de la Directiva en un sentido acorde con las exigencias derivadas de la protección de los derechos fundamentales"933.

Y, quizás de forma profética o puramente anticipatoria, la Corte de Luxemburgo finaliza su pronunciamiento señalando que "la aplicación de la Directiva está sometida al control de los órganos jurisdiccionales" - tal y como establece el art. 18 de dicha norma-, de modo que, "si tienen dudas sobre la interpretación o la validez de esta Directiva, incumbe a estos órganos jurisdiccionales plantear al Tribunal de Justicia una cuestión prejudicial' ${ }^{\prime 2}$.

\section{d) La supuesta naturaleza jurídica fundamental del derecho al respeto de la vida familiar y la inadecuación del nivel de escrutinio efectuado por el TJUE}

Existe un elemento adicional de la sentencia que conviene rescatar en este momento, porque nos servirá para valorar la adecuación del nivel de escrutinio efectuado por el TJUE en torno a las disposiciones recurridas de la Directiva 2003/86. El TJUE había arrancado el razonamiento en torno a la validez de la primera de las disposiciones impugnadas aclarando la naturaleza jurídica del respeto a la vida familiar, en tanto que derecho que sirve de matriz a la reunificación familiar de los extranjeros. Esta afirmación la realizó con carácter previo a la aplicación del test internacional. Se trata, de otro lado, de una de las escasísimas ocasiones en las que el Tribunal de Luxemburgo se refiere a su propia jurisprudencia a lo largo de esta sentencia. Su pronunciamiento no deja lugar a dudas en torno a la naturaleza jurídica de derecho que sirve de soporte jurídico o matriz a la reunificación familiar de los extranjeros:

"Con carácter preliminar procede recordar que el derecho al respeto de la vida familiar en el sentido del artículo 8 del CEDH forma parte de los derechos fundamentales que, según jurisprudencia reiterada del Tribunal de Justicia, están protegidos en el ordenamiento jurídico comunitario (sentencias antes citadas Carpenter, apartado 41, y Akrich, apartados 58 y 59). Este derecho a vivir con sus parientes próximos implica obligaciones de los Estados miembros, que pueden ser negativas, por ejemplo cuando se les obliga a no expulsar a una persona, o positivas, cuando se les obliga a autorizar a una persona a entrar y residir en su territorio" $935 "$.

931 Apartado 105.

932 Cortés Martín incide en la misma idea, afirmando que el TJUE afronta su análisis de las restricciones "realizando una lectura bastante positiva y optimista y haciendo alarde de un alto grado de confianza en la capacidad de los legisladores y administraciones nacionales responsables de su transposición y aplicación cotidiana para establecer en casos concretos un adecuado equilibrio entre intereses colectivos e individuales". CORTES MARTÍN, José Manuel. “TJUE-Sentencia de 27.06.2006, Parlamento...", op. cit. p. 228.

933 Apartado 104, STJUE, asunto C-540/03. Constante ha sido la tendencia del TJUE a lo largo de esta sentencia de recortar por vía interpretativa el alcance de esta noción para situarlo al nivel marcado por el estándar internacional - en reiterados apartados, el tribunal insistía en que la Directiva simplemente se limitaba a "mantener" el margen de apreciación existente en el sistema internacional de los derechos humanos-. Sin embargo, en este apartado nos topamos con una argumentación en sentido contrario, donde expresamente se anuncia la amplitud del margen de apreciación concedido a los EEMM por parte de la Directiva 2003/86/CE.

934 Apartado 106, STJUE en el asunto C-540/03.

935 Apartado 52. 
Tres cuestiones, que resultan centrales para nuestro trabajo, constituyen los puntos más sobresalientes de este pronunciamiento inicial. En primer lugar, la Corte de Luxemburgo proclama explícita y categóricamente el carácter fundamental del derecho al respeto de la vida familiar en el sentido del artículo $8 \mathrm{CEDH}$; en segundo lugar, el TJUE recurre a su propia jurisprudencia relativa a la reunificación familiar, pero en su aplicación a aquellas familias mixtas que están integradas por algún ciudadano comunitario - la cual, como ya señalamos se ha caracterizado por su carácter expansivo y generoso-, y, por último, la jurisprudencia anterior y propia que invoca el TJUE constituye a su vez una recepción de la jurisprudencia de Estrasburgo, reconociendo las dos ramas migratorias — negativa y positiva-, derivadas de la protección de la vida familiar de los extranjeros, esto es, la protección frente a expulsiones y la admisión de familiares.

En torno a la primera cuestión, la naturaleza jurídica fundamental que el TJUE atribuye al derecho al respeto de la vida familiar en el sentido del artículo $8 \mathrm{CEDH}$, conviene que nos detengamos brevemente, por la importancia que tiene para nuestro objeto de estudio ${ }^{936}$. Con esta breve pero contundente proclamación, el TJUE parece ir más allá del marco del Consejo de Europa, en donde el derecho a la vida familiar ocupa una posición intermedia entre los derechos considerados absolutos y aquellos derechos limitables, posición que no da pie para afirmar tan categóricamente su naturaleza fundamental.

La cuestión central para descubrir su auténtica naturaleza jurídica residiría, a nuestro juicio, en determinar si el supuesto carácter fundamental que el Tribunal de Justicia otorga el derecho a la vida familiar del artículo $8 \mathrm{CEDH}$, es compatible con el amplio e indeterminado listado de las limitaciones legítimas que amparan y justifican las injerencias en el contenido del mismo -limitaciones establecidas en el artículo 8.2 CEDH y que, con distinto tenor y un carácter más concreto aparecen diseminadas a lo largo de la Directiva- con la notable excepción del bienestar económico del país, ausente en la Directiva comunitaria.

La afirmación del TJUE en torno a la naturaleza jurídica del derecho a la vida familiar resulta técnicamente cuestionable, habida cuenta no sólo de las múltiples limitaciones que atenazan al derecho, sino fundamentalmente del elevado margen de apreciación estatal existente y de las limitaciones que constriñen al sujeto activo. Si una de las características de los derechos fundamentales es su titularidad activa universal — proclamable de todas las personas con independencia de su nacionalidad-, esta situación dista mucho de la predicable del derecho a la RF en su aplicación a extranjeros no comunitarios en la UE. De ahí que la doctrina haya denunciado un uso "bizantino"937 del término derecho fundamental por parte del TJUE. Las implicaciones migratorias que la interpretación del TEDH ha dotado a la vida familiar - y que el TJUE también asume-, no hacen sino incrementar las dificultades a la hora de poder calificar como fundamental el derecho que sirve de base a la reunificación familiar, especialmente a la luz de las limitaciones establecidas sobre los menores extranjeros y consideradas legítimas por la Corte de Luxemburgo.

$\mathrm{Si}$, pese a cuestionar su procedencia, adoptamos el mismo punto de vista del TJUE y asumimos la naturaleza fundamental de la vida familiar, resulta aún más difícilmente justificable la escasez argumentativa de la que adolece el fallo. Es más, la aproximación metodológica adoptada por el TJUE al analizar los límites al derecho a la RF fijados por la Directiva comunitaria, desmiente la autoproclamada solemnemente como naturaleza fundamental del derecho a la vida familiar. Si se

936 Conviene señalar que el TJUE califica como fundamental el derecho al respeto de la vida familiar, no a la reunificación familiar en sí misma - al menos en lo que respecta a su titularidad por los ciudadanos extracomunitarios-.

937 LAWSON, Rick. “Court of Justice of the European Communities: Family Reunification Directive...”, op. cit., p. 339. 
tratase de un derecho fundamental, los límites al mismo deberían ser objeto de una interpretación restrictiva como consecuencia del principio interpretativo del efecto útil. Además, dado que afecta a un colectivo especialmente vulnerable, las exigencias de fundamentación se elevarían exponencialmente. Ello supondría reforzar el escrutinio judicial en torno la validez de las restricciones establecidas por la Directiva. Sin embargo, de la lectura de la sentencia se desprende un nivel más bien bajo de escrutinio, y así ha sido destacado por la doctrina, denunciando lo que se considera un enfoque minimalista ${ }^{938}$.

\section{3 Valoración de la Sentencia del TJUE en el asunto C-540/03}

\section{a) La interpretación conforme del TJUE}

A nuestro juicio, la clave para comprender el sentido de este pronunciamiento reside en el esfuerzo que realiza el Tribunal de Luxemburgo para interpretar las limitaciones impugnadas a la $\mathrm{RF}$ en sentido conforme ${ }^{939}$ con los derechos fundamentales del ordenamiento comunitario. Es una postura realista y conservadora, que evita los problemas de vacío jurídico que hubiera provocado la anulación parcial de la Directiva ${ }^{940}$. Es más, dicha anulación "no habría beneficiado a nadie" ${ }^{\text {" }} \mathrm{y}$ habría reabierto otro doloroso vía crucis ${ }^{942}$ en busca del consenso necesario para adoptar un texto de reemplazo - con escasas garantías de que del mismo saliera un instrumento más robustecido desde el punto de vista de los derechos humanos-. En contrapartida, el TJUE mira hacia otro lado ante disposiciones de la Directiva que constituyen cierta degradación del derecho a la vida familiar, cuya naturaleza jurídica el propio tribunal califica de fundamental.

En su esfuerzo por preservar la validez de las disposiciones impugnadas, el TJUE recurre al test internacional y a una interpretación sistemática de la Directiva, de modo que incorpora los criterios sentados en los artículos 5 y 17 de dicha disposición, confirma su naturaleza transversal, y los vierte como exigencias concretas que los EEMM han de tener en cuenta al aplicar en sus ordenamientos internos las disposiciones controvertidas de la Directiva. La importancia del test internacional es tal, que son precisamente estas dos disposiciones contenidas en la Directiva - y que constituyen una recepción explícita del DIDH—, las que permiten salvar la compatibilidad de esta norma comunitaria con los estándares internacionales de los derechos humanos ${ }^{943}$.

938 MARTIN, D. "Comments on N.v. Inspecteur van de Belastingdienst Osst/kantoor Almelo (Case C-470/04 of 7 September 2006), European Parliament v. Council (Case C-540/03 of 27 June 2006) and Tas-Hagen and Tas (Case C-192/05 of 26 October 2006)", op. cit., p. 149.

939 En el mismo sentido, PISAPIA, Alice. "Una sentenza additiva in punto di attuazione della direttiva sul ricongiungimento familiare”; Giustizia Civile, 2007, vol. I, p. 544. CORTES MARTÍN, José Manuel. “TJUE-Sentencia de 2706.2006, Parlamento..., op. cit., p. 230.

940 En una línea similar, CORTÉS MARTÍN afirma que "el TJUE parece mostrarse comprensivo frente a las dificultades de encontrar un nuevo consenso ante una eventual anulación de la Directiva, salvando así un texto...”; en “TJUE-Sentencia de 27 de junio de 2006, Parlamento...”, op. cit p. 234. También LAWSON destaca el esfuerzo y la actitud pragmática de la Corte de Luxemburgo para evitar la anulación de la Directiva. "Court of Justice of the European Communities: Family Reunification Directive..., op. cit., p. 342.

941 LAWSON. “Court of Justice of the European Communities: Family Reunification Directive...”, op. cit., p. 342.

942 El calificativo corresponde a ALVAREZ RODRÍGUEZ, Aurelia. Algunas reflexiones urgentes relativas a la reagrupación familiar en el ordenamiento comunitario..., op. cit., p. 4.

943 IGLESIAS SÁNCHEZ, Sara. "El valor de la Directiva 2003/86/CE sobre Reagrupación Familiar a la luz de los Derechos Fundamentales y de la Sentencia del TJUE en el Asunto 540/03...”, op. cit., p. 148. 
En tres elementos radica pues la clave para la comprensión de la decisión emitida por el Tribunal de Luxemburgo: interpretación conforme, interpretación sistemática y test internacional. La habilidad del TJUE reside en recurrir reiteradamente a estos tres elementos, enfocando su argumentación en los criterios establecidos por los artículos 5.5 y 17 de la Directiva, que actúan como puntos de anclaje de su razonamiento. Esta operación permite al TJUE salvar la alegada invalidez de las disposiciones controvertidas, que pueden ser interpretadas en sentido conforme a las exigencias emanadas del sistema internacional de los derechos humanos.

El juego combinado y recurrente de estos tres elementos, permite al Tribunal de Luxemburgo sentar la exigencia de que los criterios contenidos en los artículos 5.5 y 7 -que exigen ambos la individualización en el examen de las solicitudes-, sean aplicados también en los supuestos excepcionales permitidos por las disposiciones recurridas de la Directiva. De modo que de la sentencia se extrae la obligación de que, incluso aquellos EEMM que opten por aplicar el régimen potestativo permitido por las disposiciones recurridas, deben dejar a salvo la posibilidad de conceder el derecho a la reagrupación familiar también en tales supuestos, si bien de forma excepcional ${ }^{944}$. La cuestión dependerá de lo que se deduzca del examen individualizado de la solicitud de RF tras la aplicación de los criterios previstos conjuntamente en los artículos 5.5 y 17 de la Directiva, penetrando así de forma expresa un criterio que, como señalamos, constituye doctrina asentada de Estrasburgo desde los primeros pronunciamientos emitidos en materia de RF.

En definitiva, incluso ante solicitudes planteadas por hijos del residente legal que hayan cumplido más de doce años y lleguen de forma independiente del resto de su familia, o presentadas ante las administraciones internas con posterioridad a que los hijos del residente hayan cumplido quince años o antes de que el reagrupante lleve residiendo legalmente dos o tres años en el EM, los EEMM que decidan aplicar dichas restricciones deben permitir la reunificación y resolver en sentido positivo dichas solicitudes si, — tras la aplicación y análisis individualizado del interés superior del menor y de los criterios procedentes del TEDH incluidos en el 17 de la Directiva-, se deduce que el justo equilibrio entre los intereses en conflicto exige autorizar la entrada y residencia de los familiares afectados.

Esta forma de razonar del TJUE transfiere la cuestión central sobre la que pivotava este asunto - el respeto a los derechos fundamentales-, al momento de transposición y aplicación nacional de la Directiva ${ }^{945}$, donde los EEMM siguen obligados al examen caso por caso de las solicitudes, incluso en los supuestos que decidan aplicar las limitaciones potestativas previstas por las tres disposiciones comunitarias recurridas. Lo que significa que, de la aplicación estatal de tales normas, no cabe deducir sin más una denegación del derecho a la reunificación familiar. También supone que, cuando los EEMM transpongan y apliquen en sus legislaciones internas las disposiciones de la Directiva 2003/86, habrán de tener en cuenta —incluyendo también en los sistemas administrativos establecidos para la tramitación de los procesos relativos a migraciones familiares - la jurisprudencia del TJUE emitida en este pronunciamiento.

944 CORTES MARTÍN, José Manuel. “TJUE- Sentencia de 27.06.2006, Parlamento...., op. cit., p. 229.

945 Cortes Martín considera que esta actitud del TJUE, —al transferir el control de la conformidad con los derechos fundamentales al nivel nacional, recordando a los EEMM que están obligados a respetar las exigencias de los derechos fundamentales en cada caso particular-, refleja un "realismo prudente". En contrapartida, plantea problemas de seguridad jurídica "porque los Estados no podrán limitarse a transponer y aplicar lo previsto en la Directiva, sino que deberán seguir teniendo en consideración lo previsto en la jurisprudencia del TEDH cuando apliquen las cláusulas restrictivas de este derecho. Sin embargo, las disposiciones impugnadas no contienen ninguna referencia a esta obligación". Idem, pp. 230-231. 
Con esta operación, el TJUE ha terminado reduciendo por vía interpretativa el peso del margen de apreciación en el examen de las solicitudes de reagrupación familiar ${ }^{946}$. El alcance del margen de apreciación estatal, tras esta decisión de la Corte de Luxemburgo, no será el que resulte de la Directiva sin más, sino el derivado de la conjunción entre las disposiciones de la Directiva 2003/86 y la interpretación reductora efectuada por el TJUE. Y de dicha suma, el resultado es un margen de apreciación inferior al derivado de la Directiva 2003/86/CE considerada aisladamente. En esta sentencia el TJUE termina aminorando la elevada discrecionalidad estatal que las presiones estatales, en conjunción con el requisito de la unanimidad, habían terminado vertiendo en la regulación comunitaria de la reagrupación familiar. Con ello, el Tribunal de Luxemburgo clarifica ${ }^{947}$ las obligaciones atinentes a los EEMM al implementar y aplicar la Directiva en sus ordenamientos internos, pero al precio de emitir una sentencia interpretativa ${ }^{948} \mathrm{o}$ aditiva poco al uso, ya que en ningún momento a lo largo de este pronunciamiento se hace explícito este carácter, ni tampoco el tribunal ofrece una lectura condicionada de la validez de las disposiciones recurridas, como es habitual en este tipo de sentencias ${ }^{949}$. La actitud del TJUE en esta sentencia tiene un coste a efectos de la eficacia jurídica del derecho a la reunificación familiar, pero simultáneamente acarrea la ganancia de preservar la validez de la Directiva comunitaria que le sirve de soporte.

En este pronunciamiento el TJUE ha adoptado una postura próxima a la del legislador comunitario - legislador positivo-, riesgo del que había sido advertido por el propio PE y por la Abogada General al inicio de la argumentación, cuando se ventilaba la admisibilidad del propio recurso de anulación y ambos expresaban sus temores en torno a la posible invasión de las competencias del legislador comunitario por parte del TJUE. Afirmó en ese momento el Parlamento que "una interpretación a priori de la Directiva por parte del Tribunal de Justicia como la que sugiere la Comisión supondría aplicar un remedio preventivo que invadiría las competencias del legislador comunitario' ${ }^{250}$. El Parlamento apuntaba así el peligro de las sentencias interpretativas o aditivas ante la argumentación desplegada por la Comisión de que "el Tribunal de Justicia sólo debe anular las disposiciones, como las que son objeto del recurso si no puede interpretarlas de manera conforme con los derechos fundamentales. Si la disposición controvertida permite un margen de apreciación, habida cuenta de las reglas habituales de interpretación, el Tribunal de Justicia debe precisar su sentido de manera que respete los derechos fundamentales" ${ }^{\prime 951}$.

El TJUE finalmente realizaría un tipo de interpretación conforme, como la que la Comisión había propuesto al inicio del recurso, a fin de salvar la legitimidad y la eficacia de la Directiva 2003/86/ CE. Sin embargo, conviene recordar que dos de las tres disposiciones recurridas afectaban los derechos de un colectivo especialmente vulnerable y, por ello, digno de mayor protección —los menores

946 En el mismo sentido, PISAPIA, Alice. "Una sentenza additiva in punto di attuazione della direttiva sul ricongiungimento familiare", op. cit., p. 543.

947 Idem.

948 PISAPIA, Alice. "Una sentenza additiva in punto di attuazione della Direttiva sul ricongiungimento familiare"; en Giustizia civile, 2007, vol. I, pp. 543-546. En este artículo se propone una interpretación poco usual de la sentencia del TJUE en el asunto C-540/03, quizá como consecuencia de que la doctrina italiana se halla más habituada a las sentencias interpretativas, lo que facilita su identificación en aquellos casos que no son claros, como lo es la sentencia del TJUE. La autora insiste en que el TJUE efectúa una "interpretación adeguatrice" a fin de minimizar el impacto de los efectos de este tipo de sentencias sobre el sistema comunitario.

949 Sobre el tema Vid. MARTÍN DE LA VEGA, Augusto. La sentencia constitucional en Italia: tipología y efectos de las sentencias en la jurisdicción constitucional italiana, medio siglo de debate doctrinal. Madrid, Centro de Estudios Políticos y Constitucionales, 2003.

950 STJUE, asunto C-540/03, apartado 20.

951 Idem, apartado 19. 
inmigrantes de terceros países-. Por esta circunstancia, del análisis efectuado por el Tribunal de Luxemburgo cabía haber esperado una aplicación más rigurosa del principio interpretativo del efecto útil, una interpretación restrictiva ${ }^{952}$ de las limitaciones previstas por la Directiva y, consiguientemente, un nivel muy alto de escrutinio, que la sentencia no ofrece - a mayor abundamiento, el TJUE califica la vida familiar como un derecho fundamental-.

La impresión que deja la lectura sosegada de esta sentencia es que el TJUE ha acomodado algo forzadamente la Directiva 2003/86 en el marco del respeto a los derechos fundamentales, priorizando la seguridad jurídica con respecto al mantenimiento de elevados estándares de protección de la RF a nivel comunitario ${ }^{953}$. Sin embargo, el Tribunal parece jugar al despiste, pues su actitud inicial en esta sentencia daba pie a pensar todo lo contrario. La identificación de los parámetros internacionales de validez de la Directiva con la que inició su examen del fondo del asunto había arrancado con el propósito de localizar las fuentes internacionales más garantistas, portadoras del estándar más prominente ${ }^{954}$. Con esta actitud el TJUE parecía situar el listón muy alto, generando expectativas en torno al elevado nivel de exigencia que el Tribunal habría de requerir de la Directiva y de las obligaciones derivadas de los EEMM en el ámbito de la reunificación familiar. Es sabido que unas expectativas excesivamente elevadas son fácilmente frustrables, y más cuando, en contrapartida, el Tribunal ofrece una endeble argumentación para conformarse con un estándar bajo de protección ${ }^{955}$.

952 La interpretación restrictiva no solamente venía exigida por constituir las disposiciones recurridas limitaciones a un derecho - efecto útil—, sino también por la propia Directiva, que antecede dichas restricciones con la expresión "excepcionalmente", circunstancia que impele a una interpretación de carácter restrictivo de las mismas. El TJUE no parece haberse ajustado a esta exigencia, al menos la escasez argumentativa de ciertas partes del fallo nos conducen a dicha conclusión. En el mismo sentido, ALVAREZ RODRÍGUEZ, A. Algunas reflexiones urgentes relativas a la reagrupación familiar en el derecho comunitario..., op. cit., p. 12.

953 Una visión más positiva de la sentencia del TJUE en este asunto la ofrecen Baldaccini y Toner, para quienes “it is heartening to see the Court of Justice developing (on the whole) relatively generous jurisrpudence in relation to fundamental rights connected with family reunification, drawing increasingly on the ECHR concept of respect for family and private life". BALDACCINI, A; TONER, H. (eds.). "From Amsterdam and Tampere to the Hague...", op. cit., p. 21. También LAWSON aporta un enfoque muy alentador sobre esta sentencia, estimando que el escrutinio del TJUE ha optado por una "elegante vía del medio", indicando además que este pronunciamiento está llamado a abrir caminos y calificando explícitamente a este pronunciamiento como "un buen juicio", especialmente por el empujón que da a la Carta de derechos fundamentales de la UE, así como por otorgar flexibilidad a los EEMM para regular la RF, al tiempo que les presiona para actuar en consonancia con los estándares internacionales. "Court of Justice of the European Communities: Family Reunification Directive...”, op. cit., pp. 341 y 342.. Por su parte, Iglesias Sánchez ofrece un enfoque más neutral en torno a la decisión del TJUE, incidiendo en los aspectos positivos de la Directiva que está en la base de enjuiciamiento, concretamente en el otorgamiento de un derecho subjetivo por primera vez asícomo un grado notable de armonización, que se traducen en una mayor cohesión del Espacio Europeo de Libertad, Seguridad y Justicia. IGLESIAS SÁNCHEZ, Sara. “El valor de la Directiva 2003/86...”, op. cit., pp. 145-151, espc. pp. 149 y 150.

954 Al inicio de la sentencia, el TJUE parece situar el listón muy alto, al menos lo más elevado que es posible en el ámbito internacional, como se deduce de la afirmación que el Tribunal realiza en el apartado 39 de la sentencia, con ocasión de la búsqueda de las fuentes internacionales con las que contrastar la validez de la directiva. En dicho apartado el TJUE afirmó que "aparte de la Carta Social Europea, los demás tratados internacionales alegados por el Parlamento no contienen disposiciones más protectoras que los convenios mencionados”.

955 Para SCHUTTER, la cuestión de principio más importante a la que debía responder el TJUE en este pronunciamiento consistía en derminar si la directiva podía ser en sí misma considerada responsable de infringir los derechos fundamentales reconocidos en el ordenamiento comunitario por no imponer a los EEMM el cumplimiento de obligaciones de más amplio espectro en el área del derecho a la reunificación familiar. Es obvio que la respuesta a la cuestión es negativa. Report on the Situation of Fundamental Rights in the EU in 2003,... op. cit, p. 54. 
Cabría pues afirmar que la Corte de Luxemburgo ha hecho gala del mismo pragmatismo ${ }^{956}$ que impulsó a la Comisión a sacar adelante la Directiva sobre el derecho a la reunificación familiar, aún a costa de mantener en mínimos los niveles de protección que ésta ofrece. En cualquier caso, la demanda que dio inicio a este recurso - y que había despertado grandes expectativas entre la doctrina y organizaciones no gubernamentales de defensa de los migrantes-, quizá sea justo reconocer que estaba destinada al fracaso ${ }^{957}$.

Dado que en esta sentencia es constante el recurso del Tribunal de Luxemburgo a la jurisprudencia del TEDH, quizá sea pertinente aplicar a su razonamiento uno de los criterios más asentados en el ámbito de Estrasburgo: el test del justo equilibrio de los intereses en conflicto. Como resultado de esta operación, se observa en el TJUE cierto escoramiento en favor del interés estatal, rasgo por otro lado idéntico al que subyace a la propia Directiva objeto de enjuiciamiento. Ante la embestida conservadora de los EEMM y sus temores ante el fenómeno de la inmigración familiar, la Corte de Justicia de las CCEE ha privilegiado el interés restrictivo nacional, en una materia especialmente delicada como son los derechos de los niños inmigrantes. Esta situación contrasta profundamente con la protagonizada en los últimos tiempos por el TEDH en el ámbito de la reunificación familiar ${ }^{958}$.

Pero el contraste resulta mucho más evidente si el punto de referencia se sitúa en la propia jurisprudencia del TJUE relativa a la reunificación familiar, pero emitida con respecto a aquellas familias mixtas que cuentan con algún miembro que sea ciudadano comunitario. Para ellas el Tribunal de Luxemburgo ha desarrollado una generosa y progresista línea jurisprudencial que ha ido extendiendo sucesivamente el círculo de derechos de los miembros de la familia. Es aún mayor si se tiene en cuenta cómo el TJUE ha interpretado las normas contenidas en los Acuerdos de Asociación con Turquía, esto es, con ciudadanos también extracomunitarios y sin que en dicho acuerdo existiera base jurídica para la reunificación, que, sin embargo, fue extendida a los ciudadanos turcos gracias a la construcción jurisprudencial del TJUE. El tratamiento más beneficioso a los ciudadanos comunitarios se ampara en la naturaleza fundamental de la libertad circulatoria que le sirve de soporte. Sin embargo, las diferencias de tratamiento entre no comunitarios no resultan tan fácilmente justificables. El TJUE muestra en este pronunciamiento una postura de excesiva autocontención judicial.

Con todo, a pesar a su prudencia y contención, la intervención del TJUE se ha revelado mucho más protectora que la propia Directiva 2003/86, y ello sin necesidad de anular las disposiciones más controvertidas de esta norma. Ha sido capaz de limitar por vía interpretativa el alto margen de apreciación estatal otorgado por esta norma comunitaria — si bien bajo la argumentación de que dicho margen era idéntico al establecido por los estándares internacionales de derechos humanos, señaladamente el artículo $8 \mathrm{CEDH}$. Con ello el Tribunal de Luxemburgo está contribuyendo al logro del objetivo armonizador perseguido por la Directiva sobre el derecho a la RF, pues la reducción

956 LAWSON, Rick. "Family Reunification and the Union's Charter of Fundamental Rights, Judgment of 27 June 2006, Case C-540/03", op. cit., p. 342.

957 MARTIN, D. “Comments on N. v. Inspecteur van de Belastingdienst....", op. cit., p. 152.

958 En medio de un contexto conservador, el TEDH dió un viraje radical a su jurisprudencia en materia de RF en tanto que derecho derivado de la vida familiar consagrada en el artículo $8 \mathrm{CEDH}$, potenciando la eficacia útil de esta disposición. Sin embargo, este viraje protagonizado por Estrasburgo en materia de reunificación familiar no sólo ha pasado desapercibido para la mayor parte de la doctrina, sino también para el propio TJUE pues aunque contiene citas jurisprudenciales actualizadas - la sentencia se refiere a Rodrígues da Silva, emitida por el TEDH el mismo año en que el Tribunal de Luxemburgo dictó esta sentencia-, se sigue apoyando fundamentalmente en la doctrina de Sen, sin valorar en su justa medida la apertura que ha efectuado el Tribunal de Estrasburgo en su más reciente jurisprudencia. 
del margen de apreciación provoca una disminución correlativa en el nivel de divergencias en los criterios y condiciones de ejercicio del derecho a la reagrupación familiar en su aplicación por los EEMM.

En suma, las aportaciones jurisprudenciales que contiene este asunto han de incorporarse al arsenal que prefigura el diseño jurídico de la RF de los nacionales extracomunitarios en la UE. De esta forma, el escenario en el que se desenvuelve la migración familiar está compuesto, junto con la Directiva 2003/86, por la interpretación efectuada por el Tribunal de Luxemburgo ${ }^{959}$. Las disposiciones de la Directiva han de ser aplicadas por los EEMM a la luz de la doctrina emitida por el TJUE en esta sentencia, especialmente en lo que respecta a la aplicación transversal de los criterios de origen iusinternacionalista contenidos en los artículos 5 y 17 de dicha norma.

\section{b) Riesgos asociados al uso del test internacional, con predominio del test convencional de Estrasburgo}

Como señalamos, el núcleo de esta sentencia reside en el control efectuado por el TJUE en torno al respeto de los derechos fundamentales por parte de la Directiva sobre el derecho a la RF. El escrutinio desplegado sobre esta norma comunitaria se efectúa contrastando ésta con los parámetros protectores del derecho a la vida familiar en el ámbito internacional, con una preponderancia casi absoluta del Convenio Europeo de Derechos Humanos, tal y como es interpretado por el TEDH. De hecho, a lo largo de todo este pronunciamiento, es detectable en la Corte de Luxemburgo un "esfuerzo visible por alinear su posición con el case-law del TEDH"960. El empleo del test internacional tiene lugar pese a que la Corte de Luxemburgo indica claramente que el derecho a la RF constituye un derecho fundamental del sistema comunitario - recurriendo a su propia jurisprudencia sobre la materia, si bien en su aplicación a las familias mixtas, integradas por algún ciudadano comunitario-. Cabría pues cuestionarse porqué el TJUE no optó por un parámetro autónomo de validez - como el principio general de protección a la reunificación familiar, tal y como rige en el Derecho Comunitario-.

El tipo de enjuiciamiento desplegado por el TJUE refuerza la importancia de los estándares internacionales como topes mínimos a los que se deben ajustar los derechos comunitarios para ser válidos. A pesar de que el TJUE afirma la plena compatibilidad de la Directiva con dichos estándares, a nuestro juicio esta operación de encaje se ha hecho a costa de cierta reducción de los estándares internacionales por vía interpretativa, concretamente del estándar convencional de Estrasburgo, que ha sido interpretado a la baja ${ }^{961}$ por el Tribunal de Luxemburgo, ofreciendo una visión parcial que no se ajusta a la última línea jurisprudencial progresista desarrollada por el TEDH en materia de RF.

La doctrina ha señalado que el tipo de enjuiciamiento desarrollado por el Tribunal de Luxemburgo en esta sentencia - dada la naturaleza del recurso de anulación, se trata de un enjuiciamiento abstracto de la Directiva, cuya legalidad, además, es evaluada por referencia a estándares internacionales, fundamentalmente al CEDH y a la jurisprudencia emanada del TEDH en su aplicación-

959 En el mismo sentido, PASCOUAU, Yves; LABAYLE, Henry. Conditions for Family Reunification under Strain..., op. cit., p. 8.

960 LAWSON, Rick. "Family Reunification and the Union's Charter of Fundamental Rights, Judgement of 27 June 2006, Case C-540/03", op. cit., p. 342.

961 En el mismo sentido incide Cortés Martín, quien considera que "el juez comunitario adopta una interpretación más bien estrecha de la jurisprudencia del TEDH, sin que podamos asegurar que esta última jurisdicción seguirá al TJUE cuando lleve a cabo un examen in concreto de la aplicación a nivel nacional de esas restricciones". CORTÉS MARTÍN, J. M. “TJUE—Sentencia de 20.06.2006, Parlamento..., op. cit., p. 233. 
sitúa a este órgano jurisdiccional en una posición extraña, inusual y algo embarazosa ${ }^{962}$, llegando a asumir el rol de intérprete auténtico del Convenio Europeo de Derechos Humanos ${ }^{963}$.

El uso del test convencional de Estrasburgo por parte del TJUE ${ }^{964}$ no deja de presentar riesgos, provocados fundamentalmente por el carácter altamente evolutivo de la jurisprudencia emanada del TEDH, especialmente en una materia tan dinámica como la migración familiar:

a) De un lado, existe el riesgo de que la rápida evolución jurisprudencial producida en esta materia pase inadvertida por el TJUE, quien podría por ello recurrir a parámetros convencionales ya rebasados por Estrasburgo. Ya señalamos que en el ámbito de la RF de los extranjeros —en tanto que obligación convencional positiva derivada del derecho al respeto de la vida familiar-, el TEDH ha protagonizado un marcado viraje jurisprudencial hacia una interpretación más generosa y protectora del derecho a la reagrupación. Sin embargo, el punto de partida en esta materia fue una jurisprudencia fuertemente restrictiva, con predominio del criterio elsewhere que, como denunciamos, llegaba a suponer el vaciamiento del contenido del derecho en la práctica. Como consecuencia de la relativa novedad de este giro jurisprudencial y de la ambigüedad que impregna en esta rama jurisprudencial —en la que el Tribunal de Estrasburgo no ha hecho nunca explícito dicho viraje ${ }^{965}$-, resulta difícil encontrar referencias doctrinales que estudien el mismo. En el mismo sentido, el TJUE en el asunto C-540/03 - pese a utilizar referencias actualizadas a la jurisprudencia de Estrasburgo-, sigue, sin embargo, anclada en los parámetros restrictivos de la primera línea jurisprudencial del TEDH en torno a la migración familiar.

El riesgo apuntado, a nuestro juicio, se ha materializado en la sentencia emitida a fin de resolver la demanda de anulación parcial contra la Directiva sobre reunificación familiar. De hecho, es posible encontrar referencias doctrinales que consideran que el tono restrictivo de esta sentencia del TJUE es consecuencia del empeño de este Tribunal en apoyarse en la jurisprudencia de Estrasburgo $^{966}$, de modo que el test convencional usado por Luxemburgo habría venido a reproducir la "poco amigable" 967 jurisprudencia estrasburguesa relativa los derechos de la infancia -aseveración cierta, pero sólo en lo que respecta a la primera línea jurisprudencial del TEDH sobre RF de los extranjeros-.

962 MARTIN, D. "Comments on N.v. Inspecteur van de Belastingdienst Osst/kantoor Almelo (Case C-470/04 of 7 September 2006), European Parliament v. Council (Case C-540/03 of 27 June 2006) and Tas-Hagen and Tas (Case C-192/05 of 26 October 2006", op. cit., p. 144.

963 Ídem, p. 145.

964 En torno a este tema, Martin subraya que el Tribunal de Primera Instancia de las CCEE había señalado en su momento que la validez de los actos de las instituciones comunitarias no puede examinarse por referencia al CEDH (Caso T-112/98, Mannesmannrörhen-Werk AG (2001) ECR II-729, 59), puesto que la Comunidad como tal no es parte en dicho Convenio. En parte, ésta fue la argumentación a la que recurrió el Consejo, que en sus alegaciones había argumentado que la Convención de 1950 no es parte del derecho comunitario porque la comunidad como tal no se ha adherido a dicha convención. El TJUE se desmarca de esta opinión y recurre repetidamente a la jurisprudencia de Estrasburgo a lo largo de esta sentencia. MARTIN, D. "Comments on N.v. Inspecteur van de Belastingdienst Osst/ kantoor Almelo (Case C-470/04 of 7 September 2006), European Parliament v. Council (Case C-540/03 of 27 June 2006) and Tas-Hagen and Tas (Case C-192/05 of 26 October 2006", op. cit., p. 145, y nota a pie de p. n 9 de dicha página. En torno a la alta frecuencia con que el TJUE recurre a la jurisprudencia de Estrasburgo, vid también LAWSON, Rick. "Family Reunification and the Union`s Charter of Fundamental Rights, Judgment...”, op. cit., p. 342.

965 Muy al contrario, el TEDH se ha amparado habitualmente en sentencias suyas previas de carácter altamente restrictivo, para dar paso de forma bastante ambigua a una jurisprudencia mucho más protectora de la reunificación familiar.

966 DRYWOOD, Eleanor. "Giving with one hand, taking with the other: Fundamental Rights, children and the Family Reunification Decision"; en European Law Review, № 3, 2007, p. 404.

967 McGLYNN, C. Families and the European Union: Law, Politics and Pluralism. Cambridge University Press, 2006, p. 76. 
Nuestra explicación se aleja de esta interpretación. Consideramos que la última línea jurisprudencial del TEDH en materia de reunificación familiar se revela más garantista que la interpretación efectuada por el TJUE en el asunto C-540. De modo que el problema de fondo, a nuestro juicio, residiría más bien en que el Tribunal de Luxemburgo en la sentencia objeto de análisis no ha dado debida cuenta de la reciente evolución jurisprudencial acaecida en el ámbito del Consejo de Europa respecto a los derechos de los menores inmigrantes a reunirse con sus padres - donde, como vimos, se está ofreciendo cobertura protectora incluso a ciertas situaciones de irregularidad administrativa de progenitores inmigrantes cuyos hijos, nacionales del Estado parte, actúan como reagrupantes ${ }^{968}$.

El TJUE en esta sentencia ha aplicado los criterios empleados por la primitiva línea jurisprudencial conservadora del Tribunal de Estrasburgo en torno a la RF, lo cual le sirve para poder amparar las derogaciones de la Directiva, concluyendo su compatibilidad con el CEDH y los restantes parámetros internacionales utilizados para juzgar su validez. Buena muestra de ello la constituye la insistencia del TJUE en apoyarse en la sentencia Sen, de la cual extrae los principios aplicables en materia de RF en el ámbito del Consejo de Europa. En el mismo vicio incurren también los demandantes, quienes en su argumentación en torno este tema, continúan aplicando la vieja línea jurisprudencial del TEDH. Resulta paradigmático de ello el apartado 46 de la sentencia comentada, donde el Consejo, apoyado por el Gobierno alemán y la Comisión, afirma que "el derecho al respeto de la vida familiar no equivale, por sí solo, a un derecho a la reagrupación familiar. Según la jurisprudencia del Tribunal Europeo de Derechos Humanos, es suficiente, por ejemplo, que la vida familiar sea posible en el Estado de origen". Se observa aquí un uso exclusivo del criterio elsewhere, cuyo predominio era casi absoluto en la jurisprudencia inicial del TEDH, pero que ha sido suavizado y parcialmente superado por la aplicación de otros criterios.

b) De otro lado, cabría la posibilidad de una interpretación futura del propio TEDH que desautorizara y se desmarcara del razonamiento desplegado por el TJUE en el asunto C-540/03 apelando a la jurisprudencia de Estrasburgo. En este supuesto hipotético, se trataría de un enjuiciamiento muy alejado al abstracto desplegado por el TJUE en la sentencia que evalúa la Directiva sobre el derecho a la RF. El Tribunal de Estrasburgo actuaría a partir de una demanda planteada por un ciudadano extracomunitario que se encuentre bajo la jurisdicción de un Estado Parte simultáneamente miembro de la UE-, en la cual se alegase la violación del derecho al respeto de la vida familiar del articulo $8 \mathrm{CEDH}$, como consecuencia de la denegación de las autoridades internas de dicho Estado a una solicitud de reunificación familiar.

Se trataría de un litigio suscitado a raíz de la aplicación práctica de la Directiva 2003/86 en el ámbito nacional ${ }^{969}$, en donde la denegación del derecho a la RF impulsase al extranjero afectado - tras el agotamiento de los recursos internos-, a entablar un procedimiento ante el TEDH por

968 El TJUE, en en un reciente pronunciamiento, ha cambiado el rumbo, otorgando también protección a situaciones similares a las descritas, esto es, a padres extranjeros con hijos que ostentan la nacionalidad del EM en el cual residen con sus progenitores, aún cuando los menores nunca hayan ejercido el derecho a la libre circulación. Se trata del caso Gerardo Ruiz Zambrano c. Office National de l'emploil, Asunto C-34/09, sentencia TJUE de 8 de marzo de 20011, cuya novedosa doctrina posee implicaciones de largo alcance en torno al concepto y al estatuto de la ciudadanía de la Unión.

969 LAWSON, Rick. “Court of Justice of the European Communities: Family Reunification Directive...”, op. cit., p. 341. Si bien el autor puntualiza, tomando como referencia los comentarios a esta sentencia realizados por un autor alemán (Mork, M. Nederlandse Jurisprudentie, Netherlands Court Reports, 2006, p. 4596), que en el supuesto de que el escenario apuntado llegara a materializarse en la práctica, "the chances are small that the Strasbourg Court will actually find a violation". 
violación del artículo $8 \mathrm{CEDH}$. De llegarse a producir esta última hipótesis, que no resulta descabellada, la intervención del TEDH estaría destinada a dilucidar si un acto concreto aplicativo de esta Directiva comunitaria es o no contrario al derecho a la vida familiar del artículo 8 CEDH. Esta intervención a posteriori del TEDH, convertiría al TJUE en una especie de Tribunal de Primera Instancia en materia de derechos humanos ${ }^{970}$. En el momento de cerrar estas páginas, la hipótesis apuntada no ha llegado a producirse todavía, lo cual no descarta su futura materialización en vista de la alta litigiosidad vinculada a la extranjería y la inmigración.

c) Otro riesgo - a nuestro juicio más improbable-, consistiría en que, dada la evolución jurisprudencial del Tribunal de Estrasburgo, el Tribunal de Luxemburgo se viera obligado a revisar el pronunciamiento emitido al enjuiciar la Directiva sobre el derecho a la $\mathrm{RF}^{971}$.

Todas las opciones y riesgos apuntados quedan abiertos, en vista de que el fallo del TJUE en este asunto no constituye la última palabra, como el propio Tribunal de Luxemburgo se encargó de recordar al final de la sentencia, apelando a la tutela judicial consagrada por el artículo 18 de la Directiva. De hecho, la actitud de autocontención desplegada por el TJUE en este pronunciamiento ha terminado escorando a este tribunal en una posición más próxima a los intereses nacionales de los EEMM de controlar la inmigración, que al interés individual de proteger el derecho a la reunificación familiar, situándolo en una postura muy parecida a la finalmente adoptada por la Directiva 2003/86/CE. En síntesis, la aplicación del estricto escrutinio que dedujimos en nuestro primer capítulo como exigencia jurisprudencial — derivada de la vulnerabilidad y exclusión política que afecta al colectivo de los extranjeros, en tanto que minoría insular-, sale mal parado en el asunto C-540/03.

La autocontención del TJUE ha provocado un aplazamiento ${ }^{972}$ de la cuestión central promovida por el recurso de anulación ${ }^{973}$ — esto es, del control de la compatibilidad de la Directiva con los pa-

970 MARTIN, D. "Comments on N.v. Inspecteur van de Belastingdienst Osst/kantoor Almelo (Case C-470/04 of 7 September 2006), European Parliament v. Council (Case C-540/03 of 27 June 2006) and Tas-Hagen and Tas (Case C-192/05 of 26 October 2006", op. cit., pp. 144-146, especialmente p. 146.

971 Idem, p. 146.

972 CEBADA ROMERO, Alicia. La Directiva de la Comunidad Europea sobre Reagrupación Familiar: La Sentencia del TJUE en el asunto C-540/03..., op. cit., p. 541. En palabras de la autora, pese a que el Parlamento Europeo había reclamado "una coherencia clara y sólida entre el sistema de reunificación y las obligaciones en materia de derechos humanos. Los argumentos del PE no han sido recogidos por el TJUE y pensamos que el resultado es decepcionante, a primera vista. No obstante, y a pesar de ello, conservamos un moderado optimismo porque consideramos que esta sentencia abre las puertas a una ulterior supervisión de la compatibilidad entre las medidas nacionales implementadoras y los parámetros de protección internacionales. En esa fase encontraremos probablemente una más encendida defensa de los derechos fundamentales. En nuestra opinión, se podría decir que el TJUE ha retrasado el momento en que tendrá que establecer más claramente cuáles son las limitaciones que se imponen al legislador y que derivan de la necesidad de respetar los derechos fundamentales en este ámbito". La misma idea de aplazamiento, referida tanto a la transferencia del control de la conformidad con los derechos nacionales al nivel nacional, como al planteamiento posterior de la cuestión prejudicial "como red de seguridad para pronunciarse a posteriori sobre los desarrollos normativos que se produzcan en la transposición de la Directiva y su aplicación a casos concretos”, se encuentra en CORTÉS MARTÍN, J. M. “TJUE —-Sentencia de 27.06.2006, Parlamento Europeo/Consejo, C-540/03. ¿Restricciones al reagrupamiento familiar de nacionales de terceros países versus respeto de los derechos fundamentales?", op. cit., p. 231.

973 El propio Tribunal de Luxemburgo asume este aplazamiento, pues su sentencia finaliza con dos ideas básicas e íntimamente entrelazadas: De un lado, el TJUE enfatiza la obligación que atañe a los EEMM de respetar los derechos fundamentales durante el proceso de transposición y aplicación de la Directiva en sus respectivos ordenamientos internos y, de otro, recuerda la garantía legal contenida en el artículo 18 de la Directiva sobre RF y la posibilidad de aquellas jurisdicciones que alberguen dudas en torno a la validez de sus disposiciones, de plantear ante él una cuestión prejudicial. Apartados 105 y 106 de la sentencia en el asunto C-540/03. 
rámetros internacionales de protección del derecho a la reunificación familiar. El propio Tribunal de Luxemburgo es consciente de ello, y parece apuntarlo en este pronunciamiento ${ }^{974}$, al recordar que la Directiva sobre RF está sometida al control jurisdiccional interno de los EEMM y la procedencia de futuras cuestiones prejudiciales en el supuesto de que surjan dudas sobre su aplicación o en torno a la validez de esta norma comunitaria.

La cuestión ha quedado pues remitida a un plano más concreto, donde los tribunales nacionales tendrán que ventilar la compatibilidad con los derechos fundamentales de las medidas nacionales implementadas a fin de transponer la Directiva sobre RF o de aplicación práctica de la misma. En caso de que los tribunales nacionales alberguen dudas sobre el tema, quedaría abierta la vía del planteamiento de una cuestión prejudicial ante el TJUE, el cual tendrá nuevamente la oportunidad de revisar el tema, aportando una luz más clarificadora - y quizá un escrutinio más riguroso y protector que el realizado con ocasión del recurso promovido por el PE contra la Directiva sobre el derecho a la reunificación familiar ${ }^{975}$ -

De hecho, la posibilidad apuntada ya ha tenido ocasión de producirse a raíz de un recurso presentado por el Consejo de Estado de los Países Bajos ante el Tribunal de Luxemburgo, cuyo objeto residía en una petición de decisión prejudicial en torno a la interpretación de dos disposiciones de la Directiva 2003/86/CE sobre RF. Esta cuestión prejudicial se presentó en el marco de un litigio principal suscitado entre la Sra. Chakroun - ciudadana marroquí que pretendía entrar en los Países Bajos a fin de residir con su marido, también marroquí, el cual contaba con residencia permanente en Holanda- y el Ministro de Asuntos Exteriores, en relación con la negativa a conceder un permiso provisional de residencia a la recurrente en el litigio principal. Dicho recurso fue resuelto por la Sala segunda del TJUE mediante sentencia de 4 marzo $2010^{976}$, a cuyo estudio consagraremos el siguiente apartado de nuestro trabajo.

974 Así se deduce de lo establecido en el apartado 106 de la sentencia en el asunto C-540/03, donde el TJUE recuerda que "la aplicación de la Directiva está sometida al control de los órganos jurisdiccionales puesto que, como establece el artículo 18 de dicha Directiva, «los Estados miembros velarán por que, si se deniega la solicitud de reagrupación familiar, no se renueva o se retira el permiso de residencia, o se dicta una decisión de devolver, el reagrupante y los miembros de su familia tengan derecho a interponer los recursos jurisdiccionales o administrativos, legalmente previstos». Si tienen dudas sobre la interpretación o la validez de esta Directiva, incumbe a estos órganos jurisdiccionales plantear al Tribunal de Justicia una cuestión prejudicial con arreglo a lo dispuesto en los artículos 68 CE y 234 CE”.

975 Una vision más positiva de la sentencia se encuentra en Rick Lawson, para quien se trata de un "buen juicio". “The Court has finally embraced the European Union's Charter of Fundamental Rights and has thereby started work on the next chapter in the Luxembourg human rights jurisprudence. The judgments allows for flexibility in the regulation of family reunification but at the same time puts pressure on the member states to act in accordance with human rights standards". LAWSON, Rick. "Family Reunification Directive. Court of Justice of the European Communities. Family Reunification and the Union `sCharter of Fundamental Rights, Judgement...”, op. cit., p. 342.

976 La cuestión prejudicial fue planteada con arrego a lo establecido en los artículos 68 y 234 TCE, mediante resolución de 23 de diciembre de 2008, siendo recibida en el TJUE el 29 de diciembre del mismo año. Caso Rhimou Chakroun contra Minister van Buitenlandse Zaken. 


\section{LA RESPUESTA DEL TJUE ANTE LA PRIMERA CUESTIÓN PREJUDICIAL SURGIDA EN TORNO A LA APLICACIÓN DE LA DIRECTIVA 2003/86/CE EN UN ESTADO MIEMBRO: EL CASO CHAKROUN ${ }^{977}$}

\subsection{Introducción}

El asunto Chakroun constituye el primer pronunciamiento emitido por la Corte de Luxemburgo en torno a la compatibilidad con el derecho comunitario de normas nacionales - holandesas en este supuesto- de transposición de las disposiciones comunitarias dictadas al amparo de la competencia asumida por el Capítulo IV del Tratado CE, que actualmente conforma el Título V Tratado TFEU. Este pronunciamiento, enmarcado en lo se ha dado en llamar el derecho comunitario post-Lisboa, viene nuevamente a confirmar la posición de avanzadilla que está ocupando la migración familiar dentro del derecho migratorio comunitario: Así como la Directiva 2003/86 sobre RF fue la primera norma emitida en esta materia - reflejo revelador de su trascendencia-, las disposiciones nacionales de aplicación interna de esta misma disposición comunitaria han sido también pioneras en acceder al TJUE, a fin de que este tribunal clarifique la interpretación concreta de dos de sus artículos, al tiempo que determina la conformidad con dicha Directiva de las normas encargadas de su implementación en el derecho interno holandés.

La petición de decisión prejudicial ante el TJUE - remitida por el Consejo de Estado Holandés ${ }^{978}$ - , versaba sobre la interpretación de dos disposiciones de la Directiva sobre RF: Se trataba en concreto del requisito de poseer "recursos fijos y regulares suficientes (...) sin recurrir al sistema de asistencia social del EM", - cuya prueba el EM puede exigir al presentarse la solicitud de RF-, fijado en el artículo 7.1.c) ${ }^{979}$, dentro del Capítulo IV de la Directiva 2003/86, dedicado al establecimiento de las condiciones para el ejercicio del derecho a la RF; Así como de la definición de reagrupación familiar incluida en el artículo 2. d) ${ }^{980}$, en sede de las disposiciones generales contenidas en el Capítulo I de dicha norma comunitaria y, conforme a la cual, quedan explícitamente amparados tanto los vínculos familiares anteriores como los posteriores a la entrada del reagrupante.

Ambas cuestiones están cargadas de consecuencias prácticas de enorme trascendencia de cara a la concreta aplicación de la Directiva dentro de los EEMM ${ }^{981}$ y, más allá, a la propia concepción

977 Sentencia de 4 marzo de 2010, Asunto C-578/08. TJUE/2010/53.

978 Si bien no es la única función que desempeña, el Consejo de Estado Neerlandés, en su carácter de órgano jurisdiccional con competencia en el ámbito administrativo, constituye la última instancia en materia de extranjería e inmigración en el ordenamiento jurídico holandés. Vid. artículos 73-75 de la Constitución Holandesa. KUNOY, Bjørn; MORTANSSON, Bardur. "Case C-578/08, Rhimou Chakroun v. Minister van Buitenlandse Zaken, Judgment of the European Court of Justice (Second Chamber) of 4 March 2010"; Common market law review, Vol. 47, No 6, 2010, p. 1815, nota a pie de página $\mathrm{n}^{\circ} 1$.

979 El apartado c) del artículo 7.1 de la Directiva sobre RF señala que "al presentarse la solicitud de RF el Estado miembro de que se trate podrá requerir al solicitante que aporte la prueba de que el reagrupante dispone de recursos fijos y regulares suficientes para su propia manutención y la de los miembros de su familia, sin recurrir al sistema de asistencia social del Estado miembro de que se trate. Los Estados miembros evaluarán dichos recursos en función de su naturaleza y de su regularidad y podrán tener en cuenta la cuantía de los salarios y las pensiones mínimos, así como el número de miembros de la familia”.

980 La dicción literal del apartado d) del artículo 2 de la Directiva 2003/86/CE afirma: “A los efectos de la presente Directiva se entenderá por 'reagrupación familiar', la entrada y residencia en un Estado miembro de los miembros de la familia de un nacional de un tercer país que resida legalmente en dicho Estado miembro con el fin de mantener la unidad familiar, con independencia de que los vínculos familiares sean anteriores o posteriores a la entrada del reagrupante".

981 VVAA. "Notes on the Case Law Discussion of 23 March 2010". Europa Institute, Leiden University, op. cit., s.p. 
de la RF: De un lado, el establecimiento potestativo de requisitos económicos que actúan a modo de umbrales, por debajo de los cuales se puede denegar el acceso a las diversas categorías migratorias vinculadas a la familia $-\mathrm{y}$, en este contexto, el sentido que había de otorgarse a la expresión "sistema de asistencia social", cuyo recurso excluye la posibilidad del solicitante de acceder a la RF-. De otro, la compleja cuestión de la distinción de formas migratorias de carácter familiar, tomando como criterio la fecha temporal de constitución del vínculo familiar con respecto a la entrada del principal en el Estado receptor, que da lugar a la bifurcación entre la RF en sentido estricto y la formación familiar o migración matrimonial. Se trataba de despejar si era válida la imposición nacional de requisitos económicos más estrictos sobre la formación familiar, a la luz de la Directiva 2003/86. Esta última categoría, como es bien sabido, suele estar trabada con un régimen jurídico más duro que el fijado para acceder a la residencia provisional por la vía de la RF en sentido estricto. Por ello, las dos cuestiones planteadas al TJUE, constituyen asuntos íntimamente relacionados.

La aproximación efectuada por el TJUE en este asunto demuestra un avance de gran calibre, y más si el punto comparativo se fija en la previa y mucho más mesurada postura que la Corte de Luxemburgo mantuvo al resolver el recurso de anulación contra la Directiva sobre RF. De hecho, si algo caracteriza la perspectiva adoptada por el TJUE en este pronunciamiento, es precisamente una clara actitud pro-derechos humanos ${ }^{982}$. Su razonamiento, profundamente anclado en el principio de efectividad de los derechos, potencia el efecto útil del derecho a la RF de los extranjeros procedentes de terceros países en la UE, con trascendentales repercusiones no sólo sobre la concepción y el sentido en el que han de desenvolverse las normas comunitarias relativas a la RF de los extracomunitarios ${ }^{983}$, sino también sobre cuestiones vitales del derecho comunitario migratorio, especialmente en lo que atañe al estatuto otorgado a los nacionales de terceros países y su relación con los derechos de los ciudadanos de la Unión.

\subsection{Contexto del asunto Chakroun: Litigio Principal y Cuestiones Prejudiciales}

El litigio principal había sido planteado por una ciudadana marroquí, casada con un ciudadano de la misma nacionalidad -el Sr. Chakroun-, el cual contaba con residencia permanente en Holanda, donde residía desde el año 1970. La demandante había contraído matrimonio en 1972, —esto es, apenas dos años después del establecimiento del Sr. Chakroun en Holanda- y, pese a llevar más de tres décadas casada con él, siempre había residido en Marruecos. En marzo de 2006, la señora Chakroun solicitó en la Embajada de los Países Bajos en Rabat un permiso provisional de residencia para vivir con su esposo en Holanda, siéndole denegado porque su marido no disponía de ingresos suficientes, en el sentido exigido por el ordenamiento holandés - concretamente por el Decreto Holandés de Extranjería del año 2000, que había sido modificado en 2004 con la finalidad de adaptarse a lo establecido en la Directiva 2003/86/CE sobre RF-.

982 En el mismo sentido, VVAA. "Notes on the Case Law Discussion of 23 March 2010". Europa Institute, Leiden University, 2011, s.p. http://media.leidenuniv.nl/legacy/ei-jpdiner-23-march.pdf. El artículo, dedicado a comentar recientes sentencias emitidas por el TJUE, subraya, en torno al asunto Ckakroun que "la Corte, siguiendo al Abogado General Sharpston, tomó una aproximación claramente basada en los derechos humanos en este caso".

983 A la misma conclusion llegan PASCOUAU, Yves; LABAYLE, Henry. Conditions for Family Reunification under Strain. A comparative study in nine EU member states. European Policy Center, European Migration and Diversity Programme, Belgium, November 2001, p. 8. Disponible en www.kbs-frb-be 
La normativa interna aplicable en los Países Bajos en el momento del surgimiento del litigio principal ${ }^{984}$, diferenciaba los supuestos de RF de aquellos denominados "constitución de una familia”, en función del momento de constitución temporal de los vínculos familiares: si éstos se crearon con posterioridad a la entrada del sponsor en el EM, se tipificaban como constitución de una familia —encajando en la tipología de formación familiar o migración matrimonial—; mientras que los vínculos familiares de carácter preexistente conformarían la RF. En ambos supuestos se preveía la concesión de un permiso de residencia temporal a favor del familiar implicado, pero sujeto a condiciones económicas más onerosas en el caso de que el supuesto migratorio fuese catalogado como constitución familiar. Así, mientras para la concesión del permiso de residencia por causa de RF se exigía que la persona de referencia dispusiera de un modo estable e independiente de ingresos netos cuyo importe fuera al menos igual a los criterios para acceder a prestaciones asistenciales, sin embargo, en el caso de constitución de una familia, el permiso de residencia del familiar se hacía depender de la disposición de modo estable e independiente de ingresos netos de una cuantía cuando menos igual al 120\% del salario mínimo contemplado en la ley ${ }^{985}$.

Dado que el matrimonio de la Sra. Chakroun había tenido lugar con posterioridad a la entrada y adquisición de la residencia en Holanda por parte de su marido, el supuesto era considerado como de "constitución familiar" por la normativa holandesa, sin tomar en consideración la larga duración ni del matrimonio ni de la residencia del Sr. Chakroun en Holanda. Conviene precisar que, si bien el reagrupante contaba con recursos fijos y regulares suficientes para cubrir los gastos de subsistencia generalmente necesarios, sin embargo percibía un tipo específico de subsidio de desempleo, que el ordenamiento holandés catalogaba como "prestaciones asistenciales especiales". En el momento temporal en que se plantearon los hechos litigiosos, el Sr. Chakroun percibía en concepto de subsidio de desempleo 1322,73 euros netos al mes, incluida la paga de vacaciones, cantidad que resultaba inferior al estándar ${ }^{986}$ de ingresos aplicable a los supuestos de constitución de una familia, donde la normativa holandesa vigente exigía un importe de 1.441,44 euros mensuales - frente a los 1207,91 mensuales, considerados como medios de subsistencia suficientes para el supuesto de la RF.

984 La mayoría de las disposiciones internas aplicables en el marco del litigio principal se encontraban en la Ley de Extranjería del año 2000 - cuyo artículo 16.1c) establecía como causa de denegación de un permiso de residencia temporal si "el extranjero no dispone de modo independiente y estable de suficientes medios de subsistencia o bien si la persona con la que desea residir el extranjero no dispone de modo independiente y estable de suficientes medios de subsistencia"- y, fundamentalmente en el Decreto de Extranjería del año 2000. Las disposiciones relevantes de dicho Decreto eran el artículo 1.1.r) que definía la "constitución de una familia como la RF del cónyuge, siempre que el vínculo conyugal se hubiese constituido en un momento en que la persona de referencia tuviera su residencia principal en los Países Bajos".

985 Artículos 3. 22 y 3.74 del Decreto de Extranjería holandés, reformado en 2004, y vigente al momento de plantearse el litigio principal. El artículo 3.74 de dicha norma estipulaba los medios de subsistencia considerados suficientes a efectos de migración familiar, señalando específicamente en su apartado d) que, en caso de constitución de una familia tales medios debían ser equivalentes al $120 \%$ del salario mínimo contemplado en los artículos 8 , apartado 1 , letra a, y 14 de la Wet minimumloon en minimumvakantiebijslag, incluida la paga de vacaciones mencionada en el artículo 15 de la citada Ley». El apartado a) del artículo 3.74 del Decreto de Extranjería estimaba como medios de subsistencia suficientes, para los restantes supuestos, cuando el importe de los ingresos netos fuera igual a los criterios establecidos para acceder a prestaciones asistenciales.

986 En el momento tomado en consideración a los efectos del litigio principal, el criterio para acceder a prestaciones asistenciales determinado con arreglo al artículo 21, letra c, de la Ley interna de extranjería para los interesados mayores de 21 años y menores de 65, era 1.207,91 euros al mes, mientras que, en el supuesto de constitución de familia, los medios de subsistencia se consideraban suficientes si los ingresos netos eran iguales a 1.441,44 euros al mes, incluida la paga de vacaciones. 
La señora Chakroun recurrió contra la resolución denegatoria de su permiso de residencia, dictada por el Ministro de Asuntos Exteriores, hasta agotar los recursos internos, llegando ante el Consejo de Estado, momento en que la recurrente planteó dos cuestiones prejudiciales.

En primer lugar, formuló la cuestión de si el artículo 7, apartado 1, letra c) de la Directiva había sido correctamente adaptado al Derecho interno, en la medida en que las disposiciones de extranjería vigentes en Holanda exigían al reagrupante, en el supuesto de constitución de una familia, recursos equivalentes al 120\% del salario mínimo. En segundo lugar, la Sra. Chakroun discutía la distinción que llevaba a cabo la normativa neerlandesa entre los supuestos de reagrupación familiar y constitución de una familia, en función de que el vínculo familiar fuese anterior o posterior a la entrada del reagrupante en territorio neerlandés, puesto que, a su juicio, tal distinción no se deducía del artículo 7, apartado 1, de la Directiva. La recurrente sostenía que si la solicitud controvertida en el litigio principal se hubiera considerado una petición de reagrupación familiar, en el sentido de la normativa neerlandesa ${ }^{987}$, los recursos del Sr. Chakroun serían entonces superiores al importe requerido, y ella habría obtenido el permiso de residencia solicitado.

Ante esta situación, el Consejo de Estado decidió suspender el procedimiento y remitir al Tribunal de Justicia de la Unión Europea dos cuestiones prejudiciales, coincidentes en esencia ${ }^{988}$ con las planteadas por la recurrente.

\subsection{Primera Cuestión Prejudicial: Observaciones de las partes y respuesta de la Corte de Luxemburgo}

El TJUE aborda las dos cuestiones prejudiciales señaladas en el mismo orden en que fueron formuladas. La primera de ellas giraba en torno al sentido de la expresión "recurrir al sistema de asistencia social" contenida en el art. 7.1c) de la Directiva. A fin de evitar el recurso a dicho sistema, esta disposición permite a los EEMM exigir la prueba de que el reagrupante dispone de recursos fijos y regulares suficientes. La cuestión clave formulada residía fundamentalmente en si, a fin de fijar el umbral de ingresos exigido a efectos de migración familiar, el Estado - dentro de la expresión sistema de asistencia social-, podía incluir las distintas ventajas sociales a las que los interesados podrían eventualmente tener derecho; de forma más específica, si cabría considerar para tal cómputo las "prestaciones asistenciales especiales"

987 En tal caso, la normativa interna habría tomado en consideración la regla de las prestaciones asistenciales recogida en el artículo 21, letra c, de la Ley de Extranjería, con arreglo al artículo 3.74, letra a, del Decreto de Extranjería del 2000.

988 El tenor literal de las dos cuestiones prejudiciales era el siguiente: «1). ¿Debe interpretarse la expresión "recurrir al sistema de asistencia social" contenida en el artículo 7, apartado 1, letra c), de la Directiva en el sentido de que tal expresión ofrece al Estado miembro un margen para adoptar una normativa en materia de reagrupación familiar que dé lugar a que no se permita la reagrupación familiar de un reagrupante que haya acreditado contar con recursos fijos y regulares suficientes para poder hacer frente a los gastos de subsistencia generalmente necesarios, pero que, no obstante, habida cuenta de la cuantía de dichos recursos, podrá recurrir a una prestación asistencial especial para hacer frente a gastos de subsistencia excepcionales y determinados de forma individual, a la condonación de impuestos concedida por autoridades locales en función de la cuantía de los ingresos o bien a medidas de apoyo a los ingresos en el marco de las políticas municipales de renta básica?; 2). ¿Debe interpretarse la Directiva, y en particular su artículo 2, letra d), en el sentido de que esta disposición se opone a una normativa nacional en la que, para la aplicación del requisito de ingresos establecido en su artículo 7, apartado 1, letra c), se establece una diferencia en función de si el vínculo familiar se ha constituido antes o después de la entrada del reagrupante en el Estado miembro?».

989 En el fondo de esta cuestión pivotaba la distinción que la normativa holandesa establecía entre prestaciones asistenciales generales - aquellas cuyo objeto era cubrir los gastos generales necesarios para la subsistencia- y las 
ciones previstas por el ordenamiento interno holandés-. Ello exigía previamente despejar el sentido de la expresión "sistema de asistencia social" empleado por el art. 7 de la Directiva 2003/86/CE.

En torno a esta primera cuestión, la recurrente argumentaba que la expresión "sistema social del EM de que se trate” - incluida en el art. 7.1.d) de la Directiva—, sólo podía designar una normativa nacional, mientras que las prestaciones sociales eran fijadas en Holanda por normativas de ámbito municipal. Junto con la Comisión de las CCEE, la Sra. Chakroun alegaba también que el margen de apreciación otorgado a los EEMM para adaptarse a la Directiva no debía nunca menoscabar sus objetivos ni el efecto útil de ésta. Contrariamente a ello, la exigencia holandesa de contar con recursos equivalentes a un $120 \%$ del salario mínimo, excluía en la práctica a la mayoría de los jóvenes solicitantes de la formación familiar, pues no podían cumplir el criterio de los medios de subsistencia sobre la base de un trabajo a tiempo completo ${ }^{990}$.

En este orden de ideas, la Comisión estimaba además que el elemento determinante —conforme a lo establecido en el art. 7 de la Directiva-, consistía en que el interesado dispusiera de recursos suficientes para satisfacer sus necesidades básicas sin recurrir a la asistencia social del Estado receptor. Este órgano aportaba como prueba el Informe del Consejo y el Parlamento Europeo relativo a la aplicación de la Directiva sobre $R F^{991}$, cuyo punto 4.3.3. señalaba expresamente que el importe exigido por las autoridades holandesas para evaluar la suficiencia de los recursos era el más elevado del conjunto de los EEMM de la Comunidad. La Comisión destacaba el hecho de que, si en el litigio principal, los vínculos familiares entre los esposos Chakroun hubieran existido antes de la entrada del Sr. Chakroun en territorio comunitario, el importe de ingresos tomado en consideración para evaluar la suficiencia de recursos habría sido inferior al utilizado finalmente en este asunto. Esta circunstancia servía para probar que el importe exigido por la normativa holandesa cuando los vínculos familiares preexisten a la entrada del reagrupante, corresponde al importe que basta normalmente para satisfacer las necesidades más básicas en la sociedad holandesa, mismo que sí cumplía el Sr. Chakrou.

prestaciones asistenciales de carácter especial — las controvertidas en el litigio principal—, destinadas a afrontar los gastos necesarios para la subsistencia, pero derivados de circunstancias especiales y siempre que los mismos no pudieran ser cubiertos mediante otros medios disponibles. Las prestaciones de carácter especial estaban previstas por las normativas municipales, siendo decididas por los ayuntamientos tras examinar la situación del solicitante, pudiendo adoptar muy diversas formas, entre ellas incluir una desgravación fiscal. El elemento de referencia usado por el ordenamiento holandés para determinar las necesidades de una persona y el importe al que tendría derecho en el marco de las prestaciones asistenciales generales era el salario mínimo, calculado sobre la base de aquel al que accedería una persona de 23 años. El importe correspondiente al 120\% del salario mínimo - umbral establecido para acceder a un permiso de residencia por causa de constitución de una familia-, constituía el monto más alla del cual un residente no tendría derecho ni a las prestaciones asistenciales generales ni tampoco a las especiales.

990 Como prueba de esta última circunstancia, la sra. Chakroun mencionó un informe redactado por el Ministerio de Justicia neerlandés, donde se evaluaba la incidencia negativa que sobre la inmigración de cónyuges extranjeros a los Países Bajos había tenido el incremento de los ingresos exigidos, lo cual, a juicio de la recurrente, resultaba contrario al objetivo de la Directiva 2003/86/CE sobre el derecho a la RF.

991 El punto 4.3.3. de dicho Informe, al evaluar la aplicación del requisito de "recursos fijos y suficientes" establecido en el artículo 7,1,c) de la Directiva sobre RF, constata que todos los EEMM, salvo Suecia, exigen este requisito, si bien con distintas modalidades, aplicando un rango de ingresos mensuales aproximados que oscilan desde 120 $€$ (Portugal) a $1.484 €$ (Holanda). Posteriormente la Comisión advierte que "los enfoques de 3 Estados miembros plantean preocupaciones especiales: (...) Una disposición específica en Holanda que exige en general el mayor nivel de ingresos, puede constituir una discriminación por razones de edad. En caso de constitución de una familia, se exige a cada reagrupante el $120 \%$ del salario mínimo legal de un trabajador, con independencia de su edad. Además, también se requiere un contrato de empleo de una duración mínima de un año o un contrato de trabajo de tres años. Todas estas condiciones pueden obstaculizar el derecho a la reagrupación familiar, especialmente de los más jóvenes". Informe de la Comisión al Consejo y al Parlamento Europeo relativo a la aplicación de la Directiva 2003/86/CE sobre la RF. Bruselas, 8.10.2008; COM(2008) 610 final 
La recurrente, en conjunción con la Comisión, coincidían en destacar que las autoridades holandesas habrían debido tener en cuenta, en el litigio principal, la larga duración de la residencia del sponsor en Holanda, así como del matrimonio. Al omitir esta consideración, se incumplía la exigencia de individualización del examen de la solicitud, prevista en el artículo 17 de la Directiva.

Por su parte, el Gobierno holandés sostenía que el nivel de ingresos correspondiente al 120\% del salario mínimo era conforme con el artículo 7.1.d) de la Directiva, puesto que se trataba del nivel a partir del cual ya no era posible beneficiarse de prestaciones asistenciales generales o especiales. Dicho salario mínimo sólo permitía en Holanda satisfacer las necesidades vitales, siendo insuficiente para afrontar gastos particulares individuales, lo que justificaba que se tomase en consideración un nivel de ingresos equivalente al $120 \%{ }^{992}$ del salario mínimo.

El TJUE aborda esta primera cuestión recordando la naturaleza jurídica vinculante del derecho a la RF establecido por la Directiva 2003/86 — que ya había abordado también en su pronunciamiento previo en torno a esta norma, al solventar el recurso de anulación que en su momento presentó el Parlamento Europeo-. En dicha sentencia la Corte precisó que del artículo 4.1 de la Directiva 2003/86 se extrae la imposición a los EEMM de "obligaciones positivas precisas, que se corresponden con derechos subjetivos claramente definidos (...) sin que puedan ejercer su facultad discrecionap'993. Pero, en esta ocasión, al destacar el carácter preceptivo de la obligación estatal establecida en el artículo 4.1, el TJUE va mucho más allá de su previo pronunciamiento, extrayendo del texto de la Directiva 2003/86 una regla de carácter general, a cargo de los EEMM, de autorizar la RF. Sin embargo, tal regla, puntualiza el TJUE, "no empece al cumplimiento de los requisitos establecidos en particular en el capitulo IV" de dicha norma - donde se inserta el art. 7-994. En palabras de la Corte de Luxemburgo:

"Dado que la autorización de reagrupación familiar es la regla general, la facultad prevista en el artículo 7, apartado 1, letra c), de la Directiva debe interpretarse de manera estricta. Por otro lado, el margen de apreciación reconocido a los Estados miembros no puede utilizarse de manera que menoscabe el objetivo de la Directiva, que es favorecer la reagrupación familiar, ni su efecto útil"995.

Junto a la extracción de una regla general a favor de la concesión de la RF a aquellos extranjeros que cumplan con los requisitos de la Directiva 2003/86, en este importantísimo apartado la Corte infiere otra trascendente conclusión que, sin embargo, no resulta tan nítida ${ }^{996}$ ni en el texto de la Directiva - ni en su espíritu, cabría precisar-, a saber, que el objetivo de la Directiva es favorecer la RF.

Ambas consideraciones, que se apoyan expresamente en el principio interpretativo de efectividad de los derechos - el TJCE menciona tanto el efecto útil del derecho a la RF como de la propia Directiva que lo consagra-, se deducen también, a juicio de la Corte de Luxemburgo, del segundo considerando de la Directiva, conforme al cual las medidas sobre RF deben adoptarse de conformidad con la obligación de proteger la familia y respetar la vida familiar.

992 Dicha cantidad era a su vez la generalmente utilizada por los municipios holandeses como uno de los criterios que permitía identificar a los beneficiarios potenciales de una prestación asistencial — tanto general como especial—, si bien el gobierno neerlandés reconocía que determinados municipios optaban por niveles de ingresos diferentes, que oscilaban entre el 110-130\% del salario mínimo legal.

993 El apartado 41 de la sentencia Chakroun, repite literalmente el apartado 60 de la sentencia de 27 de junio de 2006 Parlamento/Consejo, C-540/03.

994 Asunto Chakroun, apartado 42.

995 Apartado 43 de la sentencia Chakroun.

996 PASCOUAU, Yves; LABAYLE, Henry. Conditions for Family Reunification under Strain. A comparative study in nine EU member states, op. cit., p. 8. 
Con ello entra de nuevo en escena en la argumentación del TJUE tanto el art. 8 CEDH como la Carta de Derechos Fundamentales de la $\mathrm{UE}^{997}$ — profusamente alegados en su sentencia previa en torno a esta misma Directiva- que, en este enfoque pro-derechos, desembocan nuevamente en una potenciación del efecto útil del derecho a la RF consagrado en tal norma comunitaria:

"De ello se desprende que las disposiciones de la Directiva y, en particular, el artículo 7, apartado 1, letra c), deben interpretarse a la luz de los derechos fundamentales y, más concretamente, del derecho al respeto de la vida familiar consagrado tanto por el CEDH como por la Carta. Procede añadir que, según el artículo 6 TUE, apartado 1, párrafo primero, la Unión Europea reconoce los derechos, las libertades y los principios enunciados en la Carta, tal como se adoptó en Estrasburgo el 12 de diciembre de 2007, la cual tiene el mismo valor jurídico que los Tratados"998.

Resumidamente, la argumentación desplegada por el TJUE en la interpretación del art. 7.1.c) de la Directiva acoge algunos de los argumentos que habían sido empleados por la recurrente y la Comisión, todos ellos confluyentes en una visión liberal de la RF en el ámbito de la UE. Para ello, lo primero que hace la Corte es insertar el concepto de «sistema de asistencia social del Estado miembro», incluido en el artículo 7 de la Directiva, "como un concepto autónomo de Derecho de la Unión

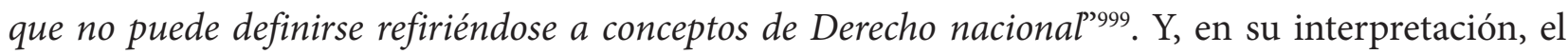
TJUE entiende que el mismo se encuentra en oposición al concepto de "recursos fijos y regulares suficientes para su propia manutención”, presente en la citada disposición de la Directiva. Por ello, la asistencia social acogería prestaciones procedentes de las autoridades públicas internas - con independencia de su nivel de actuación nacional, regional o local-, que vendrían a suplir la falta de recursos fijos y regulares suficientes.

Para llegar a esta consideración, el TJUE aplica por analogía la argumentación que desplegó en la sentencia Eind ${ }^{1000}$ — dictada en el año 2007, pero en el contexto de la libre circulación de trabajadores comunitarios y sus familiares-. Esta interpretación analógica es de enorme importancia, pues es la primera vez que el TJUE extrapola - parcialmente - su doctrina sobre la RF de ciudadanos comunitarios al ámbito de los nacionales de terceros países. El concepto de “asistencia social”, en esta perspectiva, no podría acoger una prestación que permite hacer frente a necesidades extraordinarias o imprevistas ${ }^{1001}$, como venía sucediendo en Holanda.

El Tribunal de Luxemburgo recuerda además que, al evaluar los recursos del reagrupante, la Directiva sobre RF permite al EM tomar en consideración la cuantía de los salarios y pensiones mínimos nacionales pero, puntualiza, "esta facultad debe ejercerse evitando menoscabar el objetivo

997 Esta referencia a la Carta de Derechos Fundamentales de la UE por parte del TJUE, es considerada por KUNOY y MORTANSSON como un "razonamiento inconcluso". En vista que la Corte de Luxemburgo considera que dicho instrumento jurídico tiene una autoridad legal equivalente a la que poseen los Tratados fundacionales (art. 6.1 TUE), y, por lo tanto, que el derecho comunitario primario, resulta para ambos autores "inconsistente sistemáticamente yuxtaponer la Carta con el CEDH”, considerando que el TJUE "perdió una oportunidad de emarcipar el papel de la Carta del que cumple el Convenio de Roma”. KUNOY, Bjørn; MORTANSSON, Bardur. "Case C-578/08, Rhimou Chakroun v. Minister van Buitenlandse Zaken..., op. cit., pp. 1824 y 1826-1827.

998 STJUE, asunto Chakroun, apartado 44.

999 La argumentación empleada por el TJUE para dicha inserción es la siguiente: "Habida cuenta, en particular, de las diferencias existentes entre los Estados miembros por lo que se refiere a la gestión de la asistencia social, este concepto debe entenderse en el sentido de que se refiere a prestaciones asistenciales concedidas por las autoridades públicas, sea a escala nacional, regional o local" (Apartado 45).

1000 Sentencia de 11 de diciembre de 2007, TJUE; Eind, C-291/05, apartado 29. (Citada en el apartado 46 de la sentencia Chakroun).

1001 Sentencia del TJUE, asunto Chakroun, apartados 46 y 49. 
de la Directiva, que es favorecer la reagrupación familiar, y su efecto útil”1002. Esta circunstancia, en conjunción con la obligación del examen caso por caso de las solicitudes de RF - que el TJUE extrae del artículo 17 de la Directiva el cual, como vimos, constituye una cláusula transversal que incorpora criterios jurisprudenciales del TEDH en torno a la vida familiar de los extranjeros-, permite a la Corte de Luxemburgo llegar a una de las conclusiones más trascendentales de esta sentencia:

\begin{abstract}
"Toda vez que la magnitud de las necesidades puede ser muy variable según los individuos, esta autorización debe interpretarse en el sentido de que los Estados miembros pueden indicar una determinada cantidad como importe de referencia, pero no en el sentido de que pueden imponer un importe de ingresos mínimos por debajo del cual se denegará cualquier reagrupación familiar, con independencia del examen concreto de la situación de cada solicitante. Apoya esta interpretación el artículo 17 de la Directiva, que obliga a individualizar el examen de las solicitudes de reagrupación"1003.
\end{abstract}

El párrafo transcrito resulta de vital importancia. Si ya al resolver el recurso de anulación contra la Directiva sobre RF la Corte de Luxemburgo tuvo ocasión de desvelar la trascendencia del artículo 17, ahora el TJUE aplica la regla que entonces dedujo al ámbito de las exigencias económicas que gravan el ejercicio de la RF, alumbrando de forma explícita las implicaciones concretas de esta cláusula transversal al evaluar las solicitudes de reagrupación ${ }^{1004}$. En la interpretación efectuada por el TJUE, del artículo 17-donde se establecen una serie de factores de carácter individual que el EM ha de tener en cuenta al denegar las solicitudes de $\mathrm{RF}$ - se extrae la exigencia de individualización del examen de las solicitudes de RF, criterio derivado a su vez de la jurisprudencia de Estrasburgo que ahora es incorporado abiertamente por la Corte de Luxemburgo, aplicándolo a una disposición de la Directiva.

El empleo de este criterio a la situación vigente en los Países Bajos, lleva al TJUE a estimar que el nivel de ingresos equivalente al 120\% del salario mínimo, empleado por dicho país, constituye un "importe de referencia (...) que no responde al objetivo consistente en determinar si un individuo dispone de recursos regulares para su propia manutención" ${ }^{1005}$. En vista de que distintos municipios holandeses utilizaban como importe de referencia ingresos de una cuantía inferior al umbral señalado - circunstancia que "contradice la tesis según la cual son indispensables unos ingresos correspondientes al 120\% del salario mínimo"1006_, el TJUE concluye que el porcentaje del 120\% "no es sino

1002 Idem, apartado 47.

1003 Apartado 48, sentencia Chakroun. Esta consideración del TJUE sigue, en esencia, las conclusiones formuladas por el Abogado General Sharpston, presentadas el 10 de diciembre de 2009. En el apartado 49 de las mismas, el Abogado General señalaba textualmente: "cuando se aplica un requisito de recursos, el artículo 7, apartado 1, letra c), de la Directiva obliga a los Estados miembros a evaluar los recursos del reagrupante en relación con su naturaleza y regularidad, y permite tener en cuenta el número de miembros de la familia. Además, el artículo 17 exige tomar en consideración determinadas circunstancias personales cuando se adopta una resolución negativa en relación con la reagrupación familiar. En consecuencia, la Directiva exige un examen individual de cada solicitud, excluyendo la aplicación general de ningún umbral abstracto sin tener en cuenta las circunstancias del asunto".

1004 En el mismo sentido, WIESBROCK, Anja. "Court of Justice of the European Union. The Right to Family Reunification to Third-Country Nationals under EU Law..., op. cit., p. 477. En sentido opuesto se manifiestan, KUNOY, Bjørn; MORTANSSON, Bardur. "Case C-578/08, Rhimou Chakroun v. Minister van Buitenlandse Zaken, Judgment of the European Court of Justice (Second Chamber) of 4 March 2010”, op. cit., p. Estos dos últimos autores señalan que la interpretación efectuada por el TJUE constituye una mera "clarificación respecto a la aplicación adecuada de las condiciones que reglamentan las circunstancias en las que un EM puede rechazar una aplicación de RF, pero de ninguna manera puede ser vista como un hallazgo imprevisto de la Corte. De hecho, el artículo 17 de la Directiva no deja lugar a dudas sobre esta cuestión”. En una línea similar también se inscriben PASCOUAU, Yves; LABAYLE, Henry. Conditions for Family Reunification under Strain. A comparative study in nine EU member states, op. cit., p. 8.

1005 Apartado 49, sentencia Chakroun.

1006 Apartado 50, sentencia Chakroun. 
un promedio" ${ }^{1007}$. El propio TJUE reconoce que no le compete declarar si el salario mínimo previsto por la ley neerlandesa basta para permitir a los trabajadores de dicho Estado cubrir sus necesidades diarias. Pese a ello, dado que si la solicitud de la recurrente hubiera encajado en un supuesto de RF se le habría exigido simplemente el salario mínimo, estima "que las propias autoridades neerlandesas consideran que el salario mínimo se corresponde con los recursos suficientes, en el sentido del artículo 7,apartado 1, letra c) de la Directiva"1008.

En virtud de todo lo expuesto - y en respuesta a la primera pregunta formulada por el Consejo de Estado holandés-, el Tribunal de Justicia determina, si bien de forma algo críptica, el sentido que ha de atribuirse a la expresión "recurrir al sistema de asistencia social", contenida en la Directiva:

"La expresión «recurrir al sistema de asistencia social», contenida en el artículo 7, apartado 1, letra c), de la Directiva 2003/86/CE del Consejo, de 22 de septiembre de 2003, sobre el derecho a la reagrupación familiar, debe interpretarse en el sentido de que no permite a un Estado miembro adoptar una normativa en materia de reagrupación familiar que la deniega a un reagrupante que ha demostrado disponer de recursos fijos y regulares suficientes para su propia manutención y la de los miembros de su familia, pero que, habida cuenta de la cuantía de sus ingresos, podrá no obstante solicitar una prestación asistencial especial en caso de que existan gastos particulares e individualmente determinados necesarios para su subsistencia, a desgravaciones concedidas por las autoridades municipales en función de los ingresos o a medidas de apoyo a los ingresos en el marco de las políticas municipales de renta básica”1009.

De forma más simple, uno de los requisitos que potestativamente pueden imponer los EEMM cuando un miembro de la familia solicita la autorización para reunirse con el reagrupante, es que éste tenga recursos fijos y regulares suficientes para el mantenimiento de su familia, «sin recurrir al sistema de asistencia social del Estado miembro de que se trate». Al interpretar dicho concepto, el TJUE lo encaja dentro del arsenal de conceptos autónomos del derecho comunitario, lo que aleja su definición del ámbito nacional, descartando interferencias por parte de las autoridades internas, y posibilitando una interpretación homogénea en el ámbito de la $\mathrm{UE}^{1010}$. Ello permite a la Corte de Luxemburgo poder utilizar, a nivel comunitario, una definición de sistema de asistencia social más estrecha que la que suele manejarse a nivel interno y, además, aproximarla a la que resulta aplicable en el contexto de familias mixtas integradas por ciudadanos comunitarios que ejercen su derecho a la libre circulación ${ }^{1011}$-el TJUE recurrió en este punto a la interpretación analógica con el caso Eind-.

De este modo, la Corte de Luxemburgo determina que dentro del sistema de asistencia social el EM sólo puede incluir prestaciones, subsidios, desgravaciones, ayudas o subvenciones estatales - con independencia del nivel administrativo en el que sean aprobados-, destinados a dotar al beneficiario de recursos fijos y regulares suficientes para su propia manutención y la de su familia, supliendo la carencia de los mismos. No cabe insertar conceptos afines, pero con objetivos distintos al señalado, como por ejemplo las prestaciones especiales previstas por el ordenamiento holandés. Quedarían pues excluidas dentro de tal cómputo las ayudas estatales, del tipo que fue-

1007 Idem.

1008 Apartado 51, sentencia Chakroun.

1009 Apartado 52 sentencia Chakroun.

1010 De la misma opinion es WIESBROCK, Anja. "Court of Justice of the European Union. The Right to Family Reunification to Third-Country Nationals under EU Law; Decision of 4 March 2010, Case C-578/08, Rhimou Chkaroun V. Minister van Buitenlandse Zake”, op. cit., p. 474. En una línea similar, PASCOUAU, Yves; LABAYLE, Henry. Conditions for Family Reunification under Strain..., op. cit., p. 84. 
ran, que no estén destinadas a cubrir los recursos destinados a atender las necesidades básicas del sujeto.

A tenor de esta interpretación - y siguiendo a Labayle y Pascouau ${ }^{1012}$ - cabría incluir dos tipos distintos de ayudas públicas, dentro del concepto de asistencia social: aquella ayuda dirigida a solicitantes que carecen de recursos suficientes —en cuyo caso, procedería la denegación de la RF-; frente a aquella destinada a solicitantes que disponen de recursos suficientes pero, sin embargo, se les otorga una asistencia de carácter especial a fin de poder asumir costes excepcionales - por ejemplo becas de comedor para hijos o ayudas temporales para cubrir gastos de alojamiento-. En consecuencia "el mero hecho de que el solicitante reciba una ayuda especial o asistencia social excepcional no puede constituir motivo suficiente para rechazar la RF"1013. Circunstancia que, de nuevo, obliga al Estado miembro a evaluar de forma individualizada la solicitud y el tipo concreto de ayudas públicas que está recibiendo el reagrupante.

En definitiva, en Chakroun, el TJUE efectúa una reducción considerable del margen de apreciación que compete a los Estados a la hora de imponer requisitos económicos y salariales que graven el ejercicio de la $\mathrm{RF}^{1014}$. Simultáneamente, estrecha la horquilla de exigencias económicas válidas que los EEMM pueden potestativamente exigir en el momento de presentarse la solicitud de RF, facilitando con ello el ejercicio práctico del derecho a la RF. Para iluminar la importancia práctica de esta comprensión del Tribunal de Luxemburgo, baste recordar que el contexto actual de grave recesión económica empuja a los sectores sociales más desfavorecidos — entre los que habitualmente figuran los inmigrantes - hacia los sistemas de asistencia social del país receptor. Su definición, a partir de este pronunciamiento, ha sido insertada dentro de los conceptos autónomos del derecho comunitario - y, por este medio, excluida del ámbito de influencia del margen de apreciación—, para, finalmente, ser estrechada por vía interpretativa.

Además, la Corte de Luxemburgo ha recurrido a aplicar analógicamente a los ciudadanos extracomunitarios, los criterios que dedujo en un supuesto ya decidido por esta institución relativo a la RF de ciudadanos comunitarios. Esta interpretación analógica resulta algo insólito en el ámbito de la migración familiar extracomunitaria. Esta perspectiva ha permitido a la Corte de Luxemburgo cierto acercamiento entre las exigencias económicas requeridas en el ámbito de la $\mathrm{RF}$ de nacionales de terceros países, y las que rigen la RF de ciudadanos comunitarios. Ello resulta extraordinariamente novedoso y esperanzador, a la luz del objetivo establecido ya hace tiempo en Tampere $-\mathrm{y}$ largamente desatendido en esta materia-, de establecer derechos equiparables entre ambos colectivos $^{1015}$.

\subsection{La Segunda Cuestión Prejudicial: Observaciones de las partes y respuesta de la Corte de Luxemburgo}

La segunda cuestión formulada al TJUE giraba en torno a la interpretación del concepto de RF contenido en artículo 2 letra d) de la Directiva, que comprende la reunión de un miembro de la

1012 PASCOUAU, Yves; LABAYLE, Henry. Conditions for Family Reunification under Strain. A comparative study in nine EU member states, op. cit., p. 84.

1013 Idem, traducción propia.

1014 Ibidem, p. 82.

1015 WIESBROCK, Anja. "Court of Justice of the European Union. The Right to Family Reunification to Third-Country Nationals under EU Law; Decision of 4 March 2010, Case C-578/08, Rhimou Chkaroun V. Minister van Buitenlandse Zake”, op. cit., p. 475. 
familia del reagrupante con éste, independientemente de que los vínculos familiares sean anteriores o posteriores a la entrada del reagrupante en el Estado miembro de que se trata ${ }^{1016}$. La pregunta básicamente perseguía que el TJUE aclarase si la Directiva permite establecer una distinción en función de si el vínculo familiar surgió antes o después de la entrada del residente en el Estado miembro.

De forma más específica, el Consejo de Estado holandés deseaba saber si la disposición apuntada se oponía a una norma nacional que, al aplicar los requisitos de ingresos del art. 7.1.c) de la Directiva, impusiera recursos más elevados en los casos de migración matrimonial —-diferenciación prevista por la normativa holandesa bajo la terminología de "constitución de una familia"1017_. Aunque este órgano jurisdiccional reconocía albergar dudas en torno a la posibilidad de distinguir internamente entre RF y constitución de una familia, estimaba sin embargo que la Directiva no prohibía dicha distinción, en vista de que la misma está prevista en su artículo 9 -aplicable a los refugiados- ${ }^{1018}$ —, así como en el artículo 16, apartados 1 y 5, de la Directiva 2003/109/CE relativa al estatuto de los nacionales de terceros países residentes de larga duración. Argumentaba que el establecimiento de dicha distinción era una manera de tener en cuenta la naturaleza y la solidez de los vínculos familiares - como impone el artículo 17 de la Directiva 2003/86/CE_, estimando que los lazos familiares preexistentes al hecho migratorio eran más dignos de protección y solían materializarse de forma más intensa que en los supuestos de constitución de una familia. De hecho, señalaba que al fijar como nivel de ingresos suficiente, aplicable para los supuestos de solicitudes de RF, un importe inferior a la norma general del 120\% del salario mínimo, lo que se perseguía era precisamente proteger a la familia.

Detrás de la distinción impuesta por la normativa holandesa gravitaba la búsqueda de un efecto disuasorio ante el incremento de la inmigración abusiva mediante los matrimonios de conveniencia y las sospechas de fraude que en ocasiones laten bajo la figura de la importación de cónyuges extranjeros - matrimonio que frecuentemente tiene lugar aprovechando una estancia por vacaciones en el país de origen-, por no mencionar sus mayores efectos cuantitativos y las supuestas dificultades

1016 El tenor literal de la segunda cuestión que el Consejo de Estado elevó al TJUE era el siguiente: “¿Debe interpretarse [la Directiva], y en particular su artículo 2, letra d), en el sentido de que esta disposición se opone a una normativa nacional en la que, para la aplicación del requisito de ingresos establecido en su artículo 7, apartado 1, letra c), se establece una diferencia en función de si el vínculo familiar se ha constituido antes o después de la entrada del reagrupante en el Estado miembro?»".

1017 La aplicación de diferentes exigencias según se tratase de supuestos de RF o de formación familiar, dentro de la normativa holandesa de extranjería, cubría dos ámbitos principales: de un lado, la mínima edad exigida a los esposos, y de otro, la cantidad de recursos requeridos — solo éste ultimo aspecto fue objeto de cuestionamiento y subsiguiente análisis ante el TJUE-. En los supuestos de RF, ambos cónyuges debían tener al menos 18 años de edad; para la formación familiar, se exigían 21 años como edad mínima applicable a ambos cónyuges. (Artículo 3.14 y 3.15 de la Ley de extranjería holandesa del año 2000). WIESBROCK, A. "ECJ. The Right to Family Reunification of ThirdCountry Nationals..., op. cit., p. 465.

1018 El artículo 9.2 de la Directiva 2003/86/CE, en el que se basaba el Gobierno holandés, señala que: "Los Estados miembros podrán limitar la aplicación del presente capítulo —en referencia al capítulo V, donde se fijan los requisitos que subordinan el ejercicio del derecho a la $\mathrm{RF}$ - a los refugiados cuyos vínculos familiares sean anteriores a su entrada”. Para el caso de las solicitudes de RF a favor de los familiares de los refugiados, la Directiva excluye la exigencia de probar la posesión de recursos económicos (art. 12.1) y, además, quedan también exentos de la aplicación del umbral económico, siempre y cuando los miembros de la familia solicitasen reunirse con el refugiado que actúa como reagrupante dentro del plazo de tres meses desde la concesión del estatuto de refugiado. Para justificar tales exclusiones, el Abogado General señalaba la alta probabilidad de que el miedo fundado a la persecución —que define el estatuto de refugiado—, se extienda a la familia más cercana, militando en favor de la concesión de la RF antes de que el refugiado pueda tener recursos estables y regulares en el país de acogida. 
adaptativas asociadas a esta figura ${ }^{1019}$. De hecho, la resolución denegatoria de la solicitud de la Sra. Chakroun hacía explícita la primera consideración apuntada, sobre la base del establecimiento de condiciones más estrictas cuando el nacional neerlandés o el extranjero residente contraía matrimonio mientras estaba de vacaciones en el extranjero ${ }^{1020}$.

En torno a este punto específico, la recurrente alegaba que, desde su llegada a los Países Bajos en el año 1979, su cónyuge estuvo trabajando allí durante un período de dos años con el objetivo de ahorrar el dinero necesario para la boda, de ahí que el matrimonio se hubiera contraído con posterioridad a su asentamiento en el EM. Junto con la Comisión, la señora Chakroun estimaba que la Directiva sobre RF no proporciona fundamento alguno para realizar una diferenciación entre el mantenimiento de la familia y su creación ${ }^{1021}$. Se preguntaba, además, cómo tal distinción —realizada en función del momento en el que se crean los vínculos familiares-, podía tener la más mínima relación con el hecho de satisfacer los requisitos materiales para cubrir las necesidades elementales. En cuanto a la excepción introducida por el artículo 9, apartado 2 de la Directa sobre RF, ambos consideraban que se trataba de una disposición específica relativa a la situación de los refugiados obligados a huir de su país, únicamente aplicable a dicho colectivo.

La argumentación del Abogado General se insertaba en esta misma línea ${ }^{1022}$. A su entender, la cuestión de si el vínculo familiar había sido creado antes o después de que el reagrupante entrara en el Estado de acogida no proporcionaba una base para aplicar umbrales de renta diferentes en situaciones que resultaban comparables. Tal distinción no se fundamentaba en ningún factor objetivo relacionado con el nivel de recursos requerido para mantener al reagrupante y a su familia y, además, era aplicada sin tener en cuenta las circunstancias de cada caso concreto.

1019 En el mismo sentido, VVAA. “Notes on the Case Law Discussion of 23 March 2010”. Europa Institute, Leiden University, 2011, op. cit., s.p., donde se señala que "aunque ninguno de los EEMM intervinientes expuso el argumento, una importante razón detrás de la política holandesa disuasoria de la formación familiar parece haber sido evitar la entrada de "novias importadas". El hecho de que muchos inmigrantes holandeses de segunda generación se casen con parejas procedentes de sus países de origen, frecuentemente se considera que ralentiza la integración de estos inmigrantes, en vista de que las esposas desconocen la lengua y cultura holandesas", (traducción propia).

1020 Así se deduce de lo establecido en el apartado 50 de las conclusiones del Abogado General, a lo que éste responde que "aunque se asumiera que es una premisa válida (posiblemente, sobre la base de que impide los matrimonios de conveniencia), sigue requiriendo un examen individual”.

1021 En apoyo de esta consideración alegaban el sexto considerando y el artículo 2, letra d) de la Directiva 2003/86/CE sobre RF, así como un documento de la Presidencia del Consejo (documento del Consejo 5682/01, de 31 de enero de 2001, p. 3), que demostraba la existencia, durante la elaboración de dicha norma, de un amplio acuerdo sobre el hecho de que la RF debía incluir tanto la constitución como el mantenimiento de la unidad familiar.

1022 El apartado 51 de las conclusiones del Abogado General afirma literalmente en torno a este punto: "No considero que se pueda trazar ninguna distinción objetiva de manera sistemática entre dos nacionales de países terceros que desean vivir en un Estado miembro para trabajar y formar una familia allí, uno de los cuales contrae matrimonio antes de emigrar mientras que el otro ahorra para contraerlo durante una visita a su país de origen. La diferencia entre los dos podría depender, por ejemplo, únicamente en la voluntad de los padres de la novia en aceptar o no a un yerno que aún no es económicamente independiente". Sobre la base del principio de igualdad de trato, el Abogado General negaba la existencia de fundamentación objetiva para el establecimiento de un trato más favorable en el caso de que el sponsor hubiese contraido matrimonio antes de emigrar. En palabras del Abogado General: "no parece existir ningún fundamento que pueda justificar establecer un requisito de recursos más elevado en un supuesto que en otro. El importe necesario para el mantenimiento del reagrupante y de su familia sin recurrir a la asistencia social — que es lo que el artículo 7, apartado 1, letra c), autoriza a los Estados miembros a exigir- puede, naturalmente, verse afectado por varios factores, como el número de miembros de la familia y sus edades, sus necesidades asistenciales o su capacidad de trabajar. Pero, sea cual sea el importe, en condiciones normales no puede verse afectado por el hecho de que el vínculo familiar se creara antes o después de que el reagrupante se convirtiera en residente legal en el Estado de acogida." (Apartado 42 de las Conclusiones del Abogado General). 
La argumentación desplegada por la Corte de Luxemburgo sigue en esencia las consideraciones apuntadas por la recurrente en el litigio principal quien, como señalamos, había sido apoyada por la Comisión y el Adobado General. A juicio del TJUE, la definición de RF contenida en el artículo 2, letra d. de la Directiva no realiza distinciones según el momento de celebración del matrimonio de los cónyuges ${ }^{1023}$, lo que supondría la inclusión - y protección-, dentro de dicho concepto tanto de la RF en sentido estricto como de la formación familiar. Únicamente el artículo 9, en su apartado segundo, establece una diferenciación como la señalada, si bien "esta disposición se explica por el trato más favorable concedido a los refugiados a su llegada” ${ }^{1024}$. Sobre estas dos bases, el Tribunal de Luxemburgo concluye que:

"De ello se deduce que las reglas de la Directiva, excepto su artículo 9, apartado 2, son aplicables tanto a lo que la normativa neerlandesa califica como reagrupación familiar cuanto a lo que define como constitución de una familia"1025.

En auxilio de esta visión amplia de la migración familiar, el TJUE acude al considerando sexto de la Directiva ${ }^{1026}$ - que incluye tanto el mantenimiento de la unidad familiar como la creación de vida familiar-, así como a los trabajos preparatorios de dicha norma, que fueron citados por la recurrente. Añadiendo además que la interpretación expuesta, "es conforme con el artículo 8 del CEDH y con el artículo 7 de la Carta, que no establecen distinción alguna según las circunstancias y el momento en los que se constituye una familia"1027.

Esta alusión a la jurisprudencia del TEDH en materia de RF resulta algo superficial. Un análisis detallado de la misma revela que tanto la vida familiar previa como la proyectada ${ }^{1028}$ son consideradas a efectos de la aplicabilidad del art. $8 \mathrm{CEDH}$, sin embargo se protegían de forma preferente los lazos preexistentes. En la sentencia Sen - precisamente cuando se pueda hablar del alumbramiento de un débil derecho implícito a la RF en el ámbito de Estrasburgo-, se observa una clara delimitación de los supuestos de migración familiar, favorable en principio a otorgar en exclusiva un trato protector a los vínculos familiares previos a la entrada del reagrupante en el país receptor, esto es, a la RF en sentido estricto. Con todo, a partir de Rodrigues da Silva se contemplan ya, dentro del círculo de vínculos familiares protegidos, también aquellos creados con posterioridad al establecimiento del principal en el Estado parte - incluso en ausencia de matrimonio formal ${ }^{1029}$ - En consecuencia, si bien tradicionalmente la jurisprudencia de Estrasburgo otorgó un tratamiento preferente a la RF en sentido estricto, en detrimento de los supuestos de formación matrimonial ${ }^{1030}$, la última línea jurisprudencial ha protegido de forma inequívoca también la migración matrimonial.

1023 El tenor literal del apartado 59 es el siguiente: "El artículo 2, letra d), de la Directiva define la reagrupación familiar sin realizar distinciones según el momento del matrimonio de los cónyuges, dado que precisa que se entiende por dicha reagrupación la entrada y residencia en el Estado miembro de acogida de los miembros de la familia con el fin de mantener la unidad familiar, «con independencia de que los vínculos familiares sean anteriores o posteriores a la entrada del reagrupante».

1024 Apartado 60, asunto Chakroun.

1025 Apartado 61, asunto Chakroun.

1026 El considerando sexto de la Directiva señala que: “Con el fin de garantizar la protección de la familia, así como el mantenimiento o la creación de la vida familiar, es importante fijar, según criterios comunes, las condiciones materiales para el ejercicio del derecho a la reagrupación familiar".

1027 Apartado 63, sentencia Chakroun.

1028 Vid. STEDH Abdulaziz, Cabales y Balkandali c. Reino Unido.

1029 Vid. STEDH Rodrígues da Silva y Hoogkkamaer c Países Bajos, de 31 de enero de 2006.

1030 De forma igualmente tajante sobre este punto se manifiesta WIESBROCK, Anja. "Court of Justice of the European Union. The Right to Family Reunification to Third-Country Nationals...”, op. cit., p. 474. 
En otras palabras, la jurisprudencia tradicional de Estrasburgo, estudiada con detenimiento, solía actuar en dirección exactamente opuesta a la visión que el TJUE extrae de la interpretación del artículo $8 \mathrm{CEDH}$ por parte del TEDH. En este punto pues, las observaciones del TJUE resultan claramente progresistas, apuntándose a la más reciente tendencia jurisprudencial del TEDH y llegando incluso a forzar el propio tenor literal de la Directiva 2003/86. Ya explicamos en su momento que el artículo 9.2 de esta norma, a nuestro entender daba pie para extraer la existencia de una diferenciación en el ámbito de tutela según el momento de constitución de los vínculos familiares, por no hablar de la existencia de una cierta priorización de la RF en sentido estricto a lo largo del articulado de la Directiva. Con todo ello en mente, se podrá comprender la importancia y novedad del planteamiento del TJUE en el asunto Chakroun, cuando sostiene que:

\footnotetext{
"Habida cuenta de esta falta de distinción, querida por el legislador de la Unión, en función del momento en el que se constituye la familia, y dada la necesidad de no interpretar las disposiciones de la Directiva de manera restrictiva y de no privarlas de su efecto útil, los Estados miembros carecen de un margen de apreciación que les permita introducir esta distinción en la normativa nacional de adaptación del Derecho interno a la Directiva (véase, por analogía, la sentencia de 25 de julio de 2008 Metock y otros, apartado 93). A mayor abundamiento, la aptitud de un reagrupante para disponer de recursos regulares y suficientes para su propia manutención y la de su familia, en el sentido del artículo 7, apartado 1, letra c), de la Directiva no depende de ningún modo del momento en el que se constituyó su familia"1031.
}

Al derrumbar la distinción a efectos de su tratamiento normativo entre RF en sentido estricto y migración matrimonial, el TJUE recurre nuevamente a la interpretación analógica. En esta ocasión, cita la sentencia Metock, emitida en el ámbito de la RF — pero relativa a los familiares no comunitarios de ciudadanos comunitarios-, como refuerzo interpretativo en apoyo de la inexistencia de la distinción entre las dos formas migratorias señaladas.

En base a las consideraciones apuntadas, el TJUE responde a la segunda cuestión planteada por el Consejo de Estado Holandés, afirmando que resulta contraria a la Directiva sobre el derecho a la RF, una normativa interna que establezca requisitos de ingresos diferenciados según el momento de constitución de los vínculos familiares.

"La Directiva 2003/86, y, en particular, su artículo 2, letra d), debe interpretarse en el sentido de que se opone a una normativa nacional que, al aplicar los requisitos de ingresos establecidos en el artículo 7, apartado 1, letra c), de la Directiva 2003/86, realiza una distinción en función de que los vínculos familiares sean anteriores o posteriores a la entrada del reagrupante en territorio del Estado de acogida"1032.

De esta forma, el Tribunal de Luxemburgo realiza una considerable aproximación del régimen jurídico de la RF en sentido estricto, tradicionalmente más favorable, respecto de los supuestos de migración matrimonial. La respuesta del TJUE no deja a lugar a dudas en torno a la equiparación entre los dos supuestos clásicos integrantes de la migración familiar —al menos en lo que al régimen económico se refiere, esto es, a la disposición de recursos fijos y regulares suficientes para la manutención propia y de su familia, potestativamente exigibles al examinar la solicitud - tanto si el vínculo familiar es previo a la instalación del reagrupante en el EM, como si es posterior. 


\subsection{Principales aportaciones de la sentencia Chakroun y sus implicaciones sobre el entendimiento de la RF de los extranjeros no comunitarios}

1. Con un tenor más contundente al empleado en su sentencia previa en torno a la Directiva sobre la RF —donde clarificó la naturaleza preceptiva de la obligación estatal establecida en el artículo 4.1 de conceder la RF a los extranjeros que cumplieran con sus requisitos ${ }^{1033}$-, el TJUE en Chakroun extrae de esta norma la existencia de una regla general a cargo de los EEMM de autorización de la RF. Dicha regla implica que los requisitos que gravan el ejercicio de este derecho - contenidos en el Capítulo IV de la Directiva-, han de ser objeto de una interpretación restrictiva, sin menoscabar ni el objetivo de la Directiva - favorecer la RF-, ni su efecto útil ${ }^{1034}$.

De forma complementaria a esta regla, el TJUE ha deducido que el objetivo de la Directiva 2003/86 es favorecer la RF. El objetivo de una norma impregna tanto su contenido como el sentido en el que han de ser aplicadas e interpretadas sus disposiciones. Esta circunstancia, analizada con detenimiento, está a llamada a provocar un impacto nada desdeñable en los EEMM. A la luz del objetivo de favorecer la RF que la Directiva persigue — tal y como señala con rotundidad el TJUE-, deberán ser supervisadas todas aquellas medidas limitativas del ejercicio del derecho a la RF implementadas por los EEMM ${ }^{1035}$ - cuya imposición constituye una marcada tendencia dentro de algunos países europeos ${ }^{1036}$.

Si conjugamos ahora estas dos aportaciones — la regla general y el objetivo de la Directiva-, resulta que, de esta interpretación de la Corte de Luxemburgo, se deduce con claridad que "las posibilidades de los EEMM de imponer condiciones a los nacionales de terceros países que desean reunirse con los miembros de sus familias que residen fuera han de ser interpretadas estrictamente"1037. De forma derivada, se deduce la necesidad de un escrutinio judicial intenso - tanto por parte del poder judicial interno como desde instancias supranacionales - sobre las restricciones nacionales al ejercicio del derecho a la RF. Lo que, obviamente, constituye un espaldarazo definitivo a la consolidación del derecho a la RF de los nacionales extracomunitarios en el ámbito comunitario. Además, esta interpretación, claramente garantista y reductora del margen nacional de apreciación ${ }^{1038}$, vendría a contrarrestar el escaso número de disposiciones vinculantes contenidas en la Directiva 2003/86 ${ }^{1039}$, pudiendo tener el potencial de neutralizar ciertas tentaciones restrictivas estatales —en vista de que las medidas concretas en que se plasmen tales tentativas habrán de justificarse ${ }^{1040}$ a la luz del objetivo de facilitar la RF y su efecto útil.

1033 Sentencia TJUE, de 27 de junio de 2006, Parlamento/Consejo, Asunto C-540/03; apartado 60.

1034 Apartados 43 y 44 de la sentencia Chakroun.

1035 Idem.

1036 Tras estudiar la legislación migratoria de los 27 EEMM, un estudio emprendido el año 2008 y patrocinado por el Parlamento Europeo y por la Organización Internacional delas Migraciones concluye la existencia de un clara tendencia a la restricción dela RF, especialmente mediantela imposición de requisitos de integración. International Organisation for Migration and European Parliament. Comparative Study of the Laws in the 27 EU Member States for Legal Immigration including an assessment of the conditions and formalities imposed by each Member State for newcomers. Febraury 2008, p. 66. Disponible en http://www.iom.int/jahia/webdav/shared/shared/mainsite/law/legal_immigration_en.pdf

1037 WIESBROCK, A. “ECJ. The Right to Family Reunification of Third-Country National...”, op. cit., p. 467.

1038 PASCOUAU, Yves; LABAYLE, Henry. Conditions for Family Reunification under Strain. A comparative study in nine EU member states, op. cit., p. 77.

1039 Idem, p. 479.

1040 PASCOUAU, Yves; LABAYLE, Henry. Conditions for Family Reunification under Strain. A comparative study in nine EU member states, op. cit., p. 23, si bien los autores emiten esta opinión al analizar las tentativas de algunos EEMM de incrementar las edades mínimas a efectos de la reunion de los cónyuges. 
2. Por primera vez la Corte de Luxemburgo aplica de forma concreta y depura las consecuencias derivadas de la cláusula transversal contenida en el artículo 17 de la Directiva, delimitando con claridad sus implicaciones sobre los sistemas administrativos establecidos por los EEMM para la evaluación y rechazo de las solicitudes de RF planteadas por nacionales de terceros países ${ }^{1041}$ : Quedan rotundamente excluidos sistemas que impidan el examen individualizado de las peticiones de RF dando con ello recepción de forma clara y manifiesta a lo que constituye jurisprudencia consolidada del TEDH desde las primeras sentencias emitidas en materia de RF.

Como consecuencia dimanante, se proscribe la utilización por parte de los EEMM de umbrales de renta o ingresos mínimos en el examen de las solicitudes de RF que actúen con carácter absoluto o sistemático, excluyendo el examen individual de las mismas. Tales umbrales solamente pueden actuar a modo de importes de referencia, pero no pueden implicar por su mera existencia el rechazo sistemático de las peticiones formuladas ${ }^{1042}$, lo que exige al EM la existencia preceptiva de sistemas administrativos que aseguren el examen caso por caso de las solicitudes de RF. En consecuencia, no es legítimo que el EM rechace una solicitud de RF por el único motivo de que los solicitantes no alcancen a cumplir los requisitos económicos internos ${ }^{1043}$. El examen individualizado ha de determinar si los solicitantes disponen de recursos estables, suficientes y regulares para cubrir sus necesidades y las de sus familiares dependientes, teniendo además en cuenta - como el propio TJUE aclara-, que las necesidades son variables en función de los sujetos implicados, el número concreto de miembros de la familia y el contexto específico de quienes la integran ${ }^{1044}$.

Estas consideraciones, reveladoras tanto de la influencia de Estrasburgo como del cambio de actitud del TJUE - la propia redacción del artículo 17 constituye una penetración en la Directiva sobre RF de la jurisprudencia del TEDH en torno a la vida familiar de los extranjeros-, están cargadas de implicaciones prácticas al interior de los EEMM ${ }^{1045}$. De hecho, resultaría pertinente, a la luz de esta interpretación, un examen detallado de hasta qué punto los EEMM están cumpliendo, en sus sistemas administrativos internos, con las obligaciones dimanantes de la Directiva 2003/86 ${ }^{1046}$.

3. El TJUE aboga por una concepción amplia de la migración familiar, que abarca y tiende a nivelar - al menos en lo que respecta a las condiciones económicas exigibles al evaluar la solicitud de RF-, la RF en sentido estricto y la formación familiar o migración matrimonial. Sobre este punto, el TJUE concluye que las reglas establecidas en la Directiva 2003/86 son aplicables tanto a la RF como a la migración matrimonial. Al equilibrar la RF en sentido estricto y la formación familiar, el TJUE

1041 En el mismo sentido, WIESBROCK, A. The Right to Family Reunification of Third-Country National under EU Law; Decision of 4 March 2010, Case C-578/08..., op. cit., p. 477.

1042 La misma interpretación en KUNOY, Bjørn; MORTANSSON, Bardur. "Case C-578/08, Rhimou Chakroun v. Minister van Buitenlandse Zaken, Judgment of the European Court of Justice (Second Chamber) of 4 March 2010", op. cit., p. 1827. También en PASCOUAU, Yves; LABAYLE, Henry. Conditions for Family Reunification under Strain. A comparative study in nine EU member states, op. cit., p. 82.

1043 PASCOUAU, Yves; LABAYLE, Henry. Conditions for Family Reunification under Strain. A comparative study in nine EU member states, op. cit., p. 82.

1044 Idem, los autores reiteran la doctrina del TJUE — "las necesidades pueden variar enormemente dependiendo de los individuos"-, puntualizando que las necesidades de una pareja adulta de 60 años — como los demandantes en el asunto Chakroun-, son claramente diferentes a aquellas derivadas de una pajeja joven.

1045 En idéntico sentido, VVAA. "Notes on the Case Law Discussion of 23 March 2010”. Europa Institute, Leiden University, 2011, op. cit., s.p.

1046 En el mismo sentido, PASCOUAU, Yves y LABAYLE, Henry, quienes se ocupan de coordinar un trabajo colectivo que indaga en las condiciones para el ejercicio de la RF establecidas en 9 EEMM - Bélgica, España, Francia, Alemania, Polonia, Portugal, Eslovenia, Suecia y Holanda-. Conditions for Family Reunification under Strain. A comparative study in nine EU member states, op. cit., p. 82. 
está estableciendo una "norma unificada para la protección de la vida familiar"1047 de los extranjeros, con independencia del momento cronológico de constitución de sus vínculos familiares.

Si esta idea se pone en relación con la regla general de concesión de la RF — concebida en sentido amplio-, que la Corte de Luxemburgo dedujo del artículo 4.1 de la Directiva, así como con el objetivo de facilitar la RF ésta que persigue —señalado también por el TJUE—, resultaría que dicha regla debe ser aplicable a los diversos supuestos integrantes de la migración familiar, debiendo estar dirigidas, sus normas reguladoras, al cumplimiento de dicho objetivo. En consecuencia, el EM está obligado a realizar una interpretación restrictiva de las derogaciones al derecho, tanto de la RF como de la formación familiar. Nuevamente esta interpretación desemboca en una extraordinaria potenciación del derecho a la vida familiar de los extranjeros procedentes de terceros países en el ámbito comunitario, especialmente por sus efectos disuasorios sobre la habitual tendencia estatal a obstaculizar la migración matrimonial.

4. La Corte de Luxemburgo no aclara en profundidad el alcance de la ilegitimidad de las normativas internas que establezcan una distinción entre la RF en sentido estricto y la formación familiar, no quedando nítida si la misma es general o, más bien, se circunscribe a la prohibición de imponer requisitos económicos diferenciados. A nuestro entender, del razonamiento de la TJUE no cabe deducir una prohibición genérica de tratamientos normativos diferenciados - cualesquiera que éstos sean- entre la RF y la migración matrimonial ${ }^{1048}$. Más modestamente, la sentencia Chakroun es tajante respecto al alcance puntual de la prohibición de distinción entre ambas figuras, restringida a la exigencia de requisitos de ingresos diferenciados.

No cabría en principio extrapolar reflexiones de tenor similar —esto es de carácter absolutamente equiparador-, en supuestos de políticas internas que mantengan la diversificación de exigencias entre la RF en sentido estricto y la formación familiar, en ámbitos diversos a los puramente económicos ${ }^{1049}$. La legitimidad de normativas nacionales que incluyan requisitos de integración más estrictos en el supuesto de migración matrimonial, a modo de ejemplo, o el controvertido requisito de exigir un período previo de duración del matrimonio y/o de edad de los cónyuges antes de admitir su reagrupación en el EM — exigencia que, a efectos prácticos, resulta mayoritariamente aplicable a los supuestos de vínculos familiares constituidos con posterioridad a la entrada del reagrupante en el país receptor-, en principio parecen compatibles con la Directiva 2003/86 ${ }^{1050}$, pero no obsta un pronunciamiento posterior del TJUE que ahonde en la senda equiparadora emprendida en el asunto

1047 WIESBROCK, A. “ECJ. The Right to Family Reunification of Third-Country National...”, op. cit., p.

1048 Apartado 66 de la Sentencia Chakroun, donde el TJUE responde a la segunda cuestión prejudicial planteada, señalando que la Directiva, y, en particular, su artículo 2, letra d), debe interpretarse en el sentido de que se opone a una normativa nacional que, al aplicar los requisitos de ingresos establecidos en el artículo 7, apartado 1, letra c), de la Directiva, realiza una distinción en función de que los vínculos familiares sean anteriores o posteriores a la entrada del reagrupante en territorio del Estado de acogida".

1049 Si bien la legislación holandesa, con posterioridad a la emisión de la sentencia Chakroun, abolió totalmente la distinción entre RF y constitución familiar. Tal modificación, a nuestro entender, no se deduce como consecuencia obligada de este pronunciamiento, habiendo bastado para cumplir con lo establecido por el TJUE con abolir el requisito del nivel de ingresos equivalente al 120\% del salario mínimo, a fin de equiparar los requisitos económicos aplicables a ambas categorías migratorias.

1050 En contra de la opinión manifestada en el texto se sitúa WIESBROCK, Anja. "Court of Justice of the European Union. The Right to Family Reunification to Third-Country Nationals under EU Law; Decision of 4 March 2010, Case C-578/08..., op . cit., p. 475. También a favor de la equiparación de los regímenes jurídicos de la RF y de la migración matrimonial, citando como referencia el apartado 66 de la sentencia Chakroun — que, como señalamos, se ciñe específicamente al requisito de ingresos-, se manifiestan PASCOUAU, Yves; LABAYLE, Henry. Conditions for Family Reunification under Strain. A comparative study in nine EU member states, op. cit., p. 20. 
Chakroun. La interpretación contraria a la propuesta - a la que pareció inscribirse Holanda, país que procedió a abolir totalmente la distinción entre ambas figuras con posterioridad a esta sentencia-, tendría un alcance casi revolucionario, implicando el cuestionamiento de las bases sobre las que se asienta la migración familiar, y supondría por ello la necesidad de reformas de amplio espectro dentro de muchos EEMM — quizás muchas de ellas altamente cuestionables desde la perspectiva nacional-.

5. Chakroun muestra de forma palmaria la labilidad de las fronteras entre tipologías migratorias, concretamente, de las categorías integrantes de la migración familiar, y lo absurdo que supone la aplicación rígida de límites divisorios. En este caso, la demandante en el litigio principal llevaba casada 37 años con el reagrupante, resultando inoportuno el esquema rígido de conceptualización migratoria basado en el momento temporal concreto de celebración del matrimonio, y más dado que el mismo desembocaba en la negación de un derecho que resultaba claramente predicable de la recurrente. Adicionalmente, la Sra. Chakroun - conforme a lo establecido en el recurrentemente citado artículo 4.1 de la Directiva, de redacción claramente imperativa-, constituía un miembro preceptivo de la familia, a quien los EEMM tienen la obligación positiva de autorizar su entrada y residencia, siempre que se cumplan las condiciones establecidas en el Capítulo IV y en el artículo 16 de la norma comunitaria. Esta última disposición excluye los matrimonios de conveniencia, circunstancia que en ningún modo era aplicable al matrimonio Chakroun, como revela una rápida lectura tanto de la sentencia como de sus antecedentes judiciales- donde en ningún momento el gobierno holandés puso en duda la legitimidad del tal matrimonio-.

6. Al resolver las dos cuestiones prejudiciales que le fueron planteadas, el TJUE recurre por primera vez a la interpretación analógica con dos sentencias emitidas en el ámbito de la libre circulación de los trabajadores comunitarios y de sus familias - Ernid y Metock, respectivamente-, para clarificar tanto el concepto de requisitos económicos como la ilegitimidad de la distinción entre formas migratorias familiares según el momento temporal de constitución de los vínculos familiares, a efectos de imponer exigencias económicas distintas. Analizaremos por separado ambas referencias para, posteriormente, extraer algunas conclusiones conjuntas de esta nueva actitud del TJUE:

a) Interpretación del concepto de "recursos suficientes" para el ejercicio de la RF de los nacionales extracomunitarios, citando la sentencia Ernid: En el ámbito doctrinal ${ }^{1051}$ el recurso del TJUE a Ernid ha hecho surgir la cuestión de si cabría deducir que el concepto de recursos estables y suficientes aplicable en el ámbito de la Directiva 2003/86, ha de interpretarse en sentido analógico a como tal concepto está establecido en la Directiva 2004/38/CE aplicable en el ámbito de la libre circulación de los trabajadores comunitarios y de los miembros de sus familias - la conocida como Directiva europea de Libre circulación. Conforme a esta última norma, se estiman suficientes los recursos necesarios, con independencia de su origen ${ }^{1052}$, lo que permite tomar en consideración los recursos del cónyuge o pareja, dentro del cómputo de los recursos del sponsor.

Esta cuestión permanece confusa, no siendo posible deducir su respuesta en base al escueto razonamiento empleado por la Corte de Luxemburgo en este asunto. Sin embargo, conviene retener que el estatus de ambos colectivos reposa en una importante diferencia jurídico-cualitativa: mientras que los nacionales comunitarios disfrutan de un estatus fundamental por ser titulares de una

1051 WIESBROCK puntualiza que, al referirse a la sentencia Ernid, el TJUE no solamente está comparando a los nacionales de terceros países con los ciudadanos comunitarios en general, sino con un grupo específico dentro de estos últimos, que son los comunitarios económicamente inactivos. "CJEU. The Right to Family Reunification of Third-Country National under EU Law; Decision of 4 March 2010, Case C-578/08..., op. cit., p. 474.

1052 Caso C-200/02 Zhu and Chen, (2004), TJUE I-9925, apartado 30. Citado por WIESBROCK, op. cit., p. 474. 
libertad comunitaria consagrada en los Tratados originarios - la libre circulación de los trabajadores comunitarios y los miembros de sus familias-, los nacionales extracomunitarios disfrutan de un derecho que ha sido reconocido en una norma de carácter secundario -la Directiva 2003/86/ $\mathrm{CE}$ sobre $\mathrm{RF}^{1053}$ - , y que, en consecuencia, carece del estatus jurídico fundamental predicable del anterior colectivo.

b) Al resolver la segunda de las cuestiones planteadas, el TJUE hace referencia a la sentencia Metock. En el asunto Metock ${ }^{1054}$, la Corte de Luxemburgo resolvió una petición de decisión prejudicial en torno a la Directiva 2004/38/CE relativa al derecho de los ciudadanos de la Unión y de los miembros de sus familias a circular y residir libremente en el territorio de los Estados miembros ${ }^{1055}$. La cuestión principal a resolver giraba en torno a cómo debía aplicarse internamente esta norma a los cónyuges extracomunitarios de ciudadanos europeos que habían hecho uso de su derecho a la libre circulación, y residían en un tercer país distinto al de su nacionalidad - el denominado EM de acogida-. Resumidamente, el TJUE concluyó que el cónyuge extranjero de un ciudadano comunitario podía acogerse a la Directiva mencionada "independientemente del lugar y la fecha en que contrajo matrimonio y del modo en que el citado cónyuge entró en el Estado miembro de acogida"1056, estimando además incompatible con dicha norma que el ejercicio del derecho a la RF de tales personas se hiciese depender de la residencia legal previa del cónyuge en otro Estado miembro - exigencia que había sido impuesta por las legislaciones de Dinamarca, Irlanda, Finlandia y Reino Unido.

1053 WIESBROCK, . “CJEU. The Right to Family Reunification of Third-Country...”, op. cit, p. 476.

1054 Asunto Metock, sentencia de 25 de Julio de 2008. Case C-127/08, Blaise Baheten Metock and Others v. Minister for Justice, Equality and Law Reform. En el origen del asunto Metock, se sitúa una demanda contra Irlanda planteada por cuatro nacionales extracomunitarios casados con ciudadanos comunitarios residentes en Irlanda - ninguno de tales matrimonios había sido considerado de conveniencia por el tribunal nacional de referencia- a quienes se había denegado la entrada y residencia en dicho país porque carecerían de una residencia legal previa junto a su cónyuge en otro EM. Esta sentencia suscitó bastante controversia en algunos Estados miembros, especialmente en Dinamarca, donde se sugirió que se había creado una posibilidad de eludir la legislación migratoria, lo que podría facilitar a los nacionales de terceros países «regularizar» su situación contrayendo matrimonio con un ciudadano de la UE. Sin embargo, en Metock el TJUE recordó que la Directiva 2004/38/CE no impide a los Estados miembros luchar contra el abuso de los derechos comunitarios, incluidos los matrimonios de conveniencia. En torno a esta sentencia, vid. FAHEY, Elaine. "Going Back to Basics: Re-embracing the Fundamentals of the Free Movement of Persons in Metock Case C-127/08, Metock \& others v. Minister for Justice, Equality \& Law Reform, Judgment of the European Court of Justice of 25 July 2008”; en Legal issues of economic integration, Vol. 36, № 1, 2009, pp. 83-89. ELSMORE, Matthew; STARUP, Peter. "European Court of Justice: Metock and Others - Introductory Note"; en International legal materials, No 6, 2008, pp. 858-874. COSTELLO, Cathryn. "Metock: Free movement and "normal family life" in the Union"; en Common market law review, Vol. 46, № 2, 2009, pp. 587-622. CURRIE, Samantha. "Accelerated justice or a step too far? Residence rights of non-EU family members and the Court's ruling in Metock"; en European law review, № 2, 2009, pp. 310-326.

1055 La Directiva mencionada se aplica cuando el nacional comunitario ha hecho uso de su derecho a la libre circulación y está residiendo en un EM distinto al de su nacionalidad, en cuyo caso también sus familiares no comunitarios tienen derecho a residir con su cónyuge en el nuevo EM.

1056 El tenor literal del fallo emitido en el asunto Metock es el siguiente: “1) La Directiva 2004/38/CE del Parlamento Europeo y del Consejo, de 29 de abril de 2004, relativa a derecho de los ciudadanos de la Unión y de los miembros de sus familias a circular y residir libremente en el territorio de los Estados miembros (...), se opone a una normativa de un Estado miembro que exige del nacional de un tercer país, cónyuge de un ciudadano de la Unión que reside en ese Estado miembro del que no tiene la nacionalidad, que haya residido con carácter previo legalmente en otro Estado miembro antes de su entrada en el Estado miembro de acogida para poder acogerse a las disposiciones de esa Directiva; 2) El artículo 3, apartado 1, de la Directiva 2004/38 debe interpretarse en el sentido de que el nacional de un tercer país, cónyuge de un ciudadano de la Unión que reside en un Estado miembro del que no tiene la nacionalidad que acompaña o se reúne con ese ciudadano puede acogerse a las disposiciones de esa Directiva, independientemente del momento o del lugar en el que hubieran contraído matrimonio o de las circunstancias en que ese nacional del tercer país hubiera entrado en el Estado miembro de acogida”. 
El recurso en el asunto Chakroun - por partida doble-, a la interpretación analógica con la doctrina extraída en el ámbito de la libre circulación de los trabajadores comunitarios, constituye un exponente claro del cambio de actitud del TJUE —el más revelador, pues es la primera vez que la Corte de Luxemburgo utiliza este recurso exegético en el ámbito de la RF de los nacionales extracomunitarios-. Las referencias a los asuntos Enrid y Metock, junto a la similitud de las conclusiones a las que llega el TJUE, parecen dar a entender que la Corte de Luxemburgo pretende extender su concepción amplia de las libertades circulatorias a todos los individuos afectados por el derecho comunitario, incluyendo a los nacionales de terceros Estados ${ }^{1057}$. De ser ello cierto, supondría el inicio de una tendencia hacia el acercamiento entre los regímenes jurídicos de RF aplicables a los nacionales de terceros países y a los nacionales comunitarios ${ }^{1058}$, tradicionalmente separados. Ello constituye, con diferencia, la perspectiva más innovadora de esta sentencia.

El TJUE parece haber retomado el ya lejano objetivo proclamado en el Consejo Europeo de Tampere, de octubre de 1999, de aproximar el estatuto de los nacionales de terceros países a aquel del que gozan los ciudadanos comunitarios, otorgándoles derechos comparables - circunstancia que resulta obvia en las dos cuestiones a las que da respuesta la Corte de Luxemburgo-. Parecería con ello inaugurarse una nueva época en el derecho comunitario de extranjería e inmigración —al menos en lo que respecta a la migración familiar, categoría predominante en las entradas de extranjeros- que, de confirmarse, carecería de precedentes en el derecho de la Unión.

Si ahora retomamos todas las aportaciones de esta sentencia, en conjunción con la trascendencia inherente a las cuestiones prejudiciales planteadas, así como la perspectiva pro efecto útil adoptada por el TJUE — claramente favorable al derecho a la RF y los intereses privados que protege-, se comprenderá la importancia del pronunciamiento Chakroun ${ }^{1059}$, llamado a provocar consecuencias directas de amplio alcance - y bien pragmáticas - a nivel interno, como revela palmariamente lo sucedido en los Países Bajos al poco de dictarse esta sentencia. En dicho país, el umbral establecido en torno al 120\% del salario mínimo fue eliminado rápidamente pero, junto a esta medida — derivada

1057 VVAA. "Notes on the Case Law Discussion of 23 March 2010”. Europa Institute, Leiden University, 2011, op. cit., s.p.

1058 Sobre este aspecto KUNOY y MORTANSSON concluyen que "con este juicio la Corte parece haber extendido su decisión en Metock a nacionales de terceros países", añadiendo posteriormente que "mediante su fallo en Chakroun, las reglas que rigen la RF de nacionales de terceros países residentes legales en un EM, aunque permaneciendo inconfundibles, están siendo continuamente aproximadas a aquellas que gobiernan el derecho a la RF de ciudadanos de la Unión cuyos familiares son nacionales de terceros países". "Case C-578/08, Rhimou Chakroun v. Minister van Buitenlandse Zaken, Judgment of the European Court of Justice (Second Chamber) of 4 March 2010”, op. cit., pp. 1816 y 1824 , respectivamente.

1059 La trascendencia del pronunciamiento Chakroun ha sido puesta de manifiesto de forma unánime por la doctrina que se ha ocupado de su estudio. Vid, WIESBROCK, quien señala literalmente que "aparte de la implementación holandesa del requisito de los recursos y de la distinción entre los casos de formación familiar y RF, el caso Chakroun eleva cuestiones de una naturaleza más general: ¿Cuáles son las limitaciones a la discreción nacional al imponer restricciones al ejercicio de los derechos garantizados a los nacionales de terceros países?; ¿Hasta qué punto pueden y deben los derechos de los nacionales de terceros países ser interpretados analógicamente a los derechos de los ciudadanos de la Unión?; ¿Cuáles son las implicaciones del creciente número de derechos concedidos a los nacionales extracomunitarios bajo el derecho comunitario, para el concepto de discriminación inversa?; ¿Cuál es el impacto de los principios generales del derecho comunitario sobre los derechos de los nacionales de terceros países?. WIESBROCK, Anja. "Court of Justice of the European Union. The Right to Family Reunification to ThirdCountry Nationals under EU Law; Decision of 4 March 2010, Case C-578/08, Rhimou Chkaroun V. Minister van Buitenlandse Zake"; en European Constitutional Law Review, n 6, 2010, p. 463. En esta misma línea, se ha señalado que "aunque la sentencia de la Corte en este caso constituye una clara interpretación directa de la Directiva, las consecuencias prácticas de este pronunciamiento no deben ser subestimadas". VVAA. "Notes on the Case Law Discussion of 23 March 2010”. Europa Institute, Leiden University, op. cit., s.p. 
directamente del cumplimiento de la sentencia Chakroun-, se establecieron otras, de gran calibre que, a nuestro entender, no venían directamente exigidas por este pronunciamiento: se abolió también la distinción entre formación familiar y RF - a todos los efectos, no únicamente económicosy, además, tales reformas se extendieron a la reagrupación de los nacionales holandeses ${ }^{1060}$.

Sea como fuere, es patente en esta sentencia el cambio en la perspectiva utilizada por el TJUE; frente a su anterior pronunciamiento, excesivamente contenido y respetuoso con el legislador comunitario, en Chakroun el Tribunal de Luxemburgo se pronuncia claramente a favor de la primacía de los intereses particulares - léase del derecho a la RF-, y realiza un esfuerzo sin precedentes por aplicar parte de la doctrina emitida en el ámbito de la libre circulación de ciudadanos comunitarios, a los nacionales de terceros países. La perspectiva adoptada por la Corte de Luxemburgo implica, para el conjunto normativo regulador de la migración familiar en el ámbito comunitario, que el “juez europeo ha modificado claramente el campo dentro del cual las normas relativas a la RF están operando" ${ }^{\prime 061}$. De hecho, ya se han emitido estudios que han evaluado la compatibilidad de algunas de las normativas internas reguladoras de la RF a la luz de la redefinición de las reglas en esta materia que ha provocado la interpretación efectuada por la Corte de Luxemburgo en el asunto Chakroun ${ }^{1062}$.

Podría especularse, con evidente margen de error, en torno a la causa de este viraje interpretativo, coincidente con una época de declive económico y de cierto descenso de la presión migratoria $-\mathrm{y}$, consecuentemente, también política-. En esta línea especulativa, incluso se ha afirmado que este juicio "podría ser visto como la respuesta a aquellos que en su tiempo reprocharon a la Corte por su excesiva deferencia judicial hacia el legislador"1063.

De otro lado, en Chakroun, el peso de la jurisprudencia de Estrasburgo - simplonamente interpretada por el TJUE, como ya señalamos- aun ocupando un papel relevante, es algo inferior al que la misma desempeñó en su sentencia previa en torno a la Directiva sobre RF. Tratándose de encontrar puntos coincidentes entre sendos pronunciamientos en torno a la Directiva 2003/86/CE, el TJUE profundiza con Chakroun en la senda de restricción del margen de apreciación estatal ${ }^{1064}$ que ya había mostrado, si bien de forma marcadamente más modesta, en la sentencia previa que resolvió el recurso de anulación contra dicha norma.

Esta misma línea de estrechamiento del margen de apreciación nacional resulta también apreciable - y de forma muy evidente-, en el razonamiento del Tribunal de Estrasburgo en torno al derecho a la vida familiar de los extranjeros, especialmente si éste se vislumbra en perspectiva histórico-evolutiva. Conviene no olvidar la relación directamente proporcional que existe entre la reducción de la discrecionalidad estatal y la elevación subsecuente de las garantías individuales y del nivel de escrutinio judicial. De ahí que ya se advierta con fundamento que "el caso Chakroun muestra una vez más que la libertad de los EEMM para regular la migración está crecientemente constreñida por la legislación de la Unión Europea”"1065.

$1060 \mathrm{La}$ entidad concreta de las reformas emprendidas por los Países Bajos con posterioridad a la sentencia Chakroun han sido extraídas del siguiente comentario: VVAA. "Notes on the Case Law Discussion of 23 March 2010”, op. cit., s.p.

1061 PASCOUAU, Yves; LABAYLE, Henry. Conditions for Family Reunification under Strain. A comparative study in nine EU member states, op. cit., p. 8.

1062 Se trata de un estudio colectivo donde se evalúan las legislaciones nacionales en materia de RF de nueve EEMM, entre ellos España, que ha sido citado ampliamente en esta tesis. PASCOUAU, Yves; LABAYLE, Henry. Conditions for Family Reunification under Strain. A comparative study in nine EU member states, op. cit.

1063 VVAA. "Notes on the Case Law Discussion of 23 March 2010”, op. cit., s.p.

1064 WIESBROCK, A. “ECJ. The Right to Family Reunification of Third-Country National...”, op. cit., p. 468.

1065 VVAA. "Notes on the Case Law Discussion of 23 March 2010", op. cit., s.p. 


\section{LA RELACIÓN ENTRE EL ARTÍCULO 8 CEDH Y LA DIRECTIVA COMUNITARIA SOBRE EL DERECHO A LA RF}

La ausencia en los Tratados originarios de normas relativas a los derechos fundamentales propició una jurisprudencia activista por parte del TJUE que fue progresiva construyendo un sistema autónomo de derechos en el ámbito comunitario. Para ello el Tribunal de Luxemburgo recurrió al propio Convenio de Roma, junto a los sistemas constitucionales internos de los EEMM. En una jurisprudencia reiterada, el Tribunal de Justicia estableció que el ordenamiento jurídico comunitario protegía los derechos fundamentales como principios generales del derecho comunitario, tal como se desprendían del CEDH y de la tradición constitucional común a los EEMM. Eventualmente esta línea jurisprudencial garantista de los derechos fundamentales en el sistema comunitario fue confirmada por el preámbulo del Acta Única Europea y posteriormente codificada en el artículo 6.2 TUE ${ }^{1066}$, introducido en 1992 por el Tratado de Maastricht originalmente como artículo F.2. A través de esta disposición - y ya antes, por obra del TJUE—, el CEDH ha pasado a formar parte del acquis comunitario $^{1067}$. Dado que el CEDH incluye la protección de la vida familiar — artículo $8 \mathrm{CEDH}-$ este precepto constituye, en la UE, un principio general del derecho comunitario.

Pero además, el artículo 6.2 TUE indica que, junto al Convenio de Roma, el nivel de respeto que la UE ha de proporcionar a los derechos fundamentales - en tanto que principios generales del derecho comunitario-, está también determinado por aquel extraíble de las tradiciones constitucionales comunes a los EEMM. Existirían pues dos polos de atención que derivan del artículo 6.2, en su aplicación a nuestro específico ámbito de estudio, a fin de determinar el estándar de protección que la UE ha de dispensar al derecho a la RF de los extranjeros procedentes de terceros países de un lado, el artículo $8 \mathrm{CEDH}$, tal y como es interpretado por el TEDH y, de otro, las tradiciones constitucionales compartidas o convergentes entre los EEMM. Dado que en este apartado nos centraremos sobre el primer polo de atención, conviene detenernos muy brevemente en el segundo, esto es, ¿cabría deducir un derecho a la RF para las personas mencionadas, de las tradiciones constitucionales comunes a los EEMM?.

La primera propuesta de Directiva sobre RF afirmaba explícitamente que aunque las constituciones de varios EEMM sancionan la protección de la familia, sin embargo ninguna de ellas garantiza como tal un derecho a la reunificación familiar ${ }^{1068}$. De hecho este documento enfatizaba las divergencias existentes entre los EEMM ${ }^{1069}$ en la regulación legal del derecho a la reunificación familiar, especialmente en etorno a lementos constitutivos del derecho tales como las condiciones exigibles, los plazos de espera aplicables y los familiares que pueden optar a la reagrupación. Si bien es cierto

1066 El artículo 6.2 TUE afirma literalmente que "la Unión respetará los derechos fundamentales tal y como se garantizan en el Convenio Europeo para la Protección de los Derechos Humanos y de las Libertades Fundamentales firmado en Roma el 4 de noviembre de 1950, y tal y como resultan de las tradiciones constitucionales comunes a los Estados miembros como principios generales del Derecho comunitario".

1067 GROENENDIJK, Kees. “Family Reunification as a Right...”, op. cit., p. 219. El término acquis, de origen francés, literalmente significa "que ha sido adquirido" - por la CE, se entiende, resulta especialmente adecuado para este ámbito de los derechos fundamentales, pues describe la evolución de un cuerpo normativo de derecho comunitario que se ha ido engrosando y aquilatando como consecuencia de adquisiciones procedentes de otros sistemas, tanto del ámbito nacional como del sistema internacional de derechos humanos.

1068 COM (99) 638, FINAL, 5.

1069 Sobre las distintas políticas en materia de inmigración familiar existentes en los EEMM en el período previo a la formulación de la presente directiva comunitaria, vid. Report on family reunfiication: Overview of policies and practices in IGC Participating States. Secretariat of the Inter-Governmental Consultations on Asylum, Refugee and Migration Policies in Europe, North America and Australia. IGC, Génova, marzo de 1997. 
que el derecho existe y ha sido consagrado en algunos países Europeos -llegando incluso en ocasiones a ser derivado del principio constitucional de protección de la familia ${ }^{1070}$-, con carácter general a nivel constitucional no ha sido reconocido ${ }^{1071}$. En definitiva, de las tradiciones constitucionales comunes no cabe extraer, en términos generales, un derecho a la reunificación familiar predicable con carácter general de los ciudadanos extracomunitarios, en tanto que el mismo no puede ser considerado como "común a los EEMM"1072.

\section{1 La doble condición de las disposiciones del Convenio de Roma en el ámbito comunitario}

Siguiendo a Boeles ${ }^{1073}$, los derechos consagrados en el Convenio de Roma ostentan en la UE dos cualidades distintas:

1. De un lado, dado que constituyen disposiciones de un Convenio Internacional suscrito por todos los EEMM de la UE, sus disposiciones vinculan a los EEMM en tanto que partes contratantes de dicho Tratado. Ésta constituye su cualidad "normal"1074. La eficacia jurídica concreta de estas disposiciones dependerá de lo que dispongan al respecto los diversos sistemas constitucionales de los Estados, en función de que se trate de sistemas monistas o dualistas. Conforme a esta primera cualidad, todo individuo que se encuentre bajo la jurisdicción de un EM, con independencia de su nacionalidad, puede basarse en las disposiciones del CEDH si considera que una decisión o acto de las autoridades públicas internas constituye una violación de un derecho convencional, tanto ante los tribunales internos como ante el TEDH cuando haya agotado la jurisdicción nacional. Por lo que respecta al derecho reconocido en el artículo 8 $\mathrm{CEDH}$, esta cualidad ha sido analizada en la primera parte de nuestro trabajo.

2. Pero los derechos consagrados en el CEDH, tal y como han sido interpretados por el TEDH en casos concretos que involucran como demandados a un determinado Estado Parte, han irradiado de forma horizontal al resto de los Estados de la UE, ya que constituyen principios generales del derecho comunitario. Esta es la cualidad que afecta y con la que ha de enfrentarse el Tribunal de Justicia de Luxemburgo al controlar el respeto de los derechos fundamentales por

1070 Así ha sucedido en Alemania, donde además el TC Alemán (Bundesverfassungsgericht) ha dictaminado la inconstitucionalidad del establecimiento de un sistema de cuotas para la reagrupación familiar (B VerfG 12.5.1987, E 76, 1 II). En 1978, el Consejo de Estado francés señaló que la reagrupación familiar constituía un principio general del derecho, si bien con el importante matiz que tan sólo con respecto a aquellos extranjeros que residiesen legalmente en Francia. En sentido similar en 1995, el TC italiano estimó que la reunificación familiar era "un derecho constitucional de los trabajadores". BOELES, Pieter. "Propuesta de Directiva sobre la reagrupación familiar y otras propuestas en el campo de la ley de la inmigración”; Revista CIDOB d’afers internacionals, n 53, 2001, cita a pie de pág. $\mathrm{n}^{\circ} 17$, p. 137.

1071 BOELES, Pieter. "Propuesta de Directiva sobre la reagrupación familiar..., op. cit., p. 128. De ahí que a juicio de este autor resulte "crucial” el propósito de establecer un derecho a la RF para beneficiar a los nacionales de terceros países residentes legales. Ídem, p. 137.

1072 BRINKMANN, GISBERT. “Family Reunion, Third Country Nationals and the Comunity’s New Powers...”, op. cit., p. 244. Para una análisis de la regulación legal de la RF en distintos EEMM, vid., FERNÁNDEZ SÁNCHEZ, Pablo Antonio. Derecho comunitario de la inmigración, op. cit., pp. 233-239.

1073 BOELES, Pieter. "What Rights have Migranting Third-Country Nationals?"; ZWAAN, Jaap W. And GOUDAPPEL, Flora A.N.J (eds.). Freedom, Security and Justice in the European Unión. Implementation of the Hague Programme. The Hague, TMC Asser Press, 2006, pp. 151-163.

1074 BOELES, P. “What Rights have Migranting Third-Country National?...”, op. cit., p. 153. 
las disposiciones y actos comunitarios, tanto en su aplicación a casos concretos ${ }^{1075}$ como cuando se juzga la legalidad en abstracto de normas comunitarias ${ }^{1076}$.

Aplicando estas consideraciones a nuestro objeto de estudio, resulta que el respeto a la vida familiar consagrado en el artículo $8 \mathrm{CEDH}$ refuerza su densidad normativa en el ámbito comunitario mediante las siguientes vías confluyentes:

a) De un lado constituye una disposición vinculante para todos los EEMM, que consagra un derecho que ha de respetarse en el marco de sus políticas migratorias internas. Desde este prisma, las decisiones legislativas de los EEMM adoptadas en el ámbito migratorio, así como la ejecución de las mismas, no deben constituir ni una interferencia ilegítima en el derecho a la vida familiar de los extranjeros asentados en su territorio - protección contra expulsiones o faceta negativa del derecho a la vida familiar-, ni tampoco una falta de respeto a la vida familiar de dichos sujetos - faceta positiva del derecho a la vida familiar, que ampara la reunificación familiar.

b) Por otro lado, mediante el "cauce hermeneútico"1077 configurado por el artículo 6.2 TUCE, el derecho reconocido en el artículo $8 \mathrm{CEDH}$ se erige en un principio general del derecho comunitario $^{1078}$, lo que supone que los actos y normas comunitarios deben respetar el derecho a la vida familiar tal y como es consagrado en el CEDH, y tal y como esta disposición es interpretada por el case law de Estrasburgo ${ }^{1079}$. Así mismo, los actos y normas comunitarios en materia migratoria han de ser interpretados a la luz del CEDH y de la jurisprudencia del TEDH emanada en su aplicación. Y a su vez, los actos y decisiones adoptados por los EEMM al aplicar normas comunitarias en casos particulares, deben ser también conformes a los parámetros establecidos por el artículo 8 y la jurisprudencia de Estrasburgo. En definitiva, la protección de los derechos fundamentales incorpora el derecho al respeto a la vida familiar, en su dimensión migratoria, como principio general del derecho comunitario. La conformidad

1075 Este tipo de asuntos llegará al TJUE en forma de cuestiones prejudiciales planteadas por los Tribunales internos de los EEMM.

1076 Este supuesto da lugar al denominado recurso de anulación.

1077 QUIRÓS FONS, Antonio. Derecho comunitario de extranjería..., op. cit., p. 405.

1078 Caso 4/73 Nold, Sentencia del TJUE del 14 de mayo de 1974, p. 491. En el fundamento 13 de esta sentencia, el TJUE afirma literalmente que "As the Court has already stated, fundamental rights form an integral part of the general principles of law, the observance of which it ensures. In safeguarding these rights, the Court is bound to draw inspiration from constitutional traditions common to the Member States, and it cannot therefore uphold measures which are incompatible with fundamental rights recognized and protected by the constitutions of those states. Similarly, International Treaties for the protection of human rights on which the Member States have collaborated or of which they are signatories, can supply guidelines which should be followed within the framework of community law. The submissions of the applicant must be examined in the light of these principles". En el mismo sentido se exp resa el TJUE en el Caso 260/89 ERT (1991), apartado 41. "The European Court of Justice drags inspiration from the guidelines supplied by International treaties for the protection of human rights on which the Member States have co-operated or of which they are signatories". STJUE de 18 de junio de 1991. También las sentencias de 6 de marzo de 2001, Connolly/Comisión, C-274/99 P, Rec. p. I-1611, apartado 37; de 22 de octubre de 2002, Roquette Frères, C-94/00, Rec. p. I-9011, apartado 25; de 12 de junio de 2003, Schmidberger, C-112/00, Rec. p. I-5659, apartado 71, y de 14 de octubre de 2004, Omega, C-36/02, Rec. p. I-9609, apartado 33

1079 En el apartado 35 de la sentencia que puso fin al recurso de anulación de la Directiva sobre reunificación familiar, el TJUE vuelve a incidir en este aspecto con el siguiente pronunciamiento: "Los derechos fundamentales forman parte de los principios generales del Derecho cuyo respeto garantiza el Tribunal de Justicia. Para ello el Tribunal de Justicia se inspira en las tradiciones constitucionales comunes de los Estados miembros así como en las indicaciones proporcionadas por los instrumentos internacionales relativos a la protección de los derechos humanos con los que los Estados miembros han cooperado o a los que se han adherido. A este respecto el CEDH reviste un significado particular “. STJUE C-540 Parlamento v. Consejo, Apartado 35. 
de las prácticas nacionales respecto a los derechos fundamentales puede ser revisada por los tribunales nacionales, por el TJUE y, en su aplicación a casos concretos dentro de cada EM, también por el TEDH.

c) Existe una consideración adicional que viene a reforzar la importancia del derecho convencional a la RF en la UE, y que se sitúa más allá del CEDH. La Carta Europea de Derechos Fundamentales no consagra ningún derecho explícito a la reunificación familiar, pero su artículo séptimo es casi idéntico al artículo $8 \mathrm{CEDH}$. Al artículo 7 de la Carta se refiere expresamente el segundo considerando de la Directiva sobre reunificación familiar. Además, del artículo 52.3 de la Carta —artículo II-112 (3) del Tratado por el que se establece una Constitución para Europa-, se deriva que el artículo 7 de la Carta debe tener el mismo sentido y alcance que en el Convenio de Roma ${ }^{1080}$. Por esta vía, el artículo 8 CEDH, en la interpretación efectuada por el Tribunal de Estrasburgo, vuelve a penetrar en el ámbito comunitario. La entrada en vigor del Tratado de Lisboa ha otorgado eficacia jurídica a la Carta Europea de Derechos Fundamentales, potenciando el peso de los derechos fundamentales en el ámbito comunitario.

d) Todos los EEMM de la UE son parte del Consejo de Europa y han ratificado, cada uno por separado, el Convenio Europeo de Derechos Humanos; la Unión Europea como tal no ha ratificado el CEDH. Sin embargo, el Tratado de Lisboa contempla expresamente la posibilidad de que la UE se adhiera al Convenio de Roma. De llegar a materializarse esta posibilidad cuyas negociaciones ya han sido iniciadas-, el campo estaría abonado para una más intensa sinergia jurídica entre el TEDH y el TJUE en materia de interpretación del derecho a la RF de los extranjeros ${ }^{1081}$.

\section{2 El derecho al respeto de la vida familiar como Principio General del Derecho Comunitario}

Bajo este prisma, la Directiva 2003/86/CE, en tanto que norma de derecho comunitario derivada, debe adecuarse a los parámetros fijados por el artículo $8 \mathrm{CEDH}$, en la interpretación dada por la

1080 Vid. Declaración n ${ }^{\circ} 12$ anexa al Tratado por el que se establece una Constitución para Europa sobre la Carta de los Derechos Fundamentales, donde se subraya que el artículo 7 de la Carta posee el mismo sentido que el artículo 8 CEDH.

La Abogada General sr. Kokott recordó esta vinculación en el apartado 60 de las conclusiones generales que presentó el 8 de septiembre de 2005, con ocasión del recurso de anulación parcial que el Parlamento formuló contra la Directva sobre reunificación familiar. Además la Abogada General formuló un interesante argumento para señalar la mayor trascendencia que, en materia de RF de extranjeros no comunitarios, representaba la jurisprudencia del TEDH emitida respecto al artículo $8 \mathrm{CEDH}$. En su opinión, para el caso de las familias integradas exclusivamente por ciudadanos de terceros países, el derecho comunitario no confiere un derecho a la RF similar al otorgado a aquellas familias compuestas por algún ciudadano comunitario. De ahí deduce que la jurisprudencia del TJUE emitida en asuntos relativos a los derechos de permanencia de miembros de la familia de ciudadanos comunitarios establecidos en otros EEMM, no pueda aplicarse a las familias compuestas solamente por ciudadanos de terceros países. Respecto de estas últimas familias, la trascendencia de la jurisprudencia del TEDH es mucho mayor. En sus palabras: "Por el contrario, el Derecho Comunitario no confiere un derecho comunitario similar de reagrupación familiar en el caso de familias integradas exclusivamente por ciudadanos de terceros países. Por este motivo, no pueden aplicarse sin más las manifestaciones del Tribunal de Justicia a las que acabo de referirme, y es preciso recurrir a la jurisprudencia del TEDH. A este respecto es determinante el carácter de derecho humano que presenta la protección de la familia y que, precisamente, cuando se trata de la entrada y de la permanencia en determinado Estado, se distingue de los derechos fundamentales de los ciudadanos en el sentido de que, normalmente, va a la zaga de éstos" (apartado 63).

1081 PASCOUAU, Yves y LABAYLE, Henri. Conditions for Family Reunification under Strain..., op. cit., p. 7. 
jurisprudencia de Estrasburgo. La Directiva no puede obligar ni tampoco permitir a los EMM a establecer actos o adoptar decisiones que sean contrarias al artículo 8 del Convenio de Roma, porque en ese supuesto sería la propia Directiva la que incurriría en violación de dicha disposición. Sobre este razonamiento se construyó la demanda que el Parlamento Europeo presentó al TJUE solicitando la anulación parcial de la Directiva sobre reunificación familiar. La base para ello fue el carácter dispositivo de las disposiciones recurridas, que permitían a los EEMM, libremente, aplicar derogaciones al régimen general previsto por la Directiva cuya posible incompatibilidad con respecto al CEDH fue denunciada por el PE ante el Tribunal de Luxemburgo.

Las ocasiones en que el TJUE se ha enfrentado a la Directiva 2003/86/CE, tanto en su enjuiciamiento abstracto — asunto C-540 - como en su aplicación nacional - asunto Chakroun —, este Tribunal ha adoptado un enfoque en el que el CEDH y su jurisprudencia, junto a otros instrumentos extraídos del derecho internacional de los derechos humanos, se erigieron como parámetros de validez de la propia Directiva comunitaria sobre reunificación familiar. De todos los parámetros, el método prioritario - a juzgar por las constantes remisiones a su jurisprudencia-, fue el artículo 8 CEDH y el case law de Estrasburgo ${ }^{1082}$. De forma más acusada en el asunto C/540, el TJUE se dio a la tarea de despejar la relación que existe entre el artículo $8 \mathrm{CEDH}$ y la Directiva sobre RF.

El particular enfoque del TJUE allí aplicado, al que podríamos denominar "test convencional de Estrasburgo", o recurso al estándar mínimo derivado del sistema internacional de los derechos humanos - con el CEDH a la cabeza-, nos obliga a identificar el contenido mínimo esencial del artículo $8 \mathrm{CEDH}$, extraído de la jurisprudencia emanada al respecto del TEDH, que ha de ser respetado en el ámbito comunitario y analizar a su luz la Directiva 2003/86, para localizar las fortalezas y debilidades de la misma en este ámbito. A nuestro entender, su identificación resulta de extrema importancia porque alumbra el hecho de que las referencias al case law de Estrasburgo, tanto por parte del propio TJUE en la sentencia aludida, como de la mayor parte de los estudiosos del tema, han sido rebasadas por el extraordinario dinamismo evolutivo del TEDH en materia de reunificación familiar, provocando un entendimiento así mismo algo trasnochado de la jurisprudencia de Estrasburgo.

Ya señalamos al estudiar el contenido de la Directiva 2003/86/CE que la influencia del artículo 8 CEDH y de la jurisprudencia emanada por Estrasburgo en su interpretación es patente en ella: junto a la referencia expresa a dicha disposición en el considerando segundo del Preámbulo, los criterios establecidos en los artículos 6.2 y 17 de la Directiva están literalmente extraídos del TEDH, lo que ha llevado a algún autor a señalar gráficamente que esta norma "se muestra zalamera con la jurisprudencia estrasburguesa" 1083 .

1082 LAWSON, Rick. "Family Reunification and the Union's Charter of Fundamental Rights, Judgment of 27 June 2006 , Case C-540/03", op. cit., p. 342.

1083 QUIRÓS FONS, Antonio. "El artículo 8 Convenio de Roma (1950) (CEDH) y la Directiva 2003/86/CE sobre el derecho a la reagrupación familiar: Una conquista del derecho internacional en el derecho comunitario"; Revista Española de Derecho Internacional, vol. 55, $\mathrm{n}^{\circ} 2,203$, p. 1079. La influencia de la jurisprudencia de Estrasburgo es palpable en otros medidas integrantes del derecho comunitario de la inmigración. Así, el artículo 12.3 de la Directiva sobre residentes de larga duración establece los criterios que ha de tener en cuenta un EM antes de proceder a expulsar a un residente de larga duración. Esta disposición constituye para GROENENDIJK “a short summary of the case-law of the European Court in Strasbourg on Article 8 ECHR". El mismo autor resalta la importancia de los vínculos con el país de residencia, afirmando que el nivel de integración en el Estado receptor es relevante para decidir la procedencia de la expulsión. En este artículo existe pues una recepción explícita de la doctrina de Estrasburgo sobre protección frente a expulsiones derivada del derecho a la vida familiar del artículo 8 CEDH. Lo mismo cabría decir respecto al artículo 28 de la Directiva relativa a la libertad de los ciudadanos comunitarios a moverse y residir dentro de la UE. GROENENDIJK, Kees. "Legal Concepts of integration...", op. cit., p. 122. El autor señalado, en otro artículo, al analizar la Directiva 2003/86/CE sobre la RF, indica que esta 
En la misma línea y de forma mucho más temprana, el Tribunal de Luxemburgo había acudido recurrentemente al derecho al respeto de la vida familiar, tal y como es consagrado por el artículo $8 \mathrm{CEDH}$ e interpretado por el TEDH, para afirmar expresamente que la vida familiar, en tanto que principio general del derecho comunitario, incluía el derecho a la reunificación familiar ${ }^{1084}$. Si bien es cierto que este desarrollo jurisprudencial se había producido en supuestos donde estaba en juego la reagrupación de familias integradas por algún ciudadano comunitario ${ }^{1085}$, con independencia de cuál fuera la nacionalidad de los restantes miembros de la familia. Y, dentro del ámbito de los extranjeros no comunitarios, la sentencia C-540 constituye un ejemplo elocuente de la importancia que el Tribunal de Luxemburgo otorga al artículo $8 \mathrm{CEDH}$ en materia migratoria.

\subsection{El relativismo del case law de Estrasburgo y la amplia evolución jurisprudencial en materia de RF}

TJUE y TEDH parten de esquemas metodológicos y funcionales bien distintos. El Tribunal de Estrasburgo nació como una instancia jurisdiccional internacional -la primera en su génerodestinada fundamentalmente a la protección del individuo frente a las violaciones a los derechos convencionales por parte de las instancias nacionales que habían consentido adherirse al CEDH. No podía ser de otro modo, porque el Convenio de Roma, _cuya aplicación e interpretación venía a garantizar el TEDH-, es un instrumento de protección de derechos humanos ${ }^{1086}$. Surgía así el primer sistema regional de tutela de derechos dotado de auténtica efectividad, por contar con un mecanismo jurisdiccional de garantía de los derechos consagrados en el CEDH y sus sucesivos protocolos adicionales.

Por su parte, el Tribunal de Luxemburgo no nació como una instancia protectora de derechos, sino para interpretar y dotar de homogeneidad a un ordenamiento, el comunitario, con una impronta fundamentalmente económica y carente en sus inicios de un sistema autóctono de derechos fundamentales. Fue precisamente esta laguna jurídica del sistema, junto con la creciente expansión competencial de la Comunidad y su consiguiente penetración fáctica en áreas próximas a los derechos humanos, lo que llevó al TJUE a ir colmando tal vacío mediante una jurisprudencia que recurría a dos fuentes: las tradiciones constitucionales comunes a los EEMM y el sistema convencional del Convenio de Roma y el TEDH. El TJUE hizo de la necesidad virtud y terminó, por la fuerza de

norma "codifica algo del case law de la Corte de Estrasburgo en el derecho comunitario". CHOLEWINSKI, Ryszard.

"Family Reunification as a Constitutional Right?", op. cit., p. 219.

1084 TJUE, C-60/00, Carpenter.

1085 Como ya señalamos, la interpretación del derecho a la RF de los ciudadanos comunitarios con familiares extranjeros por parte del TJUE ha sido profundamente liberal y expansiva, dando lugar a una ampliación creciente del contenido de dicho derecho, siempre que exista un nexo comunitario - familiares extranjeros de un ciudadano comunitario. En la jurisprudencia del TJUE es claramente perceptible la influencia del CEDH y del TEDH. Como muestra cabe citar el caso Comisión/Alemania C-249/86, la sentencia Singh, 7 de julio de 1992 donde al derecho a la RF se le califica expresamente como derecho fundamental respecto a los cónyuges de los ciudadanos comunitarios; la sentencia Arben Kaba de 11 de abril de 2000; el asunto Akrich, entre otros muchos.

1086 En este sentido, Harvey afirma de forma más simplificada que "the ECHR is however a human rights instrument and as such it is appropriate that its interpretation has developed in this manner". HARVEY, Colin. "Promoting Insecurity: Public Order, Expulsion and The European Convention on Human Rights"; en GUILD, Elspeth y MINDERHOUD, Paul (Eds.). Security of Residence and Expulsion. Protection of Aliens in Europe. The Hague, Kluwer Law International, 2001, op. cit., p. 45. 
los hechos, controlando el respeto de los derechos fundamentales por parte de los actos y normas comunitarios, aun sin constituir en si misma una instancia protectora de derechos ${ }^{1087}$.

Sus fuentes legitimadoras son también diferentes, lo que a su vez determina que la metodología usada por ambos órganos también difiera. Dado que la parte más abrumadora de la carga de trabajo del TEDH proviene de demandas individuales, el enfoque metodológico adoptado por este órgano ha sido puramente casuístico, lo que, de un lado, le ha dotado de mayor libertad para ensanchar el contenido de los derechos garantizados pero, por otro, ha restado coherencia y previsibilidad a sus pronunciamientos ${ }^{1088}$. La jurisprudencia resultante es profundamente dinámica y evolutiva, pero también peca de falta de sistemática, escasa claridad y frecuentemente es fuente de incertidumbre jurídica ${ }^{1089}$, cuando no se convierte en una auténtica "lotería"1090 —en palabras del juez Martens-, cuyos resultados resultan imposibles de prever con anticipación para las autoridades nacionales.

$\mathrm{Si}$ a estas consideraciones le sumamos la relativa novedad de la rama jurisprudencial representada por la RF de los extranjeros como obligación positiva, junto con la peculiar estructura normativa del art. $8 \mathrm{CEDH}$, el resultado es una exacerbación de las características señaladas —falta de claridad y de coherencia, e inseguridad jurídica. Las dos ramas extraíbles del derecho al respeto de la vida familiar en su aplicación específica para la protección de los extranjeros frente a decisiones de política migratoria adversas - protección frente a expulsiones y reagrupación familiar-, gozaban de características muy diversas hasta que, últimamente, se han ido aproximando progresivamente como consecuencia de la aplicación de principios interpretativos similares por parte del TEDH ${ }^{1091}$. Sin embargo, dicha aproximación no ha dado lugar a niveles similares de protección, gozando por el momento la protección frente a las expulsiones de garantías superiores que las que el TEDH dispensa a la reunificación de los familiares. Ello ha dado lugar a la existencia de dos umbrales diferentes de protección que ha llegado a ser calificado como una "situación absurda"1092 que, además, puede tener la consecuencia añadida de fomentar, de forma no intencionada, la entrada irregular de los extran-

1087 En la misma línea de opinión vid. DRYWOOD, Eleanor. “Giving with one hand, taking with the other: Fundamental Rights, children and the Family Reunification Decision”, op. cit., p. 405.

1088 En idéntico sentido se pronuncia LAWSON, Rick. "Family Reunifcation Directive. Court of Justice od the European Communities. Family Reunification and the Union's Charter of Fundamental Rights, Judgement...”, op. cit., p. 326.

1089 Sobre los problemas de incertidumbre que esta aproximación casuítica origina en la jurisprudencia del TEDH vid., entre otros, McHARG, Aileen. "Reconciling Humang Rights and the Public Interest: Conceptual Problems and Doctrinal Uncertainty in the Jurisprudence of the European Court of Human Rights”; en Modern Law Review, 1999, vol. ${ }^{\circ}$ 62, no 5, pp. 671-696.

1090 Resulta ilustrativa la opinión del juez Martens, miembro del TEDH y quien consideró en su momento que la falta de seguridad jurídica constituía una desventaja inherente al enfoque tradicional que efectúa el TEDH: "National administrations and national courts are unable to predict whether expulsion of an integrated alien will be found acceptable or no. The majority's case by case approach is a lottery for national authorities and a source of embarrassment for the Court. A source of embarrassment since it obliges the Court to make well-nigh impossible comparisions between the merits of the case before it and those which it has already decided". Opinión disidente formulada en el asunto Boughanemi v.Francia, relativo a un caso de expulsión de un extranjero integrado en Francia, país en el que llevaba viviendo un total de 22 años y donde afrontaba una decisión de expulsión emitida por las autoridades francesas. Boughanemi v. France, sentencia del TEDH de 24 de abril de 1996, Apartado 4 de la opinión disidente del juez Martens.

1091 El TJUE también ha reconocido estas dos ramas derivadas de la protección del derecho a la vida familiar de los extranjeros. Vid. apartado 52 sentencia emitida en el asunto C-540/03.

1092 CEBADA ROMERO, Alicia. "La directiva de la Comunidad Europea sobre reagrupación familiar: la sentencia del TJUE en el asunto C-540/03”, op. cit., p. 543. 
jeros reagrupables ${ }^{1093}$. Por lo tanto, frente al menor grado de consolidación que representa la RF, la protección frente a expulsiones de extranjeros asentados en el territorio de algún EM constituye una rama jurisprudencial de similar trayectoria temporal, pero más afianzada y dotada de un umbral de garantías jurisdiccionales superiores a las que ostenta la $\mathrm{RF}^{1094}$. En la última etapa rupturista de la jurisprudencia del TEDH, tal conclusión podría ser matizada.

En este contexto, la RF en el ámbito de la jurisprudencia de Estrasburgo fue recientemente definida por un estudioso como un "auténtico experimento internacional. Esto explica los fuertes vaivenes jurisprudenciales que ha experimentado en el escaso tiempo en que se ha ido gestando - la primera sentencia emitida por el TEDH en esta materia, Abdulaziz, data del año 1985.

Las críticas que afronta la jurisprudencia del TEDH al interpretar y aplicar el derecho al respeto de la vida familiar en el ámbito migratorio son bien representativas de una línea jurisprudencial caracterizada por su pragmatismo ${ }^{1095}$ y dinamismo al enfrentarse a problemas de derechos que en el ámbito interno pueden llegar a estar fuertemente politizados, como son los asuntos migratorios. Este fenómeno de "judicialización de la política" no es privativo del TEDH; antes bien, ha sido muy estudiado por la doctrina en el ámbito de los Estados Nacionales — donde suele producirse-, generado en parte por el fracaso de las instituciones y procesos políticos para resolver los problemas sociales más complejos. Este fenómeno también ha escalado hacia las instituciones comunitarias, sometiendo al Tribunal de Luxemburgo a turbulencias similares a las que en ocasiones enfrenta el TEDH - la sentencia en el asunto C-540, ya estudiada, constituye un buen ejemplo.

En el ámbito específico del Consejo de Europa, hemos ido asistiendo a un profundo cambio jurisprudencial en materia de RF. La primera jurisprudencia del TEDH se caracterizó por un enfoque en el que predominaba la autocontención judicial, la prudencia respetuosa frente a la soberanía nacional y la aplicación de principios interpretativos - margen de apreciación y criterio elsewhere, fundamentalmente- que se traducían en una priorización de los intereses estatales de control migratorio. En esta primera etapa todas las sentencias emitidas niegan la violación del derecho y la rigidez de los principios interpretativos - especialmente la aplicación del criterio elsewhere, esto es, la posibilidad de reconstituir la vida familiar en cualquier otro Estado distinto al EM de acogida-, conducían a la negación sistemática de la obligación del Estado Parte de autorizar la entrada y residencia del miembro de la familia a efectos de su reunificación. En otras

1093 En este sentido, CEBADA ROMERO afirma que "en vista de los diferentes enfoques aplicados, por un lado, a la expulsión, y por otro lado, a la reunificación, nos podemos preguntar si los inmigrantes no están siendo impulsados inintencionadamente a traer a su familia (particularmente a sus hijos) a Europa irregularmente. De hecho, sería muy difícil justificar la decisión de expulsar a un menor una vez que hubiese quedado demostrado que él/ella reside en territorio europeo, incluso aunque el menor hubiera entrado irregularmente en territorio europeo". Idem, p. 543.

1094 Sobre la diferente protección y grado de consolidación de las dos ramas migratorias derivadas de la protección del derecho a la vida familiar Boeles estima que el TEDH otorga cierta medida previsible de protección, tan sólo cuando la vida familiar que ya había sido permitida en el Estado de acogida, ha sido rota posteriormente como consecuencia de una medida de expulsión. Pero el autor considera que la rama relativa a la RF no otorga "un derecho adecuado a la reunión de la familia”. BOELES, P. “What Rights have..., op. cit., p. 157.

En una línea similar se inscribe Roagna al afirmar "in general, it can be said that the Court has always been more willing to protect family rights in relation to expulsion/deportation Kingdom, due to the stricter immigration rules introduced by than in relation to entry. The so called 'elsewhere approach' (implying that the family is reasonably expected to pursue family life in another state) was very strictly applied”. ROAGNA, Yvana. Protecting the Right to respect for Private and Family LIfe under the European Court of Human Rights. Strasbourg, Council of Europe Human Rights Handbooks, 2012, p 88.

1095 En torno al carácter pragmático que destila la actitud del TEDH, vid. LAWSON, Rick. "Court of Justice of the European Communities: Family Renification Directive. Family Reunification and the Union's Charter of Fundamental Rights, Judgement...”, op. cit., p. 324. 
palabras, de las primeras sentencias del TEDH no cabe deducir la existencia de un derecho a la reunificación familiar en el ámbito de Estrasburgo. Lo más que cabría sería hablar de un derecho a la reunificación que entraría en juego en circunstancias extraordinariamente excepcionales, en las que la única alternativa válida para el desarrollo de la vida familiar fuera el EM, al no resultar posible la reconstrucción familiar en ningún otro sitio.

Frente a esa situación inicial, la última línea jurisprudencial destaca por características opuestas a las apuntadas: fuerte activismo judicial e interpretación que potencia el efecto útil del respeto a la vida familiar, incluyendo - o más bien dotando de un peso específico muy diverso- a los principios y criterios interpretativos habituales, a fin de conseguir un balance más armonioso entre los intereses contrapuestos en conflicto. Es precisamente la última línea jurisprudencial, iniciada en Sen ${ }^{1096}$ y confirmada en las sentencias posteriores, la que ha operado una ampliación del contenido del derecho al respeto de la vida familiar de los extranjeros ${ }^{1097}$, hasta el punto de permitir extraer un derecho a la reunificación familiar - si bien, totalmente dependiente de las circunstancias concretas del caso-, como contenido material del derecho al respeto de la vida familiar.

Son las propias características de la jurisprudencia de Estrasburgo en general, y de esta rama jurisprudencial en particular -el principio evolutivo es potenciado por el carácter dinámico del concepto de familia y la alta sensibilidad política implícita a los asuntos migratorios- las que nos llevan a adoptar un enfoque provisional y relativo en este punto. Las conclusiones y puntos de vistas que a partir de ahora presentaremos están extraídos a partir de la jurisprudencia más reciente del TEDH en materia de RF, pero nada lleva a pensar que esta línea sea duradera o definitiva. De hecho, el viraje jurisprudencial que se ha producido no ha venido acompañado de un razonamiento simultáneo por parte del TEDH, que parece jugar al despiste recurriendo a su jurisprudencia previa para extraer de ella conclusiones divergentes.

\subsection{La existencia de vida familiar: Miembros de la familia que pueden ser reagrupados}

El TEDH, al interpretar el artículo $8 \mathrm{CEDH}$, no ha proporcionado ninguna definición concreta de familia ni listado alguno de las personas que la integran. Sin embargo, de su concepción sobre los lazos familiares incluidos dentro del concepto de "vida familiar", cabe deducir con carácter general una definición amplia, abierta, material y con tendencia expansiva de familia, superadora incluso de convencionalismos y prejuicios sociales ${ }^{1098}$.

1096 Los estudiosos de este tema suelen finalizar sus referencias en la sentencia Sen, a la que consideran como un caso aislado que, aun abriendo las puertas a la posibilidad de un derecho a la RF en el ámbito del CEDH, no permite extraer mayores conclusiones. La propia sentencia del TJUE en el asunto C-540 sigue esta misma tendencia y cita repetidamente a la sentencia Sen. En el asunto C-540/03 sólo de pasada aparece una referencia a una sentencia posterior del TEDH en materia de RF - Tuquabo-Teke- que podría ser indicio de que el cambio representado por Sen tiene visos de ser duradero.

Como ejemplo de la tendencia doctrinal a citar jurisprudencia algo rebasada en nuestro ámbito de estudio, concluyendo con ello la inexistencia de un derecho a la RF de los extranjeros en el case law de Estrasburgo, cabe citar un muy reciente estudio donde sigue subrayándose la prioridad del criterio elsewhere, pese a que en el mismo se comenta con detenimiento el asunto Rodrigues da Silva. ROAGNA, Yvana. Protecting the Right to respect for Private and Family LIfe under the European Court of Human Rights. Strasbourg, Council of Europe Human Rights Handbooks, 2012, pp. 87 y 89.

1097 GARCÍA VÁZQUEZ, Sonia. El Estatuto jurídico-constitucional del extranjero en España, op. cit., pp. 62-65.

1098 En este punto, Santolaya se refiere específicamente a la protección por parte del TEDH de "formas de vida familiar alternativa", tales como las personas de etnia gitana que viven en caravana, como ejemplo de un tipo amplio de 
En el ámbito específico de la RF de extranjeros, de la jurisprudencia emitida hasta la fecha cabe sostener que la familia nuclear está amparada de forma inequívoca, entendiendo por familia nuclear a los padres e hijos menores. El caso de los abuelos constituye aún una cuestión abierta. Desde la sentencia Marckx, habíamos extraído un concepto mínimo o esencial de familia, protegido por el $\mathrm{CEDH}$, que incluiría, al menos, a padres, hijos y abuelos. No obstante, hasta la fecha no se ha presentado ante Estrasburgo ningún supuesto concreto que incluya a abuelos a efectos de reagrupación, por lo que no nos es posible afirmar que este concepto mínimo, aplicable con carácter general a la existencia de vida familiar, sea también extensible a la vida familiar de los extranjeros en supuestos de reunificación familiar. De otro lado, en el ámbito comunitario, la reagrupación de ascendientes es vista con suspicacia, resultando dificultada por las normativas internas, a quien compete la regulación concreta de este aspecto, que fue dejado potestativamente en manos de los EEMM por la Directiva 2003/86/CE.

Respecto a quienes pueden ser considerados como miembros de una pareja, en el primer supuesto fallado en esta materia - Abdulaziz, Cabales y Balkandali- pese a que el TEDH no encontró violación del derecho a la vida familiar y no protegió la reunificación familiar de los cónyuges, sin embargo determinó con rapidez la existencia de vida familiar. Cabe concluir en principio que la relación existente entre una pareja válidamente casada y fruto de un matrimonio auténtico, es constitutiva de vida familiar a efectos del artículo $8 \mathrm{CEDH}$. Sentencias posteriores se han encargado de revalidar esta cuestión e incluso cabe ya afirmar que, en el paraguas protector del CEDH, el concepto de pareja que se maneja es abierto. La tutela no se restringe exclusivamente a las parejas casadas, amparando también a las parejas de hecho heterosexuales, especialmente cuando hay hijos de por medio $^{1099}$.

La cuestión esencial que resta por determinar es si gozaría del derecho a la RF en el ámbito de Estrasburgo una pareja de hecho heterosexual de extranjeros que no contasen con descendencia. Por el momento, todos los casos de reunificación ante el TEDH — salvo Abdulaziz - involucran a parejas con hijos, por lo que esta pregunta todavía está pendiente de ser contestada, aunque parece acertado esperar una respuesta en positivo, siempre que pudiera demostrarse el carácter estable y genuino de la pareja. Respecto a las parejas homosexuales ${ }^{1100}$, son protegidas a través del concepto más amplio de vida privada, pero hasta el momento no han merecido la tutela extraíble del derecho al respeto de la vida familiar.

Por cuanto a los hijos, el concepto de vida familiar en su aplicación a extranjeros que solicitan la RF, cubre la relación existente entre padres e hijos - tanto matrimoniales como extramatrimoniales-, siempre que sean menores de edad. En este ámbito, el TEDH mantiene la misma consideración rotunda sentada desde Marckx respecto a la no diferenciación entre hijos naturales y legítimos. Esta equiparación se puso a prueba y confirmó en el asunto Rodrígues da Silva —donde la madre brasileña de una niña holandesa, concebida fuera del matrimonio, reclamaba un permiso de

protección tutelada por el artículo $8 \mathrm{CEDH}$, que ampararía "cualquier forma de convivencia en la que se creen vínculos afectivos y materiales de dependencia mutua sea cual sea su grado de formalización o incluso el sexo de sus componentes (...) por alejada que resulte de los parámetros de la familia tradicional basada en el matrimonio". SANTOLAYA MACCHETI, Pablo. El derecho a la vida familiar de los extranjeros, op. cit., p. 80.

1099 Esta conclusión se deriva de la sentencia Rodrígues da Silva. Apartado 37.

1100 En torno a la jurisprudencia emitida por el TEDH sobre las parejas del mismo sexo sobresalen, entre otros, los siguientes pronunciamientos: Asunto Dudgeon contra Reino Unido, STEDH de 22 de octubre de 1981; Asunto Modinos contra Chipre, STEDH de 22 de abril de 1993; Asunto Salgueirio da Silva Mouta contra Portual, STEDH de 21 de diciembre de 1999; Asunto Fretté contra Francia, STEDH de 26 de febrero de 2002; Asunto Karner contra Austria, STEDH de 24 de julio de 2003. 
residencia. El TEDH resolvió rápidamente sobre la aplicabilidad del artículo 8.1, afirmando que no había duda de que existía vida familiar, en el significado del artículo 8, entre la madre y su hija: ésta ha nacido de una relación genuina, en la cual sus padres cohabitaban como si estuviesen casados ${ }^{1101}$.

Confrontaremos ahora este concepto de familia con el existente en el artículo 4 de la Directiva. Para ello nuestro análisis se circunscribirá tan sólo a aquellos miembros titulares de un derecho subjetivo, esto es, a quienes el EM está preceptivamente obligado a autorizar su entrada y residencia en su territorio.

En ambos órdenes normativos, se contempla la protección de los vínculos familiares constituidos tanto antes como con posterioridad a la entrada del reagrupante en el Estado receptor. Sin embargo, el concepto de familia en el CEDH es en principio más amplio que el restrictivo concepto de familia nuclear establecido en la Directiva ${ }^{1102}$ - reducido a la familia nuclear en su concepción más limitada posible, esto es, matrimonio e hijos, e incluso estos últimos con múltiples trabas a partir del momento en que superen los 12 años de edad. La jurisprudencia del TEDH en el ámbito específico de la RF ampara al matrimonio, a las parejas de hecho con hijos, y a los hijos menores sin establecer umbrales de edad previos a la mayoría de edad. Por contraste, en la Directiva 2003/86 la admisión de los miembros de la pareja de hecho queda a la libre discrecionalidad del EM, sin ni siquiera tornar imperativa su admisión para aquellos EEMM cuyas legislaciones internas contemplan la equiparación, para determinados efectos, entre el matrimonio y las parejas de hecho. La Directiva es muy cuestionable al dejar a la discreción de los EEMM la reagrupación de los hijos de la pareja de hecho, incurriendo de este modo en una discriminación entre hijos habidos dentro y fuera del matrimonio. La admisión de los ascendientes de primer grado queda asimismo en manos de la libre voluntad del Estado, lo que suscita dudas en torno a su compatibilidad con el concepto mínimo de familia establecido por Estrasburgo con fundamento en el artículo 8 - si bien este punto aun no ha sido confirmado en el ámbito de la RF- De otro lado, las parejas de hecho son susceptibles de protección por la jurisprudencia derivada del artículo 8 CEDH, mientras que la Directiva 2003/86 los contempla como familiares reagrupables de forma potestativa, quedando su protección a expensas del margen de apreciación estatal.

En definitiva, el concepto restrictivo de familia que mantiene la Directiva resulta difícilmente justificable a la luz de la noción amplia de familia acogida por la jurisprudencia de Estrasburgo ${ }^{1103}$, "fundada más que sobre los vínculos legales sobre la sustancia de las relaciones interpersonales"1104. Los aspectos más conflictivos de la regulación comunitaria recaen sobre las excepciones facultativas que el EM puede imponer a los hijos menores de edad, y así como sobre el carácter potestativo de la

1101 Asunto Rodrígues da Silva and Hoogkamer v. The Netherlands, 31 de enero de 2006. Apartado 37.

1102 En contra Quirós Fons, para quien el concepto de familia de la Directiva, al incluir tanto los vínculos familiares anteriores como posteriores a la entrada del reagrupante, es más generoso que la interpretación que el TEDH ha efectuado del artículo 8 CEDH. Para Fons, "el tribunal de Estrasburgo es claro en la exigencia de preexistencia de la vida familiar anterior, en este caso, a la entrada del reagrupante” y cita como jurisprudencia el apartado 68 de Abdulaziz. QUIRÓS FONS, A. Derecho comunitario de extranjería...”, op. cit., p. 407. En nuestra opinión, el TEDH ha acogido explícitamente la posibilidad de proteger también los vínculos familiares posteriores a la entrada del reagrupante.

1103 CICIRIELLO, Maria Clelia. "Il Ricongiungimento Familiare come Diritto Fondamentale del Migrante”; Comunitá Internazionale, vol. 61, n ${ }^{\circ}$ 1, 2006, p.118. La autora propone que la RF, en tanto que "derecho fundamental del ser humano", debería de predicarse tanto de los ciudadanos procedentes de terceros países — si bien matizando que cuando cuenten con residencia legal "di lungo periodo"-, como de los ciudadanos procedentes de otros EEMM que ejercitan su libertad de circulación. Considera que, de lo contrario, se incurre en una discriminación basada en el origen nacional (art. $14 \mathrm{CEDH}$ ), en el goce de las libertades y de los derechos reconocidos en el CEDH.

1104 Idem. 
admisión de las parejas de hecho y de los hijos nacidos de tales relaciones. Estos tres aspectos constituyen, a nuestro juicio, una violación del estándar mínimo convencional.

De otro lado, la Directiva convierte el cese de la vida conyugal o familiar efectiva en causa de denegación de una solicitud ${ }^{1105}$, de donde se deduce, a sensu contrario, la exigencia de vida familiar efectiva para la continuidad de la residencia por motivos de $\mathrm{RF}^{1106}$. En este aspecto la Directiva ha llevado al extremo la exigencia de efectividad de la vida familiar establecida por Estrasburgo, hasta el punto de penalizar su inexistencia con la extinción de la residencia que ya había sido concedida por causas familiares. Esta regulación provoca problemas de ajuste con la jurisprudencia de Estrasburgo, especialmente en consideración a los hijos. El TEDH no estima que la vida en común sea un requisito imprescindible para la efectividad de la vida familiar, siendo sustituible por conceptos de los que pueda derivarse la existencia de una relación de dependencia económica y/o afectiva entre los miembros de la familia implicados, como podrían ser, a título meramente ejemplificativo, la subsistencia de contactos regulares que no exigen contacto físico personal - llamadas telefónicas, cartas, apoyo financiero..-. A mayor abundamiento, en el contexto migratorio de familias separadas geográficamente durante largos períodos de tiempo, el Tribunal de Estrasburgo ha confirmado la permanencia de la vida familiar y, a partir de Sen, ha excluido la aplicación estricta del test de la responsabilidad individual.

\subsection{La amplia titularidad activa del derecho}

La titularidad activa del derecho a la vida familiar de los extranjeros en el contexto de la RF, tal y como es interpretada por el TEDH, corresponde tanto al sponsor o principal como a los miembros de su familia ${ }^{1107}$. Estamos ante una titularidad activa compartida, sin que pertenezca en exclusiva al sponsor, como suele ser habitual en los enfoques tradicionales de la migración familiar. La concepción tradicional parte de la consideración de que los derechos de los miembros de la familia son de carácter derivado o dependiente respecto de la residencia o estancia legal del sponsor en el territorio del Estado parte. Dicho carácter dependiente finaliza en el momento en que cada miembro de la familia accede a un estatuto autónomo.

El concepto dual de titularidad activa mantenido por el TEDH, ya ha tenido ocasión de desvelar su extraordinario potencial práctico. En varios pronunciamientos, han sido los hijos menores de inmigrantes, nacidos y educados en el EM, quienes han actuado en la práctica como reagrupantes, activando y amparando el proceso de reunificación con sus progenitores - que, de otro modo, hubieran tenido muy difícil la concesión del derecho en vista del carácter irregular de su estancia en el Estado de acogida.

1105 Apartado 1.b) del artículo 16 de la Directiva sobre reunificación familiar.

1106 Para Quirós Fons, esta exigencia "puede llevar a una prueba diabólica si no se tiene muy en cuenta la jurisprudencia del TEDH sobre este requisito de vida familiar efectiva, que, en síntesis, contempla, por un lado, cohabitación, admitiendo otras formas de contacto como visitas, correspondencia o llamadas telefónicas (Stc Berrehab c. Holanda, FJ 21) y, por otro, dependencia material o económica". QUIRÓS FONS, A. "Derecho comunitario de extranjería,", op. cit., nota a pie $\mathrm{n}^{\circ} 137$, p. 410.

1107 En el mismo sentido SCHAFFRIN, Dora. "Which Standard for Family Reunification of Third-Country Nationals in the European Unión?"; CARLIER, Jean-Yves and BRUYEKER, Philippe de. Immigration and Asylum Law of the EU: Current Debates. Academic Network for Legal Studies on Immigration and Asylum in Europe, Bruxelles, Bruylant, 2005, p.100. En contra, SANTOLAYA MACHETTI, Pablo. El derecho a la vida familiar de los extranjeros, op. cit., p. 110. 
En este punto la Directiva comunitaria 2003/86 es plenamente compatible con el artículo 8 CEDH. En las dos primeras propuestas, la situación era diferente y se preveía expresamente la concesión en exclusiva de la titularidad activa del derecho a favor del principal, en tanto que titular del permiso de residencia en el EM. Sin embargo - y tras una dilatada trayectoria de concepción restringida de la titularidad activa, iniciada con la Resolución armonizadora de 1993 - , la versión definitiva de la Directiva dio cabida a una concepción amplia de reagrupante ${ }^{1108}$, que incluye tanto al nacional de un tercer país que reside legalmente en un EM, como a los miembros también extranjeros de su familia que solicitan la reagrupación. En coherencia con dicha concepción, la presentación de solicitudes de reunificación puede correr a cargo tanto del principal como de sus familiares, bien sea en el EM receptor o ante las autoridades representativas de dicho EM en un tercer país ${ }^{1109}$ - cuestiones ambas que compete decidir a los EEMM. Y, en consecuencia, las resoluciones denegatorias o de retirada del permiso de residencia por causa familiar pueden ser recurridas tanto por el principal como por sus familiares reagrupables o ya reagrupados.

La concepción amplia de Estrasburgo parece haber calado en la regulación comunitaria contenida en la Directiva 2003/86, provocando sin embargo, en contrapartida, múltiples errores terminológicos a lo largo de su articulado. El punto más frágil en relación con esta cuestión, reside en la débil tutela jurídica que ofrece su artículo 18. Esta disposición proclama el derecho que asiste, tanto al sponsor como a los miembros de su familia, a acceder a los recursos jurisdiccionales o administrativos que estén legalmente previstos en el EM. Su debilidad y escasa precisión puede terminar desprotegiendo en la práctica a los titulares del derecho a la reagrupación familiar.

\subsection{Canon de protección de la RF en la Jurisprudencia de Estrasburgo respecto al derivado de la Directiva 2003/86}

La dinámica, evolutiva, audaz y extensiva elaboración jurisprudencial del TEDH ha logrado extraer del artículo $8 \mathrm{CEDH}$ cierta protección de la reagrupación familiar de los extranjeros, en tanto que requisito necesario para el disfrute del derecho al respeto de la vida familiar. En este sentido, resulta coherente la calificación de Quirós Fons, para quien la reunificación familiar en el ámbito del Consejo de Europa constituye un "derecho instrumental de otro fundamental"1110.

Respecto a la concreta protección desplegada por ambos órdenes - Consejo de Europa y Unión Europa - en relación al derecho de los extranjeros residentes a reunirse con sus familiares más próximos en el territorio del Estado parte receptor, una primera y somera aproximación revela ya el abismo existente. Por un lado, del CEDH, en la interpretación efectuada por el TEDH, es posible extraer un derecho implícito a la reagrupación familiar que, como tal, carece de formulación expresa,

1108 Apartado c) del artículo 2.

1109 Artículo 5.1 de la Directiva 2003/86.

1110 QUIRÓS FONS, Antonio. “Derecho comunitario de extranjería..., op. cit., p. 403. La construcción de Quirós Fons para explicar la relación entra la Directiva 2003/86 y el artículo $8 \mathrm{CEDH}$, resulta bastante sugerente. El autor parte de la distinción formulada por Robert Alexy entre derecho fundamental y norma iusfundamental y realiza lo que él califica como un "ejercicio de teoría jurídica". Según sus propias palabras, "la Directiva, como regla, condiciona el ejercicio del derecho y no puede impedir el cumplimiento del fin del derecho reconocido en las normas iusfundamentales, primero las positivas, directamente establecidas en la Carta de la Unión, de carácter constitucional, calificables como principios, y después las enunciadas por el TEDH en interpretación del artículo $8 \mathrm{CEDH}$, denominadas normas adscritas de derecho fundamental, calificables como reglas". El autor aclara que, en la aplicación de la Directiva, se producirá tan sólo un "conflicto entre reglas, que son desplazables entre sí, mientras que para los principios, unos preceden a otros según las circunstancias". QUIRÓS FONS. A. "Derecho comunitario de extranjería...", op. cit., p. 405. 
no es predicable con carácter general y emerge tan sólo en determinados casos concretos y en concurrencia de ciertas circunstancias particulares de los extranjeros afectados, cuya ponderación frente al interés estatal de controlar la inmigración, aconseje la priorización del interés individual en dicho supuesto. Se trata pues de un derecho muy limitado y totalmente dependiente de las circunstancias concretas presentes en un asunto - circunstancias que, por otro lado, pueden presentar un carácter un tanto excepcional y que las propias características de la jurisprudencia de Estrasburgo convierten en difícilmente previsibles. En estas condiciones, resulta difícil la calificación de la protección que la vida familiar del Convenio de Roma proyecta sobre la reunificación familiar de los extranjeros como de un auténtico derecho subjetivo, en tanto que la misma no genera obligaciones generales ni precisas para los EEMM.

La principal virtualidad del artículo $8 \mathrm{CEDH}$ ha sido establecer un estándar mínimo para la protección de la vida familiar de los extranjeros que se encuentren bajo la jurisdicción de los 46 Estados parte del Consejo de Europa ${ }^{1111}$. Y ello fue así mucho antes de que la UE empezara a preocuparse por otorgar un nivel de protección mínimamente homogéneo al derecho a la RF de los ciudadanos procedentes de terceros países y, además, en un ámbito geográfico muy superior a la UE, lo que se traduce en un radio de protección mucho más temprano y extenso.

Dicho lo anterior - y dado el carácter extremadamente evolutivo y asistemático de esta rama jurisprudencial del TEDH—, una imagen más precisa del nivel de protección predicable de la RF en el ámbito del Consejo de Europa, nos obliga a diferenciar dos etapas, de las que se derivan niveles muy diferentes de protección de dicho derecho. Un primera etapa - que finaliza con la sentencia Ahmut ${ }^{1112}$ - , caracterizada por la primacía absoluta de la aplicación del criterio elsewhere en el análisis de las demandas individuales relativas a RF. En esta fase, el TEDH partía de la premisa de que los Estados partes disfrutan del derecho a controlar la entrada y permanencia de extranjeros en su territorio, estimando que si la convivencia familiar de éstos era posible en cualquier otro territorio distinto al país receptor - fundamentalmente en el país de origen de los extranjeros, aunque no con carácter exclusivo-, la negativa del Estado parte a autorizar la admisión de los familiares del residente no constituía una injerencia ilegítima en el derecho al respeto de la vida familiar. Sobre los extranjeros recurrentes recaía probar la existencia de obstáculos al desarrollo de la vida familiar en el propio país de origen o en un tercer Estado, cuestión que, a sensu contrario, revelaba la existencia de una presunción iuris tantun de partida en contra del derecho a la RF. La rigidez extrema con que el TEDH aplicaba el criterio elsewhere provocaba el vaciamiento en la práctica del derecho a la RF o, si se prefiere, que éste pudiese desplegar tan sólo en circunstancias extremadamente excepcionales, donde obstáculos insuperables de hecho o de derecho ${ }^{1113}$ impidiesen la reconstitución de la familia del inmigrante en ningún otro lugar distinto del Estado parte de acogida.

Dado el carácter lineal y, por ello, doctrinalmente pacífico de esta primera línea jurisprudencial del TEDH - en la que, como consecuencia natural de la época en que fueron elaborados, suelen detenerse la mayoría de los estudios doctrinales sobre este tema ${ }^{114}$ - hubiera sido conveniente, a efec-

1111 GROENENDIJK, Kees. “Family Reunification as a Right under Community Law”, op. cit., p. 219.

1112 STEDH Ahmut c. Países Bajos, de 28 de noviembre de 1996.

1113 SANTOLAYA MACHETTI, Pablo. El derecho a la vida familiar de los extranjeros, op. cit., p. 110.

1114 Pese a considerar asentada la existencia de un derecho humano a la RF en aquellos supuestos donde no exista ninguna otra alternativa para la vida familiar que no sea el asentamiento de la familia en el EM, algunos autores llegan incluso a dudar de su virtualidad práctica, sosteniendo que el TEDH todavía no ha tenido ocasión de confirmar su existencia real. Entre éstos se sitúa Pieter Boeles, quien afirma que "no sabemos aún de seguro si la Corte de Estrasburgo asumiría un derecho a la reunificación familiar en casos de fuerza mayor". BOELES, Pieter. "What Rights have Migrating Third-Country Nationals?"; op. cit. p. 157. Nuevamente se trata de estudios que se paralizan en el 
tos de la adecuación de la Directiva 2003/86/CE con los estándares derivados del artículo 8 CEDH, que su articulado hubiese contemplado la obligación preceptiva de los EEMM de autorizar en todo caso la entrada y permanencia de familiares del residente en aquellos supuestos extremos, de fuerza mayor $^{1115}$, donde la continuación de la vida familiar no fuera posible en ningún otro Estado distinto al EM receptor. Esta ausencia ha sido considerada por algún estudioso como la principal crítica que merece la Directiva ${ }^{1116}$.

La sentencia Sen ${ }^{1117}$ marca el inicio de un viraje jurisprudencial, confirmado por los pronunciamientos emitidos posteriormente hasta la fecha, donde el TEDH ha restado importancia al criterio elsewhere, ha reducido considerablemente el alcance del margen de apreciación y ha equiparado - sólo parcialmente - el tratamiento otorgado a las obligaciones tanto positivas como negativas derivadas de la vida familiar, en su aplicación específica a los extranjeros. En esta fase el Tribunal de Estrasburgo sigue tomando como punto de partida el derecho soberano del Estado a controlar sus fronteras y determinar qué extranjeros autoriza a entrar y residir en su territorio. Sin embargo, ha ido adicionando nuevos criterios interpretativos que han terminado desbancando al anteriormente omnipresente criterio elsewhere, con el resultado de potenciar el efecto útil del derecho al respeto de la vida familiar y permitir el desarrollo de mayores límites a la soberanía estatal en materia migratoria -si bien dichos límites presentan todavía un carácter altamente difuso. Entre los criterios interpretativos, resulta de especial importancia la atención que el TEDH presta a la existencia de fuertes vínculos con el Estado de acogida una estancia prolongada en dicho territorio y a la presencia de hijos menores del residente, nacidos y enteramente criados en el EM, carentes de lazos con el país de origen de sus progenitores y cuyo traslado a dicho Estado a fin de disfrutar de la vida familiar, se traduciría en perturbaciones de largo alcance para toda la familia. Esta segunda línea jurisprudencial permite afirmar la consolidación de la RF como contenido material extraíble del derecho al respeto de la vida familiar, si bien, se trata todavía de un derecho muy débil, limitado y totalmente dependiente de las circunstancias particulares que concurran en los extranjeros afectados por decisiones migratorias denegatorias ${ }^{1118}$.

asunto Sen, al cual consideran un caso aislado del que no es posible todavía extraer conclusiones. A día de hoy, es posible rebatir los argumentos de Boeles porque se han pronunciado posteriormente más casos que han convertido a Sen en el inicio de una nueva tendencia, y no en un caso meramente aislado de la jurisprudencia del TEDH.

1115 BOELES, Pieter. “What rights have Migrating Third-Country National?”, op. cit., p. 157.

1116 SCHUTTER. Report on the Situation of Human Rights in the European Union in 2003, op. cit., p. 54. Este autor afirma que "it is safe to consider that the main criticism that can be levelled at the Directive is that it does not make a sufficiently clear distinction between the situation where the sponsor (...) is living on the territory of the host State without it being possible for his family life to be continued elsewhere, and the situation where, on the contrary, such family life could be continued elsewhere. In the first situation, family reunification is a human right, derived from the right to respect for family life guaranteed by Article 8 of the European Convention on Human Rights; in the second situation, it is a favour from the State, which in principle is not obligated to grant it, even though, by granting it is contribuyes to the fluourishing of family life". Sin embargo, el autor aclara a pie de página: "This distinction, however, is obscured when the sponsor has established such ties in the host country that he could not leave this country where he is residing without this resulting in a significant upheaval of his private and family life. Even if his family life could be continued elsewhere, the cost will be such that, in this case, family reunification should be considered as a human right. See for example EUr. Ct. H. R. Sen v. Netherlands...”. Idem, p. 54, nota a pie 151.

1117 STEDH Sen c. Países Bajos, de 21 de diciembre de 2001.

1118 En contra, SALES I JARDÍ, Mercè, quien afirma contundentemente que de la jurisprudencia del TEDH no cabe extraer una obligación positiva a cargo de los EEMM de autorizar a los familiares extranjeros de residentes a establecerse en tu terrotorio. La autora aludida prosigue afirmando que "el hecho, de que en una cuestión tan delicada, el legislador comunitario se haya atrevido a superar el nivel de protección que en materia de reagrupación familiar establecía el TEDH, que en este ámbito no reconoce ninguna obligación positiva y acuerda una amplia discrecionalidad a los Estados, obligando a los Estados miembros a crear un derecho de carácter general a la reagrupación familiar que sólo puede ser denegado bajo circunstancias excepcionales previstas en la misma Directiva, rompe 
Pese a las múltiples deficiencias detectables en esta rama jurisprudencial, resulta obvio que, en perspectiva, el TEDH tiende a otorgar una protección creciente a la inmigración familiar. En sus últimos pronunciamientos ${ }^{1119}$ el derecho parece haber superado su inicial carácter extremadamente excepcional, para dar cobertura a un número cada vez mayor de supuestos concretos.

Con todo, la situación en el Consejo de Europa sigue sin resistir la comparación frente a la existente en la UE a partir de la aprobación de la Directiva $2003 / 86^{1120}$. De este instrumento comunitario se deriva un derecho subjetivo a la reunificación familiar, predicable con carácter general de los ciudadanos extracomunitarios que cumplan con los requisitos fijados en ella. Dicho derecho subjetivo implica correlativas obligaciones jurídicas a cargo de los EEMM - con las excepciones de Reino Unido, Irlanda y Dinamarca - de autorizar la entrada y residencia de los miembros de la familia nuclear del extranjero residente legal en su territorio. Dado que la fecha tope para la transposición de la Directiva ya ha sido ampliamente rebasada y que las obligaciones estatales dimanantes disfrutan de cierta precisión - al menos con respecto al contenido más básico de la reagrupaciónel derecho a la reunificación familiar de los extranjeros procedentes de terceros países goza ya en la UE de eficacia directa e inmediata, siendo ejercitable ante las autoridades de los EEMM, incluso aún en el supuesto de que algunos de los países no hubiesen todavía procedido a su transposición o ésta se hubiera producido de forma incorrecta. Se trata, además, de un derecho autónomo, que si bien continúa conectado al derecho a la vida familiar que le sirve de matriz, ha logrado superar su primigenio carácter instrumental o derivado. La titularidad dual o compartida que la versión definitiva de la Directiva vino a consagrar, no hace sino subrayar el carácter autónomo de este derecho. En definitiva, en la Directiva 2003/86 el "razonamiento es exactamente el contrario"1121 al que subyace

una lanza a favor de la integración plena de los inmigrantes en su territorio". SALES I JARDÍ, Mercè. "La protección de la vida familiar de los inmigrantes en el Ordenamiento Comunitario: el derecho a la reagrupación familiar", op. cit., p. 12. En la misma línea se sitúa SANTOLAYA MACHETTI, quien señala que, "en cuanto al contenido material del propio derecho, solo en los supuestos en los que la vida familiar no es possible en ningún otro lugar, por impedimento legal o fáctico o por la absoluta inexistencia de vínculos con ningún otro país de los miembros de la familia (..) podría llegar a actuar el artículo 8 como límite de la capacidad de los Estados a la hora de establecer su política de reagrupación familiar y de aplicarla en un caso concreto". El derecho a la vida familiar de los extranjeros, op. cit., p. 97.

Dentro de la línea doctrinal que subraya el alcance extremadamente limitado del derecho a la RF en la jurisprudencia de Estrasburgo, cuestionando la existencia de tal derecho en base a la primacía del criterio elsewhere, cabría incluir, entre otros, ROAGNA, Yvana. Protecting the Right to respect for Private and Family LIfe under the European Court of Human Rights, op. cit., p. 87. LA ESPINA, Encarnación. "Singularidades y retos normativos en el control genético de la inmigración familiar hacia España, Italia y Portugal”, en Cuadernos Electrónicos de Filosofía del Derecho, no 21, 2010, p. 115. VIDAL FUEYO, M. C. "La jurisprudencia del TC en materia de derechos fundamentales de los extranjeros..”, op. cit, p. 373. RAVETLLAT BALLESTÉ, Isaac. La reagrupación familiar, op. cit., p. 28. Dentro de la línea opuesta, suscrita en esta tesis, apoyando la tutela a la RF en el ámbito de Estrasburgo, se inscribe KENGERLINSKY, Marat. Restrictions in EU Immigration and Asylum Policies in the light of International Human Rights Standards, op. cit., p. 5.

1119 Ni siquiera en la última etapa jurisprudencial del TEDH, que tiende a potenciar al máximo el efecto útil de la vida familiar y ha rebajado enormente la importancia del criterio elsewhere, cabe hablar de un auténtico derecho subjetivo a la reunificación familiar sino, mucho más matizadamente, de la consolidación de la RF como contenido material de la vida familiar en el ámbito del Consejo de Europa.

1120 En idéntico sentido se pronuncia SALES I JARDÍ, remarcando el tono marcadamente más protector de la Directiva 2003/86/CE en relación a los estándares extraíbles del derecho internacional de los derechos humanos, con el TEDH a la cabeza, y señalando expresamente que la UE con la Directiva sobre RF se ha atrevido a superar el umbral de protección establecido en esta materia por Estrasburgo; en "La protección de la vida familiar de los inmigrantes en el Ordenamiento Comunitario: el derecho a la reagrupación familiar". Madrid, European Community Studies Association, Documento Wp 0801-Derecho, 2010, pp. 10 y 12. Disponible en http://www.ucm.es/info/ audesco/dt.htm

1121 GROENEDIJK, Kees. “Family Reunification as a Right...”, op. cit., p. 219. 
en la interpretación del artículo 8 CEDH por parte del Tribunal de Estrasburgo: la aplicación del derecho al respeto de la vida familiar en casos concretos parte de la premisa del derecho soberano que ostentan los Estados en la regulación de la entrada y residencia de los extranjeros, de modo que, en este contexto, la principal virtualidad del art. $8 \mathrm{CEDH}$ es la imposición de límites que cada vez más estrictos a tal derecho soberano; por su parte, la norma comunitaria toma como premisa de partida el disfrute del derecho a la RF - y la consiguiente obligación estatal de su concesión —, por parte de aquellos nacionales de terceros países legalmente asentados dentro de los EEMM, que cumplan con los requisitos estrictamente definidos en ella, concediendo en contrapartida elevados márgenes de apreciación estatal para que los Estados puedan, en las condiciones fijadas en la norma comunitaria, establecer restricciones a dicho derecho subjetivo ${ }^{1122}$.

Por lo expuesto en estas líneas podemos concluir que la protección dispensada por la Directiva comunitaria, con todas las críticas que sobre ella se han vertido, es en principio muy superior que la derivada del difuso y vaporoso derecho a la vida familiar contemplado por el artículo $8 \mathrm{CEDH}$. En consecuencia, el estándar de protección que el derecho comunitario ofrece a la RF de los extranjeros procedentes de terceros países está muy por encima del estándar mínimo derivado del artículo $8 \mathrm{CEDH}$, tal y como es interpretado por el TEDH. Esta conclusión parece ser pacífica en la doctrina ${ }^{1123}$, y en el mismo sentido se pronunció el TJUE en la sentencia que puso fin al recurso de anulación presentado contra dicho texto comunitario.

Con todo, aunque con carácter general el estándar de la Directiva sea muy superior que el dimanante del artículo $8 \mathrm{CEDH}$, a nuestro juicio, algunos de sus preceptos se sitúan por debajo del estándar mínimo establecido por Estrasburgo ${ }^{1124}$, precisamente los que fueron objeto de controversia en el recurso de anulación ya analizado. Aunque el TJUE ya ha tenido ocasión de pronunciarse en sentido negativo sobre esta cuestión ${ }^{1125}$, consideramos que su escasez argumentativa no ha logrado

1122 Groenendijk ha señalado el TEDH toma como punto de partida de su razonamiento en torno al artículo 8 CEDH el respeto a la soberanía del Estado para controlar la entrada de extranjeros en su territorio — de ahí la centralidad del concepto de margen de apreciación otorgado a los Estados parte en asuntos migratorios en general, y en la RF en particular. En este contexto, la función desplegada por el artículo 8 consistiría en la imposición de límites - no absolutos - a este principio de derecho consuetudinario internacional. Mientras que la Directiva parte del reconocimiento del derecho a la admisión en el EM de los familiares del residente, derecho que puede ser limitado en concurrencia de las circunstancias previstas en su artículo 16. Para el examen de esas circunstancias, la Directiva ha incluido criterios derivados de la jurisprudencia de Estrasburgo - artículo 17 — aplicables a fin de poder determinar la proporcionalidad de las restricciones al derecho a la RF. Pero esta situación es radicalmente distinta a la existente en el ámbito de Estrasburgo. Mientras en la jurisprudencia del TEDH hay que encontrar un justo equilibrio entre el interés de los familiares en ser autorizados a entrar y residir en un EM y el interés estatal de controlar la inmigración, en el ámbito comunitario una decisión negativa a una solicitud de reagrupación familiar o una limitación al mismo debe ser valorada por los EEMM teniendo en cuenta los criterios establecidos en el artículo 17 de la Directiva. Bajo estos distintos prismas, el interés individual goza de una protección superior en el ámbito comunitario, mientras que en el Consejo de Europa se enfrenta al poderoso interés estatal de controlar la admisiones de extranjeros en contextos muchas veces de fuerte presión migratoria. GROENEDIJK, K. "Family Reunification as a Right under Community Law..., op. cit., pp. 219-220.

1123 Vid, a modo meramente ejemplificativo, GROENENDIJK, Kes. "Family Reunification as a Right under Community Law”, op.c it. p. 218; SALES i JARDÍ, Mercè. "La protección de la vida familiar de los inmigrantes en el Ordenamiento Comunitario: el derecho a la reagrupación familiar”. op. cit., pp. 10 y 12.

1124 De la misma opinión es GROENENDIJK, Kes. "Family Reunification as a Right under Community Law", op.c it. p. 219.

1125 La posición al respecto del TJUE en el asunto C-540 ha consistido en afirmar la primera parte de la proposición -la protección dispensada por la Directiva sobre RF es muy superior que la que se destila del artículo $8 \mathrm{CEDH}$, pues la Directiva consagra un auténtico derecho subjetivo general a la RF-, negando la segunda parte — la Corte de Luxemburgor ha afirmado explícitamente la compatibilidad del la Directiva con el artículo 8 CEDH sosteniendo que esta norma comunitaria se limita a mantener en los EEMM el mismo margen de apreciación del que éstos ya 
despejar las dudas sobre este tema, especialmente porque en apoyo de su razonamiento acude a una línea jurisprudencial del TEDH que ya ha sido ampliamente rebasada. Sobre este asunto ya nos hemos pronunciado extensamente al comentar la sentencia emitida en el caso C-540, por lo que basta aquí con dejarlo simplemente apuntado.

\subsection{La condición esencial para el ejercicio del derecho: La residencia legal del reagrupante}

En el derecho comunitario - y ello ha constituido una constante invariable desde los primeros intentos reguladores en el ámbito de la RF de los ciudadanos procedentes de terceros países-, la reagrupación está supeditada al carácter regular de la residencia del principal. La Directiva 2003/86 persiste en la misma exigencia — artículos 2. c) y 3.1-, precisando además que el período de validez del permiso de residencia expedido por el EM ha de ser superior o igual a un año, con la posibilidad de fijar períodos adicionales de espera de dos e incluso tres años, antes de que el principal pueda reagrupar a los miembros de su familia con él ${ }^{1126}$. No existe ningún resquicio que permita enervar la legalidad - más correctamente, "regularidad" - de la residencia del sponsor a lo largo del articulado de la Directiva, luego cabe afirmar que esta exigencia constituye una condición absoluta para el derecho a la RF — dejando a salvo la claúsula pasarela del art. 5.3. de la Directiva así como los supuestos de regularización por arraigo tras determinados períodos de estancia irregular, cuestión que no es tocada por la Directiva 2003/86, y depende totalmente de las políticas internas.

De otro lado, el CEDH parte para su aplicación del principio general de protección de todas aquellas personas que se hallen bajo su jurisdicción - lo que incluiría a todos los extranjeros, con independencia de la legalidad o no de su status jurídico en el Estado Parte. Sin embargo, cuando se trata de la RF en tanto que obligación positiva derivada del derecho al respeto de la vida familiar, el punto de partida de la jurisprudencia de Estrasburgo es muy similar a la Directiva, exigiéndose también que el reagrupante ostente la residencia legal en el Estado parte de acogida para tener acceso a la RF. Obviamente, el CEDH no especifica qué período concreto de residencia legal es pertinente para acceder a la reagrupación, pero del principio de proporcionalidad y de la propia jurisprudencia del TEDH, cabe extraer que éste no puede ser excesivo, a fin de no vaciar de contenido el ejercicio del derecho en cuestión. Visto desde la perspectiva del extranjero irregularmente asentado en el Estado parte, no sería legítima su expectativa de acceder a la residencia por causa de RF, tanto para él como para sus familiares, en tales condiciones ${ }^{1127}$.

disponían en virtud del case law de Estrasburgo derivado del artículo 8 CEDH. El prisma metodológico adoptado por la Corte de Luxemburgo para enjuiciar la Directiva es precisamente el estándar de protección derivado del derecho internacional de los derechos humanos, y fundamentalmente el CEDH tal y como es interpretado por el TEDH, por lo que es el propio Tribunal de Luxemburgo el que confronta la Directiva con el artículo 8 CEDH, esto es, el que examina la relación entre ambos textos.

1126 Artículo 8 de la Directiva 2003/86/CE sobre RF.

1127 En palabras del TEDH: "The Court reiterates that persons who, without complying with the regulations in force, confront the authorities of a Contracting State with their presence in the country as a fait accompli do not, in general, have any entitlement to expect that a right of residence will be conferred upon them". Este principio fue establecido por primera vez en la Decision 53102/99 Chandra and Others v. The Netherlands, de 13 de mayo de 2003. Posteriormente se repite en el apartado 43 de la STEDH Rodrígues da Silva, a la que pertenece la cita literal, y vuelve a reiterarse en términos similares en la STEDH Tuquabo-Tekle. 
En el ámbito de la aplicación del artículo $8 \mathrm{CEDH}$, con carácter general, los extranjeros en situación irregular que aspiren a la RF no tienen ningún derecho a esperar que las autoridades internas les concedan un permiso de residencia por tales motivos ${ }^{1128}$. Si bien con el importante matiz de que esta exigencia es de carácter general, lo que abre la puerta a situaciones excepcionales en las que cabría su exoneración.

Para autorizar una excepción al principio general de regularidad de la estancia, la jurisprudencia del TEDH exige preceptivamente al extranjero que en algún momento previo del tiempo que ha permanecido en el país receptor, haya tenido acceso a un estatuto legal. Y ello con independencia de cúal fuese la concreta causa que le habilitase para ello e incluso sin exigir al extranjero que, habiendo tenido la oportunidad, haya necesariamente disfrutado de un estatuto legal. Ello incluiría tanto los supuestos de irregularidad sobrevenida - muy frecuentes como consecuencia del vínculo existente entre el permiso de trabajo y el acceso a la residencia para el sponsor-, como los supuestos de irregularidad desde la entrada inicial del extranjero en el Estado receptor, como sucedió en el asunto Rodrígues da Silva.

Un panorama más riguroso de la jurisprudencia de Estrasburgo nos exige diferenciar pues dos situaciones merecedoras de tratamientos muy diversos ${ }^{1129}$ : De un lado, aquellos supuestos en los que el extranjero en situación irregular no ha tenido nunca acceso a un título que le habilitase para acceder a un estatus legal en el Estado parte, en cuyo caso, la continuación de su vida familiar no podrá tener lugar en ese Estado; De otro, el supuesto en que el extranjero pudo haber accedido a un estatus legal, con independencia de que lo hiciera o no, en cuyo caso cabe la concesión de la RF - si bien, aclara el TEDH, "de forma extraordinariamente excepcional". Nuestra opinión resta dicho carácter extremo a la concesión de la RF, en vista de que el TEDH ya ha tenido ocasión de conceder el derecho en tales circunstancias. Podríamos añadir una situación más: si el extranjero en situación irregular ha cometido delitos en el Estado de acogida, la adición del "orden público" como causa de denegación de la RF, convertía inicial la exclusión del derecho en absoluta, sin posibilidad de fisuras $^{1130}$, y situando a estos supuestos en una imposible frontera divisoria con la línea jurisprudencial de obligaciones negativas derivadas de la vida familiar o protección frente a expulsiones. Sin embargo, muy recientemente la activista jurisprudencia del TEDH, ya ha tenido ocasión de demostrar el carácter relativo de tal exclusión, otorgando la RF a extranjeros residentes de larga duración que habían cometido delitos contra la propiedad en el Estado parte de $\mathrm{e}^{1131}$.

Por lo tanto, en supuestos de estancia irregular en el territorio de un Estado Parte, será un elemento relevante que el TEDH valorará a favor de los intereses del extranjero demandante si éste, en cualquier momento a lo largo de su permanencia en el Estado miembro, ha podido ser acreedor de un status legal de residente. La posibilidad de solicitar la residencia por alguno de los motivos habilitantes reconocidos al efecto por las legislaciones internas de extranjería, daría lugar al surgimiento

1128 Vid. Apartado 39 STEDH Rodrígues da Silva...cit.

1129 "Nevertheless, the Court finds relevant that in the present case the Government indicated that lawful residence in the Netherlands would have been possible on the basis of the fact that the first applicant and Mr Hoogkamer had a lasting relationship between June 1994 and January 1997. Although there is no doubt that a serious reproach may be made of the first applicant's cavalier attitude to Dutch immigration rules, this case falls to be distinguished from others in which the Court considered that the persons concerned could not at any time reasonably expect to be able to continue family life in the host country" (Apartado 43, STEDH Rodrígues da Silva).

1130 STEDH Konstatinov c. Holanda, de 26 de abril de 2007

1131 En el mismo sentido, ROAGNA, Yvana. Protecting the Right to respect for Private and Family Life under the European Court of Human Rights, op. cit., pP. 90-92. THYM, Daniel. "Respect for Private and Family Life under Article 8 ECHR in Immigration Cases..., op. cit., p. 101. 
de una expectativa razonable para el extranjero irregular de poder continuar con su vida familiar en el territorio del Estado de acogida. De hecho, tal y como afirma el TEDH, conceder una importancia suprema al hecho de la estancia irregular del demandante, sin más consideraciones, supondría por parte de las autoridades estatales incurrir en un excesivo formalismo ${ }^{1132}$. Esta línea argumental constituye un ejemplo claro de la última tendencia jurisprudencial de tono claramente progresista por parte del TEDH en el ámbito de la RF.

En definitiva, el Tribunal de Estrasburgo no excluye la posibilidad de reconocer el derecho a la reunificación familiar a extranjeros en situación irregular. Este tipo de situaciones quedarían automáticamente excluidas bajo la Directiva 2003/86. En este aspecto, la jurisprudencia de Estrasburgo resulta pues mucho más liberal que la Directiva comunitaria sobre reagrupación familiar, que no admite ningún resquicio - salvo la claúsula pasarela del art. 5.3 y la posiblidad de que el EM recurra a procesos de regularización mal llamados extraordinarios- para permitir la reunificación de extranjeros "ilegales", terminología desechada en otros ámbitos, pero en la que la UE continúa perseverando.

\subsection{Las restricciones legítimas al derecho a la reunificación familiar}

El extenso listado de limitaciones genéricas que justifican la restricción a la vida familiar en el apartado segundo del artículo $8 \mathrm{CEDH}^{1133}$ es, en principio, más amplio que las causas de denegación previstas en el artículo 6 de la Directiva ${ }^{1134}$. En este aspecto la diferencia más sustancial reside en la ausencia del bienestar económico del país como causa de injerencia legítima en el derecho a la RF en la Directiva 2003/86; mientras que, en el ámbito de Estrasburgo, este motivo está incorporado de forma excepcional en el artículo 8.2 CEDH, condensando y monopolizando en la práctica el amplio listado de limitaciones previstas en dicha disposición, en lo que respecta a los supuestos de RF. Aunque los EEMM han llegado a alegar motivos distintos al bienestar económico estatal, el TEDH ha terminado considerado todas las demandas presentadas hasta la fecha desde la perspectiva exclusiva de la cláusula del bienestar económico del país.

La omisión del bienestar económico del país constituye una característica de la regulación comunitaria relativa a la RF de los ciudadanos extracomunitarios desde sus inicios en 1993. Ello no resta mérito a su ausencia en la Directiva, especialmente si consideramos que a lo largo de su agitada elaboración nunca incluyó en sus borradores la posibilidad de su incorporación, pese a la escalada precipitada a la baja en que finalmente se tradujo la búsqueda del consenso. Esta circunstancia determina que de la Directiva 2003/86 se derive un estándar más elevado que el existente en el sistema del CEDH con respecto a las injerencias permitidas. En consecuencia, futuras restricciones en el derecho a la reunificación familiar - derecho que, como ya señalamos, resulta especialmente vulnerable a la inestabilidad legislativa típica de la extranjería y la inmigración-, no podrán ser justificadas bajo el pretexto de preservar el bienestar económico del país. Esta circunstancia resulta especialmente bienvenida en el contexto actual de recesión económica, ya que, de otro modo, las ele-

1132 Sentencia Rodrígues da Silva, Apartado 44.

1133 El apartado segundo del artículo 8 señala que: "No podrá haber injerencia de la autoridad pública en el ejercicio de este derecho, sino en tanto en cuanto esta injerencia esté prevista por la ley y constituya una medida que, en una sociedad democrática, sea necesaria para la seguridad nacional, la seguridad pública, el bienestar económico del país, la defensa del orden y la prevención del delito, la protección de la salud o de la moral, o la protección de los derechos y las libertades de los demás".

$1134 \mathrm{El}$ artículo 6 prevé razones de orden público, seguridad pública o salud pública como causas para denegar una solicitud o retirar o denegar la renovación de un permiso ya concedido. 
vadas cifras de paro y el estancamiento económico podrían fácilmente tentar a los políticos y legisladores internos - siquiera sea con fines meramente electorales - a promover reformas en sentido limitativo bajo la excusa de proteger la economía y el mercado de trabajo autóctonos.

Sin embargo, si el término de comparación se sitúa a un nivel más concreto, a las causas previstas en el artículo sexto de la Directiva sobre RF, habría que sumarle los motivos específicos de denegación previstos en el artículo 16, en sede de sanciones - el cese de la vida conyugal o familiar efectiva, el uso de información falsa o engañosa, los matrimonios, relaciones de pareja o adopciones fraudulentos, así como el incumplimiento sobrevenido de las condiciones previstas por la Directiva. Junto a ellos, y a un nivel igualmente preocupante, la Directiva está plagada de restricciones concretas al derecho a la RF que desembocan en una ampliación de facto del aparentemente más limitado catálogo comunitario de injerencias legítimas. Especialmente controvertidas resultan las restricciones que dieron lugar al planteamiento del recurso de anulación de la Directiva por parte del Parlamento Europeo. En su argumentación, el TJUE eludió encajar las limitaciones recurridas en alguno de los motivos legítimos contemplados por el artículo $8.2 \mathrm{CEDH}^{1135}$ - en lo que quizá hubiera constituido un importante baza de cara a reforzar la compatibilidad de la Directiva con el CEDH-, ni tampoco razonó adecuadamente si las mismas superaban la exigencia de proporcionalidad implícita al requisito de la necesidad en una sociedad democrática, requerida por el test convencional de Estrasburgo. Pero además de las disposiciones recurridas, el proceso de aplicación interna de la Directiva 2003/86 permite ahora adicionar algunas limitaciones facultativas que ya han tenido ocasión de demostrar su efecto nocivo a nivel interno, especialmente la posibilidad de requerir que los extranjeros cumplan con medidas de integración ${ }^{1136}$.

En definitiva, la suma de estas concretas limitaciones desperdigadas en el cuerpo sustantivo de la Directiva 2003/86, en conjunción con la amplitud del margen de apreciación nacional concedido por esta norma, dibuja un panorama en el que resulta precipitado afirmar de forma contundente que el catálogo de injerencias legítimas a la RF de Estrasburgo resulte más dilatado que previsto en el ordenamiento comunitario para los nacionales procedentes de terceros países.

\section{9 Exigencias derivadas de la Jurisprudencia en torno al artículo $8 \mathrm{CEDH}$}

De la jurisprudencia del TEDH en aplicación del derecho al respeto de la vida familiar como obligación migratoria convencional positiva, es posible extraer determinadas exigencias que los Estados parte del Consejo de Europa deben incorporar en sus políticas migratorias internas. Todas ellas poseen una extraordinaria eficacia práctica. En virtud del artículo 6.2 TCE y de la propia jurisprudencia del TJUE, las mismas son de aplicación a las políticas de inmigración y extranjería de los EEMM de la UE.

1. De la necesidad de ponderar las circunstancias del caso a fin de extraer las obligaciones dimanantes en esta materia, se deduce que las solicitudes de reagrupación familiar deben ser

1135 Una de las cuestiones que el TJUE dejó pasar por alto en la sentencia emitida en el asunto C-540 fue la relativa a si las restricciones recurridas por el Parlamento Europeo podrían ser consideradas, a la luz del artículo 8 CEDH, como limitaciones legítimas en el derecho al respeto de la vida familiar, pese a no estar contempladas explícitamente en el apartado segundo de dicho artículo. La cuestión se trasladaría entonces a encontrar un punto de encaje de las disposiciones recurridas dentro del catálogo establecido en el apartado segundo del artículo 8 CEDH. El TJUE se limitó a afirmar que las disposiciones controvertidas podrían encajar en algunos —en plural— de los motivos establecidos en el artículo 8.2 CEDH, pero sin especificar en cúales.

1136 Apartado segundo del artículo 7 de la Directiva 2003/86. 
objeto de una valoración y examen individualizado por parte de las autoridades nacionales ${ }^{1137}$. Esta exigencia ya ha tenido ocasión de ser confirmada por el TJUE, al resolver la cuestión prejudicial formulada por los Países Bajos en torno a la interpretación de determinados artículos de la Directiva 2003/86/CE sobre RF. El examen caso por caso de las solicitudes de admisión deberá ser más riguroso cuando se trate de hijos menores, puesto que en tal caso el derecho internacional de los derechos humanos y el propio derecho comunitario exigen tener en cuenta el interés superior del menor y procurar favorecer la vida familiar ${ }^{1138}$.

2. De la anterior exigencia se extrae una consecuencia de enorme importancia práctica. El examen individualizado de los casos implica la prohibición de aquellos sistemas que supongan cierto automatismo ${ }^{1139}$ en la evaluación y denegación de las solicitudes de reagrupación. Ello excluye la aplicación de reglas generales o umbrales abstractos internos, del tipo que sean, que impidan la toma en consideración particularizada de las circunstancias del asunto. En este sentido, el establecimiento de regímenes que establezcan limitaciones numéricas al número de admisiones de extranjeros en un Estado por motivos de RF, resulta incompatible con las exigencias derivadas del artículo $8 \mathrm{CEDH}$ por impedir el examen individualizado de las solicitudes. Ello supone que un régimen de cuotas ${ }^{1140}$ que fije unos niveles de entradas numéricas periódicas, es contrario al artículo $8 \mathrm{CEDH}$. Asimismo, la fijación abstracta de umbrales mínimos de ingresos y/o rentas que actúen con carácter absoluto, esto es, que impidan el estudio individualizado de cada solicitud de RF o de formación familiar, resultan contrarios a los criterios de Estrasburgo asumidos plenamente por el derecho comunitario, tal y como atestigua la sentencia Chakroun del TJUE.

1137 En este sentido, la propia Directiva 2003/86/CE resulta plenamente respetuosa con la doctrina de Estrasburgo. Al adoptar una resolución de carácter negativo en relación a una solicitud de RF, el artículo 17 de la mencionada Directiva - el cual constituye una penetración parcial de los criterios jurisprudenciales utilizados por el TEDH en los supuestos de RF de extranjeros-, exige tomar en consideración determinadas circunstancias personales cuando se adopta una resolución negativa en relación con la reagrupación familiar. En consecuencia, la Directiva, siguiendo a Estrasburgo, exige un examen individualizado de cada solicitud de RF. El apartado 49 de las Conclusiones del Abogado General en el asunto Chakroun se pronunciaba explícitamente en torno a esta cuestión. De otro lado, dentro del ámbito doctrinal se lanzaron voces que defendían la necesidad de un examen caso por caso de las solicitudes de RF, tanto antes como después de que el asunto Chakroun confirmara la veracidad de dicha aseveración. Entre ellas, vid. GROENENDIJK, K. “Family Reunification as a Right under Community Law”, op. cit., p. 224. WIESBROCK, Anja. "Court of Justice of the European Union. The Right to Family Reunification to Third-Country Nationals under EU Law; Decision of 4 March 2010, Case C-578/08, Rhimou Chkaroun V. Minister van Buitenlandse Zake", op. cit., p. 469.

1138 Artículo 9.1 en conjunción con el sexto considerando de la Convención sobre los derechos del niño, y artículo 5.5 de la Directiva 2003/86/CE sobre reunificación familiar.

1139 IGLESIAS SÁNCHEZ, Sara. “El valor de la Directiva 2003/86/CE ...”, op. cit., p. 149.

1140 La jurisprudencia de Estrasburgo en torno al derecho a la reunificación familiar ha demostrado estar llena de consecuencias prácticas. La importancia de tomar en consideración las circunstancias concretas del caso en todas las solicitudes de RF ha demostrado ser especialmente prolífica en este punto. El TC austriaco - Verfassungsgerichtshof-declaró por este motivo contrario a la Constitución austriaca el sistema de cuotas anuales que aplicaba la República de Austria (Sentencia de 8 de octubre de 2003 en el asunto G 119, 120/03-13). Austrian Verfassungsgerichtshof 8 October 2003, na G119/03, disponible en la web del TC Austríaco: www.vfgh.fv.at. También el TC de Estonia, en el mismo sentido, estableció que los sistemas de cuota que se aplicaban para restringir la entrada de miembros de la familia de extranjeros asentados en Estonia eran contrarios a la Constitución por contravenir el artículo $8 \mathrm{CEDH}$. El contexto en que se produjo este pronunciamiento del TC de Estonia fue la adaptación que el derecho interno de este país estaba llevando a cabo a fin de estar en sintonía con el derecho comunitario en la materia, que en la época estaba constituido por la Resolución de armonización en materia de reunificación familiar del año 1993. Citado por CHOLEWINSKI, Ryszard. "Family Reunification as a Constitutional Right"; APAP, Joanna (ed.) Justice and Home Affairs in the EU. Liberty and Security Issues after Enlargement, op.cit. p. 265. 
Ambos supuestos ya han tenido ocasión de ser confirmados judicialmente, pero la exigencia de Estrasburgo que obliga a un examen estatal individualizado de las solicitudes de RF, cristalizada en el artículo 17 de la Directiva 2003/86/CE, extiende su implicaciones a otros niveles, tales como las condiciones exigidas a la vivienda, medidas de integración ${ }^{1141} \ldots$ etc. Cuando menos, tal exigencia requiere revisar los diversos sistemas internos legislativos implementados para determinar las condiciones concretas que gravan el ejercicio del derecho a la RF, y, a nivel administrativo, controlar la adecuación de los mecanismos establecidos para la recepción, estudio y resolución de las solicitudes de RF.

3. Prohibición de mantener o introducir medidas migratorias desproporcionadas que no permitan ponderar los intereses contradictorios en conflicto, a fin de mantener el justo equilibrio que ha de existir entre los mismos.

4. La posibilidad de supeditar el ejercicio del derecho a la $\mathrm{RF}$ a la existencia de recursos económicos resulta legítima siempre que éstos sean de carácter básico - a fin de no vaciar de contenido el derecho-, y que estén destinados a garantizar que el extranjero podrá afrontar los gastos de mantenimiento de su familia sin recurrir a los beneficios concedidos por los servicios de asistencia pública del Estado receptor ${ }^{1142}$. La escasa jurisprudencia de Estrasburgo relativa a las condiciones materiales que gravan el derecho, no permite extraer mayores precisiones sobre este punto. La doctrina expuesta ha sido asumida por el TJUE en el asunto Chakroun.

5. El Tribunal de Estrasburgo mantuvo durante toda su primera etapa y parte de la segunda, una clara línea divisoria entre los supuestos de RF en sentido estricto — susceptibles de tutela-, y los supuestos de formación familiar ${ }^{1143}$ - excluidos de su ámbito de protección. La aproximación tradicional del TEDH a la formación familiar fue por ello considerada como "particularmente restrictiva" 1144 . Sin embargo, a partir de Rodrígues da Silva, los vínculos familiares formados con posterioridad a la entrada del reagrupante en el Estado parte - que formalmente constituían vida familiar desde el asunto Abdulaziz-, accedieron materialmente a la protección derivada del artículo $8 \mathrm{CEDH}$. La fronteras entre ambas categorías migratorias tienden pues a diluirse. A esta concepción se ha sumado el TJUE en el asunto Chakroun ${ }^{1145}$.

6. Sólo cabe la denegación del derecho a la RF por motivos tasados y legalmente previstos. Dado que la Directiva no incluye expresamente el bienestar económico del país como restricción legítima al derecho a la reunificación familiar, "de ello parece deducirse que en el futuro no podrá aplicarse una desfavorable coyuntura económica como causa de restricción de este derecho"1146. En

1141 En el mismo sentido, WIESBROCK, Anja. "Court of Justice of the European Union. The Right to Family Reunification to Third-Country Nationals under EU Law; Decision of 4 March 2010, Case C-578/08, Rhimou Chkaroun V. Minister van Buitenlandse Zake", op. cit., p. 477.

1142 Apartado 50 de la sentencia Konstantinov c. Holanda, de 26 de abril de 2007, conforme al cual: "En principio, la Corte no considera irrazonable el requisito de que un extranjero que haya adquirido un estatus estable en un Estado contratante y que busque la reunificación familiar, tenga que demostrar poseer ingresos suficientes, independientes y duraderos, no considerados beneficios sociales, para proveer a los costos básicos de subsistencia de los miembros de su familia con quienes pretende reunirse".

1143 WIESBROCK, Anja. "Court of Justice of the European Union. The Right to Family Reunification to Third-Country Nationals under EU Law; Decision of 4 March 2010, Case C-578/08, Rhimou Chkaroun V. Minister van Buitenlandse Zake", op. cit., p. 474.

1144 Idem, p. 473.

1145 Sentencia Chakroun, apartado 63, donde el TJUE extrae la siguiente conclusion de la jurisprudencia de Estrasburgo, "esta interpretación —en referencia a la concepción amplia de RF, que abarque tanto el mantenimiento como la creación de la vida familiar - es conforme con el artículo 8 CEDH y con el artículo 7 de la Carta, que no establecen distinción alguna según las circunstancias y el momento en los que se constituye la familia”.

1146 SANTOLAYA MACHETTI, Pablo. El derecho a la vida familiar de los extranjeros..., op. cit., p. 124 
consecuencia, la ausencia del bienestar económico del país entre las restricciones comunitarias legítimas del derecho a la RF da pie para deducir que sobre su configuración normativa planea la exigencia implícita de que las conquistas ya logradas, deberían ser irreversibles.

7. Desde los inicios de esta rama jurisprudencial, se puede deducir que en aquellos supuestos donde no sea posible la continuación de la vida familiar en ningún otro lugar, la denegación de la reunificación familiar constituiría una violación del artículo $8 \mathrm{CEDH}^{1147}$. La mayor parte de la doctrina considera asentada esta línea jurisprudencial y por lo tanto el derecho humano resultante que, como tal, surgiría en supuestos excepcionales. En consecuencia, se trataría de un derecho que vendría a otorgar protección internacional tan sólo a los casos más extremos donde la denegación de la autorización de entrada a los familiares del extranjero residente en el EM constituyese una clara violación de su vida familiar, imposible de reconstituir en ningún otro lado del mundo, ante la inexistencia de vínculos de los extranjeros implicados con ningún otro Estado que no fuera el país receptor ${ }^{1148}$. Esta restrictiva línea jurisprudencial limitaba el círculo de protección que la vida familiar proyectaba sobre la inmigración familiar de los extranjeros a aquellos supuestos de nacionales de terceros países que sufran persecución o riesgo de persecución en el país de origen —asilados y refugiados—, situación que, de otro lado, ya está protegida por el artículo $3 \mathrm{CEDH}$. Aunque en la actualidad el criterio elsewhere ha sido muy suavizado por el TEDH, no obstante resultaría conveniente que la Directiva hubiera previsto en su articulado la obligación del EM de otorgar la RF a aquellos extranjeros cuya vida familiar no fuese posible reconstituir en ningún otro país.

8. De la última línea jurisprudencial, iniciada en Sen y ratificada en posteriores sentencias, cabría deducir también un derecho convencional a la RF en circunstancias en las que, aun siendo posible la reconstitución familiar en un tercer país - distinto al país de acogida-, el extranjero o los miembros de su familia poseen vínculos de gran fortaleza con el Estado receptor. En tales supuestos, la salida del país de acogida a fin de reanudar la vida familiar en un tercer Estado, provocaría "trastornos" de largo alcance para la vida privada y familiar de los extranjeros implicados, convirtiendo en ilegítima dicha opción. En esta línea, los lazos más sólidos que por el momento han sido reconocidos por Estrasburgo se producen cuando existen hijos nacidos y criados enteramente en el territorio del Estado de acogida, careciendo de vínculos con el Estado de origen de sus progenitores. En el supuesto mencionado, los hijos nacidos en el EM suelen actuar como reagrupantes, conforme al concepto amplio de titularidad activa que en torno a la RF mantiene la jurisprudencia de Estrasburgo.

9. El TEDH aboga por una concepción amplia o dual de la titularidad activa del derecho a la RF, que incluye tanto al reagrupante o sponsor como a sus familiares más cercanos, lo que redunda en

1147 SCHUTTER, Olivier De. Report of the Situation of Fundamental Rights in the European Union in 2003, op. cit., p. 55. En este sentido, el Informe sobre la situación de los derechos fundamentales en la UE correspondiente al año 2002, afirmaba también contundentemente que "When family life cannot be continued elsewhere without resulting in a violation of the right of respect for private and/or family life on account of the disruption of the living environment of the persons concernid, Article 8 of the European Convention of Human Rights guarantees the right of family reunification". Report on the Situtation of Fundamental Rights in the European Union in 2002, EU Network of Independent Experts of Fundamental Rigthts (CFR-CDF). March 31 2003, p. 87. En el mismo sentido se pronuncia CORTES MARTÍN, José Manuel. "Inmigración y derecho a la reunificación familiar en la UE: ¿Mínimo común denominador de las políticas nacionales?”; en Anuario de Derecho Europeo, no 4, 2004, p. 33. SANTOLAYA MACHETTI, Pablo. El derecho a la vida familiar de los extranjeros..., op. cit., p. 110. GARCÍA RODRIGUEZ, Isabel. Matrimonio e Inmigración. El control del consentimiento matrimonial en la reagrupación familiar. Madrid, Colex, 2008, p. 53.

1148 En el mismo sentido, CHOLEWINSKI, Ryszard. “Family Reunification as a Constitutional Right?”, op. cit., p. 263. 
un radio mayor de protección de la vida familiar. Esta concepción dual ha permeado también en la Directiva sobre el derecho a la RF, si bien a un nivel más formal que auténticamente sustancial.

10. El TEDH ya ha tenido ocasión de pronunciarse en torno a la legitimidad de las políticas migratorias internas que favorezcan a nacionales de terceros países con los que el Estado parte ha mantenido vínculos en su pasado ${ }^{1149}$, como por ejemplo los coloniales. Estos tratamientos diferenciados no constituyen en principio una discriminación por razón de raza, siendo compatibles con el principio de igualdad consagrado en el artículo $14 \mathrm{CEDH}^{1150}$.

11. En el ámbito específico de la RF, serían también admisibles tratamientos normativos preferentes a favor de los familiares extranjeros de los nacionales del Estado parte - al menos con respecto al cónyuge del nacional, único supuesto tratado por el TEDH en el asunto Abdulaziz-. Tomando por válida la doctrina Abdulaziz, en principio tendría validez el establecimiento de un régimen de reagrupación más favorable cuando el principal o sponsor sea nacional por razón de nacimiento con respecto a aquellos reagrupantes — también nacionales del Estado parte-, pero que hubieran adquirido la nacionalidad por naturalización tras años de residencia legal en dicho Estado. Sólo existen referencias a esta cuestión en una sentencia ya lejana, que constituye además el primer supuesto de RF fallado por el TEDH ${ }^{1151}$, por lo que esta conclusión debe tomarse con cierto relativismo. Con todas las precauciones necesarias, no parece desatinado afirmar que

1149 Esta cuestión se trató en la sentencia Abdulaziz, Cabales y Balkandali, y el TEDH también ha tenido ocasión de analizarlo en sede de protección frente a las expulsiones, por ejemplo en el asunto Moustaquim y C. Sin embargo, nuestras conclusiones se ciñen a lo que la jurisprudencia del TEDH nos permite deducir en asuntos relativos a RF. En el caso Abdulaziz, las demandantes extranjeras alegaban que las normas inglesas de migración incurrían en discriminación racial. El TEDH negó la violación del principio de igualdad. Al respecto Steve Peers ha destacado la debilidad de la argumentación proporcionada por el TEDH en el asunto Abdulaziz. A juicio de Peers, el TEDH comparó las normas relativas a la admisión de extranjeros con las normas aplicables a los reagrupantes con vínculos cercanos al Reino Unido, sin examinar sin embargo si dicho país establecía diferentes normas para diferentes nacionalidades de reagrupantes, por lo que cuestiona la validez de su pronunciamiento en materia de discriminación racial y por derivación, la conclusión que ofrecemos en este apartado.

1150 En la sentencia Abdulaziz la Comisión Europea de Derechos Huamnos se pronunció de forma clara sobre este punto, señalando que: "Al restringir como lo hacen la libertad de entrada, las políticas de inmigración suelen realizar distinciones basadas en la nacionalidad de las personas, e indirectamente en su raza, origen étnico o color. Aunque un Estado no podría desarrollar "una política de carácter puramente racista", el dar un trato de favor a sus nacionales o a personas procedentes de los países con los que tenga vínculos más estrechos no constituiría una “discriminación racial". (Apartado 84, Sentencia Abdulaziz, Cabales y Balkandali). El TEDH manifestó su acuerdo con la mayoría de la Comisión.

1151 Se trata nuevamente de la sentencia Abdulaziz, Cabales y Balkandali. En este asunto, el TEDH tuvo ocasión de examinar si las normas migratorias de la época incurrían en una discriminación basada en el nacimiento — tal y como alegaba una de las demandante, la sra. Baldandali-, como consecuencia de la reserva que establecían dichas normas a favor exclusivamente de las personas que hubieran nacido o uno de cuyos padres hubiera nacido en el Reino Unido, a fin de que el cónyuge no nacional de estas personas pudiera obtener una autorización de establecimiento. Dicha distinción fue posteriormente eliminada por el Reino Unido, incluso antes de que fuera dictada la sentencia Abdulaziz. Pese a ello, tanto el TEDH como la por entonces existente Comisión Europea de DH consideraron que el interés general exigía pronunciarse sobre la legitimidad o no de dicho tratamiento diferenciador. La Comisión estimaba que "una distinción basada en la simple circunstancia del nacimiento, sin tener en cuenta la situación o los méritos personales del interesado, constituye una discriminación contraria al artículo 14”. Por su parte, el Gobierno inglés demandado alegaba al respecto que la distinción se justificaba a fin de evitar la situación en la que se hallarían las mujeres que tienen estrechos vínculos con el Reino Unido si tras su matrimonio se vieran obligadas a marchar al extranjero para permanecer con sus maridos. El TEDH se apartó de la tesis de la Comisión y negó la existencia de discriminación por razón de nacimiento, afirmando que: "El fin invocado por el Gobierno es, sin ninguna duda, legítimo a efectos del artículo 14. Es cierto que una persona que, como la señora Balkandali, viva en un país durante muchos anos puede haber entablado con él fuertes vínculos, aunque no haya nacido allí. No obstante, existen en general convincentes razones sociales para otorgar un trato especial a las personas cuyos vínculos con un país derivan de su nacimiento en su territorio. Debe, pues, considerarse que la diferencia de trato 
en Abdulaziz, Cabales y Balkandali, el Tribunal tocó uno de los puntos neurálgicos de la RF, a saber, si resulta legítimo el establecimiento de tratamientos jurídicos diversos en función de la nacionalidad que ostente el principal o sponsor.

Toda la construcción comunitaria del régimen de la RF pivota sobre la diferenciación por razón de la nacionalidad, que justifica a priori el tratamiento más favorable del que disfrutan los familiares extranjeros cuando el principal es un ciudadano comunitario. Con independencia de la validez actual de la doctrina jurisprudencial emitida en este ya lejano pronunciamiento, parece claro que en el razonamiento del TEDH subyace la negación implícita del carácter fundamental del derecho a la RF. Con ello el TEDH tocó de forma muy temprana uno de los aspectos más controvertidos de esta materia y sobre el que abunda la retórica terminológica: Si se tratase de un derecho fundamental, no cabría el establecimiento de tales diferencias normativas sobre la base de la nacionalidad de sus titulares pues la íntima conexión que estos derechos tienen con la dignidad humana exige universalidad en el sujeto activo. En definitiva, la legitimidad de tratamientos de reagrupación divergentes en base a la nacionalidad del sujeto activo, vendría a contradecir el carácter fundamental del derecho a la RF. Pese a todo lo dicho, el TJUE proclamó formalmente en el asunto C-540 la naturaleza fundamental de la RF, perpetuando la "confusión semántica"1152 que parece gobernar esta materia.

12. Característica común a ambos órdenes es la tendencia tanto del TEDH como del TJUE a la reducción progresiva del alcance del margen de apreciación en los supuestos relativos a la RF. El TEDH de forma mucho más expresa ha terminado situando el inicialmente "elevado" margen de apreciación existente en las obligaciones migratorias positivas $-\mathrm{RF}$ - a niveles equiparables al existente en los casos de protección frente a expulsiones. Por su parte, el TJUE se ha dedicado a la tarea en el asunto C-540 — si bien de forma sutil—, siendo su postura mucho más expresa y protectora en el asunto Chakroun.

13. Común también es la importancia creciente que ambos Tribunales otorgan al criterio del interés superior del menor al evaluar las solicitudes de RF — si bien éste fue introducido de forma más bien tardía en el ámbito de Estrasburgo con la sentencia Sen y, a partir de ella, su importancia no ha dejado de crecer-. Algunos autores matizan que en ambos órdenes se trata de un criterio infrautilizado ${ }^{1153} \mathrm{o}$, más bien, usado desde la perspectiva de los adultos, sin situar realmente al menor y a sus intereses en el centro del razonamiento. Comparativamente hablando, el criterio del interés mejor del menor ocupa una postura prioritaria en las últimas sentencias del TEDH,

tenía un justificación objetiva y razonable y, en particular, nada prueba que sus consecuencias se hayan opuesto al principio de proporcionalidad" (Apartado 88 de la Sentencia Abdulaziz, Cabales y Balkandali).

1152 LAWSON, Rick. "Family Reunification Directive. Court of Justice of the European Communities. Family Reunification and the Union's Charter of Fundamental Rights, Judgement..., op. cit., p. 339.

1153 Alvaro Gil Robles, por entonces Comisiario de Derechos Humanos del Consejo de Europa, emitió un interesante informe con ocasión de una norma de la legislación danesa con contenido muy similar al artículo 4.6 de la Directiva, si bien la norma danesa establecía como tope los catorce años de edad del hijo menor del inmigrante — no los quince años de la Directiva-. En dicho informe Gil Robles señalaba que la aplicación rigurosa del criterio del interés superior del menor debería conducir a resolver muchas de las solicitudes de RF que afecten a los menores inmigrantes en sentido positivo. "It might reasonably be assumed, however, that family reunion will in fact be in the best interest of the child in the great majority of cases". Siguiendo la línea argumentativa de Gil Robles, cabría presumir que en la inmensa mayoría de las situaciones que involucran a hijos de inmigrantes que viven regularmente en un EM, la aplicación del artículo 9.1 de la Convención sobre los derechos del niño, debería llevar a las autoridades públicas del Estado receptor a suponer que la actuación más conveniente para el interés del menor sea aquella que le permita convivir con sus padres, es decir, la concesión de la RF. De tales supuestos habría que exceptuar casos extremos tales como violencia doméstica, explotación laboral o sexual infantil, maltrato a menores, entre otros. El informe citado está disponible en https://wcd.coe.int/ViewDoc.jsp?id=758781\&BackColorInternet=99B5 AD\&BackColorIntranet $=$ FABF45\&BackColorLogged $=$ FFC679 
siendo escasamente relevante en el enjuiciamiento del TJUE al asunto C-540 - especialmente al estimar la validez del régimen excepcional que sobre los menores permite la Directiva 2003/86-

14. Finalmente, constituye otra característica compartida por ambos sistemas regionales, su contribución a fin de propiciar una cierta armonización de los estándares de derechos humanos aplicables a los extranjeros ${ }^{1154} \mathrm{y}$, por esta vía, dotar de mayor coherencia a las políticas migratorias de los Estados parte, característica apuntada por la Organización Internacional de las Migraciones como una de las tendenciales de las actuales migraciones globales ${ }^{1155}$.

En definitiva, dentro de un panorama comunitario perfilado en su esencia por una Directiva que ha optado por un nivel bajo de protección, el derecho a la RF, en su conjunto, ha resultado ampliamente favorecido. Con ella emerge en la UE un auténtico derecho subjetivo de los nacionales procedentes de terceros países a la RF, si bien dotado de márgenes de apreciación nacional muy elevados.

En este contexto, la nota más esperanzadora con la que podemos concluir estas líneas sea recordar que la protección dispensada por el $\mathrm{CEDH}$ - especialmente a raíz de su última línea progresista-, está llamada a desarrollar una función correctora de los desequilibrios internos ${ }^{1156}$, que se revela de especial utilidad ante aquellos Estados parte tentados a abusar de los márgenes de apreciación al resolver las solicitudes de reagrupación, olvidando la obligación de interpretarlos de forma compatible con los derechos fundamentales - obligación que el TJUE ha reiterado abundantemente en la sentencia que resolvió el recurso de anulación parcial contra la Directiva comunitaria sobre el derecho A la RF. Desde esta perspectiva, la actuación del TEDH —al aplicar e interpretar el artículo $8 \mathrm{CEDH}$ en las demandas individuales entabladas contra medidas migratorias emprendidas en los distintos Estados parte-, servirá para complementar los déficits de protección que se detectan en la Directiva 2003/86 de la Directiva.

1154 GUIRAUDON, Virginie; LAHAV, Gallya. “A Reappraisal of the State Sovereignty Debate. The Case of Migration Control"; Comparative Political Studies, vol. 33, No 2, p. 174. 


\section{CAPÍTULO IV \\ LA REUNIFICACIÓN FAMILIAR EN EL ORDENAMIENTO JURÍDICO ESPAÑOL}

\section{LA EXTRANJERÍA EN EL DERECHO HISTÓRICO}

La regulación actual de la extranjería y la inmigración en el ordenamiento español gravita en torno a dos ejes: los derechos y libertades públicas están regidos por el principio de diferenciación entre españoles y extranjeros, mientras el principio de equiparación constituye el pilar en torno al cual se construye el derecho privado ${ }^{1}$. Esta dualidad contrasta con la tradición histórica española existente en esta materia, en la que, salvo contadas excepciones ${ }^{2}$, la extranjería había estado imbuida por la tendencia a la equiparación entre españoles y extranjeros, presente tanto a nivel legislativo como jurisprudencial.

El ordenamiento histórico-positivo adoptó un tratamiento muy benéfico con los extranjeros que se hallasen bajo la jurisdicción del Estado Español, hasta el punto de ser considerado como uno "de los más progresivos conocidos por la historia y el Derecho Comparado"3. Y esta característica resulta predicable de nuestro ordenamiento histórico desde fechas muy anteriores al advenimiento del Estado Constitucional.

Dentro de esta tradición se incardina el respeto jurídico a las propiedades de los extranjeros, cuya manifestación más expresiva es la inaplicación en nuestro país del derecho de aubana y la

1 ABARCA JUNCO, A. P.; ALONSO-OLEA GARCÍA, B; LACRUZ LÓPEZ, J.M; MARTÍN DÉGANO, I. y VARGAS GÓMEZ-URRUTIA, M. Inmigración y extranjería. Régimen jurídico básico. Adaptado a la Ley Orgánica 2/2009, de 11 de diciembre, de reforma de la Ley de Extranjería. Madrid, Colex, $3^{\text {a }}$ edic, 2010, p. 27. GARCÍA VÁZQUEZ, Sonia. El estatuto jurídico-constitucional del extranjero en España. Valencia, Tirant lo Blanch, 2007, pp. 28-30. PÉREZ VERA, Elisa. "La Constitución Española de 1978 y el Derecho Internacional Privado. Normas en materia de nacionalidad y extranjería”; en Revista de Derecho Público, n 86, 1982, pp. 20-21. Una visión parcialmente distinta a esta posición dominante se encuentra en SERRANO ALBERCA, J.M., para quien el sistema constitucional español parte del principio de equiparación no absoluta entre nacionales y extranjeros, correspondiendo a la ley y a los convenios internacionales la posibilidad de restingir el disfrute de los derechos consagrados a los extranjeros. "Comentarios al artículo 13.1 de la Consittución”; en GARRIDO FALLA. Comentarios a la Constitución. Madrid, 1985, 2a edic., p. 218. Sobre el tema, resulta de especial interés la obra de IRIARTE ÁNGEL, José Luis. Los derechos civiles de los extranjeros en España: el artículo 27 del Código Civil. Madrid, La Ley, Grupo Wolters Kluwer, 1988.

2 Las excepciones estarían conformadas por la Constitución de 1845 y la Constitución de 1931. La tendencia equiparadora terminaría vertiéndose en los artículos 15 del Código de Comercio y 27 del Código Civil, ambos “imbuidos (...) de un mismo espíritu internacionalista y abierto”. PÉREZ VERA, Elisa y ABARCA JUNCO, Paloma. "Artículo 13. Extranjería”; en ALZAGA VILLAAMIL, Oscar (dir.). Comentarios a la Constitución Española de 1978. Tomo II (Artículos 10 a 23). Madrid, Cortes Generales, Edersa D.L., 1996, p. 188.

3 PÉREZ VERA, E. “Artículo 13. Extranjería”, op. cit., p. 70. 
precoz abolición del derecho de naufragio ${ }^{4}$, mientras que en los países de nuestro entorno ambos derechos gozaron de amplio reconocimiento durante la Edad Media, hasta su eliminación definitiva a raíz de la Revolución Francesa.

A mediados del siglo XVI surge en España el Fuero de Extranjería, en cuya virtud se reconoció a los extranjeros que circulaban por territorio español un fuero propio y privilegiado, que atribuía en exclusiva a los denominados "jueces conservadores" - en realidad jueces protectores de los derechos de los extranjeros ${ }^{5}$ - el conocimiento de las causas civiles y criminales en las que estuvieran implicados. El ámbito de actuación de la jurisdicción especial de extranjería se fue ampliando progresivamente por vía convencional, hasta terminar generalizándose y amparando a todos los extranjeros que circulasen por España, con independencia de su concreta nacionalidad ${ }^{7}$.

A partir de la Constitución de Cádiz ${ }^{8}$ y coincidiendo con el inicio de la época codificadora, fueron varios los intentos fallidos de eliminar el fuero de extranjería ${ }^{9}$. Desde entonces, el principio

4 El derecho de aubana, consistente en la incapacidad de transmisión y recepción hereditaria de los bienes, fue de aplicación generalizada a los extranjeros durante el Antiguo Régimen en Europa. Conforme al mismo, si un extranjero moría fuera de su país y sin haberse nacionalizado en ese territorio, sus bienes pasaban automáticamente a manos de la Hacienda de dicho Estado. Por su parte, el derecho de naufragio habilitaba al señor feudal o monarca a apropiarse de los restos de un buque extranjero que hubiera naufragado cerca de sus costas, aun cuando el mismo hubiese sido maliciosamente provocado. El derecho de naufragio fue expresamente prohibido en los Fueros de Reino de Valencia de 1261. Para una visión más profunda de este tema, vid. ÁLVAREZ-VALDÉS y VALDÉS, Manuel. La extranjería en la historia del Derecho Español. Oviedo, Universidad de Oviedo, Servicio de Publicaciones, 1992, especialmente pp. 295 y 296.

5 En torno a la ordenación histórica española de la extranjería, considerándola especialmente benigna en el tratamiento de los derechos de los extranjeros, ADAM MUÑOZ, María Dolores. "El estatuto jurídico del extranjero en el sistema español: Una perspectiva histórica”; en ADAM MUÑOZ, M. Dolores y BLÁZQUEZ RODRÍGUEZ, Irene (coords). Nacionalidad, Extranjería y Ciudadanía de la Unión Europea. Madrid, Colex, 2005, p. 70; por su parte, la cita corresponde a la p. 54.

6 El Fuero de Extranjería surgió en territorio español oficialmente mediante Reales Células de 16 de marzo y de 19 de mayo de 1646, dictadas por Felipe IV. Sin embargo, los antecedentes remotos de esta figura se sitúan en los privilegios reales concedidos por Carlos V y Felipe II en territorio portugués, quienes nombraron jueces protectores encargados del conocimiento de las causas civiles y criminales que implicaran a extranjeros traunseúntes —esto es, extranjeros de paso, no radicados de forma permanente en territorio Español y sin ánimo de permanecer- que fuesen súbditos de las ciudades de la Hansa Teutónica. Tras la firma del Tratado de Utrecht, Felipe IV reguló de forma muy benigna la jurisdicción de los jueces protectores, que amparaba ya a los ciudadanos ingleses, holandeses y alemanes. Este privilegio — ser juzgados por un juez especial—, fue extendido y confirmado en 1646, en virtud de las dos Reales Células ya mencionadas. RODRÍGUEZ CARRIÓN, Alejandro y PÉREZ VERA, Elisa (cords.). Soberanía del Estado y Derecho Internacional: Homenaje al profesor Juan Antonio Carrillo Salcedo. Universidades de Sevilla, Córdoba y Málaga, Servicio de Publicaciones, 2005, p. 969.

7 ADAM MUÑOZ, parafraseando a González Campos, señala que la jurisdicción de excepción relativa a los extranjeros sufrió un proceso paulatino de "internacionalización convencional", debido fundamentalmente a motivos económicos: el impulso del comercio que, como consecuencia de la emigración española a América, quedó fundamentalmente en manos de los extranjeros. De otro lado, la misma autora señala la desaparición de los jueces conservadores a finales del siglo XVIII, siendo sustituidos por los tribunales militares, quienes a partir de entonces tendrían asignado el conocimiento de las causas que implicasen a extranjeros en nuestro país. "El estatuto jurídico del extranjero...", op. cit., p. 56.

8 Al respecto, el artículo 248 de la Constitución de 1812, establecía que "en negocios civiles y criminales no habrá más que un solo fuero para toda clase de personas". Esta disposición — como todo el texto constitucional—, no llegó a disfrutar de aplicación práctica como consecuencia del regreso al poder de Fernando VII. En cualquier caso, dentro de la aspiración a la unificación de fueros, quedaban exceptuados los ámbitos eclesiástico y militar.

9 La unificación de fueros se produciría en el año 1868, mediante un Decreto de 6 de diciembre del mismo año, norma de larga vigencia. El artículo 1.16 de dicho Decreto señalaba que "desde la publicación del presente Decreto, la jurisdicción ordinaria será la única competente para conocer de los negocios civiles y causas criminales de los extranjeros domiciliados y transeúntes”. Citado por ADAM MUÑOZ, M. D. “El estatuto jurídico del extranjero en el sistema español: Una perspectiva histórica”, op. cit., p. 79. 
de unidad de fueros - en conexión con el principio de igualdad y el tratamiento jurídico-procesal uniforme en territorio nacional-, junto con la reciprocidad de trato, lucharán por integrarse como bases rectoras del tratamiento jurídico otorgado a los extranjeros. Sin embargo, la cuestión de los derechos y la jurisdicción competente en materia de extranjería fue transferida al ámbito legislativo por la Constitución de $1845^{10}$, iniciándose los preparativos para su regulación en el Proyecto de Código Civil que por entonces comenzaba a gestarse. El retraso en la aprobación del Código, junto a la premura gubernamental, determinaron que finalmente la ordenación de la extranjería se produjese a través de una norma especial, que vino a sistematizar en una única disposición la dispersión normativa existente en este ámbito: el Real Decreto de Extranjería, promulgado el 17 de noviembre de 1852.

El Real Decreto de Extranjería constituye una norma de extraordinaria importancia. En primer lugar, como consecuencia de su longevidad, encontrándose todavía parcialmente vigente durante la primera etapa de desarrollo de la actual democracia española. De otro lado, ahonda de forma muy acentuada en la visión liberal que hacia el extranjero había caracterizado la tradición española, aunque, en contrapartida, otorgaba al poder ejecutivo un alto grado de discrecionalidad en materia de expulsiones del territorio nacional, contra las cuales no cabía recurso. A fin de mantener un tratamiento jurídico uniforme en todo el país, la norma se decantó por la pervivencia del fuero privilegiado de extranjería, que continuaba en manos de la jurisdicción militar. Sin embargo, en la práctica, el otorgamiento del fuero de extranjería fue muy restrictivo como consecuencia de la doctrina emitida al respecto por el Tribunal Supremo.

El Real Decreto de Extranjería escalonaba los derechos atribuibles a los extranjeros en función de su grado de asentamiento en territorio español, distinguiendo entre meros transeúntes, extranjeros avecindados y domiciliados ${ }^{11}$. A los extranjeros avecindados y domiciliados el ordenamiento tendía a aplicarles el principio de asimilación con los españoles en cuanto al goce de derechos civiles, con exclusión de los derechos políticos. Detrás de este tratamiento, más que ideales altruistas y humanitarios, subyacía la protección de los intereses propios del Estado Español, principalmente de carácter económico, tales como la conveniencia de atraer inversiones y comercio internacional, y a veces también las presiones políticas de Estados vecinos. Sin olvidar que el carácter emisor de mano de obra de la España decimonónica, empujaba también a favor del reconocimiento de un ordenamiento generoso con los extranjeros radicados en territorio español ${ }^{12}$ - pues el principio de equiparación o asimilación de los extranjeros con los nacionales, predominante en el Real Decreto ${ }^{13}$,

10 El apartado 42 del artículo primero de la Constitución de 1845 establecía que "una ley determinará los derechos que deberán gozar los extranjeros que obtengan carta de naturaleza o hayan ganado vecindad".

11 La categoría de extranjeros domiciliados fue introducida por el Real Decreto de Extranjería de 17 de noviembre de 1852, entendiendo por tales aquellos ciudadanos extranjeros que contaban con residencia fija o duradera por tres años y con bienes propios o modo de vida — trabajo conocido- en España. Para ellos el grado de asimilación con los españoles era máximo, hasta el punto de que el artículo cuarto del mencionado Real Decreto señalaba que los extranjeros que contasen con vecindad, junto con los extranjeros naturalizados, serían tenidos por españoles. Salvando las distancias, sería una categoría equivalente a la actual de residente permanente o de larga duración. Citado por Adam Muñoz, M.D. “El estatuto jurídico del extranjero...”, op. cit., p. 69.

12 En el mismo sentido se expresa VIDAL FUEYO, Ma del Camino. Constitución y extranjería. Madrid, Centro de Estudios Políticos y Constitucionales, 2002, p. 33.

13 En torno a esta cuestión, Adam Muñoz - a modo de valoración global del tratamiento que el Real Decreto de Extranjería brindaba a los extranjeros-, señala que cabría "resumir la filosofía del Real Decreto en un trato privilegiado y de favor para con el no nacional, el cual, en algunos aspectos incluso llegó a gozar de una situación más beneficiosa a la otorgada a los propios españoles”. A continuación puntualiza que la acentuación del tratamiento favorable a los extranjeros por parte de esta norma, se debe fundamentalmente a las presiones de las potencias europeas dominantes. "El estatuto jurídico del extranjero...”, op. cit., pp. 76-77. 
terminaría revertiéndose sobre los propios españoles emigrados, en función de la reciprocidad debida en el tratamiento jurídico de los no nacionales-.

La anhelada unificación de fueros se produciría en el año 1868, mediante un Decreto de 6 de diciembre, que vino a dar cumplimiento a la delegación legislativa que la Constitución de 1857 había establecido para la determinación y organización de los juzgados y tribunales. A partir de esta norma, el conocimiento de las causas civiles y criminales de los extranjeros domiciliados y transeúntes quedó en manos de la jurisdicción ordinaria ${ }^{14}$.

La Constitución de 1869, tras la Revolución de 1868, registra grandes progresos en materia de extranjería, hasta el punto de constitucionalizar por primera vez en España no sólo los derechos privados, sino también algunos derechos de carácter público a favor de los extranjeros ${ }^{15}$ - tales como el derecho a la intimidad del domicilio, la libertad de culto y religión, la prohibición de detención o privación de libertad salvo por causa de delito. El carácter progresivo se manifiesta además por la amplitud de los derechos reconocidos expresamente a favor de los extranjeros, entre los que destaca el reconocimiento de la libertad de establecimiento y de ejercicio de actividades laborales ${ }^{16}$. Con esta previsión se pretendían proteger los intereses económicos nacionales y fomentar la atracción de mano de obra, capital y tecnología extranjera.

El Proyecto de Constitución Federal de la República Española de 1873 vino a profundizar aún más el tratamiento progresista que la Constitución de 1869 otorgó a los extranjeros. Su Título Preliminar incluía una amplia previsión que proclamaba asegurar a favor de todas las personas todos los derechos naturales, "sin que ningún poder tenga facultad para cohibirlos, ni ley alguna autoridad para mermarlos". La Constitución de 1876, que vio la luz durante el período de la Restauración Borbónica, reduce el número de derechos reconocidos a los extranjeros. Pese a ello, sigue conservando el espíritu liberal en el tratamiento de la extranjería, consagrando el derecho de los no nacionales a establecerse en territorio español y poder ejercer en él su industria o profesión, siempre que para su desempeño no se exigieran títulos de aptitud expedidos por las autoridades españolas ${ }^{17}$. Durante esta etapa ven la luz la Ley de Enjuiciamiento Criminal de 1881, que ratifica la competencia única de la jurisdicción ordinaria en materia de extranjería, así como la Ley de Enjuiciamiento Civil de

14 Apartado 16 del artículo $1^{\circ}$ del Decreto de 6 de diciembre de 1868, conforme al cual: “desde la publicación del presente Decreto, la jurisdicción ordinaria sera la única competente para conocer de los negocios civiles y causas criminales de los extranjeros domiciliados y transeúntes".

15 ADAM MUÑOZ, M. D. “El estatuto jurídico del extranjero en el sistema español...”, op. cit., p. 53. La autora califica como "un gran avance en nuestra Historia en relación al sistema de extranjería” las aportaciones realizadas por la Constitución de 1869. En la misma línea, VIDAL FUEYO considera que el texto constitucional de 1869 "rompe radicalmente con los textos anteriores" en esta materia, recogiendo por primera vez derechos atribuidos expresamente a los extranjeros. Constitución y extranjería, op. cit., p. 32.

16 Artículo 25 de la Constitución de 1869, en virtud del cual “todo extranjero podrá establecerse libremente en territorio español, ejercer en él su industria, o dedicarse a cualquier profesión para cuyo desempeño no exijan las leyes títulos de aptitud expedidos por autoridades españolas". A juicio de PÉREZ VERA, el precepto transcrito sirvió de inspiración para la redacción posterior de los artículos 15 del Código de Comercio y 27 del Códico Civil, ambos dotados del mismo espíritu equiparador e internacionalista; en "Artículo 13. Extranjería”, op. cit., p. 188.

17 Artículo segundo de la Constitución de 30 de junio de 1876. 
1882, el Código de Comercio de $1885^{18}$ y el Código Civil de $1889^{19}$, textos todos ellos imbuidos por el espíritu de equiparación entre nacionales y extranjeros.

La llegada del siglo XX registra de forma paulatina importantes novedades en materia migratoria. El generoso régimen liberal español introdujo a partir de principios del siglo y, especialmente tras la I Guerra Mundial, un mirada más recelosa hacia el extranjero, no visible en el plano constitucional, pero si a nivel legislativo. En palabras de Borrajo Iniesta, el ordenamiento de extranjería comenzó por entonces a desarrollar una "tendencia insularista" ${ }^{20}$, representada por la introducción de restricciones a los derechos de los no nacionales. La misma resultaba especialmente acusada en el ámbito administrativo y, más concretamente, en materia de entrada, circulación y asentamiento, así como en el régimen sancionador aplicable a los no nacionales.

El Anteproyecto de Constitución de la Monarquía Española de 1929, contemplaba de forma sistemática en una única disposición la equiparación de los extranjeros residentes en España con los nacionales en materia de derechos privados, y en aquellos derechos públicos que no se reconociesen en exclusiva a los españoles ${ }^{21}$. Por su parte, la Constitución de la II República de 1931 consagró a favor de los extranjeros el derecho a la no detención salvo por causa de delito, la inviolabilidad del domicilio, la libertad de industria y comercio, la libertad de expresión, estableciendo que por ley se determinarían las garantías para poder proceder a la expulsión de extranjeros ${ }^{22}$. Sin embargo, durante el período republicano se publicaron varias normas gubernamentales que incidían en un incremento del control de la Administración sobre la circulación, residencia y el ejercicio de actividades lucrativas por parte de los extranjeros. Se trata, respectivamente, del Decreto de 4 de octubre de 1935, en virtud del cual las autoridades administrativas quedaban investidas de poderes discrecionales en el control de la residencia y circulación de los extranjeros en territorio nacional; y del Decreto de 29 de agosto de 1935, norma que condicionaba el ejercicio de actividades laborales de los extranjeros a autorización administrativa previa, cuya concesión resultaba discrecional para las autoridades españolas. En contrapartida, vieron la luz múltiples normas en materia de legislación laboral de los extranjeros, estableciendo la exigencia de retribución igualitaria y prohibiendo expresamente distintas condiciones de trabajo y salariales entre españoles y extranjeros, si bien los no nacionales sólo podrían acceder a un trabajo tras el transcurso de un plazo durante el cual se demostrase la imposibilidad de cubrir la vacante con un nacional de igual cualificación ${ }^{23}$.

18 El artículo 15 del Código de Comercio señalaba que "los extranjeros y las compañías constituidas en el extranjero podrán ejercer el comercio en España; con sujeción a las leyes de su país, en lo que se refiera a su capacidad para contratar, y a las disposiciones de este Código, en todo cuanto concierna a la creación de sus establecimientos dentro del territorio español, a sus operaciones mercantiles y a la jurisdicción de los Tribunales de la nación. Lo prescrito en este artículo se entenderá sin perjuicio de lo que en casos particulares pueda establecerse por los Tratados y Convenios con las demás potencias".

19 En su primitiva versión, el artículo 27 del Código Civil Español establecía que "los extranjeros gozan en España de los derechos que las leyes conceden a los españoles, salvo lo dispuesto en el artículo 2 de la Constitución del Estado o en tratados internacionales".

20 BORRAJO INIESTA. "El status constitucional de los extranjeros"; en MARTÍN-RETORTILLO, Sebastián (coord.). Estudios sobre la Constitución española: Homenaje al profesor Eduardo García de Enterría, Vol. 2. Madrid, Civitas, 1991, p. 704.

21 Artículo 19 del Anteproyecto de Constitución de la Monarquía Española de 1929.

22 Respectivamente consagrados en los artículos 29,31, 33, 34 y apartado tercero del artículo 31 del texto constitucional de la II República de 1931.

23 Entre otras normas indicativas de la legislación laboral en el ámbito de la extranjería, cabría mencionar el Decreto de 16 de enero de 1931, de escasísima vigencia, el Decreto de 8 de septiembre de 1932 y el Decreto de 19 de agosto de 1935. Para un estudio de esta cuestión, vid. POLO SÁNCHEZ, Ma Cristina. Derechos fundamentales y libertades públicas de los trabajadores extranjeros en España. Madrid, Consejo Económico y Social, 1994. 
En síntesis, un rápido recorrido por la tradición histórica española en la materia lleva a concluir que "nuestra legislación ha sido especialmente benigna en cuanto a la condición jurídica del extranjero, si la comparamos con la existente en esa época en otros países de Europa" ${ }^{24}$.

Sin embargo, resulta difícil sostener que, durante el franquismo, este generoso sistema continuase vigente. En materia de extranjería, la legislación guardaba silencio, por lo que al inicio del sistema franquista permaneció vigente - formalmente al menos-, la ordenación dictada en el período republicano inmediatamente anterior. El silencio del ordenamiento en materia migratoria hacía recomendable acudir, en vía negativa, a la única declaración de derechos de la época, el Fuero de los Españoles. Aquellos derechos que el Fuero no reservaba a los españoles, podían ser extendidos a los extranjeros - entre ellos la libertad religiosa, la libertad y el secreto de la correspondencia, el derecho de legalidad el derecho de propiedad privada ${ }^{25}-$.

A nivel administrativo el franquismo se caracteriza por una fuerte intensificación de los poderes de control sobre los extranjeros ${ }^{26}$. A finales del régimen se dictó el Decreto 522/1974 de 14 de febrero, regulador de la entrada, residencia y circulación de los extranjeros, el cual, en palabras de Vidal Fueyo, vino a dar "cobertura jurídica a la total arbitrariedad" 27 con que la Administración Pública venía actuando en este ámbito. El Decreto 522/1974 reemplazó al hasta entonces vigente Decreto de 29 de agosto de 1935, dictado durante el período republicano. Con esta norma se venía a plasmar jurídicamente la práctica administrativa existente hasta el momento respecto a los no nacionales, caracterizada por la "absoluta discrecionalidad e informalidad con que la Administración pública intervenía y disponía sobre los extranjeros”28.

En sintonía con esta situación, los escasísimos pronunciamientos jurisprudenciales de este período que giraban en torno a los derechos de los extranjeros son todos de carácter desestimato$\mathrm{rio}^{29}$. La situación inmediatamente preconstitucional en lo que al régimen migratorio de extranjería se refiere, viene marcada pues por un ordenamiento poco sistemático, caracterizado por un amplio despliegue reglamentario ${ }^{30}$ y que amparaba la total discrecionalidad de las actuaciones públicas, en contraste con un régimen civil y mercantil que seguía proclamando la equiparación con los nacionales.

24 ADAM MUÑOZ, M.D. “El estatuto jurídico del extranjero...”, op. cit., p. 70. Por su parte, BORRAJO INIESTA considera que la tradición histórica española en este ámbito se caracteriza por "una legislación escasa y generosa con los extranjeros en nuestra tierra”. El status constitucional de los extranjeros, op. cit., p. 698.

25 PÉREZ VERA, Elisa. "Artículo 13. Extranjería”, op. cit., p. 193.

26 Conviene precisar, siguiendo a VIDAL FUEYO, que el recrudecimiento del control de la Administración Pública sobre los no nacionales se inició durante el breve período republicano que antecedió a la dictadura franquista. La regulación contenida en los Decretos dictados en el año 1935, constituye una muestra elocuente de las notas de control y discrecionalidad administrativa que no harían sino fortificarse con el franquismo. Constitución y extranjería, op. cit., p. 34.

27 VIDAL FUEYO, M. C. Constitución y extranjería, op. cit., p. 35.

28 BORRAJO INIESTA, I. "El status constitucional de los extranjeros", op. cit., p. 705.

29 Las sentencias dictadas en este ámbito se reducen a tres, pronunciadas por el Tribunal Supremo: STS de 14 de diciembre de 1963, de 22 de noviembre de 1965 y de 7 de octubre de 1974. De esta pobre situación judicial, BORRAJO INIESTA deduce que "su escasez misma ya es síntoma elocuente de la inexistencia de derechos a proteger en los Tribunales, y el sentido desestimatorio de todos los fallos sin excepción es determinante”. Idem, p. 707 y nota a pie de pag. no 30 de dicha página.

30 FERRER PEÑA, Rosa María. Los derechos de los extranjeros en España. Madrid, Tecnos, 1989, p. 51. 


\section{EL MARCO CONSTITUCIONAL ESPAÑOL EN MATERIA DE EXTRANJERÍA E INMIGRACIÓN}

La actual Constitución Española ve la luz en medio de un contexto social marcadamente emigrante y en un contexto jurídico caracterizado por una reglamentación que, como señalamos, propiciaba la arbitrariedad de las actuaciones administrativas relacionadas con los extranjeros. El panorama social a efectos migratorios empieza a cambiar con la llegada de la democracia, registrándose desde finales de la década de los setenta discretos flujos hacia dentro del país - si bien en su mayoría integrados por los retornos de españoles emigrados-. Pese a ello, tanto la regulación jurídica como la práctica administrativa en torno a la extranjería en los inicios de la vigencia de la Constitución de 1978 se alimentaron de la "inercia" 31 del período inmediatamente precedente. La muestra más significativa de esta inercia la constituye la pervivencia de la regulación preconstitucional —incluyendo el Real Decreto de Extranjería de mediados del siglo XIX-, dada la inexistencia de una norma específica postconstitucional reguladora de esta materia, que habría de esperar hasta el año 1985 para ser aprobada ${ }^{32}$. De otro lado, dicha supervivencia constituye una señal bien elocuente de la escasa importancia que por entonces tenía la inmigración económica con destino a España, lo que propiciaba que el legislador priorizara la elaboración de otras normas, imprescindibles en el contexto de la recién inaugurada democracia, que requería la sustitución del orden jurídico franquista.

Resulta ya un tópico considerar que la Constitución Española de 1978 se muestra excesivamente escueta en materia de extranjería ${ }^{33}$. Fruto de un contexto histórico de penuria económica y marcadamente emigrante, no es de extrañar que el texto constitucional tratase de velar por la protección de los derechos de los trabajadores españoles en el extranjero, contemplado su situación en el artículo $42 \mathrm{CE}^{34}$, dentro de los principios rectores de la política social y económica. Esta disposición

31 VIDAL FUEYO, M. C. Constitución y extranjería, op. cit., p. 35. A juicio de esta autora, la mencionada inercia vino motivada por dos factores: la ambigüedad del artículo 13.1 CE y la inexistencia de una norma legal específica que regulase los derechos de los extranjeros hasta la promulgación de la LO 7/1985, de 1 de julio, sobre derechos y libertades de los extranjeros en España.

32 Con anterioridad a la promulgación de la LO 7/1985, se dictaron dos normas legales que afectaron a la nacionalidad y al derecho de asilo, a fin de adaptar la normativa postconstitucional en la materia. Se trataba, de un lado, de la Ley 51/1982, de 13 de julio, que modificó los artículos 17 a 26 del Código Civil en materia de nacionalidad y, posteriormente, la Ley 5/1984 reguladora del derecho de asilo y la condición de refugiado, desarrollada esta última por medio de un Reglamento promulgado en 1985. Ambas no afectaron al régimen general de la extranjería, que siguió estando regulado por normas de carácter preconstitucional.

33 Ruiz de Huidobro considera que la Constitución Española de 1978, en materia de extranjería e inmigración, contiene una "exigua base constitucional". "Evolución de la legislación española de extranjería e inmigración"; en RUIZ DE HUIDOBRO, J. M (ed.). Regulación legal de la extranjería e inmigración en España. Madrid, Universidad Pontificia de Comillas, 2006, p. 23. AJA, E. (coord.). La nueva regulación de la inmigración en España, op.cit., p. 19. Este último autor, sin embargo, destaca la influencia directa que la Constitución de 1978 tuvo en la regulación de la inmigración, aunque ésta "no se observó de manera tan clara e inmediata”. Entre los efectos positivos indirectos que el marco constitucional indujo sobre la extranjería, Aja destaca la imposición de la reserva de ley, en claro contraste con la tradicional regulación de esta materia mediante reglamentos y normas de rango administrativo inferior. En una línea discrepante se sitúa ALZAGA VILLAAMIL, quien, tomando el art. 13CE como un mero punto de partida e interpretándolo en conjunción con otras disposiciones constitucionales, subraya el carácter generoso de la tutela constitucional de los derechos de los extranjeros en España, sin prácticamente parangón en el derecho comparado. Derecho Político español según la Constitución de 1978. Derechos fundamentales y órganos del Estado, vol. II. Madrid, CERA, 1998, p. 53.

34 El tenor literal del artículo 42 CE establece que "el Estado velará especialmente por la salvaguardia de los derechos económicos y sociales de los trabajadores españoles en el extranjero y orientará su política hacia su retorno". En esta línea, MARZAL YETANO subraya la concordancia existente entre un país como España, "tradicionalmente caracterizado como de emigración (con unas estructuras jurídico-políticas que a menudo por tanto reflejan ese otro 
constitucional expresamente consagra la regulación de los flujos migratorios, contemplados éstos únicamente desde la perspectiva de la emigración, y no de la recepción de flujos en el interior de nuestro territorio.

Sin embargo, esta impresión de parquedad se relativiza si nuestro texto constitucional se compara con los de su entorno, donde las disposiciones constitucionales que despejen el estatuto jurídico de los extranjeros son prácticamente inexistentes ${ }^{35}$. El derecho comparado revela que la constitucionalización del régimen jurídico de los extranjeros ha sido producto de un proceso lento y tardío, tan sólo visible de forma expresa en las Constituciones promulgadas a partir de la década de los setenta del siglo $\mathrm{XX}^{36}$.

La Constitución española -en línea con los textos constitucionales de nuestro pasado y en consonancia con las Constituciones coetáneas en el tiempo-, constitucionaliza el régimen jurídico de la extranjería y la inmigración. El texto constitucional español de 1978 dedica una disposición específica a la regulación genérica del estatuto jurídico-constitucional de los extranjeros en España, el artículo 13. Su primer apartado contempla una remisión legislativa, en virtud de la cual "los extranjeros gozarán en España de las libertades públicas que garantiza el presente Título en los términos que establezcan los tratados y la ley". El apartado segundo reserva exclusivamente en favor de los españoles la titularidad de los derechos políticos reconocidos en el artículo 23, estableciendo "un límite material a lo que el legislador puede decidir en virtud de la anterior remisión"37. Pero, a su vez, esta norma excepcional que excluye a los extranjeros del goce de los derechos políticos, contiene su propia excepción. En este sentido, el artículo 13.2 in fine CE, en la redacción operada tras la reforma constitucional aprobada el 27 de agosto de 1992, especifica que queda a salvo lo que, atendiendo a criterios de reciprocidad, pueda establecerse por tratado o ley para el derecho de sufragio activo y pasivo en las elecciones municipales.

De entrada, la ubicación constitucional del artículo 13 CE refleja la importancia de esta disposición así como su proyección sobre los restantes derechos contenidos en el mismo título, en su afectación específica al colectivo de los extranjeros: insertado dentro del Título I y conformado, junto con

tipo de realidad)". Como ejemplos que prueban la realidad de España como país de emigración menciona, junto al art. $42 \mathrm{CE}$, el artículo 24.3 del Código Civil, que prevee que los descendientes de emigrantes españoles puedan conservar la nacionalidad española. El proceso de constitucionalización del derecho de inmigración, op. cit., p. 149.

35 Salvo las excepciones constituidas por el artículo 15 de la Constitución Portuguesa de 1976 o el artículo 10 de la Constitución italiana de 1947, no es posible encontrar una cláusula genérica, consagrada de forma específica al estatuto jurídico de los extranjeros en las Constituciones más veteranas de los restantes países de la Unión Europea — con exclusión de los de reciente adhesión, dotados de Constituciones más modernas que la española-. VIDAL FUEYO, Ma del Camino. Constitución y Extranjería, op. cit., p. 40, nota a pie de página n 22.

36 Podrían distinguirse tres etapas, siguiendo a González Soler, dentro del proceso de constitucionalización de los derechos fundamentales de los extranjeros. En primer lugar, se situarían las Constituciones elaboradas antes de la segunda Guerra mundial, tales como la Belga de 1831, la Luxemburguesa de 1868, la Finlandesa de 1919, la Austríaca de 1920 o la Irlandesa de 1937, donde no se contempla el régimen de la extranjería y la inmigración. Dentro de este primer grupo, el autor mencionado incluye también a la Constitución de Dinamarca de 1953 y la Francesa de 1958, pues aunque cronológicamente son posteriores a la segunda Guerra mundial, la regulación de los derechos fundamentales procede de etapas históricas muy anteriores, siendo codificada por el texto constitucional. En una segunda etapa se situarían las Constituciones promulgadas después de 1945, tales como la Alemana de 1949 o la Italiana de 1948, donde los extranjeros solamente son contemplados de forma implícita, al regularse los derechos correspondientes a toda persona. A partir de la década de los setenta, las Constituciones de Suecia de 1974, la Holandesa de 1983, la Griega de 1975 y la Portuguesa de 1976, si bien con distintos niveles de intensidad, constitucionalizan expresamente el régimen jurídico de los extranjeros. GONZÁLEZ SOLER, Olayo E. "La posición del extranjero en el ordenamiento jurídico constitucional”; en Estudios jurídicos. Ministerio Fiscal, No 4, 2002 , p. 202.

37 DÍEZ-PICAZO, Luis María. Sistema de derechos fundamentales, op. cit., p. 121. 
los artículos 11 y 12, un capítulo propio - el Capítulo primero CE-, dedicado a la regulación "de los españoles y los extranjeros". Constituye, de otro lado, una disposición excluida de la posibilidad de recurso de amparo, como el propio TC aclaró tempranamente ${ }^{38}$.

La previsión contenida en el artículo 13.1 CE otorga a la extranjería y la inmigración de un marco constitucional específico en el ordenamiento jurídico español, en virtud del cual la atribución de los derechos y libertades al colectivo de los no nacionales en territorio español se realiza ex constitutionem $^{39}$, esto es, desde dentro y a partir del texto constitucional. El TC ya ha tenido ocasión de confirmar la trascendencia de esta disposición en esta materia, al señalar que "el art. 13.1 CE es el precepto que "en nuestra Constitución establece los límites subjetivos determinantes de la extensión de la titularidad de los derechos fundamentales a los no nacionales" ${ }^{\prime \prime}$.

De esta disposición se extrae ya -eludiendo de momento la jurisprudencia constitucional emanada en torno al mismo-, un primer borrador del sistema de fuentes del derecho migratorio español, que tendría a su cabeza a la Constitución Española, especialmente su Titulo I, en cuanto al concreto régimen de derechos y libertades a disposición de los no nacionales. El texto constitucional se erige en la fuente primordial del derecho este ámbito materia, al cual se encuentran subordinadas las restantes fuentes especificadas en dicho artículo. La legislación, tanto interna como internacional, constituirían fuentes secundarias del derecho español de la extranjería y la inmigración. Dado que la legislación internacional de carácter convencional se superpone a la ley interna, ello supondría situar, tras la Constitución, a los tratados internacionales ratificados por España (art. 96CE); en tercer lugar, las fuentes del derecho español de extranjería se integrarían por las leyes internas específicas relativas a esta materia, encabezadas por la ley orgánica reguladora; $y$, finalmente, la jurisprudencia emanada de los Tribunales estaría llamada a jugar un papel clave en su configuración, con el TC a la cabeza ${ }^{41}$.

Asimismo, del artículo 13.1 CE es posible desde este momento destacar varias notas a nuestro juicio esenciales, si bien no exentas de dificultades interpretativas: de un lado su redacción inequívocamente imperativa - "gozarán" - , afirmando de forma taxativa la titularidad activa de los derechos contenidos en el Título I a favor de los extranjeros. De su tenor literal cabe extraer el principio general de reconocimiento de derechos a favor de los extranjeros ${ }^{42}$, exceptuando los de carácter político. Esta interpretación resultaría reforzada por oposición o contraste con lo establecido en el apartado segundo del mismo artículo, que ordena la exclusión de los extranjeros con respecto de la titularidad activa de los derechos políticos contenidos en el art $23 \mathrm{CE}$, también de forma taxativa. El reconocimiento en exclusiva a los españoles de tales derechos — con las precisiones establecidas en la misma

38 Auto $^{\circ}$ 182/1985 del Tribunal Constitucional, Sección $1^{\text {a }}$, 13 de marzo de 1985.

39 Es precisamente esta atribución de derechos a los no nacionales, realizada desde el interior de la Constitución Española, lo que lleva a ADAM MUÑOZ a declarar que "los derechos fundamentaes otorgados a los extranjeros en nuestro territorio son también derechos constitucionales, cualidad que supone un reforzamiento en cuanto a su protección”; en “El estatuto jurídico del extranjero ...," op. cit., pp. 87-88.

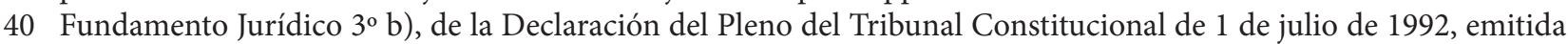
por requerimiento formulado por el Gobierno de la Nación, acerca de la constitucionalidad de los artículos I-6, II111 y II-112 del Tratado por el que se establece una Constitución para Europa, firmado en Roma el 29 de octubre de 2004.

41 En idéntico sentido se pronuncia Cruz Villalón quien, sin embargo, matiza que los distintos elementos integrantes del bloque normativo constitutivo de las fuentes del derecho español de extranjería son "en principio distintos y heterogéneos, pero situados grosso modo a un mismo nivel”. CRUZ VILLALÓN, Pedro. "Dos cuestiones de titularidad de derechos: los extranjeros, las personas jurídicas”; en Revista española de derecho constitucional, No 35, 1992, p. 193.

42 AJA, Eliseo (coord). La nueva regulación de la inmigración en España, op. cit., pp. 19-20. 
disposición-, avalaría la interpretación extensiva del reconocimiento constitucional que, a favor de los extranjeros, contempla el apartado primero del artículo $13 \mathrm{CE}^{43}$.

En segundo lugar, el art. 13.1 contiene una reserva expresa de ley referida tanto al ordenamiento interno como a los tratados internacionales, conforme a la cual corresponde a la norma de rango legal establecer "los términos" en que los extranjeros gozarán de los derechos comprendidos en el Título I CE. La parte más sustancial de la redacción constitucional es la expresa referencia a los tratados internacionales - aludidos en primer lugar-como coautores o colegisladores de los derechos de los extranjeros en España, poco habitual en las reservas legales constitucionalmente establecidas. Esta reserva específica en el ámbito normativo de la extranjería y la inmigración, parecía apuntar al destacado papel que el constituyente confería al legislador internacional en la configuración del concreto estatuto jurídico de los derechos de los extranjeros, quizá consciente de la penetración internacional que caracteriza al derecho migratorio y ante la necesidad de una protección extra para dicho colectivo. De esta cuestión se ocuparía ampliamente el TC. Y, finalmente, la tercera nota que merece atención del art. 13.1 CE es que en su redacción sobresale el uso de la expresión "libertades públicas", frente a la más común de derechos fundamentales.

\subsection{La elaboración constituyente del artículo $13 \mathrm{CE}$}

La historia de la elaboración de este precepto constitucional arroja luz sobre algunas de las cuestiones controvertidas apuntadas, especialmente en torno al significado que el constituyente atribuyó al término "libertades públicas". Este precepto trae causa del por entonces artículo 12 del Anteproyecto constitucional ${ }^{44}$. El artículo 12 tenía una estructura bipartita, con dos apartados. El primero de ellos establecía que "la condición jurídica del extranjero se regulará por la ley y los tratados, atendiendo siempre al principio de efectiva reciprocidad. Solamente los españoles serán titulares de derechos políticos". Por su parte, su apartado segundo señalaba que "los extranjeros residentes en España gozarán de las libertades públicas, en los términos que la ley establezca”.

De esta primitiva redacción sobresale, en primer lugar, la distinción entre "condición jurídica" - cuya regulación se encomendaba a la ley y los tratados conforme al principio de reciprocidad efectiva-, y "libertades públicas" —-sometidas éstas únicamente a reserva de ley interna, con exclusión de la legislación internacional, y sin dependencia del principio de reciprocidad. Su consagración en apartados distintos ha sido interpretada por la doctrina como la pretensión del constituyente de incorporar a la Constitución las líneas generales directrices de todo el derecho de los extranjeros, sin

43 En el mismo sentido se manifiesta VIDAL FUEYO, quien también recurre a la interpretación a sensu contrario del art. 13.2 CE, conectándolo sistemáticamente al primer párrafo del art 13, para deducir que los extranjeros sí podrán ser titulares del resto de derechos no incluidos en el art. 13.2 CE. Constitución y extranjería, op. cit., p. 67. En esta línea se inscribe también Bastarrachea, quien afirma literalmente que "parece que el derecho del artículo 23, es el único del que se excluye a los extranjeros, lo que contrario sensu implicaría que todos los demás derechos y libertades son de titularidad igual tanto para españoles como para extranjeros, aunque para éstos su ejercicio vendrá condicionado por lo dispuesto por los tratados y la ley. BASTARRACHEA ALBA, Esther de. "Dererchos fundamentales y libertades públicas de los inmigrantes en España"; en Revista parlamentaria de la Asamblea de Madrid, n 14, junio 2006, pp. 153-154. En un sentido más extremo se decanta PÉREZ VERA, para quien el art. 13.1 "parte de una visión restrictiva de las libertades públicas de los extranjeros, en la medida en que su goce queda subordinado a lo establecido en los tratados y la ley"; en "Artículo 13. Extranjería”, op. cit., p. 193. En este mismo sector crítico se sitúa GOIZ MARTÍNEZ, quien lamenta que con la redacción señalada "se ha perdido una oportunidad inicial en una posición igualitaria”. Derechos y libertades de los inmigrantes en España. Una visión constitucional, jurisprudencial y legislativa, op. cit., p. 37.

44 Diario de Sesiones del Congreso, de 5 de enero de 1978, n 44, p. 671. 
exclusiones ${ }^{45}$. Bajo este entendimiento, la condición jurídica haría referencia a los derechos privados de los extranjeros, especialmente a los de carácter civil y mercantil, mientras, por su parte, con la expresión libertades públicas se estarían constitucionalizando los fundamentos del derecho público de extranjería e inmigración.

La primitiva versión del artículo 13 suponía una ruptura con la tradición española en la materia. El régimen de los derechos privados de los extranjeros no solamente se apartaba radicalmente del histórico principio de equiparación con los españoles sino que, más grave aún, quedaba enteramente condicionado al principio de reciprocidad, al que, además, se le exigía carácter efectivo. Dejando a un lado su incompatibilidad con los compromisos internacionales de España en la materia ${ }^{46}$, el sometimiento genérico de la condición jurídica de los extranjeros al principio de reciprocidad efectiva fue denunciado desde distintos frentes, a lo largo de su tramitación en el Congreso, por su espíritu claramente restrictivo, la pluralidad de estatutos y la consiguiente disparidad normativa e inseguridad jurídica que conllevaba, así como los graves problemas de articulación práctica implícitos a tal principio.

Por su parte, el régimen de las libertades públicas de los extranjeros quedaba subordinado a la posesión del requisito administrativo de residencia legal en territorio español. La expresión libertades públicas era usada no solamente en el apartado segundo del artículo 12, sino como encabezamiento en exclusiva del por entonces Capítulo segundo del Anteproyecto constitucional, donde se recogían derechos fundamentales estrechamente ligados a la dignidad humana y que posteriormente conformarían la Sección primera del Capítulo segundo CE - esto es, los derechos fundamentales dotados del umbral más alto de garantías constitucionales-. En consecuencia, la exigencia de residencia suponía la exclusión de un amplio colectivo de extranjeros en territorio español -extranjeros en situación administrativa de estancia, extranjeros irregulares, estudiantes no nacionales, etcétera-, con respecto de la titularidad activa de un núcleo extenso de derechos fundamentales cuya universalidad había sido proclamada sin ambages por los grandes tratados sobre derechos humanos que España ya había ratificado ${ }^{47}$. De otro lado, de la concordancia terminológica aludida, cabe desde este momento deducir que el constituyente utilizó el término de libertades públicas como sinónimo del más amplio y habitual de derechos fundamentales ${ }^{48}$.

Las múltiples enmiendas presentadas a fin de suprimir la referencia a la reciprocidad o, al menos, la exigencia de su carácter efectivo, desembocaron finalmente en su total eliminación en el Informe de la Ponencia ${ }^{49}$. Con ello, el desarrollo de la condición jurídica de los extranjeros quedaba

45 Vid, entre otros, PÉREZ VERA, E. “Artículo 13. Extranjería”, op. cit., pp. 187-188.

46 En el mismo sentido, PÉREZ VERA indica que la redacción inicial de la que trae causa el actual artículo 13.1 era "inadmissible e inconsistente con nuestros compromisos internacionales"; en "Artículo 13. Extranjería”, op. cit., p. 187. Por su parte, GOIG MARTÍNEZ subraya que la redacción del artículo 12 del Anteproyecto de la Constitución "obviaba el propio concepto de derechos humanos que el Derecho Internacional general y la propia Teoría general de los derechos atribuyen a toda persona, independientemente del origen nacional"; en Derechos y libertades de los inmigrantes en España. Una visión constitucional, jurisprudencial y legislativa. Madrid, Universitas Internacional, $1^{\text {a }}$ edic. 2004, p. 36.

47 El Pacto Internacional de Derechos Civiles y Políticos — adoptado mediante Resolución por la Asamblea Generla de la ONU el 16 de diciembre de 1966-, fue firmado por el Estado español el 23 de septiembre de 1976, publicándose su instrumento de ratificación en el Boletín Oficial del Estado núm. 103, de 30 de abril de 1977. Su entrada en vigor tuvo lugar el 23 de marzo de 1977; Por su parte, el instrumento de ratificación por España del Pacto Internacional de Derechos Económicos, Sociales y Culturales, de 16 de diciembre de 1966, fue depositado el 27 de abril de 1977 y publicado en el BOE no 103, de 30 de abril de 1977, entrando en vigor el 27 de Julio de 1977.

48 Esta interpretación resulta pacífica entre la doctrina, vid, entre otros, VIDAL FUEYO, M.C. Constitución y extranjería, op. cit., p. 37; PÉREZ VERA, E. “Artículo 13...”, op. cit., p. 194.

49 Diario de Sesiones del Congreso, 17 de abril de 1978, no 82, p. 512. La dicción literal del art. 12.1 quedó en los siguientes términos: "La condición jurídica del extranjero se regulará por la ley y por los tratados. Solamente los españoles serán titulares de derechos políticos". 
sometida a la ley y a los tratados, sin más especificación. Sin embargo, permanecía inalterado el apartado relativo a las libertades públicas de los extranjeros, habiendo pasado inadvertido el requisito de la residencia como condición previa para la titularidad activa de las mismas, sin merecer crítica alguna por parte de los distintos grupos parlamentarios que manifestaron su oposición a la exigencia de reciprocidad efectiva como principio rector del régimen de derechos privados de los extranjeros. El mérito de su supresión tiene su origen en una enmienda in voce formulada por Gregorio Peces $\mathrm{Barba}^{50}$, integrante del grupo socialista, quien en el seno de la Comisión de Asuntos Constitucionales manifestó la frontal incompatibilidad de la exigencia de residencia legal contenida en el art. 12.2 $\mathrm{CE}$, con respecto al artículo 14 del CEDH. La disposición aludida del Convenio de Roma - que, en el momento en que tenía lugar esta discusión parlamentaria ya había sido firmado por el Estado Español sin que todavía hubiera entrado en vigor-, asegura a todos los seres humanos el goce de los derechos y libertades en él reconocidos prohibiendo expresamente las distinciones por razones de origen nacional, entre otros motivos.

Tras la aceptación de esta enmienda, el texto del segundo párrafo del artículo 12 fue modificado, proclamando las libertades públicas de los extranjeros en España, sin condicionamiento al requisito administrativo de la residencia, con la siguiente fórmula: "Los extranjeros gozarán de las libertades públicas del presente Título en los términos que la ley establezca". Pese a las evidentes mejoras que suponían la supresión de los requisitos de la reciprocidad y la residencia, la nueva redacción de los dos apartados del artículo 12 no estaba exenta de problemas. Entre ellos, se han destacado su débil contenido programático y la amplísima libertad de configuración otorgada al poder legislativo ${ }^{51}$. Ambos casaban mal con una norma que pretendía constitucionalizar las bases jurídicas de la extranjería y la inmigración en el nuevo sistema jurídico español.

Tras su aprobación sin alteraciones por el Pleno del Congreso de los Diputados, esta redacción pasaría a la Cámara alta, donde se forjaría la versión actual de este artículo. Sería durante la tramitación en el Senado cuando se limarían dos de las fallas que registraba la redacción del segundo apartado del artículo 12 del Anteproyecto. Tal y como el texto entró en la Cámara Alta ${ }^{52}$, la norma proclamaba las libertades públicas de los extranjeros en España, para cuyo desarrollo se remitía exclusivamente a la ley interna, sin mencionar los tratados internacionales. Parecía obvio que la remisión al legislador interno, sin aludir al ámbito internacional, constituía una "omisión conscientemente querida" ${ }^{33}$ - especialmente por contraste a la referencia a los tratados internacionales contenida en el apartado primero del artículo 12. Sin embargo, tal omisión, como ha destacado Pérez Vera, resul-

50 Paradójicamente el objeto de dicha enmienda era sustituir la referencia a los extranjeros residentes en España por la exigencia de que se encontrasen legalmente en España. Pese a su mayor abertura, la redacción propuesta por Peces Barba hubiese seguido suscitando serios problemas de constitucionalidad, pues sopondría la exclusión de los extranjeros en situación de irregularidad del goce de todas las libertades públicas, muchas de las cuales se predican del ser humano como tal, con independencia tanto de su nacionalidad como de su concreto estatus jurídico. Pese a ello, la enmienda estaba bien argumentada y logró promover el consenso entre las fuerzas políticas para, finalmente, dar lugar a un texto muy superior al de la enmienda de la que traía causa.

51 PÉREZ VERA, E. “Artículo 13...”, op. cit., p. 190. La autora estima que "la constitucionalización del tema merecía exigir la incorporación en la norma del principio de base sobre el que habría de construirse su posterior desarrollo legal". La supresión de la referencia al principio de reprocidad dejaba al apartado primero del por entonces todavía artículo 12, huérfano de principios inspiradores lo que, a juicio de la misma autora, terminaba otorgando al legislador una total libertad en la regulación de la materia.

52 La disposición aludida señalaba: "Los extranjeros gozarán de las libertades públicas del presente título en los términos que la ley establezca".

53 PÉREZ VERA, E. “Artículo 13. Extranjería”, op. cit., p. 191. La autora subraya al respecto que España había firmado ya los Pactos Internacionales de Naciones Unidas sobre derechos civiles y políticos, así como el de derechos económicos, sociales y culturales, ambos de 1966, así como el CEDH. 
taba escasamente coherente con la política de rápida vinculación al derecho internacional de los derechos humanos que, a lo largo de la transición política, había emprendido el Estado Español y con el espíritu garantista derivado del amplio reconocimiento de derechos contenido en el Título I CE ${ }^{54}$.

En la Comisión de Constitución del Senado se fundirían ambos apartados del artículo 12, suprimiéndose además la reserva de los derechos políticos para los nacionales, que pasaría a integrar un apartado autónomo, el segundo. Tras esta criba, el primer apartado quedaría redactado en una fórmula casi idéntica a su versión final, que sería aprobada por el Pleno del Senado, conforme a la cual "los extranjeros gozarán en España de las libertades públicas que garantiza el presente Título en los términos que establezcan los tratados y la ley reguladora de su condición jurídica”. Sobre la misma, la Comisión Mixta Congreso-Senado eliminaría la referencia a la "condición jurídica" de los extranjeros, quedando el precepto establecido en su redacción definitiva ${ }^{55}$ — con la inclusión poco habitual del término libertades públicas de los extranjeros que, como vimos, estaba ya presente desde la primitiva versión de esta disposición-.

De ahí que comenzáramos este capítulo aludiendo al doble régimen jurídico de la extranjería y la inmigración existente en el derecho español. Tras la depuración del término "condición jurídica" habida en la redacción de esta disposición, el régimen jurídico de los derechos privados sigue estando presidido por el principio de equiparación consagrado fundamentalmente en los artículos $27^{56}$ y15 del Código Civil y de Comercio, respectivamente. Al artículo 13.1 CE le corresponde el establecimiento del marco constitucional rector de los derechos públicos de los extranjeros en España, sin perjuicio de los múltiples principios rectores del derecho civil consagrados a nivel constitucional.

\subsection{Particularidades del estatuto constitucional de los extranjeros}

Si bien la trayectoria constituyente de esta disposición clarificaba el sentido amplio con que se proyectó la expresión "libertades públicas" en ella empleada, quedaban por despejar múltiples cuestiones vitales. Además, el artículo 13.1CE constituye una norma que, como consecuencia de su redacción pretendidamente ambigua ${ }^{57}$, encierra una gran complejidad interpretativa. Se ha señalado con sustento que "la norma fundamental es aquí más abierta que nunca"58; La indeterminación, apertura y vaguedad de esta disposición ofrecían sustento para interpretaciones jurídicas contradictorias, aunque, visto desde otra perspectiva, han sido precisamente estas propiedades las que

54 Idem.

55 En torno a dicha supresión, Elisa PÉREZ VERA subraya que se trata de algo que va mucho más alla de un "puro cambio redaccional", pues al eliminarse la referencia a la condición jurídica de los extranjeros, la Constitución suprimió simultáneamente todo intento de constitucionalizar el régimen jurídico-privado de los extranjeros en nuestro país, "con lo cual la norma que comentamos se limita a fijar las directrices que presidirán el goce por éstos de las libertades públicas". "Artículo 13. Extranjería”, op. cit., p. 192.

56 El artículo 27 del Código Civil proclama literalmente que "los extranjeros gozan en España de los mismos derechos civiles que los españoles, salvo lo dispuesto en las leyes especiales y en los Tratados”. Por su parte, el artículo 15 del Código de Comercio señala que "los extranjeros y las compañías constituidas en el extranjero podrán ejercer el comercio en España con sujeción a las Leyes de su país, en lo que se refiera a su capacidad para contratar, y a las disposiciones de este Código, en todo cuanto concierna a la creación de sus establecimientos dentro del territorio español, a sus operaciones mercantiles y a la jurisdicción de los Tribunales de la nación. Lo prescrito en este artículo se entenderá sin perjuicio de lo que en casos particulares pueda establecerse por los Tratados y Convenios con las demás potencias".

57 REY MARTÍNEZ, Fernando. “Análisis de la sentencia 236/2007 del TC sobre derechos de los extranjeros"; en Boletín Económico de Castilla y León, no 13, 2008, p. 29.

58 GARCÍA ROCA, Javier. "La titularidad constitucional e internacional de los derechos fundamentales de los extranjeros...", op. cit., p. 98. 
han posibilitado la adecuación actual ${ }^{59}$ de la fórmula constitucional del art. 13. CE1 a un contexto sociológico que resulta radicalmente diferente al vigente en la etapa constituyente.

Especialmente compleja se presentaba la interpretación del papel que el artículo 13.1 otorgaba al legislador interno e internacional en el desarrollo y configuración del estatuto jurídico de la extranjería y la inmigración en nuestro país. Una exégesis estrictamente literal del artículo 13.1 desembocaba e incluso propiciaba la desconstitucionalización de los derechos de los extranjeros ${ }^{60}$ ya que, al otorgar al poder legislativo interno y convencional el desarrollo de los términos en que los extranjeros gozarán en España de los derechos del Título I, parecía atribuirles una libertad de configuración amplísima. Sin embargo, una interpretación sistemática de esta norma, en conjunción con otras disposiciones colindantes del sistema constitucional de derechos español - especialmente del artículo 10 CE en sus dos apartados, a cuyo estudio dedicaremos el siguiente epígrafe-, conducía a un entendimiento bien distinto de este precepto constitucional.

A reserva de explicar más adelante el papel esencial que ha desempeñado el TC para desentrañar el significado de esta disposición constitucional — cuyo estudio se hará de forma independiente en otro apartado del presente trabajo-, conviene en estos momentos reflexionar sobre el alcance de la remisión legislativa presente en el art. 13.1 CE., especialmente en lo que respecta a la referencia expresa a los tratados internacionales. Dicha previsión, insólita en las reservas legales contenidas en el texto constitucional ${ }^{61}$, constituye, a nuestro entender, una clave explicativa de primer orden para el correcto entendimiento del artículo 13.1 CE.

Toda reserva legal conlleva, simultáneamente, una garantía para los derechos afectados y un riesgo latente en caso de extralimitación legislativa. En tanto que garantía jurídica, otorga seguridad a los derechos implicados y, por esta vía, protege a sus titulares activos ya que, en su virtud, la afectación de sus derechos por parte de los poderes públicos ha de ser aprobada necesariamente por el poder legislativo en un instrumento legal. Además, si la reserva afecta a derechos fundamentales, éstos se erigen en barreras o topes ante la libertad de actuación del legislador en la intervención legislativa sobre tales derechos ${ }^{62}$. Los riesgos implícitos a toda reserva legal se producen, obviamente, cuando la intervención del legislador es de carácter restrictivo. Siguiendo a Luis María Díez-Picazo, en la intervención legislativa sobre un derecho caben dos posibilidades:

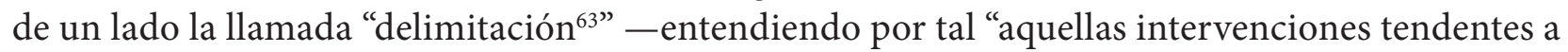
completar la indeterminación del texto constitucional, fijando hasta dónde llega un derecho”- y, de otro lado, las "restricciones" - que designarían "cualesquiera medidas, de alcance general o particular, que reducen el ámbito de aplicabilidad de un derecho"- Sobra decir que la frontera

59 BALAGUER CALLEJOM Francisco. "El contenido esencial de los derechos constitucionales y el régimen jurídico de la inmigración. Un comentario a la STC 236/2007 de 7 de noviembre”; en Revista Española de Derecho Constitucional, $\mathrm{n}^{\circ} 10,2008$, p. 481.

60 DÍEZ-PICAZO, Luis María. Sistema de Derechos Fundamentales. Madrid, Thomson-Cívitas, 2003, $1^{\text {a }}$ edic., p. 121.

61 Tan sólo se encuentra otra remisión a los convenios internacionales en el apartado cuarto del artículo 39 CE que, al contemplar a la infancia, prescribe que "los niños gozarán de la protección prevista en los acuerdos internacionales que velan por sus derechos".

62 Es la denominada vinculación negativa de la ley a los derechos fundamentales. Sin embargo, Díez-Picazo advierte que los derechos fundamentales están sometidos a una paradoja, condensada en la fórmula "legislador de los derechos fundamentales": "tratándose primariamente de barreras frente al legislador, su plena eficacia a menudo está necesitada de colaboración legislativa”. De modo que, junto a la apuntada vinculación negativa, el legislador está también afectado por una vinculación positiva, en virtud de la cual se le impone promover los derechos fundamentales a través de su desarrollo normativo. DÍEZ-PICAZO, Luis María. Sistema de derechos fundamentales, op. cit., p. 95.

63 DÍEZ-PICAZO, Luis María. Sistema de Derechos Fundamentales, op. cit. p. 103. 
entre ambos tipos de intervenciones no es clara puesto que, como el mismo autor advierte, "para averiguar cuándo hay restricción del contenido de un derecho, es preciso haber procedido antes a la delimitación del contenido de ese derecho" ${ }^{34}$.

En si misma, la inserción de una reserva legal en una disposición constitucional destinada a fijar el marco jurídico de la extranjería y la inmigración en el ordenamiento español, suponía un avance respecto a la tradición preexistente en esta materia, caracterizada por lo que ha sido calificado como una auténtica "beligerancia reglamentaria" ${ }^{65}$. Pese al carácter abierto y generoso del derecho histórico español regulador de la entrada, residencia y trabajo de los extranjeros en nuestro país, éste relegaba en la práctica a los reglamentos independientes el desarrollo de los derechos de los no nacionales ${ }^{66}$, confinando a la extranjería como un sector del ordenamiento donde terminaría campando a sus anchas la discrecionalidad administrativa. Frente a esta situación, la remisión legislativa establecida en el art. 13.1 CE otorga seguridad jurídica al marco normativo de la extranjería y la inmigración postconstitucional, al implicar la interdicción de la regulación reglamentaria autónoma ${ }^{67}$.

De otro lado, la inclusión de una reserva legal específica en nuestro ámbito de estudio puede resultar a primera vista redundante ${ }^{68}$, en vista de que todos los derechos contemplados en el Titulo I de la Constitución están sometidos a reserva legal —bien sea ordinaria u orgánica-, por imposición expresa del artículo 53 CE. En consecuencia, en función del tipo y ubicación del concreto derecho constitucional en el Título I, en su aplicación al colectivo de extranjeros, así será el tipo de ley previsto para su desarrollo, sin que, aparentemente, nada aporte la reserva legal contenida en el art. 13.1 CE. A mayor abundamiento, la inserción en el ordenamiento interno español de los tratados internacionales se produce de forma automática, sin necesidad de la intermediación de ninguna norma interna, en virtud del sistema monista contemplado en el artículo $96 \mathrm{CE}$. Conforme a dicha disposición, los tratados internacionales válidamente celebrados y ratificados por España forman parte del derecho interno, incorporándose como normas con rango legal a nuestro ordenamiento jurídico una vez que hayan sido publicadas en el BOE. Los convenios internacionales constituyen pues fuente del derecho español ostentando, además, supremacía sobre las leyes internas. Cabría pues cuestionarse el sentido de la referencia expresa a los tratados internacionales contenida en la remisión legislativa del art. 13.1 CE, cuando toda reserva legal lleva implícita la legislación internacional convencional, conforme a lo establecido en el artículo $96 \mathrm{CE}$.

Todas estas consideraciones desvelan la necesidad de buscar la función independiente y específica que cumple la reserva legal del artículo 13.1 CE en el desarrollo normativo de la extranjería y la inmigración, a fin de que la misma no se solape ni con la reserva genérica de ley establecida para los derechos fundamentales del Título I, ni con la función que cumplen los Tratados internacionales,

64 Ibidem, p. 103.

65 MIQUEL CALATAYUD, José Antonio. "Caracterización del ordenamiento español de extranjería”; Libro homenaje a Jesús López Medel, vol. 1. Madrid, Centro de Estudios Registrales, 1999, p. 377. Sobre la fuerte influencia reglamentaria del ordenamiento preconstitucional de extranjería, en detrimento del principio de legalidad, también se pronuncia FERRER PEÑA, R. M. Los derechos de los extranjeros en España. Madrid, Tecnos, 1989, pp. 51-52. En torno a la importancia esencial de la introducción constitucional de una reserva legal en este ámbito, por contraste a un panorama previo dominado por normas reglamentarias y de rango inferior, se pronuncia también AJA, Eliseo (coord.). La nueva regulación de la inmigración en España, op. cit., p. 19.

66 BORRAJO INIESTA, Ignacio. "El status constitucional de los extranjeros", op. cit., p. 708.

$67 \mathrm{Al}$ respecto, seguimos la definición de reserva legal en sentido clásico, utilizada por DÍEZ-PICAZO, Luis María. Sistema de derechos fundamentales, op. cit., p. 102.

68 Es precisamente para evitar dicha redundancia, para lo que VIDAL FUEYO se dio a la tarea de encontrarle una sentido autónomo al artículo 13.1 CE. Constitución y extranjería, op. cit., pp. 102-108 
tanto en base al artículo $96 \mathrm{CE}$, como en virtud del criterio interpretativo internacional establecido por el artículo 10.2 CE.

En la búsqueda de un sentido autónomo a la reserva legal establecida por el art 13.1, seguiremos las conclusiones de Vidal Fueyo. Esta autora contempla sistemáticamente los dos apartados del artículo $13 \mathrm{CE}$, estableciendo como punto de partida la premisa de que esta disposición "no se refiere tanto a los derechos que los extranjeros tienen, como a los que no tienen"69. Su primer apartado contempla una cláusula expansiva, en cuya virtud el legislador interno e internacional puede otorgar a los extranjeros derechos que la Constitución no les atribuye, siempre que los mismos no están excluidos a los no nacionales en virtud del art. 13.2. En palabras de Vidal Fueyo "el artículo 13.1 vendría a otorgar a los tratados internacionales un papel diferente al que nace de los artículos 96.1 CE y 10.2 CE, confiriéndoles, junto con la ley, la facultad de extender a los extranjeros derechos que no les reconoce directamente la Constitución, debidamente interpretada a la luz del artículo 10.2 CE, pero que tampoco les niega expresamente (...).La novedad de este precepto residiría en que los derechos así obtenidos van a contar con todas las garantías constitucionales propias de los derechos fundamentales"70. En idéntico sentido, Adam Muñoz concibe el artículo 13.1 CE como "un mecanismo de extensión de los derechos fundamentales articulados por la Constitución para los españoles a los extranjeros"71.

En esta interpretación, la remisión legislativa del art. 13.1 CE actuaría como una "cláusula expansiva"72 de los derechos de los extranjeros, expansión que habría de proyectarse, mediante ley interna o tratado internacional, sobre aquella franja de derechos del Título I de la Constitución que, sin excluir expresamente a los extranjeros de su titularidad activa por su conexión con la nacionalidad - como sucede con los derechos políticos del art. 23CE, con las salvedades establecidas en el art. 13.2 CE-, no están reconocidos directamente a su favor, ni implícita ni explícitamente, en el texto constitucional. De esta forma, el art. 13.1 cumpliría una función propia y específica, sin provocar redundancias o duplicidades con respecto a la reserva genérica de ley que el art. 53.1 CE establece para todos los derechos fundamentales ni con el papel desempeñado por los convenios internacionales. En esta perspectiva, la cláusula de habilitación-expansión en que se traduce la remisión legal del

69 VIDA FUEYO, M. C. “La sentencia del TC 72/2005, de 4 de abril...”, oc. cit., p. 439.

70 VIDAL FUEYO, Ma del. Camino. Constitución y extranjería, op. cit., p. 96. Entre los derechos que la Constitución no reconoce directamente a los extranjeros, pero que tampoco los excluye, la autora cita como ejemplos el derecho de acceso a un puesto de trabajo en igualdad de condiciones respecto de los españoles y la libertad de entrada en territorio español. Con carácter más específico, la autora señala el derecho a entrar en España de los ciudadanos comunitarios, que no nace del art. 19 CE, sino del Tratado de la Unión Europea, en conexión con el art. 13.1 CE. "La sentencia del TC 72/2005, de 4 de abril...", op. cit., p. 440.

71 ADAM MUÑOZ, M.D. “El estatuto jurídico del extranjero en el sistema español”, op. cit., p. 86. Esta concepción del sentido del artículo 13.1 CE, lleva a la misma autora a señalar que los dos principios vertebradores del sistema jurídico de la extranjería e inmigración en España - distintos según hablemos de derechos privados o públicos-, no son tan dispares como en principio pudiera parecer, mediante el juego combinado de los tratados internacionales y las leyes especiales. "Consideramos que el resultado es el mismo, tanto si se parte del principio no igualitario, como si se parte del principio de equiparación, ya que, en el primer caso, el juego de los tratados y las leyes, podrán dar lugar al principio de asimilación, mientras que, en el segundo supuesto, las leyes especiales y los tratados, podrán determinar que el principio de asimilación se convierta en un principio de trato desigual”. Idem, p. 87.

72 VIDAL FUEYO, M. C. Constitución y extranjería, op. cit., p. 23. En una dirección divergente se situaría Elisa PÉREZ VERA, quien parte de una "visión restrictiva de las libertades públicas de los extranjeros, en la medida en que su goce queda subordinado a lo establecido en los tratados y en la ley”. Impresión que, a juicio de la misma autora, queda limitada por lo establecido en los dos apartados del artículo $10 \mathrm{CE}$, de cuyo primer párrafo concluye que dada la vinculación de España por los tratados más relevantes en materia de derechos humanos, "los extranjeros tienen garantizados en nuestro país la práctica totalidad de los derechos recogidos en la Constitución”; en "Artículo 13. Extranjería”, op. cit, p. 193. 
art. 13.1 CE, otorga al legislador tanto interno como internacional plena libertad configurativa cuestión en la que discrepamos-, en la extensión de derechos a los extranjeros, siempre que no esté constitucionalmente prohibida tal expansión. Por ello, el art. 13.1 debe ser complementado con lo dispuesto en su apartado segundo, el cual "completaría el perfil de dicha habilitación prohibiendo que se expandan a los extranjeros los derechos reconocidos en el art. 23CE, salvo el derecho al sufragio activo y pasivo en las elecciones municipales"73.

Los derechos y libertades que fueran reconocidos a los extranjeros en virtud de la acción expansiva que el art. 13.1 CE otorga a los tratados y a la ley en el ámbito de la extranjería, gozarían de todas las garantías constitucionales, esto es, estarían dotados de la eficacia y la tutela propias de los derechos fundamentales, si bien constituirían, a juicio de la misma autora, ejemplos de derechos de configuración legal ${ }^{74}$.

En esta interpretación, la remisión legislativa contemplada en el artículo 13.1 actúa pues como una cláusula amplificatoria, de modo que de los dos tipos de intervención legislativa ya señalados, el artículo 13.1 CE habilitaría al legislador interno e internacional para delimitar el contenido de los derechos de los extranjeros, completando la indeterminación de esta disposición constitucional, en conjunción con cada uno de los derechos constitucionales consagrados a lo largo del Título I CE. En una línea similar parece inscribirse Manuel Jiménez de Parga al considerar que sobre la categoría de los derechos condicionados a configuración legal — según su propia definición "los derechos que gozan los extranjeros en los términos de la ley"75-, despliega toda su virtualidad el art. 13.1 CE. Dado que el TC también ha subrayado que la remisión legislativa para el desarrollo de los derechos de los extranjeros contenida en la mencionada disposición constitucional no implica una desconstitucionalización de los mismos, Jiménez de Parga, matizando la nomenclatura empleada, los denomina "derechos de configuración legal no desconstitucionalizadora"76.

A nuestro entender, la RF constituiría uno de estos derechos, conferido expresamente a los extranjeros mediante la acción del legislador interno, bajo la influencia determinante del derecho internacional, tanto comunitario como de la jurisprudencia procedente del TEDH. La cuestión a despejar sería - ante el silencio constitucional-, encontrar el sedimento o asiento constitucional para la recepción del derecho a la RF, cuestión que, tras múltiples especulaciones doctrinales, ha sido ventilada recientemente por el TC, como tendremos ocasión de analizar posteriormente.

Nuestra concepción del artículo 13.1 CE hace hincapié en el aspecto internacionalista de esta disposición. Resulta muy significativo que la específica remisión legislativa que en materia de derechos de los extranjeros contempla esta disposición, aluda en primer lugar a los tratados internacionales $^{77} \mathrm{y}$, con posterioridad, a la ley interna — tanto más cuanto en las remisiones legislativas

73 VIDAL FUEYO, M. C. “La sentencia del TC 72/2005, de 4 de abril...”, p. 439.

74 Idem, pp. 440-441.

75 JIMÉNEZ DE PARGA, Manuel. La inmigración en la jurisprudencia del Tribunal Constitucional Español, op. cit., s.p. Tales derechos serían, tal y como explica el autor, aquellos que admiten diferencias jurídicas en el tratamiento dispensado a españoles y extranjeros, esto es, los correspondientes a la segunda de las categorías apuntadas por el TC en la STC 104/87, al análisis de cuya jurisprudencia dedicamos más adelante un epígrafe independiente.

76 Idem.

77 La misma apreciación puede verse en el voto discrepante formulado por el magistrado don Vicente Conde Martín de Hijas a la sentencia del TC de fecha de 7 de noviembre, recaída en el recurso de inconstitucionalidad $n^{\circ} 1701-2001$, al que se adhiere también el magistrado don Jorge Rodríguez-Zapata Pérez. Si bien en esta tesis no compartimos plenamente las opiniones allí manifestadas, el voto discrepante parte de una personal interpretación del sentido del art. 13 CE: "tal precepto supone una diferenciación de partida de la posición constitucional de los españoles y de los extranjeros”, señala el magistrado discrepante. En él se afirma textualmente la importancia primordial de los 
previstas en la Constitución no suelen abundar las referencias al derecho internacional, y menos aún en el orden señalado- - A nuestro juicio, el constituyente sintió la necesidad de subrayar una diferencia al constitucionalizar las bases de un régimen jurídico que afectaba a un grupo especialmente vulnerable, como lo son las personas que carecen de la nacionalidad del Estado en el que viven. Por definición -como indica taxativamente el artículo 13.2 CE-, los extranjeros constituyen un colectivo carente de derechos políticos y que, por ello, no genera influencia sobre los legisladores - los representantes populares carecen de incentivos para atender las demandas de quienes no votarán por ellos-. En consecuencia, si la reserva de ley es en sí misma un instrumento de garantía jurídica - a pesar de que conlleva también el germen de una intervención restrictiva-, el nivel de seguridad jurídica que otorga cualquier reserva legal es de inferior rango cuando éstas afectan a los derechos de los extranjeros.

Mi tesis a fin de justificar el, llamémoslo así, carácter acusadamente "internacionalista” del diseño constitucional de los derechos de los extranjeros emanado del artículo 13.1 CE, sigue la misma línea argumentativa que anticipamos al final del capítulo primero del presente trabajo. Se recordará que entonces, al introducir el concepto de "minoría insular", sostuvimos que los extranjeros no pueden proteger sus derechos a través del proceso político mediante el ejercicio del sufragio, como se hace ordinariamente en una democracia representativa. De ahí que deban articularse otros mecanismos para proteger a los grupos sociales que no participan en el proceso político electoral, ya que el artículo 13.2 excluye expresamente a los extranjeros del proceso político. Como contrapartida, el primer apartado de dicha disposición prevé una vía alternativa para la protección de los extranjeros mediante el recurso al Derecho internacional general de carácter convencional, que sólo admitiría una intervención en sentido expansivo y no en la dirección opuesta.

De esta forma, la expresa referencia a la legislación internacional prevista en la reserva legal del artículo 13.1 CE constituiría, a nuestro juicio, una vía para reforzar la protección del colectivo destinatario de la misma - los extranjeros-, pues los tratados internacionales, llegado el caso, se erigirán en un umbral mínimo por debajo del cual no podrá descender el poder legislativo interno y, además, potencialmente constituirán vías para la ampliación del contenido de sus derechos fundamentales. La inclusión de los convenios internacionales dentro de la reserva legal en el ámbito del ordenamiento español de la extranjería y la inmigración, determina que, entre los dos tipos de intervención legislativa ya señalados, el art. 13.1 CE sólo admita una intervención convencional expansiva o amplificadora. En esta perspectiva, la mención de los tratados internacionales como fuente privilegiada del derecho de extranjería español puede ser en sí misma indicativa del grado de conciencia que pudo haber tenido el constituyente ${ }^{78}$ sobre la vulnerabilidad del colectivo extranjero destinatario de dicha disposición.

tratados internacionales en la configuración del estatuto de los extranjeros en España — “único límite discernible que la Constitución fija al legislador". Para llegar a ello, los magistrados disidentes se asientan en el hecho de que "la Constitución, cuando establece en el art. 13 el estatus de los extranjeros, remite en primer lugar a los Tratados, y en segundo lugar a la ley". Apartado $1^{\circ}$ del voto discrepante formulado a la STC 236/2007, de 8 de noviembre de 2007.

78 Bien es cierto que esta conciencia no estuvo presente desde los inicios del íter constituyente, dado que en su versión inicial los tratados internacionales sólo se mencionaban en la regulación relativa a la condición jurídica de los extranjeros - léase derechos privados-, estando ausente del desarrollo normativo de las libertades públicas. Esta omisión se suplió en la Comisión Constitucional del Senado y la lectura de las numerosas enmiendas propuestas evidencia la preocupación del constituyente por el respeto al derecho internacional en general, y al DIDH en particular, en nuestro ámbito de estudio. 
En esta visión, Ia vinculación negativa de los derechos fundamentales de los extranjeros, supondría, desde el punto de vista interno, entender que éstos actúan como límites internos a las inestables políticas migratorias ${ }^{79}$. Y, desde el punto de vista internacional, concebir a los derechos humanos - entendidos éstos como aquellos consagrados a nivel internacional ${ }^{80}$ - como barreras internacionales frente a dichas políticas ${ }^{81}$. El libre desarrollo y ejecución de las políticas migratorias se movería dentro de los límites marcados por el texto constitucional y, a un nivel más concreto, con el tope mínimo representado por los derechos fundamentales - en su concepción interna-, y por los derechos humanos - vía internacional-. En palabras de García Roca, "existirá siempre un contenido imperativo (esencial) e indisponible por el legislador de extranjería, bien en virtud del mandato constitucional o bien de la protección internacional impuesta por los tratados en la materia” Por su parte, la vinculación positiva se traduciría en la introducción -mediante la intermediación del DIDH y al hilo de su desarrollo legislativo y/o su interpretación jurisprudencial一, de facultades adicionales que se integrarían, amplificándolo, al contenido de los derechos de los extranjeros, tal y como son reconocidos a nivel interno. Pero, además, en nuestro ordenamiento, los derechos del Título I, tanto fundamentales como no, se interpretan conforme al DIDH —en virtud de lo prescrito por el art. 10.2 CE, a cuyo estudio dedicamos un epígrafe más adelante- de modo que a los elementos mencionados habría que añadir la interpretación jurisprudencial de carácter internacionalista, que ahondaría las características apuntadas.

Aunando los dos elementos apuntados, resultaría que el ordenamiento jurídico de los extranjeros en España presenta una doble vinculación a los derechos humanos: de un lado, a través de la reserva de ley expansiva del $13.1 \mathrm{CE}$ - que afecta al derecho internacional general de carácter convencional $\mathrm{y}$, de otro, mediante el reenvío interpretativo del $10.2 \mathrm{CE}$, que afecta a los tratados internacionales ratificados por el Estado español en materia de derechos humanos y a la jurisprudencia emanada de su interpretación y aplicación-, en el entendido de que los efectos desplegados por ambas normas son distintos.

En suma, el contenido internacionalista del artículo 13.1 CE vendría a contrarrestar los posibles excesos del legislador interno al desarrollar el contenido de los derechos de los extranjeros, erigiéndose el Derecho internacional convencional como límite de la afectación de los

79 FERNÁNDEZ LE GAL, Annäick. "Los derechos fundamentales de los extranjeros en situación irregular"; en FERNÁNDEZ LE GAL, A; GARCÍA CANO, S. (dirs.). Inmigración y derechos de los extranjeros. Córdoba, Universidad de Córdoba, Servicio de Publicaciones, 2005, especialmente pp. 71-77.

80 Seguimos aquí la distinción terminológica propuesta por PÉREZ-LUÑO, que reserva el término de derechos fundamentales para los consagrados a nivel interno, en el texto constitucional y con un umbral alto de garantías, frente a la expresión de derechos humanos, aplicable a aquellas facultades subjetivas reconocidas a nivel internacional y que, normalmente, gozan de umbrales inferiores de protección. El autor, sin embargo, advierte que se trata de una "tendencia, no absoluta ( ) a reservar la denominación 'derechos fundamentales' para designar a los derechos humanos positivados a nivel interno, en tanto que la fórmula 'derechos humanos' es la más usual en el plano de las declaraciones y convenciones internacionales"Ga. PÉREZ-LLUNO, Antonio Enrique. Derechos Humanos, Estado de Derecho y Constitución. Madrid, Tecnos, sexta edición, 1999, p. 31.

81 En este sentido, Bastarrechea señala que "lo dispuesto en los Tratados ratificados por nuestro país es el límite infranqueable, a nivel constitucional, para el legislador en el establecimiento de una regulación diversa para nacionales y extranjeros del ejercicio de los derechos fundamentales y libertades públicas"; ALBA BASTARRECHEA, Esther de. "Sobre Derechos y Libertades de los Extrajeros en España: comentario a la STC 236/2007, de 7 de noviembre"; en Repertorio Aranzadi del Tribunal Constitucional, No 21-22, 2008, pp. 13-30, (p. 14).

82 GARCÍA ROCA, Javier. "La titularidad constitucional e internacional de los derechos fundamentales de los extranjeros.., op. cit., p. 100. El autor prosigue argumentando que "la titularidad de un derecho fundamental procede pues directamente de la Constitución o del Derecho convencional internacional en la materia (...). La ley nacional no podría excluir como sujetos a los extranjeros de los derechos que ostenten en virtud de la protección constitucional o internacional". 
mismos. Por lo tanto, la referencia a los tratados internacionales en el primer apartado del artículo $13 \mathrm{CE}$, encontraría su más profundo sentido en conexión con la exclusión de los derechos políticos por parte de los extranjeros, establecida a renglón seguido en el siguiente apartado de la misma disposición constitucional, vinculado al concepto de "minoría insular". Se trataría de un mecanismo de compensación a fin de neutralizar ${ }^{83}$ la inherente amenaza potencial de posible reducción del contenido del derecho por parte del legislador nacional - amenaza nada desdeñable, en vista de que la extranjería suele situarse al socaire de criterios de oportunidad política. La inclusión expresa de los Tratados internacionales dentro de la reserva legal exigida por el artículo 13.1 CE otorga además sustento a las incursiones progresistas que pudiera llegar a hacer tanto el juez constitucional español como la jurisprudencia ordinaria, con el TS a la cabeza, menos expuestos que los legisladores a las presiones populares. No en vano, la línea jurisprudencial desplegada en la interpretación y aplicación de los derechos de los extranjeros se caracteriza, en términos generales, por su carácter expansivo y su elevado progresismo.

El artículo 13.1 CE se encuentra en la base de lo que podría considerarse como una acusada predisposición internacionalista del régimen jurídico-constitucional español de la extranjería y la inmigración. Predisposición que viene asimismo fomentada por la propia ambigüedad e indeterminación de la redacción del artículo 13.1 CE y por los acusados efectos internacionalistas que, en esta materia, despliega el criterio interpretativo contemplado en el artículo 10.2 CE.

La específica reserva legal convencional (art. 13.1 CE), en conjunción con la cláusula de interpretación internacionalista de los derechos del Titulo I CE (artículo 10.2 CE), nos sitúa ante un específico sector del ordenamiento jurídico español -la extranjería y la inmigración-, especialmente sensible al Derecho internacional, tanto general, como en su vertiente de DIDH. Por ello, a modo de conclusión, sostenemos que el juego combinado de ambas disposiciones desemboca en un refuerzo de la acusada tendencia internacionalista a la que, al menos en línea de principio, apunta la configuración jurídica de la extranjería y la inmigración en el ordenamiento español.

Adicionalmente, dado que el artículo 10.2 CE abre la vía a los órganos encargados de la interpretación de los tratados internacionales y éste se sitúa en el seno de un circuito jurídico supranacional como es el europeo, se abriría expresamente la puerta a la penetración del juez internacional -en nuestro ámbito, especialmente el TEDH—, para la protección de los derechos de aquellos sujetos excluidos del proceso político ${ }^{84}$.

83 Para PÉREZ VERA, el juego de neutralización o de contrapuntos no estaría en la combinación de los dos apartados del artículo $13 \mathrm{CE}$, sino en la síntesis formada por el artículo 13, de un lado, y el artículo 10, en sus dos apartados, de otro. La visión restrictiva de las libertades públicas de los extranjeros que se extrae del artículo 13.1 CE subordinados a los tratados y a la ley-, quedaría, a juicio de esta autora, limitada o contrarrestada por lo establecido en los dos artículos del artículo 10 CE. “Artículo 13. Extranjería”, op. cit., p. 193.

84 Se puede hablar así de un doble proceso que, si bien constituye una tendencia del ordenamiento actual, resulta especialmente perceptible en el sector de los derechos de los extranjeros: el creciente proceso de internacionalización de los derechos fundamentales, se produce en conexión con un correlativo - pero más tardío-, proceso de constitucionalización de los derechos humanos. La constitucionalización de los derechos humanos —esto es, el proceso de inserción de facultades procedentes del ámbito internacional en el contenido material de los derechos fundamentales internos-, resulta más visible en una materia, la extranjería que, como señalamos, se presenta en nuestro ordenamiento jurídico como especialmente permeable a las influencias internacionales. 


\section{El ARTÍCULO 10 DE LA CONSTITUCIÓN ESPAÑOLA COMO CONTEXTO INTERPRETATIVO DEL ARTÍCULO 13.1 CE}

Desde distintos espectros doctrinales ${ }^{85}$ se ha señalado abundantemente que el artículo $13.1 \mathrm{CE}$ está lejos de monopolizar la visión constitucional de la extranjería y la inmigración en nuestro país, constituyendo un mero punto de partida que requiere de una interpretación sistemática, en conjunción con las restantes y abundantes disposiciones constitucionales dedicadas tanto al establecimiento de los principios rectores del edificio dogmático-constitucional como a la ordenación de concretos derechos subjetivos. De entre las primeras, el artículo $10 \mathrm{CE}$, en sus dos apartados, ocupa un lugar de especial importancia a efectos de su exégesis sistemática con el artículo $13 \mathrm{CE}$. Mientras que, del segundo tipo de disposiciones, consagradas a lo largo de todo Título I CE, se extraen importantes perfiles constitucionales tanto respecto de la titularidad como del contenido, ejercicio y límites de los concretos derechos afectados en su aplicación a los no nacionales. En este sentido, se ha apuntado gráficamente que el artículo 13.1 CE constituye "un suerte de Big Bang, que opera su desconcentración desde el artículo $13 \mathrm{CE}$, punto de partida ineludible, hasta los demás preceptos reguladores de derechos a lo largo y ancho del entramado constitucional"s6.

Junto al artículo 13, existen pues otras prescripciones constitucionales que prefiguran el panorama normativo de la extranjería y la inmigración en España y cuya mayor virtualidad reside, prima facie, en el establecimiento de límites constitucionales sobre la segunda fuente del ordenamiento jurídico de la extranjería, esto es, sobre la legislación — tanto interna como internacional—, proporcionando claves esenciales para poder delimitar el ámbito de actuación legislativa en la modulación de los derechos de los extranjeros. Esta primera aproximación resulta necesaria para abordar posteriormente el concreto régimen jurídico de cada uno de los derechos constitucionales en su afectación a los extranjeros, en cuyo auxilio resulta esencial conjugar el artículo 13.1 junto con la cláusula constitucional específica reguladora de cada derecho.

En primer lugar, y con un alcance general, el mapa constitucional de la extranjería y la inmigración exige analizar el artículo 13.1 CE a la luz de otra disposición constitucional destinada a desarrollar un papel estructural en el diseño del sistema constitucional español de derechos fundamentales: el artículo $10 \mathrm{CE}$. El artículo 10 ostenta una ubicación privilegiada en el texto constitucional, prologando la Declaración constitucional de Derechos, en un artículo en solitario que sirve de apertura al Título I de la Constitución, bajo la rúbrica "de los derechos y libertades fundamentales". Su primer apartado ${ }^{87}$ erige a la dignidad de la persona en fundamento del orden político y la paz social. El apartado segundo consagra el derecho internacional de los derechos humanos como criterio exegético vinculante para la interpretación de las normas relativas a los derechos fundamentales.

85 Sobre la necesidad de una interpretación sistemática del Título I CE para una correcta interpretación del marco constitucional de la extranjería y la inmigración establecido en el artículo $13 \mathrm{CE}$, también se pronuncia VIDAL FUEYO, M.C. Constitución y extranjería, op. cit., p. 43. En idéntico sentido se expresa PÉREZ VERA, quien señala que "el análisis del artículo 13.1 obliga a hacer mención a otros artículos de la Constitución que configuran directamente los sujetos del derecho a que se refieren", incidiendo en la importancia de conjugar esta disposición con el artículo $10 \mathrm{CE}$, en sus dos apartados. "Artículo 13. Extranjería”, op. cit., p. 193. En esta línea se inserta también GOIG MARTÍNEZ, J.M. Derechos y libertades de los inmigrantes en España..., op. cit., p. 36.

86 GARCÍA VÁZQUEZ, Sonia. El estatuto jurídico-constitucional del extranjero en España, op. cit., p. 41. También en GOIZUETA VÉRTIZ, Juana. "Un análisis en clave constitucional del régimen jurídico de los extranjeros en España: especial referencia al derecho a la libertad de circulación y residencia”, op. cit., p. 260.

87 El artículo 10.1 proclama que "la dignidad de la persona, los derechos inviolables que le son inherentes, el libre desarrollo de la personalidad, el respeto a la Ley y a los derechos de los demás son fundamento del orden político y de la paz social". 


\subsection{Dignidad humana y derechos de los extranjeros}

En torno a la dignidad humana consagrada en el art. 10.1 CE, debe aclararse desde este momento que no constituye en sí misma un auténtico derecho fundamental, lo que excluye tanto la aplicación del régimen previsto en el artículo $53 \mathrm{CE}$ como la posibilidad de reclamar pretensiones jurídicas basadas en la apelación exclusiva a la dignidad de la persona ${ }^{88}$. Sin embargo, de su sobresaliente emplazamiento en el texto constitucional, cabe deducir "la conversión de un valor moral en un valor jurídico"89. En la misma idea incide Solozábal Echavarría quien incluso estima que el reconocimiento constitucional de la dignidad de la persona, con independencia de su ubicación, implica ya de por sí la transformación en jurídico de un valor moral ${ }^{90}$.

Si, además, se añade la consideración del tipo de norma jurídica en que este reconocimiento constitucional tiene lugar —se trata de una cláusula principial ${ }^{91}$-, se obtiene un panorama más diáfano en torno a la eficacia jurídica de esta disposición. Siguiendo a Solozábal Echavarría, de la cláusula de la dignidad de la persona en tanto que norma principial del ordenamiento jurídico, se extrae una doble eficacia: de un lado, un efecto negativo o impeditivo, consistente en la exigencia de respeto a la dignidad humana por parte de los órganos del Estado, conforme a la cual éstos han de abstenerse de emitir normas o actos que produzcan un efecto degradante o envilecedor. Implícita a esta eficacia negativa de la cláusula de la dignidad, subyace la prohibición de una visión del ser humano como mero objeto de las políticas estatales y, por lo tanto, la existencia de una perspectiva axiológica del Estado de Derecho que obliga a concebir a los poderes públicos como instrumentos al servicio de las personas y no la inversa ${ }^{92}$. Existe, además, un efecto positivo, conforme al cual la dignidad ha de orientar las tareas del Estado hacia políticas que impulsen la autodeterminación de los individuos, implicando así un política jurídica de promoción de los derechos fundamentales ${ }^{93}$. En este sentido, Díez-Picazo ha señalado que el artículo 10.1 enunciaría los fines últimos del Estado Español democrático de Derecho, constituyendo a un tiempo el fundamento de su legitimidad y la base de su eficacia ${ }^{94}$.

Pese a las múltiples dificultades que rodean su definición, resulta pacífico admitir que la dignidad humana constituye un valor insustituible, absoluto e inherente de la persona, derivado de la misma naturaleza humana ${ }^{95}$. La dignidad aparece así indisolublemente conectada a la idea misma de

88 Como subraya DÍEZ-PICAZO, la dignidad en el ordenamiento español tiene "un mero valor de criterio interpretativo, pudiéndose utilizar como argumento al servicio de una pretensión basada en otro precepto constitucional"; en Sistema de derechos fundamentales, op. cit., p. 65.

89 FERNÁNDEZ, Eusebio. "Dignidad y derechos humanos"; en SORIANO DÍAZ, Ramón; ALARCÓN CABRERA, Carlos y MORA MOLINA, Juan (directores y coordinadores). Diccionario crítico de los derechos humanos. La Rábida, Universidad Internacional de Andalucía, $1^{a}$ edic, 2000, p. 94.

90 SOLOZÁBAL ECHAVARRÍA, J. J. “Dignidad de la persona”; en ARAGÓN REYES, Manuel (coord.). Temas básicos de derecho constitucional. Tomo III. Tribunal Constitucional y derechos fundamentales. Madrid, Civitas, 2001, p. 114.

91 El propio SOLOZÁBAL ECHAVARRÍA incluye una definición de este tipo de cláusulas, a las que considera "normas definitorias de segundo grado", esto es, disposiciones que se caracterizan por su capacidad fundante de principos estructurales o legitimadora de principios axiológicos, determinando la comprensión de otras muchas normas, tanto situadas dentro como fuera del texto constitucional, con las cuales han de ser integradas o completadas. Temas básicos de Derecho Constitucional, op. cit., p. 114.

92 DÍEZ-PICAZO, L. M. Sistema de Derechos Fundamentales, op. cit., p. 65.

93 SOLOZÁBAL ECHAVARRIA, J.J. “Dignidad de la persona”, op. cit., p. 114.

94 DÍEZ-PICAZO, Luis María. Sistema de Derechos Fundamentales. Madrid, Thomson Civitas, 1a edic, 2003 , p. 64.

95 Vid, PELÉ, Antonio. Filosofía e historia en el fundamento de la dignidad humana. Tesis doctoral dirigida por Francisco Javier Ansuátegui Roig. Madrid, Universidad Carlos III de Madrid, 2006, p. 2. Por su parte, Eusebio FERNÁNDEZ 
humanidad ${ }^{96}$. Como señalara en su momento Kant, "la humanidad misma es dignidad"97. De ahí se deriva directamente un concepto de "igual dignidad"98 ya que, en tanto que valor inherente a la naturaleza humana, la dignidad es predicable de todas las personas en condiciones de igualdad absoluta.

La ecuación humanidad-dignidad-igualdad desemboca en la necesaria existencia de un núcleo de derechos fundamentales de titularidad universal, cuyo reconocimiento y garantía resultaría insoslayable para todo Estado de Derecho. De este modo, la dignidad humana se erige en premisa o pre-requisito indispensable de los derechos fundamentales, exigiendo la universalidad en la titularidad activa de un núcleo irreductible de dichos derechos. En palabras de Eusebio Fernández, la dignidad humana constituye la "idea básica y condición sine qua non para hablar de derechos fundamentales, (...) la idea universal de humanidad, por tanto, se traduce inmediatamente en el reconocimiento de un determinado número de derechos que exigen su incondicional protección por parte de la sociedad y el poder político" 99 .

La conexión indisoluble entre la dignidad humana y los derechos fundamentales se despliega en cuatro ámbitos ${ }^{100}$ : en primer lugar, en el ámbito de la legitimación o fundamentación de los derechos fundamentales —entendidos éstos como reflejos, proyecciones, desarrollos normativos o especificaciones inmediatas y necesarias de la dignidad-; en segundo lugar, en la exigencia de reconocimiento y positivación de derechos fundamentales, al menos en lo que a un núcleo duro se refiere, pues ésta constituye la única vía de ofrecer una tutela eficaz a la dignidad; en tercer lugar, en el establecimiento de un contenido esencial de los derechos fundamentales que resulte absolutamente indisponible para los poderes públicos, sin el cual se desvirtuarían tales derechos y el propio concepto de dignidad del que derivan; en cuarto lugar, en la conversión de la dignidad en una pauta o brújula que ha de orientar la interpretación de los derechos fundamentales por parte de todos los operadores jurídicos, con el TC a la cabeza.

define a la dignidad como un "valor insustituible atribuido a cada persona"; "Dignidad y derechos humanos", op. cit., p. 92.

96 En idéntico sentido, el TC ha señalado que "la dignidad es un valor espiritual y moral inherente a la persona" (STC 53/1985, F. J. $8^{\circ}$ ). Y, por su parte, Antonio PELÉ la inscribe como un valor central de la civilización occidental, formulado filosófica y moralmente dentro de dicha cultura, hasta terminar integrando ya en el siglo XXI los ordenamientos jurídicos, como fundamento de los derechos humanos. Pelé señala que "la idea de dignidad humana sería el reflejo de un progreso moral que consistiría en reconocer en la persona un valor inherente en torno del cual se estructurarían las organizaciones sociales y políticas". Filosofía e historia en el fundamento de la dignidad humana, op. cit., p. 1.

97 Para Kant "la humanidad misma es dignidad: porque el hombre no puede ser utilizado únicamente como medio por ningún hombre (ni por otros, ni siquiera por sí mismo), sino siempre a la vez como fin, y en esto consiste precisamente su dignidad (la personalidad) en virtud de la cual se eleva sobre todas las cosas (...)". Citado por PELÉ, Antonio. "Una aproximación al concepto de dignidad humana"; en Universitas: revista de filosofía, derecho y política, No. 1, 2004-2005, p. 12

98 PELÉ, A. Filosofía e historia en el fundamento de la dignidad humana, op. cit., p. 6.

99 Sobre este aspecto, Eusebio FERNÁNDEZ señala previamente que "los valores y exigencias morales y racionales que fundamentan éticamente los derechos humanos giran en torno a la idea de dignidad humana". La definición que proporciona este autor en torno al concepto de derechos fundamentales es la siguiente: "Los derechos fundamentales son los derechos morales o pretensiones humanas legítimas originadas en y conectadas con la idea de dignidad humana y los valores que la componen (autonomía, seguridad, libertad e igualdad) y, al mismo tiempo, las condiciones mínimas del desarrollo de esa idea de dignidad que, a partir de unos componentes básicos e imprescindibles, debe interpretarse en clave histórica"; en "Dignidad y derechos humanos", op. cit., p. 93. En una línea similar, Peces Barba subraya que la dignidad constituye un prius de los valores politicos y jurídicos. PECESBARBA MARTíneZ, G., La dignidad de la persona desde la Filosofía del Derecho. Madrid, Dykinson, Cuadernos "Bartolomé de las Casas, 2003, p. 12.

100 SOLOZABAL ECHAVARRÍA. “Dignidad de la persona”, op. cit., pp. 114 y 115. 
Pero quizá el mayor problema que plantea esta noción, es precisamente su definición jurídica. El uso y abuso que se ha hecho de este término desde el ámbito jurídico, en conjunción con su altísimo componente moral, ha provocado una cierta inflación del concepto, con riesgo de depreciar su contenido y convertirlo en un término superfluo ${ }^{101}$. Es pues preciso encontrar un concepto riguroso que al tiempo sea de utilidad práctica. Parece existir un consenso generalizado en apuntar al reconocimiento y respeto de la autonomía individual como la principal manifestación de la dignidad humana ${ }^{102}$. Sin embargo, una definición de este calibre no elude la vaguedad como principal dificultad implícita también en la noción de dignidad primigenia. Por ello, desde estas páginas, nos adherimos al concepto de dignidad humana propuesto desde la filosofía del derecho por el prof. Eusebio Fernández, quien define a la dignidad como "el reconocimiento del derecho a tener derechos"103.

En consecuencia, de la consagración a nivel constitucional de la dignidad humana como valor jurídico-moral y principio rector del orden político, se podría extraer el compromiso, al más alto nivel jurídico, del reconocimiento en favor de todas las personas que estén en contacto con el territorio español del derecho a tener derechos - al menos respecto de aquellos considerados más próximos a la dignidad humana, directamente derivados de ella y esenciales para su existencia-.

De esta forma, la dignidad humana, consagrada en el artículo 10.1 CE como principio rector del ordenamiento jurídico, especialmente en su aspecto dogmático de vinculación con los derechos fundamentales, queda estrechamente conectada con el artículo 13.1. de entrada, del artículo 10.1 CE se deduce la existencia de unos derechos predicables del ser humano en cuanto tal y, por tanto, compartidos por nacionales y extranjeros en régimen de igualdad en tanto que cotitulares ambos de dicha dignidad. Esta afirmación permitiría inferir la existencia de ciertos derechos que, ex constitutionen, resultan predicables también de los extranjeros - cuestión que, en el ámbito del derecho internacional de los derechos humanos, se ha protegido mediante el concepto de estándar mínimo internacional-.

El propio Tribunal Constitucional español ha subrayado en múltiples pronunciamientos la ligazón indisoluble entre los conceptos de dignidad humana y la existencia de un núcleo irreductible de

101 FERNÁNDEZ, Eusebio. “Dignidad y derechos humanos”, op. cit., p. 94. Este autor parte de la denuncia de la enorme frecuencia con la que el concepto de dignidad humana se utiliza con una "patente imprecisión", exponiendo la problemática de este concepto, cuyo alto valor molar puede conllevar el riesgo de convertirlo en una fórmula hueca. En torno a la vaguedad y las dificultades inherentes al concepto, haciendo un recorrido por la evolución del mismo vid. PELÉ, Antonio. "Una aproximación al concepto de dignidad humana”, op. cit., pp. 9-13.

102 Entre otros, PELÉ, A. para quien, “como fundamento ético y jurídico de los derechos fundamentales, la dignidad humana implica un reconocimiento de una autonomía inherente al sujeto humano", Filosofía e historia en el fundamento de la dignidad humana, op. cit., p. 8. También FERNÁNDEZ, E. "Dignidad y derechos humanos”, op. cit., p. 93.

103 Tras repasar el uso del concepto de dignidad humana en la tradición humanista y liberal-democrática, Eusebio Fernández defiende la idea de dignidad humana como un "valor insustituible atribuido a cada persona", para cuya delimitación se precisa del auxilio de otros valores, tales como la autonomía, la seguridad, la libertad y la igualdad. En su visión, los derechos humanos constituyen un reflejo ineludible de la dignidad humana, que si bien están sometidos a una gran variabilidad histórica en función de influencias socio-culturales, sin embargo existe un núcleo permanente de carácter irrenunciable. Al respecto el autor añade que "la variabilidad histórica de los derechos humanos se detiene ante los derechos más básicos, como los derechos a la vida y a la integridad física y moral, pues sin un contenido invariable de las exigencias básicas que protegen sería superfluo hablar de derechos humanos fundamentales". Concluye posteriormente que "el respeto a la dignidad humana, al valor de cada persona humana, exige el reconocimiento del derecho a tener derechos. Tener a alguien por ser humano es lo mismo que reconocerle unos derechos básicos y fundamentales”. FERNÁNDEZ, Eusebio. “Dignidad y derechos humanos”, op cit., pp. 92-94. Para SOLOZÁBAL ECHAVARRÍA, la dignidad de la persona consiste en el "derecho de toda persona a un trato que no contradiga su condición de ser racional igual y libre capaz de determinar su conducta en relación consigo mismo y su entorno"; en "Dignidad de la persona", op. cit., p. 114. 
derechos humanos. Sobre la base del pronunciamiento contenido en el primer apartado del artículo $10 \mathrm{CE}$, el alto tribunal considera que "nuestra Constitución ha elevado a valor jurídico fundamental la dignidad de la persona" ${ }^{104}$, deduciendo de su ubicación en el texto constitucional la gran relevancia de esta disposición ${ }^{105}$, y estimando que la misma constituye el "germen o núcleo de unos derechos que le son inherentes"106. Para el TC, la dignidad constituye un valor inherente a toda persona, que "se manifiesta singularmente en la autodeterminación consciente y responsable de la vida y que lleva consigo la pretensión al respeto por parte de los demás"107. En esta visión, la dignidad humana impone la existencia de un "minimum invulnerable que todo estatuto jurídico debe asegurar"108.

Y, como tendremos ocasión de analizar posteriormente con mayor detenimiento, el mismo vínculo inescindible entre la dignidad y los derechos humanos fundamentales ha sido profusamente subrayado en el ámbito específico de la extranjería y la inmigración. De hecho, el criterio de la dignidad humana constituye la columna vertebral de la argumentación desplegada por el TC al enfrentarse a los derechos de los extranjeros en España. De manera destacada, así razonó el TC en uno de los primeros y más importantes pronunciamientos en este ámbito. La lógica deductiva de su argumentación jurídica partió de la unión indisoluble entre el concepto de dignidad humana y los derechos fundamentales, para extraer un núcleo mínimo de derechos compartidos en condiciones de igualdad por nacionales y extranjeros y, respecto de los cuales, la capacidad de intervención legislativa es mínima. Desde entonces y hasta nuestros días, la cláusula de la dignidad humana constituye el criterio utilizado de forma constante por el TC para la clasificación de los distintos derechos de los extranjeros así como para deducir su titularidad activa, con el auxilio del derecho internacional de los derechos humanos. Dicha cláusula ostenta un papel de primer orden en la construcción jurisprudencial constitucional de los derechos de los extranjeros en España ${ }^{109}$, constituyendo la columna vertebral de la misma pero, al mismo tiempo, situándose también en el origen de algunos de los problemas de falta de sistemática que se detectan en ella.

\subsection{El criterio interpretativo internacional del artículo 10.2 CE}

El segundo apartado del artículo $10 \mathrm{CE}$ señala que "las normas relativas a los derechos fundamentales y a las libertades que la Constitución reconoce se interpretarán de conformidad con la Declaración Universal de los Derechos Humanos y los tratados y acuerdos internacionales sobre las mismas materias ratificados por España”. Una breve revisión de su elaboración constituyente ofrece

104 STC 53/1985, F. J. 8a; STC 57/1994, F. J. $4^{\text {o. }}$.

105 STC 53/1985, F. J. $3^{\mathrm{a}}$.

106 Idem.

107 STC 5371985 , F. J. $8^{\circ}$.

108 STC $120 / 1990$, F. J. $4^{\circ}$.

109 En este orden de ideas, MARZAL YETANO reafirma el lugar central que la noción de dignidad humana ocupa en el razonamiento de los tribunales españoles en materia de inmigración, indicando que "tanto la concesión como la denegación de derechos parecen justificarse a partir de esta idea que (...) dotaría al estatus de los extranjeros de coherencia y legitimidad". El proceso de constitucionalización del derecho de inmigración, op. cit., p. 152. Una lectura muy positiva de la utilización del criterio de la dignidad humana por parte del TC como base para tipificar los derechos de los extranjeros, en Balaguer Callejón, para quien este criterio permite "definir un núcleo intangible de derechos que son inherentes a la persona y de los que los extranjeros no pueden ser desposeídos", encontrándose en el origen de la tendencia del TC a dotar a los extranjeros de un haz de derechos cada vez más equiparable al que disfrutan los nacionales. BALAGUER CALLEJON, Francisco. "El contenido esencial de los derechos constitucionales y el régimen jurídico de la inmigración. Un comentario a la STC 236/2007 de 7 de noviembre”, op. cit., p. 485. 
claves para la comprensión de esta importante disposición constitucional, destinada a desempeñar una función especialmente significativa en el ámbito de los derechos de los extranjeros.

En su origen más remoto se sitúa una enmienda propuesta en la Comisión Constitucional del Congreso $^{110}$ que pretendía incluir un criterio interpretativo internacional que vinculase al Tribunal Constitucional en el conocimiento de los derechos fundamentales susceptibles de recurso de amparo, exclusivamente para tales derechos y en dichos procesos. En esta línea internacionalista se formularon iniciativas que pretendían incluso reemplazar la declaración autóctona de derechos en el texto constitucional, por una mera referencia a los documentos más relevantes del $\mathrm{DIDH}^{111}$. En el fondo de estas propuestas, así como de las enmiendas que se formularían más adelante en el Senado, subyacía la preocupación del constituyente por cancelar de forma definitiva el déficit democrático que en materia de derechos fundamentales arrastraba el sistema español, tras casi cuatro décadas de dictadura franquista y de ostracismo ${ }^{112}$. Sin embargo, estas iniciativas fueron rechazadas en la Cámara Baja, procediendo la versión definitiva del art. 10.2 CE de la tramitación habida en el Senado.

En la Cámara Alta una enmienda de UCD propuso la inclusión de un segundo apartado en el artículo 10 - su primer apartado ya figuraba en la que sería versión definitiva-, a fin de vincular la tutela y garantía del sistema español de derechos al DIDH ${ }^{113}$. Tras esta vinculación latía una específica intencionalidad política: se pretendía conectar un concreto derecho fundamental - el derecho y la libertad de enseñanza-, con su entendimiento internacional - concretamente en el artículo 13.3 del Pacto Internacional de Derechos Económicos y Sociales ${ }^{114}$-, por entonces concebido proclive a una comprensión conservadora de la libertad de enseñanza, propicia a la custodia de intereses privados y religiosos. El artículo 10.2 actuaría como "puerta falsa" ${ }^{115}$ para introducir una modifica-

110 Se trataba de la enmieda $n^{\circ}$ 246, formulada por el diputado Canyellas Balcells, perteneciente al grupo de Minoría Catalana. Canyellas pretendía incorporar un subapartado dentro del recurso de amparo como competencia del TC, insertándolo en el artículo dedicado a la regulación del régimen competencial atribuido al TC. El tenor literal de la mencionada enmienda establecía: "Para interpretar las normas a que se refieran dichos derechos se tomarán en consideración los Pactos Internacionales sobre los Derechos Humanos”. SAIZ ARNARIZ, Alejandro. La apertura constitucional al derecho internacional y europeo de los derechos humanos. El artículo 10.2 de la Constitución Española. Madrid, CGPJ, 1999, p. 18.

111 Enmienda $n^{\circ}$ 777, planteada por el diputado de UCD Arias Salgado. Para un estudio en profundidad de estas cuestiones, véase SAIZ ARNAIZ, A. La apertura constituciona al derecho internacional y europeo de los derechos humanos, op. cit., pp. 15-34.

112 Sobre este aspecto, Martín Retortillo recuerda el enorme peso que ostentaban los documentos internacionales sobre derechos humanos, así como el "período de autarquía y ensimismamiento" previo, que el texto constitucional en elaboración venía a clausurar. De ahí que, como obvia consecuencia, surgiese "un ansia legítima de conexión con las más ilustradas corrientes supranacionales, no digamos si se trataba de los derechos humanos, aspecto en el que era del todo auspiciable confiar en las grandes declaraciones y en los más cualificados convenios internacionales, de los que tanto esperábamos". MARTÍN RETORTILLO BAQUER, Lorenzo. "La recepción por el Tribunal Constitucional de la jurisprudencia del TEDH”; en Revista de Administración Pública, no 137, 1995, p. 8.

113 La enmienda n 707 establecía que "las libertades y los derechos serán tutelados y garantizados de conformidad con los acuerdos internacionales sobre derechos humanos ratificados por España"

114 El tercer apartado del artículo 13 del Pacto Internacional de Derechos Económicos, Sociales y Culturales de 1966, señala literalmente: "Los Estados Partes en el presente Pacto se comprometen a respetar la libertad de los padres y, en su caso, de los tutores legales, de escoger para sus hijos o pupilos escuelas distintas de las creadas por las autoridades públicas, siempre que aquellas satisfagan las normas mínimas que el Estado prescriba o apruebe en materia de enseñanza, y de hacer que sus hijos o pupilos reciban la educación religiosa o moral que esté de acuerdo con sus propias convicciones".

115 La expresión es usada por Miguel Angel APARICIO PÉREZ, quien con ella se hace eco de los argumentos usados por el entonces senador socialista Sainz de Baranda para oponerse a la enmienda que acababa de ser presentada por UCD. "La cláusula interpetativa del artículo 10.2 CE, como cláusula de integración y apertura constitucional a los derechos fundamentales"; en Jueces para la Democracia, n 6, 1989, p. 9. 
ción al artículo $25 \mathrm{CE}$, cuyo acuerdo en la Cámara baja había sido uno de los pilares del consenso. Fue precisamente esta intención subyacente, percibida desde su introducción por los restantes grupos políticos como una estratagema política para camuflar una lectura interesada del derecho a la educación, lo que provocó una reacción acalorada que estuvo a punto de comprometer el consenso constituyente $^{116}$. A fin de limar asperezas, se presentarían sucesivas enmiendas ${ }^{117}$ ya con un texto muy similar al que acabaría integrando el artículo 10.2 CE.

Superados estos escollos, finalmente el artículo 10.2 sería aprobado por la Comisión Constitucional del Senado sin que posteriormente se suscitase ninguna controversia al respecto. Es más, su destino final dista enormemente de la limitada pretensión política con que fue concebido por sus proponentes, y de los también escasos efectos jurídicos que tanto mentores como oponentes pronosticaron en su momento ${ }^{118}$. Muy al contrario, el artículo 10.2 constituyó desde el principio de la trayectoria democrática española, una disposición esencial para la comprensión interna y el establecimiento de la orientación evolutiva de todo el sistema constitucional de derechos aunque, todavía en su primera aplicación práctica, el TC usara el canon interpretativo en conexión al derecho a la educación ${ }^{119}$.

Salvo por lo que respecta al más limitado precedente constituido por el artículo 16 de la Constitución Portuguesa, el art. 10.2 CE constituye una norma pionera ${ }^{120}$, siendo bien reveladora del constitucionalismo abierto al derecho internacional con que se proyectó nuestro sistema jurídico. Y, si bien es cierto que son múltiples los artículos de la Constitución de 1978 que revelan la vocación internacional con que se ideó el régimen constitucional español ${ }^{121}$, de entre todos ellos el artículo 10.2

116 El prof. Martín Retortillo, por entonces portavoz del grupo Progresistas y Socialistas Independientes y miembro de la Comisión Constitucional del Senado, testigo pues directo de este proceso, define la acalorada y accidentada tramitación parlamentaria en el Senado del segundo párrafo del artículo $10 \mathrm{CE}$ como uno de los "momentos apasionantes, si bien muy delicados de la discusión parlamentaria que culminaría con la promulgación de la vigente Constitución". Posteriormente, continúa señalando que "a punto estuvo la discusión de hacer trizas el consenso, tan trabajosamente obtenido, y uno de los logros más destacables de toda la operación constitucional”. MARTÍN RETORTILLO, L. “La recepción por el Tribunal Constitucional de la jurisprudencia del TEDH”, op. cit., p. 7.

117 Concretamente, y con carácter apaciguador, el Grupo de Progresistas y Socialistas formularía una enmienda in voce. Las diferencias con respecto al texto finalmente aprobado como artículo 10.2 residían en dos puntos: de un lado, en que junto al criterio interpretativo, se preveía también una criterio integrador y, de otro, en el hecho de que la fórmula abierta de reenvío a los acuerdos internacionales sobre derechos humanos, hacía referencia expresa no solamente a la DUDH, sino también al CEDH y a los Pactos internacionales de 1966. La versión definitiva del artículo 10.2 CE se debe a una enmieda también in voce formulada por UCD, de la que desaparecería la referencia al DIDH como criterio integrador de los derechos y libertades.

$118 \mathrm{Al}$ respecto, Saiz Arnaiz enfatiza que, si bien es clara la connotación política con que nació esta disposición — “la escaramuza en torno al nuevo segundo párrafo del art. 10 sirvió para pacificar definitivamente el muy conflictivo tratamiento del derecho a la educación"-, su origen no puede explicarse exclusivamente en clave política. De los debates habidos tanto en el Congreso como en el Senado, este autor considera demostrada "la existencia de un acuerdo casi unánime en ambas Cámaras para identificar la nueva Constitución, en el terreno de los derechos, con una serie de documentos internacionales en los que durante mucho tiempo se reconoció en España la lucha por las libertades y la democracia, homologando así en el vértice del ordenamiento jurídico el sistema político que iniciaba su andadura con los de otros Estados parte en aquellos tratados y convenios". SAIZ ARNAIZ, A. La apertura constitucional al Derecho internacional y europeo...op. cit., pp. 31-33.

119 La primera aplicación práctica tuvo lugar en la STC 5/1981, de 13 de febrero, que puso fin a un recurso de inconstitucionalidad contra el Estatuto de Centros Escolares. Citado por SANTOLAYA MACHETTI, P. El derecho a la vida familiar... op. cit., p. 46 y nota a pie de pág. n 38.

120 En una línea similar, MANGAS MARTÍN califica el apartado segundo del artículo 10 CE con los términos de "brillante" y "progresivo"; en "Cuestiones de Derecho Internacional Público en la Constitución Española de 1978"; en Revista de la Facultad de Derecho de la Universidad Complutense de Madrid, no 61, pp. 143-184 (p. ¿?).

121 Entre las disposiciones constitucionales que, en palabras de Saiz Arnaiz "expresan la dimensión internacional de la sociedad y del Estado" se encuentran, junto al artículo 10.2 CE, los artículos 39.4, 56, 63, 75.3, 87.3, 93-97, 132.2, 
adquiere una relevancia singular. Con esta disposición, el sistema español quedaba "formalmente enganchado con los grandes textos internacionales en materia de derechos humanos"122.

El artículo 10.2 contiene un mandato vinculante en cuya virtud los derechos fundamentales y las libertades reconocidas en la Constitución, han de ser interpretadas en conformidad con la DUDH y los demás tratados internacionales ratificados por España. En base a este mandato, el DIDH se convierte en el contexto interpretativo desde el cual comprender los derechos constitucionales ${ }^{123}$. Por ello el artículo 10.2 expresaría, en palabras del TC, la inserción de la Constitución Española en un entorno internacional en materia de derechos representado por dichos Tratados internacionales ${ }^{124}$.

La primera cuestión a dilucidar en torno a los efectos y contenido concretos del art. 10.2 CE es su ámbito de aplicación, esto es, qué derechos quedan afectados por el canon interpretativo mencionado. Al respecto, Saiz Arnaiz ha defendido un concepto amplio del término "derechos fundamentales y libertades" empleado por el artículo 10.2, independientemente de la errática denominación y sistemática utilizada a lo largo del catálogo de derechos consagrado en el Título I CE. A su amparo, el mandato interpretativo del 10.2 se proyectaría sobre todos los derechos del Título I, eludiendo su colocación y el diverso sistema de garantías que respalda a los distintos derechos ${ }^{125}$.

La comprensión amplia del alcance del canon interpretativo internacionalista supondría que éste extendería sus efectos a todos los derechos constitucionales del Título I, incluyendo también a los principios rectores de la política económica y social consagrados en el Capítulo III de dicho Título $^{126}$. De otro lado, constituye una cuestión prácticamente pacífica en la doctrina asumir que los efectos del 10.2 sobre los derechos son de carácter interpretativo e integrativo exclusivamente.

En torno al primer tipo de efectos apuntados - efectos exegéticos-, el TC ha precisado el significado de la «interpretación» a la que alude el art. 10.2 CE, señalando que, en su virtud, los acuerdos internacionales sobre derechos humanos han de ser preceptivamente utilizados por los poderes públicos para la identificación del contenido de los derechos internos, sin que, por otro lado, tales

149.3, 161.1.a), 163, entre otras. SAIZ ARNAIZ. La apertura constitucional al Derecho internacional y europeo...op. cit., p. 53. MANGAS MARTÍN utiliza la misma expresión, al subrayar que la Constitución Española ha tenido en cuenta la "dimensión internacional de la sociedad y del Estado", citando los mismos preceptos constitucionales en los que se localiza lo que estima "dimensión iuspublicista”; en "Cuestiones de Derecho Internacional Público en la CE de 1978", op. cit., p. 144.

122 MARTÍN-RETORTILLO, L. "La recepción por el TC de la jurisprudencia del TEDH”, op. cit., p. 8. En esta línea, el TC ha declarado que el art. 10.2 CE establece «una conexión entre nuestro propio sistema de derechos fundamentales y libertades, de un lado, y los Convenios y Tratados internacionales sobre las mismas materias en los que sea parte España, de otro" (STC 36/1991, de 14 de febrero).

123 STC 242/1994, de 20 de julio, F. J. $5^{\circ}$ y STC 72/2005, de 4 de abril, F. J. $7^{\circ}$.

124 STC 72/1982, de 20 de octubre.

125 SAIZ ARNAIZ, A. La apertura constitucional al Derecho internacional y europeo....op. cit., pp. 72-73. Más adelante, el propio autor matiza que, a nivel práctico, el estudio de la jurisprudencia constitucional revela que "el ámbito preferente de la interpretación internacionalmente adecuada es el de los derechos fundamentales protegibles en amparo. Es lógico que así sea no sólo porque un elevadísimo porcentaje de la actividad del Tribunal Constitucional se manifiesta en las resoluciones de amparo, sino también porque es precisamente en el terreno de los derechos de libertad donde mayor intensidad (y perfección) ha alcanzado la colaboración internacional concretada mediante tratados; (...). Sin embargo, nada parece impedir que la mencionada interpretación se manifieste, señaladamente, en los recursos y cuestiones de inconstitucionalidad, más allá de los arts. 14 a 29 y 30.2 de la Constitución”. Idem, p. 76.

126 Una interpretación mucho más restringida se encuentra en Martínez Val quien, basándose en la jurisprudencia del TC, estima que el ámbito de aplicación del artículo 10.2 exclusivamente comprende los derechos consagrados en la sección 2a del Título I CE, junto con el principio de igualdad. REY MARTÍNEZ, Fernando. "El criterio interpretativo de los Derechos Fundamentales conforme a normas internacionales (Análisis del artículo 10.2 CE"; en Revista General de Derecho no 537,1989 , p. 3613, cita a pie de p. n 4. 
normas internacionales se conviertan en canon autónomo sobre las cuales poder contrastar la validez de las normas y actos susceptibles de control ante el $\mathrm{TC}^{127}$. Los preceptos constitucionales que reconocen derechos - Título I CE- deben ser interpretados de acuerdo al contenido que, para los mismos, se deriva de los Convenios internacionales sobre derechos humanos ratificados por el Estado Español, convirtiéndose el mismo en el "contenido constitucionalmente declarado"128 de los derechos y libertades internas.

En suma, la interpretación conforme del art. 10.2 CE implica la utilización obligatoria de los tratados internacionales ratificados por España por todos los poderes públicos internos, empezando por el poder legislativo, "para configurar el sentido y alcance de los derechos recogidos en nuestra Constitución" ${ }^{229}$. Ello excluiría de entrada la incorporación o importación de nuevos derechos con base internacional, en vista de que la Constitución española no ha incluido una cláusula de apertura del sistema constitucional de derechos, similar a la histórica novena enmienda de la Constitución estadounidense $\mathrm{e}^{130} \mathrm{o}$, más modernamente, al artículo 16 de la Constitución portuguesa.

Sin embargo, esto no implica que la interpretación de los derechos internos en sentido conforme a aquellos consagrados en los Tratados internacionales no permita incorporar o adicionar nuevas facultades subjetivas al contenido del derecho constitucionalmente establecido. El artículo 10.2 se revela como una disposición capaz de insuflar nuevos contenidos no expresos a derechos fundamentales explícitamente consagrados, siempre que exista en la dicción de la norma constitucional una "base textual explícita"131, esto es, una conexión constitucional entre el derecho explícito y el nuevo contenido procedente del ámbito internacional y acogido internamente a través de la interpretación efectuada por la jurisprudencia. Ello, a efectos más concretos, supone la exigencia de cierta equivalencia entre el derecho constitucional y el derecho consagrado en el ámbito internacional.

127 En palabras del propio TC, la interpretación a la que alude el art. 10.2 CE "no convierte a tales tratados y acuerdos internacionales en canon autónomo de validez de las normas y actos de los poderes públicos desde la perspectiva de los derechos fundamentales. Si así fuera, sobraría la proclamación constitucional de tales derechos, bastando con que el constituyente hubiera efectuado una remisión a las Declaraciones internacionales de derechos humanos o, en general, a los tratados que suscriba al Estado español sobre derechos fundamentales y libertades públicas. Por el contrario, realizada la mencionada proclamación, no puede haber duda de que la validez de las disposiciones y actos impugnados en amparo debe medirse sólo por referencia a los preceptos constitucionales que reconocen los derechos y libertades susceptibles de protección en esta clase de litigios, siendo los textos y acuerdos internacionales del art. 10.2 una fuente interpretativa que contribuye a la mejor identificación del contenido de los derechos cuya tutela se pide a este Tribunal Constitucional", STC 64/1991, de 22 de marzo, F. J. 4 a).

128 En la STC 236/2007, el TC declaró que "como cualquier otro poder público, también el legislador está obligado a interpretar los correspondientes preceptos constitucionales de acuerdo con el contenido de dichos Tratados o Convenios, que se convierte así en el «contenido constitucionalmente declarado» de los derechos y libertades que enuncia el capítulo segundo del título I de nuestra Constitución” (F. J. 5º. El recurso a la interpretación internacional, profusamente empleado por el alto tribunal en el ámbito de la extranjería, ha sido usado, por ejemplo, respecto del derecho de entrada y permanencia en España reconocido en el art. 19 CE. Dicho derecho, interpretado en relación al Pacto Internacional de Derecho Civiles y Políticos de 1966, ha llevado al TC a reducir el margen de maniobra legislativa en su desarrollo normativo, llevando incluso a incluir a los extranjeros dentro de su ámbito de protección (STC 94/1993 de 22 de marzo, F. 3; SSTC 242/1994 de 20 de julio, F. 5; 24/2000 de 31 de enero, F. 4).

$129 \mathrm{El} \mathrm{TC}$, en reiteradas ocasiones, ha proclamado la utilidad de los textos internacionales ratificados por España "para configurar el sentido y alcance de de los derechos fundamentales, de conformidad con lo establecido en el art. 10.2 CE». SSTC 38/1981, de 23 de noviembre, F. 4; 84/1989, de 10 de mayo, F. 5; 254/ 1993, de 20 de Julio, F. J. ¿?; 236/2007, de 7 de noviembre, F. J. 5.

130 La dicción literal de la novena enmienda a la Constitución de EEUU, a fin de no excluir aquellos derechos no expresamente consagrados en el texto constitucional, señala que "the enumeration in the Constitution, of certain rights, shall not be construed to deny or disparage others retained by the people".

131 Expresión tomada de DÍEZ-PICAZO, L.M. Sistema de derechos fundamentales, op. cit., p. 53. 
Esta vía, que parecería poco relevante en el ordenamiento español a juzgar por la relativa novedad de su sistema constitucional así como por la amplia extensión de su declaración constitucional de derechos, se ha revelado sin embargo de utilidad, especialmente en aquellas áreas jurídicas sensibles al dinamismo social, y en las que exista una gran indeterminación en el precepto constitucional declarador del derecho - condiciones ambas ampliamente cumplidas en el ámbito de la extranjería y la inmigración-.

A través del segundo tipo de efectos desplegados por el art. 10.2 CE — función reintegradora del ordenamiento jurídico-, el artículo 10.2 puede actuar como una cláusula expansiva y de actualización jurídica, en modo muy similar a como la jurisprudencia constitucional alemana ha hecho actuar a las cláusulas de dignidad de la persona y del libre desarrollo de la personalidad. Ya señalamos en su momento que ambas cláusulas no dan cabida a derechos fundamentales como tales y que, además, no son utilizadas en nuestro sistema para dar entrada por vía jurisprudencial a nuevos contenidos o garantías no consagradas de derechos constitucionales expresamente reconocidos. Tal función es despejada por la cláusula hermenéutica contenida en el artículo $10.2 \mathrm{CE}^{132}$.

La incorporación de contenidos internacionales a los derechos internos - que integraría los ya señalados efectos reintegrativos derivados del artículo 10.2 CE-, constituye sin embargo una operación íntimamente vinculada a la eficacia interpretativa de este precepto. La distinción entre efectos interpretativos y reintegrativos obedece más a finalidades descriptivo-pedagógicas que a una visión realista de las virtualidades derivadas de esta disposición constitucional, pues ambos efectos suelen darse de forma simultánea -o más bien, los efectos reintegrativos, de producirse, son una consecuencia derivada de la delimitación del ámbito material del contenido de un derecho constitucional, como consecuencia de su interpretación conforme al derecho internacional de los derechos humanos.

En este sentido, Saiz Arnaiz ha explicado abundantemente que los efectos prácticos de la distinción entre la creación ex novo de nuevos derechos y la adición de nuevas facultades a los derechos ya existentes, distan de ser claros. La relativización de la distinción resulta especialmente obvia en lo que respecta a su afectación al ciudadano, pues en el momento en que, con base en la interpretación internacionalista, una nueva facultad ha sido adicionada al contenido constitucional de un derecho constitucional preexistente, dicha facultad podrá ser ejercida y reclamada por sus titulares, con independencia de que la misma no haya adquirido ni carácter de fundamental - en el supuesto de que esté incorporada al contenido de un derecho que carezca de tal carácter-, ni autonomía propia.

En otro orden de consideraciones, cabe destacar que el artículo 10.2 emplea una formulación abierta para reenviar al DIDH. El reenvío interpretativo a los tratados y acuerdos internacionales sobre derechos humanos ratificados por España, con la DUDU a la cabeza, es plural, sin mencionar de forma expresa al CEDH. La fórmula empleada por la redacción del artículo 10.2 plantea una segunda cuestión, a saber, qué normas del DIDH han de ser empleadas para la interpretación de los derechos internos. Al respecto, el criterio utilizado por el TC Español ha sido el de "máxima apertura", lo que supone no únicamente la utilización de las normas internacionales convencionales, sino también de las decisiones emanadas de los órganos de garantía de los tratados, e incluso de otros textos internacionales derivados de organizaciones de las que España forma parte, pese a que carez-

132 Una visión contraria a la necesidad de apertura de nuestro ordenamiento se encuentra en DÍEZ-PICAZO, quien señala literalmente que "tampoco tiene mucho sentido interrogarse sobre si la jurisprudencia podría crear nuevos derechos fundamentales, carentes de base textual explícita en la Constitución. Una operación de esta índole, que no es infrecuente en otros países (Estados Unidos, Francia, etc.), sería innecesaria hoy en España, donde la Constitución es relativamente reciente, notablemente generosa en su catálogo de derechos y razonablemente abierta al nivel internacional de protección de los derechos humanos"; en Sistema de Derechos fundamentales, op. cit., p. 53. 
can de fuerza vinculante ${ }^{133}$. Sin embargo el Convenio y la jurisprudencia emanada de Estrasburgo en su aplicación e interpretación, ejercían ya en aquella época una auténtica "fascinación", de ahí que, desde sus comienzos, el TC se haya mostrado especialmente receptivo a sus pronunciamientos ${ }^{134}$.

Conviene en este punto aclarar que el funcionamiento del artículo 10.2 CE es en sentido unidireccional: únicamente en sentido expansivo, nunca en dirección restrictiva respecto del contenido constitucionalmente declarado a nivel interno para el concreto derecho objeto de interpretación. En el ámbito de Estrasburgo, esta consideración aparece reforzada por lo establecido en el art. 53 $\mathrm{CEDH}^{135}$, en cuya virtud se prohíbe el uso del Convenio de Roma para recortar derechos fundamentales internos.

En consecuencia, del carácter amplio del catálogo español constitucional de derechos así como de la inexistencia de una cláusula de incorporación de nuevos derechos al modo del artículo 16.1 de la Constitución portuguesa, podría en principio deducirse la pretensión de exhaustividad del Título I CE. Sin embargo, la incorporación de una cláusula genérica de apertura expresa al DIDH a través del mandato contenido en el art. 10.2 CE - presente a un nivel más específico en concretos derechos-, apunta al carácter "completable" o constantemente perfeccionable de los derechos constitucionales. En virtud de los efectos reintegrativos desplegados por el art. 10.2 CE, el contenido material de los derechos constitucionales puede ir ensanchándose y actualizándose mediante los tratados internacionales de derechos humanos y las decisiones emanadas de sus órganos de interpretación y aplicación. Dado que este proceso siempre suma, y no es viable el recurso a los convenios internacionales para disminuir el contenido y umbral de protección establecido internamente, el art. 10.2 CE constituye una vía de dinamización y actualización permanente de la declaración constitucional de derechos, sin necesidad de reforma constitucional.

Por ello se ha hablado del artículo 10.2 como una cláusula de aggiornamento ${ }^{136}$ capaz de engrosar facultades subjetivas al contenido material de los derechos, e incluso se la ha llegado a catalogar como "cláusula de desoxidación del ordenamiento jurídico"137. De ahí que, frente a la impresión de completud y exhaustividad que podría derivarse del sistema constitucional español de derechos, Solozábal haya declarado el carácter incompleto ${ }^{138}$ de la declaración de derechos contenida en el Titulo

133 SAIZ ARNAIZ. A. La apertura constitucional al Derecho Internacional y Europeo ..., op. cit., p. 93.

134 MARTÍN-RETORTILLO, L. "La recepción por el TC de la jurisprudencia del TEDH”, op. cit., pp. 11-12, quien, al señalar el alto grado de sensibilización internacional de los jueces del TC español y de los letrados integrantes del mismo en la fase preparatoria de las sentencias, llega a calificar el "aprecio" a las soluciones de Derecho comparado, como "excesivo" a veces.

135 SAIZ ARNAIZ especifica sobre este aspecto que "el TC no podría nunca hacer uso de la jurisprudencia de Estrasburgo para restringir, de acuerdo con ésta, el ámbito de los derechos tal y como éstos se encuentran constitucionalmente garantizados". La apertura constitucional..., op. cit., p. 165.

136 DELGADO BARRIO, J. "Proyección de las decisiones del Tribunal Europeo de Derechos Humanos en la jurisprudencia española”; en Revista de Administración Pública, no 119, 1989, p. 243. Una interpretación más matizada se encuentra en SANTOLAYA MACHETTI, para quien "aún pudiéndose afirmar que el artículo 10.2 no actúa totalmente como una cláusula de actualización del catálogo constitucional de derechos, su aplicación como criterio hermeneútico le aproxima mucho a esta figura, hasta el punto de hacer extremadamente difícil diferenciarlo en la práctica de la misma”. El derecho a la vida familiar...., op. cit., p. 53.

137 GARCÍA VAZQUEZ, Sonia y GOIZUETA VÉRTIZ, Juana. “Un análisis en clave constitucional del régimen jurídico de los extranjeros en España: especial referencia al derecho a la libertad de circulación y residencia”; en Anuario da Facultade de Dereito da Universidade da Coruña, no 11, 2007, p. 261.

138 SOLÓZABAL, J. J. “Algunas cuestiones básicas de la teoría de los derechos fundamentales”; en Revista de Estudios Políticos, $\mathrm{n}^{\circ} 71,1991$, p. 91. El autor habla sobre el carácter incompleto de la declaración de derechos, poniendo en relación esta cuestión con los criterios de ubicación sistemática utilizados en el Titulo I, así como con la terminología confusa de dicha parte de la Constitución. Posteriormente señala que "la incompletud de la regulación 
I CE. Dicha "incompletud" aboca necesariamente a la colaboración normativa del legislador en el establecimiento del régimen jurídico de los derechos, colaboración en la que los tratados internacionales de derechos humanos, a través de la vía interpretativo-reintegrativa del 10.2 CE, cumplen una función de extraordinaria importancia en nuestro sistema jurídico.

Sin embargo, los tratados internacionales no pueden ser empleados como canon autónomo sobre el cual contrastar la validez o invalidez de los actos y disposiciones normativas impugnadas ante el TC, que sólo puede medirse por referencia a los preceptos constitucionales reconocedores de derechos susceptibles de ser protegidos a través de este proceso ${ }^{139}$-el recurso de amparo-. Ello supone que no es posible que un precepto legal pueda infringir autónomamente el art. 10.2. La violación del art. 10.2 CE siempre se producirá de forma indirecta y mediata, en conexión con un acto o disposición legal que, al ser contrastado con el precepto constitucional que proclama un derecho o libertad, limita o reduce el contenido que a dicho derecho o libertad atribuyen los tratados o convenios sobre derechos humanos ratificados por España ${ }^{140}$, a cuya interpretación en sentido conforme vincula el art. 10.2.

Los tratados no se erigen pues en medidas de la constitucionalidad de la ley española. Ni siquiera en el supuesto de que una ley u otra disposición normativa contradiga un tratado internacional cabe fundamentar la pretensión de inconstitucionalidad de una ley por oposición a un derecho fundamental; En tal supuesto la medida de la constitucionalidad de la ley "seguiría estando integrada por el precepto constitucional definidor del derecho o libertad, si bien interpretado, en cuanto a los perfiles exactos de su contenido, de conformidad con el tratado o acuerdo internacional"141.

Una de las cuestiones inicialmente más controvertidas de esta disposición residía en la delimitación de su función con respecto a la técnica de integración del derecho internacional convencional prevista en el artículo 96 CE. Durante el proceso de elaboración del artículo 10.2CE, así como en los años inmediatamente posteriores a la entrada en vigor de la Constitución, se apuntó a la posible coincidencia entre ambos artículos, denunciándose el carácter reiterativo del mandato interpretativo internacional, que se solaparía con el carácter de los tratados internacionales como fuente del derecho interno, establecido por el art. $96 \mathrm{CE}$.

El mandato interpretativo internacional cumple una función distinta a la técnica de integración interna contemplada con carácter general por el artículo 96 CE. Para Mangas Martín, "lejos de ser este artículo inútil, da una nueva y distinta eficacia a tales instrumentos internacionales ratione materiae, al constituirse este artículo 10.2, a diferencia del artículo 96, en una 'cláusula de garantía', en el sentido de que las dificultades interpretativas en los derechos y libertades fundamentales deben

constitucional de los derechos fundamentales es consecuencia, primeramente, del carácter sumarial y lapidario de las formulaciones de aquéllos, que caracterizaría sobremanera a las normas "prescriptivas» constitucionales antes que a las organizativas o competenciales; pero también es función de la imposibilidad constitucional de establecer las restricciones que el disfrute simultáneo implica por todos los titulares, la necesidad de compatibilizar el ejercicio de unos derechos con el de otros, realizando las acomodaciones necesarias; o verificar la protección penal de los mismos, estableciendo sanciones a la conducta que les sea contraria; o salvar las intervenciones gubernativas o judiciales a su disfrute, como excepciones procesalmente establecidas. Todas estas causas hacen necesaria una actuación de los poderes públicos en el régimen efectivo de los derechos fundamentales, en primer término, en el plano normativo, y que alcanza antes que a nadie, evidentemente, al poder legislativo, dada la vigencia del principio de legalidad, que excluye, sobre todo, cualquier regulación de la administración sin cobertura legal”..., op. cit. p.100. 139 F. J. $5^{\circ}$ de la STC 236/2007, remitiéndose a lo proclamado en la STC 64/1991, de 22 de marzo, F. J. $4^{\circ}$.

140 F. J. 5, STC 36/19991, de 14 de febrero y F. J. 5, STC 236/2007.

141 STC 28/1991, de 14 de febrero, F. J. 5º. 
salvarse inicialmente en favor de la interpretación que suministran los referidos tratados o convenidos en materia de derechos humanos"142.

El artículo 10.2 se erige así en una garantía adicional del conjunto de los derechos constitucionales, en cuya virtud los poderes públicos no podrán adoptar una concepción nacional de los derechos que se sitúe por debajo del estandard mínimo internacional, al tiempo que garantiza una "interpretación internacionalmente homologable" 143 de los mismos. Todo ello, en sintonía con un ámbito jurídico crecientemente interdependiente y global, muy evidente en lo que respecta al menos al contexto europeo. Constituye además un foro de constante actualización de nuestra realidad jurídica, en vista de que, en palabras de Saiz Arnairz, el art. 10.2 efectúa un "reenvío movil"144, esto es, al DIDH presente y futuro, siempre que el mismo sea válidamente ratificado por el Estado Español, lo que incluiría los diversos protocolos que se vayan adicionando a los diversos tratados internacionales en vigor.

El artículo 10.2 CE resulta especialmente relevante para nuestro ámbito de estudio y, en general, para la regulación de la extranjería y la inmigración en el Estado Español. Varias son las causas que actúan sinérgicamente en este sentido, realzando la trascendencia de este criterio hermenéutico con respecto a las normas relativas a los derechos de extranjeros:

a) En primer lugar, porque los Convenios internacionales, por la materia que regulan y el ámbito internacional en el que se gestan, suelen contemplar como beneficiarios a las personas sometidas a la jurisdicción de los Estados partes, lo que incluye tanto a los nacionales como a los extranjeros asentados dentro de dichos Estados. De ahí que se haya afirmado que los tratados constituyen "fuente prolífica de normas que atañen a los extranjeros residentes o relacionados con cualquier país" ${ }^{\prime 45}$. Este primer argumento apuntaría al alto grado de probabilidad de que, estando en juego un tratado internacional ratificado por España, el mismo contenga normas que contemplen a los extranjeros presentes en territorio español como destinatarios de las mismas.

b) En segundo lugar, la virtualidad de este criterio hermenéutico es tanto mayor cuando mayor sea el grado de apertura ${ }^{146}$ - léase abstracción-, del derecho constitucional que sirve como

142 MANGAS MARTÍN, Araceli. “Cuestiones de Derecho internacional público....”, op. cit., p. 151.

143 La expresión corresponde a SANTOLAYA MACHETTI, P. El derecho a la vida familiar d elos extranjeros, op. cit., p. 48.

144 SAIZ ARNAIZ, A. La apertura..., op. cit., p. 52.

145 BORRAJO INIESTA, Ignacio. El status constitucional de los extranjeros, op. cit., p. 702.

146 En este sentido Rey Martínez ha señalado que especialmente en aquellos casos en que el tenor literal del derecho fundamental contiene un alto grado de abstracción, el artículo 10.2 tiende a actuar como una "fórmula de reintegración de los derechos fundamentales, pero sólo en la medida en que posibilita el descubrimiento de nuevos aspectos de los mismos". El autor pone como ejemplo el artículo $24 \mathrm{CE}$ cuya abstracción literal ha permitido que la técnica del artículo 10.2 actúe con gran eficacia sobre este artículo. Sin embargo, REY MARTÍNEZ niega que el artículo 10.2 sirva como fórmula de apertura a nuevos derechos proclamados por convenios internacionales, cuando éstos carecen de conexión alguna con los derechos constitucionales; en "El criterio interpetativo...., p. 3621. En una línea similar, si bien referiéndose exclusivamente al ámbito de la influencia del derecho comunitario, PÉREZ TREMPS, Pablo. "Derecho constitucional y derecho comunitario"; en TRUJILLO, Gumersindo; LÓPEZ. GUERRA, Luis María y GONZÁLEZ-TREVIJANO, Pedro José (cords.). La experiencia constitucional: (1978-2000). Madrid, Centro de Estudios Políticos y Constitucionales, 2000, pp. 607-630. De forma más limitada, Mangas Martín estima que "la técnica prevista en el párrafo segundo del art. 10 cobra virtualidad sólo en el caso de que una norma constitucional sobre esta materia no sea suficientemente clara, entonces para precisar su alcance y contenido se acudirá a las normas internacionales - ratificadas por España - para interpretar los derechos reconocidos en la Constitucion. A contrario, si el contenido de la norma constitucional es suficientemente expresivo para esa situación se aplicará únicamente su texto conforme a la Constitución"; en MANGAS MARTíN, A. "Cuestiones de Derecho internacional público en la Constitución española de 1978”, op. cit., p. 150. 
derecho "raíz" o matriz, y también cuanto más amplio sea el margen de configuración normativa otorgado al legislador en su desarrollo, pues es precisamente en este último escenario donde el ámbito internacional puede ofrecer mayor protección a las pretensiones restriccionistas internas. Ambas cualidades, apertura y margen de maniobra al poder legislativo, se dan en nuestro ámbito de estudio. Especialmente del artículo 13.1 CE son predicables su ambigüedad y apertura, pero también de las posibles disposiciones constitucionales que pueden potencialmente servir como simiente o matriz constitucional del derecho a la RF — tanto la intimidad familiar como, quizá en menor grado, la protección de la familia, ambas integradas en el Título I, sobre el cual vierte sus efectos el artículo 10.2 CE y que desde el principio se han barajado como posibles derechos matriz, hasta que el TC recientemente ha excluido la conexión de la RF con el derecho fundamental a la intimidad familiar-. De otro lado ya comentamos la laxitud que, al menos inicialmente, se otorgaba al poder legislativo en este campo. Esto revela la importancia que el criterio internacionalista está llamado a desempeñar en el ámbito jurídico de la extranjería e inmigración en general, y de la RF en particular.

c) En este sentido, el artículo 10.2 CE, aplicado a nuestro ámbito de estudio, vendría a desarrollar una función vital a fin de incorporar contenidos "internacionales" o facetas subjetivas a derechos internos, además de dibujar una hoja de ruta que permite explorar anticipadamente las tendencias internas en esta materia. La labor desplegada por el TC al despejar el estatuto jurídico de los extranjeros constituye un recordatorio práctico de la importancia del art. 10. 2 CE: El recurso del TC al criterio interpretativo internacionalista, muy habitual, es, si cabe, más recurrente en materia de extranjería, donde el alto Tribunal ha incorporado expresamente facultades procedentes del ámbito internacional en la interpretación y reintegración de derechos constitucionales, la libertad circulatoria puede servir de elocuente ejemplo.

d) De forma adicional, los efectos internacionalistas del artículo 10.2 CE se ven potenciados en el ámbito de la extranjería y la inmigración como consecuencia de la específica reserva legal internacional contenida en el artículo 13.1 CE. El juego combinado de la reserva del artículo 13.1, en conjunción con el criterio hermenéutico del 10.2, sitúan a la extranjería como un ámbito jurídico "donde la interpretación internacionalmente adecuada se ha proyectado de manera más intensa" 147 .

Desde nuestro punto de vista, la sinergia entre el artículo 10.2 CE y el artículo $13 \mathrm{CE}$ se ha visto fomentada por una serie de circunstancias superpuestas: en primer lugar, por el retraso en España para reconocer legislativamente el derecho a la RF, lo que nos situaba en una situación especialmente permeable para recibir las aportaciones que en este tema realizaba tanto Estrasburgo - la actitud pionera de la Comisión y el TEDH para otorgar protección a los extranjeros presentes en los Estados parte mediante la protección de rebote otorgada por el derecho al respeto de la vida familiar del art. $8 \mathrm{CEDH}$ - como la Unión Europea; en segundo lugar, la inicial inercia y la posterior imprevisión legislativa ante materias vitales en el ámbito de la extranjería y la inmigración, se toparon con la llegada a nuestro país de lo que ha sido calificada como una "inmigración inesperada" 148 y de rapidísimo crecimiento, haciendo aflorar nuevas necesidades sociales, y por ende, jurídicas.

147 SAIZ ARNAIZ, A. La apertura constitucional al Derecho internacional y europeo... op. cit., p. 245, cita a pie de pag. $\mathrm{n}^{\circ} 319$.

148 La expresión corresponde a Antonio IZQUIERDO, en una temprana obra de gran importancia para el estudio de la llegada de flujos migratorios a nuestro país. La inmigración inesperada. La población extranjera en España, 19911995. Madrid, Trotta, 1996. 
Todo ello explica la potencialidad y vitalidad del artículo 10.2 como cláusula de reintegración de los derechos de los extranjeros en España. En palabras de Tomás de la Quadra-Salcedo, tales cláusulas están "dirigidas a lograr una más perfecta configuración de los derechos fundamentales en el futuro en función de las necesidades que vayan emergiendo a la conciencia social y política"149. Las mismas revelan la existencia de un catálogo constitucional de derechos que, aunque formalmente cerrado, resulta enormemente permeable a la absorción y reconocimiento de nuevas dimensiones o facultades de los derechos subjetivos derivadas del sistema internacional de derechos humanos, especialmente ante la emergencia de retos y nuevas necesidades sociales, imposibles de prever en su exhaustividad por el legislador constituyente. Sobra decir que todas estas consideraciones resultan perfectamente aplicables al ámbito de la migración familiar en nuestro país.

\section{EL TRIBUNAL CONSTITUCIONAL ANTE EL ESTATUTO DE LOS EXTRANJEROS: UNA DOCTRINA INESTABLE E INACABADA}

El estudio de los concretos perfiles constitucionales de la extranjería y la inmigración en nuestro país exige, necesariamente, analizar la trayectoria seguida por el TC al abordar el estatuto jurídico de los extranjeros en España, que en su momento inscribimos como tercer fuente del derecho migratorio, tras la Constitución y la legislación. Esta necesidad resulta reforzada por dos consideraciones adicionales: de un lado, como consecuencia de la indeterminación de los preceptos constitucionales que sirven de base - tanto el art. 13 CE como la heterogénea terminología empleada con escaso rigor por el constituyente al referirse a la titularidad activa de los derechos consagrados a lo largo del Título I-; de otro lado, como el propio TC ha declarado, muchas de las situaciones más emblemáticas dentro del ámbito de la extranjería — residencia, expulsión, vida familiar, etc. — constituyen derechos de configuración legal y, más allá, muchos de los derechos del Título I, cuando se predican de los extranjeros, se convierten en derechos de configuración legal por mandato del art. 13.1 CE ${ }^{150}$.

Es precisamente sobre esta categoría jurídica ${ }^{151}$, de contornos especialmente difusos, sobre la cual la jurisprudencia de los Tribunales constitucionales ha demostrado más enérgicamente su función de "órgano de concretización jurídico-creativa de la Constitución" ${ }^{52}$ que Böckenförde asigna-

149 QUADRA-SALCEDO, Tomás de. “Apertura de los derechos fundamentales...”, op. cit., p. 130.

150 REQUEJO PAGÉS, J. L. “Derechos de configuración legal”; ARAGÓN REYES, Manuel (coord.). Temas básicos de derecho constitucional, Tomo III. Madrid, Civitas, $1^{\text {a }}$ edic. 2001, p. 135.

151 Como precisa REQUEJO PAGÉS, prácticamente casi todos los derechos fundamentales son de configuración legal en la medida en que exigen de la intervención del legislador para fijar las condicones de su ejercicio. Sin embargo, la categoría de derechos de configuración legal se reserva a “a aquellos derechos que no sólo necesitan del legislador para que éste arbitre los términos de su ejercicio (y lo haga, además, con notable discrecionalidad), sino — antes áun- para que los conforme en su contenido”. Dicha conformación ha de realizarse respetando el contenido esencial del derecho y, tanto su configuración legislativa como la interpretación que de ella realicen los órganos judiciales, se encuentra sometida a la potestad revisora del TC, "pues, de otro modo, estos derechos quedarían degradados al plano de la legalidad ordinaria”. Recapitulando, constituirían derechos de configuración legal "aquellos que, dotados - como fundamentales - de un contenido constitucional indisponible, se ejercen en unas condiciones (fijadas discrecionalmente - pero con respeto a aquel contenido - por el legislador) cuya satisfacción por parte del titular sólo puede ser impedida en los mismos términos en los que resulta constitucionalmente correcto denegar el disfrute del contenido mínimo esencial". "Derechos de configuración legal”, op. cit., pp. 134-136.

152 BÖCKENFÖRDE, Escritos sobre derechos fundamentales, op. cit., p. 95. Citado por NOREÑA SALTO, José Ramón. "Acerca del contenido esencial de los derechos fundamentales de configuración legal"; en Repertorio Aranzadi del Tribunal Constitucional, No 18, 2003, sp. En referencia específica a los derechos de configuración legal, y en aplicación 
ba, con carácter general, a la jurisprudencia constitucional relativa a los derechos fundamentales. En consecuencia si, como bien señala Diez-Picazo, la categoría de los derechos fundamentales es, esencialmente, de construcción jurisprudencial ${ }^{153}$, estas consideraciones se hacen más visibles cuando el TC se enfrenta a los derechos de configuración legal — categoría en la que suelen inscribirse los derechos más significativos del ámbito de la extranjería y la inmigración. Por lo tanto, sobre los derechos de los extranjeros, en tanto que derechos de configuración legal en su mayoría, existe una mayor probabilidad de que, junto a su función clásica de legislador negativo, el TC desempeñe un activo papel de configuración constitucional del contenido del derecho afectado. El estudio que a continuación se hará de la línea y trayectoria jurisprudencial seguida por el TC al abordar la extranjería y la inmigración, constituye una buena muestra de ello, mediante el uso combinado de las posibilidades otorgadas por el criterio interpretativo internacionalista (art 10.2 CE) y la reserva legal del art. 13.1 CE.

Como ya señalamos, la redacción abierta y ambigua del artículo $13 \mathrm{CE}$ arrojaba múltiples posibilidades interpretativas ${ }^{154}$. Desde los inicios de su andadura, este precepto ha sido considerado por el TC como la disposición clave para la determinación del régimen jurídico-constitucional de los extranjeros en España. Sin embargo, los problemas interpretativos derivados del artículo $13 \mathrm{CE}$ se encuentran también en el origen de las dificultades que, aún hoy en día, sigue encontrando el diseño de un régimen claro en este ámbito ${ }^{155}$.

Dos cuestiones a despejar del art. 13.1 CE resultaban desde el principio de especial trascendencia por su proyección sobre el futuro régimen jurídico de la extranjería en España: de un lado, el

de la doctrina de Böckenförde, Noreña Salto señala que "es, por tanto, en los derechos fundamentales de configuración legal donde se manifiesta con mayor vigor la tesis de Böckenförde, que atribuye a la jurisprudencia constitucional una auténtica competencia o función de determinación del contenido esencial de los derechos fundamentales, y no de simple exégesis de la normativa constitucional en la materia, lo que no significa, evidentemente, que el Tribunal Constitucional pueda crear derechos fundamentales de nuevo cuño, no incluidos en el texto constitucional, pero sí adaptar sus previsiones a las situaciones concretas que se le suscitan en los pertinentes recursos de amparo. En relación con los derechos fundamentales de configuración legal, aquella competencia se traduce, esencialmente, en la delimitación, sobre la base de las previsiones legales, de lo que debe entenderse incluido o excluido del propio derecho fundamental".

153 DÍEZ-PICAZO, L.M. Sistema de derechos fundamentales, op. cit., prefacio, donde este autor explica por qué los derechos fundamentales constituyen "una rama del rodenamiento de elaboración esencialmente jurisprudencial", de modo que, en ellos, las prescripciones constitucionales constituyen un mero punto de partida. En referencia específica a los derechos de configuración legal y la esencialidad que en la determinación de su contenido jurídico desarrolla la jurisprudencia constitucional, vid. NOREÑA SALTO, José Ramón. "Acerca del contenido esencial de los derechos fundamentales de configuración legal", op. cit, sp.

$154 \mathrm{Al}$ respecto MARZAL YETANO señala que "el carácter abierto del art. 13.1 obliga a una permanente revisión de sus postulados iniciales”. El proceso de constitucionalización del derecho de inmigración, op. cit., p. 157. Por su parte, GARCÍA VÁZQUEZ y GOIZUETA VÉRTIZ señalan que "este precepto siempre ha alimentado la controversia, introduciendo más confusión que luz y siendo el causante de no pocas discrepancias entre los miembros del Tribunal Constitucional”; en "Un análisis en clave constitucional del régimen jurídico de los extranjeros en España...", op. cit., p. 260. NOGUERIA GUASTAVINO destaca la "perplejidad” que produce la declaración contenida en el art. 13.1CE, añadiendo que "una interpretación estrictamente literal podría dar cobijo a posiciones restrictivas y simplificadoras en virtud de las cuales los derechos constitucionales de los extranjeros vendrían determinados, única y exclusivamente, por los Tratados internacionales y por la regulación que, en su caso, quisiera (o no) contemplar el legislador. Interpretación ésta que podría verse reforzada por el propio artículo 14 CE"; en "Los derechos sociales fundamentales de los extranjeros: las SSTC 236/2007 y 259/2007 como reconstrucción de una doctrina constitucional confusa", op. cit., p. 3

155 En el mismo sentido, VIDAL FUEYO, quien además considera que este enfoque del TC, priorizando lo establecido en el art. 13.1 CE, ha ido en detrimento de un análisis particularizado de los distintos preceptos de la Constitución que reconocen derechos fundamentales. "La jurisprudencia del TC en materia de derechos fundamentales de los extranjeros", op. cit., p. 357. 
sentido que habría de darse al término "libertades públicas" utilizado por el constituyente; de otro, el alcance de la reserva legal contenida en dicha disposición, determinando el concreto papel atribuido tanto al legislador interno como a los tratados internacionales en este ámbito. El TC intervendría de forma temprana para intentar despejar ambos términos. Para ello ha ido desplegando una compleja línea argumental que, sobre la base del artículo mencionado - interpretado sistemáticamente con el artículo $10 \mathrm{CE}$ y en conjunción con los distintos preceptos constitucionales que establecen el régimen jurídico de cada derecho fundamental—, se centraría además en ir desgranando la titularidad activa y el contenido material de cada uno de los derechos implicados.

Sin embargo, tras más de tres décadas de pronunciamientos dictados en materia de extranjería, la jurisprudencia constitucional - escasa, en términos comparativos con otras materias menos conflictivas, pero sin embargo con un número de sentencias estimatorias "superior a la media"156_, no ha logrado todavía imprimir un diseño constitucional diáfano, acabado y coherente de esta materia $^{157}$. En líneas generales, la visión del TC puede considerarse progresiva y tendencialmente abierta, pero se echa de menos una línea sistemática que sirva a efectos inductivos a los distintos operadores para poder prever líneas de actuación jurídica conformes con la Constitución. De ahí que se haya denunciado una tensión todavía abierta entre la Constitución y las sucesivas leyes de desarrollo de la extranjería y la inmigración ${ }^{158}$, patente tras las grandes reformas legislativas que se han sucedido en este ámbito, dos de las cuales han desembocado en otros tantos recursos de constitucionalidad. Si bien es justo reconocer que en este conflicto un papel destacado está siendo desempeñado por el enorme grado de tensión social que ha adquirido este tema en la sociedad española, y las consiguientes presiones que ello provoca sobre los poderes públicos, ello no obsta para denunciar la opacidad y complejidad que sigue predominando en este ámbito. Coincidimos con García Roca, en adjudicar a la inestabilidad legislativa dominante en este ámbito la responsabilidad principal que entorpece la construcción de una adecuada teoría de los derechos de los extranjeros, pues los vaivenes legislativos “impiden decantar criterios doctrinales sólidos" 159 . Este mismo autor subraya la complejidad —social, política, económica, cultural...- subyacente en los flujos migratorios que, al proyectarse sobre

156 AJA, Eliseo. "Veinte años de doctrina del Tribunal Constitucional sobre los derechos de los extranjeros...”, op. cit., p. 442. El autor revisa la jurisprudencia emitida por el TC en materia migratoria hasta el año 2001, concluyendo que todas las sentencias dictadas, menos una, se pronunciaron en recursos de amparo, — con la excepción de la emitida al resolver el recurso de constitucionalidad formulado contra la L.O. reguladora de los derechos de los extranjeros de 1985-, concluyendo que "en veinte años, 25 sentencias de amparo no son muchas, teniendo en cuenta que el número global de sentencias recaídas en el procedimiento de amparo alcanzó las 4500 aproximadamente. También el conjunto de asuntos contemplados, sumandos los autos, parece una cifra reducida. (...) ¿Por qué tan pocos amparos en un colectivo con evidentes problemas jurídicos, que además versan sobre muy diferentes derechos fundamentales?. Sólo un estudio sociológico nos aportaría respuestas fiables a esta pregunta, pero en su ausencia es lícito pensar que una causa puede encontrarse en las dificultades de los inmigrantes para acceder a la tutela judicial y en concreto al amparo, que requiere además el agotamiento de la vía judicial previa”.

157 Coincidiendo en torno a la confusión que todavía predomina en esta materia, si bien señalando que bajo una aparente máscara de claridad, NOGUEIRA GUASTAVINO, Magdalena. "Los derechos sociales fundamentales de los extranjeros: Las SSTC 236/2007 y 259/2007 como reconstrucción de una doctrina constitucional confusa”; en Iustel, s.p. Disponible en: http.//portal.uam.es/portal/page/profesor/epd2.../Iustelextranjeros.pdf Una versión impresa de este artículo puede encontrarse en "La doctrina del Tribunal Constitucional español sobre los derechos sociales de los extranjeros no comunitarios"; en Relaciones laborales: Revista crítica de teoría y práctica, o 2, 2009, pp. 335-358.

158 VIDAL FUEYO, M. C. "La jurisprudencia del Tribunal Constitucional en materia de derechos fundamentales de los extranjeros a la luz de la STC 236/2007", op. cit., p. 353.

159 GARCÍA ROCA, J. "La titularidad constitucional e internacional de los derechos fundamentales de los extranjeros y las modulaciones legales a sus contenidos”, op. cit., p. 72. 
los derechos de los extranjeros, se retroalimenta generando una "intensa tensión constitucional con la ley" ${ }^{\prime 60}$.

La jurisprudencia dictada hasta la fecha por el TC en materia de derechos y libertades de los extranjeros ha recorrido una línea evolutiva ascendente y expansiva, en la que se pueden distinguir con claridad tres fases distintas ${ }^{161}$ :

- La primera fase está presidida por la STC107/84 que, emitida para resolver un recurso de amparo, marcó la pauta inicial a la aproximación subsiguiente efectuada por el alto tribunal en torno al estatuto constitucional de los extranjeros.

- La segunda fase se inicia con la STC 115/1987, dictada para resolver el recurso de inconstitucionalidad que pendía sobre la Ley orgánica 7/1985, sobre derechos y libertades de los extranjeros en España - primera norma legal postconstitucional que fijó con carácter general el estatuto jurídico de los extranjeros procedentes de terceros países en nuestro país-.

- La tercera fase se produce en el año 1993, coincidiendo con la publicación de tres sentencias constitucionales, dictadas para resolver otros tantos recursos de amparo, con las que el TC da inicio a una línea claramente progresista en la aproximación al estatuto constitucional de los extranjeros en nuestro país.

\section{1 La primera jurisprudencia del T.C. en materia migratoria}

La STC 107/84 162 , de 23 de noviembre - que da inicio a la primera fase de la jurisprudencia constitucional en esta materia-, constituye, sin embargo, el segundo pronunciamiento del TC sobre los derechos de los extranjeros en España.

160 Idem, p. 73.

161 Parece existir cierto acuerdo doctrinal en la tipificación de tres períodos en la jurisprudencia del TC relativa a los derechos de los extranjeros. Vid, a modo de ejemplo, Eliseo AJA en "Veinte años...", op. cit., pp. 444-445; JIMÉNEZ DE PARGA, Manuel. La inmigración en la jurisprudencia del Tribunal Constitucional Español. Ponencia presentada con ocasión del décimo aniversario del TC, en el seno de la Jornada de treball del 03·10·2003 bajo el título genérico de "La protecció de les minories i els Tribunals Constitucionals", sp. Disponible en http://www.tribunalconstitucional. ad/docs/10aniversari/E-ESPANA.pdf; GARCÍA VÁZQUEZ y GOIZUETA VÉRTIZ hablan de cuatro etapas, señalando las tres que se apuntan en el texto, pero incluyendo como una segunda etapa a la sentencia emitida en el Caso Venzón en marzo de 1993, que extendió a los extranjeros la titularidad de todos los derechos consagrados en el Título I CE, con la excepción de los estipulados en el artículo 23 CE. "Un análisis en clave constitucional del régimen jurídico de los extranjeros en España..., op. cit., p. 262.

162 Esta sentencia tiene su origen en una demanda planteada por un ciudadano uruguayo que prestaba sus servicios laborales como conserje en un hostal de Barcelona, sin contar con permiso de trabajo y de residencia en España. Sin embargo, en la época en que sucedieron los hechos, los ciudadanos de origen latinoamericano estaban exentos del requisito de obtener permiso de trabajo. Tal permiso fue exigido por su empleador como reacción ante las reclamaciones laborales formuladas por el demandante — pretendía conseguir mejoras salariales y de horario laboral - y, al carecer del mismo, fue despedido. Tanto la Magistratura de Trabajo de Barcelona como el Tribunal Central de Trabajo declararon nulo el contrato de trabajo por carecer el trabajador de la correspondiente autorización de residencia, cuya concesión quedaba vinculada a la existencia de un previo permiso de trabajo. Tras ello, el ciudadano uruguayo recurrió en amparo ante el TC considerando que las resoluciones judiciales emitidas por dichos juzgados vulneraban el principio de igualdad, así como los artículos 13 y $35 \mathrm{CE}$. El TC centró la materia objeto de pronunciamiento en determinar la constitucionalidad o inconstitucionalidad de la exigencia del previo requisito de la autorización de residencia para reconocer a un ciudadano hispanoamericano la capacidad de formalizar válidamente un contrato, enjuiciada desde la perspectiva del derecho a la igualdad. Esto es, en el presente caso el TC debía determinar si los ciudadanos hispanoamericanos deben ser tratados igual que los españoles en materia de acceso al trabajo. 
Con carácter previo, el TC había debatido sobre el derecho a la tutela judicial efectiva en un recurso de amparo (en adelante RA) presentado por un extranjero - STC 11/1983 ${ }^{163}$ — en el que, tras afirmar sin ambages que la titularidad activa del derecho consagrado en el art. $24 \mathrm{CE}$ resulta predicable tanto de españoles como de extranjeros, la extranjería no suscitó controversia alguna. Una de las cuestiones principales derivadas de la STC 11/1983 reside en que el TC abordó su análisis sin poner en ningún momento en tela de juicio la legitimidad activa de los extranjeros para el planteamiento de un RA - pese a la dicción literal del artículo 53.2 CE que utiliza el término de "ciudadano"-, deduciéndose de ello una "tácita" 164 interpretación extensiva de dicha disposición.

Frente a ella, la STC 107/84 gira toda ella en torno a los derechos de los extranjeros, hasta el punto de ser considerado el primer pronunciamiento del TC en este ámbito por un amplio espectro doctrinal ${ }^{165}$. Este pronunciamietnto apunta ya, si bien de forma incipiente, algunas características importantes sobre la construcción jurisprudencial del régimen de la extranjería llevada a cabo por el TC: se trata de una teoría construida principalmente - al menos, desde el punto de vista numérico- a partir de sentencias que resuelven recursos de amparo planteados por extranjeros y, por tanto, carentes de efectos erga omnes, pero, sin embargo dotadas de efectos interpretativos generales, y donde destaca por encima de todo la "ausencia total de cuestiones de inconstitucionalidad"166. De otro lado, es una doctrina de construcción progresiva y sometida a una profunda evolución y a frecuentes reajustes.

El recurso que dio pie a la STC 107/84 se centraba principalmente en la presunta vulneración del principio de igualdad del art. $14 \mathrm{CE}$ por parte de unas resoluciones judiciales previas que proclamaban la nulidad del contrato de trabajo de un ciudadano uruguayo, por carecer éste de la autorización de residencia que el ordenamiento exigía a todo extranjero para poder trabajar en España. En síntesis, lo que debía enjuiciar el TC era si los ciudadanos extranjeros $-\mathrm{y}$, en concreto, los hispanoamericanos - debían ser tratados igual que los españoles en relación a la contratación laboral, en una época en la que los nacionales hispanoamericanos estaban exentos del permiso de trabajo ${ }^{167}$, pero su regularidad administrativa en España dependía de la obtención de autorización de residencia.

163 STC 11/1983, de 21 de Febrero de 1983.

164 VIDAL FUEYO, M.C. Constitución y extranjería, op. cit., p. 52. GARCÍA VÁZQUEZ, Sonia y GOIZUETA VÉRTIZ, Juana. "Un análisis en clave constitucional del régimen jurídico de los extranjeros en España: especial referencia al derecho a la libertad de circulación y residencia”, op. cit., p. 264.

165 Vid, entre otros, AJA, Eliseo. "Veinte años de doctrina del TC sobre los derechos de los inmigrantes", op. cit., p. 444. BASTARRACHEA ALBA, Esther de. "Derechos fundamentales y libertades públicas de los inmigrantes en España", op. cit., p. 154. Una interpretación diferente, como la aquí apuntada, en GARCÍA VÁZQUEZ, Sonia y GOIZUETA VÉRTIZ, Juana, quienes estudian la STC 11/1983 considerándola el primer pronunciamiento del TC en este ámbito. "Un análisis en clave constitucional del régimen jurídico de los extranjeros en España: especial referencia al derecho a la libertad de circulación y residencia", op. cit, p. 264.

166 AJA, Eliseo. "Veinte años de doctrina del Tribunal Constitucional sobre los derechos de los extranjeros", op. cit., p. 443. Esta ausencia resulta especialmente llamativa a la luz de las dudas de inconstitucionalidad que la LOE suscitó entre la doctrina, y las dificultades interpretativas que ofrece el marco jurídico de la extranjería. Como causas de la misma, el autor destaca la "escasa atención" que tanto la administración como los jueces han prestado a los derechos de los inmigrantes, así como su "dejadez" en la aplicación de la normativa de extranjería. Idem, p. 442.

167 Por virtud de la Ley 118/1969, de 30 de diciembre, así como de su Orden de desarrollo, de 15 de enero de 1970, que eximían de la obligación de disponer de permiso de trabajo a los nacionales hispanoamericanos que pretendiesen trabajar en España, tanto por cuenta propia como por cuenta ajena. Dicha obligación estaba prescrita con carácter general para los extranjeros en el art. 4 del Decreto 1870/1968, de 27 de julio, vigente en el momento en que se suscitaron los hechos. Vid. MIQUEL CALATAYUD, J.A. "Análisis de la posición constitucional del extranjero en España”, op. cit., p. 53. 
De ahí que la primera cuestión que examina el alto tribunal sea el principio de igualdad consagrado en el artículo $14 \mathrm{CE}$, considerando a los españoles como sus destinatarios exclusivos, salvo en los supuestos en los que sea la propia ley la que reclame la igualdad entre españoles y extranjeros ${ }^{168}$. Pese a ello, resulta destacable que en esta sentencia - al igual que sucedió en la previa y a partir de ésta, en las sucesivas habidas en este ámbito-, el TC no cuestiona en ningún momento la legitimidad activa para la interposición del propio recurso de amparo, sin atender al hecho de que el recurrente carezca de la nacionalidad española ${ }^{169}$.

Tras esta primera observación, destacan tres importantes consideraciones vertidas por el TC, dotadas, sin embargo, de escasa coherencia interna:

a) El TC niega el carácter restrictivo del término libertades públicas utilizado en el artículo 13.1 $\mathrm{CE}^{170}$. Con ello, se entiende que en la expresión libertades públicas - concebida en sentido amplio-, quedarían incluidos todos los derechos consagrados dentro del Título I de la Constitución ${ }^{171}$. Esta afirmación tiene consecuencias de primer orden en el estatuto jurídico de la extranjería en nuestro país, pues este entendimiento amplio implica también una concepción en principio extensiva de los derechos de los que a tenor de la misma disposición "gozarán” los extranjeros.

b) A continuación otorga al poder legislativo - interno e internacional- un amplísimo margen de maniobra en la configuración del régimen jurídico de los extranjeros: el TC declara expresamente que el disfrute y contenido de los derechos y libertades que afecten a este colectivo dependerá "de la libre voluntad del tratado o la ley"172, y señala además con carácter general, que todos los derechos de los extranjeros son, sin excepción, derechos de configuración legal en cuanto a su contenido ${ }^{173}$. Y en este último punto reside, a nuestro juicio, uno de los aspectos más criticables del razonamiento del TC pues, en primer lugar, se trata de una categoría legal cuyo principal problema reside en la indefinición de la misma ${ }^{174}$

168 Sobre este tema, el TC señala literalmente que "cuando el art. 14 de la Constitución proclama el principio de igualdad, lo hace refiriéndose con exclusividad a «los españoles». Son éstos quienes, de conformidad con el texto constitucional, "son iguales ante la ley», y no existe prescripción ninguna que extienda tal igualdad a los extranjeros. La inexistencia de declaración constitucional que proclame la igualdad de los extranjeros y españoles no es, sin embargo, argumento bastante para considerar resuelto el problema, estimando que la desigualdad de trato entre extranjeros y españoles resulta constitucionalmente admisible, o, incluso, que el propio planteamiento de una cuestión de igualdad entre extranjeros y españoles está constitucionalmente excluido. Y no es argumento bastante, porque no es únicamente el artículo 14 de la Constitución el que debe ser contemplado, sino que, junto a él, es preciso tener en cuenta otros preceptos sin los que no resulta posible determinar la posición jurídica de los extranjeros en España", STC 107/84, F. J. $3^{\circ}$.

169 JIMÉNEZ DE PARGA, Manuel. "La inmigración en la jurisprudencia del Tribunal Constitucional Español”, op. cit., s.p.

170 En el fundamento jurídico tercero de la STC 107/84, el alto tribunal señala de forma expeditiva, que "el término $<$ libertades públicas> no tiene obviamente un significado restrictivo", asimilándolo con los derechos y libertades reconocidos en el Título I CE.

171 ORTEGA CARBALLO, Carlos. "Los derechos fundamentales de los extranjeros en la jurisprudencia del TC"; en Justicia Administrativa, n 37, 2007, p. 8. A la misma interpretación llega MIQUEL CALATAYUD, quien extrae como conclusión de lo dispuesto en la sentencia, atribuir "a los extranjeros todo el bloque de derechos constitucionales básicos salvo aquellos que resultan excluidos"; en "Análisis de la posición constitucional del extranjero en España”, op. cit., p. 59.

172 F. J. 3º, STC 107/1984.

173 "Los derechos y libertades reconocidos a los extranjeros siguen siendo derechos constitucionales y, por tanto, dotados de la protección constitucional, pero son todos ellos sin excepción en cuanto a su contenido, derechos de configuración legal" (STC 107/1984 de 23 de noviembre, F. J. 3º). En la misma idea incide el Auto 130/1980, señalando de nuevo expresamente que todos los derechos de los extranjeros son derechos de configuración legal.

174 NOREÑA SALTO, José Ramón. "Acerca del contenido esencial de los derechos fundamentales de configuración legal", op. cit., sp. 
$y$, en segundo lugar, la asignación de forma imprecisa ${ }^{175}$ de este tipo de naturaleza jurídica a todos los derechos de los extranjeros - sin que quepan excepciones-, resulta internamente incoherente con la argumentación posteriormente desplegada por el TC en esta misma sentencia.

c) Sin embargo, a reglón seguido el TC afirma explícitamente que el art. 13.1 CE no pretende obrar una desconstitucionalización del régimen de los extranjeros, pues "la Constitución no dice que los extranjeros gozarán en España de las libertades públicas que les atribuyan los tratados y la ley, sino de las libertades <que garantiza el presente Título en los término que establezcan los tratados y la ley>, de modo que los derechos y libertades reconocidos a los extranjeros siguen siendo derechos constitucionales $y$, por tanto, dotados - dentro de su específica regulación-, de la protección constitucional" ${ }^{176}$. Con ello, el TC enmarca los derechos de los extranjeros en el ámbito constitucional, "desautorizando la teoría de que los derechos de los extranjeros hayan quedado fuera de la Constitución mediante una remisión de ésta a los tratados y a la ley”177.

Por lo tanto, el TC hace una doble negación - tanto del carácter restrictivo del término libertades públicas como de la supuesta desconstitucionalización del régimen de extranjería que, una lectura apresurada del art. 13.1 CE, podría propiciar-, y una rotunda afirmación - los derechos de los extranjeros son de configuración legal, dependiendo su desarrollo normativo de la libre voluntad del legislador interno e internacional. Sin embargo, entre ambas declaraciones existe una profunda contradicción, como tendremos ocasión de señalar posteriormente al hilo de la argumentación ofrecida más adelante por el propio TC.

En torno a la titularidad y ejercicio de los derechos por parte de los extranjeros, el TC establece una tipología tripartita que, desde entonces, repetirá hasta la saciedad en sus siguientes pronunciamientos. Y aquí reside la parte más sustancial de esta sentencia pues, aun tratándose de un recurso de amparo, el alto tribunal formula una "teoría sobre los derechos de los extranjeros de gran

175 En sentido crítico también se expresa Javier GARCÍA ROCA, quien estima que esta consideración general resulta "desproporcionada de no añadirse matices", "La titularidad constitucional e internacional de los derechos fundamentales de los extranjeros y las modulaciones legales a sus contenidos”; en REVENGA SÁNCHEZ, Miguel (coord.) Problemas constitucionales de la inmigración: una visión desde Italia y España". Valencia, Tirant lo Blanch, 2004, pp. 72 y 81. Así mismo VIDAL FUEYO subraya la contradicción inherente a este planteamiento general del TC, cuestionándose críticamente en torno a la categoría de derechos de configuración legal: “¿lo son porque sus titulares son extranjeros”, es decir: “¿añade la condición de extranjero un plus de libertad de configuración al legislador?, ¿se está diciendo que el derecho a la libertad de pensamiento de los extranjeros es un derecho de configuración legal; o que el derecho a la libertad de expresión, o el derecho a no declarar contro uno mismo son derechos de configuración legal cuando se predican de los extranjeros?"; Constitución y extranjería, op. cit., p. 55. Posteriormente la autora matiza que en esta categoría de derechos de configuración legal, la intervención del legislador no supone necesariamente un límite para el derecho afectado, "sino que, al contrario, dota de contenido a un derecho falto de plenitud", Idem, p. 63.

176 F. J. $3^{\circ}$, STC $107 / 84$.

177 ALBA BASTARRECHEA, Esther de. "Derechos fundamentales y libertades públicas de los inmigrantes en España”; en Asamblea: Revista parlamentaria de la Asamblea de Madrid, o. 14, 2006, p. 154. En este orden de ideas, CALATAYUD extrae la "inconmovilidad y autosuficiencia del artículo 13.1CE en cuanto oportunamente conferidor a los extranjeros de un haz de derechos constitucionales, otorgamiento que queda sustraído por completo a la disponibilidad del legislador ordinario y de la soberanía del Estado Español como sujeto internacional dotado de facultades autónomas para celebrar convenios con otros Estados”. MIQUEL CALATAYUD, José Antonio. "Análisis de la posición constitucional del extranjero en España"; en BORRÁS ALEGRÍA (dir.). Diez años de la Ley de Extranjería: Balance y perspectivas. Barcelona, Fundación Paulino Torras Domènech, 1995, p. 54. 
alcance"178, si bien no exenta de contradicciones internas, que se convertirá durante largo tiempo en "el punto de referencia de doctrina y jurisprudencia"179.

Para formular su teoría tripartita sobre los derechos de los extranjeros, el TC recurre a la cláusula de la dignidad humana como criterio básico de distribución y asignación de los distintos derechos, en conexión con la naturaleza particular de cada concreto derecho. En base a este criterio, será la mayor o menor proximidad de los derechos a la dignidad, lo que le permita clasificar en tres grupos a los derechos en cuanto a su atribución a los extranjeros. Para el TC:

"Existen derechos que corresponden por igual a españoles y extranjeros y cuya regulación ha de ser igual para ambos; existen derechos que no pertenecen en modo alguno a los extranjeros (los reconocidos en el art. 23 de la Constitución, según dispone el art. 13.2 y con la salvedad que contienen); existen otros que pertenecerán o no a los extranjeros según lo dispongan los tratados y las Leyes, siendo entonces admisible la diferencia de trato con los españoles en cuanto a su ejercicio"180.

En el primer grupo de derechos se sitúan aquellos inherentes al ser humano por ser imprescindibles para garantizar la dignidad y que, por tanto, "pertenecen a la persona en cuanto tal, y no como ciudadano ${ }^{181}$ ". En ellos se produce una completa igualdad entre españoles y extranjeros, exigiéndose en consecuencia una total homogeneidad en el tratamiento jurídico de ambos. El TC especifica que este primer grupo está integrado, de forma no exhaustiva, por "derechos tales como el derecho a la vida, a la integridad física y moral, a la intimidad, la libertad ideológica, etc.", pues "corresponden a los extranjeros por propio mandato constitucional, y no resulta posible un tratamiento desigual respecto a ellos en relación a los españoles" 182 . Este elenco, formulado con carácter abierto, ha sido progresivamente ampliado en sucesivas sentencias del TC.

En la segunda tipología se incluyen aquellos derechos de los que los extranjeros están excluidos por su íntima vinculación con la nacionalidad: se trata de los derechos políticos — los reconocidos en el art. 23CE, con las precisiones establecidas en el art. 13.2 CE-.

El tercer tipo de derechos presenta contornos más difusos, pues es obvio que la delimitación de los dos primeros tipos representa menores dificultades. Este tercer grupo admite diferencias en su régimen jurídico con respecto a la regulación establecida para los mismos derechos por parte de los españoles. La titularidad por parte de los extranjeros de los derechos incluidos en esta tercer tipología depende totalmente, a juicio del TC, de lo prescrito en los convenios internacionales y la ley interna. En sentido estricto, y retomando la propia argumentación del TC, este tercer grupo sería el único al que sería atribuible la naturaleza jurídica de derechos de configuración legal, mientras que los otros dos tipos anteriores no admitirían tal clasificación por expresa prescripción tanto de la Constitución como en aplicación de la presente doctrina constitucional.

Como ya anticipamos, el aspecto más incongruente del razonamiento del TC reside en la afirmación genérica vertida por el TC de que todos los derechos de los extranjeros son, sin que quepan excepciones, derechos de configuración legal. La naturaleza jurídica que el TC asigna con carácter general a los derechos de los extranjeros, resulta incompatible con el primer grupo de la trilogía de derechos $^{183}$, esto es, con aquellos que, por su íntima conexión con la dignidad humana, correspon-

178 AJA, Eliseo. "Veinte años de doctrina del TC....", op. cit., p. 445.

179 VIDAL FUEYO, M. C. Constitución y extranjería, op. cit., p. 53.

180 F. J. $4^{\circ}$, STC 107/1984.

181 F. J. 30, STC $107 / 1984$.

182 F. J. $3^{\circ}$, STC $107 / 1984$.

183 En el mismo sentido, PÉREZ VERA, E. "Artículo 13. Extranjería”, op. cit., p. 197. Una interpretación diversa se encuentra en NOREÑA SALTO, quien señaña que la propia argumentación ofrecida por el TC en esta misma 
den por igual tanto a nacionales como a extranjeros. Al menos en relación a este primer grupo, no cabe afirmar que estemos ante derechos de configuración legal sino, todo lo contrario, ante derechos excluidos de la manipulación legislativa. Y, más allá, similar argumentación es aplicable con respecto al segundo de los grupos: la exclusión de los extranjeros como beneficiarios de los derechos políticos constituye un mandato constitucional - artículos 13.2 y $23 \mathrm{CE}$-, de modo que no se alcanza a comprender la supuesta libertad de intervención legislativa, también respecto de este grupo.

El propio TC da a entender las limitaciones de su propia argumentación pues, tras atribuir una libertad casi limitada al poder legislativo interno e internacional sobre los derechos de los extranjeros, señala explícitamente que "ni siquiera esta modulación o atemperación es posible en relación con todos los derechos"184. A sensu contrario, el alto Tribunal entiende la imposibilidad de incluir a todos los derechos de los extranjeros, sin excepción, dentro de la categoría de derechos de configuración legal, excluyendo de la misma a aquellos derechos que, por ser predicables de la persona en cuanto tal, han de corresponder y ser ejercidos por nacionales y a extranjeros en igualdad de condiciones .

Desde distintos frentes doctrinales se ha subrayado además que la distribución de los distintos derechos de los extranjeros en función de su mayor o menor vinculación con la dignidad humana constituye un criterio éticamente impoluto, pero jurídicamente muy arriesgado ${ }^{185}$, por no mencionar su imprecisión ${ }^{186}$ y las dificultades de aplicación práctica que acarrea. Como tendremos ocasión de observar, a partir de esta sentencia el TC recurre constantemente al criterio de la dignidad humana a la hora de analizar el elenco de derechos atribuibles a los extranjeros, pero el mismo no ha permitido dotar de una organización sistemática a dicho elenco. De hecho, la teoría tripartita adquirirá tal peso en la argumentación del TC en posteriores sentencias, que ha llegado a convertirse en la "síntesis dogmática del régimen de derechos fundamentales de los extranjeros en España"187.

sentencia resulta matizada por la calificación genérica de que todos los derechos de los extranjeros sean derechos de configuración legal: "esta afirmación inicial — la de que todos los derechos fundamentales son, para los extranjeros, de configuración legal- es matizada por esta misma sentencia (F. 4), que distingue, desde la perspectiva de su posible atribución a los extranjeros, diversas categorías de derechos fundamentales, y, en consecuencia, admite que aquéllos son, en todo caso, titulares de determinados derechos fundamentales en igualdad de condiciones que los ciudadanos españoles, y sin necesidad de intermediación legal". NOREÑA SALTO, José Ramón. "Acerca del contenido esencial de los derechos fundamentales de configuración legal”, op. cit., sp.

184 F. J. $2^{\circ}$, STC 107/84. En el mismo sentido, Bastarrachea acude a la jurisprudencia del TC para afirmar que en ella "se observa con claridad que en estos derechos «de configuración legal» la libertad del legislador para su configuración no alcanza a los derechos directamente vinculados a la dignidad de la persona"; en ALBA BASTARRECHEA, E. "Derechos fundamentales y libertades públicas de los inmigrantes en España", op. cit., p. 154-155.

185 VIDAL FUEYO denuncia la labilidad del concepto dignidad humana como idea pre y meta constitucional, lo que lo convierte en un criterio extremadamente arriesgado y notablemente arbitrario a fin de clasificar los derechos de los extranjeros; en "La setencia del TC 72/2005, de 4 de abril, en materia de libertad de entrada y residencia de los extranjeros en España”, op. cit., p. 438. En un artículo posterior, la misma autora afirma que el criterio del grado de conexión de los distintos derechos de los extranjeros con la dignidad humana constituye una pauta interpretativa "frágil y poco esclarecedora" habida cuenta de que todos los derechos fundamentales por definición están conectados estrechamente con la dignidad y, que, además, "establecer 'grados' de dignidad nos aleja del terreno de la seguridad jurídica y nos coloca en el campo de la subjetividad"; en "La jurisprudencia del TC en materia de derechos fundamentales de los extranjeros..., op. cit., p. 363.

186 Dentro de la línea argumentativa crítica con la tipología tripartita de los derechos de los extranjeros, se sitúa GARCÍA ROCA, quien duda de su utilidad como consecuencia de su imprecisión, señalando que "dista de ser un sólido basamento desde el que razonar y debería ser superada"; en "La titularidad constitucional e internacional...", op. cit., pp. 83 y 101. En esta corriente se inserta también MIQUEL CALATAYUD, quien subraya las "imprecisiones” en su formulación. "Análisis de la posición constitucional del extranjero en España”, op. cit., p. 57

187 VIDAL FUEYO, M.C. “La jurisprudencia del TC en materia de derechos fundamentales de los extranjeros...”, op. cit., p. 358. 
Finalmente, el TC, en la STC 107/84 señala que "el problema de la igualdad en el ejercicio de los derechos (...) depende, pues, del derecho afectado"188. Aplicando esta consideración al objeto del presente recurso - el principio de igualdad respecto al derecho al trabajo ejercido por los extranjeros-, el TC estima que la Constitución sólo reconoce el derecho al trabajo para los españoles. Concluye señalando que "constitucionalmente no resulta exigible la igualdad de trato entre los extranjeros (...) y los españoles en materia de acceso al trabajo" ${ }^{189}$, desestimando con ello el recurso de amparo presentado por el ciudadano uruguayo.

Dentro de esta primera etapa se inscribe también la STC $\mathbf{9 9 / 8 5 ^ { 1 9 0 }}$, que resuelve un recurso de amparo por presunta vulneración del derecho a la tutela judicial efectiva presentado por una ciudadana alemana residente en España. Apoyándose expresamente en la doctrina emitida en la anterior sentencia, el TC profundiza en la línea de reafirmación del estatuto constitucional de los derechos de los extranjeros ${ }^{191}$, observándose un acusado peso tanto de la interpretación gramatical como del criterio exegético internacionalista en su argumentación jurídica.

Resumidamente, el TC señala que los extranjeros gozan en principio de todos los derechos del Título I, salvo los proclamados en los artículos 19, 23 y 29 - cuyo tenor literal los descarta de forma expresa $^{192}$ - . La exclusión de los extranjeros con respecto de la titularidad del conjunto de derechos que, en torno a la libertad deambulatoria, están reconocidos en el art. 19CE, parece basarse en una interpretación literal de dicha disposición, si bien esta cuestión no queda suficientemente justificada en la sentencia. La rotundidad de su exclusión queda más patente por el hecho de situar el art. $19 \mathrm{CE}$ "en el mismo plano de inaccesibilidad para los extranjeros" ${ }^{193}$, con respecto a los derechos de matriz política contemplados en los artículos 23 y 29 CE.

De otro lado, el TC estima que no es válido considerar que la titularidad y ejercicio de los derechos de los no nacionales dependa exclusivamente de la legislación interna e internacional, matizan-

188 STC $107 / 84$, F. J. $4^{\circ}$.

189 Idem.

190 STC 99/1985, de 30 de septiembre, BOE n 265, de 5 de noviembre. El recurso de amparo traía su causa de dos previos procesos penales por falso testimonio - el primero fallado sin entrar en el fondo del asunto y el segundo desestimado-, por haberse omitido en ellos la exigencia de procedibilidad consistente en la necesaria autorización previa concedida por el órgano judicial ante el que se prestó la declaración supuestamente constitutiva de aquel delito. La actora alegaba ante el TC que dicha exigencia, no prevista legalmente sino procedente de doctrina del TS anterior a la Constitución, constituía un requisito contrario a la seguridad jurídica proclamada en el artículo $17 \mathrm{CE}$ y, simuláneamente, una vulneración del derecho a la tutela judicial efectiva garantizado en el artículo 24 CE.

191 En este sentido, el TC indica: "Es verdad (...) que nuestra Constitución "es obra de españoles», pero ya no lo es afirmar que es sólo "para españoles». El párrafo 1 del artículo 13 de la Constitución no significa que los extranjeros gozarán sólo de aquellos derechos y libertades que establezcan los tratados y las Leyes, como parece entender la mencionada representación procesal. Significa, sin embargo, que el disfrute por los extranjeros de los derechos y libertades reconocidos en el título I de la Constitución (...) podrá atemperarse en cuanto a su contenido a lo que determinen los tratados internacionales y la Ley interna española”. F. J. 2º, STC 99/85.

192 En palabras del TC, "el disfrute por los extranjeros de los derechos y libertades reconocidos en el Título I de la Constitución (y que por consiguiente se le reconoce también a ellos en principio, con las salvedades concernientes a los arts. 19, 23 y 29, como se desprende de su tenor literal y del mismo art. 13 en su párrafo segundo) podrá atemperarse en cuanto a su contenido a lo que determinen los tratados internacionales y la Ley interna española", STC 99/85, F. J. $3^{\circ}$.

193 La expresión corresponde a VIDAL FUEYO, para quien resulta muy significativo de la postura del TC el hecho de que estas tres exclusiones - artículos 19, 23 y 29- queden situadas en un mismo plano igualitario, cuando es obvio que el carácter político de los artículos 23 y 29, no es comparable a los derechos deambulatorios contemplados en el art. 19 CE; en "La sentencia del Tribunal Constitucional 72/2005, de 4 de abril, en materia de libertad de entrada y residencia de los extranjeros en España”; Teoría y Realidad Constitucional, no 18, 2006, p. 436. 
do la preponderancia del legislador en el ámbito migratorio ${ }^{194}$. Sin embargo, el alto tribunal subraya que el contenido de los derechos de los extranjeros estará modulado o atemperado por los Tratados y la ley, con la exclusión de aquellos que corresponden por igual a españoles y extranjeros por resultar imprescindibles para garantizar la dignidad humana, respecto de los cuales no cabe dicha modulación. Entre los derechos que, por su íntima vinculación a la dignidad, corresponden por igual a extranjeros y españoles, el TC sitúa el derecho a la tutela judicial efectiva proclamado en el artículo 24 CE. Para llegar a esta conclusión, el TC se apoya - junto con la redacción gramatical empleada por dicha disposición constitucional-, en el criterio internacionalista del artículo 10.2 CE, recurriendo tanto a la DUDH como al CEDH. El recurso a ambos criterios interpretativos - gramatical e internacionalista-, permite al TC concluir con rotundidad la universalidad en la titularidad activa del derecho a la tutela judicial efectiva ${ }^{195}$.

La inclusión de la tutela judicial efectiva en el primero de los grupos clasificados por el TC, junto a las obvias repercusiones prácticas que tiene en la protección del estatuto jurídico de la extranjería, tiene una consecuencia añadida inmediata de gran calibre a la que el propio TC alude indirectamente en esta sentencia: La titularidad activa a favor de los extranjeros del derecho a la tutela judicial efectiva del art. $24 \mathrm{CE}$, permite al TC incluir a los extranjeros dentro de la legitimación activa para la interposición del recurso de amparo - siempre que la vulneración afecte a los derechos fundamentales objeto de RA-, pese a que la dicción literal del artículo 53.2 y de la ley que lo desarrolla —art. 41. LOTC-, sólo mencionen expresamente a los ciudadanos ${ }^{196}$. Como ya indicamos, la legitimación activa amplia para la interposición del RA había sido entendida y aplicada desde el principio por el TC, quien había admitido recursos de este tipo formulados por extranjeros sin que la falta de la nacionalidad española del recurrente hubiese supuesto obstáculo alguno. Lo relevante es que, por primera vez, este pronunciamiento desvela la argumentación subyacente a dicha práctica.

A modo de cierre de esta visión panorámica en torno a la jurisprudencia inicialmente emitida por el TC al abordar el estatuto jurídico de los extranjeros en España, cabría destacar que, si bien el alto tribunal destaca por un posicionamiento con carácter general progresista y con clara vocación internacionalista al enfrentar esta compleja cuestión interpretativa, se detectan en su construcción contradicciones internas que traslucen cierta sobrevaloración del peso aislado del artículo $13.1 \mathrm{CE}$, en detrimento de una visión más sistemática del articulado constitucional ${ }^{197}$. De otro lado, la prime-

194 En un sentido idéntico, BALAGUER CALLEJÓN indica que con la STC 99/1985, la doctrina del TC evolucionará "en un sentido más restrictivo de las posibilidades de configuración del legislador". "El contenido esencial de los derechos constitucionales y el régimen jurídico de la inmigración. Un comentario a la STC 236/2007 de 7 de noviembre", op. cit., p. 483.

195 En referencia a los derechos íntimamente vinculados a la dignidad humana, el TC afirma "pues bien, uno de estos derechos es el que «todas las personas tienen (...) a obtener la tutela efectiva de los Jueces y Tribunales», según dice el artículo 24.1 de nuestra Constitución; ello es así no sólo por la dicción literal del citado artículo («todas las personas ...»), sino porque a esa misma conclusión se llega interpretándolo, según exige el artículo 10.2 de la CE, de conformidad con el artículo 10 de la Declaración Universal de Derechos Humanos, con el artículo 6.1 del Convenio de Roma de 4 de noviembre de 1950, y con el artículo 14.1 del Pacto Internacional de Derechos Civiles y Políticos de Nueva York de 19 de diciembre de 1966, textos en todos los cuales el derecho equivalente al que nuestra Constitución denomina tutela judicial efectiva es reconocido a «toda persona» o a «todas las personas», sin atención a su nacionalidad. Por consiguiente, en el caso que examinamos, la nacionalidad alemana o española de quien nos pide amparo es irrelevante para otorgarlo o denegarlo”. F. J. 2º, STC 99/1985.

196 ALBA BASTARRACHEA, E. “Derechos fundamentales y libertades públicas de los inmigrantes en España”, op. cit., p. 154.

197 En el mismo sentido, VIDAL FUEYO señala críticamente que la interpretación del art. 13.1 "no conduce (...) a la construcción de un régimen de derechos fundamentales de los extranjeros coherente con una interpretación sistemática o finalista de nuestra Constitución”. Más adelante, la autora subraya que el TC realiza una lectura aislada 
ra jurisprudencia constitucional tiende a un entendimiento excesivamente amplio de la capacidad de configuración legislativa en materia migratoria y a una visión restrictiva de los límites que enfrenta el poder legislativo en este ámbito ${ }^{198}$, si bien el margen de intervención legislativa comienza a ser progresivamente recortado al final de esta etapa.

Con todo, la firme y temprana apuesta del TC por la constitucionalización del régimen de los extranjeros - afirmando sin ambages que son titulares de derechos que emanan directamente de la Constitución-, resultaba vital en medio de un contexto dominado por una visión legalista de la extranjería y la inmigración ${ }^{199}$, propiciada tanto por la ambigüedad y apertura de la redacción del artículo 13.1CE como por la vigencia en esta materia de un marco jurídico disperso, de rango fundamentalmente reglamentario y de corte continuista. El contexto jurídico descrito resulta predicable de los primeros años de establecimiento de la democracia española - coincidiendo con esta primera etapa jurisprudencial-, y concluye con la aprobación de la LO 7/1986 reguladora de los derechos y libertades de los extranjeros, que constituirá la primera ley postconstitucional que contempla con carácter general del estatuto de los extranjeros, en desarrollo del artículo 13.1 CE. Será precisamente la sentencia del TC emitida para resolver el recurso de inconstitucionalidad formulado contra dicha ley orgánica, la que inaugura una segunda etapa en la jurisprudencia constitucional en torno a los derechos de los extranjeros.

\subsection{La segunda etapa en la construcción del Régimen de los Derechos de los extranjeros en España por parte del TC}

La STC 115/1987 200 marca un hito decisivo en la percepción del TC sobre la extranjería y la inmigración, hasta el punto de existir coincidencia doctrinal en señalar que con ella se inicia una segunda etapa en la evolución del TC en esta materia ${ }^{201}$. Con esta sentencia el TC vino a resolver el recurso de inconstitucionalidad promovido por el Defensor del Pueblo contra algunas de las disposiciones de la LO 7/1985 reguladora de los derechos y libertades de los extranjeros —artículos 7,8, 26 y $34-$. Es importante señalar que la mencionada ley había absorbido la doctrina jurisprudencial previa emitida por el $\mathrm{TC}^{202}$.

Como punto de partida del razonamiento desplegado en esta sentencia, el TC recuerda el principio de interpretación conforme a la Constitución, en virtud del cual sólo cabe declarar la derogación de los preceptos cuya incompatibilidad con la Constitución sea indudable por resultar imposible llevar a cabo una interpretación conforme a la misma. En aplicación de este principio, el TC interpreta la detención cautelar o preventiva de extranjeros - aquella que tiene lugar mientras se sustancia el expediente de expulsión, regulada en el impugnado artículo $26.2^{203}$ de la LO 7/1985-, en sentido

de la reserva de ley del art. 13.1, prescindiendo de una interpretación sistemática de todo el Título I. Constituticón y extranjería, op. cit., pp. 65 y 66, respectivamente.

198 BALAGUER CALLEJÓN Francisco. "El contenido esencial de los derechos constitucionales y el régimen jurídico de la inmigración. Un comentario a la STC 236/2007 de 7 de noviembre”, op. cit., p. 482.

199 Idem, pp. 109-110.

200 STC 115/1987, de 7 de julio, publicada en el BOE nº 180, de 29 de julio.

201 Vid. AJA, E. "Veinte años de doctrina del TC sobre los derechos de los inmigrantes", op. cit., p. 445. La misma periodificación se deduce también del análisis efectuado por VIDAL FUEYO, M.C. Constitución y extranjería, op. cit., pp. 65 y 116.

202 AJA, E. (coord.). La nueva regulación de la inmigración en España, op. cit., p. 21. AJA, E. "Veinte años de doctrina del TC sobre los derechos de los inmigrantes", op. cit., p. 445.

$203 \mathrm{El}$ art. 26 de la LO 7/1985 establecía la posibilidad de expulsar a los extranjeros en determinados supuestos, contemplando su párrafo segundo la detención cautelar o preventiva de extranjeros mientras se sustanciaba el 
conforme a los arts. 17.2 y 25.3 CE. La cuestión clave para ello dependía fundamentalmente de la valoración que se hiciese de la intervención judicial legalmente prevista en la detención cautelar, para lo cual el TC acude nuevamente al principio de interpretación internacionalista del art. 10.2 CE.

El TC exige que el órgano administrativo, en el plazo máximo de 72 horas, solicite del juez la autorización del internamiento del extranjero pendiente del trámite de expulsión, quien deberá emitir al respecto una resolución judicial. En aplicación de la doctrina del TEDH -que exige que toda privación de libertad ha de ser controlada legalmente por un tribunal-, el $\mathrm{TC}^{204}$ afirma que la resolución judicial que decida la prolongación o no del internamiento del extranjero pendiente de expulsión, debe cumplir los siguientes requisitos: deberá ser motivada, respetar el derecho de defensa y, asimismo, ser susceptible de recurso, incluyendo expresamente el habeas corpus, tanto en la fase gubernativa previa como en lo que respecta a la prolongación judicial del internamiento. Además, el TC señala taxativamente el carácter restringido y excepcional de la medida de internamiento de los extranjeros, cuya duración máxima no podrá exceder, en ningún caso, de los 40 días establecidos legalmente ${ }^{205}$. Entendida de esta forma, la disponibilidad sobre la pérdida de libertad es judicial, sin perjuicio del carácter administrativo de la decisión de expulsión y de la ejecución de la misma, salvando el TC la constitucionalidad del apartado segundo del art. 26 de la LO 7/1985.

El núcleo central del recurso de inconstitucionalidad residía en el examen de las restricciones al ejercicio de los derechos de reunión ${ }^{206}$ y asociación por parte de los extranjeros, introducidas

expediente de expulsión por un plazo máximo de 40 días, si bien el mismo no debía prolongarse más del tiempo imprescindible para que se practicase la expulsión.

204 Sobre este aspecto, el TC declara que "la decisión judicial, en relación con la medida de internamiento del extranjero pendiente de expulsión, ha de ser «adoptada mediante resolución judicial motivada», que debe respetar los derechos fundamentales de defensa (art. 24.1 y 17.3 de la Constitución), incluidos los previstos en el art. 30.2 de la Ley Orgánica 7/1985, de 1 de julio, en conexión con el art. 6.3 del Convenio Europeo para la Protección de los Derechos Humanos y Libertades Fundamentales, así como la interposición de los recursos que procedan contra la resolución judicial y eventualmente los reconocidos en el art. 35 de la Ley Orgánica 7/1985, de 1 de julio, en conexión con el art. 5.4 del citado Convenio Europeo para la Protección de los Derechos Humanos y Libertades Fundamentales. Se cumple así la exigencia que el Tribunal de Estrasburgo estableció en su Sentencia de 18 de junio de 1971 (Caso de Wilde, Ooms y Versyp), de que toda persona privada de su libertad, con fundamento o no, tiene derecho a un control de legalidad ejercido por un Tribunal, y por ello con «unas garantías comparables a las que existen en las detenciones en materia penal». Es decir, el precepto impugnado respeta y ha de respetar el bloque de competencia judicial existente en materia de libertad individual, incluyendo el derecho de habeas corpus del art. 17.4 de la Constitución, tanto en lo que se refiere a la fase gubernativa previa, dentro de las setenta y dos horas, como también respecto a esa prolongación del internamiento en caso necesario, más allá de las setenta y dos horas, en virtud de una resolución judicial. La intervención judicial no sólo controlará el carácter imprescindible de la pérdida de libertad, sino que permitirá al interesado "presentar sus medios de defensa», evitando así que la detención presente el carácter de un internamiento arbitrario".

205 F. J. $1^{\circ}$, STC 115/1987.

206 El artículo 7 de la LO 7/1985 establecía que "los extranjeros podrán ejercitar el derecho de reunión, de conformidad con lo dispuesto en las normas que lo regulan, siempre que se hallen legalmente en territorio español. Para poder promover la celebración de reuniones públicas en local cerrado o en lugares de tránsito público, así como manifestaciones, los extranjeros deberán tener la condición legal de residentes y solicitar del órgano competente su autorización, el cual podrá prohibirlas si resultaran lesivas para la seguridad o los intereses nacionales, el orden público, la salud o la moral públicas o los derechos y libertades de los españoles". El Defensor del pueblo impugnaba parcialmente este precepto, cuestionando tan sólo la necesidad de autorización previa para promover la celebración de reuniones públicas o manifestaciones por parte de los extranjeros, establecida en el inciso segundo del art. 7. Junto a este requisito, para que los extranjeros en España pudiesen ejercer el derecho de reunión la ley orgánica exigía, además, hallarse legalmente en territorio español. Esta exigencia no fue objetada por el defensor del pueblo, sin ser tampoco enjuiciada por el TC. Habría que esperar al segundo recurso de inconstitucionalidad habido en materia de extranjería, para que el TC se enfrentase a la cuestión de la exigencia de residencia legal como requisito previo para el ejercicio de algunos derechos fundamentales de cuya titularidad, como ocurría también aquí, no se 
por la LO 7/1985, condicionados al requisito de autorización administrativa previa y a la posibilidad de suspensión gubernamental, respectivamente. Ambas restricciones fueron declaradas inconstitucionales por el TC, con los argumentos que a continuación se expondrán.

Respecto al derecho de reunión, la ley impugnada permitía su ejercicio por parte de los extranjeros pero, para el supuesto de reuniones públicas, exigía la autorización previa del órgano competente. En el examen de esta restricción, el TC parte del art. 21.1 CE, que reconoce el derecho de reunión sin referencia alguna a la nacionalidad del que lo ejerce ${ }^{207}$. Con esta argumentación, el alto tribunal parece querer dar a entender que aquellos derechos sobre cuya titularidad la Constitución española se pronuncia en términos abiertos - por ejemplo, con el uso del reflexivo "se reconoce", como ocurre con el derecho de reunión-, pertenecen ex constitutionen también a los extranjeros, con independencia de que su régimen jurídico pueda admitir modulaciones en su ejercicio con respecto a los españoles ${ }^{208}$. En estos derechos, la libertad del legislador no alcanzaría, pues, al establecimiento de las condiciones de su titularidad activa, ya que la misma viene establecida constitucionalmente. Con esta delimitación, el TC estaría abriendo la puerta a la consideración de que sólo es posible la modulación legislativa sobre la titularidad activa de aquellos derechos constitucionales que no encajaran en el grupo anterior. Esto es, sólo cabría dicha intervención legislativa en la titularidad activa, respecto de aquellos derechos que la Constitución reconoce a los españoles, sin prohibir su extensión a los extranjeros — art. 13.2 en relación al art. 23CE—. Es obvio que, dado el carácter de dichos derechos, tal intervención habría de ser únicamente en sentido extensivo a fin de reconocer a favor de los extranjeros derechos que, en principio, se reservan a favor de los españoles. Esta tesis, como ya señalamos, es sostenida por Vidal Fueyo ${ }^{209}$.

Retomando la argumentación previa, el TC debía determinar si el legislador orgánico respetó el contenido imperativo que, para el derecho de reunión, establece la Constitución. El alto tribunal no se cuestiona en ningún momento si cabe el establecimiento legal de una diferencia de trato en

excluía a los extranjeros, esto es, para afrontar la delicada cuestión de los derechos de los extranjeros en situación irregular.

207 F. J. 2º de la STC 155/1987, conforme al cual "el art. 21.1 CE afirma genéricamente que 'se reconoce el derecho de reunión pacifica y sin armas', sin ninguna referencia a la nacionalidad del que ejerce este derecho, a diferencia de otros artículos contenidos en el Tít. I, donde se menciona expresamente a los “españoles”, y a diferencia también de otras Constituciones comparadas donde este derecho expresamente se reserva a los ciudadanos".

208 En el mismo sentido, ALBA BASTARRECHEA, quien a propósito de esta argumentación del TC, sostiene que "hay derechos cuya vinculación con la dignidad humana podría ser discutible, pero que son de titularidad también de los extranjeros por mandato constitucional al disponer la propia Constitución una titularidad genérica y no específica para «los españoles» o «los ciudadanos». De esta manera, de forma negativa, el Tribunal Constitucional determina cuáles son los derechos sobre los que el legislador puede decidir la titularidad o no por parte de los extranjeros: únicamente aquellos que la Constitución, de forma expresa, reserva a los españoles o ciudadanos, a excepción de los derechos del artículo 23, cuya titularidad sólo podrá corresponder a los españoles, salvo en los términos expuestos por el artículo 13.2"; en "Derechos fundamentales y libertades públicas de los inmigrantes en España”, op. cit., p. 155. En la misma línea se inscribe GARCÍA ROCA quien, al hilo del derecho a la salud, reconocido constitucionalmente mediante el impersonal "se reconoce", señala que "una interpretación gramatical derivada de esta construcción pronominal impersonal (...) evidencia la indiferencia hacia el realizador de la acción característica de estas construcciones: el sujeto es toda persona"; en "La titularidad constitucional e internacional...", op. cit., p. 90.

209 VIDAL FUYEO, M.C. Constitución y extranjería, op. cit., p. 71, donde la autora propone que el art. 13.1 "vendría a constituir una habilitación al Estado para, mediante el tratado y la ley, y desde una plena libertad de configuración, extender a los extranjeros derechos que la Constitución no les reconoce expresamente, pero que tampoco les niega. Estos derechos van a contar con la eficacia y la tutela propia de los derechos fundamentales pero, al ser disponibles para el legislador, no pueden llamarse propiamente fundamentales”. Esta interpretación, que suscribimos, ya ha sido abundantemente analizada en apartados previos del presente capítulo. 
el ejercicio del derecho de reunión entre los extranjeros y los españoles, —de lo que se deduce que tanto el derecho de reunión como el de asociación quedan incluidos en la tercera tipología ya estudiada, aquellos derechos que admiten la modulación legislativa para el establecimiento de regímenes jurídicos diferenciados según se ejerciten por españoles o por extranjeros.

Sobre este punto, el TC estima que la necesidad de una autorización administrativa previa no constituye un requisito puramente procedimental, especialmente porque la Constitución española "ha optado por un sistema de reconocimiento pleno del derecho de reunión, sin necesidad de autorización previa (art. 21.1). Esta libertad de reunión sin autorización se constituye así en una facultad necesaria «para que el derecho sea reconocible como pertinente al tipo descrito»; al imponerse la necesidad de autorización administrativa se está desnaturalizando el derecho de reunión, consagrado en la Constitución «sin supeditarlo a la valoración discrecional y al acto habilitante y de poder implícito de la Administración»" ${ }^{210}$. En consecuencia, el TC declara la inconstitucionalidad de la exigencia legal de autorización administrativa previa para que los extranjeros pudiesen ejercitar el derecho de reunión.

En torno al derecho de asociación ${ }^{211}$ — cuya titularidad se reconocía a los extranjeros en la ley impugnada, pero estableciendo la posibilidad de suspensión administrativa cuando concurriesen determinadas circunstancias-, al TC se le planteaba la misma cuestión: determinar si el legislador respetó o no el contenido preceptivo establecido en el art. 22 CE. Para abordar esta tarea, el TC recuerda que el art. $22 \mathrm{CE}$, en contraste con otras Constituciones comparadas, reconoce también directamente a los extranjeros el derecho de asociación, subrayando asimismo el contenido del art. 22.4 de la Constitución — conforme al cual «las asociaciones sólo podrán ser disueltas o suspendidas en sus actividades en virtud de resolución judicial motivada»-. Para el TC, "este mandato del art. 22.4 constituye en puridad un contenido preceptivo del derecho de asociación que se impone al legislador en el momento de regular su ejercicio"212. De modo que el problema se traslada al estudio del art. 13.1 CE, a fin de determinar si esta disposición habilita o no al legislador a establecer una excepción para los extranjeros a la regla contenida en el art. 22.4 CE.

Uno de los aspectos más destacados de esta sentencia es que, al hilo de esta argumentación, el TC se ve obligado a examinar el alcance de la reserva legislativa establecida en el art. 13.1 CE, matizando su doctrina previa en torno la amplísima libertad de configuración legal en materia de extranjería. En este sentido, el TC señala que, aunque el art. 13.1 CE habilita al legislador para establecer condicionamientos adicionales al ejercicio de derechos fundamentales por parte de los extranjeros, éste ha de respetar en todo caso las prescripciones constitucionales. En torno al artículo 13.1 el TC estima que "no se puede estimar aquel precepto permitiendo que el legislador configure libremente el contenido mismo del derecho, cuando éste ya haya venido reconocido por la Constitución directamente a los extranjeros, a los que es de aplicación también el mandato contenido en el art. 22.4 de la Constitución. Una cosa es, en efecto, autorizar diferencias de tratamiento entre españoles y extranjeros, y otra es entender esa autorización como una posibilidad de legislar al respecto sin tener en cuenta los mandatos constitucionales" ${ }^{213}$. En consecuencia, la libertad legislativa no es en modo alguno absoluta, consti-

210 F. J. $2^{\circ}$. STC $115 / 1987$.

211 El art. 8.2 de la Ley Orgánica 7/1985, de 1 de julio, establecía: «El Consejo de Ministros, a propuesta del Ministro del Interior, previo informe del de Asuntos Exteriores, podrá acordar la suspensión de las actividades de las Asociaciones promovidas e integradas mayoritariamente por extranjeros, por un plazo no superior a seis meses, cuando atenten gravemente contra la seguridad o los intereses nacionales, el orden público, la salud o la moral pública o los derechos y libertades de los españoles».

212 STC 115/1987, F. J. $3^{\circ}$.

213 Idem. 
tuyendo el contenido esencial del derecho el tope constitucional infranqueable para la intervención legislativa en este ámbito ${ }^{214}$.

Dado que la posibilidad de suspensión administrativa es incompatible con la garantía del derecho de asociación - art. 22.4 CE-, el TC declara su inconstitucionalidad. Finalmente el TC estimó contrario al art. $24 \mathrm{CE}$ la imposibilidad que establecía la LO 7/85 ${ }^{215}$ de acordar la suspensión judicial de resoluciones administrativas en materia de extranjería, requiriendo ponderación judicial en cada caso.

Con esta sentencia, el TC operó un giró radical a la doctrina mantenida hasta el momento en materia de extranjería e inmigración. La reducción del margen de actuación legislativa sobre los derechos de los extranjeros anteriormente calificados de configuración legal - precisamente aquellos sobre los que opera la reserva legal del art. 13.1 CE-, constituye, a nuestro juicio, una de las grandes virtudes de esta sentencia. De hecho, la forma de proceder en ella del TC, declarando la inconstitucionalidad de tres de las cuatro disposiciones impugnadas, representa la consolidación de la teoría de los límites - en este caso, constitucionales - a las posibles restricciones legislativas de los derechos de los extranjeros en España. En esta línea, Eliseo Aja ha hecho énfasis en la trascendencia de este pronunciamiento, señalando que con ella el TC, "al anular las limitaciones de la ley a los derechos de los inmigrantes descartaba la posibilidad de que los derechos dependieran $<$ de los tratados y la ley> sin límites y exigía el respeto a los derechos, al menos a los afectados por la sentencia, en los términos que establecía la Constitución. El TC iniciaba así una línea progresiva de reconocimiento a los extranjeros de derechos que la Constitución parecía reservar a los españoles, que coincidía con la evolución de los Estados democráticos de Europa"216.

En el análisis realizado para evaluar las restricciones a los derechos tanto de reunión como de asociación, el TC se centró en determinar si éstas habían respetado el contenido esencial de ambos derechos. Se trata de derechos correspondientes al grupo que, por no ser considerados absolutamente imprescindibles para la dignidad humana, admiten modulaciones legislativas en su contenido material. En consecuencia, del razonamiento empleado por el TC, cabe deducir que la libertad del legislador en el desarrollo normativo de la tercera categoría de derechos - derechos de configuración legal-, se topa con el límite absoluto representado por el contenido esencial del derecho fundamental de que se trate ${ }^{217}$. Contra este sentir mayoritario se alzaron tres magistrados - don Francisco Rubio Llorente, don Francisco Tomás y Valiente y don Fernando García-Mon - en el voto particular que contiene esta sentencia. La calidad de su argumentación, lo hacen merecedor de ocupar un lugar destacado en este pronunciamiento.

214 En idéntico sentido, GARCÍA ROCA, J. "La titularidad constitucional e internacional de los derechos fundamentales de los extranjeros...”, op. cit., p. 83. También ÁLVAREZ-OSSORIO MICHEO, Fernando. "Los derechos fundamentales de los extranjeros en España”; en CARRILLO SALCEDO, J.A. La Ley de Extranjería a la luz de las obligaciones de España en Derechos Humanos. Akal, Universidad de Andalucía, 2002, p. 88. VIDAL FUEYO, M.C. Constitución y extranjería, op. cit., p. 119, quien matiza más adelante que el respeto al contenido esencial viene obligado por el art. 53.1 CE, afectando tanto a lo derechos fundamentales como a las libertades públicas; idem, p. 123.. En una línea similar, pero más crítica, se manifiesta JIMÉNEZ DE PARGA, Manuel, considerando que esta visión constituye "una interpretación my restrictiva del alcance de la cláusula que remite la regulación a la ley, de tal modo que la misma sólo permite diferencias de tratamiento, diferentes regulaciones del ejercicio de determinados derechos según se trate de españoles o de extranjeros, pero tal diferencia de regulación no permite que se vea afectado el contenido esencial del derecho"; en "La inmigración en la jurisprudencia del TC español", op. cit., sp.

$215 \mathrm{El}$ artículo 34 de la citada ley estipulaba que: “"Las resoluciones administrativas adoptadas en relación con los extranjeros serán recurribles con arreglo a lo dispuesto en las Leyes. En ningún caso podrá acordarse la suspensión de las resoluciones administrativas adoptadas de conformidad con lo establecido en la presente Ley».

216 AJA, Eliseo (coord.). La nueva regulación de la inmigración en España, op. cit., pp. 23-24.

217 En el mismo sentido, ALBA BASTARRECHEA, E. “Derechos fundamentales y libertades públicas...”, op. cit., p. 155. 
El voto particular formulado a la STC 115/1987 contiene un entendimiento distinto del artículo $13.1 \mathrm{y}$, de forma derivada, del sistema de derechos fundamentales de los extranjeros, sobre la base de una interpretación diferente del término "libertades públicas" utilizado por dicha disposición. A juicio de los tres magistrados disidentes, la concepción mantenida por el TC en torno al art. 13.1 CE supone un vaciamiento de dicha disposición, convirtiéndola en un artículo superfluo ${ }^{218}$, pues de una interpretación a contrario sensu del principio de igualdad del art. 14 CE se deduce ya la posibilidad de que, por vía legislativa, se introduzcan tratamientos jurídicos diferenciados para los extranjeros, sin necesidad de recurrir al artículo 13.1 CE.

El voto particular estima que, al usar exclusivamente el término "libertades públicas" —con exclusión expresa del de derechos fundamentales-, el art. 13.1 CE implica "que el legislador español está obligado a otorgar a los extranjeros que viven legalmente en España el uso de las libertades públicas que garantiza el Título I, pero, también sin duda, que esas libertades no tienen otro contenido que aquel que establezcan los tratados y la ley" ${ }^{219}$. No cabe pues la supresión de tales libertades públicas a los extranjeros, pero si una libertad de configuración legislativa que no es absoluta. Sin embargo, los límites al desarrollo legislativo en el ámbito de la extranjería y la inmigración no derivarían de lo prescrito constitucionalmente al regular las libertades públicas de los españoles, sino de los tratados internacionales, tal como se deduce de la conjunción de los artículos 13.1 y 10.2 del texto constitucional.

En base a esta lectura restrictiva del término libertades públicas propuesta en el voto particular $^{220}$, el contenido mínimo o esencial de los derechos fundamentales de los extranjeros estaría determinado por la Constitución y por los Tratados y Convenios sobre derechos humanos, que integrarían ambos "el bloque de constitucionalidad del régimen jurídico público de los derechos fundamentales de los extranjeros"221. Con ello, el contenido internacionalmente declarado se alzaría como el límite al legislador estatal que pretenda incluir una regulación distinta de determinados derechos de los extranjeros ${ }^{222}$. Frente a la concepción mayoritaria que cifra en el contenido esencial el límite a la libertad de configuración legislativa en esta materia, el voto disidente otorgaba a los tratados internacionales dicha función limitativa. En suma, el voto particular contiene una visión de los derechos de los extranjeros que supone dotar al legislador internacional de un margen amplio de apreciación en la determinación del contenido del estatuto jurídico de los extranjeros en España, con el límite insoslayable que deriva del estandard mínimo.

A juicio de los magistrados disidentes, el legislador puede excluir del disfrute de las libertades públicas a colectivos determinados o bien reducir su contenido. En la sentencia objeto de enjuiciamiento, se trataría de la exclusión de los extranjeros que no cuentan con residencia legal con respecto al ejercicio de los derechos de reunión y asociación. Dichas limitaciones legales encajan, a juicio

218 En el voto particular a la STC 115/1987 se afirma en relación al art 13.1 CE, que "ese precepto constitucional queda totalmente vaciado de contenido, pues es claro que si su significado se redujese, como se pretende, a la habilitación al legislador para modular o regular de manera distinta los derechos fundamentales y libertades públicas de los extranjeros en relación con los de los españoles, pero sin traspasar en ningún momento los límites implícitos o explícitos que el contenido constitucionalmente garantizado de estos derechos ha de tener, el precepto en cuestión resultaría perfectamente superfluo, pues la posibilidad de esa regulación diferenciada se deduce ya «a contrario» del art. 14 de la Constitución que refiere sólo a los españoles el principio de igualdad ante la Ley".

219 Énfasis añadido propio.

220 VIDAL FUEYO, M.C. Constitución y extranjería, op. cit., p. 122.

221 ÁLVAREZ-OSSORIO MICHEO, Fernando. "Los derechos fundamentales de los extranjeros en España"; en CARRILLO SALCEDO, J.A. La Ley de Extranjería a la luz de las obligaciones de España en Derechos Humanos. Akal, Universidad de Andalucía, 2002, p. 88. 
de los magistrados señalados, en lo autorizado por los Tratados internacionales, resultando por ello perfectamente conformes con la Constitución.

La interpretación contenida en el voto particular analizado ha sido considerada por un importante sector doctrinal más acorde con la Constitución ${ }^{223}$, además de resolver algunos importantes problemas que genera la interpretación mayoritaria del TC. Entre ellos, se ha apuntado la ausencia de un criterio claro para la asignación de los distintos derechos de los extranjeros en cada uno de los tres bloques, basado en la concreta naturaleza del derecho implicado y excluyendo como parámetros fiables tanto la literalidad del precepto constitucional que delimita el régimen jurídico de dicho derecho, como la concreta ubicación del mismo dentro del Título I CE ${ }^{224}$.

A nuestro juicio, esta visión discrepante, si bien es cierto que delimita un parámetro más diáfano para la distribución de los derechos de los extranjeros frente al vaporoso concepto de la dignidad humana, sin embargo presenta también inconvenientes que podrían llegar a superar con creces las desventajas que representa la interpretación clásica ${ }^{225}$. Entre ellos, la amplia libertad de configuración legislativa - con el tope representado por el derecho internacional general y convencional- y la potencial visión estrecha de la extranjería y la inmigración, especialmente arriesgada ante una materia sometida a excesivos vaivenes políticos y legislativos. Por no hablar del contenido habitualmente más angosto, reducido de los tratados internacionales, que podría habilitar intervenciones legislativas de carácter restrictivo, —si bien este extremo suele aparecer neutralizado por lo prescrito en los propios convenios internacionales-.

Posteriormente, en la STC 221/1988 ${ }^{226}$, dictada para resolver un recurso de amparo promovido por el Colegio Oficial de odontólogos y estomatólogos de una localidad española, el TC ofrece algunos matices que ayudan a perfilar mejor el papel que corresponde al legislador internacional en el diseño del estatuto jurídico del extranjero en España. El recurrente alegaba que la colegiación en

223 Vid, entre otros autores, PÉREZ VERA, E. “Artículo 13. Extranjería”, op. cit., p. 201. Para esta autora, la distinción entre los derechos fundamentales — no incluidos en el art. 13.1 CE-, y las libertades públcas, acogidas por dicha disposición, constituye un criterio que aporta mayor claridad, pues permite "determinar los derechos que gozan de un contenido esencial inalterable por el legisaldor frente a las libertades públicas que no tienen más contenido que el dispuesto por los tratados y la ley". El criterio propuesto por el voto particular se contrapone con el criterio mayoritario aprobado por el TC, al que esta autora califica como "confuso", conforme al cual "es la naturaleza del derecho la que delimitará a sus titulares, sin que sea definitivo ni la inclusión del mismo en el Título I, Sección $1^{\text {a }}$, de la Constitución ni tampoco la literalidad del precepto", idem, pp. 200-201. En contra de esta interpretación se encuentra otro sector donde se sitúan, entre otros muchos, VIDAL FUEYO, quien advierte que entonces no sería legítimo hablar de libertades públicas, sino más bien de "libertades legalmente reconocidas", recordando que también sobre las libertades públicas pesa la obligación de respetar el contenido esencial, tal y como prescribe el art. 53.1 CE. Constitución y extranjería, op. cit, pp. 122 y 123.

224 PÉREZ VERA, E. “Artículo 13...”, op. cit, pp. 200-201.

225 En sentido contrario al voto particular estudiado se pronuncia BASTARRACHEA ALBA, quien también subraya el riesgo que supondría el eventual carácter menos garantista de los convenios internacionales, si bien puntualiza que esta interpretación minoritaria sería posteriormente asumida por el grueso del TC a mediados de la década de los noventa; en "Derechos fundamentales y libertades públicas de los inmigrantes...”, op. cit., p. 156. En la misma línea se inscribe la interpretación efectuada por ÁLVAREZ-OSSORIO, F. "Los derechos fundamentales de los extranjeros en España”, op. cit., p. 88. En sentido crítico se incluye GARCÍA ROCA, quien "discrepa radicalmente" del voto particular analizado, señalando que el mismo constituye "una posición disidente, bien redactada y motivada y en apariencia brillante, pero estéril y formalista, desconectada de la realidad, y constitucionalmente inadecuada para los inevitables fines de integración de los inmigrantes en el Estado"; en "La titularidad constitucional e internacional de los derechos fundamentales de los extranjeros..., op. cit., p. 85. Más adelante, el mismo autor advierte que esta posición, de admitirse, terminaría desconstitucionalizando los derechos de los extranjeros en su objeto y contenido; idem, p. 108.

226 STC 221/1988, de 24 de abril. BOE nº 306, de 22 de diciembre de 1988. 
España de un Odontólogo titulado en Argentina suponía una manifiesta discriminación frente a los profesionales españoles del mismo ramo quienes, desde la supresión de la Escuela de Odontología, se veían obligados a cursar la carrera de Medicina más los estudios de la especialidad de Estomatología, de duración muy superior a los estudios equivalentes en Argentina ${ }^{227}$. El TC, respetando el tratado internacional suscrito por ambos países que permitía la convalidación de títulos argentinos, reafirma la sustancial igualdad de que gozan los odontólogos argentinos en España, confirmando su derecho a la colegiación en España en las mismas condiciones que sus homólogos españoles y desestimando el amparo por inexistencia de discriminación.

\subsection{Tercera etapa en la evaluación de la jurisprudencia Constitucional relativa al estatuto de los extranjeros}

Las sentencias dictadas en esta etapa contienen, con carácter general, doctrina más puntual no de tan amplio espectro como las emitidas previamente- pero, pese a ello, ofrecen avances muy significativos que denotan una aproximación del TC al ámbito de la extranjería y la inmigración desde una óptica claramente más progresista. El año 1993 resulta especialmente significativo porque el alto tribunal cambia su línea jurisprudencial previa respecto a los derechos proclamados por el art. $19 \mathrm{CE}$, permitiendo con ello la llegada en amparo de recursos presentados por extranjeros en una materia altamente litigiosa. Hasta dicho momento tales recursos habían sido sistemáticamente inadmitidos en aplicación de la doctrina establecida en la STC 99/85, que excluía de forma expresa a los extranjeros de la titularidad del elenco de derechos relacionados con la libertad circulatoria del art. 19 CE. El cambio es de enorme trascendencia, pues los conflictos provocados por la violación de tales derechos son cuantitativamente los más abundantes en el ámbito migratorio, especialmente los que tienen su origen en órdenes de expulsión.

La nueva línea jurisprudencial apuntada se inaugura con la STC 94/1993 ${ }^{228}$. Esta sentencia puso fin a un recurso de amparo formulado por una ciudadana filipina contra la resolución que ordenó su expulsión del territorio español, alegando vulneración del derecho a la libre elección de residencia y circulación por el territorio nacional reconocido en el art. 19 CE. La orden de expulsión fue dictada y ejecutada sin que a la actora - que contaba con permiso de trabajo y residencia recién expirados-, se le hubiese resuelto la renovación del permiso de residencia que había solicitado previamente. De hecho, la incoación del expediente de expulsión tuvo lugar el mismo mes en que las autoridades laborales habían concedido a la interesada la renovación de su permiso de trabajo.

Como cuestión previa al presente recurso, el TC se planteó si un extranjero podía ser titular del derecho fundamental de circulación y, en su caso, con qué alcance. El planteamiento de esta cuestión resulta en sí mismo sorprendente, teniendo en cuenta la rotundidad con que la jurisprudencia cons-

227 El recurso traía origen de dos sentencias previas, donde se reconocía el derecho de un odontólogo argentino a colegiarse como tal en España y ejercer en nuestro país su profesión, en aplicación de un Convenio de cooperación cultural hispano-argentino que permitía convalidar en España el título de odontología expedido en Argentina. El recurrente fundaba su demanda de amparo en dos motivos distintos. En primer lugar, alegaba la vulneración de su derecho a la tutela judicial efectiva (art. $24 \mathrm{CE}$ ), por no haber sido debidamente emplazado en la primera instancia. En segundo término, alegaba que las sentencias recurridas incurrían en discriminación contraria al art. $14 \mathrm{CE}$, pues confirmaban el agravio comparativo en que se encontraban los odontólogos españoles en relación con los titulados argentinos en odontología que deseasen ejercer esa profesión en España, mediante la convalidación del título obtenido en su país de origen.

228 STC 94/1993, de 22 de marzo. BOE no 100 de 27 de abril. 
titucional previa había excluido sistemáticamente a los extranjeros de la titularidad y disfrute del derecho proclamado en el artículo $19 \mathrm{CE}$, apoyándose en la dicción literal de dicha disposición ${ }^{229}$.

En esta ocasión - y en claro contraste con anteriores argumentaciones-, el TC estima que la interpretación gramatical del artículo 19 CE no es suficiente ${ }^{230}$ porque, junto a esta disposición es necesario considerar el art. 13.1 CE. Recurriendo pues a la interpretación sistemática, el alto tribunal conjuga la afirmación a favor del goce por los extranjeros de los derechos del Título I CE - art. 13.1CE - , con la reserva a favor "solamente" de los españoles de los derechos del artículo 23 - art. 13.2 CE-, concluyendo que "resulta claro que los extranjeros pueden ser titulares de los derechos fundamentales a residir y a desplazarse libremente que recoge la Constitución en su art. 19"231. La titularidad activa del conjunto de derechos que, en torno a la libertad deambulatoria, consagra el artículo $19 \mathrm{CE}$, se presenta como una posibilidad ${ }^{232}$ a favor de los extranjeros, pese a la dicción literal de esta disposición, que habla de los españoles. En apoyo de esta conclusión, el TC cita la línea jurisprudencial progresiva que en esta materia el Tribunal Supremo había emitido sin fisuras desde inicios de la década de los ochenta, anticipándose con ello a lo que mucho después confirmaría el TC.

De esta forma, un derecho que, retomando la clásica división tripartita, correspondería en exclusiva a los españoles — segundo grupo de derechos-, asciende a la tercera categoría — derechos que corresponden a los extranjeros en función de lo establecido por los tratados y las leyes-, como consecuencia de la interpretación integradora de corte claramente progresista efectuada por el TC, aun en contra del tenor literal del precepto constitucional. Con ello, la sentencia abre las puertas no solamente a futuros amparos presentados por los extranjeros en relación con vulneraciones cometidas en los procedimientos relacionados con la entrada y permanencia de no nacionales en te-

229 Vid, STC 99/85, de 30 de septiembre, F. J. 3º; Auto 182/85, de 13 de marzo, donde, en aplicación de la anterior doctrina, se inadmite un recurso de amparo interpuesto por un extranjero y basado en la violación de art. 19 CE, por considerar que los derechos reconocidos en dicha disposición constitucional sólo son predicables de los españoles. Esta postura del TC se repite de forma sistemática hasta el año 1993.

230 F. J. 2 ${ }^{\circ}$ STC 94/1993: "Ahora bien, la inexistencia de declaración constitucional que proclame directamente la libertad de circulación de las personas que no ostentan la nacionalidad española no es argumento bastante para considerar resuelto el problema, como ya se indicó respecto a una cuestión similar planteada por el principio de igualdad ex art. 14 CE en la STC 107/1984, fundamento jurídico 3. ${ }^{\circ}$ La dicción literal del art. 19 CE es insuficiente porque ese precepto no es el único que debe ser considerado; junto a él, es preciso tener en cuenta otros preceptos que determinan la posición jurídica de los extranjeros en España entre los que destaca el art. 13 de la Constitución”.

231 "El presente recurso suscita la cuestión previa de si un extranjero puede ser considerado titular del derecho fundamental de circulación, y en su caso con qué alcance. Tanto el Abogado del Estado como el Ministerio Fiscal enfatizan que el texto del art. 19 CE solamente alude a «los españoles». Ahora bien, la inexistencia de declaración constitucional que proclame directamente la libertad de circulación de las personas que no ostentan la nacionalidad española no es argumento bastante para considerar resuelto el problema, como ya se indicó respecto a una cuestión similar planteada por el principio de igualdad ex art. 14 C.E. en la STC 107/1984, fundamento jurídico 3. La dicción literal del art. $19 \mathrm{CE}$ es insuficiente porque ese precepto no es el único que debe ser considerado; junto a él, es preciso tener en cuenta otros preceptos que determinan la posición jurídica de los extranjeros en España, entre los que destaca el art. 13 de la Constitución. Su apartado 1 dispone que los extranjeros gozan en España de las libertades públicas que garantizan el Título I de la Constitución, aun cuando sea en los términos que establezcan los tratados y la Ley, como se dijo en las SSTC 107/1984, 99/1985 y 115/1987. Y el apartado 2 de este art. 13 solamente reserva a los españoles la titularidad de los derechos reconocidos en el art. $23 \mathrm{CE}$, con el alcance que precisamos en la Declaración de 1 de julio de 1992 y que ha sido objeto de la reforma constitucional de 27 de agosto de 1992. Por consiguiente, resulta claro que los extranjeros pueden ser titulares de los derechos fundamentales a residir y a desplazarse libremente que recoge la Constitución en su art. 19. Al afirmar lo contrario, la Sentencia de apelación aquí recurrida rompió, de manera abrupta e inexplicada, con una firme línea jurisprudencial del propio Tribunal Supremo, que se mantiene desde sus Sentencia de 25 de junio y 3 de julio de 1980 ”, F. J. $2^{\circ}$.

232 ÁLVAREZ-OSSORIO, F. "Los derechos fundamentales de los extranjeros en España”; en CARRILLO SALCEDO, J.A. (coord). La Ley de Extranjería a la luz de obligaciones de España en derechos humanos, op. cit., p. 92 
rritorio español — precisamente los más frecuentes estadísticamente en este ámbito-, cambiando radicalmente su anterior punto de vista, marcado por una denegación sistemática de la admisión de recursos de amparo presentados por extranjeros sobre la base del art. $19 \mathrm{CE}^{233}$. Además, y más importante todavía, al desprenderse de la dicción gramatical de los preceptos constitucionales para la determinación de la titularidad activa de los derechos fundamentales, permite ampliaciones futuras con respecto a derechos de cuya titularidad, en modo similar al art. 19 CE, la interpretación constitucional gramatical podría conducir a la exclusión de los extranjeros ${ }^{234}$.

Pese a este reconocimiento, el TC matiza que una "cuestión distinta, sin embargo, es el alcance que despliega la protección constitucional a los desplazamientos de extranjeros en España. La libertad de circulación a través de las fronteras del Estado, y el concomitante derecho a residir dentro de ellas, no son derechos imprescindibles para la garantía de la dignidad humana, ni por consiguiente pertenecen a todas las personas en cuanto tales al margen de su condición de ciudadano"235. En consecuencia, resulta lícita la modulación legislativa de su contenido en función de la nacionalidad de las personas, si bien es cierto que la libertad del legislador, aun siendo amplia, no es absoluta. Para dicha modulación resulta necesario, por expreso imperativo constitucional — art. 10.2 CE- recurrir a los tratados internacionales sobre la materia ratificados por España, pues los convenios internacionales suscritos por España en este ámbito no pueden ser ignorados. En el caso que nos ocupa resulta esencial, por su trascendencia interpretativa, acudir a los artículos 12 y 13 del Pacto Internacional de Derechos Civiles y políticos ${ }^{236}$, de los que se deduce que "los extranjeros que por disposición de una Ley o de un tratado, o por autorización concedida por una autoridad competente, tienen derecho a residir en España, gozan de la protección que brinda el art. 19 C.E., aún cuando no sea necesariamente en idénticos términos que los españoles, sino en los que determinen las Leyes y tratados a los que se remite el art. 13.1 C.E”.

El auxilio del criterio internacionalista resulta determinante para la concesión del amparo como consecuencia de la ilicitud de la expulsión, que fue adoptada prescindiendo de si la actora tenía o no derecho a permanecer en España ${ }^{237}$. Y, lo que es más trascendente, al proceder de esta manera, el

233 VIDAL FUEYO puntualiza que en el período que media entre la STC 107/1984, resuelta en noviembre de dicho año, y marzo de 1993, cuando se dicta la STC 94/1993 objeto de análisis, el TC inadmitió a trámite recursos de amparo formulados por extranjeros por supuesta vulneración del art. $19 \mathrm{CE}$, por estimarlo una materia de estricta legalidad para los no nacionales. "La jurisprudencia del TC en materia de derechos fundamentales ...., op. cit., p. 359.

234 En sentido idéntico, Eliseo AJA señala que con la STC 94/1993 el TC "alcanza tres nuevas fronteras: dejar de lado la dicción literal de los titulares de los derechos, reconocer a los extranjeros también los derechos del artículo 19 $\mathrm{CE}$, que sistemáticamente había sido negado hasta entonces y atraer, por esta vía, el amparo para muchas de las vulneraciones relacionadas con la entrada o la permanencia de los extranjeros en España"; en "Veinte años de doctrina del TC...", op. cit., p. 446.

235 STC 94/1993, F. J. 3º.

236 "Es pues lícito que las leyes y los tratados modulen el ejercicio de esos derechos en función de la nacionalidad de las personas, introduciendo tratamientos desiguales entre españoles y extranjeros en lo que atañe a entrar y salir de España, y a residir en ella. La libertad del legislador al configurar los derechos de los nacionales de los distintos Estados, en cuanto a su entrada y permanencia en España, es sin duda alguna amplia. Pero no es en modo alguno absoluta, como da por supuesto la Sentencia impugnada en este recurso de amparo. El Pacto Internacional de Derechos Civiles y Políticos de 1966 que - a diferencia del Cuarto Protocolo del Convenio Europeo de Derechos Humanos - se encuentra ratificado por España, no puede ser ignorado a la hora de interpretar los arts. 19 y 13 de la Constitución, por imperativo de su art. 10.2. Las Leyes y tratados que regulan la circulación de extranjeros en España deben respetar el grado, limitado pero cierto, de libertad que reconocen los arts. 12 y 13 del Pacto internacional a todas las personas que se hallan legalmente en el territorio del Estado", F. J. 3º, STC 94/1993.

237 En palabras del TC, "la Administración no puede expulsar por carecer de la documentación preceptiva a quien ha instado su expedición sin haber resuelto previamente si tiene derecho o no a obtener el permiso de residencia, pues de lo contrario vulnera el derecho fundamental que el art. 19 CE otorga limitadamente a los extranjeros". 
TC está delimitando el contenido del derecho proclamado en el art. 19 CE no por referencia al contenido esencial derivado del texto constitucional, sino del que se extrae de un tratado internacional suscrito por España. Parecería que en esta ocasión los magistrados del TC están asumiendo, sin hacerlo explícito, la doctrina que de forma minoritaria fue expuesta por los tres magistrados disidentes en la sentencia que en 198 puso fin al primer recurso de inconstitucionalidad planteado contra la ley orgánica de extranjería ${ }^{238}$. Esta forma de razonar implica que el TC está yendo más allá del criterio internacionalista exegético del art. 10.2CE, utilizando el contenido internacional de un derecho como límite indisponible del legislador interno, de modo tal que en, materia de extranjería, los tratados sobre derechos humanos suscritos por el Estado español integrarían, junto con la Constitución, "el bloque de constitucionalidad del régimen jurídico público de los derechos fundamentales de los extranjeros"239 en España, si bien esta interpretación dista de ser pacífica en el ámbito doctrinal ${ }^{240}$.

La relevancia implícita a esta forma de proceder del TC, en conjunción con la importancia de la doctrina que explícitamente avanza estimando que todo extranjero en situación de regularidad administrativa pasa a estar tutelado por el art. $19 \mathrm{CE}$ - lo que supone que sus derechos trascienden el plano de la mera legalidad, poseyendo una cobertura constitucional ${ }^{241}-$, dotan a esta sentencia, como ha señalado Eliseo Aja, de una gran trascendencia en materia migratoria ${ }^{242}$. El TC, al reconocer que el art. 19 constituye también un derecho constitucional de los extranjeros, está al mismo tiempo garantizando el derecho a permanecer en España de aquellos no nacionales que cumplan con los requisitos legalmente establecidos y, en consecuencia, ampliando el ámbito de protección

238 A la misma conclusión llega ALBA BASTARRECHEA, E. quien señala que el voto particular contenido en la STC 115/87 "fue la primera manifestación del posterior criterio mayoritario del Tribunal Constitucional que entiende que el legislador tiene la posibilidad de atribuir derechos a los extranjeros con los límites no de la regulación constitucional de los mismos derechos para los españoles, sino de la regulación de tales derechos en los tratados internacionales ratificados por España"; en "Derechos fundamentales y libertades públicas de los inmigrantes en España”, op. cit., p. 156. También es de la misma opinión ÁLVAREZ-OSSORIO, subrayando que esta doctrina minoritaria contenida en el voto particular de la STC 115/1987, sería acogida por el TC posteriormente, en la STC 94/93, afirmando que "el TC deja de anudar el límite al legislador en el contenido del derecho o libertad fundamental, es decir, en lo que sería su contenido esencial constitucionalmente declarado, para extraerlo del reconocimiento y garantía que ese mismo derecho encuentra en un concreto Tratado internacional suscrito y ratificado por el Estado español"; ÁLVAREZ-OSSORIO MICHEO, Fernando. "Los derechos fundamentales de los extranjeros en España", op. cit., p. 88. A esta interpretación también parece adherirse tácitamente Cano Bueno, cuando afirma que conforme al criterio internacional de interpretación de los derechos y libertades de los extranjeros —art. 10.2 CE—, "los extranjeros serán titulares de los derechos que la CE no reserve en exclusiva a los españoles y de los derechos cuya titularidad pueda serles otorgada, a partir de la DUDH y de los Tratados suscritos por España, entre los que cabe destacar el CEDH (...) con relación a los extranjeros las leyes y los tratados determinan el grado de difrute de los derechos y libertades, pudiendo regular su ejercicio y establecer los procedimientos que los hagan plenamente efectivos". CANO BUENO, Juan. "Los derechos de los extranjeros en España: una perspectiva constitucional”; en Corts, Anuario de Derecho Parlamentario, n 15, 2004, p. 164.

239 ÁLVAREZ OSSORIO, F. “Los derechos fundamentales de los extranjeros...”, op. cit., p. 88.

240 Radicalmente en contra de esta perspectiva se pronuncia GARCÍA ROCA, quien manifiesta que la interpretación asumida supondría una desconstitucionalización del régimen de la inmigración y extranjería en nuestro país. "La titularidad constitucional e internacional de los derechos fundamentales de los extranjeros...”, op. cit., p. 108.

241 VIDAL FUEYO, M.C. "La sentencia del Tribunal Constitucional 72/2005, de 4 de abril, en materia de libertad de entrada y residencia de los extranjeros en España”, op. cit, p. 433.

$242 \mathrm{El}$ autor continua explicando que "la razón de un cambio tan importante estriba en que el caso concreto no consistía en la vulneración de algún derecho diferenciado, que pudiera remediarse en sí mismo, sino en la vulneración general del régimen de extranjería: el derecho a permanecer en España cuando se cumplen las condiciones exigidas por la legislación. Esta protección exige la atribución a todas las personas del derecho reconocido en el artículo 19 $\mathrm{CE}$, la libertad de circulación y el derecho a entrar y salir del país libremente, siempre que se realice legalmente. Varias Sentencias posteriores han consolidado y profundizado esta orientación constitucional”. AJA, Eliseo. "Hacia la igualdad de derechos"; en La Factoría, n 5, febrero-mayo 1998 sp. 
que la Constitución les otorga. Sin embargo, conviene matizar que del amplio haz de derechos ligados a la libertad deambulatoria habría que excluir el derecho de entrada en el país, que pertenece en exclusiva a los españoles ${ }^{243}$.

La STC 116/1993 ${ }^{244}$ analiza también una orden de expulsión dictada contra un trabajador extranjero que había sido previamente despedido de forma improcedente - al solicitar su reinserción laboral tras disfrutar de un período de excedencia-. En el recurso estaban en juego, junto con el art. 24 y la libertad circulatoria del art. 19, el principio de legalidad y tipicidad sancionadora del art. 25 $\mathrm{CE}$, puesto que la expulsión fue dictada en aplicación de una norma preconstitucional —el Decreto 522/1974 sobre régimen, permanencia y expulsión de los extranjeros-, que tipificaba las conductas infractoras con escaso grado de certeza y concreción.

En respuesta a las objeciones formuladas por el Ministerio Fiscal en el sentido de que la expulsión de un extranjero no afectaba a las previsiones del art. 19 CE por aludir éste únicamente a los españoles, el TC se reafirma en su anterior doctrina ${ }^{245}$, señalando inequívocamente que "resulta claro que los extranjeros son titulares de los derechos fundamentales a residir y a desplazarse libremente que recoge la Constitución en su art. 19"246. Queda pues confirmada la titularidad activa de los derechos de libertad deambutaroria del art. 19 a favor de los extranjeros.

El TC concluye conceder el amparo ya que la sanción de expulsión carecía de la necesaria cobertura legal: la norma preconstitucional aplicada incluía conceptos que por su amplitud y vaguedad dejaban en la más absoluta indefinición los tipos punibles y, en consecuencia, impedía predecir con suficiente grado de certeza las conductas que constituían la infracción merecedora de la expulsión de los extranjeros, en transgresión del art. 25 CE.

Poco tiempo después, el TC resuelve otro recurso de amparo motivado por una orden de expulsión acordada como medida sustitutiva de la condena penal ${ }^{247}$ que se le había impuesto a un extranjero como consecuencia de la comisión de un delito de robo. La medida de expulsión se dictó en contravención de las necesarias garantías jurídicas - sin motivación ni previa audiencia del interesado ni derecho de defensa, siendo además efectuada en el mismo cuerpo condenatorio de la sentencia penal y no en un acto separado-. Se trata de la STC 242/1994 ${ }^{248}$ donde el TC da un salto cualitativo, si bien es cierto que éste se había ido gestando progresivamente en las anteriores sentencias.

243 JOVER GOMEZ FERRER, Rafael; ORTEGA CARBALLO, Carlos y RIPOLL CARULLA, Santiago. "Derechos fundamentales de los extranjeros en España. Valladolid, Lex Nova, 2010, p. 71.

244 STC 116/93, de 29 de marzo. BOE nº 107, de 5 de mayo.

245 De forma expresiva, FERNÁNDEZ-OSSORIO, en relación con la confirmación de la doctrina que el TC había emitido en la sentencia previa sobre esta materia, señala que "aquel pueden ser titulares del derecho a la libertad de circulación de la STC 94/93 (...) se transformaría en son titulares"; en "Los derechos fundamentales de los extranjeros en España”, op. cit., p. 92.

246 F. J. 2º, STC 116/1993. Con carácter previo, el TC había vuelto a repetir que "la inexistencia de declaración constitucional que proclame directamente la libertad de circulación de las personas que no ostentan la nacionalidad española no es argumento bastante para considerar resuelto el problema, como ya se indicó respecto a una cuestión similar planteada, por el principio de igualdad ex art. 14 C.E. en la STC 107/1984, fundamento jurídico 3. La dicción literal del art. 19 C.E. es insuficiente...”.

247 El problema planteado en este caso trae causa de la aplicación de lo establecido en el entonces vigente art. 21.2 de la LO 7/1985, según el cual: «Si el extranjero fuera condenado por delito menos grave y en sentencia firme, el Juez o Tribunal podrá acordar previa audiencia de aquél, su expulsión del territorio nacional como sustitutiva de las penas que fueran aplicables, asegurando en todo caso la satisfacción de las responsabilidades civiles a que hubiera lugar, todo ello sin perjuicio de cumplir, si regresara a España, la pena que le fuese impuesta»

248 STC 242/1994, de 27 de julio. BOE nº 197 de 18 de agosto de 1994. 
En este pronunciamiento, el TC amplía aún más el abanico de derechos que pueden ser potencialmente disfrutados por los extranjeros, continuando con la senda abierta por la STC 94/93. Apoyándose en la anteriormente comentada STC 116/93, el alto tribunal señala que el punto de referencia para determinar el régimen jurídico de los extranjeros parte de la "única exclusión" prevista por el artículo 23 CE para dicho colectivo - "el apartado 2 del art. 13 solamente reserva a los españoles la titularidad de los derechos reconocidos en el art. 23 C.E ${ }^{\circ 249}$. En consecuencia, salvo con la excepción única de los derechos reconocidos en el art. $23 \mathrm{CE}$, los extranjeros disfrutan de los derechos fundamentales reconocidos en el Título I $\mathrm{CE}^{250}$. De otro lado, afirma explícitamente que el legislador está limitado de forma absoluta por el contenido constitucional de los derechos de los extranjeros así como el que se deriva de los tratados internacionales ${ }^{251}$, confirmando nuevamente el papel determinante de los convenios internacionales como límites a la intervención del legislador interno en materia migratoria. Y, volviéndose a desligar del criterio interpretativo literal y gramatical, señala que "en concreta relación con el derecho de residencia y desplazamiento de los extranjeros en nuestro país, la referencia «los españoles» que abre el art. 19 C.E. no puede ser entendida como equivalente a una norma de exclusión de los extranjeros del ámbito subjetivo de dicho derecho fundamentap'252, razonamiento que podría de modo semejante extenderse a preceptos constitucionales de similar tenor.

El siguiente paso en la construcción jurisprudencial del estatuto constitucional de los derechos de los extranjeros en España fue dado por la STC 72/2005 ${ }^{253}$. Esta sentencia fue dictada para resolver un recurso de amparo presentado por un ciudadano marroquí contra la denegación de su entrada en España - fundamentada en la invalidez de su permiso de residencia, obtenido sin haber residido nunca en el estado Español-. Una lectura apresurada podría llevar a estimarla de escasa importancia, pasando desapercibida entre el acervo jurisprudencial. Sin embargo, se trata de un pronunciamiento que efectúa un acusado giro de la doctrina hasta el momento sustentada por el TC en torno a la libertad circulatoria, sin que en ningún momento se motive o se haga explícito dicho cambio ${ }^{254}$.

249 F. J. 4º. STC 116/1993.

250 El tenor literal es idéntico a la doctrina que había emitido en la STC 94/93, indicando el TC que "en los términos establecidos por la Declaración de este Tribunal de 1 de julio de 1992, «el apartado 2 del art. 13 solamente reserva a los españoles la titularidad de los derechos reconocidos en el art. 23 C.E.» (fundamento jurídico 2., STC 94/1993, cit.). Salvada esta única exclusión, las condiciones en que un extranjero ha de acceder a los derechos reconocidos en el art. 19 C.E., han de ser determinadas por el legislador, pero, una vez que estas condiciones han sido legalmente fijadas y cumplidas, puede concluirse que los extranjeros que «por disposición de una Ley, o de un Tratado, o por autorización concedida por una autoridad competente, tienen derecho a residir en España, gozan de la protección que brinda el art. 19 C.E., aun cuando no sea necesariamente en idénticos términos que los españoles, sino en los que determinen las leyes y tratados a los que se remite el art. 13.1 CE", F. J. $4^{\circ}$.

251 F. J. 4 $4^{\circ}$ STC 116/1993. Sobre este punto, el TC afirma que "efectivamente, en esta doctrina, se admite que el art. 13 C.E. autoriza al legislador a establecer restricciones y limitaciones a los derechos fundamentales que puedan disfrutar los extranjeros en España. Pero esta posibilidad no es incondicionada. De entrada, no podrá afectar a aquellos derechos «que pertenecen a la persona en cuanto tal, y no como ciudadano o, dicho de otro modo, ... aquellos que son imprescindibles para la garantía de la dignidad humana que, conforme al art. 10.1 C.E., constituye fundamento del orden político español» (STC 99/1985, fundamento jurídico 2.). Y, adicionalmente, al contenido delimitado para el derecho por la Constitución o los Tratados Internacionales suscritos por España (SSTC 115/1987, fundamento jurídico 3.; 107/1984, fundamento jurídico 3.; ó 99/1985, fundamento jurídico 2.), pues una cosa es «autorizar diferencias de tratamiento entre españoles y extranjeros, y otra es entender esa autorización como una posibilidad de legislar al respecto sin tener en cuenta los mandatos constitucionales» (en el mismo sentido, STC 112/1991, fundamento jurídico 2.)”.

252 STC $242 / 1994$, F. J. $4^{\circ}$.

253 STC 72/2005, de 4 de abril de 2005. B.O.E. no 111, de 10 de mayo de 2005.

254 En idéntico sentido, VIDAL FUEYO, Ma del Camino. "La sentencia del Tribunal Constitucional 72/2005, de 4 de abril, en materia de libertad de entrada y residencia de los extranjeros en España”; en Teoría y realidad constitucional, No 18,2006 , especialmente pp. 430 y 433. 
Precisamente por ello, es necesaria una lectura pausada de sus fundamentos jurídicos a fin de poder apreciar las novedades sustanciales que aporta esta sentencia.

El recurso traía causa en la desestimación de los recursos judiciales presentados por el recurrente contra la resolución administrativa que le denegó la entrada en territorio español, ordenando su retorno a Marruecos. Procedente de Nador, el recurrente pretendió entrar en España por el puesto fronterizo del puerto de Almería presentando su pasaporte y un permiso de trabajo y residencia en su favor, conforme prescribía la legislación entonces vigente ${ }^{255}$. Considerando inválido su permiso de residencia, las autoridades fronterizas denegaron la entrada en España. El permiso de residencia del recurrente había sido tramitado por un familiar suyo durante el proceso de regularización de extranjeros que había tenido lugar en el año $2000^{256}$, y le había sido enviado posteriormente por correo postal a Marruecos. El propio Sr. Razougui reconoció en el puesto fronterizo que él no había estado nunca en España, constituyendo la estancia continuada en nuestro país desde antes del 1 de junio de 1999 un requisito exigido para la regularización, de modo que el fraude en la consecución del permiso de residencia subyacía a la denegación de entrada, sin que en ningún momento se aclare abiertamente. El recurso se fundamentaba principalmente en la vulneración de la libertad de residencia del art. $19 \mathrm{CE}$ y del derecho a la tutela judicial efectiva. Estimando que la validez o invalidez del permiso de residencia constituía una cuestión de legalidad ordinaria, el TC no se pronuncia sobre este asunto. Igual respuesta había sido obtenida en la vía procesal previa, sustanciada mediante el procedimiento especial para la protección de los derechos fundamentales de la persona.

El TC reitera su doctrina en torno a la naturaleza no sancionatoria de las resoluciones administrativas de expulsión: en ellas no concurre la función represiva, retributiva o de castigo propia de las sanciones, sino la aplicación de la consecuencia jurídica por incumplimiento de los requisitos legales exigidos para el ejercicio del derecho de entrada en España ${ }^{257}$. Sin embargo, el grueso de la sentencia se centra en ofrecer una radiografía parcial del contenido del artículo $19 \mathrm{CE}$, acotando los ámbitos constitucionalmente protegidos de dos de los distintos derechos que alberga dicha disposición, concretamente del derecho de entrada y la libertad de residencia.

Aun reconociendo la interrelación existente entre ambos y sin precisar todavía sus titulares, el derecho de entrada se dirige, según precisa el TC, a quién está fuera de España, protegiendo la conducta consistente "en pasar de estar fuera de nuestras fronteras a encontrarse en el territorio nacional. La libertad de residencia, por su parte, protege la conducta del individuo consistente en "elegir libremente su residencia en territorio español»: es "el derecho subjetivo y personal a determinar libremente el lugar o lugares donde se desea residir transitoria o permanentemente» en España ${ }^{358}$. En consecuen-

255 Se trataban de los apartados primero y segundo del art. 23 de la LO 4/2000, de 11 de enero, sobre derechos y libertades de los extranjeros en España y su integración social. Dicha disposición establecía como requisito para entrar en España la presentación de pasaporte y de visado, aunque el visado podía ser sustituido por una autorización de residencia o documento análogo.

256 El proceso de regularización llevado a cabo en el año 2000 — abierto entre el 23 de marzo y el 31 de julio de dicho añoestuvo previsto en la disposición transitoria primera de la Ley Orgánica 4/2000 y regulado mediante el procedimiento establecido en el Real Decreto 239/2000, de 18 de febrero. Estas normas exigían para tal «regularización», entre otros requisitos, que el extranjero hubiera estado en España de forma continuada desde antes del 1 de junio de 1999. Constituyó el cuarto procedimiento de este tipo habido en España desde el primero, que tuvo lugar en 1985. Durante el mismo se presentaron un total de 246.086 solicitudes de regularización, de las cuales 146.781 fueron resueltas favorablemente. Para un estudio en profundidad de esta cuestión vid. ARANGO, Joaquín y SUÁREZ, Liliana. $L a$ regularización de extranjeros del año 2000. Centro para el Estudio de las Migraciones y la Ciudadanía, Instituto Universitario Ortega y Gasset, Madrid, 2002.

257 F. J. 30 STC 72/2005, de 4 de abril.

258 STC 28/1999, de 8 de marzo, F. J. 7, que cita el ATC 227/1983, de 25 de mayo, F. J. 2, y F. J. 4o STC 72/2005. 
cia, la invocación del derecho de residencia exige como presupuesto encontrarse ya en territorio español ${ }^{259}$ - circunstancia que, en el presente caso, no concurría en el recurrente de amparo-.

La presencia en territorio español constituye pues un requisito necesario para poder ejercer el derecho de residencia. Surge entonces la cuestión de qué ocurre en aquellos supuestos en los que el ordenamiento prevé la concesión de un permiso de residencia con anterioridad a la entrada en territorio español, es decir, sin exigir una estancia previa y continuada en nuestro país durante determinado tiempo, como suele ser lo habitual en el ámbito de la extranjería. En tales supuestos, -y aclarando que el mismo no concurre en los hechos que dan lugar al presente recurso-, el TC estima que estaríamos ante el ejercicio de un derecho legal y no constitucional.

"El extranjero que - como el ahora recurrente en amparo- no ha estado nunca en España, no puede invocar la libertad de residencia — el derecho a elegir el lugar o lugares donde se desea residir transitoria o permanentemente en el territorio español - para amparar una conducta que se sitúa en el ámbito definido por el tipo de un derecho distinto: el de entrar en el territorio nacional. Para ese extranjero la circunstancia de encontrarse ya en España constituye un presupuesto lógico - y, en este caso, también cronológico - para que pueda entrar en juego la libertad de residencia en el territorio nacional. Mientras no se haya entrado en España no es posible ejercer el derecho a elegir en ella el lugar de residencia ni, por tanto, cabe aceptar que los eventuales impedimentos u obstáculos del poder público a las pretensiones del extranjero constituyan vulneraciones de la libertad de residencia garantizada por el art. $19 \mathrm{CE}$. En su caso, serán otros los derechos vulnerados" 260 .

Aquí reside uno de los pronunciamientos más controvertidos de esta sentencia, pues es pertinente recordar que en el año 1993 el TC viró su anterior doctrina, proclamando a favor de los extranjeros la titularidad activa del conjunto de derechos proclamados en el artículo $19 \mathrm{CE}-\mathrm{y}$, con ello, atrayendo la protección constitucional que otorga esta disposición a los conflictos en materia de entrada y residencia, que constituyen el grueso de los litigios en el ámbito de la extranjería y la inmigración-. Entonces afirmó explícitamente que los extranjeros que contasen con derecho a residir en España, gozaban de la protección del artículo $19 \mathrm{CE}^{261}$. En clara contradicción con dicha teoría, ahora el TC afirma, sin más explicación, que el permiso de residencia no otorga un derecho de libertad de residencia, sino una autorización administrativa o, todo lo más, el ejercicio de un derecho legal, pero no constitucional ${ }^{262}$.

De forma sucinta, queda así enmarcado el objeto del presente recurso: Aunque el recurrente alega violación del art. 19 CE refiriéndose a la liberad de residencia, el TC concluye que el derecho que pretendió ejercer el ciudadano marroquí, siendo impedido por la resolución administrativa

259 F. J. $4^{\text {o }}$ STC 72/2005, de 4 de abril.

260 “Cuestión distinta sería la derivada de la hipotética obtención, por un extranjero, porque el ordenamiento lo haya así previsto, de un permiso de residencia antes de entrar en España por no exigirse, en tal caso, como requisito para esa obtención, el encontrarse previamente en el territorio español. Esa hipótesis no cabe descartarla por completo, pero, de un lado, no es la del caso que nos ocupa, de otro, no se estaría entonces en presencia de un derecho de libertad de residencia ex art. $19 \mathrm{CE}$, sino de una simple autorización administrativa o, todo lo más, de ejercicio de un derecho legal y no constitucional y, finalmente, cuando se intentase ingresar en España no se estaría ejercitando ese derecho a residir, sino exactamente el derecho a entrar, aunque aquél, en ese supuesto, sirviese de apoyo a éste”, F. J. 4º, STC 72/2005.

261 Esta línea se inició con la STC 94/93 (F. J...), asentándose posteriormente en las sentencias STC 116/93 y STC 242/94, todas ellas analizadas previamente en este epígrafe.

262 Este cambio jurisprudencial no advertido por el TC causa "perplejidad" a la prof. VIDAL FUEYO, quien subraya también cómo el mismo choca con la línea jurisprudencial previa, conforme a la cual, reunidos los requisitos legales para residir en España, "el extranjero no se mueve en el plano de la mera legalidad, sino que goza de la protección del art. 19 CE”. Vidal Fueyo también evidencia la incoherencia que supone esta argumentación, cuando posteriormente el TC dedica cinco fundamentos jurídicos a examinar una cuestión que él mismo ha calificado como de mera legalidad; "La STC 72/2005, de 4 de abril...", op. cit., p. 433. 
denegatoria, es el derecho de entrada y no la libertad de residencia ${ }^{263}$. Ello lleva al TC a abordar la cuestión de si existe o no un derecho fundamental de los extranjeros a entrar en España. Para acometer esta tarea, el alto tribunal explicita el iter interpretativo exigido: retomando doctrina previa, explica que se ha de partir de la literalidad del precepto constitucional —art. 19CE—, interpretado de forma sistemática junto con el art. 13, en tanto que disposición clave en la determinación de la posición jurídica de los extranjeros en España. Siendo doctrina consolidada, el TC recuerda que cabe extender a los extranjeros la titularidad activa del conjunto de derechos contenidos en el art. 19 que la Constitución reconoce a los "españoles". Esta extensión es previa a esta sentencia, pero es ahora cuando se explica en qué supuestos es lícito eludir el criterio gramatical para llegar a un resultado interpretativo distinto al que conduciría la dicción literal del precepto constitucional: cuando exista ambigüedad, o bien la misma se derive de la falta de cohesión o de coherencia sistemática ${ }^{264}$.

El recurso al art. 13.1 CE como complemento sistemático necesario en el análisis constitucional del art. 19, se salda con una interpretación de la primera disposición que arroja un panorama totalmente novedoso de la misma, aunque dotado de claroscuros.

“El art. 13.1 CE sólo se refiere a las libertades públicas de los extranjeros «en España» y ello con una doble precisión: a) no se refiere a la totalidad de los derechos de los extranjeros en España, sino sólo a derechos fundamentales; $y b$ ) dentro de éstos no recoge todos sus derechos fundamentales sino principalmente aquéllos que, previstos para los españoles — los de los arts. 19, 23, etc.-, el art. 13.1 CE extiende a los extranjeros en España, pues buena parte de los demás — derecho a la vida, libertad religiosa, libertad personal, tutela judicial efectiva, etc. - corresponden a aquéllos sin necesidad de la extensión que opera el art. 13.1 CE, es decir, sin necesidad de tratado o ley que lo establezca"265.

Tres puntos sobresalen en esta nueva panorámica del artículo 13.1 CE:

1. El TC otorga al art. 13.1 CE una función propia, hasta ahora no explicitada en el marco de la extranjería y la inmigración y, lo que es más importante, totalmente diferente a la mantenida hasta este momento por el alto tribunal desde la primera de las sentencias dictadas en relación a los extranjeros ${ }^{266}$ : se trataría de un precepto destinado a extender a los extranjeros - a través del tratado internacional o de la ley interna-, aquellos derechos fundamentales que la Constitución prevé para los españoles (como el art. 19, o el art. 23, entre otros). Mucho antes a su formulación explícita, el

263 En contra de esta postura del TC, y a favor de la procedencia de la invocación del derecho a la libertad de residencia en este concreto caso se pronuncia VIDAL FUEYO. Esta autora parte de la observación de que si bien los derechos a entrar y a residir poseen un contenido distinto, sin embargo su interrelación se acentúa cuando se trata de los extranjeros: el permiso de residencia se les exige con carácter previo para poder entrar en nuestro país y, a su vez, estando ya en España, la entrada legal a través de las fronteras constituye requisito previo para el ejercicio de la libertad de residencia. En consecuencia, "no parece del todo improcedente invocar un supuesto derecho a la libertad de residencia derivado de la posesión de una autorización administrativa que, a su vez, es conditio sine qua non para poder atravesar legalmente la frontera española de acuerdo con la legislación vigente. De hecho, al extranjero recurrente se le deniega la entrada porque los funcionarios de frontera consideran que el permiso de residencia no es válido"; en "La STC 72/2005, de 4 de abril, en materia de libertad de entrada y residencia de los extranjeros en España”, op. cit., p. 432.

264 "Y dado que en nuestro ordenamiento jurídico sólo son derechos fundamentales aquellos que la Constitución reconoce con ese carácter, «es procedente recordar que una interpretación del texto constitucional que conduzca a un resultado distinto de su literalidad sólo puede ser admitida cuando existe ambigüedad en el mismo o ésta se deriva de la falta de cohesión o coherencia sistemática (STC 72/1984, de 14 de julio, F. J. 6)» (STC 215/2000, de 18 de septiembre, F. J. 6). Nuestro punto de partida ha de ser, pues, la literalidad del art. 13.1 CE para recoger después los resultados que arroje una interpretación sistemática del precepto”, F. J. 5 STC 72/2005.

265 F. J. 5º, STC $72 / 2005$.

266 En el mismo sentido se pronuncia VIDAL FUEYO, "La STC 72/2005, de 4 de abril, en materia de libertad de entrada y residencia de los extranjeros en España”, op. cit., p. 430. 
propio TC había insinuado esta postura en la STC $115 / 87^{267}$, -siendo, por otro lado, una tesis que había sido reiteradamente defendida por la profesora Vidal Fueyo en múltiples de sus escritos ${ }^{268}$, si bien de una forma más depurada a la del TC, en un intento por dotar al art. 13.1 CE de una función autónoma que no se solapase ni con la reserva legal genérica contenida en el art. 53.1 CE ni con el papel que a los tratados internacionales otorgan los artículos 96 y 10.2 de nuestro texto constitucional-. La trascendencia de esta nueva concepción del art. 13 CE merecería una justificación mucho más pausada por parte del $\mathrm{TC}^{269}$. Además, de esta nueva postura, no se entiende bien la mención expresa que efectúa al artículo $23 \mathrm{CE}$ como ejemplo de aquellos derechos previstos para los ciudadanos españoles cuya extensión a los extranjeros es posible a través de la reserva lega -interna o internacional. Resulta, sin embargo, doctrina reiterada por el TC concebir al artículo 23 como la única exclusión expresa a los extranjeros recogida constitucionalmente, tal y como prevé el art 13.2 y con las matizaciones ahí establecidas.

2. De otro lado, implícito a este razonamiento, subyace una identificación entre los términos libertades públicas y derechos fundamentales que, si bien no constituye ninguna novedad en la jurisprudencia constitucional, sigue sin encontrar un fundamento sólido. Esta cuestión no es baladí, en vista de las importantes implicaciones que derivan de ella. En contra de esta identificación, se alzaron tres magistrados constitucionales en el célebre voto particular formulado a la STC 115/87, ya comentada, si bien el TC llega a resultados similares a los obtenidos en dicho voto particular, sin suscribir la interpretación restrictiva del término "libertades públicas" allí propuesta.

3. A juicio del TC, el objeto del art. 13.1 CE reside en la regulación de la posición jurídica de los extranjeros que ya se encuentran en territorio español ${ }^{270}$. En consecuencia, "el sujeto de derechos al que se refiere la regulación del art. 13.1 CE no es el extranjero sin más, sino el extranjero en España, el

267 F. J. 2º, STC $115 / 87$.

268 Vid, entre otros, Constitución y extranjería, op. cit., p. 107, donde VIDAL FUEYO otorga un sentido autónomo a la reserva legal contenida en el art. 13.1 CE, a fin de que ésta no tenga carácter redundante y no se solape con la reserva genérica contenida en el art. 53.1 CE. En palabras de la propia autora, “dicho precepto habilita al Estado para extender a los extranjeros, desde una plena libertad de configuración, mediante el tratado y la ley, derechos fundamentales que no nacen de la Constitución más que para los españoles, pero que tampoco están expresamente prohibidos para los extranjeros (...) Derechos, en suma, que la Constitución solo consagra en favor de los españoles pero que, a diferencia de lo que ocurre con los recogidos en el art. $23 \mathrm{CE}$, no prohíbe expresamente su extensión a los extranjeros". Se trataría de derechos tales como la libertad de entrada en España, el derecho al trabajo en su dimensión de derecho de libertad, la libertad de empresa o el libre ejercicio de profesión y oficio, entre otros. Esta interpretación del art. 13.1 se ofrece también en otros escritos de Vidal Fueyo, tales como, "La sentencia del TC 72/2005, de 4 de abril, en materia de libertad de entrada y residencia de los extranjeros en España”, op. cit., p. 435. La propia Vidal Fueyo señala en este artículo que el TC, si bien de forma tímida y sin argumentos de fondo, parece acoger esta misma interpretación del art. 13.1 CE en la STC 72/2005. La mencionada autora interpreta la remisión expresa que el art. 13.1 CE hace a las leyes y a los tratados "como un intento por establecer un cauce jurídico para extender a los extranjeros la titularidad de determinados derechos fundamentales que, como los del art. $19 \mathrm{CE}$, no nacen ex constitutione directamente a favor de los no nacionales, pero tampoco les están expresamente vedados como los del 23", idem, p. 435.

269 En la misma línea, VIDAL FUEYO lamenta que esta mutación en la jurisprudencia "no esté avalada por ninguna argumentación jurídica más allá de una supuesta (y discutible) interpretación literal”; "La STC 72/2005, de 4 de abril..., op. cit., p. 435.

270 En palabras del TC, "la redacción del apartado 1 del art. 13 CE, que se refiere a los términos en que los extranjeros gozarán de los derechos del Título I CE «en España», pone de manifiesto que la regulación de dicho precepto constitucional no tiene como finalidad reconocer derechos, en general, a los miles de millones de ciudadanos extranjeros que se encuentran en otros países ni, en concreto, convertir en derecho fundamental la eventual expectativa de entrar en España de todos los extranjeros que están fuera de nuestro país y que se presenten en nuestras fronteras, sino, precisamente, regular la posición jurídica de los extranjeros que ya se encuentran en España” (F. J. $6^{\circ}$ ). 
que ya ha entrado en nuestro país, circunstancia ésta que actúa como presupuesto de la extensión de derechos que lleva a cabo el art. $13.1 \mathrm{CE}^{271}$. . La titularidad activa de los derechos a los que afecta el art. 13.1 CE queda pues restringida al extranjero que ya ha entrado en España, en lo que constituye otra de las novedades aportadas por esta sentencia.

4. De lo que el alto tribunal deduce que "por eso, ya en su dicción literal, la regulación del art. 13.1 CE no se proyecta en concreto sobre uno de los derechos fundamentales -el derecho a entrar en España-que se reconocen en el art. $19 \mathrm{CE}$, lo que tiene como consecuencia que sólo sean titulares de este derecho fundamental los españoles" ${ }^{272}$. De forma incidental, en jurisprudencia previa ${ }^{273}$, el alto tribunal ya había sostenido que el derecho de entrada en España sólo estaba reconocido constitucionalmente a los españoles. En esta ocasión, recurre a la interpretación sistemática vía art. 10.2 CE. Tras acudir al criterio internacionalista para reforzar la señalada exclusión de los extranjeros con respecto del derecho fundamental a entrar en España, el TC concluye que "es claro, pues, que la literalidad del art. 13.1 CE, sin ninguna ambigüedad, no incluye el derecho a entrar en España como derecho fundamental de los extranjeros". Agudamente, la Prof. ${ }^{\text {a }}$. Vidal Fueyo, tras estimar que todos estos problemas interpretativos derivan de la inexistencia de una definición constitucional del término libertades públicas empleado por el art. 13.1 CE, argumenta que "es cierto que el art. 13.1 no incluye desde un punto de vista literal el derecho a entrar en España de los extranjeros, porque textualmente no incluye ningún derecho en concreto" 274 .

5. Sin embargo, que el derecho de entrada en España con carácter de fundamental sea predicable en exclusiva de los españoles, en tanto que atributo característico de la nacionalidad, no obsta para que el legislador pueda otorgarlo a los extranjeros que cumplan con los requisitos legalmente establecidos, gozando entonces de la protección otorgada por el ordenamiento a los derechos concedidos por ley $y^{275}$ y siendo tutelado conforme a las exigencias del art. $24 \mathrm{CE}^{276}$.

Estamos pues ante un pronunciamiento aparentemente humilde pero, sin embargo, pródigo en virajes respecto a la jurisprudencia precedente del TC. Virajes que corren el riesgo de pasar desapercibidos en vista de la escasa argumentación ofrecida por el alto tribunal, otorgándoles la falsa apariencia de estar continuando con una línea jurisprudencial previa.

271 F. J. $6^{\circ}$, STC $72 / 2005$.

272 "El derecho fundamental del nacional a ser en todo momento aceptado por el propio Estado y, por tanto, a entrar en su país, es uno de los elementos esenciales de la nacionalidad y, en consecuencia, una de las diferencias jurídicas básicas en el estatuto personal del nacional y el extranjero, «tradicional binomio» que sólo progresivamente va siendo objeto de "parcial superación», por ahora, en el marco de «una naciente ciudadanía europea» [Declaración del Tribunal Constitucional de 1 de julio de 1992, F. J. 3 a)]".

273 STC 53/2002, de 27 de febrero, F. J. 4.

274 VIDAL FUEYO, M. C. "La sentencia del TC 72/2005, de 4 de abril, en materia de libertad de entrada y residencia de los extranjeros en España”, op. cit., p. 434.

275 La argumentación ofrecida por el TC es la siguiente: "Este derecho lo tienen con el carácter de derecho fundamental que garantiza el art. 19 CE tan sólo los españoles, pero - a diferencia de lo que sucedía con el sufragio pasivo en las elecciones municipales - el legislador puede otorgarlo a los extranjeros que cumplan los requisitos establecidos en la ley. Que de la Constitución no se derive un derecho fundamental de los extranjeros a entrar en España no significa, evidentemente, que el derecho del extranjero a entrar en nuestro país conforme a lo regulado por la ley carezca de protección: se tiene la protección que el ordenamiento dispensa a los derechos que concede la ley y, en concreto, sí que tienen los extranjeros - aunque no hayan entrado (en el sentido jurídico estricto) en España, sino que sólo se encuentren fácticamente en territorio español, en situación, por tanto, de «sometimiento a un poder público español» [STC 53/2002, 27 de febrero, F. J. 4 a)]-el derecho fundamental a la tutela judicial efectiva -art. 24.1 CE-(SSTC 99/1985, de 30 de septiembre, F. J. 2, y 115/1987, de 7 de julio, F. J. 4) para la defensa del derecho del que se consideren asistidos ante los Jueces y Tribunales españoles". F. J. 8º, STC 72/2005.

276 Idem, F. J. $8^{\circ}$. 
A modo de síntesis, cabría destacar la incoherencia que supone proclamar el carácter legal del derecho de libertad de residencia si éste se predica de los extranjeros, cuando jurisprudencia previa sostenía claramente su naturaleza constitucional, siempre que el extranjero contase con regularidad administrativa en su estancia o residencia en territorio español. Asimismo, y como ya pusiera en evidencia Vidal Fueyo, algunos de los pronunciamientos contenidos en esta sentencia parecen ser íntimamente contradictorios. Ello es especialmente perceptible en lo que respecta a la novedosa consideración del art. 13.1 CE como una vía para la extensión a los extranjeros de aquellos derechos que la Constitución reconoce a los españoles. Esta concepción, en sí misma muy coherente, sin embargo choca con el rechazo del carácter constitucional del derecho a la libertad de residencia de aquellos extranjeros que cumplan con los requisitos fijados en la legislación de extranjería, así como con la propia exclusión del derecho de entrada ${ }^{277}$. De ahí que, en palabras de la mencionada autora, "la STC 72/05 añade más confusión a la que ya existía"278 en este ámbito.

\subsection{La STC 236/2007, de 7 de noviembre}

A finales del año 2007 el TC, en una serie de sentencias que se hicieron esperar - los múltiples recursos contra la ley reguladora de los derechos de los extranjeros, habían sido interpuestos en el año $2001^{279}$ - , resolvió el que constituía formalmente el segundo recurso de inconstitucionalidad habido en el ámbito de la extranjería y la inmigración — si bien, realmente fueron nueve los recursos interpuestos, uno de ellos declarado extinguido ${ }^{280}$, dando lugar a ocho sentencias y un auto del TC.

277 VIDAL FUEYO ha denunciado las contradicciones en las que incurre el TC en este pronunciamiento. Junto a las ya señaladas, estima que la referencia que efectúa el TC al art. 23 como ejemplo de derechos que la ley puede extender a los extranjeros también resulta contradictoria con la nueva visión que ofrece del art. 13.1 como cláusula de extensión de derechos a los extranjeros. De ahí que, ante tales contradicciones, Vidal Fueyo se pregunte legítimamente “iqué derechos, entonces, son los que extiende el 13.1 si el Tribunal excluye la mayor parte del contenido del 19 y el propio 13.2 excluye los del 23 con las salvedades que fija en este segundo apartado?, ¿cuál es el exacto elenco de derechos fundamentales que, según el TC en este pronunciamiento, corresponden a los extranjeros sin necesidad de la extensión que opera el art. 13.1 CE, es decir, sin necesidad de tratado o ley que lo establezca?"; en "La sentencia del TC 72/2005, de 4 de abril...", op. cit., p. 435.

278 Idem, p. 430.

279 En el B.O.E. del 1 de junio de 2001, constan los siguientes nueve recursos de inconstitucionalidad (en adelante RI), todos ellos admitidos a trámite mediante providencias respectivas del TC, con fecha de 22 de mayo de 2001: R.I. $n^{\circ}$ 1640/2001, promovido por el Consejo de Gobierno de la Junta de Andalucía; R.I. nº 1644/2001, promovido por el Parlamento Vasco; R.I. no 1668/2001, promovido por el Consejo de Gobierno de la Junta de Comunidades de Castilla-La Mancha; R.I. no 1669/2001, promovido por el Consejo de Gobierno de la Junta de Comunidades de Castilla-La Mancha; R.I. n 1670/2001, promovido por el Consejo de Gobierno de la Comunidad Autónoma de Baleares, R.I. n 1671/2001, promovido por la Diputación General de Aragón; R.I. n 1677/2001, promovido por el Consejo de Gobierno de la Junta de Extremadura; R.I. no 1679/2001, promovido por el Consejo de Gobierno del Principado de Asturias; R.I. no 1707/2001, promovido por el Parlamento de Navarra. Para un estudio en profundidad de estas cuestiones, vid. RODRÍGUEZ ALVAREZ, Aurelia. Ocho sentencias y un auto del Tribunal Constitucional (Balance definitvo de los recursos presentados sobre la inconstitucionalidad de la LO 8/2000), disponible en: http:// www.icam.es/docs/ficheros/200606120004_6_13.PDF. Como subraya SANTOLAYA MACHETTI, la reforma de la ley de extranjería de finales del año 2000 fue impugnada por todas aquellas CCAA que en esa época no estaban gobernadas por el Partido Popular, salvo Cataluña. La sentencia del TC tardó casi 8 años, "plazo que en forma alguna podemos considerar razonable en un asunto de esta importancia"; "La gestión de la inmigración en la VIII legislatura (2004-2008)"; en Revista del Ministerio de Trabajo e Inmigración, No 80, 2009, nota a pie de p. n 20 , p. 87.

280 Se trata del Recurso de inconstitucionalidad núm. 1670/2001, interpuesto por el Gobierno de las Illes Balears, en relación con el artículo 1, apartados 5, 6, 9 y 16 de la LO 8/2000, de 22 de diciembre, de reforma de la LO 4/2000, de 11 de enero, sobre derechos y libertades de los extranjeros en España y su integración social. 
Habían pasado exactamente dos décadas desde la resolución del primer recurso de inconstitucionalidad. Desde entonces, el panorama jurídico y social había cambiado sustancialmente, habiéndose convertido España en un país de inmigración con tasas de recepción de flujos migratorios que experimentaban por entonces un crecimiento sin precedentes respecto a las registradas en los países de nuestro entorno ${ }^{281} \mathrm{y}$, por ello, convirtiendo a la inmigración en un tema sometido a una gran presión mediática, social y electoral, con repercusiones sobre una normativa dotada de una gran inestabilidad legislativa. Sin embargo, algunos de los temas de fondo que debía resolver el TC eran, en esencia, muy similares a los que se plantearon hacía veinte años, aunque en esta ocasión el TC había de abordar cuestiones de más largo alcance y socialmente más controvertidas. Por entonces también las restricciones legislativas introducidas al ejercicio de determinados derechos fundamentales de los extranjeros (reunión, asociación...etc.), fueron objeto de enjuiciamiento. Ahora los mismos temas de fondo salían a la luz, pero por primera vez el recurso planteaba al TC la posible inconstitucionalidad de una ley que negaba el ejercicio de determinados derechos no a los extranjeros en general, sino a los que careciesen de la correspondiente autorización de estancia o de residencia en nuestro país, criterio ausente en el texto constitucional para configurar la situación jurídica de los extranjeros.

De entre las ocho sentencias emitidas por el TC para resolver los recursos interpuestos, la más trascendente es la primera de ellas, la STC 236/2007, de 7 de noviembre. Este pronunciamiento tuvo su origen en un recurso de inconstitucionalidad interpuesto por el Parlamento de Navarra contra doce preceptos de la LO 8/2000, de 22 de diciembre, de reforma de la LO 4/2000, de 11 de enero, sobre derechos y libertades de los extranjeros en España y su integración social. Poco después de su emisión, el TC dictó otras siete sentencias ${ }^{282}$ en respuesta a otros tantos recursos de inconstitucionalidad que habían sido presentados contra el mismo texto legal. Todas ellas son de carácter parcial y siguen la doctrina vertida de forma más global y sistemática en la STC 236/2007, de ahí que analice-

281 En el año 2001, España experimentó una aceleración en la recepción de flujos extraordinaria. Si bien la misma se había venido produciendo de forma paulatina dese mediados de la década de los noventa, el cambio de siglo inaugura una tendencia al alza sin parangón hasta el momento. Para el año 2001, España contaba con 1.109.060 extranjeros con permiso de residencia, cifra que representaba un 2,65\% de la población, y que suponía una tasa de crecimiento interanual, en comparación con los países de nuestro entorno, de un 23,82\%. Tras analizar esta situación, y en un estudio emitido en el año 2006, Kostova concluía que resultaba "destacable el reciente e intenso ciclo de inmigración del Sur de Europa (España, Italia, Portugal y Grecia), que habiendo sido lugar de origen en ciclos migratorios anteriores, es ahora lugar de destino ( ). De hecho estos países concentran la mayor parte del saldo absoluto y tienen también saldos migratorios relativos que superan a los del conjunto de la UE (CES, 2004). Analizando los datos de EUROSTAT sobre la evolución de la migración neta en los países europeos, es destacable de nuevo el caso de España y de Italia, ya que ellos son los que mayor aumento de la migración neta han tenido, calculando la tasa media anual acumulativa para el período 1993-2004, se obtiene el 23,62\% para España, el 33,02\% para Italia, el 17,08\% para Portugal, siendo la media el 6,61\% durante el mismo período en los 15 países miembros de la UE. Este importante aumento, especialmente en el caso de Italia y España, se produce también por el número importante de entradas irregulares e ilegales". KOSTOVA KARABOYTCHEVA, Miroslava. Una evaluación del último proceso de regularización de trabajadores extranjeros en España (febrero-mayo de 2005). Un año después. Madrid, Real Instituto Elcano, Documento de Trabajo (DT) 15/2006, agosto de 2006, p. 8.

282 STC 259/2007, de 19 de diciembre; STC 260/2007, de 20 de diciembre; STC 261/2007 de 20 de diciembre; STC STC 262/2007, de 20 de diciembre; STC 263/2007, de 20 de diciembre; STC 264/2007 de 20 de diciembre; y STC 265/2007, de 20 de diciembre. Para una visión completa, habría que añadir el Auto del TC de 1 de febrero de 2006, dando por desistido al Letrado del Gobierno de las Illes Balears, respecto al recurso de inconstitucionalidad $\mathrm{n}^{\circ}$ 1670/2001, proceso que ya señalamos fue declarado extinguido. Sobre el tema, vid. ALVAREZ RODRÍGUEZ, A. Ocho sentencias y un auto del TC.., op. cit., sp. 
mos en profundidad básicamente ésta, pues constituye una síntesis de todas las restantes - el leading case, en la terminología anglosajona ${ }^{283}$.

Los motivos de inconstitucionalidad eran múltiples, lo que explica, en conexión con la importancia intrínseca del tema, la extensión de este pronunciamiento. El grueso principal de la sentencia giraba en torno a la determinación de la supuesta inconstitucionalidad de ciertas disposiciones de la ley de extranjería - LO 4/2000, en la redacción dada tras la reforma que sufrió pocos meses después de su entrada en vigor mediante la LO 8/2000—, que condicionaban el ejercicio de determinados derechos fundamentales - reunión, asociación, libertad sindical, huelga, derecho a la educación y a la asistencia jurídica gratuita, junto a otras cuestiones- a la disposición de autorización de estancia o residencia, pese a considerar formalmente a los extranjeros como titulares de tales derechos.

Junto a los temas claves que abordaba, la importancia de esta sentencia resulta si cabe más acentuada porque el TC ofrece de forma sistematizada y unificada en un único pronunciamiento la doctrina constitucional previa dispersa, si bien es verdad que aportando escasas novedades. Además, por primera vez se planteaba ante el TC la legitimidad del establecimiento legislativo de diferencias de trato entre españoles y extranjeros y, aún dentro de éste último colectivo, basadas en la situación jurídico-administrativa del no nacional, circunstancia que, a juicio de la parte actora, carecía de cobertura constitucional.

Antes de analizar cada uno de los concretos motivos de inconstitucionalidad, el TC aborda con carácter previo dos cuestiones de fondo que enmarcan y sostienen al conjunto del recurso, abordándolas de forma separada, pese a su evidente conexión. Con esta aproximación, el alto tribunal pretende extraer criterios generales que usará posteriormente para el enjuiciamiento individual de cada uno de los concretos motivos de inconstitucionalidad. Ambas constituyen aspectos fundamentales de la dogmática de los derechos fundamentales.

1. En primer lugar, se trataba de delimitar la libertad que el art. 13.1 CE confiere al poder legislativo en la regulación del ejercicio de las libertades públicas que el Título I CE garantiza a los extranjeros en España, así como los límites a los que éste se ve sometido en el establecimiento de diferencias respecto a los nacionales ${ }^{284}$. Esta delimitación resultaba vital para poder abordar la cuestión clave de este recurso, - a saber determinar si el legislador orgánico, al establecer restricciones a los derechos de los extranjeros, había excedido la capacidad de configuración legislativa otorgada por el art. 13.1 CE-.

2. El recurso se basaba a su vez en la inconstitucionalidad de la mayoría de los preceptos impugnados, por su presunta contradicción con los tratados internacionales ratificados por España en materia de derechos y libertades. La argumentación empleada por el recurrente sostenía implícitamente

283 Un sector doctrinal, entre los que se encuentra ALVAREZ RODRÍGUEZ, sitúa a la STC 236/2007, en un plano de importancia similar a la segunda de las sentencias emitidas por el TC en respuesta a los recursos de incosntitucionalidad contra la ley de extranjería tras la reforma efectuada por el PP mediante la LO 8/2000. Se trata de STC 259/2007, de 19 de diciembre, señalando la mencionada autora que ambas "verdaderamente dan pautas interpretativas, - es decir, las importantes - son las dos primeras, puesto que el resto de las decisiones se remiten" a ellas. Ocho sentencias y un auto del TC.., op. cit., p. 6. En nuestra opinión, la STC 259/2007 sigue de lejos en importancia a la STC 236/2007, a cuyo análisis se dedican por ello las siguientes páginas de nuestro trabajo. En la misma interpretación a la propuesta en este texto, subrayando la importancia primordial de la STC 236/2007, y considerándola el leading case "donde se proyecta, de una forma más clara, la última posición del Tribunal sobre la materia”, se sitúa VIDAL FUEYO, M.C. "La jurisprudencia del Tribunal Constitucional en materia de derechos fundamentales de los extranjeros a la luz de la STC 236/2007"; en Revista española de derecho constitucional, No 85, 2009 , p. 362.

284 F. J. $2^{\circ}$, STC $236 / 2007$. 
que las restricciones contenidas en los preceptos recurridos de la ley de extranjería vulneraban la Constitución, de acuerdo con el alcance que las disposiciones constitucionales en materia de derechos y libertades habían de tener, interpretados de conformidad con los tratados internacionales ratificados por España, empleándolos como canon de constitucionalidad de las leyes. El Abogado del Estado ${ }^{285}$ rechazaba esta pretensión alegando que los Tratados internacionales están destinados a la interpretación de las normas constitucionales relativas a derechos, pero no constituyen en sí un parámetro de constitucionalidad de las leyes.

1 El primer argumento general o cuestión de fondo - el alcance de la remisión legislativa contenida en el art. 13.1-, remitía a cuestiones básicas de la teoría general de los derechos fundamentales. Para analizar este punto, el TC recopila y sistematiza doctrina previa. El grueso de su argumentación gira en torno a la clasificación tripartita de los derechos de los extranjeros, que pivota a su vez en torno al criterio de la mayor o menor vinculación de los distintos derechos con respecto a la dignidad humana. De nuevo retoma esta clasificación para ofrecer una visión unificada, amplificada y reformada de la misma que, sin embargo, analizada con detalle, conduce paradójicamente a la superación ${ }^{286}$ de la trilogía clásica. A efectos de simplificar la exposición y ofrecer un panorama sintético y más fácilmente comprensible de la amplia argumentación ofrecida por el TC para solventar esta primera cuestión general ${ }^{287}$, se expondrán los puntos más relevantes de su razonamiento, alterando levemente su orden de exposición con respecto al que figura en la sentencia.

El TC inicia su análisis reafirmando el carácter constitucional del régimen jurídico de los extranjeros, cuya fuente primera es el texto constitucional. Sistematiza los pasos que han de tomarse para la determinación ex constitutionem del estatuto jurídico de los no nacionales en nuestro país, recopilando su doctrina previa: "la titularidad y el ejercicio de los derechos fundamentales de los extranjeros en España deben deducirse de los preceptos que integran el título I, interpretados sistemáticamente. Para su determinación debe acudirse en primer lugar a cada uno de los preceptos reconocedores de derechos que se incluyen en dicho título, dado que el problema de su titularidad y ejercicio "depende del derecho afectado". Y en segundo lugar, a la regla contenida en el art. 13 CE"288.

Recuerda que la expresión libertades públicas empleada por el art. 13.1 CE no tiene sentido restrictivo, "de manera que los extranjeros disfrutarán no sólo de las libertades, sino también de los derechos reconocidos en el Título I". Esta reflexión le da pie para exteriorizar el alcance subjetivo genérico del artículo $13 \mathrm{CE}$, disposición que resulta aplicable a todos los extranjeros, con independencia

285 Para el Abogado del Estado"el segundo argumento general en el que se basa el recurso de inconstitucionalidad interpuesto por el Parlamento de Navarra sostiene que la mayoría de los preceptos legales impugnados son inconstitucionales por entrar en contradicción con los Tratados Internacionales ratificados por España en materia de derechos y libertades, los cuales en virtud del art. 10.2 CE se convertirían en canon de la constitucionalidad de las Leyes españolas. Dicho argumento se encuentra implícito en buena parte de los motivos de impugnación, pues el Parlamento de Navarra no invoca explícitamente el art. 10.2 CE si bien se sobreentiende que tal precepto es la base para fundar la inconstitucionalidad de los preceptos impugnados, a los que se reprocha su contradicción con los correspondientes artículos del Título I de nuestra Constitución y con determinados artículos de la Declaración Universal de los Derechos Humanos, del Pacto Internacional de Derecho Civiles y Políticos, y del Convenio Europeo para la Protección de los Derechos Humanos y Libertades Fundamentales. Ello es rechazado por el Abogado del Estado en el entendimiento de que aquel precepto constitucional sólo obliga a interpretar los derechos fundamentales de acuerdo con tales normas internacionales".

286 JOVER GOMEZ FERRER, Rafael, ORTEGA CARBALlO, Carlos y RIPOLL CARULLA, Santiago. Derechos fundamentales de los extranjeros en España. Valladolid, Lex Nova, 2010, p. 71.

287 Fundamentos jurídicos 3, 4 y 5, STC 236/2007.

288 F. J. $3^{\circ}$, STC $236 / 2007$. 
de las diversas situaciones jurídicas en que éstos se encuentren en España ${ }^{289}$. Esta consideración se basa en la ubicación sistemática de este precepto en el texto constitucional en conjunción con la interpretación gramatical de los términos empleados, resultando, sin embargo, implícita en la doctrina que el alto tribunal había venido manteniendo en torno el estatuto constitucional de los extranjeros.

Analizando la remisión legislativa contenida en el art. 13.1 CE, el TC sostiene que el poder legislativo cuenta con un "amplio margen de libertad" en la configuración del régimen jurídico de los extranjeros. Esta libertad no es absoluta, existiendo límites genéricos junto con otros específicos, que dependen del grupo en el que se inscriba el derecho afectado. La limitación general es graduada por el TC, constituyendo el artículo $10 \mathrm{CE}$, en sus dos apartados - y, especialmente, la dignidad de la persona consagrada en su primer párrafo-, el límite constitucional principal al que se ve sometido el legislador, tras el cual se sitúa el conjunto del Título I de la Constitución ${ }^{290}$.

El TC reconoce abiertamente las dificultades inherentes a la utilización de la dignidad humana como criterio para la categorización de los derechos de los extranjeros, "por cuanto todos los derechos fundamentales, por su misma naturaleza, están vinculados a la dignidad humana”291. A fin de dotar de mayor concreción a este criterio, el TC precisa que "el grado de conexión de un concreto derecho con la dignidad debe determinarse a partir de su contenido y naturaleza, los cuales permiten a su vez precisar en qué medida es imprescindible para la dignidad de la persona concebida como un sujeto de derecho, siguiendo para ello la Declaración Universal de Derechos Humanos y los tratados y acuerdos internacionales a los que remite el art. $10.2 \mathrm{CE}^{\mathrm{2} 292}$.

A efectos de modular el margen de intervención legislativa sobre cada uno de los derechos, "resulta decisivo el grado de conexión con la dignidad humana que mantiene un concreto derecho"293. De lo que se infiere algo sobradamente conocido, pero que esta sentencia tratará de precisar de forma más detallada: la libertad de configuración legislativa sobre el régimen jurídico de los extranjeros no es uniforme ${ }^{294}$. Por ello, abordar el margen concreto de intervención legislativa en el ámbito de la extranjería y la inmigración, exige con carácter previo analizar la mayor o menor vinculación de los derechos con la dignidad humana, punto en el que nuevamente entra en juego la clasificación tripartita, que el TC sistematiza y reformula del siguiente modo.

A) El primer grupo de derechos - aquellos inherentes a la dignidad humana y, como tales, pertenecientes a la persona en cuanto tal-, resultan predicables de los extranjeros en condiciones plenamente equiparables a los españoles. Forman una lista abierta en la que, de manera no exhaustiva,

289 En referencia al art. 13.1 CE, el TC señala que "como se deduce de su dicción y de su ubicación en el Capítulo Primero («De los españoles y los extranjeros») del Título I, este precepto constitucional se refiere a todos los extranjeros, por contraposición a las personas de nacionalidad española, a pesar de que aquéllos puedan encontrarse en España en situaciones jurídicas diversas", Idem, F. J. $3^{\circ}$.

290 "La remisión a la Ley que contiene el art. 13.1 no supone pues una desconstitucionalización de la posición jurídica de los extranjeros puesto que el legislador, aun disponiendo de un amplio margen de libertad para concretar los «términos» en los que aquéllos gozarán de los derechos y libertades en España, se encuentra sometido a límites derivados del conjunto del Título I de la Constitución, y especialmente los contenidos en los apartados primero y segundo del art. $10 \mathrm{CE}$ en los términos que seguidamente se expondrán”, F. J. 3º. Mas adelante, el TC afirma textualmente que "la dignidad de la persona, que encabeza el Título I de la Constitución (art. 10.1 CE), constituye un primer límite a la libertad del legislador a la hora de regular ex art. 13 CE los derechos y libertades de los extranjeros en España”.

291 F. J. $3^{\circ}$

292 Idem, STC 236/2007.

293 Ibidem.

294 "El legislador al que remite el art. 13.1 no goza de igual libertad para regular la titularidad y el ejercicio de los distintos derechos del Título I, pues aquélla depende del concreto derecho afectado” (F. J. 3). 
se incluirían el derecho a la vida, a la integridad física y moral, a la intimidad, la libertad ideológica, el derecho a la tutela judicial efectiva y el derecho instrumental a la asistencia jurídica gratuita, el derecho a la libertad y a la seguridad, y el derecho a no ser discriminado por razón de nacimiento, raza, sexo, religión o cualquier otra condición o circunstancia personal o social. Este listado abierto - ahora expuesto de forma unificada - , había ido siendo progresivamente desgranado por el TC a lo largo de diversas sentencias ${ }^{295}$.

En la regulación de este primer grupo de derechos imprescindibles para la garantía de la dignidad humana, "el legislador goza de una limitada libertad de configuración". "Y ello porque al legislar sobre ellos no podrá modular o atemperar su contenido ni por supuesto negar su ejercicio a los extranjeros, cualquiera que sea su situación, ya que se trata de derechos "que pertenecen a la persona en cuanto tal y no como ciudadano»" 296 .

a) Los derechos integrantes del segundo grupo - aquellos cuya titularidad se reserva en exclusiva a los españoles, quedando prohibida constitucionalmente su extensión mediante ley a los extranjeros-, son ventilados de forma expeditiva por el TC, pues no conllevan dificultades interpretativas: Son los reconocidos en el art. $23 \mathrm{CE}$, con las salvedades en él establecidas (art. 13.2 CE).

b) Formando parte de una tipología separada, el TC incluye a los derechos reconocidos ex constitutione a los extranjeros, "refiriéndonos en concreto a los derechos de reunión y asociación"297. Parece pues tratarse de un subtipo que no encajaría en puridad en ninguno de los tres clásicos. Respecto de los derechos integrantes de esta nueva tipología, que la Constitución reconoce directamente a favor de los no nacionales, el legislador también se encuentra limitado.

"Ello implica, de entrada, que el legislador no puede negar tales derechos a los extranjeros, aunque sí puede establecer «condicionamientos adicionales» respecto a su ejercicio por parte de aquéllos, si bien «ha de respetar, en todo caso, las prescripciones constitucionales (...). En tales casos (...) el mandato contenido en el precepto constitucional «constituye en puridad un contenido preceptivo del derecho [de asociación] que se impone al legislador en el momento de regular su ejercicio» por parte de los extranjeros. Para la identificación de estos derechos reconocidos ex constitutionem a los extranjeros debe tenerse especialmente en cuenta, entre otros criterios, la dicción de los preceptos del Título I reconocedores de derechos, a los que remite el art. 13.1 CE, pues en ellos se hace normalmente referencia a sus titulares utilizando distintas expresiones" 298 .

En esta tipología o subgénero, la limitación del poder legislativo es menor que en el primer grupo de derechos más íntimamente conectado a la dignidad humana, dado que el legislador puede establecer "condicionamientos adicionales" respecto a su ejercicio, mismos que serían inadmisibles en la primera categoría. Se trataría así de un tipo de derechos sobre los que el legislador gozaría, en palabras de Vidal Fueyo, de un "plus de libertad" 299 respecto a los derechos considerados imprescindibles para la garantía de la dignidad humana. Surge pues la duda de si esta tipología coincide con el grupo que en la célebre STC 107/84 estaba integrado por derechos que, parafraseando al TC, pertenecerán o no a los extranjeros según lo dispongan los tratados y las Leyes, siendo entonces admi-

295 Como el propio TC declara, “Todos ellos han sido reconocidos expresamente por este Tribunal como pertenecientes a las personas en cuanto tal, pero no constituyen una lista cerrada y exhaustiva" (F. J. $3^{\circ}$ ).

296 Idem.

297 F. J. $4^{\circ}$.

298 F. J. $4^{\circ}$.

299 VIDAL FUEYO, M.C. "La jurisprudencia del TC en materia de derechos fundamentales de los extranjeros..”, op. cit., p. 368. 
sible la diferencia de trato con los españoles en cuanto a su ejercicio ${ }^{300 " . ~ A t e n d i e n d o ~ a l ~ m a y o r ~ m a r g e n ~}$ de maniobra legislativa se aproximarían a esta tipología clásica pero, dado que se trata de derechos cuya titularidad deriva ex constitutionen, no podrían subsumirse en sentido estricto en tal categoría por sus claras conexiones con el primer grupo clásico de derechos.

La confusión que genera este nuevo subtipo no es despejada por el TC, que apela a su teoría clásica para suscribir una categoría que más bien parece autónoma o mixta, con caracteres a caballo entre los derechos del primer y tercer grupo, en la clasificación tripartita tradicional. Es precisamente este aspecto uno de los puntos más problemáticos de este pronunciamiento. El diferente grado de intervención legislativa en los derechos fundamentales en general, y en los derechos de los extranjeros en particular, constituye una cuestión sobradamente asentada en la jurisprudencia constitucional. Sin embargo, la novedad reside en que ahora el TC establece un subtipo nuevo de derechos de los extranjeros, con caracteres muy próximos al primero de los grupos - derechos fundamentales que presentan un grado mayor de conexión con la dignidad humana-, y respecto a los cuales, en la versión clásica, no se admitían regímenes jurídicos diferenciados entre españoles y extranjeros. La cuestión no es despejada por la argumentación del TC, de modo que, la teoría tripartita, tras esta remodelación, admitiría una subdivisión dentro del primer grupo, confiriendo al legislador mayor libertad en la regulación de estos derechos que incluirían los derechos de asociación y reunión -y parece ser que algunos otros, sin especificar por el TC-, o bien, simplemente cabría pensar que la clasificación tripartita tradicional se habría convertido de forma casi inadvertida en una "teoría cuatripartita" ${ }^{301}$.

a) Grupo aparte merecen "aquellos derechos que no son atribuidos directamente por la Constitución a los extranjeros pero que el legislador puede extender a los no nacionales "aunque no sea necesariamente en idénticos términos que los españoles»". Se trata de "derechos de los que serán titulares los extranjeros en la medida y condiciones que se establezcan en los Tratados y las Leyes", sobre los cuales existe un mayor margen de intervención legislativa comparativamente hablando, en relación con el grupo anterior de derechos cuya titularidad la propia Constitución reconoce a favor de los extranjeros-. En este grupo el TC incluye el derecho al trabajo, el derecho a la salud, el derecho a percibir una prestación de desempleo y el derecho de residencia y desplazamiento en España, si bien este último "con matizaciones". Este grupo correspondería en esencia a la tercera categoría dentro de la tripartición clásica.

En la regulación de este último tipo de derechos el legislador goza de una mayor libertad que, sin embargo, tampoco es absoluta ${ }^{302}$. Las condiciones de ejercicio legislativamente establecidas han de respetar tres límites para ser constitucionalmente válidas: en primer lugar, no podrán afectar a

300 F. J. $4^{\circ}$, STC $107 / 1984$

301 VIDAL FUEYO, M.C. “La jurisprudencia del TC en materia de derechos de los extranjeros...”, op. cit., p. 361. La autora lamenta que esta nueva dimensión de la teoría tripartita, que dota de un plus de libertad al legislador orgánico respecto a los derechos integrantes del nuevo grupo ya señalado, no se base en un "examen de la razonabilidad de la inclusión de la extranjería como factor diferencial en el contenido de la ley, ni se aplica un test de igualdad", apoyándose exclusivamente en la remisión legislativa del art. 13.1 CE, "sin que el Tribunal aporte más argumentos de fondo al respecto". Idem.

302 Para el TC, "se trata de derechos de los cuales los extranjeros gozarán «en España», "presupuesto de la extensión de derechos que lleva a cabo. Al regular tales derechos la libertad del legislador es más amplia ya que puede modular las condiciones de ejercicio «en función de la nacionalidad de las personas, introduciendo tratamientos desiguales entre españoles y extranjeros», si bien aquella libertad «no es en modo alguno absoluta». Efectivamente, el art. $13 \mathrm{CE}$ autoriza al legislador a establecer «restricciones y limitaciones» a tales derechos, pero esta posibilidad no es incondicionada por cuanto no podrá afectar a aquellos derechos que «son imprescindibles para la garantía de la dignidad humana que, conforme al art. 10.1 CE, constituye fundamento del orden político español», ni 
los derechos imprescindibles para garantizar la dignidad humana; en segundo lugar, el contenido esencial del derecho, tal y como prescribe el art. 53.1 CE y, finalmente, el principio de proporcionalidad - "las restricciones y limitaciones del legislador deben dirigirse a preservar otros derechos, bienes o intereses constitucionalmente protegidos y guardar adecuada proporcionalidad con la finalidad perseguida"303 —, en palabras del TC.

En suma, el TC perfila un panorama de orden decreciente en torno a la libertad legislativa en la regulación ex art. $13 \mathrm{CE}$ de los derechos y libertades de los extranjeros en España: ésta va recortándose según los diversos derechos que pueden ostentar los extranjeros vayan aproximándose a la dignidad humana, resultando indisponibles el primer grupo — salvo la nueva tipología señalada, integrada por los derechos de reunión y asociación, que admitiría un mayor margen intervención-, y gozando respecto del último grupo de una amplia libertad de configuración legislativa, constreñida por las tres limitaciones anteriormente citadas. Sin embargo, con la excepción del nuevo subgrupo apuntado - que aporta más incertidumbre y confusión que claridad en la resolución de los conflictos que plantea la extranjería-, los criterios generales que examina de forma preliminar el TC constituyen una reiteración de su jurisprudencia previa. Consecuentemente, el foco argumentativo se sitúa de forma prioritaria y casi exclusiva en la clasificación tripartita clásica y el grado de conexión de los distintos derechos con la dignidad humana ${ }^{304}$ — criterio cuya flexibilidad y abstracción, se termina vertiendo sobre la propia identificación y ubicación de los diversos derechos de los extranjeros.

Uno de los puntos neurálgicos a fin de poder resolver cuestiones clave de la sentencia, residía en la legitimidad de la autorización de estancia y residencia como presupuesto legalmente establecido para poder ejercitar determinados derechos fundamentales. El TC apoya de entrada su compatibilidad constitucional, señalando que "el legislador puede tomar en consideración el dato de su situación legal y administrativa en España, y exigir a los extranjeros la autorización de su estancia o residencia como presupuesto para el ejercicio de algunos derechos constitucionales que por su propia naturaleza hacen imprescindible el cumplimiento de los requisitos que la misma ley establece para entrar y permanecer en territorio español”305. Si bien precisa que, para que esta opción sea legítima, ha de recaer sobre "derechos constitucionales que por su propia naturaleza hacen imprescindible el cumplimiento de los requisitos que la misma ley establece para entrar y permanecer en territorio español’306.

El TC hace una valiosa proclamación a renglón seguido en torno al carácter sagrado e indisponible de los derechos que corresponden al extranjero en su condición de persona, sea cual fuere la situación administrativa en que éste se encuentre en territorio español, y de los que no se hallan desposeídos ni siquiera aquel sector que ha incumplido los requisitos legales de entrada y permanencia:

\footnotetext{
"Ahora bien, dicha opción está sometida a los límites constitucionales señalados puesto que el incumplimiento de los requisitos de estancia o residencia en España por parte de los extranjeros no permite al legislador privarles de los derechos que les corresponden constitucionalmente en su condición de persona, con independencia de su situación administrativa. El incumplimiento de aquellos requisitos legales impide a los extranjeros el ejercicio de determinados derechos o contenidos de los mismos que por su propia naturaleza son incompatibles con la situación de irregularidad, pero no por ello los extranjeros
}

«adicionalmente, al contenido delimitado para el derecho por la Constitución o los Tratados Internacionales suscritos por España»". F. J. 4º STC 236/2007.

303 Idem.

304 En el mismo sentido, VIDAL FUEYO, M. C. "La jurisprudencia del TC en materia de derechos de los extranjeros...”, op. cit., p. 363.

305 F. J. $4^{\circ}$, STC 236/2007.

306 Idem. 
que carecen de la correspondiente autorización de estancia o residencia en España están desposeídos de cualquier derecho mientras se hallan en dicha situación en España”307.

2. La segunda cuestión de fondo que afronta con carácter preliminar el TC, gira en torno al papel que desempeñan los tratados internacionales ratificados por España en materia de derechos y libertades, especialmente respecto a su utilización como canon de constitucionalidad de las leyes españolas —en este caso de la Ley orgánica 8/2000_, que es el argumento implícitamente empleado por el recurrente en los distintos motivos de inconstitucionalidad. De hecho, aunque el Parlamento de Navarra en ningún momento invocó el art. 10.2 CE como base para sustentar la inconstitucionalidad de los preceptos legales recurridos, el TC estima que éste se sobreentiende a lo largo de todo el recurso, empleando fundamentalmente como parámetros de constitucionalidad la DUDH, el PIDCP y el CEDH.

Al hilo de esta cuestión de fondo, el TC repasa su doctrina más importante en torno al valor hermenéutico de los convenios internacionales en materia de derechos humanos suscritos por España. Como es bien sabido, éstos constituyen fuentes interpretativas para identificar mejor el contenido de los derechos tutelados por el $\mathrm{TC}^{308}$, de forma que los perfiles exactos del sentido, alcance y contenido del derecho constitucional serán determinados de conformidad con el convenio internacional ${ }^{309}$.

Con el fin de esclarecer con mayor precisión los límites que afronta el legislador español al regular los derechos de los extranjeros, acude a la interpretación sistemática de la remisión legislativa interna del art. 13.1 CE en conexión con el criterio hermenéutico internacional del art. 10.2 CE. - si bien no se detiene en la remisión al legislador internacional contenida también en el art. 13.1 CE-. De esta conjunción, el TC concluye que el legislador español en materia de extranjería e inmigración resulta limitado ex art. 10.2: "el art. 13 CE autoriza al legislador a establecer restricciones y limitaciones a los derechos de extranjeros en España, pero sin afectar «al contenido delimitado para el derecho por (...) los Tratados Internacionales" 310 , que debe observar para configurar el sentido y alcance de los derechos fundamentales. De modo que al panorama que anteriormente extractamos en torno a los concretos límites que restringen al poder legislativo interno al configurar el régimen jurídico de la extranjería, habría que añadir el contenido delimitado por los convenios internacionales, que resulta fundamental a su vez para determinar el contenido esencial de un derecho y, por contraposición, aquel otro contenido periférico disponible para la mediación legislativa.

307 Ibidem. A modo de conclusión recopilatoria de la argumentación ofrecida a lo largo de sus primeros y extensos fundamentos jurídicos, el TC prosigue afirmando: "Así pues, en relación con el primer argumento general del presente recurso debemos afirmar que el art. 13.1 CE concede al legislador una notable libertad para regular los derechos de los extranjeros en España, pudiendo establecer determinadas condiciones para su ejercicio. Sin embargo, una regulación de este tenor deberá tener en cuenta, en primer lugar, el grado de conexión de los concretos derechos con la garantía de la dignidad humana, según los criterios expuestos; en segundo lugar, el contenido preceptivo del derecho, cuando éste venga reconocido a los extranjeros directamente por la Constitución; en tercer lugar, y en todo caso, el contenido delimitado para el derecho por la Constitución y los tratados internacionales. Por último, las condiciones de ejercicio establecidas por la Ley deberán dirigirse a preservar otros derechos, bienes o intereses constitucionalmente protegidos, y guardar adecuada proporcionalidad con la finalidad perseguida".

308 F. J. 5, STC 236/2007, remitiéndose a lo establecido en las SSTC 38/1981, de 23 de noviembre, F. J. 4 en la sentencia 84/1989, de 10 de mayo, F. J. 5.

309 F. J. 5 STC 236/2007, remitiéndose a la doctrina pronunciada en la STC 28/1991, de 14 de febrero, F. J. 5.

310 F. J. $5^{\circ}$, reproduciendo la doctrina asentada en el F J $4^{\circ}$ de la STC 242/1994 de 20 de Julio. Añade posteriormente que "como cualquier otro poder público, también el legislador está obligado a interpretar los correspondientes preceptos constitucionales de acuerdo con el contenido de dichos tratados o convenios, que se convierte así en el «contenido constitucionalmente declarado» de los derechos y libertades que enuncia el capítulo segundo del título I de nuestra Constitución". 
Tras reiterar su doctrina negando que los convenios constituyan canon autónomo de la validez de las leyes, el TC delimita su función respecto a este segundo argumento general o cuestión de fondo, señalando que:

\begin{abstract}
"Al enjuiciar la Ley impugnada en este proceso, nos corresponde determinar si el legislador ha respetado los límites impuestos ex art. 10.2 CE por las normas internacionales, que le obligan a interpretar de acuerdo con ellas los derechos y libertades consagrados en nuestra Constitución. (...) Las normas legales impugnadas deben ser contrastadas con los correspondientes preceptos constitucionales que proclaman los derechos y libertades de los extranjeros en España, interpretados de acuerdo con el contenido de dichos Tratados o Convenios. En consecuencia, sólo podrá declararse su inconstitucionalidad si aquellas normas con rango de Ley vulneran el contenido constitucionalmente declarado de tales derechos y libertades"311.
\end{abstract}

Así queda delimitada la tarea a la que ha de darse el alto tribunal en el examen individualizado de los concretos motivos de impugnación, que se inicia con el fundamento jurídico texto de la presente sentencia. Sin embargo, a partir de este momento, como bien ha advertido Vidal Fueyo, el TC recurrirá reiteradamente a los convenios internacionales no para ayudar a delimitar el contenido y titularidad de los derechos objeto de controversia, sino, de forma paradójica, "exclusivamente para justificar una mayor o menor < conexión> del derecho en cuestión con la dignidad humana, como argumento definitivo en orden a extender, o no, dicha titularidad a los extranjeros" ${ }^{\text {"312. }}$.

\title{
a) Los motivos concretos de inconstitucionalidad
}

El Parlamento de Navarra impugnaba en primer lugar la nueva redacción que la reforma operada mediante la LO 8/2000 había otorgado a los artículos 7.1, 8 y 11.1 de la LO 4/2000. Estas disposiciones reconocían respectivamente a todos los extranjeros los derechos de reunión, manifestación, asociación y libertad sindical, pero su ejercicio quedaba condicionado a la previa obtención de autorización de estancia o residencia en España y, en lo que respecta al ejercicio del derecho de huelga, se restringía a los extranjeros que contasen con autorización para trabajar. La argumentación del recurrente giraba en torno a la incompatibilidad de las disposiciones citadas tanto con respecto al DIDH como con la Constitución Española, en la medida en que todos los derechos señalados derivaban de la dignidad humana, estableciendo la ley una distinción en su ejercicio entre españoles y extranjeros que carecía de cobertura constitucional, al limitar su ejercicio efectivo a quienes estuviesen regularmente en España.

Para analizar las restricciones legales al derecho de reunión y manifestación, el TC determina en primer lugar su conexión con la garantía de la dignidad humana, partiendo del tipo abstracto del derecho y acudiendo al DIDH. Apoyándose en la jurisprudencia del TEDH, el TC destaca el vínculo esencial existente entre la libertad de expresión y el derecho de reunión, señalando además que "para muchos grupos sociales este derecho es, en la práctica, uno de los pocos medios de los que disponen para poder expresar públicamente sus ideas y reivindicaciones" ${ }^{\prime 13}$. El TC apunta que los

311 F. J. 50, STC 236/2007.

312 VIDAL FUEYO, M. C. "La jurisprudencia del TC en materia de derechos y libertades de los extranjeros..., op. cit., p. 365. La autora pone como ejemplo un párrafo del fundamento jurídico sexto de esta sentencia, en donde el TC se auxilia del DIDH en la interpretación del derecho de asociación, para derivar de los textos internacionales la vinculación de este derecho con la dignidad de la persona y, con ello, deducir su reconocimiento universal, con independencia de la situación administrativa del extranjero, estimando la inconstitucionalidad del precepto legal impugnado.

313 F. J. $6^{\circ}$, STC $236 / 2007$. 
principales tratados internacionales sobre derechos humanos "parecen vincularlo a la dignidad", y de ellos pueden extraerse indicaciones en torno al reconocimiento del ejercicio de ese derecho a los extranjeros ilegales. Apoyándose en su jurisprudencia previa y adoptando una interpretación estricta de los límites al derecho de reunión en tanto que manifestación del principio de libertad, tal y como también realiza el TEDH, el TC excluye que la exigencia legal de residencia legal o de estancia para poder ejercitar el derecho, constituya un mero condicionamiento adicional de los que el legislador puede modular - "el precepto debatido no se limita a condicionar el ejercicio del derecho de reunión por parte de los extranjeros en situación irregular sino que impide radicalmente cualquier ejercicio del mismo a las personas que se encuentren en España en aquella situación"314 —. Para concluir que "la definición constitucional del derecho de reunión realizada por nuestra jurisprudencia, y su vinculación con la dignidad de la persona, derivada de los textos internacionales, imponen al legislador el reconocimiento de un contenido mínimo de aquel derecho a la persona en cuanto tal, cualquiera que sea la situación en que se encuentre"315.

En consecuencia, las condiciones específicas fijadas por el legislador orgánico para el ejercicio del derecho de reunión por parte de los extranjeros que se encuentran en situación irregular, serán válidas "siempre y cuando respete un contenido del mismo que la Constitución salvaguarda por pertenecer a cualquier persona, independientemente de la situación en que se encuentre", circunstancia que no cumple la limitación legal impugnada ${ }^{316}$. "La nueva redacción dada por el precepto impugnado al art. 7.1 de la Ley Orgánica 4/2000 no realiza una modulación del derecho de reunión, estableciendo condiciones a su ejercicio, sino que niega este derecho a los extranjeros que no dispongan de autorización de estancia o residencia en España". El TC declara inconstitucional el art. 7.1 de la Ley Orgánica 4/2000, de 11 de enero, en la nueva redacción dada por Ley Orgánica 8/2000, de 22 de diciembre, por vulnerar el art $21 \mathrm{CE}$ "en su contenido constitucionalmente declarado por los textos a los que se refiere el art. 10.2 CE".

El mismo iter argumentativo seguido para declarar la inconstitucionalidad de la exclusión de los extranjeros irregulares respecto del ejercicio del derecho de reunión y manifestación, es recorrido por el TC para despejar las dudas sobre la inconstitucionalidad de los preceptos relativos a los derechos de asociación, libertad sindical y huelga en su ejercicio por los extranjeros: el TC explora el contenido del derecho - recurriendo a su jurisprudencia previa en la materia-, para posteriormente indagar en su grado de vinculación con la dignidad humana - para lo cual acude al DIDH, especialmente a la jurisprudencia del TEDH—, deduciendo su titularidad y hasta qué punto las condiciones legales para su ejercicio son constitucionalmente admisibles.

Esta operación lleva al TC a declarar la inconstitucionalidad del precepto legal que restringe el derecho de asociación ${ }^{317}$ - por excluir cualquier ejercicio de este derecho por parte de los extranjeros

\section{Idem.}

315 F. J. $6^{\circ}$, STC 236/2007.

316 VIDAL FUEYO ha subrayado el grado de contradicción inherente a esta observación del TC, pues resulta difícil conciliar la idea de que los derechos de reunión y manifestación, por su vinculación con la dignidad humana, no permiten tratamientos desiguales entre españoles y extranjeros, y sostener al mismo tiempo que, siempre que el legislador respete su contenido esencial, puede fijarse en la condición administrativa del extranjero para establecer tratos diferentes, "cuando se trata del ejercicio de derechos que la Constitución extiende a todas las personas". La autora sostiene que estas "contradicciones (...) revelan la ausencia de una interpretación coherente del régimen de derechos fundamentales de los extranjeros". "La jurisprudencia del TC en materia de derechos...”, op. cit., p. 369.

317 De hecho, el propio TC - ante la similitud tanto de los motivos de inconstitucionalidad, como de las argumentaciones de las partes-, al proceder a examinar las limitaciones legales al derecho de asociación, declara la conveniencia de acoger la argumentación ya utilizada en el anterior fundamento para enjuiciar este precepto, en base a la misma concluye que "el derecho de asociación se encuentra, pues, vinculado a la dignidad humana y al libre desarrollo de 
que carecen de autorización de estancia o residencia en España ha vulnerado el art. 22 CE en su contenido constitucionalmente declarado por los textos a los que se refiere el art. $10.2 \mathrm{CE}^{318}$-.

En ambos casos, y rompiendo la lógica interna que debería derivarse de la declaración de inconstitucionalidad de ambos derechos - reunión y asociación-, el fallo del TC no proclama la anulación de las restricciones legislativas establecidas, sino que declara la "anulabilidad" de los preceptos impugnados $^{319}$. La finalidad expresa que se pretende con tal declaración es no atentar contra la voluntar del legislador. Sin embargo, ateniéndonos a los propios argumentos del TC, el legislador orgánico se había excedido al configurar los derechos de reunión y asociación de los extranjeros ${ }^{320}$.

De otro lado, el art. 9.3 de la ley de extranjería reformada a finales del año 2000, reconocía el derecho a la educación no obligatoria sólo a los extranjeros residentes, lo que suponía la exclusión de los extranjeros menores de edad que careciesen de residencia legal en España con respecto a las enseñanzas de carácter no básico. El Parlamento de Navarra estimaba que esta exclusión era contraria al derecho a la educación reconocido en el art. 27.1CE interpretado conforme al DIDH, al que expresamente remite el art. 39.4 CE — fundamentalmente los artículos 28 de la Convención ONU sobre los derechos del niño y $26 \mathrm{DUDH}$-, entendiendo que el contenido esencial del derecho del niño a ser escolarizado comprendía tanto la enseñanza básica o elemental como la no básica.

A fin de dilucidar esta cuestión, el TC examina la dimensión prestacional del contenido del derecho a la educación constitucionalmente garantizado, reiterando que su objeto es el pleno desarrollo de la personalidad humana. Invoca el DIDH para deducir "la inequívoca vinculación del derecho a la educación con la garantía de la dignidad humana, dada la innegable trascendencia que aquélla adquiere para el pleno y libre desarrollo de la personalidad, y para la misma convivencia en sociedad"321.

la personalidad por cuanto protege el valor de la sociabilidad como dimensión esencial de la persona y en cuanto elemento necesario para la comunicación pública en una sociedad democrática. Dado que se trata de un derecho cuyo contenido está unido a esa dimensión esencial, la Constitución y los tratados internacionales lo "proyectan universalmente» y de ahí que no sea constitucionalmente admisible la negación de su ejercicio a los extranjeros que carezcan de la correspondiente autorización de estancia o residencia en España”, F. J. 7º, STC236/2007. 318 Idem.

319 F. J. 17, STC 236/2007.

320 En idéntico sentido se pronunician, entre otros, VIDAL FUEYO, quien señala que, junto a las contradicciones internas existentes en la argumentación del TC a la hora de fundamentar la inconstitucionalidad de las limitaciones legislativas que la LO 8/2000 introdujo a los derechos de reunión y asociación, el hecho de que, pese a ello, el TC no declare la nulidad de los preceptos impugnados, provoca que la "perplejidad siga en aumento al leer el fallo de la sentencia". La autora critica la argumentación que el TC ofrece para declarar su anulabilidad, señalando que la voluntad legislativa, establecida en la ley de extranjería recurrida, "se escapa de su ámbito de libertad de configuración", siendo más lógico "anular los incisos que niegan a priori el ejercicio de estos derechos fundamentales a todos los extranjeros <sin papeles $>$, sin perjuicio de que con posterioridad el legislador (una vez respetado el contenido esencial, en la confusa línea marcada por el Tribunal) pudiera establecer (o no) límites específicos a los extranjeros sin autorización administrativa". "La jurisprudencia del TC en materia de derechos fundamentales de los extranjeros..”, op. cit., p. 369. En la misma línea, BASTARRACHEA entiende que "el Tribunal Constitucional ha querido hacer un ejercicio de self retraint y dejar que sea el legislador quien en un plazo razonable fije las condiciones de ejercicio de estos derechos para los extranjeros pero esa finalidad se hubiera conseguido también declarando la nulidad de los preceptos declarados inconstitucionales pues, de todos modos, no resultarán aplicables y el legislador deberá regular esta materia"; en ALBA BASTARRECHEA, Esther de. "Sobre Derechos y Libertades de los Extrajeros en España: comentario a la STC 236/2007, de 7 de noviembre”, op. cit., p. 30.

321 F. J. 8, STC 236/2007. En contra de este uso del criterio interpretativo internacional se manifiesta VIDAL FUEYO, quien señala que "la función de los tratados internacionales no es, como pretende el Tribunal, servir de pauta para determinar la mayor o menor vinculación del derecho con la dignidad humana, sino que sirven de instrumento hermenéutico para ayudar a perfilar el contenido y, en su caso, los titulares del derecho a la educación que nuestra Constitución consagra"; "La jurisprudencia del TC en materia de derechos...., op. cit., p. 372. 
Asimismo, acude a su jurisprudencia previa sobre esta materia ${ }^{322}$, y a la interpretación que el TEDH ha efectuado del derecho a la educación reconocido en el art. 2 del Protocolo al CEDH, estimando que "de las disposiciones constitucionales relativas al derecho a la educación, interpretadas de conformidad con la Declaración universal de derechos humanos y los tratados y acuerdos internacionales referidos, se deduce que el contenido constitucionalmente garantizado de ese derecho, en su dimensión prestacional, no se limita a la enseñanza básica, sino que se extiende también a los niveles superiores, aunque en ellos no se imponga constitucionalmente la obligatoriedad y la gratuidad"323.

El TC subraya la expresión omnicomprensiva — “todos" - utilizada por el texto constitucional a fin de delimitar el círculo de beneficiarios, en perfecta coherencia con la amplia titularidad activa consagrada por los tratados internacionales. Del recurso al DIDH, fundamentalmente a la jurisprudencia del TEDH, infiere que el "derecho a la educación garantizado en el art. 27.1 CE corresponde a «todos», independientemente de su condición de nacional o extranjero, e incluso de su situación legal en España"324. En consecuencia, los extranjeros que se encuentren en España careciendo de autorización de residencia, no pueden ser privados del derecho a la educación -incluyendo tanto la enseñanza básica como la no obligatoria-, porque el "derecho de acceso a la educación no obligatoria de los extranjeros menores de edad forma parte del contenido del derecho a la educación, y su ejercicio puede someterse a los requisitos de mérito y capacidad, pero no a otra circunstancia como la situación administrativa del menor", proclamando la inconstitucionalidad de la exigencia legal de residencia para poder acceder a tal derecho.

Un recorrido argumentativo algo diverso, aunque también presidido por el uso del criterio interpretativo internacionalista ex art. 10.2CE - pero en esta ocasión no es utilizado para indagar el grado de conexión del derecho en cuestión con la dignidad humana- ${ }^{325}$, es seguido por el alto tribunal para enjuiciar la constitucionalidad de la restricción legislativa al derecho a la libertad sindical, cuyo ejercicio quedaba reservado a los extranjeros con autorización de estancia o residencia por el art. 11.1 de la LO 8/2000. El TC recurre a su consolidada jurisprudencia sobre esta materia, donde se vincula la titularidad del derecho de libertad sindical " $a$ «todos» los trabajadores en su caracterización material, y no jurídico-formal, y a «todos» los sindicatos (art. 28.1 en relación con el art. 7 CE), entendiendo de este modo la proyección universal subjetiva que de dicho derecho efectúan los tratados internacionales" ${ }^{26}$. De lo que se deriva la inadmisibilidad constitucional de la exigencia de legalidad para el ejercicio de la libertad sindical de los trabajadores extranjeros. El TC puntualiza sin embargo, que sí resulta legítimo exigir una condición legal para la celebración válida de un contrato de trabajo y para la consecuente obtención de la condición jurídica de trabajador. El legislador orgánico está

322 STC $86 / 1985$.

323 F. J. 8, STC 236/2007.

324 El TC explica, en torno a la titularidad activa amplia del derecho a la educación, que "esta conclusión se alcanza interpretando la expresión del art. 27.1 CE de acuerdo con los textos internacionales citados, donde se utilizan las expresiones «toda persona tiene» $\mathrm{o}$ «a nadie se le puede negar» el derecho a la educación. Según se ha visto, el acceso a los establecimientos escolares y el derecho a utilizar, en principio, los medios de instrucción que existan en un momento determinado, debe garantizarse, de acuerdo con el art. $1 \mathrm{CEDH}$, «a toda persona dependiente de la jurisdicción de un Estado contratante». Esta expresión, contenida en el art. $1 \mathrm{CEDH}$, interpretada conjuntamente con el art. $14 \mathrm{CEDH}$ debe entenderse que incluye también a aquellas personas no nacionales que se encuentren en una situación irregular o ilegal”, (F. J. $8^{\circ}$ ).

325 VIDAL FUEYO estima por ello "más razonable" el análisis efectuado por el TC en el enjuiciamiento de este concreto motivo de constitucionalidad. "La jurisprudencia del TC en materia de derechos..., op. cit., p. 370. También SANTOLAYA MACHETTI considera que el planteamiento seguido por el TC para dilucidar la adecuación de la regulación del derecho a la educación de los extranjeros resulta "más concluyente y más claro". "La gestión de la inmigración...", op. cit., p. 88.

326 F. J. $9^{\circ}$, STC 236/2007. 
habilitado para establecer limitaciones al derecho a la libertad sindical reconocido en el art. 28.1 CE, pero tales limitaciones no pueden excluir totalmente el ejercicio del derecho, situación producida por la legislación recurrida, porque en tal supuesto no se habría respetado el contenido esencial del derecho a la libertad sindical, "que la Constitución salvaguarda por pertenecer a cualquier persona, independientemente de la situación en que se encuentre"327. En consecuencia, no se requiere ostentar la condición de trabajador en sentido legal — sujeción a una relación laboral- para ser titular del derecho a la libertad sindical. Al igual que sucediera con los derechos de reunión y asociación, la declaración de inconstitucionalidad de la restricción legislativa al derecho a la libertad sindical no lleva emparejada su nulidad ${ }^{328}$, en lo que ha sido por ello considerado como una "militante defensa de la 'voluntad del legislador"'329.

\section{b) El T.C. Español ante la Reunificación Familiar}

El aspecto más trascendente de la sentencia 236/2007, para los efectos de nuestro trabajo, reside en que, por primera vez, el TC tiene ocasión de enfrentarse con algunos aspectos vitales del derecho a la reagrupación familiar, fundamentalmente con la cuestión de su naturaleza jurídica y, a su tenor, el encaje constitucional de este derecho, si bien éstas se tratan de soslayo.

\section{b.1 El debate doctrinal previo}

Al igual que ocurría con el Convenio de Roma, la CE guarda silencio en torno a los derechos migratorios - salvo la declaración general que, en materia de extranjería, contiene el artículo 13 $\mathrm{CE}-$. Pese a ello, en vista de la apertura y extensión que caracteriza la declaración constitucional de derechos ${ }^{330}$, son varias las disposiciones constitucionales en cuyo seno podría en principio encontrar acomodo el derecho a la RF de los extranjeros por vía interpretativa iusinternacional: fundamentalmente los derechos reconocidos en los artículos 18.1, 32.1 y el principio rector del art. 39CE. Su distinto emplazamiento determinará la aplicación de un régimen de garantías claramente diferenciado.

\section{Idem.}

328 En el caso de los derechos de reunión, asociación y sindicación, el TC estima que, pese a la inconstitucionalidad de los preceptos legales que establecían limitaciones a tales derechos, no procede declarar su nulidad "porque ello produciría un vacío legal que no sería conforme a la Constitución, pues conduciría a la denegación de tales derechos a todos los extranjeros en España, con independencia de su situación (...), puesto que ello entrañaría una clara alteración de la voluntad del legislador ya que de este modo se equipararía plenamente a todos los extranjeros, con independencia de su situación administrativa, en el ejercicio de los señalados derechos". El TC prosigue señalando que "no corresponde a este Tribunal decidir una determinada opción en materia de extranjería, ya que su pronunciamiento debe limitarse, en todo caso, a declarar si tiene o no cabida en nuesra Constitución aquélla que se somete a su enjuiciamiento". Remite a que sea el propio legislador el que establezca, "dentro de un plazo de tiempo razonable" las condiciones de ejercicio de los derechos de reunión, asociación y sindicación por parte de los extranjeros en situación irregular, sin perjuicio del eventual control de constitucionalidad de aquellas condiciones, que compete al TC. F. J. 17, STC 236/2007, fundamento íntegramente dedicado a precisar el contenido y alcance del fallo del alto tribunal.

329 VIDAL FUEYO, M.C. "La jurisprudencia del TC en materia de derechos...", op. cit., p. 371.

330 En esta línea, SANTOLAYA MACHETTI ha resaltado que "dada la amplitud de nuestra declaración de derechos la inmensa mayoría de los internacionalmente reconocidos pueden ser vinculados sin grave dificultad a uno de nuestros preceptos constitucionales, por lo que el 10.2 puede actuar, dicho en términos de Haberle, como cláusula de simpatía de los derechos humanos, es decir de apertura a la orientación europea de nuestros derechos fundamentales". Si bien el autor puntualiza que la RF tiene "un encaje mucho más forzado" en la CE. El derecho a la vida familiar de los extranjeros, op. cit., pp. 52 y 53. 
De un lado, el artículo 18.1 CE reconoce la faceta familiar del derecho a la intimidad careciendo, por tanto, de un contenido autónomo ${ }^{331}$. De otro lado, el artículo $32 \mathrm{CE}$ consagra el derecho a contraer matrimonio y, finalmente, el artículo 39, dentro de los principios rectores de la política social y económica, garantiza el deber de los poderes públicos de otorgar a la familia protección social, económica y jurídica.

El derecho fundamental garantizado en el art. 18.1 CE está dotado del nivel más alto de garantías y, como tal, no sería legítimo introducir diferencias en su régimen jurídico en función de la nacionalidad del sujeto activo, dado que se inserta en el primer grupo de derechos, dentro de la tipología clásica establecida por el TC. Esta circunstancia supone la imposibilidad de justificar la restricción en la titularidad activa que caracteriza el régimen de la $\mathrm{RF}$ - concedido en exclusiva a favor del extranjero residente-, por no mencionar las dificultades que se elevarían desde el punto de vista de su disponibilidad por parte de las políticas públicas migratorias.

Desde el punto de vista de la afinidad material existente entre el derecho a la intimidad —en su faceta familiar, reconocido por el art. 18.1 CE-, y el derecho al respeto de la vida familiar del art. $8 \mathrm{CEDH}$-en tanto que obligación positiva exigible a los poderes públicos internos de los Estados parte del Consejo de Europa-, si bien constituye una cuestión que excede los objetivos de este trabajo, baste aquí con apuntar que el contenido material del derecho convencional a la vida familiar es mucho más amplio que el más limitado ámbito protegido por la Constitución Española mediante el derecho a la intimidad ${ }^{332}$. El derecho a la intimidad, tal y como reiteradamente ha reconocido el TC, protege ámbitos de privacidad, tanto personales como familiares, del escrutinio ajeno. Sin embargo, la protección frente a intromisiones ilegítimas que otorga la intimidad personal y familiar, no es equivalente al derecho a la vida en familia y, en consecuencia, no faculta a sus beneficiarios a reclamar de las autoridades la no injerencia sobre el derecho a vivir en compañía de los familiares más próximos ${ }^{333}$.

De otro lado, la inserción del derecho a la RF como una dimensión instrumental del derecho fundamental a la intimidad familiar acarrearía dificultades prácticas. Entre ellas, la exención de un visado por causa de RF podría acarrear la vulneración del derecho fundamental consagrado en el art. 18.1 CE — negada por la interpretación jurisdiccional ordinaria ${ }^{334}-\mathrm{y}$, en último extremo, ha-

331 En el mismo sentido, SANTOLAYA MACHETTI destaca que, conforme a la doctrina del TC, la intimidad familiar constituye tan sólo "una dimensión adicional de la intimidad personal, que, en ocasiones, supone adicionar un segundo círculo de intimidad en el ámbito de la familia añadido al que corresponde como persona”. El derecho a la vida familiar...op. cit., p. 20. Marc CARRILLO subraya que la intimidad familiar, en cuanto contenido objeto de protección del derecho fundamental reconocido en el art. 18.1, proteje "la intimidad de los miembros integrantes de la familia en cuanto unidad de relaciones personales". En consecuencia, lo que se tutela a través de este derecho "no es la familia como institución sino a sus miembros en su actividad grupal. Pues la familia como núcleo social, como uno de los grupos en los que la persona puede integrarse, recibe un tratamiento específico a través del art. 39CE”. El derecho a no ser molestado. Información y vida privada. Navarra, Thomson Aranzadi, 2003, p. 51.

332 Para un estudio en profundidad de esta cuestión, vid el excelente trabajo de SANTOLAYA MACHETTI, P. El derecho a la vida familiar de los extranjeros, op. cit., pp. 77-113. Del mismo autor "Derecho a la vida privada y familiar: un contenido notablemente ampliado del derecho a la intimidad”, dentro de la obra coordinada por Santolaya, junto con Javier GARCÍA ROCA. La Europa de los derechos. El Convenio Europeo de Derechos Humanos. Madrid, CEPC, 2005, pp. 487-507.

333 VIDAL FUEYO, desarrollando más la línea argumental abierta por el TC, puntualiza que la intimdiad familiar protege "ámbitos de privacidad frente a intromisiones ilegítimas, pero no habilita a sus titulares a exigir de los poderes públicos que les aseguren una vida en común con sus familiares más cercanos". "La jurisprudencia del TC en materia de...”, op. cit., p. 373.

334 SOLANES CORELLA, Angeles. "Inmigración, derechos y exclusión”; IZQUIERDO, Antonio (coord.). El modelo de inmigración y los riesgos de exclusión. Madrid, Fundación Foessa, 2008, p. 111, nota a pie de página nº 65. 
bilitaría para acceder a la vía de amparo ante el TC, de ahí que la vinculación entre el derecho a la intimidad familiar y la RF que aparece en la ley de extranjería haya sido considerada como un "error dogmático"335.

En vista de las dificultades que, tanto desde el punto de vista de la dogmática jurídica como de la interpretación internacionalista, conlleva la consideración de la RF como una instrumento para la materialización de la intimidad familiar —-dentro del marco constitucional preferente prefigurado por el artículo 18.1CE-, las alternativas nos sitúan ante la disyuntiva de optar entre el derecho también fundamental - pero dotado de un rango inferior de garantías jurídicas-, al matrimonio recogido en el artículo 32, y el principio rector de protección a la familia consagrado en el artículo 39.

Ya señalamos en su momento que el derecho a contraer matrimonio garantizado en el art. 32.1 CE supondría excluir de su posible tutela constitucional los modelos familiares no matrimoniales, de modo que la familia como garantía institucional protegida por el art 39 CE constituye la opción jurídicamente más correcta. Concebir la RF como una vía instrumental para la protección de las familias integradas por extranjeros admite la introducción de diferencias en su tratamiento jurídico en atención a la nacionalidad e incluso a la concreta situación administrativa que ostente el titular activo, al tiempo que permite un mayor margen de maniobra en el que desenvolver las políticas públicas implementadas en este ámbito. Por ello, la ubicación de la RF como una proyección del principio rector de protección de la familia del art. $39 \mathrm{CE}$ ha sido la postura mayoritaria entre la doctrina ${ }^{336}$. En un sentido similar, el derecho a la vida familiar y a la reagrupación de los extranjeros ha sido incluido en la tercera categoría de derechos de los no nacionales - aquellos que admiten modulaciones en su contenido, titularidad y ejercicio-, recurriendo a la célebre clasificación tripartita del TC ${ }^{337}$.

335 Idem, p. 111. Por su parte, Gómez Urrutia, la califica como una “aparente confusión legal entre el derecho a la intimidad fmailiar y el derecho a la vida en familia en la ley de extranjería”; en VA RGAS GÓMEZ-URRUTIA, Marina. La Reagrupación familiar de los extranjeros en España. Normas de extranjería y problemas de derecho aplicable. Madrid, Thomson-Aranzadi, 2006, p. 109. SANTOLAYA fundamenta ampliamente "el rechazo a la mecánica identificación que realiza nuestra ley de extranjería entre el derecho a la intimidad y el derecho a la vida familiar". El derecho a la vida familiar de los extranjeros, op. cit, p. 62.

336 Vid, entre otros, SANTOLAYA MACHETTI, P. El derecho a la vida familiar de los extranjeros, op. cit, p. 62. BERNARDO, Sofía; VILAS, Ana y CUADRA, Luz Isabel. "Reagrupamiento Familiar”; Jornada sobre el Reglamento de la Ley de Derechos y Libertades de los extranjeros. Barcelona, 30 de junio de 1995. Ajuntament de Barcelona, 1995, p. 50. Las autoras estiman que el artículo $39 \mathrm{CE}$ "centra de partida en nuestro derecho positivo, la salvaguarda del reagrupamiento familiar". En conjunción con el derecho de igualdad consagrado en el artículo 14 y la prohibición de la arbitrariedad de los poderes públicos, reconocida en el artículo 9, "acaban situando el derecho en toda su protección, expresan la obligatoriedad estricta de su respeto y suponen la referencia inexcusable y obligatoria para contemplarlo en las disposiciones sobre extranjería" (p. 50). Las autoras finalizan su argumentación uniendo a las anteriores consideraciones el artículo 13.1 (los extranjeros gozarán en España de las libertades públicas que garantiza su Título I) y el deber de informar la legislación positiva (art. 53.3), para concluir que "nos encontraremos con la obligación de dar al reagrupamiento familiar del emigrante el tratamiento de derecho constitucional y de regular su posibilidad con criterios de igualdad, facilidad y no discriminación. Nos encontraremos, en definitiva, no con una medida cuyo tratamiento razonable depende del carácter conciliador o solidario de los legisladores, sino con el derecho que no puede dejar de reconocerse y aplicarse" (idem, p. 50). En la misma línea se inscribe VIDAL FUEYO, quien subraya las dificultades jurídicas que suponen conectar la RF con el derecho a la intimidad familiar, concebido éste como una dimensión de la intimidad personal. "La jurisprudencia del TC en materia de derechos fundamentales de los extranjeros...", op. cit., p. 373.

337 En esta corriente se insertan, por ejemplo, MARÍN GÁMEZ, José Angel. "Una visión de los derechos y garantías constitucionales de los extranjeros en España”; en Revista de Derecho Político, No 61, 2004, p. 59. Posteriormente, el mismo autor, tras analizar la legislación de extranjería, señala que el derecho a la RF encuentra su acomodo constitucional en la conjunción de los artículos 32 y 39, excluyendo su inclusión como parte del derecho a la intimidad familiar consagrado en el artículo 18 CE. Idem, p. 64. 
Si aplicamos ahora la doctrina constitucional, tal y como ha sido sistematizada y reformulada por el TC en la STC 236/2007, la RF se situaría entre aquellos derechos cuyo reconocimiento a favor de los no nacionales dependería de la acción normativa del legislador, tanto internacional como interno. En palabras del TC, se insertaría entre "aquellos derechos que no son atribuidos directamente por la Constitución a los extranjeros pero que el legislador puede extender a los no nacionales (...), derechos de los que serán titulares los extranjeros en la medida y condiciones que se establezcan en los Tratados y las Leyes". Sobre tales derechos el legislador posee un mayor margen de configuración normativa, siempre que las condiciones para su ejercicio respeten tres límites: no afectar a derechos imprescindibles para la garantía de la dignidad humana, no atentar contra el contenido esencial del derecho y superar el principio de proporcionalidad, en sintonía asimismo la jurisprudencia de Estrasburgo.

De otro lado, la RF evidencia las debilidades implícitas a la utilización del criterio de la dignidad humana como base para la estratificación de los derechos de los extranjeros que, como es bien sabido, es utilizado por la jurisprudencia constitucional como pilar básico en la construcción del estatuto de dicho colectivo. Retomando las críticas formuladas por Vidal Fueyo y aplicándolas a nuestro objeto de estudio, la RF constituye un buen ejemplo de la opacidad de este criterio y de los problemas prácticos que éste deja sin resolver ${ }^{338}$.

\section{b.2 La naturaleza jurídica del derecho a la RF: Su matriz constitucional}

El Parlamento de Navarra impugnaba los arts. 16.2, 17.2 y 18.4 $4^{339}$, en la nueva redacción dada por la LO 8/2000, que remitía a un posterior desarrollo reglamentario el establecimiento de las condiciones de ejercicio de los derechos a la intimidad familiar y al reagrupamiento familiar - rubricados así conjuntamente por la propia ley recurrida-. A su juicio todos ellos vulneraban la reserva de ley orgánica establecida por la Constitución (arts. 18 y $81.1 \mathrm{CE}$ ) o, alternativamente, la reserva de ley del art. 53.1 por afectar al contenido y límites del derecho a la intimidad del art. 18.1 CE y por incumplir las exigencias constitucionales establecidas para tales remisiones.

En torno a esta cuestión, conviene precisar que la disposición final primera de la LO 8/2000, en su apartado primero, atribuía rango de ley orgánica a los artículos 16, 17 y 18, concibiendo de forma implícita a la RF como un desarrollo del derecho a la intimidad consagrado en el art. 18.1 CE. El Abogado del Estado estimaba que ésta era una concepción desacertada de la RF, lo cual llevó al legislador a atribuir rango de ley orgánica a los artículos mencionados. Señalaba el Abogado del Estado que ni en la jurisprudencia constitucional ni en la Constitución se reconocía un derecho fundamen-

338 Puestos a afrontar la complicada cuestión de su grado de conexión con la dignidad humana, nos enfrentaríamos a la delicada tarea de dar respuesta a preguntas del tipo: qué resulta más próximo a la dignidad humana y, por ende, más imprescindible para su garantía, ¿el derecho de una persona a convivir con los miembros más próximos de su familia, especialmente hijos menores de edad, o derechos, de importancia vital para el Estado democrático de derecho, tales como los de reunión y asociación?. Formulada en tales términos, la pregunta plantea múltiples dilemas éticos, situando al intérprete jurídico ante una cuestión que, en último término, depende de criterios fundamentalmente subjetivos.

339 El artículo 16.2 fue erróneamente invocado por el recurrente - en lugar del art. 16.3, donde se reconoce al cónyuge y sus familiares el derecho a conservar la residencia adquirida por causa familiar, aunque se rompa el vínculo matrimonial que dio lugar a su adquisición-, remitiendo al reglamento la determinación del tiempo previo de convivencia en España que haya de acreditar en tales supuestos. Por su parte, el art. 17.2 establecía que reglamentariamente se determinarán las condiciones para el ejercicio del derecho de reagrupación y en especial del que corresponda a quienes hubiesen adquirido la residencia en virtud de un previa RF. Y, finalmente, el apartado cuarto del art. 18 remitía al reglamento la determinación de las condiciones para el ejercicio del derecho de reagrupación por quienes hayan adquirido la residencia en virtud de una previa reagrupación. 
tal a la vida familiar, en los términos del art. 8.1 CEDH, en la interpretación efectuada por el TEDH. Remarcaba que el derecho a la intimidad familiar no comprende el derecho del extranjero a la vida en familia, y el consiguiente derecho a la RF, "que son derechos de creación legal", de modo que a su juicio la regulación legal de la RF contenida en los preceptos impugnados debería concebirse como una modalidad de protección jurídica de la familia establecida en el art. 39.1 CE, en coherencia con el art. 16.3 de la DUDH, y el art. 23.1 del Pacto internacional de derechos civiles y políticos. En consecuencia, dado que la regulación recurrida constituye un cumplimiento del mandato contenido en el art. 39.1 CE - y no el desarrollo del ejercicio de un derecho fundamental-, no operaría ninguna de las dos reservas constitucionales invocadas por el recurrente. En todo caso, entendía el Abogado del Estado que, aun suponiendo que la RF de los residentes estuviera reservada a la ley, las llamadas al reglamento contenidas en las tres disposiciones recurridas se limitaban a regular las condiciones accesorias para el ejercicio de un derecho. Se trataba pues de una tarea de estricto complemento de la regulación legal, constituyendo una colaboración necesaria del reglamento con la ley.

Para poder analizar la conformidad de las remisiones reglamentarias impugnadas, el TC comprueba con carácter previo que los preceptos impugnados versan realmente sobre el derecho fundamental a la intimidad reconocido en el art. 18.1 CE, pues es éste derecho el que es objeto de las reservas de ley presuntamente infringidas. Pese a que la propia ley recurrida encuadra la regulación del derecho a la RF bajo el título genérico del "derecho a la intimidad familiar", proclamando expresamente en su art. 16.1 el derecho que asiste a los extranjeros residentes a la vida en familia y a la intimidad familiar, el TC excluye ubicar la RF como un contenido material del derecho a la intimidad en su dimensión familiar, proclamando contundentemente:

"Este derecho a la reagrupación familiar, sin embargo, no forma parte del contenido del derecho consagrado en el art. $18 \mathrm{CE}$, que regula la intimidad familiar como una dimensión adicional de la intimidad personal, y así lo ha reconocido nuestra jurisprudencia ${ }^{340 "}$.

En refuerzo de esta exclusión, el TC realiza un apretado resumen de su jurisprudencia en torno al contenido del derecho a la intimidad personal ${ }^{341}$. Este implica "la existencia de un ámbito propio y reservado frente a la acción y conocimiento de los demás," extendiéndose no sólo a los aspectos de la vida propia personal, sino también a determinados aspectos de otras personas con las que se guarde una personal y estrecha vinculación familiar, quedando estos aspectos resguardados de una publicidad no querida por su titular. Se echa en falta una argumentación más elaborada por parte del TC a fin de descartar la conexión de la RF con el derecho proclamado en el art. 18.1CE. Dado que se trata de la primera y única ocasión hasta el momento en que el TC se ha enfrentado a la RF de los extranjeros, hubiera sido deseable un mayor desarrollo sobre este punto específico, pese a lo acertado de la conclusión expuesta por el TC.

Tras excluir el derecho a la intimidad familiar como matriz constitucional del derecho a la RF, el TC pasa a examinar la jurisprudencia de Estrasburgo en torno al derecho a la vida familiar del art. 8.1 CEDH y sus conexiones con la RF de los extranjeros, desechando la equivalencia entre la vida familiar y el derecho reconocido en el art. 18.1 CE:

"La jurisprudencia del Tribunal Europeo de Derechos Humanos, en contraste con la de este Tribunal, ha deducido de aquel precepto un «derecho a la vida familiar», que comprendería como uno de sus ele-

340 STC 236/2007, F. J. 11.

341 En el fundamento undécimo el TC se remite expresamente a la dotrina emitida al respecto en las siguientes sentencias: STC 231/1988, de 2 de diciembre, F. J. 3; STC 197/1991, de 17 de octubre, F. J. 3; STC 134/1999, de 15 de julio, F. J. 5; STC 115/2000, de 5 de mayo, F. J. 4. 
mentos fundamentales el disfrute por padres e hijos de su mutua compañía (STEDH caso Johansen, de 27 de junio de 1996, aptd. 52). Sin embargo, no ha llegado a reconocer explícitamente un auténtico derecho a la reagrupación familiar derivado del art. $8 \mathrm{CEDH}$ (SSTEDH caso Abdulaziz, de 28 de mayo de 1985, \$ 68; caso Ahmut, de 28 de noviembre de 1996, aptd. 67; caso Gül, de 19 de febrero de 1996, aptds. 39-43), que sólo sería eficaz en el supuesto de que la vida familiar no fuera posible en ningún otro lugar, por impedimento legal o fáctico (SSTEDH caso Sen, de 21 de diciembre de 2001, aptds. 28-40; caso Boultif, de 2 de agosto de 2001, aptds. 53-56). Por otra parte, el Tribunal Europeo de Derechos Humanos ha admitido que en algunos casos el art. 8.1 CEDH puede actuar como límite a la posibilidad de aplicación de las causas legales de expulsión de los extranjeros, si bien teniendo en cuenta a su vez los límites impuestos por el art. 8.2 CEDH, las circunstancias del caso y la ponderación de los intereses en juego".

En síntesis, el TC, al examinar la jurisprudencia de Estrasburgo aplicable a la vida familiar de los extranjeros, llega a conclusiones muy similares a las predominantes todavía en el ámbito doctrinal, apoyándose para ello en una línea jurisprudencial ya rebasada por el TEDH. A juicio de nuestro alto tribunal, el Tribunal de Estrasburgo no ha reconocido todavía un auténtico derecho a la RF de los extranjeros derivado del derecho a la vida familiar del art. $8 \mathrm{CEDH}$ - citando para ello expresamente la primera línea jurisprudencial en este ámbito, las sentencias Abdulaziz, Ahmut y Gül, pero sin mencionar ni uno sólo de los pronunciamientos posteriores a Sen-. El TC matiza que el todavía inexistente derecho a la RF sólo sería eficaz en los supuestos de aplicación del también ya superado criterio elsewhere, esto es cuando la vida familiar no fuera posible en ningún otro lugar — basándose para ello en la sentencia Sen-. Ya señalamos que es precisamente a partir de este pronunciamiento cuando el TEDH inicia una línea jurisprudencial claramente rupturista con su jurisprudencia previa, abandonando la primacía antes absoluta del criterio elsewhere - el mismo que el TC estima como único supuesto en que del derecho convencional a la vida familiar podría extraerse cierta eficacia jurídica sobre la RF de los extranjeros en el ámbito del Consejo de Europa-.

Además, el TC subraya que el derecho del art $8 \mathrm{CEDH}$ - en contraste con lo sucedido respecto al reagrupamiento familiar-, si ha dado origen a una línea jurisprudencial protectora de aquellos extranjeros pendientes de una orden de expulsión que provoque una ruptura de su vida familiar, en cumplimiento de las condiciones fijadas en el art. 8.2 CEDH. Sobra decir que, si bies es cierto que la protección frente a expulsiones como obligación negativa derivada del respeto a la vida familiar constituye una línea jurisprudencial más sólida y asentada, la RF de los extranjeros en tanto que obligación positiva ha conocido un desarrollo sin precedentes a partir de la sentencia Sen. El avance ha sido de tal calibre que existen incluso voces autorizadas que proclaman que este derecho puede proteger, en determinadas circunstancias, la vida familiar de extranjeros en situación irregular asentados en el territorio de los Estados parte del Consejo de Europa ${ }^{342}$ - supuesto de hecho que, como es bien sabido, está excluido de la titularidad activa en aquellos países donde la RF constituye un derecho subjetivo de los extranjeros.

Tras su examen del marco de Estrasburgo, el TC repasa brevemente la configuración de la RF en el DIDH - arts 16.3 DUDH y 23.1 PIDCP - considerando que "de tales preceptos no se deduce tampoco un criterio interpretativo del art. 18.1 CE, que llevaría a entender comprendido en el mismo un derecho a la reagrupación familiar". La conclusión del TC, coincidente con la desplegada por el Abogado del Estado ${ }^{343}$, es que

342 THYM, Daniel. "Respect for Private and Family Life under Article 8 ECHR in Immigration Cases: A Human Right to Regularize Illegal Stay?; International and Comparative Law Quarterly, vol. 57, 2008, pp 87-112.

343 Tanto en la argumentación del Abogado del Estado, como en la propia del TC, aparecen tópicos muy comunes en la interpretación de la jurisprudencia emitida por el TEDH al desarrollar la RF de los extranjeros, dentro del derecho a la vida familiar reconocido por el art. $8 \mathrm{CEDH}$. El abogado del Estado afirma textualmente que el TEDH 
"nuestra Constitución no reconoce un derecho a la vida familiar en los mismos términos en que la jurisprudencia del TEDH ha interpretado el art. 8.1 CEDH, y menos aún un derecho fundamental a la reagrupación familiar, pues ninguno de dichos derechos forma parte del contenido del derecho a la intimidad familiar garantizado por el art. 18.1 CE”344.

En esta conclusión, impecable desde el punto de vista jurídico, se echa en falta una argumentación más elaborada y convincente, así como haber despejado de una vez las dudas en torno a la naturaleza jurídica del derecho a la $\mathrm{RF}^{345}$, ubicándolo expresamente, como una proyección material del principio rector de protección familiar — art 39.1 CE-.

En consecuencia, los preceptos de la LO 8/2000 en materia de RF, al no regular ni desarrollar el derecho fundamental a la intimidad familiar, no están sometidos ni a reserva de ley orgánica —art. 81.1 - , ni a la reserva de ley establecida para los derechos y libertades del capítulo II —art. 53.1 CE-, desestimando el TC este motivo de constitucionalidad. Para el TC, las reservas reglamentarias contenidas en la ley recurrida son acordes con el texto constitucional, pese a que algunos sectores doctrinales cuestionaban su legitimidad ${ }^{346}$. Finalmente, el TC considera que no es preciso pronunciarse sobre la cuestión —-sostenida por el Abogado del Estado—, de si la RF constituye una moda-

“tampoco ha proclamado una suerte de derecho ilimitado a la reagrupación familiar, sino que su doctrina ha sido establecida solamente en relación con casos de expulsión, y siempre que entrañara un riesgo cierto de quebrar la vida familiar preexistente. Por otro lado, una RF entendida como derecho fundamental del extranjero residente sería incompatible con el Tratado constitutivo de la CE (art. 63.3.a). "Apartado f), del punto 6, dentro de los Antecedentes a la STC 236/2007. Contrariamente a la opinión expuesta, esta tesis ha descrito la marcada evolución seguida por el Tribunal de Estrasburgo que, si bien con un menor grado de desarrollo y consolidación que la protección frente a expulsiones, ha creado una fértil y creativa línea jurisprudencial derivada también del derecho al respeto a la vida familiar, para la protección de la RF de los extranjeros.

344 STC 236/2007, F. J. 11. En contra la de interpretación alcanzada por el TC se pronuncia tajantemente LÓPEZ ULLA, quien concluye que la misma constituye una "falta de sintonía de la jurisprudencia del TC con la del TEDH, que (...) no encaja de todo con el mandato constitucional de interpretar los derechos fundamentales que la Constitución reconoce de conformidad con los tratados y acuerdos internacionales suscritos por España sobre la material (art. 10.2)"; "Extranjeros reagrupables", op. cit., p. 448.

345 De todas las sentencias emitidas con ocasión de los diversos recursos de inconstitucionalidad presentados contra la LO 8/2000, dos de ellas inciden muy de pasada en la naturaleza jurídica del derecho a la reagrupación familiar: junto a la STC 236/2007 de 7 noviembre, ya comentada, también la STC 260/2007, de 20 diciembre, aborda someramente esta cuestión. Sin embargo, la última sentencia citada se limita a remitirse al pronunciamiento previo dictado en noviembre, rehuyendo nuevamente una buena oportunidad para haber clarificado con mayor profundidad la naturaleza jurídica del derecho a la RF. Sobre este aspecto, en la STC 260/2007, el TC señala: "Procede, pues, comenzar con el examen de los apartados 12 y 13 del artículo 1 de la Ley Orgánica 8/2000, los cuales dan nueva redacción al art. 16.3 y añaden un nuevo art. 17.2 a la Ley Orgánica 4/2000, respectivamente. La representación procesal del Parlamento Vasco considera que la remisión reglamentaria que contienen los citados preceptos, relativos al derecho a la intimidad familiar y al reagrupamiento familiar, vulnera la reserva de Ley Orgánica ex art. $81 \mathrm{CE}$ en relación con el derecho a la intimidad del art. $18 \mathrm{CE}$. Pues bien, la cuestión planteada, una vez examinada, ha de reputarse resuelta por la doctrina que este Tribunal Constitucional ha establecido en el fundamento jurídico 11 de la STC 236/2007, de 7 de noviembre, en el que desestimamos este motivo de inconstitucionalidad al apreciar que los preceptos impugnados no regulaban ni desarrollaban el derecho fundamental a la intimidad familiar (art. 18.1 CE), ni estaban sometidos a la reserva de Ley Orgánica (art. 81.1 CE), ni a la reserva de Ley establecida para los «derechos y libertades reconocidos en el capítulo II» (art. 53.1 CE), por lo cual las remisiones reglamentarias contenidas en los artículos recurridos no habían infringido aquellas disposiciones constitucionales".

346 Sobre este punto, la profa. VIDAL FUEYO estima que la reserva reglamentaria en blanco - pese a no afectar al contenido y límites del derecho a la intimidad del art. 18.1 CE-, puede chocar con otros preceptos constitucionales: con la reserva de ley —interna e internacional - contenida en el art. 13.1 CE, como con normas que deben desarrollar el ejercicio de los derechos del Título I, e incluso con el necesario desarrollo legislativo — art. 53.3 CE- que requiere el principio rector de defensa de la familia del art. 39.1 CE, con el cual la autora conecta la RF. En definitiva, para VIDAL FUEYO, la RF constituye "una materia que ha de regularse necesariamente mediante ley". "La jurisprudencia del TC en materia de derechos fundamentales de los extranjeros...”, op. cit., p. 374. 
lidad de protección de la familia, a fin de hacer efectivo el principio rector consagrado en el art. 39.1 CE. La doctrina ha entendido que, en este punto, el TC, aun sin hacerlo expreso, parece coincidir con la opinión manifestada por el Abogado del Estado ${ }^{347}$. En nuestra opinión, en el razonamiento del TC queda implícita la inserción de la RF como un instrumento para materializar la protección de la familia del extranjero.

Al rehusar clarificar la inserción constitucional del derecho a la RF, el TC ha perdido una importante oportunidad de poner luz sobre una trascendente cuestión. Dado que la STC 236/2007 descarta su vinculación material con el derecho fundamental a la intimidad familiar, con buen criterio queda excluida la vía de amparo para la tutela del derecho a la RF y, consiguientemente, futuras oportunidades de que el TC pueda pronunciarse sobre su concreta naturaleza jurídica. Este aspecto era importante a efectos de deducir ex artículo 10.2 CE el criterio interpretativo internacional que rige en esta materia. Con todo, el constante recurso del TC a la jurisprudencia de Estrasburgo evidencia la vigencia de este parámetro, aun cuando el mismo no constituya criterio exegético del artículo $18 \mathrm{CE}$.

Con todo, con independencia de cual sea su concreto encaje constitucional —cuestión esencial a efectos de su grado de tutela - lo cierto es que, a efectos de la utilización del canon interpretativo iusinternacional contenido en el artículo 10.2 CE, esta cuestión pierde importancia. Pues, aplicando la teoría de Saiz Arnaiz, dicho canon se proyecta sobre todos los derechos reconocidos en el Título I de la Constitución. En consecuencia, si el asiento constitucional del derecho a la RF corresponde al principio constitucional de protección de la familia contenido en el Capítulo $3^{\circ}$ del Título I, también en esta hipótesis, su interpretación ha de hacerse conforme a lo previsto en los tratados internacionales y las decisiones emitidas por los órganos de garantía de los mismos. Adicionalmente, el mandato interpretativo del artículo 10.2 se encuentra favorecido y reforzado en materia de extranjería por la previsión contenida en el artículo $13 \mathrm{CE}$. A mayor abundamiento, la Ley de Extranjería potencia la fortaleza del anterior criterio hermenéutico en esta específica materia en su artículo $3.1^{348}$ zanjando esta cuestión. Confirmando el carácter preceptivo de la interpretación internacionalmente vinculada del derecho a la RF, así como el fuerte condicionamiento internacional que rige en esta materia.

La STC 236/2007 tocaba otras cuestiones de trascendencia en materia de extranjería e inmigración, que por cuestiones de espacio se tratarán muy brevemente. Entre ellas, se recurría la falta de exigencia de motivación con carácter general de la denegación de visado — resultando, sin embargo, preceptivo motivar los supuestos de denegación de visado de residencia para reagrupación familiar o para trabajo por cuenta ajena. Para el TC, la exoneración del deber de motivación de los actos administrativos denegatorios de visado no es contraria al art. $24.1 \mathrm{CE}^{349}$, puesto que constituyen actos

347 SANTOLAYA MACHETTI, P. “La gestión de la inmigración...., op. cit., p. 89; VIDAL FUEYO, M.C. “La jurisprudencia del TC en materia de derechos fundamentales de los extranjeros.., op. cit., p. 74, la autora conecta el derecho a la RF con el derecho de entrada y establecimiento del art. 19 CE y con la defensa de la familia que realiza el art. 39 CE.

348 El tenor literal del artículo 3.1 de la L.O. 4/2000, cuya redacción procede de la reforma operada mediante la L.O. 8/2000, señala que "los extranjeros gozarán en España de los derechos y libertades reconocidos en el Título I de la Constitución en los términos establecidos en los Tratados internacionales, en esta Ley y en las que regulen el ejercicio de cada uno de ellos. Como criterio interpretativo general, se entenderá que los extranjeros ejercitan los derechos que les reconoce esta Ley en condiciones de igualdad con los españoles.

349 Una posición disidente a la expresada por el TC, puede verse en VIDAL FUEYO, M.C. "La jurisprudencia del TC en materia de derechos fundamentales de los extranjeros.., op. cit., pp. 374-376. La autora subraya que si bien el extranjero no es titular de un derecho objetivo a obtener un visado, sin embargo ostenta un interés legítimo que estima suficiente para exigir la motivación de su denegación. Además, recuerda que la Ley 30/1992, exige la motivación de todo acto discrecional — como lo son los que resuelven las solicitudes de visado-, asícomo la doctrina del TS, que exige motivación en tales supuestos. También SANTOLAYA MACHETTI, quien estima que 
que ni imponen sanción alguna, ni limitan el ejercicio de ningún derecho fundamental -el TC recuerda que la obtención de visado no es un derecho del extranjero, dado que el derecho a entrar en España no constituye un derecho fundamental del que sean titulares los no nacionales, tal y como establece el art. $19 \mathrm{CE}$-. Además, reitera que se trata de actos administrativos sometidos a control jurisdiccional.

El Parlamento de Navarra recurría también la limitación de la asistencia jurídica gratuita a los extranjeros residentes. El TC proclama la inconstitucionalidad de la limitación señalada, como consecuencia de la conexión instrumental existente entre el derecho a la asistencia jurídica gratuita y el derecho a la tutela judicial efectiva. Se impugnaban también los apartados 2 y 8 del art. 57, que autorizaban la expulsión de los extranjeros condenados por conducta dolosa que constituyese delito sancionado con pena privativa de libertad superior a un año, por considerarse contrario al art. 25.1 $\mathrm{CE}$ - principio de reeducación y reinserción social y non bis in idem en conexión con los principios de legalidad y tipicidad de infracciones y sanciones-. El TC rechaza la pretendida inconstitucionalidad de tales preceptos, recordando que la expulsión es una medida que se encuentra en el marco de la política de extranjería - no constituye una pena inserta en el marco de la política criminal del Estado-, y que es lícito que la ley de extranjería subordine el derecho a residir en España al cumplimiento de determinadas condiciones, entre las que se incluye la no comisión de delitos de cierta gravedad, en concordancia con la doctrina del $\mathrm{TEDH}^{350}$.

El art. 60 de la ley recurrida - al regular el internamiento de los extranjeros en los casos de retorno-, no garantizaba que, más allá de las setenta y dos horas, correspondiese a un órgano judicial la decisión sobre la continuación o no de la limitación de la libertad. El TC estima que el precepto impugnado es susceptible de interpretarse conforme a la Constitución, señalando que a partir de las setenta y dos horas de internamiento, ha de ser el órgano judicial quien debe adoptar libremente la decisión que corresponda respecto a la continuación o no de la detención del extranjero pendiente del trámite de retorno. Finalmente, el art. 63.2 de la L.O 8/2000 establecía un plazo de alegaciones de 48 horas en el procedimiento preferente de expulsión tras la incoación del expediente sancionador que, a juicio del recurrente, violaba el art. $24 \mathrm{CE}$ por la brevedad del plazo, considerado insuficiente para una defensa eficaz. El TC desestima este último motivo de inconstitucionalidad, recordando que la brevedad de los plazos no supone per se la vulneración del derecho a la tutela judicial efectiva si con ello se pretende hacer efectivo el principio de celeridad en el procedimiento, respondiendo en este caso el plazo legalmente fijado a una finalidad razonable y necesaria.

\section{b.3 Valoración de la STC 236/2007}

La STC 236/2007, en tanto que compendio de los ochos recursos formulados contra la ley orgánica 4/2000 en la reforma operada mediante la LO 8/2000, constituye un pronunciamiento cuya

resultan "discutibles" las consideraciones realizadas por el TC en torno a la constitucionalidad de los artículos de la ley recurrida que permitían no motivar una buena parte de los visados, recurriendo para ello a una argumentación "forzada". "La gestión de la inmigración..., op. cit., p. 89.

350 Sin embargo, SANTOLAYA MACHETTI matiza que - al menos con respecto a los extranjeros que gocen de un nivel alto de arraigo en España-, el TC podría haberse planteado cuestiones similares a las que frecuentemente aparecen en los votos particulares de las sentencias del TEDH en materia de expulsión de extranjeros arraigados que entren en conflicto con el derecho a la vida familiar: Si es justificable que su tratamiento sea distinto al de los nacionales, o bien podría pensarse que la sanción adicional es discriminatoria, pensando que las leyes penales del país de destino "deberían ser normalmente suficientes para castigar los actos delictivos cometidos por un extranjero integrado de la misma manera que se consideran suficientes para castigar en el mismo supuesto a un nacional" (voto particular del Juez Voighel a la STEDH El Boujaïdi contra Francia). “La gestión de la inmigración...”, op. cit., p. 90. 
trascendencia resulta evidente, tanto en los fundamentos que declaran la inconstitucionalidad de los preceptos legales recurridos, como también en aquellos que expresan su conformidad con la Constitución ${ }^{351}$.

En síntesis, el alto tribunal debía responder a la compleja cuestión del margen concreto de maniobra legislativa en materia de derechos de los extranjeros, y hasta qué punto la posesión de un permiso de estancia o residencia puede condicionar el ejercicio de determinados derechos fundamentales, cuya titularidad formalmente proclamaba a su favor la ley recurrida. Para responder a esta cuestión, el TC se apoya fundamentalmente en dos recursos argumentativos en torno a los que de forma recurrente se construye la amplia fundamentación jurídica de esta sentencia: de un lado, la clasificación tripartita clásica basada en el criterio de la dignidad humana ${ }^{352}$; de otro el criterio interpretativo internacionalista ext. art. 10.2 CE que, a su vez, se utiliza estrechamente conectado a la teoría tripartita, para investigar el grado de conexión de los distintos derechos de los extranjeros al etéreo criterio de la dignidad humana ${ }^{353}$, conforme a lo establecido en los tratados internacionales interpretados en ocasiones de forma escasamente rigurosa ${ }^{354}-\mathrm{y}$, con ello, otorgarles una ubicación concreta dentro de dicha clasificación. Todo ello nos sitúa ante un fallo dotado de un tono general progresivo, pero tendente a recalcar y sistematizar jurisprudencia constitucional previa ${ }^{355}$, que no logra despejar algunas de las ambigüedades que proliferaban en este ámbito y que, en ocasiones, se antoja escasamente fundamentado ${ }^{356}$.

Comparativamente con los recursos empleados por el Tribunal de Estrasburgo en la interpretación de los derechos convencionales - a cuya jurisprudencia acude reiteradamente nuestro alto tribunal—, sorprende la nula utilización del principio de proporcionalidad, cuyo uso quizá hubiera conducido a idénticas conclusiones, pero con una fundamentación más elaborada ${ }^{357}$ y consistente.

351 En el mismo sentido, SANTOLAYA MACHETTI, P. “La gestión de la inmigración ...”, op. cit, p. 87.

352 Para VIDAL FUEYO, el pilar argumentativo principal de todas las sentencias emitidas en torno a la reforma de la LO 4/2000 mediante la LO 8/2000, con la STC 236/2007 a la cabeza, es la teoría tripartita que clasifica los distintos derechos de los extranjeros en función de su mayor o menor conexión con la dignidad humana. Este criterio es problemático debido a su extrema flexibilidad, pues aunque los derechos que forman parte del segundo grupo — los excluidos para los extranjeros- son fácilmente reconocibles, las otras dos categorías siguen suscitando dudas. Para esta autora "siguen existiendo interrogantes en relación con el exacto elenco de derechos que forman parte de los otros dos grupos y, lo que es más importante, siguen existiendo serias dudas respecto de las consecuencias jurídicas que se derivan de la pertenencia a uno u a otro grupo, pues el Tribunal, utilizando retóricamente esta clasificación, ha elaborado argumentaciones jurídicas y fallos radicalmente distintos". Además, denuncia que la clasificación tripartita se sigue utilizando por el TC de forma retórica, "sin una clara voluntad dogmática". "La jurisprudencia del TC en materia de derechos...", op. cit., pp. 359 y 379.

353 En el mismo sentido, VIDAL FUEYO, M.C. "La jurisprudencia del TC en materia de derechos fundamentales de los extranjeros.., op. cit., p. 365.

354 SANTOLAYA MACHETTI pone como ejemplo "sorprendente" el razonamiento internacionalista empleado para declarar la inconstitucionalidad de las limitaciones a los derechos de reunión y manifestación, asociación, sindicación y huelga: aunque reiteramente el alto tribunal acude al TEDH, sin embargo el art. 16 del CEDH "parecería abonar precisamente la tesis opuesta”. “La gestión de la inmigración...”, op. cit., p. 87.

355 VIDAL FUEYO considera que, al repetir jurisprudencia anterior, se vienen a perpetuar los interrogantes que existían en este ámbito antes del presente pronunciamiento. "La jurisprudencia del TC..., op. cit., p. 378.

356 En esta tónica, SANTOLAYA MACHETTI ha subrayado el tono escasamente persuasivo que predomina en la argumentación de esta sentencia. "La gestión de la inmigración en la VIII legislatura (2004-2008)", op. cit., p. 87.

357 Idem, p. 88. SANTOLAYA propone, en contraste con el análisis efectuado por el TC en la STC 236/20007, haber estudiado la proporcionalidad de las restricciones legislativas recurridas, su carácter necesario para una sociedad democrática y las consecuencias extraíbles para los extranjeros en situación de irregularidad, concluyendo que la regulación legal de las condiciones establecidas a los derechos de reunión, manifestación, asociación, sindicación y huega vulneraban el principio de proporcionalidad. VIDAL FUEYO también ha denunciado el hecho de que "en ningún momento el Tribunal lleva a cabo un juicio de razonabilidad para justificar la inclusión de la situación 
Si, finalmente, aplicamos a este pronunciamiento el test del escrutinio riguroso ${ }^{358}$ que, a nuestro juicio, debe reunir una resolución destinada a despejar las dudas sobre la constitucionalidad de una ley orgánica reguladora de los derechos de los extranjeros en nuestro país —en tanto que "minoría insular"-, éste se cumple de forma claramente insatisfactoria.

\subsection{La trayectoria del T.C. en materia de extranjería e inmigración}

Conviene ahora alejar nuestro enfoque para situarnos en el marco más amplio del trayecto recorrido por la doctrina constitucional dictada en materia de extranjería e inmigración. Resulta evidente que se trata de una jurisprudencia sometida a una profunda evolución, si bien algunas de las características más controvertidas proclamables de las primeras construcciones jurisprudenciales del TC en este ámbito, siguen vigentes en la actualidad: esta rama jurisprudencial ha sido considerada "cuando menos confusa" 359 , compleja y conflictiva ${ }^{360}$, echándose de menos un mayor esclarecimiento de las coordenadas constitucionales en las que ha de moverse el derecho migratorio.

Las primeras sentencias del TC que abordan el estatuto constitucional de los extranjeros suelen apegarse a la literalidad textual de los preceptos constitucionales, destilando una visión claramente constitucional, pero más bien estrecha de la extranjería y la inmigración. El TC ha ido aclarando en dirección amplificatoria el espectro y contenido de aquellos derechos que, por su íntima conexión a la dignidad humana, son predicables en condiciones de igualdad por españoles y extranjeros. Incluso derechos que inicialmente estimaba exclusivos de los españoles, en atención a la dicción literal del correspondiente precepto constitucional — señaladamente el derecho a la libre circulación por territorio nacional del art. $19 \mathrm{CE}$-, con posterioridad han sido considerados expresamente predicables también de los extranjeros. Ello ha sido posible gracias a una jurisprudencia muy internacionalizada y que ha abandonado el criterio literal en pos de una interpretación sistemática del Título I CE. En todo caso, ha sido y sigue siendo una doctrina balbuceante, contradictoria en ocasiones ${ }^{361}$, echándose en falta una línea argumental más clara ${ }^{362}$.

La aproximación del TC ha partido siempre de la premisa de la posición clave ostentada por el art. 13.1 en el régimen constitucional de los extranjeros, a fin de despejar la titularidad activa de sus derechos, en conexión sistemática con cada uno de los preceptos del Título I destinados a regular cada concreto derecho. Asimismo, el artículo 10.2 es reiteradamente empleado por el TC como recurso interpretativo clave para solventar las dudas que surjan en torno a cuestiones relativas al contenido, titularidad y límites de los derechos. Esta rama es quizá una de las más internacionalmente

administrativa del extranjero como elemento diferencial en el contenido de la norma, ni somete los preceptos cuestionados a un test de proporcionalidad". "La jurisprudencia del TC..., op. cit., p. 378.

358 VIDAL FUEYO llega a la misma conclusión, si bien en su interpretación la exigencia de someter a la norma impugnada a un estricto escrutinio, al modo norteamericano, se deriva de que los derechos enjuiciados son derechos fundamentales constitucionalmente reconocidos a favor de todas las personas. “La jurisprudencia...”, op. cit., p. 378. 359 PÉREZ VERA, Elisa. Artículo 13. Extranjería, op. cit., p. 200.

360 SANTOLAYA MACHETTI, P. “La gestión de la inmigración en la VIII legislatura...”, op. cit, pp. 87 y 90.

361 Sobre este punto, VIDAL FUEYO señala que "la doctrina del TC en materia de derechos fundamentales de los extranjeros necesitaba una reformulación que la dotara de más solidez y de más coherencia”, lamentándose de la oportunidad perdida que, sobre esta base, suponía la esperada STC 236/2007, en "La jurisprudencia del TC en materia de derechos fundamentales de los extranjeros..., op. cit., p. 361.

362 Destacando también la confusión que impera en la jurisprudencia constitucional relativa a los no nacionales, vid, VIDAL FUEYO, M.C. “La jurisprudencia del TC en materia de derechos fundamentales de los extranjeros...”, op. cit., p. 369. 
impregnadas de la jurisprudencia constitucional, por las razones que ya explicamos al analizar la conjunción simbiótica formada por los artículos 10.2 CE y 13.1CE.

Si bien algunas de las grandes cuestiones que planteaba la redacción del art. 13.1 CE han sido resueltas por el TC, otras siguen todavía expuestas a un alto grado de incertidumbre, pese a su trascendencia práctica. Entre las primeras destaca la utilización del término libertades públicas empleado por el art. 13.1 en sentido amplio y como equiparable a derechos fundamentales - aunque este punto ha sido solventado con escasa argumentación, y resta saber qué concreto concepto de derechos fundamentales de entre los admisibles constitucionalmente subyace bajo la misma-. También ha sido recientemente despejada la importante cuestión del papel que la reserva del art. 13.1 otorga a los tratados internacionales en la determinación del régimen jurídico de los extranjeros, decantándose el alto tribunal por concebir esta disposición como un cláusula expansiva de los derechos de los extranjeros - como en su momento anticipara la Prof. ${ }^{a}$. Vidal Fueyo-, otorgándoles un papel clave como vías legítimas prioritarias para el ensanchamiento y la protección de sus derechos. En materia internacionalista, solamente cabría reprochar al alto tribunal su propensión a usar este criterio exegético para solventar la etérea cuestión del grado de vinculación de cada derecho con la dignidad humana, como evidencia la STC 236/2007 363 .

De otro lado, la posición que ostenta el legislador en la configuración de los derechos de los extranjeros sigue estando dotada de perfiles poco nítidos en la doctrina del TC, echándose de menos una postura más sistemática al respecto. En el fondo, está cuestión está íntimamente relacionada con el protagonismo excesivo de la teoría tripartita y el criterio de la dignidad humana en esta construcción jurisprudencial, cayendo, quizá por ello, en excesivas sutilezas teóricas impregnadas de cierto subjetivismo y complejidad, pero que no logran desenmarañar los problemas prácticos. Este tono oscuro y confuso no constituye la mejor base de cara a ofrecer una brújula diáfana que guíe al legislador dentro del ya de por sí complejo mundo de la extranjería y la inmigración.

De este recorrido por la jurisprudencia constitucional en materia de extranjería cabe pues dibujar una línea jurisprudencial de gradual flexibilización y alejamiento del criterio de interpretación literal, así como de constante ampliación tanto del ámbito subjetivo como del contenido material de los derechos de los extranjeros ${ }^{364}$. El elevado peso que la influencia ejercida por el DIDH ostenta en el razonamiento del TC desplegado en este ámbito, está detrás de la aludida tendencia a la amplia-

363 Una crítica a este uso "exagerado" del grado de conexión con la dignidad humana recurriendo para ello al DIDH, puede verse, junto a la ya expuesta de VIDAL FUEYO, en el voto particular formulado por el magistrado don Vicente Conde Martín a la STC 236/2007, al que se adhirieron los magistrados don Jorge Rodríguez-Zapata y Roberto García-Calvo. En dicho voto particular, se afirma que "la Sentencia sitúa la clave conceptual en «la dignidad de la persona 'como fundamento del orden político y la paz social' (art. 10.1 CE) [que] obliga a reconocer a cualquier persona, independientemente de la situación en que se encuentre, aquellos derechos o contenidos de los mismos imprescindibles para garantizarla, erigiéndose así la dignidad en un mínimo invulnerable que por imperativo constitucional se impone a todos los poderes públicos, incluido el legislador» (F. J. 3), ligando después a esa clave la ratio de la declaración de inconstitucionalidad. Tal planteamiento en su generalidad de partida no me parece literalmente ajustado al art. $10 \mathrm{CE}$, ni aceptable, por exagerado, en cuanto a la vinculación a la dignidad humana de los derechos de reunión, asociación y sindicación". GONZÁLEZ BEILFUSS, Markus. "El papel de la jurisprudencia constitucional en el desarrollo del derecho público de la inmigración”; Revista catalana de Dret públic, № 40, 2010, p. 218. También en GARCÍA VÁZQUEZ, Sara. El Estatuto Jurídico-constitucional del extranjero en España, op. cit., p. 48.

364 Dado el carácter obvio de esta línea evolutiva, resulta una cuestión pacíficamente admitida entre la doctrina estudiosa de este tema. Vid, a modo de ejemplo, VIDAL FUEYO, M.C. "La jurisprudencia del TC en materia de derechos...", op. cit., p. 356. GARCÍA VÁZQUEZ, Sara. El estatuto jurídico-constitucional del extranjro en España, op. cit. p. 48. GONZÁLEZ BEILFUSS, Markus. "El papel de la jurisprudencia constitucional en el desarrollo del derecho público de la inmigración”, op. cit., p. 209. 
ción progresiva del estatuto jurídico de los extranjeros ${ }^{365}$, ofreciendo al TC sustento argumentativo para una interpretación extensiva de sus derechos. Si bien se mantiene plenamente operativa la difusa clasificación tripartita de los derechos de los extranjeros que el TC estableció tempranamente, resulta visible una propensión a engrosar el primer grupo de derechos ${ }^{366}$-los predicables en condiciones de igualdad de nacionales y extranjeros-, redundando en la equiparación apuntada.

En suma, a partir del artículo $13.1 \mathrm{CE}$ y la posibilidad de tratamientos diferenciados entre españoles y extranjeros, los pronunciamientos jurisprudenciales del TC en esta materia han ido inequívocamente señalando una acusada predisposición equiparadora ${ }^{367}$, hasta el punto de que algunos magistrados del TC han llegado a denunciar que el alto tribunal se apoya "en una interpretación sistemática del Título I CE, en la que subyace un criterio apriorístico de equiparación”368. Con todo, esta línea jurisprudencial está todavía abierta ${ }^{369}$, constatándose aun ahora "la falta de una clara y definitiva interpretación del régimen jurídico-constitucional de los extranjeros en nuestro país”370.

Para cerrar estas reflexiones, recurriremos como es habitual a la evaluación de la aplicación del test del estricto escrutinio por parte del TC, a esta concreta línea jurisprudencial. Como ha puesto de relieve Eliseo $\mathrm{Aja}^{371}$, esta rama está dominada fundamentalmente por pronunciamientos que resuelven recursos de amparo. De ellos suelen extraerse efectos interpretativos generales, originando normas subconstitucionales seguidas tanto por el poder judicial como por la Administración y que suelen penetrar en la legislación — como atestiguan las reformas legislativas emprendidas con posterioridad a tales pronunciamientos-.

En las sentencias recaídas en recursos de amparo en materia migratoria parece existir una mayor probabilidad de que se produzcan tales efectos generales. En palabras del citado autor dicha virtualidad, "parece aumentar cuando los conflictos con los poderes públicos afectan a una parte específica

365 Al mismo juicio llega GÓMEZ SÁNCHEZ. Estudios sobre las libertades. Valencia, Tirant lo Blanch, 1995 , p. 160.

366 BALAGUER CALLEJON, Francisco. "El contenido esencial de los derechos constitucionales y el régimen jurídico de la inmigración. Un comentario a la STC 236/2007 de 7 de noviembre”, op cit., p. 484.

367 Partiendo de la consideración de que el artículo $13 \mathrm{CE}$ establece un principio de equiparación restringida entre españoles y extranjeros, RUIZ DE HUIDOBRO señala que "la evolución de la jurisprudencia constitucional ha sido la de restringir la admisibilidad del trato diferenciado de los extranjeros", y ello pese a que el punto de partida tendía a propiciar la connotación "legalista" del régimen de la extranjería y la inmigración. "Evolución de la legislación española de extranjería e inmigración”; en RUIZ DE HUIDOBRO, J. M. a (ed.). Regulación legal de la extranjería e inmigración en España. Madrid, Universidad Pontificia de Comillas, 2006, pp. 22 y 23. GARCÍA ROCA también insiste en que la evolución jurisprudencial en este ámbito "ha ido en un sentido cada vez más garantista", tanto la establecida por el TC como por el TS con respecto a sus desarrollos reglamentarios; en "La titularidad constitucional e internacional de los derechos fundamentales de los extranjeros..., op. cit., p. 108. Alabando asimismo la línea evolutiva seguida por el TC en este ámbito, VIDAL FUEYO quien además señala que jurisprudencia inicial, si bien progresiva y valiente al enfrentar la compleja cuestión de los derechos de los extranjeros, adolecía de obvias contradicciones internas, y no resultaba coherente con una interpretación sistemática del texto constitucional. Constitución y extranjería, op. cit., p. 65.

368 Voto particular formulado a la STC 236/2007, por el magistrado don Vicente Conde Martín de Hijas, al que se adhieren don Jorge Rodríguez-Zapata y don Roberto García-Cavo y Montiel.

369 VIDAL FUEYO insiste en este aspecto, señalando que "el TC aún no ha llevado a cabo una interpretación cerrada del régimen de derechos fundamentales de los extranjeros en nuestro país, ni ha creado un cuerpo de sentencias que respondan a un mismo esquema metodológico"; en "La jurisprudencia del TC en materia de derechos fundamentales de los extranjeros a la luz de la STC 236/2007”, op. cit., p. 356. En la misma línea, GONZÁLEZ BEILFUSS subraya que "el reto de concretar el estatuto constitucional de este colectivo a partir de categorías dogmáticas sólidas está lejos de haberse conseguido"; en "El papel de la jurisprudencia constitucional en el desarrollo", op. cit., p. 218.

370 VIDAL FUEYO, M. C. "La jurisprudencia del TC en materia de derechos fundamentales de los extranjeros a la luz de la STC 236/2007", op. cit., p. 355.

371 AJA, Eliseo. "Veinte años de doctrina del Tribunal Constitucional sobre los derechos de los inmigrantes", op. cit., p. 442. 
y particular de la sociedad, tanto por la protección de minorías que le puede otorgar como por una capacidad superior de sensibilidad y conocimiento que puede incorporar" ${ }^{372}$. En una línea similar, se ha destacado la existencia de numerosas sentencias interpretativas del TC en materia de extranjería desde los inicios de su funcionamiento - concretamente a partir del año 1982 -, la mayor parte de ellas recaídas en recursos de amparo interpuestos por extranjeros que estimaban vulnerados sus derechos como consecuencia de una actuación administrativa o bien que se habían visto desamparados por el poder judicial ${ }^{373}$.

En consecuencia, en los procesos que afectan a los derechos fundamentales de los extranjeros en nuestro país se detecta una fuerte sensibilidad democrática por parte del TC, sin necesidad de esperar a encontrarse ante procesos de control de constitucionalidad - que serían los propicios para recaer efectos generales y, por ello, para la elaboración de una doctrina jurisprudencial en materia de extranjería e inmigración que permee todo el ordenamiento jurídico-. En síntesis, en el ámbito de los derechos de los inmigrantes, el TC parecería estar usando la vía de amparo para la protección de grupos minoritarios, en concordancia con el concepto estadounidense de minoría insular. La mayor vulnerabilidad de los extranjeros - tanto por el colectivo social y jurídico en el que se insertan, como por su exclusión del ámbito de los derechos políticos-, actúa como detonante para un control más estricto y una argumentación más detallada, otorgándoles el TC un amplio radio de protección en los procesos de amparo que les afectan ${ }^{374}$. En contraste, los recursos de inconstitucionalidad recaídos en este ámbito - si bien resueltamente protectores, intensamente penetrados por el DIDH y ventilados con una abundancia de argumentos-, no resultan tan convincentemente fundamentados, quizá como consecuencia de la insistencia del TC en apoyarse en el criterio de la dignidad humana y la clasificación tripartita de los derechos de los extranjeros, así como por el escaso uso del principio de proporcionalidad.

\section{LA CONSTRUCCIÓN NORMATIVA DE LA RF EN ESPAÑA: ANÁLISIS EVOLUTIVO DE SU REGULACIÓN CON ANTERIORIDAD A LA VIGENTE LEY DE EXTRANJERÍA}

El ordenamiento español ilustra con claridad la evolución jurídica ascendente recorrida por la inmigración familiar, fenómeno compartido tanto por los países europeos de nueva inmigración como por aquellos que gozaban de cierta tradición migratoria. Sin embargo, en los países de inmigración reciente, como España, este proceso resulta más acelerado y, por ello, más fácilmente perceptible.

En síntesis, la trayectoria normativa seguida por la migración familiar en España puede esquematizarse del siguiente modo: el punto de partida reside en la inexistencia de la figura en nuestro sistema de extranjería, lo que condenaba a esta institución al estatus de mera práctica administrativa, consentida en ocasiones, pero sometida a una amplia arbitrariedad. Posteriormente, la introducción

372 AJA FERNÁNDEZ, Eliseo. "Veinte años de doctrina del Tribunal Constitucional ...", op. cit., p. 454.

373 SANTAMARÍA IBEAS, J.J. "Los derechos fundamentales y el Tribunal Constitucional. Los infraderechos de los extranjeros en España. Reflexiones sobre la jurisprudencia constitucional”; en Derechos y Libertades. Revista del Instituto Bartolomé de las Casas, № 2, 1993-1994, p. 502.

$374 \mathrm{Si}$ bien es justo señalar que en algunas cuestiones relacionadas con la extranjería y la inmigración, el TS se ha llegado a anticipar al TC, con pronunciamientos más avanzados y progresistas, aunque sosteniendo una línea jurisprudencial "confusa, por variable". Vid. para un análisis de esta cuestión, VIDAL FUEYO, M.C. Constitución y extranjería, op. cit., pp. 43-50. La cita literal corresponde a la p. 49. 
de la RF en el ordenamiento interno se producirá primero a un nivel puramente reglamentario, siendo desarrollada por múltiples disposiciones administrativas inferiores dotadas de escasa publicidad -instrucciones, recomendaciones, circulares ministeriales internas, etc.- que, en dirección contraria al principio de legalidad, estrechaban el ejercicio de la RF mediante la introducción de requisitos de un tenor considerablemente más riguroso al predeterminado legal y reglamentariamente. Constituye una larga etapa en la que la práctica administrativa, muy obstaculizada, se superponía a los textos normativos.

Su inclusión en una norma con rango legal y con estatus de derecho subjetivo se producirá en España con la llegada del nuevo siglo. Esta ascensión normativa, desde el punto de vista de la seguridad jurídica del extranjero, se traduce en la obligación para las autoridades administrativas de conceder la RF cuando se cumplan los requisitos legalmente previstos y, por ello, en un sustancial acotamiento del anteriormente elevado margen de discrecionalidad administrativa. Sin embargo, su ascensión a la ley en España coincide con una escalada abrupta del fenómeno migratorio, cualitativa y cuantitativamente, lo que conlleva un incremento de la intervención legislativa sobre esta materia, en paralelo habitualmente a una amplificación de los condicionamientos exigidos para el ejercicio del derecho ${ }^{375}$, junto con la irrupción de una gran inestabilidad normativa.

Asimismo, la inmigración familiar en España ejemplifica la intensa interpenetración del derecho internacional en materia migratoria: el surgimiento de la RF en el ordenamiento jurídico español se producirá de forma tardía y a instancias del derecho internacional. Especialmente del procedente del ámbito comunitario en lo que concierne al aspecto normativo, pues su evolución se produce al compás de la transposición de normas comunitarias. Si en el ámbito legislativo resulta más intensa la influencia del derecho comunitario, en materia de aplicación de las normas e interpretación judicial, se observa con mayor nitidez la influencia de los parámetros de Estrasburgo, que sirven en múltiples ocasiones a jueces y tribunales para poder superar las estrecheces y rigideces normativas. En definitiva, también la jurisprudencia del TEDH termina vertiéndose en la normativa interna, si bien la mayoría de las veces de forma indirecta en virtud de la intermediación de los jueces y tribunales, con el TC a la cabeza.

La llegada del siglo XXI coincide con una progresión aritmética en los flujos migratorios que llegan a España, abriendo una nuevo período notablemente divergente del existente previamente, tanto a efectos del marco normativo como de la realidad social sobre la que se vierte la norma. De ahí que nos sirva como punto de referencia para marcar dos etapas claramente diferenciadas en el ámbito de la inmigración familiar y, más allá, de la extranjería y la inmigración en España. Visto en perspectiva - y pese a los problemas que todavía persisten en el ejercicio cotidiano del derecho-, la valoración es positiva, con una evolución en sentido claramente favorable $e^{376}$.

Los antecedentes más remotos de la RF en el ordenamiento jurídico español se sitúan en la Ley Orgánica 7/1985, de 1 de julio, sobre derechos y libertades de los extranjeros en España. Pese a no contenerse en ella referencia alguna a la RF, constituye la simiente legal de esta institución. La LO 7/85 vino a derogar el Real Decreto de 17 de noviembre de 1852, por el cual se fijaba el marco jurídico de la extranjería en España, norma que gozó de una larguísima vigencia -elocuente reflejo, por otro lado, del tradicional sesgo exportador de mano de obra que caracterizó a España desde me-

375 Similar progresión observa Ana María LÓPEZ SALA en el tratamiento normativo de la RF en los países del norte del Mediterráneo durante la década de los noventa; en Inmigrantes y Estados: la respuesta política ante la cuestión migratoria. Barcelona, Anthropos, 2005, pp. 143 y 144.

376 BELLOSO MARTÍN, Nuria. “El reagrupamiento familiar en el derecho de extranjería español”, op. cit., p. 188. 
diados del siglo XVIII-. Su vigencia se prolongó hasta el 1 de febrero del año 2000, constituyendo, — tras el Real Decreto de 1852-, la norma más longeva en este ámbito.

La LO 7/1985 ${ }^{377}$ sobre derechos y libertades de los extranjeros en España, surge a instancias del derecho comunitario, ante la inexistencia de un marco migratorio normativo adecuado en España y la correlativa preocupación que ello producía en los países europeos que habían experimentado dicho fenómeno. La primera ley de extranjería española ve así la luz en el contexto de un país enfocado en su inminente adhesión a la Comunidad Económica Europea y los consiguientes temores de los Estados miembros ante las posibles consecuencias migratorias que la incorporación de España podría acarrear, dada su situación geográfica como puerta de Europa y sus conexiones históricas con los países Latinoamericanos ${ }^{378}$. La aparición de la LO 7/85 no respondía por tanto a una necesidad social, sino más bien a la finalidad de aplacar los temores de nuestros vecinos europeos ante la inmediatez de la adhesión española a la CEE. Este contexto explica en gran parte el espíritu de control que impregnaba la ley respecto a las políticas que debían gestionar la entrada, trabajo, permanencia, establecimiento, salida y expulsión del territorio español de los extranjeros procedentes de terceros países, inscritos en el régimen general.

Pese a ello, la ley 7/1985 se presentaba formalmente con el fin de dar cumplimiento al mandato constitucional contenido en el artículo $13 \mathrm{CE}$, mediante una regulación que concretara el alcance de los derechos correspondientes a los extranjeros en España, al tiempo que actualizara en una norma de alcance general que viniese a sistematizar, sintetizar y formular los principios informadores de la situación de los extranjeros. Con ello se venía a cubrir la carencia existente hasta el momento en el ordenamiento español, que venía regulando esta materia mediante una norma que se remontaba a mediados del siglo XIX, y se evitaba la dispersión normativa que dicha carencia había generado ${ }^{379}$.

La ley declaraba como propósito general favorecer la integración de los extranjeros en la sociedad española, así como su preocupación por acomodarse al derecho internacional regulador de esta materia. Asimismo, manifestaba partir del principio de clara diferenciación entre las situaciones de legalidad - a las que afirmaba otorgar la "plenitud de derechos"-, respecto de las situaciones de irregularidad o estancia clandestina - expresamente calificadas como de "ilegalidad" - Su exposición de motivos afirmaba textualmente que, a lo largo de todo su articulado, la ley destacaba "por su preocupación por reconocer a los extranjeros la máxima cota de derechos y libertades, cuyo ejercicio

377 B.O.E. No 158, 3 de julio de 1985.

378 En términos más expresivos se pronuncia Eliseo Aja señalando que la LO 7/85 se aprobó "para dar seguridad a los miembros de la CEE de que España no sería un <coladero> de inmigrantes, ya que en aquellos países la inmigración se había cerrado drásticamente a partir de la crisis del petróleo de 1974"; en AJA FERNÁNDEZ, Eliseo (coord.). La nueva regulación de la inmigración en España. Valencia, Tirant lo Blanch, 2000, p. 22. En una línea similar SERRA, Albert; MAS, Pau; XALABARDER, Alicia y PINYOL, Gemma. "Spain”; en NIESSEN, Jan; SCHIEBEL, Yongmi y THOMPSON, Cressida (eds.). Current Immigration Debates in Europe: A Publication of the European Migration Dialogue. CIDOB, Fundation with the support of the European Commission Directorate- General Justice, Freedom and Security, September 2005, p. 5.

379 Formalmente pues, la ley se construía sobre dos premisas: la necesidad de una norma básica que, con pretensión de generalidad, regulase el marco jurídico de la extranjería y la inmigración en España, dando con ello desarrollo y cumplimiento al mandato constitucional contenido en el art. 13 de la Constitución. Esta idea, expresada literalmente en el Preámbulo de la LO 7/1985, es considerada por Goiz Martínez como una "premisa errónea" del legislador: el art. 13.1 CE no establece un mandato constitucional para que el legislador elabore una normativa específica reguladora de los derechos y libertades de los inmigrantes en España, dado que las fuentes normativas de dicho régimen jurídico se encuentran en el Título I CE, junto con el derecho internacional en materia de derechos humanos suscrito por el Estado Español. GOIG MARTÍNEZ, Juan Manuel. "Régimen jurídico y políticas sobre extranjería en España. Comentario a la STS de 20 de marzo de 2003”; en Teoría y Realidad Constitucional, no 12-13, 2003-2004, pp. 632-633. 
queda prácticamente equiparado al de los propios ciudadanos españoles, y para el que se establecen las mayores garantías jurídicas, que ciertamente sólo cede ante exigencias de la seguridad jurídica claramente definidas".

Pese a ello, la ley $7 / 85$ fue ampliamente criticada $^{380}$ por su espíritu restrictivo, en el que predominaba el control policial sobre el reconocimiento de derechos, y por la concesión de una elevadísima cota de discrecionalidad administrativa, principalmente mediante el uso y abuso de conceptos jurídicos indeterminados en la aplicación de las instituciones claves de la extranjería -empezando por la principal, la concesión del visado, cuya denegación no necesitaba ser moti$\operatorname{vada}^{381}$; y terminando por el régimen infractor y sancionador, que carecía de graduación y proporcionalidad, y se caracterizaba por una enorme plasticidad en la configuración de las causas ${ }^{382}$, casi todas ellas conducentes a la expulsión. Además, la propia flexibilidad de la ley dificultaba el control jurisdiccional sobre las actuaciones administrativas en materia de extranjería, pese a que la ley proclamaba formalmente el derecho de los extranjeros a interponer los recursos procedentes, tanto en vía administrativa como judicial ${ }^{383}$. El ejemplo más significativo y extremo de las incoherencias de la ley lo constituía el control judicial de las expulsiones - que, a tenor de lo prescrito precisamente en la misma disposición que reconocía a los extranjeros el derecho a la tutela judicial efectiva, debía efectuarse vía consular desde el país de origen del inmigrante, una vez que éste había sido ya expulsado del territorio español ${ }^{384}$.

380 Vid, a modo de ejemplo, las críticas vertidas por GOIG MARTÍNEZ, J.M., quien estima que la LO 7/85 acomete una regulación "incompleta, incorrecta y de dudosa constitucionalidad" de los derechos y libertades de los inmigrantes; en "Régimen jurídico y políticas sobre extranjería en España...”, op. cit., p. 633. Por su parte, Martínez Rodrigo denunciaba la visión utilitarista del inmigrante que impregna esta ley, así como su filosofía subyacente, "que no es la propia de una política de inmigración, sino la de una política de extranjería y de orden público". MARTÍNEZ RODRIGO, Antonio. "La ley de extranjería: una respuesta inadecuada al fenómeno migratorio"; en Acontecimiento, No 49,1998 , p. 57.

381 Véase, al respecto, BELLOSO MARTÍN, Nuria. "El reagrupamiento familiar en el derecho de extranjería español”; en Cuadernos de Realidades Sociales, 1994, pp. 185-186. La propia autora remarca que "tras una fachada de ley reconocedora de derechos y libertades de los no nacionales, se esconde, en muchas ocasiones, una normativa de carácter policial, fuertemente rígida. La filosofía inspiradora de la reglamentación sobre extranjeros en España parece ser la del <control de los extranjeros>: así, se abusa hasta términos insospechados de conceptos jurídicos indeterminados, lo que conduce a una discrecionalidad casi absoluta, o también porque quien tiene el poder de decisión, quien en definitiva aplica las normas, es un funcionario que normalmente desempeña su trabajo en la frontera y que se ve obligado a realizar funciones de médico (apreciar la validez de un certificado médico acreditativo de no padecer enfermedades contagiosas) y de juez", op. cit., p. 185-186. En el mismo sentido se pronuncia SANTOS ARNAUR, Lidia. "Conceptos jurídicos indeterminados y discrecionalidad: especial referencia al visado para la reagrupación familiar”, op. cit., pp. 444-446. AJA FERNÁNDEZ, Eliseo (coord..). La nueva regulación de la inmigración en España. Valencia, Tirant lo Blanch, 2000, p. 22. Para Eliseo Aja, se trata de una ley presidida por un espíritu restrictivo que "apenas reconocía derechos, salvo para limitarlos; en "Veinte años de doctrina del TC...", p. 441. También la opinión de SANTOLAYA MACHETTI se inscribe en esta línea, señalando que tanto el visado como su exención constituían actos discrecionales subordinados a los intereses nacionales y, como tales, "no sometidos a concretas causas jurídicas controlables por los tribunales"; en El derecho a la vida familiar de los extranjeros, op. cit., p. 149.

382 AJA, Eliseo (coord.). La nueva regulación de la inmigración en España, op. cit., p. 22.

383 Artículo 35 de la LO 7/1985.

384 Sin embargo, el Preámbulo de la ley declaraba ampulosamente que "al concretar las garantías jurídicas la Ley introduce la necesidad de la intervención judicial en la revisión de determinadas resoluciones que conllevan la salida o expulsión de los extranjeros o que implican la privación de libertad, justamente como garantía de ésta”. En sentido crítico se manifestó en su momento Eliseo AJA, quien estimaba que la situación provocada por la ley en materia de control de las expulsiones convertía en "papel mojado" el derecho a la tutela judicial efectiva. La nueva regulación de la inmigración en España, op cit., p. 22. 
Cabe advertir que si bien la RF en España hunde sus raíces en la LO 7/85, dicha norma no contempló en ningún momento esta figura. Sin embargo, contenía dos artículos relacionados incidentalmente con dicha institución, pues los mismos tomaban en consideración ciertos vínculos familiares de los extranjeros residentes para acceder de forma más simplificada tanto al permiso ordinario de residencia como al de trabajo.

De un lado, el apartado tercero del artículo $13^{385}$ recogía la posibilidad de incluir a los menores extranjeros de dieciocho años y a los incapacitados dentro del permiso de residencia otorgado al extranjero bajo cuya guarda se encontrasen, siempre a solicitud del titular de dicho permiso. De otro lado, el artículo $18.3^{386}$ otorgaba preferencia para la obtención y, en su caso, renovación del permiso de trabajo al cónyuge e hijos de aquel extranjero que fuese ya titular de un permiso de trabajo. Resulta especialmente relevante esta última disposición, especialmente a la luz de la inexistencia de un derecho a la RF, y de las suspicacias que la incorporación al mercado laboral de los familiares extranjeros dependientes del residente legal suelen plantear sobre su regulación.

La omisión de la figura de la RF en una ley que se rubricaba como de derechos y deberes de los extranjeros ${ }^{387}$ y que proclamaba formalmente como uno de sus principales propósitos generales fomentar su integración, fue en su momento duramente enjuiciada por la doctrina ${ }^{388}$, llegando a ser calificada como uno de "los vacíos clamoroso de la ley" 389 . Sin embargo, cabe encontrar interpretaciones más matizadas, como la que efectúa Santolaya. Este autor enlaza dicha omisión con la inexistencia de una necesidad social desencadenante, como consecuencia del por entonces incipiente estado de España como país receptor de inmigración que empezaba a registrar todavía la llegada aislada de trabajadores individuales que habían dejado atrás a sus familias, sin que las segundas generaciones hubieran emergido todavía como un fenómeno socialmente relevante ${ }^{390}$.

La exclusión de la migración familiar resulta llamativa si se toma en consideración que la misma se producía en un momento en el que la RF se había consolidado ya como la vía principal de entradas regulares en los Estados europeos vecinos que gozaban de cierta tradición migratoria. De otro lado, la propia exposición de motivos consideraba el parentesco entre aquellas circunstancias

385 Dicha disposición, dedicada a la regulación de las posibles situaciones jurídicas en que podían encontrarse los extranjeros en España —estancia y residencia_, afirmaba literalmente que "el permiso de residencia se podrá conceder a los menores de dieciocho y a los incapacitados. También podrá incluirse a unos y otros en el permiso correspondiente a la persona bajo cuya guarda se encuentren, si ésta así lo solicita”.

$386 \mathrm{El}$ apartado tercero del artículo 18 contemplaba diversos supuestos cuya acreditación otorgaba al extranjero preferencia para la obtención y, en su caso, renovación del permiso de trabajo, entre los que se incluía la situación del cónyuge o hijo de un extranjero que tuviese permiso de trabajo (apartado k del artículo 13.3).

387 La crítica corresponde a MARTÍNEZ, Antonio. "La reagrupación familiar”; en BORRÁS, Alegría (coord.). Diez años de la Ley de extranjería: Balance y perspectivas, op. cit., p. 287.

$388 \mathrm{Al}$ respecto, se señaló que "si algo pone de manifiesto, es el reducido valor que se da a un derecho, creemos que incuestionablemente deducido de la Constitución, pero que con ese nombre no aparece en las leyes"; en BERNARDO, S; VILAS, A y CUADRA, L. "Reagrupamiento familiar”...op. cit., p. 50. MARTÍNEZ, Antonio. "La reagrupación familiar”; en BORRÁS, Alegría (coord.). Diez años de la Ley de extranjería: Balance y perspectivas, op. cit., p. 287. Por su parte, Martínez Rodrigo denunciaba la inexistencia del reconocimiento del derecho a la vida familiar en la ley, su reconocimiento mínimo por vía reglamentaria y, sin embargo, la obstaculización de su ejercicio en la práctica administrativa. MARTÍNEZ RODRIGO, Antonio. "La ley de extranjería: una respuesta inadecuada al fenómeno migratorio", op. cit., p. 57.

389 AJA FERNÁNDEZ, E. (coord.). La nueva regulación de la inmigración en España, op. cit., p. 23.

$390 \mathrm{El}$ autor, tras constatar que la visibilidad de la RF se produce generalmente cuando el país experimenta cierta consolidación como destino de los flujos migratorios, señala que "la inmigración en esos primeros momentos era en España de trabajadores sin sus familias y esa es la realidad recogida en la norma”. SANTOLAYA MACHETTI, P. El derecho a la vida familiar de los extranjeros, op. cit., p. 144. 
— junto al nacimiento en España o el tiempo de permanencia-, que "merecen una consideración preferente para la obtención de los permisos respecto de otras situaciones de extranjería más ocasionales", al tiempo que destacaba la concepción abierta de los derechos garantizados por el Título I CE como el planteamiento de base con el que se formulaba la ley, "coherente con el propósito de no dejar para posteriores regulaciones específicas aspectos de la extranjería que puedan considerarse fundamentales". En definitiva, la RF no se incluía entre los elementos fundamentales que por ello debían ser objeto de previsión legal en la LO 7/85.

No faltaron autores que, tras su omisión, advertían con preocupación la presencia de intereses políticos subyacentes: "estamos ante una regulación no sólo torpe, sino sospechosamente dejada fuera de las leyes" ${ }^{391}$. Desde otros frentes, a los que nos adscribimos, se apuntaba que, en coherencia con la regulación del trabajo y la residencia contenida en esta ley, basada en permisos de corta duración, la significativa omisión de la RF apuntaba claramente a la intencionalidad del legislador de estimular la inmigración temporal y desincentivar la estabilización de los flujos migratorios ${ }^{392}$, evidenciando la resistencia de los Estados receptores a concebirse como países de inmigración apegándose a los viejos esquemas de inmigración estacional ${ }^{393}$.

Conviene apuntar que la ausencia de la RF en las leyes ordenadoras de la extranjería e inmigración constituyó un fenómeno compartido por los países situados al norte del Mediterráneo hasta bien avanzada la década de los noventa del pasado siglo ${ }^{394}$, y una muestra representativa de la miopía del derecho migratorio. Sea como fuere, su falta de previsión legislativa remitía la RF al estatus de mera práctica administrativa sometida al grado más absoluto de discrecionalidad ${ }^{395}$, — cuando no, de pura y simple arbitrariedad ${ }^{396}$.

La LO 7/85, que vino a inaugurar la regulación específica de los derechos de los extranjeros en España en un instrumento normativo ad hoc, conoció, en términos relativos, una larga vigencia - casi quince años-, especialmente a tenor de la inestabilidad inherente a las legislaciones de extranjería de nuestros días. Pese al espíritu de control fronterizo que subyacía a esta ley, su entrada en vigor coincide con el inicio de la llegada de importantes flujos migratorios a España, experimentando éstos un rápido crecimiento. De hecho, el año 1985 constituye el punto de inversión migratoria,

391 BERNARDO, Sofía; VILAS, Ana y CUADRA, Luz-Isabel. "Reagrupamiento familiar”; op. cit, p. 50. En una línea similar, Eliseo Aja señala que "significativamente, ni siquiera se contemplaba la posibilidad de RF". La nueva regulación de la inmigración en España, op. cit., p. 22.

392 AJA, Eliseo (coord.). La nueva regulación de la inmigración en España. Valencia, Tirant lo Blanch, 2000, p. 22.

393 Idem.

394 LÓPEZ SALA, A.M. Inmigrantes y Estados: la respuesta politica ante la cuestión migratoria. Barcelona, Anthropos, 2005, p. 143.

395 López Sala, A.M. Inmigrantes y Estados: la respuesta política ante la cuestión migratoria, op. cit., p. 143, si bien la autora no se refiere al caso específico español, sino que habla en general de la situación de la RF en los países de la Cuenca del Mediterráneo. En un tono más suave, pero igualmente crítico, se expresaban VILAS y CUADRA, señalando que la ausencia de previsión legislativa de la RF en la LO 7/85 "origina no pocas incertidumbres, numerosas ambigüedades y claras desintonías entre los principios y la práctica administrativa y jurídica, que es, dicho sea de con claridad, lo básico y determinante para el ejercicio de los derechos". BERNARDO, S; VILAS, A y CUADRA, L.I. "Reagrupamiento familiar"; en ALVAREZ, Aurelia; SANTOS, Lidia; CONABLE, Barber. Jornada sobre el Reglamento de la ley de derechos y libertades de los extranjeros. Barcelona 30 de junio de 1995, Ajuntament de Barcelona, 1995, p. 51.

396 En el Documento de trabajo de la Comisión Europea, elaborado en mayo de 1992 - y que serviría posteriormente como base para la elaboración de la Resolución de 1 de junio de 1993 de los Ministros de la UE responsables de inmigración-, se admite explícitamente que el reconocimiento normativo del derecho a la RF en la mayoría de los Estados miembros sirve "para evitar situaciones arbitrarias", a cuyo fin se establecen disposiciones legislativas al respecto. 
pasando a formar parte desde entonces nuestro país del polo de atracción de inmigrantes de Euro$\mathrm{pa}^{397}$ hasta que, en el año 2011, el saldo migratorio registrase su primer saldo negativo ${ }^{398}$.

El desarrollo normativo de la LO 7/1985, se produjo mediante dos sucesivos Reglamentos de ejecución. El primero de ellos fue aprobado mediante Real Decreto 1119/1986, de 26 de mayo; y, el segundo, una década después, mediante el Reglamento de ejecución adoptado por Real Decreto 155/1996, de 2 de febrero. Ambos contienen referencias explícitas a la figura de la RF. Conviene por ello analizar su naturaleza jurídica, si bien su previsión por vía reglamentaria - y no legal—, apunta ya importantes características sobre la débil densidad normativa y las correlativas frágiles garantías jurídicas de las facultades contenidas en la RF.

El primer Reglamento de ejecución de la Ley orgánica 7/1985 - aprobado mediante Real Decreto 119/1986 de 26 de mayo ${ }^{399}$-, constituye la primera norma jurídica del ordenamiento español que contempla la RF "como una circunstancia originadora de derechos" ${ }^{400}$. Pese a ello, esta norma reglamentaria profundizó el espíritu restrictivo que en materia de adjudicación de derechos a los extranjeros establecía la LO $7 / 85^{401}$, reforzando, con su ambigüedad, el margen de discrecionalidad administrativa existente en materia de extranjería, especialmente en el apartado de sanciones ${ }^{402}$.

La disposición adicional primera del Reglamento — situada al inicio de su articulado, bajo el título de "reagrupación familiar" - , otorgaba tratamiento preferente y tramitación de urgencia a las peticiones de visados, permisos de residencia y de trabajo formuladas por personas que se propusieran reagrupar con un miembro de la familia "debidamente instalado en España" -léase con residencia regular-. Para ello, la citada disposición exigía que el extranjero residente contase con capacidad económica suficiente para su sostenimiento, "siempre que acrediten encontrarse comprendidas en los supuestos determinados en cualquiera de los párrafos del artículo 7.2 del

397 CACHÓN RODRÍGUEZ, Lorenzo. "Marco institucional de la discriminación y tipos de inmigrantes en el mercado de trabajo en España”; en Revista española de investigaciones sociológicas, No 69, 1995, pp. 105-106. Sobre este punto, el autor especifica que "más de la mitad de los extranjeros que hay en España en la actualidad han entrado en el territorio después de 1985, el año en que se aprobó la Ley de Extranjería”.

398 Datos extraídos del Instituto Nacional de Estadística, estimación de población efectuada el 16 de abril de 2012 . En el primer trimestre del 2012, 101.184 personas —de las que 92.433 eran extranjeros_ llegaron a España; Por su parte, en el mismo período salieron de España un total de 132.535 personas —de las que 105.531 eran extranjeros-. El saldo migratorio - constituido por la diferencia entre el número de personas que entran y el que sale del país-, ofreció con ello un resultado negativo de 50.090 personas.

399 Real Decreto 1119/1986 de 26 de mayo, por el que se aprueba el Reglamento de ejecución de la LO 7/1985 sobre derechos y libertades de los extranjeros en España. BOE 12 junio 1986, N. 140.

400 BERNARDO, S; VILAS, A y CUADRA, L.I. "Reagrupamiento familiar", op. cit., p. 51. Las mencionadas autoras se pronuncian en sentido crítico, señalando su preocupación por el hecho de que sea un reglamento y no la ley, la primera norma que menciona el derecho de reagrupamiento familiar. En torno a su naturaleza jurídica, advierten que la introducción de la RF "se hace por vía de requisitos administrativos, sin formular el derecho en cuanto a tal y sometido a limitaciones formales que más que garantía se convierten en exigencias inexcusables de cumplimiento”.

401 En idéntico tenor se manifiesta Adam MUÑOZ, quien en torno al primer reglamento de extranjería postconstitucional señala que "no resulta ser en absoluto proclive al reconocimiento del ejercicio de los derechos fundamentales por parte de los extranjeros, bien al contrario, los restringe todavía más”; en El estatuto jurídico del extranjero en el sistema español, op. cit., p. 88. Para Eliseo AJA el Reglamento "reproducía todos los defectos de la Ley, y añadía algunos más", entre los que destaca la relegación de los derechos fundamentales a los últimos capítulos, la introducción del control policial de la documentación personal, carente de cobertura legal, y sin introducir una graduación en materia de sanciones de extranjería, en contradicción con el principio de seguridad jurídica; en La nueva regulación de la inmigración en España, op. cit., p. 23. En el mismo sentido se pronuncia BELLOSO MARTÍN, Nuria. "El extranjero y el reagrupamiento familiar en España”, op. cit., p. 187.

402 AJA, E (coord). La nueva regulación de la inmigración en España, op. cit., p. 23. 
Reglamento que se aprueba por el presente Real Decreto" — donde se contemplaban los familiares reagrupables-.

Para la correcta interpretación de esta disposición, conviene apuntar que la LO 7/85 introdujo la exigencia de visado como requisito general para acceder al territorio español ${ }^{403}$, considerándose excepcional su no requerimiento en el pasaporte o título de viaje del extranjero. Sin embargo, la concesión del visado quedaba enteramente al arbitrio de las autoridades públicas, no exigiéndose motivación para el supuesto de su denegación. Además, la ley ahondaba en una característica propia de las legislaciones actuales de inmigración y extranjería, a saber, la fusión entre el permiso de trabajo y el de residencia ${ }^{404}$, con importantes implicaciones prácticas: la pérdida del trabajo por parte del extranjero ponía en serio peligro la continuidad de su residencia en España ${ }^{405}$. En tiempos de precariedad laboral, los riesgos de esta simbiosis resultaban más obvios.

Siguiendo las prescripciones de la ley, el Reglamento exigía solicitar visado de residencia a todos aquellos extranjeros que deseasen trasladar su residencia a España ${ }^{406}$, recordando la primacía del interés del Estado español y sus nacionales en su resolución ${ }^{407}$. Y, más allá, enunciaba algunos vagos criterios para su expedición, señalando que se valoraría "especialmente la documentación sobre medios económicos, titulación académica o profesional del solicitante y sus posibilidades de adaptación en la sociedad española ${ }^{408 "}$. La elasticidad en su formulación convertía a tales criterios en meras "pautas de valoración que la Administración deberá tomar en consideración para resolver una petición de visado, atendiendo siempre al indicado <interés del Estado o de sus nacionales>"409 $y$, por ende, a la propia concesión o denegación del visado en un acto administrativo discrecional.

La figura de la exención de visado quedaba sumida en la misma indefinición, previendo el Reglamento que la dispensa de visado tendría carácter extraordinario ${ }^{410}$, pero sin especificar el sentido concreto de las "razones excepcionales" que autorizaban su exención. En este esquema, la doctrina

$403 \mathrm{Al}$ respecto, el artículo 12.2 de la LO 7/85 establecía que "los pasaportes y títulos de viaje de los extranjeros que pretendan entrar en territorio español deberán ir provistos del correspondiente visado, salvo lo dispuesto en las leyes internas o en Tratados Internacionales en que España sea parte”. De mayor relevancia es el apartado siguiente del mismo artículo, cuya parte final precisaba que "para la concesión del visado se atenderá al interés del Estado Español y de sus nacionales, en los términos previstos reglamentariamente. La denegación no necesitará ser motivada” (art. 12.3).

404 El artículo 15 de la LO 7/85 afirmaba literalmente que "los extranjeros mayores de dieciséis años que deseen fijar residencia en España para ejercer en ella cualquier actividad lucrativa, laboral o profesional, por cuenta propia o ajena, habrán de obtener, simultáneamente con el permiso de residencia, que expide el Ministerio del Interior, el permiso de trabajo, cuyo otorgamiento corresponderá al Ministerio de Trabajo y Asuntos Sociales y que tendrá una duración máxima de cinco años".

405 Esta simbiosis ha sido reiteradamente criticada por Javier de Lucas, quien en multiples escritos ha denunciado la vulnerabilidad y precaridad en que sitúa al inmigrante. En sentido crítico, se manifiestan también BELLOSO MARTÍN, Nuria. "El extranjero y el reagrupamiento familiar en España”, op. cit., p. 187. RAMOS QUINTANA, Margarita. El trabajo de los extranjeros en España. Madrid, tecnos, 1989, pp. 66-82.

406 Esta exigencia figuraba en el primer párrafo del artículo 7 del Reglamento de ejecución de la LO 7/85, (Real Decreto $1119 / 1986$, de 26 de mayo).

407 Apartado primero del artículo 9 del Reglamento de ejecución 1119/1986, conforme al cual “1. El representante diplomático o el Jefe de la Oficina Consular, ante quien se haya presentado la solicitud de visado, además de los informes prevenidos en los apartado 3 y 5 del artículo 7, cuando sean preceptivos, podrá requerir los informes que juzgue oportunos para resolver de acuerdo con el interés del Estado español y de sus nacionales".

408 Dichos criterios valorativos figuran en el apartado tercero del artículo 8 del Reglamento de ejecución de la LO 7/85. 409 SANTOS ARNAU, L. “Conceptos jurídicos indeterminados..., op. cit., p. 445.

410 El artículo 5.4 del Reglamento señalaba que "las autoridades gubernativas podrán eximir a un extranjero de la obligación de visado, si existiesen razones excepcionales que justifiquen tal dispensa. La exención deberá hacerse constar en el pasaporte, en el título de viaje o en documento aparte". 
dedujo la existencia de una "clara voluntad de dotar a la facultad de conceder el visado de la máxima cota de discrecionalidad"411. Tal configuración legal y reglamentaria tuvo como lógico efecto, en una proporción inversa, que el control judicial alrededor de la figura del visado - tanto en el supuesto de la denegación de su concesión como de su exención-, quedara muy dificultado ante la inexistencia de causas jurídicas concretas controlables por los tribunales ${ }^{412}$.

Una de las disposiciones más relevantes para nuestro objeto de estudio la constituye el artículo 7 del Reglamento, dedicado a regular el visado de residencia. Su apartado segundo precisaba las personas habilitadas para solicitar el visado por causa de reagrupación familiar, esto es, los beneficiarios. Aquí reside una de las características más destacables para alumbrar la naturaleza jurídica de la RF: junto a su imprevisión en la ley, el Reglamento no formula la RF como un derecho, sino como una modalidad particular de visado de residencia - “el visado por causa de reagrupación familiar”. Además, la disposición mencionada incluía un listado relativamente amplio de familiares extranjeros, tanto de ciudadanos españoles como de extranjeros residentes en España, otorgando un régimen jurídico común e igualitario a ambos tipos de reagrupantes. Este tratamiento ha sido calificado como "llamativo" 413 , ya que el foco de atención se trasladaba de la nacionalidad del reagrupante - en este caso irrelevante-, a la del familiar reagrupable. Y, de hecho, la propia redacción de la disposición parecía dar pie a interpretar que los familiares reagrupados - quienes podían solicitar el visado por causa de RF-, constituían los titulares activos del la RF, pese al carácter derivado de dicho beneficio.

Tres rasgos sobresalen pues en el tratamiento de la inmigración familiar. Los dos primeros implican una mezcla de las características más conservadoras y a un tiempo más vanguardistas de la RF: en primer lugar, la equiparación del régimen jurídico de la RF entre españoles y extranjeros residentes en España, quienes recibirán idéntico tratamiento siempre que sus familiares carezcan de la nacionalidad española; en segundo lugar, destaca la aparente contemplación de los familiares reagrupables extranjeros como posibles titulares activos, pese al carácter derivado de su residencia para el supuesto de ciudadanos de terceros países-, o de sus vínculos familiares con un ciudadano español. Esta cuestión, sin embargo, careció de trascendencia práctica alguna, - y más considerando las exiguas obligaciones que de la RF cabría derivar para las autoridades públicas-; finalmente, sobresale la extremadamente débil densidad jurídica de la figura de la RF pues, al ser contemplada como un tipo específico de visado de residencia, se convertía, al igual que éste, en un acto puramente discrecional, ajeno al control jurisdiccional y regido por criterios de oportunidad política ${ }^{414}$.

El núcleo de familiares que podían optar al visado por causa de RF consistía en el cónyuge; los hijos menores de dieciocho años o mayores de edad siempre que dependiesen legal y económicamente del reagrupante; los menores o incapacitados cuyo representante legal fuera un español o un extranjero residente en España y; los ascendientes o descendientes, sin límite alguno ${ }^{415}$. A todos

411 SANTOS ARNAU, L. “Conceptos jurídicos indeterminados y discrecionalidad...”, op. cit., p. 446.

412 SANTOLAYA MACHETTI, P. El derecho a la vida familiar de los extranjeros, op. cit., p. 149.

413 Idem, p. 145,

414 SANTOS ARNAU, L. “Conceptos jurídicos indeterminados y discrecionalidad...”, op. cit., pp. 446-447.

415 Aparte de la igualación del tratamiento jurídico aplicable a todos los familiares extranjeros — con independencia de que lo sean de nacionales españoles o de ciudadanos extranjeros que estén residiendo legalmente en España-, en lo que respecta al núcleo de familiares que pueden optar a la RF, el tratamiento es comparativamente más beneficioso que el actualmente recogido en la normativa comunitaria así como al recientemente reformado y vigente en España. Se admiten sin limitaciones los hijos adultos — sin el tope que actualmente rige en los ventiun años para los familiares de ciudadanos comunitarios o en los dieciocho años para los extranjeros adscritos al régimen general—, y lo mismo cabe decir respecto de los ascendientes y descendientes, sin fijación de grados ni límites de edad, con la única condición de probar el grado de parentesco y, para el supuesto de los hijos adultos, la dependencia económica y legal con respecto del reagrupante. 
ellos se les exigía probar el grado de parentesco y la dependencia económica ${ }^{416}$. A estos requisitos el artículo 22.4 añadía la exigencia de que el reagrupante acreditase medios de vida suficientes, así como contar con un seguro de enfermedad y una vivienda considerada normal para los ciudadanos españoles que habitasen en la zona de residencia.

A tenor del propio Reglamento, la solicitud de visado se presentaba ante la representación diplomática u Oficina Consular dentro de cuya demarcación residiera el extranjero emparentado con el español o residente legal en España ${ }^{417}$. En definitiva, el Reglamento preveía de forma muy rudimentaria la denominada RF en sentido estricto, esto es, aquella situación transnacional que protege los vínculos familiares preexistentes. Esta circunstancia se traducía en la exigencia de que los familiares reagrupables se encontrasen fuera del territorio español, obviando la circunstancia de que en un porcentaje elevado de ocasiones éstos se encontraban ya en el país receptor, si bien de forma irregular. Dado el carácter excepcional de la exención de visado, la aludida omisión suponía la exigencia general de que los familiares instalados en España en tales circunstancias regresaran a su país de origen a fin de solicitar el visado que les permitiese ejercer la RF para, una vez obtenido, regresar a España en condiciones de regularidad ${ }^{418}$.

En su conjunto - pese a constituir un avance significativo la previsión de la institución de la $\mathrm{RF}$-, la regulación contenida en el Reglamento de 1986 resultaba muy deficiente ${ }^{419}$, dejando amplios espacios para la intervención administrativa discrecional mediante la invocación de múltiples conceptos jurídicos indeterminados, a los que se subordinaba el ejercicio de la RF. En la práctica, la acreditación de la capacidad económica suficiente, la vivienda adecuada y la dependencia económica - sin mayor precisión por parte del Reglamento-, dependían de valoraciones concretas de las autoridades administrativas, dando lugar a disparidad de criterios en su aplicación y, por ende, a tratamientos desigualitarios ${ }^{420}$. Éstos resultaban todavía más discrecionales y dispares en la fase del procedimiento que dependía del familiar reagrupable - esto es, en la tramitación consular del visado por RF-, donde existía una falta generalizada de unidad de criterio en dicha tramitación, estableciendo cada consulado sus propios y requisitos documentales para acreditar $-\mathrm{y}$ valorar- los extremos mencionados.

Como muestra de la complejidad, discrecionalidad e inseguridad jurídica que dominaban la práctica administrativa de la migración familiar en esta etapa, la Dirección General del Instituto Es-

416 Requisitos fijados por el artículo 7.2 in fine, reiterados posteriormente en el artículo 22.2f), conforme al cual "siempre que se solicite la concesión de permiso de residencia por motivos de reagrupación familiar o se pretenda incluir a menores de dieciocho años o incapacitados en los permisos de residencia de las personas bajo cuya guarda se encuentren, además de los documentos reseñados en los apartados anteriores, deberá presentarse prueba suficiente de los vínculos de parentesco, así como de las correspondientes relaciones de dependencia económica”.

417 Así lo estipulaba el artículo 8.4 del Reglamento de ejecución de la LO 7/1985, de 1 de Julio, sobre derechos y libertades de los extranjeros en España. (BOE no 140, jueves 12 de junio 1986).

418 En sentido crítico se expresa SANTOLAYA MACHETTI. El derecho a la vida familiar de los extranjeros, op, cit., p. 146.

419 Así fue considerada en su momento por la doctrina, entre ellos, vid. APRELL LASAGABASTER, Concha. "El Nuevo Reglamento de la Ley Orgánica 7/1985, de 1 de Julio, sobre derechos y libertades de los extranjeros en España (Real Decreto 155/1996, de 2 de febrero); en Revista de Administración Pública, no 140, 1996, p. 327, nota a pie de pag. n 37. MARTÍNEZ RODRIGO, A. "La ley de extranjería: una respuesta inadecuada...., op. cit., p. 57. MARTÍNEZ, A. "La reagrupación familiar", op. cit., p. 197, quien a la vista de la regulación reglamentaria, deducía "la falta de normas que ordenen sistemáticamente el tratamiento de este derecho del inmigrante a vivir en familia”. AJA, E (coord.). La nueva regulación de la inmigración en España, op. cit., p. 23.

420 MARTÍNEZ, Antonio. “La reagrupación familiar”, op. cit.,p. 197. PICÓN, Celsa. “Conceptos jurídicos indeterminados y discrecionalidad...", op. cit., p. 447. SANTOLAYA MACHETTI, P. El derecho a la vida familiar de los extranjeros, op. cit., p. 146. 
pañol de Emigración —-dependiente del Ministerio de Trabajo y Seguridad Social—, publicó a principios de 1988 un Vademecum administrativo para inmigrantes que sistematizaba los requisitos y exigencias que, en el ámbito de la extranjería y la inmigración, habían ido cristalizando a lo largo de esos años. La parte más llamativa es, en primer lugar, la falta de publicidad de dicho documento ${ }^{421} \mathrm{y}$, en segundo lugar, que el mismo alumbra la existencia en el ejercicio de la RF de múltiples requerimientos que excedían con mucho la parquedad del Reglamento y de la ley. A saber, en la práctica los requisitos variaban en función de la concreta nacionalidad que ostentase el reagrupante, exigiéndose habitualmente un período previo de espera de hasta 3 años de residencia legal en España para que éste pudiera tener acceso a la RF — así sucedía, por ejemplo, para el supuesto de reagrupantes filipinos y marroquíes-, admitiendo a los ascendientes sólo cuando fueran mayores de 65 años, y con unos requerimientos documentales onerosos y de difícil obtención para el extranjero, entre otras muchas exigencias, carentes de cobertura legal y/o reglamentaria.

En definitiva, la práctica administrativa de la época en materia de inmigración familiar estaba impregnada por la exigencia tanto de los requisitos establecidos reglamentariamente, como de otros muchos considerablemente más rigurosos, y que carecían de sustento tanto legal como reglamentario. Esta situación se veía agravada además por el frecuente incumplimiento de la preferencia y urgencia que el Reglamento exigía para la tramitación del procedimiento de $\mathrm{RF}^{422}$. No en vano, los sectores involucrados en la atención a inmigrantes alertaban de las trabas que empedraban el ejercicio de la RF, junto con una "tramitación larga y onerosa"423.

Esta situación se traducía en la exclusión práctica de múltiples extranjeros residentes en España que, aun reuniendo los requisitos previstos en la norma, no pudieron reagruparse con sus familiares como consecuencia de los problemas señalados. Sobra decir que muchos de ellos acudieron a la RF de hecho, alentados por la profusión de obstáculos existentes en la heterogénea práctica administrativa. La vía más habitual para acceder a la RF de hecho consistía en traerse a España a los familiares en condición de turistas quienes, una vez sobrepasado el plazo de tres meses de estancia permitido normativamente, permanecían en territorio español en condición de irregularidad administrativa, en espera de reunir más adelante las condiciones para poder acceder a la regularidad por distintas vías: arraigo familiar, exención de visado, procedimientos de regularización...

Conscientes de la realidad social que subyacía a la ley, la disposición Transitoria segunda de la LOE 7/1985 contemplaba la posibilidad de regularizar la situación de los extranjeros que se encontrasen en España insuficientemente documentados, excluyendo a aquellos que hubiesen incurrido en causas de expulsión. Con base en este precepto, el gobierno dio paso al que sería el primer proceso de regularización ordinaria en España. El mismo hubo de prorrogarse de forma extraordinaria,

421 La doctoranda sólo ha tenido acceso a dicho Vademecum a través de la lectura de un artículo doctrinal escrito, precisamente, desde la perspectiva de la práctica administrativa vigente en la época. Para mayor información sobre los múltiples requisitos así como "las diferencias requisitorias en función de la nacionalidad del solicitante", nos remitimos a la lectura de dicho artículo. MARTÍNEZ, Antonio y equipo del DDIM. "La reagrupación familiar"; en BORRAS, Alegría (dir). Diez años de la Ley de Extranjería..., op. cit., p. 198. Los autores periodizan esta época en tres fases, tomando en cuenta la realidad práctica: La primera fase abarcaría desde la entrada en vigor del Reglamento de 1986 hasta marzo de 1992; el segundo período se extendería desde marzo de 1992 a febrero de 1994; y el tercer período comprendería desde el Acuerdo del Consejo de Ministros sobre tramitación de visados para la reagrupación de familiares extranjeros no nacionales de Estados miembros, de 1993, hasta el año 1995, fecha en que fue escrito el artículo.

422 Su exigencia venía impuesta por la disposición adicional $3^{\text {a }}$ del Reglamento. Del incumplimiento generalizado en la práctica administrativa de dicho requisito reglamentario dan cuenta MARTÍNEZ, A. y equipo de DDIM. "La reagrupación familiar”, op. cit., p. 199.

423 MARTÍNEZ RODRIGO, A. “La ley de extranjería: una respuesta inadecuada al fenómeno migratorio”, op. cit., p. 57. 
dado que el plazo inicial de tres meses concedido por la Ley para la presentación de la documentación necesaria - se exigía demostrar la presencia en España antes del 24 de julio de 1985- se reveló insuficiente. La regularización fue clausurada mediante una Orden Ministerial de 30 de enero de 1986, esto es, nueve meses después de la entrada en vigor de la ley de extranjería que sirvió de base a dicho proceso. El proceso de regularización resultó muy dificultoso, concluyendo explicablemente con la regularización de un porcentaje ínfimo de todos los trabajadores extranjeros que la solicita$\operatorname{ron}^{424}$.

La amplia y creciente bolsa de irregularidad subyacente dio pie el 26 de junio de 1990 a una interpelación al gobierno por parte del grupo parlamentario de Izquierda Unida ${ }^{425}$, que supuso el germen de la Proposición no de Ley relativa a la situación de los extranjeros en España, aprobada por el Pleno del Congreso de los Diputados el 9 de abril de 1991 y suscrita por casi la totalidad de los grupos parlamentarios. Dicha Proposición constaba de once propuestas cuya filosofía y finalidad consistían en el diseño y puesta en marcha de una política activa, coherente y global de extranjería, que - sobre la base del respeto de los intereses económicos, la cohesión social, y los vínculos históricos y culturales de España-, garantizase para el colectivo de residentes extranjeros, de acuerdo con los valores democráticos, su completa integración, otorgando la máxima cota de igualdad entre españoles y extranjeros. En el fondo, los grupos parlamentarios eran conscientes de la trascendencia de la inmigración —-tema de política de Estado, que constituiría el reto a afrontar por España en los próximo años, se afirmaba-, así como de la marcada insuficiencia e incluso fracaso de la legislación vigente, que había conducido a una situación migratoria en España calificada como de "problema grave".

Uno de los aspectos centrales de la citada proposición no de ley residía en solicitar la culminación del proceso de regularización de 1985, instando al gobierno a desarrollar la utilización del visado como instrumento de orientación de la política migratoria. En el mismo apartado - punto cuarto de la Proposición no de ley-, y entre los temas considerados importantes, se incluía la reagrupación familiar, cuya regulación vigente se consideraba inhibitoria e impeditiva de la misma y de difícil sostenimiento, estimándose necesaria su previsión legal. A tal fin, se proponía garantizar el derecho a la RF, cubriendo tanto al cónyuge como a la pareja de hecho, descendientes menores de edad y ascendientes a cargo del trabajador. Las propuestas eran tan generosas que, entre los efectos de la RF, se incluía la concesión al cónyuge y a los hijos mayores de 16 años "de un permiso individual de residencia y trabajo".

La citada proposición no de Ley relativa a la situación de los extranjeros en España impulsó el segundo proceso de regularización de extranjeros, abierto formalmente mediante la Resolución de

424 De las 43.815 peticiones registradas, tan sólo fueron regularizados 24.000 extranjeros de los que, además, en el año 1990 sólo se hallaban en situación regular 13.933. Cifras extraídas de SAGARRA TRÍAS, Eduard. La legislación sobre extranjería e inmigración: una lectura. Los derechos fundamentales y las libertades públicas de los extranjeros en España. Barcelona, Publicaciones de la Universitat de Barcelona, 2002, p. 201

425 En la sesión del 26 de junio de 1990, el Grupo Parlamentario de Izquierda Unida presentó una moción, consecuencia de interpelación, sobre medidas de política general y de inmigración a adoptar por el Gobierno para promover la regularización de la situación de los emigrantes extranjeros en España, votada favorablemente por la totalidad de los diputados asistentes a dicha sesión. Como consecuencia de esta moción, el Gobierno presentó una comunicación sobre la situación de los extranjeros en España, titulada Líneas básicas de la política española de extranjería. En dicha comunicación, el gobierno afirmó su decisión de "buscar soluciones eficaces para que aflore a la superficie la bolsa de marginación constituida por los extranjeros ilegales, articulando cuando sea posible medidas que propicien la legalización de determinados colectivos de inmigrantes en situacidn ilegal que puedan justificar su inserción en la comunidad nacional". Esta comunicación constituye por ello el origen de la proposición no de ley citada, cuyo texto fue publicado en el BOE, n 257 de 26 de octubre de 1991, pp. 34689-34690. 
7 de junio de 1991 de la Subsecretaría del Ministerio de Relaciones con las Cortes y la Secretaría del Gobierno $^{426}$, aprobada por el Consejo de Ministros. El proceso preveía regularizar a los extranjeros que se encontrasen trabajando de forma irregular en España, otorgándoles los permisos de trabajo y residencia - sin exigirles el visado-, siempre que cumplieran determinados requisitos acreditativos de su inserción y arraigo en nuestro país, contemplados en el apartado primero de la resolución. Se incluían también a los solicitantes de asilo o refugio con peticiones en tramitación u objeto de resolución denegatoria, siempre que encajasen en los criterios de regularización. Por el contrario, quedaban excluidos los extranjeros incursos en algunas causas de expulsión -las previstas en los apartados c,d, y f del art. 26.1 de la LO 7/85-, así como aquellos que, habiendo sido ya expulsados de nuestro país, se encontrasen en el período de prohibición de entrada subsiguiente a dicha expulsión.

La parte más trascendente a nuestros efectos de la Resolución de 7 de junio de 1991, residía en su Disposición Final Segunda ${ }^{427}$. En ella se contemplaba la posibilidad de regularización a favor de los familiares de los extranjeros que ya hubieran sido regularizados y que, a su vez, se encontrasen de forma irregular en España. A tal efecto, se establecía que - previa solicitud del extranjero regularizado-, se otorgase a sus familiares un permiso de residencia que se tramitaría con la "máxima urgencia”. La disposición mencionada perfilaba, en palabras de Sagarra Trías, "un <derecho expectante> para los familiares de los regularizables que les permitía, una vez que estos estuvieran regularizados, pedir su propio permiso de residencia" ${ }^{328}$. Constituía pues una vía extraordinaria para la $R F^{429}$, a fin de dar salida a la abundante situación de familiares irregulares asentados en España, pero no estaba exenta de problemas especialmente en lo que respecta a la limitación de los destinatarios ${ }^{430}$ - : solamente se incluían a los familiares de los extranjeros que habían sido documentados en este proceso, sin mencionar al también amplio colectivo de familiares irregulares de extranjeros que ya contaban previamente con residencia legal en nuestro país.

Este proceso de regularización, considerado excepcional, se enmarcaba en la adopción de una serie de medidas - contenidas en la proposición no de Ley—, "tendentes a organizar y canalizar la inmigración legal, a agilizar la tramitación de los diferentes permisos, y a dificultar la inmigración irregular" "31. La apertura de este proceso hacía evidente la presencia implícitamente tolerada de un alto porcentaje de individuos que habían recurrido a la RF de hecho, contraviniendo la normativa de inmigración y extranjería y que, a su vez, constituían tan sólo una porción del número total de extranjeros clandestinos, cuya presencia y volumen por definición resultan casi imposibles de deter$\operatorname{minar}^{432}$. El fenómeno, por entonces todavía en estado incipiente en España, ponía en evidencia el fracaso de las políticas oficiales de extranjería, especialmente si se tiene en cuenta el espíritu de control que presidía el marco legal por entonces vigente - la LO 7/85-, y su normativa de desarrollo.

426 Resolución de 7 de junio de 1991, de la Subsecretaría del Ministerio de Relaciones con las Cortes, por la que se dispone la publicación del Acuerdo del Consejo de Ministros de 7 de junio de 1991 sobre regularización de trabajadores extranjeros. BOE no 137 , de 8 de junio de 1991.

427 Dicha disposición afirmaba literalmente que "los extranjeros cuya situación haya sido regularizada, una vez recibida su documentación, podrán solicitar para los familiares comprendidos en el articulo 7.2 del Reglamento de Ejecución de la Ley Orgánica 7/1985, aprobado por Real Decreto 1119/1986, de 26 de mayo, que se encuentren en España de forma irregular, el correspondiente permiso de residencia, que se tramitará con la máxima urgencia”.

428 SAGARRA TRÍAS, Eduard. La legislación sobre extranjería e inmigración: una lectura... op. cit., p. 202.

429 La expresión corresponde a MARTÍNEZ, A. “La reagrupación familiar”, op. cit., p. 203.

430 Idem.

431 BOE no 137, de 8 de junio de 1991.

432 BRUYCKER, Philippe de. "Regularización y política migratoria en Europa”; en Revista Cidob d’Afers Internacionals, No 53, p. 182. 
Con todo, justo es recordar que el recurso regular a procesos de regularización - que constituyen "actuaciones de gestión de stocks de extranjeros" "333 a fin de lograr un mejor control de los flujos migratorios, evitando la concentración futura de irregulares y fomentar la integración de los ya presentes dentro del territorio ${ }^{434}$ - constituye un fenómeno compartido por las políticas de extranjería de nuestros vecinos europeos. En tales países, al igual que en España, estos procesos son sistemáticamente presentados con carácter excepcional. Como señala Bruycker, las regularizaciones están "destinadas a poner a cero los contadores de la inmigración”"435, soliéndose establecer con carácter previo o simultáneo a una gran reforma de la legislación sobre extranjeros. Dado que pronto los contadores vuelven a engrosarse con nuevas cifras de irregulares, los Estados recurren a las regularizaciones con cierta frecuencia. España contabiliza hasta la actualidad cinco procesos de regularización extraordinarios ${ }^{436}$, que han pasado a denominarse procesos de "normalización".

Por lo que respecta al proceso de regularización de familiares establecido en la disposición final segunda de la Resolución conjunta de junio de 1991, se saldó con un pobre resultado. La limitación en sus destinatarios, en conjunción con los problemas de coordinación que se detectaron durante la tramitación del proceso, determinaron la recepción de un número relativamente escaso de solicitudes -6464 en total, que fueron sin excepción admitidas en su totalidad a trámite, aun cuando contasen con documentación deficiente ${ }^{437}$ - En definitiva, el proceso fue incapaz de cumplir con sus objetivos iniciales, subsistiendo a su conclusión una bolsa de marginalidad muy cuantiosa. Pese a ello, el proceso de regularización general documentó a más de 112.000 extranjeros que hasta el momento habían permanecido en situación irregular, permitiendo obtener cifras mucho más fiables en torno al volumen real de inmigrantes asentados en España y sus perfiles sociológicos. Por ello, 1991 es considerado como "el año clave, en que aflora el nuevo fenómeno social" en estado muy embrionario, proyectaba retos totalmente nuevos para nuestro país.

El siguiente paso, de importancia fundamental para el régimen jurídico de la migración familiar en España, fue dado a instancias del derecho comunitario. A fin de transponer la normativa comunitaria en materia de libre circulación aplicable al régimen de acceso y residencia en territorio español

433 Idem, p. 181.

434 Sobre este aspecto, BRUYCKER señala que "cuando se decide efectuar una operación de regularización, el Estado transforma a personas que son objetivos policiales en personas jurídicas y, antes que abandonarlos a su estatuto de paria, los invita oficialmente a integrarse en una sociedad cuya organización es responsabilidad suya”. Ibidem, p. 181. Las finalidades que cubre la regularización aparecen en las pp. 179 y 184.

435 BRUYCKER, Philippe de. "Regularización y política migratoria en Europa”; op. cit., p. 179.

436 Hasta la actualidad, han sido en total cinco los procesos de regularización emprendidos por el gobierno español a fin de sacar a la luz y poder integrar a una parte importante del volumen de irregulares presente en territorio español: El primer proceso tuvo lugar durante los años 1985-1986, como resultado de la entrada en vigor de la LO 7/1985, pero sus resultados fueron escasos, hasta el punto de que no suele computarse dentro de los procesos ordinarios. La segunda regularización - que realmente vendría a culminar el infructuoso proceso de regularización previo-, se produjo en el año 1991, mediante Resolución de 7 de junio de 1991 de la Subsecretaría del Ministerio de Relaciones con las Cortes y la Secretaría del Gobierno. Apenas cinco años después, en 1996, tuvo lugar el proceso de documentación de extranjeros en situación irregular, regulado por la disposición transitoria tercera del Real Decreto 155/1996, de 2 de febrero, y desarrollado posteriormente por Acuerdo del Consejo de Ministros de 12 de abril de 1996. En el año 2000 - mediante Real Decreto 239/2000, de 18 de febrero-, se estableció el procedimiento para la regularización de extranjeros previsto en la disposición transitoria primera de la Ley Orgánica 4/2000, en conjunción con lo previsto por el Real Decreto 142/2001, de 16 de febrero, en relación con el reexamen de las solicitudes denegadas y requisitos exigidos para la regularización de los interesados. Por último, en el año 2005, mediante la Orden Pre/140/2005, de 2 de febrero, se desarrolló el procedimiento aplicable al proceso de normalización previsto en la disposición transitoria tercera del Real Decreto 2393/2004. Información disponible en http://www.mtin.es/series/04.htm

437 Datos extraídos de MARTÍNEZ, A. “La reagrupación familiar”, op. cit., pp. 204-205.

438 AJA, E. (coord). La nueva regulación de la inmigración en España, op. cit., p. 28. 
de los ciudadanos comunitarios, el 26 de junio de 1992 se aprobó el Real Decreto 766/1992 sobre entrada y permanencia en España de nacionales de Estados miembros de las Comunidades europeas y otros Estados partes en el Acuerdo sobre el Espacio Económico Europeo ${ }^{439}$. Esta norma supuso la introducción en España de un tratamiento normativo diferenciado y más privilegiado para los familiares extranjeros de ciudadanos españoles o de otros EEMM de las $\mathrm{CCEE}^{440}$, poniendo fin a la paridad existente hasta entonces entre ciudadanos españoles y residentes extranjeros que deseasen reunirse en España con sus parientes extranjeros. El hecho de que fuese una norma de origen comunitario la responsable de esta bifurcación de regímenes, da pie a Santolaya a afirmar agudamente que "los españoles obtenemos un régimen simplificado y privilegiado de ejercicio de ese derecho no en nuestra condición de tales, sino como ciudadanos comunitarios" ${ }^{341}$.

El Real Decreto 766/1992, inaugura pues una escisión de regímenes jurídicos en el seno de la RF en función de la nacionalidad del reagrupante: más privilegiado para el supuesto de ciudadanos de la UE, españoles incluidos; otro diferente para el caso de los extranjeros procedentes de terceros países. Dicha bifurcación, como es bien sabido, constituye una nota desde entonces constante en las legislaciones de extranjería e inmigración. Su aparición ponía al descubierto la necesidad de regular de forma diferenciada el tratamiento de los familiares extranjeros de ciudadanos no comunitarios residentes en España, fijando tanto el procedimiento a seguir para la solicitud de visado por reagrupación como los criterios para su resolución.

Esta regulación se produjo mediante el Acuerdo del Consejo de Ministros sobre tramitación de visados para la reagrupación de familiares de extranjeros no nacionales de Estados miembros de la Unión Europea, adoptado en su reunión del día 12 de noviembre de $1993^{442}$. Detrás del mismo, late claramente la influencia de la Resolución sobre armonización de las políticas nacionales relativas a la $\mathrm{RF}^{443}$, adoptada el 1 de junio de 1993 - esto es, cinco meses antes del citado acuerdo del Consejo de Ministros-, analizada en profundidad en el capítulo tercero de nuestro trabajo. El gobierno español no solamente había manifestado su voluntad de reformar el procedimiento de RF ante las dificultades que la práctica administrativa había hecho aflorar y la existencia de una bolsa de irregulares en constante aumento, sino que, además, debía adaptar el ordenamiento interno a los compromisos que, en materia de inmigración familiar, se habían alcanzado en el ámbito comunitario mediante dicha Resolución armonizadora.

439 Real Decreto 766/1992, de 26 de junio, sobre Entrada y Permanencia en España de Nacionales de Estados miembros de la Unión Europea y otros Estados partes en el Acuerdo sobre el Espacio Económico Europeo, firmado en Oporto el 2 de mayo de 1992 y ratificado por España el 26 de noviembre de 1993. Su vigencia se prolongó hasta el 1 de marzo de 2003.

440 Su artículo segundo, al establecer el ámbito de aplicación, señalaba literalmente: “el presente Real Decreto se aplicará también, cualquiera que sea su nacionalidad, a los familiares de los españoles y de los nacionales de otros Estados miembros de la Unión Europea y otros Estados partes en el Acuerdo sobre el Espacio Económico Europeo, firmado en Oporto el 2 de mayo de 1992 y ratificado por España el 26 de noviembre de 1993, que a continuación se relacionan: a) A su cónyuge, siempre que no estén separados de derecho. b)A sus descendientes y a los de su cónyuge, siempre que no estén separados de derecho, menores de veintiún años o mayores de dicha edad que vivan a sus expensas. c) A sus ascendientes y a los de su cónyuge, siempre que no estén separados de derecho, que vivan a sus expensas, con la excepción de los ascendientes de los estudiantes y de sus cónyuges, que no tendrán derecho de residencia”.

441 SANTOLAYA MACHETTI, P. El derecho a la vida familiar de los extranjeros, op. cit., p. 145.

442 Publicado en el BOE mediante la Resolución de 18 de febrero de 19994, de la Subsecretaría del Ministerio de la Presidencia, por la que se dispone la publicación de dicho Acuerdo, el cual figura como anexo a la mencionada Resolución (BOE nº 47, de 24 de febrero de 1994).

443 En idéntico sentido se pronuncia MARTÍNEZ, A. “La reagrupación fmailiar”, op. cit., p. 200. 
En el período que media desde la adopción en abril de 1991 de la anteriormente comentada Proposición no de ley y el presente acuerdo del Consejo de Ministros, de noviembre de 1993, transcurrieron más de dos años en los que se produjo la suspensión generalizada de la tramitación de visados de residencia por $\mathrm{RF}^{444}$. El motivo residía en el propósito gubernamental - subyacente en la Proposición no de ley-, de emprender reformas en las normas relativas a la tramitación de visados por RF. En espera de que dicha modificación tuviera lugar, transcurrieron dos largos años en los que la migración familiar quedó paralizada, con los consiguientes efectos en el incremento paralelo del recurso a la RF de hecho. La adopción del Acuerdo del Consejo de Ministros sobre tramitación de visados de RF por el régimen general de noviembre de 1993, supuso por ello la reactivación de la RF, bajo nuevas condiciones que estudiaremos a continuación.

Entre los puntos principales del acuerdo del Consejo de Ministros se encontraba la imposición de un plazo previo de residencia al reagrupante a fin de garantizar su estabilidad, sin duda por la influencia de la Resolución armonizadora que había sido acordada poco antes en el ámbito comunitario. Se introdujo así la exigencia del período de espera inexistente tanto en la ley como en el Reglamento, y consistente en la necesidad de acreditar su residencia legal en nuestro país durante más de un año y ser titular de un permiso ya renovado ${ }^{445}$ para poder solicitar la RF de sus parientes. Si bien es cierto que, como comentamos, en la práctica administrativa el plazo de espera se imponía desde hacía tiempo y, además, con mayor rigor temporal — hasta tres años de residencia legal como media-, la dulcificación del período de espera que, frente a tal situación, introducía la Resolución no oculta el hecho de que el mismo carecía de cobertura jurídica.

Asimismo, en el citado acuerdo del Consejo de Ministros destacaba también la exclusión de los familiares de los estudiantes extranjeros no comunitarios residentes en España - por carecer de la condición de residentes-, y la determinación del procedimiento de reagrupación basado en un diseño transnacional dividido en dos fases. Conforme a dicho procedimiento $-\mathrm{y}$, sobre la premisa de que los parientes reagrupables se encontrasen fuera de España ${ }^{446}$, dichos familiares debían presentar en la Oficina Consular española de su país de origen o de un tercer país la solicitud de visado por RF, aportando documentación acreditativa de su identidad, la relación de parentesco con el reagrupante y, en su caso, su dependencia legal y económica, además de un certificado de antecedentes penales y otro médico acreditativo de no padecer enfermedades transmisibles, ni drogadicción, ni enfermedades mentales trascendentes para la seguridad o el orden público. La Oficina Consular devolvería al familiar una copia sellada de la solicitud de visado, misma que el familiar reagrupable habría de hacer llegar al reagrupante instalado en España.

A partir de este momento se iniciaría la segunda fase del procedimiento, protagonizada por el reagrupante y desarrollada ante la Oficina de Extranjeros o, en su defecto, en la Comisaría de Policía

444 Datos extraídos de MARTÍNEZ, A. y equipo del DDIM. “La reagrupación familiar”, op. cit., p. 199.

445 Dichos requisitos figuraban en el punto primero del acuerdo del Consejo de Ministros, dedicado a regular su ámbio de aplicación. El apartado 4.a) del apartado segundo precisaba - al delimitar los documentos que había de presentar el reagrupante en España-, que "si el reagrupante se encuentra residiendo en España al amparo de un permiso en trámite de su primera renovación no se considerará suficiente a estos efectos la presentación del resguardo de haber solicitado la renovación de dicho permiso". Sin embargo, el apartado tercero preveía la posibilidad excepcional de que el Ministro de Asuntos Exteriores dispensase de la exigencia del requisito de tiempo mínimo previo de residencia legal del reagrupante, "cuando del conjunto del expediente y de las circunstancias concurrentes se consideren razonablemente cubiertos dicho requisito y el de capacidad económica".

446 A fin de subsanar la situación de aquellos parientes que, estando dentro de España, se hallaban en situación irregular, la Resolución conjunta sobre instrucciones generales y de procedimiento para la tramitación de visados para RF de extranjeros no nacionales de Estamos miembros de la UE, dictada poco después del Acuerdo del Consejo de Ministros comentado, otorgaba un plazo dentro del cual se preveía la exención de visado por RF para tales familiares. 
de su lugar de residencia. En esta fase, el residente extranjero en España debía presentar la copia sellada de la solicitud de visado junto con una serie de documentos - copia del permiso de residencia en vigor, acreditación de recursos económicos estables y suficientes para atender a las necesidades de la familia, incluyendo asistencia sanitaria, en el supuesto de no estar cubierta por la Seguridad Social, junto con un Acta notarial mixta de presencia y manifestaciones ${ }^{447}$ - a fin de acreditar que disponía de una vivienda de características y amplitud consideradas normales para los ciudadanos españoles que habitasen en la zona de residencia del reagrupante, teniendo en cuenta el número de familiares. La Oficina de Extranjeros o Comisaría de Policía receptora enviaría a la Dirección General de Asuntos Consulares un informe ${ }^{448}$ valorativo de la documentación presentada por el principal. Tomando en consideración tanto los informes emitidos por el Consulado como por la autoridad gubernativa, la Dirección General de Asuntos Consulares cursaría las instrucciones pertinentes al Consulado para la concesión o denegación del visado.

Uno de los puntos fuertes de técnica legislativa del Acuerdo residía en precisar los documentos concretos acreditativos de la concurrencia de los requisitos materiales exigidos para el ejercicio de la $\mathrm{RF}$ - que, hasta el momento, venían estipulados mediante conceptos jurídicos indeterminados. Esta determinación venía a acotar la discrecionalidad que dichos conceptos habían terminado vertiendo en la práctica administrativa de la RF, reforzando la seguridad jurídica del extranjero administrado.

De otro lado, el Acuerdo del Consejo de Ministros tomaba en consideración la concurrencia de competencias de distintos órganos administrativos vinculados a la inmigración familiar delegando en los Ministerios de Asuntos Exteriores, Justicia, Interior, Trabajo y Seguridad Social y Asuntos Sociales la ejecución y desarrollo concreto de las instrucciones que contenía ${ }^{449}$.

A tal fin, las Subsecretarías de los Ministerios de Interior, de Trabajo y Seguridad Social y de Asuntos Sociales, emitieron una Resolución conjunta ${ }^{450}$ de 15 de febrero de 1994, dictando instrucciones generales y de procedimiento sobre la tramitación de visados para la reagrupación familiar de extranjeros no nacionales de Estados miembros de la UE. Entre algunos sectores doctrinales minoritarios, de los que discrepamos, esta Resolución es considerada como el texto normativo donde hace irrupción formal por primera vez la RF en el ordenamiento jurídico español ${ }^{451}$.

447 Los requisitos y extremos que debía cumplir el Acta notarial mixta de presencia y manifestaciones habían sido desarrollados mediante la Circular del Consejo General del Notariado, de 19 y 20 de noviembre de 1991. Conforme a dicha Circular, en el acta notarial debía hacerse constar el título que habilitase para la ocupación de la vivienda, el número de habitaciones de que constase, uso al que se destine cada una de ellas, número de personas que habitasen en la vivienda y condiciones de equipamiento de la misma, especialmente, las relativas a la disponibilidad de agua corriente, electricidad, sistema de obtención de agua caliente y red de desagües.

$448 \mathrm{El}$ informe enviado por la autoridad gubernativa lo era previa propuesta de la Oficina de Extranjeros. En las provincias en las que aún no hubiese entrado en funcionamiento la Oficina de Extranjeros, el informe sería elaborado previa propuesta de una Comisión creada al efecto e integrada por representantes en el ámbito provincial de los Ministerios del Interior, de Trabajo y Seguridad Social y de Asuntos Sociales. Así lo estipulaba el apartado segundo de la disposición quinta de la Resolución de 16 de febrero de 1994, conjunta de las Subsecretarías de los Ministerios de Interior, de Trabajo y de Seguridad Social y de Asuntos Sociales, emitida a fin de concretar los criterios a seguir por las autoridades que, en el ámbito provincial, debían de tramitar e informar de la documentación presentada por el reagrupante en relación con la solicitud de visado por RF.

449 Disposición cuarta del Acuerdo del Consejo de Ministros sobre tramitación de visados para la reagrupación de familiares de extranjeros no nacionales de EEMM de la UE.

450 Resolución conjunta de 15 de febrero de 1994, por la que se dictan instrucciones generales y de procedimiento sobre la tramitación de visados para la reagrupación familiar de extranjeros no nacionales de EEMM de la UE. BOE No 47, de 24 de febrero 1994.

451 Así lo considera Eliseo AJA, señalando en tono crítico que la primera vez que el ordenamiento jurídico español recoge la figura de la RF lo hace mediante "una disposición de ínfimo rango", la Resolución de 15 de febrero de 
A grandes rasgos, la Resolución conjunta se centra fundamentalmente en determinar los requisitos y criterios de los informes que han de emitir el jefe de la oficina consular y la autoridad gubernativa - valorando respectivamente la documentación aportada por el familiar reagrupable y por el reagrupante-, como paso previo a las instrucciones que la Dirección General de Asuntos Consulares debe cursar para la concesión o denegación del visado.

Junto a la repetición y en ocasiones mayor precisión de algunos de los criterios ya apuntados en el acuerdo del Consejo de Ministros de que trae causa, la presente resolución conjunta contiene, a nuestro juicio, dos puntos principales. El más destacado consiste en la previsión explícita de la situación de los familiares del reagrupante que se encuentren en territorio español, esto es, de forma irregular. Con ello se venía a cubrir el vacío del citado acuerdo, que estaba dirigido exclusivamente a los familiares extranjeros del reagrupante que se hallasen fuera de España. Para los familiares en situación irregular, la Resolución conjunta preveía la posibilidad de solicitar la exención de visado, siempre que encajasen en las categorías de familiares amparadas por la Ley 7/85 y el Reglamento -art. 7.2-, y concediéndoles a tal fin un plazo para solicitar dicha exención ${ }^{452}$. Con todo, y pese a sus buenos propósitos, este proceso de regularización de familiares corrió la misma escasa fortuna que el precedente, y por idénticos motivos: deficiencias en la tramitación provocadas por la escasez de los plazos concedidos para la presentación de solicitudes, la descoordinación administrativa y la escasa publicidad del mismo, entre los más destacados ${ }^{453}$.

Y, de otro lado, la Resolución conjunta precisaba el plazo con el que contaban los familiares reagrupables que hubieran obtenido el visado de RF para solicitar, tras su entrada en territorio español, el permiso de residencia correspondiente. A tal fin, la resolución establecía que, teniendo en cuenta los informes anteriormente emitidos por la oficina consular en que se presentó la solicitud de visado y la autoridad gubernativa de la provincia en que reside el reagrupante, la Dirección General de Asuntos Consulares cursará las instrucciones a la Oficina Consular para la concesión o denegación del visado - y a tal fin, la resolución incluye como anexo un modelo de informe favorable/desfavorable del visado por RF-. En el supuesto de resoluciones positivas, los familiares reagrupables, titulares por tanto del correspondiente visado por RF, contaban con un plazo de noventa días - contados a partir de su entrada en España-, para solicitar el permiso de residencia. Así mismo, la resolución conjunta reiteraba las características de urgencia y tratamiento preferente que habían de reunir tanto las peticiones de visados por RF — tal y como había establecido el reglamento de ejecución de la LO 7/85-, como las propias solicitudes de permiso de residencia, "evitando la duplicación o aportación reiterada de documentación ya presentada por el reagrupante durante la tramitación del visado" ${ }^{54}$.

Salvo por lo que respecta a la previsión de exención de visado para los familiares irregulares, el Acuerdo del Consejo de Ministros de 12 de noviembre de 1993 y la Resolución conjunta de 1994 — considerados globalmente-, introducían requisitos más restrictivos que los fijados por vía regla-

1994, "cuando realmente se trata de un derecho fundamental". La nueva regulación de la inmigración en España, op. cit., p. 26.

452 La exigencia consistía en acreditar "de forma fehaciente" hallarse en España desde antes de la fecha de adopción del acuerdo de ministros esto es, antes del 12 de noviembre de 1993 introduciendo la fecha tope del 30 de junio de 1994 para poder solicitar la exención de visado. Disposición transitoria primera de la Resolución conjunta de 16 de febrero de 1994.

453 Para mayor información, vid. MARTÍNEZ, A. “La reagrupación familiar”, op. cit., pp. 206-208

454 Apartado séptimo de la Resolución de 16 de febrero de 1994, conjunta de las Subsecretarías de los Ministerios de Interior, de Trabajo y Seguridad Social y de Asuntos Sociales (BOE n 47, de 24 de febrero de 1994). 
mentaria y, por ello, carentes de fundamento jurídico ${ }^{455}$. En suma, normas de rango sucesivamente más bajo y de tenor progresivamente más restrictivo, disciplinaban aspectos concretos de la regulación de la inmigración familiar, constituyendo "la mayoría de las veces, el instrumento directo en el que se basa la acción pública de las autoridades administrativas" ${ }^{456}$ y por ello, de una enorme trascendencia para los extranjeros afectados.

La situación práctica resultaba totalmente paradójica si se piensa que, el punto de partida había sido la Proposición no de ley relativa a la situación de los extranjeros en España, cuyo punto cuarto - con una generosidad sin precedentes en el ordenamiento español de la época一, afirmaba literalmente que: "Será garantizado el derecho a la RF de los cónyuges de hecho y de derecho, descendientes menores de edad y ascendientes a cargo del trabajador inmigrado. Los cónyuges e hijos mayores de 16 años tendrán derecho al permiso individual de residencia y trabajo. La reagrupación familiar será tramitada en España por el trabajador residente ante los servicios correspondientes que comunicarán al consulado respectivo la decisión favorable para la concesión del visado de entrada”.

El complejo y restrictivo panorama administrativo de la RF vendría a ser complicado aún más por otras dos normas inferiores: la Circular conjunta sobre "Criterios para la aclaración de cuestiones surgidas en aplicación de las normas de extranjería"457 de 1 de julio de 1988 y la Circular 7/1994, de 28 de julio, de la Secretaría de Estado de Interior sobre exenciones de visado para la obtención de permisos o tarjetas para permanecer en territorio españo ${ }^{458}$. Especialmente trascendente resulta la segunda, pues en ella el Ministerio de Justicia e Interior fijaba los términos en que las autoridades competentes podrían conceder exención de visado a los solicitantes de permisos o tarjetas que autoricen a residir en España, tanto en el régimen general de extranjería como en el comunitario. Esta circular estableció el carácter excepcional de la dispensa de visado, estableciendo supuestos tasados en los que sería legítima la petición de exención. Entre los motivos para la concesión de exención de visado, destacaba la previsión — contenida en el apartado segundo, punto $2 \mathrm{f}$ ) —, que amparaba a los extranjeros que fueran cónyuges de residente legal extracomunitario, siempre que no se encontrasen separados de hecho o derecho y acreditasen un período previo de matrimonio de tres años a la fecha de la solicitud. El carácter extraordinariamente excepcional con que la Circular 7/94 contemplaba la exención de visado, la convertía en la norma "que de manera más contundentemente regresiva estableció los criterios limitados que se venían manifestando” 459 en este ámbito.

455 BERNARDO, S; VILAS, A y CUADRA, L.I. "Reagrupamiento familiar"; en ALVAREZ, Aurelia; SANTOS, Lidia; CONABLE, Barber. Jornada sobre el Reglamento de la ley de derechos y libertades de los extranjeros, op. cit., p. 51. Las autoras se manifiestan especialmente críticas respecto al recrudecimiento de las exigencias económicas que implicaban ambas normas, así como la exclusión de los familiares de los estudiantes extranjeros no comunitarios residentes en España. En relación con dichos requisitos, - junto con la introducción del período de espera-, estimaban que sobrepasaban el Reglamento de 1996, "desarrollando al alza" sus requisitos.

456 Idem. Las autoras van más allá, señalando que además, “el valor de estos acuerdos, resoluciones y recomendaciones es de primer orden (...) por mostrarse en ellos la auténtica voluntad política subyacente en las normas”.

457 Circular conjunta de las Direcciones Generales de Asuntos Consulares del Ministerio de Asuntos Exteriores, de Policía del Ministerio de Interior y del Instituto Español de Emigración del Ministerio de Trabajo y Seguridad Social, de 1 de Julio de 1988.

458 B.O.E de 13 de agosto de 1994.

459 BERNARDO, S; VILAS, A y CUADRA, L.I. "Reagrupamiento familiar”; en ALVAREZ, Aurelia; SANTOS, Lidia; CONABLE, Barber. Jornada sobre el Reglamento de la ley de derechos y libertades de los extranjeros, op. cit., p. 52. En conjunto, las autoras concluían que en materia de RF, las resoluciones, circulares y recomendaciones no solo limitaban de forma creciente el derecho, sino que en ocasiones lo impedían, poniendo en entredicho el valor aclaratorio y práctico de tales resoluciones. SANTOLAYA MACHETTI también remarca la "estricta concepción" mantenida por la Circular 7/1994. El derecho a la vida familiar de los extranjeros, op. cit., p. 152. En el mismo sentido, AJA, E. (coord.). La nueva regulación de la inmigración en España, op. cit., p. 31. 
En suma, el caótico panorama normativo en materia de inmigración familiar alumbraba una práctica sistemática en la que se acumulaban normas ejecutivas de rango sucesivamente inferior, que introducían requisitos más restrictivos que los prescritos por vía legal o reglamentaria para el ejercicio de la $\mathrm{RF}^{460}$. De ahí que se señalara gráficamente que, en materia de RF, "la práctica había dominado sobre el texto legal" ${ }^{461} \mathrm{y}$, a su vez, la complejidad procedimental que caracterizaba la práctica administrativa tornaba en ocasiones en inviable el ejercicio de la $\mathrm{RF}^{462}$.

Estando así las cosas, desde distintos espectros doctrinales se señalaban las insuficiencias de la regulación, insistiendo en la necesidad de una reforma que ordenase la dispersión normativa existente, disipando las dificultades aplicativas que la misma había provocado y que, al menos, reconociese la RF expresamente como un derecho subjetivo a favor de los extranjeros residentes en España ${ }^{463}$. Por otro lado, la complejidad técnica y la proliferación de decretos de desarrollo no resultaban características exclusivas de la RF, resultando extensibles a todo el ordenamiento de la extranjería e inmigración de la

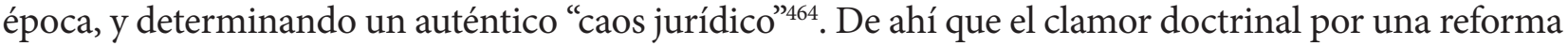
normativa fuese compartido desde otros muchos sectores - incluyendo asociaciones de inmigrantes y el propio Defensor del Pueblo-, que presionaron activamente por el mismo objetivo.

Tal reordenación normativa tendría lugar en el año 1996, mediante el segundo Reglamento de ejecución de la LO 7/85, aprobado por Real Decreto 155/1996, de 2 de febrero, cuya vigencia se prolongaría hasta el 1 de agosto de 2001. Entre las razones justificativas de la reforma reglamentaria, destacaban el incremento registrado en la población extranjera residente en España a partir de 1986, y la consecuente necesidad de adaptación normativa ${ }^{465}$, así como la acomodación del ordenamiento interno a la doctrina del TC y a los compromisos internacionales suscritos por España, fundamentalmente en materia de admisión de trabajadores extranjeros y de RF.

Con carácter general, el nuevo reglamento contemplaba avances importantes. Entre ellos, destacaba un reconocimiento más amplio de derechos, a los que dedicaba un capítulo propio - el preeliminar-, una visión más estable de la inmigración mediante la introducción del permiso de residencia permanente - art. 52-, ambos en conexión con el objetivo último perseguido de fomentar la integración, explícito en su Exposición de Motivos, así como la graduación de las infracciones y sanciones. Seguía, sin embargo, dotando a las autoridades administrativas de una notable discrecionalidad $^{466} \mathrm{y}$, paradójicamente, algunos de los problemas del nuevo reglamento derivaban precisamente de sus mejoras más importantes, que resultaban contrarias a la LO 7/85 a la que desarrollaba ${ }^{467}$.

460 En similar sentido, MARTÍNEZ, A. “La reagrupación familiar”, op. cit., p. 205.

461 BELLOSO MARTÍN, Nuria. “El extranjero y el reagrupamiento familiar en España”, op. cit., p. 186. La expresión es utilizada por esta autora en referencia específica a la Ley orgánica 7/85 y a la práctica subsiguiente en materia de RF. 462 FLORES GIMÉNEZ, Fernando. “El Nuevo Reglamento de Extranjería: ¿una ampliación de derechos?”, op. cit., p. 131.

463 Así lo reclamaban, entre otros, BERNARDO, S; VILAS, A y CUADRA, L.I. “Reagrupamiento familiar”, op. cit., p. 52. 464 De esta forma queda gráficametne descrita la normativa de inmigración de la época en AJA, E. (coord.). La nueva regulación de la inmigración en España, op. cit., p. 27.

465 El ordenamiento interno no solo había de adaptarse a la nueva realidad del fenómeno migratorio, sino también a la Ley 30/1992, de 26 de noviembre, sobre Régimen Jurídico de las Administraciones Públicas y del Procedimiento Administrativo Común. A nivel comunitario, resultaba necesaria la acomodación al Tratado de la Unión Europea y al Convenio de aplicación del Acuerdo de Schengen. Y, además, el Reglamento recogió la doctrina emitida por el TC en la sentencia 115/1987, que había declarado la inconstitucionalidad de determinados artículos —7, 8, art. 34.2- de la LO 7/1985.

466 FLORES GIMÉNEZ, Fernando. “El nuevo Reglamento de Extranjería: ¿una ampliación de derechos?”; en Revista Vasca de Administración Pública, nº 47, p. 117.

467 AJA, E. (coord.). La nueva regulación de la inmigración en España, op. cit., p. 27. 
En materia de inmigración familiar, el Reglamento contenía una regulación mucho más precisa de esta figura pero, realmente, suponía una mera continuación ${ }^{468}$ de la regulación reglamentaria previa. Así se constata en lo que respecta a los puntos neurálgicos de la RF: familiares reagrupables, procedimiento para el ejercicio del derecho y, también, respecto a la débil naturaleza jurídica de la RF, que seguía sin constituir un auténtico derecho subjetivo de los extranjeros residentes en nuestro país.

Al margen de otros artículos auxiliares, el art. 54 del Reglamento - bajo el indicativo título de “permiso de residencia para $\mathrm{RF}$ ”, contenía la ordenación principal de esta institución. Significativamente, su regulación había quedado fuera del capítulo preliminar del reglamento, dedicado a la regulación de los "derechos y libertades de los extranjeros en España". En consecuencia, la RF seguía siendo considerada bajo la limitada premisa de una circunstancia de hecho que, en base a la consideración de los vínculos familiares cercanos con un residente en España, facilitaba a los parientes la adquisición de un visado y permiso de residencia. Ello excluía de entrada su concepción como un auténtico derecho subjetivo ${ }^{469}$, y seguía poniendo en manos de las autoridades administrativas considerables márgenes para su apreciación.

Con respecto al tratamiento de los familiares reagrupables - apartado segundo del art. 54 del Reglamento 155/1996-, quedaban incluidos los mismos parientes que en la normativa reglamentaria previa: cónyuge no separado de hecho ${ }^{470}$ o de derecho; hijos menores de edad solteros y que no hayan formado una unidad familiar independiente; incapacitados y menores cuyo representante legal sea el residente extranjero, así como los ascendientes que dependan económicamente de él y siempre que existan razones que justifiquen la necesidad de autorizar su residencia en España. Entre las escasísimas novedades registradas en este punto convendría mencionar la previsión, por primera vez en nuestra regulación, de que el cónyuge del residente no separado podría residir con el

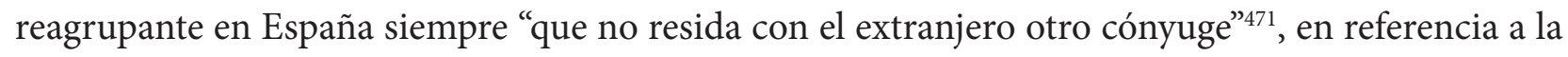
prohibición de los matrimonios poligámicos.

De otro lado, el Reglamento se mostraba categórico respecto al carácter dependiente del permiso de residencia concedido a estos familiares, cuya vigencia estaba vinculada a la residencia legal en España del reagrupante, así como al mantenimiento de las circunstancias que sirvieron de base para su concesión $\mathrm{n}^{472}$. Asimismo, se contemplaban los supuestos para que el cónyuge e hijos del reagrupante pudieran acceder a un permiso de carácter independiente ${ }^{473}$. En la regulación del permiso de

468 SANTOLAYA MACHETTI, P. El derecho a la vida familiar de los extranjeros, op. cit., p. 151.

469 SANTOLAYA MACHETTI, P. El derecho a la vida familiar de los extranjeros, op. cit., p. 151.

470 La exclusión del cónyuge separado de hecho y de derecho - mientras que, en el ámbito comunitario solo se excluía al cónyuge que estuviera separado de derecho-, fue en su momento duramente criticada por Bernardo, Vilas y Cuadra, quienes estimaban que incluir la separación de hecho implicaba "una injerencia en la intimidad de la pareja, con la correspondiente investigación policial, que llevaría a contrariar el principio constitucional del derecho a la intimidad". BERNARDO, S; VILAS, A y CUADRA, L.I. "Reagrupamiento familiar", op. cit., p. 54.

471 Artículo 54.2 del segundo Reglamento de ejecución de la LO 7/1985. El apartado sexto del mismo artículo incidía en la misma idea, estableciendo que "no se podrá conceder un permiso de residencia a un extranjero como cónyuge de un residente extranjero cuando otro cónyuge de éste ya resida con anterioridad en España”. En sentido crítico se manifiestaron también Bernardo, Vilas y Cuadra, estimando que prohibir que no residiese con el extranjero residente otro cónyuge constituía una limitación que "llevaría a decidir sobre un derecho legal reconocido por una legisalción de otro estado, estableciendo una preferencia donde existe una igualdad, y forzando a establecer unos requisitos para determinar qué cónyuge tiene mas derecho". BERNARDO, S; VILAS, A y CUADRA, L.I. "Reagrupamiento familiar", op. cit., p. 55.

472 Apartado 4 del artículo 54 del Reglamento de ejecución 155/1996.

473 Los apartados 5 y 7 del artículo 54 del Reglamento regulaban el acceso a un estatus independiente por parte del cónyuge e hijos del reagrupante. El cónyuge obtendría el permiso de residencia independiente cuando obtuviese un permiso de trabajo, o bien acreditase haber convivido en España con su cónyuge durante dos años, o en caso 
residencia por $\mathrm{RF}$, al mencionar el derecho que amparaba a los familiares de los extranjeros residentes legales para residir en territorio español junto con el reagrupante, el Reglamento hacía expresa referencia a la conformidad con las normas del derecho internacional ${ }^{474}$ - mención que, sin penetrar al articulado de la norma, había estado siempre presente en la exposición de motivos de todas las reformas habidas hasta el momento en este ámbito, incluyendo también ésta-.

La tramitación de los expedientes de visado de residencia - prevista en el artículo 30 del Reglamento-, así como del permiso de residencia por reagrupación familiar, seguía las pautas precedentes, contemplándose también un tratamiento preferente para las peticiones de visados y permisos de residencia por causa de reagrupación familiar ${ }^{475}$. El Reglamento incluía una pequeña variación en la regulación del procedimiento bifásico de RF, de modo que el mismo había de ser iniciado por el reagrupante, quien debía pedir informe de la autoridad gubernativa de la provincia donde residiese, con anterioridad a que el familiar reagrupable solicitase el visado ante la autoridad consultar representante de España en su país de origen ${ }^{476}$. Dicho informe estaba dotado de carácter vinculante ${ }^{477}$ y tenía como finalidad acreditar que el residente reunía las condiciones exigidas para la RF previstas en los apartados 5 y 7 del artículo 56 de dicho reglamento, e idénticas a las previas: disponer de medios de vida ${ }^{478}$, garantías de asistencia sanitaria y vivienda suficientes para él y sus familiares, así como ser titular de un permiso de residencia ya renovado. La importancia del carácter vinculante del informe gubernativo a efectos de la concesión o no del visado, no debe subestimarse ya que, además de facilitar el control judicial en los supuestos de denegación, otorgaba cierto carácter reglado a la propia $\mathrm{RF}^{479}$.

La migración familiar seguía contando con un procedimiento de resolución acelerado ${ }^{480}$ perceptible especialmente en las solicitudes de permisos de residencia por RF, que habían de resolverse en un plazo de mes y medio - esto es, la mitad del plazo máximo estipulado para resolver con carácter general las solicitudes de extranjería, fijado en tres meses-. Por su parte, los expedientes de solicitud de visado por causa de RF se resolverían dentro del plazo general, esto es, "en todo caso, en el plazo de tres meses". Todas las resoluciones debían ser motivadas y notificarse formalmente al interesado ${ }^{481}$.

En un intento de prevenir futuras fragmentaciones normativas, el Reglamento preveía los motivos excepcionales en los que cabía conceder la exención de visado, incluyendo "motivos de interés público, humanitarios, de colaboración con la justicia o de atención sanitaria, y siempre que se

de fallecimiento del reagrupante. Por su parte, los hijos del reagrupante accederían a un permiso de residencia independiente al alcanzar la mayoría de edad.

$474 \mathrm{Al}$ respecto, el apartado primero del artículo 54 del Reglamento señalaba que "los familiares de los extranjeros que residan legalmente en España podrán residir con éstos, conforme a lo dispuesto en las normas de derecho internacional y los requisitos previstos en la Ley Orgánica 7/1985 y este Reglamento".

475 Disposición adicional sexta del Reglamento de ejecución de la LO 7/1985, aprobado mediante el Real Decreto 155/1996, de 2 de febrero.

476 Artículo 28 del Reglamento.

477 Artículo 23.3 del segundo Reglamento de ejecución de la LO 7/1985.

478 Sobre este aspecto, el art. 56.4 del Reglamento aclaraba que "se entenderá que el solicitante tiene medios de vida suficientes cuando cuente con un permiso de trabajo en España o cuando sus recursos económicos superen el nivel mínimo que se establezca en la norma de desarrollo correspondiente".

479 SANTOLAYA MACHETTI, P. El derecho a la vida familiar de los extranjeros, op. cit., p. 152.

480 Disposición adicional segunda del Reglamento de Ejecución de la LO 7/1985, aprobado mediante Real Decreto 155/1996, de 2 de febrero.

481 Idem, apartado cuarto del artículo 57. 
pueda presumir la buena fe del solicitante" ${ }^{482}$, y delegando en el Ministerio de Justicia e Interior los términos precisos en que habían de traducirse tales supuestos.

En cumplimiento de dicha remisión, se dictaría poco tiempo después la Orden del Ministerio de Justicia e Interior sobre Exenciones de Visado ${ }^{483}$. En ella se fijaban los términos en que las autoridades competentes podrían conceder exención de visado a los solicitantes de permisos o tarjetas que autorizasen a residir en España, tanto en el régimen general como en el comunitario. Entre los motivos que habilitaban para dispensar de visado se situaban múltiples supuestos de lazos familiares, quedando incluidos los extranjeros menores de edad que fuesen hijos de españoles o de extranjeros residentes legales en España; los extranjeros que fuesen cónyuges de extranjero residente legal, no nacional de un Estado miembro de la Unión Europea o del Espacio Económico Europeo - siempre que no se encontrasen separados de hecho o derecho y que acreditasen un periodo previo de matrimonio de tres años a la fecha de la solicitud-; los extranjeros que acreditaran ser ascendientes directos de un menor español residente en España que vive a sus expensas; $y$, también, supuestos de arraigo sin existencia de vínculos familiares, otorgando protección a los extranjeros que hubiesen residido previamente de forma legal en España durante un período mínimo de dos años ininterrumpidos en los diez años anteriores. Asimismo, a efectos de preservar la seguridad jurídica y reforzar el control judicial, la Orden ministerial establecía la obligación de motivar las resoluciones sobre peticiones de exención de visado, indicando, en su caso, la concurrencia de los motivos enumerados en el apartado segundo de la misma ${ }^{484}$.

El tenor abierto y progresista de los motivos de exención contemplados por la citada orden y la abundancia de los mismos, reflejaban un espíritu muy distante al carácter extremadamente excepcional con que la Circular 7/1994 había contemplado poco tiempo antes la misma institución de la exención de visado. La importancia a efectos prácticos de los supuestos contemplados resulta obvia, otorgando protección a múltiples situaciones que resultan muy frecuentes en el ámbito de la extranjería y la inmigración. Y, en materia específica de RF, tutelando a aquellos familiares que hubiesen experimentado situaciones de irregularidad, sin necesidad de exigir el retorno a su país de origen a fin de solicitar allí el visado del que carecían, siempre que cumpliesen los requisitos fijados.

En la evolución normativa de la migración familiar conviene mencionar el Acuerdo de la Comisión de Política Social y Empleo, aprobado mediante Acuerdo del Pleno del Congreso de 23 de junio de 1998. Dicho Acuerdo contenía un informe ${ }^{485}$ en el que - en base a la consideración de la RF como un mecanismo esencial para la integración de los inmigrantes-, se reclamaba la necesidad de afrontar una modificación a fondo de su tratamiento normativo. El mismo se erigió en antecedente de la reforma legislativa de gran magnitud que tendría lugar en el año 2000, mediante la Ley Orgánica 4/2000, de 11 de enero, sobre derechos y libertades de los extranjeros en España y su integración social.

482 Artículo 56.9. Por su parte, el apartado octavo del mismo artículo establecía que «el extranjero que solicite permiso de residencia y carezca del correspondiente visado deberá acreditar que ha sido eximido con anterioridad de la obligación de visado por la autoridad que haya de resolver sobre la concesión del permiso de residencia».

483 Orden de 17 de abril de 1996 (BOE de 17 de abril de 1996).

484 Apartado quinto, punto tercero de la Orden de 11 de abril de 1996.

485 Informe de la Subcomisión para estudiar la situación de los españoles que viven fuera, así como la de los inmigrantes y refugiados que han llegado a nuestro país, conocer a fondo sus necesidades y reivindicaciones prioritarias y proponer las medidas legales y sociales que es conveniente adoptar para solucionar los problemas existentes. BOCG de 15 de Julio de 1998. 
Con la Ley Orgánica 4/2000 se inaugura una nueva etapa en el marco jurídico y social de la extranjería y la inmigración en nuestro país, con características divergentes a las previas. Fundamentalmente, marca la irrupción de una gran turbulencia normativa, al compás de una realidad migratoria que experimentaría una aceleración tan intensa ${ }^{486}$, que convertirían la realidad de la inmigración en España en un "fenómeno sin precedentes en Europa" $"$ "87.

Con independencia de su escasa fortuna, la Ley orgánica 4/2000 coincidió pues con la apertura de un período en el que la inmigración en España asumiría rasgos hasta el momento inéditos. En el año 2007, España encabezaba ya la lista de países receptores de inmigración registrando una de las tasas más altas de inmigrantes, alcanzada en un período temporal considerablemente corto. La grave crisis económica que se inicia ese mismo año y su fuerte incidencia sobre el mercado laboral español, produjo una desaceleración de los flujos de entrada, resultando ésta visible a finales del año 2008 - fecha que constituye "el punto de inflexión entre el auge y la contracción" 488 de la inmigración en nuestro país - La grave coyuntura económica existente en el momento de cerrar estas páginas y su previsible prolongación, - junto con los saldos emigratorios positivos registrados desde el año 2011-, insinúan, siguiendo a Arango, que atravesamos un período transitorio en materia migratoria $^{489}$. Aun es pronto para determinar si afrontamos el inicio de un nuevo ciclo migratorio en España.

\section{LA REGULACIÓN DE LA RF EN EL SIGLO XXI: UN INESTABLE MARCO NORMATIVO}

Con la llegada del nuevo siglo, la inestabilidad legislativa se instalaría en la regulación de la extranjería y la inmigración en nuestro país, resultando especialmente visible en materia de migración familiar. El grado de obsolescencia normativa $-\mathrm{y}$, consecuentemente, también doctrinal - resulta muy elevado: reformas y estudios doctrinales quedan rápidamente desfasados, para estupor de los afectados y desesperación del estudioso. Como ya señalamos, los rasgos más polémicos de los flujos migratorios resultan exacerbados en la inmigración de carácter familiar. La inestabilidad normativa no podía ser una excepción, resultando modificada casi invariablemente esta institución como

486 Durante la década de los noventa, la cifra de inmigrantes en España experimentó un ritmo constante pero moderado de crecimiento, registrándose a finales de dicha década en España un porcentaje total de extranjeros que rondaban el $1 \%$ de la población total, situándonos todavía muy lejos de las medias que registraban los países europeos. A principios de 2007, la proporción de extranjeros residiendo en España constituía el 9,9\% del total de la población, lo que reflejaba el hecho de la intensa velocidad con que nuestro país pasó a figurar entre los principales países de destino de los flujos. CEBOLLA BOADA, H. y GONZÁLEZ FERRER, A. La inmigración en España (2000-2007) ..., op. cit., p. 14.

487 CEBOLLA BOADA, H. y GONZÁLEZ FERRER, A. La inmigración en España (2000-2007) ..., op. cit., p. 16. Los mismos autores, señalan que el informe sobre la población mundial relativo al año 2006 publicado por la ONU situó a España como el décimo país mundial por el número de extranjeros residentes, cuando diez años antes en dicho informe España ni siquiera figuraba nuestro país - pese a que, como puntualizan ambos, España ya constituía en 1996 un país de inmigración-. Idem, p. 12. A 1 de enero de 2007, el alto ritmo de llegadas de inmigrantes, situaba a España "a la cabeza de los países receptores de inmigración" tanto para dicha fecha como para el año anterior. $L a$ inmigración en España (2000-2007) ..., op. cit. p. 12. La inmigración en España (2000-2007) ..., op. cit., p. 19.

488 ARANGO, Joaquín. "Del boom a la crisis: La inmigración en España a fines de la primera década del siglo XXI”, op. cit., p. 33.

489 Idem, p. 51. El autor prosigue señalando prudentemente que "el fenómeno migratorio se encuentra en España en un compás de espera", recomendando abrir debates en profundidad — ante la ausencia de un análisis serio y profundo en los años previos en torno a esta cuestión-, concluyendo que "el alcance y la envergadura de los cambios en el medio y largo plazo que para la inmigración va a suponer la actual crisis cuando ésta termine son de imposible determinación”. Ibidem, p. 53. 
consecuencia de las numerosas reformas que se han ido sucediendo desde la entrada del nuevo siglo - ocupando la RF, en la mayor parte de ellas, un papel central dentro de las motivaciones que han movido al legislador o al ejecutivo a acometer tal reforma.

Como es bien sabido, el texto normativo actual - la popularmente conocida como ley de extranjería - procede de principios del año 2000, cuando vio la luz la Ley Orgánica 4/2000, de 11 de enero, sobre derechos y libertades de los extranjeros en España y su integración social ${ }^{490}$, que supuso la derogación de la LO 7/1985, hasta entonces vigente.

Entre los antecedentes que prepararon el camino a la elaboración de un nuevo marco normativo migratorio, destacaban - junto con la inadecuación de la anterior ley-, una realidad social que registraba cotas muy elevadas de flujos migratorios, y el ya citado Acuerdo de la Comisión de Política Social y Empleo sobre inmigrantes y refugiados, aprobado por el Pleno del Congreso de los Diputados, el 23 de junio de $1998^{491}$. Este Acuerdo dejaba translucir una percepción muy diferente del inmigrante de la contenida en la normativa previa: una visión más humanitaria, enfocada en otorgarles derechos que no se circunscribían únicamente a aquellos más vinculados a la dignidad humana a fin de fomentar su participación activa en la vida social, cultural, profesional, educativa e incluso política de la sociedad de acogida, con la finalidad última de primar su integración. Esta nueva aproximación al fenómeno migratorio impregnaría de forma notoria tanto el espíritu como la letra de la LO 4/2000.

El nuevo texto legal fue fruto de un proceso parlamentario muy crispado, que si bien se proyectó e inició su andadura como una ley de amplísimo consenso, finalmente se saldó con la ruptura del mismo en el Senado, habiendo de ser aprobada por el procedimiento de urgencia, justo el último día de la legislatura y en pleno período electoral. La radicalización del debate parlamentario habido en el Senado, junto con el anuncio de inminentes reformas legislativas por parte del partido en el poder, constituían signos premonitorios de la efímera existencia de la nueva ley ${ }^{492}$.

La LO 4/2000 venía imbuida de un espíritu de ruptura respecto a la normativa previa, basado en el reconocimiento a los extranjeros de los derechos consagrados en el Título I de la Constitución en igualdad de condiciones respecto de los españoles ${ }^{493}$, cuyos términos concretos precisaba la ley. Fue precisamente su espíritu liberal -interpretado por ciertos sectores como generosidad excesiva

490 Aprobada por las Cortes el 22 de diciembre de 1999, su entrada en vigor se produjo el 1 de febrero del 2000. (B.O.E. de 12 de enero de 2000).

491 En el citado Acuerdo, puede lerse: "La Subcomisión entiende que los emigrantes no pueden ser considerados solamente como mano de obra, sino como personas titulares de derechos, en especial, al desarrollo personal y social, con respeto a su propia identidad cultural, a la igualdad de trato, eliminando toda forma de discriminación por motivo de nacionalidad o raza, particularmente en los ámbitos de las condiciones laborales, profesionales, educativas, cultura, de vivienda, de sanidad...”. BOGC de 15 de Julio de 1998. Citado por SANTAOLAYA MACHETTI, Pablo (coord.). Comentarios a la Nueva Ley de Extranjería. Valladolid, Lex Nova, 2000, p. 55. Junto a este antecedente, Eliseo AJA señala que la LO 4/2000 tuvo otro precedente en los trabajos que la Consejería de Bienestar Social de la Generalitat de Cataluña realizó a lo largo de 1998 con la idea de elaborar una ley autonómica para la integración de los inmigrantes. Finalmente, la iniciativa fue abandonada y la Consejería pasó el texto de la misma al Grupo parlamentario de CIU en las Cortes, quien lo presentaría en marzo de 1998 como proposición de ley en el Congreso de los Diputados, constituyendo el germen de la LO 4/2000. La nueva regulación de la inmigración..., op. cit., p. 40.

492 En el mismo sentido se expresa GOIG MARTÍNEZ, quien señala que la LO 4/2000, "como consecuencia del convulsivo proceso de tramitación parlamentaria, nacía aquejada de una fuerte provisionalidad"; en "Régimen jurídico y políticas sobre extranjería en España..., op. cit., p. 637.

493 Así lo proclamaba expresamente el primer párrafo del artículo 3 de la Ley 4/2000. El contraste con la LO 7/85 lo establece Goig Martínez: la nueva ley determinaba la igualdad en el goce de los derechos y libertades del Título I por los extranjeros, mientras que en la Ley de 1985 era un "mero criterio interpretativo". GOIG MARTÍNEZ, J.M. "Régimen jurídico y políticas sobre extranjería en España...”, op. cit., p. 635. 
llamada a engendrar un efecto llamada entre la población inmigrante-, una de las principales causas de su fracaso.

Junto a su carácter progresivo, la característica más destacada de la LO 4/2000 fue su exigua vigencia. Apenas ocho meses después de su entrada en vigor, la LO 4/2000 fue modificada por la LO 8/2000 que, pese a presentarse formalmente como una reforma legislativa, en el fondo inauguró un nuevo régimen jurídico de la extranjería en España ${ }^{494}$. De esta forma se abría la etapa más inestable y turbulenta, normativamente hablando, de la regulación del régimen general de la extranjería y la inmigración en España.

A diferencia de su precedente, la $\mathbf{L}$.O. 8/2000 ${ }^{495}$ contaba con una exposición de motivos que justificaba la reforma a fin de lograr una mayor adaptación a la realidad social de la inmigración en España - se afirmaba que durante la vigencia de la LO 4/2000 se habían detectado "aspectos en los que la realidad del fenómeno migratorio supera las previsiones de la norma”-, así como para cumplir con los compromisos internacionales, especialmente en dos puntos: las conclusiones adoptadas en el Consejo de Tampere en torno a la creación de un espacio de libertad, seguridad y justicia ${ }^{496}$, y el acervo Schengen sobre régimen de entrada, condiciones de expedición de visados, estancia de extranjeros y responsabilidad y sanciones a transportistas, incluyendo un amplio conjunto de medidas relativas a la lucha contra la inmigración ilegal. Asimismo, la nueva normativa partía de la necesidad de abordar la inmigración "como un hecho estructural que ha convertido a España en un país de destino de los flujos migratorios y, por su situación, también en un punto de tránsito hacia otros Estados", con un planteamiento global y coordinado en el tratamiento de este fenómeno. La reforma respetaba la estructura articulada de la Ley Orgánica 4/2000 y, pese a su talante marcadamente restrictivo, afirmaba que las modificaciones relativas al régimen de los derechos y libertades de los extranjeros en España destacaban por la "preocupación en reconocer a los extranjeros la máxima cota de derechos y libertades", con un tenor literal casi idéntico al contenido en la exposición de motivos de la Ley 7/1985.

A la L.O. 8/2000, le seguiría la reforma operada mediante la L.O. 11/2003, de 29 de noviembre, de medidas concretas en materia de seguridad ciudadana, violencia doméstica e integración social de los extranjeros ${ }^{497}$. Esta ley se insertaba dentro del conjunto de medidas legislativas de desarrollo del Plan de lucha contra la delincuencia, que había sido aprobado por el gobierno en septiembre del año 2002. Entre las novedades principales, destacaba la introducción de la regla general de sustitución de la pena por la expulsión para aquellos extranjeros que, careciendo de residencia legal en España, cometiesen delitos castigados con pena de prisión inferior a seis años ${ }^{498}$, el aumento de la penalidad para el supuesto de tráfico ilegal de personas, la tipificación del delito

494 Con similar tenor se pronuncia RAVETLLAT BALLESTÉ, quien considera que la LO 8/2000 "supuso en realidad un nuevo marco normativo de derechos y deberes de los extranjeros en España”; La reagrupación familiar, op. cit., p. 26. Para GOIG MARTÍNEZ, el texto de la LO 8/2000, comparada con su precedente, constituyó un "claro retroceso", especialmente en materia de estatus de los extranjeros. "Régimen jurídico y políticas sobre extranjería en España...”, op. cit., p. 639. Para este mismo autor, junto a una nueva ley totalmente diferente a la anterior -la reforma afectó al 80\% del articulado-, la LO 8/2000 suponía un retorno a una situación muy parecida a la contemplada por la LO 7/1985. Idem, p. 637.

495 Ley Orgánica 8/2000, de 22 dediciembre, de reforma de la Ley Orgánica 4/2000, de 11 de enero, sobre derechos y libertades de los extranjeros en España y su integración social. B.O.E. n 307, 23 de diciembre de 2000.

496 Consejo Europeo de Tampere, de 15 y 16 de octubre de 1999.

497 B.O.E. no 234, de 30 de septiembre de 2003.

498 La finalidad de esta regla general consistía en "evitar que la pena y su cumplimiento se conviertan en forma de permanencia en España quebrantando así de manera radical el sentido del ordenamiento jurídico en su conjunto", tal y como afirmaba explícitamente la Exposición de Motivos de la Ley 11/2003, de 29 de septiembre. 
de mutilación genital o ablación —incluyendo además la pena de inhabilitación especial para el ejercicio de la patria potestad en el caso de que la víctima fuera menor de edad o incapaz, siempre que el juez lo estimase adecuado para el interés del menor, y la introducción de ciertas mejoras en la resolución judicial que disponía el ingreso de los extranjeros en un centro de internamiento, a fin de que las resoluciones de expulsión no quedasen sin efecto ante la imposibilidad de hallar al extranjero.

Ese mismo año se produciría la tercera modificación legislativa en esta materia, mediante la L.O. 14/2003, de 20 de noviembre ${ }^{499}$. Nuevamente la reforma venía precedida por la necesidad de adaptar el marco legal a los continuos cambios de un fenómeno tan mutable como el migratorio que, en los escasos dos años de vigencia de la $\mathrm{LO} 8 / 2000$, había experimentado un rápido incremento en el número de residentes extranjeros en España. Además, esta ley venía a acatar la sentencia de la sala $3^{a}$ del TS, de 20 de marzo de 2003, que había declarado la ilegalidad de determinados preceptos del desarrollo reglamentario, estipulando la regulación legal preceptiva de ciertos contenidos previstos en el Reglamento de ejecución de la Ley Orgánica 4/2000, aprobado por Real Decreto 864/2001, de 20 de julio. En dicha sentencia se había establecido la nulidad de la prohibición reglamentaria de la RF en cadena. En este sentido, la LO 14/2003-, a fin de evitar fraudes en las reagrupaciones en cadena -incorporaba a la ley la necesidad de que el residente en España que lo fuese en virtud de una previa reagrupación, debía ser titular de una autorización de residencia independiente como presupuesto para ejercer el derecho a reagrupar a sus propios familiares, incluyendo requisitos concretos para el supuesto de que tal ejercicio se produjese por parte de ascendientes previamente reagrupados.

Salvo en el aspecto mencionado, las modificaciones introducidas por la L.O. 14/2003 no afectaron ni al catálogo de derechos de los extranjeros ni a la estructura de la LO 4/2000, persiguiéndose, con carácter general, la mejora de la gestión mediante la simplificación de los trámites administrativos en materia de extranjería e inmigración. Entre las reformas más importantes se incluía la obligación de proveerse de una tarjeta de identidad de extranjero como documento acreditativo de la autorización administrativa para residir, en adaptación al derecho comunitario, además de la eliminación de la figura de la exención de visado, cuyos supuestos de hecho pasaban ahora a integrarse en el ámbito de la autorización de residencia temporal por circunstancias excepcionales.

Más recientemente, el régimen jurídico de los derechos y libertades de los extranjeros no comunitarios en España fue nuevamente modificado a finales del 2009 como consecuencia de la reforma operada mediante la L.O. $2 / \mathbf{2 0 0 9}^{500}$. Constituye la última reforma registrada hasta el momento en el ámbito de las normas de rango legal, aunque quizá ostente por poco tiempo tal título en vista del cambio en el ejecutivo acaecido en las últimas elecciones legislativas, que ya ha venido acompañado de recientes cambios en el marco de la extranjería ${ }^{501}$ - si bien se apunta como prioritaria una futura modificación reglamentaria-.

499 Ley Orgánica 14/2003, de 20 de noviembre, de Reforma de la Ley Orgánica 4/2000, de 11 de enero, sobre derechos y libertades de los extranjeros en España y su integración social, modificada por la Ley Orgánica 8/2000, de 22 de diciembre; de la Ley 7/1985, de 2 de abril, Reguladora de las Bases del Régimen Local; de la Ley 30/1992, de 26 de noviembre, de Régimen Jurídico de las Administraciones Públicas y del Procedimiento Administrativo Común, y de la Ley 3/1991, de 10 de enero, de Competencia Desleal. B.O.E. n 279, de 21 de noviembre de 2003.

500 Ley Orgánica 2/2009, de 11 de diciembre, de reforma de la LO 4/2000, de 11 de enero, sobre derechos y libertades de los extranjeros en España y su integración social. B.O.E. nº 6, de 7 de enero de 2005.

501 Entre ellas, destacadamente la eliminación de la tarjeta sanitaria para los extranjeros irregulares —con la excepción de menores y mujeres embarazadas - mediante el Real Decreto ley 16/2012, que supuso la modificación del artículo 12 de la LO 4/2000, conforme al cual "los extranjeros inscritos en el padrón del municipio en el que tengan su domicilio habitual, tienen derecho a la asistencia sanitaria en las mismas condiciones que los españoles”. Dicho Decreto Ley 
Con excepción de la LO 4/2000 — cuya corta vigencia imposibilitó la elaboración del reglamento de desarrollo-, cada reforma legislativa ha venido secundada de su correspondiente desarrollo reglamentario. De modo que a las reformas legislativas analizadas hay que sumar las subsiguientes modificaciones reglamentarias en una materia en la que la importancia del Reglamento no puede subestimarse pues, al desarrollar aspectos concretos de carácter administrativo, posee una enorme incidencia sobre la realidad práctica que afrontan los extranjeros en España.

En el ámbito reglamentario, la efervescencia normativa ofrece el siguiente panorama acumulativo: la LO 8/2000 fue desarrollada por el Real Decreto 864/2001, de 20 de julio ${ }^{502}$. Once de sus disposiciones serían anuladas posteriormente por la sentencia del Tribunal Supremo de 20 de marzo de 2003, a la que acabamos de hacer referencia, por estimar que el desarrollo reglamentario carecía de cobertura legal al incluir restricciones a derechos de los extranjeros previstos legalmente. Este Reglamento sería por ello posteriormente modificado por el Real Decreto 2393/2004, de 30 de diciembre ${ }^{503}$. A su vez, la ley de extranjería en su versión actualmente vigente - que procede de la reforma acaecida en diciembre de 2009-, sería objeto de un desarrollo reglamentario muy tardío, mediante un Reglamento de ejecución que, tras ser largamente esperado, vio la luz en abril del año $2011^{504}$.

A efectos de sintetizar y, en vista de la auténtica turbulencia normativa que está afectando a la migración familiar en España, abordaremos de forma conjunta la evolución jurídica de esta institución, contemplando de forma panorámica cómo las distintas reformas han ido reconfigurando el tratamiento de esta materia, al hilo del análisis de cada uno de sus principales elementos integrantes: titularidad activa, familiares reagrupables, requisitos para el ejercicio del derecho y efectos de la RF. Se incidirá en la regulación actualmente vigente - LO 2/2009- pero, al hilo de su estudio, se abordarán, si quiera de forma anecdótica, las múltiples vicisitudes y vaivenes que han sacudido el marco jurídico de la inmigración familiar en España a partir del año 2000.

Sin embargo, antes de exponer la regulación vigente, consideramos esencial reflejar la importancia numérica de la inmigración familiar en nuestro país y la progresión claramente ascendente que ésta ha registrado. Su significación queda patente de forma nítida en las cifras que exponemos en la tabla ${ }^{505}$ que figura a continuación. La misma rastrea la evolución de las solicitudes de RF formuladas, así como de las autorizaciones iniciales de residencia concedidas por causa de RF y

entró en vigor en agosto de 2012, resultando constitucionalmente ilegítima su utilización para recortar un derecho constitucional, reconocido en el art. 43. La reforma reglamentaria, actualmente en gestación, prevé también reformas en los Centros de Internamiento de Extranjeros, que pasarán a denominarse Centros de estancia controlada de extranjería, dando prioridad al alojamiento de extranjeros con antecedentes penales pendientes de expulsión.

502 Real Decreto 864/2001, de 20 de julio, por el que se aprueba el Reglamento de ejecución de la Ley Orgánica 4/2000, de 11 de enero, sobre derechos y libertades de los extranjeros enEspaña y su integraciónsocial, reformada por Ley Orgánica 8/2000, de 22 de diciembre. B.O.E. n 174, de 21 de julio de 2001. Su entrada en vigor tuvo lugar el 30 de junio de 2011.

503 Real Decreto 2393/2004, de 30 de diciembre, por el que se aprueba el Reglamento de la Ley Orgánica 4/2000, de 11 de enero, sobre derechos y libertades de los extranjeros en España y su integración social. B.O.E. nº 6, de 7 de enero de 2005.

504 Real Decreto 557/2011, de 20 de abril, por el que se aprueba el Reglamento de la Ley Orgánica 4/2000, sobre derechos y libertades de los extranjeros en España y su integración social, tras su reforma por Ley Orgánica 2/2009. B.O.E. nº 103, de 30 de abril de 2011.

505 Tras la acumulación de reformas legislativas, el título de la ley de extranjería actualmente vigente reza como sigue: Ley Orgánica 4/2000, de 11 de enero, sobre derechos y libertades de los extranjeros en España y su integración social (BOE núm. 10, de 12 de enero), en su redacción dada por la LO 8/2000, de 22 de diciembre (BOE núm. 307, de 23 de diciembre), por la Ley Orgánica 11/2003, de 29 septiembre (BOE núm. 234, de 30 de septiembre), por la Ley 
su peso relativo, expresado en porcentajes, con respecto al total de autorizaciones de residencia iniciales expedidas, a partir del cambio de siglo, a nacionales de terceros países.

\section{LA RF EN CIFRAS: EVOLUCIÓN DE LAS AUTORIZACIONES \\ DE RESIDENCIA POR RF EN ESPAÑA, 2000-2010}

\begin{tabular}{|c|c|c|c|}
\hline$A \tilde{N} O$ & $\begin{array}{c}\text { Solicitudes } \\
\text { de autorizaciones } \\
\text { de Residencia por RF }\end{array}$ & $\begin{array}{c}\text { Autorizaciones de Residencia } \\
\text { iniciales concedidas } \\
\text { por causa de } R F\end{array}$ & $\begin{array}{c}\text { Porcentaje de Aurorizaciones de Residencia } \\
\text { por RF sobre el total de las autorizaciones } \\
\text { de Residencia inicial expedidas }\end{array}$ \\
\hline 2000 & 7.197 & 7 & No disponible \\
\hline 2001 & 10.028 & 52 & No disponible \\
\hline 2002 & 18.541 & 14.063 & $5 \%$ \\
\hline 2003 & 32.561 & 33.814 & $17 \%$ \\
\hline 2004 & 103.998 & 71.532 & $28 \%$ \\
\hline 2005 & 74.852 & 74.919 & $10 \%$ \\
\hline 2006 & 113.146 & 97.759 & $38 \%$ \\
\hline 2007 & 144.584 & 128.161 & $39 \%$ \\
\hline 2008 & 103.640 & 150. 101 & $38 \%$ \\
\hline 2009 & 82.521 & 100.620 & $30 \%$ \\
\hline 2010 & No disponible & 89.905 & $34,9 \%$ \\
\hline
\end{tabular}

\section{LA LEY ORGÁNICA 2/2009 ¿ÚLTIMA REFORMA DE LA LEY DE EXTRANJERÍA? MODIFICACIONES EN EL RÉGIMEN DE LA INMIGRACIÓN FAMILIAR}

La que hasta el momento de cerrar estas páginas constituye la última reforma de la Ley Orgánica sobre derechos y libertades de los extranjeros en España y su integración social, fue aprobada por el Congreso de los Diputados el 26 de noviembre de 2009, mediante la LO $2 / 2009$, tras un período de tramitación parlamentaria que se prolongó durante casi un año

Orgánica 14/2003, de 20 de noviembre (BOE núm. 279, de 21 de noviembre) y por la Ley Orgánica 2/2009, de 11 de diciembre (BOE núm 299, de 12 de diciembre).

506 Las cifras que maneja Eurostat difieren de las expuestas en este trabajo, en lo que respecta al año 2009. Según los datos que revela la Comisión Europea, para el año 2009 se expidieron en España un total de 125.288 autorizaciones de Residencia por RF —esto es, 24.688 más de las que figuran en la tabla anexa-, cifra que representaría el 43,1\% del total de autorizaciones iniciales de residencia concedidas en España a lo largo del año 2009. La causa de esta discrepancia se debe a que Eurostat computa dentro de la categoría de residencia por causa de RF muchas de las solicitudes que en España se califican como de residencia no lucrativa. 
—el Anteproyecto había sido aprobado por el Consejo de Ministros el 19 de diciembre de 2008-. Es hasta la fecha la cuarta modificación legislativa en esta materia.

La LO 2/2009 consta de un Preámbulo a modo de exposición de motivos, un extenso artículo único donde se introducen todas las modificaciones al texto de la Ley Orgánica 4/2000, así como dos disposiciones adicionales, una derogatoria y tres disposiciones finales. Con esta estructura, el articulado de la Ley 4/2000 quedaba intacto - aun cuando su contenido variaba sustancialmente-, pues se trata de una reforma de amplio calado que afectaba a todos los títulos de la ley, modificando más de cincuenta de sus 71 preceptos integrantes.

A diferencia de las previas, esta reforma legislativa había venido precedida por una amplia ronda de consultas con distintas instituciones vinculadas al ámbito migratorio, cuyos informes fueron estudiados por el gobierno, y algunas de cuyas propuestas terminaron vertiéndose en el texto de la ley. Asimismo, su elaboración se caracterizó por la voluntad de diálogo y búsqueda del acuerdo con actores sindicales, empresariales y organizaciones no gubernamentales, entre otros, a fin de obtener el mayor grado de consenso. Pese a todo, y en claro recordatorio a previas y polémicas reformas migratorias - concretamente la habida a finales del año 2000-, la ley nacía con el rechazo del principal partido de oposición, el cual, simultáneamente a su aprobación, ya había manifestado su intención futura de cambiar la normativa de extranjería e inmigración en cuanto tuviese la oportunidad, en claro desafío a la anunciada "vocación de equilibrio y permanencia"507 con que nacía esta reforma. Dado que dicho partido ocupa actualmente el ejecutivo y cuenta con una holgada mayoría absoluta, podemos adelantar, con escaso margen de error, que el marco jurídico de la extranjería es muy probable que vuelva a ser modificado poco después de cerrar la redacción de estas páginas.

Junto al dinamismo e inestabilidad intrínsecos al fenómeno migratorio en los últimos tiempos - y que dan pie al gobierno a proclamar la necesaria adaptación normativa ${ }^{508}$-, los motivos expresamente declarados ${ }^{509}$ que latían tras la reforma son fundamentalmente tres, tal y como proclama expresamente la exposición de motivos. En primer lugar, la necesaria incorporación a la ley de la doctrina que el TC había sostenido en respuesta a los recursos de inconstitucionalidad formulados contra la LO 8/2000. En ellos el TC había declarado la inconstitucionalidad de las restricciones a los derechos fundamentales de reunión, asociación, sindicación, huelga, asistencia jurídica gratuita y educación, cuyo ejercicio había quedado condicionado a la previa obtención de una autorización de estancia o de residencia por los artículos impugnados de la ley recurrida. En segundo lugar, quedaba

507 Presentación rubricada por la entonces Secretaria de Estado de Inmigración y Emigración, Da. Consuelo Rumí Ibáñez, a la versión consolidada de la Ley Orgánica 4/2000, de 11 de enero sobre derechos y libertades de los extranjeros en España y su integración social, en su redacción dada por las leyes orgánicas 8/2000, de 22 de diciembre, 11/2003, de 29 de septiembre, 14/2003, de 20 de noviembre y 2/2009, de 11 de diciembre, editada por la Subdirección General de Información Administrativa y Publicaciones del del Ministerio de Trabajo e Inmigración. Madrid, Colección Textos Legales, No 85. Disponible en: http://www.mtin.es, p. 8

508 Sobre este aspecto —encabezando el punto III del Preámbulo—, se afirma literalmente que "la inmigración es una realidad que está en constante cambio. Por ello, el legislador está obligado a adaptar su normativa reguladora, si quiera que la misma proporcione soluciones efectivas a los nuevos retos que se plantean". Posteriormente, en el apartado IV, al recopilarse las causas justificativas de la reforma, se menciona como tercera causa "la necesidad de adaptar la referida Ley Orgánica a la nueva realidad migratoria en España, que presenta unas características y plantea unos retos diferentes de los que existían cuando se aprobó la última reforma de la ley".

509 Idem y Apartado IV del Preámbulo de la LO 2/2009, de 11 de diciembre, donde se sintetizan en tres los motivos que justifican esta reforma: a) La necesidad de incorporar a esta LO la jurisprudencia del TC, redactando de forma acorde con la Constitución, los artículos de la LO 8/2000 que fueron declarados inconstituciobnales; b) La incorporación al ordenamiento jurídico de las Directivas europeas sobre inmigración pendientes de transposición o que no se han transpuesto plenamente; c) Adaptación a la nueva realidad migratoria, transpuesta literalmente en el anterior pie de página. 
pendiente la transposición al derecho español de nueve Directivas comunitarias en materia de inmigración $^{510}$ — circunstancia que aborda la reforma-, con la sonada ausencia de la Directiva 2003/86/ CE sobre el derecho a la RF, injustificadamente omitida en el repertorio de pendientes comunitarios. En este sentido, la reforma es presentada como la respuesta a una obligación legal. Sin embargo, su gran alcance, que no se restringe al cumplimiento de estos compromisos pendientes, se justifica formalmente por un afán de modernización y adaptación de la normativa legal a una realidad social que ha sufrido un "considerable impacto migratorio" —en tan sólo década y media, la sociedad española ha registrado un crecimiento de su población extranjera de más de cuatro millones, se recuerda desde instancias gubernamentales-. Esta circunstancia constituye la tercera causa justificativa de la reforma, motivando una revisión de amplio espectro que dé "soporte a la política migratoria de los próximos años", en busca de "una gestión ordenada y garantista de las migraciones".

Entre sus principales objetivos expresos, la reforma persigue incrementar la eficacia en la lucha contra la inmigración clandestina, reforzando los instrumentos de control y sanción. A tal fin, la ley aumenta con carácter general las sanciones económicas previstas para todas las infracciones, prevé nuevas infracciones para evitar actuaciones fraudulentas, y amplía el plazo de internamiento - de 40 a 60 días - para dotar de mayor eficacia a las medidas de suspensión y devolución de extranjeros en situación de irregularidad. Este objetivo se ve neutralizado por la finalidad explícita de lograr un perfeccionamiento del sistema de canalización legal de los flujos de carácter laboral —se puntuali$\mathrm{za}$-, "reforzando la vinculación de la capacidad de acogida de trabajadores inmigrantes a las necesidades del mercado de trabajo", tal y como proclama el punto segundo del apartado V del Preámbulo, lo que obviamente no incluiría los movimientos migratorios vinculados a la familia. De otro lado, el reforzamiento de la integración, considerado uno de los ejes centrales de la política migratoria, se erige en otro de los objetivos capitales que persigue explícitamente la reforma, mediante la inclusión de instrumentos esenciales para el desarrollo de una política de integración "por primera vez", se afirma, -lo que supone un reconocimiento de su inexistencia previa, pese a que las sucesivas exposiciones de motivos desde la LO 7/1985 insistían reiteradamente en la integración — a fin de "lograr un marco de convivencia de identidades y culturas"511.

Asimismo se busca potenciar la coordinación y cooperación entre las actuaciones de las distintas Administraciones Públicas con competencias migratorias. La importancia de esta cuestión en la práctica administrativa de los últimos años se ha demostrado vital, al hilo del incremento tanto del volumen de flujos experimentado hasta el año 2008, como de las competencias vinculadas al ámbito migratorio que han ido absorbiendo las Comunidades Autónomas - fundamentalmente

510 Según se especifica en el Preámbulo de la LO 2/2009, quedaban pendientes de incorporar al ordenamiento jurídico español las Directivas que habían sido aprobadas con posterioridad a la penúltima reforma de la Ley 4/2000, de 11 de enero, realizada en diciembre de 2003. Las mismas aparecen enlistadas en el Preámbulo, a cuya lectura nos remitimos.

511 A tal fin, en el Título Preliminar de la ley se han introducido dos nuevas disposiciones: de un lado, el artículo 2 bis, que define la política migratoria, estableciendo los principios y ejes de actuación de la misma y delimitando su marco competencial; de otro, el artículo 2 ter, que establece los principios y actuaciones en materia de integración de los inmigrantes, sobre la base de la consideración de que la integración social de los extranjeros constituye un principio vertebrador de la política de inmigración (art. 2 bis 2.c) LO 2/2009). Sobre este último aspecto, David Moya se pronuncia en sentido crítico, destacando en principio el carácter positivo de la inclusión expresa de la integración en el nuevo art. 2 ter - al que califica como una de las principales novedades de esta reforma-, pero lamentando posteriormente que dicha disposición no "ofrezca fundamento jurídico suficiente como para imponer obligaciones a las CCAA en materia de integración, especialmente si éstas disponen de títulos competenciales propios vinculados a la misma (servicios sociales, sanidad...), más aún cuando algunos Estatutos han incorporado expresamente la integración social de los extranjeros como una competencia propia"; en MOYA MALAPEIRA, David. La reforma de la Ley de Extranjería. Real Instituto Elcano, Documento de Trabajo nº 20, abril de 2009, p. 5. 
en el ámbito de la acogida y la integración y en materia de ejecución laboral一, y que finalmente han ido incorporándose al catálogo competencial mediante reforma estatutaria. Esta circunstancia ha provocado, de forma derivada, la necesidad de adaptar la normativa a este nuevo panorama competencial, objetivo que late también detrás de la aprobación de esta reforma legislativa. Junto al mismo, se persigue institucionalizar la participación de las organizaciones sindicales y empresariales más representativas en materia migratoria.

La secretaria de Estado incluía, además, entre las finalidades de la LO 2/2009, otorgar mayor tutela a los extranjeros inscritos en los colectivos más vulnerables - menores no acompañados, víctimas de trata de personas y violencia de género, entre los que se sitúa a la pareja de hecho del reagrupante, que la reforma incluye ahora entre los familiares reagrupables-. Y, en materia de derechos de los extranjeros, se introducen múltiples modificaciones en el Título I de la ley, que persiguen el objetivo último de establecer un marco de derechos y libertades "que garantice a todos el ejercicio pleno de los derechos fundamentales". A tal fin, la LO 2/2009 afirma reconocer a los extranjeros los derechos fundamentales "cualquiera que sea su situación en España, así como el establecimiento progresivo de acceso a los otros derechos basado en el refuerzo del estatus jurídico a medida que aumenta el período de residencia legal"512, reforzando su estatus de acuerdo a la consolidación de su residencia en territorio español.

De forma esquemática, se ha señalado que el plan maestro que subyace a esta última reforma legislativa pretende combinar el reforzamiento de las garantías y la integración del extranjero que goza de regularidad administrativa en España, con el establecimiento de una línea más dura en la previsión y ejecución de las diversas medidas de retorno de los extranjeros en situación de irregularidad ${ }^{513}$, - cuya ejecución está siendo obstaculizada por la vía de hecho como consecuencia de la crisis económica ${ }^{514}$ - Pese a ello, con carácter global la reforma ofrece un balance restrictivo, evidenciando que la tendencia al control y obstaculización migratorios parece ser común a los distintos partidos que se turnan en el poder, con independencia de su concreto color político. Y, pese a afectar a un elevado número de disposiciones legales, se ha denunciado su carácter materialmente limitado, resultando, en el fondo, una "reforma en clave de mínimos" ${ }^{15}$, que parchea el preexistente modelo de gestión migratoria, sin alterar esencialmente sus bases.

La nueva regulación de la migración de carácter familiar — contenida en los apartados dieciocho a veintiuno de la LO 2/2009, mediante los que se modifican los artículos 17 a 19 de la LO 4/2000_, se perfilaba como una de las novedades de mayor calado de la reforma. Constituye sin duda una de las modificaciones de más entidad del Título I de la ley, junto con la adaptación de los derechos de asociación, reunión, sindicación y huelga a la doctrina que el Tribunal Constitucional sentó en las sentencias 236/2007, de 7 de noviembre y 259/2007, de 19 de diciembre. No viene mal recordar que la RF, omnipresente en todas las reformas legislativas y reglamentarias habidas a partir del año 1986, nuevamente ocupaba un lugar prioritario - la modificación de la RF fue anunciada por el ministro

512 Apartado VII del Preámbulo de la L.O. 2/2009.

513 Moya puntualiza que esta línea de actuación predominante constituye la nota en común tanto a la última reforma legal de la extranjería, como a la reciente actividad gubernamental desarrollada en este ámbito. MOYA, David. "La reforma de la Ley de extranjería", op. cit., p. 20.

514 Muy recientemente, en el XXII Encuentro de la Abogacía sobre Derecho de Extranjería y Asilo —celebrado en Valencia del 6 al 9 de junio de 2012-, abogados especializados en extranjería daban cuenta de que, en la actualidad, las expulsiones de extranjeros tienden a ser sustituidas por la imposición de multas. Tal sustitución — provocada por motivos económicos, dado que resulta más barata para el Estado que la ejecución de la expulsión-, constituye una medida más acorde a la doctrina mantenida por el TS en esta materia.

515 MOYA, David. “La reforma de la Ley de extranjería”, op. cit., p. 20. 
de trabajo e inmigración en junio de 2008, con anticipación a las restantes-, reflejando su acusado peso en el marco de las políticas migratorias.

La migración familiar sigue integrando el Capítulo II del Título I de la Ley, dedicado a la regulación de los derechos y libertades de los extranjeros. Con una estructura casi idéntica —salvo por lo que respecta a la adicción del art 18bis-, la reforma legislativa afectó a todos menos uno de los preceptos que conforman el Capítulo II (arts. 16-19), quedando inalterado tan sólo el artículo 16, cuya redacción principal procedía de la LO 8/2000. Resumidamente, los cambios legislativos afectaron especialmente a los familiares reagrupables, estableciendo nuevos requisitos para el ejercicio de la RF, regulando en un artículo separado el procedimiento exigido - que antes se contemplaba conjuntamente con los requisitos-, y dotando de nuevos efectos a la RF. De todos ellos, las modificaciones más significativas se volcaron sobre los beneficiarios de la reagrupación que, tal y como rezaba el Preámbulo, quedaban acotados "básicamente a los familiares que integran la familia nuclear" y que, como es bien sabido, delimitan los más sustanciales efectos multiplicadores intrínsecos a la inmigración familiar. Sin embargo, cuestiones vitales para el ejercicio del derecho quedaban relegadas al desarrollo reglamentario que, con enorme retraso respecto a las previsiones iniciales, tendría lugar en abril del año $2011^{516}$.

El nuevo tratamiento de la migración familiar venía siendo justificado casi exclusivamente en lo que respecta a sus puntos menos controvertidos: la ampliación de los familiares reagrupables mediante la protección de la pareja de hecho y el acceso inmediato al mercado laboral de los parientes reagrupados. Respecto de estos dos aspectos, se declaraba que la modificación constituía una mejora de la RF y, en relación al acotamiento de los familiares reagrupables, se afirmaba en el Preámbulo que, con ella, la regulación de la RF se situaba "en línea con lo que ocurre en la mayoría de los países de nuestro entorno" ${ }^{17}$ - más livianamente, la secretaria de Estado lo calificaba como una "modulación" de la regulación, en el marco del derecho europeo-. Con ello, la española, que ostentaba junto a la francesa el ranking de ser una de las legislaciones europeas más liberales ${ }^{518}$ en el ámbito de la inmigración familiar, se ha alineado con las restantes normativas europeas ${ }^{519}$ en su concepción minimalista del concepto de familia nuclear, aprovechando el margen de apreciación que en esta materia permitía la Directiva 2003/86/CE sobre el derecho a la RF —dando parcial cumplimiento a

516 El nuevo Reglamento sería aprobado mediante Real Decreto 557/2011, de 20 de abril, por el que se aprueba el Reglamento de la Ley Orgánica 4/2000, sobre derechos y libertades de los extranjeros en España y su integración social, tras su reforma por Ley Orgánica 2/2009. B.O.E., n 103, de 30 de abril de 2011.

517 Apartado VII del Preámbulo de la L.O. 2/2009, de 12 de diciembre de 2009.

518 En un estudio publicado poco después de la entrada en vigor de la Directiva comunitaria 2003/86/CE sobre el derecho a la RF, sus autores analizaban el impacto real de esta norma comunitaria sobre el estatus de los nacionales de terceros Estados residentes en los distintos EEMM de la UE. Para ello, los autores partieron de un análisis individualizado de los regímenes internos existentes en seis Estados Europeos - España, Francia, Luxemburgo, Alemania, Bélgica y Austria - en el momento inmediatamente anterior a la adopción de dicha Directiva. El estudio concluye señalando inequívocamente a Francia y a España como aquellos países que, en el momento temporal señalado, contaban con regímenes de RF más generosos, comparativamente hablando. SCHNEIDER, H. y WIESBROCK, A. “The Council Directive on Family Reunification: Establishing Proper Rights for Third Country Nationals?”, en SCHNEIDER, H. (ed.). Migration, Integration and Citizenship. A challenge for Europe's Future. Vol II. Forum Maastricht, Maastricht, 2005, pp. 35-69.

519 Esta circunstancia puede calificarse como un supuesto de reformatio in peus. Por su parte, Francia, anticipándose a lo ocurrido en nuestro país, aprobó en octubre de 2007 un proyecto de ley de "control de la inmigración", endureciendo sensiblemente la inmigración familiar: se incrementaron los ingresos económicos exigidos para poder traer a los familiares, se incluyó la exigencia de un examen de conocimientos y valores de la República, que habían de pasar los candidatos a la reagrupación antes de poder acceder a Francia, así como de un test de ADN a fin de verificar la filiación familiar para eliminar la posibilidad de fraude. 
los augurios más pesimistas que, en su momento, alertaron de la posibilidad de rebajas del estándar interno en vista del tono restrictivo que domina dicha norma comunitaria-.

\subsection{La titularidad activa del derecho a la RF}

Dos disposiciones de la L.O. 2/2009 afrontan de forma directa esta cuestión —apartado primero y segundo del artículo 16, y el artículo 17-, a reserva de otros artículos que inciden indirectamente en ella, así como las especificaciones introducidas por vía reglamentaria —-fundamentalmente en el artículo 56-.

La regulación principal corre a cargo del artículo 16 de la LO 2/2009, bajo el encabezamiento de "derecho a la intimidad familiar". Su apartado primero con una redacción que ha permanecido invariable desde la LO 4/2000 atribuye el "derecho a la vida en familia y a la intimidad familiar" a los extranjeros residentes, puntualizando que "en la forma prevista en esta Ley orgánica y de acuerdo con lo dispuesto en los Tratados internacionales suscritos por España". De este reconocimiento inicial cabe destacar varios aspectos.

a) La formulación genérica del derecho proclamado en el art. 16.1 otorga la titularidad activa en régimen de monopolio a los "extranjeros residentes", esto es, al reagrupante en su concepción tradicional. El apartado segundo de dicha disposición confirma la exclusividad de la titularidad activa a favor de los extranjeros residentes en España ${ }^{520}$, quienes ostentan el derecho a reunirse en territorio español con los familiares legalmente previstos. Esta cuestión será nuevamente reiterada por la disposición siguiente - el art. 17-, al contemplar a los familiares reagrupables: los beneficiarios del derecho son especificados desde el punto de vista de aquellos familiares que el "extranjero residente" tiene derecho a reagrupar con él en España. Los parientes reagrupables quedan pues excluidos de la titularidad activa del derecho.

b) La expresión "extranjeros residentes", para su correcto entendimiento, ha de ser interpretada en conjunción con el artículo primero de la ley, que delimita el ámbito de aplicación de la misma. A los efectos de su aplicación, se consideran extranjeros a quienes carezcan de la nacionalidad española ${ }^{521}$. Por su parte, el tercer apartado del mismo precepto remite a las normas comunitarias la regulación del régimen aplicable a los nacionales de los Estados miembros de la Unión Europea ${ }^{522}$, circunstancia que es interpretada como una exclusión indirecta de los nacionales comunitarios ${ }^{523}$ — habida cuenta que las exclusiones del ámbito de aplicación de la presente ley quedan establecidas en el artículo siguiente, el segundo- - De la conjunción de estos preceptos, se concluye que por extranjero residente habrá de entenderse a aquellas personas que carezcan de la nacionalidad española o de la nacionalidad de cualquier

520 En el mismo sentido, ÁLVAREZ RODRÍGUEZ, Aurelia. "La reagrupación familiar como vehículo de integración”; en ÁLVAREZ CONDE, E. y PÉREZ MARTÍN, E. (Dirs.). Estudios sobre Derecho de extranjería. Madrid, Instituto de Derecho Público, Universidad Rey Juan Carlos, 2005, p. 233. También RAVETLLAT BALLESTÉ, I. La reagrupación familiar, op. cit., p. 29. FREIRE CORREIA, Ana Carina. "El derecho a la reagrupación familiar en el derecho español y comunitario"; en Revista de Derecho Migratorio y Extranjería, n² 23, 2010, p. 122.

521 Artíulo 1.1 del texto consolidado de la L.O. 4/2000, que incorpora las sucesivas reformas legislativas acaecidas en esta materia, incluyendo la operada mediante L.O. 2/2009.

522 La dicción literal del artículo 1.3 afirma que "los nacionales de los Estados miembros de la Unión Europea y aquellos a quienes sea de aplicación el régimen comunitario se regirán por las normas que lo regulan, siéndoles de aplicación la presente ley en aquellos aspectos que pudieran ser más favorables."

523 RAVETLLAT BALLESTÉ, I. La reagrupación familiar, op. cit., p. 27, si bien el autor hace referencia al artículo 1.2 de la Ley Orgánica 4/2000 — en la redacción previa a la reforma operada por la LO 2/2009— que, aun con cambios en su formulación textual, permanence en esencia idéntica, si bien ahora regulada en el artículo 1.3. 
Estado miembro de la UE, quedando circunscrito el ámbito de aplicación de esta ley a los extranjeros no comunitarios. Será a éstos a quienes se aplique el concepto de reagrupante, siempre que cuenten con un determinado tipo de residencia temporal cualificada en territorio Español.

c) En directa correspondencia con el carácter familiar de esta tipología migratoria, la condición de reagrupante se atribuye al extranjero residente que cumpla determinadas condiciones legalmente establecidas, sin que ésta quede subordinada al desarrollo de una actividad laboral en territorio español ${ }^{524}$.

Con excepción del art. 16.1, la redacción actual de la titularidad activa del derecho a la RF procede de la reforma que la LO 8/2000 efectuó a finales del año 2000 sobre el texto de la Ley 4/2000, aprobada a principios de ese mismo año. La LO 4/2000 ${ }^{525}$ reconocía - por primera vez en el derecho español-, la doble titularidad activa del derecho, cubriendo también a los familiares reagrupables, circunstancia avalada tanto a nivel doctrinal ${ }^{526}$ como jurisprudencial ${ }^{527}$. De la misma se derivaba una protección superior para los parientes del residente. El reconocimiento de los reagrupables como titulares activos, junto con el reagrupante, suponía dotarles del derecho a la obtención del por entonces denominado permiso de residencia — autorización de residencia en la terminología actual一, tal y como proclamaba el art. 17, junto con la facultad de recurrir en igualdad de condiciones con respecto al sponsor, e incluso la "obligación reforzada de motivación por parte de la Administración”"528 en caso de resoluciones negativas.

Además, la doble titularidad activa colocaba en situación de paridad la voluntad tanto del extranjero residente como del familiar reagrupable, a efectos de iniciar el procedimiento de reagrupación familiar. Sin embargo, podía provocar situaciones problemáticas en la práctica. Sobre este aspecto, Eliseo Aja señaló que podrían llegar a producirse supuestos de solicitud unilateral de reagrupación por parte de los familiares reagrupables, aún en contra de la voluntad del residente — “y por lo tanto, "reagrupante a pesar suyo" ${ }^{529}$, matizaba-. Sin embargo, Aja reconocía el carácter excepcional de tales supuestos, en los que el sponsor no sólo no podría oponerse a la llegada de sus parientes, sino que además estaría obligado a asistirles, tal y como prescribe el derecho civil. Sea como fuere, la amplia titularidad activa dotaba de más autonomía a los familiares del residente y, precisamente por ello, parecía allanarles el terreno para poder ejercer a su vez en el futuro el derecho a reagrupar a sus propios parientes, al subrayar que los reagrupables tenían "derecho a la situación

\section{Idem, p. 29.}

525 El segundo apartado del artículo 16 —en la redacción dada por la LO 4/2000, de 11 de enero-, afirmaba literalmente que "los familiares de los extranjeros que residan en España a quienes se refiere el artículo siguiente, tienen derecho a la situación de residencia en España para reagruparse con el residente”.

526 HERNÁNDEZ HERNÁNDEZ, María Angeles y SERRANO RODRÍGUEZ, José A. hacen referencia explícita al reconocimiento bilateral del derecho a la RF en la LO 4/2000, cubriendo tanto al reagrupante como a los familiares reagrupables; en "Comentarios a la nueva regulación de la inmigración en España"; en Scripta Nova: Revista electrónica de geografía y ciencias sociales, No 5, 94, 2001, sp. Disponible en: http://www.ub.es/geocrit/sn-94-40.htm. Por su parte, GOIG MARTÍNEZ menciona "el derecho de los familiares del residente legal a obtener la residencia para reagruparse”, desaparecido a raíz de la reforma efectuada por la LO 8/2000; en "Régimen jurídico y políticas sobre extranjería en España..., op. cit., p. 639.

527 Vid, F. J. 2 STSJ Madrid de 16 de mayo de 2003 (BDB TSJM 13204/2003), donde el Tribunal Superior de Justicia de Madrid proclama que "el art. 16 de la LO 4/2000, en su original redacción, que es la que resulta de aplicación al caso presente, atendida la fecha de iniciación del expediente, reconoce a los extranjeros residentes en España el derecho a la vida familiar y a la intimidad familiar, y a los familiares de aquéllos el derecho a la situación de residencia en España para reagruparse con el recurrente".

528 AJA, Eliseo (coord.). La nueva regulación de la inmigración en España, op. cit., p. 139.

529 Idem. 
de residencia en España”. Sin embargo, esta titularidad dual gozó de una escasísima vigencia, siendo rápidamente eliminada tras la reforma operada mediante la LO 8/2000, que reinstaló la titularidad activa restringida exclusivamente a favor del residente extranjero en España, vigente desde entonces.

En consecuencia, el concepto tradicional o restrictivo de reagrupante como titular activo en exclusiva del derecho a la RF constituye una constante en el ordenamiento jurídico español, desde que por vía reglamentaria se introdujo por primera vez esta figura en la regulación migratoria, en el año1986 - salvo la efímera vigencia de la LO 4/2000 - . Cabría cuestionarse su compatibilidad con los estándares internacionales, especialmente en lo que respecta al derecho comunitario y al ámbito de Estrasburgo. Aunque a nivel comunitario la Directiva 2003/86 ha optado por un concepto amplio de reagrupante y, por ello, por una titularidad dual en esta materia —art. 2.d) —, sin embargo la redacción amplia y opcional de esta disposición ${ }^{530}$ - por no hablar de las incoherencias terminológicas que esta ampliación de la titularidad activa ha provocado en el texto de la Directiva-, permiten concluir que corresponde al EM determinar esta cuestión dentro de su derecho interno. En consecuencia, en este punto la legislación española resulta compatible con la Directiva comunitaria 2003/86/CE. Mayores dificultades provoca su encaje dentro del concepto amplio de titularidad activa sostenido desde sus inicios por la jurisprudencia de Estrasburgo, especialmente a la luz de sus últimos pronunciamientos.

La LO 2/2009 sigue proclamando la titularidad activa del derecho a favor de los extranjeros residentes (apartados 1 y 2 del art. 16) lo que, de entrada, tiene dos implicaciones: en primer lugar, otorga un peso cualificado al reagrupante, de cuya voluntad unilateral depende en exclusiva el inicio del procedimiento de $\mathrm{RF}^{531}$; en segundo lugar, obliga a deslindar ${ }^{532}$ la titularidad activa, a favor del sponsor, respecto de los beneficiarios posibles del derecho — donde se incluyen los familiares reagrupables-.

En esta materia, la legislación española ha excluido siempre, como titulares del derecho a la RF, a los extranjeros en situación de irregularidad administrativa. La exigencia de residencia legal, como señalamos al inicio de este trabajo, constituye una constante en las legislaciones de los países receptores de flujos migratorios a nivel mundial y es compatible con lo establecido en el art. 19.6 de la Carta Social Europea ${ }^{533}$.

Sobre este punto, el art. 30 bis, en su primer apartado, señala que "son residentes los extranjeros que se encuentren en España y sean titulares de una autorización para residir”, determinando su segundo apartado - redactado conforme a la LO 2/2009-, que los residentes podrán encontrarse en la situación de residencia temporal o de residencia de larga duración. La restricción de la titula-

530 La definición comunitaria de reagrupante aparece contenida en el art. 2, apartado c) de la Directiva 2003/86, conforme al cual es considerado como tal "la persona nacional de un tercer país que, residiendo legalmente en un EM, solicita la RF o los miembros de cuya familia la solicitan".

531 A idéntica conclusión llega FREIRE CORREIA, Ana Carina, quien afirma que no caben solicitudes unilaterales de RF por parte de los familiares reagrupables. "El derecho a la reagrupación familiar en el derecho español y comunitario", op. cit., p. 122.

532 Idem.

533 El apartado sexto del artículo 19 de la Carta Social Europea afirma textualmente que las partes contratantes se comprometen "a facilitar en lo posible el reagrupamiento de la familia del trabajador extranjero a quien se le haya autorizado para establecerse dentro del territorio". En el mismo sentido, SANTOLAYA MACHETTI, P. El derecho a la vida familiar de los extranjeros, op. cit., p. 155. En sentido diametralmente opuesto se inscribe FREIRE CORREIRA, quien critica que la intimidad familiar y el correlativo derecho a que todo extranjero que viva en España conviva con sus familiares - reconocido por el art. $18 \mathrm{CE}$ "a toda persona"-, quede legalmente supeditado a la regularidad de la residencia; en "El derecho a la reagrupación familiar en el derecho español y comunitario", op. cit.p. 121. 
ridad activa a los extranjeros residentes resulta coherente con la naturaleza de la RF como derecho de configuración legal, despejada por el TC en las diversas sentencias que resolvieron los recursos de inconstitucionalidad interpuestos contra la LO 8/2000. Si, como muchas voces doctrinales apuntaban con anterioridad a dicho pronunciamiento jurisprudencial, la RF constituyese un derecho fundamental, resultaría muy difícilmente justificable esta titularidad activa restringida, frente a la universalidad que caracteriza a tales derechos ${ }^{534}$.

Para poder ejercitar el derecho a la RF (art. 18.1), al extranjero se le exige con carácter general haber obtenido la renovación de su autorización de residencia inicial, — salvo para el supuesto de que desee reagruparse con sus ascendientes, en cuyo caso ha de estar en posesión de la residencia de larga duración.

Con la nueva redacción de la ley, se han producido cambios terminológicos a fin de armonizar la terminología con la empleada en el ámbito comunitario, especialmente al hilo de la transposición de la Directiva 2003/109/CE sobre residentes de larga duración. En este sentido, la anteriormente calificada como residencia permanente, pasa a ahora a denominarse residencia de larga duración (art. 30.2) pero, en cuestión de fondo, permanece invariable la situación inmediatamente precedente: tienen derecho a la residencia de larga duración aquellos extranjeros que hayan gozado de residencia temporal en España durante cinco años de forma continuada (art. 32.2). Con carácter práctico, ello supone que si el extranjero desea reagruparse con sus ascendientes - con las limitaciones introducidas por la LO 2/2009 en el art. 17, que analizaremos posteriormente-, ha de contar con la residencia de larga duración obtenida tras cinco años de residencia continuada en España.

Respecto a la residencia temporal, la más importante a efectos del ejercicio con carácter general de la RF, el cambio legislativo supuso inicialmente una situación de incertidumbre transitoria, hasta la aprobación del Reglamento de desarrollo de la LO 2/2009. El nuevo Reglamento especifica en su art. 52 que el nacional de un tercer estado que haya sido autorizado a permanecer en España en virtud del derecho a la RF ejercicio por el extranjero residente, se halla en situación de residencia temporal por razón de reagrupación familiar. En consecuencia, tanto la autorización para permanecer en España a que da lugar el ejercicio de la RF como la situación administrativa que habilita al reagrupante para poder reagrupar a sus familiares, encaja en la residencia de carácter temporal - aunque, como es obvio, que al sponsor se le exija como mínimo haber obtenido una autorización para residir durante un año en España, no obsta para que puedan ejercer el derecho quienes haya residido por más tiempo e incluso posean ya la residencia de larga duración-.

En la normativa vigente, la residencia temporal sigue constituyendo aquella situación que autoriza a permanecer en España por un período superior a tres meses e inferior a cinco años (art. 31.1 L.O. 2/2009). Por debajo de los tres meses, el extranjero se hallaría en situación de estancia. La renovación de la residencia temporal también continúa produciéndose a instancias del interesado, pero la novedad reside en que la nueva redacción de la ley establece que tanto la duración de la au-

534 En esta línea se inscribe SANTOLAYA MACHETTI, quien critica la pretensión del legislador de enlazar el derecho a la RF con el derecho a la intimidad familiar, "dotándole aparentemente de carácter de derecho fundamental, ligado al art. 18.1CE, aunque sin sacar de ello la consecuencia natural de su universalización, y en concreto, la imposibilidad de distinción entre extranjeros en situaciones de regularidad e irregularidad". El derecho a la vida familiar de los extranjeros, op. cit., p. 154. Vid, entre los autores que niegan expresamente el carácter fundamental de la RF, negando su vinculación con la intimidad familiar y considerándolo una derivación de la obligación legal de protección de la familiar (art. $39 \mathrm{CE}$ ), junto al ya señalado Santolaya Machetti, El derecho a la vida familiar..., op. cit., pp. 26 y 62, también se sitúa GOIG MARTÍNEZ, "El derecho a la reagrupación familiar de los inmigrantes"; en Teoría y realidad constitucional, No 14, 2004, p. 246. 
torización inicial de residencia temporal como de las sucesivas renovaciones, "se establecerá reglamentariamente" (art. 31.1 $1^{535}$ in fine).

En esta materia, el Reglamento de desarrollo de la LO 2/2009 ha introducido algunas importantes novedades. La autorización inicial de residencia temporal continúa teniendo la duración de un año - arts. 49. 2 y 63.5-. Sin embargo, su renovación cubre un período de dos años - artículos 63.5 y $72.2^{536}$ - mientras que, previamente, tal renovación era de carácter anual. La ampliación de la cobertura temporal proporcionada por la renovación de la autorización de residencia temporal por causa de RF afecta positivamente al extranjero, especialmente en la actual coyuntura de precariedad laboral, con altísimas cifras de desempleo.

En síntesis, la autorización inicial de residencia de carácter temporal dura un año, tras el cual su renovación cubriría un período temporal bianual. Con posterioridad a la subsiguiente renovación, se adquirirían los cinco años de residencia temporal continuada que habilitan a acceder a la residencia de larga duración, pudiendo a partir de entonces el extranjero residir en España indefinidamente y trabajar en igualdad de condiciones que los españoles (art. 32.1 de la L.O. 2/2009).

Exceptuando el supuesto de reagrupación de ascendientes - que requiere del reagrupante ser titular de una autorización de residencia de larga duración ${ }^{53}$ - el nuevo marco jurídico exige con carácter general al sponsor haber obtenido la renovación de su autorización de residencia inicial ${ }^{538}$ para poder reagruparse con sus familiares en España. A nivel práctico, la situación actual en este específico punto supone una continuación de la existente con anterioridad, que prescribía un período mínimo previo de residencia legal en España de un año y haber obtenido la autorización para residir por, al menos, otro año ${ }^{539}$. Ahora bien, el artículo 56.1 del Reglamento permite la presentación de la solicitud de RF cuando el extranjero reagrupante tenga autorización para residir en España durante un año como mínimo y haya solicitado la autorización para residir por al menos otro año más, - aunque todavía no cuente con dicha renovación-. Si bien posteriormente la misma disposición reglamentaria puntualiza, en coherencia con la ley, que la concesión de la autorización de residencia al familiar reagrupable sólo tendrá lugar cuando se haya producido la efectiva renovación de la autorización de residencia del sponsor.

A fin de facilitar el procedimiento administrativo, la ley vigente especifica que el extranjero residente que desee ejercer el derecho a la RF podrá presentar la solicitud de RF de forma simultánea a la renovación de su autorización de residencia ${ }^{540}$. Se trata de una previsión establecida con el fin de evitar demoras de tramitación, en el entendido de que el reagrupante solamente podrá obtener una

$535 \mathrm{El}$ artículo 31 de la Ley de extranjería, en su primer apartado, señala textualmente que "la residencia temporal es la situación que autoriza a permanecer en España por un período superior a 90 días e inferior a cinco años. Las autorizaciones de duración inferior a cinco años podrán renovarse, a petición del interesado, atendiendo a las circunstancias que motivaron su concesión. La duración de las autorizaciones iniciales de residencia temporal y de las renovaciones se establecerá reglamentariamente".

536 El Artículo 72 del nuevo Reglamento, al contemplar los efectos de la renovación de la autorización de residencia temporal y trabajo por cuenta ajena, señala en su apartado primero que "la renovación de la autorización de residencia y trabajo por cuenta ajena se hará por un periodo de dos años, salvo que corresponda una autorización de residencia de larga duración, y permitirá el ejercicio de cualquier actividad en cualquier parte del territorio nacional. Los efectos de la autorización renovada se retrotraerán al día inmediatamente siguiente al de la caducidad de la autorización anterior”. La misma duración de dos años se preve para el supuesto de la renovación de la autorización de residencia temporal en el supuesto de residencia no lucrativa (art. 63.5 del Reglamento).

537 Artículo 18.1 de la L.O. 2/2009 y artículo 56.1.a) del Reglamento de ejecución.

538 Artículo 18.1 de la L.O. 2/2009.

539 Art. 18.2, en la redacción dada por la LO 14/2003, de 20 de noviembre.

540 Apartado primero in fine del artículo 18 bis de la L.O. 2/2009. 
resolución favorable a su solicitud de autorización de residencia por RF a partir del momento en que haya obtenido la renovación de su autorización de residencia inicial, y siempre que cumpla con los requisitos establecidos en la ley.

En consonancia con el concepto restrictivo de reagrupante, el inicio del procedimiento para el ejercicio del derecho a la RF queda en manos exclusivamente del extranjero residente, siendo pues su voluntad absolutamente determinante para el inicio del proceso. A tal fin, el reagrupante deberá solicitar una autorización de residencia por reagrupación familiar a favor de los miembros de su familia con quienes desee reunirse en España. Así lo especifica claramente el apartado primero del artículo 18 bis que, aunque introducido por la última reforma legislativa, no ha variado el procedimiento anteriormente existente, quedando ahora regulados los requisitos procedimentales en un artículo independiente. Con mayor rotundidad se expresa en este punto el Reglamento, señalando que el extranjero que desee ejercer el derecho a la RF deberá solicitar "personalmente ante la Oficina de Extranjería competente para su tramitación, una autorización de residencia temporal a favor de los miembros de su familia que desee reagrupar" ${ }^{\prime 41}$.

La excepción a la norma general se produce en el caso de que el reagrupante sea un residente de larga duración ${ }^{542}$ en otro Estado miembro de la UE, que esté residiendo en España. En este supuesto, los familiares reagrupables podrán presentar la solicitud, adjuntando prueba de residencia como miembro de la familia del residente de larga duración en el primer Estado miembro, esto es, aquel país que concedió al actual reagrupante el estatuto de residente de larga duración ${ }^{543}$.

El reciente desarrollo reglamentario ha optado por especificar de forma detallada la documentación precisa que el reagrupante ha de acompañar a la solicitud de RF, que deberá cumplimentarse en modelo oficial ${ }^{544}$. Esta detallada información, que habitualmente corría a cargo de circulares e instrucciones internas de la Secretaría de Estado de Inmigración y Emigración, pasa a ser objeto de regulación reglamentaria, lo cual supone un avance a efectos de mayor transparencia y seguridad jurídica.

De otro lado, y profundizando en la línea de exhaustividad que caracteriza la última reforma reglamentaria, esta norma señala que, tras la presentación en forma de la solicitud de RF —o la subsanación de los defectos que correspondan- el órgano competente la tramitará y resolverá lo que proceda, recabando de oficio el informe de los servicios competentes de la Dirección General de la Policía y la Guardia Civil en materia de seguridad y orden público, así como el del Registro Central de Penados. En caso de que se cumplan los requisitos fijados, el órgano administrativo competente resolverá la autorización de residencia por RF, suspendiendo la eficacia de la autorización hasta la

541 Artículo 56.2 del Reglamento de ejecución de la L.O. 2/2009.

$542 \mathrm{El}$ estatuto de residente de larga duración fue establecido en el ámbito comunitario a fin de armonizar, dar un tratamiento equitativo en todo el territorio comunitario y otorgar seguridad jurídica a los nacionales procedentes de terceros países que, habiendo residido legal e ininterrumpidamente en el territorio de un EM durante cinco años, se trasladaban a residir a otro EM. El objetivo era que no perdieran el estatuto privilegiado que habían adquirido por el hecho de trasladarse a vivir a otro país dentro del ámbito geográfico de la UE, gozando además de protección reforzada contra la expulsión, en coherencia con los criterios aplicados por el TEDH. La regulación de su estatuto jurídico está contenida en la Directiva 2003/109/CE del Consejo de 25 de noviembre de 2003, relativa al estatuto de los nacionales de terceros países residentes de larga duración.

543 Apartado segundo del art 18 bis, redactado por la LO 2/2009, a fin de transponer en el derecho interno la Directiva 2003/109/CE del Consejo, de 25 de noviembre 2003, relativa al estatuto de los nacionales de terceros países residentes de larga duración.

544 Apartado tercero del artículo 56 del Reglamento de ejecución de la L.O. 2/2009. 
expedición del visado a favor de los familiares reagrupables y la efectiva entrada de éstos en territorio nacional durante el tiempo de vigencia de éste ${ }^{545}$.

Y, continuando con la tradición vigente en esta materia, el Reglamento especifica que los procedimientos en materia de migración familiar — tanto la solicitud de RF, como la tramitación del visado de los familiares y la renovación de sus autorizaciones de residencia por RF-, serán objeto de tramitación preferente ${ }^{546}$, - reflejo elocuente del carácter humanitario de este tipo de procesos migratorios y la fuerte impregnación de los derechos humanos en su regulación.

Finalmente, en materia de procedimiento, la reciente reforma reglamentaria incluye una previsión que parece destinada a clausurar la situación previamente existente, caracterizada por la opacidad, escasez y falta de sistematicidad en la información estadística relativa a solicitudes y efectivas concesiones de autorizaciones de RF, - ya denunciada en este trabajo, y que dificultaba el conocimiento de la situación real de la migración familiar en España-. El apartado 8 del artículo 56 del Reglamento vigente indica que la Secretaría de Estado de Inmigración y Emigración ha de remitir información estadística con periodicidad trimestral y desglosada por nacionalidad, sexo y edad del reagrupado - si bien referida en exclusiva a las solicitudes y concesiones de autorizaciones iniciales de residencia por RF-, a los órganos competentes de cada Comunidad Autónoma y de la Federación Española de Municipios y Provincias, a fin de que sean trasladados a los Ayuntamientos correspondientes.

En el análisis de la titularidad activa del derecho y la regulación del inicio del procedimiento de RF, resta por concluir su grado de compatibilidad con la legislación comunitaria. Ya indicamos que el concepto restrictivo de reagrupante por el que finalmente se ha decantado la legislación española, excluyendo de su protección a los familiares reagrupables, resulta compatible con la Directiva $2003 / 86^{547}$. Nada se contiene en la normativa española en torno al controvertido requisito comunitario exigido al sponsor de contar con "una perspectiva fundada de obtener un derecho a la residencia permanente" - incluido en la regulación del período de espera del artículo 3.1 de la Directiva 2003/86- . Dicha perspectiva se entiende pues implícita en la obtención de la renovación de la autorización de residencia inicial, requerida al reagrupante por la redacción actual del art. 18.1 de la L.O. 2/2009.

a) El artículo 16.1 L.O 2/2009 atribuye la titularidad de los derechos a la "vida en familia e intimidad familiar" a los extranjeros residentes. Este reconocimiento excluye de entrada la situación de estancia, esto es, de aquellos extranjeros no comunitarios que permanecen en territorio español por un tiempo inferior a tres meses de duración. Tras esta exclusión se encuentra implícita la exigencia de estabilidad que la Directiva 2003/86 impone para el disfrute del derecho a la RF, esto es, la perspectiva fundada de residencia duradera.

545 Artículo 56.5, apartado a) del Reglamento de extranjería. De esta situación se excepciona el supuesto de familiares de residentes de larga duración-UE.

546 Artículo 56.7 del Reglamento de ejecución de la L.O. 2/2009.

$547 \mathrm{Si}$ bien la normativa comunitaria maneja un concepto amplio de reagrupante —apartado c) del artículo 2- la elasticidad con que éste aparece formulado, mediante el uso de la conjunción disyuntiva "ó", da a entender que se trata de una cuestión cuya decisión compete libremente al EM. Este concepto amplio de reagrupante se refleja en la regulación de la presentación de la solicitud (art. 5.1 de la Directiva), siendo posible su presentación tanto por parte del sponsor como por sus familiares, sin embargo la cuestión queda abierta, dependiendo su regulación concreta de la decisión que adopten los EEMM. Además, señalamos en su momento que, a lo largo de su articulado la propia Directiva 2003/86 incurría en múltiples inconsistencias sistemáticas y terminológicas, optando materialmente — aunque no formalmente-, por el concepto tradicional de reagrupante. 
b) El derecho cuya titularidad se atribuye a los extranjeros residentes es el "derecho a la vida en familia y a la intimidad familiar". La ambigua naturaleza jurídica del derecho a la RF, contemplada de pasada en el artículo 16, queda intacta en la nueva redacción de la L.O. $2 / 2009$.

Esta redacción podría interpretarse como una alusión a los derechos que, a juicio del legislador español, actúan como simiente o matriz internacional - vida en familia-, e interna/constitucional -intimidad familiar - respectivamente del derecho a la $\mathrm{RF}^{548}$. El aspecto internacional no resulta problemático, pero no se entiende bien la insistencia del legislador en seguir vinculando la RF con el derecho a la intimidad familiar, cuando el TC ya se ha pronunciado expresamente sobre este punto — con anterioridad a la redacción de la ley actualmente vigente-, negando tal vinculación.

El encabezamiento del artículo 16 - que constituye el pórtico del capítulo II dedicado a la normación de la inmigración familiar - , reza literalmente "derecho a la intimidad familiar". Su apartado primero proclama ambiguamente que "los extranjeros residentes tienen derecho a la vida en familia y a la intimidad familiar en la forma prevista en esta Ley Orgánica y de acuerdo con lo dispuesto en los Tratados internacionales suscritos por España”. Y esta naturaleza es nuevamente confirmada por el art. 16.2, cuya redacción procede de la reforma legislativa operada mediante la LO 8/2000.

La conexión material o instrumental entre la RF y el derecho a la intimidad familiar ha sido desmentida por el $\mathrm{TC}^{549}$, negando que la RF forme parte del contenido del derecho fundamental a la intimidad familiar garantizado por el art. 18 CE. De modo que, si tal y como afirma la Exposición de Motivos, uno de los objetivos prioritarios que persigue la reforma es la incorporación de la doctrina jurisprudencial, no cabe más que colegir que se ha desaprovechado la ocasión de clarificar a nivel legislativo la naturaleza jurídica del derecho a la RF. El mantenimiento de esta ambigua redacción parece constituir una incoherencia legislativa. $\mathrm{Si}$, tal como parece sobreentender la ley, el derecho a la RF estuviese materialmente conectado al derecho a la intimidad familiar, serían difícilmente justificables dos aspectos asentados de este derecho: de un lado, la omnipresente restricción de su titularidad activa a favor de los extranjeros que cuenten con residencia legal en el territorio del Estado receptor - frente a la titularidad universal inherente a los derechos fundamentales de este calibre-; de otro, el notable grado de intervención del legislador interno e internacional sobre el contenido del derecho, cuyo ejercicio - tal y como sigue sosteniendo el art. 16.1 in fine-, se supedita a "la forma prevista en esta Ley Orgánica y de acuerdo con lo dispuesto en los Tratados internacionales suscritos por España”. Esta proclamación alude a la naturaleza de la RF como derecho de configuración legal -interno e internacional - y por ende, sujeto a un alto margen de maniobra legislativa en coherencia con el elevado margen de apreciación estatal otorgado por la Directiva comunitaria 2003/86.

548 La vinculación entre la RF y el derecho a la intimidad familiar, de la que parte el art. 16, llevó por ejemplo a Eliseo AJA a considerar que la LO 4/2000, objeto de su comentario, otorgaba al derecho a la RF la posición que a su juicio debía tener, como derecho fundamental derivado del derecho a la intimidad familiar. De esta posición, el mencionado autor extraía que la RF debía ser objeto de protección por la vía preferente y sumaria, pudiéndose llegar al amparo constitucional; en La nueva regulación de la inmigración en España, op. cit., p. 138. La misma vinculación es establecida por Goig Martínez, al interpretar el texto del artículo 16, en la versión correspondiente a la LO 4/2000. GOIZ MARTÍNEZ, J.M. “Régimen jurídico y políticas sobre extranjería en España..”, op. cit., p. 635. A idéntica interpretación llega Santolaya, quien, sobre la base de la redacción de los artículos 16 y 17, señala que "es claro que esta opción del legisaldor implica la pretensión de configurar la RF como un derecho ligado a la intimidad familiar, otogándole el contenido que hemos visto poseee en el Derecho internacional y, en particular, en el CEDH y en la jurisprudencia del TEDH"; El derecho a la vida familiar...op. cit., p. 154.

549 F. J. 11, STC 236/2007. 
En cualquier caso, lo que se desprende con claridad del texto de la ley desde que ésta, a partir del año 2000, pasó a acoger la regulación de la RF, es su naturaleza jurídica como derecho subjetivo del extranjero residente en España, y no una mera facultad graciable o discrecional en manos de las autoridades públicas ${ }^{550}$. Dicha naturaleza se encuentra en perfecta sintonía con el carácter preceptivo de las obligaciones que la Directiva 2003/86 551 impone a las autoridades públicas de los Estados Miembros — reiteradamente confirmado por el TJUE-.

\subsection{Familiares reagrupables}

La regulación de este aspecto es uno de los más trascendentes de la migración familiar, tanto desde el punto de vista del extranjero residente y su familia, como desde la perspectiva del Estado receptor, porque de su tratamiento normativo dependerán los principales efectos multiplicadores implícitos a la RF y, por esta vía, su incidencia poblacional y sociológica, así como sobre las estructuras del Estado de bienestar del país de acogida ${ }^{552}$. No en vano la regulación de los beneficiarios de la inmigración familiar ha experimentado continuos vaivenes desde que, a partir de la LO 4/2000, la RF se incorporara a la ley, en lo que constituía un auténtico salto cualitativo desde su anterior previsión exclusivamente reglamentaria.

Ya señalamos que el concepto de familia no es unívoco a nivel jurídico, constituyendo el ámbito migratorio y, concretamente, las migraciones familiares, un apartado específico donde la definición de los familiares conforma un concepto autónomo - en el que, además, proliferan diversas regulaciones, dependiendo el concepto de familiar fundamentalmente de la nacionalidad que ostente el reagrupante ${ }^{553}$.

A grandes líneas, la regulación proporcionada por la LO 4/2000 seguía en esencia los lineamientos delineados por el Reglamento de extranjería de 1996, si bien con un talante mucho más progresista y dotando de mayor precisión a algunos aspectos, acotando con ello la discrecionalidad administrativa en el ejercicio del derecho. Sin embargo, tras la reforma operada poco después mediante la LO 8/2000, la cuestión de los familiares reagrupables emergería como una de las más complejas de afrontar, introduciendo un tenor restrictivo que, con carácter general, el paso del tiempo ha ido agudizando.

En este sentido, sobre los beneficiarios de la RF — contemplados en el art.17-, han recaído las modificaciones más sustanciales operadas por la última reforma legislativa efectuada mediante la LO 2/2009. El objetivo que con ella se perseguía — tal y como proclamaba la Exposición de Motivos de dicha ley-, era acotar los beneficiarios de la RF a los miembros integrantes de la familia nuclear

550 En idéntico sentido se manifiesta RAVETLLAT BALLESTÉ, I. La reagrupación familiar, op. cit., pp. 27-28.

551 Artículo 4.1 de la Directiva 2003/86 sobre el derecho a la RF.

552 La asunción de que el incremento en la recepción de flujos migratorios implica un aumento correlativo en los gastos de carácter social y cultural que debe afrontar el Estado receptor, está siendo crecientemente desmentida por investigaciones que han analizado el impacto económico que la inmigración, y concretamente la RF, implican para el Estado receptor. Entre otros trabajos recientes, cabe destacar, en el ámbito español, el realizado por Pablo VÁZQUEZ VEGA. "Reagrupamiento familiar de los inmigrantes: Efectos sobre la afiliación e incidencia en los gastos de protección social”. Madrid, Ministerio de Trabajo e Inmigración, diciembre de 2009. Disponible en http:// www.seg-social.es/prdi00/groups/public/documents/binario/129736.pdf

553 En sentido crítico en torno a la falta de uniformidad que sobre el término familiares existe en el ámbito migratorio, tanto en el ordenamiento comunitario como en el interno español, se pronuncia ALVAREZ RODRÍGUEZ, A. "La RF como vehículo de integración", op. cit., p. 245. 
en sentido estricto, dificultando la reagrupación de los ascendientes ${ }^{554}$. Subyacente a esta restricción, además de posicionar a España en línea con sus vecinos europeos - donde, en materia migratoria, es dominante la tendencia a conceptos restrictivos de familia-, late el objetivo de recortar los efectos multiplicadores de la RF, reducir la presión sobre el mercado laboral - de ahí que se establezca un tope de edad para la reunificación de los ascendientes, coincidente con la edad de jubilación- y, posiblemente, sobre las estructuras del Estado de bienestar.

En esta línea, el nuevo tratamiento normativo parece asumir los mayores costes sociales que para el Estado receptor acarrea el grupo de adultos mayores sin que éstos, a cambio, contribuyan a sufragar los gastos públicos. De ahí que los ascendientes, limitados ahora al primer grado de parentesco con el reagrupante, constituyan el colectivo donde la última reforma legislativa se ha traducido en un mayor endurecimiento de los requisitos exigidos para su admisión. Pese a ello, investigaciones recientes en torno al impacto económico que la migración familiar supone para el Estado receptor -basadas en una comparación entre los gastos y las aportaciones que los familiares reagrupados suponen desde el punto de vista de la Seguridad Social-, han concluido que la RF "no supone un coste elevado en términos de prestaciones en el momento actual, con lo que limitar la entrada de inmigrantes a nuestro país por esta vía no parece ser la medida más adecuada si lo que persiguen estas limitaciones es aliviar los problemas de sostenibilidad a los que se enfrenta la Seguridad Social"555.

Desde un punto de vista jurídico-formal, la última reforma no ha logrado eliminar la confusión y complejidad que siempre han acompañado la redacción de los artículos que determinan los familiares amparados por la RF, dificultando la comprensión de elementos que resultan vitales para el contenido y el ejercicio de este derecho. En vista de las numerosas oportunidades que el legislador ha tenido para su eliminación en las sucesivas reformas de esta materia, - y también de las voces que denunciaban y aconsejaban su corrección tanto desde el ámbito doctrinal ${ }^{556}$ como institucional $^{557}$-, no cabe sino interpretar que su permanencia constituye un elemento de técnica jurídica conscientemente mantenido por el legislador, pues otorga una gran flexibilidad en la práctica administrativa. Con todo, el actual Reglamento parece disipar parte de la misma, con una regulación que, hasta el momento, es la más detallada de cuantas han visto la luz en esta materia.

La equívoca y confusa redacción resulta especialmente perceptible en la regulación del cónyuge del residente, cuya protección dentro del círculo de los familiares reagrupables mantiene la ley vigente - como viene siendo una constante desde la introducción de la RF en el ordenamiento jurídico español, y con una redacción que apenas ha sufrido variaciones de interés desde el año 2000-. El artículo 17.1. a), redactado conforme a la LO 2/2009 exige para poder ser reagrupado, que el cónyuge no se encuentre separado de hecho o de derecho, y que el matrimonio no se haya celebrado en fraude de Ley, en alusión a los matrimonios de conveniencia o complacencia.

554 Artículo 17.1.d) de la Ley Orgánica 2/2009, de reforma de la LO 4/2000.

555 VÁZQUEZ VEGA, Pablo. Reagrupamiento familiar de los inmigrantes: efectos sobre la afiliación e incidencia en los gastos de protección social, op. cit., p. 5.

556 ÁLVAREZ RODRÍGUEZ, Aurelia. “La reagrupación familiar como vehículo de integración”; op. cit., pp. $233-236$.

557 Vid, a modo de ejemplo, el Dictamen emitido por el Consejo de Estado el 12 de junio de 2003, sobre el Anteproyecto de Ley orgánica de reforma de la LO 4/2000, de 11 de enero, sobre derechos y libertades de los extranjeros y su integración social, modificada por la LO 8/2000, de 22 de diciembre. En dicho Dictamen, el Consejo de Estado - tras constatar la compatibilidad constitucional del texto de la reforma por entonces en proceso de gestación-, señalaba el carácter confuso y ambiguo de la regulación tanto de la RF como del régimen de visados. En torno a la RF, denunciaba su carácter "cuanto menos confuso", que ofrecía dudosa cobertura al futuro reglamento, aconsejando una regulación más simple y eficaz. Expediente 1639/2003. 
La preocupación ante el incremento experimentado en España por este tipo de matrimonios simulados, especialmente a partir del año 1995, llevó a la Dirección General de los Registros y del Notariado a emitir una Instrucción de 31 de enero de 2006, sobre los matrimonios de complacencia ${ }^{558}$. En ella se contienen una serie de directrices con el fin de auxiliar a los encargados de los Registros Civiles españoles - tanto en España como en el extranjero-, a la hora de abordar el tratamiento jurídico de este fenómeno. Constituye un único documento que unifica directrices previas dispersas, en vista de que, como señala la propia Instrucción, el número de resoluciones dictadas por la Dirección General de los Registros y del Notariado en relación con los matrimonios de conveniencia es "incontable".

Tal y como explica la citada Instrucción, los matrimonios de complacencia suelen pactarse mediando un precio, lo que convierte al matrimonio en un negocio jurídico simulado, considerado nulo. Por matrimonio simulado, con carácter general, se entiende "aquel cuyo consentimiento se emite, por una o ambas partes, en forma legal pero mediante simulación, esto es, sin correspondencia con un consentimiento interior, sin una voluntad real y efectiva de contraer matrimonio, excluyendo el matrimonio mismo en la finalidad y en los derechos y obligaciones prefijados por la Ley, o bien un elemento o propiedad esencial del mismo. En el matrimonio simulado se da, por tanto, una situación en que la declaración de voluntad emitida no se corresponde con la real voluntad interna ${ }^{559 "}$.

La Instrucción emplea la terminología de matrimonios de complacencia, entendiendo por tales aquellos supuestos "en los el que el verdadero objetivo pretendido por una o ambas partes es el de obtener determinados beneficios en materia de nacionalidad y de extranjería o el estipendio recibido o prometido a uno de los contrayentes"560. Se trata de supuestos muy delicados y que encierran grandes dificultades probatorias, pues cuando el Encargado del Registro Civil examina el expediente matrimonial previo a la autorización del matrimonio, debe tener en cuenta tanto el respeto al derecho fundamental a contraer matrimonio libremente - ius connubii-, como la presunción de buena fe de los contrayentes. Sin embargo, el ius connubii no ampara los matrimonios simulados, por ser éstos falsos matrimonios y nulos jurídicamente. El respeto a ambos extremos determina la exigencia, contenida en la Instrucción, de que el Encargado del Registro Civil alcance una certeza moral plena de hallarse en presencia de un matrimonio simulado para poder acordar la denegación de la autorización del matrimonio o de su inscripción. A tal fin, dichos funcionarios pueden mantener entrevistas personalizadas con los cónyuges, en las que cabe utilizar criterios tanto objetivos como subjetivos ${ }^{561}$ para determinar la validez del matrimonio.

Retornando a la figura del cónyuge como familiar reagrupable, no se contempla en modo alguno el matrimonio poligámico, prohibiéndose reagrupar a más de un cónyuge, aunque la Ley personal del extranjero admita esta modalidad matrimonial. En este sentido, para reagrupar a su cónyuge, el Reglamento actualmente vigente ${ }^{562}$ — con una redacción más parca a la anteriormente estableci-

558 Instrucción de 31 de enero de 2006, de la Dirección General de los Registros y del Notariado, sobre los matrimonios de complacencia. B.O.E. no 41, de 17 de febrero de 2006.

559 Apartado IV de la Instrucción sobre los matrimonios de complacencia.

560 Apartado IV de la Instrucción de 31 de enero de 2006, de la Dirección General de los Registros y del Notariado, sobre los matrimonios de complacencia.

561 PASCOUAU, Y; LABAYLE, H. Conditions for Family Reunification under Strain, op. cit., p. 27.

562 Punto $4^{\circ}$ del apartado a) del párrafo tercero del artículo 56 del Real Decreto 557/2011, de 20 de abril, por el que se aprueba el Reglamento de la Ley Orgánica 4/2000, sobre derechos y libertades de los extranjeros en España y su integración social, tras su reforma por Ley Orgánica 2/2009. 
da ${ }^{563}$-, exige incluir una declaración jurada del reagrupante de que no reside con él en España otro cónyuge o pareja, entre los documentos que el sponsor debe acompañar junto con la solicitud de RF.

Sobre la posición del cónyuge, la LO 4/2000 introdujo por primera vez un reforzamiento de su posición jurídica, mediante dos previsiones que continúan vigentes desde entonces:

a) La ruptura del vínculo matrimonial - que dio lugar a la adquisición de la residencia en España por parte del cónyuge del reagrupante-, no conllevará la pérdida del estatus de residente. Esta norma protectora se ha mantenido desde entonces encontrándose actualmente recogida en el artículo 16.3 de la LO 2/2009, si bien con algunas adicciones que encomiendan al reglamento la previsión del tiempo previo de convivencia marital necesario. En el momento de su introducción con la LO 4/2000, Eliseo Aja conectó esta previsión con la regulación del permiso de residencia temporal, deduciendo de ambas el carácter autónomo "del permiso del reagrupado respecto del reagrupante con carácter general" ${ }^{64}$. Sobre este punto, la reforma habida mediante la LO 8/2000 introdujo la precisión de que correspondía al reglamento la determinación del tiempo previo de convivencia en España que había que acreditarse en estos supuestos ${ }^{565}$, a fin de mantener la residencia adquirida por reagrupación, aún roto el vínculo matrimonial que dio lugar a tal adquisición.

Esta habilitación reglamentaria subsiste en la actualidad, estableciendo al respecto el Reglamento vigente que el cónyuge reagrupado podrá obtener una autorización de residencia y trabajo independiente cuando se rompa el vínculo conyugal que dio origen a la situación de residencia, teniendo lugar dicha ruptura por separación de derecho o divorcio, "siempre y cuando acredite la convivencia en España con el cónyuge o pareja reagrupante durante al menos dos años"566.

b) En el supuesto de que el extranjero residente se encuentre separado y casado en segundas o posteriores nupcias, sólo podrá reagrupar con él al nuevo cónyuge si acredita que la disolución de sus anteriores matrimonios ha tenido lugar tras un procedimiento jurídico que fije la situación del cónyuge anterior y de sus hijos comunes en cuanto al uso de la vivienda común, a la pensión compensatoria y a los alimentos que correspondan a los hijos menores ${ }^{567}$. Desde su introducción por la LO 4/2000 hasta la actualidad, esta norma se ha ido refinando sucesivamente, sustituyéndose la

563 Sobre este punto, el art. 42.2.f) del Reglamento de extranjería previo a la última modificación reglamentaria Real Decreto 2393/2004, de 30 de diciembre-, en desarrollo del art. 17.1 del texto legal también previamente vigente —en este punto idéntico a lo que prescribe la LO 2/2009_, exigía al reagrupante aportar una declaración firmada por él. En dicha declaración, el reagrupante había de declarar, bajo juramento o promesa, que no residía en España con ningún otro cónyuge distinto de aquel al que pretendía reagrupar y que había de identificar en el mismo documento. La declaración finalizaba con una advertencia en la que literalmente se establecía que "caso de no ser cierta, implicaría la comisión de una infracción tipificada en el artículo 53.c) de la Ley Orgánica 4/2000, de 11 de enero, en su redacción dada por las Leyes Orgánicas 8/2000 y 14/2003, y en consecuencia, podría ser sancionado de conformidad con lo dispuesto en el Título XI del R.D. 2393/2004, de 30 de diciembre, por el que se aprueba su reglamento de ejecución".

564 AJA, E. (coord). La nueva regulación de la inmigración en España, op. cit., p. 143. Este autor proseguía señalando que "ninguna incidencia en el permiso de residencia tendrá la ruptura del vínculo matrimonial entre reagrupante y reagrupado, o la situación legal de aquél en cada momento, en tanto que éste tiene su permiso de forma autónoma e independiente al de aquél, y la misma autonomía, lógicamente, posee el permiso de cualquier otro familiar reagrupado".

565 Segundo párrafo del artículo 16.3 de la LO 4/2000, en la redacción operada mediante la LO 8/2000. Esta habilitación reglamentaria fue en el momento de su introducción aplaudida por el Consejo de Estado, quien señaló que: "Sin una determinación normativa de tales supuestos, que solo el reglamento por su mayor flexibilidad puede hacer, quedaría vacía la lógica cautela contra los matrimonios en fraude de ley contenida en el ya vigente artículo 17 a) de la Ley 4/2000". Apartado 11 del Dictamen del Consejo de Estado 2606/2000, de 28 de julio de 2000.

566 Apartado 2.a) del artículo 59 del Reglamento de extranjería vigente, de 30 de abril de 2011.

567 Artículo 17.1a) de la L.O. 2/209 y artículo 53.a) del Reglamento de 30 de abril de 2011. 
referencia a la separación por la exigencia de disolución del matrimonio o matrimonios previos del reagrupante, incluyendo incluso los supuestos de disolución por nulidad matrimonial. Tal sustitución ofrece mayor rigor al precepto, al tiempo que es acorde a la doctrina del TS ${ }^{568}$. También ha ido ampliándose la previsión de que el procedimiento jurídico de disolución fije la situación de alimentos que le corresponden a los hijos, cubriendo no solamente a los menores, sino también a los hijos mayores que se hallen en situación de dependencia.

Durante la tramitación parlamentaria de la LO 4/2000, de la que proviene, esta previsión fue considerada excesivamente patenalista por IU en una enmienda que proponía su eliminación. Frente a dicha objeción, se argumentó que requerir que el reagrupante extranjero cumpliera con las obligaciones de asistencia debidas tanto al excónyuge como a los hijos habidos en matrimonios previos, suponía una exigencia de igualdad con respecto a la que el Código Civil establecía para los españoles que se encontrasen en situaciones similares, incluyéndose finalmente en el texto de la ley. Aja ha puesto en evidencia que esta previsión origina muy relevantes problemas prácticos, "en la medida en que parece forzar a que la Administración oficie de institución de fiscalización de la actividad de terceros Estados" ${ }^{669}$; En otro extremo de la balanza, la aportación de los documentos acreditativos del procedimiento jurídico que ha supuesto la disolución del vínculo matrimonial previo, pese a los problemas prácticos que pueda acarrear al reagrupante, es interpretado como un elemento que dota de seguridad jurídica y garantiza el rigor de dicha ruptura ${ }^{570}$.

En el caso de segundas nupcias o posteriores, la RF cubre al nuevo cónyuge, siempre que se acrediten los anteriores extremos, pero no queda claro en la redacción de la ley si se protege a los familiares del nuevo cónyuge, lo que incluiría también a los hijos del mismo. La indefinición de este extremo constituye un ejemplo de la confusión que domina en la redacción de los beneficiarios de la RF. El Consejo General del Poder Judicial, en el informe que emitió en relación al Anteproyecto de la última reforma legislativa, concluía que con la reforma quedaban excluidos los familiares del cónyuge en segundas o posteriores nupcias ${ }^{571}$. Este aspecto no aparece especificado en la ley, pero sobre este punto la última reforma reglamentaria señala los requisitos que, a efectos de acreditación, el extranjero residente casado en segundas o posteriores nupcias deberá reunir para reagrupar con él "al nuevo cónyuge y a sus familiares" 572 . Esta importante adición reglamentaria apunta claramente a la inclusión no solamente de los hijos menores del nuevo cónyuge, sino de los restantes parientes reagrupables, como sujetos beneficiarios de la migración familiar.

568 Vid. Sentencia del Tribunal Supremo de 1 de julio de 2010, F. J. 2º. En una línea similar, entre la doctrina española, Juan Manuel LÓPEZ ULLA califica la sustitución del término separación por el de disolución operada mediante la LO 2/2009, como una "mejora técnica que hay que saludar, pues como es sabido en nuestro ordenamiento la celebración de un nuevo matrimonio exige la extinción del anterior, lo que no sucede con la mera separación legal”. "Extranjeros reagrupables"; en GAVIDIA SÁNCHEZ, Julio V. (coord.) Inmigración, familia y Derecho. Madrid, Marcial Pons, 2011, p. 450.

569 A fin de superar tales inconvenientes prácticos, AJA propone como solución reductora de dichos problemas "entender que la Administración controlará los anteriores extremos sólo en caso de solicitud de parte interesada, en especial la primera esposa"; La nueva regulación de la inmigración en España, op. cit., p. 140. En referencia a todos los requisitos legales exigidos para poder reagrupar al cónyuge, —en conjunción con la confusa redacción empleada para la delimitación del término cónyuge-, ALVAREZ RODRÍGUEZ consideraba que su cumplimiento implicaba "la superación de una prueba diabólica"; en "La reagrupación familiar como vehículo de integración”, op. cit., p. 233. 570 Así lo interpreta RAVETLLAT BALLESTÉ, cuya opinión suscribimos. La reagrupación familiar, op. cit., p. 29.

571 Informe del CGPJ al Anteproyecto de L.O. de Reforma de la LO 4/2000, de 11 de enero. CGPJ, 2009, p. 28. “Por lo que respecta al cónyuge y los descendientes, en el caso de segundas o poteriores nupcias (art. 17.2a), el derecho a reagrupar alcanza al nuevo cónyuge, pero no a sus familiares, como prevé la Ley vigente"

572 Artículo 53. a) del Reglamento de 30 de abril de 2011, de desarrollo de la L.O. 2/2009. 
El ordenamiento español no contempla la imposición de edades mínimas sobre la figura de los cónyuges - posibilidad excepcional permitida por el artículo 4.5 de la Directiva sobre el derecho a la RF-, salvo las que, con carácter general, rigen en el ámbito del derecho civil ${ }^{573}$. Esta circunstancia, en conjunción con el hecho de que el cónyuge aparezca contemplado en primer lugar dentro del listado de parientes reagrupables del artículo 17, permiten sostener que, en concurrencia de los requisitos exigidos, la RF constituye un derecho absoluto para el cónyuge del reagrupante ${ }^{574}$-si bien con las precisiones que ya señalamos en torno a la configuración legal de este derecho-.

Una de las novedades más importantes de la LO 2/2009, reside en la protección como familiar reagrupable de la pareja de hecho del residente extranjero, acogiendo la ley lo que venía siendo una reclamación doctrinal mayoritaria ${ }^{575} \mathrm{y}$, al tiempo, un criterio jurisprudencial aplicado por el $\mathrm{TS}^{576}$ y conforme a la doctrina sostenida por el TEDH en esta materia. A tal efecto, el apartado cuarto del artículo 17, establece una equiparación a efectos de la RF entre la persona que mantenga con el extranjero residente una relación de afectividad análoga a la conyugal y el cónyuge. Como requisito para que se produzca tal equiparación, la ley exige que la relación sentimental "esté debidamente acreditada y reúna los requisitos necesarios para producir efectos en España". Se trata de cuestiones vitales a efectos de impedir fraudes a la ley que, ante la imprecisión de la norma legal, quedan relegadas al desarrollo reglamentario: al efecto, el art. 17.5 especifica que reglamentariamente se determinarán las condiciones para acreditar la relación de afectividad análoga a la conyugal.

Tales precisiones aparecen incluidas en el artículo 53 del Reglamento vigente. Con una confusa redacción ${ }^{577}$, la última reforma reglamentaria especifica que, a efectos de migración familiar, se con-

573 El artículo 166.5 del Cógido Civil contempla la minoría de edad como un impedimento para contraer matrimonio. Con todo, habría que precisar que el matrimonio celebrado por contrayentes menores de 14 años no se permite, pero cuando el menor tiene entre 14 y 16 años de edad puede contraer matrimonio siempre que cuente con dispensa judicial, y cuando cuenta entre 16 y 18 años, basta que el contrayente menor obtenga la emancipación y quede constancia literal de la misma en la certificación de nacimiento (artículo 46 C.C.).

574 En el mismo sentido se pronuncian PASCOUAU, Yves y LABAYLE, Henri. Conditions for Family Reunification under Strain, op. cit., p. 20.

575 A modo de ejemplo, vid., RAVETLLAT BALLESTE, I. La reagrupación familiar, op. cit., p. 30, quien aplicando doctrina constitucional (STC 222/1992, de 11 de diciembre), sostenía que "cabe la equiparación entre el matrimonio y la unión de hecho estable cuando se trata de aplicar normas que contemplan exclusiva o preporderantemente la situación de convivencia y afectividad”. En el mismo sentido, ÁLVAREZ RODRÍGUEZ, A. "La reagrupación familiar como vehículo de integración", op. cit., p. 235.

576 Sentencia de 11 de octubre de 1999 (recurso de casación 10/1996). En ella el TS estima que hay arraigo en territorio español por razones de RF cuando existe unión de hecho marital estable y continuada, a efectos de declarar procedente la suspensión de un acuerdo de expulsión. Con ello, otorga relevancia jurídica a la convivencia marital, estimando que, de no equiparar tal situación a la matrimonial en orden a apreciar la existencia de arraigo por razones de reagrupación familiar, constituye una infracción de su doctrina jurisprudencial. En tales casos, el TS estima más digno de protección el interés particular de quien solicita la suspensión de la orden de expulsión mientras se tramita el proceso judicial, que el interés general de ejecutar de forma inmediata dicha orden de expulsión. En aplicación de esta doctrina jurisprudencial, pueden consultarse, entre otras, la Sentencia del TS de 15 de noviembre de 1999, donde el TS confirma que existe equiparación entre la convivencia marital de hecho y el matrimonio, a efectos de apreciar la existencia de arraigo familiar con el fin de justificar la suspensión cautelar del acuerdo de expulsión del territorio español. En una línea similar, aunque sin hacer referencia expresa a la RF, el TC había sentado doctrina señalando que aunque el matrimonio y la convivencia de hecho no constituyan instituciones equiparables, sin embargo, ello no supone que "toda medida que tenga como únicos destinatarios a los cónyuges, con exclusión de quienes conviven establemente en unión de hecho, sea siempre y en todos los casos compatible con la igualdad jurídica y la prohibición de discriminación que la Constitución garantiza en su art. 14", STC 222/1992, de 11 de diciembre.

577 La redacción literal del art. 53.b) del Reglamento de 30 de abril de 2011 señala erróneamente que "se considerará que existe relación de análoga afectividad a la conyugal”, en lo que sin duda deberá ser subsanado mediante una futura fe de erratas. 
siderará que existe relación de afectividad análoga a la conyugal en dos supuestos tasados: en primer lugar, cuando tal relación se encuentre inscrita en un registro público establecido a tales efectos y no haya sido cancelada; $y$, en vista de que en muchos países de origen tales registros pueden no estar previstos, el Reglamento contempla también la inclusión de las parejas de hecho no registradas, pero siempre que "se acredite la vigencia de una relación no registrada, constituida con carácter previo al inicio de la residencia del reagrupante en España" - lo que implica la exclusión de las parejas creadas posteriormente a la adquisición de residencia del sponsor, esto es, de los supuestos típicos de migración matrimonial para las parejas de hecho extranjeras no registradas-. Las parejas registradas habrán de presentar copia certificada de tal registro; por su parte, para la acreditación de las parejas no registradas, el Reglamento otorga prevalencia a aquellas que presenten "documentos emitidos por una autoridad pública" ${ }^{778}$, sin perjuicio de la posible utilización de cualquier otro medio de prueba admitido en derecho. En la práctica administrativa, a las relaciones de pareja no registradas se les exige una cohabitación previa de al menos dos años, con anterioridad a la llegada del reagrupante a España ${ }^{579}$.

A fin de evitar situaciones abusivas, la ley y el reglamento explicitan que las situaciones de matrimonio y de análoga relación de afectividad se considerarán incompatibles entre sí, y se prohíbe reagrupar a más de una pareja de hecho, "aunque la ley personal del extranjero admita estos vínculos familiares" ${ }^{580}$, en sintonía con lo previsto respecto a los matrimonios poligámicos.

La inclusión de la pareja de hecho del extranjero residente entre el círculo protegido de los familiares reagrupables es, con diferencia, la novedad más destacada y plausible de la ley. Pese a las dificultades probatorias que encierra, supone una norma evolutiva coherente con la generalizada evolución social que se ha producido en el ámbito de las relaciones de pareja ${ }^{581}$. De otro lado, constituye una previsión que encaja a la perfección con los criterios flexibles que, en el ámbito de la migración familiar aplica el TEDH, que en su última línea jurisprudencial incluye inequívocamente a la pareja de hecho dentro del ámbito de los familiares reagrupables, incluso en supuestos fronterizos con la residencia irregular, con los matices ya estudiados ${ }^{582}$. La protección de la pareja de hecho había sido unánimemente defendida por la doctrina, que sistemáticamente había criticado esta exclusión en las reformas previas de la ley de extranjería ${ }^{583}$. Las relaciones de convivencia análogas a las conyugales representan mayores dificultades probatorias y además conllevan una probabilidad muy superior

578 Punto segundo del artículo 53 apartado b), del Reglamento de extranjería vigente.

579 PASCOUAU, Yves; LABAYLE, Henri. Conditions for Family Reunification under Strain, op. cit., p. 34. Sobre este aspecto, los autores, que han estudiado comparativamente nueve países europeos que aplican la Directiva sobre el derecho a la RF —entre ellos España-, concluyen que en nuestro país no se han establecido procedimientos específicos para examinar la validez de las parejas de hecho a efectos de la migración familiar, lo cual no debe entenderse como que tales exámenes no se produzcan, teniendo éstos lugar al examinarse las solicitudes de RF.

580 Artículo 17.4 de la L.O. 2/2009 y artículo 53 b) in fine del Reglamento.

581 PASCOUAU, Yves; LABAYLE, Henri. Conditions for Family Reunification under Strain, op. cit., pp. 31-32.

582 Vid. STEDH Rodrigues da Silva.

583 Sobre este punto, ALVAREZ RODRÍGUEZ señaló en su momento que la anterior exclusión de la pareja de hecho como familiar reagrupable podría ser considerada inconstitucional, por vulneración del artículo 18 CE y por ser discriminatoria en aplicación de la doctrina tanto del TC (STC 240/94) como del TEDH. "La RF como vehículo de integración", op. cit., nota a pie de pag. 64. En la misma línea, pero con un tenor más liberal, se pronunciaba RAVETLLAT BALLESTÉ quien, al comentar la ley vigente con anterioridad a la reforma operada en el año 2009 -y en aplicación de la doctrina del TC-, señalaba que "cuando la ley de extranjería y su reglamento de desarrollo hacen mención a la reagrupación del cónyuge, debe entenderse incluida en tal categoría también al acompañante sentimental del reagrupante extranjero, con independencia del hecho del matrimonio e, incluso, de su orientación sexual"; en La reagrupación familiar, op. cit., p. 30. 
de fraude, de ahí las cautelas que ha introducido el reglamento para prevenir el abuso a la ley ${ }^{584}$. Con todo, resulta difícilmente justificable, - especialmente a la luz de la última jurisprudencia del Tribunal de Luxemburgo, que tiende a la equiparación entre la RF en sentido estricto y la formación familiar- que hayan quedado excluidas las parejas de hecho no inscritas constituidas con posterioridad al inicio de la residencia del reagrupante en España - limitación que no rige para el supuesto de las relaciones inscritas-.

Como ya apuntamos, la Directiva 2003/86 ${ }^{585}$ incluía a la pareja no casada nacional de un tercer país que mantenga con el reagrupante una relación estable debidamente probada, o bien al nacional de un tercer país que constituya con el reagrupante una pareja registrada, entre los familiares reagrupables con carácter facultativo para el Estado Miembro, dejando esta cuestión en manos del margen de apreciación estatal. En uso de esta libertad, el gobierno español finalmente ha optado por acoger a la pareja de hecho dentro del concepto de familia nuclear protegible a través de la migración familiar, equiparándola con las uniones matrimoniales a todos los efectos que se deriven del capítulo de la ley dedicado a la regulación de la $\mathrm{RF}^{586}$. A fin de facilitar la acreditación de los vínculos familiares en estos supuestos, y en previsión de las deficiencias que en esta materia puedan existir en los ordenamientos de los países de origen, la Directiva establece que, cuando se examine una solicitud relativa a la pareja no casada del reagrupante, los Estados miembros tendrán en cuenta elementos tales como hijos comunes, la cohabitación previa, el registro de la pareja y cualquier otro medio de prueba fiable ${ }^{587}$. En consecuencia, la introducción de la pareja de hecho dentro de los familiares reagrupables constituía una cuestión dejada a la libertad del EM, por la que finalmente se ha decantado la ley.

El ordenamiento español ha amparado pues un concepto amplio de pareja de hecho ${ }^{588}$, incluyendo tanto a las parejas registradas como a las no registradas. Sin embargo, la exclusión reglamentaria de la formación familiar respecto de las parejas no inscritas constituye un aspecto que - si bien podría resultar pacífico a la luz del texto de la Directiva comunitaria-, no lo es en la actualidad, tal y como esta norma ha sido recientemente interpretada por el TJUE en el asunto Chakroun, y en base a la jusisprudencia del TEDH.

Los hijos menores - del residente y del cónyuge - constituyen los segundos familiares reagrupables contemplados en la ley de extranjería (artículo 17. 1.b) ${ }^{589}$. La LO 2/2009 ha optado por un tratamiento más generoso, facilitando algunos de los requisitos exigibles para poder reagrupar a los hijos. De un lado, ha eliminado la exigencia de no estar casados como requisito para poder reagrupar

584 Raquel ARAGÓN, en un estudio de carácter teórico-práctico sobre las novedades de la LO 2/2009 en el ámbito de la RF, estima que la acreditación de la relación de convivencia análoga a la conyugal habrá de hacerse mediante certificación expedida por el órgano encargado del registro de parejas de hecho, siendo éste de carácter público y la certificación ha de tener una antigüedad máxima de tres meses; en “La RF en la nueva LO 2/2009...", op. cit., s.p.

585 Artículo 4.3 de la Directiva sobre el derecho a la RF.

586 La nueva redacción de la ley es inequívoca en este punto, señalando literalmente que "la persona que mantenga con el extranjero residente una relación de afectividad análoga a la conyugal se equiparará al cónyuge a todos los efectos previstos en este capítulo, siempre que dicha relación esté debidamente acreditada y reúna los requisitos necesarios para producir efectos en España" (artículo 17.4 de la L.O. 2/2009).

587 Artículo 5.2 de la Directiva 2003/86/CE sobre el derecho a la RF.

588 PASCOUAU, Yves; LABAYLE, Henri. Conditions for Family Reunification under Strain, op. cit., pp. 34 y 35 . Más adelante, ambos autores especifican que aquellos países - como Alemania y Bélgica-, que sólo conceden la RF a las parejas registradas son menos liberales, en el sentido de obligar a sus miembros "a entablar procedimientos administrativos a fin de dar una existencia legal a su vida en común”.

589 La dicción literal del párrafo 1.b) del artículo 17 contempla como familiares reagrupables a "los hijos del residente y del cónyuge, incluidos los adoptados, siempre que sean menores de dieciocho años o personas con discapacidad que no sean objetivamente capaces de proveer a sus propias necesidades debido a su estado de salud". 
a los hijos menores, que previamente había estado presente de forma constante desde la LO 4/2000. La supresión de la exigencia de soltería viene a resolver un problema práctico que había desvelado la anterior regulación: el agravio comparativo que se producía entre los hijos menores comunes del reagrupante y su cónyuge, sujetos al requisito de estar solteros para poder entrar a España para vivir con sus progenitores extranjeros, mientras que para los menores representados por el reagrupante —aun si ser hijos de éste-, la legislación no preveía tal exigencia ${ }^{590}$.

En este aspecto, la regulación interna resulta más liberal que la contenida en el ámbito comunitario, donde se establece que los hijos menores no han de estar casados (art. 4.1.b), si bien los tratamientos nacionales más favorables encajan dentro del régimen previsto en la Directiva (art. 3. 5 Directiva 2003/86). De otro lado, las prevenciones contenidas en la legislación española en torno a la guardia y custodia de los hijos, así como las relativas a los hijos adoptivos — que están también cubiertos por la ley—, resultan acordes con las disposiciones comunitarias ${ }^{591}$ —art. 4.1.c)—.

Además la ley, en su redacción actual, permite la reagrupación de hijos mayores de edad, siempre que se trate de personas con discapacidad, que no sean objetivamente capaces de proveer a sus propias necesidades debido a su estado de salud. Este tratamiento constituye una suavización y por ello resulta más generoso que el esquema vigente con anterioridad, donde la ley incluía el término de "incapacitados" en referencia a los hijos mayores de edad del residente y del cónyuge que podría beneficiarse de la reagrupación. Dicha expresión suponía la exigencia legal de condicionar la reagrupación del hijo adulto del extranjero al hecho de que hubiese sido objeto de una previa declaración formal de incapacitación ${ }^{592}$, de conformidad con la ley española o su ley personal. La LO 2/2009 sustituyó la incapacidad para poder agrupar a los hijos mayores de edad, introduciendo en su lugar el requisito de tratarse de "personas con discapacidad" que no sean capaces de atender a sus necesidades por problemas de salud. Este nuevo requisito, a efectos prácticos, supone la desaparición de la exigencia formal de previa declaración de incapacitación ${ }^{593}$. En consecuencia, el texto final de la reforma constituye una reproducción casi literal de la disposición concordante de la Directiva - artículo 4.2.b)—, de la que, con un tenor más liberal, la ley española ha eliminado la referencia a la exigencia de soltería en los hijos adultos del reagrupante pero, en contrapartida, exige incapacidad -requisito ausente en la norma comunitaria-.

Con la salvedad de los dos cambios mencionados, la normativa española sigue permitiendo reagrupar a los hijos comunes del residente y del cónyuge, incluidos los adoptados, siempre que sean menores de dieciocho años o bien mayores, con las precisiones ya mencionadas - personas con discapacidad que no sean objetivamente capaces de proveer a sus propias necesidades debido a su estado de salud-. Cuando se trate de hijos de uno solo de los cónyuges se requerirá, además, que éste ejerza en solitario la patria potestad o que se le haya otorgado la custodia y estén efectivamente a

590 Esta situación llevó a la doctrina a denunciar que los hijos del reagrupante fueran " $<$ de peor derecho $>$ que aquellas otras personas respecto de las cuales ostente el reagrupante su representación legal y que no tiene por qué ser sus propios hijos"; en RAVETLLAT, I. "La reagrupación familiar”, op. cit., p. 32.

591 LABAYLE, H; PASCOUAU. Directive 2003/86/EC on the Right to Family Reunification. Study on the Conformity checking of the Transposition by Member States of 10 Directives in the sector of Asylum and Immigration, op. cit., p. 48.

592 Dictamen del Consejo General del Poder Judicial al Anteproyecto de LO de reforma de la LO4/2000, de 11 de enero, sobre derechos y libertades de los extranjeros en España y su integración social, op. cip., p. 28.

593 "No se trata de una incapacidad jurídica, sino una incapacidad física o mental, acreditada mediante cualquier prueba admitida en derecho”. ARAGÓN, Raquel. "La RF en la Ley Orgánica 2/2009, de 11 de diciembre, de Reforma de la Ley Orgánica 4/2000 de 11 de enero"; en Inmigración y Derechos Humanos: Inmigración y Familia. IV Simposio Internacional de Inmigración, Fundación Ciudadanía y Valores, Valencia, 9 de abril de 2010, sp. Disponible en: http://www.funciva.org/uploads/ficheros_documentos/1271517308_raquel_aragon_web.pdf 
su cargo, a fin de evitar que la figura de la RF pueda cubrir un supuesto de secuestro internacional ${ }^{594}$, cuya probabilidad se incrementa en supuestos de ruptura de la relación entre los progenitores. En el supuesto de hijos adoptivos, deberá acreditarse que la resolución por la que se acordó la adopción reúne los elementos necesarios para producir efecto en España, esto es, en conformidad con lo establecido al efecto por el Derecho internacional privado ${ }^{595}$. Se trata pues de una regulación que sigue manteniendo en lo sustancial el tratamiento que para la reagrupación de los hijos se estableció a principios del año 2000 con la LO 4/2000. Esta ley, a su vez, incluía en este punto un tratamiento muy similar al establecido previamente en el Reglamento de 1996, si bien con algunas precisiones que suponían mejoras de cara a la seguridad jurídica: por ejemplo, frente al Reglamento, que de forma más indeterminada hablaba de hijos menores comunes del reagrupante y su cónyuge, la LO 4/2000 precisaba que los hijos fuesen menores de dieciocho años, según la ley española o su ley personal y suprimió la anterior exigencia de dependencia paterna, que generaba dificultades prácticas de cara a su comprobación.

Dado que la pareja de hecho se equipara a todos los efectos con el cónyuge en materia de RF -art. 17.4 L.O. 2/2009-, es obvio que dentro de los familiares objeto de reagrupación quedan también amparados los hijos del residente y de la persona con la que ésta/a mantenga una relación de afectividad análoga a la conyugal - tanto comunes como los nacidos del miembro de la pareja o del reagrupante-, así como los hijos adoptados, en iguales condiciones que las anteriormente establecidas. Como aspecto destacable, cabría mencionar que la inclusión expresa de los hijos de la pareja del reagrupante se produjo por vía reglamentaria — art. 53. c del Reglamento de 30 de abril de 2011—, no conteniéndose ninguna referencia sobre este punto en la ley. Comparativamente con la norma comunitaria - redactada en términos potestativos para los hijos de la pareja de hecho-, el ordenamiento español resulta notablemente más generoso, contemplando no solamente su protección, sino también eliminando el requisito de soltería previsto en la directiva.

De otro lado, la LO 2/2009 mantiene la posibilidad de que el extranjero residente pueda reagrupar a menores de dieciocho años o mayores de esa edad que no sean objetivamente capaces de proveer a sus propias necesidades debido a su estado de salud, y que estén representados por el reagrupante ${ }^{596}$. La novedad más sustancial en este concreto punto reside en la sustitución de la expresión "incapaces" ${ }^{597}$, por la de mayores de dieciocho años que no sean capaces de atender a sus necesidades como consecuencia de su estado de salud. Durante la tramitación de esta última reforma, la expresión de la anterior ley fue sustituida a su vez por la de "incapacitados", circunstancia que introducía mayores problemas. Como puso de manifiesto el Consejo General del Poder Judicial en su informe ${ }^{598}$ al anteproyecto de reforma, el término incapacitados exige una previa declaración formal de incapacitación, suscitando con ello problemas de conciliación con el artículo 4.2.b) de la Directiva 2003/86/CE, donde no consta en ningún momento la exigencia de incapacitación formal.

594 En el mismo sentido, RAVETLLAT BALLESTÉ, I. La reagrupación familiar, op. cit., p. 32.

595 Este requisito implica exigir equivalencia entre la adopción que ha tenido lugar en el país de origen o un tercer país, y la adopción tal y como es regulada por el ordenamiento español. Siguiendo a RAVETLLÁAT, la equivalencia se traduce en dos extremos: de un lado, en la igualdad entre los derechos y obligaciones de los hijos biológicos y los adoptivos y, de otro, en la ruptura definitiva de los lazos biológicos con la familia de origen. "La reagrupación familiar", op. cit., p. 31.

596 Artículo 17.1c) de la L.O. 2/2009.

597 Desde principios del año 2000, y sin cambios hasta la llegada de la LO 2/2009, la regulación permitía reagrupar a "los menores de dieciocho años o incapaces cuando el residente extranjero sea su representante legal" (apartado c del artículo 17).

598 Dictamen del Consejo General del Poder Judicial al Anteproyecto de L.O. de reforma de la L.O. 4/2000, de 11 de enero, sobre derechos y libertades de los extranjeros en España y su integración social, op. cip., p. 28. 
Para la reagrupación de los menores y mayores de edad que, aun sin ser hijos del reagrupante, no sean capaces de proveer a sus propias necesidades, la legislación vigente sigue exigiendo que el reagrupante sea su representante legal, pero añade el requisito de que "el acto jurídico del que surgen las facultades representativas no sea contrario a los principios del ordenamiento español” "599. Este supuesto ha demostrado tener una gran incidencia práctica, pudiendo amparar por esta vía la llegada de familiares del extranjero que no quedaban protegidos dentro del restrictivo concepto de familia, entre los que podrían incluirse sobrinos, primos, hermanos ${ }^{600}$.

La reagrupación de representados tiene especial relevancia en la inmigración procedente de África, donde - con respecto a menores en situación de abandono-, resulta muy arraigada la práctica del acogimiento familiar permanente o Kafala, sin equivalente en el derecho español, pero con ciertas similitudes con la figura de la adopción ${ }^{601}$. En el derecho español, sólo se estima que la kafala otorga la representación legal al adulto que ha acogido al menor abandonado, cuando la misma ha sido constituida ante la autoridad judicial o administrativa del país receptor, sin contar con la presencia de los padres biológicos de éste. Si los padres biológicos existen y estuvieron presentes en la constitución de la kalafa, el derecho español no reconoce la representación legal al adulto que se hizo cargo del menor bajo esta figura. En este último supuesto el menor acogido, para entrar en territorio español, habría de hacerlo no mediante la RF, sino a través de la figura del desplazamiento temporal de menores recogida en el art. 93 del Reglamento, que tiene carácter transitorio y conlleva el compromiso de retornar al menor a su país de origen ${ }^{602}$. Con la adición agregada por la L.O. 2/2009, la práctica de este tipo de representación de menores sin correlato en el ordenamiento español, ha quedado dificultada.

Uno de los cambios más sustanciales de la reforma operada por la LO 2/2009 en materia de familiares reagrupables, ha recaído sobre los ascendientes del reagrupante. La ley ha restringido la posibilidad de que el residente pueda traerse a España a sus familiares ascendientes, estableciendo como norma general la reagrupación tan sólo de ascendientes en primer grado del reagrupante y de su cónyuge y fijando un tope de edad - sesenta y cinco años-, por debajo del cual no caben las reagrupaciones ${ }^{603}$. Anteriormente, el tratamiento legal y reglamentario no establecía limitación ni respecto al grado ni respecto a la línea de parentesco entre el ascendiente y el reagrupante o su cónyuge, mientras que la reagrupación de descendientes, paradójicamente, quedaba limitada a los hijos, suscitando críticas entre la doctrina ${ }^{604}$. Si bien conviene puntualizar que, aunque el tope de edad no

599 Artículo 17. 1. c) de la L.O. 2/2009.

600 RAVETLLAT BALLESTÉ, I. La reagrupación familiar, op. cit., p. 32.

601 Las diferencias más notables residen en que, a diferencia de la adopción, en la kafala el menor acogido no adquiere derechos hereditarios ni tampoco el apellido del adulto que lo acoge — denominado kafil—, responsable sin embargo de su manutención y educación, y con el que adquiere vínculos familiares. QUIÑONES ESCÁMEZ, Ana; RODRÍGUEZ BENOT, Andrés; ZEKRI, Houda y OUHIDA, Jamila. Kafala y adopción en las relaciones hispanomarroquies. Madrid, Gobierno de Canarias, 2009, pp. 127-128.

602 Idem, pp. 137-138. En torno a la kafala, ya han tenido ocasión de pronunciarse los tribunales españoles. Vid, a modo de ejemplo, sentencia del Tribunal Superior de Justicia de Andalucía, Sala de lo Contencioso-Administrativo (Sección 1a), de 14 de septiembre de 2004

603 Artículo 17. 1, apartado d) de la L.O. 2/2009.

604 Vid, a modo de ejemplo, RAVETLLAT, I. La reagrupación familiar, op. cit., p. 36, quien, en sentido crítico, lamentaba la limitación de grado existente con anterioridad a la entrada en vigor de la LO 2/2009, para reagrupar a descendientes; con respecto a los ascendientes, cabía reagrupar con independencia del grado y de la línea de parentesco, lo que incluía la protección de los ascendientes colaterales que estuviesen a cargo del reagrupante o de su cónyuge. La aludida reforma se ha producido con un saldo restrictivo, con la introducción de la limitación de ascendientes únicamente al primer grado, sin que hayan sido suavizadas las exigencias de grado requeridas para la reagrupación de descendientes. 
existía antes de la LO 2/2009 ni en la letra de la ley ni en su desarrollo reglamentario, sin embargo, en la práctica administrativa y judicial los visados por RF se otorgaban únicamente a mayores de 65 años ${ }^{605}$.

En suma, con la nueva ley el reagrupante sólo podrá reunirse en España con sus progenitores y los de su cónyuge - o "pareja", como bien puntualiza el Reglamento, ante la omisión de la ley sobre este punto-, siempre que éstos sean mayores de sesenta y cinco años, sin que sea posible reagrupar a los abuelos o bisabuelos, en el supuesto de que éstos vivan y dependan económicamente del reagrupante.

La reagrupación de estos ascendientes sigo estando condicionada a la concurrencia de un concepto jurídico indeterminado: se exige que existan razones que justifiquen la necesidad de autorizar la residencia de los ascendientes en España. Es obvio que su indeterminación abre un amplio abanico de posibilidades de intervención $-\mathrm{y}$ restricción administrativa - , pero la misma ha estado presente en la norma desde la LO 4/2004 que, hasta el momento, constituía con diferencia la norma que preveía el tratamiento más generoso para la reagrupación de ascendientes. Persiste también la exigencia de que los ascendientes reagrupables estén a cargo del reagrupante o de su cónyuge o pareja de hecho que, en la práctica administrativa y judicial, se traducía en la necesidad de acreditar dependencia económica. Antes de la última reforma reglamentaria - pese a que el art. 39 del antiguo Reglamento había quedado derogado-, quedó vigente su apartado e ${ }^{606}$, conforme al cual se entendía que los familiares estaban a cargo siempre que el reagrupante acreditase, durante al menos el último año de su residencia en España, la transferencia de fondos a sus familiares, o bien que ha soportado gastos de su familia "en una proporción que permita inferir una dependencia económica efectiva". El actual Reglamento ha perpetuado esta exigencia, si bien concretando con mayor detalle alguno de los extremos ${ }^{607}$. Su artículo 53 entiende que los ascendientes están a cargo del reagrupante, siempre que se acredite "que, al menos durante el último año de su residencia en España, ha transferido fondos o soportado gastos de su familiar, que representen al menos el 51\% del producto interior bruto per cápita, en cómputo anual, del país de residencia de éste, según lo establecido, en materia de Indicadores sobre renta y actividad económica por país y tipo de indicador, por el Instituto Nacional de Estadística”.

Sin embargo, por vía reglamentaria se ha desaprovechado la oportunidad de concretar el concepto jurídico indeterminado "razones que justifiquen la necesidad de autorizar la residencia de ascendientes en España", de cuya concurrencia en abstracto se sigue haciendo depender dicha autorización. En consecuencia, la profusión de conceptos jurídicos indeterminados - característica del ámbito de la extranjería y la inmigración-, alcanza cotas más elevadas en la regulación de los ascendientes, permitiendo con ello una práctica administrativa flexible que puede propiciar la diversidad de ejercicios, requisitos y niveles de exigencia a lo largo del país.

Además, con la reforma operada por la LO 2/2009, la RF de los ascendientes se ha visto notablemente agravada por la introducción de la exigencia de adquirir previamente la residencia de larga duración para que el reagrupante pueda reunirse con estos parientes ${ }^{608}$. Ello supone que, frente al

605 Idem, p. 35.

606 En el mismo sentido se pronuncia Raquel ARAGÓN. “La RF en la nueva LO 2/2009...”, op. cit., s.p.

607 En su estudio comparativo entre las normativas sobre RF vigentes en 9 países miembros de la UE, PASCOUAU y

LABAYLE concluyen que, con dicha especificación reglamentaria, España se sitúa entre los países que con mayor precisión definen las pruebas de dependencia exigidas para poder reagrupar a ascendientes. Conditions for Family Reunification under Strain, op. cit, p. 47.

608 Artículo 18.1, redactado conforme a la L.O. 2/2009. 
plazo general de un año establecido como período de espera para la reunificación con los restantes familiares reagrupables, el reagrupante ha de contar con cinco años de residencia regular y continuada en España para poder reagruparse con sus ascendientes, en las condiciones restrictivas especificadas por la ley. Las nuevas exigencia establecidas para los ascendientes del reagrupante no son de aplicación a las renovaciones de las residencias vigentes con anterioridad a la entrada en vigor de la LO 2/200960. Con todo $-\mathrm{y}$ aun teniendo en cuenta que la reagrupación de ascendientes constituye una disposición facultativa en la Directiva comunitaria sobre el derecho a la RF-, su limitada admisión en el ordenamiento español plantea problemas de encaje con dicha norma comunitaria.

Si se analizan estas novedades a la luz de la Directiva 2003/86, el resultado es dispar. De un lado, la limitación de los ascendientes al primer grado, resulta coherente con lo estipulado en la normativa comunitaria que contempla la figura de los ascendientes restringiéndolos a la línea directa y en primer grado del reagrupante o de su cónyuge ${ }^{610}$. Mayores problemas suscitan las restantes restricciones introducidas por la última reforma. Nada dice la Directiva en torno a la fijación de un umbral de edad para la admisión de los ascendientes, de lo cual cabría deducir que esta limitación interna podría ser compatible, siempre que respetara el requisito de permitir la entrada y residencia de aquellos ascendientes a cargo del reagrupante y que carezcan de apoyo familiar adecuado en el país de origen.

Las dificultades de compatibilidad con la Directiva se vuelven insostenibles en lo que respecta a la exigencia interna que establece, con carácter general, que el reagrupante haya adquirido la residencia de larga duración para poder reagrupar a sus ascendientes en territorio español. Este aspecto guarda relación directa con el concepto y requisitos exigidos al reagrupante, para el cual la Directiva 2003/86 estipula la fijación de un período de espera previo de residencia regular en el territorio de un Estado miembro que oscila entre un mínimo de un año y un máximo de dos años —artículos 3.1 y 8.1, interpretados conjuntamente- . Cuando la norma comunitaria habla de residencia permanente, lo hace en un plano más bien abstracto, para exigir que en el reagrupante concurra una perspectiva fundada de obtener un derecho a la residencia permanente - art. 3.1-. El plazo de cinco años de residencia continuada que, a efectos prácticos, implica la introducción ex novo por la L.O 2/2009 de la exigencia de obtener la residencia de larga duración para poder reagrupar a los ascendientes, no encuentra acomodo en la Directiva comunitaria ${ }^{611}$ - que si bien es clara respecto a la salvaguarda de la facultad que tienen los EEMM para contemplar tratamientos internos más favorables, también lo es en la fijación de un tope mínimo de protección por debajo del cual los Estados no podrán introducir regulaciones más restrictivas-.

La única excepción que al respecto contempla la Directiva 2003/86 es la posibilidad de fijar un período de espera de tres años como máximo, siempre y cuando la legislación existente en el Estado miembro en la fecha de adopción de la Directiva 2003/86 tenga en cuenta su capacidad de acogida - art. 8.2-. Esta posibilidad excepcional no es aplicable al Estado Español, cuya legislación migratoria no ha contemplado nunca la capacidad de acogida - esto es, el establecimiento de cupos numéricos-. Por lo tanto, ni siquiera en su formulación más excepcional y restrictiva -fijación de un período de espera de tres años al reagrupante que, insistimos, resulta inaplicable en territorio español-, la Directiva no contempla la posibilidad de un período tan extenso como los cinco años de residencia regular y continuada que, con carácter general, el ordenamiento español exige al reagrupante para poder reunirse con sus ascendientes. Por ello, durante la tramitación de la ley se

609 ARAGÓN, Raquel. “La RF en la nueva LO 2/2009...”, op. cit., s.p.

610 Artículo 4.2 apartado a) de la Directiva 2003/86 sobre el derecho a la RF.

611 En similar términos críticos en torno a la violación de la Directiva comunitaria se expresan LABAYLE y PASCOUAU.

Conditions for Family Reunification under Strain, op. cit., p. 61. 
alzaron voces muy autorizadas que prevenían de esta incompatibilidad, aconsejando la supresión de este requisito $^{612}$. Pese a ello, la norma prosperó incluyendo una disposición que, a todas luces, resulta contraria al derecho comunitario vigente en materia de RF de extranjeros procedentes de terceros países.

En la regulación contenida en la LO 4/2000 se contemplaba la reagrupación de los ascendientes del residente extranjero, sin límite de grado, exigiéndoles dependencia económica respecto del reagrupante y la concurrencia de razones que justificasen la necesidad de autorizar su residencia en España. Su carácter progresista se reflejaba además en la posibilidad abierta de autorizar la reagrupación de cualquier otro familiar que no encajara en ninguno de los anteriores supuestos cónyuge, hijos menores o incapacitados, menores de dieciocho o incapaces respecto de los que el extranjero residente fuera su representante legal y ascendientes dependientes económicamente-, si bien dotando de discrecionalidad a la Administración pública, puesto que la ley exigía sin mayor determinación justificar la necesidad de autorizar su residencia en España por razones humanitarias -apartado e) del art. 17, en la versión primigenia de la LO 4/2000. Esta amplia previsión residual fue eliminada en la reforma legislativa que tuvo lugar poco después a su entrada en vigor, mediante la LO $8 / 2000^{613}$, sin que la misma haya hecho acto de aparición desde entonces.

En la actualidad, a raíz de la reforma realizada mediante la L.O. 2/2009, reminiscencias de dicho requisito han vuelto a hacer su aparición en el texto de la ley, que prevé la posibilidad excepcional de reagrupar a ascendientes menores de sesenta y cinco años "cuando concurran razones de carácter humanitario"614, siempre que se cumplan las demás condiciones establecidas. La especificación de cuándo se entiende que confluyen tales razones humanitarias ha corrido a cargo del Reglamento de extranjería ${ }^{615}$.

De otro lado, la introducción del tope de la edad para la reagrupación de los progenitores podía dar lugar a situaciones familiares muy complicadas y hasta paradójicas: cabe el supuesto de que, tras el cumplimiento de los requisitos pertinentes, uno de los progenitores del reagrupante pueda

612 Así lo recomendó el Consejo de Estado en el Dictamen emitido al Anteproyecto de ley de reforma de la LO 4/200, donde se afirma literalmente que "aunque no se imponga a los Estados miembros la reagrupación de los ascendientes, sí parece que, en caso de que se opte por aceptar tal posibilidad, deben respetarse las exigencias que la Directiva recoge en su capítulo IV y, en particular, cuando no se trata de una restricción relativa a los ascendientes reagrupables, sino de los requisitos exigibles al residente reagrupante (como es el de que la residencia legal previa exigida no supere los dos años). De acuerdo con ello, entiende el Consejo de Estado que debe suprimirse o modificarse la exigencia del artículo 18.1 proyectado, de que los ascendientes solamente podrán ser reagrupados a partir del momento en que el solicitante adquiera la residencia de larga duración”. Dictamen del Consejo de Estado al Anteproyecto de la Ley Orgánica de reforma de la Ley Orgánica 4/2000, de 11 de enero, sobre Derechos y Libertades de los Extranjeros en España y su Integración Social, aprobado el 25 de junio de 2009.

613 El Consejo de Estado, al estudiar el texto del Anteproyecto de Ley Orgánica de reforma de la Ley Orgánica 4/2000, de 11 de enero, sobre Derechos y Libertades de los Extranjeros en España y su Integración Social, estimó que la misma constituía "una verdadera válvula de inseguridad, dado lo indeterminado e indeterminable de ciertas relaciones de parentesco en ciertas culturas, especialmente del África subsahariana, en ámbitos donde no faltan situaciones coyunturales que permitan invocar razones humanitarias", de modo que su eliminación fue muy bien reicbida por esta institución. Apartado 11 del Dictamen 2606/2000, de 28 de Julio de 2000.

614 Artículo 17,1,d) de la L.O. 2/2009.

615 Sobre este aspecto, el artículo 53.e) del Reglamento vigente puntualiza que "se considerará que concurren razones humanitarias, entre otros casos, cuando el ascendiente conviviera con el reagrupante en el país de origen en el momento en que este último obtuvo su autorización; cuando el ascendiente sea incapaz y su tutela esté otorgada por la autoridad competente en el país de origen al extranjero residente o a su cónyuge o pareja reagrupada; o cuando el ascendiente no sea objetivamente capaz de proveer a sus propias necesidades. (...) Cuando el órgano competente para resolver el procedimiento tuviera dudas sobre la concurrencia de otra razón de excepción del requisito, elevará consulta previa a la Dirección General de Inmigración". 
acogerse a la RF por ser mayor de 65 años, quedando excluido su cónyuge o pareja por motivos exclusivamente de edad. En previsión de situaciones similares que pudieran producirse en la práctica, la LO 2/2009 permite reagrupar a ascendientes cuyas edades se sitúen por debajo de los sesenta y cinco años, siempre que concurran razones de carácter humanitario. El Reglamento ha concretado que se entenderán por razones humanitarias a tales efectos cuando el ascendiente del reagrupante, - o de su cónyuge o pareja-, sea cónyuge o pareja del otro ascendiente, siendo este último mayor de sesenta y cinco años. En estos casos, el Reglamento permite la presentación conjunta de las solicitudes de autorización de residencia por RF, puntualizando que la aplicación de la excepción del requisito de la edad respecto al ascendiente menor de sesenta y cinco años estará condicionada a que la autorización del otro ascendiente sea concedida ${ }^{616}$.

Si los ascendientes reagrupados desean a su vez ejercer el derecho de RF y traerse a España a sus propios familiares, están regidos por condiciones distintas a las que, con carácter general, rigen la llamada RF en cadena o en cascada ${ }^{617}$. Los ascendientes reagrupados sólo podrán ejercer la RF tras obtener la condición de residentes de larga duración y acreditar solvencia económica lo que, en la práctica, supone haber residido durante cinco años de forma continuada y disponer de medios económicos suficientes para su manutención y la de los familiares que pretendan reagrupar. Mientras que, con carácter general, para poder a su vez reagrupar a sus propios parientes, a los restantes familiares reagrupados en territorio español se les exige contar con una autorización de residencia y trabajo obtenida de forma independiente a la autorización del reagrupante - junto con el cumplimiento de los restantes requisitos legalmente establecidos-. Por idénticos motivos a los ya apuntados, el requisito de residencia de larga duración exigido a los ascendientes reagrupados para poder ejercer a su vez el derecho a la RF, no resulta compatible con la normativa comunitaria ${ }^{618}$.

Como situación excepcional, la ley permite el ejercicio de la RF a los ascendientes que han sido reagrupados en España cuando éstos tengan a su cargo hijos menores de edad, o hijos con discapacidad que no sean objetivamente capaces de proveer a sus propias necesidades debido a su estado de salud. En tales supuestos, se les permitirá reagruparse con sus hijos al amparo de las condiciones generales establecidas en el art. 17.2, sin necesidad de esperar a haber adquirido la residencia de larga duración - art 17.3 in fine-.

Dentro del capítulo de los ascendientes, merece mención aparte la situación de los ascendientes extranjeros de ciudadanos españoles, cuya anómala regulación venía heredada de la normativa previa $^{619}$. Con la LO 2/2009 se ha pretendido afrontar una de las situaciones más problemáticas que había planteado la entrada en vigor del Real Decreto 240/2007, de 16 de febrero, sobre entrada, libre circulación y residencia en España de ciudadanos de los Estados miembros de la Unión Europea y de otros Estados parte en el Acuerdo sobre el Espacio Económico Europeo ${ }^{620}$. Esta norma regula las con-

\section{Idem.}

617 Las condiciones generales a las que queda sujeta la RF realizada por parientes ya reagrupados, están fijadas en el artículo 17.2 de la L.O. 2/2009. Por su parte, las condiciones particulares que rigen la RF practicada por ascendientes ya reagrupados en territorio español, aparecen recogidas en el apartado siguiente de la misma disposición.

618 LABAYLE y PASCOUAU. Conditions for Family Reunification under Strain, op. cit., p. 61.

619 La redacción original de la LO 4/2000 contenía un apartado f) dentro del artículo 17 —familiares reagrupables-, incluyendo dentro de su ámbito de aplicación a "los familiares extranjeros de los españoles, a los que no les fuera de aplicación la normativa sobre entrada y permanencia en España de nacionales de Estados miembros de la Unión Europea”. Este apartado fue eliminado en la reforma operada mediante la LO 8/2000, siendo en su momento celebrada esta eliminación por el Consejo de Estado, quien estimaba que su previsión en la anterior versión de la ley "supone defraudar toda la política común in fieri por parte de la UE y anuncia futuros conflictos normativos". Dictamen del Consejo de Estado 2606/2000, op. cit., apartado 11. 
diciones para el ejercicio de los derechos de entrada, salida, libre circulación, estancia, residencia y trabajo en España por parte de los ciudadanos de otros Estados miembros de la Unión Europea y de los restantes Estados parte en el Acuerdo sobre el Espacio Económico Europeo. Como es bien sabido, la norma resulta aplicable también a los familiares de ciudadanos comunitarios o de otro Estado parte en el Acuerdo sobre el Espacio Económico Europeo, cuando le acompañen o se reúnan con él - y con independencia de cual sea la nacionalidad de dichos familiares-, estableciendo al efecto un régimen de RF más ventajoso que el aplicable para los extranjeros no comunitarios y sus familias.

El Real Decreto 240/2007 — modificado el 2 de julio de 2009-, obedecía a la necesidad de transposición interna de la Directiva 2004/38/CE, del Parlamento Europeo y del Consejo, relativa al derecho de los ciudadanos de la Unión y de los miembros de sus familias a circular y residir libremente en el territorio de los Estados miembros. La disposición final tercera de este Decreto modificaba el Reglamento de ejecución de la LO 4/2000 —aprobado por Real Decreto 2393/2004, de 30 de diciembre-, mediante la adición de dos nuevas disposiciones adicionales: la decimonovena y la vigésima. La Disposición adicional decimonovena estaba dirigida a facilitar la entrada y residencia de los familiares de ciudadanos de un Estado miembro de la Unión Europea o de otro Estado parte en el Acuerdo sobre el Espacio Económico Europeo, no incluidos en el ámbito de aplicación del Real Decreto 240/2007.

Por su parte, la disposición vigésima - la importante para nuestros efectos-, contenía la normativa aplicable a miembros de la familia de un ciudadano español que careciese de la nacionalidad de un Estado miembro de la Unión Europea o de un Estado parte en el Acuerdo sobre el Espacio Económico Europeo ${ }^{621}$. En su virtud, la RF de extranjeros no comunitarios que fueran ascendientes directos de ciudadano español o de su cónyuge, pasaba a regirse por el Reglamento de extranjería, quedando con ello excluidos del régimen comunitario, e insertados en el ámbito de aplicación más estricto establecido por el régimen general de extranjería. Se exceptuaban aquellos ascendientes de ciudadano español o los ascendientes del cónyuge de ciudadano español que fueran titulares de una tarjeta de familiar de residente comunitario en vigor o susceptible de ser renovada en marzo de 2007, fecha de la entrada en vigor del mencionado Real Decreto. Los restantes familiares de ciudadano español - cónyuge, pareja de hecho registrada, sus descendientes directos y los de su cónyuge o pareja registrada, siempre que fueran menores de veintiún años o mayores de dicha edad que vivan a su cargo, o incapaces ${ }^{622}$-, seguían amparados por el régimen comunitario.

La exclusión del régimen comunitario de los ascendientes directos de ciudadano español o de su cónyuge constituía una notable excepción al principio general contenido en el artículo 1.3 de la ley ${ }^{623}$ —en la redacción dada por la LO 2/2009-, que excluye a los nacionales de los Estados miembros de la Unión Europea de su ámbito de aplicación, salvo para aquellos aspectos que pudieran serles más favorables. De otro lado, no se alcanzaban a comprender las causas de dicha exclusión — de la que el Real Decreto, con una técnica jurídica muy deficiente y una redacción farragosa, no proporcionaba

$621 \mathrm{El}$ apartado segundo de la disposición adicional vigésima del Reglamento de extranjería, introducido por el Real Decreto 240/2007, tenía el siguiente tenor literal: "la reagrupación familiar de ascendientes directos de ciudadano español, o de su cónyuge, se regirá por lo previsto en la sección $2 .{ }^{\text {a }}$ del capítulo I del título IV del presente reglamento".

622 Párrafos a), b), c) y d) del apartado segundo de la Disposición adicional vigésima del Reglamento de extranjería, tras la modificación efectuada por el Real Decreto 240/2007.

623 Conforme prescribe el apartado tercero del artículo 1, "los nacionales de los Estados miembros de la Unión Europea y aquellos a quienes sea de aplicación el régimen comunitario se regirán por las normas que lo regulan, siéndoles de aplicación la presente ley en aquellos aspectos que pudieran ser más favorables". 
pistas en ningún momento ${ }^{624}$ - Sean cuales fueren las causas, lo cierto es que la misma implicaba un agravio comparativo con respecto al régimen aplicable a la reagrupación de ciudadanos comunitarios instalados en territorio español que quisieran reunirse en España con sus progenitores, cualquiera que fuera la nacionalidad de estos últimos. Para tales supuestos, al ciudadano español se le exigía el cumplimiento de los mismos y gravosos requisitos establecidos para que un extranjero no comunitario residente en España pudiese reagrupar a sus ascendientes no comunitarios, pues resultaba aplicable el régimen general de extranjería, a cuyo estudio dedicamos este capítulo. Con ello, quedaba seriamente en entredicho el principio de igualdad de trato entre ciudadanos españoles y el resto de los ciudadanos europeos, estando ambos amparados por el estatuto de la ciudadanía de la Unión.

Esta situación, calificada expresamente como discriminatoria por el Defensor del Pueblo ${ }^{625}$, y denunciada retiradamente por la doctrina ${ }^{626}$, llevó a varias organizaciones de defensa de derechos humanos, vinculadas algunas de ellas a la inmigración, a presentar un recurso contencioso-administrativo ante el Tribunal Supremo.

Entre tanto, la última reforma del marco legal de la extranjería y la inmigración —operada mediante la LO 2/2009_, vino a agravar notablemente dicha situación, como consecuencia del endurecimiento del régimen previsto para la reagrupación de los ascendientes. De modo que, con la entrada en vigor de la LO 2/2009, los ciudadanos españoles que pretendan traerse a España a sus progenitores extranjeros han visto como el régimen previo ha resultado todavía más restringido, estableciendo un tope mínimo y genérico de 65 años, inexistente antes de la reforma. El agravio comparativo resulta evidentemente mayor si la referencia comparativa se sitúa nuevamente con los ciudadanos comunitarios no españoles residentes en España, que se encuentren en la misma situación que sus homólogos españoles, y pretendan traerse a sus ascendientes a vivir con ellos en territorio español: el ciudadano español sólo podrá reagrupar, con carácter general, a sus ascendientes en primer grado - padres - siempre que éstos hayan cumplido ya los sesenta y cinco años, debiendo justificar que éstos dependen económicamente de él, así como la concurrencia de razones suficientes que justifiquen la necesidad de autorizar su residencia en España, y, adicionalmente, demostrar que tiene medios económicos suficientes y que dispone de una vivienda adecuada.

La solución prevista por la LO 2/2009 a esta problemática no deja de ser superficial, pues su disposición adicional segunda, - bajo el título de "RF de ciudadanos españoles respecto a sus familiares nacionales de terceros países" -, se limita a prever que para estos casos se podrán establecer por vía reglamentaria condiciones especiales más favorables, respecto de las previstas en esta Ley. Sin embargo su redacción es potestativa, con lo cual sería legítimo que el Reglamento no se ocupara de

624 Para un estudio analítico y crítico del Real Decreto 240/2007, véase ORTEGA GIMÉNEZ, Alfonso. "El Real Decreto 240/2007, de 16 de febrero: El nuevo régimen jurídico de los ciudadanos comunitarios en España”; en Anuario Meixcano de Derecho Internacional, vol X, 2010. pp. 519-537. Resultan especialmente recomendables las reflexiones contenidas en las pp. 534-536, donde el autor expone los múltiples interrogantes que deja sin resolver esta disposición, así como la oportunidad perdida por el legislador español para ofrecer un auténtico régimen preferente para los ciudadanos comunitarios.

625 Resolución de 28 de noviembre de 2007 del Defensor del Pueblo (No de expediente 07028086).

626 Vid, a modo de ejemplo, RAVETLLAT BALLESTÉ, Isaac. La reagrupación familiar, op, cit., pp. 19-21. PEÑA PÉREZ, Alejandro. "Estatus jurídico de los ascendientes en el actual régimen comunitario: especial referencia a los ascendientes de ciudadano español o de su cónyuge"; en Revista de derecho migratorio y extranjería, No. 22, 2009, pp. 83-106. PALOS NADA, Margarita. "La reagrupación familiar en el derecho español. Especial consideración de la situación jurídica de los ascendientes de españoles con posterioridad al RD 240/2007”; en BALADO RUIZGALLEGOS, Manuel (coord.). Inmigración, Estado y Derecho: perspectivas desde el siglo XXI. Madrid, Bosch, 2008, pp. 579-604. 
esta cuestión, con los inconvenientes prácticos que ello supondría. Por ello, la doctrina denunció el carácter técnicamente defectuoso de esta previsión, fundamentalmente como consecuencia de una redacción abierta y poco minuciosa, que debería haber abordado con mayor precisión una cuestión tan compleja como la reagrupación de los familiares extranjeros de ciudadanos españoles ${ }^{627}$.

Sin necesidad de que sobre este punto se pronunciara el retardado desarrollo reglamentario de la L.O. 2/2009, esta situación fue solucionada por vía jurisprudencial. El Real Decreto 240/2007 sobre entrada, libre circulación y residencia en España de ciudadanos de los Estados miembros de la U.E. y de otros Estados parte en el Acuerdo sobre el Espacio Económico Europeo, había sido recurrido ante el TS por la Federación de Asociaciones pro Inmigrantes en Andalucía «Andalucía ACOGE» y por la Asociación pro Derechos de Andalucía. El recurso fue resuelto mediante sentencia emitida el 1 de junio de $2010^{628}$. En ella el TS anuló varias expresiones contenidas en múltiples artículos que habían sido impugnados, afectando, entre otras, a la disposición adicional decimonovena ${ }^{629}$ y eliminando totalmente la controvertida disposición adicional vigésima.

Con ello, el TS determinaba la aplicación del régimen comunitario a los ascendientes extracomunitarios de ciudadanos españoles y de su cónyuge o pareja de hecho registrado. Sin embargo, la propia sentencia dejaba en situación de indefinición a los familiares que sí estaban cubiertos por el régimen comunitario y que aparecían contemplados - conjuntamente con los ascendientes-, dentro de la misma norma que había sido anulada en su totalidad por dicho tribunal. Concretamente, en esta situación se hallaban el cónyuge de ciudadano español, siempre que no hubiera recaído el acuerdo o la declaración de nulidad del vínculo matrimonial o divorcio ${ }^{630}$; la pareja con la que éste/a mantuviera una unión análoga a la conyugal inscrita en un registro público; los descendientes directos de español, y los de su cónyuge o pareja registrada; menores de veintiún años, mayores de dicha edad a su cargo, o incapaces; junto con los ascendientes de ciudadano español y de su cónyuge o pareja registrada que vivan a su cargo, y que ya hubieran obtenido la tarjeta de familiar de residente comunitario.

Las dificultades prácticas que conllevó la ejecución y aplicación de la doctrina contenida en la sentencia aludida del Tribunal Supremo, dieron pie a la publicación de unas instrucciones sobre su aplicación, emitidas en marzo del 2010 por la Secretaría de Estado de Inmigración y Emigración, adscrita al Ministerio de Trabajo e Inmigración ${ }^{631}$.

627 MOYA, David. "La reforma de la Ley de extranjería”, op. cit., p. 21. El autor denuncia la falta de detalle de la ley no solamente en este concreto aspecto, sino con carácter general en la regulación de otras cuestiones igualmente complejas que aborda la ley, entre las que destaca la protección de las víctimas del tráfico de personas, el padrón, el fraude en la obtención de autorizaciones y en el acceso a la nacionalidad, subrayando, dentro de ésta última, la regulación de los matrimonios de conveniencia.

628 Sentencia de 1 de junio de 2010, de la Sala Tercera del Tribunal Supremo, por la que se anulan varias expresiones de los artículos 2, 3, 4, 9 y 18 y disposición final tercera del Real Decreto 240/2007, de 16 de febrero. B.O.E. No 266, de 3 de noviembre de 2010.

629 La expresión "parentesco hasta segundo grado» contenida en el párrafo primero, apartado a) de la disposición adicional decimonovena del Real Decreto 2393/2004 fue anulada por el TS, así como también la Disposición Final Tercera, apartado dos (Disposición Adicional vigésima del Real Decreto 2393/2004, de 30 de diciembre).

630 La expresión "separación legal" también fue anulada por el TS. Con ello, la separación legal carecía de efectos en relación con la aplicación del régimen comunitario de extranjería al cónyuge extracomunitario, tanto de ciudadano comunitario como de ciudadano español.

631 Instrucción DGI/SGRJ/03/2010/ sobre aplicación de la sentencia del Tribunal Supremo, de 1 de junio de 2010, relativa a la anulación de varios apartados del Real Decreto 240/2007, de 16 de febrero, sobre entrada, libre circulación y residencia en España de ciudadanos de los Estados miembros de la Unión Europea y de otros Estados parte en el Acuerdo sobre el Espacio Económico Europeo. 
Finalmente, esta situación vino a ser regulada en la disposición vigésimo primera del Reglamento de extranjería actualmente vigente, bajo la rúbrica de "facilitación de la entrada y residencia de los familiares de ciudadano de un Estado miembro de la Unión Europea o de otro Estado parte en el Acuerdo sobre el Espacio Económico Europeo, no incluidos en el ámbito de aplicación del Real Decreto 240/2007". En esta disposición, el Reglamento contempla la posibilidad de expedir una autorización de residencia, o bien un visado de residencia por circunstancias excepcionales, a favor de aquellas personas que no quedaron contempladas dentro del ámbito de aplicación del artículo 2 del Real Decreto 240/2007, siempre que encajen en alguna de las siguientes circunstancias: Que se trate de la pareja extranjera con la que un ciudadano de la Unión mantiene una relación estable debidamente probada; o bien que, aun tratándose de otro familiar - tanto en línea directa como colateral, consanguínea o por afinidad-, en su país de procedencia, esté a cargo o viva con el ciudadano comunitario, o cuando por motivos graves de salud o discapacidad, sea estrictamente necesario que dicho ciudadano se haga cargo de su cuidado personal. En tales supuestos, el Reglamento obliga a las autoridades a "facilitar" la expedición bien sea de una autorización de residencia o bien de visado para residir por circunstancias excepcionales, tras examinar las pruebas presentadas para acreditar los extremos exigidos ${ }^{632}$, estableciendo que las denegaciones habrán de ser motivadas, tras estudiar detenidamente los vínculos personales alegados en la solicitud.

Con todo, el cambio operado a raíz de la sentencia emitida por el TS el 1 de junio de 2010 y su posterior formalización por vía reglamentaria, ha provocado, en la práctica, un "aumento alarmante" ${ }^{633}$ del número de inscripciones de parejas de hecho constituidas por ciudadanos comunitarios y extranjeros, en los registros municipales, como una vía presumiblemente fraudulenta para acceder a la tarjeta de residente de familiar comunitario.

Antes de finalizar el estudio del tratamiento normativo de los parientes reagrupables, conviene mencionar los mecanismos establecidos para demostrar la veracidad de los vínculos familiares a fin de poder acceder a la migración familiar. En esta materia, el Reglamento de extranjería, en la versión adoptada en abril del 2011, sigue la tónica previa y dominante en Europa, exigiendo - junto a copia del pasaporte o título de viaje en vigor del familiar a reagrupar-, copia de la documentación acreditativa de los vínculos de parentesco o de la existencia de la unión de hecho y, en su caso, de la dependencia legal y económica ${ }^{634}$. La parte más relevante es la posibilidad, aceptada por las auto-

632 A tales efectos, el Reglamento de extranjería establece que "las autoridades exigirán la presentación de acreditación, por parte de la autoridad competente del país de origen o procedencia, que certifique que está a cargo del ciudadano de la Unión o que vivía con él en ese país, o la prueba de la existencia de motivos graves de salud o discapacidad que requieran estrictamente que el ciudadano de la Unión se haga cargo del cuidado personal del miembro de la familia. Igualmente se exigirá prueba suficiente de la existencia de una relación estable con el ciudadano de la Unión" (disposición adicional vigésimo tercera).

633 Así era calificado el incremento espectacular producido en el número de parejas de hecho mixtas inscritas en los diversos ayuntamientos de nuestro país desde que, a partir del año 2010, a raíz de la sentencia del TS, se permitiera tal inscripción como medio para acceder a la tarjeta de residente de familiar comunitario. En un artículo recientemente publicado en El País se da cuenta de esta situación, explicando que la Secretaría General de Inmigración y Emigración dictó una nota interna, instando a las Delegaciones del Gobierno y a las Subdelegaciones a comunicar a las Brigadas de extranjería las sospechas de fraude de cualquier anotación de parejas de hecho, paralizando el expediente. En dicha nota interna se afirma textualmente que "en el caso de que existan sospechas razonables de la existencia de un presunto abuso, fraude o irregularidad (por ejemplo, dudas de si el matrimonio se ha disuelto o anulado, sospecha de que el familiar se ha ausentado del territorio español por un período superior a seis meses en un año (...) la Oficina de Extranjería no expedirá al familiar de ciudadano de la Unión la tarjeta de residencia permanente, tras verificar la duración de la residencia, hasta que no queden acreditados fehacientemente los requisitos establecidos".

"El Gobierno pone bajo vigilancia las uniones de hecho de inmigrantes", El País, 1 de mayo de 2012.

634 Artículo 56.3.b) del Reglamento de extranjería vigente. 
ridades migratorias, de suministrar pruebas de los vínculos familiares mediante test de ADN, a los que se suele recurrir cuando está en juego la reagrupación de menores procedentes de países donde no esté generalizado que éstos sean registrados en el momento del nacimiento. En tales supuestos, el certificado de registro, - emitido con posterioridad al nacimiento y con ocasión de solicitudes de RF-, solía ser objeto de muchos recelos ${ }^{635}$. A fin de cubrir tales supuestos, desde al año 2006 se admiten las pruebas genéticas que, aun sin estar contempladas en la norma, resultan una práctica consular habitual a efectos de comprobar los lazos de parentesco en el ámbito de la migración familiar ${ }^{636}$, corriendo con los gastos de su realización los solicitantes extranjeros ${ }^{637}$.

\subsection{La protección de los vínculos creados en el Estado de acogida: La figura del arraigo}

Del tratamiento normativo que la LO 2/2009 y su Reglamento de ejecución otorgan a los familiares reagrupables, se extrae una regulación que se acomoda a los estándares comunitarios — salvo lo relativo al excesivo período de espera exigido, con carácter general, para poder reagrupar a los ascendientes y para que estos a su vez puedan reagrupar a sus parientes. Cabría también concluir que los parientes objeto de reagrupación son contemplados desde la perspectiva de personas extranjeras que se encuentran residiendo fuera de las fronteras españolas ${ }^{638}$ quienes, a través de la RF, obtendrían un visado y una autorización de residencia que les habilitaría para entrar y permanecer legalmente en territorio español, a fin de reunirse con el reagrupante. Este enfoque -en línea de principio coherente con lo establecido en el artículo 5.3 de la Directiva 2003/86 ${ }^{639}$ - determina la priorización, en el derecho español, de la denominada RF en sentido estricto. La compatibilidad de esta situación con el régimen tendente a la equiparación entre los distintos tipos de migración familiar que se desprende de la reciente doctrina emitida por el TJUE en el asunto Chakroun —así como, con mayor contundencia, de la jurisprudencia emitida por el Tribunal de Estrasburgo a partir de la sentencia Rodrigues da Silva- suscita serias dudas.

Para los supuestos en los que los parientes se encuentren ya en territorio español, el ordenamiento español prevé la figura, contemplada con carácter excepcional, del arraigo ${ }^{640}$ —cuya impor-

635 La admisión de tales pruebas y los problemas que planteaban los países de origen donde — como es el caso de República Dominicana- los progenitores no registran a sus hijos al nacer, han sido extraídos del estudio comparativo realizado por PASCOUAU y LABAYLE. Conditions for Family Reunification under Strain, op. cit., p. 41.

636 Para un estudio en profundidad de las pruebas de AND en las solicitudes de RF vid el completo análisis efectuado por SPINA, Encarnación "Singularidades y retos normativos en el control genético de la inmigración familiar hacia España, Italia y Portugal”; en Cuadernos Electrónicos de Filosofía del Derecho, no 21, 2010, pp. 105-132. Para una perspectiva más amplia de esta cuestión vid TAITZ, J.; WEEKERS, E.M., MOSCA, D.T. “The last resort: exploring the use of DNA testing for Family reunification"; Health and Human Rights, vol. 6, n.1, 2002, pp. 21-32.

$637 \mathrm{Al}$ respecto, PASCOUAU y LABAYLE puntualizan que el coste de unas pruebas de AND en España ronda los 300 euros aproximadamente, circunstancia que "puede constituir una carga financiera significativa" para los solicitantes. Conditions for Family Reunification..., op. cit., p. 43.

638 En el mismo sentido, RAVETLLAT BALLESTÉ, I. La reagrupación familiar, op. cit., p. 29. El autor llegaba a esta conclusión al analizar el texto del artículo 17 LO 4/2000, en la versión vigente con anterioridad a la última reforma, en conjunción con lo previsto en el art. 39 del Real Decreto 2393/2004, de 30 de diciembre. También PASCOUAU y LABAYLE, op. cit., p. 53.

639 A la misma interpretación llegan SERRANO VILLAMANTA, J.; ALONSO HEDROSA, G; LORA-TAMAYO, G; HERNÁNDEZ DE LA ORDEN, M.J y MARTÍNEZ RODRIGO, A. “La reagrupación familiar”, op. cit., p. 10. LABAYLE y PASCOUAU. Conditions for Family Reunification under Strain, op. cit., p. 54.

640 La figura del arraigo que, pese a su previsión excepcional, ha revestido una gran importancia práctica, se contempla con carácter general en el artículo 31.1 de la L.O. 2/2009, en sede de los distintos tipos de autorizaciones que dan lugar a la residencia de carácter temporal en España. Dicha disposición habilita a la Administración para "conceder una 
tancia práctica es muy destacada, al menos en lo que respecta al arraigo social—. El arraigo posibilita que el extranjero, en situación previa de irregularidad, acceda a una autorización de residencia de carácter temporal y por circunstancias excepcionales, sin exigírsele el visado. Con ello, esta figura viene a ser el correlato de la ya extinta exención de visado. Pese a su carácter residual, constituye en la práctica la figura que da lugar a un mayor número de regularizaciones de extranjeros asentados.

La regulación detallada del arraigo corresponde al Reglamento ${ }^{641}$ que, en su versión actual, sigue, en esencia, la línea previamente existente. Cabría, sin embargo, destacar dos importantes novedades del nuevo texto del Reglamento. En primer lugar, se ha introducido la figura del arraigo familiar. Su penetración en nuestro ordenamiento obedece - como señala la propia exposición de motivos - a las exigencias de la doctrina mantenida por el TJUE y los tribunales españoles. Aunque no se menciona la doctrina del TEDH, ya señalamos que, a partir de Rodrigues da Silva y hasta la actualidad, el Tribunal de Estrasburgo contempla la posibilidad de regularizar - mediante el acceso al derecho a la RF-, a progenitores extranjeros con hijos menores nacidos en el territorio del Estado parte de acogida, en las circunstancias ya precisadas al estudiar su jurisprudencia. En segundo lugar, el Reglamento ha reducido el período de relación laboral exigido a efectos de acceder y poder acreditar el arraigo laboral.

En consecuencia, el arraigo, en su regulación actual, abarca tres figuras distintas, dirigidas todas ellas a la protección de los diversos vínculos creados por los extranjeros en territorio español, aun cuando los mismos hayan sido originados en situación de irregularidad administrativa. Incluye el arraigo familiar, social y laboral.

El arraigo familiar ${ }^{642}$ cubre a extranjeros que sean padre o madre de un menor que cuente con nacionalidad española. Para poder acceder al arraigo familiar, el extranjero solicitante debe estar a cargo del menor y convivir con él, o bien, aun en ausencia de convivencia, encontrarse al corriente de sus obligaciones paternofiliales. También ampara a los hijos de progenitores que originariamente hayan sido españoles.

De mayor importancia tanto cualitativa, como a efectos de nuestro estudio, es el arraigo social, que permite acceder a una autorización temporal de residencia a aquellos extranjeros que acrediten la permanencia continuada en España durante un periodo mínimo de tres años. Para poder ampararse en el arraigo social, el extranjero ha de cumplir con tres requisitos acumulativos: carecer de antecedentes penales - tanto en España, como en su país de origen o en un tercer país en el que previamente haya vivido-; contar, en el momento de la solicitud, con un contrato de trabajo firmado por el trabajador y el empresario para un periodo temporal no inferior a un año; y tener vínculos familiares con otros extranjeros residentes o, en su defecto, presentar un informe de arraigo que acredite su integración social. El arraigo social contempla un concepto de vínculos familiares más estricto que el núcleo de parientes amparados por el derecho a la RF. De este modo, el arraigo social

autorización de residencia temporal por situación de arraigo, así como por razones humanitarias, de colaboración con la Justicia u otras circunstancias excepcionales que se determinen reglamentariamente. En estos supuestos no será exigible el visado".

641 Capítulo I del Título V del Reglamento de 20 de abril de 2011, concretamente los artículos 123 a 130; A efectos de la acreditación de arraigo social, el artículo 128.2.b) del Reglamento exige "presentar documentación acreditativa del grado de parentesco alegado o, en su caso, el correspondiente informe de arraigo. Igualmente, en caso de solicitarse la exención de la necesidad de contar con un contrato de trabajo, se deberá presentar documentación acreditativa de contar con medios económicos suficientes o, en su caso, del cumplimiento de los requisitos previstos en relación con la actividad por cuenta propia”.

642 El arraigo familiar está regulado en el artículo 124.3 del Reglamento de extranjería vigente. 
protege exclusivamente a los cónyuges o parejas de hecho registradas, ascendientes y descendientes en primer grado y línea directa.

La tercera figura incluida dentro del arraigo, es el de carácter laboral ${ }^{643}$. El arraigo laboral permite obtener una autorización de residencia temporal a aquellos extranjeros que acrediten permanencia continuada en España durante un periodo mínimo de dos años. Los requisitos, establecidos reglamentariamente, consiste en carecer de antecedentes penales y demostrar la existencia de relaciones laborales con una duración mínima de seis meses.

A efectos de la concesión del arraigo, en sus distintas modalidades, la ley exige con carácter previo que las Comunidades Autónomas o los Ayuntamientos emitan un informe sobre la integración social del extranjero con domicilio habitual en su territorio ${ }^{644}$. Los criterios que la autoridad ha de tomar en consideración en la emisión de dicho informe constituyen una penetración parcial - $\mathrm{y}$ liberal - de la doctrina del TEDH, incluyendo "el período de permanencia, la posibilidad de contar con vivienda y medios de vida, los vínculos con familiares residentes en España, y los esfuerzos de integración a través del seguimiento de programas de inserción sociolaborales y culturales". Destaca fundamentalmente el peso destacado del test de integración en territorio español sin que simultáneamente se considere los vínculos existentes con el país de origen, así como la ausencia total del test de los obstáculos y la inclusión del test de responsabilidad a favor del inmigrante mediante la valoración de los esfuerzos de integración realizados por el inmigrante.

Recientemente los medios de comunicación han especulado sobre la posibilidad de que el gobierno estudie eliminar la figura del arraigo social y laboral ${ }^{645}$, por fomentar la inmigración irregular. En lo que afecta a nuestro ámbito de estudio, la supresión del arraigo social, de llegar a materializarse, daría lugar a una situación incompatible con los estándares internacionales vigentes, concretamente de los derivados de la jurisprudencia del TEDH. Por su parte, el arraigo familiar ha quedado blindado en virtud de la doctrina emitida por el $\mathrm{TJUE}^{646}$ - a la que alude explícitamente la exposición de motivos del actual Reglamento de extranjería, al justificar su introducción-y, en nuestra opinión, también está avalado por la jurisprudencia del TEDH.

\subsection{Requisitos y efectos de la reagrupación familiar}

La L.O. 2/2009 ha introducido importantes modificaciones, la mayor parte de ellas de carácter liberal, en el régimen jurídico de los familiares que han obtenido una autorización de residencia por

643 Artículo 124.1 del Reglamento de 30 de abril de 2011.

644 Artículo 68.3 L.O. 2/2009, desarrollado, —en lo que respecta a la acreditación del arraigo social—, en el artículo 124.2 in fine del Reglamento, conforme al cual, dicho informe "deberá ser emitido y notificado al interesado en el plazo máximo de treinta días desde su solicitud, en éste deberá constar, entre otros factores de arraigo que puedan acreditarse por las diferentes Administraciones competentes, el tiempo de permanencia del interesado en su domicilio habitual, en el que deberá estar empadronado, los medios económicos con los que cuente, los vínculos con familiares residentes en España, y los esfuerzos de integración a través del seguimiento de programas de inserción sociolaborales y culturales. Simultáneamente y por medios electrónicos, la Comunidad Autónoma deberá dar traslado del informe a la Oficina de Extranjería competente".

645 El 25 de noviembre de 2001, el Diario El País publicó al respecto una noticia titulada "el Partido Popular planea eliminar la regulación de inmigrantes por arraigo social o laboral”.

646 Vid, Asunto C-127/08 Blaise Baheten Metock y otros contra Minister for Justice, Equality and Law Reform, sentencia de 25 de Julio de 2008 y el asunto C-34/09, Gerardo Ruiz Zambrano contra Office national de l'emploi, sentencia de 8 de marzo 2011. 
causa de RF. En conjunto, el espíritu de la reforma en este punto aspira a dotar a los reagrupados de condiciones de mayor autonomía, a fin de facilitar su integración en territorio español.

Una de las novedades más destacadas y aplaudidas de la última reforma reside en que la autorización de residencia por RF concedida al cónyuge e hijos reagrupados que hayan alcanzado la edad laboral, habilitará para trabajar sin necesidad de ningún otro trámite administrativo ${ }^{647}$. Esta medida pretende favorecer la integración de los familiares reagrupados en España, en coherencia con la concepción del acceso al empleo como uno de los factores principales de integración de los inmigrantes, establecida así explícitamente en el apartado segundo in fine del artículo 2 ter -introducido ex novo por la L.O. 2/2009 y dedicado íntegramente a contemplar la integración de los inmigrantes. La anterior exigencia de solicitar autorización para trabajar, que pesaba sobre el cónyuge e hijos reagrupados, queda eliminada $-\mathrm{y}$, consecuentemente, los artículos 41.6 y 96 del Reglamento 2393/2004, de 30 de diciembre, quedaron derogados con la entrada en vigor de la L.O. 2/2009 por contradicción con lo establecido en el art. 19.1 de dicha norma - procediendo a dárseles de alta en la Seguridad Social ${ }^{648}$.

La equiparación entre cónyuge y relación análoga a la sentimental a efectos de RF, supone que, tanto la pareja de hecho del reagrupante como los hijos de éstos podrán incorporarse también de forma automática al mercado laboral español, sin necesidad de realizar ningún trámite administrativo $^{649}$.

Junto a esta importante cuestión, la última reforma legislativa ha dotado de un tratamiento más generoso a la adquisición de residencia autónoma por parte tanto del cónyuge del reagrupado como de sus hijos ${ }^{650}$. En todos los supuestos de adquisición de residencia independiente por parte de los parientes reagrupados, su duración concreta dependerá del tiempo previo de vigencia de la situación de residencia por RF, fijándose por vía reglamentaria una vigencia mínima de un año ${ }^{651}$.

Respecto del cónyuge reagrupado - y, por extensión, también de la pareja de hecho-, se prevé que pueda obtener una autorización de residencia independiente cuando disponga de medios económicos suficientes para cubrir sus propias necesidades. Esta exigencia constituye una mejora significativa respecto a la situación previamente vigente, que subordinaba la adquisición de un estatus independiente por parte del cónyuge reagrupado a la previa obtención de una autorización administrativa para trabajar.

La ley especifica que corresponderá al desarrollo reglamentario la determinación de la forma y la cuantía de los medios económicos considerados suficientes para que los familiares reagrupados

647 El artículo 19.1, en la redacción dada por la LO 2/2009, afirma literalmente que: "La autorización de residencia por reagrupación familiar de la que sean titulares el cónyuge e hijos reagrupados cuando alcancen la edad laboral, habilitará para trabajar sin necesidad de ningún otro trámite administrativo”. El desarrollo reglamentario puntualiza al respecto que la autorización de residencia por RF habilita al cónyuge, pareja de hecho o hijos reagrupados "para trabajar por cuenta ajena o por cuenta propia, en cualquier parte del territorio español, ocupación o sector de actividad" (artículo 58.4 del Reglamento de 30 de abril de 2011).

648 Raquel Aragón indagó en su momento sobre las vertientes prácticas que la reforma introducida por la L.O. 2/2009 implicó sobre la migración familiar, obteniendo para ello el auxilio del responsable de RF de la Subdelegación del gobierno de Valencia. A partir de la reforma, la policía hubo de incluir en las tarjetas de RF la inscripción "habilita a trabajar". ARAGÓN, Raquel. "La RF en la LO 2/2009, de 11 de diciembre, de Reforma de la LO 4/2000 de 11 de enero", op. cit., sp.

649 Idem.

650 Apartados 2 y 3, respectivamente, del artículo 19, redactado conforme a la L.O. 2/2009.

651 Artículo 59.6 del Reglamento de desarrollo de la L.O. 2/2009, aprobado el 30 de abril de 2011. 
puedan obtener una autorización independiente ${ }^{652}$. En el período intermedio entre la entrada en vigor de la L.O. 2/2009 y la publicación de su reglamento de ejecución, la reforma se tradujo en la posibilidad a favor del cónyuge del reagrupante o de su pareja de hecho, de obtener la autorización de residencia independiente cuando acreditase uno de los siguientes extremos ${ }^{633}$ : medios de vida suficientes - equivalentes a los exigidos para una autorización temporal de residencia, de carácter no lucrativo-; o bien el alta en la seguridad social y un contrato laboral de un año que prevea una atribución salarial igual o superior al salario mínimo interpreprofesional en catorce pagas; y, finalmente, aportar el alta en la seguridad social.

La reforma reglamentaria de abril de 2011 vino a clarificar esta cuestión, especificando los requisitos exigidos para que el cónyuge o pareja reagrupado obtuviesen una autorización de residencia y trabajo independiente ${ }^{654}$. A tales efectos, se les exige contar con medios económicos suficientes para la concesión de una autorización de residencia temporal no lucrativa o, en su defecto, contar con uno o varios contratos de trabajo de duración mínima de un año - de los que se derive una retribución no inferior al salario mínimo interprofesional-, pudiendo también acceder al estatus independiente cuando cumplan los requisitos exigibles para la concesión de una autorización de residencia temporal y trabajo por cuenta propia. Junto a los tres requisitos mencionados, de carácter excluyente, se exige también que el cónyuge o pareja de hecho reagrupado no tenga deudas con la Administración tributaria o de Seguridad social. A estos supuestos, habría que añadirle las causas habituales de acceso a un estatuto independiente: por ruptura del vínculo que dio origen a la situación de residencia, o bien por causa de muerte del reagrupante. La ruptura del vínculo conyugal ha de ser por separación de derecho o divorcio, equiparándose a tal supuesto la finalización de la vida en pareja - y subsiguiente cancelación de la inscripción, para parejas registradas-, siempre que en estos casos se acredite haber convivido en España con el cónyuge o pareja reagrupante durante al menos dos años.

La ley prevé un supuesto de adquisición automática de residencia independiente para "la cónyuge reagrupada" - en femenino, mientras que con anterioridad a la reforma se utilizaba el término neutro de cónyuge-, cuando ésta haya sufrido violencia de género y sin necesidad de cumplir con los requisitos generales ${ }^{655}$. La LO 2/2009 ha flexibilizado las exigencias, permitiendo la obtención de autorización de residencia y trabajo independiente desde el momento en que se haya dictado a favor de la cónyuge reagrupada tanto una orden de protección ${ }^{656}$ — como preveía la legislación previa$\mathrm{o}$, en su defecto, bastando el informe del Ministerio Fiscal que indique la existencia de indicios de violencia de género - inciso introducido por la última reforma-. Dentro del término "la cónyuge", habrá de entenderse incluida también a la pareja de hecho femenina que mantenga una relación estable con el reagrupante y sea víctima de violencia de género.

Sin embargo, con la reforma legal han quedando excluidos los supuestos - estadísticamente más excepcionales pero también posibles-, del esposo o pareja de hecho masculina de la residente extranjera víctimas de violencia doméstica — que, al menos por lo que respecta a la relación matrimonial, quedaban amparados por la redacción previa a la LO 2/2009. Sobre este aspecto, el Re-

652 Artículo 19.4 de la L.O. 2/2009.

653 Los datos han sido extraidos del estudio realizado por ARAGÓN, Raquel. "La RF en la nueva LO 2/2009...”, op. cit., s.p.

654 El artículo 59 del Reglamento de extranjería contempla la residencia independiente de los familiares reagrupados. 655 Art. 19.2 in fine, en la redacción correspondiente a la L.O. 2/2009.

$656 \mathrm{El}$ art. 544 ter de la Ley de Enjuiciamiento Criminal regula las órdenes de protección dictadas a favor de las víctimas de violencia doméstica. 
glamento de extranjería se ha pronunciado en sentido expansivo pues, al concretar la autorización independiente a favor de las víctimas de violencia de género, utiliza el término neutro de "cónyuge o pareja reagrupado" - sin restringirlo al sexo femenino-, y, asimismo, amplifica la cobertura protectora tutelando a los mismos destinatarios cuando sean víctimas de un delito por conductas violentas ejercidas en el entorno familiar. En consecuencia, con el Reglamento quedan amparados tanto el cónyuge como la pareja de hecho del reagrupante, con independencia del sexo, frente a las conductas delictivas de carácter violento ejercidas en entorno doméstico —encajen éstas o no en el delito de violencia de género-, habilitándoles para acceder a un estatuto autónomo.

Por su parte, los hijos reagrupados podrán acceder a un estatus independiente cuando alcancen la mayoría de edad y dispongan de medios económicos suficientes para atender a sus propias necesidades ${ }^{657}$. A nivel práctico, queda también eliminada la necesidad previa de obtener una autorización para trabajar y, - respecto a la acreditación de medios económicos suficientes-, ésta tendrá lugar cuando el hijo adulto encaje en alguno de los tres supuestos previamente mencionados, aplicables a los mismos efectos para el cónyuge o pareja reagrupada. En la misma situación se incluyen los menores reagrupados sobre los que el sponsor ostente la representación legal. Por vía reglamentaria, se ha ampliado la cobertura protectora ofrecida por la ley, estableciéndose que también obtendrán una autorización de residencia independiente los hijos y representados del reagrupante al alcanzar la mayoría de edad, siempre que hayan residido en España durante cinco años.

Los ascendientes reagrupados en España quedan sujetos a condiciones más exigentes para la obtención de la residencia independiente. Ésta sólo será posible, cuando previamente hayan obtenido una autorización para trabajar. El Reglamento puntualiza que los efectos de dicha autorización de residencia independiente quedan supeditados a las exigencias legales. Se trata de un recordatorio de los onerosos requisitos que pesan sobre los ascendientes reagrupados para poder, a su vez, ejercer el derecho a reagrupar a sus propios parientes: para ello han de adquirir previamente la residencia de larga duración - tras cinco años de residencia continuada en España-, y acreditar solvencia económica.

A fin de evitar situaciones de desamparo - y en consonancia con las exigencias comunitarias-, la muerte del reagrupante sigue constituyendo causa de adquisición de la autorización de residencia independiente por parte de los familiares que hubieran sido reagrupados en España ${ }^{658}$. La ley establece que las condiciones en qué esta se otorgará habrán de ser determinadas reglamentariamente pero, sobre este aspecto, guarda silencio el reglamento.

En cuanto a los requisitos de carácter material exigidos para poder reagrupar a sus familiares, el reagrupante debe acreditar que dispone de vivienda adecuada y medios económicos suficientes para cubrir sus necesidades y las de su familia una vez reagrupada ${ }^{659}$. Los términos concretos de ambos extremos quedan delegados al desarrollo reglamentario. Si bien, a renglón seguido, el nuevo texto

657 Apartado tercero del artículo 19 de la L.O. 2/2009, desarrollado por el apartado cuarto del artículo 59 del Reglamento de extranjería, reformado el 30 de abril de 2011.

658 Artículo 19.5 de la L.O. 2/2009.

659 Art. 18.2 en la redacción correspondiente a la LO 2/2009. Su desarrollo reglamentario, extremadamente detallado, corresponde al artículo 55, bajo el título "requisito sobre vivienda adecuada a acreditar por un extranjero para la obtención de una autorización de residencia por reagrupación a favor de sus familiares". A su vez, esta última disposición ha sido concretada mediante la Instrucción de DGI/SGRJ/4/2011, sobre aplicación del Reglamento de la Ley Orgánica 4/2000, sobre derechos y libertades de los extranjeros en España y su integración social, en materia de acreditación de la disposición de vivienda adecuada en procedimientos sobre residencia por reagrupación familiar. En dicha instrucción — a cuya lectura remitimos—, se detallan los requisitos diferenciados exigibles, en función de si se trata de una autorización de residencia por causa de RF de carácter inicial, o de una renovación. 
de la ley contiene dos nuevas e importantes especificaciones: de un lado, en el cómputo de medios económicos no podrán incluirse aquellos procedentes del sistema de asistencia social, en perfecta consonancia con la sentencia del TJUE en el asunto Chakroun; de otro, el informe sobre la adecuación de la vivienda corresponderá a las Comunidades Autónomas o, en su caso, a los Ayuntamientos - art 18.2 in fine-, de forma indistinta. La acreditación de estos extremos mediante acta notarial, - muy habitual en los supuestos prácticos en los que se producían demoras en los informes bien sea del Ayuntamiento o de las CCAA—, se entiende vigente ${ }^{660}$.

La situación es, pese a los cambios de redacción efectuados por la LO 2/2009, idéntica a la vigente con anterioridad: en vez de vivienda adecuada, la ley hablaba de "alojamiento adecuado" y empleaba el término "medios de subsistencia suficientes" ${ }^{661}$ —en lugar del de medios económicos suficientes utilizado actualmente por la ley vigente-. Lo que si constituye una novedad introducida en la última reforma, es la previsión que los ingresos provenientes del sistema de asistencia social, no computarán en la valoración de los ingresos exigidos a efectos de la RF, teniéndose en cuenta, sin embargo, otros ingresos aportados por el cónyuge que resida en España y conviva con el reagrupante en dicho cómputo ${ }^{662}$.

Asimismo, para dar respuesta a un problema denunciado desde diversas instancias sociales, el nuevo texto legal exige coordinación entre la Administración receptora de solicitudes de RF que afecten a menores en edad de escolarización y las autoridades educativas competentes, de modo que las primeras deberán comunicar a las segundas una previsión sobre los procedimientos de RF iniciados, a fin de que se puedan habilitar las plazas necesarias en los centros escolares correspondientes ${ }^{663}$. Con ello se pretende evitar la descoordinación previa, con menores extranjeros siendo incorporados al sistema escolar a lo largo de todo el curso académico, con los problemas de readaptación en las aulas que ello provocaba.

En definitiva, el ordenamiento español recientemente modificado, tanto por vía legal como reglamentaria, se mueve cómodamente dentro de los amplios márgenes de actuación permitidos por la Directiva. Con carácter general, presenta luces y sombras. La inclusión de la protección de la pareja de hecho del reagrupante dentro de los parientes reagrupables supone una adaptación al carácter abierto y liberal de familia que mantiene el TEDH, solventando al mismo tiempo problemas de contradicción que, con la anterior normativa, emergían respecto a asentada jurisprudencia del $\mathrm{TC}^{664}$. De

660 ARAGÓN, Raquel. “La RF en la nueva LO 2/2009...”, op. cit., sp.

$661 \mathrm{El}$ anterior término de "medios de subsistencia”, podría interpretarse como un concepto más genérico donde cabría englobar medios de naturaleza económica junto con otros que, aun no implicando liquidez económica inmediata, fueran susceptibles de ser convertidos en tales, como por ejemplo la propiedad de bienes inmuebles.

662 Artículo 18.2 de la L.O. 2/2009.

663 Artículo 18.3 de la L.O. 2/2009.

664 Vid, entre otras, STC 222/1992, de 11 de diciembre; STC 6/1993, de 18 de enero; STC 47/1993, de 8 de febrero. Especialmente destacable resulta la STC 222/1992 donde el alto tribunal, - a propósito de una cuestión de inconstitucionalidad motivada en torno al artículo 58.1 de la Ley de Arrendamientos Urbanos, que excluía a las parejas de hecho del derecho a la subrogación en el alquiler de la vivienda urbana-, señaló que: "Nuestra Constitución no ha identificado la familia a la que manda proteger con la que tiene su origen en el matrimonio, conclusión que se impone no sólo por la regulación bien diferenciada de una institución y otra (arts. 32 y 39), sino también, junto a ello, por el mismo sentido amparador o tuitivo con el que la Norma fundamental considera siempre a la familia y, en especial, en el repetido art. 39, protección que responde a imperativos ligados al carácter «social» de nuestro Estado (arts. 1.1 y 9.2) y a la atención, por consiguiente, de la realidad efectiva de los modos de convivencia que en la sociedad se expresen. El sentido de estas normas constitucionales no se concilia, por tanto, con la constricción del concepto de familia a la de origen matrimonial, por relevante que sea en nuestra cultura -en los valores y en la realidad de los comportamientos sociales- esa modalidad de vida familiar. Existen otras junto a ella, como corresponde a una sociedad plural, y ello impide interpretar en tales términos restrictivos una norma 
otro lado, la mayor obstaculización a la reagrupación de los ascendientes, si bien siendo en principio compatible con la jurisprudencia de Estrasburgo — que, hasta el momento, no ha tenido ocasión de analizar demandas en torno a la RF que impliquen a ascendientes-, provoca problemas de encaje con las disposiciones comunitarias, concretamente en lo relativo al excesivo plazo de espera previsto tanto para que el reagrupante pueda reunirse con sus ascendientes como para que éstos, a su vez, puedan ejercer el mismo derecho con respecto a sus propios parientes.

\section{EL PODER JUDICIAL ANTE EL DERECHO A LA RF: BREVE RESEÑA JURISPRUDENCIAL}

En el examen del tratamiento que el poder judicial ha otorgado a la RF así como de la influencia de la vida familiar del extranjero para su concesión, seguiremos las dos etapas que señalamos en su momento al recorrer el marco normativo de esta figura - separadas por la entrada en vigor de la LO 4/2000, coincidiendo con la llegada del nuevo siglo-. Por razones fundamentalmente de espacio, el análisis se limitará a realizar un rápido itinerario por las sentencias más importantes dictadas en nuestro ámbito de estudio.

Como apuntamos en su momento, la primera norma legal postconstitucional que expresamente contemplaba los derechos de los extranjeros en España - L.O. 7/85- y su correspondiente desarrollo reglamentario, estaban dotados de un tenor fuertemente restrictivo y discrecional. El sistema migratorio se edificaba sobre la premisa de la obligatoriedad del visado como instrumento discrecional en manos de la Administración, a fin de controlar con carácter previo los flujos migratorios. El ordenamiento jurídico no precisaba las causas que determinaban su concesión o denegación y, a mayor abundamiento, su denegación no necesitaba ser motivada ${ }^{665}$. De otro lado, el visado ejercía una influencia condicionante de primer orden, en tanto abría la puerta a la posterior concesión de un permiso de residencia y de trabajo. En consecuencia, el punto de partida residía en la existencia de una normativa que dificultaba el control judicial de los actos administrativos en materia de extranjería y de inmigración, situación reforzada por unas prácticas que subrayaban aún más la discrecionalidad ${ }^{666}$ - acusadamente en lo que respecta a la exención de visado, en tanto la misma se preveía con carácter excepcional一.

Pese a todo lo dicho, existe una copiosa jurisprudencia protectora de los derechos de los inmigrantes, derivada de la aplicación e interpretación de la LO 7/85 y sus dos reglamentos de ejecución - cuyos criterios no fueron incluidos sin embargo en la exposición de motivos de la LO 8/2000, de 22 de diciembre, de reforma de la LO 4/2000- La aproximación de la jurisprudencia ordinaria — con el Tribunal Supremo a la cabeza ${ }^{667}$ - al derecho a la RF y a la extranjería en general, destaca por el carácter generalmente progresista, extensivo y abierto de sus pronunciamientos. Incluso cabe afirmar que el TS ha sido pionero en el reconocimiento de ciertos derechos de los extranjeros que

como la que se contiene en el art. 39.1, cuyo alcance, por lo demás, ha de ser comprendido también a la luz de lo dispuesto en los apartados 2 y 3 del mismo artículo". (F. Jo. 8º, STC 222/1992).

665 Artículo 12.3 in fine LO 7/1985.

666 SANTOS ARNAU, Lidia. “Conceptos jurídicos indeterminados..., op. cit., 445.

667 En este sentido, AJA señala que "el TS ha sostenido una interpretación amplia de la exención de visados y ha trasladado el reconocimiento de derechos laborales y sociales de los españoles a los extranjeros en cuestiones como el derecho a las prestaciones por desempleo. Progresivamente los demás tribunales han ido asumiendo todas estas líneas jurisprudenciales, no sin dificultades, por el inconveniente que supone la inexistencia de normas escritas que consagren el derecho con claridad". La nueva regulación de la inmigración..., op. cit., p. 26. 
tardaron en permear al TC. El ejemplo paradigmático lo constituyen los derechos conectados a la libertad deambulatoria - reconocidos en el artículo 19 CE-.

El tratamiento jurisprudencial benefició especialmente a la RF. Considerada como un tipo específico de visado y, como tal, de carácter discrecional, se consolidó de forma muy temprana como un ámbito donde no resultaba razonable la ausencia de motivación. Las primeras sentencias de esta materia que llegan al Tribunal Supremo datan de principios de la década de los noventa, coincidiendo con un período en que la inmigración comienza a ser una realidad visible en España y "la legalidad vigente demuestra su enorme potencial de arbitrariedad"668.

Como ejemplo especialmente significativo de la temprana intervención protectora del TS cuya interpretación y asunción de los parámetros constitucionales resultó más visionaria que la propia del TC en esta materia-, destaca la sentencia de 19 de noviembre de $1990^{669}$. En ella el TS debía analizar la validez jurídica de una sentencia previa de la Audiencia Nacional que había desestimado el recurso interpuesto por una ciudadana extranjera - casada con un ciudadano ghanés residente en Madrid-, contra la resolución del Ministerio de asuntos exteriores denegándole la autorización de visado por causa de RF. La resolución denegatoria impugnada carecía de motivación, limitándose a señalar vagamente que "no es posible acceder" a lo solicitado — si bien esto era algo acorde tanto con la Ley Orgánica 7/85 como con el Reglamento de ejecución de 1986, que estipulaban la ausencia de motivación tanto para el visado como para su exención-.

En este pronunciamiento el TS recuerda que, conforme al art. 9.3 CE, no cabe la arbitrariedad en la actuación de los poderes públicos, señalando, además, que "los actos administrativos deben ser motivados cuando limiten derechos subjetivos" ${ }^{670}$, en aplicación del art. 43 de la Ley de procedimiento administrativo. Asimismo, conjuga este argumento con el deber que corresponde a los poderes públicos de asegurar la protección social, económica y jurídica de la familia (art. 39 CE) protección, afirma, "a la que tienen derecho también las familias de extranjeros" (art. 4 LO 7/85) ${ }^{671}$. En consecuencia, inserta de forma implícita la RF como mecanismo para tutelar a las familias de los extranjeros, dentro de la obligación genérica de protección a las familias consagrada en el art. 39 CE.

A la vista de la conjunción de estos dos argumentos, el TS parece extraer un deber no sólo de motivación, sino de concesión del visado por causa RF en aquellos supuestos en los que, estando por medio la familia, concurren como en este caso los requisitos legales y reglamentarios para su obtención: la solicitante era cónyuge de un extranjero residente en España — tal y como establecía el art. 7.2.a) del Reglamento de extranjería de 1986- y, adicionalmente "no consta, en cambio, la razón de causa impeditiva alguna". En este contexto, el TS declaró el derecho de la recurrente a obtener el visado por causa de RF solicitado. Con esta argumentación, en palabras de Santolaya Machetti, "la RF encuentra un claro apoyo constitucional que hace que toda su normativa deba ser aplicada a favor de la plenitud del derecho"672 — en línea con la reciente doctrina extraída por el TJUE en el asunto Chakroun-.

668 Idem, p. 27. Eliseo Aja continúa subrayando que "hasta el TS y el TC llegan algunos casos que escandalizarían a cualquier demócrata, porque significan que la Constitución no se tiene en cuenta con los inmigrantes".

669 Sentencia de la Sección 5a de la Sala de lo Contencioso-Administrativo del TS, de 19 noviembre 1990 (RJ $1990 \backslash 8767$ ). 670 F. J. 4 y 7, sentencia del TS de 19 de noviembre de 1990.

$671 \mathrm{El}$ artículo cuarto de la LO 7/85, con un tenor similar al artículo 13.1 CE, afirmaba que "los extranjeros gozarán en España de los derechos y libertades reconocidos en el Título I de la Constitución, en los términos establecidos en la presente ley y en las que regulen el ejercicio de cada uno».

672 SANTOLAYA MACHETTI, P. El derecho a la vida familiar de los extranjeros, op. cit., p. 151. 
Respecto al visado en general y las competencias del Ministerio de Interior para controlar a su través la entrada de extranjeros, el TS señala explícitamente que "el precepto legal —en relación a los artículos 13.2 de la LO 7/85 y el art. 7.6 del Reglamento de 1986- está redactado en términos que permiten afirmar que la discrecionalidad en el otorgamiento o denegación de la autorización no es absoluta" ${ }^{73}$. Concluye con contundencia que "dándose los requisitos legales, los extranjeros tienen derecho a obtener el visado de su pasaporte o documento análogo. No hay base para sostener lo contrario"674. Con ello, el TS limitaba el carácter discrecional del visado como instrumento de control de la política migratoria que, tanto la normativa aplicable como la práctica administrativa de la época habían consagrado, abriendo la puerta a su control jurisdiccional. Dicho control judicial quedaba reforzado en materia de RF, por los argumentos expuestos anteriormente en conjunción con las obligaciones dimanantes del $\mathrm{DIDH}^{675}$.

Además, el TS señaló también que, conforme a la ley —art. 4 de la LO 7/1985, cuya dicción recordaba al art. $13 \mathrm{CE}$ - los extranjeros gozarán en España de los derechos y libertades reconocidos en el Título I de la Constitución, concluyendo que "por tanto, tienen el de entrar o salir en España (art. 19 de la Constitución) siempre que se den los requisitos que menciona aquella ley orgánica, y el derecho a la protección de la familia (art. 39)"'676.

La sentencia del TS de 19 de noviembre de 1990 contiene pronunciamientos importantes al menos en tres aspectos vitales del ámbito de la extranjería y la inmigración —-todos ellos representativos del talante progresista del TS-:

a) Respecto a la naturaleza jurídica de la RF — que se ventila de pasada-, el TS asume implícitamente su inclusión dentro del art. $39-\mathrm{y}$ no de la intimidad familiar del art. 18 CE. Esta cuestión, resuelta de forma expeditiva tanto en ésta como en sucesivos pronunciamientos del TS, dio durante mucho tiempo pie a elucubraciones doctrinales hasta que, recientemente, el TC, con idéntica rapidez, excluyó que la RF formase parte del contenido material del derecho a la intimidad familiar sin que explícitamente llegase a insertarla dentro del ámbito de la protección familiar del art. 39 CE. En consecuencia, la temprana declaración del TS aporta más luz sobre esta cuestión que el razonamiento desplegado por el TC a finales del año 2007.

b) En torno a la controvertida cuestión de la falta de motivación de los visados y de su exención ${ }^{677}$, el TS estima - contrariamente a la dicción de la normativa aplicable en la época-, que no resulta razonable la ausencia de motivación, especialmente en los supuestos de RF. Sobre este concreto tema, la argumentación del TS ha experimentado altibajos ${ }^{678}$, llegando

673 F. J. 5º, sentencia del TS de 19 de noviembre de 1990.

674 F. J. $4^{\circ}$, sentencia del TS 19 de noviembre de 1990.

675 En el mismo sentido, Adroher Biosca, quién señala que la intensificación del control judicial en materia de RF se explica, además, por tratarse de una obligación procedente del derecho internacional de los derechos humanos, así como por el carácter preciso de los motivos legales y reglamentarios establecidos para su concesión; en ADROHER BIOSCA, Salomé. “La entrada, la permanencia y la salida de extranjeros de España”; en ADROHER BIOSCA, Salomé y CHARRO BAENA, Pilar (coords.). La inmigración: derecho español e internacional. Madrid, Bosch editores, 1995, p. 292.

676 F. J. $6^{\circ}$, sentencia del TS de 19 de noviembre de 1990.

677 Los artículos 5.4 y 2.3 del Real Decreto 1119/1986 contemplaban la posibilidad de que las autoridades gubernativas pudieran eximir de la obligación de visado a los extranjeros que querían trasladar la residencia a España, cuando existieran razones excepcionales que justificasen tal dispensa.

678 En torno al visado, el TS mantuvo inicialmente una doctrina más restrictiva. Es constante en su jurisprudencia la consideración de que no existe un derecho subjetivo a la obtención del visado que se deduzca del art. $13 \mathrm{CE}$, sin embargo el carácter de éste varía en su jurisprudencia. La sentencia de 30 de septiembre de 1992 señala expresamente 
a afirmar en posteriores sentencias ${ }^{679}$ que la ausencia de motivación de visados resultaba aplicable cuando éste se solicitaba en el país de origen del extranjero ante las representaciones diplomáticas y consulares del Estado Español, mientras que no era aplicable cuando el visado - su exención - se solicitaba dentro del territorio español. Esta particular distinción, llevó a Santolaya a señalar que constituye un "curioso razonamiento que parece admitir pacíficamente que la Administración exterior actúa conforme a un ordenamiento jurídico distinto al de las restantes Administraciones públicas" ${ }^{\prime 60}$. De otro lado, la avanzada doctrina del TS y su posterior impregnación en el poder judicial, determinaría que ya a principios de la década de los noventa ${ }^{681}-$ y pese a que la exención de visado era contemplada por la norma con carácter excepcional-, en la práctica se concediesen más exenciones de visados que visados.

c) El TS incluye expresamente a los no nacionales dentro del ámbito de aplicación de las diversas libertades deambulatorias reconocidas en el art. $19 \mathrm{CE}$ - en una época en la que el TC interpretaba todavía en sentido literal dicha disposición, excluyendo de su ámbito a los extranjeros-.

La cuestión de la naturaleza jurídica de la RF retornaría en múltiples ocasiones posteriores al TS, quien volvería a encajar su tratamiento normativo en la protección constitucional de la familia ${ }^{682}$. Además, el TS le otorgará también muy tempranamente la categoría jurídica de derecho subjetivo ${ }^{683}$ - ausente tanto de la parquedad de la ley como de su desarrollo reglamentario durante dicha época.

Este enfoque liberal de la RF se detecta también en otro temprano pronunciamiento del Tribunal Supremo, la sentencia de 24 de abril de $1993^{684}$. Se trataba de determinar si concurrían en el caso las circunstancias excepcionales exigidas por la normativa entonces vigente - arts. 5.4 y 22.3 del Reglamento de ejecución 1119/1986, de la LO 7/1985 sobre derechos y libertades de los extranjeros en España- que justificaban la exención del visado para la residencia por causa de RF. Tal exención había sido confirmada por la sentencia de instancia, pero fue posteriormente recurrida ante el TS por el Abogado del Estado.

La solicitante era una extranjera - cónyuge de residente coreano legalmente establecido en España-, cuyas hijas vivían y se encontraban escolarizadas en nuestro país. El Abogado del Estado alegaba que en la sentencia previa no se había acreditado que en la peticionaria concurriesen las razones excepcionales para justificar la dispensa del visado para residencia.

El TS recuerda que, de concurrir tales circunstancias excepcionales, la autoridad administrativa debe dispensar del visado para residencia, en aplicación de lo establecido por los dos artículos antes citados del primer Reglamento de desarrollo de la LO 7/1985. La primera cuestión a destacar es que

que el visado corresponde al ejercicio de una potestad discrecional de la Administración, lo que confiere a éste libertad de apreciación en aras de velar por la preservación de intereses públicos ligados a la protección tutelar de intereses del Estado español y de sus nacionales. Posteriormente, tiende a reducir el carácter discrecional de su concesión para las autoridades administrativas, reforzando el control judicial.

679 STS de 13 de junio de 1991, y de 1 de octubre de 1992.

680 SANTOLAYA MACHETTI, P. El derecho a la vida familiar de los extranjeros, op. cit., p. 150.

681 Los datos corresponden al año 1993 y son tomados de AJA, Eliseo. La nueva regulación..., op. cit., p. 31.

682 STS de 1 de octubre de 1992.

683 En el mismo sentido se pronuncian BERNARDO, S; VILAS, A y CUADRA, L.I. "Reagrupamiento familiar"; en ALVAREZ, Aurelia; SANTOS, Lidia; CONABLE, Barber. Jornada sobre el Reglamento de la ley de derechos y libertades

de los extranjeros, op. cit., p. 53

684 RJ/1993/2766. Sala de lo Contencioso Administrativo (sección 6a). 
la dicción literal de ambos preceptos utilizaba una expresión potestativa - podrá685 eximir de la obligación de visado - como la consecuencia jurídica aplicable por parte de la autoridad administrativa a aquellos extranjeros en que concurriesen razones excepcionales. La interpretación del TS que la concurrencia de tales razones excepcionales determina —como obligación de resultado para la autoridad administrativa-, el deber de autorizar la exención de visado, constituye en sí mismo un ejemplo de interpretación favorable a los derechos de los extranjeros.

De otro lado, la inserción en el reglamento de "razones excepcionales" que dispensaban de la obligación genérica de contar con visado para poder penetrar en territorio español, constituye un ejemplo del uso de conceptos jurídicos indeterminados. Aplicando doctrina previa, el TS advierte que la inserción de un concepto jurídico indeterminado no otorga una potestad discrecional a la Administración Pública pues, en tal caso, sólo existe una única solución justa a la cual ha de llegar la autoridad administrativa, tras la valoración de los hechos probados ${ }^{686}$. Esta teoría goza de gran relevancia dado que la legislación de extranjería es un campo fértil para la inserción de conceptos jurídicos indeterminados.

Dado que la solicitante se encontraba ya en España, este caso gira en torno a la dispensa de visado para residencia y si la Administración valoró correctamente las circunstancias concurrentes. El TS analiza el significado del concepto indeterminado "razones excepcionales", con la finalidad de acotar el margen de operatividad de la Administración Pública en su aplicación al caso concreto. Y en este punto reside la mayor aportación de este pronunciamiento, pues para el TS el concepto de razones excepcionales tiene un alcance cualitativo, lo que excluye de la norma su dimensión meramente cuantitativa o reiterada.

\footnotetext{
"No cabe reducir su significado, como sostiene el Abogado del Estado, al meramente temporal, como opuesto y contrario a frecuente, corriente u ordinario, sino que tiene, fundamentalmente, un valor cualitativo y equivalente a importante, trascendente o de peso, cualquiera que sea la frecuencia o reiteración con que se produzca”.
}

Aplicando esta connotación cualitativa, el TS valora que todos los miembros de la familia se encontraban en territorio español, contando el padre de familia con permiso de trabajo y residencia, —constituyendo pues una "legítima reagrupación familiar" - , lo que exime a la solicitante de salir de España con el fin de obtener el visado de residencia. Con ello, el TS está materializando doctrina previa, pues desde principios de la década de los noventa exigía valorar la excepcionalidad de los motivos de dispensa de visado, a cuyo efecto habían de tenerse en cuenta las circunstancias personales, sociales, económicas, familiares, etc. que concurriesen en el extranjero ${ }^{687}$.

$685 \mathrm{El}$ artículo 5, destinado a consagrar la obligación de visado como requisito general previo para que los extranjeros pudiesen entrar en territorio español, establecía en su apartado cuarto que "las autoridades gubernativas podrán eximir a un extranjero de la obligación de visado, si existiesen razones excepcionales que justifiquen tal dispensa. La exención deberá hacerse constar en el pasaporte, en el título de viaje o en documento aparte”. Por su parte, el artículo 22 precisaba la documentación necesaria para formalizar la solicitud del permiso de residencia. El tercer apartado del artículo 22 disponía que la autoridad competente podría eximir al solicitante del permiso de residencia, y de la presentación del visado para residencia cuando existieran razones excepcionales que justificasen dicha dispensa.

686 Sobre este punto, el TS afirma de forma contundente que "la simple inclusión de un concepto indeterminado en la norma a aplicar no significa, sin más, que se haya otorgado capacidad a la Administración para decidir con libertad y renunciar a la solución justa del caso. Aquélla viene obligada a la única decisión correcta después de valorar los hechos probados. No estamos, pues, ante una potestad discrecional sino ante el deber de otorgar la dispensa del visado si se dan tales circunstancias excepcionales". F. J. 2º, STS de 24 de abril de 1993.

687 STS de 23 de junio de 1992, 30 de mayo de 1991 y 22 de febrero de 1991. 
La exención de visado de residencia constituye para el TS la única solución justa del caso, estando injustificada su denegación. En apoyo de esta conclusión, el Tribunal recuerda la existencia de una norma administrativa con rango de circular que, entre las diversas circunstancias consideradas como excepcionales para eximir del visado, incluía el caso actual, esto es, que se tratase de cónyuge de extranjero que contase con permiso de residencia en España ${ }^{688}$.

En la sentencia de 24 de abril de 1993, el TS otorga pues contenido normativo específico a un concepto jurídico indeterminado - razones excepcionales para la exención de visado-, acotando con ello el margen de actuación administrativa, en beneficio de los extranjeros administrados. Para situar en su contexto la interpretación efectuada por el TS en este pronunciamiento, baste recordar el carácter restrictivo con que la legislación administrativa había terminado contemplando la exención de visado - cuyo paso final y más vistoso lo constituye la Circular 7/94 de la Secretaría de Interior-. Asimismo, en el año $1991^{689}$ el propio TS había declarado que en la apreciación de la concurrencia de tales circunstancias excepcionales, había de reconocerse un razonable margen de discrecionalidad a la Administración, lo que nuevamente alumbra la trascendencia de su nueva concepción. Adicionalmente, el TS dota de cierta estabilidad a la RF — ausente en la normativa aplicable - , al confirmar que su concesión constituye, en principio, un motivo excepcional justificativo de la exención de visado. Las aportaciones jurisprudenciales de este pronunciamiento, constituirán desde entonces doctrina asentada, repetida en múltiples sentencias posteriores ${ }^{690}$.

En un caso que llegó poco tiempo después, y con connotaciones casi idénticas ${ }^{691}$, el TS aplicó el concepto cualitativo de razones excepcionales ${ }^{692}$ para confirmar la excepción de visado que, a favor de la solicitante, había concedido en su momento el Tribunal superior de Justicia de las Islas Baleares y contra la cual recurrió el Abogado del Estado ante el TS. La solicitante era una ciudadana extranjera que mantenía una relación de convivencia estable con un español, fruto de la cual habían nacido dos hijas. El Tribunal superior de Justicia de las Islas Baleares había concedido exención de visado sobre la base de que dicha convivencia constituía una de las razones excepcionales exigidas para tal exención.

La trascendencia del caso deriva de que el TS se enfrenta a la RF de las parejas de hecho, mediando hijos, equiparando su tratamiento al aplicable a los cónyuges. Asimismo, avanza doctrina en torno a la utilización de la RF como cauce para regularizar la residencia de familiares - concretamente cónyuges- que ya están en territorio español, sin necesidad de retornar al país natal a fin de obtener el visado del que carecieron en su entrada inicial al país. A juicio del TS:

\footnotetext{
"Si el propio Reglamento, al que nos venimos refiriendo, establece en su art. 7.2 la posibilidad de que se pueda solicitar el visado, por causa de reagrupación familiar, por el cónyuge de un extranjero residente en España, no es razonable ni justificable que si dicho cónyuge se encuentra también en España, como sucede en este caso, se le obligue a salir fuera de España para proveerse del visado con el fin de solicitar permiso de residencia. Este, sin duda, es uno de los supuestos contemplados por los citados arts. 5.4 y 22.3 del
}

688 Circular conjunta de las Direcciones Generales de Asuntos Consulares del Ministerio de Asuntos Exteriores, de Policía del Ministerio del Interior y del Instituto Nacional de Emigración del Ministerio de Trabajo y Seguridad Social, sobre «Criterios para la aclaración de cuestiones surgidas en aplicación de las normas sobre extranjería», de fecha 1 de Julio de 1988.

689 Sentencia del Tribunal Supremo de 30 de mayo de 1991.

690 Vid, a modo de ejemplo, las SSTS de 24 de abril de 1993, y de 19 de diciembre de 1995. En el mismo sentido se pronuncia SANTOLAYA MACHETTI, P. El derecho a la vida familiar..., op. cit., p. 166.

691 Sentencia de 8 de noviembre de 1993, de la Sala de lo Contencioso-Administrativo del Tribunal Supremo (Sala 3ª, Sección $6^{\mathrm{a}}$ ).

692 Idem, F. J. $2^{\circ}$. 
Reglamento, aprobado por Real Decreto 1119/1986, de 26 mayo, de exención del visado para residencia por existir razones excepcionales, como acertadamente ha considerado la Sala de primera instancia, cuya sentencia debe, en consecuencia, confirmarse con desestimación total del recurso de apelación deducido contra la misma por el Abogado del Estado".

Repasemos a continuación algunos de los más significativos pronunciamientos correspondientes a la segunda etapa, esto es, aquellos dictados a partir de la entrada en vigor de la efímera L.O. 4/2000 y las subsiguientes reformas. Corresponden a una época muy dinámica, que ha registrado simultáneamente un incremento muy acelerado de la llegada de flujos a nuestro país, la instalación de un convulso marco normativo en esta materia y, en la actualidad, el descenso moderado de los flujos $^{693}$ en lo que de momento parece constituir una etapa transitoria ${ }^{694}$ cuyos efectos todavía no se pueden prever.

En marzo del año 2003 el TS resolvió el recurso contencioso-administrativo interpuesto por la Federación de asociaciones Pro Inmigrantes contra el Real Decreto 864/2001, de 20 de julio, por el que se aprobó el Reglamento de ejecución de la LO 4/2000, de 11 de enero, sobre derechos y libertades de los extranjeros en España y su integración social, reformada por la Ley Orgánica 8/2000, de 22 de diciembre. Entre los múltiples artículos impugnados destaca, a los efectos de nuestro estudio, el artículo $41.5^{695}$ del Reglamento de ejecución, que condicionaba el ejercicio del derecho a la RF por parte de los familiares que hubieran adquirido la residencia en virtud de una reagrupación previa, a la tenencia de un permiso de residencia obtenido independientemente del permiso del reagrupante, y siempre que se acreditara reunir los demás requisitos previstos legalmente.

Los recurrentes sostenían que esta disposición —al permitir a los parientes reagrupados en España ejercer el derecho de reagrupación de sus propios familiares, únicamente cuando contasen con un permiso de residencia obtenido con independencia del alcanzado en virtud del derecho de reagrupación que en su día permitió su residencia legal en España-, era contraria a lo establecido en el artículo 17.2 de la Ley Orgánica 4/2000, en la redacción efectuada por la LO 8/2000696. Este último precepto hacía referencia expresa al derecho de reagrupación que correspondía a quienes hubiesen adquirido la residencia en virtud de una previa reagrupación, cuyas condiciones quedaban relegadas al desarrollo reglamentario. En consecuencia, el TS debía enjuiciar si la restricción contenida en el

693 Según datos extraídos del Instituto Nacional de Estadística, los extranjeros instalados en nuestro país en enero de 2012 representaban un $12 \%$ de la población, alcanzando una cifra de 5,7 millones. Computando también a los residentes que han adquirido la nacionalidad española, la cifra ascendería a 6,7 millones de personas, esto es, un $14 \%$ de la población. De enero a octubre de 2012, el colectivo de los extranjeros, uno de los más afectados por la crisis económica, ha experimentado un descenso de 120.000 personas, que han decidido retornar a sus países de origen o probar fortuna en terceros Estados. Aun siendo un descenso significativo, la salida de no nacionales de nuestro país representa tan sólo un $2 \%$ de las cifras de residentes regulares, lo que supone que el grueso del colectivo de los extranjeros, pese al grave contexto económico y el recorte en las prestaciones sociales acaecido, han decidido por el momento permanecer en nuestro país.

694 Así califica expresamente a los tiempos que corren en la actualidad Joaquín ARANGO. "Del boom a la crisis: La inmigración en España a fines de la primera década del siglo XXI”, op. cit., p. 33.

695 La dicción literal del art. 41.5 del Reglamento de ejecución de la LO 4/2000, en la redacción efectuada por la LO 8/2000, era la siguiente: "Los extranjeros que hubieran adquirido la residencia en virtud de reagrupación podrán, a su vez, ejercer el derecho de reagrupación de sus propios familiares, siempre que cuenten ya con un permiso de residencia obtenido independientemente del permiso del reagrupante y acrediten reunir los requisitos previstos en la ley orgánica 4/2000, reformada por la ley orgánica 8/2000 y en este Reglamento para proceder a a dicha reagrupación".

696 El tenor literal del artículo 17.2, en la versión correspondiente a la LO 8/2000, era el siguiente: “Reglamentariamente, se determinarán las condiciones para el ejercicio del derecho de reagrupación y, en especial, del que corresponda a quienes hayan adquirido la residencia en virtud de una previa reagrupación". 
art. 41.5 del reglamento constituía o no una extralimitación reglamentaria en relación a lo estipulado legalmente.

La regulación de la RF en cadena ya había sido objeto de consideración previa por el Consejo de Estado, en el dictamen ${ }^{697}$ emitido por esta institución con ocasión de la tramitación de la primera reforma legislativa a la LO 4/2000, que daría lugar a la LO 8/2000. En su informe ${ }^{698}$, el Consejo de Estado emitió un juicio globalmente positivo sobre el por entonces todavía proyecto de ley, aunque formuló consideraciones críticas en torno a algunos puntos, entre ellos sobre el derecho a la RF. En torno a la migración familiar, el Consejo de Estado se centró en dos aspectos, a su juicio problemáticos: de un lado, consideraba que la RF en cadena constituía una institución peligrosa, de modo que aconsejaba "precisar que la residencia adquirida por tal concepto no dará lugar a ulteriores reagrupamientos”. Dentro de la RF en cadena, el Consejo de Estado advertía especialmente sobre aquella concedida a favor de los ascendientes que habían entrado en España a fin de reagruparse con el sponsor, aconsejando que los descendientes del ascendiente reagrupado - el segundo residenteno pudiesen optar a un nuevo reagrupamiento, a fin de evitar cadenas indefinidas y sucesivas de reagrupaciones. "Si no se puntualiza este extremo, el juego de los actuales apartados b) - y en menor medida de los a) y c) - y d) del artículo 17 puede provocar un indefinido reagrupamiento por 'sifón', dada la elasticidad de las relaciones de parentesco en determinadas culturas. Bastaría, para evitarlo, señalar que "la residencia adquirida en virtud de reagrupamiento no dará lugar a ulteriores agrupamientos", advertía el Consejo de Estado. Además, esta institución consideró necesario revisar y perfeccionar la redacción del artículo 17.d) ${ }^{699}$ del anteproyecto de ley, que incluía a los ascendientes del reagrupante o de su cónyuge dentro de los familiares reagrupables, sin que sobre este punto ofreciera mayores precisiones.

El punto clave residía en que la LO 8/2000 - que por primera vez había previsto la regulación del procedimiento para poder ejercer la $\mathrm{RF}$-, delegaba en dos de sus disposiciones ${ }^{700}$ al reglamento, la determinación de las condiciones para que los parientes reagrupados pudiesen ejercer, a su vez, el derecho que "correspondía" a éstos a reagruparse con sus propios familiares. Pero el Reglamento, en el desarrollo de tales condiciones, introdujo la exigencia de obtener la residencia independiente para que el reagrupado pudiese a su vez ejercer la RF con sus propios familiares. Ello, a efectos prácticos, suponía obtener una segunda residencia totalmente independiente a la originaria. En consecuencia, el Tribunal Supremo debía analizar si el Reglamento se había o no extralimitado, introduciendo una

697 Dictamen núm. 2.606/2000 del Consejo de Estado, de 28 de julio de 2000, al Anteproyecto de Ley Orgánica de reforma de la Ley Orgánica 4/2000, de 11 de enero, sobre Derechos y Libertades de los Extranjeros en España y su Integración Social.

698 El propio TS hace un resumen de las observaciones vertidas por el Consejo de Estado en el aludido dictamen, pero lo sorprendente es que las mismas resultan incorrectas. A juicio del TS, el Consejo de Estado habría interesado la supresión de un inciso final que figuraba en el proyecto de ley, que decía "la residencia obtenida en virtud de reagrupación no dará lugar a ulteriores reagrupaciones". Una vista somera al dictamen del consejo de Estado, conduce a la conclusión exactamente contraria. El Consejo de Estado previene en contra de la RF en cadena - a la que llega a calificar como RF en sifón, en alusión a la cadena indefinida de futuras reagrupaciones a las que puede dar lugar-, aconsejando su prohibición y, por lo tanto, la introducción del inciso anulado por el TS.

699 Art. 17.d) en la redacción de la LO 8/2000: “d) Los ascendientes del reagrupante o su cónyuge, cuando estén a su cargo y existan razones que justifiquen la necesidad de autorizar su residencia en España”.

700 Se trataba del art. 17.2, conforme al cual "Reglamentariamente, se determinarán las condiciones para el ejercicio del derecho de reagrupación y, en especial, del que corresponda a quienes hayan adquirido la residencia en virtud de una previa reagrupación"; y, de otro lado, el art. 18.4 "Reglamentariamente se determinarán las condiciones para el ejercicio del derecho de reagrupación por quienes hayan adquirido la residencia en virtud de una previa reagrupación". 
restricción que carecía de cobertura legal, en contra del principio de legalidad. El recurso fue resuelto mediante la STS de 20 de marzo de $2003^{701}$.

La cuestión sobre la que gravitaba esta parte de la sentencia residía en determinar si el reglamento, en el apartado recurrido, respetaba o no el derecho legalmente reconocido a la reagrupación en cadena $^{702}$. Sobre esta cuestión, el TS inicia su argumentación recordando la doctrina asentada por el Consejo de Estado en torno a las remisiones reglamentarias:

"Una cosa es que reglamentariamente se fijen determinadas condiciones para hacer algo, que es lo que la Ley expresamente prevé, y otra muy distinta es que reglamentariamente se prohíba hacer ese algo, que es lo que el proyecto pretende"703.

Esta aproximación deja entrever la extralimitación en la que ha incurrido el Reglamento de extranjería recurrido, privando por vía reglamentaria del derecho consagrado legalmente en el art. 17.2 .

\begin{abstract}
"En nuestra opinión exigir la obtención de un segundo permiso de residencia, obtenido independientemente del permiso del reagrupante, para poder ejercer el derecho de reagrupación familiar reconocido en la Ley, supone privar a quienes han obtenido la residencia por reagrupación del derecho reconocido en el n² del artículo 17 de la Ley para ejercer ese derecho en relación con sus propios familiares. La posición adoptada reglamentariamente limita el ejercicio del derecho de reagrupación familiar a quienes gocen de un segundo permiso de residencia obtenido de forma independiente a las circunstancias familiares que permitieron su propia reagrupación, es decir, se elimina por vía reglamentaria lo que el Consejo de Estado denomina reagrupación en cadena y que es una posibilidad que viene establecida en el texto legal ${ }^{704 "}$.
\end{abstract}

Con esta argumentación, el TS anuló la restricción reglamentaria contenida en el art. 45 del Reglamento. La reacción no tardó en llegar y, poco tiempo después de esta sentencia, la reforma introducida mediante la LO 14/2003, consagró la exigencia legal de obtener la residencia independiente como requisito previo para que los familiares reagrupados en España pudiesen a su vez reagrupar a sus parientes y, con ello, "elevó a rango legal las restricciones reglamentarias"705 que habían sido anuladas por el TS.

Otro de los preceptos reglamentarios impugnados era el art. 49.2 - en sus subapartados d) y e)-, que contemplaban la exención de visado que correspondía a los extranjeros que fueran cónyuges de español o de extranjero residente legal en España, tanto nacional como no nacional de un Estado parte del Acuerdo sobre el Espacio Económico Europeo. Los requisitos exigidos para ello eran que no se encontrasen separados de hecho y reuniesen las condiciones exigidas por el art. 17 de la LO 4/2000, reformada por la LO 8/2000, así como acreditar la convivencia en España durante al menos un año. Para los nacionales extra comunitarios se exigía además que no estuvieran separados de hecho - y de derecho- y que, tras acreditar convivencia en España durante al menos un año, el cónyuge tuviese además autorización para residir al menos otro año.

La impugnación se basaba en que, a juicio de los recurrentes, la exigencia reglamentaria de acreditar la convivencia "en España" iba más allá del requisito establecido en el art. 31.7 de la LO 4/2000,

701 Tribunal Supremo, Sala de lo Contencioso, (Nº de Recurso: 488/2001).

702 Artículo 17.2 de la L.O. 8/2000.

703 STS de 20 de marzo de 2003, F. J. $5^{\circ}$.

704 Idem.

705 RELAÑO PASTOR, Eugenia. "Los continuos cambios de la política de inmigración en España”; en Migraciones Internacionales, vol. 2, n 3, p. 129. 
en la redacción dada por la LO 8/2000 706 , que no hacía referencia a que dicha convivencia hubiera tenido lugar dentro del territorio español. De hecho, el precepto legal no establecía condición alguna a la convivencia - salvo el requisito temporal mínimo de haberse prolongado durante un año-, para que pudiera concederse la exención de visado a quien fuese cónyuge de residente en España.

Para el TS, exigir por vía reglamentaria que dicha convivencia tuviese lugar necesariamente en España, implicaba:

"una restricción que va más allá de la exigencia legal y quiebra por tanto el principio de legalidad, amén de que supone obligar a permanecer en territorio español durante un año en situación irregular. $\mathrm{Si}$ el legislador hubiera querido imponer el requisito de convivencia en España hubiera efectuado la remisión al artículo 16 de la Ley, comprendido en el mismo capítulo relativo a la RF, y que sí se refiere a residencia en España ${ }^{707 "}$.

Por estas consideraciones, el TS anuló el precepto reglamentario mencionado.

Mención especial merece la sentencia n⿳0 645/1996, de 4 de julio, de la Sala de lo Contencioso Administrativo del Tribunal Superior de Justicia de Cataluña, que aborda el tema de la reagrupación familiar por parte de la pareja no casada y del mismo sexo ${ }^{708}$. Su trascendencia es obvia, tanto porque la protección de la pareja de hecho penetraría en la ley mucho después de este pronunciamiento, en el año 2009, como además, por proyectar el tema de la discriminación por razón de orientación sexual. Resulta una muestra bien elocuente de la tutela que ofrecen los tribunales, interpretando la ley en sentido expansivo y ampliamente protector.

En el presente caso, los recurrentes - un ciudadano español y su pareja de hecho del mismo sexo, un colombiano- impugnaban la denegación del Ministerio de Asuntos Exteriores de la petición de solicitud de visado de residencia por RF a favor del ciudadano de nacionalidad colombiana. El acto recurrido era presunto, ya que la denegación de la solicitud de visado se había producido por la vía del silencio administrativo. Ante dicho silencio, el recurrente español —en representación de su pareja colombiana-, dirigió una petición al embajador de España en Colombia, solicitando a favor de éste la concesión de un visado de residencia para poder entrar a establecerse en España por un mínimo de dos años, argumentando "haber decidido conjuntamente y en libertad llevar a cabo un proyecto de vida en común”. El Cónsul de España remitió al Ministro de Asuntos Exteriores los formularios de solicitud de visado junto con la documentación presentada. La Dirección General del Ministerio resolvió que procedía denegar el visado por residencia de RF, por "no darse la relación de parentesco exigida por la reglamentación vigente con familiar español o extranjero residente en España”. La legislación aplicable al caso, por la fecha del recurso, eran tanto la LO 7/85 —el visado estaba regulado en su art. 12- como el Reglamento de ejecución de 1986, que contemplaba los familiares reagrupables en su art. 7.

$706 \mathrm{El}$ artículo 31 de la LO 8/2000 regulaba la residencia temporal. Su apartado séptimo contemplaba la exención de visado, señalando que "excepcionalmente, por motivos humanitarios o de colaboración con la Justicia, podrá eximirse por el Ministerio del Interior de la obligación de obtener el visado a los extranjeros que se encuentren en territorio español y cumplan los requisitos para obtener un permiso de residencia. Cuando la exención se solicite como cónyuge de residente, se deberán reunir las circunstancias de los artículos 17 y 18 y acreditar la convivencia al menos durante un año y que el cónyuge tenga autorización para residir al menos otro año".

707 STS de 20 de marzo de 2003 , F. J. $6^{\circ}$.

708 Para un comentario en profundidad de esta sentencia, vid. FÉLIX BALLESTA, Ma Angeles. "Reflexiones en torno a la reagrupación familiar"; en MARTÍNEZ-TORRÓN, Javier (ed.). La libertad religiosa y de conciencia ante la justicia constitucional. Actas del VIII Congreso Internacional del Derecho Eclesiástico del Estado. Granada, Comares, 1998, pp. 451-463. 
El recurso había sido instado a través del cauce jurisdiccional de protección de los derechos fundamentales de la persona regulado en la Ley 62/1978, alegando violación de los artículos 10.1, 13, 14, 15, 16, 17 y 19 CE. Debido al carácter presunto del acto administrativo objeto de impugnación, el Abogado del Estado instó como causa de inadmisibilidad la falta de acto administrativo recurrible. Esta causa fue rechazada por el TSJ de Cataluña con carácter previo a la resolución del fondo del asunto, aplicando la doctrina del TC tanto en torno a la tutela judicial efectiva como al principio constitucional de sujeción de la Administración a la ley y al Derecho (art. 103 CE) y, con ello, actuando conforme al principio antiformalista que caracteriza al TS.

El Tribunal Superior de Justicia de Cataluña recuerda la jurisprudencia constitucional —STC 47/1993, de 8 de febrero- conforme a la cual:

"la Constitución no identifica a la familia que manda proteger en el art. 39.1 con la familia tradicional, porque la interpretación abierta de este precepto desde el carácter 'social' que conforma al Estado español, procura tener acogida modos de convivencia que en la sociedad se expresan de forma real y efectiva, de modo que no cabe colegir una diferenciación necesaria entre familias matrimoniales y no matrimoniales, aunque las familias matrimoniales y las convivencias extramatrimoniales no expresen realidades equivalentes, subrayando que no toda medida que tenga como únicos destinatarios a los cónyuges, con exclusión de quienes conviven establemente en unión de hecho, puede ser compatible con la igualdad jurídica y la prohibición de discriminación que la Constitución garantiza en su art. 14".

La resolución impugnada es enjuiciada por el TSJ de Cataluña desde tales parámetros constitucionales, estimando que la escueta motivación que la misma ofrecía resulta contraria al orden público de las libertades por desconocer el art. $14 \mathrm{CE}$, lesionando simultáneamente el derecho al libre desarrollo de la personalidad - art. $10 \mathrm{CE}$ - . Asimismo, el TS valora que al invocar el derecho a la RF, los recurrentes no han realizado abuso de derecho o fraude de ley, puesto que la solicitud de visado por RF venía acompañada de una declaración notarial en la que el recurrente español se comprometía formalmente a hacerse cargo de los gastos de su pareja colombiana en España, acreditando su voluntad de consolidar un proyecto de vida en común, como confirmaría posteriormente su madre en la prueba testifical.

El problema de fondo residía en que la legislación de la época no contemplaba la posibilidad de uniones entre personas del mismo sexo, careciendo éstas de una opción jurídica que les permitiese ejercer su derecho al matrimonio - art. 32-, estimando el TSJ de Cataluña que:

"Este Tribunal, que es el juez ordinario de los derechos fundamentales en Cataluña, debe señalar que el silencio del legislador en regular de modo general el régimen jurídico de las uniones civiles y de las uniones sociales de hecho no autoriza a la Administración a desconocer, en el ejercicio de sus potestades discrecionales actuables en la concesión de visados, el derecho de los ciudadanos españoles y extranjeros a no ser discriminados sin justificación objetiva y razonable por razón del vínculo de convivencia estable acreditado que les ligue, al encontrarse vinculadas directa e inmediatamente las autoridades administrativas a garantizar los derechos fundamentales y libertades públicas reconocidas en la Constitución, entre las que cabe mencionar el derecho a la igualdad y el derecho a la intimidad — el derecho a la vida privada y familiar en la expresión del art. 8 del $\mathrm{CEDH}$-, sin necesidad de la previa interpositivo (sic) del legislador como ha subrayado el Tribunal Constitucional"709.

Resulta destacable el recurso argumentativo al artículo 8 CEDH y a la jurisprudencia de Estrasburgo, en la que el TSJ de Cataluña se había apoyado previamente para señalar que "el propio TEDH ha referido (...) que si es legítima la preocupación de los Estados de frustrar las tentativas de bordear las restricciones a la inmigración, no se debe privar a los ciudadanos extranjeros de las garantías jurídicas

709 Sentencia nº 645/1996 de 4 de julio, del Tribunal Superior de Justicia de Cataluña (sección 2a), F. J. $4^{\text {o }}$. 
que se establecen en el CEDH"710, subrayando con ello la obligatoriedad de que los ordenamientos migratorios internos se desenvuelvan en el respeto a los derechos convencionales, fundamentalmente el art. 8 CEDH.

Con todo, la parte más relevante de este pronunciamiento lo constituye la interpretación constitucional conforme del ordenamiento jurídico, sobre cuya base el TSJ de Cataluña señala la obligatoriedad de las autoridades españolas con competencias migratorias de "reinterpretar el artículo 7 del Reglamento", a fin de incluir entre los familiares reagrupables a las parejas de hecho estables y permanentes, tanto heterosexuales como homosexuales.

"El principio de interpretación de todo el ordenamiento conforme a la Constitución obliga a las autoridades del Ministerio de Asuntos Exteriores y a las autoridades diplomáticas y consulares, a reinterpretar el art. 7 del Reglamento de ejecución de la Ley Orgánica de Derechos y Libertades de los extranjeros en España, aprobado por Real Decreto 119/86, de 26 de mayo, de modo que estarán legitimados para solicitar el visado de residencia por causa de reagrupación familiar además del cónyuge de un español o extranjero residente en España, así mismo, la persona que conviva de forma estable y permanente, en análoga relación de afectividad a la del cónyuge, con independencia de su orientación sexual, para no desconocer el contenido esencial del derecho a la igualdad que se garantiza por el art. 14 de la Constitución”711.

En base a esta revolucionaria reinterpretación de la cláusula reglamentaria de los familiares reagrupables, el TSJ de Cataluña declara la nulidad de pleno derecho de la resolución administrativa impugnada por vulnerar los artículos 14 y $10 \mathrm{CE}$, obligando a la Administración a retrotraer el expediente administrativo al momento procedimental adecuado a fin dictar una resolución expresamente motivada desde el respeto al principio de constitucionalidad y al principio de legalidad administrativa.

La interpretación del concepto de familiares reagrupables, previsto reglamentariamente, en el contexto del principio constitucional de igualdad y de libre desarrollo de la personalidad ${ }^{712}$ convierten a este pronunciamiento en una muestra muy elocuente de la capacidad del poder judicial para trascender la literalidad de la norma en su afán de proteger derechos de los extranjeros, así como de las potencialidades de apertura expansiva que otorga la interpretación evolutiva de los preceptos. Resulta a todas luces una sentencia muy avanzada para su época ${ }^{713}$. Con todo, la jurisprudencia del $\mathrm{TS}^{714}$ del momento ya había establecido los parámetros que permitían, en circunstancias tasadas, otorgar a las parejas de hecho una protección equiparable a la concedida a las uniones matrimoniales.

Más rigurosa suele mostrarse la jurisprudencia respecto a la interpretación de la controvertida cuestión de la reagrupación de ascendientes. La interpretación de los requisitos legalmente exigi-

710 Idem, citando el TSJ de Cataluña la doctrina del TEDH emitida en sentencia de 25 de junio de 1996.

711 Sentencia no 645/1996 de 4 de julio, del Tribunal Superior de Justicia de Cataluña (sección 2a), F. J. $4^{\text {o }}$.

712 FÉLIX BALLESTA, Ma Angeles. “Reflexiones en torno a la RF”, op. cit., p. 452.

713 Tales novedades han llevado a FELIX BALLESTA a considerar que, según este pronunciamiento "para no desconocer el contenido esencial del derecho a la igualdad que se garantiza en el art. $14 \mathrm{CE}$, estarán legitimados para solicitar el visado de residencia por causa de RF, además del cónyuge de un español o extranjero residente en España, la persona que conviva de forma estable y permanente, en análoga relación de afectividad a la del cónyuge, con independencia de su orientación sexual” - parafraseando la propia sentencia. Idem, op. cit., p. 452.

714 En torno a la doctrina jurisprudencial que equipara la convivencia more uxorio al matrimonio, a efectos de la inmigración familiar — tanto a fin de justificar la exención de visado de residencia como para justificar la situación de arraigo en España-, vid, entre otras, las siguientes sentencias del Tribunal Supremo: STS de 10 de marzo de 1998; STS de 15 de noviembre de 1999; STS de 6 de mayo de 2000; STS de 6 de junio de 2000; STS de 13 de noviembre de 2000; STS de 18 de octubre de 2001. 
dos para poder reagrupar a los ascendientes representa, con diferencia, la línea jurisprudencial más dura dentro de la interpretación judicial del derecho a la RF. Especialmente severa suele mostrarse la apreciación de concurrencia de la exigencia de dependencia económica con respecto del reagrupante, requerida para poder proceder a la reagrupación de ascendientes. En esta línea dura, destaca la determinación jurisprudencial de requisitos que vienen a concretar las exigencias legales y reglamentarias - y que, contrariamente a lo habitual en este ámbito-, constituyen requerimientos que elevan el rigor establecido por la norma escrita. El ejemplo más claro lo constituye la exigencia de que el familiar ascendiente sea mayor de 65 años, inexistente en el texto de la ley y del reglamento hasta su introducción mediante la LO 2/2009, que vino a complicar el panorama jurídico para la reagrupación de este tipo de familiares.

Cuando el reagrupante recurre la denegación del visado de RF para un familiar, el enjuiciamiento se concentra en el Tribunal Superior de Justicia de Madrid, único competente para el conocimiento y resolución de litigios en materia de visados ${ }^{715}$. A modo de muestreo, abordaremos tres sentencias dictadas por el TSJM, que resuelven otros tantos recursos contenciosos administrativos interpuestos por extranjeros residentes contra las resoluciones consulares denegatorias de visados de residencia por causa de RF.

Resulta significativa la Sentencia del TSJ de Madrid de 21 de junio de 2002 ${ }^{716}$, que resolvía el recurso contencioso-administrativo formulado por el reagrupante contra la resolución consular denegatoria de la solicitud de visado de residencia para RF para su padre, residente en Marruecos. Tras constatar que el recurso había sido presentado dentro del plazo legalmente establecido - ya que la Administración del Estado alegaba que el mismo era inadmisible por extemporáneo-, el TSJM se centra en examinar la concurrencia en este supuesto de la situación de dependencia económica del ascendiente respecto del reagrupante - determinante de la posibilidad de concederle visado por causa de RF-. La normativa aplicable, en razón a la fecha de la resolución impugnada, eran los artículos 16.2 y 17.d) de la LO 4/2000, que exigían dependencia económica así como razones que justificasen la necesidad de autorizar la residencia en España del ascendiente.

El reagrupante alegaba que la edad de su padre -63 años- y el hecho de que éste careciese de profesión y trabajo en su país natal - Marruecos, donde además no existe pensión de jubilación-, eran determinantes de la necesidad de que éste se trasladase a vivir con él a España, a fin de no caer en situación de indigencia. El TSJM constata que el progenitor del recurrente cuenta con otros hijos mayores de edad en Marruecos, que pueden hacerse cargo de él. Estima por ello que las circunstancias alegadas no integran por sí mismas la situación de dependencia económica exigida legalmente para conceder el visado por $\mathrm{RF}^{717}$. El TSJM desestima el recurso, declarando que la denegación de la solicitud de visado para reagruparse con su padre - emitida por el Consulado General de España en Nador-, es conforme a derecho.

En la misma fecha que la anterior, el TSJM emitió su sentencia de 21 de junio de $2002^{718}$, que nuevamente se centraba en examinar un recurso contencioso-administrativo contra la resolución

715 Sobre este aspecto se pronuncia en sentido crítico Bazzaco, quien señala el alargamiento temporal entre dos y tres años provocado por la práctica - habitual entre embajadas y consulados españoles-, de no contestar a los recursos contra la denegación de concesión de visados por RF, obligando al extranjero a recurrir ante el Tribunal Superior de Justicia de Madrid. BAZZACO, Eduardo. "España frente a la inmigración. Obsesiones, incumplimientos y vulneraciones"; en El Viejo topo, no 255, 2009, p. 53.

716 BDB TSJ 32210/2002.

717 F. J. 5º, STSJM de 21 de junio de 2002.

718 BDB TSJ 32212/2002. 
consular denegatoria de la solicitud de visado emitida por el Consulado General de España en Nador - si bien en este caso se trataba de un visado para visita familiar. El objetivo del mismo era permitir la entrada en España de la madre del recurrente, a fin de visitar a su hijo para una estancia inferior a tres meses. La causa para la denegación consular se fundó en la falta de justificación de dependencia.

La normativa aplicable en el supuesto de visita familiar era el artículo 5 del Convenio de Aplicación del Acuerdo de Schengen de 19 de junio de 1990, que exige - entre otros requisitos-, poseer un visado válido y justificar documentalmente tanto el objeto de la estancia prevista, como disponer de medios adecuados de subsistencia para el período de estancia y para el regreso al país de procedencia o a un tercer Estado. El TSJM constata que habían quedado documentalmente acreditados tales extremos - art 5.1.c) del Convenio de Schengen-, pues constaba en acta notarial de manifestaciones la asunción del compromiso por parte del reagrupante de atender todos los gastos que originase la estancia de su madre en España, junto con dos de sus nóminas acreditativas de ingresos y la certificación bancaria de que éste mantenía una cuenta corriente abierta en España con saldo suficiente $^{719}$. Por ello, el TSJM estima el recurso contencioso-administrativo, declarando la nulidad de la resolución consular que había denegado la solicitud de visado para visita familiar.

El 16 de mayo de 2003, el TSJM emitió una sentencia ${ }^{720}$ que resolvía el recurso interpuesto por un nacional marroquí residente legal en España, contra la resolución del Consulado General de España en Casablanca, mediante la que se denegó el visado de residencia para RF solicitado por su padre. La denegación se produjo argumentándose que el solicitante del visado para RF era padre de 12 hijos y no había justificado su dependencia económica respecto de su hijo residente en España. Por su parte, el recurrente invocaba la vulneración del derecho a la vida familiar —arts. 16 y 17 de la LO 4/2000, en su redacción original, aplicable al caso por la fecha en que se inició el expediente-, en conexión con los artículos 39 y $53.3 \mathrm{CE}$, señalando que la circunstancia de ser ascendiente de un residente constituía causa de exención de visado.

El TSJM reconoce que el derecho a la RF posee el contenido "configurado por las leyes de desarrollo, según resulta de los arts. 39 y 53 de la Constitución Española”721, examinando por ello el cumplimiento de los presupuestos contemplados en el art. 17.d) de la LO 4/2000 ${ }^{722}$. Tras recordar que la carga de la prueba recae sobre la parte actora $-\mathrm{y}$ dado que las partes no solicitaron el recibimiento del proceso a prueba-, el Tribunal valora las que constan en las actuaciones administrativas, de las que se deduce que el padre del reagrupante es viudo y residente en Marruecos. Sin embargo, el reagrupante no aportó ningún medio de prueba en orden a justificar la situación económica de su progenitor ni tampoco se justificó —ni siquiera mediante mínimos indicios-, que el solicitante del visado necesitase cuidados en España por no recibir ayuda ni atenciones de sus restantes hijos residentes en Marruecos. Tampoco aparece acreditada su dependencia económica respecto al hijo residente en España, constando solamente que el reagrupante y otro hijo del solicitante de visado, también residente en España comenzaron a enviar dinero a su padre, pero solamente con posterioridad a la fecha en la que recayó la resolución denegatoria de la petición de visado de residencia por RF.

719 F. J. 3a, STSJM de 21 de junio de 2002 (BDB TSJ 32212/2002).

720 BDB TSJ 13204/2003.

721 STSJM, de 16 de mayo de 2003, F. J. $2^{\circ}$.

722 Dicha disposición, en su redacción original, exigía que "el ascendiente residente en el extranjero dependa económicamente del reagrupante residente en España y que, además, existan razones que justifiquen la necesidad de autorizar la residencia de aquél en España”. 
Al no haber quedado justificadas ni la dependencia económica ni la concurrencia de razones que hagan necesaria la concesión de residencia al padre del reagrupante, el TSJM desestimó el recurso, quedando patente en su interpretación judicial la necesidad de una prueba sólida de la dependencia económica del ascendiente respecto del reagrupante. Respecto a la concurrencia de razones que hagan necesaria la concesión de la residencia por RF a favor del ascendiente, el tribunal se centra en aspectos tales como la existencia de más hijos o parientes cercanos en el país de origen que puedan hacerse cargo del ascendiente, a fin de "descartar situaciones de desasistencia en cualquiera de los órdenes de su vida por sus otros hijos residentes en el país de origen de que se trate"723.

A modo de recapitulación, cabría subrayar pues el destacado papel desarrollado por el poder judicial, con el TS a la cabeza, en la interpretación favorable y extensiva del derecho a la RF de los extranjeros en España. De forma temprana, se detecta la asunción jurisprudencial del principio constitucional de sujeción de la Administración al ordenamiento jurídico que, en nuestro ámbito de estudio, se traduce en una decidida actitud de frenar progresivamente la discrecionalidad que caracterizaba la figura del visado - incluido el de RF - a fin de lograr la plena fiscalización judicial de este ámbito de actuación administrativa, secularmente dominado por la prevalencia del interés público en su regulación ${ }^{724}$. Esta orientación judicial, al reforzar el peso de los intereses individuales superando las estrecheces de la norma, ha provocado décadas de "desencuentros" 725 con la legislación de extranjería.

Desde múltiples frentes doctrinales, se ha destacado el papel protector de los derechos de los extranjeros desempeñado por el poder judicial, "mitigando las exigencias impuestas por la Administración" ${ }^{\prime 26} \mathrm{y}$, en múltiples ocasiones, actuando en contra y a pesar de la literalidad restrictiva de la norma. En esta materia, el mayor rigor parece aplicarse al entendimiento de los requisitos que gravan la reagrupación de los ascendientes.

Cabe pues subrayar la existencia de dos tendencias confluyentes, que vendrían a incrementar la eficacia de cada una de ellas tomada aisladamente: de un lado, los principios constitucionales consagrados en los artículos $103 \mathrm{CE}, 17.3$ y el art. 24, actuaban conjuntamente para reducir las áreas de actos y decisiones del poder ejecutivo exentos de control judicial; $y$, de otro, una actitud generalmente progresiva hacia la extranjería, que determinaba una interpretación en clave extensiva de las múltiples limitaciones legales — en cuyo apoyo actuaba decididamente el DIDH, utilizado especialmente en las sentencias emitidas a partir de la década de los noventa, priorizando la jurisprudencia de Estrasburgo en torno al art. $8 \mathrm{CEDH}-$. En sintonía con el colectivo al que se dirigía, el poder judicial, en la práctica, ha desempeñado un papel clave en el avance de los derechos de los extranjeros, anticipando con su actuación futuras reformas normativas.

723 STSJM de 16 de mayo de 2003, F. J. 3º. Sentencias posteriores del mismo tribunal han revalidado estos aspectos, especificando las exigencias probatorias en materia de RF de ascendientes. Destaca entre ellas la sentencia del Tribunal Superior de Justicia de Madrid, de 19 de julio de 2004 que, a juicio de Isaac RAVETLLAT "concreta las exigencias exigibles para la reagrupación de un ascendiente con un carácter más cualificado, como el ser mayor de 65 años, necesidad de ayuda física y afectiva de la familia, la ausencia de profesión y la consecuente dependencia económica acreditada mediante el envío de remesas”. La reagrupación familar, op. cit., pp. 35-36.

724 En una línea similar, SANTOLAYA ha subrayado la existencia de una "tendencia expansiva del control judicial sobre toda actividad administrativa", que se manifestaba de forma más acusada en el ámbito de la extranjería y la inmigración. El derecho a la vida familiar, op. cit., p. 150.

725 PECES MORATE, Jesús E. “Las Declaraciones de derechos y su efectividad respecto de los inmigrantes”; en Inmigración y Derecho. Consejo General del Poder Judicial, 2002, p. 192.

726 Idem, p. 193. Por su parte, AJA ha destacado que, "frente a una normativa generalmente restrictiva, los jueces continuaron aplicando criterios amplios que anulaban las estrictas decisiones administrativas". AJA, Eliseo (coord.). La nueva regulación de la inmigración en España, op. cit., p. 31. 



\section{CONCLUSIONES}

1. El cierre de fronteras producido a mediados de la década de los setenta y la introducción de fuertes restricciones a la entrada de inmigrantes en Europa, fomentó la instalación de una inmigración de asentamiento y con tendencia a traer a sus familiares al país receptor. La migración familiar - tradicionalmente considerada como una forma migratoria secundaria-, emergería como una categoría de extraordinaria relevancia, tanto por su influencia en el número de admisiones futuras de extranjeros, como sobre la configuración social, demográfica y cultural de las sociedades de acogida. Desde entonces, su importancia no ha dejado de aumentar hasta constituir el canal principal de entradas regulares de inmigrantes en la mayor parte de países europeos, situándose por encima de la inmigración de carácter laboral. A pesar de que la crisis económica ha ralentizado los flujos migratorios desde el año 2007, la RF se ha consolidado como la categoría migratoria dominante a nivel mundial.

Adicionalmente a su intrínseca importancia cuantitativa y cualitativa, todas las diversas categorías migratorias terminan engrosando las cifras de migración familiar o tienen el potencial de desembocar en futuras admisiones de parientes de los extranjeros instalados dentro del Estado receptor. De otro lado, el incumplimiento de los requisitos jurídicos exigidos para su ejercicio, frecuentemente da lugar a la $R F$ de hecho - ejercida en condiciones de irregularidad-, cuya difícil cuantificación no encubre la magnitud de su volumen.

2. El incremento acelerado de la inmigración familiar fue inicialmente percibido como un efecto colateral inesperado del bloqueo a la inmigración laboral. Esta imprevisión explica que, desde el ámbito doctrinal, la inmigración asociada a la familia fuese escasamente estudiada y construida de forma marginal respecto de la inmigración de carácter laboral. La inmigración familiar se enmarcaba en el esquema de un ciclo migratorio iniciado casi exclusivamente por trabajadores masculinos y la posterior reunión en el Estado de acogida con los familiares dependientes más próximos. El estudio de la RF fraguaría por ello en un marco teórico estereotipado, cuyas características principales se construirían por contraposición a la inmigración laboral, conceptualizándose como una categoría migratoria secundaria, de asentamiento permanente, altamente feminizada y de carácter no económico, a la que se adjudicaba una escasa influencia sobre el mercado laboral del país receptor.

Sin embargo, en la actualidad el patrón teórico tradicional que servía de sustento a la migración familiar ha perdido parte de su virtualidad explicativa. Entre las tendencias actuales de los flujos migratorios que cuestionan estas bases destaca su creciente feminización - que la propia RF fomenta-, provocando la irrupción de modelos migratorios mucho más complejos, donde las motivaciones migratorias se presentan entremezcladas, desdibujándose los límites entre las categorías tradicionales sobre cuya distinción reposaba la construcción dogmática tradicional de la RF.

3. La extraordinaria relevancia que ha adquirido la migración familiar ha inducido a un creciente atrincheramiento del Estado para el mantenimiento del control sobre sus resortes normativos, 
como una vía esencial de control y selección de inmigrantes. Para ello dos elementos resultan fundamentales: de un lado, la particular definición de familia; de otro, las concretas condiciones establecidas para su ejercicio.

La migración familiar reposa sobre una definición autónoma de familia, habitualmente fijada por el país receptor, en cuya determinación los Estados europeos aplican visiones restrictivas, limitando los parientes reagrupables a aquellos comprendidos estrictamente dentro de la familia nuclear. Estas definiciones angostas funcionan como vías primarias de contención migratoria, pues determinan sus más destacados efectos cuantitativos. Como mecanismo adicional para el control de flujos, la regulación de la migración familiar está gravada por múltiples condicionantes, entre los que destacan dos: (1) el carácter regular de la residencia del reagrupante, condición definitoria de la regulación de esta materia a nivel mundial; (2) la exigencia de cierta estabilidad en la estancia del sponsor, mediante la imposición de plazos previos de permanencia legal en el país receptor antes de poder solicitar la RF.

Junto a estos condicionantes, las legislaciones exigen otros muchos requisitos - recursos económicos, vivienda adecuada, seguro médico, condiciones de integración, etc.-, cuya intensidad y rigor son variables, pero cuya importancia práctica es de primer orden, pues exigencias excesivamente gravosas pueden llegar a vaciar de contenido el derecho. Una característica en la que están confluyendo los países de larga tradición migratoria y los Estados europeos reside en la tendencia a incorporar requisitos crecientemente rigurosos en el tratamiento normativo de la migración familiar.

4. Con independencia de la concreta categoría implicada, la inmigración de nuestros días constituye un proyecto de carácter fundamentalmente familiar. En la medida en que detrás de todas las tipologías late la familia como unidad primaria de toma de decisiones, las categorías tradicionales se relativizan.

Sin embargo, la inmigración de la familia generalmente no se produce de forma simultánea, sino en fases sucesivas. Cuando la unidad familiar está fragmentada por las fronteras, su reconstitución exige el cruce de las mismas, generándose un punto de intersección entre dos segmentos del orden jurídico tradicionalmente distantes: la extranjería y la protección de la familia. Ello exige de los Estados difíciles equilibrios entre los controles migratorios y sus obligaciones internacionales de respetar y promover la vida familiar, traduciéndose en restricciones crecientes sobre la potestad estatal soberana de controlar la admisión y condiciones de residencia de los extranjeros dentro de su territorio.

5. A raíz de las políticas de inmigración cero iniciadas en la década de los setenta, el DIDH se introdujo en el ámbito migratorio, ejerciendo un creciente condicionamiento sobre las políticas migratorias internas. En tanto que mecanismo para permitir la unidad familiar, la inmigración familiar quedaba conectada con consideraciones humanitarias y éticas que están en la base del concepto de derechos humanos $-\mathrm{y}$, de entre ellos, fundamentalmente con el derecho a la vida familiar- $y$, simultáneamente, se erigía en un obstáculo inherente a la eficacia en la gestión de las políticas de contención de flujos.

En la medida en que no son activamente seleccionados por el Estado, resultando vinculante su admisión, los familiares cercanos del residente extranjero quedaban insertados en la categoría de "inmigrantes humanitarios", "no solicitados" — e incluso "no deseados" - La migración familiar se convertiría por ello - junto con el asilo- en una de las escasas excepciones toleradas por los países 
receptores, al tiempo que pasaban a constituir los aspectos políticamente más sensibles dentro del ya de por sí controvertido ámbito de la extranjería y la inmigración.

La vinculación a los derechos humanos situaba a la migración familiar en el punto de confluencia de múltiples dinámicas contradictorias, fundamentalmente la representada por el conflicto entre la protección de intereses nacionales inherente a la soberanía estatal y la protección de intereses individuales subyacente a los derechos humanos. De otro lado, la penetración del DIDH detraía parcialmente a la migración familiar de la soberanía exclusiva del Estado-Nación, para ubicarla en un complejo - $-\mathrm{y}$ habitualmente contradictorio - entramado normativo caracterizado por la interacción de múltiples regímenes jurídicos: ordenamiento nacional, regional, internacional y supranacional.

El DIDI terminaba con ello incidiendo sobre prerrogativas estatales íntimamente vinculadas con la soberanía nacional, como son el control fronterizo y la determinación de las condiciones de admisión, residencia y derechos de los extranjeros. La influencia de los estándares internacionales sobre la migración familiar resultaría determinante gracias a la actitud pionera de las instituciones del Consejo de Europa y a la intermediación expansiva ejercida por el poder judicial interno - que actuó penetrado por la jurisprudencia de Estrasburgo-, logrando vencer las resistencias estatales al reconocimiento del derecho de los extranjeros a la RF.

6. En el ámbito europeo, la migración familiar supone la reunión, dentro del territorio del Estado de acogida, del extranjero residente con su familia nuclear. En consecuencia, su concesión implica el reconocimiento del derecho a inmigrar-abarcando tanto la entrada como la residencia en el país receptor- al menos respecto de los familiares más próximos del reagrupante, bajo un régimen jurídico más ventajoso que el que rige el régimen general en el territorio del mismo Estado. En contrapartida, los familiares extranjeros admitidos por motivos de RF suelen gozar de un haz de derechos inferiores a aquellos reconocidos a los inmigrantes de carácter laboral. Esta circunstancia procede del carácter dependiente de su admisión, transmitiéndose inicialmente al estatus jurídico de los parientes reagrupados y determinando con ello la concepción tradicional de la migración familiar como un derecho derivado.

La RF presenta una naturaleza jurídica mixta o multidimensional, pero con claro predominio de su faceta prestacional. Las primeras actuaciones públicas que involucra podrían insertarse dentro de la categoría de los derechos de primera generación, agotándose cronológicamente al expedirse la primera autorización de entrada y residencia por causa familiar y las subsiguientes renovaciones que procedan. Sin embargo, posteriormente se traduce en la concesión a favor de los parientes admitidos de derechos adicionales a dicha autorización, vinculados a las estructuras del Estado de bienestar, que implican esfuerzos presupuestarios para el país receptor y se dilatan en el tiempo. Su proyección prestacional se encuentra en el origen de parte de las resistencias a su concesión, así como de algunos extendidos prejuicios en la sociedad de acogida.

7. La RF constituye una especie dentro del género denominado "migración familiar" o "inmigración familiar", que engloba los distintos tipos de procesos migratorios vinculados a la familia. De entre los diversos subtipos que incluye, dos resultan fundamentales: la reunificación o reagrupación familiar en sentido estricto; y la formación familiar o inmigración matrimonial.

La RF en sentido estricto constituye el tipo de migración familiar dominante en el ordenamiento y en la doctrina jurídica. Se inicia a raíz de la emigración de un pariente al territorio del país receptor, en tanto que el resto de la familia permanece en un tercer Estado. Para su definición resulta vital el carácter preexistente de los vínculos familiares del extranjero/a residente, que resultaron fracturados 
como consecuencia de la emigración no simultánea de los miembros de la unidad familiar. Por su parte, la formación familiar o inmigración matrimonial abarca diversos movimientos migratorios que giran en torno a la entrada y establecimiento de la pareja extranjera del sponsor en el Estado receptor. La nota común a estos desplazamientos reside en el hecho de que los vínculos familiares se han formado con posterioridad a la entrada del principal en el país de destino, y amparan una noción más amplia de reagrupante. La formación familiar ha sido encuadrada tradicionalmente como un subtipo específico dentro de la RF. Sin embargo, sus características singulares y, especialmente, sus efectos diferenciados con respecto a la RF en sentido estricto, la hacen merecedora de una conceptualización e incluso de un tratamiento normativo diferenciado, pues constituye uno de los aspectos más complejos dentro de la inmigración familiar.

Con todo, recientemente el TJUE en el asunto Chakroun, ha apostado por un tratamiento jurídico que tiende a la equiparación entre las diversas categorías integrantes de la inmigración familiar, con independencia del momento de constitución de los vínculos familiares. En la misma línea niveladora había incidido ya antes el TEDH.

8. La migración familiar acumula múltiples facetas intrínsecamente problemáticas, que proceden de su ubicación en el punto de confluencia de múltiples tensiones conflictivas. La RF encaja simultáneamente en las dos ramas más importantes de las políticas públicas dirigidas a los extranjeros: Política de inmigración y política de extranjería. Su concesión supone inicialmente para el Estado receptor autorizar la entrada y residencia de los familiares extranjeros del reagrupante, insertándose como una de las más relevantes facetas de la política pública migratoria. Pero, simultáneamente, la migración familiar se erige en uno de los más importantes vehículos para facilitar su integración, lo que sitúa a esta categoría dentro de las políticas públicas de extranjería. Dado que ambas ramas reposan sobre la protección de intereses potencialmente contradictorios, la RF concentra y acumula las dificultades propias de cada una de ellas, incluyendo las tensiones derivadas del conflicto de intereses subyacente.

Considerada como el componente central de la política pública de inmigración, la migración familiar engloba múltiples características que alumbran su complejidad: De un lado, constituye la tipología migratoria que muestra mayor propensión al asentamiento definitivo. De otro, genera efectos multiplicadores sobre el número de entradas y de residentes extranjeros, con incidencia inflacionista sobre las admisiones futuras de inmigrantes: al otorgar el derecho de residencia al reagrupante, el Estado deberá aceptar nuevas admisiones posteriores a favor de sus familiares. De modo que el número de admisiones final es muy superior al representado inicialmente por los inmigrantes primarios, convirtiendo a esta categoría en uno de los mayores desafíos para el país receptor.

Las facetas problemáticas de la migración familiar se condensan sobre la formación familiar o inmigración matrimonial, precisamente la categoría que está experimentando un mayor crecimiento cuantitativo. Los efectos multiplicadores y la formación de cadenas migratorias parecen generar consecuencias más intensas en la formación familiar, como consecuencia de su apertura cronológica. En segundo lugar, representa retos superiores de cara a la integración pues implica la admisión de extranjeros adultos procedentes principalmente del entorno de las comunidades de origen; $y$, finalmente, dado que los valores culturales suelen transmitirse dentro del núcleo familiar, es la figura a la que se le adjudica un potencial superior de repliegues culturales. Esta situación, unida a los problemas de fraude a través de la figura de los matrimonios de conveniencia, multiplica los recelos ante la inmigración matrimonial, como un fenómeno que socava los controles migratorios y contra el que se alzan fuertes restricciones. 
9. La migración familiar constituye el factor fundamental para la creación tanto de cadenas migratorias como del concepto más amplio de redes, vinculadas ambas a la transnacionalidad en que se desarrollan los flujos migratorios y al mantenimiento de fluidas relaciones entre las sociedades de origen y destino de la migración. Basadas en vínculos personales de carácter esencialmente familiar, las cadenas y redes migratorias, una vez establecidas, provocan efectos inductores geométricos sobre la inmigración, convirtiéndose en canales migratorios acumulativos, que habitualmente se desenvuelven mediante dinámicas situadas al margen de las políticas migratorias del Estado de acogida. Este factor exógeno tiende a acelerar la dinámica propia de los flujos migratorios, lo que explica en parte su resistencia en contextos económicos recesivos e incluso su crecimiento en el seno de políticas migratorias restrictivas, aminorando la influencia sobre el comportamiento del inmigrante de los factores de atracción propugnados por las teorías neoclásicas de la inmigración. Los efectos inductores de la inmigración familiar sobre nuevas admisiones de extranjeros no se detienen en los cauces regulares, proyectándose su potencial multiplicador también sobre futuras entradas irregulares.

10. La configuración jurídica de la RF hunde sus raíces en el DIDH. Sin embargo, en el nutrido cuerpo de normas de muy diversa naturaleza que lo integran, no es posible encontrar un reconocimiento expreso de este derecho, salvo en textos relativamente recientes, que lo contemplan con calculada imprecisión. Por ello, su construcción en el ámbito europeo, tanto a nivel doctrinal como jurisprudencial, se encauzó mediante su vinculación a dos principios jurídicos expresamente consagrados en el plano internacional, cuya titularidad no se restringía a los nacionales de un Estado receptor: la unidad familiar y, en menor medida, el principio de libertad de circulación. Dado que este último no obliga jurídicamente a los Estados a admitir en su territorio a personas extranjeras, la protección de la migración familiar se afianzaría en conexión con el principio de la unidad familiar que, a su vez, desemboca en dos derechos que gozan de amplio reconocimiento en el DIDH: el derecho a contraer matrimonio y fundar una familia, y el derecho a la vida familiar. Por presentar un contenido protector más amplio, el derecho a la vida familiar — al garantizar la facultad de disfrutar de una vida común en el seno de la unidad familiar-, terminó consolidándose como el principal derecho matriz en que se engarzaría la tutela internacional de la inmigración de carácter familiar.

En esta forma de razonar se inscribe la temprana actividad de la ya extinta Comisión Europea de Derechos Humanos, cuyas premisas seguiría el TEDH a partir de la década de los ochenta, encajando la posible protección que podía brindar el Convenio de Roma al derecho de los extranjeros a residir con sus parientes en el territorio de los Estados parte, como un contenido implícito del derecho al respeto de la vida familiar consagrado en el art. $8 \mathrm{CEDH}$ - excluyendo su extracción de otras disposiciones alternativas del $\mathrm{CEDH}$ que también ofrecían cobertura protectora a los extranjeros y a su entorno social y personal no exclusivamente familiar, tales como, por ejemplo, el más amplio derecho a la vida privada, reconocido en la misma disposición-. La UE, apoyándose en la jurisprudencia del TEDH, también ha vinculado la RF con el derecho a la vida familiar.

En consecuencia, en el contexto de familias migrantes la RF se concibe en Europa como el correlato jurídico del derecho a la vida familiar de los extranjeros, a modo de derecho implícito o indirecto derivado del mismo. En último término, esta construcción jurídica se percibe como una vía instrumental para la protección de la familia, en tanto que célula social básica amplia y expresamente garantizada por el DIDH.

11. En el DIDH es posible encontrar un abundante cuerpo de instrumentos internacionales de consistencia normativa muy variable - recomendaciones, declaraciones, tratados - relacionados con la RF. La característica común es que, otorgando todos ellos protección a la institución familiar 
con diversas formulaciones, sin embargo, ninguno ofrece una definición de familia. Esta materia queda reservada a las legislaciones estatales, que cuentan para su regulación con un considerable margen de apreciación. En el ámbito específico de la RF, casi todos estos instrumentos concurren en otra característica muy notable: la falta de proclamación expresa del derecho, circunstancia que determina que del principio de unidad familiar no quepa deducir sin más, un derecho correlativo a la RF de idéntica densidad normativa. Y, en las ocasiones en que la RF se nombra expresamente, los documentos internacionales coinciden en una formulación débil y vaga, que diluye su vinculatoriedad jurídica.

El reconocimiento de la RF a nivel internacional no se ha formulado pues como un auténtico derecho subjetivo que genere correlativas obligaciones jurídicas de admisión de la familia inmigrante para el Estado receptor. A lo sumo, podría hablarse de la existencia de una recomendación o de un fuerte imperativo moral internacional que actúan como condicionantes estatales, impeliendo a los Estados a facilitar en lo posible la RF de los extranjeros asentados en sus respectivos territorios o, más modestamente, impulsándoles a minimizar la incidencia de las políticas migratorias sobre su vida familiar. En este sentido, tanto la OIT como la ONU coinciden en señalar que, pese a la protección extensiva que tanto los instrumentos regionales como universales otorgan a la familia, el derecho internacional no obliga a los Estados a garantizar la RF. Su consagración como derecho se encuentra todavía en una especie de limbo jurídico.

La excepción a esta situación generalizada la representa el escenario europeo, en un doble sentido: de un lado, en el ámbito del Consejo de Europa, donde la protección ofrecida por el TEDH ha logrado imponer límites materiales crecientes sobre el poder discrecional de los Estados para determinar las admisiones y condiciones de establecimiento de familiares de extranjeros asentados en su territorio; y, de otro, en la UE, donde por primera vez en un ámbito supranacional la RF de los extranjeros ha ascendido al estatus de derecho subjetivo. Con todo, aun en estos supuestos de mayor protección regional, en el derecho internacional sólo cabría concluir la existencia de un todavía muy precario, limitado y condicionado derecho subjetivo a la RF, sometido a un amplio margen de apreciación estatal.

12. En el ámbito del Consejo de Europa, la cláusula del respeto de la vida familiar reconocida en el artículo $8 \mathrm{CEDH}$ se ha revelado como la plataforma jurídica exclusiva de las demandas sobre migración familiar, pese a existir otras disposiciones del Convenio de Roma —artículos 3, 12, 14-o concretos derechos - vida privada - con potencial migratorio. Su protección fue tempranamente canalizada por las instituciones de Estrasburgo mediante su encaje como contenido material implícito del derecho al respeto de la vida familiar. La Comisión y posteriormente el TEDH, impulsados por el carácter constitucional que la protección de la familia gozaba dentro de los Estados partes - y las prácticas judiciales internas de algunos de ellos-, trascendieron la literalidad del precepto a fin de tutelar a las familias de los extranjeros en dos situaciones específicas: de un lado, frente a medidas migratorias que al denegar solicitudes de entrada o residencia a favor de sus parientes, incidían de forma indirecta sobre la vida familiar de los extranjeros asentados en el Estado parte y, de otro, frente a medidas de exclusión o expulsión que provocaban una injerencia directa sobre el mismo derecho. Si bien cronológicamente la RF constituye una línea jurisprudencial algo anterior en el tiempo, la protección frente a expulsiones ha logrado un mayor grado de consolidación.

El alumbramiento de la protección del derecho a la RF de los extranjeros se asienta sobre doctrina reiterada de las instituciones de Estrasburgo en torno al contenido del derecho a la VF, a saber, "el disfrute de la compañía mutua entre padres e hijos constituye un elemento fundamental de la vida familiar". En el caso de familias separadas entre las fronteras de diversos países - siendo uno de 
ellos Estado parte del Consejo de Europa-, la mutua compañía exige la reunión de sus miembros en el territorio de uno de los dos países implicados. El TEDH debe valorar las circunstancias que rodean la situación particular de los demandantes y el justo equilibrio entre los intereses en conflicto, para determinar si el Estado ha violado sus obligaciones convencionales. En esta perspectiva, la autorización de la entrada y/o residencia de los familiares del extranjero residente dentro del Estado parte no constituye un fin en si mismo, sino un medio instrumental necesario para evitar la violación indirecta o derivada que su denegación provocaría - a modo de efecto rebote- sobre el derecho convencional al respeto de la vida familiar. Por eso el derecho a la RF se erige como una condición previa necesaria para dotar de plena efectividad a un derecho explícito del Convenio, en su aplicación a extranjeros asentados dentro del territorio de alguno de los Estados contratantes. Con todo, la construcción jurisprudencial del derecho a la RF se asienta sobre la premisa del respeto al derecho soberano que asiste al Estado para regular los flujos migratorios y controlar la entrada y permanencia de extranjeros en su territorio.

Varios factores jurídicos se han conjugado a fin de propiciar el surgimiento del derecho a la RF, pese a no estar reconocido como tal en el texto del Convenio de Roma:

12.1 En primer lugar, la redacción poco ortodoxa del artículo 8.1, que reconoce que todos tienen derecho al "respeto" de la vida familiar. Esta formulación constituye una de las particularidades más destacables de esta disposición, pues los restantes derechos convencionales son consagrados de forma directa. De la misma se extrae, de un lado, la exigencia de preexistencia de la vida familiar respecto a la medida migratoria estatal —interpretada flexiblemente por el TEDH-, y fundamentalmente, la posibilidad de derivar obligaciones convencionales positivas que exigen la adopción de medidas de actuación estatal destinadas a promover, desarrollar y garantizar el disfrute efectivo de la VF. La configuración del derecho a la RF desde sus inicios ha sido insertada como una obligación convencional positiva inherente al respeto de la VF, en coherencia con su naturaleza prioritariamente prestacional. Su carácter positivo ha permitido a los extranjeros recurrir medidas migratorias adversas bajo la invocación de "falta de respeto" — en ausencia de interferencia o injerencia estatal—, constituyendo la migración familiar el primer ámbito en el que el TEDH admitió tal tipo de invocaciones.

12.2 El uso de principios hermenéuticos por parte del TEDH que potenciaban la creatividad de sus pronunciamientos, permitiendo cercar el amplio margen de maniobra estatal que rige en asuntos migratorios. Entre ellos, cuatro resultan fundamentales para explicar la génesis del derecho a la RF: el principio de interpretación evolutiva, el principio de efectividad o efecto útil de los derechos convencionales y, especialmente, la protección de rebote y las obligaciones positivas surgidas a su amparo —concebidas ambas como emanaciones del principio de efectividad-.

Aplicada a nuestro objeto de estudio, la protección de rebote supone concebir que la garantía plena del disfrute efectivo del derecho a la vida familiar de los extranjeros conlleva para los poderes públicos, en determinadas circunstancias, autorizar la RF de sus parientes, pues lo contrario provocaría como resultado una afectación indirecta o derivada - o por efecto rebote - del derecho al respeto de su vida familiar. En esta perspectiva, la ruptura de los vínculos familiares y consiguiente separación familiar debida de forma directa — protección frente a expulsiones-, o indirecta - RF-, a medidas migratorias internas del Estado parte, constituiría una violación del Derecho internacional regional. De otro lado, la temprana inserción de la familia dentro de los conceptos autónomos del derecho convencional -STEDH Marckx c. Bélgica-, permitió al TEDH un mayor margen de actuación al dictaminar demandas que involucraban a familias inmigrantes. 
12.3 La estructura normativa de la norma convencional a la que fue anclada la RF, amplificaba el resultado de los criterios hermenéuticos empleados por el TEDH para abordar esta materia: En los dos apartados que conforman el artículo $8 \mathrm{CEDH}$, concurren varias características que convierten a esta disposición en una cláusula especialmente propicia para la expansividad de los derechos que consagra.

a) Su primer párrafo reconoce una multiplicidad de derechos íntimamente conectados a la esfera de la personalidad — vida privada, vida familiar, respeto al domicilio y la correspondencia-, formulados como principios y, por lo tanto, caracterizados por la abstracción e imprecisión de su alcance. Constituye pues una norma con estructura de principio, necesitada de interpretación a fin de concretar y maximizar los valores por ella tutelados.

b) El Convenio protege "la vida familiar" — no la familia - , lo que ha terminado eximiendo al TEDH de la necesidad de proporcionar un concepto convencional de familia, permitiendo la plasticidad de la vida familiar y la protección de un amplio abanico de modelos familiares en su seno. La familia es un concepto culturalmente condicionado, tanto temporal como geográficamente y, por ende, relativo, coyuntural y plurivalente. La diversidad de la familia, en tanto que concepto culturalmente condicionado, dota a su concepción jurídica de una gran elasticidad y permeabilidad a las circunstancias históricas concretas. En los últimos tiempos la permeabilidad del concepto de familia está también conectada a los avances científicos, pues éstos han propiciado la irrupción de nuevas estructuras familiares. Podríamos por ello decir que, además de culturalmente, la familia es un concepto biológica o científicamente supeditado.

Aquellos derechos que, como la vida familiar, se conectan con conceptos cultural, ética y hasta científicamente condicionados, están más intensamente afectados por el fenómeno de la mutabilidad histórica que, con carácter general, influye sobre los derechos subjetivos. En consecuencia, el derecho a la vida familiar constituye una noción extraordinariamente porosa a influencias externas. Por lo mismo, la vida familiar resulta especialmente susceptible al principio de interpretación evolutiva habitualmente empleado por el TEDH en su razonamiento.

c) Por su parte, el segundo apartado del artículo $8 \mathrm{CEDH}$ establece los límites posibles a los derechos reconocidos en el apartado primero. Utiliza una amplia cláusula que define las restricciones legítimas a tales derechos recurriendo a la enumeración de una extensa lista de conceptos jurídicos indeterminados, cuya imprecisión exige dotar al Estado de un amplio margen de apreciación. Los conceptos jurídicos indeterminados y la aplicación de la teoría del margen de apreciación en el artículo 8.2, constituyen factores que abren el campo interpretativo, propician el casuismo y, por ende, dificultan la sistematicidad de las decisiones del TEDH -elementos que son reiteradamente criticados por la doctrina dedicada al estudio de esta novedosa rama jurisprudencial一.

d) La previsión expresa de restricciones insertan al derecho a la vida familiar - junto con todos aquellos proclamados por los artículos 8 a $11 \mathrm{CEDH}$ - en la categoría de los derechos relativos o cualificados, en contraposición a los derechos absolutos que no admiten derogación. Pero, a diferencia de sus congéneres, entre las peculiaridades que singularizan la amplia redacción de las limitaciones contempladas en el artículo 8.2 CEDH destaca especialmente la inclusión del "bienestar económico del país". Esta cláusula, de carácter inédito en el texto del Convenio, posee una importancia extrema para nuestro objeto de estudio, ya que concentra las alegaciones formuladas por los Estados partes $-\mathrm{y}$ admitidas por el TEDH - , para justificar 
las medidas estatales de incidencia sobre la vida familiar de los extranjeros en el ámbito específico de la RF.

La interacción entre el carácter abierto de la formulación del derecho a la vida familiar —art. 8.1 $\mathrm{CEDH}-$, en conjunción con la amplitud de las limitaciones tasadas y formuladas como conceptos jurídicos indeterminados - art. 8.2-, potencian la apertura de esta disposición, convirtiéndola en una cláusula especialmente proclive al ensanchamiento de los derechos que consagra. Si sumamos todas las variables apuntadas - incluyendo la elasticidad inherente a la familia en tanto que concepto culturalmente condicionado-, y las situamos en el contexto de una organización internacional protectora de derechos que se mueve en un ámbito geográfico mayor y culturalmente más heterogéneo, se comprenderá que el artículo 8 constituye un terreno especialmente fértil para la interpretación útil, dinámica, creativa y evolutiva, explicando en parte el tipo de estrategia acometida por las instituciones de Estrasburgo para alumbrar en su seno el derecho de los extranjeros a la RF.

13. Desde que, a mediados de la década de los ochenta, el TEDH se enfrentara por primera vez a un supuesto en que se alegaba que una medida estatal migratoria violaba el derecho a la RF de los extranjeros, hasta el momento de cerrar estas páginas, se observa en los pronunciamientos emitidos sobre este tema una profunda evolución, delimitando dos etapas claramente diferenciadas por la sentencia Sen.

13.1 En la primera etapa se enmarcan tres sentencias emitidas por el TEDH en el lapso temporal de once años que media entre 1985 y el año 1996. Se trata de los asuntos Abdulaziz, Cabales y Balkandali; Gül contra Suiza y, finalmente, Ahmut contra Holanda. Todos ellos se caracterizan por una aproximación a la migración familiar muy deferente con el interés general estatal de controlar la inmigración y, por ello, muy restrictiva hacia los intereses particulares.

Los parámetros convencionales utilizados por el TEDH para la evaluación de las circunstancias del caso en esta etapa, son tres: el test de los obstáculos, el test de la responsabilidad individual, y el test de la integración. Entre todos ellos, ostenta una prioridad absoluta el test de los obstáculos o criterio elsewhere, en virtud del cual el TEDH considera que la reconstitución de la vida familiar del extranjero ha de producirse, con carácter general, en cualquier tercer país - distinto al Estado parte de acogida del reagrupante-, salvo que existan obstáculos insalvables o razones especiales que recomienden la reunión de la familia dentro del país receptor demandado. Los obstáculos han de ser de carácter jurídico, careciendo de entidad para estimar la violación del derecho los meramente fácticos que afronten los demandantes a fin de retornar a su tierra natal para reconstruir allí su unidad familiar.

Para evaluar tales obstáculos o razones especiales, el TEDH aplica los otros dos parámetros convencionales mencionados. El test de la responsabilidad individual, que exige a los inmigrantes no haber cometido infracciones a las normas migratorias y que la residencia separada de la familia del demandante no sea imputable a su actuación, asumiendo implícitamente que la decisión de emigrar - y no la medida migratoria adversa - , es la causante de la ruptura de la unidad familiar, y llegando a asignar a tal decisión un carácter irrevocable. Así aplicado, el test de la responsabilidad individual imputa a los extranjeros demandantes la responsabilidad de la degradación en su vida familiar, de la que se quejan ante Estrasburgo, de modo que la decisión estatal denegatoria de la RF no les privaría, en principio, de su derecho a disfrutar del tipo de vida familiar por el que optaron al emigrar, dejando atrás a su familia.

Por último, el test de la integración, que durante esta etapa es de carácter unilateral: evalúa solamente la fortaleza de los vínculos que cualquiera de los demandantes conservan con el país de 
origen o con un tercer Estado, sin valorar alternativamente su grado de integración en el Estado parte receptor, deducida principalmente de la duración temporal de su estancia en dicho país. Asimismo, dentro de este test, la Corte valora el grado de dependencia de los menores implicados, traduciéndose habitualmente en determinar si existen familiares cercanos - distintos a los progenitores - que puedan quedarse a su cargo en un tercer Estado, otorgando escasa relevancia a la edad de los niños afectados.

El Tribunal conjuga estos tres parámetros con rigor, al tiempo que enfatiza el amplio margen de apreciación presente en esta materia, situando a los intereses individuales de los extranjeros en una postura de clara desventaja. La conjunción de estos factores determina la existencia de una presunción de partida en contra de la concesión de la RF en la mayoría de supuestos constitutivos de migración económica, circunstancia que es avalada por los tres pronunciamientos integrantes de esta etapa, todos ellos desestimatorios. La condición regular de la estancia constituye un requisito esencial para poder optar a la RF y la exigua cobertura convencional de la migración familiar se reduce a los supuestos de RF en sentido estricto, donde el extranjero cuente con una vida familiar preexistente que dejó atrás al emigrar al Estado parte.

Sobre la base de esta construcción inicial, las posibilidades de extraer un derecho a la RF de la formulación contenida en el art. $8 \mathrm{CEDH}$ - si bien admitido expresamente por parte del TEDH como contenido potencial del derecho al respeto de la vida familiar-, resultan extraordinariamente limitadas, casi nulas desde el punto de vista material.

Además, los tres parámetros son progresivamente endurecidos en su aplicación, determinando una configuración jurisprudencial extraordinariamente restrictiva e in crescendo del derecho a la $\mathrm{RF}$, que se traduciría en una muy limitada obligación para los Estados partes del CEDH — deducible del art. 8- de permitir la entrada y/o residencia de familiares de inmigrantes regularmente asentados tan sólo en circunstancias extremadamente excepcionales, muy próximas al asilo. Incluso cuando éstas se presentan ante el TEDH - como testimonia el asunto Gül contra Suiza, donde los demandantes afrontaban circunstancias humanitarias particularmente difíciles-, así como en concurrencia de situaciones que, desde el punto de vista del derecho comunitario, ampararían la concesión del derecho - asuntos Abdulaziz, Cabales y Balkandali contra Reino Unido y Ahmut contra Holanda, donde algunos de los demandantes habían adquirido la nacionalidad del Estado parte receptor-, la Corte de Estrasburgo niega la violación del derecho a la RF. Con todo, entre los magistrados del TEDH se observa una creciente fisura, al tiempo que el margen de apreciación resulta progresivamente disminuido para equipararlo — formalmente - al existente en el ámbito de las obligaciones migratorias negativas.

Autocontención judicial y respeto a la soberanía estatal constituyen pues las premisas sobre las que reposa la aproximación de Estrasburgo a la RF en esta primera etapa, de forma que al aplicar el test del justo equilibrio de los intereses en conflicto —introducido en Gül_, la Corte tiende a sobredimensionar el interés de los Estados de controlar los flujos migratorios, reduciendo el efecto útil que del artículo $8 \mathrm{CEDH}$ podría extraerse sobre la RF de los extranjeros.

Trazando un paralelismo, y salvadas las distancias históricas, cabría afirmar que la primera fase en la construcción del derecho a la RF por parte del TEDH está imbuida por una filosofía muy próxima a la que impregnó en su momento a los países europeos que recibieron flujos migratorios bajo la primacía del modelo del trabajador huésped o invitado: la RF, de tener lugar, habría de producirse en el Estado de origen del inmigrante - o en cualquier otro tercer país con el que los miembros de la familia tuviesen vínculos, distinto en todo caso al Estado receptor-, de ahí que 
el sistema se construyera con vistas a desestimular la instalación de la familia del extranjero en la sociedad de acogida. Esta concepción subyacente frena el despliegue del derecho a la RF, pese a que en Abdulaziz se admitiera su anclaje normativo como contenido implícito del derecho al respeto de la vida familiar.

13. 2 La sentencia Sen contra los Países Bajos, emitida en 2001, marca un punto de inflexión en la jurisprudencia de Estrasburgo, traduciéndose en un robustecimiento del peso que ostentan los intereses individuales en el marco de migración familiar. El TEDH flexibiliza todos los criterios jurisprudenciales aplicables, facilitando el ejercicio efectivo de la RF:

a) En Sen se produce una ampliación del test de integración, aplicándose en sentido bidireccional para examinar simultáneamente tanto los vínculos con el Estado de origen, como con el de acogida - faceta inédita hasta el momento-. El TEDH valora positivamente por primera vez tanto el carácter legal como la duración del asentamiento en el país receptor, fundamentalmente el nacimiento allí de hijos del reagrupante, y la corta edad de los menores implicados.

b) Introducción del criterio del interés superior del menor, ostentando un peso privilegiado en la argumentación del TEDH: la atención prestada al bienestar de los hijos menores nacidos y criados en la sociedad de acogida, se erige como un sólido obstáculo para la reconstitución de la vida familiar en un tercer país.

c) La aportación fundamental de la sentencia Sen es un nuevo entendimiento del test de los obstáculos, rebajando notablemente sus umbrales de exigencia: en sentido opuesto a su concepción previa, se analiza si la reunión de la familia en el Estado parte de acogida - en vez de en el país de origen de alguno de los demandantes-, constituye el medio más adecuado para el desarrollo de la vida familiar, sirviendo por primera vez para sustentar la protección del derecho a la RF. Además, el test de los obstáculos se examina en conexión con el test de la integración —en su nueva acepción bidireccional—, otorgando una importancia mayor a los vínculos creados en el país de residencia que a los mantenidos con el Estado de origen. En esta valoración conjunta, el TEDH toma en consideración la estabilidad jurídica de la estancia y, fundamentalmente, el nacimiento allí de otros hijos del reagrupante, sin apenas vínculos con el país natal de sus padres, quienes actuarán como los más relevantes obstáculos al regreso de la familia al país de origen de los progenitores. Esta perspectiva del test de la integración hace que el test de los obstáculos desempeñe un papel contrario al que jugaba en la primera jurisprudencia, permitiendo el surgimiento de obstáculos al retorno al país de origen.

d) Aligeramiento del test de la responsabilidad individual, suavizando su concepción respecto a la decisión de emigrar y sus consecuencias sobre las relaciones paternofiliales. El TEDH por primera vez admite abiertamente que el hecho de emigrar, no puede considerarse como una decisión irrevocable de fijar, para siempre, su lugar de residencia en el país y sólo guardar con ella vínculos esporádicos y distendidos, de renunciar definitivamente a su compañía y de abandonar así toda idea de reunir a su familia. Además, la Corte hace explícitos los criterios que han de ser tenidos en cuenta en esta sede a fin de ponderar los intereses concurrentes, a saber, la edad de los menores afectados, su situación en su país de origen y el grado de dependencia con respecto a sus progenitores.

La suma de todos las aportaciones mencionadas, determina que el TEDH subraye la falta de proporcionalidad inherente a las alternativas planteadas al emigrante para hacer valer el derecho a la RF como consecuencia de la aplicación rígida del test de los obstáculos —obligándole a elegir entre 
renunciar al estatus y la vida familiar establecida en el país de acogida o bien permanecer allí, pero a costa de rehusar a la compañía de sus hijos-. Con todo, en Sen el Tribunal acoge una concepción todavía muy estrecha y precaria de la migración familiar, restringiendo la protección otorgada por el art. $8 \mathrm{CEDH}$ a supuestos de RF en sentido estricto, a favor exclusivamente de hijos menores y sobre el presupuesto de la estancia legal del extranjero reagrupante.

Sen, dictada por unanimidad pese a la novedad y al calado de sus planteamientos, constituye un pronunciamiento confuso y ambiguo, donde el TEDH se empeña en citar sus precedentes previos para, paradójicamente, desmontar casi por completo el acervo jurisprudencial preexistente. Ello explica que las novedades que aporta hayan pasado desapercibidas para un sector doctrinal, así como para algunos de los Tribunales que aplican la doctrina de Estrasburgo, entre ellos el TC español.

13.3 Casi simultáneamente a la sentencia Sen, fue emitida una Recomendación del Comité de Ministros del Consejo de Europa, sobre el Estatus Legal de las Personas Admitidas por motivos de RF. A ésta le seguiría otra Recomendación de la Asamblea Parlamentaria, sobre Movilidad humana y derecho a la $R F$, aprobada en 2004. Ambas apuestan decididamente por promover la migración familiar en el seno del Consejo de Europa, reflejando un cambio de mentalidad que anticipa y refuerza, respectivamente, el viraje jurisprudencial que estaba teniendo lugar en la Corte de Estrasburgo. La influencia de estas Recomendaciones es especialmente perceptible en la introducción del criterio del interés superior del menor que el TEDH realiza en Sen - que jugará un papel crecientemente preponderante en su argumentación-, así como en abrir un resquicio a la posibilidad de otorgar la $\mathrm{RF}$ a inmigrantes irregulares de larga duración.

13.4 Las sentencias dictadas durante la primera década del presente siglo, posteriores a Sen y a las dos Recomendaciones citadas - Tuquabo-Tekle; Rodrigues da Silva y Hoogkamer; y Konstatinov, todas contra Holanda-, conforman una segunda etapa en el modo de abordar la RF en el marco del artículo $8 \mathrm{CEDH}$, de un tenor marcadamente progresista, activista y humanitario. Todas ellas profundizan en la línea liberal emprendida en Sen, al tiempo que ofrecen intentos de sistematizar y clarificar los criterios que rigen las obligaciones convencionales en el ámbito de la migración familiar, aportando luz sobre una materia que, desde sus inicios, ha sido criticada desde la doctrina por ser confusa, incoherente, discrecional y ambigua. Todos los test convencionales son aligerados, destacando entre ellos la priorización del interés superior del menor como sólido criterio capaz de neutralizar el interés general del Estado de controlar la inmigración familiar, subsumido en la cláusula del bienestar económico del país.

Como aspecto más relevante y, simultáneamente, revelador del activismo judicial que domina esta segunda etapa, el TEDH por primera vez examina - y concede - a la luz del Convenio de Roma, solicitudes de RF planteadas en dos circunstancias hasta ahora inéditas dentro de los supuestos de hecho analizados en Estrasburgo:

a. Solicitudes formuladas por extranjeros en situación de irregularidad administrativa. En tales supuestos, la RF constituye una vía para regularizar a nacionales de terceros países que cuentan con vínculos familiares en el país de acogida.

b. Solicitudes planteadas por extranjeros irregulares donde, adicionalmente, el demandante que aspira a la reagrupación ha cometido delitos contra la propiedad en el territorio del Estado parte de acogida.

Ambos supuestos constituyen casos fronterizos, donde confluyen elementos tanto de la expulsión como de la migración familiar — los dos aspectos que han erigido al artículo $8 \mathrm{CEDH}$ en una norma de protección convencional de los extranjeros-, incrementando las dificultades de 
deslinde entre ambas. En el asunto Rodrigues da Silva se hacen explícitos por primera vez los criterios de distinción que le permiten asignar una naturaleza positiva a la medida migratoria estatal objeto de impugnación, delimitando la sutil línea que los separa respecto de las obligaciones negativas.

Dada su trascendencia, ofrecemos un intento de sistematización de la compleja - y todavía bastante ambigua - doctrina que la Corte de Estrasburgo está recientemente aplicando para enjuiciar estos supuestos migratorios limitrofes o fronterizos.

I. Supuestos de RF de hecho: Como principio general la Corte señala que si la creación de la vida familiar se produjo en una época en la que las personas afectadas eran conscientes del carácter irregular de su status migratorio, en tales casos, es probable que sólo en las más excepcionales circunstancias el rechazo del familiar extranjero constituya una violación del artículo 8 (...), sin tener ningún derecho a esperar que les sea concedido un permiso de residencia (Rodrigues da Silva, apartado 43).

Sin embargo, la contundencia formal con que se enuncia este principio es rebajada por el propio TEDH, al señalar que si las autoridades estatales conceden una importancia suprema al hecho de la estancia irregular del demandante, sin más consideraciones, incurrirían en un excesivo formalismo. En consecuencia, la estancia irregular constituye tan sólo un criterio más, dentro de los que deberán ser tomados en consideración en el análisis del justo balance entre los intereses concurrentes.

Entre los principales factores que actúan como circunstancias excepcionales atenuantes, habilitando la continuación de la residencia en el Estado parte aún en situaciones de irregularidad, se encuentra una que el TEDH encaja dentro del test de la responsabilidad individual: En tales supuestos será un elemento relevante a favor de los intereses del extranjero demandante que, en cualquier momento a lo largo de su permanencia en el Estado miembro, haya podido acceder a un estatus regular. La posibilidad de haber podido solicitar la residencia por encajar en alguno de los motivos habilitantes previstos por las legislaciones internas - aun cuando dicha solicitud nunca haya llegado a formalizarse-, daría lugar al surgimiento de una expectativa razonable para el extranjero irregular de poder continuar con su vida familiar en el territorio del Estado receptor, al serle reconocido su derecho a la RF.

Los principales test empleados para el enjuiciamiento de las circunstancias concurrentes en los supuestos de RF de hecho, son los tres habituales, con una dimensión distinta: Test de los obstáculos, integración y responsabilidad individual.

a) En estos casos el TEDH mantiene una concepción más estricta del test de los obstáculos, exigiendo la concurrencia de obstáculos de carácter insuperable para la reconstitución de la vida familiar en el país de origen de alguno de los demandantes. Con todo, $-\mathrm{y}$ a diferencia de la primera etapa-, se valoran en su seno tanto los obstáculos jurídicos como los puramente fácticos. La mayor dureza de este test, dirigida a la protección del interés general del Estado, está relacionada con la contravención de las normas internas migratorias subyacente a estos casos.

b) Test de la integración en el Estado de acogida —ostentando un peso superior que los vínculos recíprocos en el país natal-: Entre los criterios convencionales que sustentan la protección de los intereses individuales destaca el grado de ruptura efectiva de la RF como consecuencia de la medida estatal denegatoria de la residencia. En su seno, el TEDH valora el interés superior de los hijos menores del extranjero irregular; cuando los menores han nacido y han sido criados en el Estado parte de acogida, careciendo de vínculos con el país de origen de sus padres, actuarán de facto como reagrupantes, erigiéndose el mantenimiento de su vida 
familiar en el Estado parte como el más relevante obstáculo al retorno de sus progenitores al país natal.

c) Test de la responsabilidad individual, en apoyo habitualmente de los intereses estatales: El TEDH evalúa si hay en juego factores de control migratorio - tales como un historial de incumplimientos del derecho migratorio que convierta en precaria la persistencia de la vida familiar en el Estado parte-, y consideraciones de orden público que apoyen la exclusión.

II. Confluencia de irregularidad y comisión de delitos: En estos supuestos -asunto Konstantinov c. Holanda-concurren dos circunstancias agravantes para la RF, situándose por ello en zona muy próxima a los casos de expulsión. El interés individual ya no se enfrenta únicamente al interés estatal de controlar la inmigración familiar y el gasto público - genéricamente subsumido en el "bienestar económico del país”-, sino también al interés general de protección del orden público y prevención del delito. Esta situación provoca un punto de partida favorable en principio a los intereses estatales.

Los supuestos de hecho analizados hasta el momento por el TEDH involucran a demandantes extranjeros que han permanecido todo el tiempo en situación irregular durante su estancia en el Estado contratante, sin haber disfrutado de ninguna autorización migratoria previa $-\mathrm{y}$ sin posibilidad de optar a ella-, y que han cometido delitos contra la propiedad dentro de dicho territorio. En aquellas situaciones en las que a la situación de irregularidad del inmigrante se aúne un comportamiento delictivo, las posibilidades de concesión del derecho a la RF amparándose en su vida familiar ya constituida dentro del país receptor, son extraordinariamente limitadas. El principio general aplicable será el derecho legítimo que asiste al Estado parte a denegar el ejercicio del derecho a la RF en su territorio, expulsando del mismo a dicho inmigrante.

Esta doctrina se supedita a casos de concesión inicial de un permiso de residencia que involucre a extranjeros irregulares que han cometido delitos contra la propiedad en el Estado parte de acogida, supuesto en donde sería legítima su expulsión. Pero en los casos típicos de expulsión - que exigen la previa retirada del estatus de residente-, el Estado habrá de tener en cuenta factores adicionales tales como el tiempo de residencia, la gravedad del delito, el grado de consolidación de la vida familiar del afectado en el país de acogida, etc., que rigen las obligaciones negativas migratorias en el ámbito de la VF.

13.5 En los últimos tiempos parece estar abriéndose una nueva etapa de corte rupturista en la jurisprudencia del TEDH en torno a este tema, pródiga en avances doctrinales de gran entidad, pero al mismo tiempo muy ambigua.

En esta etapa se enmarcan tres recientes pronunciamientos - Agraw v. Suiza; Nunez v. Noruega y Osman v. Dinamarca, emitidos durante el verano de los años 2010 y 2011-. En ella la Corte de Estrasburgo se muestra muy proclive a amparar la RF de los extranjeros, derrumbando, de hecho, algunos de los pilares sobre los que se erigía su construcción tanto normativa como jurisprudencial. Señaladamente tres: a) la exigencia previa del carácter regular de la residencia de los solicitantes extranjeros; b) la exclusión del concepto de vida privada, que ahora se admite expresamente a fin de ampliar la cobertura protectora de los extranjeros en supuestos que reúnen caracteres que dificultan la aplicación exclusiva del derecho a la vida familiar, como por ejemplo en presencia de hijos adultos jóvenes; c) y el tratamiento secuencial diferenciado entre obligaciones migratorias positivas y negativas.

Otra característica singular de esta última etapa jurisprudencial es que, enfrentado a supuestos de RF con características muy próximas a las obligaciones migratorias negativas, el TEDH rehúsa expresamente su catalogación, alegando que rigen principios muy similares. Pese a ello, al enjuiciar 
estos casos procede de forma equívoca, otorgándoles implícitamente el carácter de obligaciones positivas e inicialmente, sin entrar a examinar la posible legitimidad de las restricciones estatales bajo el prisma del apartado segundo del artículo 8 -asunto Nuñez v. Noruega-, en cuyo seno tiene lugar de forma explícita el análisis de la proporcionalidad de la injerencia, bajo la rúbrica de la evaluación de su necesidad en una sociedad democrática. La insistencia en rechazar su tipificación persistiendo en su tratamiento diferenciado-, provoca algunas contradicciones en su razonamiento, que resultan especialmente perturbadoras en una fase en la que el TEDH está emprendiendo una línea de sistematización y mayor transparencia de sus criterios jurisprudenciales. Sin embargo, en dos de las sentencias que integran esta etapa - Agraw v. Suiza y Osman v. Dinamarca, la primera de ellas anterior al asunto Nuñez-, la Corte analiza la justificación de las medidas migratorias adversas al amparo del artículo 8.2, circunstancia inédita hasta el momento en el ámbito de la RF de los extranjeros en Estrasburgo.

En esta etapa la fortaleza del interés supremo del menor es de tal calibre, que es capaz de enervar el principio general aplicable a solicitudes de RF de hecho y en las que confluye una conducta delictiva por parte del extranjero. La Corte, aun reconociendo expresamente el peso del interés general del Estado y la proporcionalidad de la medida estatal de expulsión, otorga una mayor consideración al interés supremo de los hijos, tanto menores nacidos en el Estado de acogida - Nunez-, como adultos próximos a la mayoría de edad que, sin haber nacido allí, han pasado la mayor parte de su vida en el país receptor - Osman- Esta circunstancia determina la apreciación de la existencia de violación del artículo $8 \mathrm{CEDH}$ - aun en concurrencia de múltiples circunstancias agravantes-, y el reconocimiento del derecho a la $\mathrm{RF}$.

Con ello, la Corte en esta última fase está embarcada en una actitud de decidido activismo judicial en la que - aun reiterando enfáticamente el derecho que compete al Estado parte de controlar la entrada y establecimiento de no nacionales en su territorio-, de forma material reduce notablemente el margen de apreciación nacional al evaluar las solicitudes de admisión de extranjeros por causas familiares.

Cabría pues concluir que la irregularidad de la estancia de los solicitantes no constituye un óbice para la admisión de sus pretensiones de acceder a la RF, convirtiéndose con ello la migración familiar en una vía para regularizar a extranjeros que cuenten con hijos nacidos en el Estado parte, quienes actúan como reagrupantes de sus progenitores. Similar línea de razonamiento está presidiendo también las últimas decisiones del TJUE — asunto Gerardo Ruiz Zambrano-, sin embargo en ella tiene un peso muy relevante, junto al interés superior de los hijos menores, el hecho de que éstos ostentan la nacionalidad del EM — factor al que el TEDH no otorga relevancia alguna en su argumentación, siendo sustituido por la importancia del test de integración en el Estado de acogida-.

14. Cuando el TEDH examina una demanda migratoria, la primera tarea consiste en evaluar la aplicabilidad del artículo 8, analizando si el vínculo entre los demandantes constituye vida familiar. Constituye jurisprudencia constante considerar que la VF, en el sentido del art. 8 CEDH, presupone la existencia de una familia. Sin embargo, el TEDH no ha proporcionado ninguna definición de familia ni listado alguno de las personas que la integran. Esta cuestión es abordada adoptando un punto de vista muy pragmático, ya que "la existencia o no de VF es esencialmente una cuestión de hecho que depende de la existencia real en la práctica de vínculos personales estrechos". Esta aproximación revela la concepción generalmente amplia, liberal, fáctica y casuística de la familia, superadora de prejuicios sociales y de vocación marcadamente expansiva. 
Sin embargo, al evaluar la VF de los extranjeros en supuestos que involucran medidas migratorias, los test convencionales empleados por el TEDH para determinar la existencia de VF registran una mayor opacidad y, lo que es más trascendente, se detecta una aproximación al concepto de familia más exigente y restrictiva. No obstante su carácter comparativamente más estrecho, es palpable en la jurisprudencia de Estrasburgo en el marco de la RF, una tendencia a la progresiva ampliación del concepto de vida familiar, de la que determinados fallos — destacadamente Abdulaziz, Rodríguez da Silva y Osman v. Dinamarca- constituyen un claro referente.

En la sentencia Marckx - fuera del ámbito migratorio-, el TEDH apuntó un concepto convencional mínimo o esencial de familia que incluiría, al menos, a padres, hijos y abuelos. No obstante, hasta la fecha no se ha presentado ningún supuesto que incluya ni a ascendientes ni a nietos a efectos de su reagrupación, por lo que no es posible afirmar que este concepto sea también extensible a la vida familiar de los extranjeros en el marco de la RF. Simplificando al extremo, cabría considerar como familiares extranjeros reagrupables dentro del ámbito de Estrasburgo, a los integrantes de la familia nuclear, entendiendo por tal exclusivamente a los padres, hijos menores, cónyuges y parejas de hecho heterosexuales.

Por cuanto a los hijos, el concepto de VF en su aplicación a extranjeros que solicitan la RF, cubre la relación existente entre padres e hijos, tanto matrimoniales como extramatrimoniales —en este último supuesto, nacidos "de una relación genuina, en la que sus padres cohabitaron como si estuvieran casados" -, siempre que sean menores de edad y sin establecer umbrales de edad previos a la mayoría de edad.

La edad de los menores y su grado de dependencia es un criterio recurrente, normalmente aplicado en sede de valoración del test de la integración. La edad de los hijos actúa en relación inversa a las posibilidades de concesión de la RF. Ante su proximidad a la mayoría de edad, el TEDH aplica case-law consolidado, considerando que las relaciones entre parientes adultos no necesariamente atraen la protección del artículo 8, exigiendo elementos adicionales de dependencia respecto de sus progenitores, que vayan más allá de los lazos emocionales normales -STEDH Konstantinov-. Con todo, aun en el supuesto de hijos a punto de cumplir la mayoría de edad y que permanecieron en el país de origen, no se excluye la aplicación del artículo 8, como atestigua el asunto Tuquabo-Tekle.

Sin embargo, muy recientemente, en el asunto Osman v. Dinamarca, el TEDH ha otorgado protección a hijos que han rebasado la mayoría de edad mientras esperaban la resolución de su recurso ante Estrasburgo - ampliando la cobertura mediante la aplicación de la cláusula de la vida privada-. A fin de determinar la existencia de VF entre "jóvenes adultos y sus padres", exige que los hijos aún no hayan formado un núcleo familiar propio. De confirmarse la protección de los hijos adultos en el seno de la RF, ello acarrearía importantes consecuencias prácticas en la forma en que esta cuestión se aborda tanto en el ámbito nacional como en el comunitario.

La relación existente entre una pareja válidamente casada y fruto de un matrimonio auténtico es constitutiva de vida familiar a efectos del artículo $8 \mathrm{CEDH}$. El TEDH exige que el matrimonio sea "legal" y "no ficticio", lo que supone la exclusión de los denominados matrimonios en blanco o de conveniencia, confirmando la relevancia del test de la autenticidad de los vínculos, en su aplicación específica a parejas casadas en un contexto migratorio. Cuando el matrimonio se ha contraído en un tercer Estado, en principio su validez jurídica no se cuestiona, priorizándose el elemento intencional o psicológico sobre el jurídico-formal, y bastando a estos efectos una VF "suficiente". Sentencias posteriores -Rodrigues da Silva; Nuñez contra Noruega - han ampliado el concepto de pareja para 
incluir también, en el paraguas protector del art. $8 \mathrm{CEDH}$, a las parejas de hecho heterosexuales, especialmente cuando hay hijos de por medio.

15. Respecto al establecimiento temporal de los vínculos familiares objeto de protección - y el concepto subyacente de migración familiar tutelado por el TEDH-, Abdulaziz expandió el concepto de la vida familiar de los extranjeros, admitiendo que la VF proyectada o planificada, pero aun no plenamente establecida, podía atraer la protección del artículo 8. Con ello, la Corte de Estrasburgo estaba simultáneamente amplificando la posible tutela de la migración familiar, para cubrir también potencialmente los supuestos de formación familiar. En la misma línea, la sentencia Sen ensanchó el ámbito de las obligaciones convencionales positivas dimanantes del respeto a la VF de los extranjeros: éstas ya no se restringían a permitir el mantenimiento de los lazos familiares normales de los extranjeros asentados en los Estados parte, sino que exigen del Estado que permita y facilite el desarrollo de su vida familiar dentro de su ámbito territorial. Este entendimiento vigoroso y activo de la VF daba entrada a una visión más amplia de la migración familiar, que incluiría —al menos como posibilidad potencial— la tutela de la migración matrimonial.

Tales avances, sin embargo, no se materializaron en la etapa que media entre tales sentencias. De modo que desde Abdulaziz - cuando la doctrina se apunta sin llegar a materializarse- hasta la sentencia Sen, el TEDH sólo otorgó cobertura a la RF en sentido estricto, esto es, a la familia nuclear del extranjero que ya tenía establecida una vida familiar en el momento de presentación de la solicitud de entrada o residencia a favor de sus parientes ante el Estado parte demandado, excluyéndose la tutela material de la formación familiar.

La situación cambia radicalmente con la sentencia Tuquabo-Tekle, que amplía la cobertura de la migración familiar para tutelar también los supuestos de formación familiar. Esta cuestión fue ventilada por el TEDH de forma expeditiva, como si se tratara de una línea continuista con su jurisprudencia previa. Ello ha provocado entendimientos dispares entre la doctrina y los Tribunales que aplican la jurisprudencia de Estrasburgo.

Siguiendo la doctrina sentada en Tuquabo-Tekle, los últimos pronunciamientos emitidos en esta materia manejan un concepto amplio de la migración familiar, protegiendo los vínculos familiares creados tanto antes como después del establecimiento del extranjero en el Estado parte y, por lo tanto, equiparando la RF en sentido estricto con la formación familiar, al menos en lo que respecta a los relaciones paterno-filiales. La última línea jurisprudencial del TJUE ha llegado a un entendimiento similar de la inmigración familiar.

16. Deslinde entre obligaciones migratorias positivas y negativas: En el asunto Rodrigues da Silva, el TEDH ofreció por primera vez un intento de sistematizar los criterios que rigen la asignación de una naturaleza positiva a una obligación migratoria, clarificando así su deslinde respecto de las obligaciones negativas. El detonante para esta clasificación vino dado por la naturaleza mixta que presentan los supuestos migratorios fronterizos o limítrofes entre la RF y la expulsión, que comenzaron a llegar por entonces ante el TEDH. Los casos fronterizos están conformados por solicitudes de RF formuladas en condiciones de irregularidad - en concurrencia o no de comisión de delitos-. La oscuridad terminológica y las dificultades de distinción entre ambos tipos de obligaciones resultan especialmente agudas en estos casos, que presentan contornos muy difusos.

Conforme al TEDH, para diferenciar los casos de RF al amparo del artículo 8.1 CEDH de otros supuestos migratorios colindantes también insertados en este enclave, el criterio viene determinado por el carácter inicial de la autorización estatal denegatoria impugnada y la afectación indirecta que ésta provoca sobre la VF del extranjero. 
La clave en los supuestos de migración familiar en tanto que obligaciones positivas, reside en que la medida estatal impugnada deniega la entrada inicial o bien un primer permiso de residencia. En este ámbito, el Tribunal de Estrasburgo reitera la necesidad de examinar las circunstancias concretas concurrentes, a fin de determinar si el Estado incumplió con su obligación positiva de permitir la entrada o la residencia - en ambos casos con carácter inicial-, del extranjero en su territorio. En la valoración de tales circunstancias, el TEDH declara aplicar principios similares a los que rigen en el ámbito de las obligaciones negativas. Es más, desde Konstatinov la Corte estima innecesaria tal catalogación pues en ambos supuestos concede "cierto" margen de apreciación al Estado parte, insistiendo en la necesidad de mantener un justo equilibrio entre los intereses concurrentes. Con todo, en el análisis de las demandas relativas a la RF, el TEDH restringía siempre su examen al apartado primero del artículo 8 , sin entrar a valorar la posible justificación de la injerencia desde la perspectiva del apartado segundo de dicho precepto - hasta que, muy recientemente, parece haber cambiado su tratamiento-.

La distinción entre obligaciones migratorias negativas y positivas es en ocasiones más formal que real - los asuntos Agraw contra Suiza, Nunez contra Noruega y Osman contra Dinamarca, son ejemplificativos de la proximidad entre estas figuras-. Por eso, desde estas páginas, aun celebrando el esfuerzo de sistematización desplegado por la Corte, lo consideramos aún insuficiente, a la vista de la oscuridad que sigue dominando esta materia. Los criterios que deslindan obligaciones migratorias derivadas del respeto a la vida familiar de los extranjeros - aun siendo necesarios, desde nuestro punto de vista - se revelan extremadamente débiles en su aplicación por parte del TEDH, incurriéndose en inconsistencias y contradicciones que dificultan la comprensión y sistematización de esta doctrina jurisprudencial.

17. La RF como obligación convencional positiva y su nivel más atenuado de enjuiciamiento: Las medidas migratorias adversas - tanto positivas como negativas - recurridas ante el TEDH por un extranjero por colisionar con su vida familiar, son analizadas mediante un método escalonado de enjuiciamiento. Uno de los aspectos procedimentales más singulares del método de evaluación empleado por el TEDH para abordar las demandas relativas a solicitudes de RF, reside en la habitual omisión del análisis del apartado segundo del artículo 8.

En el ámbito de las obligaciones migratorias negativas, el TEDH evalúa en primer lugar si la injerencia constituye una medida de la que el Estado debió abstenerse. Posteriormente, examina su posible justificación determinando si se trata de una medida prevista en la ley y si la misma está amparada por alguna de las restricciones legítimas contempladas en el apartado segundo del Convenio de Roma - habitualmente en relación con el orden público interno-, aplicando para ello el análisis secuencial que permite la aplicación explícita del principio de proporcionalidad mediante la vía de la cláusula de la necesidad en una sociedad democrática.

Por contraste, al examinar demandas relativas a denegaciones de RF, el TEDH no entra a valorar la posible justificación de la falta de respeto estatal en base a algunas de las limitaciones legítimas tasadas en el artículo 8.2, restringiendo su examen al apartado primero de dicha disposición. Con todo, en la sentencia Gül el TEDH introdujo la justa ponderación de intereses en el examen de las demandas sobre RF que, desde entonces, ha sido constante. La aplicación del test del justo balance de intereses parece ofrecer un nivel de escrutinio ligeramente inferior a la aplicación estricta del principio de proporcionalidad que tiene lugar al amparo de la cláusula de la necesidad en una sociedad democrática. Y, con carácter general, la omisión del examen de las limitaciones legítimas contenidas en el artículo 8.2 CEDH y la subsiguiente justificación de la medida estatal - constante a lo largo de toda su jurisprudencia relativa a esta rama hasta el año 2010 - redunda en un papel 
menos significativo del principio de proporcionalidad y, por ende, cierto desequilibrio a favor de los intereses estatales y menores posibilidades de defensa para los extranjeros.

El examen secuencial seguido por el TEDH en materia de RF es, cuantitativa y cualitativamente, inferior al desplegado en el ámbito de las obligaciones migratorias negativas, de lo que, consecuentemente, se deduce un menor grado de escrutinio. La explicación a esta forma de proceder del TEDH podría residir en el íntimo convencimiento de que, cuando está en juego un autorización de entrada o residencia de carácter inicial las obligaciones del Estado parte con respecto a dicho extranjero - aun cuando éste ya esté dentro de su territorio-, son de menor entidad que cuando el no nacional ya ha disfrutado de una autorización previa concedida por tal Estado.

Sin embargo, la situación descrita - constante a lo largo de las casi tres décadas de vida de esta rama jurisprudencia- cambió radicalmente en los asuntos Agraw contra Suiza y Osman contra Dinamarca. En ellos el TEDH rechazó expresamente tipificar la obligación migratoria — aun cuando ambos constituyen supuestos de RF y como tales enfoca su análisis- y, por primera vez, empleó el método secuencial de razonamiento en tres fases, analizando la justificación de la medida estatal restrictiva a la luz del apartado segundo del artículo 8 - esto es, evaluando si la misma poseía un fundamento legal, si perseguía un fin legítimo y, finalmente, su necesidad en una sociedad democrática para el cumplimiento de dicha finalidad-.

Para complicar aún más las cosas, en la sentencia Nunez contra Noruega -fallada con posterioridad tanto a Agraw como a Osman- el TEDH volvió a eludir el análisis del apartado segundo del artículo 8, y ello pese a que en este asunto concurrían múltiples circunstancias agravantes que lo aproximaban a los supuestos de protección frente a expulsiones.

En consecuencia, la confusión que domina el tratamiento procedimental empleado por el TEDH para el análisis de las obligaciones convencionales migratorias positivas, no ha hecho sino aumentar en las últimos tiempos. El análisis secuencial introducido por primera vez en los asuntos Agraw y Osman suponía, a nuestro entender, la unificación del tratamiento de todas las obligaciones migratorias - tanto positivas como negativas-, en coherencia con la vigencia de principios similares, largamente enfatizada por el TEDH. Con ello parecían quedar clausuradas tres décadas de tratamiento diferenciado, durante las cuales los supuestos de RF habían recibido un escrutinio jurídico de menor entidad en el ámbito de Estrasburgo. Sin embargo, en Nunez contra Noruega el TEDH volvió a eludir el análisis del artículo 8.2 CEDH, reinstaurando con ello su anterior tratamiento diversificado de las obligaciones migratorias - y ello sin mediar explicación alguna, esto es, con la misma oscuridad con que la Corte había cambiado radicalmente su forma de analizar los supuestos de RF al dictaminar los asuntos Agraw y Osman-.

A nuestro juicio las obligaciones migratorias derivadas del artículo $8 \mathrm{CEDH}$ - tanto positivas como negativas - tienen como colectivo destinatario a los extranjeros sobre quienes, en tanto que minoría insular, el TEDH debería desplegar un test de escrutinio estricto. Por ello, desde estas líneas abogamos por un tratamiento procedimental unificado de ambos tipos de obligaciones, sin excluir el análisis de la justificación de la medida estatal migratoria cuestionada ante Estrasburgo, al abrigo del artículo 8.2. La omisión del examen del apartado segundo del artículo 8 en los que hemos catalogado como casos fronterizos resulta aún más difícil de justificar —vid, por ejemplo el asunto Nunez v. Noruega-. En tales supuestos de RF, existe una amplia coincidencia con respecto a las restricciones legítimas invocadas en presencia de obligaciones migratorias negativas. Esta proximidad exigiría, a nuestro juicio, la aplicación de idénticos parámetros de enjuiciamiento, 
especialmente ante la insistencia del Tribunal en recordar la similitud de los principios aplicables a ambos tipos de obligaciones.

18. Si enfocamos el tratamiento jurisprudencial otorgado a la inmigración familiar en el ámbito de Estrasburgo desde una perspectiva evolutiva, cabría concluir que, en la actualidad, el razonamiento jurídico empleado por la Corte de Estrasburgo descansa sobre premisas contrarias a las empleadas en sus pronunciamientos iniciales.

En su primera etapa, el TEDH examinaba las demandas sobre RF partiendo de la existencia de una presunción en su contra - susceptible de ser destruida por los extranjeros que demostrasen obstáculos jurídicos insalvables a la reconstitución de su vida familiar en un tercer Estado-; Por contraste, en la última etapa de su jurisprudencia, el TEDH parte de una presunción iuris tantum a favor de la concesión del derecho a la RF, que puede ser superada por el Estado parte demandado mediante una sólida argumentación.

En consecuencia, la línea jurisprudencial liberal emprendida en Sen -y confirmada en los últimos pronunciamientos - otorga un poderoso sustento para afirmar que los Estados partes del Consejo de Europa están vinculados por obligaciones positivas en materia migratoria, que recortan el margen de apreciación que rige la imposición interna de criterios reguladores de la admisión de familiares de extranjeros asentados — tanto regular como irregularmente-, en el Estado parte de acogida.

La migración familiar en el ámbito de Estrasburgo se concibe en un sentido amplio amparando tanto la RF como la formación familiar-, pero no constituye una obligación con carácter general, como reiteradamente proclama el TEDH. La Corte exige por ello un análisis detallado e individualizado de las circunstancias particulares del caso y del interés individual de los extranjeros demandantes, a fin de ser contrastadas con el interés general de controlar la inmigración. Con todo, un análisis minucioso de la jurisprudencia de Estrasburgo permite avalar la consolidación de esta rama jurisprudencial y la existencia de un derecho a la RF para los extranjeros regulares, así como también de un limitado - pero potencial- derecho a favor de los irregulares, en circunstancias muy tasadas y aún cuándo éstos hayan delinquido en el Estado parte. En ambos supuestos, el Tribunal de Estrasburgo protege únicamente la familia nuclear del extranjero, amparando tanto los vínculos familiares precedentes como aquellos constituidos con posterioridad a la entrada del reagrupante en el Estado parte, sin que quepa afirma que los primeros ostentan primacía sobre los segundos - como sucedía hasta las sentencias Sen y Tuquabo-Tekle.

El avance revolucionario que se ha producido en esta rama jurisprudencial, en conjunción al carácter temprano de la intervención del TEDH, otorga a las instituciones de Estrasburgo un papel esencial en el proceso de internacionalización del derecho a la RF, abriendo rutas que después serían transitadas por el TJUE y, a su través, por todo el derecho comunitario migratorio. Pese a ello, sería deseable una mayor sistematización y claridad en los criterios aplicados por el TEDH y en el análisis secuencial empleado para evaluar las circunstancias concurrentes, que cancelara definitivamente el alto grado de ambigüedad y confusión que siguen dominando esta rama jurisprudencial.

19. El antecedente comunitario más remoto de la regulación comunitaria actualmente vigente en materia de migración familiar de los extranjeros - la Directiva 2003/86/CE sobre el derecho a la RF-, es la Resolución sobre Armonización de Políticas Nacionales relativas a la RF, adoptada en junio de 1993. Fruto de la colaboración intergubernamental, constituye el primer intento de aproximar las normas y prácticas nacionales en este ámbito. La Resolución carecía de fuerza jurídica vinculante, conteniendo un conjunto de principios consensuados que habrían de actuar como pautas para 
aproximar los criterios en que habían de desenvolverse las políticas nacionales de RF, con el fin de rebajar el alto grado de heterogeneidad que presentaban las regulaciones y prácticas de la época. Tal y como estaba regulada en la resolución, la RF no constituía un derecho subjetivo reclamable ante las autoridades públicas de cualquier EM, sino una prerrogativa estatal cuya concesión seguía dependiendo de la libre voluntad del Estado.

Con independencia de sus múltiples carencias, la Resolución estaba llamada a cumplir una función que trascendía su exigua eficacia jurídica: Servir a modo de guía que debía orientar las prácticas y políticas relativas a la RF de los distintos EEMM, especialmente relevante a efectos de la reforma futura de las legislaciones internas. Esta función de brújula resultó especialmente trascendente para aquellos Estados que - como España-, no habían procedido todavía a configurar legislativamente la RF, sirviendo para impulsar su regulación expresa y con ello incrementando sus garantías jurídicas. De este modo, la aprobación de la Resolución armonizadora por parte del Estado Español desencadenó la reforma del por entonces vigente Reglamento de extranjería para colmar dicha laguna, dando entrada al derecho a la RF a fin de adaptar las normas y prácticas españolas a los principios en ella acordados. Esta Resolución fue el detonante del acuerdo del Consejo de Ministros de 12 de noviembre de 1993 sobre tramitación de visados para la reagrupación de familiares de extranjeros no nacionales de EEMM de la Unión Europea que fijó los criterios para resolver las solicitudes de RF de ciudadanos de terceros países. La Resolución constituyó el único instrumento vigente en materia de RF que los EEMM fueron capaces de acordar dentro del ámbito del tercer pilar, pasando a formar parte del acquis comunitario sobre inmigración y asilo.

La adquisición de competencias en el ámbito migratorio por parte del Tratado de Ámsterdam - Título IV Tratado CE, que actualmente conforma el Título V Tratado TFEU_, clausuró la etapa previa de colaboración gubernamental, convirtiendo a la inmigración en una competencia comunitaria de carácter compartido con los EEMM, y vinculándola al objetivo de la consecución de la UE como un espacio de libertad, seguridad y justicia. Con ello las instituciones comunitarias se añadían a los EEMM en la formulación de políticas y normas en aquellos ámbitos materiales atribuidos a la UE. Entre los ámbitos materiales atribuidos a la UE, figuraba expresamente la RF -art. 63.3 del Tratado de Ámsterdam- que, por su compleja naturaleza, fue exenta del plazo general de cinco años otorgado al Consejo para la adopción de normas en el ámbito del asilo y la inmigración. Pese a ello, la primera norma de derecho comunitario derivado emitida haciendo uso de la nueva atribución competencial migratoria, sería precisamente la Directiva 2003/86/CE, sobre el derecho a la $R F$. El lugar prioritario que ostenta la migración familiar dentro de las normas y políticas comunitarias destinadas a regular la admisión de extranjeros, ha sido ratificado posteriormente en las sucesivas intervenciones que han tenido lugar en este ámbito.

20. Como consecuencia del marco jurídico con elementos intergubernamentales, vigente durante su elaboración, así como de su accidentado proceso de negociación, la Directiva 2003/86/CE sobre el derecho a la RF tiene un tenor marcadamente restrictivo. La tendencia dominante vira hacia un mayor estrechamiento del derecho, endureciendo sus condiciones de ejercicio. Para valorar esta norma, conviene comprobar su adecuación al logro de los tres objetivos que declara expresamente perseguir:

a) Fijar las condiciones de ejercicio del derecho a la RF de los nacionales de terceros países residentes legales en el territorio de los EEMM (art. 1): Mediante una formulación laxa $-\mathrm{y}$ en ocasiones altamente imprecisa-, la Directiva recoge condiciones onerosas para ejercer el derecho, reflejando las legislaciones nacionales más conservadoras. Aplicándosele el test 
convencional del justo equilibrio, la Directiva prioriza los intereses estatales, estableciendo un estándar bajo de protección.

b) Armonizar la regulación de la inmigración familiar (párrafo 16 del preámbulo): La Directiva es pródiga en cláusulas facultativas y reservas, concediendo a los EEMM elevados márgenes de apreciación que anticipan su débil efectividad y la correlativa baja intensidad de su objetivo armonizador. Sin embargo, su cláusula de emplazamiento — art. 19- le dota de un carácter transitorio, recayendo sobre la Comisión la obligación periódica de informar sobre su aplicación en los EEMM.

c) La Directiva ante el derecho a la RF: Esta norma otorga por primera vez un derecho subjetivo autónomo y general a la RF para los nacionales procedentes de terceros países que cumplan con las condiciones exigidas - si bien predicable solamente a favor de los miembros de la familia nuclear, y aún contemplando sobre ellos restricciones excepcionales-. Con todo, el derecho instaurado constituye una garantía legal mínima en todo el territorio de la Unión - erigiéndose la propia Directiva en una cláusula de stand still—, que goza de una cobertura geográfica sin precedentes en el derecho migratorio.

La situación existente antes de la adopción de la Directiva 2003/86/CE, clarifica la naturaleza jurídica del derecho a la RF y sus aportaciones en el ámbito de la migración familiar. Antes de su aprobación, la RF de los extranjeros extracomunitarios constituía una prerrogativa estatal y, como tal, sujeta casi enteramente a la discrecionalidad del Estado. Los esfuerzos desplegados en busca de fórmulas de convergencia entre los EEMM resultaron vanos, como consecuencia de la endeble vinculación jurídica de los instrumentos comunitarios intergubernamentales acordados en el seno del tercer pilar.

Con todo, el derecho a la RF en la Directiva 2003/86 se halla lejos de constituir un derecho fundamental. Los amplísimos márgenes de apreciación estatal y las restricciones que operan sobre la titularidad activa, impiden hablar de la RF como un derecho fundamental. Más modestamente, la Directiva consagra un derecho de configuración legal, todavía predominantemente estatal. Elementos básicos del derecho siguen dependiendo del legislador interno y, aún sobre muchos de los aspectos prediseñados por la normativa comunitaria, las políticas internas puedan desenvolverse cómodamente. En el reparto competencial, continúa predominando la figura del legislador nacional. Pese a ello, el condicionamiento internacional en la configuración jurídica del derecho a la RF parece destinado a ocupar un papel cada vez más relevante en el contexto geográfico europeo.

d) La Directiva ante el objetivo de fomentar la integración — párrafo 15 del Preámbulo—: En la Directiva son identificables dos perspectivas de integración. De un lado, prevalece en ella un concepto tradicional e inclusivo, conforme al cual la concesión de derechos constituye una condición previa para facilitar la integración. Este es el punto de partida al que explícitamente se adhiere, al considerar la RF como un mecanismo necesario para la vida en familia y un vehículo esencial para la integración. Las mayores debilidades en este punto se deben al carácter restrictivo de la noción de familia y la precariedad del estatuto de los parientes reagrupados - destacando las limitaciones para acceder a un estatuto autónomo, así como al mercado laboral一.

Durante la fase final de su negociación se insertó una concepción selectiva y con tintes asimilacionistas de la integración, entendida como condición previa para la concesión de derechos, incluyendo la propia autorización de entrada. Aquí se incluyen las disposiciones que facultan a los EEMM a imponer criterios previos de integración — tanto a los hijos a partir de los doce años (art. 
4.1 in fine), como con respecto a los restantes integrantes de la familia (art. 7.2) -, la exigencia potestativa de una edad mínima de 21 años al reagrupante y a su cónyuge (art. 4.5), y la imposición de medidas de integración como condicionante para el propio mantenimiento de la residencia por causa familiar (art. 16.1.a y 7.2) .

Ambos conceptos de integración resultan íntimamente contradictorios, provocando que la Directiva se mueva en un complejo e inestable equilibrio - que viene a reflejar las contradicciones internas sobre las que se construye la migración familiar. Esta norma no renuncia a los objetivos de contención - tratando de minimizar tanto los efectos multiplicadores de la migración familiar, como sus supuestas consecuencias sobre los mercados laborales autóctonos y los respectivos Estados del bienestar- pero, simultáneamente, tampoco renuncia a la integración, siquiera en su aspecto más básico.

Las lógicas contradictorias quedan al descubierto en el propio articulado, provocando discordancias, como la que resulta de las exigencias aplicables a los menores de 12 años, con respecto al cónyuge - artículos 4.1 in fine y 4.5, respectivamente-. Pese a ello, la Directiva ha sido formulada con una visión en mente inclusiva de la integración, que resulta dominante, configurándola como un instrumento básico de integración.

Debido a las múltiples deficiencias que lastran la aplicación interna de la Directiva comunitaria sobre el derecho a la RF, la Comisión Europea cerró en marzo del 2012 un debate público -basado en el denominado Libro Verde sobre el derecho a la RF-, destinado a definir la estrategia comunitaria más adecuada para simplificar y mejorar la regulación de la migración familiar en la UE. Entre dichas estrategias, se apunta expresamente a la modificación de su articulado. En consecuencia, en esta materia el futuro está abierto.

21. Simultáneamente, el TJUE, con su interpretación, está reconfigurando el marco en que se desenvuelve la aplicación nacional de la Directiva 2003/86. Este órgano ha perfilado con mayor nitidez el contenido sustantivo del derecho a la RF, estrechando el concepto del margen de apreciación establecido en el texto de la Directiva. Con ello, el Tribunal ha depurado las limitaciones que atañen tanto al legislador comunitario como a los poderes legislativos y administrativos nacionales en la configuración y desarrollo del derecho a la reunificación familiar, mediante pronunciamientos con características próximas a las sentencias interpretativas, que están transformando el marco en el que se desenvuelve la migración familiar extracomunitaria.

La Directiva 2003/86/CE ha sido interpretada por el Tribunal de Justicia de Luxemburgo en dos ocasiones. La primera tuvo lugar como consecuencia de un recurso de anulación parcial interpuesto por el Parlamento Europeo dos meses después de la publicación de dicha norma, resuelto mediante sentencia de 27 de junio de 2006 (Asunto C-540/03).

21.1 Asunto C-540/03: El objeto del recurso consistía en la solicitud de anulación de tres disposiciones de la Directiva, por su presunta violación del derecho al respeto de la vida familiar, del principio de no discriminación por razón de la edad y del criterio del interés superior del menor. Los artículos recurridos contemplaban derogaciones potestativas al régimen general de obligaciones, concediendo a los EEMM un margen de apreciación a fin de permitirles mantener o adoptar disposiciones nacionales que podrían ser potencialmente incompatibles con los derechos fundamentales mencionados.

El TJUE evaluó la legalidad de la Directiva por referencia a los estándares internacionales, revelando su razonamiento la centralidad del test internacional - fundamentalmente del test 
convencional de Estrasburgo-, en el escrutinio de la validez de las disposiciones recurridas. A tal fin, y sobre la base del art. 6 TUE, identificó dentro del DIDH las fuentes normativas de las obligaciones estatales en materia de migración familiar que contienen umbrales de protección más elevados, y que actuarían como parámetros de validez de la propia Directiva. De dicha operación, el Tribunal concluyó que, del estándar internacional vigente, no cabe deducir un derecho subjetivo de los extranjeros a que sus parientes sean admitidos en el territorio de un Estado.

Apoyándose en el art. 4.1 de la Directiva - que contempla los familiares cuya entrada preceptivamente debe autorizar el EM-, el TJUE señaló rotundamente que la Directiva 2003/86 otorga a sus titulares un auténtico derecho subjetivo a la RF, que obliga a los poderes públicos de los EEMM, en los supuestos determinados por tal norma, a autorizar la entrada y residencia de aquellos familiares del residente legal que cumplan con las condiciones requeridas, sin que puedan ejercer su facultad discrecional. De esta forma, la Directiva 2003/86 se sitúa muy por encima de los estándares internacionales protectores de la migración familiar.

Respecto a las disposiciones concretas recurridas, dos de ellas -artículos 4.1 in fine y 4.6 contenían restricciones facultativas a los derechos de los menores inmigrantes, y la tercera -el artículo 8- contemplaba la imposición de un período de espera que podía oscilar de entre dos a tres años. El TJUE avaló su validez, considerando que el margen de apreciación concedido por tales disposiciones no excedía de aquel derivado de la jurisprudencia de Estrasburgo. Para ello la Corte de Luxemburgo recurrió a una interpretación sistemática del texto de la Directiva, afirmando que las disposiciones controvertidas, al ser aplicadas por los EEMM, deben interpretarse a la luz de los principios que figuran en los artículos 5.5 de la misma Directiva - que obliga a los EEMM a tener debidamente en cuenta el interés mejor del menor-, y 17 -que les obliga a tener en cuenta un conjunto de elementos, entre los que figuran los vínculos familiares de la persona. Ambas disposiciones constituyen una recepción del DIDH, codificando, en el ámbito comunitario, criterios extraídos de la Convención de los Derechos del Niño - artículo 5.5 de la Directiva- y del case-law del TEDH - artículo 17 de la Directiva. Su lectura conjunta salva la validez de la Directiva, pues al verter los criterios establecidos en sus artículos 5.5 y 17, quedaría debidamente salvaguardada la preceptiva ponderación de los intereses en conflicto, exigida por la jurisprudencia de Estrasburgo.

La necesidad de ponderar, en las circunstancias concretas de cada caso, los respectivos intereses en conflicto, constituye una de las principales aportaciones de este pronunciamiento, materializando con ello una doctrina sólidamente asentada por el TEDH: el EM receptor ha de tener en cuenta las circunstancias personales de los implicados al decidir sobre una solicitud de RF, lo que, finalmente, desemboca en la exigencia de individualización del examen de las solicitudes en materia de migración familiar — pese a que el tenor literal de la Directiva no mencione tal obligación-.

La interpretación sistemática y conforme desarrollada por el TJUE, permite concluir que el EM que aplique las excepciones potestativas, sigue obligado a examinar la solicitud en interés del menor y procurando favorecer la vida familiar, desestimando el recurso de anulación. En consecuencia, los EEMM que opten por aplicar los artículos recurridos, han de dejar a salvo la posibilidad de conceder la RF incluso en tales supuestos - cuestión que dependerá de lo que se deduzca del examen individualizado de las solicitudes tras la aplicación de los criterios previstos conjuntamente en los artículos 5.5 y 17-. Esta forma de razonar ha terminado transfiriendo la cuestión central sobre la que giraba este asunto - la compatibilidad de la Directiva con los derechos fundamentales-, al momento de transposición y aplicación nacional de dicha norma. 
El pronunciamiento del TJUE constituye una sentencia con tintes interpretativos que reduce el margen de apreciación estatal en el examen de las solicitudes de RF y, por esta vía, contribuye al logro del objetivo armonizador perseguido por la Directiva 2003/86. Sin embargo, dado que estaban en juego los derechos de un colectivo especialmente vulnerable -la infancia inmigrante-, del análisis efectuado por el Tribunal cabría haber esperado una aplicación más rigurosa del principio interpretativo del efecto útil, una interpretación restrictiva de las limitaciones recurridas $y$, consiguientemente, un nivel muy alto de escrutinio, que la sentencia no ofrece. La actitud de autocontención desplegada por la Corte de Luxemburgo en la primera sentencia emitida en torno a la Directiva 2003/86, ha terminado priorizando la seguridad jurídica, imbuyendo de cierta precariedad al derecho de los menores extranjeros a la RF.

De otro lado, a pesar de que el Tribunal afirma la compatibilidad de la Directiva con los estándares internacionales, a nuestro juicio esta operación de encaje se ha realizado a costa de cierta reducción del estándar convencional derivado del art. $8 \mathrm{CEDH}$, que ha sido interpretado a la baja, ofreciendo una visión superficial, que no se ajusta a la última línea activista y decididamente progresista desarrollada por la Corte de Estrasburgo en materia de RF. La rápida evolución jurisprudencial producida en esta materia parece haber pasado inadvertida para el Tribunal de Luxemburgo, que ha recurrido a parámetros convencionales ya rebasados.

21.2 La segunda ocasión en que el Tribunal de Justicia de Luxemburgo interpretó la Directiva sobre el derecho a la RF, tuvo lugar a raíz de una petición de decisión prejudicial formulada por el Consejo de Estado de los Países Bajos; fue fallada el 4 de marzo de 2010 (Asunto Chakroun). El asunto Chakroun versaba sobre la interpretación de dos disposiciones de la Directiva sobre RF los artículos 7.1.c) y 2.d)—, que planteaban ante el TJUE la validez de la imposición nacional de requisitos económicos más estrictos sobre la formación familiar $-\mathrm{y}$, en este contexto, el sentido que había de otorgarse a la expresión "sistema de asistencia social", cuyo recurso excluye la posibilidad del solicitante de acceder a la RF-, así como la propia definición de migración familiar protegida por la Directiva.

La Corte de Luxemburgo, sobre la base de la variabilidad de la magnitud de las necesidades personales, determinó que la autorización para imponer requisitos económicos “debe interpretarse en el sentido de que los EEMM pueden indicar una determinada cantidad como importe de referencia, pero no en el sentido de que pueden imponer un importe de ingresos mínimos por debajo del cual se denegará cualquier reagrupación familiar, con independencia del examen concreto de la situación de cada solicitante. Apoya esta interpretación el artículo 17 de la Directiva, que obliga a individualizar el examen de las solicitudes de reagrupación".

Para llegar a tal conclusión, el TJUE inserta el «sistema de asistencia social del EM» dentro del arsenal de conceptos autónomos del derecho comunitario - - , por este medio, lo excluye del ámbito de influencia del margen de apreciación - para, finalmente, reducirlo por vía interpretativa. En esta perspectiva, la asistencia social acogería prestaciones procedentes de las autoridades públicas internas - con independencia de su nivel de actuación-, destinadas exclusivamente a suplir la falta de recursos fijos y regulares suficientes para la manutención del interesado/a y de su familia. La Corte de Luxemburgo utiliza una definición de sistema de asistencia social más estrecha que la que suele manejarse a nivel interno y, lo que es más trascendente, la aproxima a la que resulta aplicable en el contexto de familias mixtas integradas por ciudadanos comunitarios que ejercen su derecho a la libre circulación -el TJUE recurrió en este punto a la interpretación analógica con el caso Eind, dictado en el contexto de la libre circulación de trabajadores comunitarios y sus familias. 
En cuanto a la segunda cuestión prejudicial planteada, el TJUE señala que la definición de RF contenida en el artículo 2, letra d. de la Directiva no realiza distinciones según el momento de celebración del matrimonio de los cónyuges. De ello deduce que las reglas de la Directiva son aplicables con independencia del momento cronológico de constitución del vínculo familiar. En auxilio de esta concepción amplia de la migración familiar, el TJUE señala que la misma "es conforme con el artículo 8 del CEDH y con el artículo 7 de la Carta, que no establecen distinción alguna según las circunstancias y el momento en los que se constituye una familia" - cuestión que nuevamente alumbra el entendimiento superficial que el TJUE sostiene de la jurisprudencia de Estrasburgo, donde inicialmente se otorgaba un tratamiento preferente a favor de los vínculos familiares preexistentes-. En respuesta, el TJUE concluye que resulta contraria a la Directiva sobre el derecho a la RF, una normativa interna que establezca requisitos de ingresos diferenciados según el momento de constitución de los vínculos familiares.

En claro contraste con la actitud desplegada en su sentencia previa, en el asunto Chakroun el TJUE adopta una perspectiva pro-derechos humanos, potenciadora del efecto útil del derecho a la RF de los extranjeros procedentes de terceros países en la UE. Entre las principales aportaciones para forjar un derecho a la RF más robustecido que el que emana directamente de la Directiva, cabría destacar:

A) El TJUE extrae del art. 4.1 la existencia de una regla general de autorizar la RF de aquellos extranjeros que cumplan con los requisitos de la Directiva. Además, infiere una trascendente conclusión que, sin embargo, no resulta tan clara ni en el texto de la Directiva —ni en su espíritu一, a saber, que el objetivo de la Directiva es favorecer la RF. Ello implica que los requisitos que gravan el ejercicio de este derecho han de ser objeto de una interpretación restrictiva, sin menoscabar ni el objetivo de la Directiva, ni su efecto útil y, consecuentemente, que las limitaciones nacionales al derecho a la RF también han de ser objeto de un escrutinio judicial intenso. Esta interpretación garantista y reductora del margen nacional de apreciación, constituye un paso definitivo para la consolidación del derecho a la RF, pudiendo tener el potencial de neutralizar ciertas tentaciones restrictivas estatales.

B) Por primera vez la Corte de Luxemburgo aplica de forma concreta y depura las consecuencias derivadas de la cláusula transversal contenida en el artículo 17 de la Directiva, delimitando con claridad sus implicaciones sobre los sistemas administrativos establecidos por los EEMM para la evaluación y rechazo de las solicitudes en materia de migración familiar: Quedan rotundamente excluidos sistemas que impidan el examen caso por caso de las peticiones de RF. Como consecuencia dimanante, se proscribe la utilización por parte de los EEMM de umbrales de renta o requisitos de ingresos mínimos en el examen de las solicitudes de RF que excluyan a priori la evaluación individual de las mismas.

C) El TJUE sostiene una concepción amplia de la migración familiar, que incluye tanto el mantenimiento de la unidad familiar como la creación de vida familiar, abogando por nivelar la RF en sentido estricto y la formación familiar. Sobre este punto, el TJUE concluye que las reglas establecidas en la Directiva 2003/86 son aplicables a ambas categorías, optando claramente por reforzar la tutela de la vida familiar, con independencia del momento cronológico de constitución de los vínculos familiares. En consecuencia, el EM estaría obligado a realizar una interpretación restrictiva de las derogaciones al derecho, tanto de la RF como de la formación familiar. Nuevamente esta interpretación desemboca en una potenciación del derecho a la vida familiar de los extranjeros, especialmente por sus efectos disuasorios sobre la tendencia estatal a obstaculizar la migración matrimonial. 
Con todo, la Corte de Luxemburgo no aclara en profundidad el alcance de la ilegitimidad de las normativas internas que establezcan una diferenciación entre la RF en sentido estricto y la formación familiar, no quedando nítida si la misma es general o, más bien, se circunscribe a la prohibición de imponer requisitos económicos diversos. A nuestro entender, del razonamiento de la TJUE no cabe deducir una prohibición genérica de tratamientos normativos diferenciados entre la RF y la migración matrimonial. Más modestamente, la sentencia Chakroun es tajante respecto al alcance puntual de la prohibición de distinción entre ambas figuras, restringida a la exigencia de requisitos de ingresos diferenciados.

D) El TJUE recurre por primera vez a la interpretación analógica con dos sentencias emitidas en el ámbito de la libre circulación de los trabajadores comunitarios y de sus familias - Asuntos Ernid y Metock-, extrapolando parcialmente su doctrina sobre la RF de ciudadanos comunitarios al ámbito de los nacionales de terceros países. Ello permite al TJUE efectuar una notable reducción del margen de apreciación que compete a los Estados a la hora de imponer requisitos económicos y salariales que graven el ejercicio de la migración familiar.

Las referencias a los asuntos Enrid y Metock, parecen entrever que la Corte de Luxemburgo ha iniciado un nueva trayectoria de extensión de su concepción amplia de las libertades circulatorias a todos los individuos afectados por el derecho comunitario, incluyendo a los nacionales de terceros Estados. De ser ello cierto, supondría el comienzo de una tendencia hacia el acercamiento entre los regímenes jurídicos de RF aplicables a los nacionales de terceros países y a los ciudadanos comunitarios. Ello constituye, con diferencia, la perspectiva más innovadora de esta sentencia, revelando el cambio de actitud del TJUE. Este órgano parece haber retomado el ya lejano objetivo proclamado en el Consejo Europeo de Tampere, de aproximar el estatuto de ambos colectivos, otorgándoles derechos comparables. Parecería con ello inaugurarse una nueva época en el derecho comunitario migratorio - al menos en lo que respecta a la migración familiar-que, de confirmarse, carecería de precedentes en el derecho de la Unión.

22. El derecho al respeto de la vida familiar, tal y como es interpretado por el TEDH, constituye un principio general del derecho comunitario. Desde este prisma, la Directiva 2003/86 debe adecuarse a los parámetros fijados por el artículo $8 \mathrm{CEDH}$, en la interpretación efectuada por la jurisprudencia de Estrasburgo. Conviene por ello deducir el estándar de protección de la RF en el ámbito comunitario y en el Consejo de Europa.

El estándar de protección establecido por la Directiva 2003/86 es claramente superior que el extraíble delajurisprudencia deEstrasburgo. ElTJCE - asunto C/540 - ha reconocido reiteradamente - e impulsado - la fortaleza del derecho a la RF creado por la Directiva comunitaria, frente a la menor densidad normativa del derecho indirecto a la RF que cabe derivar del derecho convencional al respeto de la vida familiar. Desde esta perspectiva, la Directiva, con carácter general, respeta el estándar convencional de Estrasburgo. Sin embargo, la última línea jurisprudencial del TEDH ha abierto espacios para la protección de los vínculos familiares creados por extranjeros irregulares con independencia del momento cronológico de su constitución, e incluso aun cuando concurran delitos en el Estado parte-, reconociendo la vida familiar como plataforma de regularización y, con ello, superando en este concreto aspecto el estándar ofrecido por la Directiva 2003/86. Una futura reforma del texto de la Directiva, de llegar a materializarse, tendría que prever una vía similar que, aun excepcionalmente, ofreciera cobertura a tales situaciones - mayor en todo caso que la que actualmente dispensa la cláusula pasarela contenida en el art. 5.3 de la normativa comunitaria-, a fin de acomodarse a los parámetros convencionales. 
De otro lado, en las dos ocasiones en que el TJUE ha interpretado la Directiva 2003/86 resulta constante el recurso a la jurisprudencia de Estrasburgo. Por ello, resulta pertinente aplicar a su razonamiento uno de los criterios más asentados en el ámbito del Consejo de Europa: el test del justo equilibrio de los intereses en conflicto.

La autocontención desplegada por el TJUE en la sentencia que resolvió el recurso de anulación de la Directiva, determinó cierto escoramiento a favor del interés estatal de controlar la migración familiar. Frente a ella, en el asunto Chakroun el Tribunal de Luxemburgo se pronunció tajantemente a favor de la primacía de los intereses particulares - léase del derecho a la RF-, realizando un esfuerzo sin precedentes por aplicar parte de la doctrina emitida en el ámbito de la libre circulación de ciudadanos comunitarios, a los nacionales de terceros países. Tratándose de encontrar puntos coincidentes entre ambos pronunciamientos, el TJUE profundiza en Chakroun la senda de restricción del margen de apreciación estatal que ya había mostrado, si bien de forma marcadamente más modesta, en su primera sentencia —en este concreto aspecto resultan coincidentes el TEDH y el TJUE-.

En visión panorámica, la perspectiva adoptada recientemente por la Corte de Luxemburgo implica, para el conjunto normativo regulador de la migración familiar en el ámbito comunitario, que este Tribunal está de hecho transformando el tablero de juego en que tales reglas se están aplicando, suavizando el tenor restrictivo de la Directiva y facilitando el ejercicio práctico del derecho a la RF de los nacionales extracomunitarios.

Dada la relación directamente proporcional existente entre la reducción de la discrecionalidad estatal y la elevación subsecuente de las garantías individuales que arrompan al derecho y del nivel de escrutinio judicial, cabría concluir que la última línea interpretativa emprendida tanto por el TJUE como por el TEDH en torno al derecho a la vida familiar de los extranjeros, revela la creciente influencia condicionante del derecho internacional sobre los parámetros sobre los que gira la regulación interna de la migración familiar en el ámbito europeo.

23. La constitucionalización del régimen de los extranjeros ha constituido un proceso tardío y lento, perceptible en las Constituciones promulgadas a partir de la década de los setenta del siglo XX. La Constitución Española, en consonancia tanto con los textos constitucionales de nuestro pasado como con sus coetáneas, dedica una disposición específica a la regulación del estatuto jurídico de los extranjeros en España en una norma peculiar - el art. 13- que, a causa de su ambigua redacción y su textura normativa abierta, encierra una gran complejidad interpretativa. La configuración del marco constitucional de la extranjería que emana de dicha disposición, presenta una vocación marcadamente internacionalista, como consecuencia directa de la llamada prioritaria al legislador internacional contenida en la remisión legislativa que contempla el primer apartado del artículo $13 \mathrm{CE}$ :

a) De su redacción imperativa, en conjunción con la exclusión de los extranjeros únicamente con respecto del goce de los derechos políticos — art. 13.2 CE-, se extrae a priori una interpretación extensiva del reconocimiento de los derechos proclamados en el Título I a favor de los extranjeros. Ello provee seguridad jurídica al marco normativo de la extranjería y la inmigración, al implicar la prohibición de la regulación reglamentaria de carácter autónomo, rompiendo con la tradición preexistente en esta materia.

b) La parte más sustancial de la remisión legislativa prevista en el art. 13.1 CE reside en la expresa referencia a los tratados internacionales - aludidos en primer lugar-, como colegisladores de los derechos de los extranjeros en España. Dicha previsión, inusual en las reservas legales constitucionalmente establecidas, constituye, a nuestro entender, una clave explicativa de primer orden para el correcto entendimiento de esta disposición y, sobre su base, del diseño constitucional del estatuto jurídico de los extranjeros en el ordenamiento español. 
Cabría en primer lugar cuestionarse el sentido de la referencia expresa a los tratados internacionales contenida en la remisión legislativa del art. 13.1 CE, dado que toda reserva legal lleva implícita la legislación internacional convencional y todos los derechos contemplados en el Título I están a su vez sometidos a reserva legal por imposición expresa del art. 53 CE. En la búsqueda de un sentido autónomo a tal reserva legal, seguimos la postura de Vidal Fueyo avalada por la jurisprudencia constitucional-, para quien los dos apartados del artículo $13 \mathrm{CE}$ han de ser interpretados sistemáticamente, bajo la premisa de que la remisión legislativa prevista en el apartado primero permite otorgar a los extranjeros derechos no concedidos expresamente por el texto constitucional, pero de cuya titularidad activa tampoco están excluidos. La remisión legislativa internacional del art. 13.1 CE actuaría como una habilitación amplificatoria, de modo que la única intervención legislativa sobre los derechos de los extranjeros consistiría en el auxilio de los tratados internacionales para la delimitación de su contenido con efecto expansivo, prohibiéndose intervenciones en sentido restrictivo que pretendiesen acudir a los convenios como pretexto para rebajar los estándares internos, o para situar éstos por debajo del estándar internacionalmente establecido.

c) A nuestro entender, la acción expansiva, y por ende, protectora, que el artículo 13.1 CE confiere a los tratados internacionales, encuentra su pleno significado en conexión con la exclusión de los extranjeros con respecto de los derechos políticos, contemplada en el apartado segundo de la misma disposición.

El constituyente sintió la necesidad de subrayar una diferencia al constitucionalizar las bases de un régimen jurídico que afectaba a un grupo altamente vulnerable, como lo son las personas que no ostentan la nacionalidad del Estado en el que viven. Por definición - como indica taxativamente el artículo 13.2 CE- los extranjeros constituyen un colectivo carente de derechos políticos y que, por ello, genera escasa influencia sobre los representantes populares, quienes carecen de incentivos para atender las demandas de aquellos que no votarán por ellos. Los extranjeros no pueden proteger sus derechos a través del proceso político mediante el ejercicio del sufragio - como se hace ordinariamente en una democracia representativa-, encajando en el concepto de "minoría insular", de procedencia estadounidense. En consecuencia, si la reserva de ley es un instrumento de garantía, el nivel de seguridad jurídica que ésta otorga es de inferior rango cuando recae sobre derechos de los no nacionales. Dado que el art. 13.2 CE les excluye expresamente del proceso político, deben articularse mecanismos suplementarios para proteger a los grupos sociales que no participan en el proceso electoral.

24. El primer apartado del art. 13 CE prevé una vía adicional para la protección de los no nacionales en España, mediante el recurso al derecho internacional general de carácter convencional para el desarrollo de los términos y condiciones del estatuto jurídico de los extranjeros en territorio español, que sólo admitiría una intervención en sentido expansivo - con lo cual al tiempo que se les ofrece una vía de tutela supletoria, también se neutraliza el riesgo de intervenciones restrictivas, inherente a toda reserva legislativa.

La reserva legal internacionalista del artículo 13.1 CE constituiría un canal para reforzar la protección del colectivo destinatario de la misma - los extranjeros-. Conforme al mismo, los tratados internacionales y la interpretación jurisprudencial supranacional se erigirán en un umbral mínimo por debajo del cual no podrá descender el poder legislativo interno - ni tampoco el poder judicial interno al proveer justicia a dicho colectivo- $y$, además, constituirán vías potenciales para la ampliación del contenido de los derechos fundamentales de dicho colectivo. 
La vinculación negativa del legislador con respecto a los derechos fundamentales de los extranjeros, supondría, desde el punto de vista interno, entender que éstos actúan como límites a las inestables políticas migratorias. Y, desde el punto de vista internacional, concebir a los derechos humanos como barreras internacionales frente a dichas políticas, destinados a la amplificación del haz de facultades subjetivas que comprende el contenido interno de los derechos de los extranjeros en territorio español. El libre desarrollo y ejecución de las políticas migratorias se movería dentro de los límites marcados por el texto constitucional y, a un nivel más concreto, con el tope mínimo representado por los derechos fundamentales - en su concepción interna-, y por los derechos humanos - vía internacional-. Por su parte, la vinculación positiva se traduciría en la introducción - mediante la intermediación del derecho internacional convencional y, en general, del DIDH-, de facultades adicionales que se integrarían, amplificándolo, al contenido de los derechos de los extranjeros, tal y como son reconocidos a nivel interno. Esta consideración resulta central para entender la configuración del derecho a la RF.

25. Si bien el artículo 13 constituye la disposición clave en esta materia, constituye un mero punto de partida, debiendo ser interpretada de forma sistemática, fundamentalmente en conjunción con el artículo $10 \mathrm{CE}$, en sus dos apartados, así como con las disposiciones consagradas a lo largo del Título I CE. Sobre la base del artículo 13.1 CE, se extrae una acusada predisposición internacionalista del régimen constitucional español de la extranjería, fomentada por la propia ambigüedad e indeterminación de su redacción y por los efectos que, en esta materia, despliega el criterio interpretativo contemplado en el artículo 10.2 CE. En consecuencia, una interpretación sistemática del artículo $13 \mathrm{CE}$ conduce a un reforzamiento de la vocación iusinternacionalista con la que fue diseñado el marco jurídico migratorio en el ordenamiento español.

a) El artículo 10.1 CE erige a la dignidad de la persona en fundamento del orden político y la paz social. La ecuación humanidad-dignidad-igualdad desemboca en la existencia preceptiva de un núcleo irreductible de derechos fundamentales de titularidad activa universal, cuyo reconocimiento y garantía resultaría insoslayable para todo Estado de Derecho. La dignidad humana queda así estrechamente conectada al artículo 13.1, permitiendo deducir ex constitutionen un núcleo mínimo pero irreductible de derechos predicables del ser humano en cuanto tal, y por tanto, compartidos en condiciones de igualdad por nacionales y extranjeros, respecto de los cuales la capacidad de intervención legislativa es mínima. El TC ha partido reiteradamente de esta interpretación sistemática, constituyendo el art. 10.1 CE el fundamento constante de la argumentación desplegada para enfrentarse a los derechos de los extranjeros, con el auxilio constante del DIDH.

b) Por su parte, el apartado segundo del art. 10 CE consagra el DIDH como criterio exegético vinculante para la interpretación de las normas constitucionales relativas a los derechos fundamentales. Este canon interpretativo, que extiende sus efectos sobre todos los derechos reconocidos en el Título I CE, convierte al DIDH en el marco de referencia para la comprensión de los derechos constitucionales. Sus efectos son de carácter interpretativo e integrativo. En virtud de los primeros, el contenido internacionalmente declarado de los derechos humanos resulta vinculante para identificar el contenido de los derechos internos. En base a los efectos reintegrativos, el contenido material de los derechos constitucionales puede ir ensanchándose y actualizándose, mediante la incorporación de facultades subjetivas procedentes de los tratados internacionales de derechos humanos y de las decisiones emanadas de sus órganos de interpretación y aplicación. Dado que este proceso es siempre en sentido expansivo, el art. 10.2 CE constituye una vía permanente de dinamización de la declaración constitucional de 
derechos. Si bien el artículo 10.2 CE menciona expresamente a la DIDU, ha sido el Convenio de Roma y la jurisprudencia emanada de los órganos de Estrasburgo en su aplicación e interpretación, la fuente privilegiada a la que reiteradamente recurre el TC español para interpretar el alcance y contenido de los derechos constitucionales, mostrándose desde sus primeros pronunciamientos especialmente receptivo a la jurisprudencia del TEDH.

c) El artículo 10.2 CE constituye una disposición especialmente relevante para la migración familiar en particular, y para la extranjería y la inmigración en general, por varias razones:

c.1. Los tratados sobre derechos humanos constituyen habitualmente fuentes de normas que contemplan derechos cuyos destinatarios son los extranjeros.

c.2. La virtualidad del criterio hermenéutico internacional parece ser superior, cuanto mayor sea el grado de apertura y abstracción del derecho constitucional que actúa como simiente o matriz a la recepción del contenido internacionalmente vinculante del derecho humano equivalente, y también cuanto más amplio sea el margen de configuración otorgado al legislador en su desarrollo, características ambas que concurren en nuestra materia. En este escenario el ámbito internacional puede ofrecer mayor protección a las pretensiones restriccionistas internas.

c.3. El recurso habitual del TC al criterio interpretativo internacionalista es más intenso en materia de extranjería. La receptividad del TC al DIDH — con el TEDH a la cabeza-, ha permitido que la cláusula hermenéutica del art. 10.2 CE despliegue en el ámbito de los derechos de los extranjeros una importantísima función de carácter fundamentalmente reintegrativo. Con ello el canon interpretativo proporciona una garantía añadida, que se superpone al mecanismo de protección suministrado por el art. 13.2 en el ámbito específico de los derechos de los extranjeros.

c.4. Los efectos internacionalistas del artículo 10.2 CE se han visto reforzados por la reserva legal internacional contenida en el artículo 13.1 CE. En la migración familiar, esta sinergia fue potenciada por el retraso de nuestro ordenamiento para reconocer legislativamente el derecho a la RF, propiciando un contexto especialmente permeable a las aportaciones tanto de Estrasburgo como de la Unión Europea. Cuando por primera vez es reconocido el derecho a la RF en España - por vía reglamentaria, y de forma altamente condicionada y arbitraria-, éste penetra a instancias de la Recomendación comunitaria sobre armonización en materia de RF, la cual a su vez estaba imbuida del espíritu de Estrasburgo.

c.5. La remisión legislativa del art. 13.1 CE despliega toda su virtualidad sobre los derechos que admiten modulación y condicionamiento legislativo - la tercera categoría de derechos de los extranjeros, según la clasificación tripartita establecida por el TC-. Por otro lado, los efectos exegéticos del art. 10.2 se proyectan sobre todos los derechos del Título I CE, incluyendo los principios rectores, donde el TC parece haber implícitamente enraizado el encaje constitucional del derecho de los extranjeros a la RF, al contemplarla como una vía instrumental para la protección de la familia. En consecuencia, la migración familiar constituye un campo fértil para la interpretación iusinternacionalista. Sin embargo, el TC no ha explotado las posibilidades interpretativas del derecho a la VF, como consecuencia de un entendimiento superficial y rebasado de la jurisprudencia de Estrasburgo.

26. El ordenamiento jurídico de los extranjeros presenta una doble vinculación a los derechos humanos: de un lado, a través de la reserva de ley expansiva del 13.1 CE que afecta al derecho internacional general de carácter convencional - y que sirve como mecanismo adicional de tutela para 
la minoría insular representada por el colectivo de los extranjeros en territorio español-; y, de otro, mediante el reenvío interpretativo contenido en el 10.2 CE, que afecta a los tratados internacionales ratificados por el Estado español en materia de derechos humanos y a la jurisprudencia emanada de su interpretación y aplicación. En el entendido de que los efectos desplegados por ambas normas son distintos, si bien su juego sinérgico confluye en lo que respecta a la adicción de facultades subjetivas procedentes del derecho internacional público sobre el contenido constitucionalmente declarado de los derechos de los extranjeros - mediante la expansión del art. 13.1 y por la vía reintegrativa del art. 10.2 CE-, profundizando con ello tanto la vocación internacional del estatuto de la extranjería como la tutela de sus derechos.

El contenido internacionalista del marco constitucional de la extranjería y la inmigración, vendría a contrarrestar los posibles excesos del legislador interno al desarrollar el contenido de los derechos de los extranjeros, erigiéndose el Derecho internacional convencional como límite de la afectación de los mismos. Por lo tanto, la referencia a los tratados internacionales en el primer apartado del artículo $13 \mathrm{CE}$, encontraría su más profundo sentido en conexión con la exclusión de los derechos políticos por parte de los extranjeros, establecida a renglón seguido en el siguiente apartado de la misma disposición constitucional, vinculado al concepto de "minoría insular" donde encajan los extranjeros no comunitarios. Se trataría de un mecanismo de compensación a fin de neutralizar la amenaza potencial de reducción del contenido de sus derechos por parte del legislador interno - amenaza nada desdeñable, en vista de que la extranjería suele situarse al socaire de criterios de oportunidad política y constituye una materia jurídicamente muy inestable.

27. El carácter "internacionalista" del diseño constitucional de los derechos de los extranjeros, ofrece sustento al activismo judicial en materia de extranjería e inmigración. La inclusión expresa de los Tratados internacionales dentro de la reserva legal exigida por el artículo 13.1 CE y el canon interpretativo del art. 10.2 CE, otorgan base a las incursiones progresistas que pudiera llegar a hacer tanto el TC español como el poder judicial, con el TS a la cabeza, menos expuestos que los legisladores a las presiones populares. No en vano, la línea jurisprudencial desplegada en la interpretación y aplicación de los derechos de los extranjeros se caracteriza, en términos generales, por su carácter expansivo y su elevado progresismo. También explica que, en aquellos derechos de los extranjeros sometidos a márgenes de apreciación elevados y sobre los que no había voluntad interna para su reconocimiento jurídico — como la $\mathrm{RF}$ - , su construcción se haya realizado a remolque del derecho internacional, primero en vía jurisprudencial y de forma extremadamente casuística hasta, posteriormente, encontrar acomodo en normas jurídicas internas de rango sucesivamente más elevado. La evolución normativa de la inmigración familiar en el ordenamiento español constituye un ejemplo elocuente de todo ello.

En suma, la interacción de los artículos 13.1 y $10.2 \mathrm{CE}$, junto con la actitud internacionalista desplegada por el TC español, han determinado que la extranjería en nuestro ordenamiento constitucional se perfile como una materia intensamente penetrada por el derecho internacional.

28. El TC tuvo ocasión de enfrentarse al derecho a la RF con ocasión de los ocho recursos de inconstitucionalidad que fueron presentados a raíz de la reforma operada a la Ley Orgánica 4/2000, mediante la LO 8/2000, que, entre otras, recurrían las remisiones reglamentarias contenidas en la ley para el establecer las condiciones de ejercicio de los derechos a la intimidad familiar y al RF —rubricados así en el texto legal-. En la STC 236/2007 — que sintetiza la respuesta ofrecida a tales recursos- el TC, con buen criterio jurídico, excluyó la conexión material entre el derecho a la RF y la faceta familiar del derecho fundamental a la intimidad reconocido en el artículo $18 \mathrm{CE}$, descartando expresamente la equivalencia entre éste último y el más amplio derecho convencional 
a la vida familiar. Con ello, quedaba cerrada la vía de amparo para la protección del derecho a la $\mathrm{RF}$ - pese a la equívoca vinculación que la ley vigente mantiene entre la intimidad familiar y la RF, procedente de la L.O. 4/2000-.

El TC no exteriorizó la matriz constitucional del derecho a la RF, si bien parece desprenderse su ubicación como un instrumento para la protección de la familia de los extranjeros — art. 39 CE- En un escueto razonamiento que destaca por su remisión constante a la jurisprudencia de Estrasburgo, un nivel bajo de escrutinio en este concreto aspecto y el nulo uso del principio de proporcionalidad, el TC se apoyó en la primera - y ya superada - línea argumental empleada por el TEDH, negando que del artículo $8 \mathrm{CEDH}$ pudiera derivarse un derecho a la RF para los extranjeros instalados en los Estados parte. A nuestro entender, el TC desaprovechó las posibilidades interpretativas abiertas por el artículo 10.2 CE, especialmente en lo que respecta a la oportunidad de clarificar la naturaleza jurídica del derecho a la RF y utilizar en toda su extensión el art. 8 CEDH como criterio interpretativo del derecho a la RF, en conexión con el principio rector de protección de la familia. Para el alto tribunal español, ha pasado desapercibida la evolución en sentido expansivo experimentada por la jurisprudencia del TEDH.

Aplicando a nuestro objeto de estudio la doctrina constitucional reformulada y sistematizada en la STC 236/2007, la RF se situaría entre aquellos derechos de los extranjeros, no atribuidos directamente por la Constitución, cuya extensión a su favor depende de la acción normativa del legislador -internacional e interno- y que, por ello, están sujetos a un mayor margen de configuración legislativa. El TC ha establecido expresamente la necesidad de que la intervención legislativa sobre tales derechos de configuración legal respete, entre otros límites, el principio de proporcionalidad, en sintonía con la jurisprudencia de Estrasburgo. Desde estos parámetros, se debe valorar la escasa utilización del principio de proporcionalidad por parte del TC español. Cabría objetar que el TEDH aplica al derecho a la RF el test del justo equilibrio, esto es, un nivel ligeramente más atenuado que el principio estricto de proporcionalidad usado en el ámbito de las obligaciones negativas. En consecuencia, al menos el test del justo equilibrio debería haber estado presente en el razonamiento empleado por el TC para despejar las dudas de constitucionalidad surgidas por las remisiones reglamentarias establecidas para el ejercicio del derecho a la RF y, más allá, el principio de proporcionalidad debería impregnar con mayor intensidad sus pronunciamientos en materia de extranjería e inmigración.

29. La penetración del DIDH en la configuración jurídica interna de la RF, exige valorar el cumplimiento de los estándares de Estrasburgo por parte de la normativa comunitaria y del ordenamiento español, al menos respecto a tres de sus aspectos principales: la titularidad activa del derecho, el concepto de familia y la posibilidad de acceder a la RF pese a que el extranjero solicitante se halle en situación de irregularidad administrativa.

a) La concepción que el TEDH mantiene en torno a los lazos familiares constitutivos de VF, determina la titularidad activa del derecho consagrado en el art. $8 \mathrm{CEDH}$. Desde sus inicios, se deduce de la jurisprudencia de Estrasburgo una titularidad amplia, dual o compartida del derecho a la VF de los extranjeros, predicable tanto del reagrupante como de los miembros de su familia - sin que pertenezca en exclusiva al sponsor, como suele ser habitual en los enfoques tradicionales de la migración familiar-. Este concepto dual resulta coherente con la formulación amplia del derecho proclamado en el artículo $8 \mathrm{CEDH}$, y ya ha tenido ocasión de desvelar su potencial práctico, permitiendo que los hijos menores actúen como reagrupantes de sus progenitores extranjeros. 
En este aspecto, la Directiva comunitaria 2003/86 resulta plenamente compatible con el artículo $8 \mathrm{CEDH}$. A diferencia de sus precedentes normativos, la versión definitiva de la Directiva dio cabida a una concepción amplia de reagrupante y a una titularidad dual — art. 2.d) - . En coherencia con esta concepción, la presentación de solicitudes de RF puede correr a cargo tanto del principal como de sus familiares, bien sea en el EM receptor o ante las autoridades representativas de dicho Estado en un tercer país. Consecuentemente, las resoluciones denegatorias del permiso de residencia por causa familiar pueden ser recurridas tanto por el principal como por sus familiares. En contrapartida, esta concepción dual ha provocado múltiples errores terminológicos a lo largo del articulado de la Directiva 2003/86/CE, constituyendo la débil tutela jurídica otorgada por su artículo 18 el punto más frágil en este aspecto.

En el ordenamiento español, el concepto tradicional de reagrupante como titular activo en exclusiva del derecho a la RF constituye una constante desde la introducción de la RF — salvo por lo que respecta a la efímera vigencia de la L.O. 4/2000- En consonancia con este concepto restrictivo, el inicio del procedimiento para ejercer el derecho a la RF queda en manos exclusivamente del extranjero residente, resultando determinante su voluntad unilateral. Aunque la Directiva 2003/86 ha optado por una titularidad dual, sin embargo su redacción amplia y opcional deja en manos del EM la determinación de esta cuestión. En este punto, la legislación española resulta compatible con la Directiva comunitaria 2003/86. Sin embargo, su encaje dentro del concepto amplio sostenido por la jurisprudencia del TEDH resulta problemático, especialmente a la luz de sus últimos pronunciamientos.

b) Si se confronta el concepto convencional de la familia de los extranjeros con el existente en el artículo 4 de la Directiva - circunscribiendo el análisis a aquellos miembros titulares de un derecho subjetivo-, cabría concluir que la noción de familia mantenida por la jurisprudencia de Estrasburgo es en principio más amplia y protectora que el concepto comunitario de familia nuclear. Del artículo $8 \mathrm{CEDH}$ se extrae una noción de familia que ampararía al matrimonio, a las parejas de hecho heterosexuales, a los hijos menores con independencia de su filiación y, excepcionalmente, a los hijos adultos siempre que existan razones adicionales de dependencia - pudiendo en este último supuesto reforzarse la protección ofrecida por la VF mediante la alegación de violación del derecho a la vida privada-.

Por contraste, en la Directiva 2003/86 la admisión de los miembros de la pareja de hecho queda a la libre discrecionalidad del EM y, lo que resulta más difícilmente justificable, también la reagrupación de sus hijos. La admisión de los ascendientes en primer grado depende de la libre voluntad del Estado, si bien esta cuestión no ha sido todavía despejada por el TEDH. Una futura reforma de la Directiva debería contemplar el carácter preceptivo de la admisión del cónyuge, la pareja de hecho y de los hijos menores, sin que quepa establecer restricciones excepcionales sobre estos familiares, a fin de adaptarse al canon de Estrasburgo.

En el ordenamiento español, el nuevo tratamiento de la migración familiar ha ampliado los familiares reagrupables mediante la protección de la pareja de hecho, resultando en este punto acorde con la jurisprudencia de Estrasburgo. Simultáneamente, ha introducido restricciones para la admisión delos ascendientes - cuestión que, en el ámbito de Estrasburgo, todavía no ha sido despejada, resultando en principio compatible con los cánones convencionales-. Con ello, el ordenamiento español se ha alineado con las restantes normativas europeas en su concepción minimalista de la familia nuclear, aprovechando el margen de apreciación que en esta materia permitía la Directiva 2003/86/CE. Sin embargo, la exigencia general de contar con cinco años de residencia regular y continuada en España para que el reagrupante pueda reunirse con sus ascendientes $-y$ para que éstos, a su vez, puedan ejercer el derecho a reagruparse con sus propios familiares-, excede los plazos de espera previstos 
por el derecho comunitario - artículos 3.1 y 8.1 de la Directiva-. Asimismo, resulta difícilmente justificable a la luz del test convencional del justo equilibrio entre los intereses.

c) La última línea jurisprudencial mantenida por el TEDH permite contemplar la RF como vía excepcional para la regularización de inmigrantes - habitual pero no necesariamente de larga duración- que cuenten con sólidos vínculos familiares en el Estado de acogida. En esta misma línea, la Directiva sobre el derecho a la RF incluye una cláusula excepcional que posibilita acceder a la RF a extranjeros en situación de irregularidad administrativa —art. 3.5 in fine-, consintiendo la presentación de solicitudes cuando los miembros de la familia estén ya dentro del territorio del EM receptor. Con ello, la Directiva se adapta a las exigencias derivadas de la jurisprudencia más reciente de Estrasburgo.

Por su parte, la legislación española proclama la titularidad activa del derecho a favor en exclusiva de los extranjeros residentes. Esta restricción resulta coherente con la naturaleza de la RF como derecho de configuración legal, despejada ya por el TC. Con todo, siempre se han previsto vías excepcionales que permiten el acceso a la migración familiar en situaciones de RF de hecho. A partir de la reforma operada por la LO 14/2003, se eliminó la figura de la exención de visado, cuyos supuestos de hecho pasaron a integrar la autorización de residencia temporal por circunstancias excepcionales. En el orden interno, la previsión expresa de las figuras del arraigo familiar y, especialmente, del arraigo laboral -al tutelar los vínculos familiares, sociales y profesionales de los extranjeros en situación previa de irregularidad administrativa-, resulta una exigencia ineludible a la luz de la última línea jurisprudencial del TEDH. Últimamente se especula sobre su inminente reforma a fin de eliminar el arraigo familiar, hipótesis que, de llegar a producirse, provocaría conflictos con la línea jurisprudencial iniciada a partir de Rodrigues da Silva.

30. Cabría finalmente situar nuestro ángulo de enfoque de la inmigración familiar en una perspectiva más elevada. Desde este punto de vista, la configuración jurídica del derecho a la RF y el sinuoso trayecto recorrido para ello, constituyen una proyección concreta del Derecho de nuestro tiempo, caracterizado por la internacionalización del ordenamiento jurídico en general y, en particular, de los derechos fundamentales. Si bien en el siglo XX el derecho constitucional informaba el derecho internacional público en cuanto al catálogo de derechos y la aspiración a garantizarlos, a principios del siglo XXI la relación de influencia parece invertirse, procediéndose a una progresiva constitucionalización de ciertos contenidos iusinternacionales, a grado tal que la separación material entre ambas disciplinas se ha venido difuminando en la teoría y en la práctica.

En este contexto, la extranjería y la inmigración se están relevando como un precoz laboratorio jurídico, donde se experimentan y certifican algunas de las notas más sobresalientes del constitucionalismo de nuestros días: destacadamente, la penetración del DIDH como un condicionante del derecho interno cada vez más vigoroso, dando lugar a ordenamientos jurídicos permeables, crecientemente complejos, cincelados a base de múltiples piezas interactivas cuyo engranaje conjunto plantea serios retos para los intérpretes jurídicos. Sin embargo, al mismo tiempo la internacionalización del derecho constitucional ofrece cotas ascendentes de armonización que, analizadas con optimismo, apuntan a un futuro ordenamiento jurídico global más coherente y con estándares crecientemente elevados. Ello resulta especialmente evidente en lo que respecta al derecho de extranjería en el contexto geográfico europeo, donde desde instancias jurisdiccionales supranacionales - TEDH y TJUE - se están fijando estándares cada vez más prominentes sobre las políticas migratorias internas. 



\section{BIBLIOGRAFÍA}

ABARCA JUNCO, Ana Paloma; ALONSO-OJEA, B; LACRUZ LÓPEZ, J.M.; MARTÍN DÉGANO, I. y VARGAS GÓMEZ-URRUTIA, M. Inmigración y Extranjería. Régimen jurídico básico. Madrid, Colex, 2a ed., 2008.

- y VARGAS GÓMEZ-URRUTIA, Marina. "Derecho a la intimidad familiar"; en ESPLUGUES MOTA, Carlos (coord.). Comentarios a la Ley de Extranjería. Valencia, Tirant lo Blanch, 2006, pp. 417-445.

- y VARGAS GÓMEZ-URRUTIA, Marina. "Familiares reagrupables"; en ESPLUGUES MOTA, Carlos (coord.). Comentarios a la Ley de Extranjería. Valencia, Tirant lo Blanch, 2006, pp. 447-494.

ACEDO PENCO, Ángel. "El derecho a la intimidad familiar y la reagrupación familiar en la nueva Ley de extranjería”; en PERALTA CARRASCO, Manuel (dir.). I Jornadas sobre la Ley de Extranjería e Inmigración. Cáceres, 26 a 29 de marzo de 2001. Facultad de Derecho. Cáceres, Universidad de Extremadura, 2003, pp. 43-52.

ADAM MUÑOZ, María Dolores y BLÁZQUEZ RODRÍGUEZ, Irene. Nacionalidad, extranjería y ciudadanía de la Unión Europea. Madrid, Colex, 2005.

- "El estatuto jurídico del extranjero en el sistema español: Una perspectiva histórica"; en ADAM MUÑOZ, María Dolores y BLÁZQUEZ RODRÍGUEZ, Irene (coords). Nacionalidad, Extranjería y Ciudadanía de la Unión Europea. Madrid, Colex, 2005, pp. 53- 89.

ADOBATI, Enrica. "La Corte di giustizia respinge il ricorso contro la direttiva n. 2003/86/CE sul diritto al ricongiungimento familiare dei cittadini dei paesi terzi”; en Diritto comunitario e degli scambi internazionali, 2006, pp.527-530.

ADROHER BIOSCA, Salomé. "La entrada, la permanencia y la salida de extranjeros de España"; en ADROHER BIOSCA, Salomé, CHARRO BAENA, Pilar (coords.). La inmigración. Derecho español e internacional. Barcelona, Bosch, 1995.

AGUDO ZAMORA, Miguel J. El Tribunal Constitucional y el Convenio Europeo de Derechos Humanos. Universidad de Córdoba, Servicio de Publicaciones, 2001.

AGUELO NAVARRO, Pascual y ÁLVAREZ RODRÍGUEZ, Aurelia. Normativa comentada sobre derecho de extranjería. Valladolid, editorial Lex Nova, 2001.

- y CHUECA SANCHO, Ángel G. "Los derechos humanos de los extranjeros en la doctrina constitucional: (La STC 236/2007, de 7 de noviembre)"; Revista de Derecho Migratorio y Extranjería, No 16, 2007, pp. 91-141.

- "Derechos humanos y legislaciones de extranjería”; en FERNÁNDEZ SOLA, Natividad y CALVO GARCÍA, Manuel (cords.). Inmigración y Derechos. Segundas Jornadas derechos humanos y libertades fundamentales. Mirá editores, 2001, pp. 215-235.

- "La reforma de la ley de extranjería y los derechos y libertades de los extranjeros. El recurso de inconstitucionalidad frente a la LO 14/2003, de 20 de noviembre"; Revista de Derecho Migratorio y Extranjería, No 5, 2004, pp. 103-108.

- "Notas urgentes sobre la Ley Orgánica 4/2000, de 11 de enero, sobre Derechos y Libertades de los Extranjeros/as en España y su integración social, en su redacción dada por la Ley Orgánica 8/2000, de 22 de diciembre. Pautas de actuación que suscita la lectura del texto legal"; Aequalitas: Revista jurídica de igualdad de oportunidades entre mujeres y hombres, № 6, enero-abril 2001, pp. 37-46.

AGUILAR BENÍTEZ DE LUGO, Mariano y GRIEDER MACHADO, Hilda. "La reagrupación familiar de los extranjeros en España”; en RODRÍGUEZ BENOT, Andrés y HORNERO MÉNDEZ, Cesar (coords.). El nuevo derecho de extranjería: estudios acerca de la Ley Orgánica sobre los derechos y libertades de los extranjeros en España y su integración social. Madid, Comares, 2001, pp. 97-144.

AGUILAR VILLALOBOS, José. "Inmigración, más allá de una ley de extranjería: la ética de la hospitalidad”; Nueva Revista de política, cultura y arte, No 77, septiembre-octubre 2001, pp. 26-32.

AGUIRRE, Mariano. "Los conflictos económicos y sociales y la paz: el caso de los estados frágiles”; TEZANOS, José Féliz y GUERRA, Alfonso (coords.). La paz y el derecho internacional: III Encuentro Salamanca. Madrid, Sistema, 2005, pp. 73-82.

AJA FERNÁNDEZ, Eliseo (coord.). La nueva regulación de la inmigración en España. Valencia, Tirant lo Blanch, $1^{\text {a }}$ edición, 2000. 
AJA FERNÁNDEZ, Eliseo. "Veinte años de doctrina del Tribunal Constitucional sobre los derechos de los inmigrantes"; La democracia constitucional: Estudios en homenaje al profesor Francisco Rubio Llorente. Madrid, Congreso de los Diputados, Vol. 1, 2002, pp. 439-456.

- y DÍEZ BUESO, Laura. "La participación política de los inmigrantes"; Puntos de Vista: Cuadernos del Observatorio de las Migraciones y la Convivencia Intercultural de la Ciudad de Madrid, No 2, 2005, pp. 7-20.

- y CABELLOS, M. A. "La reagrupación familiar"; en AJA, E. La nueva regulación de la inmigración en España. Valencia, Tirant lo Blanch, 2000, pp. 136-145.

- "La evolución de la normativa sobre inmigración"; AJA, Eliseo y ARANGO, Joaquín (eds.). Veinte años de inmigración en España. Perspectivas jurídica y sociológica (1985-2004). Barcelona, Fundación CIDOB, 2006.

AKANDIJ-KOMBE, Jean-François. "Positive obligations under the European Convention on Human Rights. A guide to the implementation of the European Convention on Human Rights". Human rights Handbooks, No 7. Strasbourg, Council of Europe, 2007.

DE ALBA BASTARRECHEA, Esther. “Derechos fundamentales y libertades públicas de los inmigrantes en España”; en Asamblea: Revista parlamentaria de la Asamblea de Madrid, No. 14, 2006, pp. 151-162.

- "Sobre derechos y libertades de los extranjeros en España. Comentario a la STC 236/2007, de 7 de noviembre"; Repertorio Aranzadi del Tribunal Constitucional, Thomson-Aranzadi, 2007, Tomo III, 1ª ed., pp. 2491-2508.

- "Sobre derechos y libertades de los Extranjeros en España: comentario a la STC 236/2007, de 7 de noviembre"; en Repertorio Aranzadi del Tribunal Constitucional, no 21-22, 2008, pp. 13-30.

ALBERT GUARDIOLA, María Carmen y MASANET RIPOLL Erika. "Los matrimonios mixtos en España, ¿espacios de construcción intercultural?”; Revista OBETS n 1, 2008, pp. 45-71.

ALEXY, Robert. Teoría de los derechos fundamentales (Traducción de Ernesto Garzón Valdés). Madrid, Centro de Estudios Constitucionales, 1993.

ALONSO PÉREZ, Francisco. "El Derecho a la Reagrupación Familiar de los Extranjeros. Innovaciones introducidas por la Ley Orgánica 14/2003, de 20 de noviembre (RCL 2003, 2711)”; en La Ley No 6006/2004 AÑO XXV. La Ley Actualidad, Madrid. 28 de abril de 2004.

ÁLVAREZ CIENFUEGOS SUÁREZ, José Ma " "La perspectiva constitucional de los derechos y libertades de los extranjeros en España”; en ÁLVAREZ CIENFUEGOS SUÁREZ, José Ma (dir.). Reflexiones sobre la nueva ley de extranjería. Madrid, Cuadernos de Derecho Judicial, Consejo General del Poder Judicial, 2001, pp. 11-38.

ÁLVAREZ CORTÉS, Juan Carlos. "Algunas cuestiones básicas sobre la regulación del derecho a la reagrupación familiar en España”; en SALINAS DE FRÍAS, Ana (coord.). Inmigración e integración: aspectos sociales y legales. Sequitur, 2008, pp. 177-193.

ÁlVAREZ RODRÍGUEZ, Aurelia. "Matrimonios mixtos simulados: Mecanismos de sanción”; Boletín del Colegio de Abogados de Aragón, No 136, 1995.

- "Acceso a la nacionalidad española por los inmigrantes e hijos de inmigrantes. ¿Integración o estrategia para obtener la equiparación de derechos?”; GARCÍA ROCA, Joaquín y LACOMBA, Joan (eds.). La inmigración en la sociedad española. Una radiografía multidisciplinar. Barcelona, ediciones Bellaterra, 2008, pp. 607-630.

- "Directiva 2003/109/CE versus legislación española actual: ¿la transposición exige la modificación de la LO 4/2000?; Revista de Derecho Migratorio y Extranjería No 15, 2007, pp. 9-42.

- "La ley española de extranjería: problemas que plantea en materia de discriminación por razón de nacionalidad"; SOROETA LICERAS, Juan (ed.). Cursos de Derechos Humanos de Donostia-San Sebastián. Universidad del País Vasco, 1999, pp. 247-303.

- "La nueva Ley española de extranjería: ¿ruptura o incumplimiento de Tampere? ¿innovación o seguimiento del modelo italiano?”; Migraciones, No 7, 2000, pp. 89-135.

- "La reagrupación familiar como vehículo de integración”; ÁLVAREZ CONDE, E. y PÉREZ MARTÍN, E. (dirs.). Estudios sobre Derecho de extranjería. Madrid, Instituto de Derecho Público, Universidad Rey Juan Carlos, 2005, pp. 211-248.

- "La reagrupación familiar. Residencia no laboral"; AGUELO NAVARRO, P. y ÁLVAREZ RODRÍGUEZ, A. V Curso de iniciación a la Práctica de Derecho de Extranjería. Valladolid, Lex Nova, enero 2006, pp. 343-459.

- "La transposición de Directivas de la UE sobre inmigración. Las directivas de reagrupación familiar y de residentes de larga duración"; Documentos CIDOB: Migraciones, No 8, 2006.

- "Movimientos migratorios y derecho de la nacionalidad. Especial referencia a la legislación española vigente y a las propuestas de reforma”; Cursos de derechos humanos de Donostia-San Sebastián. Universidad del País Vasco, Servicio de Publicaciones, Vol, 2, 1999, pp. 107-178.

- "Nacionales de terceros países familiares de un ciudadano comunitario en el territorio de su propio estado: ¿ régimen de extranjería general o aplicación de la normativa comunitaria relativa a la libre circulación? (A propósito de la STJCE de 23 de septiembre de 2003)"; CALVO CARAVACA, Alfonso Luis y CASTELLANOS RUIZ, Esperanza. El derecho de familia ante el siglo XXI: aspectos internacionales. Madrid, Colex, 2004, pp. 23-42. 
ÁLVAREZ RODRÍGUEZ, Aurelia. "Residencia temporal en virtud de reagrupación familiar (artículos 38-44)”. RAMOS QUINTANA, Margarita Isabel y ROJAS RIVERO, Gloria Pilar (coord.). Comentarios al Reglamento de extranjería, 2007. Lex Nova, pp. 255-303.

- Algunas reflexiones urgentes relativas a la reagrupación familiar en el derecho comunitario. A propósito de la publicación de la Directiva 2003/86/CE del Consejo, de 22 de septiembre de 2003, sobre derecho el derecho a la reagrupación familiar." http://www.icam.es/docs/ficheros/200407190008_6_4.pdf

- "Derecho a residir en España de los ascendientes de los no nacionales: de la flexibilidad de la jurisprudencia del TJCE y del TS a la rigidez de la normaitva vigente y futura”; en Revista de Derecho Migratorio y Extranjería, № 9, 2005. pp. 9-43.

- "Directiva 2003/109/CE versus legislación española actual: ¿la transposición exige la modificación de la LO 4/2000?”; en Revista de Derecho Migratorio y Extranjería, № 15, julio 2007, pp. 9-42.

- "La transposición de Directivas de la UE sobre migración. Las directivas de reagrupación familiar y de residentes de larga duración”; en Documentos CIDOB, serie Migraciones, No 8, marzo 2006, pp. 1-122.

- "Nacionales de terceros países familiares de un ciudadano comunitario en el territorio de su propio Estado: ¿Régimen de extranjería general o aplicación de la normativa comunitaria relativa a la libre circulación?" (A propósito de la STJCE de 23 de septiembre de 2003); en CALVO CARAVACA, Alfonso-Luis y CASTELLANOS RUIZ, Esperanza. El Derecho de familia ante el siglo XXI: Aspectos internacionales. Madrid, Editorial Constitución y Leyes, Colex, 2004. pp. 23-41.

ANDERFUHREN-WAYNE, Cynthia S. "Family Unity in Immigration and Refugee Matters: United States and European Approaches"; en International Journal of Refugee Law, Vol. 8, No3, 1996. pp. 347-382.

ANGUIANO TÉLLEZ, María Eugenia. “Inmigración laboral extracomunitaria en España: explorando perfiles y trayectorias laborales”; Migraciones No 10, 2001, pp. 11-134.

ANTONIO GONZÁLEZ, Jesús de. "Un centroafricano <sin papeles> (o el porqué de la conveniencia de la LO 4/2000, de 11 de enero, sobre derechos y libertades de los extranjeros en España y su integración social)"; Revista de la Facultad de Derecho de la Universidad Complutense, No 92, 1999-2000, pp. 331-340.

APA, Joanna. The Rights of Immigrant Workers in the European Union. An Evaluation of the EU Public Policy process and the Legal Status of Labour Immigrants from the Maghreb Countries in the New Receiving States. Kluwer Law International, The Hague, Netherlands, 2002.

APARICIO PÉREZ, Miguel Ángel. "La cláusula interpretativa del artículo 10.2 CE, como cláusula de integración y apertura constitucional de los derechos fundamentales"; en Jueces para la Democracia, No 6, 1989, pp. 9-18.

APRELL LASAGABASTER, Concha. "El Nuevo Reglamento de la Ley Orgánica 7/1985, de 1 de Julio, sobre derechos y libertades de los extranjeros en España (Real Decreto 155/1996, de 2 de febrero)"; en Revista de Administración Pública, No 140, 1996, pp. 313-333.

ARAGÓN BOMBÍN, Raimundo. "La integración social de los inmigrantes a través de los aspectos legales"; CHECA y OLMOS, Francisco, CHECA, Juan Carlos y ARJONA GARRIDO, Ma Ángeles. Inmigración y derechos humanos: la integración como participación social. Barcelona, Icaria, 2004, pp. 81-108.

ARAGÓN REYES, M; ASENSI SABATER, J; BIGLINO CAMPOS, P.; CARRILLO LÓPEZ, M. y PÉREZ CALVO, A. "Encuestra sobre la Ley de Extranjería y la Constitución”; Teoría y Realidad Constitucional, № 7, 2001, pp. 9-97.

ARANGO VILLA-BELDA, Joaquín. "Dificultades y dilemas de las políticas de inmigración”; en Anuario de la Facultad de Derecho de la Universidad Autónoma de Madrid, No 7, 2003, pp. 53-66.

- "España: la inmigración en la encrucijada"; en HERRERA CLAVERO, F.; ROA VENEGAS, J.M.; RAMÍREZ SALGUERO, S.; RAMÍREZ FERNÁNDEZ, S; MATEO CLAROS, F. (coords.). Inmigración, interculturalidad y convivencia. Ceuta, Instituto de Estudios Ceutíes, Congreso Nacional sobre inmigración, interculturalidad y convivencia, 2004, pp. 23-33.

- "Las < Leyes de las Migraciones> de E. G. Ravenstein, cien años después"; en Revista Española de Investigaciones Sociológicas, 1985, pp. 7-26.

- "Una nueva era en las migraciones internacionales"; en Revista de Occidente, No 268, 2003, pp. 5-20.

- y SANDELL, Rickard (coords.). Inmigración: Prioridades para una nueva política española. Informes Elcano. Madrid, Instituto Universitario Ortega y Gasset y Real Instituto Elcano de Estudios Internacionales y Estratégicos, 2004.

- "Dificultades y dilemas de las políticas de inmigración”; en Anuario de la Facultad de Derecho de la Universidad Autónoma de Madrid, No 7, 2003, pp. 53-65.

ARCE JIMÉNEZ, Elena. "Los familiares extranjeros del español en el derecho de extranjería. (Libertad de circulación y de residencia en el Nuevo "espacio de libertad, seguridad y justicia")"; Revista de Derecho Migratorio y Extranjería, No 12,2006 , pp. 21-47.

- "Los nuevos inmigrantes en situación documental irregular: familiares reagrupables que se encuentran en españa sin haber seguido el procedimiento de reagrupación familiar"; en Revista de derecho migratorio y extranjería, № 8 , 2005, pp. 261-270. 
ARCOS, Crescencio. “El empantanamiento migratorio en los EEUU: Derechos humanos y reunificación familiar”. IV Simposio Internacional de Inmigración y Derechos Humanos: Inmigración y Familia, Valencia, 9 de abril de 2010. http://www.funciva.org/uploads/ficheros_documentos/1271516974_crescencio_arcos_web.pdf

ARENAL MOYÚA, Celestino del. "La nueva sociedad mundial y las nuevas realidades internacionales: un reto para la teoría y para la política”; en Cursos de Derecho Internacional y Relaciones Internacionales de Vitoria Gasteiz, No 21, 2001-2002, pp. 17-86.

- "Cambios en la Sociedad Internacional y Organización de las Naciones Unidas"; en Jornadas sobre el Cincuenta Aniversario de las Naciones Unidas. Asociación Española de Profesores de Derecho Internacional y Relaciones Internacionales, Colección Escuela Diplomática No 2, Madrid, 1995, pp. 7-24.

ARENAS GARCÍA, Rafael. "La incompatibilidad del Derecho español con el comunitario en materia de reagrupación de familiares de comunitarios (Comentario a la STJCE, Sala 2a , de 14 de abril de 2005)"; La Ley: Revista jurídica española de doctrina, jurisprudencia y bibliografía, No 6340, 31 octubre de 2005.

ARGEREY VILAR, Patricia (coor.) El fenómeno de la inmigración en Europa. Perspectivas jurídicas y económicas. Madrid, Dykinson, 2005.

- y ESTÉVEZ MENDOZA, Lucana. “El triángulo Ampliación- Inmigración-Terrorismo. Los grandes retos actuales de Europa”. Documento de Trabajo de la cátedra Jean Monnet de Integración económica. Universidad Complutense, Facultad de CC Económicas. Disponible en: http://www.ucm.es/BUCM/cee/cjm/0402/0402.pdf

ARIAS FERNÁNDEZ, Gil y RAMÍREZ SÁNCHEZ, Belén (coords). Actas del seminario sobre asilo, inmigración y cruce de fronteras. Madrid, Universidad Antonio de Nebrija D.L, 2001.

ARNALDO ALCUBILLA, Enrique. "El derecho de sufragio de los extranjeros en las elecciones locales"; Revista Española de Derecho Constitucional, No 34, enero-abril 1992, pp. 67-97.

ARNULL, Anthony. "Family Reunification and Fundamental Rights"; en European Law Review, No 5, 2006, pp. 611-612.

ARRESE IRIONDO, Ma Nieves. "Multiculturalidad y vida familiar en la jurisprudencia del Tribunal Europeo de Derechos Humanos: La reagrupación familiar”; en LASAGABASTER, Iñaki (coord.). Multiculturalidad y laicidad: A propósito del Informe Stasi. Herrarte, 2004, pp. 197-214.

ARRIAGA IRABURU, Inés. El derecho a la vida familiar de los extranjeros en la jurisprudencia de Estrasburgo. Pamplona, Eunsa, $1^{\text {a }}$ ed., junio de 2003.

ARZOZ SANTISTEBAN, Xabier. "La relevancia del derecho de la Unión Europea para la interpretación de los derechos fundamentales constitucionales”; en Revista Española de Derecho Constitucional, No 74, mayo-agosto 2005, pp. 63110.

ASENSI SABATER, J. Políticas de la sospecha. Migraciones internacionales y principios constitucionales. Valencia, Tirant lo blanch, 2004.

AVCI, Gamze. "Immigrant Categories: The Many Sides of One Coin?”; en European Journal of Migration and Law, No 1, 1999, pp. 199-213.

BACIGALUPO SAGGESE, Mariano. "Bases de la política comunitaria europea en materia de visados, asilo e inmigración”; en Revista de Derecho de la Unión Europea, No 5, 2003, pp. 57-76.

- "Visados, asilo, inmigración y otras políticas relacionadas con la libre circulación de personas (El Espacio de Libertad, Seguridad y Justicia)”; en LINDE PANIAGUA, Enrique (coord.). Políticas comunitarias, Colex, Editorial Constitución y Leyes, Madrid, 2002, pp. 183-220.

BAJO SANTOS, Nicolás. "La familia migrante y sus redes"; en Anuario Jurídico y Económico Escurialense, № 36, 2003 , pp. 687-712.

BALBONI, Marco y FICCHI, Luisa. "Diritto di ingresso e ricongiungimento familiare”; en Diritto, immigrazione e cittadinanza, 2006, pp.107-109.

BALDACCINI, Anneliese; TONER (Helen). "From Amsterdam and Tampere to the Hague: An Overview of Five Years of EC Immigration and Asylum Law"; BALDACCINI, A. y GUILD, Elspeth and TONER, Helen (eds.). Whose Freedom, Security and Justice? EU Immigration and Asylum Law and Policy. Hart Publishing, Oxford and Portland, Oregon, 2007, pp. 1-22.

BALDWIN-EDWARDS, M. y SCHAIN, M. A. “The Politics of Immigration. Introduction”; en BALDWIN-EDWARDS \& SCHAIN (eds.). "The Politics of Immigration in Western Europe”; en West European Politics No 17, Vol. 2, 1994, pp. 1-16.

- "The Emerging European Immigration Regime: Some Reflections on Implications for Southern Europe; en Journal of Common Market Studies, Vol. 35, No 4, diciembre 1997, pp. 497-519.

BAÑÓN HERNÁNDEZ, Antonio M. "El modelo de integración difundido por la prensa española. A propósito del pañuelo de Fátima”; CHECA, Francisco; CHECA, Juan Carlos y ARJONA, Ángeles (eds.). Inmigración y derechos humanos. La integración como participación social. Barcelona, Icaria, 2004, pp.229-262.

BARRETT, Gavin. "Family Matters: European Community Law and Third-Country Family Members"; Common Market Law Review, Vol. 40, 2003, pp. 369-421. 
BARRETT, Gavin. “The Rights of Third-Country Family Members Under European Community Law”; in M. C. LUCEY and C. KEVILLE, Irish Perspectives on EC Law, Dublin, Round Hall Ltd, 2003, pp. 345-392.

BARTOLE, Sergio; CONFORTI, Benedetto; RAIMONDI, Guido. Commentario alla Convenzione Europea per la tutela dei diritti dell'uomo e delle libertà fondamentali. Cedam, Padova, 2001.

DE ALBA BASTARRECHEA, Esther. "Derechos fundamentales y libertades públicas de los inmigrantes en España”; en Revista parlamentaria de la Asamblea de Madrid, No 14, junio 2006, pp. 151-162.

BATTAINI-DRAGONI, Gabriela. "The Distinctive Role of the Council of Europe in Migration Management: The Case of the Euro-Mediterranean Region”; en European Journal of Migration and Law, No 4, 2003, pp. 491-497.

BATTISTELLA, Graziano. "Family Reunification: Policies and Issues"; en Asian and Pacific Migration Journal, Vol. 4, No 2-3, 1995, pp. 233-250.

BELLO MARTÍN-CRESPO, María Pilar. Las directivas como criterio de interpretación del derecho nacional. (Especial consideración de la jurisprudencia del TS en la aplicación de normas de derecho mercantil). Madrid, Civitas, 1999.

BELLOSO MARTÍN, Nuria. "El reagrupamiento familiar en el derecho de extranjería español”; Cuadernos de realidades sociales, No 43-44, 1994, pp. 175-196.

BENVENISTI, Eyal y DOWNS, George W. "National Courts, Domestic Democracy, and the Evolution of International Law"; en The European Journal of International Law, Vol. 20, № 1, 2009, pp. 59-72.

BERNARDO RÓDENAS, Sofía. “Mujer e inmigración”; Aequalitas, No 6, enero-abril 2001, pp. 34-36.

BERNARDO, S; VILAS, A y CUADRA, L.I. "Reagrupamiento familiar"; en ALVAREZ, Aurelia; SANTOS, Lidia; CONABLE, Barber. Jornada sobre el Reglamento de la ley de derechos y libertades de los extranjeros. Barcelona 30 de junio de 1995, Ajuntament de Barcelona, 1995, pp. 45-55.

BERTOZZI, Stefano. "Europe's Migration Policy. A comprehensive international strategy or a pressing domestic concerní?"; en Documentos CIDOB. Migraciones № 16, mayo 2008, pp. 1-45.

BERTOZZI, Stefano. “Migrazione legale: C'e Veramente bisogno di piú Europa?”; en Rivista Italiana di Diritto Pubblico Comunitario, 2006, pp. 109-1049.

BEUTIN, Ricklef; CANOY, Marcel; HORVATH, Anna; HUBERT, Agnes; LERAIS, Frédéric; SOCHACKI, Myriam. "Reassessing the Link between Public Perception and Migration Policy"; en European Journal of Migration and Law, No 9, 2007, pp. 389-418.

BIN, Yu. Immigration Multiplier: A new Method of Mesuring the Immigration Process, 2006. Disponible en http://paa2006. princeton.edu/download.aspx?submissionId=61643

BLANCO FERNÁNDEZ DE VALDERRAMA, Cristina. "La integración de los inmigrantes. Fundamentos para abordar una política global de intervención”; Migraciones, No 10, 2001, pp. 207-248.

BLANCO FERNÁNDEZ DE VALDERRAMA, Cristina. "Avances para la creación de una política común de inmigración y asilo en la Unión Europea”; en La Inmigración en la UE: Situación y perspectivas para Euskadi. Bilbao, Consejo Vasco del Movimiento Europeo, $1^{\text {a }}$ ed., 2003, pp. 23-34.

BLANQUER CRIADO, David Vicente. "Familia y matrimonio en la Ley de Extranjería. (Comentario a la Sentencia del TSJ del País Vasco de 30 de septiembre de 1997)"; Revista Española de Derecho Administrativo, No 99, 1998, pp. 443-464.

BLAT MELLADO, Concha. "Reflexiones sobre los derechos de los extranjeros y el estándar mínimo internacional de derechos humanos. De la letra a la realidad"; Revista Valenciana d'Estudis Autnómics, No 28, tercer trimestre 1999, pp. 245- 265.

BLAZQUEZ PEINADO, María Dolores. “La Transposición en el Derecho Español de la normativa Comunitaria sobre libre circulación y residencia de los ciudadanos de la Unión y miembros de su familia": El Real Decreto 240/2007 de 16 de febrero; en Revista de Derecho Comunitario Europeo, año No 11, No 27, 2007, pp. 595-622.

BLAZQUEZ RODRÍGUEZ, Irene y GUTIÉRREZ CASTILLO, Víctor Luis. Derecho de la Unión Europea sobre Inmigración y Asilo. Compilación sistemática y comentada de la normativa comunitaria. Madrid, Dykinson, 2006.

- "El derecho del ciudadano de la Unión a una libertad de circulación y residencia"; en MUÑOZ ADA, María Dolores y BLÁZQUEZ RODRÍGUEZ, Irene (coords). Nacionalidad, Extranjería y Ciudadanía de la Unión Europea. Madrid, Colex, 2005, pp. 175-197.

- "Hacia una armonización del derecho a la reagrupación familiar en la Unión Europea: la Directiva 2003/86, de 22 de septiembre"; Libro de Ponencias del II Congreso sobre la familia en la Sociedad del siglo XXI, celebrado en Sevilla el 3 de marzo de 2004. Madrid, 2004, pp. 417-426.

- "Hacia una política común de inmigración en la Unión Europea"; en Revista del Poder Judicial, No 66, 2002, pp.107-142.

- "El derecho del inmigrante a una vida en familia. Una perspectiva desde el derecho comunitario europeo"; Annaïck Fernández Le Gal (dir.), Sandra García Cano (dir.). Inmigración y derechos de los extranjeros, Universidad de Córdoba, Servicio de Publicaciones, 2005, pp. 179-201.

- "La reagrupación familiar: Complejidad y desigualdades del régimen jurídico actual”; en Portularia 3, 2003. pp. 263-283. Disponible en Internet: http://dialnet.unirioja.es/servlet/articulo? codigo $=808163$ 
BOELAERT-SUOMINEN, Sonja. "Non-EU Nationals and Council Directive 2003/109/EC on the Status of ThirdCountry Nationals who are Long-Term Residents: Five Paces Forward and Possibly Three Paces Back"; en Common Market Law Review, No 42, 2005, pp. 1011-1052.

BOELES, Pieter y KUIJER, A. "Harmonization of family reunification"; en A New Immigration Law for Europe? The 1992 London and 1993 Copenhaguen Rules on Immigration. Nederlands centrum buitenlanders, Utrecht, 1993, pp. 25-34.

- "Directive on Family Reunification: Are the Dilemas Resolved?"; en European Journal of Migration and Law, № 3 , 2001, pp. 61-71.

- "Propuesta de Directiva sobre la reagrupación familiar y otras propuestas en el campo de la ley de inmigración”; en Revista CIDOB d'Afers Internacionals, No 53, 2001, pp. 125-138.

- "What Rights have Migrating Third-Country Nationals?"; ZWAAN, Jaap W. And GOUDAPPEL, Flora A.N.J (eds.). Freedom, Security and Justice in the European Union. Implementation of the Hague Programme. The Hague, TMC Asser Press, 2006, pp. 151-163.

BOERI, Tito; HANSON, Gordon and MCCORNICK, Barry. Immigration Policy and the Welfare Syxtem. A Report for the Fondazione Rodolfo Debenedetti in Associatin with The William Davidson Institute. Oxford University Press, New York, 2002.

BONET PÉREZ, Jordi. Las políticas migratorias y la protección internacional de los derechos y libertades de los inmigrantes. Un análisis desde la perspectiva del ordenamiento jurídico español. Bilbao, Universidad de Deusto, Instituto de Derechos Humanos, 2003.

BOOTH, Alan; CROUTER, Ann C; LANDALE, Nancy (eds.). Immigration and the Family. Research and Policy on U.S. Immigrants. Lawrence Erlbaum Associates Publishers, New Jersey, 1997.

BORJAS, George J. y BRONARS, Stephen G. "Immigration and the Family"; en Journal of Labor Economic, Vol. 9, No 2, 1991, pp. 123-148.

BORRAJO INIESTA, Ignacio. "El desafío de la inmigración”; en RODRÍGUEZ IGLESIAS G.C. y TORREBLANCA, J.I. (coords.). Superar la crisis constitucional profundizando en la integración europea: cuatro propuestas. IX Informe Elcano. Madrid, junio 2007, pp. 53-67.

- "El desorden administrativo de la inmigración en España”; en Anuario de la Facultad de Derecho de la Universidad Autónoma de Madrid, No 7, 2003, pp. 119-133.

- "El status constitucional de los extranjeros"; en Estudios sobre la Constitución española. MARTÍN-RETORTILLO BAQUER, Sebastián (coord.). Homenaje al Profesor Eduardo García de Enterría. Civitas, Madrid, tomo II, 1991, pp. 697-766.

- "El desorden administrativo de la inmigración en España"; MARTÍNEZ CAPDEVILLA, Carmen; REMIRO BRETONS, Antonio (cords.). Movimientos migratorios y derecho. Madrid, B.O.E., 2003, pp. 119-133.

BORRÁS RODRÍGUEZ, Alegría. "Los estatutos de los extranjeros en España”; ESCOBAR HERNÁNDEZ, Concepción. Extranjería e Inmigración en España y la Unión Europea. Madrid, Colección Escuela Diplomática No 3, 1998, pp. 12-27.

BORRAZ, Fernando; POZO, Susan y ROSSI, Máximo. "And what About the Family Back Home?. International Migration and Happiness". Documento No 03/0, Departamento de Economía, Facultad de Ciencias Sociales, Universidad de Montevideo, marzo 2008. Disponible en: http://ssrn.com/abstract=1155108

BOUCAUD, Pascale. Migrant workers and their families. Protection within the European Social Charter. Strasbourg, Council of Europe Publishing, Human Rights Social Charter Monographs, No 4, 1996.

BOYD, Monica. "Family and Personal Networks in International Migration: Recent Developments and New Agendas"; en International Migration Review, Vol. 23, № 3, 1989, pp. 638-670.

BOYLE, Paul. "Gender Inequality in Employment Status following Family Migration in GB and the US: The Effect of Relative Occupational Status”; en International Journal of Sociology and Social Policy, Vol. 19, 1999, pp. 109-143.

BRAGE CAMAZANO, Joaquín. "Aproximación a una teoría general de los derechos fundamentales en el Convenio Europeo de Derechos Humanos"; en Revista Española de Derecho Constitucional, No 74, mayo-agosto 2005, pp. $111-138$.

BRIDGE, John. "American Analogues in the Law of the European Community"; en Anglo-America Law Review, No 11, 1982. pp. 130-154.

BRINKMAN, Gisbert. "Family Reunion, Third Country Nationals and the Community's New Powers"; en Elspeth Guild and Carol Harlow (eds.). Implementing Amsterdam: Immigration and Asylum Rights in EC Law. Oxford, Hart Publishing, 2001.

- "Family Reunification of Third-Country Nationals: Access of Family Members to Social Protection Benefits"; en European Journal of Migration and Law, No 4, 2002. pp. 291-308.

BRONCKERS, Marco. "The relationship of the EC Courts with other International Tribunals: Non-Committal, Respectful or Submissive?”; en Common Market Law Review, № 44, 2007, pp. 601-627. 
BRYCESON, Deborah Fahy y VUORELA, Ulla (eds.). "Transnational Families in the Twenty-first Century"; en BRYCESON, D y VUORELA, U (eds.). The Transnational Family. New European Frontiers and Global Networks. Oxford/New York, Berg Publishers, 2002.

BUCHANAN, William. "Myths of Family Reunification. Immigrants disrupt familias to start process"; en The Social Contract, fall 1996.

BUEREN, VAN Geraldine. “The International Protection of Family Members' Rights as the 21st Century Approaches”; en Human Rights Quarterly, Vol. 17, 1995, pp. 732-765.

BURGOS GALLEGO, Tomás. "España y la llamada de Teseo"; en BALADO RUIZ-GALLEGOS, Manuel (coord.). Inmigración, Estado y Derecho: perspectivas desde el siglo XXI. Barcelona, Bosch, 2008, pp. 129-152.

BUSTAMANTE, Jorge. "Immigrant's Vulnerability as Subjects of Human Rights"; en International Migration Review, Vol. 36, № 2, 2002, pp. 333-354.

CABRIA PALMÓN, Miriam. "Matrimonio de conveniencia”; en Noticias Jurídicas, mayo 2007. Disponible en: http:// noticias.juridicas.com/articulos/45-Derecho\%20Civil/200705-41412321412789896.html

CABRINI, Luigi. "La ley de extranjería en el marco de los convenios internacionales"; en ÁLVAREZ CIENFUEGOS SUÁREZ, José Ma (dir.). Reflexiones sobre la nueva ley de extranjería; Cuadernos de Derecho Judicial, Madrid, Consejo General del Poder Judicial, 2001, pp. 70-85.

CACHÓN RODRÍGUEZ, Lorenzo. "La integración de y con los inmigrantes en España: debates teóricos, políticas y diversidad territorial”; Política y sociedad, Vol. 45, № 1, 2008, pp. 205-235.

CALLOVI, Giuseppe. "Il ricongiungimento delle famiglie straniere nella Comunità Europea". SCABINI, Eugenia y DONATI, Pierpaolo (dirs.). La famiglia in una società multietnica. Milano, Vita e Pensiero, 1997, pp. 103-122.

CAMACHO RUEDA, Eduardo: "El convenio de Schengen: los cimientos de la fortaleza europea"; en Mientras tanto, No. 68-69, 1997, pp. 167-180.

CAMAS RODA, Ferran. "Reagrupación familiar en España: especial referencia al régimen de los menores y de las parejas de hecho". Ponencia presentada en el IV Congreso de Inmigración en España. Ciudadanía y Participación. Girona, del 10 al 13 de noviembre de 2004. http://www.girodata.com/cidc/Reagrupación\%20familiar\%20en\%20España.pdf

CAMPO CABAL, Juan Manuel (coord.). Comentarios a la Ley de Extranjería (Ley Orgánica 4/2000 reformada por la Ley Orgánica 8/2000). Madrid, Civitas, 2001, 1ª ed.

CANEDO ARRILLAGA, María Pilar. "La comunitarización del derecho internacional privado en la Unión Europea y su incidencia en la política de inmigración”; en Cuadernos Europeos de Deusto, № 36, 2007, pp. 107-126.

CANEDO ARRILLAGA, María Pilar. "La Propuesta de la Directiva Comunitaria sobre Reagrupación Familiar: Algunos comentarios desde el Derecho Internacional Privado"; en CALVO CARAVACA, A. L. y IRIARTE ÁNGEL, J. L. Mundialización y Familia. Editorial Colex, 2001, pp. 121-142.

- "La reagrupación familiar en los instrumentos internacionales. La perspectiva del menor"; en LAZARO GONZÁLEZ, Isabel E; CULEBAS LLANA, Irene (coords.). Nuevos retos que plantean los menores extranjeros al derecho. IV Jornadas sobre Derecho de los Menores (20 y 21 de octubre de 2005). Madrid, Publicaciones de la Universidad Pontificia Comillas, Madrid, 2006.

CANEDO ARRILLAGA, María Pilar. "Reflexiones sobre la reagrupación familiar de nacionales de terceros Estados en la Unión Europea”; en CALVO CARAVACA, Alfonso-Luis y CASTELLANOS RUIZ, Esperanza. El Derecho de familia ante el siglo XXI: Aspectos internacionales. Editorial Constitución y Leyes, Colex, 2004.

CANETA, Emanuela. “The EU policy on Return of Illegally Staying Third-Country Nationals”; en European Journal of Migration and Law, No 9, 2007. pp. 435-450.

CARACCIOLO DI TORELLA, Eugenia; MASSELOT, Annick. “Under Construction: EU Family Law”; en European Law Review, No 29, 2004. pp. 32-51.

- y REID, E. "The Changing Shape of the 'European Family' and Fundamental Rights"; en European Law Review; 2002, No 27 pp. 80-90.

CARBALLO ARMAS, Pedro. "Inmigración y derechos fundamentales en la Unión Europea: una aproximación a los instrumentos jurídico-políticos de integración de los extranjeros en España”; Revista de Derecho Constitucional Europeo, No 5, enero-junio 2006, pp. 279-293.

CARINGELLA, Francesco. "El derecho de los extranjeros. En particular, el derecho a la unidad familiar"; en Derecho de extranjería: VI coloquio Ítalo-español. Madrid, Tribunal Supremo, 2006, pp. 27-34.

CARLOS NIETO, Luis. "Menores y extranjeros: Un solo marco jurídico"; en PANTOJA GARCÍA, Félix y NIETO GARCÍA, Luis Carlos (dirs.). Los derechos de los menores extranjeros. Madrid, Consejo General del Poder Judicial, Estudios de Derecho Judicial No 104, 2007, pp. 10-32.

CARRASCOSA GONZÁLEZ, Javier. "Matrimonios de conveniencia y nacionalidad española”; Anales de Derecho, Universidad de Murcia, No 20, 2002, pp. 7-34.

CARRERAS, Francesc de. "Función y alcance del artículo 10.2 de la Constitución"; Revista Española de Derecho Constitucional, No 60, septiembre-diciembre 2000, pp. 321-341. 
CARRILLO LÓPEZ, Marc. "Reflexiones constitucionales sobre la inmigración en España y la Unión Europea”; en Revista de Derecho de la Unión Europea, No 5, 2003, pp. 77-81.

CARRILlO SAlCEDO, J.A. El Convenio Europeo de Derechos Humanos. Madrid, Tecnos, 2004. $1^{\text {a }}$ edic, reimpresión.

- "Protección de derechos humanos en el Consejo de Europa: hacia la superación de la dualidad entre derechos civiles y políticos y derechos económicos y sociales”; en Revista de Instituciones Europeas, 18, 2, 1991. Soberanía de los Estados y derechos humanos en el Derecho Internacional contemporáneo. Madrid, Tecnos, 1995.

CARRILlO, Marc. "La Carta de Derechos Fundamentales de la Unión Europea”; Revista Vasca de Administración Pública, No 65, II, 2003, pp. 145- 165.

CASCAJO CASTRO, José Luís. La tutela constitucional de los derechos sociales. Madrid, Centro de Estudios Políticos y Constitucionales, 1988.

CASTELLÀ I ANDREU, Josep Maria. "El artículo 10.2 de la Constitución como canon de interpretación de los derechos fundamentales”; en APARICIO PÉREZ, Miguel Ángel (coord.). Derechos constitucionales y pluralidad de ordenamientos. Barcelona, Cedecs editorial, 2001, pp. 141-164.

CASTLES, Stephen, BOOTH, Heather y WALLACE, Tina. Here for Good: Western Europe's New Ethnic Minorities. London, Pluto Press, 1984.

- y MILLER, Mark J. La era de la migración. Movimientos internacionales de población en el mundo moderno. Traducción de la $3^{\text {a }}$ edición en lengua inglesa a cargo de Luis Rodolfo Morán Quiroz, Instituto Nacional de Migración. México, Porrúa, 2004.

- "Factors that Make and Unmake Migration Policies"; en International Migration Review, Vol. 38, No 3, 2004 , pp. 854-884.

CEBADA ROMERO, Alicia. "La directiva de la Comunidad Europea sobre reagrupación familiar: la sentencia del TJCE en el asunto C-540/03"; en ALDECOA LUZÁRRAGA, Francisco y SOBRINO HEREDIA, José Manuel (coords.). Migraciones y desarrollo: II Jornadas Iberoamericanas de Estudios Internacionales. Montevideo, 25, 26 y 27 de octubre de 2006, 2007, pp. 537-552.

- "The Coherence of the European Union as an International Actor: Facing the Challenge of Immigration and Asylum"; en Jean Monnet Working Paper 07/2006.

CEBOLLA BOADO, Héctor y GONZÁLEZ FERRER, Amparo. La inmigración en España (2000-2007). De la gestión de flujos a la integración de los inmigrantes. Madrid, Centro de Estudios Políticos y Constitucionales, 2008.

CECCO, Francesco de. "Room to Move?. Minimum Harmonization and Fundamental Rights"; en Common Market Law Review, No 43, 200. Pp. 9-30.

CEINOS SUÁREZ, Ángeles. "Los derechos y libertades de los trabajadores extranjeros en la Ley Orgánica 8/2000 Comentario a las sentencias TC 236/2007, de 7 de noviembre y 259/2007, de 19 de diciembre; Repertorio Aranzadi del Tribunal Constitucional, Thomson-Aranzadi, 2007, Tomo III, $1^{\text {a }}$ ed., pp. 2473-2489.

CERÓN RIPOLL, Paloma. "Inmigrantes dominicanas: Camino hacia la reagrupación familiar"; en Habitar, vivir, prever: actas del V Congreso de la Población Española. Bellaterra, Universidad Autónoma de Barcelona, Departament de Geografía, 1995, pp. 35-42.

CHECA, Francisco; CHECA, Juan Carlos y ARJONA, Ángeles (eds.). Inmigración y derechos humanos. La integración como participación social. Barcelona, Icaria, 2004.

CHITI, Mario P. “Third Country Nationals and EU Law; Human Rights and Pluralism”; en European Review of Public Law, Vol. 7, No 3, 1995. pp. 577-597.

CHOCRÓN GIRÁLDEZ, Ana María. "Notas sobre la aplicación de las garantías y principios del artículo 24 de la Constitución a los procedimientos previstos en materia de extranjería”; ALONSO BURÓN, José Carlos y SÁNCHEZ-RODAS NAVARRO, Cristina (coords.). Aspectos puntuales del nuevo Reglamento de Extranjería., 2005, pp. 287-308.

CHOLEWINSKI, Ryszard. "Family Reunification and Conditions Placed on Family Members: Dismantling a Fundamental Right"; en European Journal of Migration and Law, No 4, 2002, pp. 271-290.

- "The Protection of the Right of Economic Migrants to Family Reunion in Europe"; en The International and Comparative Law Quarterly, Vol. 43, No 3, Jul. 1994, pp. 568-598.

- "Family Reunification as a Constitutional Right?"; APAD, Joanna (ed.). Justice and Home Affairs in the EU. Liberty and Security Issues alter Enlargement. Edward Elgar Publishing, Ceps, Cheltenham-Northampton, 2004, pp. 259273.

- Irregular Migrants: Access to Minimum Social Rights. Council of Europe Publishing, Strasbourg, 2005.

- Migrant Workers in International Human Rights Law. Their Protection in Countries of Employment. Clarendon Press, Oxford, 1997.

- "Strasbourg's Hidden Agenda? The Protection of Second-Generation Migrants fro Expulsion under Article 8 of the ECHR”; en Netherlands Quarterly of Human Rights, Vol. 12, 1994. pp. 287-306.

- "The Protection of the Right of Economic Migrants to Family Reunion in Europe"; en The International and Comparative Law Quarterly, Vol. 43, No 3 July, 1994, pp. 568-598. 
CHOLEWINSKI, Ryszard. "Family Reunification and Conditions Placed on Family Members: Dismantling a Fundamental Human Right?”; en European Journal of Migration and Law, No 4, 2002, pp. 271-290.

CHRISTIAN JOPPKE. “The Legal-domestic Sources of Immigrant Rights. The United States, Germany, and the European Union”; Comparative Political Studies, Vol. 34, No 4, 2001, pp. 339-366.

CHUECA SANCHO, Ángel G. "Ley de extranjería y tratados internacionales: una violación permanente e internacionalmente comprobada”; en Revista de Derecho Migratorio y Extranjería, No 7, 2004, pp. 123-138.

- La expulsión de extranjeros en la Convención Europea de derechos humanos. Egido Editorial S.L., Zaragoza, 1998.

- "Avanza la ratificación de la convención de los derechos de todos los trabajadores migratorios y sus familiares"; en Revista de derecho migratorio y extranjería, №. 8, 2005, pp. 271-272

CLELIA CICIRIELLO, Maria. "Ricongiungimento Familiare come diritto fondamentale del migrante"; Comunità internazionale, Vol. 61, No. 1, 2006, pp. 109-119.

COHEN, Robert. Global Diasporas: An Introduction. Seatle, University of Washington Press, 1997.

COLECTIVO IOÉ. "Ciudadanos e intrusos: La opinión pública española ante los inmigrantes"; ENCINA, Javier y MONTAÑÉS, Manuel (cords.). Construyendo colectivamente la convivencia en la diversidad: Los retos de la inmigración. Unilco, 2006, pp. 43-72.

- "Flujos migratorios internacionales. Marco de comprensión y características actuales"; en Revista Migraciones, No 9, 2001, pp. 7-45.

— “Inmigrantes extranjeros en España: ¿Reconfigurando la sociedad?”; ENCINA, Javier y MONTAÑ́S SERRANO, Manuel (cords.). Construyendo colectivamente la convivencia en la diversidad: los retos de la inmigración. Universidad Libre para la Construcción Colectiva, 2006, pp. 19-42.

- "Mujeres migrantes en España. Proyectos migratorios y trayectorias de género"; en Ofrim Suplementos. Oficina Regional para la Inmigración de la Comunidad de Madrid, 1998, pp. 11-38.

- Inmigración y ciudadanía. España en el contexto de las migraciones internacionales. Madrid, editorial Fundamentos, 2003.

COLEMAN, David. “Trends in fertility and intermarriage among immigrant populations in Western Eurpe as measures of integration"; en Journal of Biosocial Science, No 26, 1994, pp. 107-136.

COLLADO COLLADO, Daniel. "Los cambios operados en materia de reagrupación familiar”; en PERALTA CARRASCO, Manuel (dir.). I Jornadas sobre la Ley de Extranjería e Inmigración. Cáceres, 26 a 29 de marzo de 2001. Facultad de Derecho. Cáceres, Universidad de Extremadura, 2003, pp. 89-93.

COLOMER VIADEL, Antonio. "Evolución de las normas sobre inmigración en Europa. Entre la integración solidaria y la desconfianza temerosa"; en EIRAS ROEK, Antonio y GONZÁLEZ LOPO, Domingo L. (coord.). La inmigración en España. Actas del Coloquio Santiago de Compostela, 6-7 de noviembre de 2003. Santiago de Compostela, Universidad de Santiago de Compostela, 2004.

- Inmigrantes y Emigrantes. Valencia, editorial Universidad Politécnica de Valencia, 2006.

COMBALÍA, Zoila. "Estatuto de la mujer en el derecho matrimonial islámico"; Aequalitas, No 6, enero-abril 2001, pp. 15-20.

CONNELLY, A.M.: "Problems of interpretation of Article 8 of the European Convention on Human Rights"; en International and comparative law Quarterly, Vol 35, 1986, pp 567-593.

CONTI, Roberto y FOGLIA, Raffaele. "Ricongiungimento familiare e tutela dei diritti fondamentali"; en Il Corriere giuridico, 2006, pp.1134-1137.

COOKE, Thomas J. "Migration in a Family Way"; en Population, Space and Place, No 14, 2008, pp. 255-265.

COPPEL, J. and O’NEILL, A. “The European Court of Justice: Taking Rights Seriously?”; en Comonn Market Law Review, 1992, pp. 669-692.

CORCHETE MARTÍN, María José. "Los nuevos derechos”; en Teoría y Realidad Constitucional, No 20, 2007, pp. 535556.

CORCUERA ATIENZA, Javier. "El reconocimiento de los derechos fundamentales en la Unión Europea: el final de un túnel”; en MORODO, Raúl y VEGA, Pedro de (dirs.). Estudios de Teoría del Estado y Derecho Constitucional en honor de Pablo Lucas Verdú, Tomo IV. Servicio de Publicaciones de la Facultad Derecho de la Universidad Complutense, Madrid, 2000, pp. 2307-2340.

CORNELIUS, Wayne A. "Spain: The Uneasy Transition from Labor Exporter to Labor Importar”; en MARTIN, P./ HOLLIFIELD, J. (eds.). Controlling Immigration: A Global Perspective, Standford University Press, Standford, 1994, pp. 303-326.

- y TAKEYUKI, Tsuda; MARTIN, Philip y HOLLIFIELD, James F. Controlling Immigration. A Global Perspective, second edit. Standford, Standford University Press, 2004.

CORTÉS MAISONAVE, Almudena. "Codesarrollo y Migración: una lógica transnacional. Reflexiones desde el caso Español”; en Puntos de Vista: Cuadernos del Observatorio de las Migraciones y la Convivencia Intercultural de la Ciudad de Madrid, No. 8, 2006, pp. 7-27. 
CORTÉS MARTÍN, José Manuel. "Inmigración y derecho de reunificación familiar en la Unión Europea: ¿mínimo común denominador de las políticas nacionales?”; en Anuario de derecho europeo, No. 4, 2004, pp. 27-54.

- “TJCE - Sentencia de 27.06.2006, Parlamento Europeo/Consejo, C-540/03. ¿Restricciones al reagrupamiento familiar de nacionales de terceros países versus respeto de los derechos fundamentales"; en Revista de Derecho Comunitario Europeo, Año No 11, № 26, 2007, pp. 219-237.

COSTELLO, Cathryn. "Metock: Free movement and 'normal family life' in the Union"; en Common market law review, Vol. 46, No 2, 2009, pp. 587-622.

CREMONA, M. "Citizens of third countries: Movement and employment of migrant workers within the European Unión”; en Legal Issues of European Integration, 1995, n. 2, pp. 87 ss.

CRESPO NAVARRO, Elena. "La Directiva 2003/109/CE del Consejo relativa al estatuto de los nacionales de terceros Estados residentes de larga duración y la normativa española en la materia”; Revista de Derecho Comunitario Europeo, No 18, mayo-agosto 2004, pp. 531-552.

CRIADO, María José. “Vieja y nueva emigración”; en CRIADO, M. J. La línea quebrada: Historias de vida de migrantes. Madrid, Consejo Económico y Social, 2001.

CRUZ VILLALÓN, Pedro. "Dos cuestiones de titularidad de derechos: los extranjeros, las personas jurídicas"; Revista Española de Derecho Constitucional, No 35, 1992, pp. 63-84.

CUADRA FERNÁNDEZ, Luz I. "Derecho a la reagrupación familiar en la legislación española”; Aequalitas, № 6, eneroabril 2001, pp. 28-33.

CVETIC, Goran, "Immigration Cases in Strasbourg: The Right to Family Life Under Article 8 of the European Convention", en International and Comparative Law Quarterly, Vol. 36, N. o 3, julio de 1987, pp. 647-655.

FELDMAN, D. “The developing scope of article 8 of the ECHR”; en European Human Rights Law Review No 3, 1997, pp. 265-274.

D'ENTREMONT, Alban. “Aspectos demográficos y sociales de las inmigraciones”; OTADUY, Jorge; TEJERO, Eloy y VIANA, Antonio. Migraciones, Iglesia y Derecho. Actas del V Simposio del Instituto Martín de Azpilcueta sobre Movimientos migratorios y acción de la Iglesia. Aspectos sociales, religiosos y canónicos. Instituto Martín de Azpilcueta, Universidad de Navarra, 2003, pp. 83-108.

DE LA CUADRA SALCEDO, Tomás. “Tratados internacionales y apertura de los derechos fundamentales”; en Revista de la Facultad de Derecho de la Universidad Complutense No 61, 1980, pp. 129 y ss.

DE LUCAS, Javier. "Algunas propuestas para comenzar a hablar en serio de política de inmigración”; en DE LUCAS, J. y TORRES, F (eds.). Inmigrantes: ¿cómo los tenemos? Algunos desafíos y (malas) respuestas. Madrid, Talasa, pp. 23-48.

DE LUCIA, Amelia. "Human Migratory Flows"; en International Journal of Anthropology, Vol. 19, № 1-2, 2004, pp. 1-18.

DELAET, Debra L. U.S. Immigration Policy in a Age of Rights. Westport, Praeger Publishers, 2000.

DELGADO BARRIO, Javier. "Proyección de las decisiones del TEDH en la jurisprudencia española"; en Revista de Administración Pública, No 119, 1989, pp. 233-254.

DELGADO GODOY, Leticia. "Los determinantes y las dimensiones de la política de inmigración en España, 19852007”; PALOMAR OLMEDA, Alberto (coord.). Tratado de Extranjería: aspectos civiles, penales, administrativos y sociales. Navarra, Thomson-Aranzadi, $3^{\text {a }}$ ed., 2007, pp. 39-68.

DELMAS-MARTY, Mireille (ed.). Verso un'Europa dei diritti dell'uomo. Ragion di Stato e diritti umani nel sistema della Convenzione europea. Padova, Cedam, 1994.

DIAGO DIAGO, Ma del Pilar. "La concepción islámica de la familia y sus repercusiones en el Derecho internacional privado español”; Aequalitas, No 6, enero-abril 2001, pp. 6-13.

- "Respeto a la identidad cultural, derecho a la vida privada y familiar. Una aproximación de Derecho internacional privado"; en FERNÁNDEZ SOLA, Natividad y CALVO GARCÍA, Manuel (cords.). Inmigración y Derechos. Segundas Jornadas derechos humanos y libertades fundamentales. Mirá editores, 2001, pp. 195-214.

DÍAZ BARRADO, C. "Reconocimiento y protección de los derechos fundamentales en la Unión Europea"; en Derecho de Extranjería, Asilo y Refugio. Ministerio de Asuntos Sociales, Madrid, 1995.

DÍAZ GORFINKIEL, Magdalena y TOBÍO, Constanza. “¿Una nueva organización familiar? Madres trabajadoras y servicio doméstico inmigrante: percepciones e implicaciones”; en Revista de estudios de juventud, No 67, 2004, pp. $127-144$.

DÍAZ GREGO, María. “Derecho de extranjería y jurisprudencias del Tribunal Constitucional, del TEDDH y del TJUE.” Anuario MIG. La hora de la integración. Legislación y Jurisprudencia, 2011, p. 422.

DÍEZ DE VELASCO, Manuel (coord.). Instituciones de Derecho Internacional Público, Decimotercera ed. Madrid, Tecnos, 2001.

DÍEZ-PICAZO, Luis María. Sistema de Derechos Fundamentales. Madrid, Civitas, $1^{\text {a }}$ ed., 2003.

DIJK, Van P. "Protection of "Integrated" Aliens Against Expulsion under the European Convention on Human Rights"; en European Journal of Migration and Law, No 1, 1999, pp. 293-312. 
DIOS PINTADO, Sofía. “Inmigración y extranjería en el debate parlamentario español”; HERNÁNDEZ PEDREÑO, Manuel y PEDREÑO CÁNOVAS, Andrés (cords.). La condición inmigrante: Exploraciones e investigaciones desde la región de Murcia. Murcia, Universidad de Murcia, 2005, pp. 175-180.

DOSWALD-BECK, L. “The Meaning of the Right to Respect for Private Life under the European Convention on Human Rights"; en Human Rights Law Journal, 1983, Vol. 4, № 3, pp. 283-309.

DOUGLAS-SCOTT, Sionaidh. "A Tale of Two Courts: Luxembourg, Strasbourg and the Growing European Human Rights Acquis"; en Common Market Law Review, No 43, 2006, pp. 629-665.

DOUGLAS, Gillian. “The Family and the State under The European Convention on Human Rights"; en International Journal of Law and the Family, Vol. 2, 1988, pp. 76-105.

DRYWOOD, Eleanor. "Giving with one hand, taking with the other: Fundamental Rights, children and the Family Reunification Decision”; en European Law Review, № 3, 2007, pp. 396-407.

DUFFY, P. Jan (P. J.). "The protection of privacy, family life and other rights under article 8 of the ECHR"; en Yearbook of European law, Vol 2, 1982, pp. 191-238.

DUMON, W. A. "Family Migration and Family Reunion"; en International Migration, vol. 14, No 1-2, 1976, pp. 53-83.

DWORKIN, Ronald. Los derechos en serio (Traducción de Marta Guastavino). Barcelona, Ariel Derecho, 1977, 5a reimp.

EISSEN, Marc-André. El Tribunal Europeo de Derechos Humanos. Madrid, Civitas, $1^{\text {a }}$ edición, 1985.

ELY, John Hart. Democracy and Distrust. A Theory of Judicial Review. Cambridge, Harvard University Press, 1980.

ESCOBAR HERNÁNDEZ, Concepción. "Extranjería y ciudadanía de la Unión Europea”; en ESCOBAR HERNÁNDEZ, C. (coord.), Extranjería, Inmigración en España y en la Unión Europea. Colección Escuela Diplomática, No 3, Madrid, 1998, pp. 103-126.

- "La protección internacional de los derechos humanos"; en DÍEZ DE VELASCO, Manuel (coord.). Instituciones de Derecho Internacional Público. Madrid, Tecnos, Decimotercera ed., 2001.

- "La reciente evolución de la problemática del asilo y la inmigración en la Unión Europea: Algunas notas sobre la Cumbre de Tampere"; en Tiempo de Paz, Vol. 25, 1999, pp. 229-247.

ESPLUGUES MOTA, Carlos Aurelio. "Inmigración y Derecho de Extranjería (Especial referencia a la reagrupación familiar)"; en Cuadernos de Derecho Judicial, No 8, 2002, pp. 89-142.

ESTEBAN DE LA ROSA, Gloria. "Reagrupación familiar”; MONEREO PÉREZ, José Luis y MOLINA NAVARRETE, Cristóbal. Comentario a la Ley y al Reglamento de Extranjería e integración social (LO 4/2000, LO8/2000 y RD 864/2001). Granada, Comares, 2001, pp. 280-313.

ESTEVE GARCÍA, Francina y ILLAMOLA DAUSÁ, Mariona. "Report on the Development of Migration Law in Spain in 2003"; CARLIER, Jean-Yves and BRUYEKER, Philippe de. Immigration and Asylum Law of the EU: Current Debates. Academic Network for Legal Studies on Immigration and Asylum in Europe, Bruxelles, Bruylant, 2005, pp. 598-616.

- European Migration in the 1980s. Trends and Policies. Conference of European Ministers Responsible of Migration Affairs. Strasbourg, 6-8 May 1980. Strasbourg, Council of Europe, 1981.

EZQUERRA UBERO, J.J. "El derecho a vivir en familia de los extranjeros en España: Ensayo de valoración de la normativa aplicable"; en Migraciones, No1, 1997, pp. 177-216.

FACH GÓMEZ, Katia. "Propuesta de Directiva relativa al estatuto de los nacionales de terceros países residentes de larga duración en la Unión Europea”; en Revista de Derecho Migratorio y extranjería, No 2, 2003, pp. 53-64.

FAIST, Thomas. The Volumen and Dynamics of International Migration and Transnational Social Spaces. Oxford, Oxford University Press, 2000.

FAMIGLIETTI, Gianluca. "La reagrupación familiar de los inmigrantes en la normativa italiana"; en REVENGA SÁNCHEZ, Miguel (coord.). Problemas constitucionales de la inmigración: Una visión desde Italia y España. II Jornadas Italo-españolas de Justicia Constitucional. Valencia, Tirant lo Blanch y Giurffré Editore, pp. 453-461.

FASSBENDER, B. "El principio de proporcionalidad en la jurisprudencia del TEDH”; en Cuadernos de Derecho Público, No 5, 1998, pp 51-73.

FEIK, R. “The Austrian Quota System Concerning Family Reunification, the Green Card discusión and Europe’s New Immigration Policy; en DE BRUYCKER, Ph (dir.). The emergence of an European Immigration Policy. Bruylant, Bruselas, 2003. pp.

FELDMAN, David. "The Developing Scope of Article 8 of the European Convention on Human Rights"; en European Human Rights Law Review, 1997, No 3, pp. 265-274.

FÉLIX BALLESTA, Ma Angeles. "Reflexiones en torno a la reagrupación familiar”; en MARTÍNEZ-TORRÓN, Javier (ed.). La libertad religiosa y de conciencia ante la justicia constitucional. Actas del VIII Congreso Internacional del Derecho Eclesiástico del Estado. Granada, 13-16 de mayo de 1997. Granada, Comares, 1998, pp. 451-463.

FERNÁNDEZ COLLADOS, Ma Belén. "Las controvertidas excepciones previstas en la Directiva 2003/86/CE de reagrupación de familiares de nacionales de países terceros. Comentario a la STSJCE de 27 de junio de 2006 (TJCE 2006, 177)"; en Aranzadi Social, № 22, 2006. 
FERNÁNDEZ COLLADOS, Ma Belén. y SERRANO VILLAMANTA, J. y CARDENAL CARRO, M. "Régimen de entrada, permanencia y salida de los extranjeros en España”; PALOMAR OLMEDA, Alberto (coord.). Tratado de Extranjería: aspectos civiles, penales, administrativos y sociales. Navarra, Thomson-Aranzadi, $3^{\mathrm{a}} \mathrm{ed} ., 2007, \mathrm{pp}$. 281-352.

FERNÁNDEZ DE CASADEVANTE ROMANI, Carlos (coord.). Derecho Internacional de los Derechos Humanos. Madrid, Editorial Dilex, S.L., 2000.

FERNÁNDEZ GARCÍA, Eusebio. "La Declaración de 1948: dignidad humana, universalidad de los derechos y multiculturalismo"; LUCAS MARTÍN, Francisco Javier de (dir.). Derechos de las minorías en una sociedad multicultural. Cuadernos de Derecho Judicial, No 11, Madrid, 1998, pp. 225-250.

FERNÁNDEZ LE GAL, Annaïck y GARCÍA CANO, Sandra (dirs.). Inmigración y derechos de los extranjeros. Córdoba, Servicio de Publicaciones de 1 universidad de Córdoba, 2005, pp. 67-86.

FERNÁNDEZ NIETO, Josefa. "Sobre la constitucionalidad de la Ley de Extranjería: los derechos a la reagrupación familiar, a la intimidad y a la tutela judicial efectiva de los extranjeros en España"; en Jueces para la Democracia, № 51, 2004, pp. 50-62.

FERNÁNDEZ SÁNCHEZ, Pablo Antonio. "El derecho a la reagrupación familiar de los extranjeros"; CARRILLO SALCEDO, Juan Antonio (coord.). La ley de extranjería a la luz de las obligaciones de España en derechos humanos. Madrid, Akal, 2002, pp. 179-192.

FERNÁNDEZ SÁNCHEZ, Pablo Antonio. “El derecho de reagrupación familiar de los extranjeros”; en Derecho y conocimiento, No 1, 2001, pp. 375-395. Derecho comunitario de la inmigración. Atelier, Barcelona, 2006.

- "El derecho de reagrupación familiar de los extranjeros"; en La ley de extranjería a la luz de las obligaciones de España en derechos humanos. Akal, 2002, pp. 179-192. También disponible en Derecho y Conocimiento: Anuario Jurídico sobre la sociedad de la información y del conocimiento. No1, 2001, pp. 375-394.

FERNÁNDEZ SEGADO, Francisco. "El nuevo régimen jurídico de los derechos y libertades de los extranjeros en España”; Revista Gallega de Administración Pública, № 28, 2001.

FERNÁNDEZ SOLA, Natividad. "Distintas aproximaciones de la Unión Europea al fenómeno de la inmigración. Variedad tipológica de inmigrantes en la Unión Europea”; en FERNÁNDEZ SOLA, Natividad y CALVO GARCÍA, Manuel (coords). Inmigración y derechos. Zaragoza, Mira editores, 2001. pp. 125-146.

FERNÁNDEZ-MIRANDA Y LOZANA, Enrique. "La política de inmigración en España”; PASTOR ANTOLÍN, Luis Jesús (coord.). Globalización y migraciones hoy: diez años de continuos desafíos. Universidad de Valladolid, Centro Buen Día, 2002, pp. 63-74.

FERNÁNDEZ, Eusebio. "Dignidad y derechos humanos"; SORIANO DÍAZ, Ramón; ALARCÓN CABRERA, Carlos y MORA MOLINA, Juan (dirs.). Diccionario crítico de los derechos humanos. Sevilla, Universidad Internacional de Andalucía, 2000.

FERRAIOLO, Stefano. “Immigrazione, asilo, accoglienza: gli effetti pratici del 'vento di Tampere'. Direttive, regolamenti e applicazioni nei diritti nazionali”; en Diritto e Giustizia, № 20, 22 mayo de 2004.

FERRERO, Ruth. “¿La UE como actor en las políticas de inmigración de los Estados Miembros? Una aproximación al escenario Euromediterráneo"; en ZAPATA-BARRERO, Ricard y PINYOL, Genma (eds.). Los gestores del proceso de inmigración. Actores y redes de actores en España y Europa. Barcelona, Fundación CIDOB, 2008, pp. 11-22.

FLETCHER, Maria. "EU Governance Techniques in the Creation of a Common European Policy on Immigration and Asylum”; en European Public Law, Vol. 9, No 4, 2003, pp. 533-562.

FONSECA MORILLO, Francisco J. "Los derechos de los nacionales de terceros países en la Unión Europea. Situación jurídico-política tras la proclamación de la Carta de los Derechos Fundamentales de la Unión”; en Revista CIDOB de Afers Internacionals, No 53, 2001, pp. 77-95.

FOURLANOS, Gerassimos. Sovereignty and the Ingress of Aliens: With Special Focus on Family Unity and Refugee Law (Paperback). Stockholm, Almqvist \& Wiksell Internat, Stockholm, 1986.

FRANCO, Patricia. "Sul Diritto all'Unitá familiare nel Diritto Europeo en el Diritto Italiano"; en Il Diritto di Famiglia e delle Persone, 2007, No 36, vol, I, pp. 522-547.

FREEMAN, Gary P. "Migration Policy and Politics in the Receiving States"; en International Migration Review, Vol. 26, No 4, 1992, pp. 1144-1167.

- “Can Liberal States Control Unwanted Migration?"; en The Annals of the America of Political and Social Science, Vol. 534, No 1, 1994, pp. 17-30.

- "Modes of Immigration Politics in Liberal Democratic States"; en International Migration Review, Vol. 29, № 4, 1995, pp. 881-902.

- "The declive of sovereignty? Politics and immigration restriction in liberal states"; en JOPPKE, C. (ed.). Challenge to the Nation State: Immigration in Western Europe and the United States. Oxford, Oxford University Press, 1998, pp. 86108.

FREIXES SANJUÁN, Teresa. “Criterios básicos de la jurisprudencia europea en materia de derechos de los extranjeros”; en MARZAL, A. (coord.). Migraciones económicas masivas y derechos del hombre. Ponencias presentadas en la 
séptima sesión del Seminario Permanente de Derechos Humanos de la Facultad de Derecho ESADE, de la Universidad Ramón Llull, en marzo de 2001 en Barcelona. Barcelona, Bosch, 2002, pp. 91-122.

- "Integración europea y derecho de inmigración (extranjería y multilevel constitutionalism en la Unión Europea)"; BALADO RUIZ-GALLEGOS, Manuel (dir.). Inmigración, Estado y Derecho. Barcelona, Bosch, 2008, pp. 193-222.

FRIEDMAN, Lawrence Meir. Privates Lifes. Families, Individuals and the Law. Cambridge, Harvard University Press, 2004.

FROWEIN, J. "Concluding report to the Heidelberg Colloquium on the Legal Position of Aliens in National and International Law”; en FROWEIN, J y STEIN, T. (Eds.). Die Rechtstellung von Ausländern nach Staatlichem Recht und Völkerrecht. Springer-Verlag, Berlin, 1987, pp. 2082-2090.

GALIANA SAURA, Ángeles. "Problemas técnico-formales y de factibilidad en la LO 4/2000 sobre derechos de los inmigrantes en España y su integración social”; en FERNÁNDEZ SOLA, Natividad y CALVO GARCÍA, Manuel (cords.). Inmigración y Derechos. Segundas Jornadas derechos humanos y libertades fundamentales. Mirá editores, 2001, pp. 265-284.

GARCÍA AMADO, Juan Antonio. “PPor qué no tienen los inmigrantes los mismos derechos que los nacionales?”; en Revista de Derecho Migratorio y Extranjería; No 3, 2003, pp. 9-28.

GARCÍA BLANCO, Pedro Pablo. "Marco jurídico de la inmigración en España"; Anuario Jurídico y Económico Escurialense, No XXX, 1997, pp. 417-444.

GARCÍA-CALABRÉS, Francisco. Inmigrantes en España. Claves para comprender un fenómeno mundial. Madrid, Laberinto, 2009.

GARCÍA COSO, Emiliano. "Los progresos en el diseño de una regulación europea común en materia de inmigración extracomunitaria”; en RUIZ DE HUIDOBRO DE CARLOS, J. M. (coord.). Regulación legal de la extranjería e inmigración en España. Madrid, Publicaciones de la Universidad Pontificia de Comillas, 2006, pp. 51-86.

GARCÍA DE ENTERRÍA, Eduardo. "EL valor en derecho español de la jurisprudencia del TEDH”; en Boletín del Ilustre Colegio de Abogados de Madrid, No 1, 1987, p. 9.

GARCÍA MURCIA, Joaquín. "La política comunitaria de inmigración en la Constitución Europea"; Revista del Ministerio de Trabajo y Asuntos Sociales, No 57, 2005, pp. 217-240.

GARCÍA ROCA, Francisco Javier. "La titularidad constitucional e internacional de los derechos fundamentales de los extranjeros y las modulaciones legales a sus contenidos"; en REVENGA SÁNCHEZ, Miguel (coord.). Problemas constitucionales de la inmigración: Una visión desde Italia y España. II Jornadas italo-españolas de Justicia constitucional. Valencia, Tirant lo Blanch, 2005, pp. 71-108.

- "La interpretación constitucional de una declaración internacional. El Convenio Europeo de Derechos Humanos y bases para una globalización de los derechos"; en Revista Iberoamericana de Derecho Procesal Constitucional, № 5, 2006, pp. 139-182

- "La muy discrecional doctrina del margen de apreciación nacional según el Tribunal Europeo de Derechos Humanos: Soberanía e Integración”; en Teoría y Realidad Constitucional, No 20, 2007, pp. 117-143.

GARCÍA RODRÍGUEZ, Isabel. Matrimonio e Inmigración. El control del consentimiento matrimonial en la reagrupación familiar. Madrid, Colex, 2008.

- "The Right to Family Reunification in the Spanish Law System"; Spanish Yearbook of International Law, Vol. VII (1999-2000), pp. 1-37.

- "Resolución del Consejo de 4 de diciembre de 1997, sobre las medidas que deberán adoptarse en materia de lucha contra los matrimonios fraudulentos"; Revista Española de Derecho Internacional, Vol. 50 No 1, 1998, pp. 378-383.

GARCÍA RUIZ, J. Luis. "La condición de extranjero y el Derecho Constitucional español”; REVENGA SÁNCHEZ, Miguel. Problemas constitucionales de la inmigración: una visión desde Italia y España. II jornadas Italo-españolas de Justicia Constitucional. Valencia, Tirant lo Blanch, 2005, pp.489-586.

GARCÍA VÁZQUEZ, Sonia. "Derechos y libertades de los extranjeros en España: el derecho a la reagrupación familiar"; en Anuario da Facultade de Dereito da Universidade da Coruña, No 7, 2003, pp. 439-466.

- El estatuto jurídico-constitucional del extranjero en España. Valencia, Tirant lo Blanch, 2007.

- y GOIZUETA VÉRTIZ, Juana. "Un análisis en clave constitucional del régimen jurídico de los extranjeros en España: especial referencia al derecho a la libertad de circulación y residencia”; en Anuario da Facultade de Dereito da Universidade da Coruña, No 11, 2007, pp. 257-277.

GARCÍA ZÚÑIGA, Rocío. “El derecho a la reagrupación familiar”; en Trabajo Social Hoy, № 36, segundo cuatrimestre 2002, pp. 39-48.

GARRIDO GÓMEZ, María Isabel. "El derecho de reagrupación familiar en el ámbito de la Unión Europea”; en La Constitución Española en el ordenamiento comunitario (III): XVIII Jornadas de estudio, 1999, pp. 1107-1147.

GASCÓN ABELLÁN, Marina. Nosotros y los otros: El desafío de la inmigración. Lección inaugural del curso académico 2000. Ciudad Real, Gabinete del Rector de la Universidad de Castilla-La Mancha, 2001.

GAYA SICILIA, Regina. "Inmigración, matrimonio y derecho"; en Estudios jurídicos en Homenaje al Profesor Luis DíezPicazo, T. III, Madrid, Thomson-Cívitas, 2003, pp. 4631-4656. 
GEDDES, Andrew. Immigration and European integration. Towards fortress Europe?. Manchester University Press, European Policy Research Unit Series, United Kingdom, 2000.

- "International Migration and State Sovereignty in an Integrating Europe"; en International Migration, Vol. 39, No 6, febrero de 2001, pp. 21-42.

GELLES, Richard J; LEVINE, Ann. Sociología ( $2^{\mathrm{a}}$ ed.). Cuaderno con aplicaciones en países de habla hispana. McGrawHill, México D.F., 2000.

GIDDENS, Anthony. Sociología. Madrid, Alianza Editorial, 4a edición, primera reimpresión, 2004.

GIMÉNEZ ROMERO, Carlos. "Dinamización comunitaria en el ámbito de la inmigración. Apuntes y propuestas sobre participación, mediación y codesarrollo"; en RUBIO MARTÍN, Mo José y MONTEROS, Silvina (coords.) La exclusión social. Teoría y práctica de la intervención. Madrid, CCS, 2002.

- "Familias en la inmigración. Su integración en la sociedad receptora”; BOROBIO, Dionisio (coord.). Familia e Interculturalidad. Universidad Pontificia de Salamanca, Salamanca, 2003, pp. 129-196.

GLICK SCHILLER, Nina; BASCH, Linda y SZANTON BLANC, C. "From immigrant to transmigrant: Theorizing transnational migration”; en Anthropological Quarterly, 1995, № 68, pp. 48-63.

BASCH, Linda y SZANTON BLANC, Cristina. Towards a Transnational Perspective in Migration: race, class, ethnicity and nationalism reconsidered. New York, New York Academy of Sciences, 1992.

- "Citizens in Transnational Nation-States: The Asian Experience"; en OLDS, K; DICKEN, P; KELLY, P.F.; KONG, L. YEUNG, H.W.C. (ed.). Globalisation and the Asia-Pacific: Contested Territories. London, Routledge, 1998.

GOIG MARTÍNEZ, Juan Manuel. "El derecho a la reagrupación familiar de los inmigrantes"; Teoría y Realidad Constitucional, No $14,2^{\circ}$ semestre 2004, pp. 239-271.

- "Régimen jurídico y políticas sobre extranjería en España. Comentario a la STS de 20 de marzo de 2003"; Teoría y Realidad Constitucional, No 12-13, $2^{\circ}$ semestre 2003-1º semester 2004, pp. 631-654.

- Derechos y libertades de los inmigrantes en España. Una visión constitucional, jurisprudencial y legislativa. Madrid, Universitas Internacional, $1^{\text {a }}$ ed., 2004.

- “Tribunal Constitucional y derechos de los extranjeros: comentario a la reciente jurisprudencia en materia de extranjería"; Teoría y Realidad Constitucional, No 22. 2008, pp. 625-649.

GÓMEZ CAMPELO, Esther. "El derecho de reagrupación familiar según la Directiva 2003/86/CE"; en Actualidad administrativa, No 13, 2004, pp. 1551-1560.

- “La compleja aplicación de la Directiva 2003/86/CE sobre el derecho a la reagrupación familiar”; en Revista Española del Tercer Sector, № 12, mayo-agosto 2009, pp. 73-99.

GÓMEZ CIRIANO, Emilio José. "Inmigración y Familia”; PENA GONZALEZ, Miguel Anxo y GALINDO GARCÍA, Ángel (eds.). Inmigración y estructuras sociales. Salamanca, Universidad Pontificia de Salmanca, 2006, pp. 179-208.

- La invisibilidad de los inmigrantes irregulares en el nuevo marco normativo de extranjería; PECES MORATE, Jesús Ernesto (dir.). Inmigración y Derecho. Estudios de Derecho Judicial, No 41, 2002, Consejo General del Poder Judicial, pp. 217-230.

GÓMEZ CRESPO, Paloma. "Gestación y puesta en práctica de la reagrupación familiar como estrategia”; en Migraciones No 5, 1999, pp. 55-86.

- “La aplicación de la normativa de <reagrupación familiar>: ¿Flexibilidad o arbitrariedad?”; OFRIM Suplementos, No 7, 2000, pp. 85-101.

GÓMEZ MOVELLÁN, Antonio. “Unión Europea, inmigración y el nuevo Reglamento de la ley de extranjería española: un comentario crítico"; en Jueces para la Democracia, No 26, 1996, pp. 60-68.

GÓMEZ-URRUTIA, M. Vargas. "La reagrupación familiar de los extranjeros en el derecho comunitario de la inmigración. Algunas contradicciones en las esferas de la libre circulación de personas en el Derecho comunitario"; en CALVO CARAVACA, Alfonso-Luis y CASTELLANOS RUIZ, Esperanza. El Derecho de familia ante el siglo XXI: Aspectos internacionales. Editorial Constitución y Leyes, Madrid, Colex, 2004, pp. 819-844.

- "De Estrasburgo a Luxemburgo: Lugares comunes, encuentros y desencuentros en el derecho a la reagrupación familiar”; coord. por Francisco ALDECOA LUZÁRRAGA, José MANUEL SOBRINO HEREDIA en Migraciones y desarrollo: II Jornadas Iberoamericanas de Estudios Internacionales, Montevideo, 25, 26 y 27 de octubre de 2006. 2007, pp. 581-600.

GONZÁLEZ BEILFUSS, Markus. "El régimen de la reagrupación familiar”; en Aargullol I MURGADAS, Enric (dir.). Inmigración y transformación social en Cataluña, Vol. 2. Estudio Jurídico Comparado. Bilbao, Fundación BBVA D.L., 2007, pp. 127-142.

- "El papel de la jurisprudencia constitucional en el desarrollo del derecho público de la inmigración”; Revista catalana de Dret públic, № 40, 2010, pp. 203-222.

GONZÁLEZ FERRER, Amparo. Estrategias familiares y laborales en la emigración. Reagrupación familiar, elección de parejas y empleo de los inmigrantes en el país de destino. Madrid, Consejo Económico y Social, 2008. 
GONZÁLEZ FERRER, Amparo. La inmigración de origen familiar (II): el control de flujos y el proceso de integración en España. Real Instituto Elcano, Ari, junio de 2011.

GONZÁLEZ LÓPEZ, R. "Régimen jurídico de la Reagrupación familiar tras la entrada en vigor del Real Decreto 864/2001, que aprueba el Reglamento de ejecución de la Ley Orgánica 4/2000, modificada por la Ley Orgánica 8/2000", en Aranzadi, Sentencias del TSJ y otros Tribunales, № 2, 2002.

- "Régimen jurídico de la reagrupación familiar en la Ley de Extranjería"; Revista Xurídica Galega, No 36, 2002, pp. 45- 60.

GONZÁLEZ MARTÍN, Nuria (coord.) Familia, inmigración y multiculturalidad: Una perspectiva jurídica comparada. México, Editorial Porrúa, Universidad Nacional Autónoma de México, 2006.

GONZÁLEZ SÁNCHEZ, Enrique. "Asilo e inmigración en la Unión Europea”; en Revista de Derecho Comunitario Europeo, No 13, septiembre/diciembre 2002, pp. 833-856.

GONZÁLEZ SOLER, Olayo E. "La posición del extranjero en el ordenamiento jurídico constitucional"; Estudios jurídicos. Ministerio Fiscal, No 4, 2002, pp. 195-238.

GONZÁLEZ TORRALBA, Herminia. "Familias y hogares transnacionales: una perspectiva de género"; en Puntos de Vista 2007, No 11, pp. 7-25.

GONZÁLEZ VEGA, Javier. “PPero realmente existe una política euroepa de inmigración? Dificultades y retos para su concreción”. Eikasia, Revista de Filosofía, año II, 10, mayo 2007, pp. 49-75. Disponible en: http://www. revistadefilosofia.org

GONZÁLVEZ PÉREZ, Vicente. “La inmigración en España: causas y perspectivas según el contexto europeo”; en PASTOR ANTOLÍN, Luis Jesús (coord.). Globalización y migraciones hoy: diez años de continuos desafíos. Universidad de Valladolid, Centro Buendía, 2002, pp. 19-42.

- "España, encrucijada de la inmigración internacional. La aportación de las mujeres”; GARCÍA ROCA, Joaquín y LACOMBA, Joan (eds.). La inmigración en la sociedad española. Una radiografía multidisciplinar. Barcelona, ediciones Bellaterra, 2008, pp. 45-74.

GORTÁZAR ROTAECHE, Cristina. “Two Immigration Acts and the End of Millennium”; en European Journal of Migration and Law, No 1, Vol. 4, 2002, pp. 1-21.

- "Familia y cultura. La familia inmigrante en la normativa de la UE"; en BOROBIO, Dionisio (coord.) Familia e interculturalidad. Salamanca, 2003, pp. 215-228.

- "De las políticas de 'Inmigración 0' a la Inmigración selectiva"; en La inmigración en la Unión Europea: Situación y perspectivas para Euskadi. Bilbao, Consejo Vasco del Movimiento Europeo, 2003, pp. 187-209.

GREER, Steven. The European Convention on Human Rights. Achievements, Problems and Prospects. Cambridge, Cambridge University Press, 2006.

GREESE, Gillian; DYCK, Isabel y MCLAREN, Arlene. "Reconstituting the Family: Negotiating Immigration and Settlement". Research on Immigration and Integration in the Metropolis (RIIM), Centre of Excellence, Vancouver, 1999, paper 99-10. Disponible en: http://riim.metropolis.net/Virtual\%20Library/1999/wp9910.pdf

GROENENDIJK, Kees, GUILD, Elspeth y DOGAN, Halil. Security of Residence of long-term Migrants. A comparative study of law and practice in European Countries. Council of Europe, Germany, 1998.

- y GUILD, Elspeth. “Converging Criteria: Creating and Area of Security of Residence for Europe's Third Country Nationals"; en European Journal of Migration and Law, No 3, 2001, pp. 37-59.

- "Long-Term Immigrants and the Council of Europe"; GUILD, Elspeth y MINDERHOUD, Paul (ed.). Security of Residence and Expulsion. Protection of Aliens in Europe (colección: Immigration and Asylum Law and Policy in Europe, volume 1). Kluwer Law International, The Hague-London-Boston, 2001. pp. 7-22.

- "Legal Concepts of Integration in EU Migration Law"; en European Journal of Migration and Law, No 6, 2004, pp. 111-126.

- "Family reunification as a right under Community Law"; en European Journal of Migration and Law, Volume 8, Number 2, 2006, pp. 215-230.

GUENDELSBERGER, J. “The Right to Family Unification in French and United States Immigration Law”; en Cornell International Law Review, Vol. 21, 1988, pp. 1-102.

GUILD, Elspeth (compilation and commentary). The Developing Immigration and Asylum Policies of the European Union. Adopted Conventions, Resolutions, Recommendations, Decisions and Conclusions. Kluwer Law International, The Hague, 1996.

- The Legal Framework and Social Consequences of Free Movement of Persons in the European Union. Kluwer Law International, The Hague-Boston-London, 1999.

- and MINDERHOUD, Paul (eds.) Security of Residence and Expulsion: Protection of Aliens in Europe. La Haya, Kluwer Law International, 2001.

- y PEERS, Steve. "Deference or Defiance? The Court of Justice's Jurisdiction over Immigration and Asylum"; GUILD, Elspeth and HARLOW, Carol (ed.). Implementing Amsterdam. Immigration and Asylum Rights in EC Law. Hart Publishing, Oxford-Portland, 2001. pp. 267-289. 
GUILD, Elspeth. Commission Initiative: Proposal for a decision on establishing a Convention on rules for the admission on third-country nationals to the member states of the EU. Immigration Law Practitioners Association Memorandum, European Update, September 1997.

- "Discretion, Competence and Migration in the European Union"; European Journal of Migration and Law, № 1, 1999, pp. 61-87.

GUIRAUDON, Virgine y LAHAV, Gallya. "A Reappraisal of the State Sovereignty Debate. The Case of Migration Control"; en Comparative Political Studies, vol, 33, No 2, 2000, pp. 163-195.

- "European Courts and Foreigner's Rights: A Comparative Study of Norms Diffusion”; en International Migration Review, Vol. 34, No 4, 2000, pp. 1088-1125.

GURAK, Douglas T. y CACES, Fe. "Redes migratorias y la formación de sistemas de migración”, en MALGESINI, Graciela (comp.). Cruzando fronteras. Migraciones en el sistema mundial. Barcelona, Icaria-FHE, 1998, pp. 75-110.

GUTIÉRREZ ESPADA, Cesáreo. "El derecho de reunificación familiar del extranjero en España (desde la perspectiva de un internacionalista)"; en Anales de Historia Contemporánea, № 19, 2003, pp. 103-121.

GUTIÉRREZ GUTIÉRREZ, Ignacio. "La configuración legal de los derechos fundamentales de los extranjeros"; GARCÍA HERRERA, Miguel Ángel (coord.). Constitución y democracia: 25 años de Constitución democrática en España. Actas del Congreso celebrado en Bilbao los días 19 a 21 de noviembre de 2003, Vol. 1, 2005, pp. 329-334.

HAILBRONNER, Kay y POLAKIEWICZ J. "Non-EC Nationals in the European Community: The Need for A Coordinated Approach"; Duke Journal of comparative and international law, No 3, 1992, pp. 49-88.

- "European Immigration and Asylum Law under the Amsterdam Treaty"; en Common Market Law Review, № 35, 1998, pp. 1047-1067.

- "General Rapport"; en HIGGINS, Imelda (ed.). Migration and Asylum Law and Policy in the European Union. FIDE 2004 National Reports. United Kingdom, Crambridge Universtiy Press, 2004, pp. 455-476.

- Immigration and Asylum Law and Policy of the European Union. Kluwer Law International, The Hague-LondonBoston, 2000.

- "The Treaty of Amsterdam and Migration Law"; en European Journal of Migration and Law, No 1, 1999, pp. 9-27.

HANDOLL, John. "The Long-Term Residents Directive”; CARLIER, Jean-Yves y BRUYCKER, Philippe de (dir.). Immigrations and Asylum Law of the EU: Current Debates. Actualitè du droit européen de l'immigration et de l'asile. Brulyant, Bruxelles, 2005, pp. 144-160.

HANSEN, Ransall. "Migration, Citizenship and Race in Europe: Between Incorporation and Exclusion"; en European Journal of Political Research, No 35, 1999, pp. 415-444.

HARRIS, D.J.; O’BOYLE, M.; WARBRICK, C. Law of the European Convention on Human Rights. Butterworths, London, 1995.

HARVEY, Colin. "Promoting Insecurity: Public Order, Expulsion and the European Convention on Human Rights"; Security of Residence and Expulsion. Protection of Aliens in Europe. Immigration and Asylum Law and Policy in Europe, volume 1, Kluwer Law International, The Hague-London-Boston, 2001. pp. 41-57.

HEDEMANN-ROBINSON, M. "Third-Country Nationals, European Union Citizenship and Free Movement of Persons: A Time for Bridges rather than Divisions?”; en Yearbook of Euroepan Law, No 16, 1996, pp. 321- 362.

- "From Object to Subject? Non-EC Nationals and the Draft Proposal of the Comisión for a Council Act Establishing the Rules for Admisión of Third-Country Nationals to the Member States"; en Yearbook of European Law, № 18, 1998, pp. 289-335.

HEINBERG, John; HARRIS, Jeffrey y YORK, Robert. "The Process of Exempt Immediate Relative Immigration to the United States"; en International Migration Review, Vol. 23, № 4, 1989, pp. 839-855.

HENKIN, Louise (ed.). The International Bill of Rights: The Covenant on Civil and Political Rights. Washington, Columbia University Press, November 1981.

HERVEY, Tamara K. "Migrant workers and their families in the European Union: The Pervasive Market Ideology of Community Law”; SHAW, Jo y MORE Gilliam. New Legal Dynamics of European Union. Clarendon Press, Oxford, 1995. Pp. 91-110.

- "A gendered Perspective on the Right to Family Life in European Community Law"; en N.H. NEUWAHL y A. ROSAS (eds.). The European Union and Human Rights. Kluwer Law International, Netherlands, 1995, pp. 221-234.

HIGGINS, Imelda (ed.). Migration and Asylum Law and Policy in the European Union. FIDE 2004 National Reports. United Kingdom, Cambridge University Press, 2004, General Rapporteur by Kay Hailbronner, pp. 455-476.

HILSON, Chris. "What's in a right? The relationship between Community, Fundamental and Citizenship rights in EU law"; en European Law Review, Vol. 29, October 2004, pp. 636-651.

HO, Christine G. T. "The Internationalization of Kindship and the Feminization of Caribbean Migration: the Case of Afro-Trinidadian Immigrants in Los Angeles"; en Human Organization, Vol. 52, № 1, 1993, pp. 32-40.

HOFFMANN, Bernd Von (ed.). Towards a Common European Immigration Policy. Reports and discussions of a Symposium held in Trier on October 24 ${ }^{\text {th }}$ and 25th, 2002. Frankfurt, Peter Lang GMBH, 2003. 
HOLLIFIELD, James Frank. Immigrants, Markets and States: the Political Economy of Postwar Europe. Cambridge, Harvard University Press, 1992.

- “The Emerging Migration State”; en International Migration Review, Vol. 38, No 3, 2004, pp. 885-912.

HONOHAN, Iseult. "Reconsidering the Claim to Family Reunification in Migration"; en Political Studies, 2008.

HOOGENBOOM, T. "Integration into Society and Free Movement of Non-EC Nationals; en Symposium: The status of non-Community nationals in Community law"; European Journal of International Law, 1992, Vol. 36, No 3, pp. 36- 54.

HUTCHINSON, Michael R. "The Margin of Appreciation Doctrine in the European Court of Human Rights"; en The International and Comparative Law Quarterly, Vol. 48, No 3 (Jul., 1999), pp. 638-650.

IGLESIAS SÁNCHEZ, Sara. "La aplicación directa de la Directiva 2003/109/CE a los nacionales de terceros Estados que acrediten ser titulares del Estatuto de los residentes de larga duración en otros Estados miembros de la Unión Europea"; en Revista de Derecho Migratorio y Extranjería, № 19, 2008, pp. 81-98.

- "El valor de la Directiva 86/2003 sobre reagrupación familiar a la luz de los derechos fundamentales y de la sentencia del TJCE en el asunto 540/03"; en Revista de Derecho Comunitario Europeo, No 26, 2007, pp. 125-153.

INTERNATIONAL MIGRATION OUTLOOK: Annual Report. SOPEMI, Ediciones correspondientes a los años 2008, 2009, 2010, 2011 y 2012. Summary in English. Disponible en: http://www.oecd.org

INTERNATIONAL ORGANIZATION FOR MIGRATION (IOM). Derecho Internacional sobre Migración, № 7, 2006.

- "Migration Terminology". World Migration 2008.

IZQUIERDO ESCRIBANO, Antonio. “España como país de acogida”; Cuenta y Razón, No 73-74, 1992, pp. 28-34.

- La inmigración inesperada: la población extranjera en España (1991-1995). Madrid, Trotta, 1996.

_ "Panorama de la inmigración en España al alba del siglo XXI"; Mediterráneo Económico, No 1, 2002, pp. $247-264$.

- "La inmigración en España y las consecuencias de una política restrictiva: 2000-2003"; Revista Asturiana de Economía, № 30, 2004, pp. 53-83.

- y FERNÁNDEZ, Belén. "Panorama de la inmigración en España”; ALTED VIGIL, Alicia y ASENJO, Almudena (cords.). De la España que emigra a la España que acoge. Madrid, Fundación Francisco Largo Caballero, 2006, pp. 444-466.

- y LEÓN-ALFONSO, Sandra. "La inmigración hacia dentro: argumentos sobre la necesidad de coordinación de las políticas de inmigración en un Estado multinivel”; Política y sociedad, Vol. 45, No 1, 2008, pp. 11-39.

- "Terremoto en los cimientos del modelo migratorio"; GARCÍA ROCA, Joaquín y LACOMBA, Joan (eds.). La inmigración en la sociedad española. Una radiografía multidisciplinar. Barcelona, edicions Bellaterra, 2008, pp. 7592.

JACOBS, Francis G.; WHITE, Robin C.A. The European Convention on Human Rights. New York, Oxford University Press, Clarendon Paperbacks, 2a ed., 1996.

JACOBSON, David. Rights Across Borders: Immigration and the Decline of Citizenship. Baltimore, Johns Hopkins University Press, 1996.

JAECKEL, Liv. "The duty to protect fundamental rights in the European Community"; en European Law Review, Vol. 28, No 4, August 2003, pp. 508-527.

JASSO, Guillermina, and ROSENZWEIG, Mark R. "Family Reunification and the Immigration Multiplier: U.S. Immigration Law, Origin-Country Conditions, and the Reproduction of Immigrants"; en Demography № 23 , August 1986, pp. 291-311.

- "Sponsors, Sponsorship Rates and the Immigration Multiplier"; en International Migration Review, Vol. 23, № 4, 1989, pp. 856-888.

JASTRAM, Kate. "Family Unity: The New Geography of Family Life"; en Migration Information Source, Mayo de 2003. Disponible en: www.migrationinformation.org

JIMÉNEZ ÁLVAREZ, Mercedes. "Donde quiebra la protección: Las reagrupaciones familiares sin garantías"; en PANTOJA GARCÍA, Félix y NIETO GARCÍA, Luis Carlos (dirs.). Los derechos de los menores extranjeros. Madrid, Consejo General del Poder Judicial, Estudios de Derecho Judicial No 104, 2007, pp. 53-76.

JIMÉNEZ DE PARGA, Manuel. La inmigración en la jurisprudencia del Tribunal Constitucional. Ponencia presentada con ocasión del décimo aniversario del TC, en el seno de la Jornada de treball del 03·10·2003, bajo el título genérico de "La protecció de les minories i els Tribunals Constitucionals", sp. Disponible en: http://www.tribunalconstitucional. ad/docs/10aniversari/E-ESPANA.pdf

JIMÉNEZ PIERNAS, Carlos. "La comunitarización de las políticas de inmigración y extranjería: especial referencia a España”; en Revista de Derecho Comunitario Europeo, No 13, 2002, pp. 857-894.

- "La política y legislación española sobre extranjería e inmigración y su conformidad con el derecho europeo e internacional en la materia"; en ZLATA DRNAS DE CLÉMENT (coord.). Estudios de derecho internacional en homenaje al profesor Ernesto J. Rey Caro.Vol. 2, 2002, pp. 893-924. 
JIMÉNEZ, Carlos; MALGESINI, Graciela. Guía de conceptos sobre migraciones, racismo e interculturalidad. Catarata, Consejería de Educación de la Comunidad de Madrid, Madrid, 2000.

JOHNSON, Nancy. "Breadth of Family Law Review under the European Court of Human Rights: Kroon v. The Netherlands"; en Harvard International Law Journal, No 36, 1995, pp. 513-527.

JOPPKE, Christian. "Immigration Challenges the Nation State"; en JOPPKE, C. (ed.). Challenge to the nation-state: Immigration in Western Europe and the United States. Oxford, Oxford University Press, 1998, pp. 5-46.

- "Why Liberal States Accept Unwanted Immigration?"; en World Politics, No 50, 1998, pp. 266-293.

- Immigration and the Nation-State: The United States, Germany and Great Britain. Oxford, Oxford University Press, 1999.

- y MARZAL, Elia. "Courts, the new Constitutionalism and Immigrant Rights: The Case of the French Conseil Constitutionnel”; en European Journal of Political Research, vol 43, № 6, 2004, pp. 823-844.

JORNA, Santos y BOTE, Susana. "Derechos fundamentales de los extranjeros en España”; en PERALTA CARRASCO, Manuel (dir.). I Jornadas sobre la Ley de Extranjería e Inmigración. Cáceres, 26 a 29 de marzo de 2001. Facultad de Derecho. Cáceres, Universidad de Extremadura, 2003, pp. 13-21.

JOVER GOMEZ FERRER, Rafael; ORTEGA CARBALlO, Carlos y RIPOLL CARULLA, Santiago. Derechos fundamentales de los extranjeros en España. Valladolid, Lex Nova, 2010.

KELSEN, Hans. Teoría General del Derecho y del Estado, 5a reimpr. Traducción de Eduardo García Máynez. México, UNAM, 1995.

KENGERLINSKY, Marat. Immigration and Asylum Policies in the Eu in the context of the European Convention on Human Rights. Questioning the Legality of Restrictions, (2007); disponible en http//aukaa.az/documents/Immigration Asylum\%20Policies.Kengerlinski\%20M.pdf

- "Restrictions in EU Immigration and Asylum Policies in the light of International Human Rights Standards"; Essex Human Rights Review, Vol. 4, № 2, september 2007, pp. 1-19.

KHOO, Siew-Ean. "Sponsorhip of relatives for migration and immigrant settlement intention"; en International Migration, Vol. 41, No 5, 2003, pp. 177-199.

KINGSTON, James. "Human Rights and the European Union- An Evolving System"; M. C. LUCEY and C. KEVILLE. Irish Perspectives on EC Law. Dublin, Round Hall Ltd, 2003, pp. 271-290.

$\mathrm{KOCH}$, Ida Elisabeth. "Economic, Social and Cultural Rights as Components in Civil and Political Rights: A Hermeneutic Perspective"; en The International Journal of Human Rights, Vol. 10, o 4, diciembre 2006, pp. 405-430.

KOFMAN, Eleonore. Contemporary European Migrations, Civic Stratification and Citizenship. Paper presented at International Migrations: New Patterns, New Theories. Nottingham Trent University, 11-13 September 2000.

- "Family-Related Migration: A Critial Review of European Studies"; en Journal of Ethnic and Migration Studies, Vol. 30, No 2, 2004, pp. 243-262.

- y MEETOO, Veena. "Family Migration"; Wold Migration 2008: Managing Labour Mobility in the Evolving Global Economy. International Organization for Migration, 2008.

KRALER, Albert y KOFMAN, Eleonore. "Civic Stratification, Gender and Family Migration Policies in Europe”; Paper presented at Conference European Dynamics of Citizenship. Public Policies and Migrant Activities. IMISCOE Network Cluster B3, Legal Status, citizenship and political participation. Central European University, Budapest, 31 May-2 June 2006. Disponible en: http://research.icmpd.org/fileadmin/Research-website/Project_material/NODE/ Kofman-Kraler-CivicStratification-Final.pdf

- y KOFMAN, Eleanore (coords.). "Family migration in Europe: policies vs reality"; en IMISCOE, Integration and Social Cohesion in Europe. Policy Brief, No 16, agosto 2009. Disponible en http://research.icmpd.org/1291.html

KRIEKEN, Peter J. van (compiled and introduced by). The Consolidated Asylum and Migration Acquis. The EU Directives in an Expanded Europe. T.M.C. Asser Press, The Hague, 2004.

KUIJPER, P.J. "Some legal problems associated with the communitarization of policy on visas, asylum and immigration under the Amsterdam Treaty and incorporation of the Schengen acquis"; en Common market law review, Vol. 37, No 2, 2000, pp. 345-366.

KUNOY, Bjørn; MORTANSSON, Bardur. “Case C-578/08, Rhimou Chakroun v. Minister van Buitenlandse Zaken, Judgment of the European Court of Justice (Second Chamber) of 4 March 2010"; Common market law review, Vol. 47, No 6, 2010, pp. 1815-1830.

LABACA ZABALA, María Lourdes. "El derecho a la vida familiar de los inmigrantes en la legislación de extranjería"; Saberes No 3, 2005, http://www.uax.es/publicaciones/archivos/SABDER05_009.pdf

_ "El reagrupamiento familiar en el derecho español”; Noticias Jurídicas, mayo 2005.

- "La prohibición del reagrupamiento familiar polígamo en la legislación de extranjería”; Sentencias del TSJ y AP y otros Tribunales, No 1, 2005; BIB 2005/723.

- El reagrupamiento familiar en el derecho español; Revista IMES de Direito, año 6, № 11, julio/diciembre 2005, pp. 159-210. Disponible en: http://www.uscs.edu.brrevistasacademicas/revista/dir11.pdf 
LA SPINA, Encarnación. "La transposición de la Directiva 2003/86/CE en Italia. ¿Hacia la armonización legislativa de la reagrupación familiar?”; en Revista de Derecho Migratorio y Extranjería, № 15, julio 2007, pp. 195-208.

- "Singularidades y retos normativos en el control genético de la inmigración familiar hacia España, Italia y Portugal", en Cuadernos Electrónicos de Filosofía del Derecho, No 21, 2010, pp. 105- 132.

LAHAV, Gallya. "International versus National Constraints in Family-Reunification Migration Polices"; en Global Governance, № 3, 1997, pp. 349-372.

LAMBERT, HÉLÈNE. “The European Court of Human Rights and the Right of Refugees and Other Persons in Need of Protection to Family Reunión”; en International Journal of Refugee Law, Vol. 11, No3, 1999, pp. 427-450.

- "A Missed Opportunity? EU Law and Asylum in the twenty-first Century"; en TRIDIMAS, Takis \& NEBBIA, Paolisa. European Union Law for the Twenty-First Century. Rethinking the New Legal Order, volume 2. Oxford and Portland Oregon, Hart Publishing, 2004, pp. 361-375.

- The position of aliens in relation to the European Convention on Human Rights. Strasbourg, Council of Europe publishing, 2006.

LANDOLT, Patricia y DA, Wei Wei."The Spatially Ruptures Practices of Migrant Families: A Comparision of Immigrants from Salvador and the People's Republic of China"; en Current Sociology, Vol. 53, No 4, July 2005, pp. 625-653.

LAPARRA, Miguel. "La dinamica de la integración social de los inmigrantes y su impacto en la sociedad de acogida. La perspectiva desde Navarra"; Política y sociedad, Vol. 45, No 1, 2008, pp. 167-186.

LASAGABASTER HERRARTE, Iñaki (Dir.). El Convenio Europeo de Derechos Humanos. Comentario sistemático. Madrid, Thomson Civitas, $1^{\text {a }}$ ed., 2004.

LAVENEX, Sandra; UCARER, Emek M (eds.). Migration and the Externalities of European Integration. Lanham, EEUU, Lexington Books, 2002.

LAWSON, Rick. "Family Reunification and the Union's Charter of Fundamental Rights, Judgment of 27 June 2006, Case C-540/03, Parliament v. Council”; European Constitutional Law Review 2007, Vol. 3, pp. 324-342.

LÁZARO GONZÁLEZ, Isabel. "La reagrupación familiar de los extranjeros en España. Previsible incidencia de la futura directiva sobre el derecho a la reagrupación familiar"; en Migraciones, No 12, 2002, pp. 43-79.

LEACH, Philip. Taking a Case to the European Court of Human Rights. New York, Oxford University Press, Blackstone's Human Rights Series, second sedition, 2005.

LEE, Evereth S. "A Theory of Migration"; en Demography, No 3, Vol. 1, 1966, pp. 47-57.

LIDDY, Jane. "The concept of family life under the European Convention on Human Rights”; en European Human Rights Law Review, 1998, Vol. 1, pp. 15-25.

LIEVENS, John. "Interethnic Marriage: Bringing in the Context through Multilevel Modeling"; en European Journal of Population, 1998, Vol. 14, pp. 117-155.

LIROLA DELGADO, Isabel. “¿Por fin una política de inmigración de la Unión en el Tratado de Lisboa?”; MARTÍN Y PÉREZ DE NANCLARES, José (coord.). El Tratado de Lisboa: la salida de la crisis constitucional. Madrid, Iustel, 2008, pp. 539-548.

LÓPEZ BARBA, Elena y GARCÍA SAN JOSÉ, Daniel I. "El derecho de reagrupación familiar en el nuevo régimen jurídico de la inmigración en España a la luz de las obligaciones internacionales asumidas en el Convenio Europeo de Derechos Humanos: un análisis crítico"; Revista del poder judicial, No 64, 2001, pp. 43-82.

- "Extranjería y Reagrupación Familiar"; SÁNCHEZ-RODAS NAVARRO, C. (coord.). Extranjeros en España: Régimen Jurídico. Murcia, Laborum. 2001, pp. 155-187.

- "Principales modificaciones legislativas al derecho a la reagrupación familiar". Derechos y Libertades de los Extranjeros en España. Cantabria, Gobierno de Cantabria, 2003, pp. 841-875.

- "El cónyuge en la nueva perspectiva jurídica del derecho a la reagrupación familiar"; III Seminario sobre la investigación de la inmigración extranjera en Andalucía. Sevilla, Dirección General de Coordinación de Políticas Migratorias, Consejería de Gobernación, Junta de Andalucía, 2003, pp. 61-75.

- "El ejercicio del derecho a la reagrupación familiar en el Real Decreto 2393/2004"; en ALONSO BURÓN, José Carlos (coord.) y SÁNCHEZ-RODAS NAVARRO, Cristina (dir.). Aspectos puntuales del nuevo Reglamento de Extranjería. Murcia, Laborum, 2005, pp. 167-204.

- "El derecho a la vida en familia y a la intimidad familiar de los extranjeros de terceros países en España"; CARRASCO DURÁN, Manuel; PÉREZ ROYO, Francisco Javier; URÍAS MARTÍNEZ, Joaquín y TEROL BECERRA, Manuel José (coords.). Derecho constitucional para el siglo XXI: actas del VIII Congreso Iberoamericano de Derecho Constitucional, Vol. 2, 2006, pp. 4973-4985.

- "El derecho a la vida en familia y a la intimidad familiar de los extranjeros de terceros países en España"; en PÉREZ ROYO, F.J.; CARRASCO DURÁN, M; URÍAS MARTÍNEZ, J y TEROL BECERRA, M.J (coords). Derecho constitucional para el siglo XXI: actas del VIII Congreso Iberoamericano de Derecho Constitucional. Vol. 2, 2006, pp. 4973-4985. 
LÓPEZ BARBA, Elena y GARCÍA SAN JOSÉ, D. "El derecho de reagrupación familiar en el nuevo régimen jurídico de la inmigración en España a la luz de las obligaciones asumidas en el Convenio Europeo de Derechos Humanos: Un análisis crítico"; en Revista del poder judicial, № 64, 2001, pp. 43-82.

LÓPEZ GARRIDO, Diego. "La ley de extranjería frente a la Constitución: el Convenio Europeo de derechos humanos"; Globalización y migraciones hoy: diez años de continuos desafíos, 2002, pp. 75-80.

LÓPEZ GUERRA, Luis María. "Democracia, división del poder y Poder Judicial"; en El Poder Judicial en el Estado Constitucional. Lima, Palestra, 2001.

- "Hacia un concepto europeo de derechos fundamentales"; Revista Vasca de Administración Pública. № 65, 2, 2003, pp. 191-204.

LÓPEZ SALA, Ana María. Inmigrantes y Estados: la respuesta política ante la cuestión migratoria. Barcelona, Anthropos editorial, 2005.

LÓPEZ TRIGAL, Lorenzo. "La desigual distribución de la inmigración en España. Una exploración en las regiones interiores y atlánticas peninsulares"; GARCÍA ROCA, Joaquín y LACOMBA, Joan (eds.). La inmigración en la sociedad española. Una radiografía multidisciplinar. Barcelona, edicions Bellaterra, 2008, pp. 93-112.

LÓPEZ ULLA, Juan Manuel. "El derecho de los extranjeros a reunir a la familia"; Boletín de la Facultad de Derecho, UNED, No 20, 2002, pp. 223-245.

- "Instrumentos para la integración social en la Ley de Extranjería"; en Nuevas Políticas Públicas, № 2, 2006, pp. 226261.

- "Extranjeros reagrupables"; en GAVIDIA SÁNCHEZ, Julio V. (coord.) Inmigración, familia y Derecho. Madrid, Marcial Pons, 2011, pp. 447-479.

LÓPEZ-MUÑIZ GOÑI, Miguel. La nueva Ley de Extranjería. Guía práctica y jurisprudencia. Madrid, Colex, 2006, 4a ed.

LORIENTE SAINZ, Francisco Javier. "La reagrupación famliar"; LAFONT NICUESA, Luis (coord.). Extranjería. Legislación, comentarios y jurisprudencia. Valencia, Tirant lo Blanch, 2008, pp. 107-136.

LOSADA GONZÁLEZ, Herminio. "Estatuto legal de los extranjeros en España"; PALOMAR OLMEDA, Alberto (coord.). Tratado de Extranjería: aspectos civiles, penales, administrativos y sociales. Navarra, Thomson-Aranzadi, $3^{\mathrm{a}}$ ed., 2007, pp. 145-198.

LOWE, Nigel y DOUGLAS, Gillian. Families across Frontiers. Martinus Nijhoff Publishers, The International Society of Family Law, The Hague-Boston-London, 1996.

LUCAS MARTÍN, Javier de. El desafío de las fronteras. Derechos humanos y xenofobia frente a una sociedad plural. Madrid, Temas de Hoy, 1994.

- "El marco jurídico de la integración"; en Jueces para la Democracia, № 38 julio de 2000.

- "El objetivo de integración en las políticas de inmigración"; Inmigración y Derecho. Madrid, Consejo General del Poder Judicial, 2002, pp. 127-141.

- "Sobre las políticas de inmigración en un mundo globalizado"; en Anuario de la Facultad de Derecho de la Universidad Autónoma de Madrid, № 7, 2003, pp. 2352.

LUNDSTRÖM, Karin. "Family Life and the Freedom of Movement of Workers in the European Union"; en International Journal of Law, Policy and the Family, № 10, 1996, pp. 250-280.

MACDONALD, Ronald St. John. "The Margin of Appreciation in the Jurisprudence of the European Court of Human Rights"; en International Law at the time of its Codification, Essays in honour of Judge Roberto Ago, Vol. III. Milán, A. Giuffré, 1987, pp. 187-208.

MACRİ, Fabio: "La Corte di giustizia sul diritto al ricongiungimento familiare dei cittadini di Stati terzi: la sentenza Parlamento c. Consiglio"; en Il diritto dell'Unione Europea, 2006, pp.793-817.

MAHONEY, Paul. "Judicial activism and Judicial Self-restraint in the European Court of Human Rights: Two Sides of the Same Coin"; en Human Rights Law Journal, № 11, 1990, pp. 57-88.

MALGESINI, Graciela. "Reflexiones sobre migraciones, cooperación y codesarrollo"; en Arxius de sociologia, №. 5, 2001, pp. 123-146.

MANGAS MARTÍN, Araceli y LIÑÁN NOGUERAS, Diego J. Instituciones y derecho de la Unión Europea. Madrid, Tecnos, $5^{\mathrm{a}}$ ed., $3^{\mathrm{a}}$ reimpresión, 2008.

MARÍN CONSARNAU, D.B. "Reagrupación familiar y parejas de hecho"; Las fronteras de la ciudadanía en España y la Unión Europea. Actas del II y III Encuentro de Jóvenes Investigadores en Derecho de Inmigración y Asilo, celebrado en Girona, del 10 al 12 de noviembre de 2005. Girona, 2006, pp. 199-210. http://www.udg.es/dretpublic/Joves/ ponències/Diana\%20Marin\%20Consarnau.doc

MARÍN GÁMEZ, José Angel. "Una visión de los derechos y garantías constitucionales de los extranjeros en España”; en Revista de Derecho Político, № 61, 2004, pp. 37-78.

MARÍN LÓPEZ, Antonio. "Los derechos políticos de los extranjeros en España"; Revista Española de Derecho Internacional, Vol. 43, № 2,1991, pp. 351-373.

MARÍN, P and O CONNELL. "The European Convention and the Relative Rights of Resident Aliens"; European Law Review, No 5, 1994, pp. 4-29. 
MARIÑO MENÉNDEZ, Fernando (dir.). Derecho de Extranjería, Asilo y Refugio. Madrid, Ministerio de Asuntos Sociales, Inserso, 1995.

MARQUINA, Antonio. "El lento proceso de elaboración de una política de inmigración común en la Unión Europea”; en MARQUINA, Antonio (ed.). Flujos migratorios norteafricanos hacia la Unión Europea. Asociación y diplomacia preventiva. Madrid, Agencia Española de Cooperación internacional, 1997, pp. 91-122.

MARTÍN ARRIBAS, Juan José. “La actual política de inmigración de la UE. Reflexiones Jurídicas”. Ponencia presentada en el I Congreso Internacional sobre Migración y Diversidad Cultural, Salamanca, 6-9 febrero 2007.

MARTÍN LÓPEZ, Enrique. Textos de Sociología de la Familia. Un relectura de los clásicos (Linton, Tönnies, Weber y Simmel). Madrid, Ediciones Rialp, Instituto de Ciencias para la Familia, Universidad de Navarra, 1993.

MARTÍN MARÍA, Belén. "La reforma de la Ley de extranjería”; Iuris: Actualidad y Práctica del Derecho, № 48, 2001, pp. 31-38.

MARTÍN MARTÍNEZ, Magdalena. "Ordenando el desorden. El estatuto jurídico de los inmigrantes en la Unión Europea”. SALINAS DE FRÍAS, Ana (dir.). Inmigración e integración: Aspectos sociales y legales. Madrid, ediciones Sequitur, 2008, pp. 158-177.

MARTÍN MORENO, José Luis. "Extranjeros en situación irregular: dignidad de la persona y derechos fundamentales a la tutela judicial, educación, sindicación, reunión y asociación (STC 236/2007, de 7 de noviembre)"; Aletheia, No 4, 2007, pp. 64-108.

MARTÍN PALLÍN, José Antonio. "Política común de la Unión Europea en materia de extranjería”; en MARTÍN PALLÍN, J.A. (dir.) Extranjeros y Derecho Penal, Cuadernos de Derecho Judicial, IV- 2003. Madrid, Consejo General del Poder Judicial, 2003, pp. 235-279.

MARTÍN Y PÉREZ DE NANCLARES, José. La inmigración y el asilo en la Unión Europea: hacia un nuevo espacio de libertad, seguridad y justicia. Editorial Constitución y Leyes, COLEX, 2002.

- "La inmigración en la Unión Europea: La difícil configuración de una política de inmigración"; en Revista de Derecho de la Unión Europea, No 5, 2003, pp. 83-90.

- "La inmigración y el asilo en la Unión Europea: presente y futuro"; en Anuario de la Facultad de Derecho de la Universidad Autónoma de Madrid, № 7, 2003, pp. 93-118.

- "La inmigración y el asilo en la Unión Europea. Aspectos jurídico-políticos"; en España como frontera de la Unión Europea: implicaciones para la Guardia Civil, 2005, pp. 29-42.

- "El reto de la inmigración: sobre la conveniencia de una política común europea al estilo de la prevista en la Constitución Europea”; en Revista General de Derecho Europeo, № 11, 2006, s.p.

MARTÍN RETORTILLO BAQUER, Lorenzo. "La recepción por el Tribunal Constitucional de la jurisprudencia del TEDH”; en Revista de Administración Pública, No 137, 1995, pp. 7-29

MARTIN, D. "Comments on N.v. Inspecteur van de Belastingdienst Osst/kantoor Almelo (Case C-470/04 of 7 September 2006), European Parliament v. Council (Case C-540/03 of 27 June 2006) and Tas-Hagen and Tas (Case C-192/05 of 26 October 2006"; en European Journal of Migration and Law, Vol. 9, No 1, 2007, pp. 141-157.

MARTIN, Philip L; HOUSTOUN, Marion F. "European and American Immigration Policies”; en Law and Contemporary Problems, No 45, Vol. 2, 1982, pp. 29-54.

MARTINELLO, Marco. La Europa de las migraciones. Por una política proactiva de la inmigración. Barcelona, Ediciones Bellaterra, 2003.

MARTÍNEZ RODRÍGUEZ, Antonio. "Las migraciones: un signo de los tiempos". Jalones para una pastoral inmigrante. Delegación Diocesana de Migraciones de Madrid y Editorial Verbo Divino, Estella, 1995.

MARTÍNEZ, Antonio y equipo del DDIM. "La reagrupación familiar"; BORRAS FERNÁNDEZ, Alegría (dir.). Diez años de la Ley de extranjería: Balance y perspectivas. Barcelona, Fundación Paulino Torras Domènech, 1995, pp. 196-208.

MARZAL YETANO, Elia. El proceso de constitucionalización del derecho de inmigración. Estudio comparado de la reformulación de los derechos de los extranjeros por los tribunales de Alemania, Francia y España. Derechos precarios y emergentes. Madrid, Dykinson, 2009.

MASSEY, Douglas S. Worlds in Motion: Understanding International Migration at the End of Millenium. Oxford Universtiy Press, 1998.

MASSÓ GARROTE, Marcos F. "Aspectos políticos y constitucionales sobre la participación electoral de los extranjeros en el Estado nacional”; Revista de Estudios Políticos, No 97, 1997, pp. 159-194.

MATIA PORTILLA, Francisco Javier (Dir.). Crisis e Inmigración. Reflexiones interdisciplinares sobre la inmigración en España. Valencia, Tyrant lo Blanch monografías, 2012.

McCRUDDEN, Christopher. "Human Rights and Judicial Use of Comparative Law"; en ÖRUXÜ, Ersin. Judicial Comparativism in Human Rights Cases. The United Kingdom National Committee of Comparative Law, London, 2003, pp 1-22.

MCGLYNN, Clare. “A Family Law for the European Unión?”; en SHAW, Jo (ed.). Social Law and Policy in an Evolving European Unión. Oxford, Portland, 2000, pp. 223-241. 
MCGLYNN, Clare. "Families and the European Union Charter of Fundamental Rights: Progressive Change or Entrenching the Status Quo?"; en European Law Review, № 26, 2001, pp. 582-598.

- "Challenging the European Harmonisation on Family Law: Perspectives on "The Family"; en BOELE-WOELKI, Katharina (ed.). Perspectives for the Unification and Harmonisation of Family Law in Europe. Intersentia, Antwerp, New York, 2003, pp. 219-237.

- Families and the European Union. Law, Politics and Pluralism. Cambridge University Press, Cambridge, New York, 2006.

MEIJERS COMMITTEE. Memorandum on Immigration and Asylum in the VVD-CDA Coalition Agreement of 30 September 2020. Standing Committee of Experts on International Immigration, Refugee and Criminal Law, Utrecht, November 2010, pp. 1-16. http://www.commissie-meijers.nl

MELOSSI, Dario. "Inmigración e inadaptación: observaciones sobre la identidad y el control social en la construcción de una <nueva> democracia europea”; Revista Vasca de Administración Pública, No 53 (II), 1999, pp. 59-69.

MENSKI, W. "Family migration and the new Inmigration Rules"; en Tolley's Inmigration and Nationality Law and Practice, Vol. 8, No 4, 1994, pp. 110-122.

MERRILLS, J.G. The Development of International Law by the European Court of Human Rights. Manchester, Manchester University Press, 1988.

MESSINA, Anthony M. “The not so Silent Revolution: PostWar Migration to Western Europe”; en World Politics, Vol. 49, No 1, 1996, pp. 130-154.

MiElle BULTERMAN. "Case C-540/03, Parliament v. Council, Judgment of the Grand Chambert of 27 June 2006 , [2006] ECR I-5769”; en Common Market Law Review, Vol. 45, № 1, 2008, pp. 245-259.

MILLER, Mark J. "Opportunities and Challenges for Migrant and Migrant-Background Youth in Developed Countries”. Short version Report submitted to United Nations Social and Economic Council, 15 July, 2006. Disponible en: http:// www.udel.edu/readhistory/resources/2005_2006/summer_06/short.pdf

MIQUEL CALATAYUD, José Antonio. “Consideraciones referentes a la sentencia del Tribunal Constitucional acerca de determinados preceptos de la Ley Orgánica sobre los derechos y libertades de los extranjeros en España”; La Ley: Revista jurídica española de doctrina, jurisprudencia y bibliografía, № 1, 1990, pp. 975-999.

- "Análisis de la posición constitucional del extranjero en España"; BORRÁS, Alegría (dir.). Diez años de la Ley de extranjería: Balance y perspectivas. Barcelona, Fundación Paulino Torras Domènech, 1995, pp. 49-81.

- "Caracterización del ordenamiento español de extranjería"; Libro homenaje a Jesús López Medel, Vol. 1. Madrid, Centro de Estudios Registrales, 1999, pp. 347-405.

MIRAUT MARTíN, Laura (ed.). Justicia, Migración y Derecho. Madrid, Dykinson S.L., 2004.

MOLINER NAVARRO, Rosa María. “Reagrupación familiar y modelo de familia en la Ley Orgánica 8/2000 de Derechos y libertades de los extranjeros en España”, en Actualidad Civil, No 14/2001, Vol.2, pp. 487-519.

— "El concepto de <familia nuclear> en la Directiva europea 2003786/CE sobre reagrupación familiar"; en ABRIL CAMPOY, Juan Manuel y AMAT LLARI, Ma Eulalia (coords.). Homenaje al Profesor Lluis Puig I Ferriol, Vol. II. Valencia, Tirant lo Blanch, 2006, pp. 1789- 1807.

MONEREO ATIENZA, Cristina. "Derecho a la reagrupación familiar de los hijos menores de países terceros. Sentencia del Tribunal de Justicia (Gran Sala) de 27 de junio de 2006 (TJCE 2006, 177). Parlamento Europeo/ Consejo de la Unión Europea”; en Aranzadi social, No 6, 2007.

- y TRIGUERO MARTÍNEZ, Luis Angel. "Repensar los derechos sociales fundamentales de los extranjeros. A propósito de las sentencias del Tribunal Constitucional 236/2007, de 7 de noviembre y 259/2007 de 19 de diciembre (I); Relaciones laborales, No 6, 2008, pp. 15-49.

- y TRIGUERO MARTÍNEZ, Luis Angel. "Repensar los derechos sociales fundamentales de los extranjeros. A propósito de las sentencias del Tribunal Constitucional 236/2007, de 7 de noviembre y 259/2007 de 19 de diciembre (II); Relaciones laborales, No 1, 2008, pp. 365-387.

MONTES DEL CASTILLO, Ángel. "La integración de los inmigrantes en los proyectos de desarrollo. Algunas condiciones para que funcione el codesarrollo”; en MARTÍNEZ MARTÍNEZ, M. M. Y MONTES DEL CASTILLO, A (coords.) Migraciones, cultura y desarrollo. Murcia, Universidad de Murcia, 2008, pp. 205-216.

MORANO-FOADI, S. Y STELIOS, A. The convergence of the European Legal System in the treatment of Third Country Nationals in Europe: the CJEU and ECtHR jurisprudente. Oxford Brookes University, 2010. http://ssrn.com/ abstract $=1729139$

MORENILLA RODRÍGUEZ, José María. Los sistemas para la Protección Internacional de los derechos humanos. Madrid, Centro de Publicaciones del Ministerio de Justicia, 1986.

MOTOMURA, H. “The Family and Inmigration: A Roadmap for the Ruritanian Lawmaker"; en The American Journal of Comparative Law, Vol. 43, No 4, otoño 1995, pp. 511-544.

MOWBRAY, Alastair. R. The Development of Positive Obligations under the European Convention on Human Rights by the European Court of Human Rights. Hart Publishing, Oxford and Portland, Oregon, 2004. 
MOYA ESCUDERO, Mercedes. "La expulsión de extranjeros del territorio nacional: dudosa garantía de los derechos fundamentales"; La Ley, № 1, 1986, pp. 1025-1042.

- "El derecho a la reagrupación familiar en la Ley de Extranjería"; La Ley, № 1, 2000, pp. 1691-1703.

- "Derecho a la reagrupación familiar (arts. 16, 17, 18 y 19)"; MOYA ESCUDERO, M (coord.). Comentario sistemático a la Ley de Extranjería. Granada, Comares 2001, pp. 673-707.

MUÑOZ AUNIÓN, Antonio. Política migratoria de la Unión Europea. Valencia, Tirant lo blanch, 2008.

MURRAY, J. El derecho de vivir en familia para los inmigrantes en Europa. Un derecho fundamental y un factor clave para la integración. Madrid, 2000.

NÄIR, Sami. "Flujos migratorios y codesarrollo"; en Tiempo de paz, No. 57, 2000, pp. 122-126.

- y GOYTISOLO, Juan. El peaje de la vida. Madrid, Aguilar, 2a ed., 2001, p. 22.

- Y vendrán... las migraciones en tiempos hostiles. Barcelona, Planeta, 2006.

- "Codesarrollo para las migraciones"; en Estudios en homenaje al profesor Gregorio Peces-Barba, Vol. 4. Madrid, Dykinson, 2008, pp. 657-674.

NAUCK, Bernhard y SETTLES, Barbara H. "Immigrant and Ethnic Minority Families: An Introduction"; en Journal of Comparative Family Studies, Vol. 32, № 4, 2001, pp. 461-464.

NIVALAINEN, Satu. "Determinants of Family Migration: Short Moves versus Long Moves"; en Journal of Population Economics, № 17, 2004, pp. 157-175.

OELLERS-FRAHM, Karin. "The Contribution of the Council of Europe of the Legal Position of Aliens"; FROWEIN, J y STEIN, T. (Eds.). Die Rechtstellung von Ausländern nach Staatlichem Recht und Völkerrecht. Springer-Verlag, Berlin, 1987, pp. 1724-1773.

ONG HING, Bill. Deporting Our Souls. Values, Morality and Immigration Policy. Cambridge University Press, New York, 2006.

OOSTEROM-STAPLES, Helen. "The Family Reunification Directive: A Tool Preserving Member State Interest or Conducive to Family Unity?"; en BALDACINI, Anneliese, GUILD, Elspeth and TONER, Helen (eds.). Whose Freedom, Security and Justice?. EU Immigration and Asylum Law and Policy. Oxford and Portland, Oregon, Hart Publishing, 2007, pp. 451-488.

OPROMOLLA, Adriana. "Children's rights under Articles 3 and 8 of the European Convention: Recent case law"; en European Law Review, № 3, 2001, pp. 42-57.

ORDÓÑEZ SOLÍS, David. El estatuto administrativo de los extranjeros en clave judicial. Madrid, editorial Reus, 2008.

ORTEGA CARBALLO, Carlos. "Los derechos fundamentales de los extranjeros en la jurisprudencia del Tribunal Constitucional"; Justicia Administrativa, №. 37, 2007, pp. 5-28.

ORTEGA CARBALLO, Carlos. "Los derechos fundamentales de los extranjeros después de la Sentencia del Tribunal Constitucional 236/2007, de 7 de noviembre"; Justicia administrativa, № 40, 2008, pp. 5-30.

ORTEGA MARTÍN, Eduardo (dir.). Hacia un derecho unitario europeo en materia de extranjería. Madrid, Consejo General del Poder Judicial, Estudios de Derecho Judicial 81, 2006.

ORTEGA MARTÍN, Eduardo. Manual Práctico de Derecho de Extranjería. Madrid, Europea de Derecho D.L., $3^{\text {a }}$ ed., 2005.

ORTIZ-ARCE DE LA FUENTE, Antonio. "La extranjería no comunitaria en el marco de la Comunidad Económica Europea. Hacia la configuración de una política migratoria comunitaria y el reforzamiento de los controles exteriores"; en Revista del Centro de Estudios Constitucionales, № 12, mayo-agosto 1992, pp. 207-231.

- "Los extranjeros no comunitarios ante el derecho comunitario europeo. Las actuaciones de las instituciones comunitarias, de las instancias gubernamentales y de los gobiernos de los Estados comunitarios"; en Derecho de extranjería, asilo y refugio. Ministerio de Asuntos Sociales, Madrid, 1995.

ORÜCU, Esín (ed.). Judicial Comparativism in Human Rights Cases. United Kidgdom Comparative Law Series, volume 22, UKNCCL, London, 2003.

OSPINA SÁNCHEZ, Gloria Inés. "La inmigración que nos cogió desprevenidos: el vaivén de las políticas de extranjería"; UNISCI Discussion Papers, No 15, octubre 2007, pp. 219-233.

PAJARES, Miguel. "Las políticas comunitarias en inmigración y asilo"; en Migraciones No 10, diciembre 2001, pp. 7-58.

PALOMAR OLMEDA, Alberto y HERVÁS BAUTISTA, Marina. Guía de Extranjería. Cizur Menor, Thomson-Aranzadi, $1^{\text {a }}$ ed., 2006.

PALOMAR OLMEDA, Alberto. "Apuntes sobre el desarrollo legal postconstitucional de la regulación de extranjeros en España”; PALOMAR OLMEDA, Alberto (coord.). Tratado de Extranjería: aspectos civiles, penales, administrativos $y$ sociales. Navarra, Thomson-Aranzadi, $3^{a}$ ed., 2007, pp. 105-144.

- "La sentencia del Tribunal Constitucional de 7 de noviembre de 2007: la inconstitucionalidad parcial de la Ley Orgánica de Extranjería”; PALOMAR OLMEDA, Alberto (coord.). Tratado de Extranjería: aspectos civiles, penales, administrativos y sociales. Navarra, Thomson-Aranzadi, $3^{\text {a }}$ ed., 2007, pp. 995-1012. 
PALOS NADAL, Margarita. "La extinción de las tarjetas de familiar de residente comunitario a nacionales de terceros países en virtud de separación de derecho o divorcio. Principales consecuencias jurídicas”; Revista de Derecho Migratorio y Extranjería; № 13, 2006, pp. 199-207.

PALOS NADAL, Margarita. "La reagrupación familiar en el derecho español. Especial consideración de la situación jurídica de los ascendientes de españoles con posterioridad al RD 240/2007"; en BALADO RUIZ-GALLEGOS, Manuel (coord.). Inmigración, Estado y Derecho: perspectivas desde el siglo XXI. Barcelona, Bosch, 2008, pp. 579-604.

PAPADEMETRIOU, Demetrios y HAMILTON, Kimberly A. Converging Paths to Restriction: French, Italian and British Responses to Immigration. Washington DC, Carnegie Endowment for International Peace, 1996.

- International Migration: Global Trends and Issues. Migration Policy Institute, 2008. Disponible en: http://www.acvz. com/publicaties/International\%20Migration_\%20Papademetriou\%20200811.pdf

- y SUMPTION, Madeleine; TERRAZAS, Aaron; BURKERT, Carola; LOYAL, Stephen and FERRERO-TURRIÓN, Ruth. "Migration and Immigrants Two Years after the Financial Collapse: Where Do We Stand?"; Report for the BBC World Service, Migration Policy Institute, 2010.

PAPAGIANNI, Georgia. Institutional and Policy Dynamics of EU Migration Law. Martinus Nijhoff Publishers, Leiden, The Netherlands, 2006.

PARELLA, Sonia. "Los vínculos afectivos y de cuidado en las familias transnacionales. Migrantes ecuatorianos y peruanos en España”; en Migraciones Internacionales, Vol. 4, № 2, julio-diciembre 2007, pp. 151-188.

PARR, Nick; LUCAS, David y MOK, Magdalena. "Branch Migration and the International Dispersal of Families"; en International Journal of Population Geography, No 6, 2000, pp. 213-227.

PARRA ALBERCA, Sandra. “Reagrupación familiar: ¿Derecho de quién?”; en Otrosí.net. Revista online del Ilustre Colegio de Abogados de Madrid. Disponible en: http://www.otrosi.net/index.php?option=com_content\&task=view\&id=502

PARSONS, Craig A. \& SMEEDING, Timothy M (eds.). Immigration and Transformation of Europe. Reino Unido, Cambridge University Press, 2006.

PASCOUAU, Yves; LABAYLE, Henry. Conditions for Family Reunification under Strain. A comparative study in nine EU member states. European Policy Center, European Migration and Diversity Programme, Belgium, November 2001. Disponible en www.kbs-frb-be

PASTOR ANTOLÍN, Luis Jesús (coord.). Globalización y migraciones hoy: Diez años de continuos desafíos. Valladolid, Universidad de Valladolid, 2002.

PECES-BARBA MARTÍNEZ, Gregorio; FERNÁNDEZ LIESA, Carlos R. y LLAMAS CASCÓN, Ángel. Textos básicos de Derechos Humanos (Con estudios generales y especiales y comentarios a cada texto nacional e internacional). Madrid, Aranzadi Editorial, 2001.

- La dignidad de la persona desde la Filosofía del Derecho. Madrid, Dykinson, Cuadernos Bartolomé de las Casas, 2003.

PECES MORATE, Jesús Ernesto. “Garantías jurisdiccionales para los extranjeros. Medidas cautelares en el proceso”; en ÁLVAREZ CIENFUEGOS SUÁREZ, José Ma (dir.). Reflexiones sobre la nueva ley de extranjería. Madrid, Cuadernos de Derecho Judicial, Consejo General del Poder Judicial, 2001, pp. 214-257.

PEDONE, Claudia. Tú siempre jalas a los tuyos. Las cadenas y las redes Migratorias ecuatorianas hacia España. Tesis doctoral dirigida por María Dolores García Ramón. Universitat Autónoma de Barcelona, 2004. http://www. tesisenxarxa.net/TDX-1027104-170605

PEERS, Steve. "Raising Minimum Standars or Racing for the Bottom?. The Commission's Proposed Migration Convention"; GUILD, E. (ed.). The Legal Framework and Social Consequences of Free Movement of Persons in the European Union. Kluwer Law International, Centre of European Law, 1993, pp. 149-167.

- "Towards Equality: Actual and Potential Rights of Third-Country Nationals in the European Union"; en Common Market Law Review, No 33, 1996, pp. 7-50.

- "Building Fortress Europe: The development of EU Migration Law"; en Common Market Law Review, No 35, 1998, pp. 1235- 1272 .

- "Justice and Home Affairs"; en International and Comparative Law Quarterly, Vol. 49, Part. 1, January 2000, pp. 222-227.

- "Legislative Developments on Migration in the European Union"; en European Journal of Migration and Law, No 5, 2003, pp. 387-410.

- "The European Court of Justice and the European Court of Human Rights: Comparative Approaches"; en ÖRUXÜ, Ersin. Judicial Comparativism in Human Rights Cases, The United Kingdom National Committee of Comparative Law, London, 2003, pp. 107-129.

- "EU Immigration and Asylum Law: Internal Market Model or Human Rights Model?"; en TRIDIMAS, T . y NEBBIA, P. (eds.). European Union Law for the Twenty-First Century: Rethinking the New Legal Order, Vol. 1. Oxford, Hart Publishing, 2004, pp. 345-360.

- "Family Reunion and Community Law". WALKER, Neil (ed.). Europe's Area of Freedom, Security and Justice. Oxford, New York, Oxford University Press, Academy of European Law, 2004, pp. 143-197. 
PEERS, Steve. "Implementing equality? The Directive on long-term resident third-country nationals"; en European Law Review, No 4, 2004, pp. 437-460.

- and ROGERS, Nicola. "EU Immigration and Asylum Law. Text and Commentary"; Immigration and Asylum Law and Policy in Europe, volume 12. Martinus Nijhoff Publishers, Leiden, The Netherlands, 2006, pp. 573-598.

- "Key Legislative Developments on Migration in the European Union"; en European Journal of Migration and Law, No 9, 2007, pp. 451-456.

- “The Jurisdiction of the Court of Justice over EC Immigration and Asylum Law: Time for a Change?"; BALDACCINI, Anneliese; GUILD, Elspeth and TONER, Helen. Whose Freedom, Security and Justice?. EU Immigration and Asylum Law and Policy. Hart Publishing, Oxford and Portland, Oregon, 2007, pp. 85-108.

PELÉ, Antonio. "Una aproximación al concepto de dignidad humana”; en Universitas: Revista de filosofía, derecho y política, No 1, 2004-2005, pp. 9-13.

- Filosofía e historia en el fundamento de la dignidad humana. Tesis doctoral dirigida por Francisco Javier Ansuátegui Roig. Madrid, Universidad Carlos III de Madrid, 2006.

PERALTA CARRASCO, Manuel. "El Reglamento de la Ley de Extranjería. Breves notas sobre su contenido y aplicación práctica”; en PERALTA CARRASCO, Manuel (dir.). I Jornadas sobre la Ley de Extranjería e Inmigración. Cáceres, 26 a 29 de marzo de 2001. Facultad de Derecho. Cáceres, Universidad de Extremadura, 2003, pp. 53-63.

PÉREZ DE LOS COBOS ORIHUEL, Francisco. "Las políticas de inmigración"; en Tribunal Social: Revista de seguridad social y laboral, No 133, 2002, pp. 9-18.

PÉREZ GÓMEZ, Manuel “La inmigración tras el Tratado de Amsterdam”; en El espacio Europeo de Libertad, Seguridad y Justicia. Madrid, Ministerio del Interior, Secretaría General Técnica, D.L. 2000, pp. 97-102.

- "Spain"; en HIGGINS, Imelda (ed.). Migration and Asylum Law and Policy in the European Union. FIDE 2004 National Reports. United Kingdom, Crambridge Universtiy Press, 2004, pp. 371-381.

PÉREZ INFANTE, José Ignacio. "El marco legal y la problemática del empleo de los extranjeros en España: una perspectiva económica”; GARCÍA ROCA, Joaquín y LACOMBA, Joan (eds.). La inmigración en la sociedad española. Una radiografía multidisciplinar. Barcelona, ediciones Bellaterra, 2008, pp. 113-156.

PÉREZ MARTÍN, Elena. "El derecho al respeto de la vida familiar y la reagrupación familiar de los hijos menores de extranjeros en la Unión Europea”; en Revista General de Derecho Público Comparado, № 1, 2007.

PÉREZ MILLA, José Javier. "Configuración normativa y jurisprudencial de un derecho de reagrupación de la familia”; en Revista Aragonesa de Administración Pública, 1999, No 14, pp. 419-438.

PÉREZ SOLA, Nicolás. "La reciente jurisprudencia constitucional en materia de extranjería: comentario a las sentencias del Tribunal Constitucional relativas a la inconstitucionalidad de la Ley Orgánica 8/2000"; Revista de Derecho Migratorio y Extranjería, No. 17, 2008, pp. 33-57.

PÉREZ TORTOLA, A. "La reagrupación familiar desde la perspectiva de la jurisdicción contencioso-administrativa"; en Regularización de trabajadores extranjeros y reagrupación familiar de inmigrantes extranjeros en España. Barcelona, ed. Fundación Paulino Torres, 1994.

PÉREZ VILLALOBOS, Ma Concepción. "Nuevos desarrollos en materia de derechos fundamentales en los ordenamientos europeos: la situación jurídica del extranjero"; en Revista de la Facultad de Derecho de la Universidad de Granada, No 5, 2002, pp. 229-255.

PÉREZ-MADRID, Francisca. Inmigración y libertad religiosa. Un estudio desde la Ley de Extranjería. Madrid, Civitas, 2004.

PERRUCHOUD, Richard; JENNY, R.K. y GOODWIN-GILL, Guy S. “Basic Humanitarian Principles Applicable to Non-Nationals"; en International Migration Review, Vol. 19, № 3, 1985, pp. 556-569.

- "Family Reunification"; en International Migration, № 27, Vol. 4, 1989, pp. 509-524.

- “Normas legales para la protección de los trabajadores migrantes”. Organización Internacional para las Migraciones, Notas de población. CELADE, Santiago, Chile, Año XXVIII, No 73, sept. 2001, pp. 273-303. Disponible en la dirección: http://www.eclac.org/publicaciones/xml/2/8852/lcg2124P_9.pdf

PICÓ LORENZO, Celsa. "Desencuentros entre la legislación de extranjería y la jurisprudencia. Experiencias en la aplicación del ordenamiento de inmigración. Diferente tratamiento del fenómeno migratorio por los jueces y tribunales: entre el acierto y la oportunidad"; PECES MORATE, Jesús Ernesto (dir.). Estudios de derecho judicial, No 41, 2002, pp. 231-294

- “Nuestra errática normativa sobre extranjería. Especial referencia a las regularizaciones y al arraigo"; Jueces para la Democracia, No 43, 2002, pp. 62-71.

PILLITU, P. A. "La tutela della famiglia naturale nella Convenzione europea dei diritti dell'uomo"; en Rivista di Diritto Internazionale, 1989, Vol. 72, No 4, pp. 793 y ss.

PISAPIA, Alice. "Una sentenza additiva in punto di attuazione della Direttiva sul ricongiungimento familiare"; en Giustizia civile, 2007, Vol. I, pp. 543-546.

PLENDER, Richard. International Migration Law. Martinus Nijhoff Publishers revised second Edition, Dordrecht, London, 1988. 
PRADA SOLAESA, Jorge Ricardo de. "La jurisprudencia de los órganos del Convenio Europeo de Derechos Humanos en relación a los extranjeros"; PICÓ LORENZO, Celsa (dir.). Extranjeros. Madrid, Consejo General del Poder Judicial, 1995, pp. 463-503.

PRADA, Miguel Ángel de. "Flujos migratorios internacionales hacia España. Especificidad en la región de Murcia"; HERNÁNDEZ PEDREÑO, Manuel y PEDREÑO CÁNOVAS, Andrés. La condición inmigrante: exploraciones e investigaciones desde la región de Murcia. Murcia, Universidad de Murcia, 2005, pp. 61-74.

PRECHAL, S. Directives in European Community Law. A Study of Directives and Their Enforcement in National Courts. Clarendon Press, Oxford, $2^{\text {a }}$ edición, 2005.

PUENTE EGIDO, José. "El fenómeno migratorio desde una perspectiva histórica y de Derecho internacional"; Intervención en el Seminario Leyes españoles y derechos humanos de los inmigrantes. Instituto Fe y Secularidad, 1996. Memoria académica 1995-1996.

- "El impacto del derecho comunitario europeo en la Constitución Española”; en ZLATA DRNAS DE CLÉMENT (coord.). Estudios de derecho internacional en homenaje al profesor Ernesto J. Rey Caro, Vol. 2, 2002, pp. 1641-1665.

QUERALT JIMÉNEZ, Argelia. "Los usos del canon Europeo en la jurisprudencia del Tribunal Constitucional: Una muestra del proceso de armonización europea en materia de derechos fundamentales"; en Teoría y Realidad Constitucional, No 20, 2007, pp. 435-470.

QUIRÓS FONS, Antonio. “Derecho comunitario de extranjería: Directiva 2003/86/CE sobre reagrupación familiar y reforma del derecho interno español”; en Anales de Derecho, № 21, Universidad de Murcia, 2003, pp. 383-415.

- "El artículo 8 del Convenio de Roma y la Directiva 2003/86/CE sobre el derecho a la reagrupación familiar: Una conquista del Derecho Internacional en el Derecho comunitario"; en Revista Española de Derecho Internacional, Vol. 55, No 2, 2003, pp. 1074-1078.

- "Derecho a la reagrupación familiar"; SÁNCHEZ JIMÉNEZ, Ma A. Derecho de extranjería. Un análisis legal y jurisprudencial del regimen jurídico del extranjero en España (jurisprudencia y formularios). Murcia, Diego Marín Librero editor, 2005, pp. 199-226.

RAMOS QUINTANA, Margarita Isabel. "Extranjeros en situación irregular en España: derechos atribuidos, limitaciones a la libertad y medidas de carácter sancionador: la jurisprudencia reciente del Tribunal Constitucional”; Revista de Derecho Migratorio y Extranjería, No 19, pp. 47-80.

- "Normativa applicable a miembros de la familia de ciudadano español que no tengan la nacionalidad de un EM de la UE o de un Estado parte en el Acuerdo sobre el Espacio Económico Europeo"; RAMOS QUINTANA, Margarita I. (dir.) y ROJAS RIVERO, Gloria P. (coord.). Comentarios al Reglamento de Extranjería. Valladolid, Lex Nova, 2007, $1^{\text {a }}$ ed., pp. 1017-1020

- "Facilitación de la entrada y residencia de los familiares de ciudadano de un EM de la UE o de otro Estado parte en el Acuerdo sobre el Espacio Económico Europeo, no incluidos en el ámbito de aplicación del Real Decreto 240/2007, de 16 de febrero, sobre entrada, libre circulación y residencia en España de ciudadanos de los Estados miembros de la UE y de otros Estados parte en el Acuerdo sobre el Espacio Económico Europeo"; RAMOS QUINTANA, Margarita I. (dir.) y ROJAS RIVERO, Gloria P. (coord.). Comentarios al Reglamento de Extranjería. Valladolid, Lex Nova, 2007, $1^{\text {a }}$ ed., pp. 1011-1015.

- "Una política de inmigración para un modelo de inmigración: la integración a través del empleo"; RAMOS QUINTANA, Margarita I. (dir.) y ROJAS RIVERO, Gloria P. (coord.). Comentarios al Reglamento de Extranjería. Valladolid, Lex Nova, 2007, $1^{\text {a }}$ ed., pp. 21-34.

RAVETLLAT BALLESTÉ, Isaac. La reagrupación familiar. Barcelona, Bosch, 2008.

RECIO, Eugenio. "Origen, significado y resultados de los flujos migratorios masivos por motivos económicos en el mundo actual”; Migraciones económicas masivas y derechos del hombre. J.M. Bosch editor, 2002, pp. 19-42.

REA, Andrea. "La europeización de la política migratoria y la transformación de la otredad”; en Revista Española de Investigaciones Sociológicas, № 116, 2006, pp. 157-184

RELAÑO PASTOR, Eugenia. “¿Sancionar al inmigrante o proteger las fronteras?. Un análisis crítico de la Ley de Extranjería 14/2003 de 20 de noviembre, y la política de inmigración común de la Unión Europea”; en La Ley, № 3, 2004, pp. 1678-1690.

- "Los continuos cambios de la política de inmigración en España”; en Migraciones Internacionales, Vol. 2, No 3, 2004 , pp. 110-141.

REVENGA SÁNCHEZ, Miguel. Seguridad Nacional y Derechos Humanos. Estudios sobre la jurisprudencia del Tribunal de Estrasburgo. Navarra, Aranzadi, 2002.

REY MARTÍNEZ, Fernando. "El criterio interpretativo de los derechos fundamentales conforme a normas internacionales (análisis del artículo 10.2 CE)”; en Revista General de Derecho No 537, 1989, pp. 3611-3632.

- “Análisis de la sentencia 236/2007 del Tribunal Constitucional sobre derechos de los extranjeros”; Boletín económico de Castilla y León, №. 13, 2008, pp. 29-31. 
RIDAURA MARTÍNEZ, Ma Josefa. "El respeto de la vida privada y familiar en la Constitución Europea”; en CARRILLO, Marc y LÓPEZ BOFILL, Hector. La Constitución Europea: actas del III Congreso Nacional de Constitucionalistas de España, Madrid, 2006, pp. 495-510.

RIPOL CARULLA, Santiago. "El 'Nuevo Orden Internacional': ¿Un nuevo concepto para un nuevo contexto?”; en Revista CIDOB de Afers Internacionals, № 27, 1995, pp. 59-76.

- El sistema europeo de protección de los derechos humanos y el Derecho español. La incidencia de las sentencias del Tribunal Europeo de Derechos Humanos en el ordenamiento jurídico Español. Barcelona, Atelier libros jurídicos, 2007.

RIVAS NIETO, Pedro. "La nueva política y la identidad colectiva en la gestación de los conflictos. Algunas claves para entender el fenómeno migratorio a principios del siglo XXI”; en PENA GONZÁLEZ, Miguel Anxo y GALINDO GARCÍA, Ángel (eds.). Inmigración y estructuras sociales. Salamanca, Publicaciones Universidad Pontificia de Salamanca, 2006, pp. 267-281.

ROAGNA, Yvana. Protecting the Right to respect for Private and Family LIfe under the European Court of Human Rights. Strasbourg, Council of Europe Human Rights Handbooks, 2012.

ROBINSON, Kathryn. "Marriage Migration, Gender Transformations and Family Values in the 'Global Ecumene"; en Gender, Place and Culture, Vol. 14, No 4, 2007, pp. 483-497.

RODRÍGUEZ BENOT, Andrés y YBARRA BORES, Alfonso. "Las claves de la reforma de extranjería”; La Toga, No 125, marzo 2001, pp. 31-33.

RODRÍGUEZ IGLESIAS, Gil Carlos y VALLE GÁLVEZ, Alejandro. "El derecho comunitario y las relaciones entre el TJCE, el TEDH y los Tribunales Constitucionales Nacionales"; en Revista de Derecho Comunitario 2/47, pág. 366.

RODRÍGUEZ RUIZ, Blanca. "El coste de los derechos fundamentales. Un comentario de la STC 49/1999, de 5 de abril”; en Teoría y Realidad Constitucional, No 3, primer semestre 1999, pp. 315-340.

RODRÍGUEZ, Ángel. "El carácter supranacional en España de la Convención Europea de Derechos Humanos"; La democracia constitucional: Estudios en homenaje al profesor Francisco Rubio Llorente. Madrid, Congreso de los Diputados, Vol. 1, 2002, pp. 305-316.

ROGERS, Nicola. "Immigration and the European Convention on Human Rights: Are New Principles Emerging?"; en European Human Rights Law Review, No 1, 2003, pp. 53-64.

- and SCANNELL, Rick. Free Movement of Persons in the Enlarged European Unión. London, Thomson, Sweet and Maxwell, 2005.

ROIG MOLÉS, Eduardo. "Los derechos de los extranjeros: titularidad y limitación”; REVENGA SÁNCHEZ, Miguel. Problemas constitucionales de la inmigración: una visión desde Italia y España. II jornadas Italo-españolas de Justicia Constitucional. Valencia, Tirant lo blanch, 2005, pp.587-631.

ROLDÁN BARBERO, J. "La Unión Euroepea y los nacionales de terceros Estados: la posible política de inmigración comunitaria"; en OLESTI RAYO, Andreu (coord.). Las incertidumbres de la Unión Europea después del Tratado de Ámsterdam. Barcelona, Bosch, 2000, pp. 237-270.

ROSELL FERRER, Jordi. Todo sobre derechos y deberes de los emigrantes en la Comunidad Económica Europea. Barcelona, editorial De Vecchi, 1987.

RUGGIERO, Roberto. Instituciones de Derecho Civil, traducción de la $4^{\text {a }}$ ed. italiana anotada y concordada con la legislación española por Ramón Serrano Suñer y José Santa-Cruz Tejeiro, 4 a ed. Madrid, Instituto Editorial Reus, D.L. 1977-1979. Tomo II, Vol. II.

RUIZ BAUDRIHAYE, J. “La reagrupación familiar en España y en la Unión Europea”; en Regularización de trabajadores extranjeros y reagrupación familiar de inmigrantes extranjeros en España. Barcelona, ed. Fundación Paulino Torres, 1994.

RUIZ CASTILLO, María del Mar. "Marco legal de la inmigración en la Unión Europea”; en Revista de Derecho Social, No 21, 2003, pp. 29- 48.

RUIZ DE HUIDOBRO DE CARLOS, José María. “Evolución de la legislación española de extranjería e inmigración”; en RUIZ DE HUIDOBRO, J. Ma. (ed.). Regulación legal de la extranjería e inmigración en España. Madrid, Universidad Pontificia de Comillas, 2006, pp. 22-50.

RUIZ LEGAZPI, Ana. El arraigo familiar en España. Publicación web, disponible en http://www.pcb.ub.es/idp/cat/2_ recerca/immig/pdf/tj_ruiz.pdf

RUIZ LÓPEZ, Blanca y RUIZ VIEYTEZ, Eduardo J. Las politicas de inmigración: la legitimación de la exclusión. Bilbao, Universidad de Deusto, 2001.

RUIZ MIGUEL, Carlos. El derecho a la protección de la vida privada en la jurisprudencia del Tribunal Europeo de Derechos Humanos. Madrid, Cuadernos Cívitas, 1ª ed. 1994.

- "La naturaleza jurídica multidimensional de los derechos fundamentales"; en APARICIO PÉREZ, Miguel Ángel (coord.). Derechos constitucionales y pluralidad de ordenamientos. Barcelona, Cedecs editorial, 2001, pp. 165-177. 
RUSSO, Carlo; QUAINI, Paolo M. La Convenzione Europea dei Diritti dell'Uomo e la Giurisprudenza della Corte di Strasburgo. Milano, Giuffrè Editore, seconda edizione, 2006.

SAGARRA TRÍAS, Eduard. "Los derechos políticos y públicos de los extranjeros en la Ley Orgánica 8/2000 de 22 de diciembre de 2000"; en ÁLVAREZ CIENFUEGOS SUÁREZ, José $\mathrm{M}^{\mathrm{a}}$ (dir.). Reflexiones sobre la nueva ley de extranjería. Madrid, Cuadernos de Derecho Judicial, Consejo General del Poder Judicial, 2001, pp. 39- 67.

- Artículo 13 de la Declaración Universal de los Derechos Humanos. Asociación para las Naciones Unidas en España. Barcelona, Icaria, Antrazyt, 1998.

SAIZ ARNAIZ, Alejandro. La apertura constitucional al derecho internacional y europeo de los derechos humanos: el artículo 10.2 de la Constitución Española. Madrid, Consejo General del Poder Judicial, 1999.

- "El Tribunal de Justicia de las Comunidades Europeas como Tribunal Constitucional"; en MORODO, Raúl y DE VEGA, Pedro. Estudios de Teoría del Estado y de Derecho Constitucional en honor de Pablo Lucas Verdú. Instituto de Investigaciones Jurídicas de la UNAM y Facultad de Derecho de la Universidad Complutense. Madrid, 2000. Tomo IV, pp. $2425-2460$.

- "La Carta de los Derechos Fundamentales de la Unión Europea: entre el Derecho Comunitario y el Derecho Internacional de los Derechos Humanos"; en Azpilcueta Cuadernos de Derecho, № 17, 2002, pp. 41-47.

SALAZAR PEÑAS, Rachel. Children of Global Migration. Transnational Families and Gendered Woes. Stanford University Press, 2005.

SALES i JARDÍ, Mercè. "La protección de la vida familiar de los inmigrantes en el Ordenamiento Comunitario: el derecho a la reagrupación familiar". Madrid, European Community Studies Association, Documento Wp 0801-Derecho, 2010. Disponible en http://www.ucm.es/info/audesco/dt.htm

SALZBERG, Marc. "The Marckx Case. "The Impact on European Jurisprudence of the European Court of Human Rights' 1979 Marckx Decision Declaring Belgian Illegitimacy Statutes Violative of the European Convention on Human Rights"; en Denver Journal of International Law and Policy, 1984, Vol. 13, pp. 283-299.

SAMERS, Michael. "<Globalization>, the Geopolitical Economy of Migration and the <Spatial Vent>"; en Review of International Political Economy, Vol. 6, № 2, 1999, pp. 166-199.

SÁNCHEZ JIMÉNEZ, Ma Ángeles (coord.). Derecho de extranjería. Un análisis legal y jurisprudencial del régimen jurídico del extranjero en España (jurisprudencia y formularios). Murcia, Diego Marín librero editor, 2005.

SÁNCHEZ LEGIDO, Ángel. La reforma del mecanismo de protección del Convenio Europeo de Derechos Humanos. Madrid, Editorial Colex 1995.

SÁNCHEZ-RODAS NAVARRO, Cristina. "Cuestiones atinentes al derecho a la reagrupación familiar de los extranjeros de terceros países en España como instrumento para su inserción socio-laboral”; Revista del Ministerio de Trabajo e Inmigración, № 63, diciembre de 2006, pp. 297-314.

SANTAMARÍA IBEAS, José Javier. "Los derechos fundamentales y el Tribunal Constitucional: los infra-derechos de los extranjeros en España. Reflexiones sobre la jurisprudencia constitucional”; Derechos y Libertades, Revista del Instituto Bartolomé de las Casas, año № 1, № 2, 1993-1994, pp. 731-750.

SANTOLAYA MACHETTI, Pablo. El derecho a la vida familiar de los extranjeros. Valencia, Tirant lo Blanch, 2004.

- y DÍAZ GREGO, María. El sufragio de los extranjeros. Un estudio de Derecho comparado. Madrid, Centro de Estudios Políticos y Constitucionales, 2008.

- "La gestión de la inmigración en la VIII legislatura (2004-2008)"; en Revista del Ministerio de Trabajo e Inmigración, No 80, 2009, pp. 81-95.

SANTOS ARNAU, Lidia. "Conceptos jurídicos indeterminados y discrecionalidad: especial referencia al visado para la reagrupación familiar”; PICÓ LORENZO, Celsa (dir.). Extranjeros. Madrid, Consejo General del Poder Judicial, 1995, pp. 439-462.

SANZ CABALLERO, Susana. "El Tribunal Europeo de Derechos Humanos y las uniones de hecho"; en Repertorio Aranzadi del Tribunal Constitucional, № 2, 2003, pp. 2481-2498.

- "Interferencias entre el Derecho Comunitario y el Convenio Europeo de Derechos Humanos (Luxemburgo versus Estrasburgo); ¿Quién es la última instancia de los derechos fundamentales en Europa?”; en Revista de Derecho Comunitario Europeo, año № 8, № 17, 2004, pp. 117-160.

- La familia en perspectiva internacional y europea. Valencia, Tirant lo Blanch, 2006.

SARMIENTO, Daniel; MIERES MIERES, Luis Javier; PRESNO LINERA, Miguel. Las sentencias básicas del Tribunal Europeo de Derechos Humanos. Estudio y jurisprudencia. Pamplona, Editorial Aranzadi, Thomson Civitas, 2007, $1^{\text {a }}$ ed.

SARTORI, Giovanni. La sociedad multiétnica. Pluralismo, multiculturalismo y extranjeros. Madrid, Taurus, 2001.

SASSEN, Saskia. Losing Control? Sovereignty in an Age of Globalization. New York, Columbia University Press, 1996.

- "Beyond Sovereignty: De-Facto Transnationalism in Inmigration Policy; en European Journal of Migration and Law, No 1, 1999, pp. 177-198.

- “Globalization or Denationalization?"; en Review of International Political Economy, Vol. 10, № 1, 2003, pp. 1-22. 
SASSEN, Saskia. "La formación de las migraciones internacionales: implicaciones políticas”; en Revista internacional de filosofía política, No 27, 2006, pp. 19-39.

SCHAFFRIN, Dora. "Which Standard for Family Reunification of Third-Country Nationals in the European Unión?"; CARLIER, Jean-Yves and BRUYEKER, Philippe de. Immigration and Asylum Law of the EU: Current Debates. Academic Network for Legal Studies on Immigration and Asylum in Europe, Bruxelles, Bruylant, 2005, pp. 91-143.

SCHERMERS, Henry G. "Human Rights of Aliens in Europe"; en N.H. NEUWAHL y A. ROSAS (eds.). The European Union and Human Rights, Kluwer Law International, Netherlands, 1995, pp. 119-131.

SCHIBEL, Yongmi. Monitoring and influencing the transposition of EU immigration law. The family reunion and long term residents Directives. Grupo de Política de Inmigración (MPG). Issue Paper prepared for the European Migration Dialogue, september 2004. Disponible en: www.migrant.at/EMD-issue-paper\%201.pdf

- Los derechos de movilidad en Europa. Grupo de Política de Inmigración (MPG), Bruselas, enero de 2006. Disponible en: http://www.ciudad-derechos.org/espanol/pdf/eeg.pdf

SCHNEIDER, H. y WIESBROCK, A. "The Council Directive on Family Reunification: Establishing Proper Rights for Third Country Nationals?"; en SCHNEIDER, H. (ed.). Migration, Integration and Citizenship. A challenge for Europe's Future. Vol II. Forum Maastricht, Maastricht, 2005, pp. 35-69.

SCHUTTER, Olivier de. Report of the Situation of Fundamental Rights in the European Union in 2003. EU Network of Independent Experts of Fundamental Rigthts (CFR-CDF). January 2004. http://ec.europa.eu/justice_home/cfr_ cdf/doc/report_eu_2003_en.pdf

SCOTT, Sam and CARTLEDGE, Kim H. "Migrant Assimilation in Europe: A Transnational Family Affair”; International Migration Review, Vol. 43, No 1, 2009, pp. 60-89.

SERRANO GARCÍA, J.M. y MENDOZA NAVAS, N. (cords.). Estudios sobre extranjería. Valencia, Tirant lo Blanch, 2005.

SILVA, Manuel. "Las grandes líneas de la evolución legislativa española sobre la inmigración a la luz de los derechos del hombre"; Migraciones económicas masivas y derechos del hombre. J.M. Bosch editor, 2002, pp. 189-210.

SNYDER, Francis. "Three Challenges for European Constitutionalism in the twenty-first Century;" en TRIDIMAS, Takis \& NEBBIA, Paolisa. European Union Law for the Twenty-First Century. Rethinking the New Legal Order, volume 1. Oxford and Portland Oregon, Hart Publishing, 2004, pp. 9-15.

SOLANA CORELLA, Ángeles. "Perspectiva jurídica sobre el régimen de reagrupación familiar”; CABEZA PEREIRO, Jaime y MENDOZA NAVAS, Natividad (coords.). Tratamiento jurídico de la inmigración. Bomarzo, 2008, pp. 217 252.

SOLÉ, Carlota, PARELLA, Sonia y CALVANCANTI, Leonardo (coords.). Nuevos retos del transnacionalismo en el estudio de las migraciones. Madrid, Ministerio de Trabajo e Inmigración, 2008.

SOLÓZABAL ECHAVARRÍA, J. J. "Algunas cuestiones básicas de la teoría de los derechos fundamentales"; en Revista de Estudios Políticos, No 71, 1991, pp. 87-110.

- "Dignidad de la persona"; en ARAGÓN REYES, Manuel (coord.). Temas básicos de derecho constitucional. Tomo III, Tribunal Constitucional y derechos fundamentales. Madrid, Civitas, 2001, pp. 113-116.

SOPEMI. "Comparative analysis of the legislation and the procedures governing the immigration of family members in certain OECD countries”; en Trends in International Migration, 2000, pp. 26-105.

SOREL, Alexander. "Asylum, Migration and Border Controls in the Hague Programme"; ZWAAN, Jaap W.; GOUDAPPEL, Flora A.N.J (eds.). Freedom, Security and Justice in the European Unión. Implementation of the Hague Programme. The Hague, TMC Asser Press, 2006, pp. 11-16.

SORIANO DÍAZ, Ramón; ALARCÓN CABRERA, Carlos y MORA MOLINA, Juan (directores y coordinadores). Diccionario crítico de los derechos humanos. La Rábida, Universidad Internacional de Andalucía, 1ª ed., 2000.

SOTO GARCÍA, Mercedes. "La elaboración del estatuto constitucional de los extranjeros por la jurisprudencia constitucional: el ejemplo del Consejo Constitucional francés”; REVENGA SÁNCHEZ, Miguel (coord.). Problemas constitucionales de la inmigración: una vision desde Italia y España. II Jornadas Italo-españolas de Justicia Constitucional, El Puerto de Santa María, 3-4 de octubre de 2003. Valencia, Tirant lo Blanch, 2004, pp. 633-646.

SOYSAL, Jasmin. Limits of Citizenship. Migrants and Postnational Membership in Europe. Chicago, University of Chicago Press, 1994.

STALFORD, Helen. "Concepts of Family under EU Law. Lessons from the ECHR”; en International Journal of Law, Policy and the Family, Vol. 16, 2002, pp. 410-434.

- "Regulating Family Life in post-Amsterdam Europe"; en European Law Review, № 28, 2003, pp. 39-52.

STAPLES, Helen. The Legal Status of Third Country Nationals Resident in the European Unión. The Hague, Kluwer Law International, 1999.

STARR, S. and BRILMAYER, L. "Family Separation as a Violation of International Law"; en Berkeley Journal of International Law, No 21, 2003. pp. 213 - 287.

STEIN, Eduardo. "Evolución de la protección jurídica de los trabajadores migratorios en el derecho internacional”; en O.I.T. Cuadernos de Trabajo sobre Migración No 4, 2001. 
STOLCKE, Verena. "Qué entendemos por integración social de los inmigrantes"; CHECA, Francisco; CHECA, Juan Carlos y ARJONA, Ángeles (eds.). Inmigración y derechos humanos. La integración como participación social. Barcelona, Icaria, 2004, pp. 17-46.

STOREY, Hugo: “The Right to Family Life and Immigration Case law at Strasbourg”; en International and comparative law quarterly, Vol. 39, 1990, pp. 328-344.

SUÁREZ-OROZCO, Carolo y SUÁREZ-OROZCO, Marcelo M. La infancia de la inmigración. Madrid, Morata, 2003.

SVEN REHER, David y REQUENA, Miguel (eds.). Las múltiples caras de la inmigración en España. Madrid, Alianza Editorial, 2009.

SWINDELLS, Heather. "The European Convention on Human Rights and its Impact on Family"; en Speakers Presentations to the 2001 World Congress on Family Law and the Rights of Children and Youth. Disponible en www. lawrights.asn.au/docs/swindells2001.pdf

SZABO, Imre. "Historical Foundations of Human Rights and Subsequent Developments"; VASAK, Karel (ed.). The International Dimension of Human Rights, Vol. I. Paris, Westport, Greenwood Press, 1982.

TAJADURA TEJADA, Javier. "Constitución y extranjería: Los derechos de los extranjeros no comunitarios en España”; en Revista de Derecho Migratorio y Extranjería, № 7, 2004, pp. 9-52.

TEITELBAUM, Michael S. "Skeptical Noises about the Immigration Multiplier"; en International Migration Review, Vol. XXIII, No 4, 1989, pp. 893-899.

TÉLLEZ, Juán José. Moros en la costa. Madrid, Debate, 2001.

TERRÓN i CUSÍ, Anna. "El debate sobre la inmigración en la Unión Europea”; en Revista CIDOB de Afers Internacionals, No 53, pp. 13-30.

- "Inmigración e integración en la Unión Europea"; en FERNÁNDEZ SOLA, Natividad y CALVO GARCÍA, Manuel (coords). Inmigración y derechos. Zaragoza, Mira editores, 2001, pp. 147-154.

THOMASSEN, Henrik. “The Danish Rules on Family Reunification”; CARLIER, Jean-Yves and BRUYEKER, Philippe de. Immigration and Asylum Law of the EU: Current Debates. Academic Network for Legal Studies on Immigration and Asylum in Europe, Bruxelles, Bruylant, 2005, pp. 519-529.

THYM, Daniel. "Respect for Private and Family Life under Article 8 ECHR in Immigration Cases: A Human Right to Regularize Illegal Stay?”; International and Comparative Law Quarterly, Vol. 57, 2008, pp. 87-112.

- Respect for Private and Family Life- The European Perspective. University of Konstanz, TEAM Workshop, 2011. Disponible en http://migration.unikonstanz.de/index.php?eID=tx_nawsecuredl\&u=0\&file=fileadmin/jura/ jurafzausl/Veranstaltunge_Vortraege_Download/Family_Reunification/Thym.pdf

TIBURCIO, Carmen. The Human Rights of Aliens under International and Comparative Law. The Hague, Martinus Nijhoff Publishers, 2001.

TICHENOR, Daniel J. Dividing Lines. The Politics of Immigration Control in América. Princeton University Press, 2002.

TOMUSCHAT, Christian. "The legal status of non-citizens of the EU. General Introduction"; en European Review of Public Law, Vol. 7, No 3, 1995, pp. 543-563.

- Human Rights. Between Idealism and Realism. Oxford, New York, Oxford University Press, Academy of European Law and European University Institute, 2003.

TONER, Helen. "Partnership Rights, Migration and EC Law"; en TRIDIMAS, Takis \& NEBBIA, Paolisa. European Unión Law for the Twenty-First Century. Rethinking the New Legal Order. Vol. 2. Internal Market and Free Movement Community Policies. Oxford and Portland Oregon, Hart Publishing, 2004, pp. 349-370.

- Partnership Rights, Free Movement, and EU Law. Hart Publishing, Oxford and Portland Oregon, 2004.

TRAPPENBURG, Margo. "Restricting Family Rights: Philosophical Reflections on Transnational Marriages"; HONOHAN, I; JENNINGS, J. (eds.). Republicanism in Theory and Practice. London, Routledge, pp. 173-185.

TRUJILLO PÉREZ, Antonio Javier. "La inmigración en el bloque de la constitucionalidad”; SALINAS DE FRÍAS, Ana (coord.). Inmigración e integración: aspectos sociales y legales. Sequitur, 2008, pp. 139-157.

TRUYOL Y SERRA, Antonio. Los derechos humanos: Declaraciones y Convenios Internacionales. Madrid, Tecnos, 2000, $4^{\text {a }}$ ed.

UNITED NATIONS-INSTRAW. “Feminization of Migration 2007”, Gender, Remittances and Development. Working Paper 1, Santo Domingo, República Dominicana. http://www.un-instraw.org/en/downloads/gender-remittancesand-development/ working-paper

VALLE GÁlVEZ, Alejandro del. "Control de fronteras y Unión Europea”; en Anuario de la Facultad de Derecho de la Universidad Autónoma de Madrid, No 7, 2003, pp. 67-92.

— "El frágil estatuto internacional y europeo del inmigrante irregular"; VÁLLE GÁLVEZ, A. y ACOSTA SÁNCHEZ, Miguel Ángel. Inmigración irregular y derecho: VIII Jornadas Autonómicas de Derecho Internacional Humanitario. Cádiz, Universidad de Cádiz, 2005, pp. 137-149.

VALLE GARAGORRI, Rafael. "La Cumbre Europea Extraordinaria de Tampere"; en El espacio europeo de libertad, seguridad y justicia. Madrid, Ministerio del Interior, Secretaria General Técnica, D.L. 2000, pp. 147-154. 
VALLEJO MARTÍN, Macarena. "Influencias de la reagrupación familiar y la posesión de hogar en el apoyo social de inmigrantes”; en ROMAY MARTÍNEZ, José (ed.). Perspectivas y retrospectivas de la Psicología Social en los albores del siglo XXI. Madrid, Biblioteca nueva D.L., 2007, pp. 349-355.

VALLESPÍN OÑA, Fernando. "Globalización y política: la crisis del Estado”; en ARTETA AISA, A. GARCÍA GUITIÁN, E. Y MÁIZ, R (coords.). Teoría política: poder, moral, democracia. Madrid, Alianza D.L., 2003, pp. 402-423.

VAN OUTRIVE, Lode. "Historia del Acuerdo y del Convenio de Schengen"; en Revista CIDOB de Afers Internacionals, No 53, pp. 43-61.

VAN WALSUM, Sarah. "Comment on the Sen Case. How Wide is the Margin of Appreciation Regarding the Admission of Children for Purposes of Family Reunification”; en European Journal of Migration and Law, №4, 2003, pp. 511520.

VARGAS GÓMEZ-URRUTIA, Marina. "La reagrupación familiar de los extranjeros en el Derecho Comunitario de la inmigración”; en CASTELLANO RUIZ y CALVO CARAVACA (coords.). El Derecho de Familia en el siglo XXI: Aspectos internacionales. Madrid, Colex, 2004, pp. 193-212.

- La Reagrupación Familiar de los Extranjeros en España. Normas de extranjería y problemas de derecho aplicables. Navarra, editorial Thomson Aranzadi, 2006.

VÁZQUEZ GARCÍA, Dolores. "El tratamiento de los menores en el marco de las migraciones europeas: el reagrupamiento familiar y la protección de los derechos humanos"; Revista de la Facultad de Derecho de la Universidad Complutense, No 93, 2000, pp. 324-334.

VÁZQUEZ, Sonia. "Derechos y libertades de los extranjeros en España: el derecho a la reagrupación familiar"; en Anuario da Facultade de Dereito da Universidade da Coruña, № 7, 2003, pp. 439-466.

VELÁZQUEZ SÁNCHEZ, Ma del Mar. “¿La regulación del derecho a la reagrupación familiar o defensa de una política restrictiva de la inmigración?. Comentario a la Sentencia del Tribunal de Justicia de las Comunidades Europeas de 27 de junio de 2006, C-540/2003"; en Revista General de Derecho Europeo, No 12, enero de 2007.

— "La reagrupación familiar en la Unión Europea: Comentario a la Directiva 2003/86"; en Revista General de Derecho Europeo, No 4, 2004.

VICENTE BLANCO, Dámaso-Javier. "Una regulación integral de la inmigración para Europa”; en Revista de Derecho de la Unión Europea, No 5, 2003, pp. 91-113.

VIDAL FUEYO, María del Camino. "La nueva Ley de extranjería a la luz del texto constitucional”; Revista Española de Derecho Constitucional, mayo-agosto 2001, pp. 179-218.

- Constitución y extranjería. Los derechos fundamentales de los extranjeros en España. Madrid, Centro de Estudios Políticos y Constitucionales, 2002.

- "La sentencia del Tribunal Constitucional 72/2005, de 4 de abril, en materia de libertad de entrada y residencia de los extranjeros en España”; Teoría y Realidad Constitucional, No 18, 2006, pp. 429-441.

- "La jurisprudencia del Tribunal Constitucional en materia de derechos fundamentales de los extranjeros a la luz de la STC 236/2007"; en Revista Española de Derecho Constitucional, o 85, 2009, pp. 353-379.

VILA COSTA, B. "El extranjero no comunitario: Actualidad y evolución en materia de política común de inmigración: ¿Hacia un posible estatuto coherente?”; en Anuario Internacional CIDOB, No 1, 1996, pp. 161-172.

VILANOVA TRÍAS, Pere. “¿Estados de facto’ versus 'fallidos o frágiles’?: Unas notas acerca de la dificultad teórica para establecer nuevas tipologías”; en Relaciones internacionales: Revista académica cuatrimestral de publicación electrónica, No. 10, 2009.

VILAR, María José. "El marco legal de la inmigración actual en España: del contexto jurídico comunitario a la vigente ley de extranjería"; ALTED VIGIL, Alicia y ASENJO, Almudena (cords.). De la España que emigra a la España que acoge. Madrid, Fundación Francisco Largo Caballero, 2006, pp. 467-479.

VILLAVERDE MENÉNDEZ, Ángel Ignacio. "Concepto, contenido, objeto y límites de los derechos fundamentales”; La democracia constitucional: Estudios en homenaje al profesor Francisco Rubio Llorente. Madrid, Congreso de los Diputados, Vol. 1, 2002, pp. 317-363.

- "El reagrupamiento familiar y la política de contingentes"; Revista Aragonesa de Administración Pública, № extra 6, 2003, pp. 141-176.

VVAA. "Cumbre de Tampere"; Europa Junta, No 75, octubre de 1999, pp. 2-12.

— "Reagrupación familiar de inmigrantes: problemas, disfunciones y soluciones posibles"; ARAGÓN BOMBÍN, Raimundo y BARTLETT, Jaime (cords.). Integración de inmigrantes: del proceso de regularización a la reagrupación familiar. Barcelona, Fundación Paulino Torras Domènech, 1994, pp. 49-109.

- "Family Reunification"; Office of United Nations High Commissioner for Human Rights. November 2005. Disponible en http://www2.ohchr.org/english/issues/migration/taskforce/docs/familyreunification.pdf

- "The Tampere summit: The ties that bind of the Policemen's Ball" (editorial comments); Common Market Law Review, No 36, 1999, pp. 119-126.

- El fenómeno migratorio en la Unión Europea: Un reto para todos. Madrid, Comunidad de Madrid, Consejería de Presidencia, 2006. 
VVAA. Inmigración, derechos humanos y relaciones internacionales. Antecedentes, situación actual y perspectivas de futuro. León, Junta de Castilla y León, Ponencias desarrolladas en las Jornadas de Inmigración, derechos humanos y relaciones internacionales, 29 y 30 de septiembre, 2004.

- La inmigración en la Unión Europea: Situación y perspectivas para Euskadi. Bilbao, Consejo Vasco del Movimiento Europeo, 2003.

- The Family. Organisation and protection within the European Social Charter. Study compiled by the Directorate of Human Rights on the basis of the case law of the Committee of Independent Experts. Council of Europe Press, Human Rights. Social Charter Monographs, No 1, Strasbourg, printed in Germany, 1995.

- "Notes on the Case Law Discussion of 23 March 2010". Europa Institute, Leiden University, s.p. Disponible en http://media.leidenuniv.nl/legacy/ei-jpdiner-23-march.pdf

WALKER, Neil. "In Search of the Area of Freedom, Security and Justice: A Constitutional Odyssey"; WALKER, Neil (ed.). Europe's Area of Freedom, Security and Justice. Oxford, New York, Oxford University Press, Academy of European Law. 2004, pp 3-37.

WARBRICK, Colin. "The Structure of Article 8”; en European Human Rights Law Review, 1998, vol 1, pp. 32-44.

WEATHERILL, Stephen. "Why Harmonise?"; en TRIDIMAS, Takis\& NEBBIA, Paolisa. European Union Law for the Twenty-First Century. Rethinking the New Legal Order, volume 2. Oxford and Portland Oregon, Hart Publishing, 2004, pp. 11-32.

WEEKS, J; HEAPHY, B y DONOVAN, C. Same Sex Intimacies. Families of Choice and Other Lilfe Experiments. London, Routledge, 2001.

WEISS, Friedl and WOOLDRIDGE, Frank. Free Movements of Persons within the European Community. European Monographs, The Netherlands, Kluwer Law Internacional, second ed., 2007.

WIESBROCK, Anja. "Court of Justice of the European Union. The Right to Family Reunification to Third-Country Nationals under EU Law; Decision of 4 March 2010, Case C-578/08, Rhimou Chkaroun V. Minister van Buitenlandse Zake"; European Constitutional Law Review, № 6, 2010, pp. 462-480.

WILLY, Alexander. "Free Movement of Non-EC Nationals. A Review of the Case-Law of the Court of Justice"; en European Journal of International Law, No 53, 1992, pp. 53-64.

WITHERS, Suzanne D; CLARK, Willian A. y RUIZ, Trizia. "Demographic Variations in Housing Cost Adjustments in US Family Migration"; en Population, Space and Place, No 14, 2008, pp. 305-325.

WOLLENSCHLÄGER, Michael (ed.). Asylum and Integration in Member States of the EU. Integration of Recognized Refugee Families as Defined by the Geneva Convention Considering their Status with the Respect to the Law of Residence. BWV, Berliner Wissenschafts-Verlag, Berlin, 2003.

ZABALO ESCUDERO, María Elena. "Legislación española de extranjería: evolución y experiencias en su aplicación”; OTADUY, Jorge; TEJERO, Eloy y VIANA, Antonio. Migraciones, Iglesia y Derecho. Actas del V Simposio del Instituto Martín de Azpilcueta sobre Movimientos migratorios y acción de la Iglesia. Aspectos sociales, religiosos y canónicos. Instituto Martín de Azpilcueta, Universidad de Navarra, 2003, pp. 109-133.

- "Relaciones internacionales de familia y derecho de los extranjeros a vivir en familia"; Revista de Derecho Migratorio y Extranjería, Na 18, Julio 2008, pp. 45-80.

ZAPATA-BARRERO, Ricard. "El tratamiento de la Unión Europea de los inmigrantes extra-comunitarios"; en FERNÁNDEZ SOLA, Natividad y CALVO GARCÍA, Manuel (coords). Inmigración y derechos. Zaragoza, Mira editores, 2001, pp. 111-123.

- "Fundamentalismo estatal de la UE en torno a la inmigración"; en Revista Cidob d’Afers Internacionals, № 53, 2001, pp149-176.

ZLOTNIK, Hania. The Global Dimensions of Female Migration. Migration Information Source. March, 2003.Disponible en http://www.migrationinformation.org/Feature/display.cfm?ID=109Sobr

ZORRILLA, Virginia. “La reagrupación familiar”; en Escritura pública, No. 37, 2006, pp. 64-66.

ZWAAN, de Jaap W. "EU Asylum and Immigration Law and Policy: State of Affairs in 2005"; ZWAAN, Jaap W. and GOUDAPPEL, Flora A.N.J (eds.). Freedom, Security and Justice in the European Unión. Implementation of the Hague Programme. The Hague, TMC Asser Press, 2006, pp. 91-149. 